\title{
URBANIZACIÓN MARGINAL E IMPACTO AMBIENTAL EN LA CIUDAD DE MONTERÍA
}

\section{JHON WILLIAM PINEDO LÓPEZ}

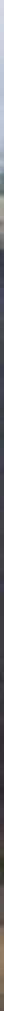





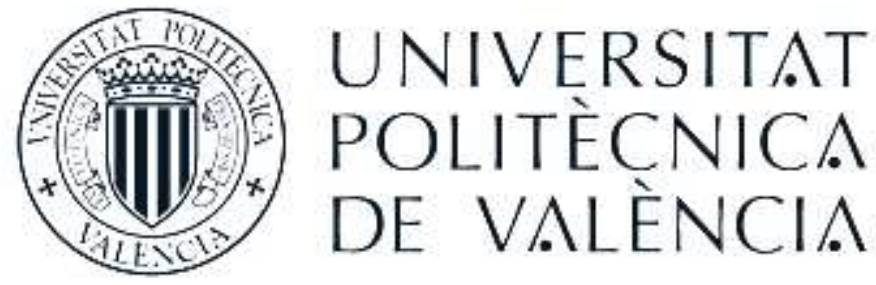

URBANIZACIÓN MARGINAL E IMPACTO AMBIENTAL EN LA CIUDAD DE MONTERÍA

TESIS DOCTORAL

PRESENTADA POR JHON WILLIAM PINEDO LÓPEZ

DIRGIDA POR DR. D. FERNANDO GAJA I DÍAZ

UNIVERSIDAD POLITÉCNICA DE VALENCIA

DEPARTAMENTO DE URBANISMO

VALENCIA, MARZO DE 2012 

A Dios por otorgarme la fortaleza suficiente para resistir en los momentos de dificultad.

A mi madre por su absoluta comprensión y amor incondicional durante toda una vida.

A mis hijos, hermanas y sobrinos por la confianza depositada y por su paciente espera.

A Loli, Amparo y Katia, por la valentía de acompañarme en esta gran aventura. 



\section{AGRADECIMIENTOS}

En primer lugar agradezco a mi director Fernando Gaja i Díaz por su extraordinario acompañamiento durante todo el tiempo de la investigación, sus valiosos aportes y por sus continuas manifestaciones de solidaridad y cooperación, que hicieron posible la culminación satisfactoria de esta tesis doctoral.

A Gustavo Vivas y a todos los funcionarios de la Universidad Politécnica de Valencia, principalmente a los del Vicerrectorado de Cooperación, por su gran colaboración.

A Zulma Salamanca, Mélida Martínez, Luz Matilde Mora, José Luis Ramos, Joaquín García-Roca, Ignacio Lucas y Néstor Rueda por todo el apoyo moral en la bella ciudad de Valencia.

A Víctor Negrete Barrera en Montería por su amable y desinteresada contribución.

A todos ellos, reitero mis más grandes agradecimientos. 



\section{INDICE GENERAL}

RESUMEN. .XXII

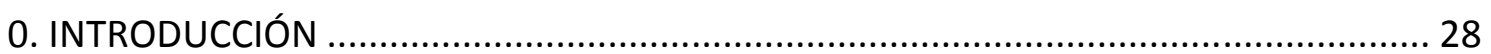

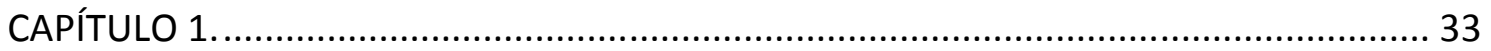

1. PROBLEMA, JUSTIFICACIÓN, OBJETIVOS Y METODOLOGÍA................................... 33

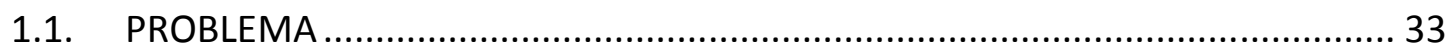

1.1.1. Descripción del problema................................................................... 33

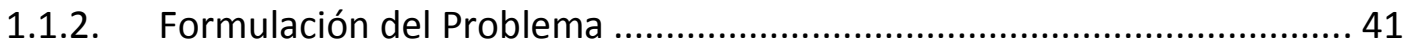

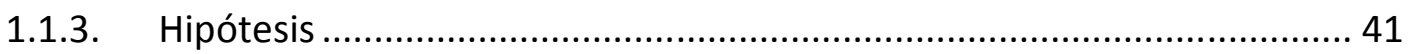

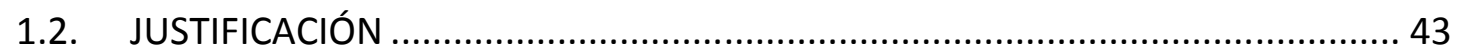

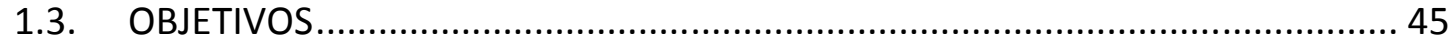

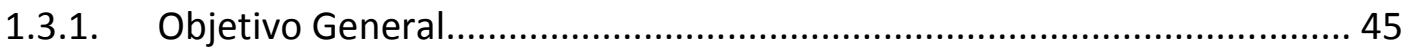

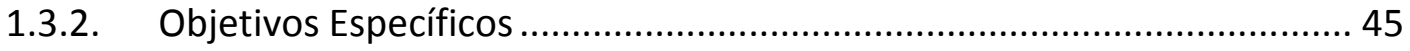

1.4. METODOLOGÍA

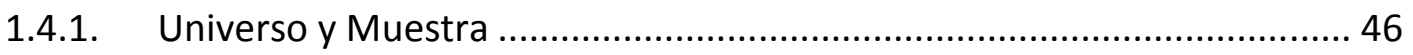

1.4.2. Instrumentos de Medición ................................................................... 47

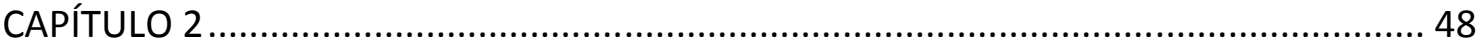

2. MARCO TEÓRICO, CONTEXTO GEOGRÁFICO Y ANTECEDENTES ............................. 48

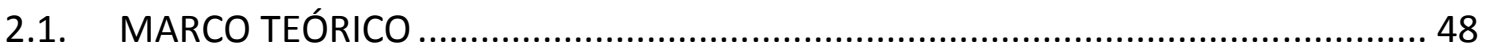

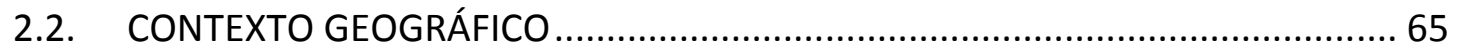



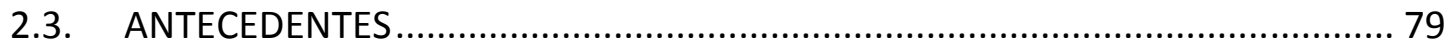

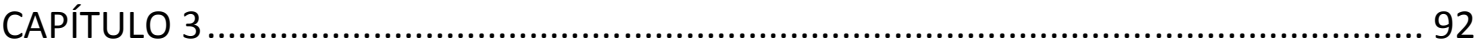

3. MODELOS ECONÓMICOS EN COLOMBIA, DIVISIÓN POLITICO-ADMINISTRATIVA Y

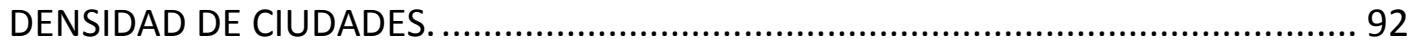

3.1. MODELOS ECONÓMICOS EN COLOMBIA..................................................... 93

3.1.1. Modelo de Industrialización por Sustitución de Importaciones (ISI) ....... 93

3.1.1.1. Impacto del Modelo Estructuralista en Colombia ................................. 96

3.1.1.2. Impacto del Modelo Estructuralista en Montería .............................. 100

3.1.2. MODELO DE GLOBALIZACIÓN ECONÓMICA NEOLIBERAL........................ 105 
3.1.2.1. Impacto de la Globalización en Colombia ....................................... 108

3.1.2.2. Impacto socio-económico de la Globalización en Montería. .............. 113

3.2. DIVISIÓN POLÍTICO-ADMINISTRATIVA Y JERARQUÍA DE CIUDADES EN

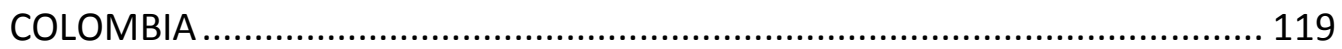

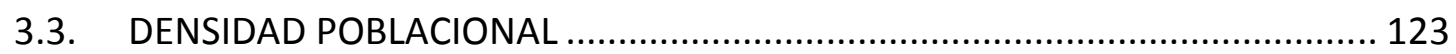

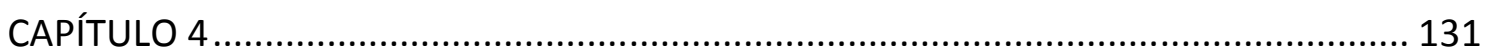

4. CIUDAD FORMAL Y CIUDAD INFORMAL EN COLOMBIA .................................... 131

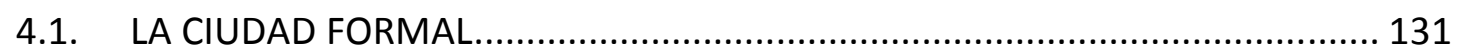

4.1.1. Las ciudades colombianas antes de la ley 388 de $1997 \ldots \ldots \ldots \ldots \ldots . . . . . . . . . . .133$

4.1.2. Los programas de vivienda pública en Colombia................................. 134

4.1.3. La vivienda pública en Montería .......................................................... 139

4.1.4. Montería y el Plan de Ordenamiento Territorial (POT) ......................... 154

4.1.5. Montería y los planes de desarrollo ..................................................... 177

4.1.5.1. Plan de Desarrollo 2001-2003 …...................................................... 178

4.1.5.2. Plan de Desarrollo 2004-2007 ........................................................... 180

4.1.5.3. Plan de Desarrollo 2008-2011 ......................................................... 189

4.1.6. Presupuesto de Montería como limitante del desarrollo urbano ......... 196

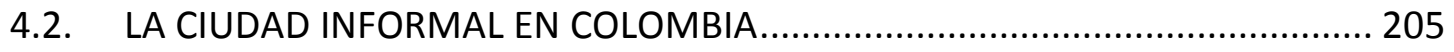

4.2.1. La ciudad informal en Montería ............................................................ 211

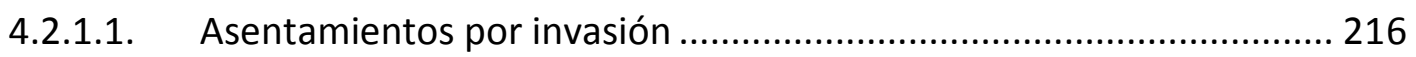

4.2.1.1.1. Surgimiento, ubicación y situación de las invasiones de Montería.... 222

4.2.1.2. Asentamientos informales por fraccionamientos privados .............. 245

4.1.2.3. Asentamientos Informales por fraccionamientos públicos................ 251

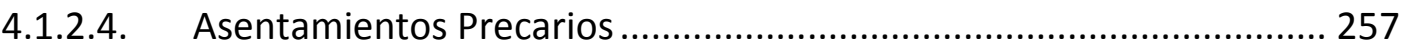

4.1.2.5. Asentamientos Semi-consolidados................................................ 262

4.1.2.6. Asentamientos Consolidados ............................................................ 266

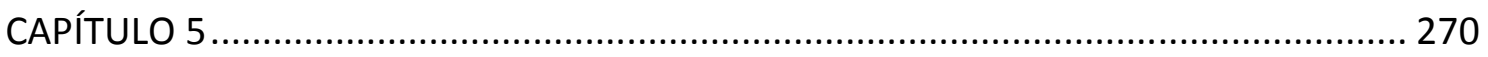

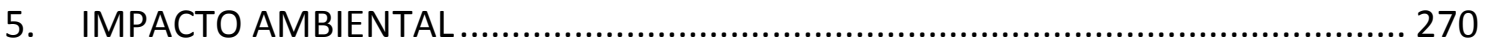

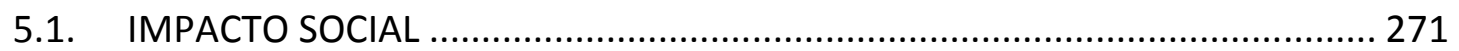

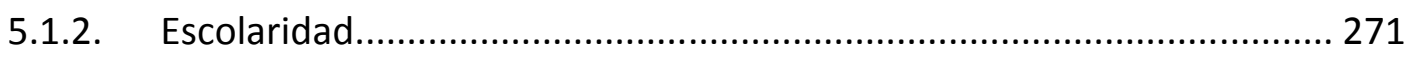

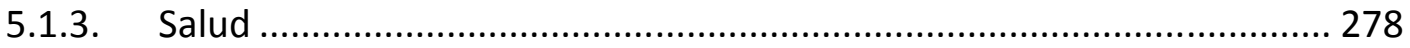

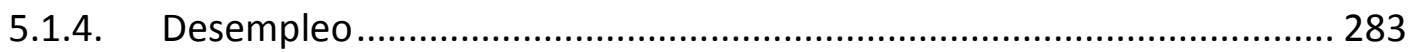




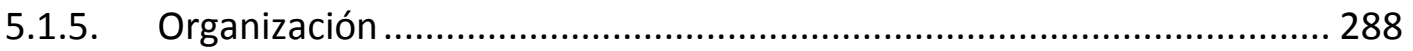



5.1.7. Participación ciudadana ................................................................... 298

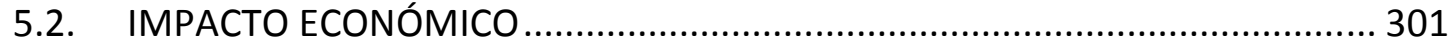

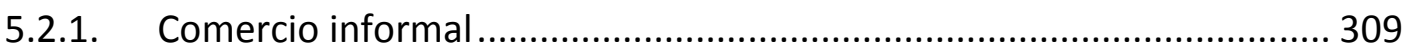

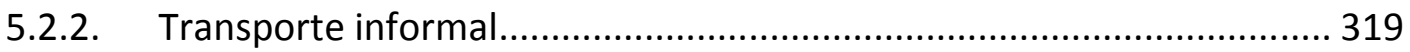

5.2.3. Servicio de telecomunicación informal ................................................... 329

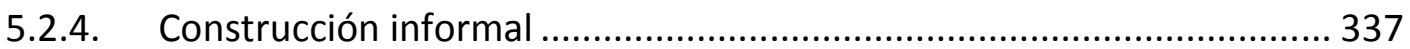

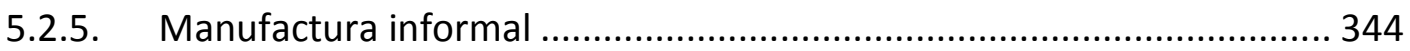

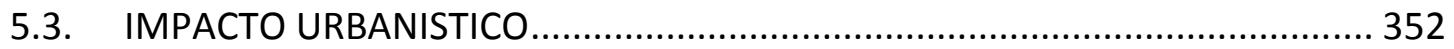

5.3.1. Las piezas urbanas como escenarios de intervención correctora ............... 354

5.3.1.1. Pieza urbana Occidental .................................................................. 358

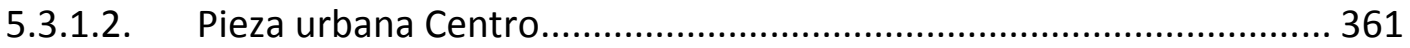



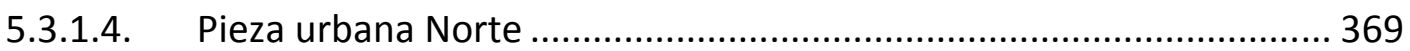

5.3.1.5. Pieza urbana Oriental. .................................................................. 374

5.3.2. Del trazado regular al trazado irregular …………………………....... 378

5.3.3. Densidad poblacional local ............................................................... 447

5.3.4. Servicios públicos básicos. Instalación y normalización.......................... 450

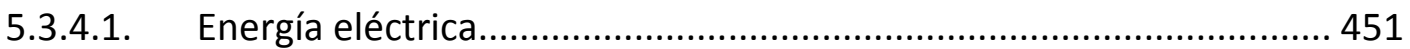

5.3.4.2. Agua potable y saneamiento básico ................................................. 452

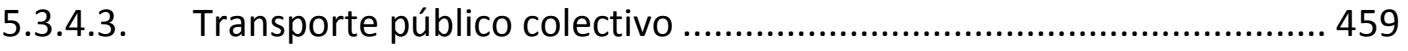

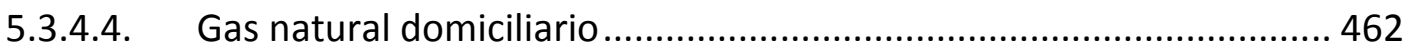

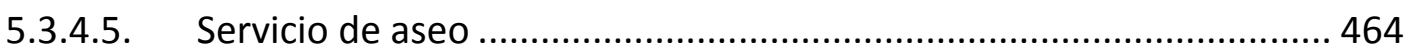

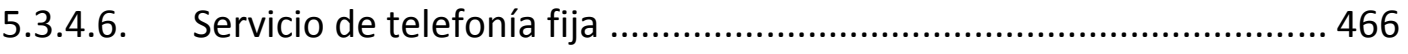

5.3.4.7. Algunas consideraciones sobre la calidad de los servicios públicos... 468

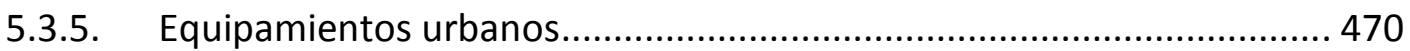

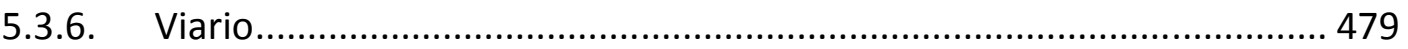

5.3.7. Déficit de Espacio Público..................................................................... 485

5.3.8. La Urbanización Marginal de Montería comparada con la de otros

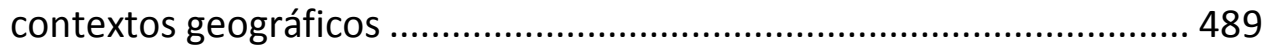

5.3.9. Un análisis sobre el modelo de Intervención en estos asentamientos.. 501 
5.3.10. Una propuesta de intervención pública en asentamientos informales. 504

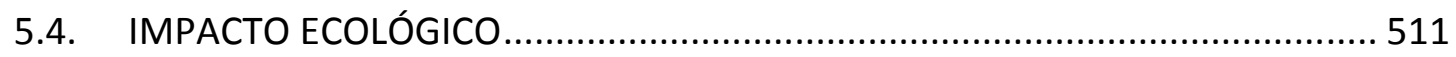

5.4.1. Condiciones medioambientales y perspectivas ................................. 517

5.4.2. Dificultades para la sostenibilidad ecológica y otros impactos............... 520

5.4.3. Impacto generado por la red de canales de aguas pluviales ................. 528

5.4.4. El fenómeno de la Tubificación en la invasión el Cerro ........................ 532

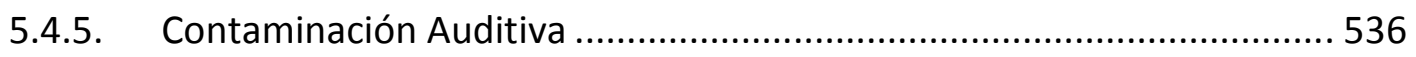

5.4.6. Un esquema de valoración de impacto ecológico de la Urbanización

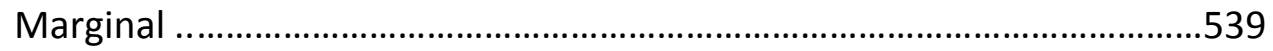

5.4.7. Del esquema de impacto ambiental inicial a un esquema final............. 551

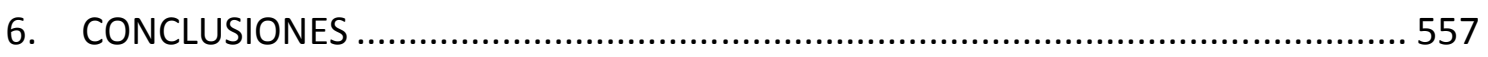

6.1. CONCLUSIONES ASOCIADAS A ASPECTOS SOCIALES Y JURÍDICOS ............... 557

6.2. CONCLUSIONES ASOCIADAS A ASPECTOS URBANÍSTICOS Y

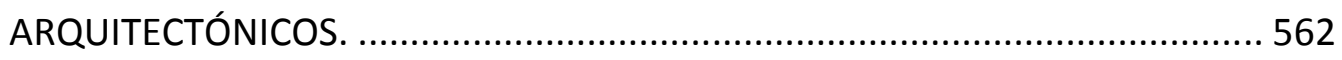

6.3. CONCLUSIONES ASOCIADAS A ASPECTOS ECONÓMICOS ............................ 571

6.4. CONCLUSIONES ASOCIADAS A ESPECTOS ECOLÓGICOS ...............................574

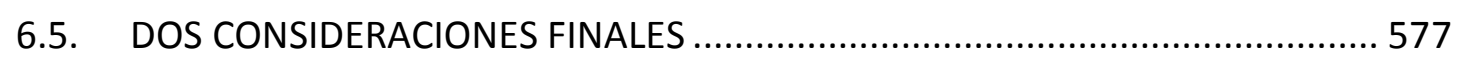

7. REFERENCIAS Y BIBLIOGRAFÍA COMPLEMENTARIA .......................................... 578

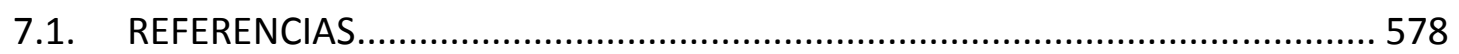

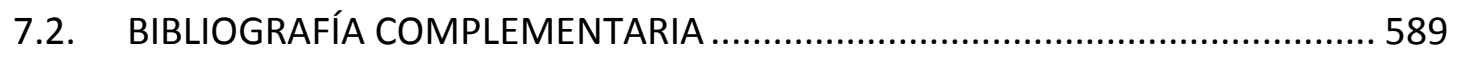

ANEXO 


\section{INDICE DE ILUSTRACIONES}

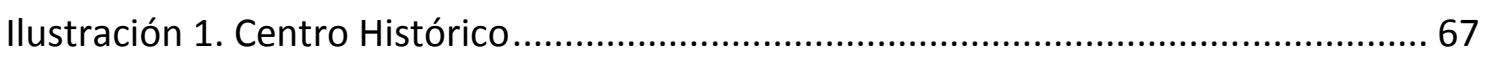

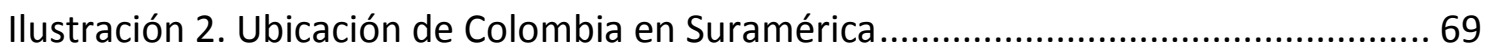

Ilustración 3. Montería en Córdoba y en Colombia ........................................................ 70

Ilustración 4. Características físicas del territorio ........................................................ 71

Ilustración 5. Áreas de conflicto armado cercanas a Montería ......................................... 73

Ilustración 6. Indicadores socioeconómicos en Montería .......................................... 74

Ilustración 7. División político-administrativa por corregimientos.............................. 76

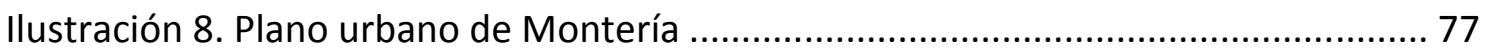

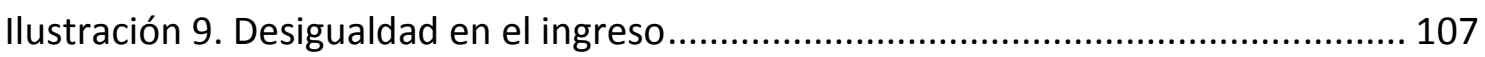

Ilustración 10. Crecimiento del PIB vs tasa de desempleo en Colombia ...................... 109

Ilustración 11. Evolución del empleo informal como porcentaje del empleo total..... 110

Ilustración 12. Tasa Global de Fecundidad para América Latina a partir de 1950....... 124

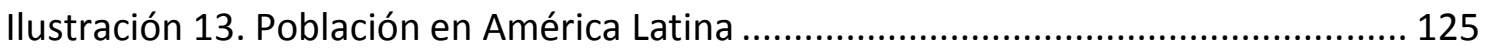

Ilustración 14. Ciudades latinoamericanas más pobladas 2010 ................................... 126

Ilustración 15. Densidad poblacional en principales ciudades..................................... 126

Ilustración 16. Densidad poblacional en ciudades colombianas................................... 128

Ilustración 17. Población ciudades colombianas....................................................... 128

Ilustración 18. Vivienda tipo de primeros programas de promoción pública............... 135

Ilustración 19. Programas de vivienda pública en Bogotá ........................................... 136

Ilustración 20. Perspectiva aérea del barrio Kennedy en Bogotá ............................... 137

Ilustración 21. Construcción de vivienda pública en Colombia.................................... 137

Ilustración 22. Plano de vivienda pública en Montería ............................................... 140

Ilustración 23. Estado de entrega vivienda pública................................................... 141

Ilustración 24. Plano de los primeros barrios de promoción pública en Montería ..... 142

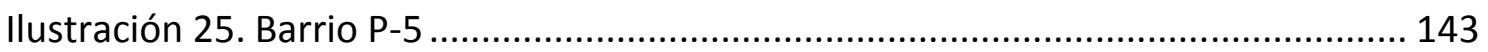

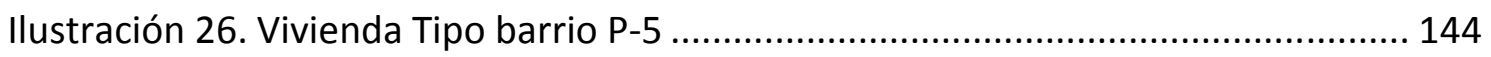

Ilustración 27. Barrios la Ribera y la Pradera ............................................................ 145

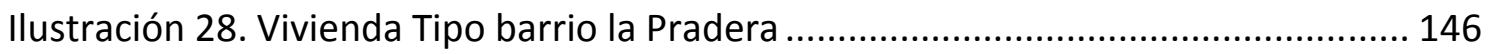

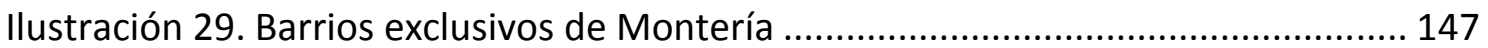

Ilustración 30. Barrios de vivienda pública de los años 80......................................... 148

Ilustración 31. Plano de los Robles y el Alivio ............................................................. 150

Ilustración 32. Planos de los barrios Minuto de Dios y los Colores.............................. 151

Ilustración 33. Vivienda Tipo de los últimos proyectos................................................. 152

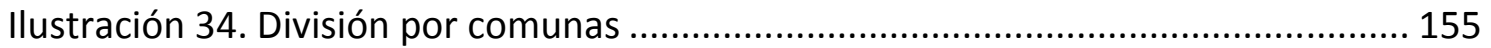

Ilustración 35. Red de parques y centralidades programadas ..................................... 160

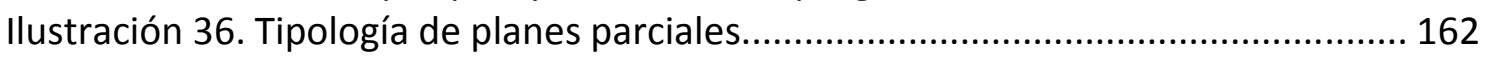

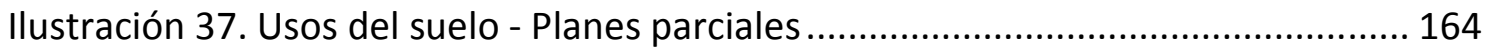



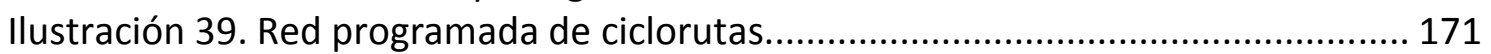

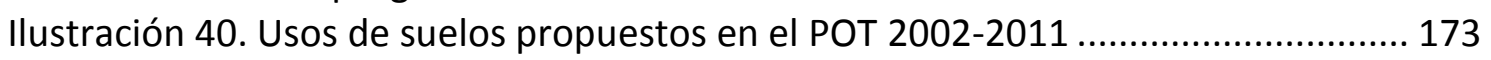

Ilustración 41. Usos del suelo y perímetro urbano ..................................................... 182

Ilustración 42. Planes parciales Comfacor, los Mangos y Furatena ............................... 192 


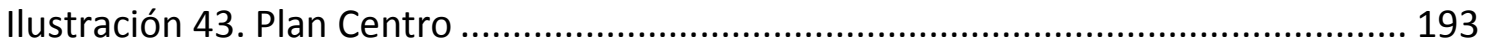

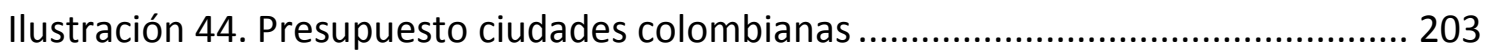

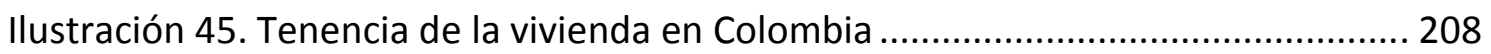

Ilustración 46. Evolución demográfica en Montería ..................................................... 213

Ilustración 47. Barrios surgidos por procesos de invasión ........................................... 223

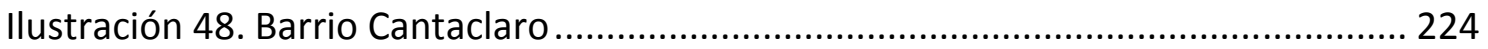

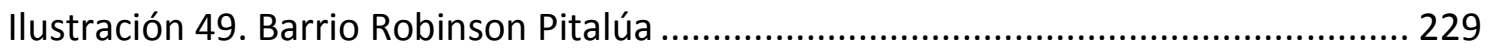

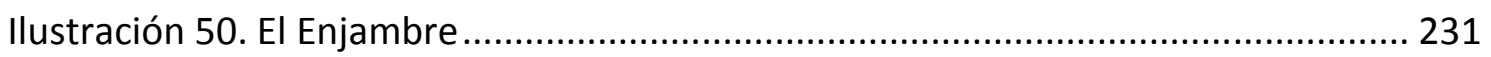

Ilustración 51. Invasiones 7 de Mayo, 20 de Julio y Camilo Torres.............................. 233

Ilustración 52. Ubicación Villa Jiménez y Villa Cielo .................................................... 235

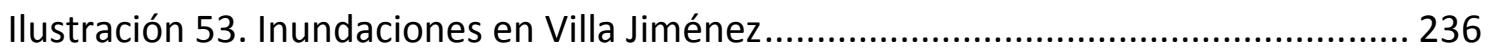

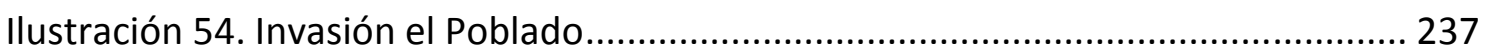

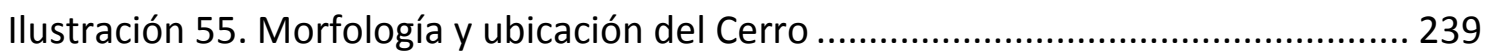

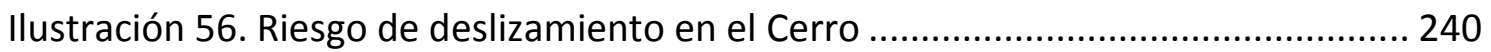

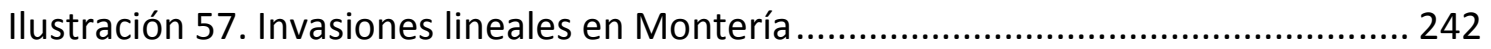

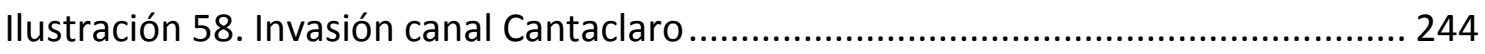

Ilustración 59. Procesos de autopromoción en Bogotá ............................................. 247

Ilustración 60. Barrios por fraccionamientos privados irregulares ............................ 250

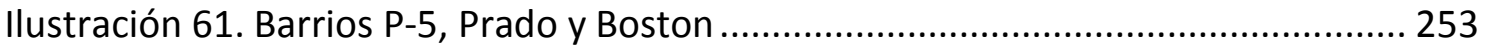

Ilustración 62. Fraccionamientos públicos Policarpa, Santafé, Santander y San M. ... 254

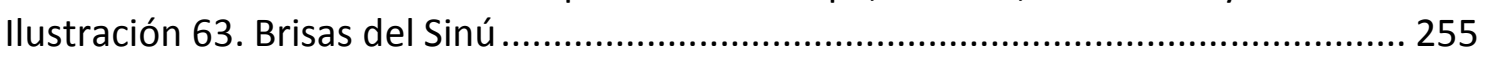

Ilustración 64. Barrios por fraccionamientos públicos.............................................. 256

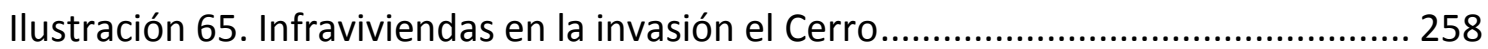

Ilustración 66. Asentamientos Nuevo Milenio - Villa Jiménez - el Poblado ................ 259

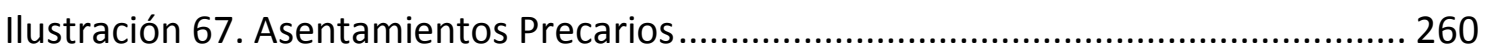



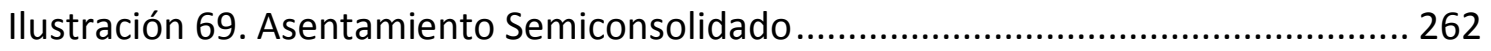

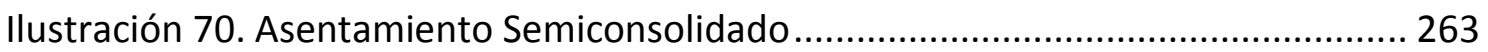

Ilustración 71. Inicio de dotaciones públicas - vía de acceso -cancha deportiva ........ 264

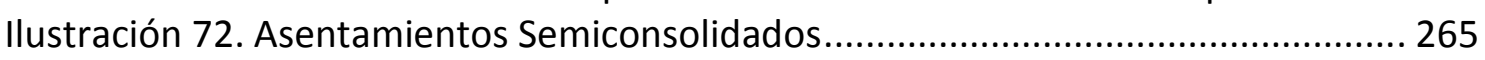

Ilustración 73. Vías - canales - puentes y equipamientos en barrios consolidados .... 267

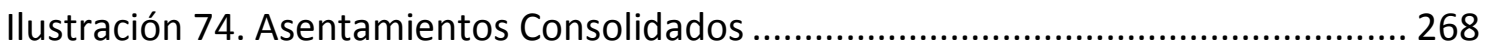

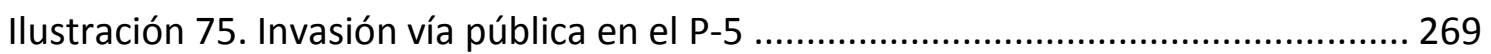

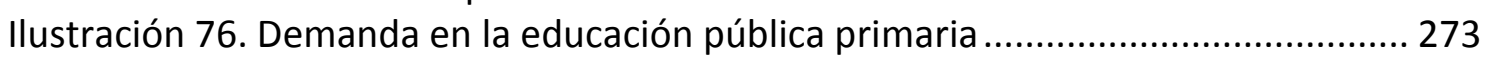

Ilustración 77. Principales patologías en infantes de asentamientos informales......... 282

Ilustración 78. Tasa de desempleo en Montería y en Colombia 2003 - 2010.............. 284

Ilustración 79. Desempleo en ciudades colombianas 2010 ....................................... 285

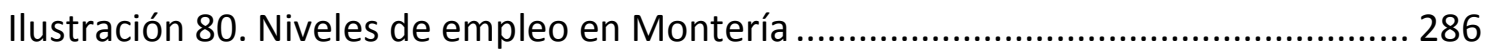

Ilustración 81. Ciudades más inseguras en el mundo ................................................ 291

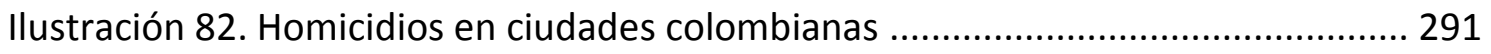

Ilustración 83. Delitos ocurridos en Montería entre los años 2002 y 2009 .................. 294

Ilustración 84. Barrios de alta vulnerabilidad a la delincuencia...................................... 296

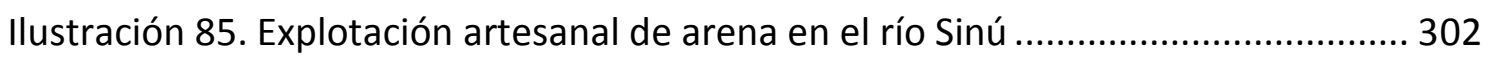

Ilustración 86. Estructura de la fuerza de trabajo en Montería ................................... 303

Ilustración 87. Población ocupada por actividad en Montería ..........................................304

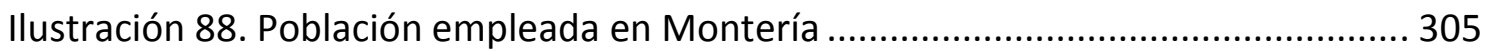

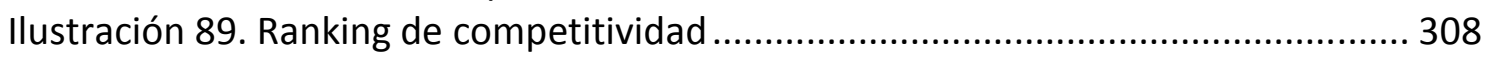




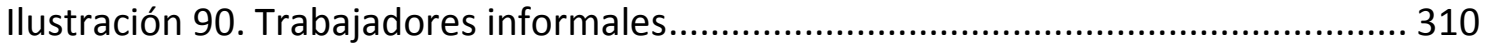

Ilustración 91. Invasión espacio público por comercio informal ................................. 311

Ilustración 92. Rangos de edad de trabajadores informales......................................... 312

Ilustración 93. Menores de edad en trabajo informal .................................................. 313

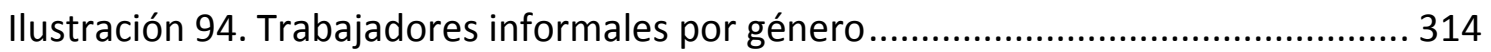

Ilustración 95. Niveles de escolaridad de los trabajadores infórmales........................ 314

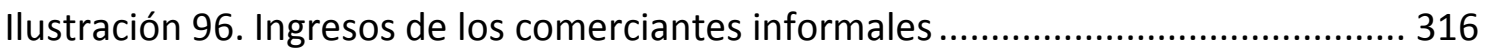

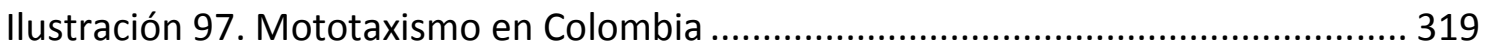

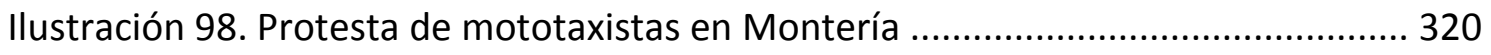

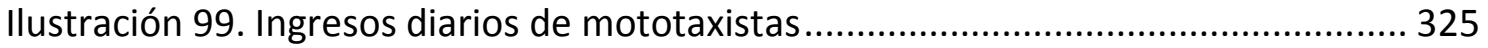

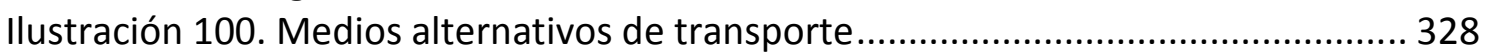

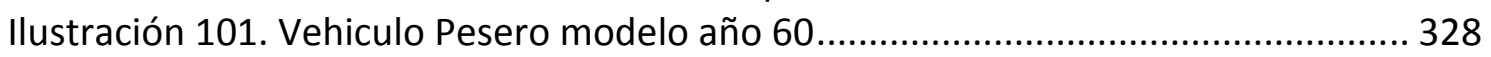

Ilustración 102. Revendedores callejeros de minutos a celular en Colombia .............. 330

Ilustración 103. Localización de antenas de telefonía celular...................................... 333

Ilustración 104. Café Internet (SAI) en el barrio informal el Poblado .......................... 335

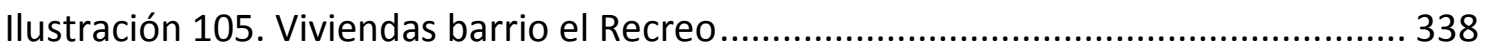

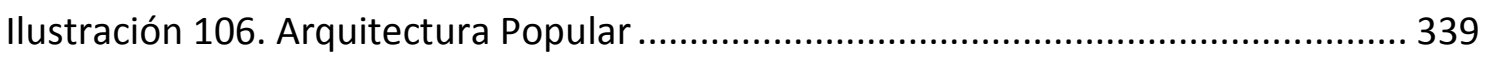

Ilustración 107. Viviendas autoconstruidas barrio el Prado ...................................... 341

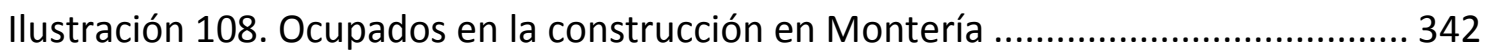

Ilustración 109. Construcción de bodegas en el norte de la ciudad .............................. 343

Ilustración 110. Producción informal de bloque para construcción ............................. 346

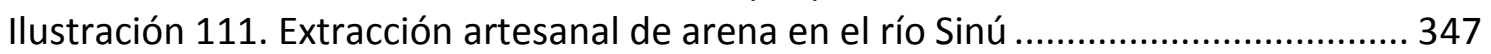

Ilustración 112. Distribución de la ocupación en Montería ...................................... 349

Ilustración 113. Lustrador de zapatos en la avenida primera .................................... 350

Ilustración 114. Porcentaje de población informal en principales ciudades del país.. 351

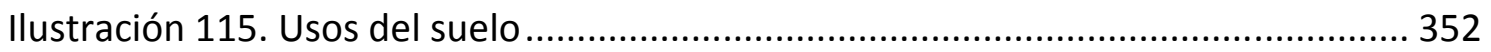

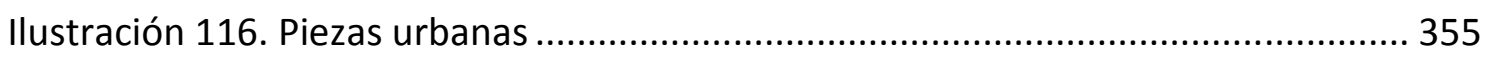

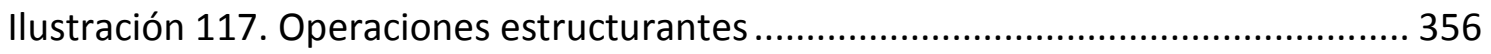

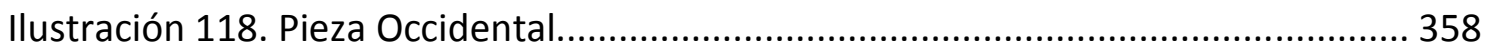

Ilustración 119. Asentamientos precarios y semiconsolidados pieza occidental ........ 359

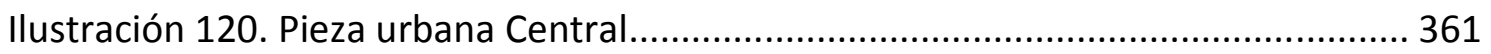

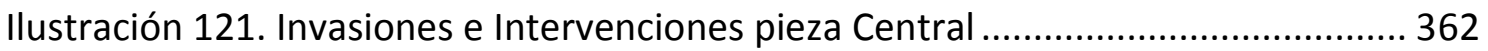

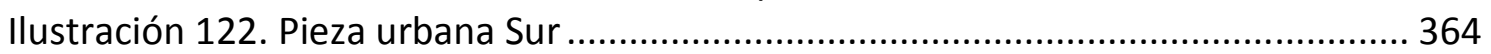

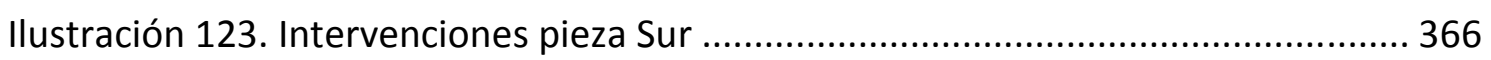

Ilustración 124. Obras inconclusas y eje ambiental proyectado en el sur .................... 367

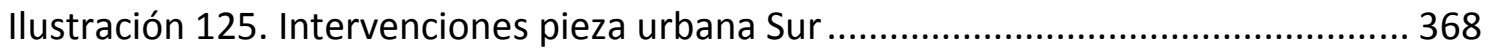

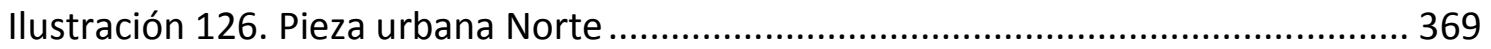

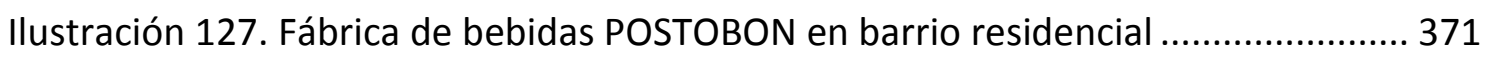

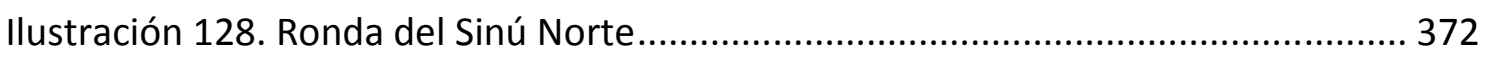

Ilustración 129. Nuevas intervenciones y desaciertos urbanísticos ............................. 373

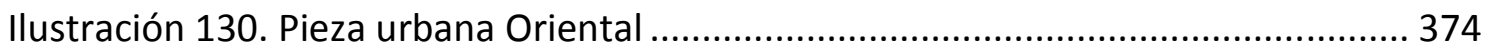

Ilustración 131. Invasión a humedales Villa Caribe y los Araujos en la pieza Sur ......... 375

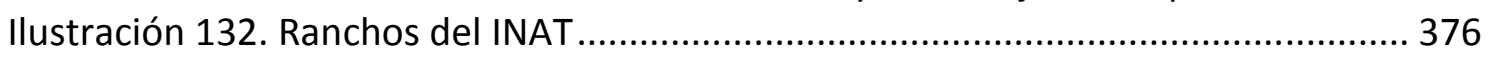

Ilustración 133. Cuadricula del centro y primeros trazados irregulares ...................... 379

Ilustración 134. Barrios Sucre- invasión Sucre - el Carmen - los Laureles.................... 380

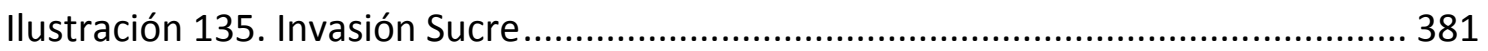

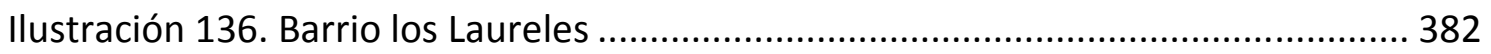




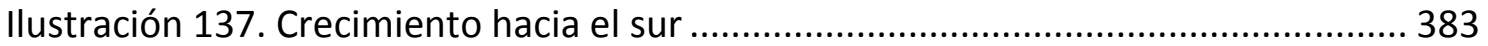

Ilustración 138. Barrios Policarpa - Alfonso López - las Colinas - P-5 ........................ 385

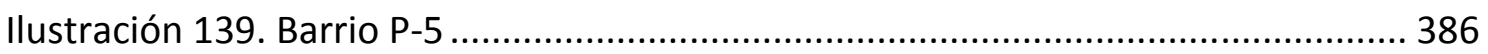

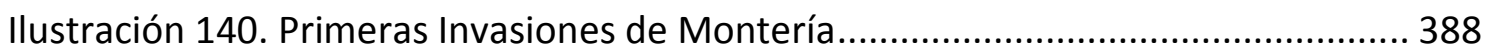

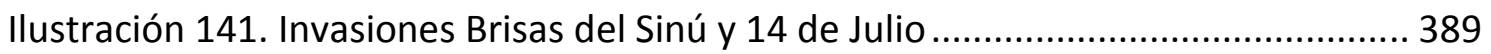

Ilustración 142. La Pradera y el crecimiento hacia el oriente ..................................... 391

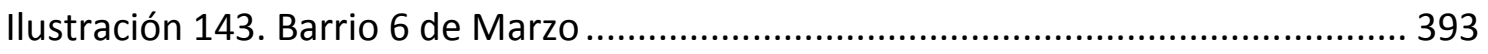

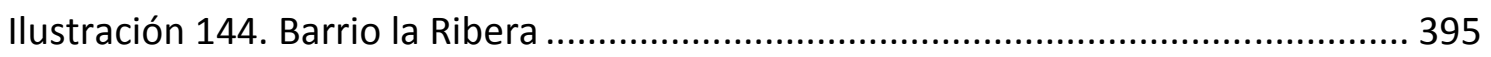

Ilustración 145. Informalidad y perímetro urbano sector occidental ........................... 396

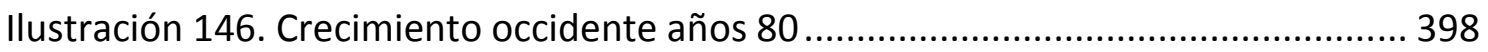

Ilustración 147. Barrio el Dorado - mayor superficie del occidente ............................. 399

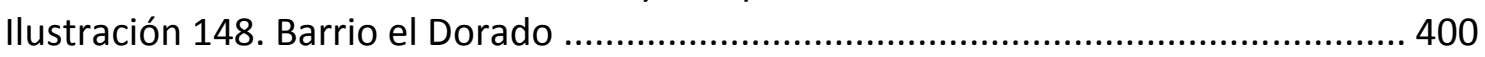

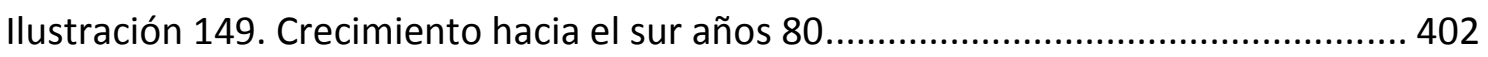

Ilustración 150. Nuevos ejes de crecimiento informal en el sur................................... 405

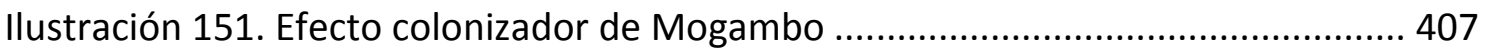

Ilustración 152. Impacto de Villa Margarita y Panzenú en expansión urbana sur....... 409

Ilustración 153. Surgimiento de 7 de Mayo y Cantaclaro ........................................... 411

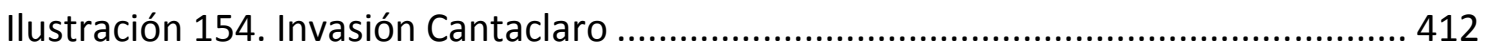

Ilustración 155. Sectores de la invasión Cantaclaro ...................................................... 414

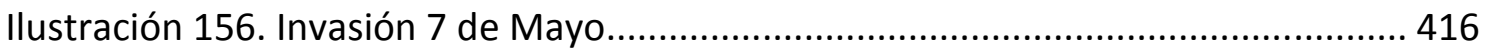

Ilustración 157. Programas del INURBE en el occidente ............................................. 418

Ilustración 158. Informalidad por fuera del perímetro urbano en el occidente........... 421

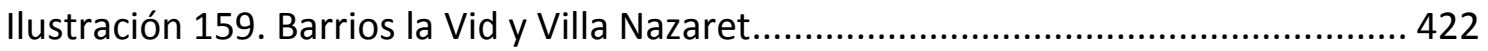

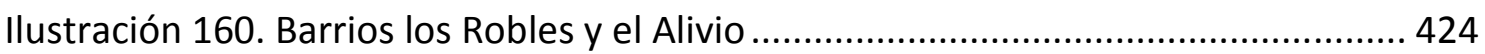

Ilustración 161. Asentamientos informales de la cuarta oleada en el norte y oriente 427

Ilustración 162. Asimetría en el aprovechamiento del suelo........................................429

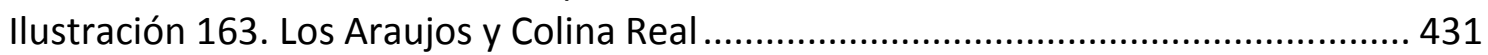

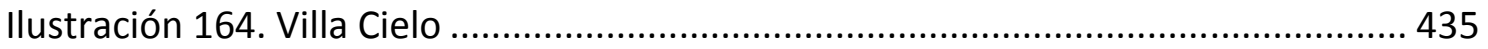

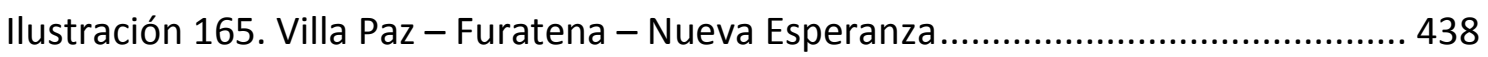

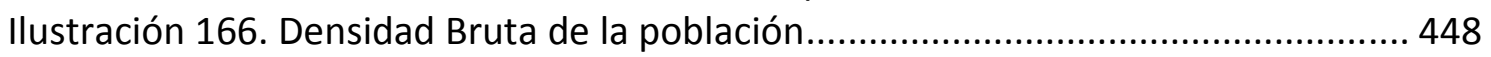

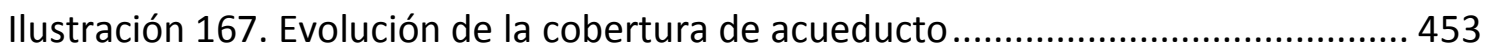

Ilustración 168. Cobertura de alcantarillado sanitario................................................ 455

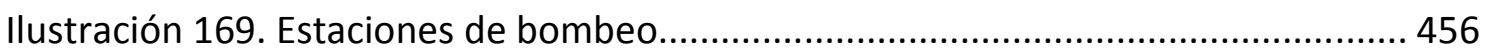



Ilustración 171. Rutas del sistema estrategico de transporte público propuesto ....... 461

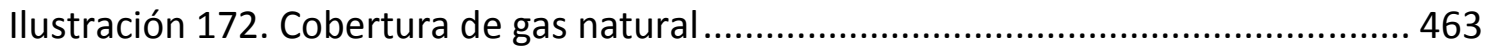

Ilustración 173. Frágil cobertura de energía eléctrica en Villa Jiménez....................... 469

Ilustración 174. Equipamientos colectivos básicos con significativas superficies ....... 473

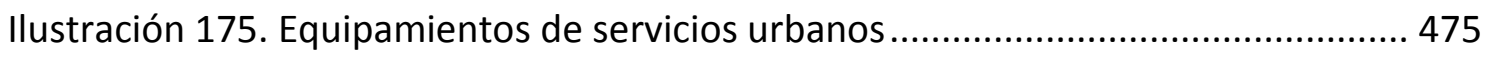

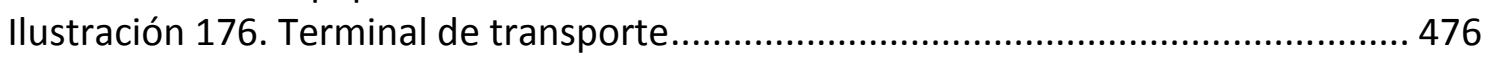

Ilustración 177. Equipamientos de alto impacto ambiental .........................................478

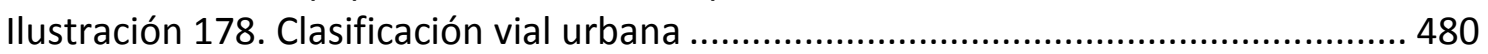

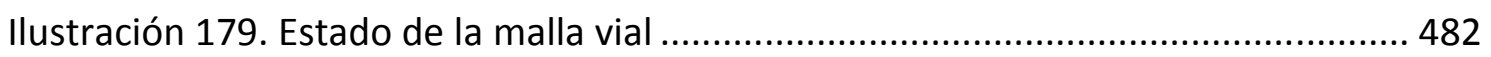

Ilustración 180. Metros de espacio público por Habitante......................................... 486

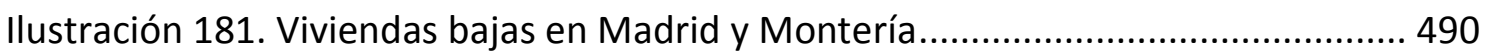

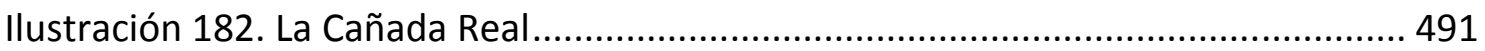

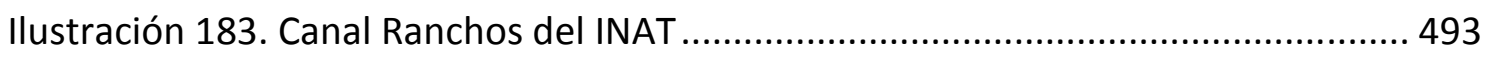




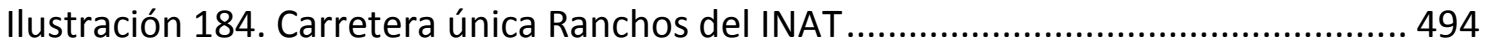

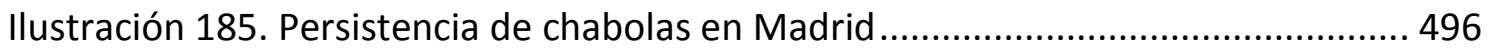

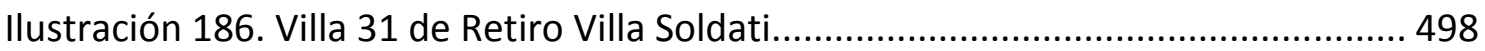

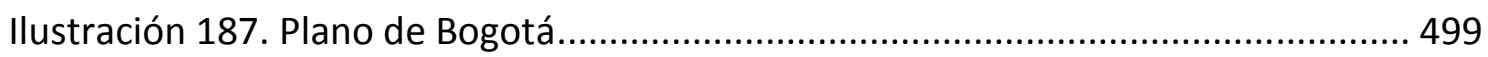

Ilustración 188. Ocupación cerros de Bogotá .............................................................. 500

Ilustración 189. Favelas consolidadas en Río de Janeiro............................................. 505

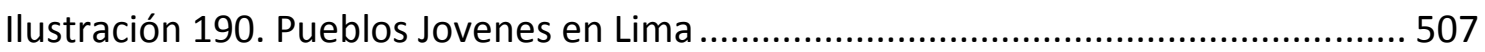

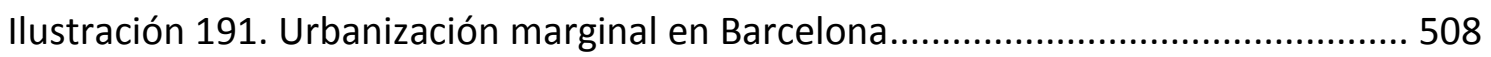



Ilustración 193. Erosión sobre el río Sinú ................................................................... 513

Ilustración 194. Amenaza por remoción en masa...................................................... 514

Ilustración 195. Erosión y remoción en masa en la reserva natural Sierra Chiquita ... 515

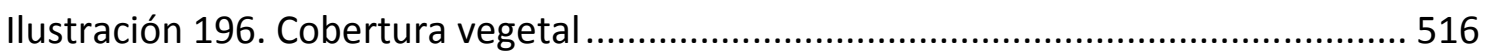

Ilustración 197. Ubicación de Montería en ranking nacional de competitividad ........ 518

Ilustración 198. Relleno sanitario de Montería......................................................... 519

Ilustración 199. Desplazados Ilegados a Montería entre 1996 y 2008 ........................ 521

Ilustración 200. Emplazamiento de la Vid y los Nísperos en la ciénaga Berlín ............. 522

Ilustración 201. Emplazamientos sobre la reserva Sierra Chiquita y ciénagas ........... 523

Ilustración 202. Vulnerabilidad a inundaciones ....................................................... 524

Ilustración 203. Emplazamiento barrios Caribe y Villa Caribe en humedal .................. 525

Ilustración 204. Esquema de camellones construidos en zonas cenagosas .................. 527

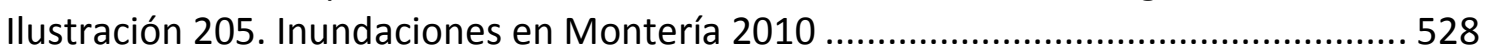

Ilustración 206. Sedimentación en canales de asentamientos semiconsolidados ...... 529

Ilustración 207. Red de canales y áreas de drenajes................................................. 530

Ilustración 208. Canales pluviales revertidos pero receptores de aguas residuales ... 531

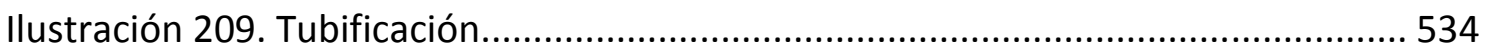

Ilustración 210. Ocupación en el cerro Sierra Chiquita ................................................ 535

Ilustración 211. Sectores con mayor contaminación auditiva ..................................... 537

Ilustración 212. Impacto ecológico de la Urbanización Marginal ..................................546

Ilustración 213. Efectos ecológicos generados por actividades humanas .................... 547

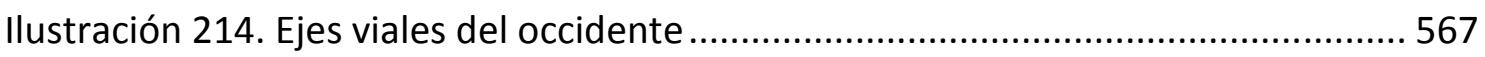




\section{INDICE DE TABLAS}

Tabla 1 Evolución de la población en Latinoamérica ..................................................... 34

Tabla 2 Población en situación de Informalidad en capitales latinoamericanas ........... 35

Tabla 3. Precios del suelo en capitales sudamericanas entre 2002 - 2006................... 36

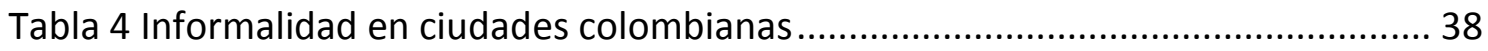

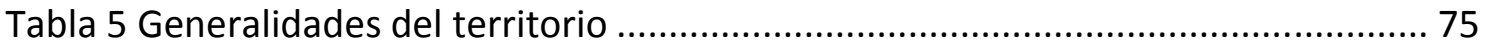

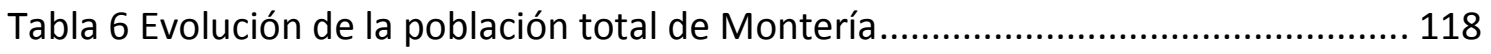

Tabla 7 Jerarquía de centros urbanos en Colombia .................................................... 122

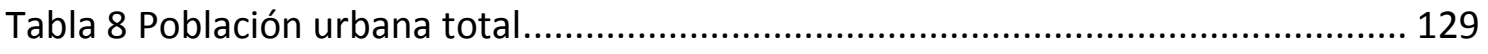

Tabla 9 Proyectos y construcción de viviendas por departamentos.......................... 138

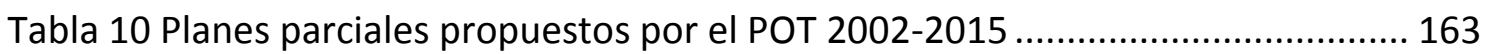

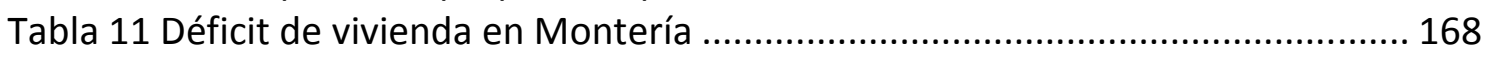

Tabla 12 Presión fiscal y su evolución en Colombia y otros países de la región ........... 197

Tabla 13 Evolución de la población urbana en Montería........................................... 212

Tabla 14 Población y déficit cuantitativo de vivienda por estrato año 2000 .............. 214

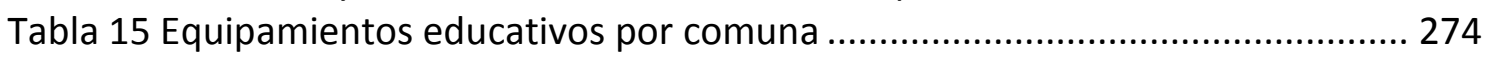

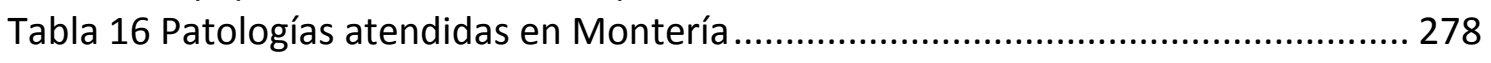

Tabla 17 Beneficiarios del subsidio de salud en Montería......................................... 280

Tabla 18 Desmovilizados residentes en Montería ...................................................... 293

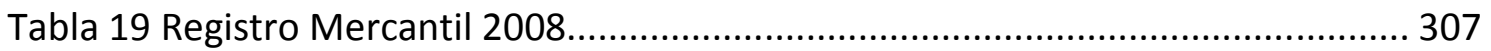

Tabla 20 Número de licencias de construcción en Montería........................................ 340

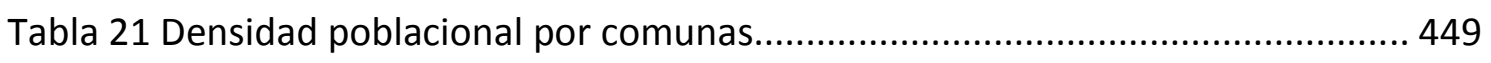

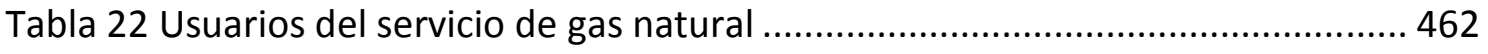

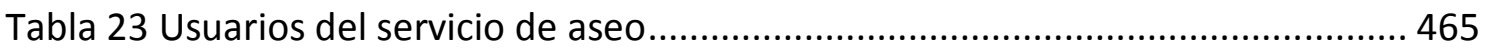

Tabla 24 Distribución del equipamiento educativo ................................................ 471

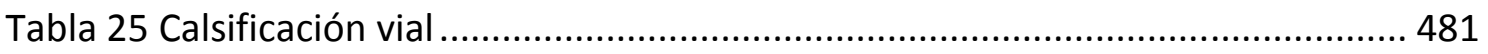

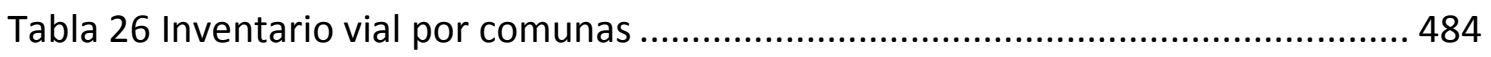

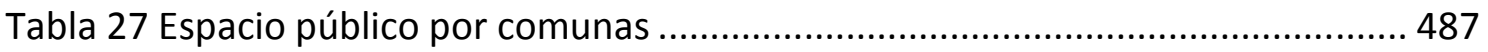

Tabla 28 Situación actual de los humedales de Montería ........................................... 526 


\section{INDICE DE ESQUEMAS}

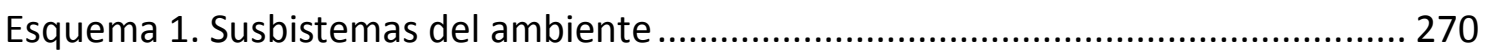

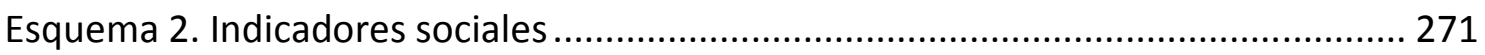

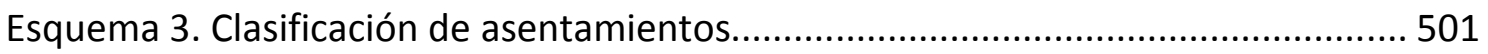

Esquema 4. Intervención en asentamientos Informales......................................... 503

Esquema 5. Modelo de Intervención pública en asentamientos informales............... 509

Esquema 6. Impacto de los asentamientos informales sobre ecosistemas locales.... 511

Esquema 7. Impacto ecológico de la Urbanización Marginal en Montería .................. 542

Esquema 8. Impacto ambiental de la Urbanización Marginal....................................... 551

Esquema 9. Resultado final del Impacto Ambiental de la Urbanización Marginal ...... 553 


\section{ABREVIATURAS UTILIZADAS}

CEPAL: Comisión Económica para América Latina

COMFACOR: Caja de Compensación Familiar de Córdoba

CONPES: Consejo de Política Económica y Social.

DANE: Departamento Nacional de Estadística

DNP: Departamento Nacional de Planeación

FONVIVIENDA: Fondo Nacional de la Vivienda

ICT: Instituto de Crédito Territorial

IDH: Informe de Desarrollo Humano

INURBE: Instituto de Reforma Urbana

MAVDT: Ministerio de Ambiente, Vivienda y Desarrollo Territorial

PIB: Producto Interno Bruto

POT: Plan de Ordenamiento Territorial

PNUD: Plan de Naciones Unidas para el Desarrollo 


\section{RESUMEN}

En esta tesis doctoral se analiza el impacto ambiental que tiene la urbanización marginal en una ciudad colombiana. Para ello, se aborda el estudio del fenómeno a partir de un enfoque multidisciplinar, que permite, por un lado, identificar las múltiples causas que estimulan este tipo de ocupación, y por el otro, presentar explicaciones lógicas acerca de su conformación, evolución, consolidación e impacto. El contexto geográfico de estudio es la ciudad de Montería; la investigación se realiza en ocho años, y el periodo analizado transcurre entre 1952 y 2010.

La tesis muestra, a partir de diferentes enfoques disciplinares, el efecto negativo que la ocupación irregular causa a los subsistemas ecológico, social, económico y urbanístico, y los respectivos fenómenos que dicho efecto genera en cada uno de ellos, o colectivamente; es decir, la alteración de los ecosistemas locales, los riesgos sanitarios, la insalubridad, los desequilibrios económicos y las deficiencias urbanísticas que inciden negativamente en la calidad ambiental urbana de la ciudad de Montería. Además, se establecen diferentes categorías de asentamientos, asociadas esencialmente, a elementos de tipo constructivo, origen del dominio, tiempo de conformación y percepción de sus ocupantes.

El enfoque multidisciplinar con que se aborda esta investigación exigió recurrir a una diversidad de elementos teóricos que provienen no sólo del urbanismo, sino de otras disciplinas como la arquitectura, la economía, la ecología, el derecho y la sociología, y dentro de los cuales destacamos los conceptos tradicionales de urbanización, o ciudad, "informal", "marginal, "espontánea", "irregular" "subnormal", "asentamiento de desarrollo progresivo", y "vivienda de autoconstrucción". Igualmente se aportan nuevos elementos teóricos, que posibilitan una mejor comprensión y explicación del fenómeno, y la ampliación de un glosario, hasta ahora un tanto polémico. Estos conceptos son: "vivienda subnorma", "vivienda de transición" "ciudad subnorma", "urbavillanización", "asentamiento de lento desarrollo", "desarrollo retardado" "precario", "semiconsolidado", y "asentamiento informal de promoción pública".

Para el logro de los objetivos fue necesario el estudio del fenómeno en otros contextos geográficos, dentro y fuera del país, mediante rigurosa consulta bibliográfica o a través 
del trabajo de campo. En este orden de ideas, los datos se obtuvieron directamente de fuentes primarias, y en gran dimensión de fuentes secundarias de alta fiabilidad, principalmente de expertos latinoamericanos, europeos y norteamericanos, de elevado reconocimiento internacional en el área del urbanismo y el medioambiente. Como complemento de los datos existentes, se presentan nuevos esquemas de análisis de impacto ambiental y una propuesta de intervención en asentamientos informales.

La investigación arroja una serie de conclusiones, que de acuerdo a su impacto, son relacionadas de la siguiente manera: a) conclusiones asociadas a aspectos sociales y jurídicos; b) asociadas a aspectos urbanísticos y arquitectónicos; c) a aspectos económicos, y d) a aspectos ecológicos. Para llegar a cada una de ellas se tuvo en cuenta el rol que juegan los diferentes actores que participan en este fenómeno, principalmente el del gobierno central, la administración municipal, la comunidad, los urbanizadores irregulares, los propietarios de suelo y las Organizaciones No Gubernamentales (ONG). Finalmente, una de estas conclusiones principales permitió establecer que el principal problema en esta ciudad, no son los asentamientos informales, ni su número, ni la población como tal, sino las condiciones sociales, económicas, urbanísticas y ecológicas que resultan de su emplazamiento en sitios no aptos para vivienda, o susceptibles de reserva natural. 


\section{RESUM}

En aquesta tesi doctoral s'analitza l'impacte ambiental que té la urbanització marginal en una ciutat colombiana. Per a això, s'aborda l'estudi del fenomen a partir d'un enfocament multidisciplinari, que permet, d'una banda, identificar les múltiples causes que estimulen aquest tipus d'ocupació, i de l'altra, presentar explicacions lògiques sobre la seua conformació, evolució, consolidació i impacte. El context geogràfic d'estudi és la ciutat de Montería, la investigació es fa en vuit anys, i el període analitzat transcorre entre 1952 i 2010.

La tesi mostra, a partir de diferents enfocaments disciplinaris, l'efecte negatiu que l'ocupació irregular dels terrenys causa als subsistemes ecològic, social, econòmic i urbanístic, i els respectius fenòmens que aquest efecte genera en cada un d'ells, o col-lectivament, és a dir, l'alteració dels ecosistemes locals, els riscos sanitaris, la insalubritat, els desequilibris econòmics i les deficiències urbanístiques que incidixen negativament en la qualitat ambiental urbana de la ciutat de Montería. A més a més, s'establixen diferents categories d'assentaments, associades essencialment, a elements de tipus constructiu, origen del domini, temps de conformació i percepció dels seus ocupants.

L'enfocament multidisciplinari amb què s'abordà aquesta investigació va exigir recórrer a una diversitat d'elements teòrics que provenen no només de l'urbanisme, sinó d'altres disciplines com l'arquitectura, l'economia, l'ecologia, el dret i la sociologia, i dins dels quals destaquem els conceptes tradicionals d'urbanització, o ciutat "informal", "marginal," espontània ","irregular", "subnormal ", "assentament de desenvolupament progressiu ", i "habitatge d'autoconstrucció". Igualment s'aporten nous elements teòrics, que possibiliten una millor comprensió i explicació del fenomen, i l'ampliació d'un glossari, fins ara una mica polèmic. Aquests conceptes són: "habitatge subnorma", "habitatge de transició" "ciutat subnorma", "urbavillanització", "assentament de lent desenvolupament", "desenvolupament retardat" "precari", "semiconsolidat", i "assentament informal de promoció pública" . 
Per l'assoliment dels objectius va ser necessari l'estudi del fenomen en altres contextos geogràfics, dins i fora del país, mitjançant rigorosa consulta bibliogràfica o mitjançant el treball de camp. En aquest ordre d'idees, les dades es van obtenir directament de fonts primàries, $i$ en gran mida de fonts secundàries d'alta fiabilitat, principalment d'experts llatinoamericans, europeus i nord-americans, d'elevat reconeixement internacional en l'àrea de l'urbanisme i el medi ambient. Com a complement de les dades existents, es presenten nous esquemes d'anàlisi d'impacte ambiental i una proposta d'intervenció en els assentaments informals.

La investigació aporta una sèrie de conclusions, que d'acord al seu impacte, són relacionades de la següent manera: a) conclusions associades a aspectes socials $\mathrm{i}$ jurídics, b) associades a aspectes urbanístics i arquitectònics; c) a aspectes econòmics, i d) a aspectes ecològics. Per arribar a cadascuna d'elles es va tindre en compte el rol que juguen els diferents actors que participen en aquest fenomen, principalment els del govern central, l'administració municipal, la comunitat, els urbanitzadors irregulars, els propietaris de sòl i les Organitzacions No Governamentals (ONG). Finalment, una d'aquestes conclusions principals va permetre establir que el principal problema en aquesta ciutat, no són els assentaments informals, ni el seu nombre, ni la població com a tal, sinó les condicions socials, econòmiques, urbanístiques i ecològiques que en resulten del seu emplaçament en llocs no aptes per a habitatge, o susceptibles de reserva natural. 


\begin{abstract}
This thesis analyzes the environmental impact of marginal urban development in a Colombian city. In order to do so, the research addresses the phenomenon from a multidisciplinary approach that allows, first, to identify the multiple causes that encourage this type of occupation, and second, to present logical explanations about their formation, evolution, consolidation and impact. The geographical context of the study is the city of Montería, the research was carried out in eight years, and the analyzed period of time is this between 1952 and 2010 .
\end{abstract}

The thesis shows, from different disciplinary approaches, the negative effect that causes irregular occupation of ecological, social, economic and urban development subsystems, and the related phenomena generated in each, or collectively, that is, disruption of local ecosystems, health risks, insalubrity, economic imbalances and deficiencies that adversely affect urban environmental quality in the city of Monteria. In addition, different categories of settlements, associated mainly to construction type, domain origin, time of creation and perception of the occupants are established.

The multidisciplinary approach that guides the research require the use of a variety of theoretical elements that come from not only urbanism, but from other disciplines such as architecture, economics, ecology, law and sociology, among which we highlight traditional concepts of urban development, or "informal", "marginal", "spontaneous", "irregular" and "subnormal" city, settlement of progressive development, and "selfmade housing" Likewise, we provide new theoretical elements that enable a better understanding and explanation of the phenomenon, and the expansion of a glossary, yet somewhat controversial. These concepts are: "subrule housing", "transitional housing", "subrule city", "urbavillanización", "settlement of slow development," "delayed development" "precarious", "semi consolidated" and "public advocacy informal settlement".

To achieve the objectives it has been necessary to study the phenomenon in other geographical contexts, inside and outside the country through rigorous literature 
search or through fieldwork. In this sense, the data was obtained directly from primary sources, and large amount of highly reliable secondary sources, mainly from Latin American, European and US experts of high international recognition in the area of urbanism and the environment. To supplement existing data, new schemes of environmental impact analysis and a proposal for intervention in informal settlements are developed.

The research shows a number of conclusions, which according to their impact, are listed as follows: a) findings related to social and legal aspects; b) associated with urban and architectural aspects c) economic aspects, and d) ecological aspects. To reach each of them the role played by different actors involved in this phenomenon, mainly the central government, local government, community, irregular developers, land owners and NGOs have taken into account. Finally, one of the main findings established is that the main problem in this city, are not the informal settlements, their number, or population as such, but the social, economic, urban and ecological resulting from their location in sites unsuitable for housing, or likely to become nature reserve. 


\section{INTRODUCCIÓN}

"El primer impacto visual de un conjunto urbano, cualquiera que sea su dimensión, es decisivo para entender qué gente lo habita, cuál es su historia, cuál su identidad, cuál su grado de apego a los valores estéticos y a los valores cívicos. Las calles, las plazas, los edificios públicos y religiosos son el retrato más evidente del alma de una comunidad”1.

En esta investigación se intenta realizar un detallado estudio sobre la conformación, evolución y consolidación de los asentamientos informales en la ciudad de Montería. Igualmente se pretende explicar los efectos ecológicos, sociales, urbanísticos y económicos de estos asentamientos, surgidos generalmente, al margen de la urbanización ${ }^{2}$ o de alguna (s) de las normas urbanas de construcción.

El interés por el estudio de este fenómeno, está determinado en gran medida, por experiencias del pasado y por las carencias o conflictos del presente, que se relacionan directamente con la inexistencia de adecuados equipamientos educativos, recreativos, deportivos y culturales, y con la coexistencia de canales de aguas residuales y vertederos satélites.

La investigación intenta exponer los desaciertos cometidos y permitidos por los actores que intervinieron e intervienen en el proceso de conformación de estos asentamientos y los elevados costos sociales, ambientales y económicos que representan dichos desaciertos. En el mismo sentido se expone la enorme distancia que hay entre la ciudad construida y esa ciudad sostenible de la que tanto se habla y se

\footnotetext{
${ }^{1}$ López Morales, Gloria (2006): "Globalización y Desarrollo Local” en AA.VV. Manejo y Gestión de Centros Históricos. Conferencias de los encuentros internacionales II y III de 2003 y 2004 . Ediciones Boloña. La Habana, pp. 71-75.

2 El concepto de urbanización marginal en esta investigación representa no solamente a las urbanizaciones incompletas o al margen del planeamiento sino también a los asentamientos surgidos por invasión, por fraccionamientos privados irregulares e incluso por fraccionamientos públicos para vivienda de autoconstrucción. Es decir, el concepto incluye a todos los asentamientos que carecen, o carecieron, total o parcialmente de las obras de urbanización primaria de redes de servicios públicos de agua, energía, saneamiento y teléfono.
} 
promueve en las diferentes cumbres mundiales realizadas sobre hábitat y medioambiente ${ }^{3}$.

El objetivo central de esta investigación está orientado a determinar el impacto ecológico, social, urbanístico y económico generado por la urbanización marginal en Montería. Igualmente se orienta a categorizar estos asentamientos de acuerdo a origen $^{4}$ y a calidad ${ }^{5}$ y a establecer correlaciones entre las diferentes categorías, para lo cual se hace necesaria una adecuada construcción documental y cartográfica del fenómeno.

Esta investigación busca establecer el impacto generado por la urbanización marginal, en el preciso momento que se extiende el debate sobre la relación entre el modelo económico neoliberal denominado "Globalización" ${ }^{6}$ y la crisis ecológica que vive el planeta. En la investigación se establece que este modelo ha representado incrementos de tipo cuantitativo ${ }^{8}$ para algunas ciudades, regiones y países; pero de igual forma ha desencadenado desequilibrios de tipo cualitativo (calidad de vida y

\footnotetext{
${ }^{3}$ Se han celebrado múltiples cumbres pero preferimos citar Hábitat I en 1976, Cumbre de la Tierra en 1992, Hábitat II en 1996, y el Protocolo de Kioto de 1997, en las que se exponen abiertamente las preocupaciones por los problemas ambientales de los asentamientos humanos, pero que realmente no tienen un eco muy fuerte en la clase dirigente ni en la población de esta ciudad.

${ }^{4}$ De acuerdo con su origen son clasificados en tres categorías: invasión, fraccionamiento privado y fraccionamiento público. Estas tres categorías serán definidas dentro del Marco Conceptual en el capítulo 2.

${ }^{5}$ Según su Calidad Urbanística se clasificaron en tres estados: precarios, semi-consolidados y consolidados. Igualmente se abordará su definición en el capítulo 2 .

${ }^{6}$ El debate sobre el origen de esta palabra, se considera superado después del año 2006. En este sentido, el diccionario de la lengua Española, registra su entrada en este año y la define como "Ia tendencia de los mercados y de las empresas e extenderse, alcanzando una dimensión mundial que sobrepasa las fronteras nacionales".

7 Gaja i Díaz, distingue tres aspectos claves sobre este fenómeno: la degradación del ecosistema mundial; la contaminación generada por los residuos y el agotamiento de los recursos no renovables. Gaja i Díaz, Fernando (2002): Revolución Informacional, Crisis Ecológica y Urbanismo. Ediciones U.P.V. Valencia. Pág. 38.

${ }^{8}$ En economía este concepto se refiere a indicadores como: producto interior bruto, ingreso per cápita, inflación y exportaciones, los cuales expresan crecimiento pero no representa necesariamente desarrollo humano ni distribución equitativa del ingreso.
} 
desarrollo humano) entre países y al interior de ellos, así como entre las ciudades y dentro de ellas.

La elección del título de esta investigación, está de cierta forma, inspirada por el trabajo desarrollado por el Profesor Joan Busquets sobre las coreas de Barcelona y publicado con el nombre de Urbanización Marginal ${ }^{9}$. No obstante, dentro de nuestro estudio los conceptos de barrio marginal, asentamiento marginal y urbanización marginal son considerados sinónimos.

En esta investigación, el concepto de urbanización marginal se utiliza para hacer referencia tanto a urbanizaciones irregulares como a asentamientos marginales; es decir, lo marginal aquí no sólo significa constituirse al margen del reglamento urbano o del planeamiento, sino que representa igualmente exclusión social, política, cultural y económica.

Por las características del contexto estudiado, este trabajo requiere abordar tres fenómenos afines y complementarios, pero diferentes en sus dimensiones y características: urbanización marginal, asentamiento informal y ciudad informal. Sin embargo, para el caso de Montería puede resultar más aproximado hablar de asentamiento que de urbanización, debido a las deficiencias urbanísticas y legales que éstos presentan.

Las singularidades de cada contexto, así como las limitaciones y dificultades para acceder a las fuentes primarias y secundarias de información, prolongaron a ocho años el tiempo dedicado a esta investigación. La falta de información, la desinformación así como la desactualización de algunos documentos y planos institucionales fueron elementos limitantes, pero a la vez estimulantes para la obtención o construcción de la información requerida.

Esta investigación transcurre dentro de los siguientes interrogantes: ¿cuál es el número real de asentamientos constituidos al margen del planeamiento? ¿Estos asentamientos resuelven de manera efectiva el problema de la vivienda? ¿Están sus

\footnotetext{
${ }^{9}$ Busquets Cano, Joan (1999): La Urbanización Marginal. Ediciones UPC. Barcelona. 256 Pág.
} 
habitantes integrados: social, económica y físicamente a la ciudad? ¿Cuáles son los factores que determinan la pasividad de las autoridades locales frente a este fenómeno? ¿Quién asume los costos generados para la consolidación de estos sectores?

¿Es la regularización de la propiedad individual, la solución para lograr la inclusión social de sus habitantes? ¿Cuáles fueron los instrumentos diseñados por el Plan de Ordenamiento Territorial POT del año 2002 para corregir y frenar este fenómeno? ¿Resultaron efectivos estos instrumentos o surgieron nuevos asentamientos después de su aprobación en el 2002? ¿Cuántos años transcurren desde la invasión hasta la consolidación, legalización e integración? ¿Cuáles son las principales características de las urbanizaciones promovidas por el Estado? ¿Tienen responsabilidad las instituciones del Estado en la informalización de la Ciudad? ¿Existe relación entre desempleo y vivienda informal? ¿El nivel de informalidad de la ciudad está determinado por el presupuesto municipal?

Se establece como hipótesis central que la urbanización marginal genera un impacto ambiental para la ciudad de Montería, el cual incide directamente sobre cuatro elementos claves: ecológico, social, económico y urbanístico. El impacto en el primer elemento está relacionado con la alteración del paisaje natural; el segundo incide en la segregación social; el tercero con el empleo informal y el cuarto con la estructura urbana. Las repercusiones para los dos primeros son de carácter negativo, mientras que para el tercero y el cuarto representa tanto efectos positivos como negativos.

En el trabajo se asumen otras seis hipótesis, y dentro de las cuales destacamos principalmente que, la regularización de la propiedad de la vivienda o la legalización del lote no son instrumentos suficientes para lograr la solución de los problemas sociales, ambientales, económicos y físicos que padecen los habitantes de los asentamientos informales, debido a que no contribuyen a la integración física del sector ni a la cohesión social.

Esta es una investigación de ciencia aplicada, exploratoria, transversal y con enfoque retrospectivo y los instrumentos para la recolección de información utilizados fueron 
fundamentalmente: la entrevista individual, entrevista colectiva y la encuesta, que se combinaron con observaciones directas y fotografías a los asentamientos informales de la ciudad. El trabajo de campo estuvo complementado con la consulta de archivos y documentos institucionales como el plan de ordenamiento territorial y los planes de desarrollo municipal.

La estructura del trabajo la conforman siete capítulos: el primero incluye el problema, justificación, objetivos y metodología; en el segundo capítulo se desarrolla el marco teórico, el contexto geográfico y los antecedentes; el tercero se refiere a modelos de económicos, división político administrativa de Colombia y densidad poblacional de ciudades latinoamericanas, en el cuarto capítulo se aborda el tema de la ciudad formal, al igual que el de la ciudad informal; el quinto, por su parte, corresponde al impacto social, económico, urbanístico y ecológico de la urbanización marginal; en el sexto capítulo se establecen todas las conclusiones a las que nos condujo esta investigación, y finalmente, el séptimo contiene los referentes bibliográficos y la bibliografía complementaria.

Sin embargo, destacamos que a lo largo de todo el documento se encuentran conceptos afines como los enunciados en párrafos anteriores y términos como: crisis ecológica, huella ecológica; marginal e irregular; inclusión, exclusión social; formal e informal; urbanismo o urbanización; crecimiento ordenado y crecimiento espontáneo; legal e ilegal; barrio o asentamiento, entre otros, que más bien corresponden a dimensiones contextuales diferentes. 


\section{CAPITULO 1.}

\section{PROBLEMA, JUSTIFICACIÓN, OBJETIVOS Y METODOLOGÍA}

\subsection{PROBLEMA}

\subsubsection{Descripción del problema}

"Los asentamientos precarios constituyen la manifestación física y espacial de la pobreza y la desigualdad en un país mayoritariamente urbano. El crecimiento natural de la ciudades, el influjo migratorio de las zonas rurales, la ausencia de alternativas económicas para la población, así como la ineficacia de las administraciones y políticas generan una dinámica de crecimiento urbano informal e incompleto en las ciudades colombianas ${ }^{\prime 10}$.

El fenómeno de la urbanización marginal no se circunscribe exclusivamente a países subdesarrollados, pero precisamente son estos escenarios geográficos los que padecen con mayor intensidad dicho fenómeno, debido a las condiciones estructurales de pobreza y subdesarrollo ${ }^{11}$, es decir, este tipo de ocupación irregular del suelo, es más frecuente en aquellos países en los que predominan abiertas desigualdades en la distribución del ingreso, elevadas tasas de desempleo, bajos niveles de escolaridad y debilidad institucional.

En estos países, al igual que en los industrializados, el precio del suelo, y por ende, el de la vivienda, no es determinado por el libre juego entre oferta y demanda ${ }^{12}$, sino

\footnotetext{
10 Departamento Nacional de Planeación DNP (2004). Documento 3305 de 2004. Lineamientos para optimizar la política de desarrollo urbano. Santafé de Bogotá. Pág. 12.

${ }^{11}$ Arango Escobar, Gilberto (1990): La Ciudad Informal siglo XXI. Universidad Nacional de Colombia. Medellín. Pág. 6.

12 Rudolf Eberstadt se refirió a la especulación inmobiliaria al considerarla un obstáculo entre la oferta y la demanda de suelo, originada por la tensión entre dos precios: el primitivo y el de venta. Eberstadt, Rudolf (2009): Manual sobre la cuestión y el origen de la Vivienda. En García, Marta y Alonso José (Coordinadores) [2004]: Constructores de la Ciudad Contemporánea. Universidad de Navarra. España. Pp. 349-357.
} 
más bien por su escasez artificial o por el costo de oportunidad que representa cada suelo, o mejor dicho, de las expectativas que genera su vocación inicial o su localización. Estos dos factores de encarecimiento del precio de la vivienda, sumados a los precarios ingresos de la población y al crónico déficit presupuestario, terminan por estimular el mercado informal de suelos, las ocupaciones ilegales y las ventas fraudulentas en las ciudades de estos países.

El fenómeno de la informalidad en el contexto de Latinoamérica y el Caribe está muy ligado, inicialmente, al incremento demográfico, principalmente después de la segunda mitad del siglo $\mathrm{XX}$, y a los intensos flujos migratorios de zonas rurales a centros urbanos. Este subcontinente experimentó un aumento significativo de la población, al pasar de 240 millones en el año 1950 a 500 millones en el 2000, situación que fue acompañada de un crecimiento del número de personas alojadas en viviendas precarias, quienes pasaron de 30 millones a 150, alojados en aproximadamente 25 millones de estas viviendas ${ }^{13}$.

\begin{tabular}{|cccc|}
\hline AÑO & HABITANTES & POBLACION TUGURIZADA & POBLACION URBANA \% \\
\hline $\mathbf{1 9 5 0}$ & 240.000 .000 & 30.000 .000 & $45 \%$ \\
\hline $\mathbf{1 9 7 0}$ & 276.146 .849 & 70.000 .000 & $60 \%$ \\
\hline $\mathbf{1 9 8 0}$ & 351.677 .799 & 90.000 .000 & $65.3 \%$ \\
\hline $\mathbf{1 9 9 0}$ & 429.775 .378 & 120.000 .000 & $71 \%$ \\
\hline $\mathbf{2 0 0 0}$ & 507.932 .044 & 150.000 .000 & $75.3 \%$ \\
\hline $\mathbf{2 0 1 0}$ & 583.699 .449 & 170.000 .000 & $78.4 \%$ \\
\hline
\end{tabular}

Fuente: Camargo, Angélica. Informalidad Urbana (2004) con ajustes del autor. Tabla 1. Evolución de la población en Latinoamérica

Este cuadro permite apreciar la enorme presión ejercida por el aumento de la población sobre el área urbana y el sostenido aumento de la población tugurizada en los centros urbanos, que ya para el año 2010 se estimaba cercana a los 170 millones de personas, alojadas principalmente en las grandes capitales de la región, como: Ciudad de México y Sao Paulo, con más de 15 millones de habitantes; Buenos Aires con más

\footnotetext{
${ }^{13}$ Camargo, Angélica (2004): Perfil de la Informalidad Urbana. Universidad Piloto de Colombia. Santafé de Bogotá.
} 
de 12, Lima, con una población cercana a los 8 millones y Bogotá con un número similar al de la capital peruana, para el año en mención.

La concentración de la población no solamente en las grandes capitales, sino en medianas y pequeñas ciudades, aumentaría de manera sostenida los niveles de informalidad urbana y el número de asentamientos informales en cada uno de estos países. La población residente en estos asentamientos alcanzaría niveles superiores al $20 \%$, y en algunos casos, como el de Tegucigalpa y Ciudad de México, la tasa de informalidad llegaría al 40\%.

\begin{tabular}{|ccc|}
\hline CIUDAD & POBLACION INFORMAL & \% DE LA POBLACION \\
\hline BUENOS AIRES & 1.380 .000 & $16.70 \%$ \\
\hline RIO DE JANEIRO & 1.400 .000 & $20 \%$ \\
\hline BOGOTA & 1.400 .000 & $24 \%$ \\
\hline SAU PAULO & 3.400 .000 & $22 \%$ \\
\hline QUITO & 750.000 & $30 \%$ \\
\hline TEGUCIGALPA & 320.000 & $40 \%$ \\
\hline LIMA & 2.623 .000 & $37 \%$ \\
\hline MEXICO D.F. & 7.200 .000 & $40 \%$ \\
\hline
\end{tabular}

Fuente: Clivchevsky, Nora. 2003.

Tabla 2. Población en situación de Informalidad en capitales latinoamericanas

El incremento de la población informal no obedece exclusivamente a los cambios demográficos, pero evidentemente que ello contribuye a la aparición de un nuevo protagonista. ¿Cuál es este protagonista? Este protagonista es el desproporcionado aumento de los precios de los terrenos urbanizables o urbanizados para la construcción de vivienda, que sumado a otros protagonistas macroeconómicos, como el desempleo, las elevadas tasas de interés y los altos déficits presupuestarios de estos países, hacen de la vivienda un bien inalcanzable para algunos sectores de la sociedad. En este sentido, conviene destacar que un ciudadano medio de la región latinoamericana para reunir el valor completo de un lote en el mercado formal de suelos, requiere generalmente de promedios cercanos a los 12 años de ahorro, con 
tasas no inferiores al $20 \%$ del ingreso ${ }^{14}$.

En el caso concreto de Colombia, el tiempo promedio requerido para adquirir un lote en el sector formal, con el mismo porcentaje de ahorros, se puede estimar entre 5 y 10 años, pero la posibilidad de acceder a vivienda formal con los mismos ahorros es más reducida, principalmente para el ciudadano que gana el salario mínimo legal, equivalente a \$US 240 del año 2010, o para aquel que se encuentra trabajando en la economía informal.

\begin{tabular}{|ccc|}
\hline CIUDAD & M $^{2}$ FORMAL EN \$US & M $^{2}$ INFORMAL EN \$US \\
\hline LIMA & 54.2 a 113 & 20 a 30 \\
\hline BUENOS AIRES & 12 a 50 & 8 a 20 \\
\hline RIO DE JANEIRO & 50 a 120 & 14 a 90 \\
\hline QUITO & 20 a 60 & 3 a 20 \\
\hline BOGOTÁ & 91 & 20 a 30 \\
\hline
\end{tabular}

Fuente: Smolka, Martin 2003

Tabla 3. Precios del suelo en capitales sudamericanas entre 2002 - 2006

La ciudad de Bogotá ofrece uno de los suelos urbanizados más costosos de la región sudamericana, y como se aprecia en el cuadro, el costo promedio del metro cuadrado equivale a 91 dólares americanos para el año 2002 (unos \$US 100 del 2010), y la mejor posibilidad se presenta en el mercado informal donde se puede aún conseguir el metro cuadrado a \$US 30 para el año 2002 (\$US 40 del 2010). No obstante, los precios en las ciudades colombianas para un lote formal de $100 \mathrm{~m}^{2}$ oscila entre \$US 3.000 y \$US 50.000 , correspondiendo, evidentemente, los precios más elevados a los de la capital del país.

La respuesta a estos elevados precios se encuentra en los altos niveles de concentración de la población que presentan estas capitales desde los años cincuenta, y en los niveles de concentración de la tierra que caracteriza a estos países,

\footnotetext{
${ }^{14}$ Smolka, Martín (2003): "Informalidad Urbana y precios de la tierra". Lincoln Institute of Land Policy. Texto disponible en http://www.lincolninst.edu/pubs/825 Informalidad--pobreza-urbana-y-precios-de$\underline{\text { la-tierra }}$
} 
principalmente a Colombia ${ }^{15}$. Este comportamiento del mercado de suelos en Latinoamérica consolidó un escenario paralelo informal tan dinámico, hasta el punto de que el crecimiento de los asentamientos informales supera el crecimiento urbano general de diferentes ciudades.

Ahora, la urbanización como se concibe en Colombia, no es sinónimo de progreso ni de desarrollo humano y la urbanización marginal contribuye aún más con estas circunstancias. En este sentido, resulta pertinente mostrar las estadísticas que sobre este fenómeno presenta un estudio realizado por la Universidad del Rosario ${ }^{16}$, donde se manifiesta que 1.3 millones de Hogares viven en condiciones de precariedad (de 11 millones en el país), incluyendo a Bogotá con un total de 1.240 asentamientos de origen informal, que ocupan 7.109 hectáreas, de las 31.000 que corresponden al área urbana, con aproximadamente 1.320 .000 habitantes. El mismo estudio revela un déficit de vivienda en Colombia de 2.3 millones, de los cuales 1.5 es cuantitativo y 0.8 cualitativo, cifras estas que coinciden con los datos revelados posteriormente por

15 Según el Informe de Desarrollo Humano de 2011, Colombia registra una de las más altas desigualdades en la propiedad rural de América Latina y del mundo, con un coeficiente GINI de tierras de 0,86 . Este mismo informe, establece la incidencia de cinco factores técnicos en la desigualdad y en la alta concentración de la tenencia de las tierras: a) desactualización del catastro rural; b) poco avance en la relación catastro-registro; c) modernización inconclusa de la oficina de Registro de Instrumentos Públicos; d) seria desigualdad en los avalúos catastrales por hectáreas, y e) atrasos en información y deficiencias en su acceso. Adicionalmente reconoce, la incidencia de la operación de fuerzas del mercado, narcotráfico, grupos armados, la cultura del rápido enriquecimiento y la avidez de la renta. En cuanto a desactualización del catastro rural, el Instituto Geográfico Agustín Codazzi, estableció que para el año 2009 el 44.3\% (de 3.8 millones de predios rurales) de los predios se encontraba en esta situación. En lo referente a tamaño de la propiedad, la pequeña propiedad (entre 5 - 50 has), está conformada por 3.147.189 propietarios, que poseen 12.687 .495 has, distribuidos en 2.360 .488 predios; la mediana (50500), por 402.902 propietarios, 14.770 .086 has, y 123.997 predios, y la gran propiedad (mayor de 500 has), ocupaba 10.957 .770 has, en 8.230 predios y 56.542 propietarios. En cuanto a estructura de la propiedad, el informe presenta la más alta asimetría, mediante los siguientes rangos: 1) microfundio con el $10.59 \%$ del área total, el $80.49 \%$ de los predios y el $78.31 \%$ de los propietarios del país; 2 ) la pequeña propiedad con $19.1 \%, 13.66 \%$ y $14.72 \%$ respectivamente; 3 ) la mediana propiedad con $18.2 \%$, del área total, $4.49 \%$, de predios, y $5.83 \%$ de los propietarios, y 4) La gran propiedad concentra el $52 \%$ de la tierra en el $1.15 \%$ de los propietarios, con apenas $0.86 \%$ de los predios. Un dato bien relevante en este documento es el relacionado con el avalúo catastral, cuya metodología permite que las pequeñas propiedades paguen mayores impuestos que la gran propiedad. Ver más datos de este informe en http://www.pnudcolombia.org/indh2011/index.php/el-informe/informe-completo

${ }^{16}$ Universidad del Rosario (2007): Política de Vivienda - Alcances y Perspectivas. Revista Universidad, Ciencia y Desarrollo. Fascículo 11. Santafé de Bogotá. Disponible en http://www.urosario.edu.co/urosario files/3f/3fd62460-2c03-46e6-a455-5315894deee1.pdf. 
Carlos Alberto Torres ${ }^{17}$.

Estos déficits se traducen en incrementos continuos de vivienda precaria, así como del número de hectáreas informales y de asentamientos irregulares en las principales ciudades colombianas. Indudablemente que en términos absolutos, las cifras más altas de informalidad se encuentran en Bogotá, pero en términos relativos, los problemas son similares a los de las ciudades de Medellín, Cali, Barranquilla, que presentan en promedio tasas cercanas al $25 \%$ de superficies informales.

\begin{tabular}{|c|c|c|c|c|c|}
\hline CIUDAD & $\begin{array}{l}\text { ASENTAM. } \\
\text { INFORMAL }\end{array}$ & $\begin{array}{c}\text { AREA INFORMAL } \\
\text { (Hectáreas) }\end{array}$ & $\begin{array}{c}\text { AREA TOTAL } \\
\text { (Hectáreas) }\end{array}$ & $\begin{array}{l}\text { POBLACION } \\
\text { INFORMAL }\end{array}$ & $\begin{array}{c}\text { POBLACIÓN } \\
\text { TOTAL }\end{array}$ \\
\hline BOGOTA & 1240 & 7109 & 31.000 & 1.320 .000 & 6.332 .000 \\
\hline MEDELLÍN & 112 & 2100 & 15.000 & 560.000 & 2.223 .078 \\
\hline CALI & 127 & 2200 & 14.000 & 560.000 & 2.068 .387 \\
\hline BARRANQUILLA & 90 & 2200 & 13.000 & 360.000 & 1.694 .879 \\
\hline CARTAGENA & 80 & 1900 & 12.500 & 171.000 & 902.000 \\
\hline MONTERIA & 35 & 1600 & 4900 & 110.000 & 364.825 \\
\hline
\end{tabular}

Fuente: Elaboración Propia con base en Universidad del Rosario (2007); Maestre (2005), y Torres 2009 Tabla 4. Informalidad en ciudades colombianas

En la ciudad de Cali el número de asentamientos de origen informal ascienden a 127, emplazados en un área de 2.450 hectáreas, que concentran aproximadamente a 560.000 personas. Esa misma tendencia se observa en las ciudades de Medellín, donde un número similar a la población informal de Cali, reside en 112 de estos asentamientos, en un área de 2.200 hectáreas, y de Barranquilla, cuyos sectores informales concentran unos 360.000 residentes en 2.200 hectáreas que se distribuyen en 90 asentamientos ${ }^{18}$.

La ciudad de Cartagena de Indias, por su parte, concentra aproximadamente a 171.000 personas en 80 asentamientos que suman unas 1.900 hectáreas $^{19}$. La informalidad en

\footnotetext{
${ }^{17}$ Torres, Carlos Alberto (2009): Ciudad Informal Colombiana. Universidad Nacional de Colombia. Pág. 91. Disponible en: http://es.scribd.com/doc/53976196/Ciudad-Informal-Colombiana.

18 Ibíd. Pág. 164

19 Maestre Corena, Jaime (2005): Hábitat Popular en Cartagena. El Asentamiento Informal; única alternativa para los pobladores urbanos y los inmigrantes de escasos recursos. Revista de Ciencias Humanas y de la Salud pp. 41-51.
} 
esta ciudad, referente turístico internacional, tiene un mayor impacto que en el resto de ciudades, ya que los niveles de miseria de la población informal, contrastan abiertamente con los niveles de opulencia que se presentan en el centro histórico, lo cual es aprovechado por los delincuentes organizados para fomentar, lo que desde esta investigación, denominamos como turismo ilegal; es decir niños, jóvenes y adultos vulnerables que son inducidos o explotados a través de los ya conocidos turismo sexual o turismo de narcóticos, promovidos por mafias de distintos orígenes. Esta situación ha generado una polarización social demasiado riesgosa, traducida en el blindaje de algunas zonas y la negación a los cartageneros de disfrutar de algunos sectores de su ciudad.

Dejamos las estadísticas de la informalidad en otras ciudades colombianas y de su impacto sobre el turismo de Cartagena, para dedicarnos ahora sí, a nuestro objeto de estudio, es decir la ciudad de Montería. Esta ciudad del Caribe colombiano, con apenas 4.900 hectáreas de perímetro urbano y una población de 364.825 habitantes $^{20}$, concentra a 110.000 personas en 1.600 hectáreas informales, correspondientes al 32\% del total, que se distribuyen en los denominados “asentamientos subnormales"

Esta elevada informalidad urbana está relacionada con los precarios niveles de desarrollo socio-económico que históricamente ha presentado esta ciudad, principalmente, en materia de desempleo y subempleo, fuentes generadoras de informalidad urbana. El informe de coyuntura económica regional, elaborado por el Banco de la República ${ }^{22}$ para el año 2007 determinó la tasa de desempleo en 14.3\%, la de subempleo en $38.6 \%$, y la de informalidad económica en $69.21 \%$. En cuanto a vivienda la ciudad presenta un déficit aproximado a las 30.000 unidades $^{23}$, y el número

\footnotetext{
${ }^{20}$ Censo Nacional realizado por el Departamento Nacional de Estadística (DANE) 2005 y disponible en www.dane.gov.co

21 Negrete Barrera, Víctor (2000): Los Asentamientos Subnormales de Montería. Fundación del Sinú. Montería. Pág. 37.

22 Banco de la República y Departamento Administrativo Nacional de Estadística, DANE (2007): Informe de Coyuntura Económica Regional para el Departamento de Córdoba. Montería. Pág. 90.

23 Información suministrada por la Arquitecta Tahary Gambín Vargas, Coordinadora de la Oficina Municipal de la Vivienda de Montería. Diciembre de 2008.
} 
de "asentamientos subnormales" reconocidos por el plan de ordenamiento, asciende a treinta y $\operatorname{cinco}^{24}$.

Los precarios niveles de desarrollo se encuentran ligados directamente a factores macroeconómicos ${ }^{25}$ como el desempleo, la tasa de interés, bajos ingresos, inflación, elevados flujos migratorios internos, que además de asentamientos informales, contribuyen significativamente al fomento de actividades económicas informales, como el Mototaxismo (transporte público en motocicleta), comercio, manufactura, telecomunicaciones y construcción no regulada.

Las actividades informales desarrolladas en estos asentamientos, y en toda la ciudad, generan tensiones sociales y conflictos urbano-ambientales, principalmente por uso inapropiado del espacio público por parte de comerciantes estacionarios y semiestacionarios. Igualmente hay tensiones por el uso incontrolado de motocicletas que prestan el servicio público urbano e intraurbano de transporte público, así como por el ruido generado por equipos musicales en sitios de consumo de licores en dichos asentamientos.

El principal problema de estos asentamientos, a nuestro juicio, es su ubicación en zonas de alto riesgo no aptas para uso residencial y/o en áreas de gran valor ambiental, que generan impactos ambientales irreversibles para los ecosistemas locales. Igualmente, las actividades y los residuos producidos en estos sectores tienen un fuerte impacto social, ecológico y económico, que se convierten en razones suficientes para considerar el fenómeno de la urbanización marginal como un problema susceptible de investigación.

\footnotetext{
24 El Plan de Ordenamiento Territorial 2002-2011, estableció la existencia de 35 "asentamientos subnormales" en la ciudad de Montería. Esta determinación se realiza a partir de criterios que tienen en cuenta el origen ilegal del dominio, es decir aquellos surgidos por invasión, pero en esta investigación se corrobora que este número es superior, si se tiene en cuenta otras transgresiones a las normas urbanas.

25 Clivchesky, Nora (2003): Pobreza y Acceso al Suelo Urbano. Algunos interrogantes sobre las políticas de regularización en América Latina. CEPAL. Santiago de Chile. Pág. 5. Disponible en: http://www.eclac.org/publicaciones/xml/0/14390/lcl2025e.pdf
} 


\subsubsection{Formulación del Problema}

En esta investigación surgen múltiples interrogantes y dentro de los cuales podemos destacar las siguientes formulaciones: ¿Es el Estado Colombiano, a través de sus instituciones, promotor de los Asentamientos Informales en la ciudad de Montería? ¿Cuáles son las principales características de los asentamientos informales en Montería? ¿Están sus habitantes integrados: social, económica y físicamente dentro de la ciudad? ¿Cuáles son los factores que determinaron la pasividad de las autoridades locales frente a este fenómeno? ¿Quién asume los costos generados para la consolidación de estos sectores?

¿Es la regularización de la propiedad individual, la solución para lograr la inclusión social y física? ¿Cuáles fueron los instrumentos diseñados por el Plan de Ordenamiento del 2002 para corregir y contener este fenómeno? ¿Han resultado efectivos estos instrumentos? ¿Surgieron nuevas invasiones después de la aprobación del Plan? ¿Cuántos años transcurren desde la invasión hasta la consolidación, legalización e integración? ¿Está determinado el nivel de informalidad urbana por el presupuesto municipal? ¿Existe relación entre informalidad económica e informalidad urbanística?

\subsubsection{Hipótesis}

La hipótesis central de esta investigación es que la urbanización marginal genera un impacto ambiental para la ciudad de Montería, el cual incide directamente sobre cuatro elementos claves: ecológico, social, económico y urbanístico. El impacto en el primer elemento, está relacionado con la alteración del paisaje natural; el segundo incide en la segregación social, el tercero, en el trabajo informal y el cuarto en la morfología urbana de la ciudad. Las repercusiones para los dos primeros y el cuarto son de carácter negativo, mientras que para el tercero, tiene tanto aportes positivos como negativos. Otras hipótesis planteadas en el desarrollo de este estudio son las siguientes:

$\checkmark$ La regularización de la propiedad de la vivienda o la legalización del lote no son 
suficientes elementos para lograr la solución de los problemas sociales, económicos y físico-espaciales que padecen los habitantes de los asentamientos informales. La experiencia dejada por procesos anteriores de regularización y titulación de predios y viviendas demuestra que por esta única vía no se llega a la integración física y a la cohesión social.

$\checkmark$ La urbanización marginal brinda soluciones de tipo habitacional, pero no contribuye en diversos casos a construir tejido social y urbano. Estos sectores quedan marginados de servicios sociales, educativos y culturales.

$\checkmark$ En el periodo comprendido entre la conformación, la evolución y la consolidación de un asentamiento pueden transcurrir entre diez y cuarenta años. La consolidación no garantiza servicios sociales ni dotaciones públicas y es sólo un instrumento que permite la formalización del dominio legal del predio, pero no necesariamente la normalización urbanística del asentamiento.

$\checkmark$ Es mucho más costoso para el Estado, desde el punto de vista financiero, la consolidación y la reubicación de asentamientos informales, que la prevención de las invasiones en espacios naturales de protección.

$\checkmark$ El plan de ordenamiento territorial no ha sido un instrumento efectivo para lograr el reordenamiento de la ciudad ni para controlar el surgimiento de nuevas invasiones y urbanizaciones marginales.

Los asentamientos informales producen pocos residuos, pero su inadecuada disposición por parte de un sector de la población, así como la sedimentación producida por las aguas residuales de las alcantarillas a cielo abierto generan problemas de salud pública, principalmente para la población infantil. 


\subsection{JUSTIFICACIÓN}

El incremento demográfico presentado en la ciudad de Montería durante los últimos treinta años, obedece por un lado a la tasa de natalidad, y por el otro, a los desplazamientos del campo a la ciudad, originados ya sea de forma voluntaria o involuntaria. Los desplazamientos voluntarios están relacionados con la búsqueda de oportunidades en la ciudad, ante las precarias condiciones que se viven en el campo, y los involuntarios, también conocidos como forzados, son generalmente ocasionados por las disputas territoriales de actores armados al margen de la ley ${ }^{26}$.

Los elevados flujos migratorios del campo a la ciudad desencadenaron la proliferación de numerosos asentamientos informales en condiciones precarias, los cuales evolucionaron y se consolidaron con el paso de los años, hasta convertirse en barrios populares legalmente constituidos. Gran parte de estos asentamientos se ubicaron en zonas de alto valor ambiental y en zonas de alto riesgo para el hombre y para la naturaleza.

Las instituciones, las autoridades y la dirigencia política contribuyeron y contribuyen, por error u omisión, a la promoción y proliferación de estos asentamientos informales en nuestra ciudad. Por falta de autoridad o por predominio de intereses se ha sido permisivo y complaciente con este fenómeno, y hasta este momento, no hay recursos financieros ni políticas públicas que brinden oportunamente soluciones habitacionales adecuadas y urbanizaciones ajustadas al marco normativo y al urbanismo sostenible.

La realización de este estudio es pertinente debido a que este fenómeno se ha convertido en un modelo institucional de ocupación que no contribuye a la sostenibilidad ecológica, social, económica y urbanística de esta ciudad. Como modelo de ocupación presenta significativos desaciertos, que hasta la fecha no han sido estudiados con el suficiente rigor científico que corresponde, ni con la responsabilidad

\footnotetext{
${ }^{26}$ En nuestro territorio han tenido presencia los grupos insurgentes del Ejército Popular de Liberación EPL, Corriente de Renovación Socialista CRS, Partido Revolucionario de los Trabajadores PRT, las Fuerzas Armadas Revolucionarias de Colombia FARC y Grupos Paramilitares. Sin embargo, destacamos que ya los tres primeros se reinsertaron a la vida civil mediante acuerdos nacionales.
} 
social que amerita. En este sentido el desarrollo de esta tesis resulta relevante porque contribuye a la construcción de conocimiento sobre el tema de la urbanización marginal, los cuales representan significativos aportes para la disciplina del urbanismo. 


\subsection{OBJETIVOS}

\subsubsection{Objetivo General}

El objetivo central de esta investigación es determinar las condiciones en que se conforman, evolucionan y consolidan los asentamientos informales en la ciudad de Montería y establecer el impacto ecológico, económico, social y urbanístico generado por este tipo de intervenciones. Éste se logra a través de la elaboración de esquemas de clasificación de asentamientos y de valoración de efectos negativos causados sobre cualquiera de los factores que conforman el ambiente.

\subsubsection{Objetivos Específicos}

- Identificar, cuantificar y clasificar los asentamientos informales en la ciudad de Montería de acuerdo con su origen: invasión; fraccionamiento irregular, y fraccionamiento público.

- Clasificar los asentamientos informales de acuerdo con su calidad urbanística: precarios; semi-consolidados, y consolidados, y, determinar niveles requeridos de intervención.

- Identificar los ecosistemas que conforman el territorio urbano de Montería y determinar el deterioro que éstos han sufrido como consecuencia del establecimiento de asentamientos humanos.

- Establecer la incidencia de los asentamientos informales en la transformación morfológica de la ciudad.

- Determinar los desequilibrios generados por las actividades económicas de producción y de consumo en estos asentamientos.

- Establecer las relaciones y las diferencias entre los asentamientos informales y los formales, en lo referente a morfología, tipología y dotaciones públicas. 


\subsection{METOdOLOGÍA}

Es una investigación de ciencia aplicada, exploratoria, transversal, con enfoque retrospectivo y los instrumentos de recolección de información que se utilizaron fueron fundamentalmente: entrevista individual, entrevista colectiva, fotografías y observación directa a cada uno de los asentamientos informales de la ciudad. El trabajo de campo estuvo complementado con la consulta de archivos y de documentos institucionales como el Plan de Ordenamiento Territorial POT y los Planes de Desarrollo del municipio.

Por ser una investigación no experimental y transversal con enfoque retrospectivo, se parte de datos históricos e información institucional, que deben ser complementados con la construcción de nuevos datos, para lo cual se recurre a la realización de trabajo de campo en diferentes asentamientos informales de esta ciudad. Este trabajo de campo, además de los instrumentos ya mencionados, también utiliza la observación directa como elemento clave para la obtención de datos y propósitos de la investigación.

\subsubsection{Universo y Muestra}

De acuerdo con datos del Plan de Ordenamiento Territorial del 2002-2015 y el plano actualizado de la ciudad, elaborado por Planeación Municipal, la ciudad de Montería está conformada por 212 barrios, dentro de los cuales 35 fueron declarados en condiciones de informalidad o "Subnormalidad". Sin embargo, en este estudio se logró corroborar la existencia de esos 212 barrios, pero con un mayor número de asentamientos informales al establecido por el plan de ordenamiento; es decir, el número de barrios surgidos en condiciones urbanísticas marginales o con algún tipo de transgresión a las normas asciende aproximadamente a 100. Por lo tanto, con este significativo número, la muestra de asentamientos a estudiar se eligió de manera intencionada en cada sector de la ciudad.

Por el sector occidental los estudios de casos se orientaron a los barrios el Bongo, la Esperanza, el Poblado, el Dorado, Rancho Grande, Nuevo Horizonte, la Palma y Mi 
Ranchito; por el oriente fueron elegidos los barrios Villa Cielo, Cantaclaro y Ranchos del INAT; la zona del sur fue estudiada principalmente en los barrios Brisas del Sinú, Policarpa, Pastrana Borrero, Furatena, 2 de Septiembre, Santa Rosa, el Paraíso, Candelaria, el Cerro, los Araujos, Mogambito, Edmundo López, Robinson Pitalúa y la Candelaria; en el centro se eligió la invasión de Sucre, y en el norte los Barrios 7 de Mayo, 20 de Julio y Camilo Torres. Independientemente de la inter-actuación que se tuvo en un centenar de asentamientos informales, preferimos delimitar el trabajo a estos barrios por la situación de precariedad habitacional y urbanística en la que se encuentran.

\subsubsection{Instrumentos de Medición}

Los indicadores utilizados para determinar las categorías y los niveles de informalidad (de acuerdo con origen y calidad urbanística) de cada asentamiento, se traducen en número de viviendas construidas con materiales transitorios, número de viviendas inacabadas arquitectónicamente, número de años de constituido el asentamiento, déficit de espacio público en metros cuadrados, densidad poblacional, número de trabajadores informales y superficie natural intervenida en hectáreas, calidad de los servicios públicos, y número de viviendas o predios en condiciones de legalidad o ilegalidad. 


\section{CAPÍTULO 2}

\section{MARCO TEÓRICO, CONTEXTO GEOGRÁFICO Y ANTECEDENTES}

\subsection{MARCO TEÓRICO}

Los elementos teóricos que facilitarían una mejor comprensión del fenómeno de la urbanización marginal y su impacto ambiental no se encuadran en una sola área de estudio, y por el contrario, una acertada explicación de dicho fenómeno requiere necesariamente de elementos provenientes de diferentes disciplinas como el derecho, la sociología, el urbanismo, la economía y la arquitectura. En este sentido, consideramos fundamental definir en este apartado, conceptos claves que serán incorporados en el desarrollo de la investigación.

En primer lugar, es oportuno establecer que esta investigación discurre dentro del contexto del urbanismo, situación ésta que invita, casi que de manera obligada, a definir su concepto e incorporarlo como punto de partida de este marco teórico, pero no con el objetivo de definir su condición de disciplina o ciencia, sino con el propósito de lograr una aproximación conceptual más interdisciplinaria. En segundo lugar, conviene anotar que la investigación también incorpora conceptos ecológicos, sociales y económicos, incluidos algunos localismos, que deben ser claramente definidos para la mejor comprensión del estudio.

Bajo estas perspectivas, consideramos conveniente definir, en una primera sección, además del concepto de urbanismo, otros referentes conceptuales como el de urbanización, marginal, informal, ambiente, barrio, asentamiento, infravivienda, impacto ambiental e invasión. En una segunda parte se establecen definiciones para los conceptos de asentamiento subnormal, asentamiento precario, semiconsolidado, consolidado, asentamiento informal por fraccionamiento privado y asentamiento informal de promoción pública. En una tercera sección se definen algunos conceptos particulares surgidos a partir de esta investigación y dentro de los cuales se incluyen el de subnorma, urbavillanización, asentamientos de lento desarrollo, viviendas de transición. Finalmente se define el concepto de oleada, utilizado para determinar los periodos de surgimiento de los diferentes asentamientos informales de Montería. 
Comenzamos anotando que el urbanismo es mucho más que el estudio de la ciudad, es decir, su radio de acción no se limita exclusivamente a las áreas urbanas, sino que, por el contrario, tiene en cuenta igualmente aglomeraciones rurales o suburbanas. En este sentido nos identificamos con Le Corbusier ${ }^{27}$, quien en una perspectiva amplia considera al urbanismo como la ordenación de los lugares y de los locales diversos que deben abrigar el desarrollo de la vida material, sentimental y espiritual en todas sus manifestaciones, ya sea individuales o colectivas en aglomeraciones urbanas o agrupamientos rurales, velando por funciones básicas como el habitar, desplazarse, trabajar y recrearse.

En la misma línea se encuentran Campus Venuti ${ }^{28}$, Pierre Lavedan ${ }^{29}$ y Astengo ${ }^{30}$. Este último considera además que el estudio del urbanismo debe recoger otros problemas existentes en la ciudad y dentro de los que se incluyen los relacionados con aspectos económicos, sociales, culturales y políticos. En este sentido, también nos identificamos con este autor, y hacia ellos apunta nuestro estudio, pero admitiendo que no se puede dejar de considerar aspectos ecológicos relacionados con la alteración o agotamiento de los ecosistemas.

Una última aproximación al concepto de urbanismo es la de Folguera ${ }^{31}$, quien lo considera como una ciencia, suma de varias, encargada de planificar y dar forma a la totalidad del territorio y de la ciudad, sin participación de actuaciones espontaneas, con el objetivo de dar una estructura orgánica a la vida social y económica. Este autor manifiesta igualmente, y con ello estamos de acuerdo porque evitaría la depredación

\footnotetext{
27 Le Corbusier (1989): Principios de Urbanismo. La Carta de Atenas. Editorial Ariel, S.A. Barcelona. Pág. 145.

${ }^{28}$ Citado por Gaja i Díaz, Fernando (2002): Op. Cit. Pág. 5.

${ }^{29}$ La síntesis de su obra se encuentra comentada por Esteban de Tomás y José Luque (Comp.) [2004]: Constructores de la Ciudad Contemporánea. Una aproximación disciplinar a través de los textos. Departamento de Urbanismo de la Universidad de Navarra. España. pp. 547 - 553.

${ }^{30}$ Astengo, Giovanni (1966): Enciclopedia Universale dell'Arte. Instituto per la Collaborazione Culturales. Roma En: Luque Valdivia, José (coordinador) y Marrodán, Esperanza (2004). Constructores de la Ciudad Contemporánea. Universidad de Navarra. España. pp. 99 -109.

${ }^{31}$ Folguera Grassi, Francisco (1959). Urbanismo para Todos. Colegio Oficial de Arquitectos de Cataluña. Barcelona. En: Luque, José; Puy, Juan Pablo y Oto, Alberto (2004). Op. Cit. pp.367-373.
} 
de importantes ecosistemas naturales, que el suelo debe ser intervenido por razones de utilidad pública como base común de la vida social de las comunidades urbanas.

Otro de los conceptos importantes dentro de esta investigación es el de urbanización, definida por el diccionario de la lengua española como "la conversión o preparación de un terreno en poblado, por medio de apertura de calles y de dotación de servicios públicos", es decir, la transformación de suelos rurales, sub-rurales o de expansión urbana a suelos urbanos aprovechables, ya sea para usos residenciales, industriales, comerciales o dotaciones, mediante delineaciones e intervenciones. Sin embargo, autores representativos de la disciplina del urbanismo tienen interpretaciones más amplias, que incorporan no solamente consideraciones de tipo constructivo sino también argumentos relacionadas con aspectos sociales.

Dentro de estos autores destacamos a Cerdá $^{32}$, quien considera que la urbanización no es solamente uno o varios albergues, considerados individual o aisladamente, sino un agrupamiento bien organizado de éstos, en donde sus moradores puedan comunicarse entre sí y prestarse servicios recíprocos. En otras palabras, él destaca dentro de la urbanización, además de los albergues, las vías y los servicios, otros aspectos claves como la sociabilidad y la comunicatividad. Con respecto a estos dos últimos aspectos, consideramos la gran incidencia que sobre ellos tiene la construcción de adecuados equipamientos de bienestar, o por el contrario el impacto generado a partir de la inexistencia de ellos.

Siguiendo con otros autores, Castells ${ }^{33}$, considera que la urbanización es la producción de las formas espaciales a partir de la estructura social de base, es decir un proceso de organización y desarrollo a partir de la relación entre fuerzas productivas, clases sociales y formas culturales. Nos identificamos ampliamente con esta definición porque permite una mejor comprensión de los problemas asociados a la ocupación del espacio, específicamente el del surgimiento de la urbanización marginal o de los

\footnotetext{
${ }^{32}$ Cerdá, Idelfonso (1968): Teoría General de La Urbanización, Institutos de Estudios Fiscales. Barcelona. Pág. 36

${ }^{33}$ Castells, Manuel (1974): La Cuestión Urbana. Ediciones Siglo XXI. México. pp. 14 - 26.
} 
procesos de autoconstrucción. Incluso, este autor se muestra partidario de sustituir el problema de la urbanización por el examen de la producción social de formas espaciales, situación está, con alto grado de pertinencia para el contexto colombiano.

Otro concepto importante es el de Abercrombie ${ }^{34}$, quien entiende la práctica de la urbanización como un proceso de sanidad, belleza y conveniencia, asociado al desarrollo de un área de terreno para hacerlo habitable, mediante la dotación de calles, avenidas, áreas de recreación, agua potable, alcantarillado sanitario, alcantarillado pluvial, energía eléctrica, teléfonos y aseo urbano. En este sentido, consideramos que toma relevancia una de las principales preocupaciones planteadas en esta investigación, relacionada con los aspectos de insalubridad que caracterizan a la urbanización marginal, fundamentalmente a aquellas emplazadas en zonas de alta vulnerabilidad ambiental.

En este orden de ideas delimitamos la urbanización a un concepto técnico directamente relacionado con procesos constructivos, principalmente al de instalación de redes de servicios básicos y tomamos cierta distancia de conceptos relacionados a la ordenación urbana y/o a la concentración de personas alojadas en las ciudades dentro de un territorio determinado. Igualmente se establece a partir de esta definición, una diferencia entre los conceptos de urbanización y de barrio, frecuentemente interpretados como sinónimos en el contexto geográfico de estudio, en donde suele denominarse urbanización a suelos parcialmente dotados y también a proyectos de vivienda unifamiliar o multifamiliar.

Entonces, mientras la urbanización no necesariamente cuenta con edificaciones, el barrio si cuenta con ellas, ya sea por vías legales o de hecho, es decir, de origen administrativo, o iniciativa urbanística, o en su defecto producto de una invasión. Lynch $^{35}$, considera que el barrio tiene unas características físicas que lo determinan y dentro de las cuales destaca la textura, el espacio, la forma, los detalles, los símbolos,

\footnotetext{
${ }^{34}$ Su obra es analizada por Maider Alustiza y José Luque En Luque, José y otros. Op.Cit p.p. 47 - 55.

35 Lynch, Kevin (1994): La Imagen de la Ciudad. Gustavo Gili, S.A. Barcelona. Pág. 84
} 
el tipo de construcción, el uso, las actividades, los habitantes, el grado de mantenimiento y la topografía. Esta definición es suficiente para establecer su diferencia con un terreno urbanizado sin edificar y para considerarlo como un elemento estructurador social, espacial, e incluso, polifuncional.

Por su parte, Aldo Rossi ${ }^{36}$ considera que el Barrio es un sector de la ciudad, íntimamente vinculado a su evolución y a su naturaleza, caracterizado por cierto paisaje urbano, cierto contenido social y una función propia. Con respecto a esta definición, nos manifestamos de acuerdo con este autor, pero consideramos que esa función propia a la que él se refiere es susceptible de ser modificada, o mejor dicho se encuentra permanentemente influenciada por factores relacionados con la legalidad o ilegalidad de su origen.

Esta ilegalidad a la que hacemos referencia es definida por el diccionario de la lengua española como falta de legalidad, aquello en contra de la ley, al margen de la ley o por fuera de las normas. Es decir, todas las actividades que incumplen las normas sociales o reglas formales establecidas, ya sea de manera individual o colectiva, en un contexto, económico, político, cultural, geográfico o urbanístico, tienden a catalogarse, o mejor, son catalogadas como: ilegales, marginales, informales o irregulares. En este orden de ideas, para esta investigación, desarrollada dentro del contexto del urbanismo, toda urbanización que no cumpla con las normas establecidas será considerada dentro de la categoría de marginal, informal, irregular o alegal.

Aunque también se puede denominar urbanización ilegal, consideramos pertinente no utilizar este calificativo, por lo menos en el contexto geográfico de estudio, y más bien preferimos mejor proponer para un futuro, el concepto de urbanización alegal, el cual es definido por el diccionario de la lengua española, en su vigésima tercera edición, como aquello no regulado ni prohibido, es decir lo que funciona o se admite sin haber sido reglamentado legalmente. Esta apreciación, incluso, ya fue expuesta en Colombia

36 Rossi, Aldo (1971): La arquitectura de la Ciudad. Gustavo Gili, S.A. Barcelona. Pág. 105. 
por Carlos Alberto Torres ${ }^{37}$, quien considera que la informalidad no es sinónimo de ilegalidad. Sin embargo, conviene anotar que ya en la década de los ochenta, José Matos $\mathrm{Mar}^{38}$, había incorporado el concepto de alegalidad para hacer referencia a un estilo dominante e invasor en la construcción del espacio urbano de Lima.

Los términos informal e informalidad, a su vez ya habían sido acuñados en 1972 por la Organización Internacional del Trabajo (OIT), para describir una serie de empleos intensivos en mano de obra, baja productividad y reducidos niveles de ingresos, o para hacer referencia a todas las actividades realizadas sin ser reglamentadas pero que tienen fines lícitos. Es decir, esta institución incorpora a partir de esas dos realidades, los conceptos de empleo informal e informalidad urbanística, utilizados ampliamente a lo largo de esta investigación, principalmente en los apartados correspondientes a impacto económico e impacto urbanístico.

Idéntica línea sigue el $\mathrm{DANE}^{39}$ en Colombia para el sector de la economía, al establecer que el sector informal se puede abordar a partir del empleo o también de las actividades, pero delimitándolos a tres aspectos: naturaleza jurídica, tamaño de la empresa y el tipo de contabilidad llevada. Igualmente considera que el grado de informalidad está relacionado con la desvinculación al sistema de seguridad social, evasión de impuestos e inexistencia en el registro mercantil. Sin embargo, por la realidad del contexto geográfico, consideramos un gran desacierto asociar informalidad con tamaño de una empresa, sobre todo, cuando es ampliamente conocido que son las microempresas de menos de diez trabajadores las primeras obligadas a contribuir con los impuestos que le son exonerados a la gran empresa y a las compañías multinacionales.

\footnotetext{
37 Torres, Carlos Alberto (2009): Ciudad Informal Colombiana. Universidad Nacional de Colombia. Bogotá. Pág. 47. Texto disponible en http://es.scribd.com/doc/53976196/Ciudad-Informal-Colombiana

38 Matos Mar, José (1984): Desborde Popular y Crisis del Estado. Institutos de Estudios Peruanos IEP.
Lima. Pág. 78. Texto disponible en http://lanic.utexas.edu/project/laoap/iep/ddtlibro.25pdf
}

39 Departamento Nacional de Estadística DANE (2001): Estudio sobre el Sector Informal. www.dane.gov.co 
Una interpretación conceptual más aproximada al tema de esta investigación, y con la cual nos identificamos por contribuir significativamente con nuestro objetivo de estudio, la tiene Clichevsky ${ }^{40}$, quien distingue dos tipos de informalidad urbana: una referente al dominio y la otra concerniente a la urbanización. La primera está relacionada con la falta de títulos de propiedad de la vivienda, y la segunda con la transgresión de las normas de construcción de la ciudad, es decir, establece informalidad de la vivienda e informalidad urbanística del asentamiento, o si se quiere, del alojamiento individual y del alojamiento colectivo.

Siguiendo esta línea, y de acuerdo con el contexto geográfico de esta investigación, consideramos entonces que la informalidad de la vivienda se asocia directamente con la forma irregular de ocupación y/o construcción, que puede ser por medio de invasión o a través de fraccionamiento irregular, ya sea en terreno público o privado, mientras que la informalidad urbanística del asentamiento, expresa las condiciones urbanoambientales desfavorables de éste, debido a su emplazamiento en zonas de alto riesgo ambiental no aptas para usos residenciales, o a la transgresión de una o varias de las normas urbanas, principalmente las de urbanización.

Las zonas de alto riesgo ambiental, para el caso de Montería, se refieren a terrenos inundables, ciénagas, laderas, riberas y bosques, pero también a aquellos ubicados cerca de infraestructuras eléctricas, lagunas de oxidación, alcantarillas a cielo abierto y vertederos. En este orden de ideas, los procesos de ocupación en estas condiciones no solo representan riesgo para los ecosistemas locales, sino que también representan un grave riesgo para la salud y la vida de las personas, o lo que en otras palabras se puede expresar como impacto negativo de la urbanización marginal.

La expresión urbanización marginal ya fue utilizada en España por Joan Busquets ${ }^{41}$, quien la considera "como bolsas de terrenos muy cerradas y de escasa conexión con la ciudad, generalmente con perfil accidentado y mala orientación solar, que siguen un

\footnotetext{
${ }^{40}$ Clichevsky, Nora (2000): Informalidad y Segregación Urbana en América Latina. Una aproximación. CEPAL. División de Asentamientos Humanos. Santiago de Chile. Disponible en: www.eclac.org/publicaciones/xml/8/5638/lcl1430e.pdf

${ }^{41}$ Busquets, Joan (1999): Op. Cit. Pág. 78
} 
proceso de consolidación independiente al planeamiento establecido o a las normas técnicas que lo regulan". Con excepción de lo relacionado con la orientación solar, de poca o nula incidencia en Colombia, consideramos que esta definición es una aproximación acertada del fenómeno, de gran compatibilidad con este marco teórico y con los procesos de formación de asentamientos de autoconstrucción del contexto colombiano.

Consideramos pertinente también, incluir el significado de marginal que tiene Germani $^{42}$, quien asocia este concepto a sectores de la población que se encuentran segregados en "áreas no incorporadas al sistema de servicios urbanos, en viviendas improvisadas y sobre terrenos ocupados ilegalmente". Este autor, bajo este enfoque sociológico, considera que la marginación es una situación social de aislamiento e inferioridad, o dicho de otra manera, es la separación de una persona hasta el punto de quedar excluida socialmente. Nos identificamos con sus postulados, pero adicionando que de acuerdo con el contexto geográfico, esa marginación puede estar encaminada a excluir no solamente a personas sino a familias, o incluso, a grupos sociales específicos, tal y como lo define el diccionario de la lengua española.

El mencionado diccionario define la marginalidad como "la falta de integración de una persona o de una colectividad en las normas sociales comúnmente admitidas". Esta expresión es utilizado frecuentemente por autoridades y sociedad para referirse a la condición de personas, familias o colectivos que carecen de servicios de educación, salud, recreación, cultura y de trabajo remunerado. Sin embargo, en este sentido Nateras ${ }^{43}$, utiliza el término Población Marginal, delimitándolo a sectores de la ciudad no incorporados al sistema de servicios urbanos o con un acceso muy restringido a dicho sistema, y además, según él, con características ecológicas diferentes a las de los sectores dominantes.

\footnotetext{
${ }^{42}$ Germani, Gino (1973): El concepto de marginalidad. Nueva Visión. Buenos Aires. Citado por Fernández Naranjo, Roberto (2007): "Concepción Sociológica sobre el tema Marginalidad". Texto disponible en http://www.monografias.com/trabajos44/marginalidad/marginalidad2.shtml

${ }^{43}$ Nateras Rivas, José (1996). San Martín de Tucumán un ejemplo de urbanización marginal en una metrópoli latinoamericana. Universidad de Málaga. En: Gómez López, Claudia (2000): Influencia de la promoción pública de la vivienda en el desarrollo de la mancha urbana de la ciudad de San Miguel de Tucumán. Elementos para la comprensión urbana. Tesis Doctoral. UPV. Valencia.
} 
Con estos elementos, se puede establecer entonces, que la urbanización marginal no solamente equivale a bolsas cerradas de terrenos de escasa conexión con la ciudad, ni a viviendas ocupadas ilegalmente, como lo manifiestan los dos mencionados autores, sino que es un modelo de ocupación que se desarrolla por medio de emplazamientos en el extrarradio o en la periferia urbana, ya sea de forma legal o ilegal; es decir, son procesos de ocupación surgidos a través de invasiones ${ }^{44}$, fraccionamientos irregulares privados, fraccionamientos públicos para procesos de autoconstrucción y/o programas incompletos de vivienda de promoción pública, que pueden quedar conectados o desconectados de la ciudad, o en cualquier situación de marginalidad por falta de dominio legal o por transgredir alguna (s) de las normas urbanísticas.

Después de haber delimitado el concepto de urbanización marginal, pasamos ahora a definir el de impacto ambiental, entendiendo por impacto, al efecto dejado o causado en alguien o en algo, por una acción o suceso, que puede ser favorable o desfavorable. El diccionario de la lengua española puntualiza que el impacto es el choque de un proyectil u otro objeto contra algo, o la marca que dicho choque produce, pero también lo define como el conjunto de consecuencias provocadas por un hecho o una actuación que afecta a un entorno o ambiente social o natural. Es decir, las modificaciones del entorno natural como consecuencia de obras u otras actividades.

Por otro lado el concepto de ambiente, es definido más ampliamente por el Diccionario Larousse de García-Pelayo $1964^{45}$, quien lo define como el compendio de valores naturales, sociales y culturales existentes en un lugar y en un momento determinado que influyen en la vida material y psicológica del hombre. En esa misma línea Cantarino ${ }^{46}$, extiende su definición al conjunto de circunstancias físicas, culturales, económicas y sociales que rodean a los seres vivos. Este autor considera que el ser humano necesita un entorno donde caminar, distraerse, disfrutar $y$

\footnotetext{
${ }^{44}$ Definida por el diccionario de la lengua española como la acción y efecto de invadir, de entrar por la fuerza, de ocupar por vías de hecho un lugar.

${ }^{45}$ Citado por García-Abad, Alonso (2007): "El Medio Ambiente: Concepto, Significado y Carácter". Pág. 2. Documento disponible en http://www.geogra.uah.es/igabad/pdf 06-07/DOC02.pdf

${ }^{46}$ Martín Cantarino, Carlos (1992): El Estudio de Impacto Ambiental. Publicaciones Universidad de Alicante. Alicante. Pág. 22
} 
relacionarse con sus semejantes; igualmente resalta, y con ello estamos totalmente de acuerdo, que ambiente es más que fauna, flora y bellos paisajes.

"El ambiente es un conjunto ordenado de interrelaciones y el hombre depende de su ambiente y éste a su vez es un sistema de relaciones, donde no es fácil alterar un elemento sin afectar a otros, quizás más importantes ${ }^{\prime 47}$. Bajo esta definición, el autor mencionado termina considerando que evaluar el ambiente significa determinar si nos encontramos en un entorno favorable para vivir, en donde se satisfagan de forma digna las necesidades básicas.

Otros autores como Gómez Orea ${ }^{48}$, y Monedero ${ }^{49}$, asocian ambiente con factores bióticos y abióticos, en el que interactúan elementos físicos, biológicos, sociales, económicos, culturales y estéticos. Este último autor, considera "que el concepto de ambiente erróneamente se ha asimilado al de medio" y establece una diferencia entre los dos conceptos, ya que delimita el primero únicamente a factores físico-químicos y bióticos, mientras que al ambiente incorpora además factores socioculturales que influyen sobre el factor físico-químico.

De acuerdo con lo expuesto, en esta investigación se interpretará por ambiente al sistema conformado por los siguientes cuatro subsistemas: ecológico, social, económico y urbanístico. En este orden de ideas, el impacto ambiental de la urbanización marginal expresará el efecto causado por ésta, a los subsistemas ecológico, social, económico y urbanístico, y los respectivos fenómenos que dicho efecto genera en cada uno de ellos, o colectivamente; es decir, la alteración de los ecosistemas locales, los riesgos sanitarios, insalubridad, desequilibrios económicos y deficiencias urbanísticas, que inciden negativamente en la calidad ambiental urbana.

\footnotetext{
47 Dorney, R.S. (1977): Environmental Assessment: the ecological dimension. Citado en: Martín Cantarino, Carlos (1992): Ibíd. Pág. 23

${ }^{48}$ Gómez Orea, Domingo (1992): Evaluación de Impacto Ambiental. Editorial Agrícola España S.A. Madrid

${ }^{49}$ García-Abad, Alonso (2007): Op. Cit. Pág. 3
} 
Siguiendo con otros conceptos, consideramos conveniente definir el vocablo asentamiento, que será utilizado a lo largo de esta investigación para hacer referencia a los sectores de la ciudad que surgieron en condiciones precarias y apartados de las características del barrio que ya hemos señalado en este mismo apartado. Esta definición de asentamiento se sustenta en la establecida por el diccionario de la lengua española, que lo define como la instalación no definitiva de colonos en tierras que han de expropiarse.

En estas condiciones estableceremos una clasificación de asentamientos para referirnos a todos aquellos sectores que surgieron mediante procesos de invasión o fraccionamientos irregulares de terrenos, e incluso a los fraccionamientos públicos para procesos de autoconstrucción de vivienda. Esta clasificación comienza a partir de la constitución y culmina en el proceso de consolidación legal y urbanística. Por lo tanto, en su origen los denominamos asentamientos precarios; en una segunda etapa se denominan asentamientos semi-consolidados, y en una tercera fase son denominados asentamientos consolidados.

El asentamiento precario es el constituido por viviendas de mala calidad, construidas con materiales inestables y de desecho dentro de los que sobresalen el cartón, plástico, lata (chapa) y la madera y se caracteriza además por la falta de servicios públicos básicos, equipamientos comunales, hacinamiento, insalubridad e inexistencia de títulos de propiedad. El asentamiento semiconsolidado es aquel conformado por viviendas de materiales constructivos transitorios y por viviendas de materiales definitivos, algunas de ellas arquitectónicamente terminadas y otras en procesos de construcción; carecen de infraestructuras, de algunos equipamientos, no cuentan con todos los servicios públicos y no todas las familias cuentan con el dominio legal de la vivienda.

Por su parte, los asentamientos consolidados son aquellos localizados en áreas más centrales, conectados con el resto de la ciudad, viviendas terminadas, prestación de la mayoría de servicios públicos básicos, con excepción de saneamiento básico, existencia de equipamientos colectivos y dominio legal de la vivienda. No obstante, carecen de espacios libres, zonas verdes, infraestructuras de gran impacto e intervenciones 
arquitectónicas de gran calidad. El uso residencial es combinado con otros aprovechamientos, principalmente, servicios, comercio, e incluso, industria artesanal o de baja intensidad.

La otra clasificación de asentamientos que establecemos desde acá tiene que ver con el origen de éstos, e incluye tres tipos: asentamiento por invasión; asentamiento por fraccionamiento irregular, y asentamiento por promoción pública. Estas tres categorías de asentamientos, con diferentes orígenes, presentan características urbanísticas afines, que se traducen en deficiencias arquitectónicas de las viviendas, transgresión a la norma urbana o falta de dominio legal del predio; es decir, a pesar de su diferencia de origen, adquieren, o manifiestan, características físicas similares de informalidad, debido a la violación permanente de las normas urbanísticas o de construcción.

El asentamiento por invasión, evidentemente, es aquel constituido mediante ocupación de terrenos por vías de hecho, que descartan inicialmente, cualquier proceso legal de parcelación, urbanización y edificación. Cada uno de estos procesos se realiza paulatinamente, principalmente el de la edificación de la vivienda, que se inicia con materiales transitorios de bajo costo para evitar pérdidas ante posibles desalojos. Este asentamiento se caracteriza por su elevado aprovechamiento residencial, por sus bajas o nulas superficies para dotaciones públicas y por emplazamientos en zonas de gran riqueza natural no aptas para usos residenciales. Sin embargo, también se puede caracterizar por emplazarse en zonas ambientalmente degradadas o cercanas a infraestructuras viarias o ferroviarias.

El asentamiento por fraccionamiento irregular en esta investigación, a diferencia de lo que manifiesta Clivchesky ${ }^{50}$, es aquel que se desarrolla, ya sea clandestinamente, o infringiendo alguna de las normas de la legislación vigente, es decir, aquellos lotes que fueron vendidos para viviendas de autoconstrucción sin haber presentado ante las

\footnotetext{
${ }^{50}$ Clivchesky, Nora (2000): Op. Cit. Pág. 4. Esta autora, establece diferencias entre loteos irregulares y loteos clandestinos o "piratas". Sin embargo, desde esta investigación, y a pesar de estar de acuerdo con esta diferencia, se prefiere incorporar a ambos dentro de una categoría más amplia, que denominamos "asentamientos por fraccionamientos irregulares".
} 
autoridades los planos o documentos correspondientes para aprobación, o los lotes que no cumplen con una o varias de las normas urbanísticas mínimas para usos residenciales.

Por asentamiento informal de promoción pública, definimos a todos aquellos surgidos por medio de fraccionamientos públicos con fines de autoconstrucción que se realizaron en áreas precariamente urbanizadas o con significativas deficiencias en cuanto a espacio público, accesibilidad, infraestructura de servicios públicos y equipamientos urbanos. Su informalidad no radica en aspectos relacionados con el dominio del terreno o tenencia legal de la vivienda, sino por las transgresiones a las disposiciones normativas del urbanismo. Tanto estos asentamientos, como los de fraccionamiento irregular son denominados eufemísticamente por las autoridades como "Barrios de Desarrollo Progresivo".

En esta investigación, no nos identificamos con esta denominación ni con la de "vivienda de desarrollo progresivo", razón por la cual consideramos más apropiado, incorporar los conceptos de "Asentamientos de Lento Desarrollo" o si se prefiere de “Asentamientos de Desarrollo Retardado" y "Vivienda de Transición". Nos parece más aproximado, debido a que la terminación arquitectónica de la vivienda y la consolidación urbanística de estos asentamientos, en no pocos casos, puede tardar periodos superiores a los cuarenta años.

Estas viviendas de "desarrollo progresivo" o de "transición", generalmente corresponden a infraviviendas, entendidas éstas, como aquellos alojamientos individuales o colectivos que no cumplen con estándares mínimos de calidad, asociados a materiales constructivos, superficie, accesibilidad física, seguridad de la tenencia, estabilidad estructural, iluminación, ventilación, infraestructura de redes de servicios básicos y eliminación de desechos a costos razonables ${ }^{51}$. Estas infraviviendas, o el conjunto de ellas, son conocidas en Latinoamérica con los siguientes nombres: Tugurio (Colombia), Arrabal (Ecuador), Callampa (Chile), Rancho (Venezuela), Favela

\footnotetext{
51 En la conferencia Hábitat II, celebrada en 1996 en Estambul, se establece que una vivienda es adecuada cuando cumple con los aspectos mencionados.
} 
(Brasil), Cantegril (Uruguay), Jacal (México), Villa miseria (Argentina), y Barriada o Pueblo Joven (Perú). En España son conocidas como Chabolas, con excepción de Cataluña, en donde se denominan "Coreas", mientras que en Montería son denominadas como "vivienda subnormal", término que no compartimos desde esta investigación, por considerarlo incierto, y porque consideramos más apropiado proponer el de vivienda subnorma; es decir, aquella construida por debajo de las normas de construcción o del urbanismo y que contribuye a la conformación de lo que denominamos "Ciudad Subnorma".

Esta ciudad que denominamos "subnorma" se refiere a la misma que otros autores denominan de "marginal", "informal", "espontánea" o "irregular", es decir, aquella ciudad construida al margen del planeamiento o de las normas urbanísticas, por fuera de aspectos formales jurídicos, de manera no planificada, constituida por ocupación ilegal de terrenos. Sin embargo, consideramos que el término ciudad subnorma, por su mayor claridad puede resultar más aproximado, menos sesgado y menos discriminatorio, que los utilizados hasta ahora.

Conviene destacar que los términos de ciudad espontánea, informal y marginal son los más utilizados hasta la fecha y los que han obtenido mayor reconocimiento internacional en diferentes disciplinas. En este orden de ideas, resaltamos el concepto de Lavedan ${ }^{52}$, quien la denomina "ciudad espontánea", y considera que ésta es más natural, en función de las necesidades a corto plazo, que la misma ciudad planificada. Por otra parte, Arango ${ }^{53}$ la llama "ciudad marginal" y la define "como los espacios urbanos producidos al margen o en contraposición al orden formal”.

Emilio Dahau ${ }^{54}$, define como "ciudad informal" a "la ciudad producida a partir de la vivienda cuya implantación antecede a una urbanización paulatina y en general

\footnotetext{
52 Lavedan Pierre (1952): Historia del Urbanismo. Citado por: Luque Valdivia, José y Otros (2004): Op. Cit. pp. $547-553$.

${ }^{53}$ Arango Escobar, Gilberto (1990): Op. Cit. Pág. 11.

54 Duhuo, Emilio (2003): La ciudad Informal. El orden urbano y el derecho a la ciudad. Trabajo presentado en el congreso de ANPUR, Belo Horizonte. Disponible en http://www.fcp.uncu.edu.ar/upload/duhau-2003.pdf
} 
problemática de las áreas de este modo incorporadas al uso habitacional". Considera, igualmente este autor, y con ello estamos de acuerdo, que en ella predomina la irregularidad jurídica en el parcelamiento y la propiedad del suelo, la producción de los bienes colectivos se da de manera progresiva y los espacios públicos son demasiado reducidos.

Saldarriaga Roa ${ }^{55}$, también la denomina ciudad informal y la define como aquella que se construye al margen de las instituciones o de las empresas que hacen parte de la estructura básica de las sociedades en las cuales se presenta. Con él coincidimos cuando manifiesta que su desarrollo es dilatado en el tiempo y se lleva a cabo en fases o etapas en las que participan activamente sus habitantes.

Teniendo en cuenta el concepto de los anteriores autores, consideramos desde acá, que la ciudad informal, marginal, espontánea o subnorma, es un modelo de ocupación adoptado, y a la vez, un escenario de lucha, de supervivencia, de exclusión y de interacción, que surge, no tan espontáneamente, por las necesidades de vivienda de la población carente de recursos para acceder a la oferta de vivienda privada o pública. Sin embargo, consideramos obligatorio no dejar por fuera de este marco conceptual la siguiente definición, que se realiza de la denominada "Ciudad Espontánea":

"Asentamiento urbano resultado de decisiones particulares sucesivas, relacionadas entre sí consecutivamente pero sin referencia común a un planteamiento general previo. Esta expresión fue acuñada por el historiador Pierre Lavedan para oponerla al concepto de ciudad planificada cuyas trazas y localizaciones siguen, en mayor o menor medida, unas pautas predefinidas de forma concreta mediante planos, cálculos y escritos diversos. La ciudad espontánea se realiza no de forma absolutamente caótica, sino acorde con necesidades individualizadas, en cada decisión, de establecer un nuevo uso, construir un edificio o prolongar una calle por ejemplo. Cada nueva acción toma en cuenta las particularidades urbanas preexistentes para aprovecharlas e insertarse mejor en ellas, pero no se plantea su contribución al conjunto. Las consecuencias de esta forma de evolución pueden ser poco importantes en asentamientos pequeños pero generan, sin embargo, grandes dificultades funcionales en núcleos urbanos

\footnotetext{
${ }^{55}$ Saldarriaga Roa, Alberto (2001): La Ciudad Informal en Colombia: ¿problema o solución? En Piñón, Juan Luis (coord.) [2001]: La Recomposición de la Ciudad Informal. CICI - UPV. Valencia. pp. 41 - 52.
} 
mayores más necesitados de formas racionalizadas que faciliten la instalación de costosas infraestructuras, así como la realización de funciones complejas de circulación y distribución ${ }^{\prime \prime 56}$.

Coincidimos con esta definición, en que evidentemente no se constituyen de forma absolutamente caótica, pero no la delimitamos estrictamente a necesidades individuales sino también a necesidades colectivas o de grupos sociales específicos, que varían de acuerdo a cada contexto geográfico o temporal. Es decir, este tipo de "ciudad" adquiere características similares en algunos países o por el contrario diferencias notables, ocasionadas por la topografía, el clima y en general por las condiciones socio-naturales; por ejemplo, el caso de España y Colombia, muestra dos realidades diferenciadas cuando se comparan profundamente, o también cuando se comparan ciudades colombianas de diferentes regiones.

Otro concepto importante que proponemos y utilizaremos dentro de esta investigación es el de "Urbavillanización", el cual es un oxímoron que incorpora dos términos opuestos en el contexto geográfico de estudio: urbanización y villa, y que lo definimos como aquellas urbanizaciones incompletas 0 irregulares que presentan características similares a las de las últimas "villas miserias" de Argentina, o a las de cualquier otra invasión en Latinoamérica, tanto en sus aspectos físicos como socioeconómicos, pero que a diferencia de estas últimas, no se originan por invasión de terrenos, sino mediante procesos legales de acceso al suelo.

Finalmente, incorporaremos en el capítulo quinto de la investigación, las expresiones "primera oleada", "segunda oleada", "tercera oleada" y "cuarta oleada", para hacer referencia a los diferentes periodos que transcurrieron entre los años 1960 y 2.000 , y que permitieron el surgimiento, no aislado ni disperso, sino en bloque de asentamientos informales en cualquiera de sus modalidades, pero principalmente de invasiones. En este sentido, destacamos que la primera oleada se refiere al periodo que transcurre de 1960 a 1969; la segunda va de 1970 a 1989; la tercera de 1990 a

\footnotetext{
56 Zoido Florencio y Otros (2000): Diccionario de geografía urbana, urbanismo y ordenación del territorio. En González Zapata, Gloria (2009): Gestión de los Asentamientos Informales: Un Asunto de Política Pública. Universidad Nacional de Colombia. Medellín. pág. 33
} 
1999, y la cuarta oleada entre los años 2000 y 2010. La importancia de esta caracterización obedece a que cada una de ellas tuvo diferenciadas incidencias sobre la estructura urbana de la ciudad.

Esencialmente, dentro de los anteriores conceptos se desarrolla esta investigación de urbanismo, que reiteramos, además de analizar el fenómeno de la urbanización marginal, también se dedica a identificar el impacto ambiental dentro de los cuatro escenarios planteados en este marco teórico. Bajo estas perspectivas, se considera oportuno establecer la similitud o diferencia entre algunos términos frecuentemente interpretados de manera distorsionada, y que a lo largo de este estudio serán literalmente utilizados con fines explicativos o descriptivos. 


\subsection{CONTEXTO GEOGRÁFICO}

\subsubsection{Historia de Montería}

Montería fue fundada el $1^{\circ}$ de mayo de 1777 por Antonio de la Torre y Miranda, pero su gran dinámica poblacional, económica y urbanística solo llegaría hasta comienzo del siglo XX, cuando se intensifica sus relaciones con Cartagena de Indias por medio del río Sinú y el mar Caribe como medios de comunicación. La actividad comercial, agrícola y ganadera fue paralela con la bancaria, iniciada en 1905 cuando fue fundado, con capital local, el Banco del Sinú. Esta dinámica seguiría posteriormente en 1938 cuando se vincularon la Caja Agraria y el Banco de Bogotá; en 1943 con la apertura del Banco Central Hipotecario; 1944 con el Banco Comercial Antioqueño y 1951 con el Banco del Comercio $^{57}$.

Hasta la primera mitad del siglo XX la comunicación con otras regiones se realizaba a través del río Sinú, especialmente con la población de Lorica y Cartagena de Indias. Hasta 1951 la ciudad pertenecía al departamento de Bolívar y a partir de 1952 comienza su vida administrativa como capital del departamento de Córdoba. Se inicia una era de relativo progreso y se adelanta la construcción de importantes tramos viales que permiten la comunicación con nuevos destinos como Barranquilla y Medellín. Las primeras salas de cine abren sus puertas en la década de los años 40 al igual que los clubes y bares cuando se comienza a dinamizar nuestra economía.

En lo referente a su ordenación inicial y al aspecto político-administrativo, destacamos que la fecha de fundación anotada anteriormente, corresponde a elección del terreno, pero también a la reubicación de los pobladores del asentamiento de Las Monterías, ubicado en una zona inundable cercana al sitio donde quedo emplazada definitivamente la ciudad. En ese mismo año de 1777, Antonio de la Torre trasladó la capilla a un lugar seco no inundable, trazó las calles, repartió solares a 170 familias que sumaban un total de 884 personas, y le dio el nombre de San Jerónimo de Montería ${ }^{58}$.

\footnotetext{
${ }^{57}$ Exbrayat, Jaime (1996). Historia de Montería. Tercera Edición. Editorial Domus Libri. Montería.

58 Crismatt Mouthon, Carlos (2009): La Fundación de Montería. Texto disponible en http://www.cordoba.gov.co/cordobadigital/Cordoba_Monteria.html
} 
En el año de 1783 San Jerónimo de Montería fue elevada a la categoría de Parroquia con derecho a Sacerdote; en 1807 fue categorizada como Villa; en 1821 el Congreso de Cúcuta divide a Colombia en siete departamentos y Montería queda incorporada al departamento del Magdalena; en 1824 cuando se establece la división de los Departamentos en Provincias y éstas en Cantones, queda bajo el dominio políticoadministrativo de la provincia de Cartagena, pero perteneciendo al Cantón del Sinú, cuya capital era Lorica; en 1860 mediante la Ley 27, Lorica es elevada a la categoría de Provincia y Montería a la de Distrito; en 1923 mediante Ordenanza 42 del 27 de abril de la Asamblea del departamento de Bolívar es exaltada a la calidad de municipio. Finalmente, por medio de la ley 9 de 1951 del 18 de noviembre y el Decreto Reglamentario 1392 de 1952, es creado el departamento de Córdoba y Montería queda como su capital ${ }^{59}$.

En cuanto a su trazado inicial, el historiador monteriano Edgardo Puche ${ }^{60}$ anota que tanto las calles como las carreras nominales actuales fueron originalmente nombradas. En la década de los años veinte del siglo XX ya se destacaba dentro de las carreras, el callejón 20 de Julio, hoy avenida Primera; callejón Antonio de la Torre, hoy avenida segunda y el Callejón 11 de Noviembre, hoy avenida tercera. En 1930 fueron surgiendo nuevos callejones como la Pola, Nariño, Sucre, Heredia, Mutis y Caldas, dentro de la expansión que la ciudad presentaba hacia el oriente, sector éste con las mejores características para usos residenciales.

Por su parte las calles más importantes de esa época correspondieron a: Granada, hoy 21; de la Caridad, ahora 22; de Jesús, actualmente la 23; del Rosario, 24; Victoria, 25; Molinos, 26; San Jerónimo, 27; del Carmen, 28; del Cementerio, 29 y del Comercio, actualmente calle 30, siendo el límite por el norte lo que hoy es la calle 34. Cómo dato significativo, destacamos que la calle del Comercio, también fue denominada calle de los Turcos, debido a la gran presencia de inmigrantes sirio-libaneses, italianos y

\footnotetext{
59 Negrete, Víctor y Garcés, Miguel (2010): Análisis Sociopolítico de Montería y propuestas sobre liderazgo, participación y compromiso ciudadano. Ediciones UNISINU. Montería. Pág. 12. Texto disponible en http://www.viva.org.co/cajavirtual/svc0211/articulo0848 211.pdf

${ }^{60}$ Puche, Edgardo (1988): Crónicas y Estampas Monterianas. Gráficas Urra. Montería. Pág. 49.
} 
franceses, quienes llegaron a la ciudad para establecerse inicialmente como comerciantes y posteriormente como terratenientes y dirigentes políticos.

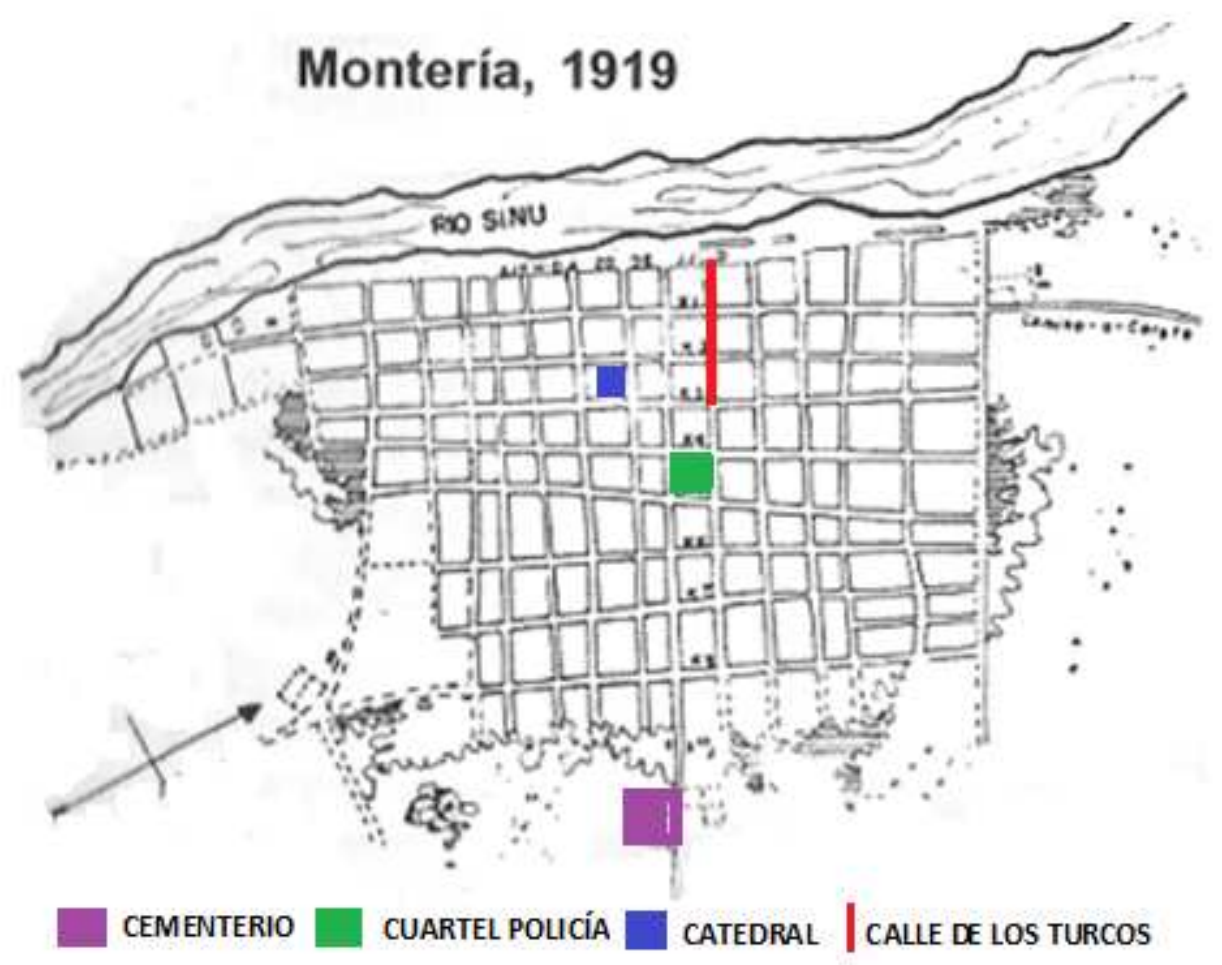

Fuente: Negrete, Víctor (2007): Lucha por la tierra y Reforma Agraria en Córdoba. UNISINÚ llustración 1. Centro Histórico

Los primeros equipamientos educativos comenzaron a construirse en la misma década de los años veinte: en un orden cronológico se destaca la construcción de la escuela la Sagrada Familia en 1923; Instituto del Sinú en 1924; escuela urbana de Varones, escuela urbana de Niñas y colegio Valencia Villegas en 1932; liceo Bolivariano en 1948, y colegio nacional José María Córdoba en el año de $1948^{61}$. Este último, al igual que las escuelas de varones y niñas fueron los equipamientos públicos que se construyeron cuando la ciudad aún pertenecía al departamento de Bolívar.

Todos estos equipamientos, con excepción del colegio nacional José María Córdoba, fueron construidos en el sector que hoy constituyen lo que se denomina centro de la ciudad, y que corresponden a los barrios históricos de Colón, la Ceiba, Chuchurubí y Montería Moderno. El mencionado colegio se construyó en el oriente hacia la vía a

\footnotetext{
${ }^{61}$ Ibíd. Pág. 58.
} 
Medellín, cuando ya se habían incorporado nuevos barrios como Ospina Pérez, el Edén I, Nariño, Sucre, San José, Chambacú, Pueblo Nuevo y Balboa.

Posteriormente, en la década de los cincuenta seguiría la construcción de nuevos equipamientos y el comienzo de infraestructura vial, principalmente las carreteras hacía Medellín y Cartagena. En esa misma época comenzarían las tensiones por la vivienda, que conducirían al desarrollo del primer programa de vivienda pública y a la primera invasión de terrenos en el sur de la ciudad. El primer programa de vivienda pública fue el del barrio Obrero en el año 1951 y la primera invasión fue denominada 14 de Julio, en honor a la fecha de toma en el año $1959^{62}$; por el número de viviendas públicas, que apenas fue de sesenta, y el tamaño del terreno invadido, ninguno de los dos tuvo mayor impacto sobre el plano urbano. Sin embargo, en el capítulo de impacto urbanístico, ampliaremos sobre ellos, ya que son el punto de partida de sucesivos programas públicos e invasiones, que actualmente conforman el espacio construido de esta ciudad, y se constituyen en el objeto de estudio de esta investigación.

\footnotetext{
62 Esta fecha fue documentada por Crismatt Mouthon en publicación digital titulada "Barrio La Granja", que se encuentra disponible en http://monteriasiglo20.tripod.com/la granja.html y que además coincide con la que suministran testigos de la época como Miguel Castro, Lamberto López, y Fermín Castro, quienes por medio de diversas entrevistas han contribuido con importantes datos históricos para esta investigación.
} 


\subsubsection{Ubicación geográfica y generalidades del territorio.}

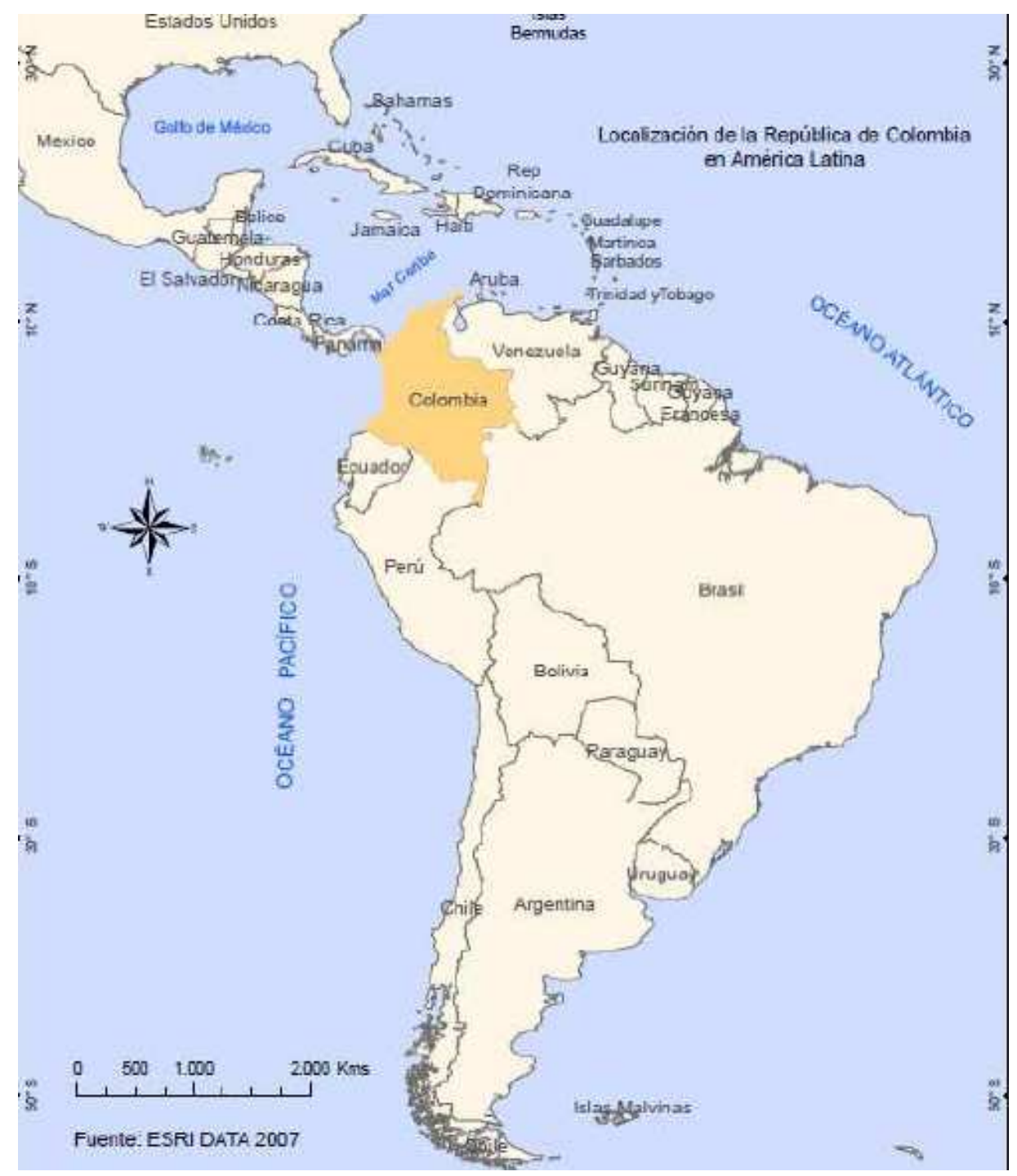

Fuente: http://es.wikipedia.org/wiki/Archivo:SAM pol.png llustración 2. Ubicación de Colombia en Suramérica 


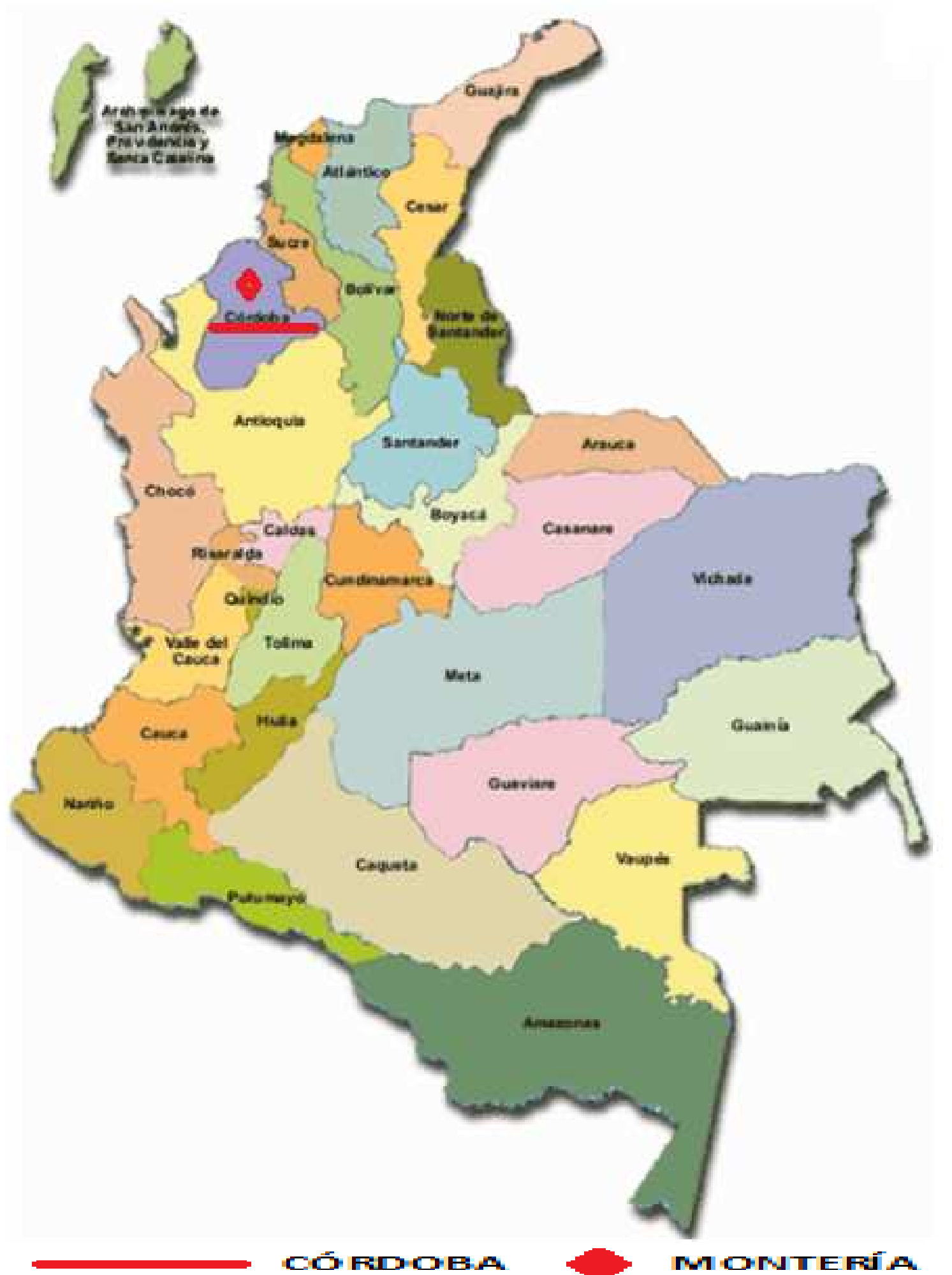

Fuente: http://www.google.com.co/division-politica-de-colombia.html llustración 3. Montería en Córdoba y en Colombia

La ciudad de Montería, capital del departamento de Córdoba, está ubicada en la costa Caribe de la República de Colombia, América del Sur. Como se observa en las imágenes el país se encuentra en la parte norte del subcontinente y nuestra ciudad de estudio se 
ubica al norte de Colombia en la región Caribe, pero en zona interior y a 100 kilómetros del mar Caribe. La distancia con Bogotá, Medellín y Cartagena es de 750 $\mathrm{Km}, 400 \mathrm{Km}$ y $300 \mathrm{Km}$ respectivamente.

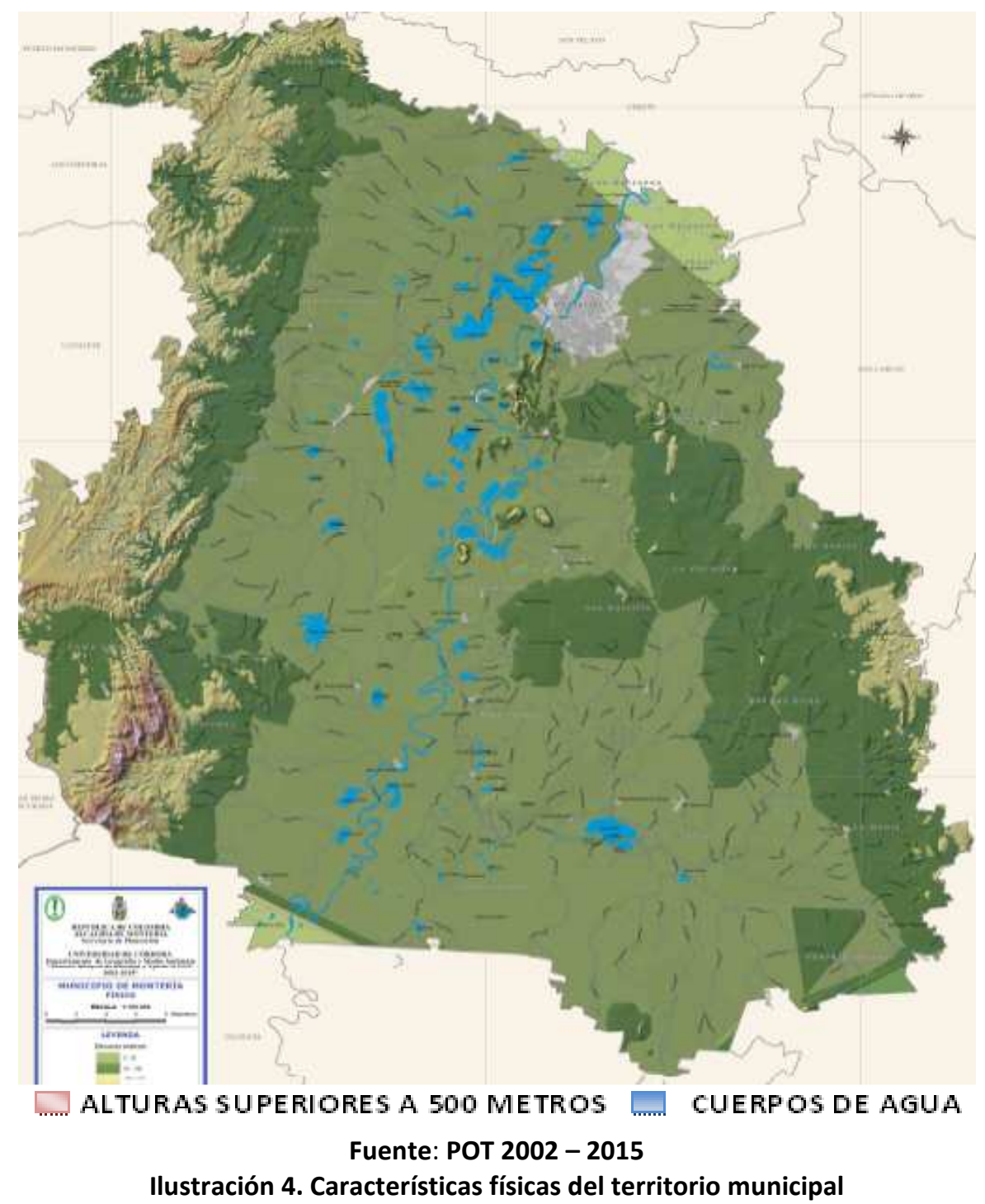

El territorio municipal es de 320.459 hectáreas en las que habitan 381.525 habitantes, de los cuales 288.192 se encuentran en zona urbana y 93.333 en zona rural ${ }^{63}$. Este territorio está conformado por importantes ecosistemas naturales como el río Sinú, que lo atraviesa de sur a norte, incluida el área urbana. Igualmente se destacan cuerpos de aguas, principalmente ciénagas y humedales; serranías con bosques;

\footnotetext{
63 Departamento Administrativo Nacional de Estadística DANE (2005): Censo Nacional de Población. Disponible en www.dane.gov.co
} 
planicies con bosque seco tropical; planicies con pastos; bosques ribereños, y colinas entre otros. Estas últimas, al igual que la mayoría de cuerpos de aguas, predominan en el occidente del territorio municipal, mientras que las llanuras lo hacen en el oriente o margen derecha del río.

Las colinas hacen parte de las serranías de San Jerónimo y Abibe en el corregimiento de las Palomas en el sur occidente del municipio, con pendientes variadas que promedian los 250 metros de altura sobre el nivel del mar (M.S.N.M.), pero que en algunos casos, superan los 500 metros $^{64}$. También se identifican en este sector ondulaciones que corresponden a las denominadas "colinas bajas", equivalentes a alturas inferiores que generalmente no superan el promedio de cincuenta metros sobre el nivel del mar.

La actividad económica depende de la ganadería, la agricultura y los servicios, pero el 98\% de las unidades económicas en el área urbana son micro y pequeñas empresas, que no superan los cincuenta trabajadores ${ }^{65}$. Como dato importante destacamos que las unidades económicas denominadas "microempresas" no superan los diez trabajadores ni tienen activos superiores a los 500 salarios mínimos mensuales vigentes en Colombia ${ }^{66}$, es decir, aquellas con activos inferiores a \$US 112.000 del 2010.

La principal actividad es la ganadería pero ésta no genera los suficientes empleos para la población rural; la agricultura es la segunda actividad y su base es la producción de arroz, maíz, algodón y plátano pero igualmente no se aprovecha todo el potencial agrológico del territorio. Por su parte, el empleo urbano es generado por el comercio al por menor y al por mayor, por los restaurantes y por los hoteles. En estos tres sectores, el empleo informal es superior al empleo formal y de un total de 130.890

\footnotetext{
${ }^{64}$ Alcaldía de Montería (2011): Ajustes al Plan de Ordenamiento Territorial de Montería (2002-2015). Montería. Diagnostico Parte I. Pág. 14.

${ }^{65}$ Castillo Osorio, Benjamín (2007): Dinámica del Sector Empresarial en Montería. Universidad del Sinú. Montería. Colombia.

${ }^{66}$ Clasificación realizada según el artículo 2 de la Ley 905 de 2004 que modifica la Ley 509 de 2000, sobre micro, pequeña y mediana empresa en Colombia (Mipyme).
} 
ocupados, 90.588 pertenecen al sector informal y 40.302 al sector formal, siendo el comercio y los servicios los que más personas ocupan con un total aproximado a $43.000^{67}$.

Sobre la población de esta ciudad, es importante anotar que en su tamaño tiene un fuerte impacto los flujos migratorios del campo a la ciudad, aspecto que iremos ampliando a lo largo de la investigación. Estos flujos migratorios son de tipo voluntario (buscando oportunidades) y de tipo forzado (conflicto interno armado), y en ellos juega un papel determinante la ubicación cercana a las zonas de conflicto de los Montes de María en el departamento de Sucre, el Urabá antioqueño, la zona del San Jorge, el sur de Bolívar y el Urabá chocoano.

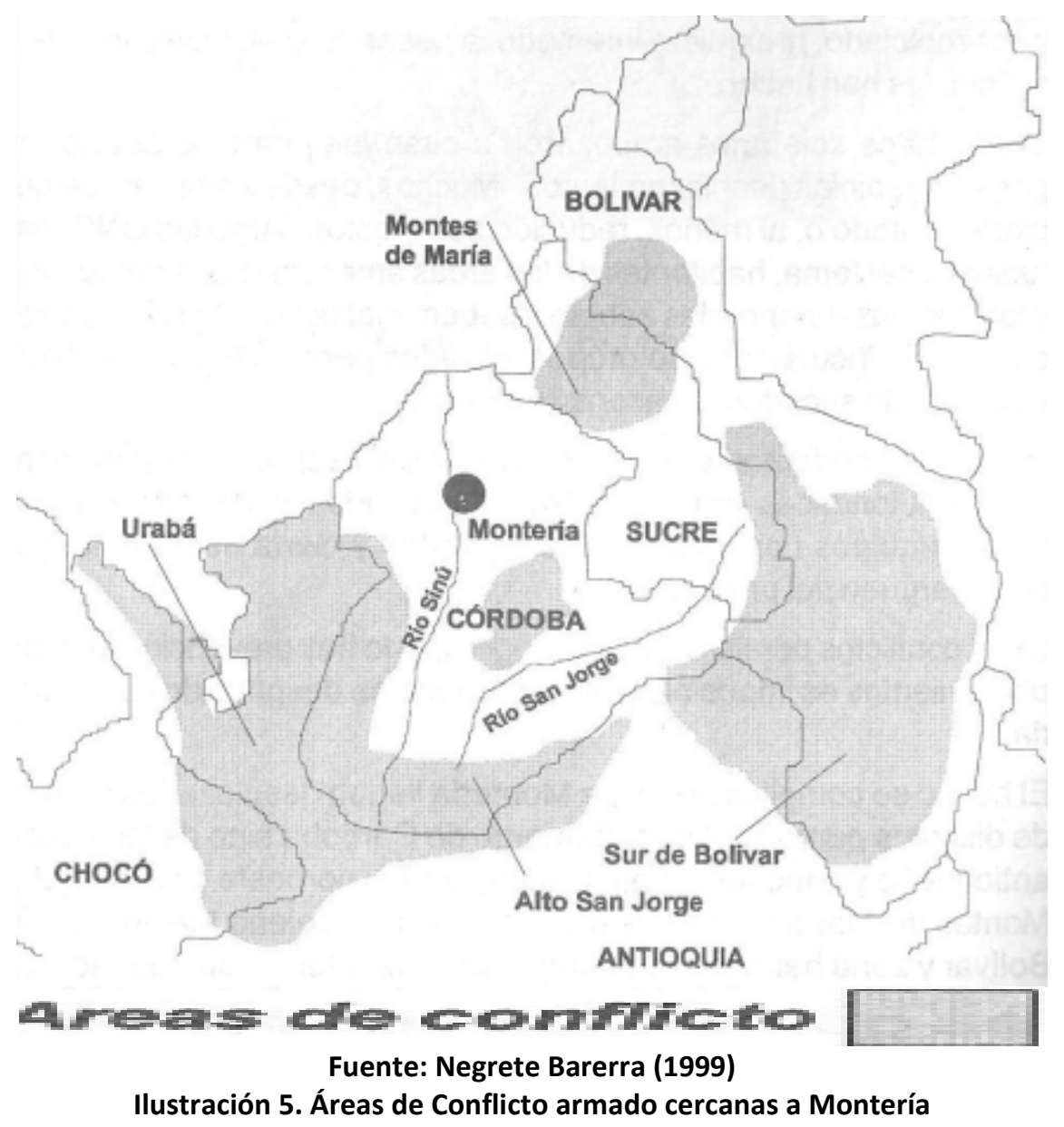

En cuanto a gran infraestructura física, la ciudad cuenta con un aeropuerto, el cual será ampliado por una concesión, una terminal terrestre de transporte, dos carreteras

${ }^{67}$ Banco de la República (2007): Op. Cit. Pág. 90. 
principales que nos conectan con Medellín y el interior del país, y otra que comunica con la ciudad de Sincelejo y el resto de la región Caribe. En lo referente a vías rurales, éstas se encuentran en estado de precariedad, y a nivel urbano hay gran déficit de ellas, de equipamientos y de zonas verdes.

Los servicios públicos hasta principios de la década de los noventa fueron prestados por empresas públicas municipales o nacionales, pero a partir de 1994 comenzaron a ser prestados por empresas privadas de capital externo, que ampliaron paulatinamente cobertura, calidad y costos de las tarifas. No obstante, la permanente situación de irregularidad de muchos asentamientos no ha permitido coberturas del $100 \%$ en ninguno de los servicios básicos, y por el contrario, servicios como el saneamiento básico aún no logran llegar al 50\% de cobertura.

En lo referente a aspectos socio-económicos sobresalen problemas relacionados con el desempleo, bajos niveles de escolaridad de la población, inasistencia escolar de niños de sectores vulnerables, deficiencia en los servicios básicos, vivienda inadecuada, desigualdad de género, concentración de la tierra, trabajo infantil, bajas cobertura de la educación pública, principalmente la educación superior, trabajo informal, y en general, elevados niveles de miseria de un gran sector de sus habitantes.

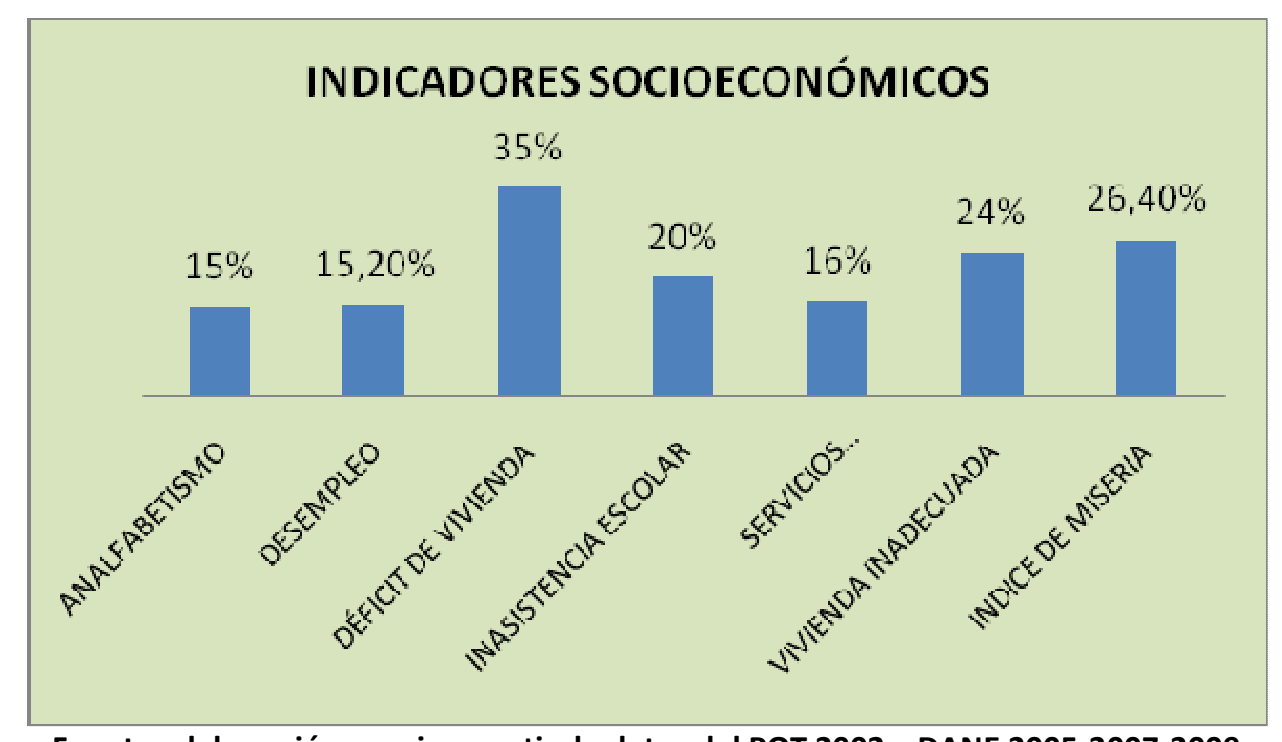

Fuente: elaboración propia a partir de datos del POT 2002 y DANE 2005-2007-2009 Ilustración 6. Indicadores Socioeconómicos en Montería 
La tasa de desempleo generalmente no supera el $20 \%$, pero esa cifra es bastante engañosa, ya que la metodología establecida por el DANE, excluye a trabajadores informales que no reúnen las características socio-laborales de empleados, ni cuentan con seguridad social, situación ésta que será ampliada con estadísticas en el apartado correspondiente a impacto económico. Esta situación sumada a los elevados niveles de analfabetismo, sumen en la miseria a un gran sector de habitantes de la ciudad y a los que llegan del campo, que en promedio corresponden al 26\% de la población.

Los niveles de miseria se asocian principalmente a las personas en alto estado de vulnerabilidad como desempleados o trabajadores informales, cuyos ingresos no permiten la satisfacción de necesidades básicas de alimentación, vivienda, agua potable o servicios de salud. Este concepto en economía es sinónimo de indigencia, es decir, del concepto que hace referencia a aquellas personas que sobreviven con menos de un dólar diario en promedio.

\begin{tabular}{|c|c|}
\hline Población Total (Censo DANE 2005) & $378.970 \mathrm{Hab}$. \\
\hline Población Urbana (Censo DANE 2005) & $286.575 \mathrm{Hab}$. \\
\hline Población Rural (Censo DANE 2005) & $92.395 \mathrm{Hab}$. \\
\hline$\%$ Población Urbana & $75,6 \%$ \\
\hline \% Población Rural & $24,4 \%$ \\
\hline Superficie Municipal (POT 2002-2011) & 320459,7 Has \\
\hline Superficie Urbana (POT 2002-2011) & 4092,0 Has \\
\hline$\%$ Superficie Rural & $98,7 \%$ \\
\hline$\%$ Superficie Urbana & $1,3 \%$ \\
\hline Corregimientos & 28 \\
\hline Veredas & 168 \\
\hline Unidades Espaciales de funcionamiento & 9 \\
\hline Manzanas & 4583 \\
\hline Barrios & 207 \\
\hline Comunas & 9 \\
\hline
\end{tabular}

Entre otras generalidades del territorio, destacamos que la división políticoadministrativa del municipio a nivel rural se encuentra conformada por 28 corregimientos y 168 veredas, que son agrupados estratégicamente en Unidades 
Espaciales de Funcionamientos (UEF), con el objetivo de obtener un mejor aprovechamiento económico del territorio. La UEF número 1, tiene una superficie de 43.600 hectáreas y la conforman los corregimientos de Morindó, Santa Clara, Caño Viejo Palotal y Santa Lucía; la 2 tiene 31.800 hectáreas y la integran Nuevo Paraíso, Martinica y Leticia; la 3 tiene 22.000 hectáreas y la constituyen Pueblo Buho y Loma Verde; la 4 con 59.500 hectáreas la conforman Jaraquiel, las Palomas y Guasimal; la 5 con 25.600 hectáreas está integrada por el Cerrito, la Victoria y Patio Bonito; la 6 con 44.200 hectáreas está constituida por Guateque, San Isidro, San Anterito y Nueva Lucía; la 7 tiene 47.800 hectáreas y de ella hacen parte Santa Isabel, Tres Palmas y Tres Piedras; la 8 la constituyen Buenos Aires, la Manta, Nueva Esperanza y tiene 31.300 hectáreas, y la UEF 9 corresponde al corregimiento de Garzones con una extensión de 2.500 hectáreas.

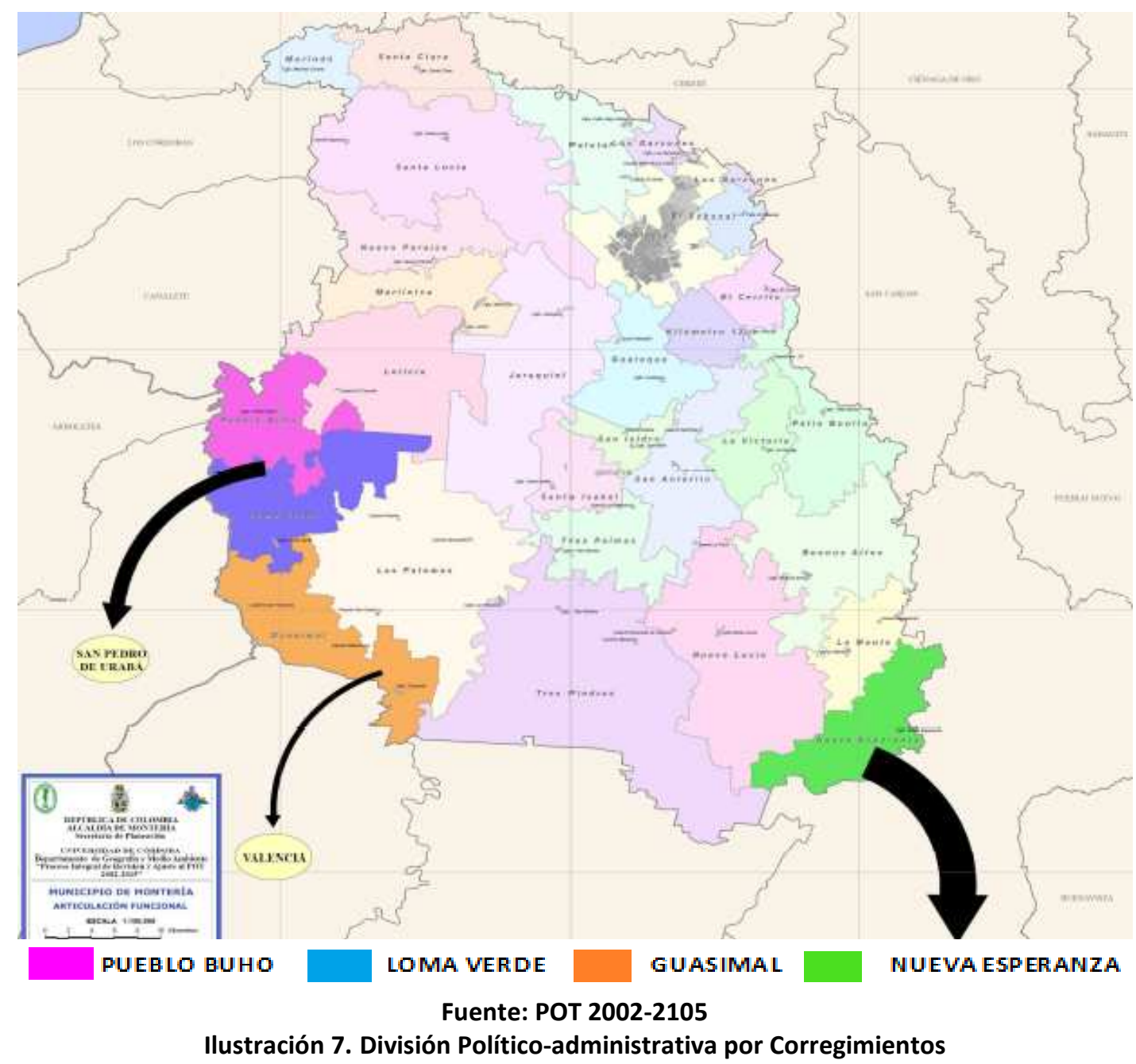


Los corregimientos del Sabanal, Nueva Lucía, el Kilometro 12, Palotal, el Cerrito, Garzones, Guateque, Jaraquiel, Martinica y Nuevo Paraíso son los de mayor cercanía a la zona urbana y por lo tanto los de mejor integración espacial y económica; mientras que Pueblo Buho y Loma Verde de la UEF 4, por la distancia y falta de vías adecuadas, se ven obligados a integrarse económicamente al municipio de San Pedro de Urabá en el departamento de Antioquia. Igual situación se presenta entre el corregimiento de Guasimal y el municipio de San Pedro de Urabá en Antioquia y entre el corregimiento de Nueva Esperanza y el municipio de Planeta Rica.

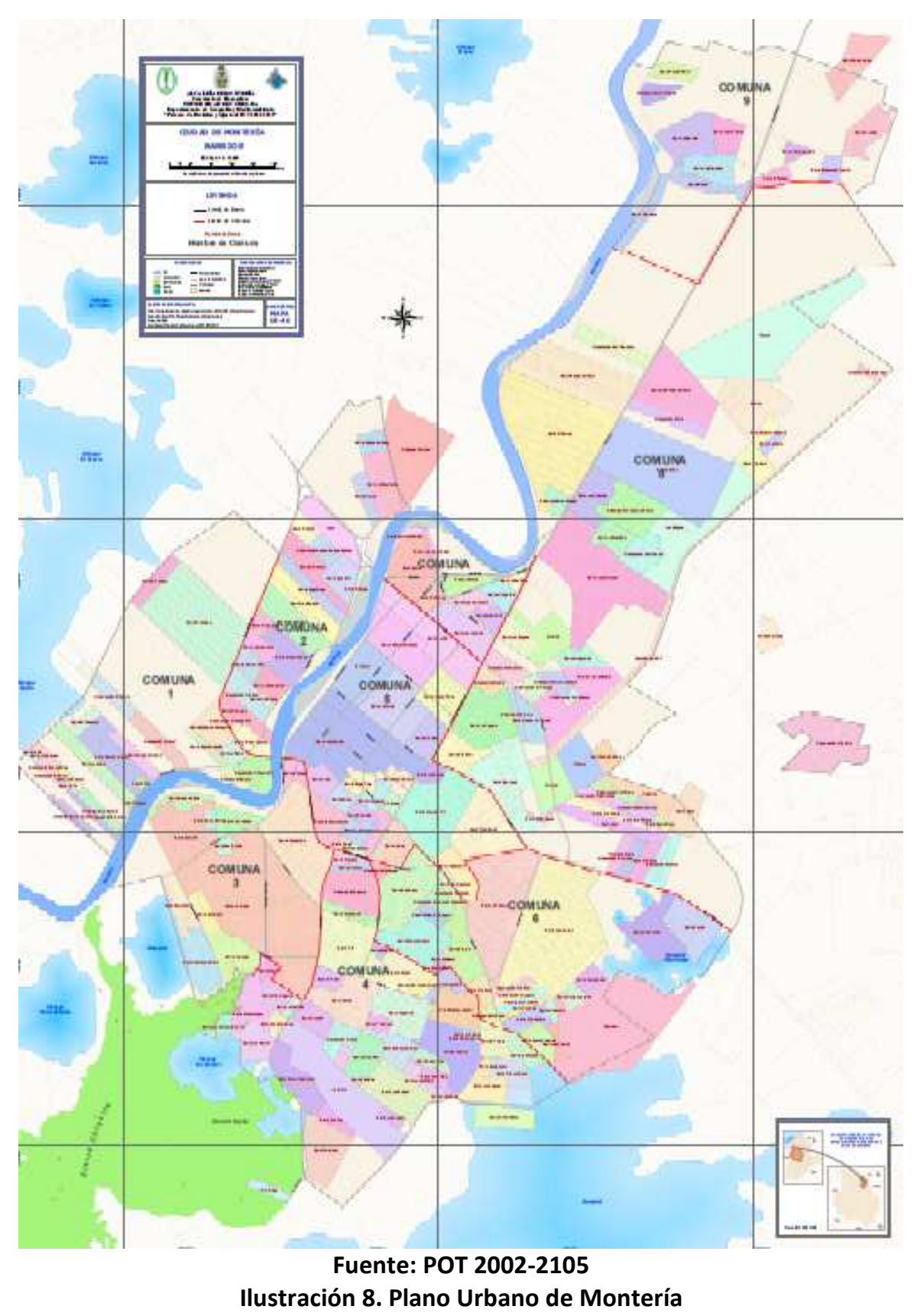


En lo que concierne al área urbana la ciudad está conformada por 207 barrios que se agrupan en nueve comunas ${ }^{68}$, con el objetivo, por lo menos sobre el papel, de articular el territorio más eficientemente. Este número de barrios, sumados a media docena de invasiones no reconocidos, pero que físicamente existen (Casa Finca, Nuevo Milenio, el Enjambre, Ranchos del INAT y el Privilegio), totalizan 4.583 manzanas dentro de un perímetro urbano que asciende a 4.900 hectáreas y concentra el 75.6 de la población del municipio, los cuales habitan en 79.458 viviendas $^{69}$.

Consideramos que los datos socio-económicos aquí expresados y las generalidades descritas sobre el territorio, brindan algunos elementos de juicio, aunque no de manera detallada, pero si suficientes para tener una mejor idea acerca del contexto geográfico de estudio y su ubicación a nivel subcontinental, nacional, regional y local. Sin embargo, anotamos, anticipándonos a probables dudas, que varios de estos datos serán ampliados o complementados más detalladamente, en la medida de su correspondiente pertinencia, y sin perder de vista el objetivo central de esta investigación.

\footnotetext{
${ }^{68}$ La comuna es una sectorización establecida por el POT 2002-2011 y sobre la cual se ampliará en el capítulo III.

69 Censo de Población y Encuesta Nacional de Hogares realizado por el DANE 2005 y disponible en www.dane.gov.co
} 


\subsection{ANTECEDENTES}

Sobre el fenómeno de la urbanización marginal existe un número significativo de estudios que han sido realizados por destacados investigadores latinoamericanos y europeos, pertenecientes a diferentes disciplinas, principalmente la arquitectura, la sociología, la antropología, el derecho y la economía. Evidentemente, estas investigaciones expresan enfoques disciplinares que analizan aspectos aislados o integrados, pero asociados a la parcelación, ocupación, edificación, relaciones sociales, estructura urbana, actividades económicas y consolidación de este tipo de urbanización.

En este orden de ideas, estudios realizados desde la economía se enfocan a denominar el fenómeno de informal; en el derecho, o jurídico, de ilegal; en la arquitectura de espontánea; en la sociología de marginal, y en lo urbanístico los estudios se encaminan a denominarla urbanización de desarrollo progresivo y a analizar su impacto sobre la morfología urbana o las relaciones con el territorio. Sin embargo, se evidencia que algunos enfoques tienden a conducir a conclusiones homogéneas, a pesar de la heterogeneidad disciplinar, histórica, geográfica y política de los contextos.

Consideramos oportuno iniciar el Estado de la Cuestión con el trabajo realizado por el Fondo Nacional de Salud y Bienestar Social del Perú (FNSBS) en el año 1960, denominado "Barriadas de Lima Metropolitana"70. En este trabajo se establece una clasificación de dichas barriadas a partir de aspectos asociados a sus cualidades de formación, tenencia de terrenos y usos anteriores de los suelos ocupados, que permite identificar situación dominial del lote individual, origen de los terrenos consolidados y condiciones de salubridad del asentamiento. Los resultados del estudio muestran emplazamientos en terrenos municipales, estatales y particulares; igualmente identifican diferentes categorías de ocupantes dentro de los que sobresalen propietarios, poseedores, inquilinos e invasores.

\footnotetext{
70 Fondo Nacional de Salud y Bienestar Social (FNSBS). 1960. Barriadas de Lima Metropolitana. Departamento de Servicio Social y Vivienda. Sección de Investigaciones Sociales. Lima
} 
La situación de las barriadas en Lima no escapó a la mirada internacional y durante esa misma década llegaron investigadores extranjeros con el objetivo de analizar de cerca este fenómeno. Entre estos investigadores destacamos al arquitecto británico John Turner, quien en el año de 1963 publicó su trabajo denominado "Lima barriadas today $^{\prime \prime 1}$, en el que destaca aspectos positivos de estos asentamientos a partir de una comparación que realiza con otros sectores deprimidos del centro de la ciudad de Lima. En este trabajo concluye que las barriadas representan la solución al problema urbano de la falta de vivienda y corresponden a iniciativas creativas dentro de un urbanismo no oficial pero efectivo.

Este mismo autor publicó dos años más tarde el estudio denominado "Lima Barriadas and Corralones: suburbs vs slums ${ }^{\prime \prime 2}$, en el cual destaca factores demográficos económicos y políticos, asociados a altas tasas de natalidad, a precarios salarios e incapacidad de los gobiernos para contener la explosión demográfica y la conformación de barriadas. Igualmente considera que las barriadas son los asentamientos más viables económica y socialmente para sus habitantes en términos de desarrollo, permitiendo el acceso a la autoconstrucción y la participación vecinal hasta convertirse en barrios dotados de servicios públicos. Concluye que antes de la supresión del asentamiento se debería considerar el hecho de comprender, apoyar y guiar los procesos sociales naturales por los que los residentes llegados se transforman en ciudadanos participantes.

Fueron muchos los aportes realizados por este investigador, razón por la cual consideramos pertinente mencionar otro importante estudio publicado en 1976 y denominado "Vivienda, todo el poder para los usuarios. Hacía la economía en la construcción del entorno" ${ }^{\prime 73}$, en el que cuestiona la forma como en son excluidos los habitantes y la comunidad en general de los procesos de planeación y construcción de la ciudad. Igualmente realiza una distinción entre urbanismo "por" y urbanismo "para"

\footnotetext{
${ }^{71}$ Turner, John (1963): “Lima barriadas today”. Architectural Digest, 33 (8), pp. 375-380 72 (1965): “Lima Barriadas and Corralones: suburbs vs. slums". Ekisties. Vol. 19 73 (1976): Vivienda todo el poder para los usuarios. Hacía la economía en la construcción del entorno. Blume. Madrid.
} 
la gente, resaltando que la residencia no se limita solamente a la aspiración de habitar en un lugar confortable, sino que implica una iniciativa popular para crear vida de espacios comunitarios de acuerdo con circunstancias sociales y físicas especificas de cada lugar. Concluye que no siempre hay caos ni desorden, y más bien interpreta organización en la ocupación de los terrenos fiscales, en las políticas internas o locales, convivencia armónica de millares de personas sin servicios públicos y en la transformación paulatina del tugurio inicial en vivienda edificada con materiales duraderos.

Otro autor no latinoamericano que se preocupó por estudiar este fenómeno fue el norteamericano William Magnin, quien en el año de 1963, mediante el estudio denominado "Urbanisation case history in Perú"74, destaca los aspectos positivos de las barriadas y la fuerza de estos colectivos para consolidar los procesos dentro de una economía de mercado. En la misma línea de Turner, concluye que los habitantes de dichas barriadas son muy trabajadores y dan respuestas creativas o audazmente empresariales a condiciones adversas y llenas de obstáculos legales por parte de un Estado con grandes limitaciones en el cumplimiento de funciones básicas. Su enfoque se orienta más a analizar aspectos de tipo socio-económico que arquitectónicos, urbanísticos o territoriales.

En la misma década de los años sesenta, y específicamente en 1968, se publica el estudio del peruano José Matos Mar, denominado "Urbanización y Barriadas en América del $\mathrm{Sur}^{\prime \prime 75}$, que describe a las barriadas como un fenómeno social con patrón de establecimiento; con rasgos físicos, sociales y económicos, estructurados mediante invasión de terrenos vacíos, preferiblemente en terrenos periféricos de dominio público. En este estudio se destaca la alta incidencia que tiene la población proveniente de áreas rurales en el surgimiento de la urbanización acelerada en la periferia de las principales ciudades latinoamericanas.

\footnotetext{
${ }^{74}$ Mangin, William (1963):“Urbanisation case history in Peru”. En Architectural Digest, 33 (8): 366-370

${ }^{75}$ Matos Mar, José (1968): “Urbanización y Barriadas en América del Sur”. IEP. Lima. Perú.
} 
Este mismo autor publicaría en 1977 otro estudio denominado "Barriadas de Lima $1957^{\prime 76}$, en donde expresa estadísticamente la conformación y consolidación de las barriadas de esta ciudad a partir de 1954, después del surgimiento de la invasión Ciudad de Dios. En las conclusiones se resalta la incidencia que tuvieron las condiciones estructurales, asociadas a desigualdades sociales y económicas, en la conformación de las primeras barriadas. Igualmente se destaca la organización en la ocupación de los terrenos, pero también se hace referencia al oportunismo de quienes se unen aprovechándose de dicha organización.

Consideramos oportuno incluir un tercer estudio de este autor, el cual fue publicado en 1984 con el apoyo del Instituto de Estudios Peruanos (IEP) de Lima y denominado "Desborde Popular y Crisis del Estado"77, donde analiza históricamente la relación de subordinación y de opresión colonial que antecede a la conformación de las barriadas y los contrastes entre lo rural y lo urbano, que finalmente determinan la concentración de grandes contingentes de migrantes en los procesos de urbanización en Lima. En este trabajo, el autor identifica las contradicciones de un Estado que pretende el avance capitalista sin reestructurar el sistema de propiedad en el campo, que se caracteriza por un enorme poder terrateniente, y que inciden en el crecimiento de un sistema de relaciones que se opone a la formalidad, y estimula la ilegalidad, la alegalidad, la clandestinidad y semiclandestinidad.

Otro importante trabajo fue realizado por el venezolano Alberto Lovera en 1983 y denominado "Indagaciones sobre la producción de viviendas en los barrios de Ranchos $^{\prime \prime 7}$. En este estudio los barrios de ranchos son analizados como área de alojamiento de los sectores de más bajos ingresos y no como ámbito de marginalidad. Se analizan principalmente formas de agrupación, procesos de ocupación, mejoramiento progresivo, dialéctica entre pobladores y el Estado para obtener los servicios básicos, y la respuesta estatal frente al fenómeno de ocupación colectiva de

\footnotetext{
${ }^{76}$ Matos Mar, José (1977): “Las barriadas de Lima 1957”. IEP, Lima. Perú.

77 Matos Mar, José (1984): Op. Cit.

78 Lovera, Alberto (1983): "Indagaciones sobre la producción de viviendas en los barrios de ranchos". Revista Interamericana de Planeación” Vol. XVII Nº5.
} 
los terrenos urbanos por parte de los sectores de menores ingresos. Este autor establece dentro de sus conclusiones que el fenómeno de los ranchos no es una manifestación transitoria.

Siete años más tarde, en 1990, cuando el problema aumentaba en todo el subcontinente, la Comisión Económica para América Latina (CEPAL), publicó un amplio informe denominado "La Marginalidad Urbana en América Latina: la dimensión espacial $^{\prime 79}$. En este informe también se considera que la informalidad urbana no es un fenómeno transitorio, sino que es la expresión permanente del funcionamiento de la sociedad capitalista dependiente; es decir, el considerado desajuste temporal de las migraciones, difícilmente sería superado por la dinámica del sector moderno. Las conclusiones se orientan a expresar que la crisis del déficit habitacional y el aumento de la marginalidad urbana, son principalmente estimulados por el empobrecimiento de la población y los restringidos presupuestos públicos.

Posteriormente, en 1998, se publicó un destacado trabajo del mexicano Emilio Duhau, denominado "Hábitat Popular y Política Urbana" ${ }^{80}$, en el que se analizan los procesos mediante los cuales los sectores populares acceden al suelo, especialmente el de la autopromoción de vivienda. Igualmente destaca el papel del Estado como agente pasivo y/o activo de las demandas populares y su doble papel cuando las califica de irregulares o cuando las admite por medio de la regularización. Establece tres formas de acceder informalmente al suelo: a) por medio de fraccionamientos irregulares; $b$ ) fraccionamientos clandestinos, y c) por medio de invasión. El autor concluye en este estudio, que los asentamientos marginales son espacios de seminstitucionalización y que las actuaciones por parte del gobierno suelen ser manipuladas con fines políticos y de relaciones clientelares entre partidos políticos y habitantes de dichos asentamientos.

\footnotetext{
${ }^{79}$ CEPAL (1990): La Marginalidad Urbana en América Latina: la dimensión espacial. Santiago de Chile. CEPAL.

${ }^{80}$ Duhau, Emilio (1998): Hábitat Popular y Política Urbana. Miguel Ángel Porrua. México.
} 
En el año 2003 se conoce otro interesante estudio de este mismo autor, denominado "La ciudad informal, el orden urbano y el derecho a la ciudad"81, donde analiza la ciudad informal a partir de la aceptación de un orden formal, que jerarquiza en tres subconjuntos de normas: a) relacionadas con los derechos de propiedad; b) relacionadas con la regulación de la apropiación del suelo y usos, y producción de la ciudad, en cuanto a conjunto de edificaciones, infraestructuras y espacio público, y c) las relacionadas con la regulación de las prácticas urbanísticas urbanas u orden reglamentario urbano en lo referente a tránsito, transporte público, equipamiento y mantenimiento de plazas o parques. En este trabajo, establece diferencias entre ciudad informal e informalidad urbana, que se traducen en favelas o loteos irregulares (ciudad informal), y en ruptura del orden urbano público en la producción de bienes y servicios colectivos (informalidad urbana). Concluye que la formalización de la ciudad informal debe estar orientada no solo a la integración física sino también a la social.

Unos años antes, específicamente en 1988, Edesio Fernándes y Ann Varley publicaron un estudio denominado "Ciudades llegales" 82 , donde se analiza la proliferación de formas de ilegalidad, principalmente la de economía informal, a partir de procesos de exclusión social y segregación espacial. Consideran que la ilegalidad urbana tiene que ser comprendida no solamente desde el punto de vista político y de mercado, sino en función del orden jurídico. Concluyen que la ilegalidad urbana no proviene exclusivamente de los sectores populares, y por el contrario, también se origina en sectores de mayores ingresos, cuyas prácticas ilegales son respaldadas con altos niveles de impunidad. En este sentido cuestionó agudamente a los condominios cerrados, porque impiden la libre circulación de todos en las calles y a las playas que son bienes de uso común.

No se pueden dejar de mencionar los trabajos de la investigadora argentina Nora Clivchesky, quien en el año 2000, con el respaldo de la división de Asentamientos Humanos de la CEPAL con sede en Santiago de Chile, publicó un estudio denominado

\footnotetext{
${ }^{81}$ Duhau, Emilio (2003): Op. Cit.

82 Fernandes, Edesio y Varley, Ann (1998): Ciudades Ilegales. Promesha. Cochabamba, Bolivia
} 
“Informalidad y Segregación Urbana en América Latina. Una aproximación" ${ }^{83}$. En este trabajo la autora identifica dos tipos de informalidad y dos tipos de segregación: en cuanto a la primera determina una informalidad relacionada con el dominio del predio y una informalidad asociada al asentamiento, principalmente cuando éste transgrede las normas urbanísticas u ocupa terrenos por vías de hecho. En lo referente a la segunda, distingue dos tipos: segregación socio-económica, que incluye indicadores como el nivel de ingresos, instrucción y condiciones materiales de vida; y segregación socio-cultural que tiene en cuenta aspectos ligados a la nacionalidad, idioma, religión y etnia. Sin embargo, la autora reconoce la dificultad para establecer indicadores o procedimientos que permitan obtener estimaciones comparables de la segregación residencial.

Otro estudio de esta autora fue publicado en el año 2003, y denominado "Pobreza y Acceso al Suelo Urbano. Algunos interrogantes sobre las políticas de regularización en América Latina", donde a partir de un enfoque economicista, concluye que el fenómeno de la informalidad se genera, entre otros aspectos, por condiciones macroeconómicas como el desempleo, bajos salarios y políticas del Estado. Establece igualmente que el suelo es escasamente regulado y controlado en la comercialización, y su acceso depende de la solvencia de los demandantes, de la renta que los propietarios desean obtener, de la inflación y de la tasa de interés. Sobre los procesos de regularización considera que tienen solamente un carácter simbólico de legalidad. Este trabajo realiza un aporte importante al analizar la participación de testaferros en el mercado informal de suelos.

En ese mismo año Martim Smolka, publica un estudio denominado "Informalidad, pobreza urbana y precios de la tierra" ${ }^{\prime 84}$, que se orienta a realizar un análisis del fenómeno a partir de los elevados precios de los suelos urbanizados en América Latina. Sin embargo considera que no es el único factor sino uno de varios factores generadores de informalidad dentro del mercado de suelos. Concluye que la

\footnotetext{
${ }^{83}$ Clivchesky, Nora (2000): Op. Cit.

${ }^{84}$ Smolka, Martím (2003): Op. Cit.
} 
informalidad es demasiado costosa pero es la única salida para las familias urbanas de bajos ingresos, principalmente para aquellas que no tienen acceso a créditos en el sistema financiero, precisamente por carecer de las credenciales requeridas por dicho sector. Sostiene además que las políticas de normalización o desmarginalización además de costosas, contribuyen a agravar el problema que pretenden solucionar, debido a que incentiva el surgimiento de nuevos asentamientos irregulares.

Consideramos oportuno incluir un estudio poco difundido pero a nuestro juicio relevante, realizado por el arquitecto argentino Víctor Saúl Pelli en el año 1997, y denominado "El Sector Popular en la Construcción del Hábitat" ${ }^{85}$. En el estudio, este investigador asocia a la informalidad o pobreza habitacional como sinónimo de insuficiencia y estado permanente de no satisfacción de necesidades básicas. Manifiesta que los sectores populares tienen una inserción imperfecta, desventajosa y precaria en el tejido y en la estructura del conjunto social, pero destaca a su vez, que el hábitat popular se compone de elementos tangibles e intangibles.

Los elementos tangibles tienen que ver con la ubicación física en áreas residuales y acceso imperfecto a servicios públicos y sociales, mientras que los intangibles, él los relaciona con: el desconocimiento de los códigos de convivencia; desconocimiento o manejo precario de mecanismos legales y administrativos, y ubicación desventajosa en las transacciones sociales y políticas. Este autor, además de considerar el concepto de sectores excluidos incorpora el concepto de sectores degradantemente incluidos con imposibilidad de gestión, carencia critica, físicamente asentados pero no conectados o desfavorablemente conectados.

Igualmente incorpora los conceptos de marginalidad pasiva y de marginalidad creativa, resaltando que en América Latina, más allá de la necesidad de casa, hay una necesidad global de modificación positiva de su inserción en la ciudad física y social, de acceso a mayores espacios y cuotas de poder en la gestión de su hábitat, incorporación en paridad de derechos y de obligaciones, además de una restauración de sus

\footnotetext{
${ }^{85}$ Pelli, Víctor (1997): "El Sector Popular en la Construcción democrática del Hábitat". Texto disponible en http://habitat.aq.upm.es
} 
deformaciones. En cuanto a producción social del hábitat destaca procesos autogestionarios colectivos y considera que se requiere de organización y de solidaridad, prácticas comunitarias, ejercicio directo de la democracia, autoestima y convivencia social. En este trabajo también se destaca la existencia de "ciudadanos sin ciudad" y "ciudad sin ciudadanos", habitando en "vivienda subnormal", ciudad formal e informal, barrio marginal, además de la subordinación de los derechos sociales a los derechos mercantiles de las grandes corporaciones.

Mientras estos investigadores se dedicaban a estudiar el fenómeno en Latinoamérica, Joan Busquets comenzaba a analizarlo desde España, y concretamente en Barcelona, en el laboratorio de urbanismo de la Universidad Politécnica de Cataluña, iniciaba "el estudio de los barrios de coreas" dentro de su investigación doctoral, que más tarde, en 1999, fue publicada con el nombre de "La Urbanización Marginal”86. En este trabajo se analiza ampliamente la morfología parcelaria, la tipología edificatoria, características topográficas, situación geomorfológica, tamaño de los barrios, ubicación, tipos de acceso y estado de las viviendas de dichas urbanizaciones. Este autor identifica contradicciones entre voluntad política y recursos para regularización, pero encuentra varias opciones para su legalización y realiza una propuesta de intervención orientada a la legalización, urbanización y ordenación futura de estos sectores.

También en España, en el año 1987, Joaquín Casariego Ramírez realizó un estudio, denominado "Las Palmas. Dependencia, Marginalidad y Autoconstrucción" ${ }^{87}$, que analiza causas y dimensión de la Marginalidad Urbana en Canarias, a partir de la insolvencia de los demandantes y de la política pública de vivienda de una región periférica. Este autor, considera que este fenómeno es una forma de desarrollo urbano que se contrapone al crecimiento ortodoxo, y donde los conflictos funcionales derivan de la competencia entre los usos residenciales, comerciales, terciarios y dotacionales. Una de las principales conclusiones del estudio determina que los efectos de la

\footnotetext{
${ }^{86}$ Busquets i Grau, Joan (1999): Op. Cit.

${ }^{87}$ Casariego Ramírez, Joaquín (1987): Las Palmas. Dependencia, Marginalidad y Autoconstrucción. Instituto de Estudios de Administración Local, Madrid.
} 
dependencia económica incrementan la marginalidad urbana, principalmente en regiones periféricas.

En el contexto colombiano destacamos el trabajo realizado por Gilberto Arango Escobar con el respaldo de la Universidad Nacional de la ciudad de Medellín en el año 1990, y denominado "La Ciudad Informal en el Siglo XXI"88, donde sostiene que la urbanización informal es el resultado de condiciones estructurales de pobreza y subdesarrollo, que además, se ven agravadas por el tipo particular de relaciones económicas, sociales y políticas. Considera a la invasión como la modalidad más predominante y conflictiva, pero también resalta el papel de la irregularidad jurídica en el parcelamiento, la propiedad del suelo, la producción progresiva de la vivienda y de los bienes colectivos. De igual forma analiza la evolución de los usos del suelo a partir de las necesidades de comercio, servicios de proximidad y aparición de centralidades locales.

Otro estudio importante en el contexto nacional fue realizado en el año 2001 por el arquitecto Alberto Saldarriaga Roa y denominado "La Ciudad Informal en Colombia: ¿problemas o solución ?"89, $^{\prime \prime}$ orientado a destacar varios aspectos que inciden o hacen parte del fenómeno, tales como: a) aspectos sociales; b) pobreza y comunidad; c) aspectos físico - ambientales, referidos a la segregación o deterioro ambiental; d) jurídicos, que tiene que ver con regulación urbanística y gestión del suelo, y por último, e) factores de tipo económico, relacionado con el funcionamiento del mercado. Este autor sostiene que diversas fuerzas internas compiten por conquistar, construir, ordenar, conservar o destruir el espacio urbanizado y la presencia del Estado se manifiesta en unas normas urbanas que, en el mejor de los casos, son atendidas por unos pocos y la mayoría de las veces no son tenidas en cuenta. Concluye que este modo de hacer ciudad no depende de las instituciones o empresas que hacen parte de la estructura básica de las sociedades en las cuales se presenta, pero no las exonera de su cuota de participación.

\footnotetext{
${ }^{88}$ Arango Escobar, Gilberto. (1990): Op. Cit.

${ }^{89}$ Saldarriaga Roa, Alberto (2001): Op. Cit.
} 
A los trabajos de Alberto Saldarriaga se suman los de Carlos Alberto Torres, quien publicó en el año 2001 el estudio "Nuevas periferias Urbanas y Tendencias de la Ciudad Informal en Colombia en los años 90"90, donde incorpora el concepto de urbanismo pirata, e incluso, lo define como el urbanismo no regulado por las normas ni las leyes del mercado. En este trabajo el autor analiza el impacto que tienen, para la economía y el paisaje urbano, las conexiones ilegales o artesanales efectuadas por la comunidad para auto-proveerse de servicios públicos, y a las cuales denomina "perdidas negras".

Este mismo autor fue coordinador de un estudio publicado por la Universidad Nacional de Colombia sede Bogotá en el año 2009 y denominado "Ciudad Informal Colombiana ${ }^{\prime \prime 1}$. En este trabajo se realiza de manera conjunta un diagnostico de la Ciudad Informal en las principales ciudades colombianas a partir de una caracterización general de la problemática, que incluye tres dimensiones: 1) ambiental- físico espacial; 2) sociocultural, y 3) económica. Dentro de las conclusiones destacan los principales problemas ambientales que ocasiona la ocupación de terrenos de protección y asilamiento de los tendidos férreos, en zonas destinadas al aislamiento de las redes de alta tensión, sobre redes de poliductos o gasoductos, o en terrenos con pendientes superiores a $45^{\circ}$.

La Universidad Nacional de Colombia ese mismo año también respaldó otra publicación de investigación conjunta denominada "Procesos Urbanos Informales y Territorios", con la coordinación de Mercedes Castillo ${ }^{92}$. Este trabajo es realizado en formato de colección de ensayos que se articulan por el hilo conductor de la informalidad, y en los que se analizan los problemas urbanos y la intervención estatal desde la perspectiva del mejoramiento Integral de barrios, la participación comunitaria y los procesos de autoconstrucción de viviendas. En el estudio no se ofrecen conclusiones definitivas pero se exponen discusiones pertinentes sobre los procesos urbanos informales y su relación con el territorio.

\footnotetext{
90 Torres, Carlos Alberto (2001): "Nuevas periferias Urbanas y Tendencias de la Ciudad Informal en Colombia en los años 90". En Piñón, Juan Luis (Coord.) [2001]. Op. Cit. pp. 151- 157.

91 Torres Carlos Alberto (coord.) [2009]: Op. Cit.

92 Castillo, Mercedes (edit.) [2009]: Procesos Urbanos Informales y Territorios. Universidad Nacional de Colombia. Bogotá.
} 
El arquitecto David Millán es otro de los investigadores colombianos con gran interés por el estudio de este fenómeno, y dentro de sus trabajos destacamos uno publicado en el año 2001, y denominado "De la Generación Espontánea a la Formalidad Planificada". En este estudio el autor sostiene que la ciudad informal o "no ciudad", como él la nombra, es la respuesta que los grupos marginados generan ante la segregación socio-económica establecida en los sistemas urbanos que habitan. Igualmente interpreta a esta ciudad como un conjunto de elementos (tangibles) y comportamientos (intangibles) que forman parte del mismo territorio urbano. Por último, destaca que en vez de grandes ciudades lo que existe actualmente son "trozos de no ciudad" y "trozos de ciudad".

Terminamos el recorrido por el contexto colombiano con la arquitecta Gloria González Zapata $^{93}$, quien en el año 2009, con el respaldo de la Universidad Nacional de Colombia, sede Medellín, publicó un destacado trabajo denominado "Gestión de los Asentamientos Informales: Un Asunto de Política Pública". Este estudio realiza un amplio análisis del problema de la vivienda en Colombia en diferentes periodos de la historia, pero su contexto de estudio lo termina delimitando a la ciudad de Medellín y a los programas públicos de normalización de asentamientos informales de las denominadas "comunas", principalmente el conocido "Programa Integral de Mejoramiento de Barrios Subnormales de Medellín" (PRIMED). En este análisis, la autora destaca los aspectos positivos de la normalización y el papel que cumplen el Estado, la Participación Ciudadana, la Cooperación de ONG, Gobiernos Extranjeros y Organismos Multilaterales.

No podríamos terminar este apartado de antecedentes, sin destacar un par de trabajos realizados en la ciudad de Montería. El primero corresponde al investigador monteriano Víctor Negrete Barrera ${ }^{94}$, quien en el año 1999, con el respaldo de la organización no gubernamental Acción contra el Hambre, publicó el libro "Los Asentamientos Subnormales de Montería". En el trabajo, este investigador social

\footnotetext{
${ }^{93}$ González Zapata, Gloria (2009): Op. Cit.

94 Negrete Barrera, Víctor (1999): Los Asentamientos Subnormales de Montería. Acción Contra el Hambre y UNISINU. Montería.
} 
realiza un inventario de estos asentamientos y describe características socioeconómicas de sus habitantes y el papel desempeñado por los líderes comunitarios en la organización, conformación y consolidación de las invasiones en esta ciudad. Igualmente destaca el papel de la mujer, la participación comunitaria, y las organizaciones cívicas en la solución de los principales problemas de esta población.

El segundo y último trabajo del contexto local, fue realizado por la antropóloga antioqueña Gloria Isabel Ocampo 95 , en el año 2003, con su estudio "Urbanización por Invasión. Conflicto Urbano, Clientelismo y Resistencia en Córdoba". En esta investigación, la autora hace un análisis de los invasores como movimiento social y de las diferentes identidades sociales que adoptan a la hora de lograr reconocimiento legal a sus demandas. Igualmente analiza: 1) la relación entre clientelismo y movimientos sociales en Montería; 2) la manera como los movimientos sociales desafían al Estado y 3) la participación y el papel del paraestado en estos procesos.

Son numerosos los trabajos realizados sobre Urbanización Marginal o Ciudad Informal en Latinoamérica a partir de la década de los cincuenta, y en Colombia después del año noventa, periodo en que se incrementa este fenómeno, como consecuencia de los desplazamientos forzados de zonas rurales hacia las principales ciudades. Sin embargo, consideramos que los estudios referenciados corresponden a los más significativos de la región, eso sí, sin dejar de reconocer la alta probabilidad de no haber incluido trabajos de gran mérito.

\footnotetext{
${ }^{95}$ Ocampo, Gloria Isabel (2003): Urbanización por Invasión. Conflicto Urbano, Clientelismo y Resistencia en Córdoba. Revista Colombiana de Antropología. Vol.39, enero-diciembre, pp.237-272. Disponible en: http://www.icanh.gov.co/recursos user//RCA\%20Vol\%2039/v39a08.pdf
} 


\section{CAPÍTULO 3}

\section{MODELOS ECONÓMICOS EN COLOMBIA, DIVISIÓN POLITICO-ADMINISTRATIVA Y DENSIDAD DE CIUDADES.}

En este apartado se pretende describir, aunque no exclusivamente de manera economicista, el impacto generado en Colombia por dos modelos antagónicos que fueron adoptados por la mayoría de países latinoamericanos en estos últimos setenta años de la historia. Estos modelos son el de Industrialización por Sustitución de Importaciones (ISI), iniciado después de la primera gran depresión de la economía, y el modelo de Apertura Económica, también denominado Neoliberalismo. El primero es abiertamente intervencionista y promotor de vivienda pública; mientras que el segundo es defensor de la libre competencia, pero generador de inequidad, migraciones, vivienda informal y problemas ambientales.

Fundamentalmente, el objetivo principal de este apartado es el de describir las características socio-políticas y socioeconómicas de un contexto geográfico que antecedieron y sucedieron a dichos modelos, principalmente al Neoliberal, así como la incidencia que cada uno de ellos tuvo en la provisión de vivienda y en la aparición o consolidación del fenómeno de estudio. Es decir, en este apartado no nos concentramos directamente en el fenómeno de estudio, sino en los elementos que ambientaron el escenario para el surgimiento de la urbanización marginal en la ciudad de Montería. 


\subsection{MODELOS ECONÓMICOS EN COLOMBIA}

\subsubsection{Modelo de Industrialización por Sustitución de Importaciones (ISI)}

Este modelo también conocido como Estructuralista de la $\mathrm{CEPAL}^{96}$, surge a partir de las consideraciones del economista argentino Raúl Prebisch ${ }^{97}$, quien entendió que el subdesarrollo no era un simple estado de atraso sino un patrón de funcionamiento y de evolución especifica de ciertas economías, a las que denominó periféricas. Estas economías periféricas se caracterizaban por: elevados niveles de subempleo, desempleo, dependencia de la exportación de materias primas y alimentos, desarrollo desigual en las relaciones de intercambio y déficit de la balanza comercial. El desarrollo desigual al que se refiere consistió básicamente, y sigue consistiendo, en dos elementos claves: el deterioro de los precios de los productos exportados por la periferia con respecto a los bienes que importa de los países del centro; y a la diferencia entre los ingresos medios entre la periferia y el centro.

A las propuestas de Prebisch se unieron más adelante el chileno Oswaldo Sunkel y el brasileño Celso Furtado, quienes se preocuparon por el subdesarrollo latinoamericano, la crisis de la deuda, la inflación y el medio ambiente. Estos economistas vieron la necesidad de que los países latinoamericanos se desarrollaran desde dentro, y consideraron la sustitución de importaciones y la inversión pública como estrategia para la industrialización. Este modelo se caracterizaría por la intervención del Estado en la economía, por la promoción de la industrialización y por la reducción de las relaciones de intercambio con otras economías.

Aníbal Pinto, fue otro economista chileno que respaldó la teoría estructuralista de la CEPAL, y propuso fortalecer el papel del Estado en la economía a través del modelo de sustitución de importaciones con énfasis tecnológico y de diversificación. Destacó las

\footnotetext{
${ }^{96}$ La Comisión Económica para América Latina CEPAL, fue establecida por la resolución 106 del Consejo Económico y Social, de 25 de febrero de 1948, y comenzó a funcionar ese mismo año. En su resolución 1984/67, de 27 de julio de 1984, el Consejo decidió que la Comisión pasara a llamarse Comisión Económica para América Latina y el Caribe.

97 Sobre este economista de la CEPAL se puede encontrar un estudio más amplio de su obra en Kay, Cristóbal (1998): Revista Nueva Sociedad № 158 pp. 110 - 119. Disponible en http://biblioteca.hegoa.ehu.es/system/ebooks/7009/original/Estructuralismoyteoriadeladependen.pdf.
} 
diferencias estructurales que existen entre los países latinoamericanos y rechazó los excesos e ineficiencias que generaba el Estado, sobre todo, cuando su desarrollo depende básicamente de las exportaciones de recursos naturales o materias primas.

La etapa inicial o primera fase de este modelo fue la sustitución de bienes de consumo masivo no duraderos e insumos básicos, mientras que la segunda fase aplicó restricciones a los bienes de consumo duradero y bienes de capital. Esta protección generó empleo industrial en forma directa pero estimuló también la migración interna, desprotegiéndose de cierto modo el campo y la agricultura, que no contaron con el crédito requerido para generar el empleo que suponía.

La industrialización interna de los países se convirtió, entonces, en la ilusión de la región y tenía el serio compromiso de producir aquellos bienes que antes había que importar, se debía sustituir las importaciones por producción generada internamente. Esta estrategia de crecimiento buscaba incentivar la creación de una industria nacional orientada a los mercados internos, y cuya sustentabilidad estaba dada por políticas de protección a la industria doméstica.

En este escenario, el rol principal lo tenía el Estado, el cual era el gran inversor, el propietario, y era el administrador de una proporción muy importante de los medios de producción. Tuvo el control del mercado financiero, la propiedad, la inversión, la gestión en casi todos los sectores de la economía, y las decisiones políticas asociadas a todos estos ámbitos. Además de tener un papel importante en la economía, tenía la responsabilidad de orientar el desarrollo mediante políticas económicas y alianzas con diferentes actores de la sociedad (empresarios-gremios-sindicatos).

Estas alianzas intentarían alcanzar el desarrollo social, y en el caso de algunos países se logró la expansión de la educación primaria, programas amplios de atención básica de salud, una legislación laboral que privilegiaba la seguridad y estabilidad en el empleo, un sistema de seguridad social que se abría a todo tipo de prestaciones, programas de acceso a vivienda, subsidios, créditos y facilidades de acceso a dichos créditos o subsidios. 
Si bien este modelo no logró que nuestras industrias fueran competitivas a nivel internacional si logró generar confianza en muchos sectores internos de la sociedad, resolviendo aspectos claves del ciclo de vida de las personas, particularmente el empleo, el salario, la educación de los hijos, la salud, la vejez, la vivienda, la integración social. Cada uno de esto aspectos estuvo garantizado por el Estado durante los primeros veinte años de vigencia del modelo en algunos países, y treinta en otros, hasta cuando comenzaron los problemas presupuestarios e inflacionarios.

El modelo comenzó a presentar problemas a partir de los últimos años de la década del setenta, fundamentalmente por los altos niveles de endeudamiento del sector público, y mostró que las economías de nuestros países sufrían de crecientes dificultades para lograr el crecimiento económico o no crecían a la tasa mínima necesaria. Por tanto, era imposible seguir financiando una política social que ya se mostraba insostenible debido a la ineficiencia de las instituciones y a la corrupción de funcionarios públicos y privados.

El exceso del gasto público de un estado paternalista, o benefactor, ocasionaría que los empresarios asumieran comportamientos conformistas y los sindicatos estatales no asumieran la responsabilidad social que le correspondía; es decir, exigían mucho y aportaban poco a la productividad de las empresas, hasta ocasionar su quiebra, amparados en los fueros sindicales. En este sentido, tanta subvención e improductividad, arrastraría incuestionablemente a los gobiernos latinoamericanos a déficits persistentes, emisiones de dinero incontroladas, presiones inflacionarias y exceso de endeudamiento externo.

Finalmente, la pauperización del campo, la situación precaria en algunas ciudades, la crisis de crecimiento, de balanza comercial, la inflación inmanejable, el endeudamiento externo y los graves problemas sociales (incluido los déficit de vivienda), darían punto final a este modelo finalizando la década de los ochenta. El endeudamiento externo de los países propiciaría los ajustes estructurales por parte de los organismos multilaterales de crédito y la imposición de un modelo económico de libre mercado y con poca o nula intervención del Estado en asuntos de economía, servicios y provisión de vivienda. 


\subsubsection{Impacto del Modelo Estructuralista en Colombia}

El modelo de industrialización por sustitución de importaciones comenzó a implantarse en nuestro país en la década de los cincuenta y se caracterizó más por la protección, que por la innovación, y de cierta forma propició el desarrollo de algún tejido industrial hasta los años setenta. Sin embargo, las limitaciones del mercado interior generaron una barrera a nuestra industria y la protección se convirtió en un fenómeno desfavorable para la economía nacional, ya que ninguna empresa creció más allá de las oportunidades del mercado interno, y el país siguió viviendo de las exportaciones tradicionales de café, carbón, petróleo y flores.

Se le asignó un papel preponderante al sector secundario y a la aplicación de una política comercial proteccionista, que intentó por este camino alcanzar la industrialización, y donde el Estado colombiano adquirió un gran protagonismo como productor industrial, e intentó con poca responsabilidad, modernizar el agro. La modernización del sector primario pretendería el mejoramiento de la productividad rural, y para ello se fortaleció los recursos de la Caja de Crédito Agrario, principal institución financiera de crédito para las personas del campo.

La sustitución de importaciones en Colombia buscó proteger inicialmente a las industrias de alimentos, bebidas, tabaco, vestuario, calzado, muebles, imprenta y cueros. Posteriormente se orientó a proteger los bienes de capital, textiles, caucho y minerales no metálicos, industria de papel, productos químicos, derivados del petróleo y del carbón, metales básicos e industria metalmecánica.

El surgimiento de nuevas empresas industriales, los altos niveles de desempleo rural y la gradual pauperización del campo estimularon los flujos migratorios ${ }^{98}$ campo-ciudad

98 En los flujos migratorios en Colombia, principalmente en las tres últimas décadas, tiene gran relevancia el desplazamiento forzado, originado en la lucha por la tierra, o más bien en las disputas por el territorio. Esta situación es corroborada por el Informe de Desarrollo Humano para Colombia 2011, donde se registra el desplazamiento de 3.600.000 personas durante los últimos trece años (1997-2000), que constituyen 836.000 familias. El mismo informe establece que el $60 \%$ de esas familias provienen de zonas rurales; el $24 \%$ de centros poblados, y el $15 \%$ de cabeceras municipales. Como dato adicional el informe revela que el $80 \%$ de las familias desplazadas de zonas rurales se consideraban propietarias de tierras, pero únicamente el $21.5 \%$ de ellas tenía escrituras legales de propiedad. Por su parte las cifras de La Consultoría para los Derechos Humanos y el Desplazamiento (CODHES), establece un 
a partir de la década de los sesenta, principalmente hacia las ciudades de Bogotá, Medellín, Cali y Barranquilla, que concentraban la industria. Sin embargo, el crecimiento económico en el país no fue suficiente para aliviar la pobreza y la falta de oportunidades de un gran sector de la población, ni se logró romper con la desequilibrada distribución del ingreso.

Las demás ciudades, con excepción de Bucaramanga y Cartagena, no vieron ampliada su estructura industrial y siguieron dependiendo de la economía agraria campesina y de los empleos que generaba el Estado. Fue precisamente este último, el principal empleador en las ciudades intermedias y municipios de menor jerarquía, por intermedio de sus empresas de servicios públicos de educación, salud y seguridad, que vincularon en condiciones favorables a profesores, profesionales de la salud y a personal de la fuerza pública.

Con este panorama, se consolidaba para esta época el movimiento sindical, consiguiendo grandes conquistas, que con el transcurrir de los años se volvieron financieramente insostenibles, principalmente para las empresas más ineficientes del sector industrial que no cumplieron con las expectativas generadas por el modelo, ni lograron tecnificarse, o mejorar procesos. Estas empresas en vez de contribuir con el empleo, aumento de exportaciones o desarrollo del país, más bien, se dedicaron a sostenerse con los subsidios y las subvenciones públicas, hasta convertirse en una pesada carga para el Estado.

La política económica y social se diseñó con criterios centralistas y durante el periodo en que transcurrió este modelo se concentraron los mejores servicios e infraestructuras en Bogotá, capital del país, que llegó a concentrar gran parte del poder político, económico y militar, y donde se ubicaron los mejores hospitales, universidades e infraestructuras de todo tipo. Sin embargo, también se construyeron

desplazamiento de 5.200 .000 personas durante los últimos veinticinco años. Más información sobre estos datos los encuentra disponible en http://www.pnudcolombia.org/indh2011/index.php/elinforme/informe-completo 
grandes infraestructuras en las ciudades de Barranquilla, Medellín y Cali, situación que permitió fortalecer, en gran medida, los flujos migratorios hacia estas ciudades.

Ciudades intermedias como Pereira, Cúcuta, Manizales, Armenia e Ibagué constituyeron algunas industrias en el sector de alimentos y bebidas, que únicamente lograban abastecer mercados locales, regionales y en algunos casos nacionales. Estas ciudades adquieren una jerarquía subregional dentro del país y su expansión física no fue desaforada debido a que no se constituyeron en polos de atracción industrial; el crecimiento poblacional fue acorde con las posibilidades de empleo que brindaron en el momento y se establecieron universidades públicas importantes como la tecnológica de Pereira y la Nacional de Manizales.

Infortunadamente en el país no se construyeron grandes infraestructuras de comunicación que sirvieran de apoyo a la actividad económica, y por la topografía, o por mala administración de recursos, no quedó un inventario favorable en autopistas, puertos aéreos, marítimos, redes ferroviarias, hospitales, universidades, escuelas, viviendas y grandes equipamientos. En este sentido la peor parte, evidentemente la llevaron las ciudades periféricas, que aún siguen careciendo de grandes escenarios deportivos, recreativos, culturales y educativos.

En cuanto a la construcción de viviendas se debe anotar que los programas de promoción pública no fueron la excepción, y la gran mayoría de proyectos se otorgaron a los departamentos de Antioquia, Valle del Cauca, Atlántico y a la ciudad de Bogotá. El Estado, a través del Instituto de Crédito Territorial (ICT), encargado de la vivienda pública, otorgó entre los años 1949 y 1990, un total de 2.454 proyectos de vivienda en todos los departamentos del país, de los cuales 808 (263.048 unidades) correspondieron a los departamentos $\operatorname{citados}^{99}$. Sobre este tema, ampliaremos en el apartado de vivienda subsidiada en Colombia.

\footnotetext{
${ }^{99}$ Centro de Estudios de la Construcción y el desarrollo Urbano CENAC (2004): "Empleo generado en los planes de construcción del Instituto de Crédito Territorial". Documento disponible en http://www.cenac.org.co/noticias eventos.shtml
} 
La población urbana durante ese periodo creció a tasas anuales cercanas al $4 \%$ anual, y el problema de la vivienda, que ya venía incrementándose desde años anteriores, se agudiza con las dinámicas migratorias campo ciudad, que comienzan de cierta forma a tugurizar las ciudades colombianas y las limitaciones del presupuesto público impiden la respuesta adecuada de los gobiernos en cuanto a vivienda pública, lo cual origina el surgimiento de populosos asentamientos informales en todo el territorio nacional.

Concluimos este análisis, resaltando que uno de los grandes obstáculos para financiación se originó en la mala administración de los recursos de las empresas comerciales, industriales y de servicios del Estado, por parte de la clase política, quienes las llevaron a la quiebra parcial o total. Igualmente resaltamos el despilfarro del erario público, la carga laboral desmedida, beneficios particulares exagerados, privilegios, amiguismos, prebendas políticas y concesiones que no permitieron mejores resultados de un modelo que intentaba, por lo menos en el papel, mejorar el rumbo del país.

Debido a la ineficiencia demostrada por el sector industrial a lo largo de tres décadas, se comienza a abandonar este modelo para basar el desarrollo en el sector externo, y la industria se convierte en un sector de apoyo. Estos cambios se inician en el gobierno de Carlos Lleras Restrepo, cuando ya operaba el Frente Nacional ${ }^{100}$ y ante la urgente necesidad de lograr el equilibrio fiscal, sanear la balanza de pagos, mejorar el volumen de divisas y aumentar las reservas internacionales. Dentro de los cambios realizados se incluye una nueva reforma agraria que pretendía la desconcentración de la tierra y el control de mercados de terrenos urbanos y suburbanos. Sin embargo, ninguno de los objetivos fueron posibles y los terratenientes de suelos suburbanos siguieron concentrando, parcelando o urbanizando irregularmente.

\footnotetext{
${ }^{100}$ El Frente Nacional fue una coalición política entre liberales y conservadores durante los años de 1958 a 1970 y cuyos objetivos fueron la alternancia de la presidencia de la República de Colombia, los escaños en el congreso y la repartición en partes iguales de la burocracia en todos los niveles de gobierno. Este pacto fue firmado en Benidorm, España el 24 de julio de 1956 por Alberto Lleras Camargo y Laureano Gómez.
} 
No podemos terminar este análisis del contexto colombiano, sin mencionar las transformaciones morfológicas que se presentaron en las diferentes ciudades del país como consecuencia del crecimiento de la población urbana, y que dio paso a los primeros planes reguladores de las principales capitales colombianas, elaborados según patrones urbanísticos funcionalistas. Es decir, ya no se sigue organizando el espacio físico con base en la retícula colonial española como soporte de actividades múltiples y polifuncionales, sino que se hace en función de una red vial jerarquizada de alto costo y una zonificación unifuncional y segregante ${ }^{101}$, que posibilita la aparición de fraccionamientos irregulares e invasiones de terrenos periféricos, principalmente de dominio público.

\subsubsection{Impacto del Modelo Estructuralista en Montería}

La ciudad de Montería al igual que la gran mayoría de ciudades periféricas del país, no logró fortalecer su estructura económica durante este modelo y la base de la economía siguió siendo el sector primario, encabezado por la ganadería y producción de algodón, maíz, arroz y sorgo. Sin embargo, dicho sector no logró tecnificarse durante el periodo del modelo, y por el contrario, las condiciones en el campo desmejoraron para los pequeños propietarios y para los campesinos jornaleros, mientras la tierra seguía concentrada en manos de latifundistas que la dedicaron principalmente a la ganadería.

Las actividades en el campo también fueron respaldadas por la Caja de Crédito Agrario, encargada de otorgar créditos a los pequeños propietarios campesinos, y por el Instituto Nacional de Adecuación de Tierras (INAT), encargado de los distritos de riego. No obstante, ni agricultura ni ganadería, generaron los empleos que se demandaban en la región y las condiciones en el campo, además, comenzaron a degradarse por la falta de infraestructura para la producción y comercialización de bienes y servicios. Con este panorama, la agricultura siguió siendo mayoritariamente campesina, con poco recurso técnico, sin la tecnología adecuada, escasos recursos financieros, sin

\footnotetext{
${ }^{101}$ Arango, Gilberto (1982): "El Frente Nacional y las Políticas de Vivienda en Colombia: algunas hipótesis". Documento disponible en http://www.bdigital.unal.edu.co/3018/1/GAE09-TF4237.pdf
} 
centros de acopios ni vías para que los campesinos comercializaran favorablemente sus productos y dejaran la dependencia del Instituto de Mercadeo Agropecuario (IDEMA).

La industria no llegó a la ciudad y la población dependía significativamente de los empleos públicos, totalmente controlados por un reducido grupo de políticos locales que manejaban a su antojo todas las entidades públicas y por supuesto el empleo. Estas instituciones no eran numerosas pero si lo suficientemente significativas dentro de la región, empleaban a personal calificado y no calificado, ofreciendo estabilidad laboral, condiciones favorables y privilegios que difícilmente pueda encontrar en la actualidad un trabajador.

El empleo urbano dependía de empresas como la Electrificadora de Córdoba, las Empresas Públicas Municipales de Montería (encargadas de proveer todos los servicios públicos domiciliaros), los funcionarios de la administración municipal, departamental y nacional con sede en la ciudad, de escuelas, colegios, universidad de Córdoba, banco Ganadero, Caja Agraria, Banco Popular, Central Hipotecario, Comercial, Policía Nacional, Ejercito, Departamento Administrativo de Seguridad (DAS), Instituto de Mercadeo Agropecuario, Instituto Nacional de Adecuación de Tierra (INAT), Instituto Colombiano Agropecuario (ICA), Instituto Colombiano de la Reforma Agraria (INCORA), Empresa Nacional de Telecomunicaciones (TELECOM), Banco Industrial, Instituto de Bienestar Familiar, Hospital San Jerónimo, Banco de Bogotá, y la Dirección de Impuestos y Aduanas Nacionales (DIAN), entre otras.

Como bien lo expresan los datos anteriores, el Estado era el principal agente empleador en esta ciudad, mediante la banca, empresas de servicios públicos, escuelas, hospitales e instituciones de apoyo; y la población empleada, o con aspiraciones de serla, debía estar vinculado activamente a un partido político o someterse a la voluntad de éstos. Este empleo público era complementado con una reducida oferta del sector privado, básicamente generada por restaurantes, salas de cine, comercios, tiendas, transporte, almacenes de cadena nacional, farmacias, supertiendas, escuelas privadas y clínicas particulares. 
La industria privada no llegó pero si lo hizo la empresa pública a través de todas las instituciones mencionadas, y acceder a ellas era un verdadero privilegio que estaba reservado a dinastías enquistadas en el poder y a sus gregarios. En este sentido, anotamos que un grupo reducido de familias se apropió estratégicamente de las principales empresas estatales, hasta saquearles el último céntimo y llevar a nuestra ciudad a ser una de las capitales más atrasadas del país.

El empleo asignado a los gregarios estaba constituido por las plazas de servicios generales, aseadores, porteros, operarios, secretarias y obreros, mientras que los no pertenecientes a los grupos políticos quedaron marginados crónicamente de la torta burocrática y fueron obligados a refugiarse en actividades económicas informales o a incorporarse a la fuerza pública; es decir al ejército, policía, infantería de marina y Departamento Administrativo de Seguridad (DAS).

Las actividades económicas informales de la época fueron básicamente talleres de mecánica, latonería (chapa), pintura, soldadura, panaderías, construcción, manufactura de alimentos, bebidas, confecciones, elementos de aseo, refrescos, transporte, extracción de arena y piedra del río Sinú, pesca y transporte. Este último era realizado por camperos particulares que se utilizaban como vehículos de servicio público, tenían capacidad para ocho pasajeros y prestaban servicio urbano e interurbano.

Por otro lado, el acceso a la educación pública, que por mandato constitucional es un derecho de los colombianos fue convertido por los políticos de Montería como un escenario clientelar, y los cupos para la educación básica, media y superior fueron excesivamente limitados o estuvieron sujetos a los avales de políticos, quienes por mucho tiempo manejaron a su antojo, y siguen manejando, el control de la educación.

Las escuelas y colegios públicos que se abrieron entre los años sesenta y ochenta fueron Cristóbal Colón, María Goretti, José María Córdoba, Lorenzo María Lleras, Luis López de Mesa, Policarpa Salavarrieta, Departamental de Bachillerato Nocturno, Liceo Femenino del Sinú, Pablo Neruda, Cecilia de Lleras, General Santander y la Normal de Varones, entre otros. Sin embargo, estas escuelas no alcanzaron a satisfacer la 
demanda real de los jóvenes en edad de estudiar ni a garantizar óptimos niveles de calidad, como consecuencia de la precariedad de sus instalaciones e inexistencia de laboratorios.

En cuanto a oferta de educación superior, anotaremos que fue demasiado limitada para atender a los jóvenes de la región, y solamente se ofrecía programas relacionados con el sector primario y algunas licenciaturas para cubrir las plazas de las escuelas y colegios que durante el modelo se abrieron. Los principales programas que ofreció la Universidad de Córdoba fueron: agronomía, medicina veterinaria, idiomas, matemáticas, sociales y biología, pero ni la ciudad ni el departamento lograron contar durante la vigencia de este modelo, con facultades de arquitectura, medicina, sociología, antropología, ingenierías o economía.

Ahora, como dato importante dentro de este análisis, resaltamos que en la década de los años sesenta, cuando comienza el Estado a constituirse en el principal empleador, nuestra ciudad contaba con una población de 124.105 habitantes ${ }^{102}$, distribuidos en aproximadamente una docena de barrios que hoy conforman el centro de la ciudad. Montería, entonces se convierte en un escenario más atractivo que el campo y en receptor de los primeros flujos de migrantes rurales de la región.

Con el aumento de la población y en pleno auge del modelo estructuralista de la CEPAL, el Estado comienza la provisión de vivienda a los nuevos demandantes urbanos de la ciudad de Montería, y se inicia una serie de programas de promoción pública bajo la coordinación del Instituto de Crédito Territorial (ICT). Estos programas fueron la Granja, el P-5, el Prado, Boston, la Pradera, Villa Margarita, Panzenú, Buenavista, la Coquera, Mogambo, la Ribera, el Puente, Rancho Grande, Pastrana Borrero, Policarpa, Santafé, la Ribera, Panamá, el Tambo, Simón Bolívar y Santander. La ubicación y el impacto morfológico de cada uno de estos barrios serán analizados detalladamente en el capítulo sobre impacto urbanístico.

\footnotetext{
${ }^{102}$ Alcaldía de Montería (2002): Plan de Ordenamiento Territorial de Montería 2002 -20011. “Ahora nos toca a todos". Montería.
} 
La mayoría de estos proyectos, por no decir que todos, generó el surgimiento de asentamientos informales e invasiones, que contribuyeron al crecimiento físico y a la solución alternativa de viviendas pero no a la calidad urbanística ni al cumplimiento de las reglas de urbanización. Sin embargo, durante el periodo de este modelo, se logró la construcción (aunque con baja calidad arquitectónica y precarios diseños), de algunos equipamientos educativos, deportivos, recreativos y de salud.

Dentro de estos equipamientos, además de los educativos ya mencionados, se destaca la construcción del estadio de beisbol 18 de Junio, el coliseo descubierto de la Circunvalar (para boxeo y baloncesto), parques locales, canchas para futbol y beisbol en el barrio P-5, Universidad de Córdoba, escuela Antonia Santos, pavimentación de vías urbanas hacía el sur y se construyen vías intermunicipales e interdepartamentales al norte y oriente de la ciudad, las cuales nos conectan con la ciudad de Cartagena de Indias y Medellín respectivamente. El impacto urbanístico de estos equipamientos también será analizado en el capitulo V de esta investigación.

Ya para el año 1985, cuando el modelo comienza a agonizar, la ciudad cuenta con una población cercana a 250.000 habitantes, y con aproximadamente sesenta barrios. No obstante, reiteramos que en este incremento, los flujos migratorios juegan un papel importante, ya que Montería se convierte en receptora de migrantes rurales, pero también en emisora de población hacia las ciudades de Barranquilla, Medellín, Bogotá y Maracaibo en Venezuela.

El modelo llegaría a su final en el año 1990, cuando el presidente Cesar Gaviria (19901994), decide embarcarnos en el modelo Neoliberal que nos impusieron los organismos financieros multilaterales y el capital transnacional. Se inician una serie de reformas laborales y con ello llegan las negociaciones, el desmonte de sindicatos, el cierre de hospitales, escuelas, empresas públicas, privatizaciones y concesiones al capital extranjero. Igualmente, comenzaron las elecciones populares de alcaldes y gobernadores, quienes hasta la nueva constitución de 1991, fueron designados desde el gobierno central en Bogotá. 
Por último, el paso de un Estado benefactor a uno no intervencionista (o gendarme), disminuiría la oferta de vivienda pública y aumentaría las tasas de desempleo, como consecuencia del cierre de muchas empresas estatales (incluido el Instituto de Crédito Territorial), y el desmonte de subsidios o subvenciones a empresas. El impacto de la disminución de los programas de vivienda, los altos niveles de desempleo y los incrementos del suelo urbano en la ciudad de Montería, se traducirían en informalidad económica e informalidad urbanística, tal y como se demostrará en los próximos apartados.

\subsubsection{MODELO DE GLOBALIZACIÓN ECONÓMICA NEOLIBERAL}

La Globalización, proveniente de la palabra inglesa globalization, o del término Mundialización, derivado del francés mondialisatión, no es un proceso reciente y por el contrario se puede asociar al año 1492, cuando se da el encuentro entre el viejo y nuevo mundo, y los imperios establecen las relaciones metrópolis - colonia. El significado de este concepto generó algunos debates que fueron superados en el año 2006, cuando el diccionario de la lengua española registra su entrada, definiéndolo como "Ia tendencia de los mercados y de las empresas a extenderse, alcanzando una dimensión mundial que sobrepasa las fronteras nacionales".

Uno de los máximos exponentes de este modelo en el siglo XX y lo que va del XXI es Milton Friedman ${ }^{103}$, gran defensor del libre mercado y del monetarismo neoclásico, quien propone desmontar el estado de bienestar y considera que la intervención estatal distorsiona los mercados, ante lo cual recomienda la disminución de su tamaño. Los gobernantes más representativos de este modelo fueron Augusto Pinochet en Chile, Margaret Thatcher en Inglaterra y Ronald Reagan en Estados Unidos, quienes defendieron la liberalización del comercio, la libre circulación de las mercancías y los flujos de capital.

Es un modelo que se sustenta también en la flexibilidad laboral, desregulación de la economía y en las privatizaciones de empresas estatales, pero mediante formulaciones

\footnotetext{
${ }^{103}$ Friedman, Milton (1996): Capitalismo y Libertad. Ediciones Rialp. México.
} 
sin mucho rigor científico; por ejemplo, esa tesis de que "todo lo público es poco eficiente", o que solamente "el mercado corrige las distorsiones de la economía". Sobre estos aspectos se puede anotar, que su aplicación se traduce no en bienestar general, sino en degradación de las condiciones laborales o salariales de los empleados, maximización de los beneficios de los empresarios, en eliminación de subsidios o subvenciones para trabajadores, beneficios al capital especulativo, desigualdad entre regiones y depredación de recursos naturales no renovables.

Para algunos autores como Castells ${ }^{104}$, la globalización es un proceso multidimensional, donde la producción de bienes y servicios se da por medio de redes productivas conformadas por cerca de cincuenta mil multinacionales y algo más de cuatrocientas mil empresas auxiliares, que incluyen la ciencia, la tecnología, la comunicación y se encuentran estructuradas en centros de investigación universitarios y/o empresariales. Considera este autor que el mundo de las comunicaciones se desarrolla con marcada concentración de los medios de comunicación, al igual que instituciones políticas multilaterales o supranacionales.

Amartya Sen ${ }^{105}$ considera que la Globalización debe ir acompañada de un progreso social y los problemas deben resolverse con políticas públicas acertadas que complementen el funcionamiento de la economía de mercado, mediante óptima distribución de los recursos físicos, desarrollo del recurso humano, reglas comerciales e instituciones políticas, económicas y sociales que hagan extensiva la difusión del conocimiento. Considera igualmente que en la actualidad hay muchas desigualdades y asimetrías en la economía mundial, y por si sola, la Globalización de las relaciones de mercado puede ser un medio totalmente inadecuado para alcanzar la prosperidad mundial.

\footnotetext{
${ }^{104}$ Castell, Manuel (2007): “Globalización y antiglobalización”. Diario El País. 24 de julio. Madrid. España. Artículo disponible en www.elpais.com/articulo/opinión

105 Sen, Amartya (2000): Desarrollo y Libertad. Planeta. Madrid.
} 
Borja y Castells ${ }^{106}$ consideran que el proceso de globalización e informalización de las fases de producción, distribución y gestión, modifican profundamente la estructura espacial y social de las ciudades en todo el planeta. Igualmente sostienen que este proceso es el sentido más directo de articulación entre lo global y lo local, y los efectos socio- espaciales de esta articulación varían según los niveles de desarrollo de los países, su historia urbana, su cultura e instituciones; pero es precisamente en esa articulación donde se encuentra la fuente de procesos de transformación urbana para mejorar la calidad de vida en las ciudades.

Ahora bien, la Globalización como modelo de dominación e ideología predominante, logró agudizar la fragmentación de la sociedad, situación que se refleja en la polarización al interior de las regiones o mediante la distribución desigual del ingreso, mala calidad del empleo, pésimas condiciones de alojamiento y privatización de los servicios públicos básicos. Si bien, el ingreso en algunos países siempre presentó niveles de desigualdad, con este modelo esta desigualdad se incrementaría de manera significativa.

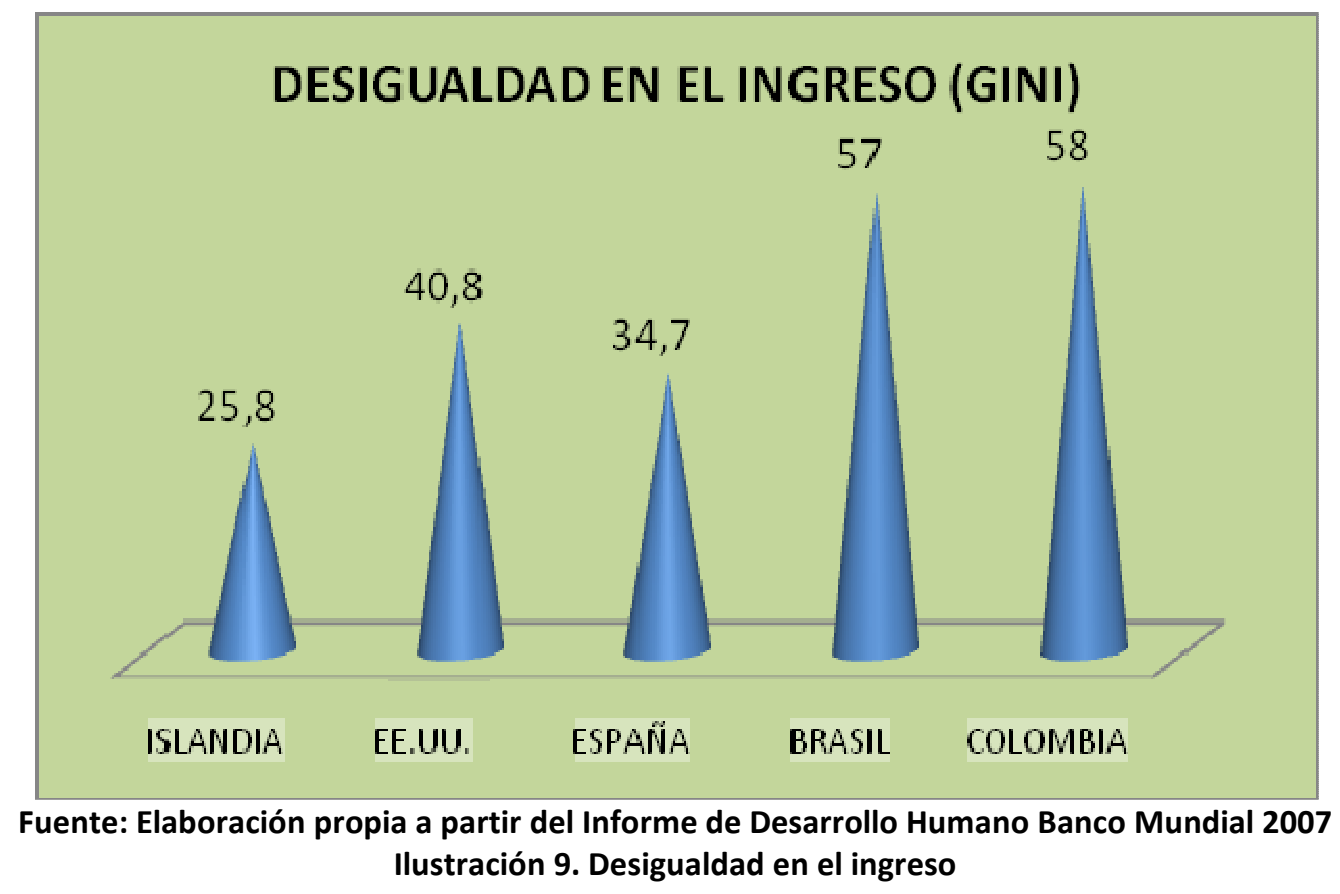

Este indicador mide la diferencia entre ingreso inferior e ingreso superior dentro de un país o lo que es lo mismo el abanico entre los que más tienen y los que menos tienen.

${ }^{106}$ Borda, Jordi y Castells, Manuel (1997): Local y Global. Ediciones Tauros. Madrid. 
La desigualdad será superior en la medida que el indicador se acerque a 100, y para el caso de la referencia que se expresa en el gráfico, se evidencia un nivel muy alto en los dos países latinoamericanos, sin desconocer su magnitud en Estados Unidos y España, lo que indica, independientemente del grado de desarrollo de cada país, que este modelo contribuye a extender la distancia entre afortunados y marginados. No obstante, es evidente que la diferencia es mayor en los países subdesarrollados, donde además, el capital transnacional está exonerado de significativos impuestos, y por tanto, le corresponde a los trabajadores y pequeñas empresas locales tributar los recursos necesarios para el funcionamiento del Estado.

\subsubsection{Impacto de la Globalización en Colombia}

En el contexto colombiano, las reformas legislativas para facilitar este modelo se iniciaron durante el periodo 90 - 94 del presidente Cesar Gaviria Trujillo, a través del plan de desarrollo nacional denominado "la Revolución Pacífica" y la redacción de una nueva constitución política en el año de 1991. Esta última fue redactada por una asamblea nacional elegida democráticamente y dentro de sus principales novedades incorporó la descentralización administrativa y la elección popular de alcaldes y gobernadores.

Dentro de las principales reformas legislativas, se destaca la aprobación de la Ley 50 de 1990, que facilita la flexibilidad laboral requerida por los empresarios pero desmejora ostensiblemente las condiciones laborales de los trabajadores públicos y privados. Esta flexibilidad permitió libertad a las empresas para contratar o despedir trabajadores sin recurrir a indemnizaciones, mediante los denominados "contratos basuras", así como las disminuciones salariales que disminuyen las posibilidades de ahorro a los trabajadores, principalmente a los cerca de seis millones que ganan el salario mínimo legal de $\$ 535.600$ para el año 2011 y equivalentes a unos 200 Euros aproximadamente.

Con un salario mínimo tan precario, los trabajadores colombianos, así como los que se refugian en actividades informales de economía, no tienen ninguna posibilidad de establecer un margen de ahorro que les permita adquirir bienes costosos como la vivienda o acceder a los servicios de educación y/o salud privada que el Estado no 
proporciona. En estas condiciones cada núcleo familiar termina convirtiéndose en un micro - estado que debe resolver individualmente el problema de la educación, la salud y de la vivienda.

En cuanto al empleo, con la entrada de capitales extranjeros se perdieron muchos puestos de trabajo sobre todo en el sector de servicios y concretamente en el sistema financiero, y un ejemplo de ello es la privatización de la banca pública, que dejó sin empleo a cientos de empleados, por recortes extremos o por incorporación de sistemas tecnológicos avanzados. Con estas privatizaciones y con la flexibilización laboral los sindicatos fueron diezmados o desintegrados en las empresas privadas y el desempleo tuvo incrementos que fueron maquillados mediante una metodología oficial flexible que incorporaba como empleados a los trabajadores informales o incluso a los desempleados crónicos.

CRECIMIENTO DEL PIB VS TASA DESEMPLEO EN COLOMBIA

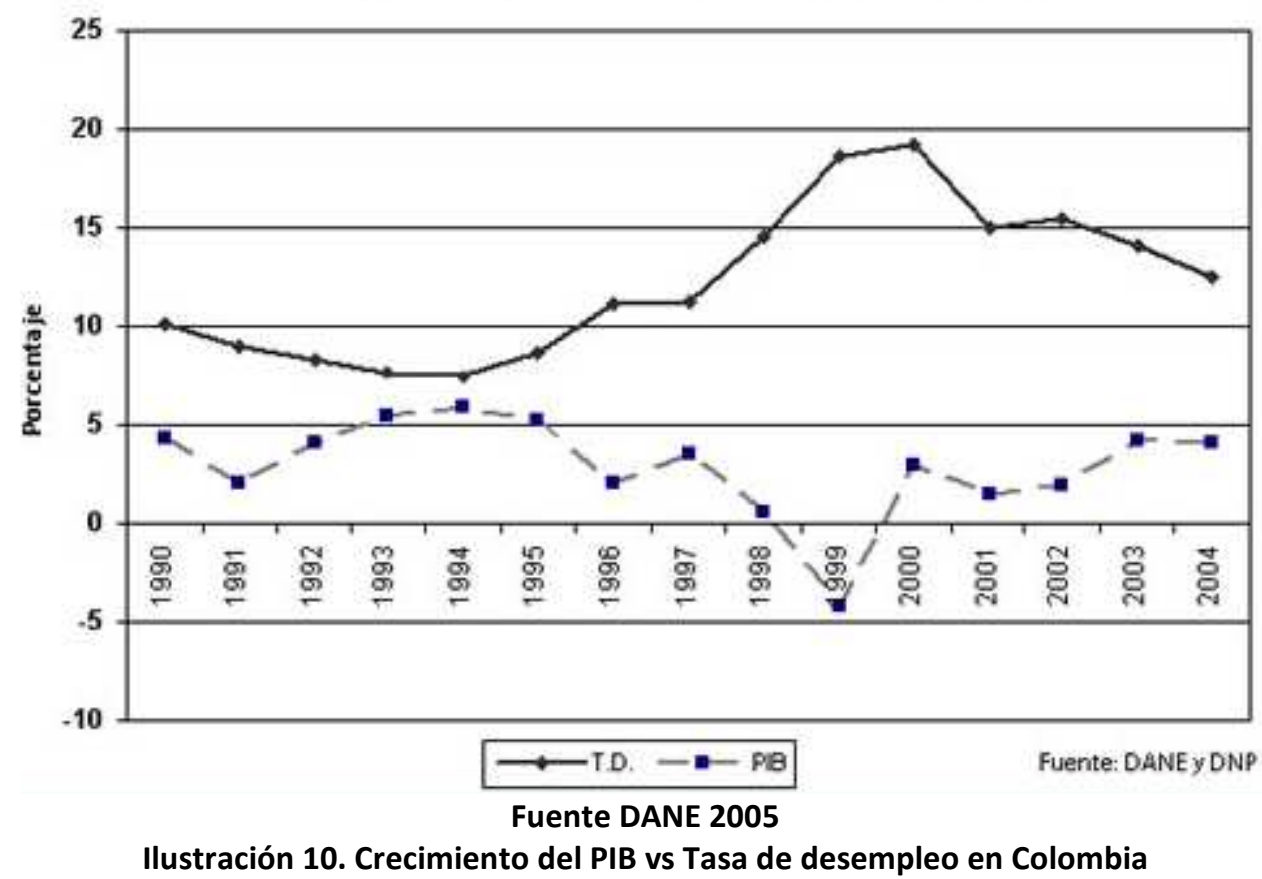

En este gráfico se muestra el incremento anual del desempleo en Colombia y el estancamiento de la producción nacional expresado a través del Producto Interior Bruto (PIB), a partir del año de 1990, cuando se incorpora abruptamente el modelo neoliberal en Colombia y se inician las reformas laborales y sociales que permitirían su desarrollo. Ni las reformas ni el modelo contribuyeron en los primeros diez años con el aumento de la producción o del empleo, y por el contrario, se evidenció un incremento 
del desempleo y el deterioro del PIB a partir de 1994, que desencadenó el cierre de pequeñas y medianas empresas nacionales, sin posibilidades de competir con empresas extranjeras.

Esta situación, sumada a los ajustes estructurales dejó por fuera del mercado laboral a cerca de 2, 5 millones de colombianos que no tuvieron otra alternativa de subsistencia sino la de recurrir a la economía informal. Esta cifra de desempleo es muy generosa, pero reiteramos que ello obedece a los altos niveles de informalidad urbana que se aprecia en las calles de las ciudades colombianas y que el Departamento Nacional de Estadística DANE, corrobora por medio de su información.

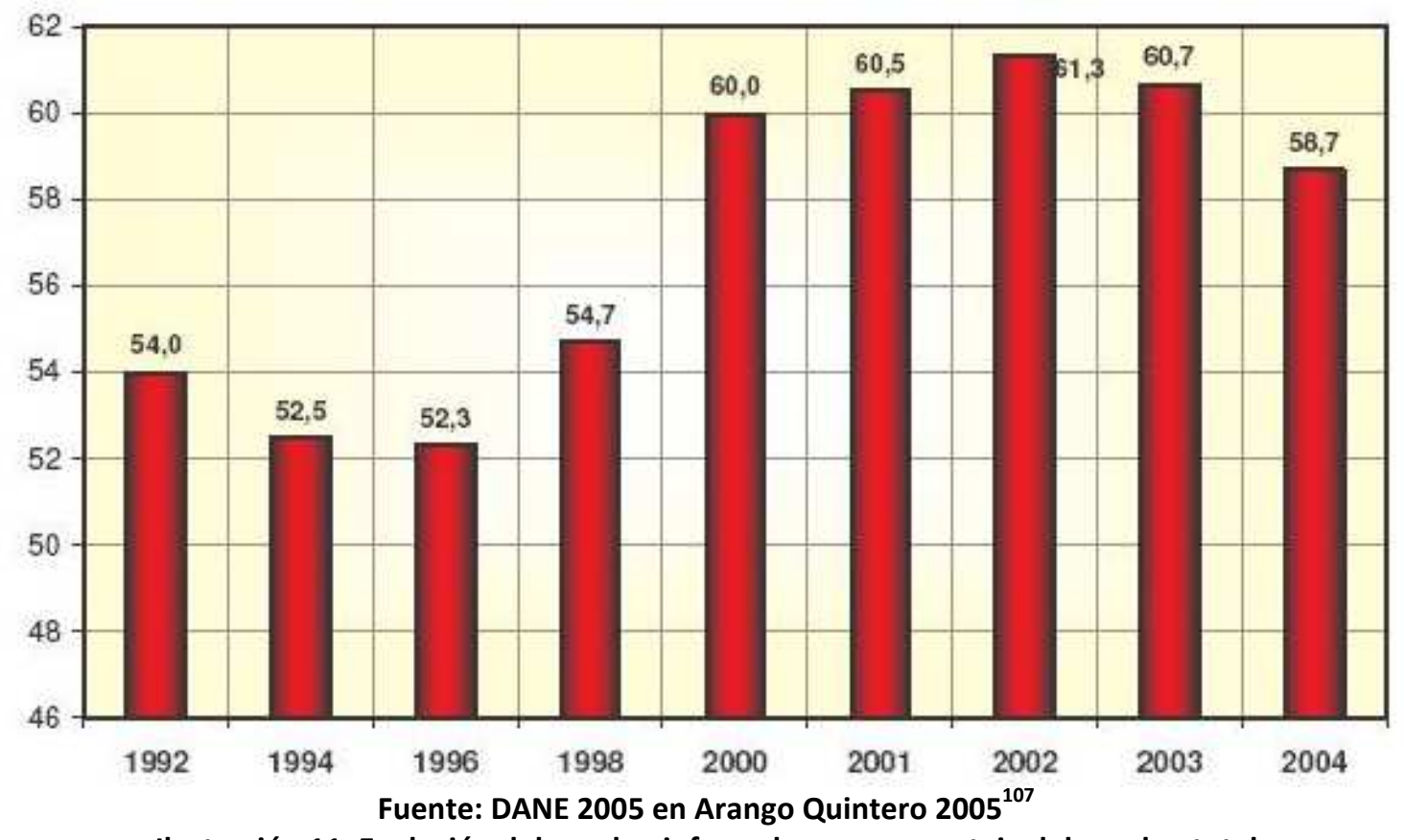

Ilustración 11. Evolución del empleo informal como porcentaje del empleo total

En valores absolutos las cifras de trabajadores informales superan los seis millones de personas en Colombia, lo cual se evidencia tanto en las principales capitales como en las ciudades intermedias, mediante la venta de todo tipo de productos en andenes, plazas, avenidas, centros históricos, escenarios deportivos, recreativos, culturales y

\footnotetext{
${ }^{107}$ Arango Quintero, Juan Carlos. Aproximación a los procesos de transmisión de la desigualdad social y económica en Colombia: 1990-2000. En publicación: Desigualdad y exclusión en Colombia (1990-2000) Los problemas nutricionales desde una aproximación del enfoque de las capacidades humanas. Tesis (Maestría en Ciencia Política). Colombia: IEP UDEA, Instituto de Estudios Políticos, Universidad Antioquia, 2005. [Citado: 13/9/2011]. Disponible en: http://bibliotecavirtual.clacso.org.ar/ar/libros/colombia/iep/tesis/hambre-democracia.pdf
} 
educativos. En cuanto a la informalidad económica, el cuadro nos muestra que el modelo neoliberal en vez de contribuir a disminuirla lo que logró fue aumentarla a niveles desproporcionados, principalmente después del año 2000, en pleno auge de la inversión extranjera y desgravación de aranceles.

En lo que a educación se refiere, anotaremos que este modelo la convirtió en uno de los negocios más rentables del mercado, para lo cual fue necesaria la aprobación de la Ley 30 de 1992 sobre educación superior, la 60 de 1993 referente a descentralización de la educación y la Ley 115 de 1994 general de educación. Estas leyes, permitieron mayor autonomía de los empresarios y de los gobiernos locales, y aumento de la cobertura básica, pero hasta ahora no contribuyen con el mejoramiento de la calidad de este servicio ni el acceso de todos los sectores de la población en igualdad de condiciones.

La ley 30 de 1992 de Educación superior, quizá la de mayor impacto en el país, establece que cualquier persona natural o jurídica puede crear instituciones de educación superior en los términos previsto en ella. La aprobación de esta ley tuvo como resultado la apertura de nuevos instituciones de educación superior en todo el país, y la llegada a Montería de una docena de universidades sin la suficiente infraestructura administrativa o física para garantizar un servicio de óptima calidad.

Dejando el tema de la educación y pasando a la salud, nos parece oportuno anotar, que quizá, es el sector más afectado, como consecuencia de los ajustes estructurales del modelo neoliberal o por las "recomendaciones" del Fondo Monetario Internacional a partir de la década de los noventa. En este periodo se inició una maratónica campaña de cierre de hospitales públicos y de puestos de salud, que facilitó el camino a los empresarios de la salud, quienes apoyados en ley 100 de 1993, aprovecharon para convertir este servicio en otra de las mercancías más rentables del mercado. Esta Ley también permitió el ingreso de entidades bajo la figura de sociedades anónimas, con lo cual las pensiones de los colombianos dejaron de ser administradas por el Estado y fueron a parar a manos de inversionistas extranjeros como el BBVA y el Banco Santander Hispano. 
Para garantizar la libre entrada de las empresas privadas la ley prohibió la creación de nuevas cajas, fondos o entidades de previsión o de seguridad social del sector público en cualquier nivel, pero dejó abierta la posibilidad de que si se constituyesen como Entidades Promotoras de Salud (EPS) o Instituciones de Servicios de Salud (IPS). Sin embargo, los legisladores blindaron sus pensiones al proteger el Fondo de Previsión Social del Congreso, encargado de administrar los recursos de su jubilación.

Concluimos manifestando que el modelo neoliberal no ha sido la solución a los problemas macroeconómicos de Colombia ni ha permitido alcanzar mejores niveles de desarrollo para el país y que el crecimiento económico de los últimos años es insostenible, ya que se obtiene fundamentalmente por medio de la explotación de recursos naturales no renovables como el petróleo, carbón y níquel. Este crecimiento, además se ha visto favorecido por las actividades realizadas por empresas multinacionales dentro del territorio, que como ya es sabido de antemano, repatrían sus utilidades, y no se tienen en cuenta para un indicador más real como el Producto Nacional Bruto PNB ${ }^{108}$.

Este crecimiento económico además es estéril, ya que sus frutos no se distribuyen equitativamente dentro del país, así como tampoco se reinvierten las elevada utilidades de multinacionales ni de grupos económicos nacionales. Igualmente aumenta la concentración de la renta, la tierra, la inequidad, la tasa de indigencia, el desempleo, la violencia, las privatizaciones, la mendicidad, los desplazados, asentamientos informales, emigrantes, problemas sociales y ambientales.

Con respecto a estos datos, el DANE ${ }^{109}$, registraba ya para el año 2008 más de dos millones y medio de personas desempleadas, cuatro millones de subempleados, más de cinco millones de trabajadores informales, y veinte millones en la absoluta

\footnotetext{
${ }^{108}$ El producto Nacional Bruto PNB es el indicador más real del crecimiento económico de un país. Su valor resulta de sumar al PIB la producción de las empresas colombianas e inversiones nacionales en el exterior y de restar la producción realizada dentro del territorio por inversionistas extranjeros y empresas de otro país. En economías débiles como la nuestra el PNB siempre es inferior al PIB como consecuencia de la repatriación de utilidades que realizan las multinacionales a sus países de origen.

109 Departamento Nacional de Estadística DANE (2009): Gran Encuesta Integrada de Hogares con base en el Censo del 2005. http://www.dane.gov.co. Consultado 3 de junio de 2009.
} 
pobreza $^{110}$. En el mismo sentido, el número de desplazados según el CODHES $^{111}$, superaba los cinco millones de personas y el salario mínimo resultaba insuficiente en una economía de mercado, obstruyendo así el acceso de más de un millón de familias a vivienda digna.

En lo político, el modelo incrementó la sumisión de los últimos gobiernos hacia el capital transnacional y hacia intereses externos, mientras que en lo socio-económico logró generar nuevas pautas de consumo, nuevas formas de vestir, nuevos estilos de vida, música, cine, arte y literatura, que contribuyen a mejorar el nivel de vida de los sectores más privilegiados de la sociedad, pero que no alcanzan a ser disfrutados por los grupos sociales más vulnerables, quienes finalmente terminan marginados, no solamente de los bienes y servicios importados, sino también de un bien local tan importante como la vivienda.

\subsubsection{Impacto socio-económico de la Globalización en Montería.}

Como ya se anotaba, en 1991 se redacta la nueva constitución política de Colombia, que se convierte en plataforma normativa del modelo neoliberal y en instrumento para reducir las funciones del Estado y aumentar la participación de la iniciativa privada en la provisión de bienes y servicios. Esta nueva constitución política permitiría la aprobación de leyes complementarias, que facilitarían la realización de los correspondientes ajustes estructurales requeridos por dicho modelo, y que finalmente tendrían un fuerte impacto sobre la reducción del empleo en Colombia. Con el objetivo de brindar los suficientes elementos de juicio para este análisis, consideramos

\footnotetext{
${ }^{110}$ EI DANE determina que se encuentran en situación de pobreza aquellas personas cuyo ingreso no es suficiente para adquirir lo básico de la canasta familiar. Esta última está conformada específicamente por alimentos, vivienda y servicios públicos.

${ }^{111}$ Consultoría para los Derechos Humanos y el Desplazamiento CODHES (2008): Población desplazada en Colombia. En este informe se establece que la tasa de desplazados es de 632 por cada 100.000 habitantes y que en promedio 1503 personas son desplazadas diariamente. Es el segundo país después de Sudan con mayor número de desplazamientos. No obstante, y despertando algunas dudas, las cifras que presenta el gobierno apenas ascienden a 2.6 millones y las de la Red de Solidaridad a 1.1 millones de desplazados por la violencia. http://www.codhes.org. Consultado junio 3 de 2009.
} 
oportuno, enunciar las principales leyes complementarias que permitieron el funcionamiento del neoliberalismo a nivel local.

Con los ajustes estructurales realizados a partir de 1991, comienza el cierre de empresas del Estado, que para esa época se constituían en una fuente importante de empleo en la ciudad de Montería. Igualmente se inicia una época de recortes y fusiones de las empresas sobrevivientes, así como la llegada de nuevas firmas privadas a la ciudad. En la llegada de empresas tuvieron gran incidencia las leyes 100 y 30 de 1993, porque contribuyeron a la apertura de nuevas oficinas bancarias, fondos administradores de cesantías y pensiones, universidades y escuelas privadas, emisoras, almacenes de cadena y centros comerciales.

La descentralización administrativa debió complementarse con la Ley 136 de 1994, sobre modernización de municipios, y con la Ley 134 del mismo año, sobre participación ciudadana. La primera establece categorías para los municipios e incorpora unas variables de tipo demográfico y presupuestario para dicha categorización; mientras que la segunda, fija nuevos instrumentos para la participación de los ciudadanos en la vida política (nacional, departamental o municipal). Dentro de dichos mecanismos se destacan la revocatoria del mandato, el plebiscito, la consulta popular y el cabildo abierto.

Además de las anteriores leyes se aprobó la ley 115 general de educación y la 60 de 1993 sobre descentralización de la educación, que le dan mayor autonomía a los municipios para manejar los recursos de la educación, así como su planeación, coordinación y dirección. Igualmente, en ese mismo año se aprueba la ley 99 de medio ambiente y posteriormente la ley 388 de 1997 o Ley Orgánica de Ordenamiento Territorial, que permite a los municipios orientar su propio desarrollo a través de la proyección espacial de su territorio, y los obliga a elaborar sus planes de ordenamiento territorial.

Mediante la ley 690 de 1993, se determinan las normas orgánicas sobre la distribución de competencias y recursos, y se establecen los instrumentos para la descentralización de los servicios públicos de educación, salud, agua potable y provisión de vivienda. En 
lo referente a educación, busca que los municipios sean responsables de la administración del servicio, de la financiación, construcción, dotación y mantenimiento de la infraestructura, así como la inspección y vigilancia de los servicios educativos estatales.

Igualmente, esta ley define la distribución de los recursos del situado fiscal ${ }^{112}$ y de la participación de los municipios en los ingresos corrientes de la nación. Indica cuales son los requisitos que deben cumplir los departamentos y los municipios para que la nación entregue los recursos y las competencias a una administración autónoma.

En el área de la salud, esta Ley establece que el municipio debe dirigir el sistema local de salud, ejercer las funciones establecidas, realizar acciones de fomento de la salud, prevención de la enfermedad, financiar la dotación, construcción, ampliación, remodelación y mantenimiento de las instituciones de prestación de los servicios a su cargo. La ley también determina que los entes territoriales (municipios o departamentos), deben prestar servicios de tratamiento y rehabilitación de primer, segundo o tercer nivel; siempre y cuando su capacidad científica, tecnológica, financiera y administrativa se lo permita.

Otra ley que se incorporó para facilitar el proceso de descentralización fue la 152 de 1994, por medio de la cual se establece la Ley Orgánica del Plan de Desarrollo, que brinda los mecanismos y procedimientos para la elaboración, aprobación, ejecución, seguimiento, evaluación y control de los planes de desarrollo a nivel nacional, departamental o municipal. En este orden, el presidente de gobierno debe someterlo a consideración del congreso de la República, el gobernador ante la asamblea departamental, y el alcalde ante el concejo municipal, dentro de un plazo no superior a seis meses (presidente), y tres para alcaldes y gobernadores, posteriores a la posesión.

Mientras el marco legislativo se ampliaba para facilitar el desarrollo del modelo, la ciudad se iba transformando demográfica, física y económicamente. En lo económico

\footnotetext{
112 El situado fiscal es un porcentaje de los ingresos corrientes de la nación destinados a los departamentos para educación y salud. Se encuentra establecido en el artículo 356 de la Constitución Nacional. Esta destinación ha sido incorporada al sistema general de participaciones a través de la ley 715 de 2003.
} 
se había privatizado la banca pública, fueron liquidadas instituciones como el Instituto de mercadeo agropecuario (IDEMA), el Instituto de reforma agraria (INCORA), el Instituto colombiano agropecuario (ICA), se liquidó el Instituto de Crédito Territorial (ICT), para darle paso al Instituto de Reforma Urbana INURBE, encargado de la provisión de vivienda pública y también la empresa de telecomunicaciones (TELECOM). Por su parte, las empresas de servicios públicos fueron transferidas a empresas privadas, y comenzaron a llegar las empresas de telefonía móvil COMCEL y CELUMOVIL y MOVISTAR.

Con la llegada de la telefonía móvil y la privatización de la televisión cambian de manera significativa las telecomunicaciones así como la información en el país y en la ciudad. Estos teléfonos penetraron con unos precios muy altos, que solamente podían ser pagados por una minoría de usuarios con capacidad de adquirirlos por unos \$US 500 del año 1994. Así mismo, entran los canales $\mathrm{RCN}^{113}$ y Caracol $^{114}$, cuyos propietarios son los mismos grupos económicos de las empresas de telefonía celular, quienes quitan protagonismo a la televisión estatal, hasta reducirla y relegarla.

La televisión privada logra incorporar nuevos programas, con formatos internacionales que invaden los hogares, nuevos géneros musicales se toman las emisoras y al mercado llegan nuevos productos, marcas, licores, electrodomésticos y automóviles. Así mismo se destaca la llegada masiva de productos de primera necesidad o de bienes suntuosos, que se unen a la Coca Cola y a Colgate Palmolive, y dentro de los cuales sobresalen: Parmalat, Kellows, Nesquik, Levis, Diesel, Kelvin Clain, Nike, Adidas, Reebok, Puma, Sara, Heineken y Buchanan.

Montería alcanza dentro de la costa norte de Colombia un lugar importante como ciudad capital de departamento y centro urbano regional intermedio, que la convierten en una ciudad prestadora de servicios, altamente dependiente del comercio, pero con escasa generación de industrias. Sin embargo, se consolida una

\footnotetext{
113 Radio Cadena Nacional, RCN es una empresa radial y de televisión controlada por el grupo económico Ardila Lule.

${ }^{114}$ Cadena Radial de Colombia, Caracol controlada por el grupo Santodomingo y con participación en los medios de comunicación escrito y en la televisión privada.
} 
producción artesanal que logra competir con algunas líneas de productos nacionales o importados.

En esta industria artesanal se destacan la producción de alimentos, bebidas, confecciones, elementos de aseo y materiales para la construcción, que abastecen el mercado local, departamental, e incluso, regional. Estas empresas se encuentran dispersas por toda la ciudad y su crecimiento comienza a generar ciertos traumas en algunos sectores, principalmente aquellas que fueron incorporando maquinaria o que utilizan insumos químicos en sus procesos de producción.

A pesar del auge del sector de los servicios y de la producción artesanal en el área urbana, estimulados en gran parte por el modelo neoliberal, la agricultura y la ganadería no pierden la primacía dentro de la estructura económica municipal, y siguen siendo una fuente de ingresos significativa para un reducido sector de la sociedad, principalmente grandes ganaderos y terratenientes. De estos dos sectores, el más competitivo es la ganadería, con una producción de un millón ochocientos mil litros día y sacrificio de diez mil bovinos mensuales ${ }^{115}$, que sirve para abastecer el mercado local y vender excedentes a la ciudad de Medellín y al país vecino de Venezuela. Sin embargo, esta actividad no genera suficientes empleos para la población rural y las condiciones de sus trabajadores siguieron tan lamentables, o quizás peor, que en el modelo estructuralista de la CEPAL.

Esa dinámica económica, evidentemente, estuvo asociada a significativos incrementos de la población total del municipio y al surgimiento de nuevos barrios, que convirtieron a Montería en la principal concentración urbana de la región de Córdoba, Sucre y el Urabá antioqueño. Durante los primeros doce años de aplicación del modelo neoliberal, la población urbana aumentó su tamaño en $23 \%$, al pasar 235.356 habitantes en el año 1993 a $288.192^{116}$ en el 2005, estimulando el surgimiento de aproximadamente veinte asentamientos irregulares y solamente seis barrios de promoción pública.

\footnotetext{
${ }^{115}$ Alcaldía de Montería (2002): Op. Cit. Diagnostico. Parte II

116 Ibídem. Pág. 320.
} 


\begin{tabular}{|c|c|c|c|c|c|c|}
\hline AÑO & \multicolumn{2}{|c|}{ CABECERA } & \multicolumn{2}{c|}{ RESTO } & \multicolumn{2}{c|}{ TOTAL } \\
\hline 1951 & 23682 & TC $\%$ & 53375 & TC $\%$ & 77057 & TC $\%$ \\
\hline 1964 & 70531 & 8,75 & 53374 & 0,02 & 124105 & 3,73 \\
\hline 1973 & 104.129 & 4,92 & 73887 & 3,63 & 178016 & 4,08 \\
\hline 1985 & 169074 & 4,12 & 73441 & 0,05 & 242515 & 2,61 \\
\hline 1993 & 235356 & 4,22 & 73150 & 0,04 & 308506 & 3,05 \\
\hline 1995 & 243576 & 1,73 & 73676 & 0,35 & 317252 & 1,40 \\
\hline 1996 & 248000 & 1,81 & 74041 & 1,005 & 322041 & 0,75 \\
\hline 2005 & 288192 & 2,70 & 93333 & 0,31 & 381525 & 2,273 \\
\hline
\end{tabular}

Fuente: Plan de Ordenamiento Territorial de Montería 2002-2011

Tabla 6. Evolución de la Población Total de Montería

Este incremento poblacional y físico estuvo acompañado de asfaltado o pavimento en concreto de nuevos ejes viales en el centro, sur y occidente de la ciudad, que se convierten en soporte del creciente tráfico motorizado, esencialmente de motocicletas. En esta etapa comienza la instalación y ampliación de nuevas infraestructuras de redes de agua potable, energía y alcantarillado; inicialmente por el municipio y posteriormente por medio de concesiones a las empresas privadas de capital nacional y extranjero que llegaron al país.

Con el crecimiento sostenido de la población urbana y la privatización de los servicios públicos básicos ganaron protagonismo elementos como el bloque de arena, cemento, asfalto, hormigón, automóvil y motocicleta, convirtiendo a Montería en un escenario caótico y ruidoso, en el que la tranquilidad y el peatón son relegados totalmente. Sin embargo, las elevadas tasas de desempleo, informalidad, fraccionamientos irregulares e invasiones no disminuyen la dimensión obtenida en el modelo estructuralista de la CEPAL, y por el contrario, estos indicadores, al igual que el número de viviendas precarias aumentan significativamente con el modelo neoliberal.

Finalizamos este análisis, manifestando que el modelo neoliberal en vez de mejorar las condiciones socio-económicas de la población, produjo el efecto contrario, principalmente en materia de empleo y vivienda. En cuanto al primero, el cierre de las empresas estatales o la privatización de ellas desencadenaron altos niveles de informalidad económica y disminución de la oferta de vivienda pública, que se tradujo a su vez en incremento de asentamientos informales y de vivienda precaria. Estos factores, además, estuvieron acompañados por las migraciones forzadas, que se 
agudizaron durante este modelo, y que precisamente se encuentra asociado a la lucha por la tierra y la utilización de métodos violentos por parte de algunos actores armados, o terratenientes, para apropiarse de ella.

\subsection{DIVISIÓN POLÍTICO-ADMINISTRATIVA Y JERARQUÍA DE CIUDADES EN COLOMBIA}

Colombia está dividida política y administrativamente en departamentos, municipios, corregimientos departamentales, corregimientos municipales, caseríos e inspecciones de policías. En la actualidad existen oficialmente 32 departamentos, 1.101 municipios y 8.059 centros poblados, entre corregimientos, veredas, caseríos e inspecciones de policía.

Los antecedentes del territorio se remontan al año 1542, fecha en la cual, el país se encontraba conformado por las gobernaciones de Santa Marta, Cartagena y Popayán. Posteriormente entre el año 1550 y el año 1717 se instaló la Real Audiencia de la Nueva Granada, dependiente del virreinato del Perú y compuesta por las tres gobernaciones existentes y el Nuevo Reino de Granada con sede en Santafé.

De 1717 a 1810 se crean los virreinatos en América y dentro de ellos el de la Nueva Granada, conformado por la Capitanía General de Venezuela, Quito y Santafé. Nueve años más tarde en 1819 se conformó la Gran Colombia con los departamentos de Venezuela, Cundinamarca y Ecuador.

Para el año de 1821 la asamblea constituyente dividió territorialmente a Colombia en departamentos, provincias, cantones y parroquias. Seguidamente el Congreso decretó mediante Ley 25 de 1824 la constitución de 12 departamentos, los cuales estaban conformados por 38 provincias y 2.583 .799 habitantes ${ }^{117}$.

En 1863 la constitución de Rionegro creó los Estados Unidos de Colombia, formado por nueve estados y en 1886 una nueva constitución decretó la República Unitaria,

\footnotetext{
${ }^{117}$ DANE (2010): División Político - Administrativa de Colombia. www.dane.gov.co . Consultado 5 de febrero de 2010.
} 
conformada por nueve departamentos regidos por el sistema de centralización política y descentralización administrativa.

En 1904, un año después que Colombia pierde a Panamá, el presidente Rafael Reyes decretó una nueva distribución político - administrativa, conformada por un distrito capital (Bogotá), una intendencia (Guajira), un territorio nacional (Meta) y 25 departamentos. Esta distribución fue modificada en 1936 por la reforma constitucional del presidente Alfonso López Pumarejo, quien por medio del Acto Legislativo 01 creó las intendencias y comisarías.

La última modificación a la división político - administrativa se realizó en la nueva constitución de 1991, la cual pretende la modernización del Estado y la descentralización administrativa. En esta nueva carta, las intendencias y comisarías son erigidas como departamentos e igualmente se definen como entidades territoriales a los departamentos, los distritos, los municipios y los territorios indígenas.

La Constitución de 1991 considera al municipio como la entidad fundamental de la división político - administrativa del Estado y la ley 136 de 1994 sobre modernización de los municipios establece la categorización de éstos. El artículo 60 de esta Ley, modificado por el artículo 2ㅇ de la Ley 617 de 2000, clasifica a los municipios y distritos de acuerdo con el tamaño de su población e ingresos corrientes de libre destinación. Esta clasificación contiene las siguientes categorías:

- Categoría Especial para los municipios con población superior a 500.000 habitantes e ingresos anuales superiores a los 400.000 salarios mínimos legales mensuales (SMLM) (\$US 160.000.000).

- Primera Categoría para los municipios con población entre 100.001 y 500.000 mil habitantes e ingresos anuales superiores a 100.000 SMLM (\$US 40.000.000) e inferiores a 400.000 MSLM (\$US 160.000.000). 
- Segunda Categoría para aquellos con población entre 50.001 - 100.000 e ingresos entre $50.000-100.000$ SMLM.

- Tercera Categoría: 30.001 - 50.000 Habitantes e Ingresos entre $30.000-50.000$ SMLM.

- Cuarta Categoría: 20.001 - 30.000 Habitantes e Ingresos entre 25.000 - 30.000 SMLM.

- Quinta Categoría: 10.001 - 20.000 Habitantes e ingresos 15.000 - 25.000 SMLM.

- Sexta Categoría para los municipios menores de 10 mil habitantes y con ingresos inferiores a 15.000 SMLM

Por su parte, el Departamento Nacional de Planeación (DNP) considera municipios urbanos a las poblaciones con más de 10.000 habitantes residentes en su cabecera, y municipios rurales a los que no alcanzan ese número de habitantes. Esta misma institución estableció inicialmente la existencia de 240 centros urbanos jerarquizados a partir de regiones funcionales ${ }^{118}$ o metrópolis principales.

Igualmente se dejaron definidos centros subregionales, centros de relevo principal, centros de relevo secundario, centros locales principales, centros locales secundarios y centros urbanos básicos. En el siguiente gráfico se muestra la jerarquización de los centros urbanos en Colombia.

\footnotetext{
${ }^{118}$ El DNP considera que una región funcional es una red de ciudades, en donde una de ellas, proyecta su influencia sobre las demás.
} 


\begin{tabular}{|cccccc|}
\hline CATEGORÍAS & BOGOTÁ & MEDELLÍN & CALI & BARRANQUILLA & TOTAL \\
\hline METROPOLIS REGIONALES & 1 & 1 & 1 & 1 & 4 \\
\hline CENTROS SUBREGIONALES & 7 & 3 & 3 & 6 & 2 \\
\hline CENTROS DE RELEVO PRINCIPAL & 13 & 2 & 6 & 4 & 23 \\
\hline CENTROS DE RELEVO SECUNDARIO & 8 & 9 & 5 & 11 & 45 \\
\hline CENTROS LOCALES PRIMARIOS & 16 & 8 & 10 & 6 & 49 \\
\hline CENTROS LOCALES SECUNDARIOS & 18 & 15 & 10 & 33 & 74 \\
\hline CENTROS URBANOS BÁSICOS & 14 & 7 & 20 & 63 & 240 \\
\hline TOTAL & 77 & 45 & 55 & 204 & 26 \\
\hline
\end{tabular}

Fuente: Mejía, Luz Adriana 2004

Tabla 7. Jerarquía de Centros Urbanos en Colombia

Dentro de la jerarquía de ciudades en Colombia, es preciso anotar que, Bogotá es la capital de la República de Colombia y la gran metrópoli nacional, mientras que las ciudades de Medellín, Cali, Barranquilla y Bucaramanga son consideradas metrópolis intermedias. En el mismo sentido, el Departamento Nacional de Planeación, establece la existencia de siete centros subregionales (Cúcuta, Cartagena, Manizales, Pereira, Ibagué, Pasto y Villavicencio), y de veintiocho centros regionales intermedios (Armenia, Montería, Neiva, Santa Marta, Palmira, Valledupar, Sincelejo, Buenaventura, Itagüí, Tunja, Soacha, Tulua, Bello, Girardot, Florencia, Cartago, Sogamoso, Buga, Duitama, Envigado, Soledad, La Dorada, Riohacha, Floridablanca, Ipiales, Yumbo, San Andrés, Dos Quebradas).

Un aspecto importante para destacar es la conformación de nuevas áreas metropolitanas que se vienen organizando a partir de la Constitución política de 1991 y de la Ley Orgánica 128 de 1994, que permiten que ya para el año 2009 la consolidación de las áreas metropolitanas de Medellín, Bucaramanga, Barranquilla, Cúcuta, Pereira y Valledupar. Igualmente se encuentran configuradas pero no reconocidas las de Bogotá, Cali y Popayán.

El área metropolitana del Valle de Aburrá fue creada por ordenanza № 34 de 1980 y está conformada por: Medellín, Bello, Barbosa, Copacabana, La Estrella, Girardota, Itagüí, Caldas y Sabaneta. Como dato importante manifestamos que es la única área metropolitana que ejerce como autoridad ambiental en el país. 
Por su parte el área metropolitana de Bucaramanga fue creada por ordenanza № 20 de 1981 y conformada inicialmente por Bucaramanga, Floridablanca y Girón. En el año 1986 se incorporó el municipio de Piedecuesta. En este mismo año se conformó también el área metropolitana de Barranquilla por medio de ordenanza № 28, y conformada por Barranquilla, Soledad, Puerto Colombia, Galapa y Malambo.

Las últimas áreas metropolitanas se crearon en el año 1991 y 2005. En 1991 se crearon: la de Cúcuta por medio del Decreto 000508, y la de Centro Occidente por ordenanza 014 y conformada por los municipios de Pereira, Dosquebradas y la Virginia; mientras que en el 2005 se creó la de Valledupar. Se encuentran en procesos de creación las de Villavicencio, Girardot, Cartagena, Manizales, Santa Marta, Armenia, Sincelejo, Boyacá y Nariño.

\subsection{DENSIDAD POBLACIONAL}

Antes de referirnos a la densidad urbana, comenzaremos recordando que, los países subdesarrollados presentan mayores tasas de crecimiento poblacional y de fecundidad que los países industrializados. Sin embargo, es oportuno anotar que la Tasa Global de Fecundidad en América Latina ha logrado una reducción equivalente al 64\%, al pasar de 5.9 hijos por mujer en el periodo entre $1950-1955$ a 2.1 en el periodo $2010-2015^{119}$.

\footnotetext{
${ }^{119}$ CEPAL [2010]: Población y Salud en América Latina. Santiago de Chile.
} 




En la disminución del promedio de la región influyen positivamente los países de Uruguay, Cuba, y de cierta manera, Brasil que ha logrado a partir de los años setenta, reducir su tasa global de fecundidad a niveles inferiores del promedio. En el caso de Colombia, esta tasa ha logrado descender de 6.8 hijos por mujer en 1960 a 2.15 en el 2009, mientras que la tasa general se redujo a 83 nacimientos por cada mil mujeres en edad fértil.

En cuanto a población, resaltamos que los países más poblados siguen siendo Brasil y México, mientras que Uruguay, Paraguay, Ecuador y Bolivia, por cuestiones geográficas, o más bien de superficie, mantienen los tamaños más reducidos de población. Por su parte Colombia, con un número cercano a los cuarenta y cinco millones de habitantes, presenta un tamaño de población similar al de Argentina, e incluso al de España en Europa. 


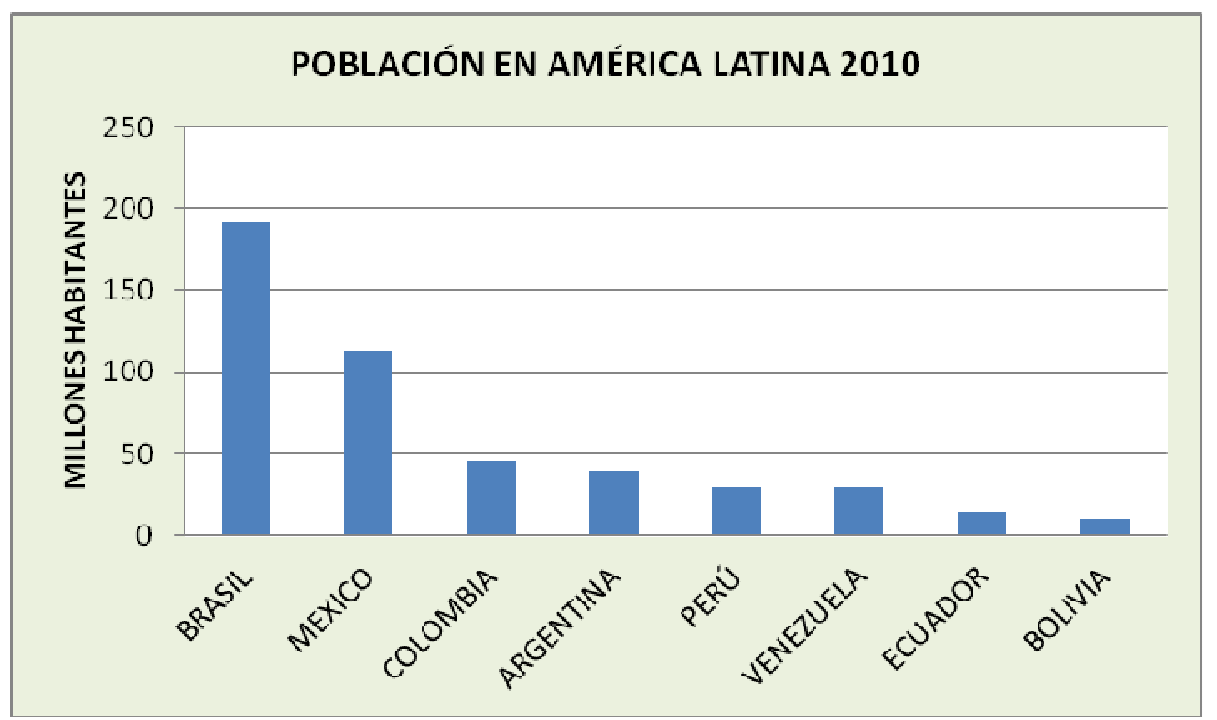

Fuente: http://es.wikipedia.org/wiki/Am\%C3\%A9rica_Latina Ilustración 13. Población en América Latina

El incremento de la población en los países latinoamericanos ha ido acompañado de una fuerte concentración urbana, que para el año 2010 se encuentra representada en un $75 \%$, con un aumento proporcional de población tugurizada estimada en 170 millones de personas ${ }^{120}$. Esta concentración urbana obedece básicamente a una estructura industrial altamente oligopolizada y con una orientación espacial fuertemente concentrativa, que aparece tardíamente en la década de los años sesenta y se establece cerca a las fuentes de provisión de materias primas o de energía ${ }^{121}$.

La concentración urbana en Latinoamérica es un fenómeno cuya consolidación comienza a partir de la década de los setenta, principalmente en países como México, Brasil, Argentina, Chile, Perú y Colombia. Ya en el año 2005 cuatro ciudades latinoamericanas superaban los 10 millones de habitantes: Ciudad de México, 18.9 millones; Sao Paulo, 19.5; Buenos Aires, 12.8 y Río de Janeiro 11.1. Igualmente se encontraban tres ciudades con población entre 5 y 10 millones de personas: Lima, 8.1; Bogotá, 7.5 y Santiago de Chile con 5.8 millones.

\footnotetext{
${ }^{120}$ Camargo, Angélica (2004): Op. Cit. Pág. 24.

121 Cuervo González, Luis Mauricio (1997): Evolución Reciente de las Disparidades Económicas Territoriales en América Latina. Texto disponible en http://www.eumed.net/libros/2010d/766/Primacia\%20urbana\%20caracteristicas\%20del\%20concepto\% 20y\%20evolucion\%20historica\%20del\%20fenomeno\%20en\%20America\%20Latina.htm
} 


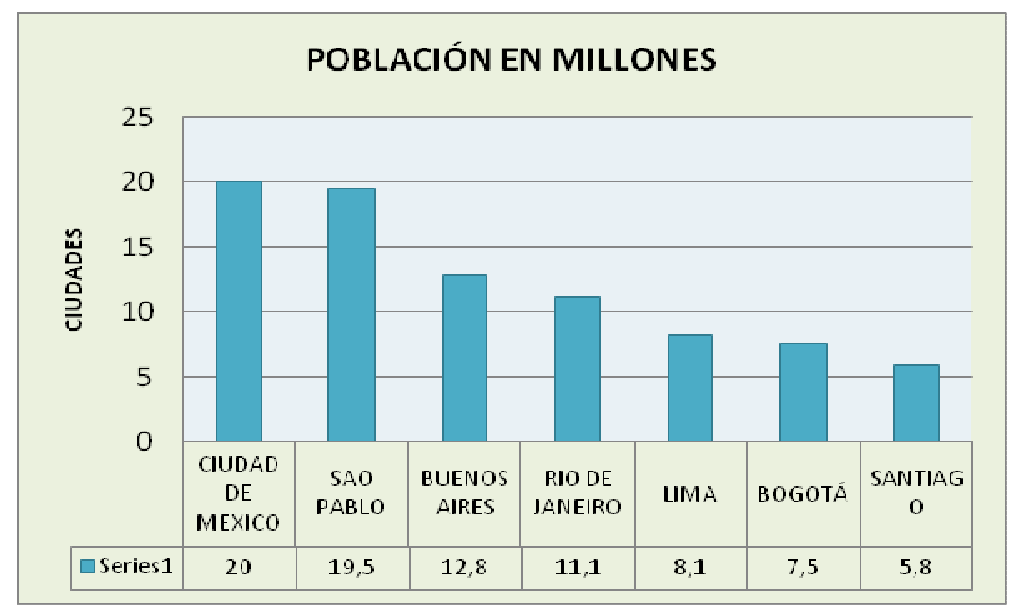

Fuente: Elaboración propia con datos de la CEPAL

Ilustración 14. Ciudades Latinoamericanas más pobladas 2010

Así mismo, para esa fecha hay catorce ciudades que tienen entre dos y cinco millones de habitantes y dentro de las cuales se destacan Belo Horizonte, Porto alegre, Recife, Guadalajara, Monterrey, Ciudad de Guatemala, San salvador, Caracas, Fortaleza, Medellín, La Habana, Cali, Guayaquil y Brasilia. En el rango entre uno y dos millones de habitantes se registran en el área veintisiete capitales, sobresaliendo Maracaibo, Campiñas, Valencia, Puebla, Puerto Príncipe, Barranquilla, Quito, Manaos, La Paz, Toluca, Córdoba, Monterrey, Rosario, Curitiba, Asunción, Ciudad de Panamá y Santa Cruz.

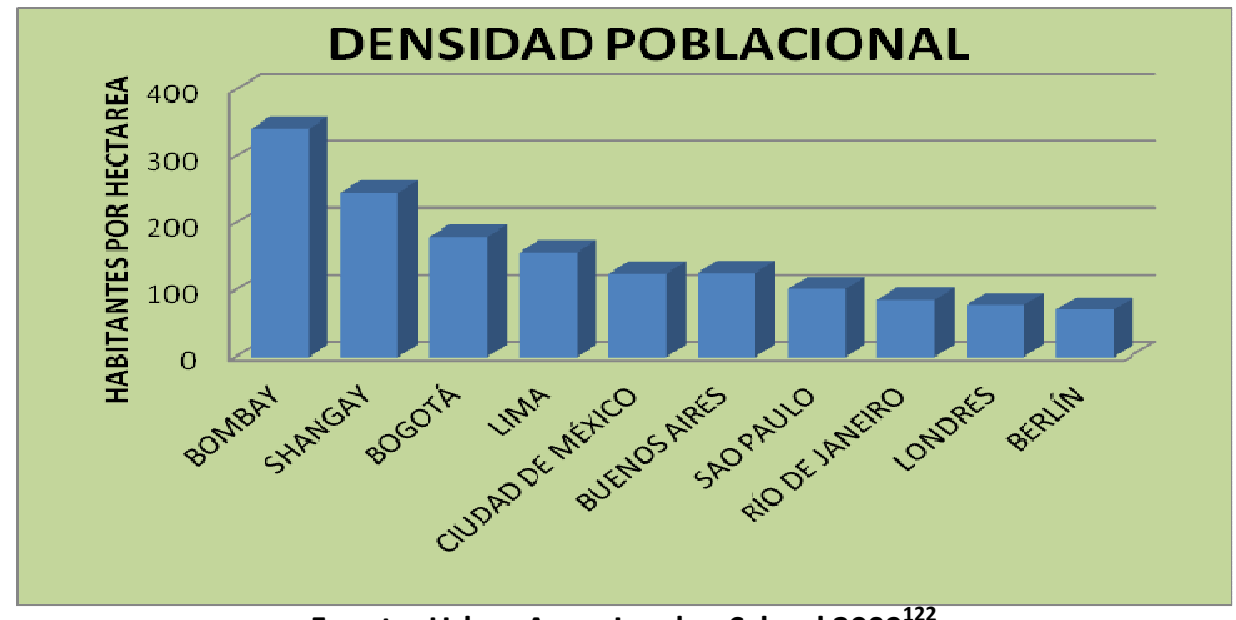

Fuente: Urban Age - London School $2009^{122}$

llustración 15. Densidad poblacional en principales ciudades

122 En Alcaldía de Bogotá (2010): Bogotá: Ciudad de Estadísticas. Boletín N²2. Densidades Urbanas. Disponible en http://www.sdp.gov.co/resources/Cartilla 22 Densidad Urbana Bogota.pdf 
A pesar del tamaño de su población, las ciudades latinoamericanas no son las más densas del mundo. Sin embargo, presentan densidades altas con respecto a las densidades de algunas ciudades europeas, principalmente Londres y Berlín, con promedios cercanos a los 80 habitantes por hectárea. Sobre este particular, destacamos que los promedios de las principales capitales de Latinoamérica se encuentran cercanos a los 150 Habitantes/ha, con excepción de Bogotá, cuyo número asciende a 180, y Río de Janeiro con apenas 86 habitantes por hectárea.

Este promedio cercano a los 150 habitantes/ha, incide directamente sobre los niveles de informalidad de la vivienda y calidad urbanística que presentan los asentamientos periféricos de las principales capitales y ciudades latinoamericanas. En este orden de ideas, ninguna de las capitales, o principales ciudades de este subcontinente, independientemente de sus niveles de densidad poblacional, escapa a la existencia de significativos sectores de informalidad urbana o a la presencia de población tugurizada, que en promedio se encuentra cercana al $30 \%$ del total de la población ${ }^{123}$.

En lo referente a densidad de las ciudades colombianas, destacamos, que presentan diferencias similares a la de las principales capitales latinoamericanas, situación que obedece fundamentalmente a factores económicos de localización de industria y a aspectos topográficos, que a su vez, inciden en la tipología edificatoria. En el caso especifico de Montería, con predominio de vivienda unifamiliar, la densidad es de 55 Habitantes/ha, cifra muy inferior a la de Bogotá, Medellín o Tunja; ciudades éstas, con mayor participación de vivienda multifamiliar y con menor disponibilidad de suelo urbanizable.

${ }^{123}$ Camargo, Angélica (2004): Op. Cit. Pág. 12 


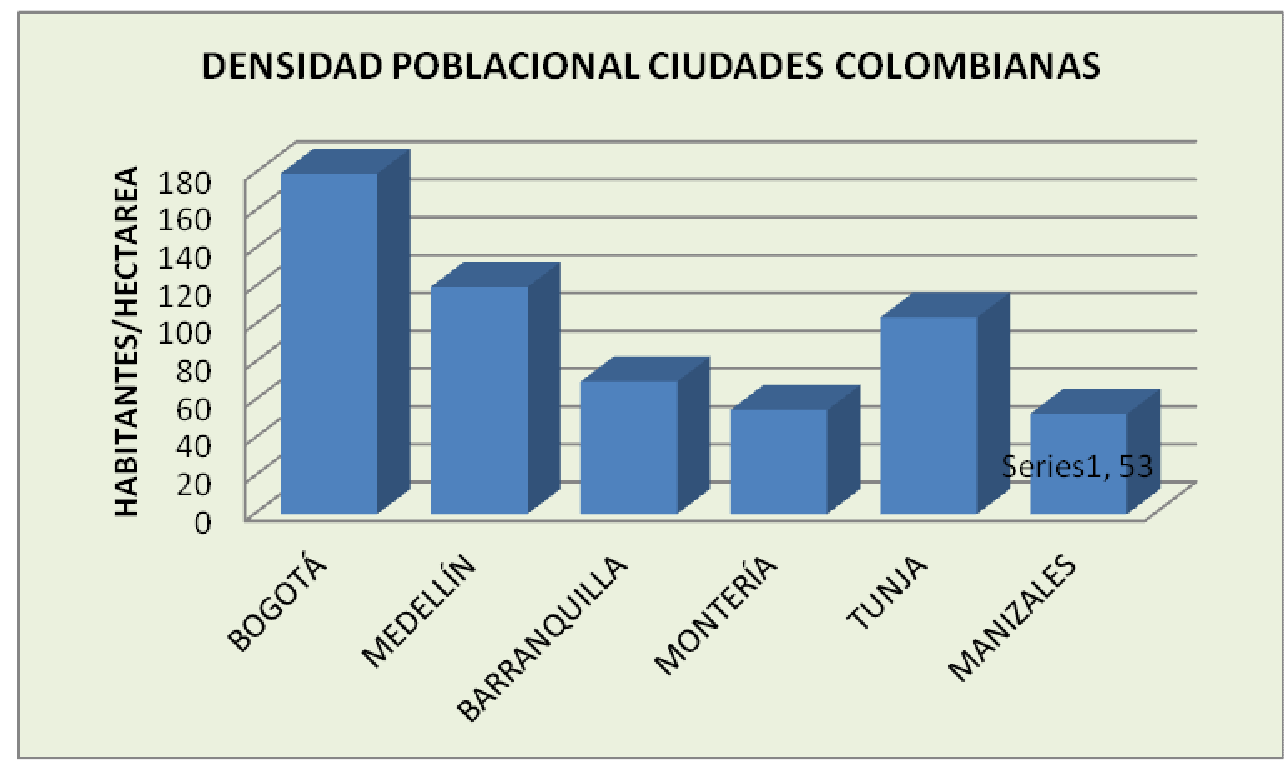

Fuente: elaboración propia a partir de datos del DNP 2007 Ilustración 16. Densidad poblacional en ciudades colombianas

De las ciudades colombianas, Bogotá es la única con población superior a siete millones de habitantes, correspondientes al $24 \%$ de la población urbana total. No obstante, también se presenta gran concentración urbana en Medellín y Cali, con más de dos millones de habitantes cada una, y en menor proporción la ciudad Barranquilla, con una población cercana al millón y medio de personas. Por su parte, Cartagena, Bucaramanga y Pereira, se encuentran en un tercer nivel con poblaciones cercanas al millón de habitantes.

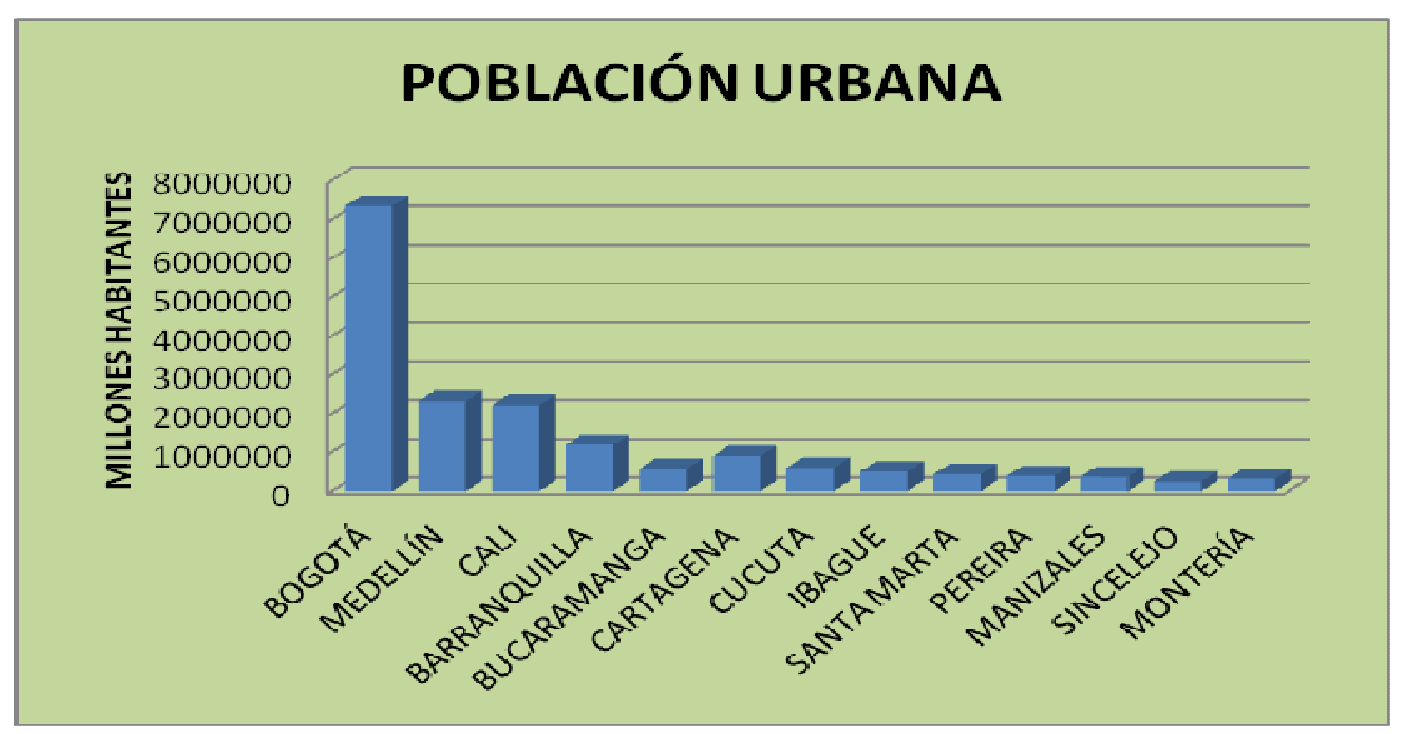

Fuente DANE 2010

Ilustración 17. Población ciudades colombianas 
En el cuarto nivel de ciudades encontramos treinta y un ciudades con población entre cien mil y quinientos mil habitantes, y dentro entro de las cuales se destacan Ibagué, Manizales, Neiva, Villavicencio, Cúcuta, Armenia, Santa Marta, Valledupar, Pasto, Popayán, Riohacha, Sincelejo y Montería. Entre todas ellas suman un poco más de siete millones seiscientos mil habitantes, correspondientes también al $24 \%$ de la población urbana total del país.

Es sorprendente la concentración de la población en la capital de la República, cuyo número actual de habitantes asciende a 7.347. 795, superando incluso, el número de habitantes que suman Medellín (2.309.446), Cali 2.207.994), Barranquilla (1.182.493), Cartagena (899.200) y Bucaramanga (567.286). En el mismo sentido, dobla la población total de las ciudades de Cúcuta, Ibagué, Santa Marta, Pereira, Manizales, Sincelejo, y Montería, todas ellas cercanas a los 500 mil habitantes. En la siguiente tabla se puede apreciar el tamaño de la población urbana con su correspondiente estructura.

\begin{tabular}{|cccc|}
\hline RANGO DE POBLACIÓN & CIUDADES & $\begin{array}{c}\text { POBLACIÓN } \\
\text { URBANA }\end{array}$ & $\%$ \\
\hline $\mathbf{5}$ MILLONES & 1 & 7.014 .111 & $21 \%$ \\
\hline $\mathbf{1 . 0 0 0 . 0 0 0}-\mathbf{5 . 0 0 0 . 0 0 0}$ & 3 & 5.677 .981 & $17 \%$ \\
\hline $\mathbf{5 0 0 . 0 0 0 - 1 . 0 0 0 . 0 0 0}$ & 3 & 2.192 .210 & $7 \%$ \\
\hline $\mathbf{1 0 0 . 0 0 0}-\mathbf{5 0 0 . 0 0 0}$ & 31 & 7.687 .906 & $24 \%$ \\
\hline $\mathbf{5 0 . 0 0 0}-\mathbf{1 0 0 . 0 0 0}$ & 41 & 2.832 .679 & $9 \%$ \\
\hline$<\mathbf{5 0 . 0 0 0}$ & 1019 & 7.296 .248 & $22 \%$ \\
\hline TOTAL & 1098 & 32.701 .135 & $100 \%$ \\
\hline
\end{tabular}

Fuente: Universidad Nacional - DANE - DNP (2007)

Tabla 8. Población Urbana Total

Ahora, en cuanto a tendencias de concentración urbana se estimó desde el año 2006, que para el año 2010 la población urbana sería del 78\% y el número de habitantes en todo el país ascendería a cuarenta y dos millones de personas. Igualmente se proyectó que el número de ciudades con más de un millón de habitantes pasaría de cuatro a siete y aquellas con más de cien mil habitantes aumentarían de treinta y ocho a cincuenta y cinco $^{124}$.

\footnotetext{
${ }^{124}$ Presidencia de la República, DNP y MAVDT (2006): Construir ciudades amables. Visión II Centenario. En http://www.presidencia.gov.co. Consultado abril de 2009.
} 
No obstante, la concentración de la población se traduce en tasas de desempleo superiores al $14 \%$, en informalidad económica por encima del $60 \%$, y en informalidad urbanística cercana al $30 \%$ del territorio urbano ${ }^{125}$, lo cual quiere decir que el crecimiento demográfico urbano no ha ido acompañado de acertadas políticas urbanas ni de políticas sociales que estimulen el equilibrio social y económico dentro de cada territorio.

En este orden de ideas, manifestamos que el crecimiento urbano sin políticas públicas acertadas finalmente es un elemento dinamizador de empleo informal, y por supuesto, de asentamientos informales, tanto en las principales capitales como en ciudades intermedias, incluida Montería; es decir, el aumento de la densidad poblacional ha venido acompañado del crecimiento de la ciudad informal.

${ }^{125}$ DANE (2010): Información disponible en www.dane.gov.co 


\section{CAPITULO 4}

\section{CIUDAD FORMAL Y CIUDAD INFORMAL EN COLOMBIA}

\subsection{LA CIUDAD FORMAL}

La ciudad formal en Colombia se ha desarrollado por medio de procesos de urbanización planificada de carácter estatal que incluyen las fases fundamentales de: parcelación (loteo), urbanización y edificación ${ }^{126}$, que suelen ser ejecutadas por entidades públicas de orden nacional, o local, e igualmente entre ambas. También participan promotores privados, quienes parcelan y/o urbanizan, sin encargarse de la edificación, generalmente ejecutada de manera individual por el comprador del lote. En pocos casos, estos promotores urbanos se encargan totalmente de las tres fases y luego lo trasladan a compradores con suficiente capacidad de pago para adquirir la vivienda terminada.

La urbanización planificada de carácter privado en Colombia se ha dedicado en los últimos años a la modalidad de conjuntos residenciales cerrados ${ }^{127}$, donde el loteo, la urbanización y la edificación se hacen de forma simultánea por un promotor privado, generalmente de vivienda en serie unifamiliar o multifamiliar con cerramientos y restricción de acceso, en lo que se denomina régimen de copropiedad. Estos barrios terminan convirtiéndose en instrumentos de segregación física y social, con altos impactos para la integración y para la movilidad.

La existencia de barrios formales en las ciudades colombianas ha estado ligada a su actividad económica, al volumen de programas de vivienda pública y al nivel de ingresos de sus habitantes. Sobre este último aspecto es importante anotar que los aspectos más valorados por las familias están relacionados con la propiedad de la vivienda, tamaño, espacios diferenciados, calidad arquitectónica, espacio para negocio, ubicación, independencia, seguridad y tranquilidad.

\footnotetext{
${ }^{126}$ Sola-Morales i Rubio, Manuel (1997): Las Formas de Crecimiento Urbano. Ediciones UPC. Barcelona

${ }^{127}$ Este el nombre que reciben los asentamientos intramuros en Colombia, y que ya no son exclusivos de sectores de altos ingresos, sino por el contrario, es un fenómeno expandido a clases medias y sectores populares.
} 
Los espacios diferenciados dentro de la vivienda que más se tienen en cuenta los sectores populares a nivel nacional son el baño, cocina, sala y alcobas; en cambio espacios como el jardín, antejardín, el patio y la terraza no son muy tenidos en cuenta en el interior del país pero si son valorados de manera significativa en la región Caribe y específicamente en la ciudad de Montería, debido a sus condiciones climáticas. Igualmente conviene recordar la importancia de la ubicación, el precio y primordialmente el sistema de financiación.

En lo referente a la planeación en Colombia, destacamos que durante el siglo XX este proceso fue liderado de manera autónoma por cada una de las principales ciudades del país, a través de la elaboración de planes reguladores o planes directores. Los primeros surgieron de iniciativas locales, ante la inexistencia de una Ley de la República en materia de Ordenamiento Territorial, que sirviera como eje articulador para el diseño de políticas urbanas de desarrollo. Dentro de las ciudades que planearon autónomamente su desarrollo sobresalen: Bogotá, Medellín, Cali, Barranquilla, Bucaramanga y Tumaco.

Los urbanistas, Karl Brunner, Le Corbusier, Josep Lluís Sert y Paul Wiener, visitaron nuestro país y contribuyeron con la elaboración de planes reguladores o pilotos de las ciudades mencionadas. Con su asesoría directa, o sin ella, se aprueba en el año 1945, el primer Código de Urbanismo de la ciudad de Bucaramanga ${ }^{128}$; en 1948 se elaboraron los planes de Medellín y Tumaco; en 1949 los de Cali y Bogotá y en 1951 el de Barranquilla ${ }^{129}$.

En el caso específico de Montería, su crecimiento no fue el producto de ningún plan de ordenamiento, sino de medidas momentáneas de intervención, o corrección, ejercidas por los funcionarios locales de planeación e infraestructuras. El primer instrumento de planeación fue el código de urbanismo que se aprobó mediante Acuerdo Municipal №

\footnotetext{
${ }^{128}$ Rueda, Néstor (2002): Evolución de las Políticas Normativas y Planes de Ordenamiento Urbano en la ciudad de Bucaramanga durante el siglo XX. Revista M Vol. 1 № 2.

${ }^{129}$ Schnitter, Patricia (2003): Los Planes Urbanísticos de Josep Lluís Sert y Paul Wiener. Revista Scripta Nova. Vol. VII № 146. PP. 1-8.
} 
026 del año de 1992, con el objetivo de controlar el crecimiento desordenado de la ciudad y estuvo vigente hasta el año 2002, fecha en la que se aprobó el primer y único plan de ordenamiento territorial hasta el momento.

Este plan de ordenamiento fue aprobado mediante Acuerdo № 0018 de octubre 31 de 2002 del Concejo de Montería, con el objetivo de regular la ocupación, el uso y la explotación del territorio. Teóricamente fue concebido como instrumento facilitador del crecimiento armónico y desarrollo de la ciudad, bajo criterios de sostenibilidad ambiental, humana, económica y social.

Los propósitos de este plan fueron "concertados" con el objetivo de integrar física y espacialmente una parte de la ciudad, que fue constituida al margen de las normas urbanísticas y del planeamiento. Igualmente se pretendía mejorar la calidad urbanística de los barrios que no ofrecían a sus residentes las dotaciones públicas necesarias para el desarrollo integral del ser humano.

\subsubsection{Las ciudades colombianas antes de la ley 388 de 1997.}

Como ya se comentaba en el aparatado anterior, el puerto de Tumaco y las principales cinco capitales de Colombia, fueron los ámbitos de las primeras experiencias de planeación, antes de que el ordenamiento territorial se convirtiera en obligatorio para cada municipio por medio de la Ley Orgánica de Ordenamiento Territorial del año 1997. Estos planes siguieron los patrones funcionalistas que predominaban para la década de los años cuarenta, en los que el espacio físico se organizó mediante redes viales jerarquizadas y zonificación unifuncional.

En estos primeros planes, la unidad vecinal fue propuesta como unidad básica de planeamiento para Medellín y para Cali, pero no para Bogotá, a la que se le aplicó el modelo de "sector" propuesto por Le Corbusier, al considerarse que la unidad vecinal resultaba pequeña para organizar barrios de gran superficie y con población superior a treinta y cinco mil habitantes. 
Por su parte, el resto de ciudades capitales siguieron un patrón de crecimiento urbano sustentado en la espontaneidad y en los intereses locales de algunos actores políticos o económicos. No obstante, cada una de ellas partió de trazados iniciales o fundacionales que por lo menos permiten, en el mejor de los casos, una aceptable lectura de su actual estructura urbana y la explicación de algunas intervenciones urbanísticas, esencialmente aquellas relacionadas con los programas públicos de vivienda y sus respectivos emplazamientos.

\subsubsection{Los programas de vivienda pública en Colombia.}

La preocupación por el problema de la vivienda en Colombia surge a partir de 1918, debido a las precarias condiciones sanitarias en que vivían los sectores sociales más vulnerables. Es en este año cuando se aprueba la Ley 46 con el objetivo de financiar la construcción de viviendas higiénicas por medio de aportes municipales, y para lo cual, toda ciudad con población superior a quince mil habitantes debía destinar obligatoriamente el $2 \%$ de su presupuesto para el desarrollo de vivienda popular ${ }^{130}$. En el ámbito de la vivienda, este periodo, que va de 1918 a 1939, se conoce también como Fase Higienista.

La "Junta de Habitaciones para Obreros" sería la primera entidad pública encargada de financiar proyectos de vivienda popular en Colombia, y a su vez permitiría la construcción del barrio obrero "Restrepo" de Bogotá en el año 1930, y la del también barrio obrero "Centenario", tres años más tarde y en la misma ciudad, con la coordinación del departamento de Urbanismo de la Secretaría de Obras Públicas y la asesoría de Karl Brunner.

130 Espinosa, León (2006): El Estado en la Construcción de las Áreas Residenciales en Bogotá. http://facartes.unal.edu.co. Consultado 24 de mayo de 2010. 




Fuente: Brunner, Karl. Manual de Urbanismo. Tomo $\|^{131}$

Ilustración 18. Vivienda tipo de primeros programas de promoción pública

Las imágenes corresponden a la planta arquitectónica y a las viviendas tipo del barrio Centenario, el cual se convirtió en un importante proyecto de viviendas para obreros, con una superficie de $17 \mathrm{~m} \times 17$ y está conformada por una habitación, cuarto de baño, cocina y un gran patio para cultivos de auto-subsistencia. Estas viviendas se caracterizaron principalmente por la gran superficie de los lotes y por las posibilidades de ampliación en el futuro.

En el año 1939 se crea el Instituto de Crédito Territorial (ICT) por medio del Decreto Ley 200 del 28 de enero, entidad que nace como una institución de crédito para fomentar la construcción de viviendas higiénicas en zonas rurales de Colombia y es conformada con aportes del gobierno nacional, los departamentos y los municipios. Este periodo se conocería como Fase Institucional y se extendería hasta el año 1965.

Tres años más tarde, en 1942, se crea la sección de vivienda urbana por medio del Decreto Ley 1579, con el objetivo de orientar recursos a municipios para la construcción de barrios populares. Ese mismo año se constituye la Caja de Vivienda Popular de Bogotá y cinco años después, por medio de la Ley 57 se crea la Caja de Vivienda Militar. Con estas instituciones, y el apoyo del Banco Central Hipotecario, el

${ }^{131}$ En Espinosa Restrepo, León (2000): El Estado en la construcción de las áreas residenciales de Bogotá. Maestría en Urbanismo. Universidad Nacional. Bogotá. Texto disponible en http://www.facartes.unal.edu.co/portal/publicaciones/urbanismos/urbanismos2/Estado construccion areas residenciales.pdf 
estado colombiano buscaba resolver el problema de alojamiento de obreros y empleados oficiales.

Con mayores recursos para alojamientos urbanos, en el año 1949 el ICT desarrolló el proyecto los Alcázares en Bogotá, el cual se destaca por ser el primero en construir viviendas en serie. Ese mismo año se construyó el barrio Muzo en esa misma ciudad, con edificaciones dispuestas en medio de áreas verdes y vías peatonales para la movilidad.

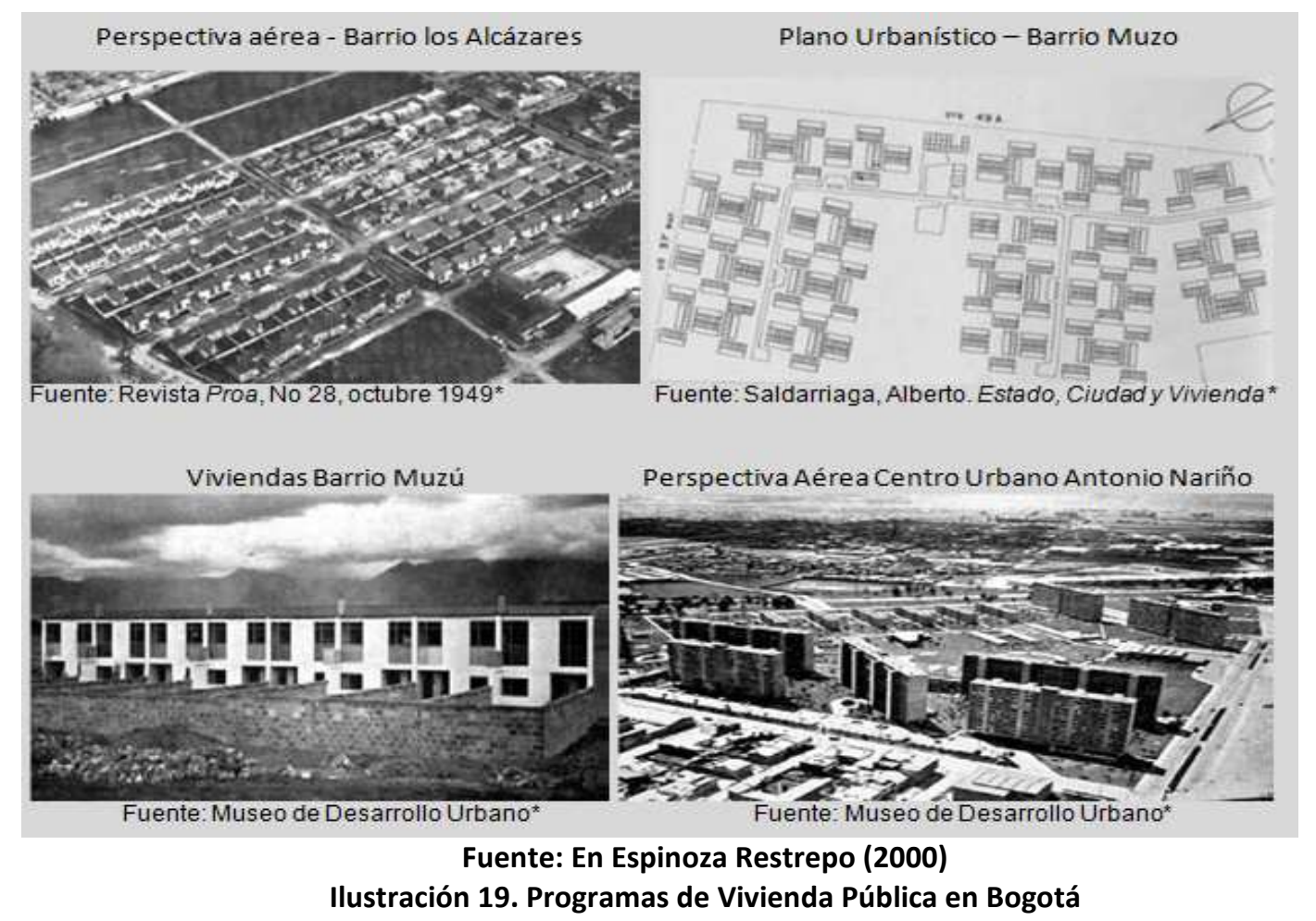

En el año 1948 esta institución inició la construcción directa de vivienda y diez años más tarde inicia los planes de autoconstrucción de vivienda urbana. Como dato importante, anotamos que en ese periodo, concretamente en el año 1961, se obtienen créditos y recursos externos provenientes de los Estados Unidos por medio del programa de cooperación internacional "Alianza para el Progreso", que permitió la adjudicación de catorce mil soluciones de vivienda en el proyecto Ciudad Kennedy en Bogotá. 


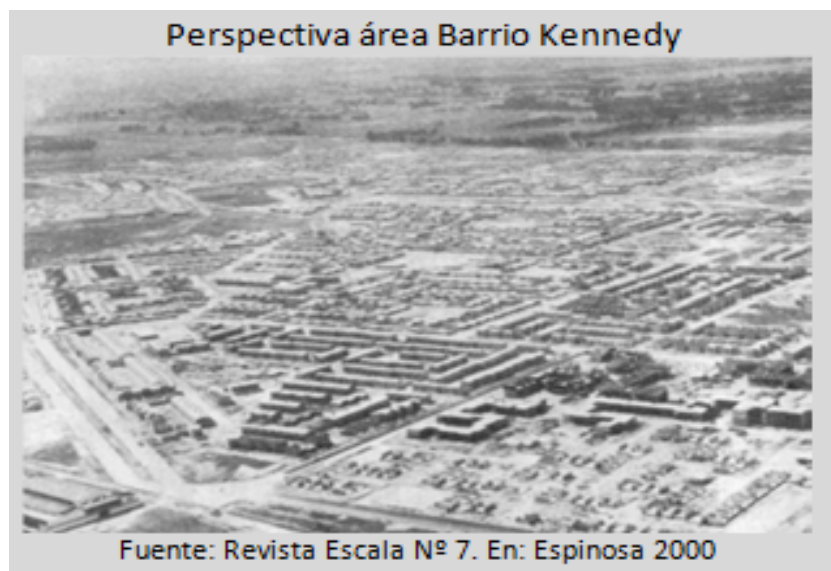

Ilustración 20. Perspectiva aérea del barrio Kennedy en Bogotá

Los proyectos arquitectónicos se iniciaron en los años cuarenta pero fue a partir del año 1957, cuando la acción del ICT se concentra con gran intensidad en las áreas urbanas de todo el país. No obstante, se destaca que en el periodo comprendido entre 1937 y 1956 (año éste en que desaparece el área de vivienda rural), se construyeron aproximadamente 14.000 viviendas en municipios considerados rurales. Igualmente es importante anotar que hasta el año 1991 (año de liquidación del ICT), se ejecutaron 2.621 proyectos de vivienda urbana en todo el país, que permitieron la construcción de 548.497 viviendas $^{132}$.

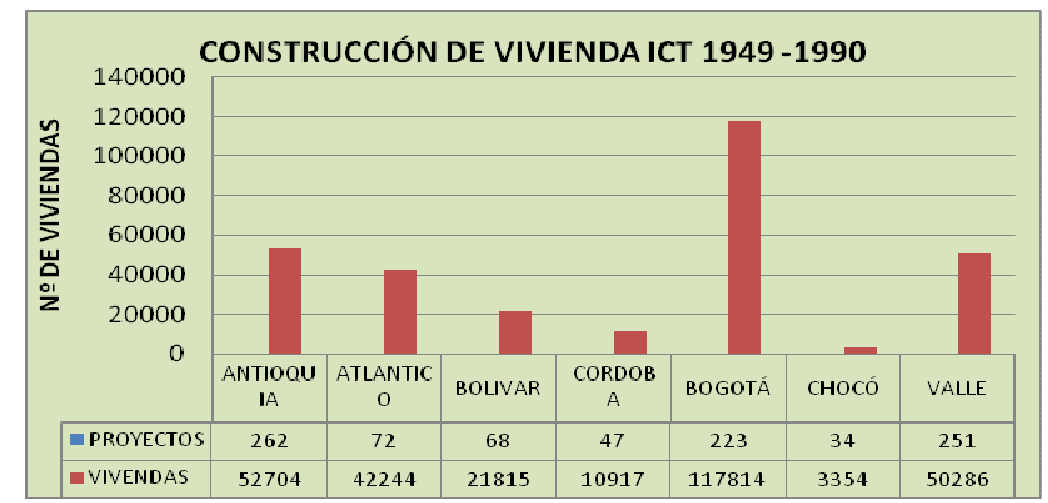

Fuente: Contraloría General de la República en Arango (1982) Ilustración 21. Construcción de vivienda pública en Colombia

En una abierta manifestación de centralismo, la ciudad de Bogotá concentró 223 proyectos, que permitieron la construcción de 117.814 viviendas, correspondiente al

\footnotetext{
132 Maya Sierra, Tania (2000): "Áreas residenciales y desarrollo urbano en Bogotá". Maestría en Urbanismo. Universidad Nacional de Bogotá. Texto disponible en: http://facartes.unal.edu.co/portal/publicaciones/urbanismos/urbanismos2/Areas residenciales desarr ollo urbano.pdf
} 
$21.5 \%$ del total de viviendas construidas por el ICT en todo el territorio nacional ${ }^{133}$. Igualmente se evidencia gran concentración en los departamentos de Antioquia y Valle del Cauca, que junto con la capital absorbieron el 30\% de todos los programas de promoción pública, en un escenario conformado por otros veintinueve departamentos.

Esta concentración en los tres departamentos de mayor desempeño económico, tuvo un fuerte impacto sobre otras regiones, principalmente de la costa Caribe colombiana y de la región del pacifico. En este sentido, Córdoba y Chocó, los dos departamentos más pobres y atrasados de Colombia, solamente se vieron favorecidos con un reducido número de proyectos (81), que escasamente permitieron la construcción de 12.000 viviendas; es decir el $3 \%$ de todos los proyectos desarrollados en el país y el $2 \%$ de las viviendas construidas en todo el territorio nacional.

\begin{tabular}{|ccccc|}
\hline SECCIONAL & No de Proyectos & $\begin{array}{c}\text { \% } \\
\text { proyectos }\end{array}$ & No de viviendas & $\begin{array}{c}\text { \% } \\
\text { viviendas }\end{array}$ \\
\hline Antioquia & 262 & 9.95 & 52.704 & 9.48 \\
\hline Atlántico & 72 & 2.73 & 43.244 & 7.78 \\
\hline Bolívar & 68 & 2.58 & 21.815 & 3.92 \\
\hline Caldas & 136 & 5.16 & 24.145 & 4.34 \\
\hline Cesar & 74 & 2.81 & 7.570 & 1.36 \\
\hline Córdoba & 47 & 1.78 & 10.917 & 1.99 \\
\hline Distrito Capital & 223 & 8.47 & 117.814 & 21.20 \\
\hline Chocó & 34 & 1.29 & 3.354 & 0.60 \\
\hline Guajira & 33 & 1.26 & 1.901 & 0.34 \\
\hline Magdalena & 55 & 2.09 & 9.313 & 1.67 \\
\hline Sucre & 29 & 1.10 & 5.107 & 0.91 \\
\hline Valle & 251 & 9.53 & 50.286 & 9.05 \\
\hline Otros & 1337 & 51 & 200.327 & 37 \\
\hline Total & $\mathbf{2 . 6 2 1}$ & 100 & 548.497 & 100 \\
\hline
\end{tabular}

Fuente: Contraloría General de la República en Arango (1982)

Tabla 9. Proyectos y Construcción de Viviendas por Departamentos

Departamentos de bajo desarrollo socioeconómico como Sucre y La Guajira, resultaron más afectados que los anteriores, y recibieron menos del $50 \%$ de las viviendas asignadas a Chocó y Córdoba, a pesar de tener poblaciones similares y déficit de viviendas homogéneos. Como dato relevante destacamos que otros departamentos

${ }^{133}$ Ibídem. Pág. 31. 
del interior, con población similar a los del Caribe, recibieron el 51\% de los proyectos correspondientes a 200.327 unidades, mientras que todos los del Caribe escasamente sumaron el 13\%, que no superan las 90.000 viviendas.

Si bien es admisible la diferencia en el tamaño de la población entre los departamentos analizados, consideramos que esta distribución es altamente inequitativa, sobre todo porque ni siquiera tuvo en cuenta los altos déficit de vivienda, las precarias condiciones socio-económicas de sus habitantes, ni la débil estructura económica de cada una de estas regiones. Sin embargo, también debemos destacar que dentro del departamento de Córdoba se presentó otro gran desequilibrio en la construcción de vivienda, que se tradujo en la edificación de cerca de nueve mil viviendas en Montería, correspondiente a más del $80 \%$ del total departamental.

\subsubsection{La vivienda pública en Montería}

En este apartado nos parece oportuno recordar las diferencias entre los programas de vivienda pública terminada y los fraccionamientos públicos para autoconstrucción de viviendas. Como sus nombres lo indican, el primero se orientó a la venta de la vivienda construida, mientras el segundo, estuvo orientado a la cesión gratuita de un lote de dominio público para la auto-construcción del alojamiento por parte de los beneficiarios. Por lo tanto, aquí nos concentraremos en el análisis de los primeros y dejaremos los segundos para analizarlos con más detalle en el apartado correspondiente a asentamientos informales por fraccionamientos públicos.

Ahora bien, la creación de este instituto en el año 1939, y la apertura de la sección de vivienda urbana en 1942, permitiría a todos los municipios del país la posibilidad de acceder a proyectos de vivienda pública con recursos del gobierno central. Estos primeros proyectos se caracterizarían por ofrecer soluciones unifamiliares en amplios lotes, cuyas superficies para el caso de Montería, alcanzaban hasta los 162 metros cuadrados ( 9 x 18), y por presentar favorables condiciones urbanísticas.

El Instituto de Crédito Territorial (ICT), como entidad encargada de la vivienda pública, comenzó actividades en Montería en el año de 1951, y dentro de los programas 
desarrollados hasta la fecha se establecieron las dos modalidades que anteriormente señalábamos, y que desde esta investigación, preferimos denominar como "asentamientos de promoción pública de vivienda" y "asentamientos informales por fraccionamientos públicos". Estas denominaciones ya fueron definidas oportunamente dentro del marco conceptual de este estudio.

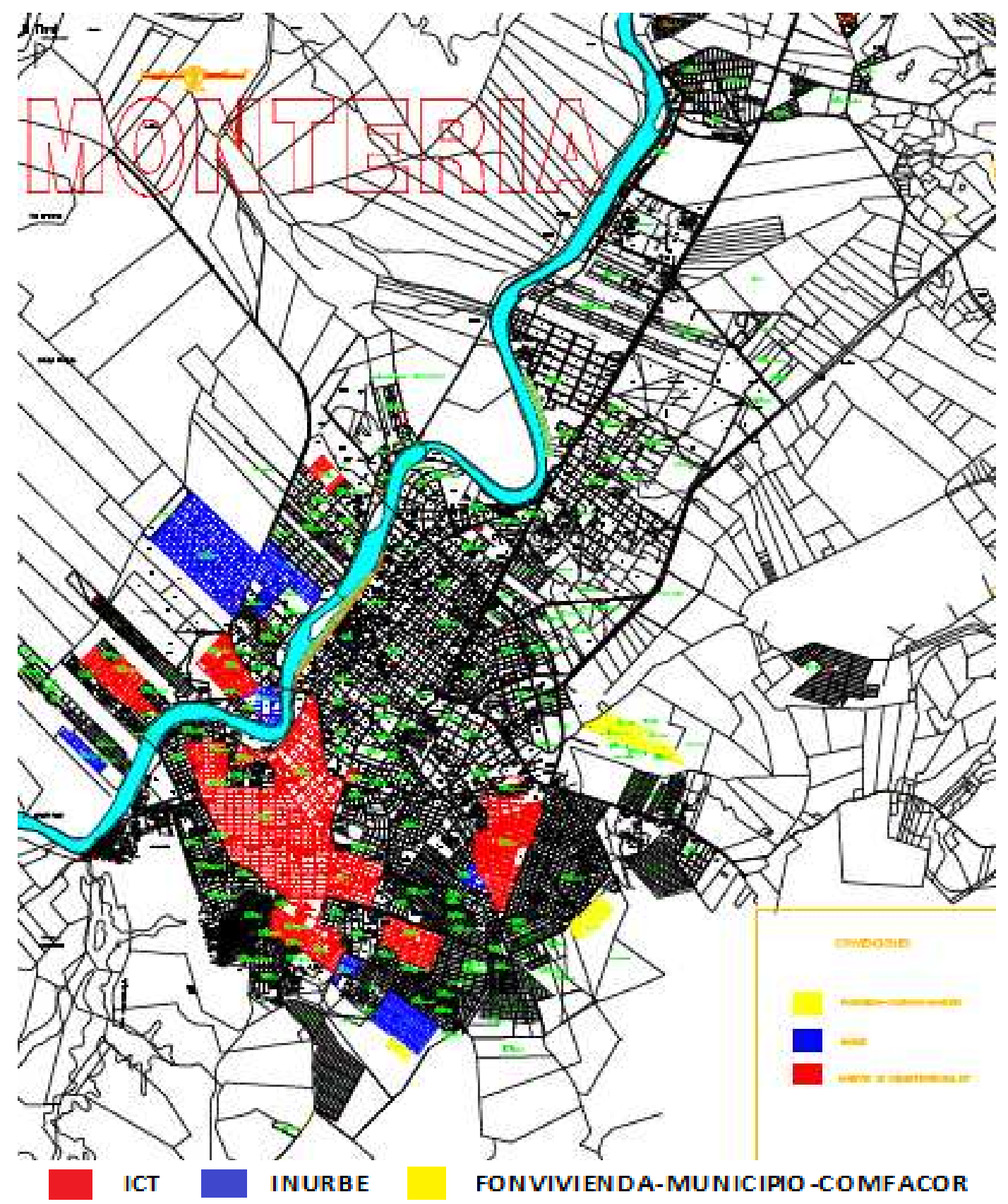

Fuente: elaborado por Elkin Herrera y Jhon Pinedo 2011 Ilustración 22. Plano de Vivienda Pública en Montería 
Los primeros programas del ICT en Montería son clasificables dentro de la primera modalidad, ya que los objetivos de los proyectos estuvieron dirigidos a la construcción de la vivienda, la entrega a su beneficiario y a la financiación de la misma. En esta modalidad, el Instituto fue el encargado del proceso de parcelación, urbanización y edificación en serie de la vivienda, que para todos estos casos correspondió a unifamiliar en planta baja.
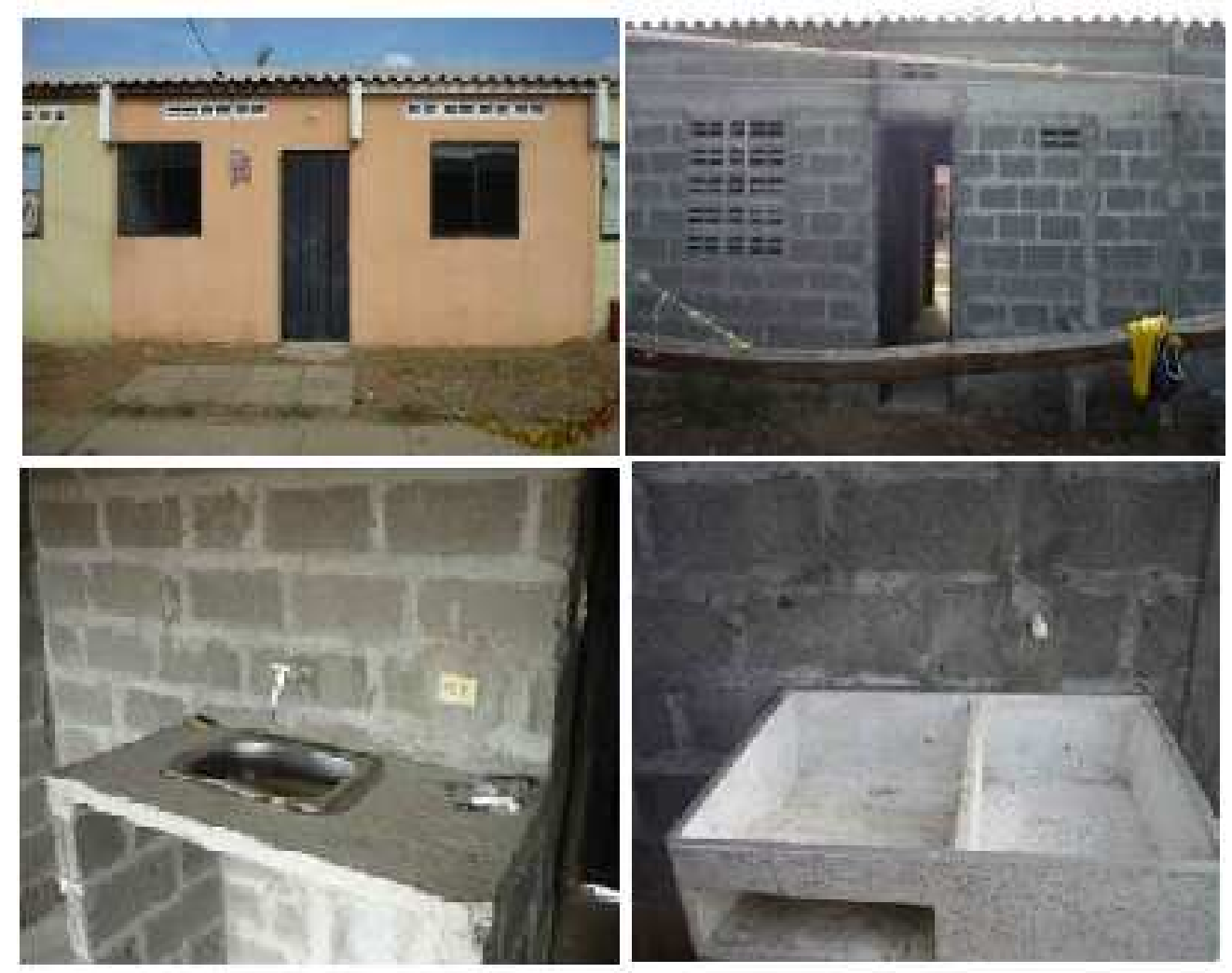

Fuente Fotográfica: Alcaldía de Montería 2010

Ilustración 23. Estado de entrega Vivienda Pública

Esta ha sido la tipología predominante en los programas de promoción pública de vivienda en Montería, que generalmente se entregan inconclusas, pero con posibilidades de ampliación o de remodelación. Esta modalidad de entrega se denomina popularmente como entrega en obra negra, que no es más que la vivienda en su estado rustico, sin pañetes, estucado, enchapados baldosines, con deficiencia en los servicios y sin ningún tipo de acabados; eso sí, muy bien maquillada en su fachada. 

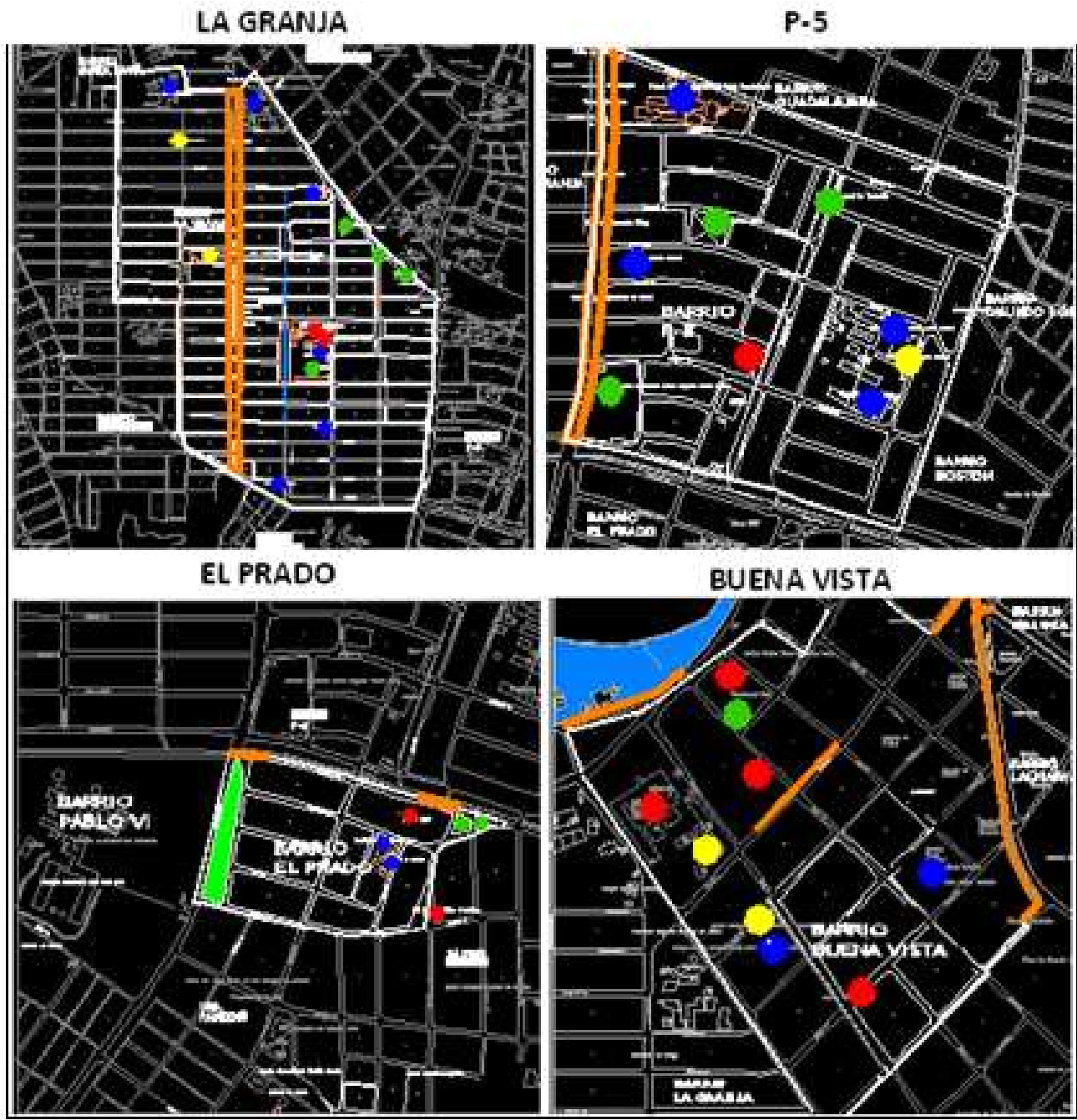

\section{educativo $\bigcirc$ zona verde - INSTItucional - MIXTo Religioso}

Fuente: González, Mélida y Otros (2005): Antecedentes de La Vivienda Subsidiada en Montería. Unisinú. Ilustración 24. Plano de los primeros barrios de promoción pública en Montería

El primer proyecto de vivienda pública en Montería fue el del barrio Obrero, y como anotábamos anteriormente, fue desarrollado en el año 1951, con apenas sesenta viviendas y sin mayor impacto sobre el plano urbano. Sin embargo, la década de los sesenta, sería el periodo en que comenzarían a desarrollarse los primeros programas masivos de vivienda en el sur de la ciudad, con los proyectos de Buenavista, la Granja, la Coquera y el P-5.

Estos cuatro proyectos fueron realizados dentro del planeamiento urbano, a distancias considerables del centro de la ciudad, con nuevo tipo de manzana, y nuevos esquemas viales que contribuirían a la aparición del transporte público urbano, a los primeros 
fraccionamientos públicos por parte del ICT, y a los primeros fraccionamientos privados irregulares. Los fraccionamientos públicos que surgieron con estos programas de vivienda terminada fueron el Prado y Boston en el entorno del P-5, y Policarpa Salavarrieta, San Martín, Pastrana Borrero, Santander y Santafé en terrenos cercanos al barrio la Granja. Sobre ellos, reiteramos, haremos referencia en el apartado correspondiente.

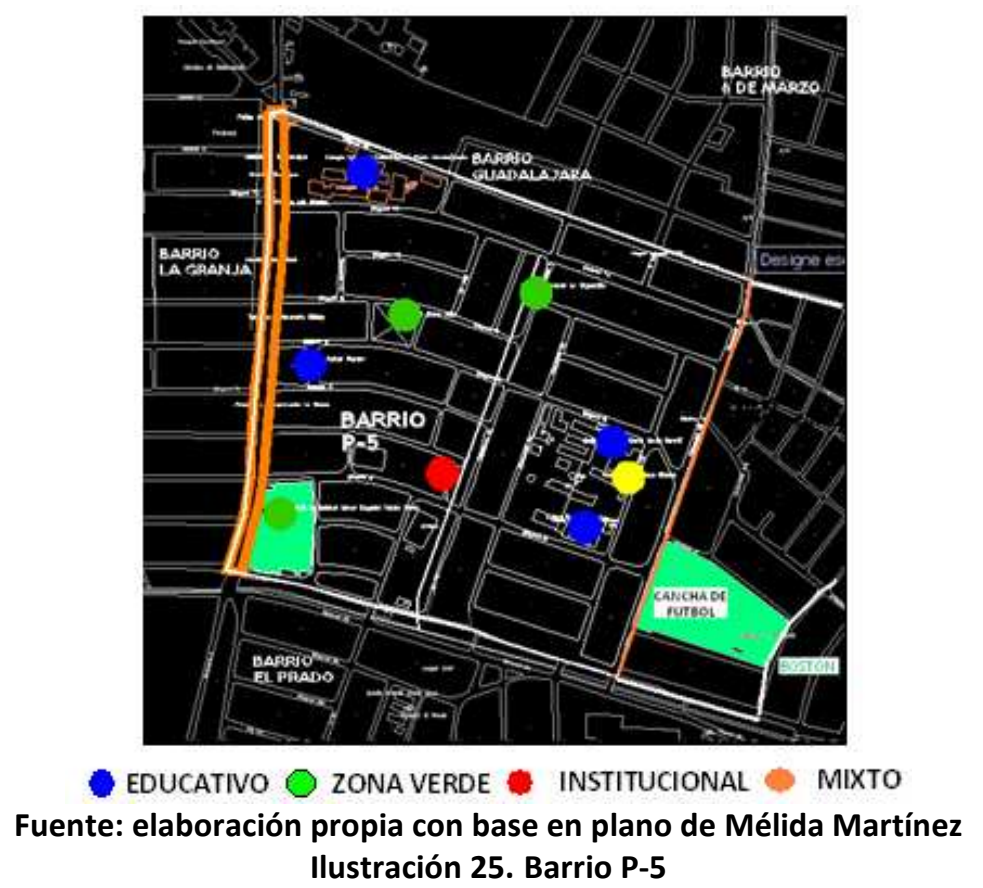

La mayor disposición de espacio público y equipamientos de estos primeros cuatro programas públicos se encuentra en el P-5, donde se ubican actualmente los colegios Cristóbal Colón y María Goretti, el estadio de beisbol menor Eugenio Valdez y la cancha de futbol que lleva el mismo nombre del barrio. Esta cancha de futbol integra al P-5 con el barrio Boston y la de beisbol lo integra con el barrio el Prado; ambas, sombreadas de verde en la ilustración 25. 

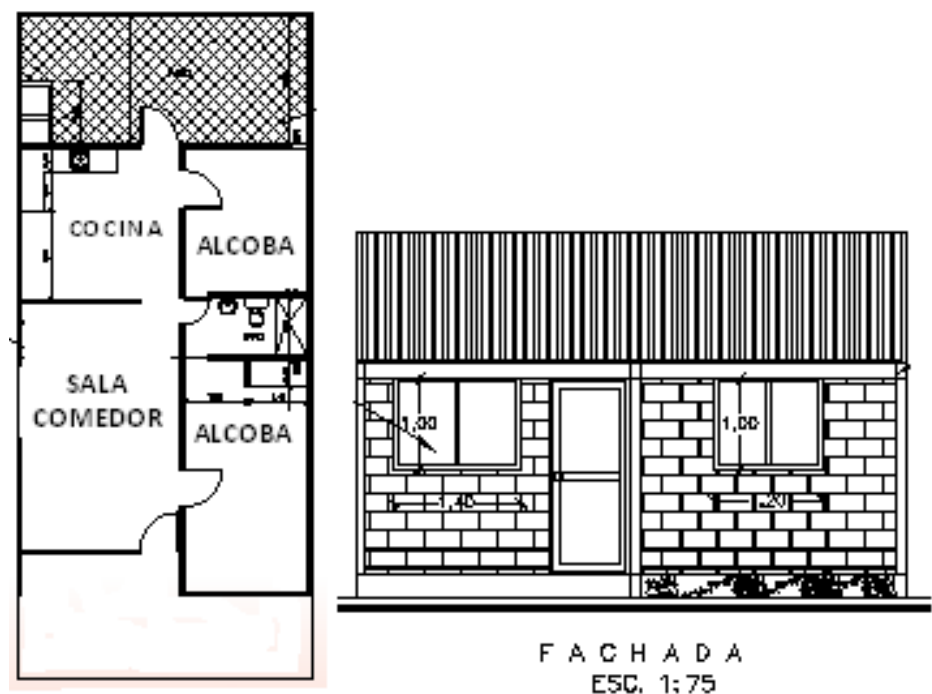

F A C H A D A

E5C. 1:75

Plano elaborado por Mélida González

Ilustración 26. Vivienda Tipo barrió P-5

La vivienda unifamiliar construida en lote de 162 metros cuadrados ( $9 \times 18$ ), que se entregó a los beneficiarios del P-5, estuvo conformada inicialmente por una salacomedor, una alcoba principal de 20 metros, cuarto secundario, cocina, cuarto de baño y patio de labores. El espacio para baño y cocina fue muy reducido, pero la superficie del lote permitiría su ampliación, así como la construcción de una nueva habitación. En total fueron 65 metros cuadrados de suelo construido para las viviendas de este proyecto y también para las de la Granja, Buenavista y la Coquera.

En la misma década de los sesenta se presentaron invasiones en las zonas verdes de esos dos primeros proyectos públicos, que en su momento fueron llamadas popularmente como "Toldo Sucio"134. Estas ocupaciones irregulares forzaron al ICT a desarrollar un nuevo proyecto de fraccionamiento público en el año 1969, denominado barrio Santafé, en el que se ofrecieron 158 lotes para las familias invasoras de esa época.

El crecimiento de la población, así como la elevada demanda de vivienda, originaron en ese mismo año una nueva invasión a orillas del río Sinú, que posteriormente se

\footnotetext{
${ }^{134}$ Esta información no se encuentra documentada pero fue obtenida de fuente primaria por medio de entrevista realizada por Jhon Pinedo López a Lamberta López, del Barrio Boston; Eustorgia Castro del Prado, y Antonio López Castro del P-5. Las dos primeras fueron beneficiarias de Lotes en el año 1965 y el último fue beneficiario de vivienda en el año 1963. Entrevista realizada 17 de septiembre de 2009.
} 
convirtió en nuevo programa de legalización de lotes por parte del ICT. Este programa fue denominado Brisas del Sinú y permitió la legalización de 173 viviendas en unas condiciones urbanísticas y ambientales bastante precarias. Tanto este barrio como Santafé serán analizados en el apartado correspondiente a asentamientos informales por fraccionamientos públicos.

Para la década de los años setenta, la dinámica de crecimiento de la ciudad continuaría con los proyectos de vivienda pública de la Ribera y de la Pradera, en 1970 y 1973 respectivamente. En el primero se construyeron 540 casas y en el segundo 2.109 viviendas en lotes de 98 metros cuadrados $(7 \times 14)$ y con diseños diferentes a los de los primeros programas de promoción pública.

La Pradera se convertiría en el proyecto dinamizador del oriente de la ciudad, y la Ribera haría lo propio en el occidente. Estos dos proyectos, al igual que la Granja en el sur, serían a la postre, las intervenciones que marcarían la pauta para el surgimiento de asentamientos informales actualmente consolidados, y en aceptables condiciones urbanísticas. Dentro de los favorecidos por las dotaciones públicas de estos tres programas de promoción se encuentran: Cantaclaro en el oriente; Rancho Grande en el occidente y San Martín en el sur.

LA RIBERA

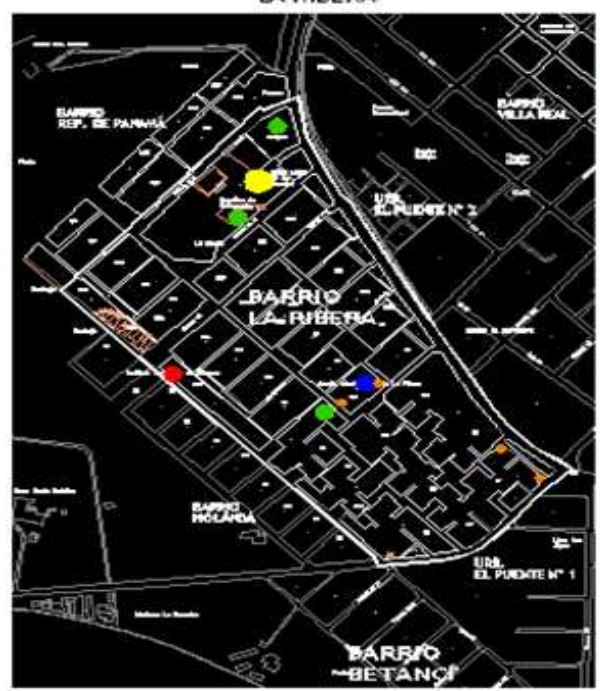

LA PRADERA

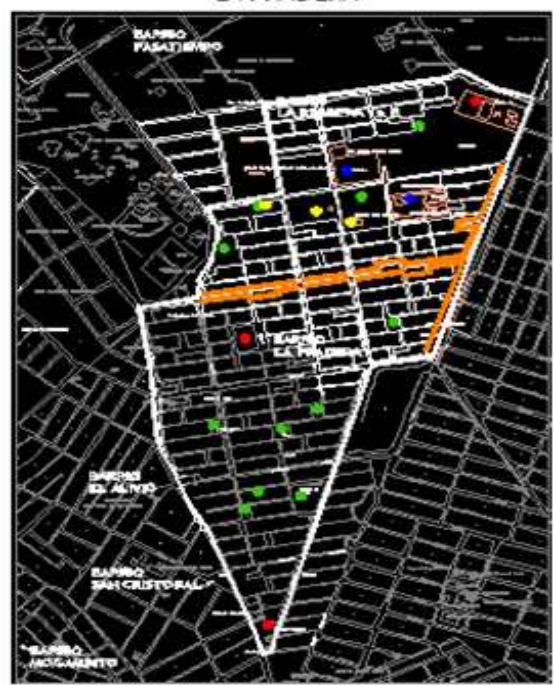

educativo zONA Verde anstitucional $\rightarrow$ MIXTo

RELIGIOSO

Fuente: González, Mélida y otros (2005)

Ilustración 27. Barrios La Ribera y La Pradera 
Para el diseño de estos nuevos proyectos no se contó con la misma disponibilidad de terrenos que se tuvo en los primeros y por el contrario se presentaron restricciones que limitaron las superficies de las viviendas, los equipamientos y las vías. Estos dos barrios incorporaron conceptos diferentes de manzanas con aceptables reservas para dotaciones públicas, especialmente la Pradera, y la principal novedad en cuanto a espacio público, estuvo asociada a la diminución de los perfiles viales internos y a la pavimentación de los mismos.

Los dos proyectos estuvieron dotados de equipamientos colectivos y de redes de infraestructura básica que facilitaron la integración social de sus beneficiarios. En este sentido, la superficie asignada para dotaciones de cada proyecto se aproximó al 35\% del total del área, en la que se ubicaron principalmente equipamientos educativos, recreativos, deportivos y religiosos. Es importante anotar que las plazas, los parques y las canchas deportivas son identificados dentro de cada plano por una misma convención; lo cual explica el predominio del color verde en cada uno de ellos.

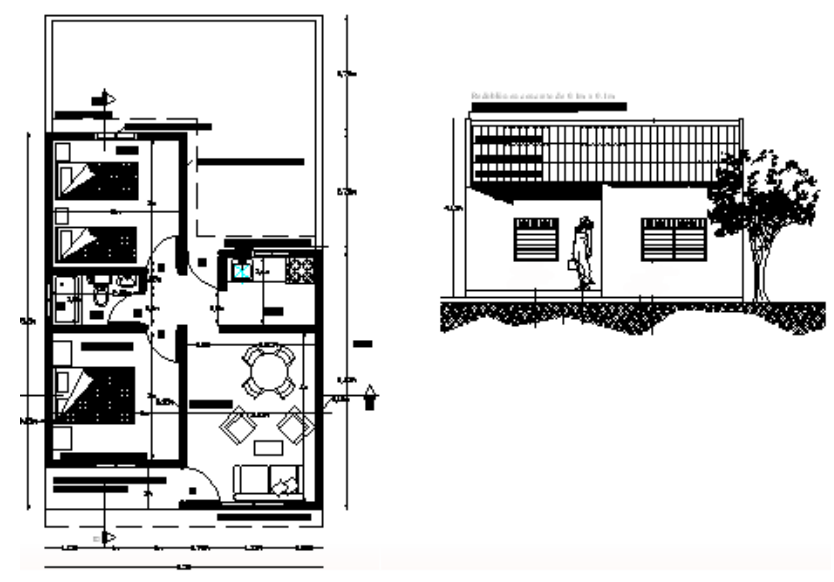

Plano Elaborado por Mélida González llustración 28. Vivienda Tipo Barrio La Pradera

Las viviendas fueron entregadas en el año 1973, durante el periodo del Presidente Misael Pastrana Borrero, en lotes de 162 metros cuadrados ( $9 \times 18$ ) y estuvieron dotadas de una sala-comedor, dos habitaciones, cocina, un cuarto de baño y un patio de labores que brindaba la posibilidad de ampliación de la vivienda. El proyecto fue dotado con siete parques, cinco canchas deportivas, vías con diferentes perfiles, agua potable y alcantarilladlo. 
Los programas de promoción pública en Montería tuvieron un receso durante el periodo 1974 - 1978 del presidente Alfonso López Michelsen, quien en su Plan de Desarrollo "Para Cerrar la Brecha", no tuvo como prioridad la construcción de viviendas en el país. Este receso en la oferta pública de vivienda estimuló los fraccionamientos privados irregulares, así como las invasiones en estos cuatro años, las cuales se manifestaron a través de la constitución de los barrios la Esperanza en 1975, 7 de Mayo en 1976 y Nueva Esperanza en 1977; sin embargo también se conformaron barrios confortables de iniciativa privada como el Recreo, Urbina y Costa de Oro ${ }^{135}$. Estos barrios se pueden apreciar delimitados dentro del círculo y rectángulos de color verde que aparecen en el siguiente plano.

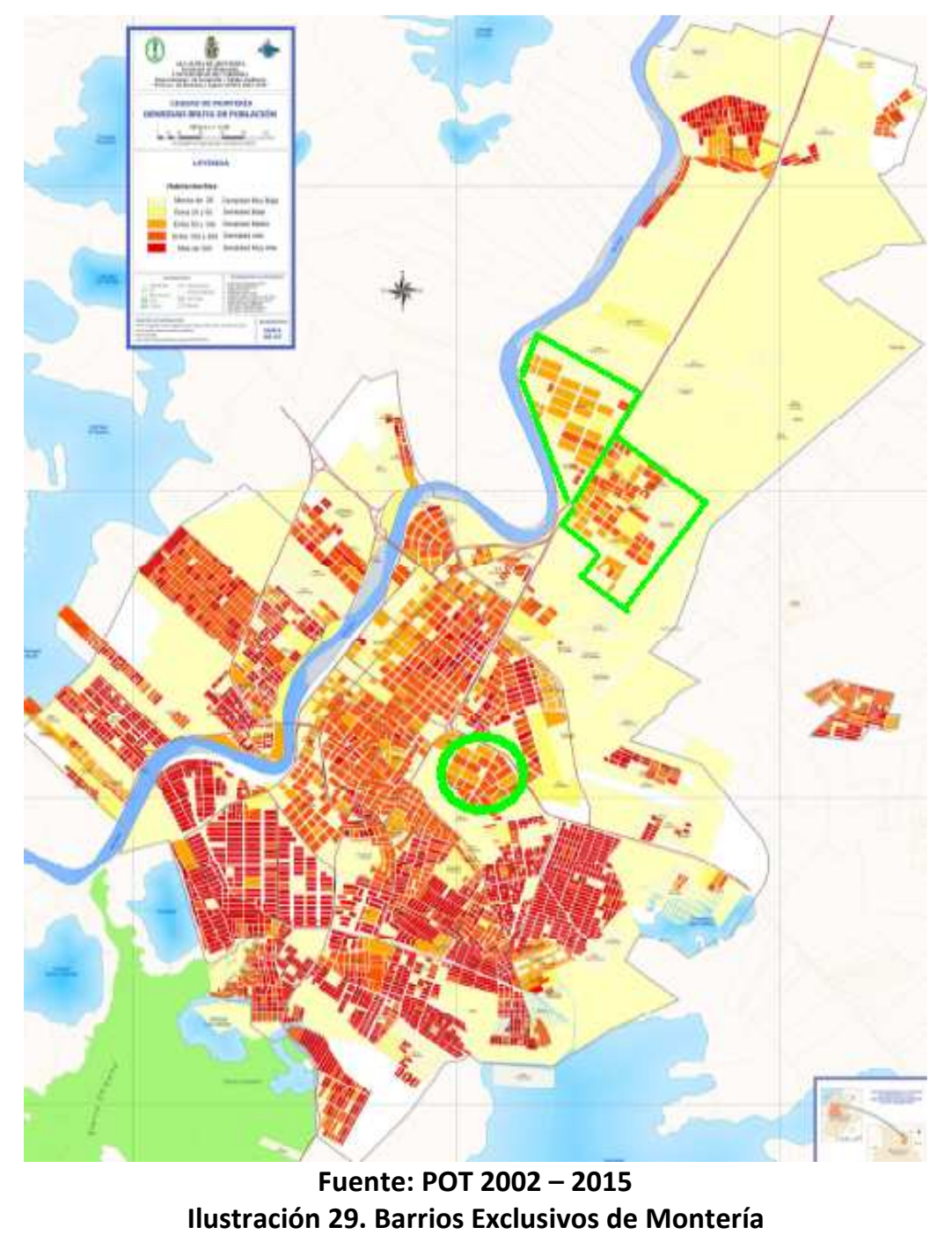
${ }^{135}$ Negrete, Víctor (1994): Los Desplazados por la Violencia en Colombia. El Caso de Córdoba. Acción
Contra el Hambre - Universidad del Sinú Montería. 
Finalizando la década de los años setenta y ya en el periodo del presidente Julio Cesar Turbay Ayala, 1978 - 1982, reaparecen los programas de vivienda pública con el proyecto del Barrio Panamá, construido sobre la margen izquierda del Río Sinú en una superficie de seis hectáreas, que permitió la oferta de 216 viviendas edificadas en 15 manzanas. Este proyecto fue integrado espacialmente con el de la Ribera, lo cual permitió mayor aprovechamiento de las dotaciones públicas y equipamientos como el colegio la Ribera, la cancha de futbol y la iglesia católica.

El auge de los programas de vivienda pública en Montería se daría durante el gobierno del presidente Belisario Betancur Cuartas, 1982 - 1986, quien por medio de su plan de desarrollo "Cambio con Equidad", le dio gran prioridad al problema del alojamiento en Colombia, e incorporó el programa denominado "Casas sin Cuota Inicial". En este periodo se desarrollaron los proyectos de los barrios Panzenú, Simón Bolívar, Villa Margarita, el Tambo, Rancho Grande y Mogambo.

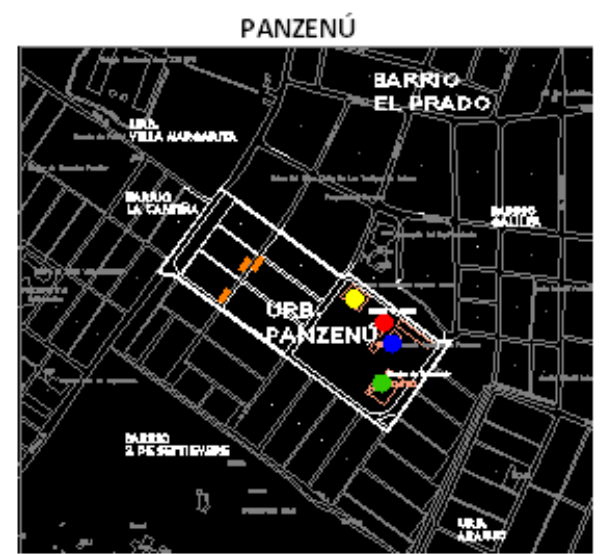

VILLA MARGARITA

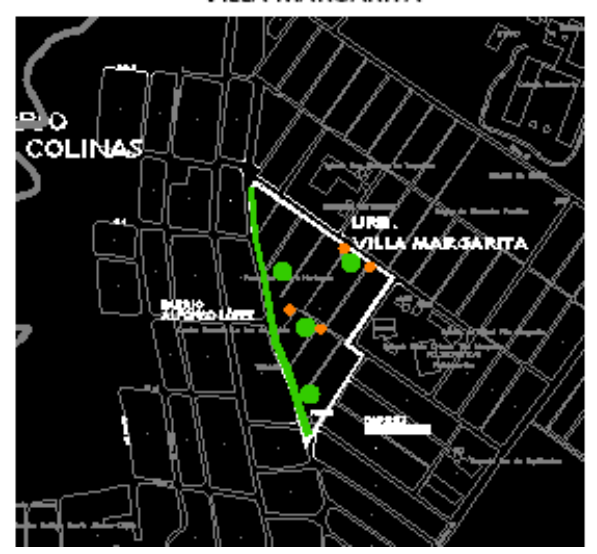

Elaboración propia a partir de planos de Mélida González llustración 30. Barrios de Vivienda Pública de los años 80

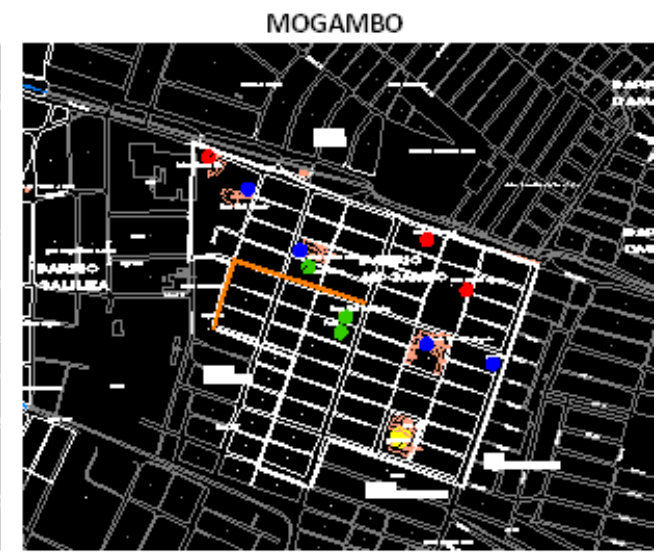

SIMÓN BOLIVAR

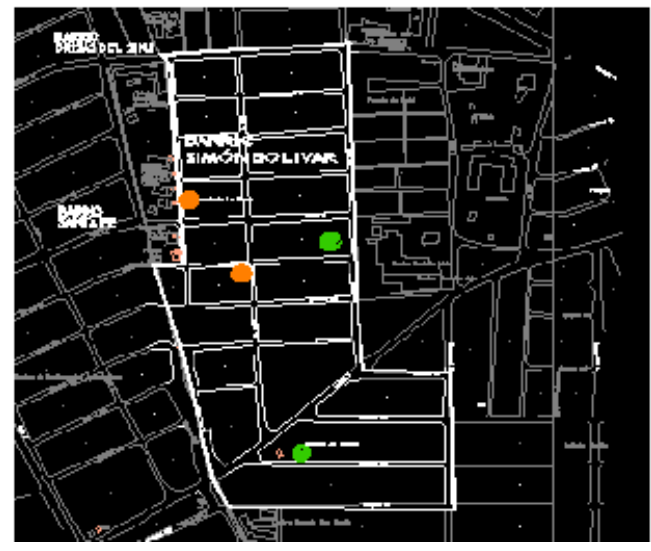


En total se ofrecieron 2.624 viviendas en estos seis proyectos, que permitieron solucionar el problema de igual número de familias en un periodo en el que la demanda de vivienda en Montería había sobrepasado cualquier proyección oficial. En el barrio Panzenú se construyeron 482 viviendas; en el Simón Bolívar, 158; Villa Margarita, 469; el Tambo, 152, Rancho Grande 360 y Mogambo, 1.103 unidades.

Estos barrios fueron construidos en el sur y occidente de la ciudad, y generaron una fuerte dinámica en ambos sectores, que fue aprovechada por todos los actores sociales e institucionales para establecer fraccionamientos irregulares, fraccionamientos públicos e invasiones. Estos proyectos presentaron menor calidad urbana que los primeros programas públicos, lo cual se vio reflejado en la distribución de los espacios públicos y en el tamaño de la vivienda en cada uno de ellos.

En este periodo surgieron paralelamente fraccionamientos públicos e irregulares, así como invasiones que hacían crecer la mancha urbana hacia el sur y occidente de la ciudad bajo esquemas de diseños muy diferentes a los patrones urbanísticos utilizados en los barrios Buenavista, la Granja y P-5. Los asentamientos informales que se constituyeron en esta etapa fueron: el Ceibal en 1982; Robinson Pitalúa, 25 de Agosto, San Cristóbal, la Palma y Bolsillo Largo en 1985, y el Bongo en 1986, que aparecerán ilustrados en el capítulo de impacto urbanístico de la urbanización marginal.

En la misma década, pero ya en el periodo del presidente Virgilio Barco 1986 - 1990, seguiría el crecimiento asociado a fraccionamientos públicos, fraccionamientos irregulares e invasiones. En este periodo se desarrolla el proyecto de vivienda pública del Dorado, que ofreció 234 viviendas en el occidente de la ciudad en el año 1987, que permitiría el surgimiento de fraccionamientos irregulares e invasiones como el Campano, el Paraíso, y Media Tapa en el mismo año; Cantaclaro, $1^{\circ}$ de Mayo, la Candelaria, Mogambito, la Campiña, 2 de Septiembre y Casa Finca en 1988, y Santa Rosa en 1989. El impacto de estos asentamientos sobre la morfología urbana será analizado detalladamente en el capítulo quinto. 

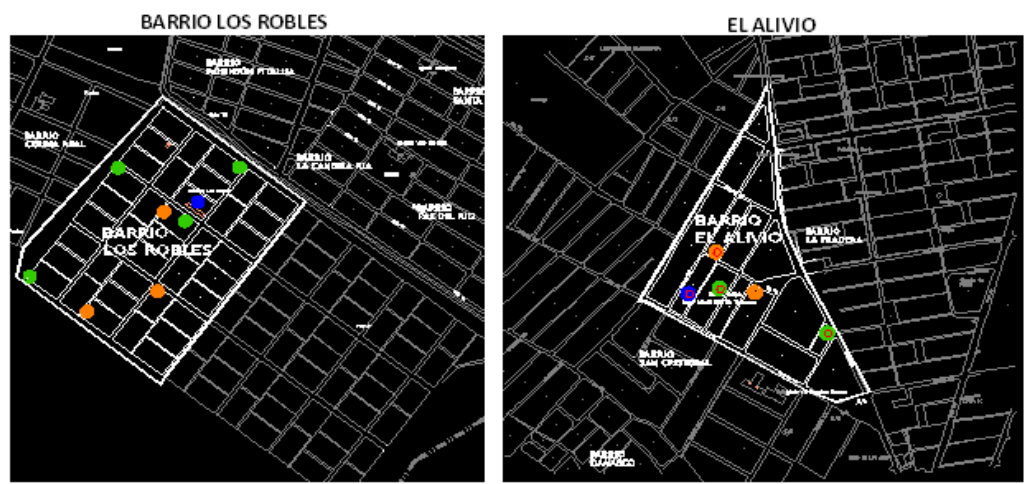

Planos elaborados por Mélida González Ilustración 31. Plano de Los Robles y El Alivio

Para la década de los años noventa es liquidado el ICT y por medio de la Ley 3 de 1991 se crea el Instituto Nacional de Reforma Urbana INURBE, para que asuma las funciones de promotor de vivienda pública. Este Instituto iniciaría una serie de programas de vivienda construida, así como de fraccionamientos públicos en áreas totalmente marginales o al lado de asentamientos informales; estas dos características del programa - lote o vivienda - , determinarían la morfología de la manzana de cada nuevo proyecto.

Se desarrollaron seis proyectos de viviendas entre el periodo $1992-2000$, que apenas lograron ofrecer 690 soluciones de alojamiento en el occidente y en el sur de ciudad. En el occidente, se construyeron 65 viviendas en la Urbanización el Puente en 1992; 85 casas en el barrio las Viñas, 1993; 116 en el Dorado, 1995, y 67 en Casita Nueva, 1997. En el sur se desarrollaron los programas de los Robles, con 201 casas y el Alivio con 166 unidades, las cuales se entregaron entre 1997 y el año 2000.

El periodo 1990 - 2000, fue de relativa tranquilidad si se compara con los movimientos ocurridos durante la década de los setenta y de los ochenta. En este periodo, a pesar de la baja oferta de vivienda pública, no se realizaron significativos fraccionamientos irregulares ni invasiones de terrenos. No obstante, hubo la necesidad de realizar un fraccionamiento público de lotes por parte del municipio.

Este fraccionamiento público fue denominado Colina Real y tuvo como objetivo la reubicación de la población de la invasión el Cerro, que para esa época resultaba afectada por las lluvias y por los frecuentes deslizamientos de tierra. Este barrio fue 
ubicado en una superficie de 17 hectáreas en el sur de la ciudad, y permitió asignar 597 lotes de 98 metros cuadrados (7 x 14).

El panorama urbano con el que la ciudad de Montería cerraba el milenio era bastante traumático, puesto que el crecimiento físico había desbordado ya todos los cálculos imaginables en los últimos treinta años. Los servicios públicos básicos eran insuficientes ante la avalancha de barrios informales, y el presupuesto del municipio era demasiado exiguo para la instalación de redes básicas o para desarrollar los proyectos de vivienda popular que permitieran la destugurización de esta ciudad.
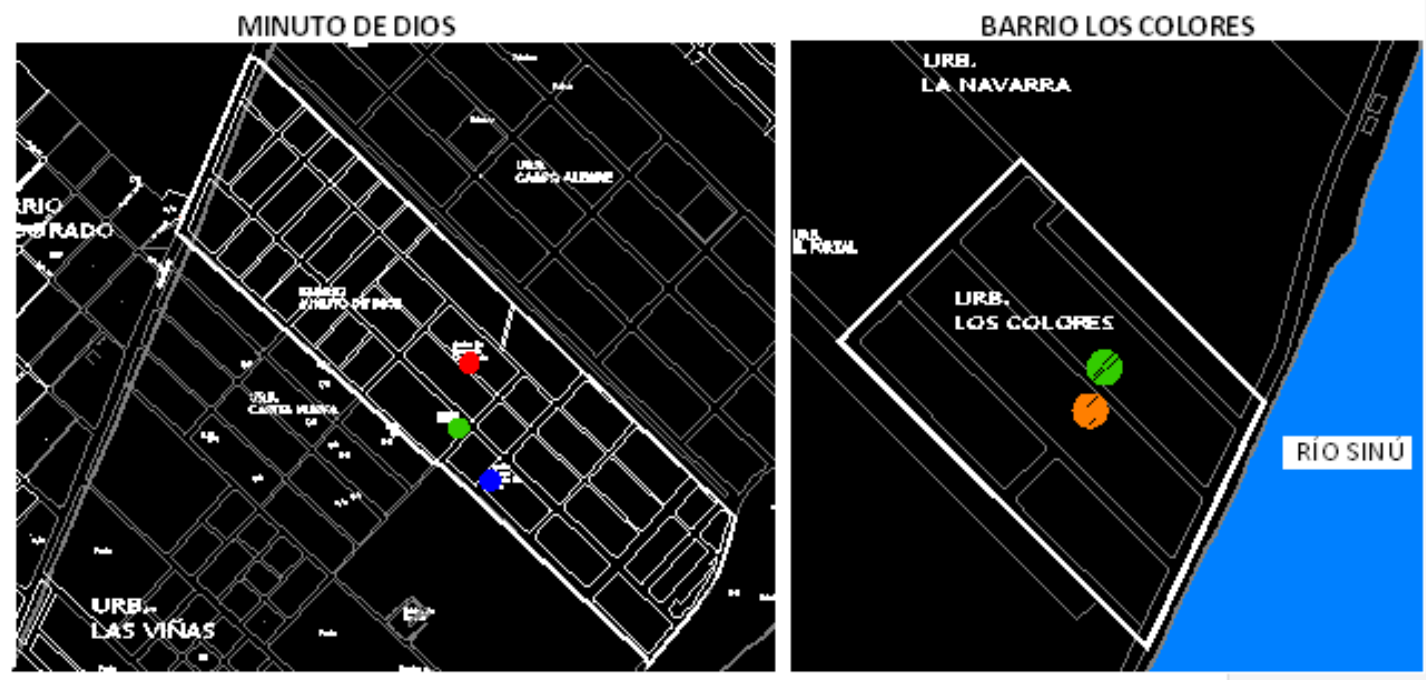

Fuente Plano elaborados por Mélida González llustración 32. Planos de los barrios Minuto de Dios y Los Colores

Los últimos proyectos de viviendas subsidiadas por el INURBE en Montería fueron los Colores en el año 2002 y el Minuto de Dios en el 2003, por medio de los cuales se otorgaron 85 y 164 viviendas, respectivamente. Los dos proyectos se desarrollaron en la margen izquierda del Río Sinú, y estimularon simultáneamente nuevos fraccionamientos públicos e irregulares que tugurizaron gran parte del sector suroccidental de esta ciudad.

Los barrios informales surgidos en este sector, a partir de estos dos proyectos y de los distintos fraccionamientos, fueron: el Portal, Navarra, la Palma, el Campano, Nueva Esperanza, el Ébano, la Vid, Villa Nazaret y Casa Finca. Estos asentamientos se establecieron en zonas inundables pero sin adecuados sistemas de drenajes y en 
precarias condiciones urbano-ambientales, que los hicieron vulnerables a frecuentes inundaciones en los periodos invernales.

Las últimas parcelaciones comenzaron a realizarse en el año 2004, fecha en la que fue liquidado el INURBE, y la promoción pública de la vivienda en Colombia quedó bajo la responsabilidad de los municipios, las cajas de compensación familiar y el Fondo Nacional de la Vivienda. En Montería dicha responsabilidad fue asumida por la Oficina Municipal de Vivienda y la Caja de Compensación Familiar de Córdoba COMFACOR.

Además de los fraccionamientos irregulares del occidente, también se presentó para este periodo, la proliferación de fraccionamientos y de urbanizaciones hacia el sur y el norte de la ciudad. Hacia el sur se constituyeron Santa Isabel, los Nogales, el Paraíso, los Alpes, Vereda Tropical y Villa Rocío; y hacia el norte, las urbanizaciones Altos de California I y II, el Privilegio, Versalles, Portal de Armería, Sevilla, Mérida y Palermo.

Los proyectos de vivienda pública entregados durante este nuevo periodo son: urbanización COMFACOR, Nueva Belén, Nueva Jerusalén y los Cedros, por medio de los cuales se ofrecieron 1.200 viviendas de 98 metros cuadrados $(7 \times 14)$, conformadas por dos habitaciones, una sala-comedor y un cuarto de baño. Estos cuatro proyectos fueron desarrollados en el norte y oriente de la ciudad, y permitieron reubicar a 196 familias de las Invasiones Ranchos del INAT y El Campano.

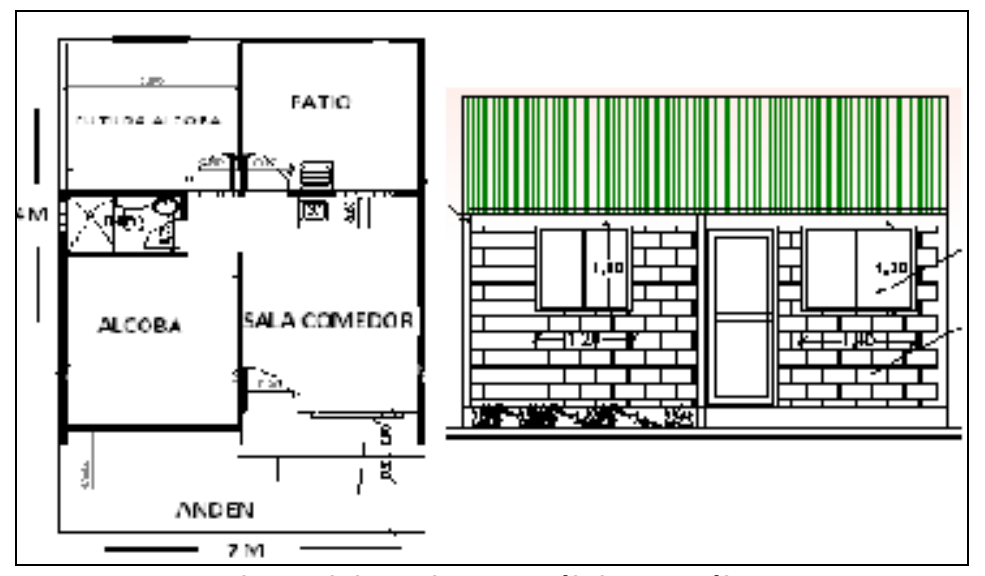

Plano elaborado por Mélida González

Ilustración 33. Vivienda Tipo de los últimos proyectos 
En total son cerca de doce mil unidades de viviendas de promoción pública construidas en estas cinco décadas en Montería, lo cual equivale al $\mathbf{2 2} \%$ del total de las viviendas en esta ciudad. No obstante, hay que decir que a pesar de su carácter institucional, solamente se desarrollaron bajo favorables criterios urbanísticos los primeros proyectos correspondientes a los barrios Buenavista, la Granja - el P-5, la Pradera y la Ribera. Estos favorables criterios urbanísticos se refieren básicamente a amplios perfiles viarios, construcción de equipamientos y oferta de áreas verdes y espacios libres.

Sin embargo, el resto de proyectos de promoción pública fueron desarrollados bajo fuertes limitaciones de presupuesto o de suelo, que no permitieron brindar calidad en la vivienda ni óptima calidad urbanística del asentamiento. En este sentido, algunos asentamientos de promoción pública de Montería surgieron en condiciones urbanísticas tan deficientes, que no les permitió diferenciarse urbanísticamente de las invasiones o fraccionamientos irregulares, más allá de su formalidad en origen o en el dominio de los suelos.

Si estos proyectos de vivienda construida se desarrollaron bajo niveles de informalidad urbanística, es decir, al margen de alguna de las normas del reglamento urbano, los fraccionamientos públicos terminarían por estimular los fraccionamientos irregulares privados y por informalizar a la ciudad. Estos loteos oficiales consiguieron aliviar la presión de suelo por parte de los destechados pero no lograron solucionar el problema del alojamiento, ni garantizar el desarrollo urbano de Montería.

Los anteriores aspectos permiten responder afirmativamente a uno de los interrogantes formulados en esta Investigación. ¿Es el Estado Colombiano promotor de los asentamientos Informales en Montería? La respuesta resulta afirmativa, al corroborar que los programas de promoción pública del ICT, el INURBE, y el Fondo Municipal de la Vivienda fueron, evidentemente una apuesta parcial de solución, pero con demasiados riesgos urbano-ambientales, que estimularon directa 0 indirectamente, la configuración de una ciudad urbanísticamente informal. Esta tesis será ampliada en el capítulo v mediante el análisis del impacto urbanístico de cada uno 
de los programas públicos de vivienda terminada y de los fraccionamientos públicos para autoconstrucción de viviendas.

\subsubsection{Montería y el Plan de Ordenamiento Territorial (POT)}

El Plan de Ordenamiento Territorial de Montería fue aprobado por el acuerdo 0018 del Concejo Municipal de esta ciudad en el año 2002, durante la administración del alcalde Luis Jiménez Espitia, y denominado "Ahora Nos Toca a Todos". En el documento editado figuran participantes de diversos sectores de la sociedad, dentro de los que se destacan técnicos, políticos y algunos líderes comunitarios.

No obstante, en este primer plan no se destaca una nutrida participación de la ciudadanía, de organizaciones cívicas, ni de las instituciones de educación superior. Sobre este particular, y después de consultar a más de 500 alumnos durante varios años de docencia en las universidades de Montería, se puede apuntar que ninguno de ellos reconoció haber participado de alguna reunión o socialización de este plan, ni como estudiantes ni como miembros de organizaciones sociales.

En este sentido, consideramos que la difusión del proceso no fue la adecuada o se falló a la hora de convocar o de informar, eso sí, sin dejar de reconocer que gran sector de nuestra población es apática a cualquier proceso participativo; es decir la comunidad no fue excluida directamente, sino que se les invitó, pero no se les orientó sobre la importancia de la participación comunitaria en la planificación del territorio, ni de los objetivos de la concertación.

La vigencia de este plan de ordenamiento se estableció en diez años (2002-2011), y dentro de los aspectos más significativos a nivel urbano destacamos la división político-administrativa en nueve comunas. Esta sectorización por comunas establece como propósito, identificar y organizar los espacios susceptibles de tratamientos urbanísticos diferenciales en razón de sus características y teniendo en cuenta aspectos topográficos, físico-estructurales, socio-económicos y de ubicación ${ }^{136}$.

\footnotetext{
${ }^{136}$ Alcaldía de Montería (2010): Ajustes del POT 2002-2011. Cap. I. Expediente Municipal del Plan de Ordenamiento Territorial. Pág. 32.
} 


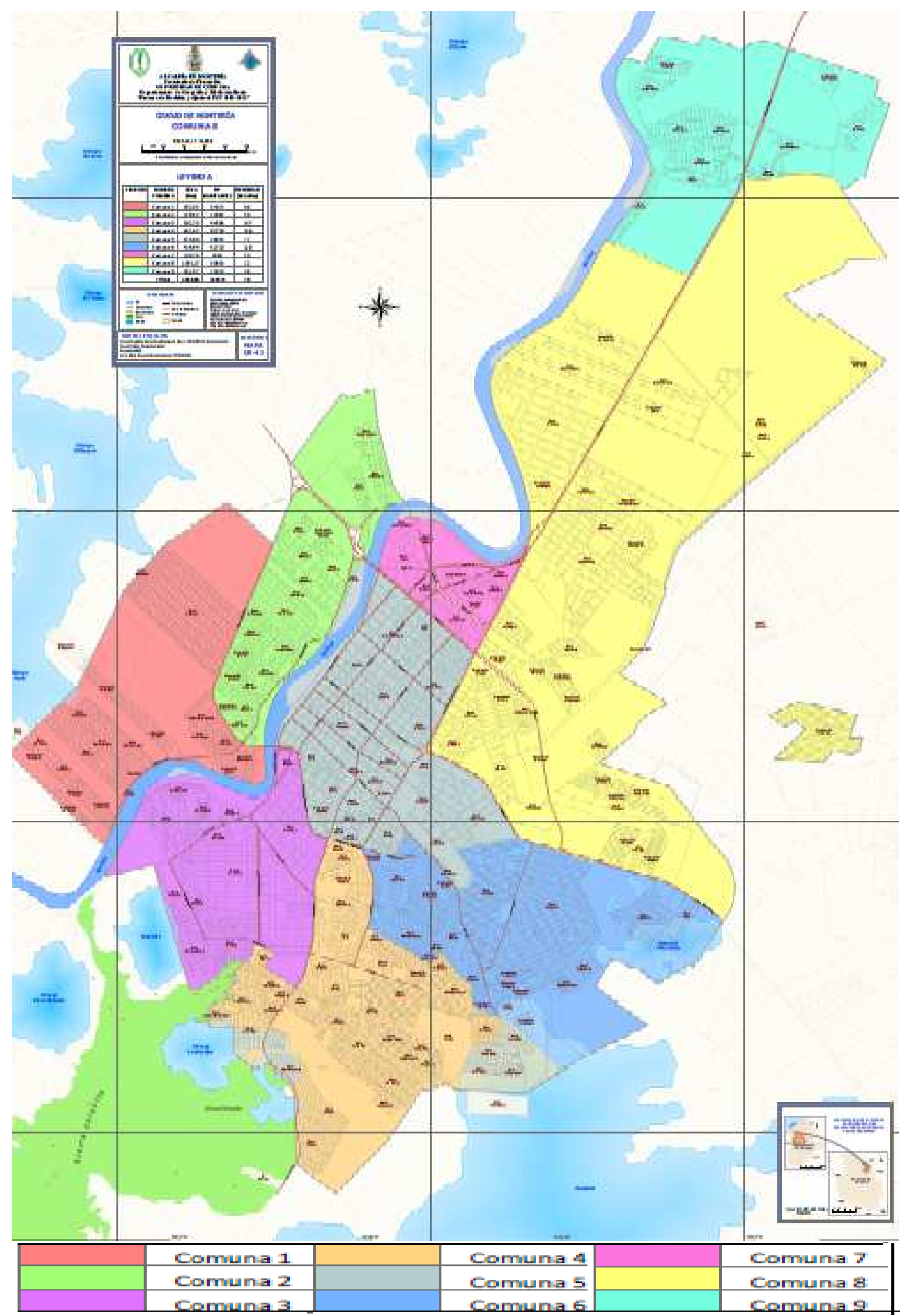

Fuente POT 2002-2015

Ilustración 34. División por Comunas

La comuna 1 se encuentra ubicada en el sector sur-occidental y está conformada por los barrios: los Colores, el Portal, Navarra, la Palma, Rancho Grande, el Campano, Casa 
Finca, Mi Ranchito, Betancí, Nuevo Horizonte, Caracolí, el Puente 1, la Ribera, Nueva Holanda, el Dorado y el Poblado. El desarrollo de este sector no supera las tres décadas y se caracteriza por la combinación de oferta de vivienda pública subsidiada, loteo clandestino y ocupación ilegal. En esta comuna, el Plan de Ordenamiento Territorial de Montería 2002-2011, consideró como asentamientos informales a los barrios la Palma, Rancho Grande, el Campano, Casa Finca, el Dorado y el Poblado.

La comuna 2 se ubica en los sectores occidental y noroccidental de la ciudad, y la conforman: Río de Janeiro, el Puente 2, el Amparo, Urbanización Villa Real, Villa Nueva, la Esmeralda, las Viñas, Casita Nueva, Minuto de Dios, Campo Alegre, la Alboraya, Magdalena, el Tambo, el Rosario, Urbanización Manuel Antonio Buelvas, Juan XXIII, el Bongo, Villa Luz, el Bongo y la Esperanza. En esta zona el POT clasificó a la Esperanza y al Bongo como asentamientos informales y destacó la necesidad urgente de reubicación de este último, por encontrarse ubicado en un espacio natural para protección como la rivera del Río Sinú.

En el sur de la ciudad se encuentra la comuna 3, la cual está conformada por: Brisas del Sinú, Nuevo Milenio, Santafé, Simón Bolívar, la Coquera, el Tendal, Buenavista, la Granja, Santa Lucía, Santander, Policarpa Salavarrieta, San Martín y Pastrana Borrero. Esta zona se puede considerar como la primera área de ensanche de la ciudad y su desarrollo comenzó en la década de los años 60 por medio de las intervenciones del Instituto de Crédito Territorial (ICT). Los asentamientos informales aquí, son Brisas del Sinú y Nuevo Milenio.

La comuna 4, ubicada en el sur-oriente de Montería, es la más numerosa y se encuentra conformada por Granada, Miraflores, Urbanización Samaria, Guadalajara, P5, Damasco, Mogambito, el Prado, Boston, Alfonso López, Villa Margarita, los Araujos, Panzenú, las Américas, Robinson Pitalúa, las Colinas, los Nogales, los Robles, 2 de Septiembre, Colina Real, Candelaria, Santa Rosa, Paz del Rio, el Enjambre, Santa Rosa, Ranchitos, Galilea, Pablo VI, Edmundo López II y el Paraíso. Los barrios Informales de este sector son: Damasco, San Cristóbal, Mogambito, Edmundo López II, Colinas, 2 de Septiembre, la Campiña, Colina Real, Robinson Pitalúa, Santa Rosa, Paz del Río, Candelaria, el Enjambre y Ranchitos. 
La comuna 5 la conforman barrios del centro y oriente de la ciudad. En ella se encuentran barrios históricos como la Ceiba, Chuchurubí, Montería Moderno, Nariño, Colón, Santa Clara, la Ceiba, Ospina Pérez, Urbina, Pasatiempo, Balboa, Chambacú, el Coliseo, Balboa, los Álamos, el Edén, la Julia, Obrero, Risaralda, Costa de Oro, Tacasuan, 14 de Julio, la Victoria, Pueblo Nuevo y Lacharme. Este es el sector más regular de la ciudad y el POT no consideró ningún asentamiento informal.

En la comuna 6 se encuentran los barrios del oriente de la ciudad, destacándose en este sector la invasión Cantaclaro, que con una superficie de 87 hectáreas se constituye en el asentamiento informal más grande de Montería. Igualmente pertenecen a esta comuna el barrio de promoción pública de la Pradera y los barrios constituidos por fraccionamientos privados informales del 6 de Marzo, Edmundo López I, Villa Rosario, Caribe, Villa Rocío, el Diamante, el Alivio, Villa Ana y San Cristóbal.

La comuna 7 presenta menor superficie, pero es una de las más dinámicas por su ubicación. Está conformada por los barrios Sucre, invasión Sucre, Laureles I, Laureles II, Prado Norte, Villa del Río, Altos del Country, el Carmen, Industrial, Luis Carlos Galán y Alamedas del Sinú. En esta comuna se encuentra una de las zonas más degradadas arquitectónica y socialmente, la cual es utilizada como mercado de drogas y escenario para la indigencia. En esta área el POT reconoce como Informal únicamente a la invasión Sucre.

Contrariamente a lo expuesto en el párrafo anterior, la comuna 8 presenta la mayor superficie dentro de la distribución física de la ciudad. Así mismo, manifiesta los mayores contrastes socioeconómicos y socio- espaciales, que se reflejan en la ubicación de barrios de estratos tan disimiles como el Recreo y Ranchos del INAT, o como la Castellana y el 25 de Agosto, en el mismo norte de la ciudad. Otros barrios que se encuentran aquí son: San Francisco, Urbanización Sevilla, los Bongos, los Alcázares, Castilla la Nueva, los Ángeles, Brizalia, San José, el Edén II, Limonar, el Mora, los Robles del Norte, Villa Sorrento, Villa Fátima, la Floresta, Bonanza, 25 de agosto y la Española. En esta zona es donde mayor desarrollo han tenido las urbanizaciones propiamente dichas y dentro de las cuales destacamos algunas promovidas por el sector público y otras promovidas por la iniciativa privada. Sin embargo, resaltamos que los 
asentamientos Ranchos del INAT y 25 de Agosto son el producto de dos invasiones en la década de los ochenta.

En el norte de la ciudad, encontramos la comuna 9 que se encuentra conformada principalmente por barrios homogéneos física y socialmente. En ella se encuentra el populoso sector de Mocarí y algunas invasiones como el 20 de Julio y el Camilo Torres a orillas del río Sinú. Otros barrios que la conforma son: 7 de Mayo, el Bosque, los Cedros, Villa Fátima, COMFACOR, Altos de California I y Altos de California II. Las viviendas de las invasiones aquí ubicadas, presentan tendencias evolutivas lentas y la precariedad del espacio público es uno de los aspectos más desequilibrantes. Los asentamientos informales registrados por el POT fueron: Villa Fátima, 7 de mayo, Camilo Torres y 20 de Julio.

Por otro lado, este plan de Ordenamiento Territorial incorpora, mediante su artículo 194, unos instrumentos de intervención integral para la ciudad, que denomina como "operaciones estructurantes". Por la amplitud de este tema y por las diferentes escalas que se manejan en la ciudad, preferimos trasladar su análisis para el capítulo de impacto urbanístico. No obstante destacamos las cuatro principales operaciones que se definieron a escala urbana:
a) la operación de áreas marginales;
b) crecimiento programado;
c) configuración del centro urbano y
d) cualificación de áreas consolidadas.

Estas operaciones estructurantes se encuentran detalladas en el capítulo de Ejecuciones del componente general de este plan y obliga a cada administración municipal a desarrollar el conjunto de acciones que en materia de ordenamiento territorial programa para su período legal y de acuerdo con lo definido en el respectivo Plan de Desarrollo ${ }^{137}$.

\footnotetext{
${ }^{137}$ El plan de desarrollo tiene su origen en el artículo 339 de la Constitución Política de Colombia y la Ley 152 de 1994, que establece los mecanismos para su elaboración, aprobación, ejecución, seguimiento, evaluación y control. Aunque en ellas no se establece una definición de éste, desde aquí lo definimos
} 
Siguiendo con el análisis de este plan, en el artículo 186 se definen las acciones orientadas a mejorar la convivencia ciudadana y la identificación del ciudadano con su territorio. Con el objetivo de apoyar los programas de convivencia ciudadana y facilitar la apropiación del territorio por parte de los ciudadanos, el plan propone las siguientes acciones:

1. Recuperación, mejoramiento y dignificación del espacio público urbano, en particular del espacio público representativo y de aquel que complementa las acciones definidas en las políticas de patrimonio, renovación, vivienda, equipamientos e infraestructuras viales y de transporte, que constituyen también parte integrante del espacio público urbano.

2. Valoración del patrimonio cultural urbano, considerado como la consolidación de la historia de la ciudad en el territorio y de su "memoria", como un elemento clave en la conformación de las comunidades urbanas".

Estas acciones buscan resolver los problemas encontrados en la fase de diagnostico y que son básicamente los siguientes: a) la falta de identidad con el territorio; b) la pérdida de la memoria histórica; c) el déficit de espacio público y d) el poco respeto por el espacio público. Estos cuatro problemas, sumados además, a las deficientes condiciones arquitectónicas de dichos espacios, se constituyen en fuertes obstáculos para el desarrollo social, económico, urbano y ambiental de Montería.

En este sentido, el plan pretende ampliar la oferta de espacio público ${ }^{138}$, que en la actualidad no supera el promedio de $1.60 \mathrm{~m}^{2}$ por habitante, y en el caso de algunas comunas, como la $\mathrm{N}^{\circ} 9$, apenas asciende a $0.77 \mathrm{~m}^{2}$ por habitante ${ }^{139}$. Para superar este

como el instrumento legal que contiene el programa de gobierno del alcalde y los programas, subprogramas, proyectos y metas establecidas.

138 El Decreto 1504 de 1988 sobre espacio público, establece en su artículo 2, que éste se encuentra conformado por elementos arquitectónicos y naturales, relacionados con el sistema orográfico, hídrico y paisajístico. Este tema será ampliado en el apartado 5.3.8.que se refiere precisamente al déficit de espacio público en Montería.

139 Ortega, Jorge; Valencia, Nidia; y Restrepo, Marleny (2007): “La Economía Política de la Pobreza y la Desigualdad Social: El caso de Montería". Texto disponible en http://www.javeriana.edu.co. 
déficit el plan en su artículo 298 propone una reserva de suelo superior a 500 hectáreas destinadas a intervenir y construir una gran red de parques.

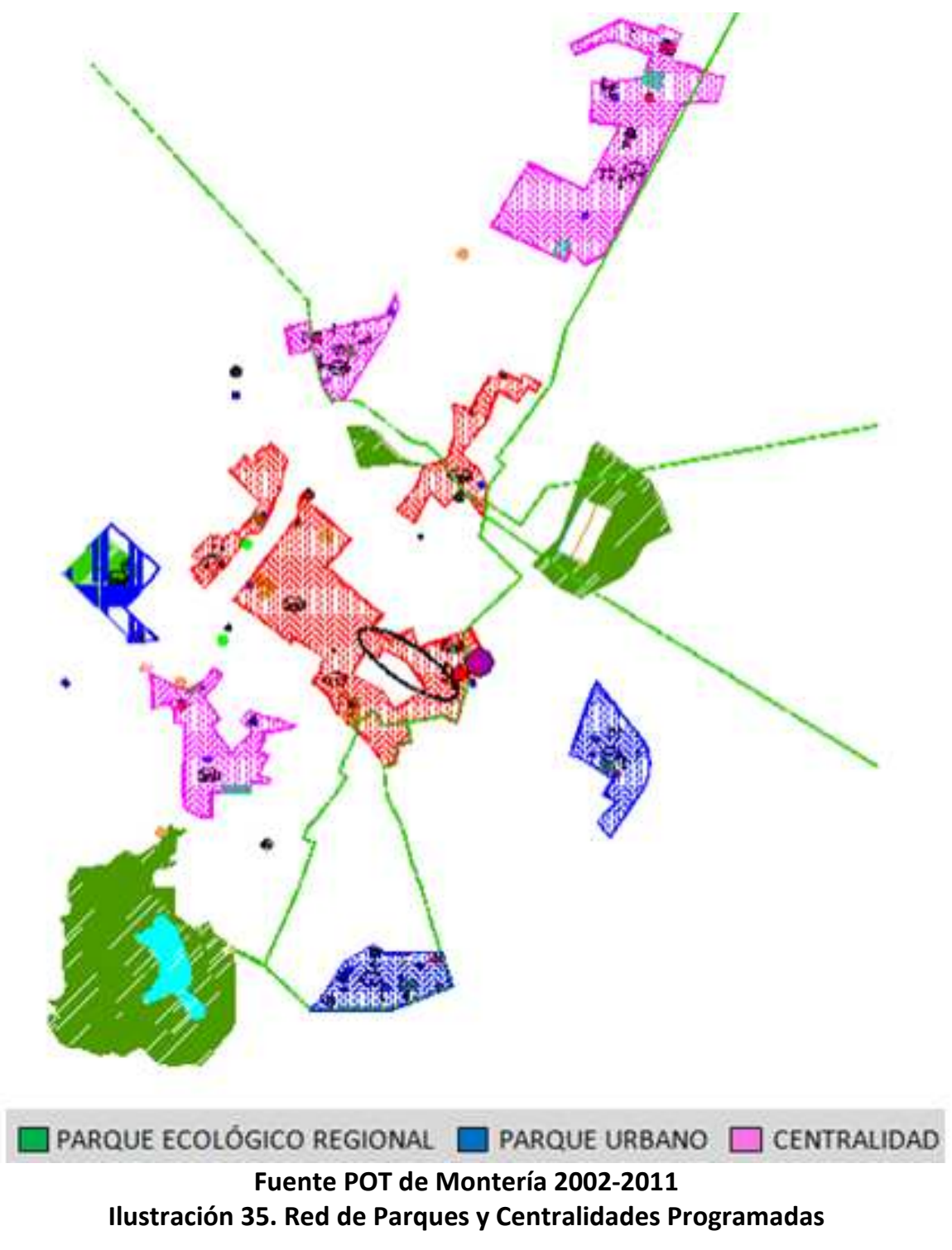

En esta red de parques se proponen tres escalas, que corresponden a la zona, urbana y regional. La primera escala corresponde a la superficie comprendida entre 10 y 20 hectáreas; la segunda es aquella superior a 20 hectáreas y categoría regional se considera al área con valor ambiental y gran superficie, como es el caso de la reserva de Sierra Chiquita con 308 hectáreas. Si bien, estas superficies se dispusieron sobre el papel, la verdad es que después de diez años de realizada la reserva, aún la ciudad sigue careciendo de parques, y a decir verdad, las condiciones naturales y legales de los suelos, dificultan la viabilidad de incorporarlos como áreas verdes urbanas. 
Dentro de los parques a intervenir y a construir se encuentran: el parque ecológico recreacional Sierra Chiquita con 308 hectáreas y los parques urbanos de la Villa Olímpica (20.7), Laguna Norte (127.29), Laguna Sur (107.38), la Estancia (111.78), Caribe (84.23) y Central (17.6). Así mismo se programó construir los parques zonales de Berlín (32.12 has), Teherán (10 has), y uno de escala local en el barrio COMFACOR (1.18). Como anotábamos, no se han construido ninguno de los parques urbanos ni regionales, y de los aquí mencionados, solamente se cumplió oportunamente con la construcción del parque local de COMFACOR.

En lo que tiene que ver con el parque ecológico regional de Sierra Chiquita, éste reflejaría un gran impacto de tipo ambiental sobre la ciudad, ya que se proyectó como un espacio de recreación pasiva, destinado a proteger 308 hectáreas de gran riqueza natural e hídrica en el sur de Montería. Este parque, es a su vez, el principal pulmón de la ciudad y su apertura debe convertirse en una inaplazable prioridad para la administración municipal

En el mismo sentido, es importante destacar que los parques zonales se encuentran programados en el occidente y norte de la ciudad, sumando un total de 48 hectáreas, que se distribuyen de la siguiente manera: Berlín y Teherán con superficies de 32 y 10 hectáreas, respectivamente, se encuentran ubicados en el occidente, y los parques de la Villa Olímpica y Mocarí en el norte de la ciudad. Sobre estos dos últimos, destacamos que la denominada "Villa Olímpica", es un gran espacio abierto con precarias intervenciones arquitectónicas en las canchas de futbol y softbol.

Con la intervención y construcción de la red de parques, el plan de ordenamiento pretende integrar física y socialmente a la ciudad, por medio de la consolidación de nuevas centralidades de gran jerarquía, así como centralidades de segundo y tercer nivel. En las centralidades de gran jerarquía se proyecta la construcción del estadio de futbol y de otros equipamientos deportivos, que permitan la recreación activa para los habitantes de los diferentes sectores de la ciudad, mientras que en las centralidades de segundo y tercer nivel se pretende la construcción de los parques zonales y urbanos programados. 
En lo referente a planes parciales ${ }^{140}$, en el artículo 53 de este plan se ajusta la información relacionada con las áreas propuestas para el desarrollo de suelo urbano por medio de este instrumento y se proponen cuatro tipologías de planes: 1) plan parcial de expansión urbana; 2) plan de mejoramiento integral; 3) plan parcial de renovación urbana, y 4) plan parcial de desarrollo prioritario. Estos planes fueron propuestos para realizarse en el corto, mediano y en largo plazo, y hasta el año 2010 sólo se han desarrollado media docena de ellos, todos por iniciativa de las empresas privados y no del municipio.

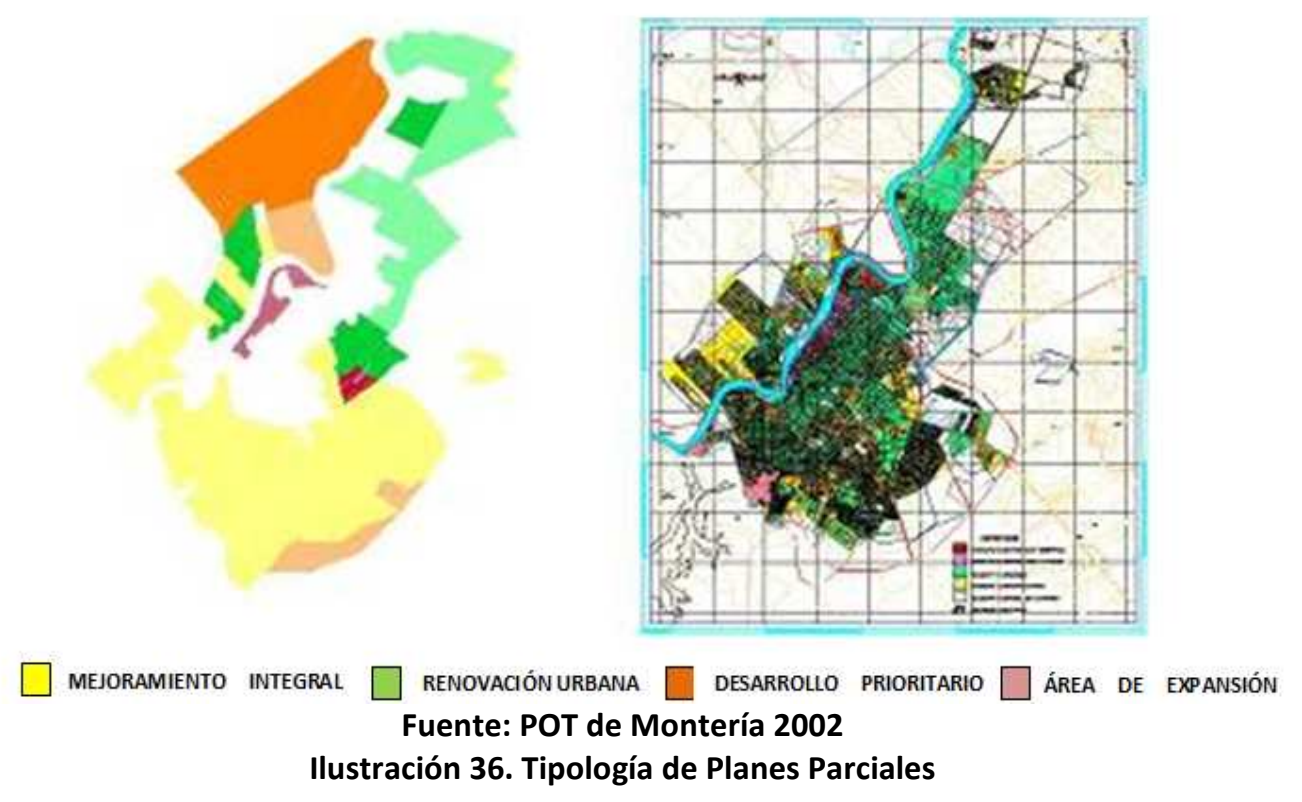

Las áreas destinadas para expansión urbana corresponden a 1525.48 hectáreas, de las cuales se encuentran programadas 815.36 para el corto plazo y 710.12 para el mediano plazo. En el mismo orden, el área del plan parcial destinado a mejoramiento integral asciende a 1.101.19 hectáreas; el de desarrollo prioritario a 858.60, y el de renovación urbana a 57.69 hectáreas. Estas superficies son significativas, si se tiene en cuenta que el área del perímetro urbano no supera las 4.900 hectáreas; es decir el área programada para intervención por medio de este instrumento asciende al 72\%, lo cual denota, por un lado, amplios desequilibrios urbanísticos en esta ciudad, pero por otro, una buena disposición para intervenir en la mayor parte de la ciudad.

\footnotetext{
140 Los planes parciales son uno de los seis ejes estratégicos de este plan de ordenamiento territorial. Los otros cinco son: 1) medio ambiente y recursos naturales; 2) eje regional; 3) usos del suelo; 4) vivienda, y 5) espacio público. Expediente Municipal. Pág. 237.
} 


\begin{tabular}{|c|c|}
\hline PLAN PARCIAL & ÁREA \\
\hline CALIFORNIA & 14.27 \\
\hline CIUDADELA COMFACOR & 33.80 \\
\hline FILADELFIA & 8.46 \\
\hline FURATENA II & 130.65 \\
\hline LA GLORIA & 48.49 \\
\hline LOS MANGOS & 52.48 \\
\hline COCA COLA & 2.1 \\
\hline PALMA VERDE & 17.33 \\
\hline POLTAL DE NAVARRA & 4.60 \\
\hline PORTAL DE LA CANDELARIA & 34.96 \\
\hline SAN ANTONIO & 20.85 \\
\hline TERMINAL DE TRANSPORTE & 16.04 \\
\hline SEVILLA & 27.87 \\
\hline TERUEL & 12.35 \\
\hline SANTA ELENA & 11 \\
\hline PICACHO & 70 \\
\hline VILLANOVA & 15.30 \\
\hline SAN JERONIMO & 71.90 \\
\hline TOTAL & 587.42 \\
\hline
\end{tabular}

Fuente POT 2002-2015. Acuerdo. Pág. 43

Tabla 10. Planes Parciales propuestos por el POT 2002-2015

En total son dieciocho planes parciales programados con 587.42 hectáreas, que se concentran principalmente en el suroriente y en el norte de la ciudad. En el suroriente se localizan ocho planes que corresponden a Portal de Navarra, Filadelfia, Coca Cola, San Antonio, la Candelaria, Terminal, California, Villanova y Santa Elena; en el norte, se programaron cinco: Picacho, Sevilla, los Mangos, San Jerónimo y Palma Verde. Por su parte, en el sur se proyectaron, la Gloria y Furatena II; mientras que en el occidente se dispusieron los de Teruel y COMFACOR. 


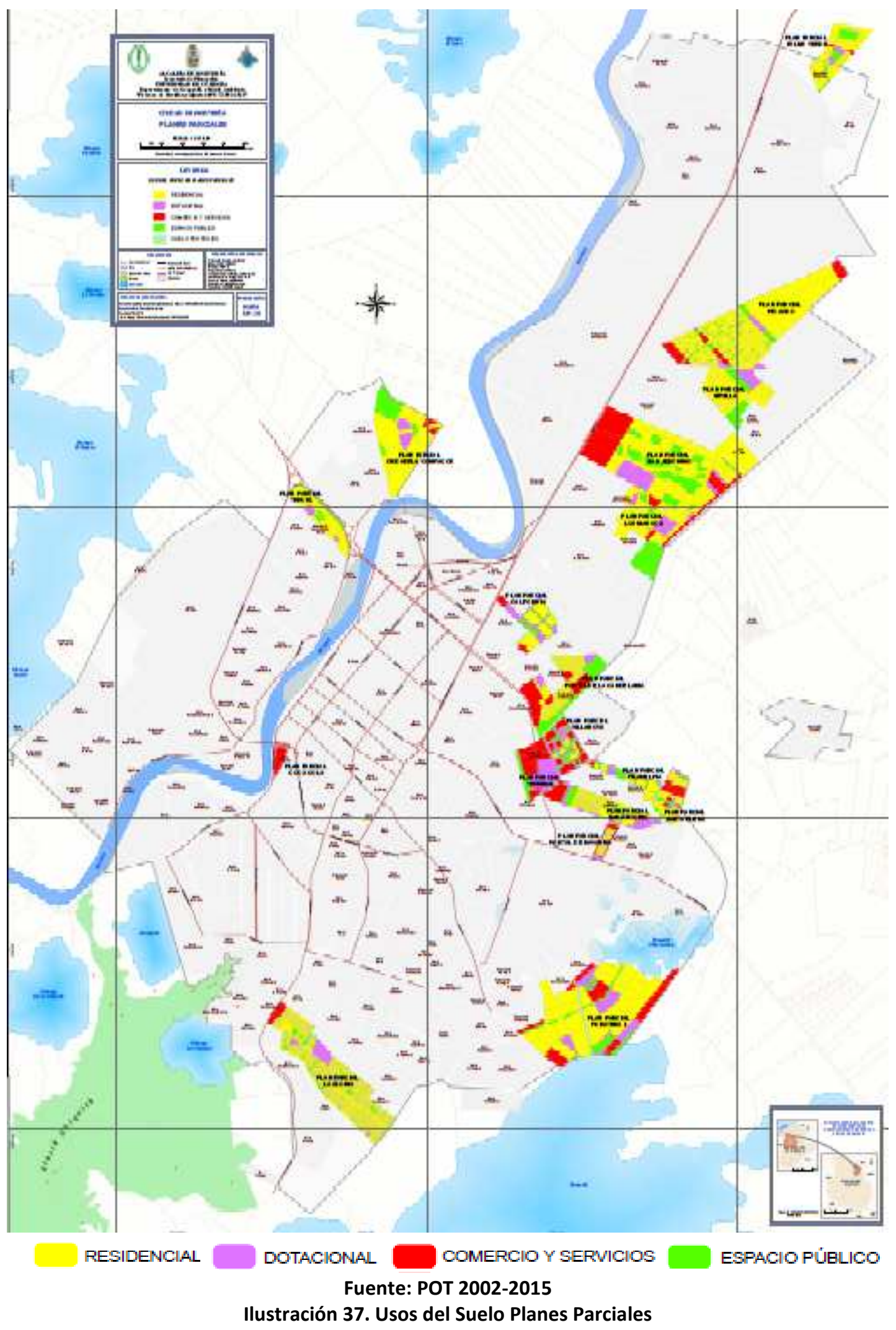

Los planes parciales de mayor superficie son Furatena II y la Gloria en el sur con 130.65 y 48.49 Has respectivamente, y San Jerónimo en el norte, con un área de 71.90 Has destinadas principalmente a uso residencial. Igualmente sobresale en el occidente el 
plan parcial de la ciudadela COMFACOR, donde se tiene programada la construcción de 2.100 viviendas públicas de interés social (VIS), en un área de 33.80 Has. Como datos importantes destacamos la construcción del mega-colegio los Araujos en el sector de la Gloria, y del hipermercado Carrefour en el sector de Coca Cola, próximo al río Sinú, en un terreno de 2.1 Has.

Quizás el sector de mayor dinamismo ha sido el del Terminal, con 16.4 Has intervenidas, porque se construyó la estación de transporte intermunicipal en un área de siete hectáreas y el resto de la superficie se destinó a comercio y servicios, que ya se encuentran consolidados. No se puede decir lo mismo de los planes de Villanova, que a pesar de su cercana ubicación a la estación, aún no logra consolidar su gran superficie comercial, principalmente por la especulación de suelos que se viene presentando.

En lo referente a la preservación de los recursos naturales, este plan establece algunas políticas, a nuestro juicio abstractas, puesto que no determina con gran claridad las estrategias o los programas a ejecutar para el logro de objetivos orientados a la conservación de los recursos o recuperación de los ecosistemas intervenidos. No obstante, destacamos que para recuperar y conservar el sistema ecológico de Sierra Chiquita definió la siguiente política de corto plazo:

"Protección, conservación, restauración y mejoramiento del potencial ecológico, paisajístico y recreacional ofrecido por importantes ecosistemas estratégicos urbanos, ampliando la disponibilidad y cobertura del espacio público en cumplimiento de su función social y ecológica atendiendo a objetivos de apropiación sostenible ${ }^{\prime 141}$.

A pesar de la claridad con que fueron redactadas estas políticas, ello no es suficiente, ya que las diferentes administraciones municipales aún no diseñan una política pública ambiental coherente, que permita garantizar el logro de los objetivos de mediano y largo plazo. Sin embargo, es oportuno destacar la gestión que viene cumpliendo la Corporación de los Valles del Sinú y del San Jorge (C.V.S.), como órgano rector del

${ }^{141}$ Alcaldía de Montería (2002): Plan de Ordenamiento Territorial 2002-2011. Art. 180. 
medio ambiente y la intención de la administración 2008 - 2011, en la promoción de programas de educación ambiental en escuelas y comunidades.

Hasta el momento no se ha logrado el objetivo de mejoramiento del entorno urbano, afectado principalmente por contaminación de ruido, contaminación hídrica e invasión del espacio público, pero si se ha realizado un esfuerzo por parte de la C.V.S., para proteger el potencial paisajístico de los principales ecosistemas con que cuenta el territorio municipal, principalmente la reserva de Sierra Chiquita y la ribera del río Sinú. En la siguiente imagen se observan algunos de los ecosistemas que el plan pretende proteger y conservar.

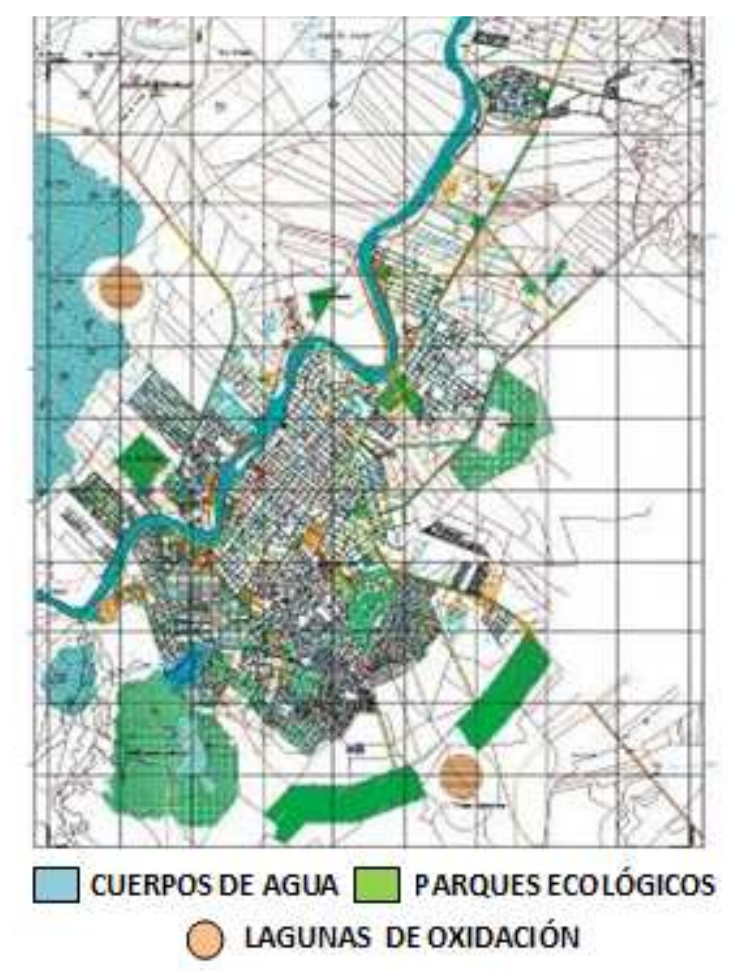

Fuente: POT de Montería 2002-2011

Ilustración 38. Ecosistemas Protegidos

Otro artículo importante dentro de análisis para esta investigación, es el 182, por medio del cual, se establecen las políticas para la construcción de vivienda de interés social que permitan reducir el déficit de alojamiento que presenta la ciudad y el precio actual de la vivienda. En este aspecto, en el plan de ordenamiento se incorporan las siguientes acciones: 
1. Generación, mediante actuación pública, de oferta masiva de suelos urbanizados para la construcción de Vivienda de Interés Social y especialmente Vivienda de Interés Social Prioritaria.

2. Establecimiento de mecanismos que eviten el desarrollo informal de programas de vivienda para familias de bajos recursos.

3. Mejoramiento de las zonas construidas en vivienda con deficiencias en espacios públicos, redes de infraestructura o equipamientos colectivos.

4. Establecimiento de programas de reasentamiento humanos.

5. Generación de mecanismos que permitan la participación del sector privado en la atención a la demanda de Vivienda de Interés Social Prioritaria.

6. Generación de mecanismos que permitan la gestión asociada entre el sector público y el sector privado de proyectos urbanísticos integrales que produzcan suelo apto para el desarrollo de programas de Vivienda de Interés Social.

La política de vivienda diseñada por el plan de ordenamiento propuso la construcción anual de mil viviendas para reducir el gran déficit habitacional existente, estimado por este mismo plan en treinta mil unidades. Este déficit se estableció a partir de la diferencia entre número de hogares y viviendas construidas en Montería, de acuerdo con el censo realizado por el Departamento Administrativo Nacional de Estadística (DANE), en el año 1993. Sin embargo, consideramos pertinente presentar a continuación, de manera detallada el déficit, establecido por el DANE en el año 2005. 


\begin{tabular}{|c|c|c|c|c|c|c|}
\hline \multirow{2}{*}{ CARACTERISTICA } & \multicolumn{2}{|c|}{ CABECERA URBANA } & \multicolumn{2}{|c|}{ RESTO } & \multicolumn{2}{|c|}{ TOTAL } \\
\hline & No. & $\%$ & No. & $\%$ & No. & $\%$ \\
\hline Total hogares & 64.536 & 100,0 & 19.994 & 100,0 & 84.530 & 100,0 \\
\hline Hogares sin déficit & 16.364 & 25,4 & 3.660 & 18,3 & 20.024 & 23,7 \\
\hline Hogares con déficit & 48.172 & 74,6 & 16.333 & 81,7 & 64.506 & 76,3 \\
\hline - Déficit cuantitativo & 8.641 & 13,4 & 3.244 & 16,2 & 11.885 & 14,1 \\
\hline - Estructura & 1.953 & 3,0 & 2.269 & 11,3 & 4.221 & 5,0 \\
\hline - Cohabitación & 4.359 & 6,8 & 976 & 4,9 & 5.334 & 6,3 \\
\hline - Hacinamiento no mitigable & 2.329 & 3,6 & 0 & 0,0 & 2.329 & 2,8 \\
\hline - Déficit cualitativo & 39.532 & 61,3 & 13.089 & 65,5 & 52.621 & 62,3 \\
\hline - Solo estructura & 111 & 0,2 & 2.525 & 12,6 & 2.636 & 3,1 \\
\hline - Solo hacinamiento mitigable & 212 & 0,3 & 418 & 2,1 & 630 & 0,7 \\
\hline - Solo servicios & 28.805 & 44,6 & 1.046 & 5,2 & 29.851 & 35,3 \\
\hline - Solo cocina & 155 & 0,2 & 44 & 0,2 & 199 & 0,2 \\
\hline - Estructura y hacinamiento mitigable & 0 & 0,0 & 585 & 2,9 & 585 & 0,7 \\
\hline - Estructura y servicios & 4.316 & 6,7 & 5.576 & 27,9 & 9.892 & 11,7 \\
\hline - Estructura y cocina & 17 & 0,0 & 157 & 0,8 & 174 & 0,2 \\
\hline - Hacinamiento mitigable y servicios & 1.670 & 2,6 & 248 & 1,2 & 1.918 & 2,3 \\
\hline - Hacinamiento mitigable y cocina & 0 & 0,0 & 67 & 0,3 & 67 & 0,1 \\
\hline - Servicios y cocina & 1.181 & 1,8 & 25 & 0,1 & 1.206 & 1,4 \\
\hline - Estructura, hacinamiento mitigable y servicios & 768 & 1,2 & 1.938 & 9,7 & 2.706 & 3,2 \\
\hline - Estructura, hacinamiento mitigable y cocina & 0 & 0,0 & 48 & 0,2 & 48 & 0,1 \\
\hline - Estructura, servicios y cocina & 1.592 & 2,5 & 214 & 1,1 & 1.807 & 2,1 \\
\hline - Hacinamiento mitigable, servicios y cocina & 204 & 0,3 & 40 & 0,2 & 243 & 0,3 \\
\hline - Estructura, hacinamiento mitigable, servicios y cocina & 502 & 0,8 & 157 & 0,8 & 659 & 0,8 \\
\hline
\end{tabular}

Fuente: DANE 2005

Tabla 11. Déficit de Vivienda en Montería

Es conveniente destacar que el déficit cuantitativo es apenas de 8.641 viviendas, mientras el déficit cualitativo, es decir el número de viviendas con algún tipo de carencias, supera las treinta mil unidades y dentro de las cuales se encuentran incluidas aquellas que deben ser reubicadas por encontrarse en riesgo geográfico o de salubridad. Sobre este particular es importante anotar, que son acertadas las proyecciones realizadas en este plan, en cuanto a la construcción de mil viviendas anuales, con el objetivo de disminuir dicho déficit.

En lo referente a reubicación de familias, se destacan los esfuerzos realizados por las últimas dos administraciones municipales, ya que lograron reubicar a familias de los sectores informales de Ranchos del INAT, Pueblo "Pescao", el Campano, el Cerro y Jerusalén. Entre los años 2004 y 2010, se logró la reubicación de mil veinte familias de los mencionados sectores, en las nuevas urbanizaciones de Nueva Belén, Nueva Jerusalén y los Araujos ${ }^{142}$.

\footnotetext{
${ }^{142}$ Esta información ha sido obtenida directamente de la coordinadora de la oficina de la vivienda de Montería (2008-2011), Tahary Gambín Vargas, mediante entrevista realizada el día 13 de enero de 2009. y además se encuentra disponible en la página web de la alcaldía municipal. www.monteriacordoba.gov.co.
} 
En cuanto a construcción de viviendas, la administración de León Fidel Ojeda (20042007), se comprometió a construir cuatro mil viviendas de interés social, es decir mil por año, y solo alcanzó a entregar mil viviendas en todo el periodo de su alcaldía. No obstante, es oportuno anotar que a pesar de las limitaciones presupuestales, esta cifra, si bien no es muy significativa, por lo menos contribuye a la disminución progresiva del déficit de viviendas, y además, logró cumplir parcialmente con las reubicaciones programadas por el plan de ordenamiento territorial.

La administración municipal actual fue más prudente con el número de soluciones de vivienda para el periodo 2008-2011 y apenas se comprometió a facilitar la construcción de 3.000 viviendas. En este proceso de los últimos años participan el Fondo Financiero de Proyectos (FONADE), la Caja de Compensación Familiar de Córdoba (COMFACOR), Alcaldía de Montería, el Fondo Nacional de la Vivienda (FONVIVIENDA), la Diócesis de Montería ${ }^{143}$ y las Juntas de Acción Comunal.

Dejando de lado el tema de la vivienda y pasando al tema de la desmarginalización de asentamientos, este plan en su artículo 190 pretende lograr este objetivo mediante la localización de equipamientos de carácter zonal y local en áreas periféricas. En este sentido, y con el propósito de lograr integración física y cohesión social, el plan de ordenamiento territorial contempla las siguientes acciones:

1. Conformación de una red de equipamientos jerarquizada que responda a las exigencias funcionales y a la conformación de la estructura urbana propuesta.

2. Localización de nuevos equipamientos de alta jerarquía en el centro, con el fin de fortalecer sus funciones primarias $y$ aprovechar sus condiciones de accesibilidad actual y su potencial futuro con los sistemas de transporte masivo.

\footnotetext{
143 La Diócesis de Montería, como institución eclesiástica local y propietaria de algunos terrenos urbanos, ha participado en proyectos aislados de vivienda en esta ciudad.
} 
3. Localización de nuevos equipamientos de escala zonal con el fin de potenciar el ordenamiento y las funciones de centralidad en zonas estratégicas dentro del tejido residencial.

4. Desarrollo de programas de desmarginación mediante la localización de equipamientos de carácter zonal y local en áreas periféricas.

A pesar de lo programado, la ciudad sigue presentando actualmente un déficit de equipamientos de servicios comunitarios y de dotaciones públicas, especialmente en las comunas 1, 2, 3 y 4, ubicadas en el occidente y sur de la ciudad, debido a que las intervenciones programadas se vienen realizando principalmente en la pieza central y oriental. Este tema, al igual que el de la construcción de la vivienda será ampliado con más detalles en el capítulo $V$ de Impacto Urbanístico.

Consideramos pertinente anotar que hasta la fecha del 2011 el Plan de ordenamiento, ha sido ignorado por algunos funcionarios públicos, quienes consciente o inconscientemente, no logran detener el surgimiento de nuevos asentamientos informales, reducir el déficit de espacio público, mejorar la oferta de equipamientos y desmarginalizar el gran número de asentamientos informales de la periferia; es decir, varios de los programas incluidos en el plan le quedaron grande a unos funcionarios, y dentro de ellos se destaca: 1) la no reubicación de Villa Jiménez; 2) La nueva invasión de Sierra Chiquita; 3) La nueva invasión de Ranchos del INAT, y 4) La no reubicación del Bongo.

Igualmente, se incumplió con otros proyectos programados en el corto y mediano plazo y dentro de los cuales se pueden citar: pescadería minorista, bulevar del comercio, mercado central, ampliación de andenes, plazas centrales, ciudadela cultural, foro municipal, villa olímpica y complejo deportivo y un centro de negocios. Sin embargo, se cumplió a satisfacción con la construcción del puente sobre el río Sinú, avenida 20 de Julio, avenida de la constitución, terminal de transporte y ampliación de la cobertura de acueducto y alcantarillado. Como dato adicional, destacamos que la obra más costosa fue la del puente sobre el río (\$US 12.000.000), la cual no era prioritaria en el momento, ni fue concertada con la comunidad. 
Otros proyectos que fueron programados dentro del plan para el sur y occidente de la ciudad, y que aún (año 2011), no se han ejecutado son: plaza de mercado, centros culturales y artísticos, red de ciclorrutas, plaza urbana, prolongación de la avenida primera, el parque recreacional Caribe y parque urbano la Estancia. Dentro de estos proyectos se programó el Plan Maestro de Ciclorrutas (PMC) conformado por una red principal, una red secundaria y una red ambiental y recreativa, que se ha incumplido en un 95\%. Sobre este último aspecto, es pertinente anotar la desidia de los diferentes administradores, para mejorar la movilidad de más de veinte mil personas que utilizan este medio de transporte en Montería.

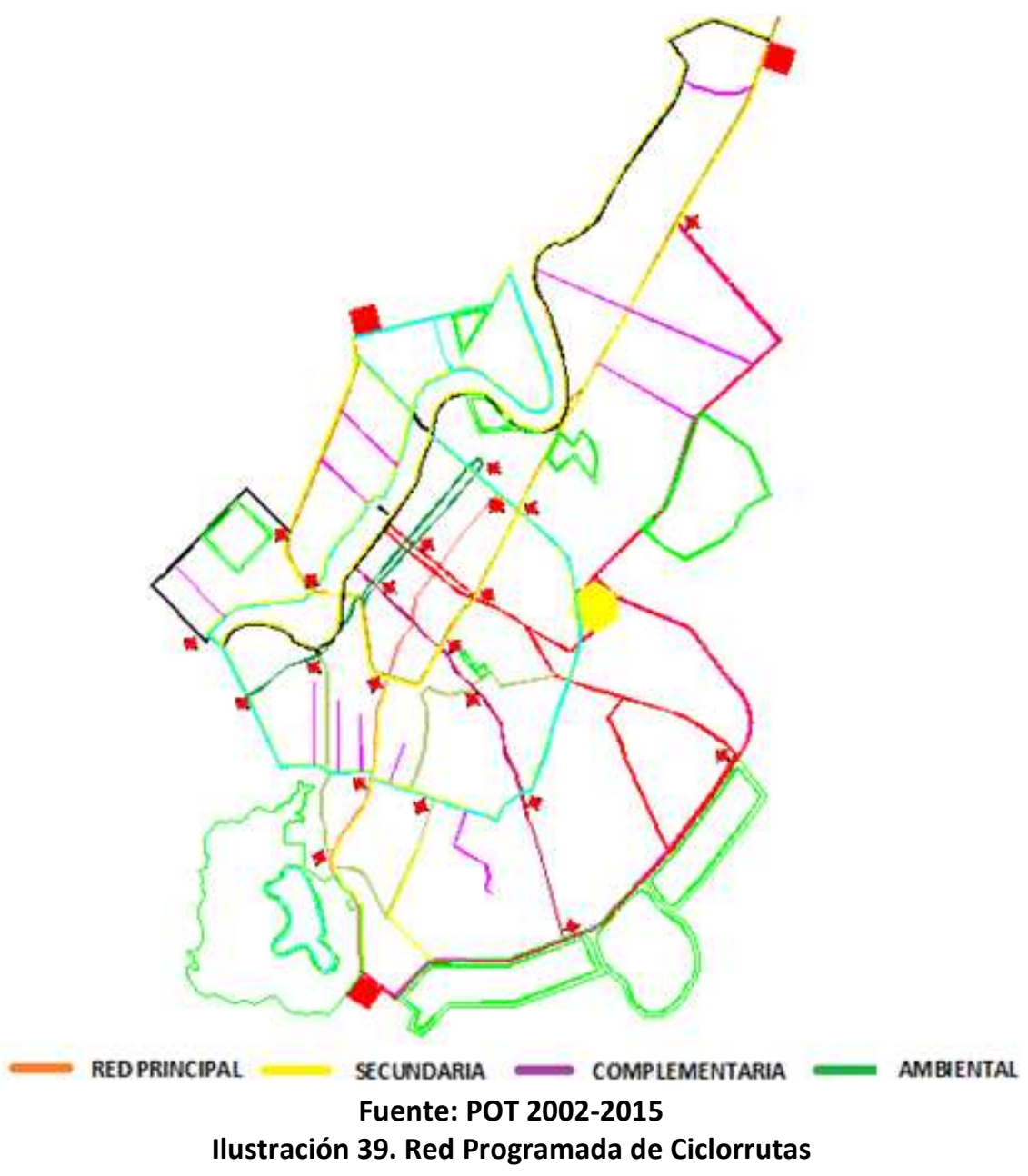

Se establecieron unas prioridades a corto plazo que no se han cumplido hasta la fecha (año 2011), ni se han construido las siguientes ciclorrutas de la red principal: carrera 9, desde los Araujos hasta el puente de la calle 42; Transversal 5W vía Arboletes; calle 22 
hasta la 56 con circunvalar; avenida $1^{\text {a }}$ a calle $5^{\text {a }}$ barrio la Coquera; carrera $1 \mathrm{~W}-$ Transversal 5W y la del barrio Mogambo desde la calle 1 hasta la diagonal 2C.

Igualmente, no se han construido redes secundarias ni terciarias en el suroriente, principalmente las programadas para conectar los asentamientos informales de Furatena, Villa Jiménez y Cantaclaro. En pocas palabras, de 123 kilómetros de cicloruta programados, escasamente se encuentran ejecutados 5 kilómetros.

Se programaron de igual forma, la construcción de obras necesarias para garantizar el control de inundaciones y la protección de las zonas urbanas bajas en el occidente y sur, así como la descontaminación de los humedales de las ciénagas de Berlín, el Cerrito y el Faro. Otra obra programada fue el Manejo Integral de Residuos Sólidos (MIRS) para la recolección, el transporte, el tratamiento y la disposición final de estos. Para este plan se estableció un plazo inferior a un año y fue coordinado por Planeación Municipal, la C.V.S. como órgano ambiental y la empresa Aseo Total. Este proyecto ha dejado mucho que desear puesto que, reiteramos, aun existe una política pública ambiental coherente.

En este plan de ordenamiento también se estableció la construcción de escenarios deportivos, culturales, terminal de transportes, bienestar social, central de abastos y plazas de mercado. El plazo fijado fue de dos años a partir de la aprobación del plan y hasta el momento sólo se ha cumplido con la ejecución de la terminal de transporte. Otra meta establecida fue la de garantizar la consecución de un promedio de $15 \mathrm{~m}^{2}$ de espacio público por habitante en el horizonte de este plan, que como se comentaba anteriormente, aún no supera los $\mathbf{2} \mathbf{m}^{2}$ por habitante para la ciudad.

El artículo 319 de este plan se refiere al desarrollo urbanístico progresivo, y en él se establece lo siguiente: "los proyectos urbanísticos destinados a vivienda de interés social prioritaria podrán contemplar el desarrollo progresivo de las obras de urbanismo y saneamiento respectivos, siempre y cuando se garantice a cargo del urbanizador responsable la obligación de provisionar redes de servicios y equipamientos". Este artículo, al final de cuentas, contribuyó a abrir las puertas a nuevos asentamientos de 
baja calidad urbanística, y/o urbanizados incompletamente, tal y como se reflejará en el capítulo de impacto urbanístico.

En lo que tienen que ver con el eje estratégico de usos del suelo, este plan a través de su artículo 365, establece las siguientes categorías: residencial neta, residencial con zonas de comercio y servicios, y residencial productiva, permitiendo en alguna de ellas usos comerciales, e incluso industria liviana, tal y como se describe en el siguiente gráfico.

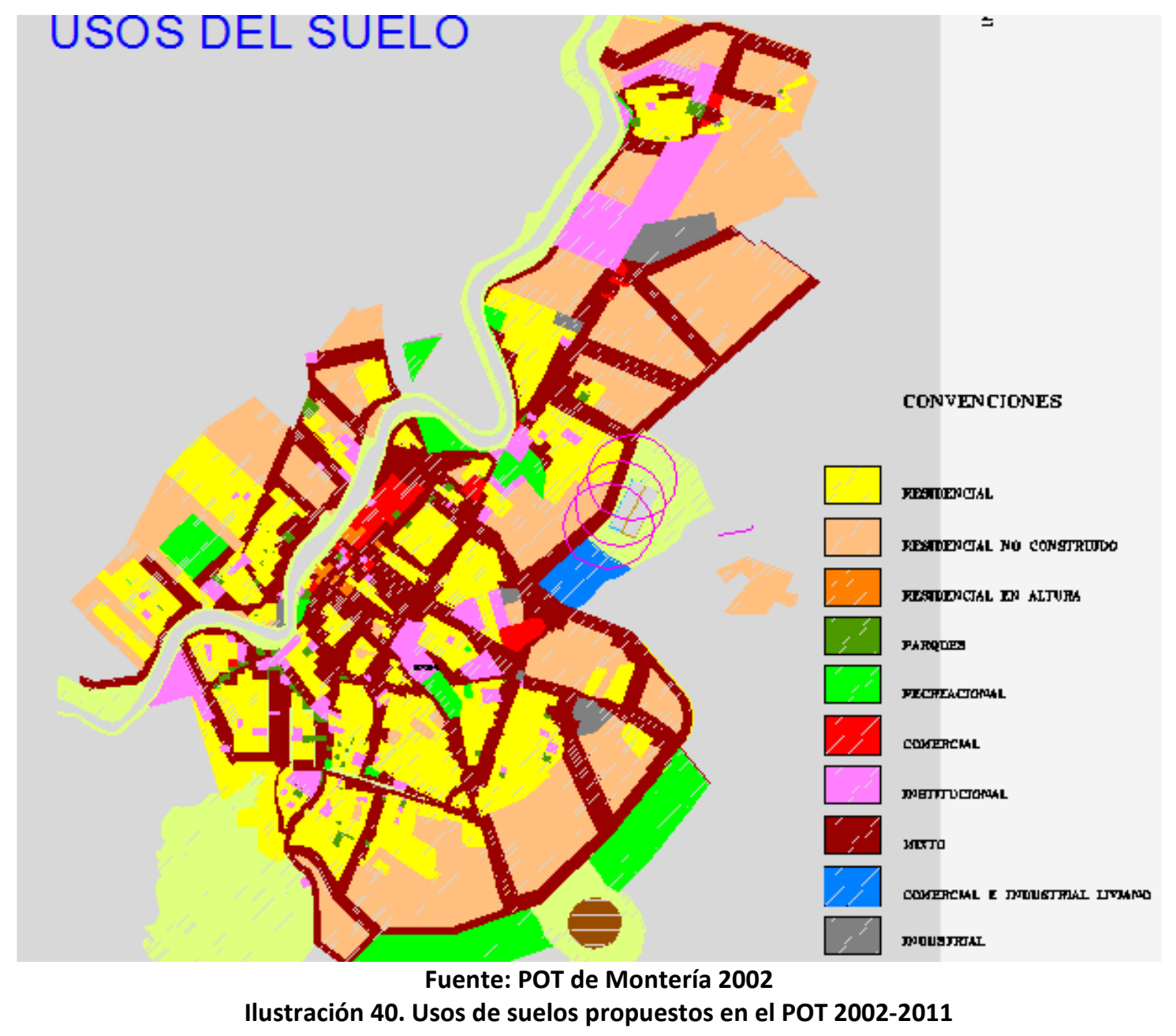

Con esta categorización el plan pretende la renovación urbanística de algunos sectores degradados como Sucre y la zona industrial, y la consolidación de nuevos sectores comerciales, institucionales y dotacionales. En este sentido, se consolidó a través del instrumento del plan parcial, el sector comercial del oriente, varios sectores residenciales en el norte y una nueva zona comercial e industrial en el nororiente de la 
ciudad. Si con evidencias, hemos cuestionado algunos artículos por ser demasiado genéricos, también debemos destacar la efectividad de este artículo porque permitió consolidar o recuperar sectores, en lo físico y funcional.

Finalizaremos el análisis de este plan de ordenamiento territorial con los artículos 566 y 567, porque a nuestro juicio, son los instrumentos legales más precisos con los que cuenta el alcalde para corregir desequilibrios urbanos y promover el desarrollo de los asentamientos irregulares e incorporarlos a las normas urbanísticas. En este sentido, el artículo 566, establece que la legalización es "el procedimiento mediante el cual se adoptan medidas administrativas encaminadas a reconocer oficialmente la existencia de un asentamiento o edificio y la incorporación al perímetro urbano cuando fuese necesario". Esto sirvió para que posteriormente la Administración y el Concejo municipal, incorporaran oficialmente a Villa Cielo dentro del perímetro urbano, y a su vez, las empresas de servicios públicos pudieran aumentar la cobertura de sus redes. Sobre este particular, también se ampliará en el capítulo v.

Por su parte, el artículo 567, establece que se delegue en el alcalde la legalización de barrios, asentamientos y desarrollos en general. Con este instrumento, el alcalde Marcos Daniel Pineda García (2008-2011), se propuso la meta de legalizar 5.000 viviendas ubicadas en los sectores informales de Montería. Finalizado el año 2010, y a uno de culminar su periodo de gobierno, había logrado la legalización de 2.500 predios. No obstante, es oportuno anotar que este proceso de escrituración, no ha ido acompañado de un proceso de mejoramiento físico de la vivienda ni urbanístico del asentamiento.

El análisis permite manifestar inicialmente que este plan es una buena iniciativa, ya que a lo largo de su contenido propone básicamente un modelo favorable de ciudad compacta, la defensa y equilibrio del patrimonio ecológico, ampliación de dotaciones públicas y el desarrollo urbano de los asentamientos informales, entre otros. ¿Pero realmente qué ha pasado? A nuestro juicio, se han logrado avances en materia de ordenación y de intervención urbana, como la reclasificación en los usos del suelo y la incorporación de planes parciales, que de haberse planteado oportunamente, 
hubiesen podido evitar la informalización urbanística de la ciudad, al igual que significativos desequilibrios sociales, urbanos y ambientales.

Sin embargo, anotamos que esta buena iniciativa no se puede traducir en mejores resultados, debido a que el municipio no cuenta con los suficientes instrumentos de tipo financiero y en este caso el logro de algunos objetivos depende exclusivamente de la empresa privada. Sobre este aspecto resulta oportuno anotar que las plusvalías establecidas por el plan y los recursos obtenidos por ellas ${ }^{144}$, hasta la fecha son demasiado irrisorios, impidiendo la financiación parcial o total de proyectos urbanos, tal y como lo establece el propio plan.

Los escasos recursos obtenidos mediante las plusvalías, la dependencia de recursos del gobierno central y la falta de inversionistas en esta ciudad, permiten comprender porque un plan de ordenamiento, con gran similitud al de Cali, Medellín o Bogotá (si con gran similitud, ya que fue diseñado e inspirado en éstos), no tiene el mismo impacto al de otras ciudades. Es decir, los objetivos de este plan, y fundamentalmente desmarginalización y ampliación de dotaciones, no se pueden lograr sin los recursos municipales necesarios, y en este sentido, Montería, a pesar de incorporar un plan técnica y legalmente viable, tiene una gran desventaja con las ciudades mencionadas, que cuentan con empresas, inversionistas y funcionarios más calificados.

Con respecto a la cualificación de los funcionarios, consideramos que éstos no han estado a la altura del plan de ordenamiento, ni tienen la imparcialidad requerida para la toma de decisiones, incluso prevaricando frecuentemente, pero al amparo de la impunidad generada por el poder político y/o económico de quienes los mantienen en dichos cargos. Es evidente que los funcionarios se preocupan más por responder a los intereses particulares de acumulación de capital de sus jefes, que a lograr los objetivos del plan, situación que puede ser aceptable, siempre y cuando no genere más desequilibrios sociales y ambientales, o por lo menos contribuyan a mitigarlos.

\footnotetext{
144 El arquitecto Heber Castro, primer liquidador de las plusvalías de la administración municipal de Montería y asesor de planes parciales manifestó que los recursos obtenidos a través de este instrumento, durante los primeros años no superaron los treinta millones de pesos anuales, es decir, quince mil dólares americanos por año. Esta información fue obtenida mediante entrevista concedida a Jhon Pinedo en la oficina de planeación municipal el día 19 de diciembre de 2009.
} 
Esta última afirmación se sustenta en el favorecimiento abierto que refleja algunas intervenciones de las últimas dos administraciones municipales, e incluso que se pretenden ampliar con los ajustes ${ }^{145}$ realizados a este mismo plan en el año 2011. Dentro de estos ajustes se modifican algunas propuestas, que buscaban un mayor dinamismo para el occidente y para el sur, y que sorpresivamente fueron trasladadas para el oriente de la ciudad. Se destacan, dentro de dichas modificaciones, la construcción del estadio de futbol en un sitio diferente al propuesto inicialmente y la construcción excesiva de estaciones de gasolina en zonas residenciales no adecuadas para ello.

Por último, ante los aciertos y desaciertos del plan vigente, y los desequilibrios que puedan generar los ajustes realizados en materia de recualificación, preferimos anotar en esta investigación, los interrogantes que oportunamente manifestamos en el debate realizado por la comisión de tierras del Concejo municipal, el día lunes 10 de octubre de 2010, y al cual se asistió como representante de la academia, por invitación de los miembros de dicha corporación municipal. Estos interrogantes fueron los siguientes: ¿Esta ciudad requiere más estaciones de gasolina que equipamientos? ¿EI desarrollo hacia oriente tiene como objetivo la concentración o la dispersión? ¿En esta ordenación se tiene en cuenta únicamente la lógica de la economía, pero que pasa con las lógicas sociales, ambientales e históricas? ¿La ciudad requiere 120 kilómetros de ciclo-rutas para mejorar la movilidad de los ciclistas o 3 kilómetros de ciclo-paseo para una minoría? ¿Se están corrigiendo los desequilibrios del pasado, pero realmente se están previniendo los del futuro? ¿Las plusvalías generadas por la edificación en altura son proporcionales a los traumas que genera esa tipología edificatoria? ¿Cómo en una zona planificada para vivienda unifamiliar se está permitiendo la construcción de edificios de hasta 14 alturas? ¿Estas redes resistirán, se ampliarán o colapsarán? ¿La incorporación de la invasión Villa Jiménez al perímetro urbano, es coherente con el objetivo de lograr el equilibrio ambiental y proteger los ecosistemas locales que

\footnotetext{
${ }^{145}$ Los ajustes de este plan estuvieron orientados más que todo a recualificar terrenos y a trasladar algunas de las obras programadas hacia dicho sector, y no tuvo como objetivo central modificaciones orientadas a lograr el equilibrio territorial del sur ni del occidente de la ciudad. Sin embargo, destacamos que estos ajustes, permitieron mejorar la cartografía digital y las estadísticas socioeconómicas de la población, constituidas inicialmente, a nuestro juicio, en las principales deficiencias del plan original.
} 
propone el POT? ¿Responde este plan a intereses mercantiles, ambientales o políticos? ¿Participaron todos los actores sociales en la elaboración de este plan, tal y como lo ordena la ley? ¿Hay estrategias para la recuperación de las ciénagas ubicadas en zona rural?

Concluimos estos razonamientos manifestando que como académicos fuimos invitados a una sesión del concejo, pero no se tuvo conocimiento ni se fue invitado a participar en la construcción de dichos ajustes. No obstante, desde la óptica del ciudadano, se manifiesta desde esta investigación, que no hubo respuesta oportuna a los interrogantes formulados, y finalmente, sin pena ni gloria, en el año de 2011 fueron aprobados los ajustes al plan, que por lo observado durante los últimos meses, tienden a aumentar desequilibrios urbanos y a favorecer a los automovilistas y no a los ciclistas ni a los peatones.

\subsubsection{Montería y los planes de desarrollo}

Aunque en el apartado anterior, en la nota pie de página 137, se estableció el origen de estos planes, consideramos oportuno establecer algunas diferencias entre éste y el plan de ordenamiento territorial: 1) el plan de desarrollo tiene su origen en la ley 142 de 1994 y el plan de ordenamiento en la ley 388 de 1997; 2) el primero es de corto plazo (4 años), mientras que el segundo es de largo plazo (10 a 12 años); 3) en el primero, se consignan los programas y proyectos (sociales, económicos, arquitectónicos o urbanísticos) de gobierno de un alcalde y en el segundo, el modelo urbano con las estrategias y compromisos a seguir por los diferentes actores sociales del territorio, $y, 4)$ aunque ambos los aprueba el concejo municipal mediante acuerdo, los planes de desarrollo son responsabilidad individual del alcalde y los planes de ordenamiento son de responsabilidad compartida, entre varias administraciones municipales. 


\subsubsection{Plan de Desarrollo 2001-2003}

El plan de desarrollo 2001 - 2003, fue aprobado por acuerdo 002 del año 2001 del Concejo de Montería durante la administración municipal del alcalde Luis Jiménez Espitia. Este plan incorpora cinco "mega-proyectos" ${ }^{146}$ que se apoyan en seis prioridades representadas en estrategias, programas y acciones, que a continuación enunciamos:

1. Sistema de Servicios Públicos Básicos Rurales (agua potable, alcantarillado, energía, aseo y sanidad).

2. Sistema Municipal Multimodal de Transportes (Terminales de transporte, central de abastos, vías, puertos fluviales, aeropuerto, puentes sobre el río Sinú).

3. Banco de Tierras (vivienda interés social, planes parciales, reubicación de asentamientos, áreas de producción agropecuaria, parque industrial de alta tecnología)

4. Sistema Municipal de Aguas y Parques: Montería ecológica y turística (recuperación Avenida Primera, Sierra Chiquita, Ciénaga de Betancí, corredor del río Sinú) CEAM

5. Montería, municipio cultural y educativo (telecomunicaciones, bibliotecas, escenarios culturales).

Las seis prioridades que este plan considera necesarias para mejorar los niveles de desarrollo del municipio son en su orden:

1. empleo permanente y producción;

2. desmarginación;

3. desarrollo participativo;

4. conciencia ciudadana;

5. organización territorial, y

6. gestión pública.

\footnotetext{
${ }^{146}$ El concepto de mega-proyecto en este plan de desarrollo, concretamente se refiere a las principales intervenciones urbanas que se proponen durante el periodo de gobierno.
} 
En lo relacionado con el empleo y la producción, se puede destacar que, dentro de las ocho acciones diseñadas, la primera, pretendía la conformación de una red de entidades, orientada a la generación de empleo para jóvenes de asentamientos informales, madres cabeza de familia, discapacitados y desplazados por la violencia. En este aspecto del empleo, lo más rescatable, sin ser muy efectivos, fueron algunos cursos cortos de capacitación y una serie de programas de orientación dirigidos a esta población.

La desmarginación establecida por este plan como una prioridad, tenía como objetivo ideal, el de mejorar la calidad de vida de la población residente en áreas marginales a través de la intervención integral, que permitiera superar las deficiencias de la vivienda, la infraestructura y los servicios públicos básicos de los asentamientos precarios, e integrarlos al tejido social y urbano.

La estrategia, que este plan de desarrollo, diseñó como apoyo para la desmarginación de áreas deprimidas, aparece expresada textualmente de la siguiente manera:

"Intervenir sobre el entorno público y social combinando el esfuerzo de la Administración Municipal y las entidades locales, departamentales y nacionales, con la vinculación de la comunidad y el sector privado, de forma tal que los habitantes de dichos asentamientos se conviertan en gestores, aportantes y garantes de permanencia de la acción realizada y no en simples receptores de una acción estatal. Lo anterior, asegurará la coordinación y suma de esfuerzos humanos, físicos y financieros que permitirán terminar el equipamiento físico y social de los asentamientos que han surgido de procesos de desarrollo inadecuados a causa de la pobreza económica, la inseguridad y los desplazamientos forzosos. Esta estrategia exige la coordinación entre las empresas de servicios públicos y sociales, para que los cronogramas de las obras y prestación de los servicios, se ejecuten simultáneamente, se consulten y armonicen $^{1147}$

\footnotetext{
${ }^{147}$ Plan de Desarrollo de Montería 2001-2003. Capítulo II. Prioridad № 2. Desmarginación. Estrategia № 3. Disponible en. www.alcaldiademonteria.tripod.com/plan desarrollo02.html.
} 
En este aspecto, la administración municipal intentó promover la asociación de propietarios en unidades de actuación urbanística para desarrollar planes parciales que mejoraran los estándares de calidad en la oferta de vivienda, y contener el crecimiento de las urbanizaciones informales y de invasiones en terrenos de gran impacto ambiental. De la misma manera, pretendió fomentar la participación activa de las comunidades vulnerables, en la solución del problema de la vivienda y del mejoramiento urbanístico de los asentamientos precarios, semiconsolidados y consolidados.

Un déficit fiscal que ascendía a 40 mil millones de pesos (20 millones de dólares), y las limitaciones de tipo financiero, no hizo posible la materialización de muchos de las acciones contempladas en este plan, y dentro de los que se deben mencionar: la reubicación de viviendas en zonas de alto riesgo; renovación urbana; recuperación del espacio público; oferta de vivienda de interés social, y construcción de nuevos equipamientos.

No obstante, se realizaron los diseños de la terminal de transporte, la prolongación de algunas vías urbanas, equipamiento comercial en el sur y se desarrolló la primera fase del proyecto del parque lineal de la Ronda del Sinú. Así mismo, se otorgaron 2400 lotes con servicio para vivienda de interés social por parte del Instituto Nacional de Reforma Urbana INURBE, pero no se pudo neutralizar la expansión de asentamientos precarios como los Colores y el Minuto de Dios.

\subsubsection{Plan de Desarrollo 2004-2007}

Este plan fue denominado "Construyamos el municipio por el camino correcto" ${ }^{148} \mathrm{y}$ aprobado por acuerdo municipal № 0006 de 2004, durante la administración del

\footnotetext{
148 Con respecto al lema de los planes de desarrollo, y específicamente al de éste, consideramos oportuno anotar, que su contenido es más político que técnico, y precisamente, son propuestos desde campaña, aprovechando siempre una coyuntura, que generalmente le permite conquistar votos, independientemente de la plataforma política o de la viabilidad de los proyectos. En otras palabras, en democracias débiles, la publicidad juega un papel importante, y esto lo saben explotar muy bien en este contexto los "expertos" en marketing político. Sin embargo, reiteramos, que la coyuntura social o económica, juega un papel importante en la elección del lema, y en realidad dota de mucho contenido, lo que aparentemente carece de él.
} 
alcalde León Fidel Ojeda. La misión del plan, por lo menos sobre el papel, se encaminaba a lograr una ciudad con mejor desarrollo físico-espacial, con capacidad de aprovechar las potencialidades del suelo de manera sostenible; la reubicación de asentamientos ubicados en zonas de alto riesgo y la recuperación del espacio público.

Dentro de los objetivos de este plan sobresalen la convivencia, la participación, la protección del medioambiente, la calidad de vida de los habitantes, el desarrollo físicoespacial del municipio, la modernización de la administración pública, la orientación de la inversión y el mejoramiento del hábitat. Este último se refiere a la construcción de vivienda digna y en armonía con el entorno natural y urbano, con el propósito de convertir a Montería como el primer biomunicipio ${ }^{149}$ de la región Caribe.

En materia de vivienda, se determinó que para la fecha existía un déficit cuantitativo y cualitativo de aproximadamente 38.820 viviendas, de los cuales el 60\% correspondían a los estratos 1, 2 y 3, de una población estimada por el DANE en 343.607 habitantes. Igualmente, el plan determinó que se encontraban disponibles 2.050 hectáreas (41.41\%) del área total urbana, para desarrollar programas de vivienda de manera racional y sin necesidad de expandir el área urbana del municipio.

149 Este plan define el concepto de biomunicipio como "aquél que se basa en el marco del desarrollo sostenible, como una opción económica y ambiental y tiene como principio fundamental el crecimiento económico para el mejoramiento de la calidad de vida, razón por la cual no se constituye en un freno al desarrollo urbano y rural del municipio". (Plan de Desarrollo, 2004, capítulo I. Objetivos) 


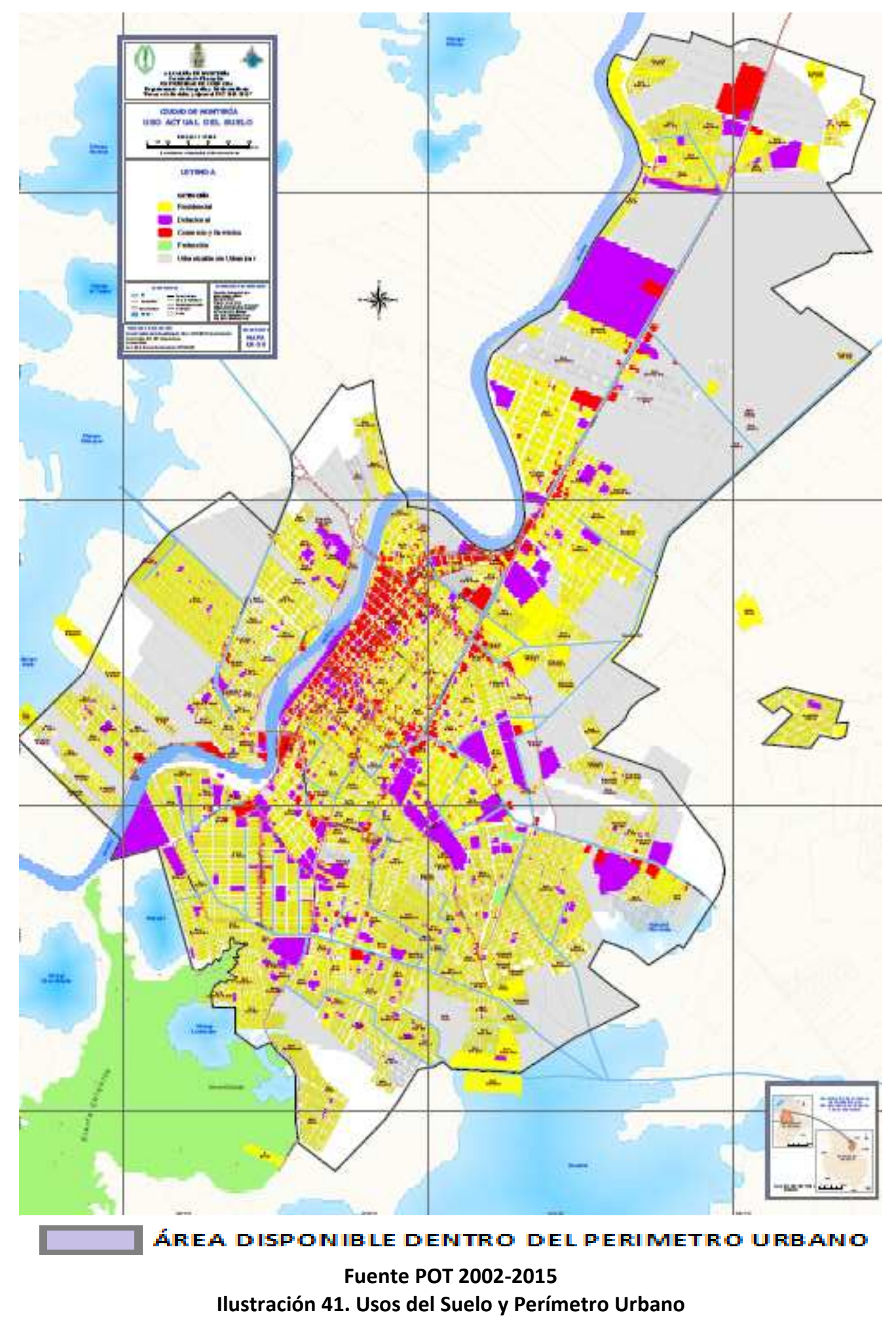

Los datos del plan, en esta materia, reflejaban la existencia de 3.620 viviendas tipo tugurio en barrios formales; 5.912 unidades en asentamientos precarios y cerca de 2.900 en barrios semiconsolidados o de transición. El total de estas viviendas ascendía a 12.400 unidades y la población afectada era calculada en 71.400 habitantes, lo cual 
hacia inferir que unos 18.000 hogares eran demandantes efectivos de vivienda, de un total de 61.665 en la zona urbana. Es oportuno señalar, que dichas viviendas no se encuentran concentradas, sino por el contrario, dispersas por toda el área urbana; por lo tanto, consideramos conveniente analizar su ubicación en el siguiente apartado, de ciudad informal.

Los objetivos que se propusieron para solucionar el problema de la vivienda, estuvieron acompañados de estrategias, metas $\mathbf{y}$ acciones $^{150}$, a las que no se les definieron indicadores precisos. Dentro de los seis objetivos que se establecieron como alternativas en este plan de desarrollo, se rescata por su claridad y por su interés en la Tesis, el que apuntó a la Gestión y Coordinación para la reubicación de viviendas localizadas en zonas de alto riesgo y de desarrollo incompleto; los demás no fueron suficientemente claros, y además la formulación de cada uno de ellos, no permitió su valoración; sin embargo, estimamos prudente citarlos:

1. Gestionar y coordinar programas de vivienda nueva dirigidos a la población más vulnerable.

2. Gestionar y coordinar la reubicación de viviendas localizadas en zonas de alto riesgo o de desarrollo incompleto.

3. Gestionar y coordinar mejoramiento de vivienda con el fin de disminuir el déficit cuantitativo en la población más vulnerable.

4. Homogenizar el tipo de vivienda necesaria para la población vulnerable.

5. Regularizar y controlar los precios del mercado en el municipio.

6. Fomentar, a través del sector de la construcción, la generación de empleos productivos en el municipio.

\footnotetext{
${ }^{150}$ Aunque todos los planes de desarrollo de la ciudad hablan de estrategias, metas y acciones, ninguno de ellos establece un marco conceptual para definir estos términos. No obstante, desde esta investigación, y después de analizar cada una ellas, establecemos las siguientes diferencias: las estrategias son instrumentos (proyectos o programas), que contribuyen al logro de los objetivos de largo plazo (en este caso cuatro años) trazados por el plan; las acciones son actividades concretas de esos instrumentos (subprograma o subproyecto), y las metas son, a nuestro juicio, la consecución del objetivo de esas acciones, es decir, el resultado de lo programado. Precisamente, es en esta instancia donde se quedan cortos estos planes.
} 
Como se comentó anteriormente, el objetivo número dos fue el de mejor formulación, y además se complementó con el desarrollo de programas de regularización, legalización y titulación de predios de propiedad del municipio, así como con el fomento de alianzas estratégicas entre las organizaciones no gubernamentales, las cajas de compensación y las organizaciones populares de vivienda (OPV) ${ }^{151}$.

Por último, es importante anotar que a este objetivo se le establecieron metas definidas como las siguientes:

1. Coordinar y gestionar la reubicación o mitigar el riesgo a 500 familias ubicadas en asentamientos de desarrollo incompleto en el municipio.

2. Coordinar y gestionar la adquisición de terrenos para el desarrollo de soluciones habitacionales de proyectos nuevos.

3. Coordinar y gestionar la reubicación de $500^{152}$ familias localizadas en zonas de alto riesgo.

\section{Coordinar y gestionar el mejoramiento habitacional de 500 familias.}

5. Legalización de los terrenos invadidos que son propiedad del municipio.

En lo referente a política social, este plan diagnosticó las siguientes problemáticas: 1) altos índices de violencia; 2) baja calidad de vida; 3) poca capacidad para responder a los retos de la modernidad, 4) escaso desarrollo científico y tecnológico; 5) reducidos niveles de participación ciudadana, y 6) inequidad en el acceso a la salud, educación,

\footnotetext{
151 Definición de Organizaciones Populares de Vivienda. Se entiende por Organizaciones Populares de Vivienda aquellas que han sido constituidas y reconocidas como entidades sin ánimo de lucro cuyo sistema financiero sea de economía solidaria y tengan por objeto el desarrollo de programas de vivienda para sus afiliados por sistemas de autogestión o participación comunitaria. Estas Organizaciones pueden ser constituidas por sindicatos, cooperativas, asociaciones, fundaciones, corporaciones, juntas de acción comunal, fondos de empleados, empresas comunitarias y las demás que puedan asimilarse a las anteriores, en los términos previstos por la Ley 9 de 1989. (Decreto 2391/89, Art. 1ㅇ)

${ }^{152}$ En este plan se dio prioridad de reubicación a las 500 familias que conforman la invasión del Cerro, debido al alto riesgo que representan los continuos deslizamientos de tierra. Sin embargo, después de realizada dicha reubicación, todo sigue igual, ya que no se destruyeron los ranchos, e igual número de familias invadieron nuevamente.
} 
cultura, deporte y recreación ${ }^{153}$. Con el objetivo de corregir estas problemáticas sociales, el plan incorporó la denominada "política de desarrollo social integral", que se enmarcaba dentro de cinco grandes principios durante:

\author{
1. Ambientar las condiciones para que San Jerónimo de Montería sea un Modelo \\ de Municipio Saludable.
}
2. Proporcionar Educación con Calidad, Cobertura y Eficiencia para todos sus habitantes.

3. Crear la Cultura Ciudadana de Convivencia en todos sus espacios.

${ }^{153}$ La inequidad en el sector salud y educación se refleja en los deficientes indicadores de cobertura y calidad.

"En la ciudad de San Jerónimo de Montería a diciembre de 2003, la población afiliada al Régimen Subsidiado Público (SISBEN), es de 79.436 lo que genera una cobertura de $41.2 \%$ el cual está por debajo de la cobertura del país y del departamento. Si se tiene en cuenta la población clasificada en los niveles 1, 2 y 3 del SISBEN, el potencial es de 192.907, con el cual el déficit de cobertura corresponde a 116.369 personas. Este déficit es del 60\%, y se considera dentro del Índice de Necesidades Básicas Insatisfechas del municipio" (PD, 2004, Cáp. II. Salud).

"En el sector de la educación, en Montería existen para el año 2003, 131 establecimientos educativos de preescolar, primaria, secundaria y media vocacional, de los cuales el $46 \%$ son de carácter oficial y 54\% de carácter privado, que conforman la oferta de establecimientos educativos para la demanda escolar del Municipio. Sin embargo, los establecimientos del sector oficiales poseen 237 subsedes, las cuales carecen de computadores, vídeos o televisores, 23 carecen de laboratorios en las áreas básicas, 61 carecen de servicios de bienestar, 8 carecen de servicios de acueducto y alcantarillado, 12 carecen del servicio de energía y en el área rural 2, y 295 presentan serias carencias en la infraestructura física y en los ambientes (aulas, salones de profesores, salas de ayudas, jardines) que no permiten impartir una educación con niveles de calidad aceptables en el Municipio" (PD, 2004, Cáp. III. Educación).

"Las Necesidades Básicas Insatisfechas - NBI de la población urbana de Montería es del 40.8\%, y del área rural del 78.2\%. El 49.7\% del total de la población carece de los servicios básicos, índices que superan los promedios regionales y nacionales. Igualmente la población en miseria, alcanza en el área urbana un $20.5 \%$ y en la rural un $45 \%$ y el promedio municipal del $26.4 \%$. Estos datos son basados en el censo de 1993, y están corroborados por la estratificación de población, la cual señala que el 39.6\% de la población vive en estrato 1 y el $27.7 \%$ en el estrato 2 , situación que índica que el $67.3 \%$ de la población vive en estado de pobreza absoluta. Si a los índices anteriores se le suma el 19.3\% de población en estrato 3, teniéndose en cuenta que variables como servicios públicos, vivienda y desempleo, espacios libres, recreación, educación y salud, son igualmente deficitarios en este sector, tendríamos una alta población marginada, (86.6\%) en toda la ciudad incluida el área rural". (PD, 2004. Cap. IV Perfil Social) 
4. Lograr una participación Comunitaria permanente de todos los estamentos de la sociedad (Junta Administradoras Locales, Ediles, Concejales).

5. Alcanzar un Desarrollo Humano Sostenible como finalidad primaria, en donde los Monterianos entiendan la necesidad de preservar el medio ambiente como elemento fundamental para el desarrollo de las futuras generaciones

El diseño de estas propuestas también tuvo en cuenta que la distribución de usos del suelo en esta ciudad no se había realizado con criterios prospectivos, sino legalizando actuaciones de hecho en lugares que tienen vocación diferente para el establecimiento de residencias permanentes. Otros aspectos importantes que se tuvieron en cuenta fueron las tensiones sociales generadas por conflictos entre usos urbanos y la tasa de crecimiento poblacional de los últimos quince años, que de acuerdo con los datos históricos de población, incorporó anualmente un promedio de trece mil personas; es decir una insostenible tasa de crecimiento de 4.35\%, que afortunadamente no continuó el mismo ritmo.

En lo referente a servicios públicos, este plan consideró que, además de los servicios domiciliarios, el municipio debía extender este concepto a otras actividades como la seguridad ciudadana y defensa nacional, y los servicios de información básica a la comunidad ante cualquier trámite relacionado con sus funciones. En esta dinámica, esta administración inició procesos de concertación con las empresas privadas de servicios públicos que permitieron posteriormente mejorar la cobertura y la calidad de energía eléctrica, agua potable, saneamiento básico, gas domiciliario, telefonía convencional y telefonía celular.

En el sector de la educación, se plantearon objetivos ambiciosos, que buscaban generar un cambio de actitud del monteriano o mayor sentido de pertenencia e identidad con la ciudad y el patrimonio ecológico. Infortunadamente estos objetivos no fueron logrados en su totalidad, debido a que no hubo una apropiada articulación entre los recursos de la academia, sector público, empresa y comunidad. 
Las metas que el plan estableció para mejorar cobertura y calidad de la educación, con el objetivo de lograr una mejor articulación de la sociedad con el entorno ecológico y mejores relaciones sociales fueron las siguientes:

$\checkmark$ Construcción, adecuación y remodelación de 295 aulas, en el periodo 2004-2007

$\checkmark$ Construcción de 72 unidades sanitarias para el sector urbano y rural, en el periodo 2004-2007.

$\checkmark$ Construcción y remodelación de 23 laboratorios para el sector urbano y rural.

$\checkmark$ Dotación de 14 bibliotecas para el sector urbano y rural, 2004-2007.

$\checkmark$ Construcción de 4 muros de cerramiento para las instituciones educativas del sector urbano

$\checkmark$ Construcción de 8 unidades administrativas para el sector urbano y rural.

$\checkmark$ Construcción de 8 aulas múltiples para el sector urbano.

$\checkmark$ Dotación de los servicios públicos de agua, energía, teléfono a 25 instituciones educativas del sector urbano y rural, dotación de pupitres, adecuación y pintura para 15 instituciones educativas del sector urbano y rural, en el periodo 20042007

$\checkmark$ Conocimiento y uso del Internet para 2.827 docentes, periodo 2004-2007

$\checkmark$ Estímulos a la excelencia académica a 15 instituciones educativas.

En cuanto al manejo ambiental, se diseñaron programas tendientes a la conservación del caudal del Río Sinú, al mejoramiento del manejo de aguas residuales y a la optimización del manejo de los residuos sólidos. El desarrollo de estos programas estaría complementado con proyectos de mejoramiento de la infraestructura para agua potable y saneamiento básico que se expresaron por medio de las siguientes metas:

1. Conservación del caudal Río Sinú, a través de la Corporación que se creará para efecto. A finales del 2004 se debe tener adelantado los convenios Interinstitucionales con la Corporación de los Valles del Sinú y el San Jorge (CVS), y tener como mínimo la primera acción de importancia para la conservación del Río. 
2. Mejoramiento del manejo de aguas residuales: A diciembre del 2004 en el centro de la ciudad debe tener restituido su alcantarillado.

3. Optimización del manejo de residuos sólidos: A diciembre del 2004 se debe estar trabajando con la nueva alternativa para el manejo integral de los residuos sólidos al igual que se debe tener el Plan Maestro para el Manejo y aprovechamiento de los residuos sólidos, y a diciembre 2007 se debe tener una planta de tratamiento de lixiviados.

Efectivamente, al finalizar esta administración se habían realizado los diseños y estudios para la ampliación del acueducto y alcantarillado, así como la aprobación del nuevo relleno sanitario para la ciudad. En el aspecto de redes, se restituyeron $8 \mathrm{~km}$ de redes de acueducto y $10 \mathrm{~km}$ de redes de alcantarillado, que permitieron ampliar y mejorar la cobertura de estos servicios a una extensión de $300 \mathrm{~km}$ para el primero y 70 Km para el segundo, hasta el año 2007.

Por último, conviene destacar el programa sobre recuperación del espacio público, y denominado, "Rescatando Espacios para disfrutar la Construcción de la Ciudad por el Camino Correcto", el cual buscaba devolverle a la ciudadanía los espacios públicos usurpados por el comercio informal y automóviles y así crear una cultura de protección de dichos espacios, que a su vez permitan seguridad e identidad para todos los habitantes de la ciudad.

Con este programa se inició un proceso complejo, que pretendía desalojar a los comerciantes informales invasores del espacio público del centro de la ciudad desde hace más de treinta años, pero su gran inconveniente fue no lograr definir alternativas colectivas para estos comerciantes ni los escenarios apropiados para su reubicación. Fueron pocos los espacios que se lograron recuperar, más sin embargo, se logró avanzar en la elaboración de base de datos del sector informal y de programas de sensibilización que favorecerían a la siguiente administración. 


\subsubsection{Plan de desarrollo 2008-2011}

El plan de desarrollo 2008 - 2011 "Juntos Hacemos Más" fue aprobado por acuerdo municipal Na 003 del 27 de mayo de 2008 por el Concejo de Montería. Tiene como misión, mejorar las condiciones sociales, económicas, urbanísticas, ambientales, administrativas y culturales de esta ciudad. Se estructura a partir de cinco grandes líneas estratégicas de acción:

1. Montería, una ciudad de oportunidades

2. Productividad social

3. Desarrollo rural y competitividad

4. Montería una ciudad amable y dinámica

5. Gobierno Participativo con Corresponsabilidad

Dentro de los diferentes programas que contiene este plan, resulta pertinente enunciar el programa denominado "Vivienda Digna con techo Propio", el cual fue diseñado con el objetivo de mitigar el déficit habitacional en zona urbana y rural. Este programa está conformado por los siguientes subprogramas: 1) promoción a la construcción de viviendas de interés social; 2) viviendas para familias desplazadas; 3 ) reubicación de familias, y 4) vivienda saludable.

El subprograma de construcción de Vivienda de Interés Social (VIS) ${ }^{154}$, tendría como meta, promover la construcción de 2400 unidades para familias necesitadas y carentes de viviendas durante el periodo 2008-2011. Este subprograma se realizaría con recursos del municipio y del Ministerio de Vivienda Ambiente y Desarrollo Territorial (MAVDT), mediante las siguientes modalidades: a) producción de vivienda de interés social; b) mejoramiento de vivienda; c) construcción en sitio propio; d) compra de vivienda usada, y 5) compra de vivienda nueva.

\footnotetext{
154 Por vivienda de interés social (VIS), se entiende a aquella que reúne los elementos mínimos de habitabilidad, calidad arquitectónica y diseño urbanístico, y cuyo precio máximo es de 135 salarios mínimos mensuales vigentes SMLMV (\$US 30.000 - 38.000 año 2011). Este concepto se incorpora inicialmente en la Ley 9 de 1989 de Reforma Urbana, luego en la Ley 388 de 1997 de Ordenamiento Territorial, y finalmente en la Ley 3 de 1991, que crea el Sistema Nacional de Vivienda de Interés Social, y además reforma el Instituto de Crédito Territorial (ICT).
} 
El subprograma de viviendas para familias desplazadas tiene como meta la construcción de 600 viviendas de interés social para este tipo de población y el municipio lo cofinanciará con recursos nacionales y de cooperación internacional, por medio de organizaciones no gubernamentales y programas de la Red de la Presidencia de la República.

Los subprogramas 3 y 4 , de reubicación de familias y de viviendas saludables, no definieron metas cuantitativas, pero se establecieron para reubicar a aquellas familias ubicadas en zonas de alto riesgo no mitigable y para mejorar las condiciones sociales o físicas de los habitantes del barrio informal Cantaclaro. Este último subprograma se desarrollaría dentro de un plan piloto de Mejoramiento Integral de barrios del Ministerio de Vivienda, Ambiente y Desarrollo Territorial (MAVDT), y el municipio de Montería.

El programa de Mejoramiento Integral de Barrios se financiaría con un $80 \%$ de recursos aportados por el MAVDT y el Departamento de Desarrollo territorial, y el $20 \%$ restante será la contrapartida aportada por el municipio de Montería. El objetivo del programa se orientaría a mejorar las condiciones urbanísticas de barrios precarios y a la satisfacción de necesidades básicas de sus habitantes.

Por su parte el programa denominado "Montería una Ciudad Amable y Dinámica" fue diseñado con el propósito de lograr una ciudad más segura y agradable para residentes y/o visitantes. Este programa, a su vez, se apoya en 240 subprogramas, que se enmarcan principalmente dentro de la capacitación, intervención, concientización y gestión para el logro de dichos propósitos. Estos subprogramas se desarrollan atendiendo a diferentes demandas, pero por su relación con el objetivo de esta tesis e impacto, destacamos los siguientes:

\footnotetext{
* Vivienda Digna Con Techo Propio

* Desarrollo urbano

* Vías para el desarrollo

* Canalización primaria red de drenaje

* Tratamiento erosión río Sinú y reforestación.

* Tratamiento de Residuos Sólidos y Aseo.

* Redes de alcantarillado para una higiene adecuada.
} 


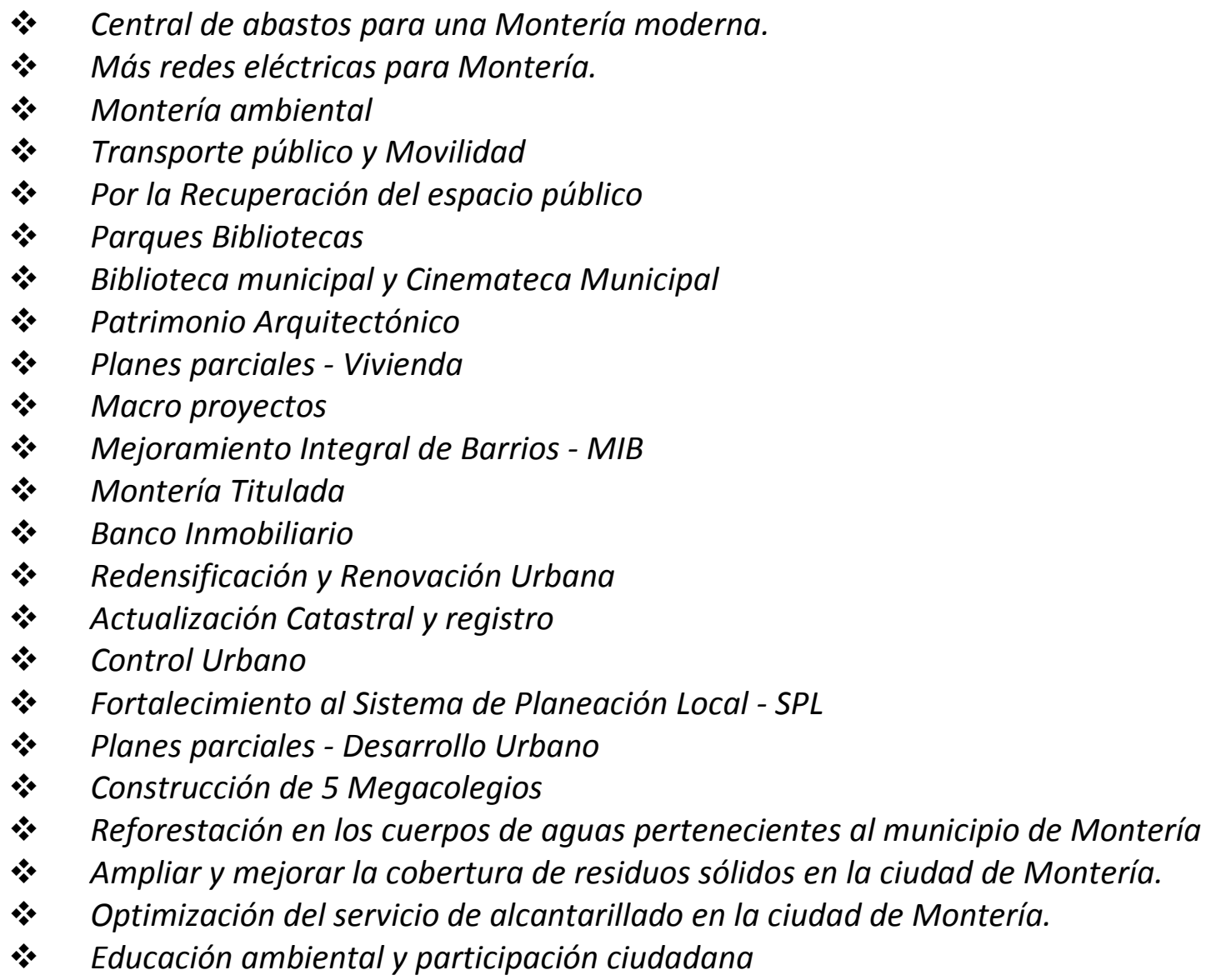

Dentro de las metas de estos programas resultan más prioritarias y claramente medibles, aquellas relacionadas con la oferta de vivienda de interés social, dotaciones públicas e infraestructuras de redes de acueducto y alcantarillado. En tal sentido, esta administración, apoyada en el plan de desarrollo, consideró la necesidad de generar 170 hectáreas de suelos urbanizables para construcción de viviendas, que se obtendrían por medio de los planes parciales: Furatena, Portal de Navarra, Portal de la Candelaria, Los Mangos, Sevilla, Filadelfia y COMFACOR. 


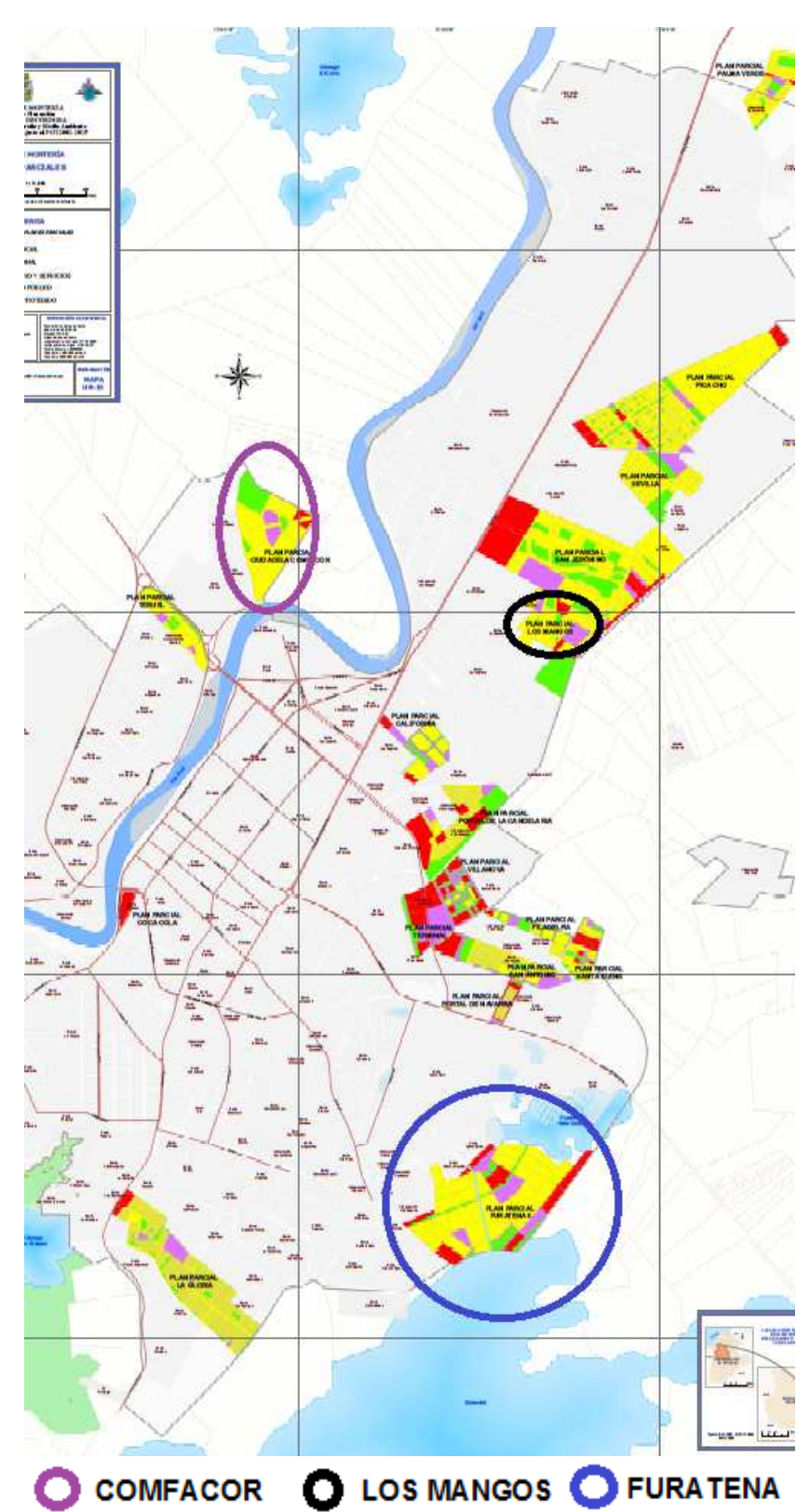

Elaboración propia a partir de datos del POT 2002-2015

Ilustración 42. Planes Parciales Comfacor, Los Mangos y Furatena

Uno de los subprogramas más representativos para los habitantes de sectores informales, fue el de Montería Titulada, el cual estableció como meta, la titulación de tres mil predios edificados o sin edificar, pero habitados con anterioridad al año 2000. Las prioridades en este proyecto fueron las familias residentes en predios de los barrios Cantaclaro, las Viñas y Galilea. No obstante, es oportuno anotar que, en otros asentamientos aun existen predios sin titulación, principalmente en asentamientos precarios y semiconsolidados. 
Por otra parte, anotamos que el programa de desarrollo urbano de este plan, se orienta a lograr un mejor aprovechamiento del territorio y del medio ambiente. Igualmente, pretende reordenar la ciudad a partir de proyectos de ordenamiento, control, renovación urbana y redensificación. En estos dos últimos aspectos, se establecieron metas de recuperar 77.000 metros cuadrados de sectores deteriorados en el centro de la ciudad, a través del Plan centro.

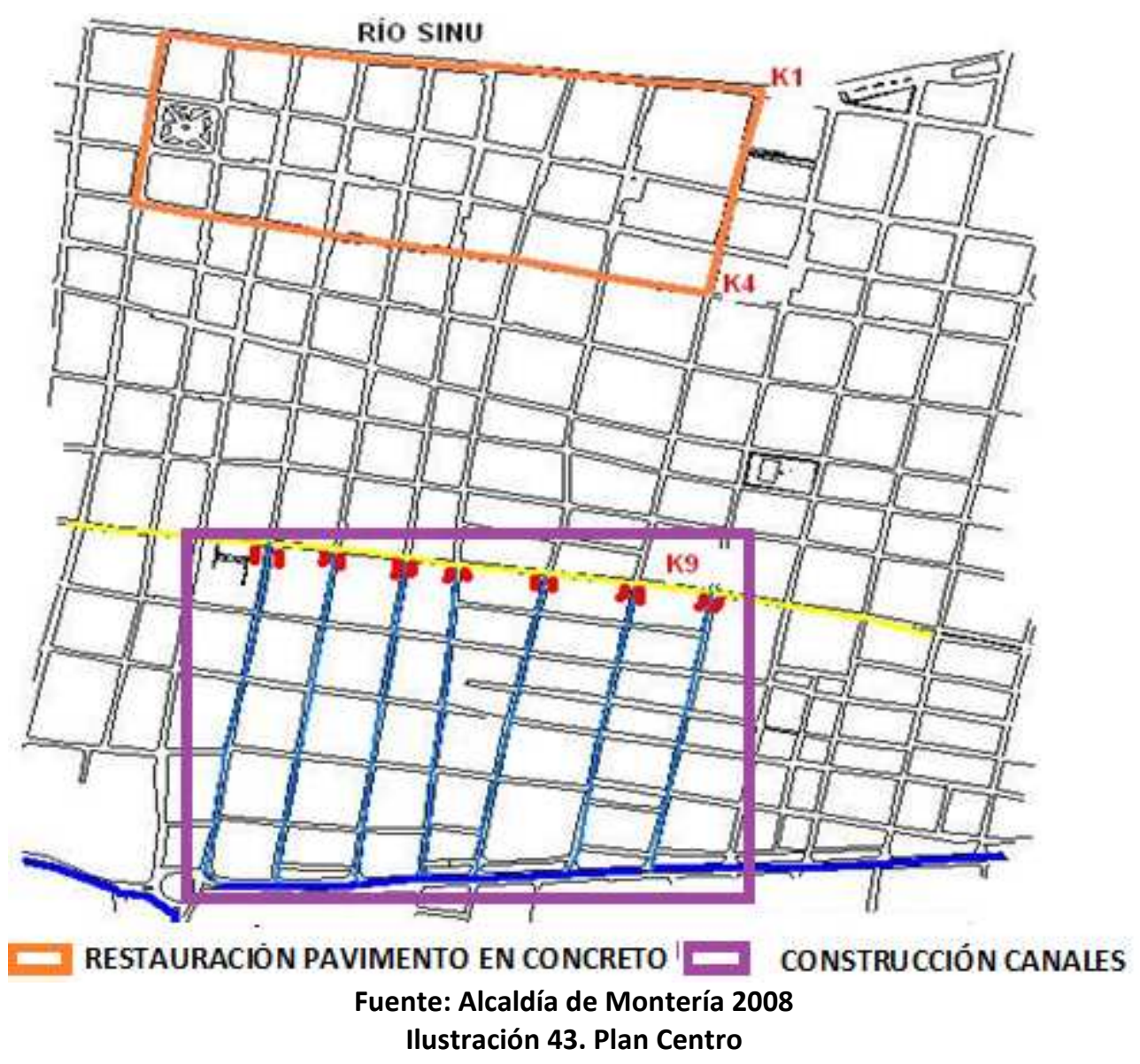

Dentro de los objetivos del plan centro se encuentran la restauración del pavimento de las avenidas primera, segunda, tercera y cuarta, entre calles 27 y 40 , al igual que la recuperación del espacio público, actualmente invadido por comerciantes estacionarios y automóviles. Igualmente se establece la construcción de 3.200 metros de tubería de 24" para mejorar la evacuación de aguas pluviales en las calles 30, 31, $32,33,34,35$ y 36 , entre las carreras novena y avenida circunvalar, que transcurre paralela al canal colector central. 
Este plan propuso también la remodelación de los dos parques centrales, la jerarquización de los perfiles viales, la peatonalización de algunas calles, suprimir bahías de parqueo, la ubicación de parqueos estratégicos, señalización de la ciudad, ampliación de andenes. Sin embargo, después de tres años de aprobado, solamente se ha avanzado en la restauración del pavimento de la calle 27 , y parcialmente las carreras segunda y tercera, así como de uno de los dos parques centrales. Este atraso, a nuestro juicio, obedece básicamente a la falta de concertación con la comunidad, principalmente la población informal que trabaja en este sector de Montería, y a los intereses particulares del gremio de comerciantes, quienes se oponen obstinadamente a la peatonalización de algunas calles, aduciendo que "afectará sus ingresos".

Para el logro de los diferentes objetivos, la administración municipal le entregó un papel protagónico a la Secretaría de Planeación Municipal de Montería, que a partir de 2008 debía responsabilizarse por la aplicación de la normativa urbana y específicamente por la exigencia de estudios de control a planes parciales, unidades de actuación urbanística, edificaciones en procesos constructivos y recuperación del espacio público. Sin embargo, a través de la observación se corroboró que en el sector, los automovilistas, motociclistas y comerciantes informales, siguen irrespetando el espacio público.

Dejamos el plan centro y retomamos nuevamente el plan de Desarrollo "Juntos Hacemos Más", para referirnos al programa de Recuperación del Espacio Público en la ciudad, y por medio del cual se pretende el rescate, uso y adecuación de dicho espacio, pero a decir verdad, ofreciendo por parte de la administración municipal, muy pocas alternativas de solución para comerciantes informales, y sobre todo, para los peatones, quienes siguen padeciendo la soberbia de automovilistas y motociclistas.

En este aspecto, los resultados de este programa no son aún satisfactorios, ya que se evidencia una marcada tendencia a recuperar el espacio público invadido por la población informal, pero no so aprecia la misma rigurosidad para recuperar el espacio que invaden automovilistas y motociclistas; es decir se ejerce autoridad con los más 
débiles y no hay gobernabilidad para controlar a los conductores que siguen aparcando en andenes e irrespetando permanentemente a peatones y ciclistas.

En el tema medioambiental anotamos que, este plan se orienta simplemente a enunciar problemáticas y a establecer juicios de responsabilidades a las anteriores administraciones, pero sin definir una clara política pública ambiental. No obstante, destacamos, que por lo menos, el plan incorpora el desarrollo de los siguientes subprogramas de gestión y/o sensibilización: Planificación Ambiental Montería (PAM); Prevención y Control de la Degradación Ambiental (PREDEAM); Gestión Integral de Recursos Hídricos (GIRH), y Proyectos Educativos Ambientales Montería (PREA).

Sobre este último tema, es importante destacar que, el programa más dinámico hasta la fecha, es el de los Proyectos Educativos Ambientales para Montería, ya que estableció como metas, el desarrollo de dichos proyectos en las escuelas del municipio. Hasta el año 2010, estaban ejecutándose 61 de estos proyectos en igual número de instituciones educativas del municipio, y su objetivo principal se dirigía a la concientización de la comunidad estudiantil en aspectos relacionados con el respeto y la conservación del medio ambiente. Sin embargo, reconocemos que esto no es suficiente para corregir los desequilibrios urbano-ambientales de la ciudad y que se requiere de más compromiso, programas, proyectos y recursos por parte de todos los actores sociales, incluida la administración municipal.

Finalizamos este análisis de los planes de desarrollo, destacando sus fuertes tendencias a incorporar gran número de programas, subprogramas y proyectos, que evidentemente, son bien formulados por asesores externos de los alcaldes, y por supuesto, viables técnicamente. Sin embargo, consideramos que no son el producto de una responsable planificación, sino del oportunismo político de candidatos que inscriben demasiadas propuestas en su programa de gobierno ${ }^{155}$ con el objetivo de

155 El programa de Gobierno es el "proyecto político que los candidatos a ser elegidos popularmente como mandatarios someten a consideración de la ciudadanía e inscriben ante la Registraduría Nacional del Estado Civil, y contiene las propuestas elaboradas a partir de las expectativas de los actores locales que comparten su tesis y su visión de futuro, la forma como se aprovecharán los potenciales y recursos, y los proyectos estratégicos que emprenderá para garantizar la prestación de los servicios públicos a su cargo, y el mejoramiento de las condiciones de bienestar y desarrollo de la población en general". 
cautivar votos, pero sin considerar razonablemente las posibilidades reales de cumplirlas. Es decir, las propuestas de los aspirantes, muchas veces poco probable de financiar en cuatro años de gobierno, terminan convirtiendo el plan de desarrollo en un instrumento político y no en un verdadero instrumento de desarrollo para la ciudad.

\subsubsection{Presupuesto de Montería como limitante del desarrollo Urbano}

El presupuesto de gastos en Montería fue de tan sólo \$US 101.000 .000 en el año 2008; \$US 130.000 .000 en el 2009 y $\$$ US 165.000 .000 en el $2010^{156}$. Estas cifras, evidentemente, son insuficientes para atender todas las necesidades del municipio, y dicha insuficiencia obedece a la débil estructura económica de la ciudad, a la escasa generación de empleo formal y a la precaria recaudación fiscal del municipio; ésta última es consecuencia de los elevados niveles de informalidad de la economía, con tasa superior al 69\%, de la población económicamente activa (PEA). Por amplitud y pertinencia, el análisis de la informalidad económica y del empleo, se realizarán con más detalles en el quinto apartado, correspondiente a impacto económico.

Sobre la presión fiscal en Colombia, consideramos oportuno destacar, que si bien es baja con respecto a otros países de la región, su porcentaje tampoco es de los más bajos de Latinoamérica, y a nuestro juicio, en esta relación tiene una gran incidencia precisamente los altos niveles de desempleo y el escaso tejido empresarial del país y sobre todo el de algunas ciudades, dentro de las que por supuesto sobresale Montería,

[Departamento Nacional de Planeación (2008): Orientaciones para elaborar los Programas de Gobierno. DNP. Bogotá. Pág. 6. Texto disponible en http://www.confenacol.org/cartillas/Cartillaelaborar.pdf]. El programa de gobierno que se inscribe, se apoya legalmente en el artículo 259 de la Constitución Política y la Ley 131 de 1994, y se materializa posteriormente en la elaboración del plan de desarrollo, el cual debe ser presentado por el alcalde al Concejo Municipal para su aprobación. La presentación del Plan de Desarrollo ante el concejo debe realizarse durante los primeros noventa días de gobierno, y su incumplimiento puede llevar a la revocatoria del mandato.

${ }^{156}$ Alcaldía de Montería (2010): El Presupuesto estimado de ingresos, rentas y recursos de capital en moneda colombiana fue de \$202.822.534.760 para el 2008; \$260.549.948.270 en el 2009 y $\$ 332.330 .946 .361$ en 2010. Documento disponible en: http://www.monteriacordoba.gov.co/presupuesto.shtml?apc=fpxx1\&x=1731482 
debido a los altos niveles de informalidad mencionadas y a las pocas posibilidades de inversión en la economía real.

\begin{tabular}{|c|c|c|}
\hline & Promedio 1990-1999 & Promedio $2000-2008$ \\
\hline GRUPO 1 & 21,5 & 25,2 \\
\hline Brasil & 25,9 & 32,7 \\
\hline Uruguay & 22,2 & 22,4 \\
\hline Argentina & 20,1 & 25,1 \\
\hline Costa Rica & 17.9 & 20.7 \\
\hline GRUPO 2 & 14,6 & 16,5 \\
\hline Chile & 18.0 & 19.5 \\
\hline Honduras & 13,5 & 15,9 \\
\hline Nicaragua & 14.0 & 19,3 \\
\hline Panamè & 15,8 & 15,3 \\
\hline Colombia & 13.3 & 16.8 \\
\hline एबत् & 14.6 & 15,3 \\
\hline Bolivia & 14.3 & 18,9 \\
\hline Venezuela & 15,3 & 13,9 \\
\hline El Salvador & 11,8 & 13,7 \\
\hline GRUPO 3 & 9,8 & 11,8 \\
\hline Paraguary & 11.5 & 12,4 \\
\hline México & 11.3 & 10.7 \\
\hline Ecuador & 9,8 & 13,6 \\
\hline Guatemala & 9,3 & 11,7 \\
\hline R. Dominicana & 10,3 & 13,6 \\
\hline Haiti & 6.5 & 9,0 \\
\hline Promedio simple AL & 14,6 & 16,9 \\
\hline Promedio ponderado AL & 19,0 & 20,6 \\
\hline
\end{tabular}

Fuente: Gómez Sabaini para CEPAL $2010^{157}$

Tabla 12. Presión Fiscal y su evolución en Colombia y otros países de la región

En el caso específico de Montería, reiteramos, su débil estructura económica no permite obtener grandes recursos por la vía tributaria, y como es obvio, sus ingresos quedan sujetos en gran medida a los no tributarios y a las transferencias realizadas por la nación. Esta situación fue corroborada con el análisis del presupuesto 2010, en donde los ingresos tributarios, escasamente ascienden al $5.96 \%$ del ingreso total de rentas, estimado para dicho año, y los ingresos no tributarios corresponden al $94.04 \%$. Sin embargo, estos últimos tienen una alta dependencia de las transferencias nacionales, que se traduce en $63.3 \%{ }^{158}$.

\footnotetext{
157 En Ramírez, Juan Carlos (2010): Gasto Social y Presión Fiscal. CEPAL. Texto disponible en http://www.slideshare.net/alianzaporlaninez/gasto-social-y-presin-fiscal

${ }^{158}$ El Art. 1 del Decreto 0962 del 2009 del presupuesto de ingresos, rentas y recursos de capital para el año 2010, establece los ingresos tributarios en $\$ 30.940 .000 .000$ (US\$15.000.000), y los ingresos no tributarios en $\$ 301.390 .946 .361$ (US\$150.000.000). Dentro de los recursos no tributarios la mayor dependencia proviene de las transferencias, con $\$ 190.919 .079 .205$ (US\$95.000.000). Este presupuesto se encuentra disponible en: http://monteria-cordoba.gov.co/presupuesto.shtml?apc=f1p-1731482$\underline{1731482 \& x=1731482}$
} 
El total de presupuesto de ingresos para el año 2010, en moneda colombiana, ascendió a $\$ 332.330 .946 .361$, pero consideramos que con los recursos destinados a inversión en infraestructura, es poco probable que se cumplan los objetivos prioritarios del plan de desarrollo. En este sentido, resaltamos que el total asignado a proyectos de infraestructura para ese año no supera $\$ 16.000 .000 .000$ (\$US 8.000.000), una cifra muy pobre, si se compara con todos los proyectos programados en dichos plan.

Igualmente se observa un gran desequilibrio, en cuanto a asignación de dinero, entre diferentes proyectos, afirmación ésta que se corrobora con las siguientes asignaciones: 1) para ampliación, remodelación y construcción de acueducto y alcantarillado, obra prioritaria, solamente se destinan \$1.441.000.000 (\$US 700.000); 2) construcción de equipamiento deportivo \$1.015.000.000 (\$US 500.000); 3) equipamiento cultural \$162.875.153 (\$US 80.000); 4) electrificación \$1.200.000.000 (\$US 600.000); e) infraestructura vial y de transporte \$9.957.315 (\$US 4.950.000); f) conservación y control ambiental \$2.959.002.601 (\$US 1.500.000), y, g) construcción de vivienda y rehabilitación de asentamientos humanos, obras éstas de gran prioridad, escasamente se asignaron $\$ 523.000 .000$, (\$US 260.000) $)^{159}$.

La suma total de las anteriores asignaciones no superan el $5.2 \%$ de los recursos totales del presupuesto, destinada a gastos de inversión, que ascienden a \$308.521.852.114, y como anotábamos, son extremadamente inferiores a las necesidades de inversión y a los proyectos programados en el plan de desarrollo. No obstante, conviene anotar que, en las cifras de gastos de inversión se incluyen \$190.919.079.205 de recursos provenientes de las transferencias con destinación específica para educación, de los cuales \$5.800.000 (\$US 2.700.000) se destinaron a la construcción, ampliación o remodelación de equipamientos educativos, pero no aparecen reflejados dentro de la asignación de los proyectos anteriormente enunciados. Es decir, si se compara la asignación para inversión de proyectos, sin incluir las transferencias de educación, la cifra no corresponde al 5.2\%, sino al $12 \%$, del total de recursos para inversión, a

\footnotetext{
${ }^{159}$ Art. 2 del Decreto 0962 de 2009: Presupuesto General de Montería 2010. Pág. 10-20.
} 
nuestro juicio, igualmente baja para cumplir con los planes de desarrollo, y peor aún, para corregir los numerosos problemas de la ciudad informal.

Ahora, en cuanto al presupuesto per cápita de Montería, debemos anotar que para el año 2010, éste apenas asciende a \$948.865, es decir unos \$US 470, cifra muy baja, evidentemente, si se compara con las ciudades de Bogotá en Colombia o de Valencia en España, con presupuestos per cápita respectivos de \$US 1000, y \$US $1.151^{160}$, pero sorprendentemente cercanas a los de las ciudades de Medellín y Cali, con \$US 539, y \$US 471, respectivamente ${ }^{161}$. No obstante, consideramos que este promedio es elevado para la capacidad real del $67 \%$ de la población monteriana, ubicadas en los estratos socio-económicos 1 y 2 , y cuyos ingresos anuales no superan el promedio de \$US $2.500^{162}$.

En este sentido, destacamos que la desigualdad en el ingreso de los colombianos ${ }^{163}$ es otro de los problemas históricos a los que se enfrenta el presupuesto de la ciudad, debido al reducido número de contribuyentes con alta capacidad de renta. Sobre este aspecto, conviene anotar que el $\mathbf{9 7 . 6 \%}$ de los impuestos directos del municipio,

${ }^{160}$ Los datos obtenidos para la ciudad de Valencia arrojan un ingreso per cápita de $857 €$, que al cambio del Banco Central Europeo el día 14 de octubre del 2011, representan US\$1.151.

${ }^{161}$ Datos elaborados a partir del presupuesto de cada ciudad y del tamaño de su población para el año del 2009.

${ }^{162}$ La población de Montería, de acuerdo con sus ingresos, se encuentra dividida en seis estratos: el 67.3 $\%$ de los hogares reside en barrios de estratos socio-económicos 1 y 2 ; el $19.3 \%$ en el estrato 3 ; el $6 \%$ en el 4 ; el $5.2 \%$ en el 5 , y apenas un reducido $2.2 \%$ de los hogares se encuentran dentro del estrato 6 , de un total de 80.534 Hogares. En los estratos 1 y 2, los más deprimidos de la ciudad, los ingresos promedios familiares mensuales no superan el salario mínimo legal mensual vigente (SMLMV), es decir unos US\$250 del año 2010; principalmente aquellas familias que se desempeñan en el sector informal de la economía. POT 2002-2011. Aspectos Socioeconómicos. Diagnostico Parte I.

${ }^{163}$ Colombia es el país más desigual de Latinoamérica y el cuarto de todo el mundo, con un coeficiente GINI de 0,58 y veinte millones de pobres absolutos de un total de cuarenta millones de habitantes. EI $10 \%$ más rico de la población se queda con el $50 \%$ del PIB, mientras que el $10 \%$ más pobre, apenas obtiene un mísero $0.6 \%$. A esto se le suma que los más pobres tienen que sostener en promedio a seis personas, y los más ricos solo a dos. Igualmente existen escandalosas diferencias regionales; por ejemplo, el ingreso promedio de un chocoano es seis veces inferior al de un bogotano, y ochocientos municipios de un total de 1100, mantienen niveles de pobreza superiores al $66 \%$. En términos concretos esta inequidad es el producto de una política tributaria regresiva que prefiere gravar el consumo de todos y no la propiedad de la tierra ni su uso. Véase Informe "Desigualdad Extrema". En Revista Semana del día 12 de Marzo de 2012. Disponible en http://www.semana.com/nacion/desigualdadextrema/153207-3.aspx 
provienen del impuesto predial unificado; es decir de $\$ 11.177 .000 .000$ estimados, se obtuvieron $\$ 10.915 .000 .000$, y escasos $\$ 262.000 .000$ por impuesto de circulación y tránsito ${ }^{164}$.

Bajo esta perspectiva, los ingresos tributarios del municipio ${ }^{165}$ (tomando como referencia el presupuesto de rentas del año 2010), quedaron constituidos en 36\% por impuestos directos y $64 \%$ de impuestos indirectos. Los dos impuestos directos que se gravan en esta ciudad son el predial unificado y el de circulación y tránsito, mientras que los indirectos son cinco: 1) Delineación urbana; 2) Espectáculos públicos 3) Impuestos de avisos, tableros y vallas; 4) Industria y comercio, y 5) Otros impuestos. Por medio de los impuestos indirectos el municipio proyectó obtener $\$ 19.762 .500 .000^{166}$ (\$US 10.000.000).

Por su parte, los ingresos obtenidos por la vía de las rentas y recursos de capital ascienden a $\$ 110.411 .867 .161$ (\$US 55.000.000), cifra a nuestro juicio, irrisoria para una capital con tanto potencial de recursos naturales y con más de trescientos mil habitantes. Dentro de estos ingresos se registran los obtenidos por: a) participación en rodamiento vehicular; b) concesiones de servicios públicos; c) contribuciones parafiscales, d) regalías; e) fondos especiales, f) tasas y derechos, y g) recuperación de cartera.

En cuanto a las concesiones de servicios públicos, resaltamos que el proceso de privatizaciones de las dos últimas décadas permitió, no solamente trasladar el monopolio de dichos servicios a las empresas privadas, sino también, el detrimento patrimonial de municipios, debido a venta de activos subvalorados y establecimiento de concesiones desfavorables de acueducto, alcantarillado, alumbrado público, aseo y transporte. En el caso de Montería, destacamos que sobre estas concesiones se proyectaron para el 2010, ingresos cercanos a los $\$ 40.000 .000 .000$ (\$US 20.000.000),

\footnotetext{
${ }^{164}$ Art. 2 del Decreto 0962 de 2009: Presupuesto General de Montería 2010. Pág. 7.

${ }^{165}$ Los ingresos tributarios deben financiar los gastos de funcionamiento del municipio, y por ley y sostenibilidad no pueden ser inferiores a dichos gastos. Estos ingresos se estimaron para el 2010 en $\$ 30.940 .000 .000$ (US\$15.000.000). Ibíd.

${ }^{166}$ Ibíd.
} 
cifras que a juzgar por lo facturado a los usuarios, no favorecen, ni a éstos, ni al municipio.

Con respecto a estas concesiones o a las privatizaciones, no se puede dejar de anotar que el país entregó demasiados privilegios a las empresas extranjeras llegadas al territorio, y con ello generó gran malestar en los propietarios de empresas nacionales, quienes debían seguir soportando la carga tributaria que gravaba a la producción, a pesar de la entrada de nuevos contribuyentes, paradójicamente exonerados de algunos impuestos, por parte de los últimos gobiernos neoliberales. Esta situación, contribuyó a incrementar aún más, los niveles de evasión tributaria ${ }^{167}$, practicados con gran frecuencia por un gran sector de empresarios nacionales e internacionales.

En el caso de los grandes contribuyentes, reiteramos, es el Estado el encargado de entregar concesiones innecesarias por medio de regímenes especiales ${ }^{168}$, en una decisión poco favorable para la economía, porque exonera de impuestos a quienes los pueden pagar, y aumenta la presión fiscal sobre la población de ingresos más precarios, precisamente pequeños empresarios y trabajadores de dichas empresas, que deben pagar impuesto a la renta de $33 \%$ como sociedades comerciales e impuestos al valor agregado IVA del $16 \%$ en el consumo de bienes y servicios.

\footnotetext{
167 La legislación colombiana en materia tributaria tiene muchos vacíos que aprovechan los contribuyentes para disminuir o eludir, el pago de impuestos, incluso sin recurrir a la ilegalidad y sin posibilidad de ser sancionados, pero evidentemente a través de métodos antiéticos, como por ejemplo, ampararse en sistemas simplificado, cuando realmente pertenecen a régimen común; es decir no facturando ventas cuando tienen la obligación de hacerlo y declararlas. Igualmente dividen los negocios para que por su tamaño, quede exonerado de impuestos. Sin embargo, es claro que en un país como Colombia, además de los vacios jurídicos, también inciden factores sociales y políticos asociados a la desconfianza en el gobierno, a la impunidad, a la falta de represión a ese delito y a la corrupción administrativa. Las cifras de evasión en el país, de acuerdo con la Dirección de Impuestos y Aduanas Nacionales, (DIAN), se establecen en el $27 \%$. Ante estos elevados indicadores y con el objetivo de disminuir este fenómeno, el gobierno expidió el Decreto 2670 de 2010, que determina fuertes sanciones de tipo económico para los evasores, principalmente a los del impuesto al patrimonio, a quienes se les obligará a pagar hasta el $160 \%$ del valor total. Ver más datos en "Evasión tributaria es del $27 \%$, continua la búsqueda para su disminución". Texto disponible en http://actualicese.com/actualidad/2011/07/11/evasion-tributaria-es-del-27-continua-la-busqueda-parasu-disminucion/

${ }^{168}$ El Estatuto Tributario establece varias tarifas según el contribuyente: 1) una tarifa de impuestos de renta del 33\% para sociedades comerciales; 2 ) un tarifa de impuesto en el régimen especial del $20 \%$, que incluso, pueden reducirse a $0 \%$., para dichos contribuyentes, y 3) Tarifa de impuestos en personas naturales del $33 \%$.
} 
A los problemas fiscales que limitan el presupuesto se suma además los gastos desproporcionados de algunas instituciones públicas y los elevados recursos que absorbe un sector parasitario, mediante contratos de intermediación, asesorías, interventorías, suministros y consultorías que pocos aportes realizan al desarrollo urbano, o al mejoramiento de la calidad de vida de los monterianos. En este sentido, estimamos contraproducente que con un presupuesto tan reducido y con los precarios ingresos de sus habitantes, se destinen anualmente $\$ 22.609 .094 .247^{169}$ (\$US 12.000.000), para gastos de funcionamiento de cuatro entidades: alcaldía, concejo, contraloría y personería. Igualmente consideramos desacertada la elevada asignación de recursos a programas y subprogramas poco efectivos para la comunidad, pero si muy significativos para contratistas e intermediarios políticos ${ }^{170}$.

Ahora, dentro de los aspectos analizados de este presupuesto consideramos oportuno destacar el aspecto positivo que representa la disminución de los servicios de la deuda, reducida a $\$ 1.200 .000 .000$ (\$US 600.000), como resultado del proceso de reestructuración de pasivos en el que se encuentra el municipio desde el año $2003^{171}$. No obstante, consideramos conveniente replantear la forma de asignar recursos para lograr un mejor aprovechamiento de ellos y así evitar endeudamientos que limitan el desarrollo urbano y el bienestar de los habitantes de esta ciudad.

\footnotetext{
${ }^{169}$ Presupuesto municipal año 2010. Capítulo II Gastos de Funcionamiento. Pág. 11

${ }^{170}$ En el capítulo III de Gastos de Inversión del presupuesto del 2010, aparecen relacionados una serie de programas y subprogramas de gobierno por valor total de 308.521.852.114, de los cuales, como ya anotábamos, solamente se asignan a proyectos concretos de infraestructura el $6 \%$. Si bien se observan programas y subprogramas relevantes, también se observan otros, tendientes a facilitar la participación de sectores parasitarios, que no saben hacer otra cosa diferente a la de alimentarse de los recursos públicos, y además con gran apetito, o mejor dicho, con apetito voraz. Esta forma de administrar y de programar, es a nuestro juicio, la principal causa de las precarias condiciones urbano-ambientales de esta ciudad y de la elevada incultura política por parte de sus habitantes, que no cuestionan, sino por el contrario, más bien, consciente o inconscientemente, tienden a identificarse con estas prácticas.

${ }^{171}$ Montería se acogió a la Ley 550 de 1999 de Reestructuración de Pasivos, mediante resolución 127 del 30 de enero del 2003 y la cuantificación de sus acreencias ascendió a \$49.000.000.000 (US\$25.000.000). Sin embargo, el acuerdo entre el municipio y sus acreedores se firmó el 6 de julio de 2004, y los pagos finalizarán en el año 2012. "Municipio de Montería: Informe de la Situación Fiscal a 30 de Junio de 2005". Texto consultado el día 18 de octubre y disponible en http://www.irc.gov.co/portal/page/portal/MinHacienda/haciendapublica/daf/entidadesterritoriales/vig enciadiciembre2006/MONTERIA.PDF
} 
Consideramos posible mejorar los ingresos del presupuesto, sin recurrir a endeudamientos innecesarios, en la medida que se descentralice la producción y se ambiente el escenario local para la apertura de empresas generadoras de empleo y con alto potencial de tributación, pero para ello también se requiere de mayor inversión nacional en infraestructura vial, aeroportuaria y portuaria. En este orden de ideas, estimamos oportuno anotar que la elevada concentración del empleo y de la producción en el centro del país, termina por generar desequilibrios presupuestales en las ciudades periféricas, y especialmente en las del Caribe colombiano.

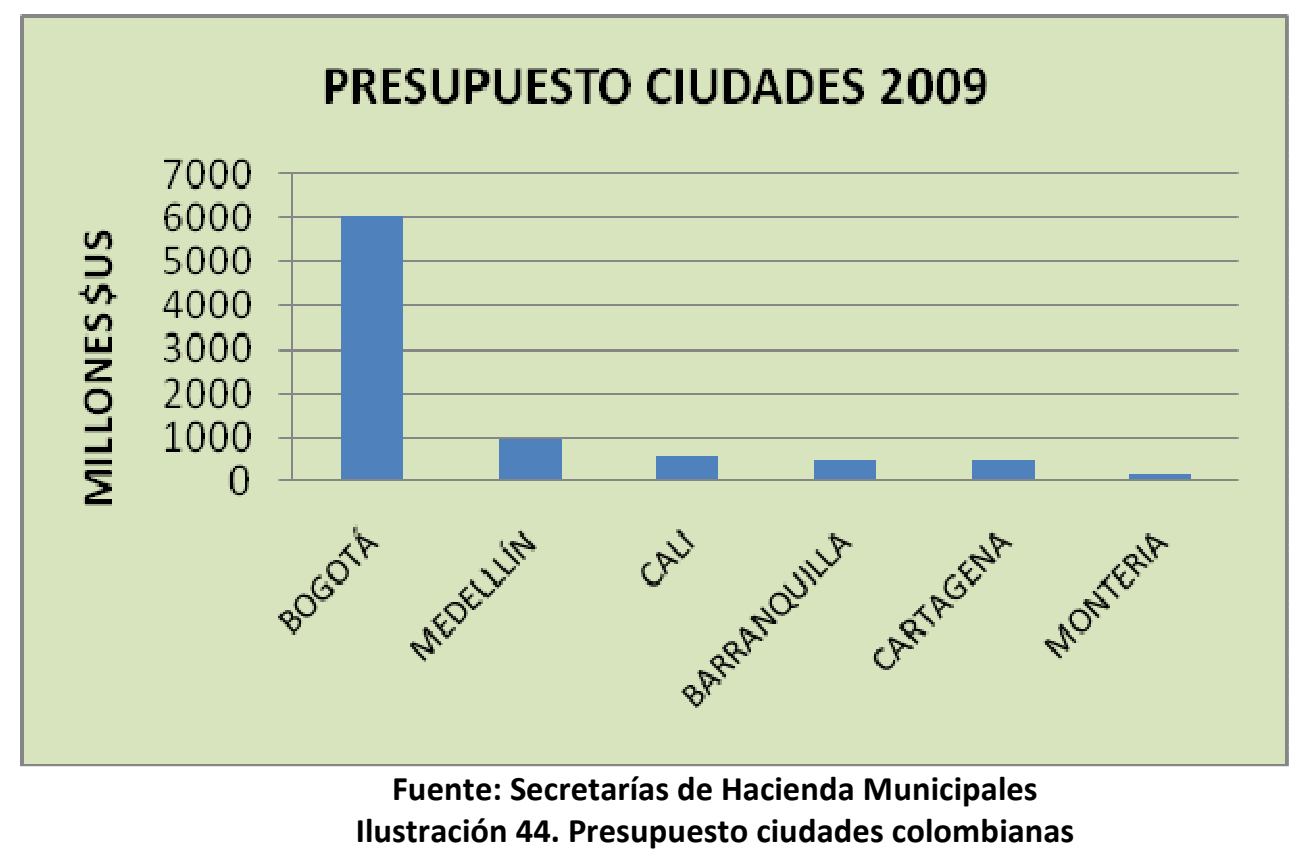

En esta comparación gráfica del año en mención, se intenta exponer la inferioridad de presupuesto de Montería con respecto al de Cartagena y Barranquilla, y su mayor diferencia con Cali y Medellín, y ni hablar de la distancia con el presupuesto de todas ellas con Bogotá. En cada una de estas ciudades se evidencian obras de desarrollo urbano e infraestructuras de gran importancia, mientras que en nuestra ciudad las limitaciones de presupuesto, dificultan una mayor asignación de recursos para mejorar la calidad urbanística y las condiciones de vida de la población.

Por último, a todo lo anterior se le suma que el municipio de Montería no cuenta con empresas industriales ni comerciales de su propiedad que le permitan obtener recursos de capital para sus gastos, como si las tienen otras ciudades; por ejemplo, 
Bogotá y Medellín, que son propietarias de la Empresa de Teléfonos y de las Empresa de Servicios Públicos, y con la enorme satisfacción de que cada una de ellas genera utilidades netas anuales ${ }^{172}$, que se transfieren a sus respectivos presupuestos de inversiones, desmitificando así la promovida falacia neoliberal de que "la empresa pública es ineficiente".

En este orden de ideas, y después de analizar las dificultades que impiden la realización de los programas contenidos en los planes de desarrollo de Montería, consideramos que si no se aplican las medidas encaminadas a mejorar la estructura económica de la ciudad, el presupuesto seguirá presentando dificultades para conseguir los recursos necesarios para financiar sus gastos, e igualmente quedará sujeto a las precarias transferencias nacionales y a los escasos recursos tributarios, con el agravante de que hasta la fecha, éstos no son asignados eficientemente. No obstante, conviene recordar que dichas medidas, precisamente se encuentran propuestas en los planes de desarrollo y en el plan de ordenamiento territorial; es decir, esto más que un problema técnico o de recursos, es fundamentalmente un problema de actitud frente a la vida.

172 Las Empresas Públicas de Medellín es una de las empresas más rentables del País, lo cual se demuestra con las utilidades netas de 1.13 billones de pesos (aproximadamente US\$600.000) obtenidas entre enero y septiembre del 2010. Reiteramos, estos ingresos contribuyen al incremento del presupuesto de esa ciudad. Esta información se encuentra disponible en http://www.elcolombiano.com/BancoConocimiento/U/utilidades de epm en 2010 suman \$113 billo nes/utilidades de epm en 2010 suman $\$ 113$ billones.asp

Por otro lado, la Empresa de Teléfonos de Bogotá, es una entidad de propiedad de este municipio, cuyas utilidades se destinan a financiar el presupuesto de la Universidad Distrital. Fue constituida en 1884, tiene activos por 4.8 billones de pesos (US\$2.400.000.000), y a pesar de estar compitiendo con gigantes multinacionales, obtuvo utilidades superiores a $\$ 200.000 .000 .000$ en el 2010 , es decir unos US\$100.000.000. Más datos sobre este informe se pueden consultar en http://www.elespectador.com/noticias/bogota/articulo-275760-proponen-plan-de-salvamento-etb 


\subsection{LA CIUDAD INFORMAL EN COLOMBIA}

"La urbe de finales del siglo XX y principios del XXI no es una ciudad tan claramente delimitada. La ciudad hoy parece ser una gama de ilegalidades, con formas bastante explícitas, y otras por el contrario, invisibilizadas o disimuladas. Interpretar el fenómeno de la ilegalidad nos exige entenderla, no como ejercicio exclusivo de los sectores populares, sino como una práctica de "negociaciones" cotidianas desde las cuales se está erigiendo la ciudad. La ilegalidad en la producción de la ciudad se expresa tanto en las construcciones precarias en zonas de alto riesgo, en loteos clandestinos e irregulares, en el control armado del espacio público ejercido en barrios periféricos; como en el cercamiento de quebradas para uso privativo de urbanizaciones cerradas, en el cerramiento de parques recreativos de uso público y en la ocupación ilegal de andenes por el comercio o los vehículos, o la eliminación de éstos por nuevas urbanizaciones en los estratos medios y altos ${ }^{\prime 173}$.

Comenzamos este recorrido por la ciudad informal manifestando que, su surgimiento en Colombia es una respuesta a varios factores: a) crecimiento demográfico elevado; b) desplazamientos voluntarios y forzados de los campos a las ciudades; c) reparto inequitativo de la riqueza; d) ausencia de un adecuado escenario normativo de planificación, y e) política pública de vivienda poco coherente con el contexto socioeconómico de algunas regiones.

Las primeras ciudades donde se presenta este fenómeno, son evidentemente las de mayor concentración de población: Bogotá, Medellín, Cali, Bucaramanga y Barranquilla, que a partir de los periodos de instalación de la industria, comienzan a experimentar procesos de ocupación por vías de hecho y/o por venta fraudulenta de lotes o por transacciones sobre urbanizaciones irregulares; es decir, por invasión, por venta clandestina de lotes sin claridad del dominio, y por venta de lotes en

${ }^{173}$ Cit. En: Peter, Brand, Coupé, Françoise y Ortiz, Catalina (2006): Suelo Urbano y Vivienda para la Población de Ingresos Bajos: Estudios de caso: Bogotá - Soacha - Mosquera; Medellín y Área Metropolitana. Development Planning Unit - DPU. University College London. Medellin. 2006. Pág. 38. 
urbanizaciones incompletas, que no realizaron todos los trámites ante la respectiva oficina de planeación ${ }^{174}$.

Estas ciudades iniciaron en la década de los años sesenta un proceso de crecimiento demográfico, como consecuencia de la llegada de pobladores rurales que buscaban mejores oportunidades de vida, y quienes de entrada, experimentaron las dificultades para acceder a la vivienda, e incluso al mercado laboral. El resultado de estas situaciones no pudo ser diferente al de la manifestación de los primeros brotes de informalidad urbanística e informalidad económica, que con el tiempo se consolidaron como grandes fenómenos y se trasladaron a las capitales menores.

Las principales características de esta ciudad informal, desde la óptica de las instituciones, son entre otras: 1) deterioro de la calidad de vida de sus moradores; 2) deficiencia en los servicios públicos, vialidad y equipamientos; 3) precariedad de títulos, evasión fiscal, y 4) extra-costos al presupuesto público. Sobre este último aspecto agregamos que dichos extra-costos se generan cuando el Estado debe reparar a posteriori, las deficiencias de la acción clandestina, que entre otras cosas, generaron altos ingresos a urbanizadores espontáneos, o peor aún, a propietarios, testaferros o usurpadores de terrenos, sin haber realizado ningún tipo de inversión. Esta situación es la que se ha denominado socialización de costos y privatización de los beneficios, en el que la precariedad de muchos alimenta la afluencia de unos pocos ${ }^{175}$.

En este sentido, por ejemplo, destacamos que los costos unitarios por desmarginalización de cada vivienda informal estimados para una ciudad como Bogotá, equivalen a $\$ 4.758 .997$ a precios de 2003 (\$US 2.400), y comprende inversiones por regularización de la infraestructura de servicios públicos, vías, obras de

\footnotetext{
${ }^{174}$ En el capítulo II, correspondiente a descripción del problema se muestran los niveles de informalidad urbanística en las principales ciudades del país, que incluye superficie y población residente en dichas superficies. Sin embargo, resaltamos que estos niveles corresponden al $23 \%$ de la superficie urbana de Bogotá, promedios cercanos al 20\% para Medellín, Cartagena, Cali, Barranquilla, y $32 \%$ del perímetro urbano de Montería.

175 Jaramillo, Samuel y otros (2006): Informalidad de la vivienda en Bucaramanga y Cartagena. Documento CEDE Universidad de los Andes. Bogotá. Pág. 22.
} 
mitigación de riesgo, titulación, atención de emergencias y reasentamientos ${ }^{176}$. Sin embargo, consideramos que estos costos realmente no son tales para el gobierno, y por el contario, representan más bien un fuerte ahorro para sus deteriorados presupuestos, ya que lo invertido en desmarginalización escasamente equivale al $30 \%$ del precio de una vivienda pública de interés social en el contexto colombiano. Sobre este tema, y específicamente para el caso de Montería, ampliaremos en el capítulo de impacto urbanístico.

En cuanto a los precios de vivienda en Colombia, destacamos que los más reducidos, y a los que posiblemente pueden acceder los sectores más vulnerables de la población, a precios del 2005, son los siguientes: 1) vivienda de interés social en el sector privado, $\$ 19.000 .000$ (\$US 9.000); 2) vivienda de interés social en el sector solidario ${ }^{177}$, $\$ 17.395 .000$ (\$US 8.500), y 3) vivienda de interés social del sector público, $\$ 16.000 .000$ (\$US 8.000). En cambio, el precio de un lote en el sector informal es de apenas $\$ 3.205 .000$ (\$US 1.500), si el sector se encuentra consolidado, y $\$ 2.800 .000$ (\$US 1.400), si aún permanece en estado precario ${ }^{178}$. Conviene anotar que el promedio de área construida en estas viviendas es de $56 \mathrm{~m}^{2}$ y el de sus lotes es de $86 \mathrm{~m}^{2}$; por su parte el tamaño de los lotes informales es de $90 \mathrm{~m}^{2}$, e incluso, en ciudades como Montería, superan los $120 \mathrm{~m}^{2}$.

Es pertinente destacar que las viviendas de interés social en cualquiera de los sectores, ha venido reduciendo sistemáticamente su tamaño: en la década de los ochenta era de $75 \mathrm{~m}^{2}$ construidos, en los noventa se redujo $60 \mathrm{~m}^{2}$ construidos y a partir del 2000 el espacio construido se limita a $36 \mathrm{~m}^{2}$, situación ésta, abiertamente aberrante. En el mismo sentido, las superficies de sus lotes pasaron de $108 \mathrm{~m}^{2}$ (7 x 14), a $84 \mathrm{~m}^{2}(7 \times 12)$,

\footnotetext{
${ }^{176}$ Ibíd. Pág. 23.

177 En Colombia se denomina así al sector de la economía social, regulado por la Ley 454 de 1998. Por medio de la cual se determina el marco conceptual que regula la economía solidaria, se transforma el Departamento Administrativo Nacional de Cooperativas en el Departamento Administrativo Nacional de la Economía Solidaria, se crea la Superintendencia de la Economía Solidaria, se crea el Fondo de Garantías para las Cooperativas Financieras y de Ahorro y Crédito, se dictan normas sobre la actividad financiera de las entidades de naturaleza cooperativa y se expiden otras disposiciones.
}

${ }^{178}$ Brand, Peter; Coupé, Françoise y Ortiz, Catalina (2006): Op. Cit. pág. 78. 
y finalmente a $66 \mathrm{~m}^{2}(6 \times 11)$. Situación similar sucedió con los lotes informales, pero a diferencia de las viviendas de interés social, su tamaño mínimo no es inferior a los 84 $\mathrm{m}^{2}$, lo cual lo hace más atractivo para los demandantes de vivienda.

Sin embargo, destacamos que en los procesos de informalidad urbanística, por lo menos en el contexto colombiano, las superficies de los lotes informales varían de acuerdo con: el tamaño de la ciudad, el área del lote formal, el precio del $\mathrm{m}^{2}$ y la disponibilidad de suelo urbano. En el caso de Bogotá, por ejemplo, los lotes que ofrecen los promotores informales tienen un área de $72 \mathrm{~m}^{2}(12 \times 6)$, mientras que algunos proyectos de origen formal, apenas alcanzan los $30 \mathrm{~m}^{2}$ de superficie construida en lotes cuyas áreas no superan los $40 \mathrm{~m}^{2}$ de suelo $(8 \times 5)$.

Por otra parte, es significativo destacar la incidencia de algunos indicadores en la configuración de la ciudad informal en Colombia, y dentro de los cuales sobresalen los relacionados con las formas de tenencia de la vivienda. Dichos indicadores manifiestan la relación entre el porcentaje de familias propietarias de vivienda y las no propietarias, durante los años 2003 y 2008. La relación relativa, realizada a partir de valores absolutos cercanos a los once millones de familias, se aprecia claramente en la siguiente ilustración.



Fuente: DANE (2005): Encuesta de Calidad de Vida 2003 y $2008^{179}$ Ilustración 45. Tenencia de la Vivienda en Colombia

\footnotetext{
${ }^{179}$ Encuesta Nacional de Hogares (ENH): Datos expandidos con proyecciones de población con base en los resultados del censo 2005 y disponibles en www.dane.gov.co
} 
El tema de la tenencia de la tierra en Colombia, a nuestro juicio, es un factor clave, que incide en los procesos de informalidad urbanística de las ciudades, ya que su estructura y formas de dominio desatan frecuentes conflictos entre actores sociales, que a su vez terminan en despojos violentos y desplazamientos forzados de pequeños propietarios, e incluso en usurpaciones de reservas naturales del Estado e invasiones a significativos ecosistemas naturales. El grado de estos conflictos se refleja con claridad en los niveles de informalidad en la tenencia de la tierra que presenta el país, y que de acuerdo con el Informe de Desarrollo Humano para Colombia 2011, se encuentran en $54 \%$ de los bienes protegidos, tanto individual como colectivamente ${ }^{180}$.

Bajo esta perspectiva, los conflictos por la tierra rural y la informalidad en la tenencia de la misma ${ }^{181}$, también se trasladan a zonas urbanas con la llegada de los desplazados, quienes no tienen opciones diferentes a las de ocupar terrenos por vías de hecho, o presionar a las instituciones para que permitan su ubicación en suelos fiscales o privados, aptos o no aptos para usos residenciales, urbanizados o sin urbanizar, o en el remoto de los casos, para la adjudicación de viviendas terminadas. Igualmente, en lo relacionado con el ingreso, no tienen opciones diferentes a las de incorporarse a empleos precarios o actividades económicas informales de subsistencia.

\footnotetext{
${ }^{180}$ PNUD (2011): IDH para Colombia año 2011. Pág. 279. En este mismo informe se destaca, como ya lo habíamos anotado, que los conflictos por la tierra han desplazado en los últimos 11 años un número cercano a las 800.000 familias, de las cuales el $80 \%$ se consideran propietarias, pero solamente el $20 \%$ posee escrituras legales que certifican su dominio sobre la tierra. Para una mejor ilustración acerca de la tenencia y de sus conflictos, destacamos los siguientes datos: Superficie total 113.891 .400 has; de las cuales las zonas de reservas constituyen el $44.7 \%$, el $25.2 \%$ es propiedad colectiva indígena, $11 \%$ de parques nacionales rurales y un poco menos del $5 \%$ corresponde a territorios colectivos de las comunidades afrocolombianas. Sin embargo, en el informe se destacan unos conflictos de usos que se traducen en la ocupación de áreas de reserva por parte de 2.9 millones de personas; la sobreexplotación ganadera (extensiva) que ocupa 39.2 millones de has con una productividad reducida, de 0.84 cabeza/ha, y utilizando más del $70 \%$ de suelos aptos para cultivo de alimentos; la agricultura apenas utiliza 4.9 millones de has (21\%) de un potencial de 21.5 millones, y, la minería, con el mayor impacto ambiental negativo, paradójicamente ocupa un poco más de 5 millones de has, que precisamente, son las zonas de mayores conflictos y desplazamientos más recientes.

181 Para el Programa de Naciones Unidas para el Desarrollo, la informalidad de los derechos de propiedad sobre la tenencia de la tierra en Colombia está asociada con la existencia de conflictos por la tierra, regulaciones adecuadas y los altos costos de transacción en la formalización. Así mismo destacan que la preponderancia de esta informalidad se explica por: a) la expansión de la frontera agrícola, que ha promovido la ocupación de baldíos; b) las restricciones al mercado de tierras, impuestas por la legislación; c) los altos costos impuestos por los procesos de titulación y registro de tierras, especialmente para los pequeños propietarios, y d) el costo de formalizar los derechos de propiedad para un agricultor promedio significa una alta proporción frente a las ganancias que deriva del predio.
} 
Ahora, estas dificultades de los desplazados y el bajo poder adquisitivo de los sectores urbanos más vulnerables, sumadas a la incapacidad presupuestaria del Estado para dar respuestas a sus demandas, explican los actuales niveles de informalidad urbanística que presentan las ciudades colombianas actualmente, como consecuencia de las ocupaciones por vías de hecho, por fraccionamientos irregulares o por urbanizaciones informales. Sin embargo, consideramos que esta informalidad, por lo menos en cuestión del dominio de las viviendas, tiende a disminuir en el futuro con las campañas de titulación de predios y regularización de asentamientos que se vienen adelantando desde el año 2006, con el segundo mandato presidencial de Álvaro Uribe Vélez ${ }^{182}$.

En cuanto a infraestructura, generalmente las áreas informales carecen de redes de servicios básicos, situación que el urbanizador espontáneo, o intermediario, aprovecha posteriormente para crear organizaciones entre los pobladores y desarrollar conjuntamente tareas de suministro de bienes comunitarios, de movilización y reivindicación frente a las autoridades, pero siempre con el respaldo de actores políticos y/o líderes comunitarios locales. Claro que en algunas ciudades, principalmente del Caribe, el urbanizador espontaneo suele ser un líder comunitario o un político de bajo rango, quien es el encargado de organizar a la comunidad.

\footnotetext{
182 El Plan de Desarrollo 2002-2006 "Hacia un Estado Comunitario", tuvo como objetivo principal la denominada "seguridad democrática", que buscaba la recuperación del territorio por parte del Estado. No obstante, en el capítulo II de este plan se incluye un programa de impulso a la vivienda y erradicación de la urbanización ilegal, mediante subsidios, incentivos y financiación, que establece como meta la financiación de 400.000 viviendas en todo el país, con el concurso de las administraciones municipales y las cajas de compensación familiar. Esta meta se fija a partir de un déficit cuantitativo nacional de 1.130.000 viviendas y de 3.228.751 hogares urbanos no propietarios de viviendas y con ingresos familiares inferiores a mil dólares. Sobre estas cifras, consideramos pertinente revelar los siguientes datos: a) en el periodo en mención se entregaron 395.886 subsidios de vivienda, equivalentes a 3.7 billones de pesos (unos US\$1.700.000.000); b) durante ese mismo periodo se construyeron en promedio anual 110.000 viviendas (60.000 públicas y 50.000 privadas; c) con la entrada anual de 235.526 hogares, el déficit cuantitativo de vivienda aumentó a 1.307 .757 viviendas, lo cual requiere incrementar la producción anual de vivienda a 280.000 unidades; d) se legalizó el dominio de más de cincuenta mil viviendas de asentamientos irregulares pero las condiciones urbanísticas de dichos asentamientos siguieron siendo precarias; e) el gasto público en vivienda apenas se situó en el 0.30 del PIB, cifras muy inferiores a las de Venezuela (1.04\%), Chile (1.10\%) y España (1.45\% del PIB). Estos datos se encuentran disponibles en http://www.dnp.gov.co/Portals/0/archivos/documentos/GCRP/PND/PND.pdf y en http://www.congresocamacol.com/adminsite/memorias/temp/archiArchivo20100423021011.pdf
} 
Una vez definida esta organización en los asentamientos informales, se inician largos procesos de adecuación de terrenos, instalación de redes de servicios básicos, construcción de equipamientos y titularización de predios, que finalmente los convierten en barrios formales con redes socioeconómicas y sociopolíticas muy dinámicas. Es decir, la consolidación del asentamiento, después de veinte o treinta años, es el resultado de la conformación de colectivos sociales y/o promotores de cooperación, que se encargan de gestionar proyectos o recursos ante la administración municipal, organizaciones no gubernamentales y agencias de cooperación nacional o internacional.

Finalizamos este recorrido de la ciudad informal en Colombia, destacando que su expansión sobre el territorio de las principales ciudades, incluida Montería, genera un impacto ambiental significativo, al ocupar zonas de alto riesgo, riberas de ríos, quebradas, humedales y colinas, que generalmente son ocupados por vías de hecho, 0 por fraccionamientos directos de propietarios, testaferros o usurpadores. En cualquiera de estas tres modalidades, el proceso de ocupación de terrenos termina por alterar el funcionamiento de alguno de los anteriores ecosistemas.

\subsubsection{La ciudad informal en Montería}

Comenzamos manifestando que el establecimiento de los asentamientos informales en la ciudad de Montería es el producto, fundamentalmente, de un marcado desequilibrio entre demanda y oferta de vivienda, a partir de la década de los años cincuenta, cuando se inician los flujos migratorios del campo a la ciudad. En este periodo, empieza el incremento desproporcionado de la población urbana y de la demanda de la vivienda, a las cuales, ni el Estado ni el mercado, son capaces de resolver de manera satisfactoria, sino por el contrario, de forma poco efectiva $y$ desordenada. 


\begin{tabular}{|cccccc|}
\hline AÑO & $\begin{array}{c}\text { CABECERA } \\
\text { Población T.C. } \%\end{array}$ & $\begin{array}{c}\text { TOTAL } \\
\text { Población T.C.\% }\end{array}$ & FUENTE \\
\hline 1951 & 23.682 & - & 77.057 & - & DANE \\
\hline 1964 & 70.531 & $\begin{array}{c}197 \\
\%\end{array}$ & 123.905 & $60 \%$ & DANE \\
\hline 1973 & 104.129 & $47 \%$ & 178.016 & $43 \%$ & DANE \\
\hline 1985 & 169.074 & $62 \%$ & 242.515 & $36 \%$ & DANE \\
\hline 1995 & 243.576 & $44 \%$ & 317.252 & $30 \%$ & DANE \\
\hline 2005 & 286.175 & $18 \%$ & 381.525 & $20 \%$ & DANE \\
\hline
\end{tabular}

Fuente: POT de Montería 2002 - DANE

Tabla 13. Evolución de la Población Urbana en Montería

El incremento de la población a partir de esta década se explica por la creación del departamento de Córdoba en el año 1952, y por supuesto, por el comienzo de la vida administrativa de Montería como capital de departamento y sede de las principales autoridades civiles y militares. Este hecho político-administrativo, se ve complementado en la siguiente década con la consolidación del modelo económico estructuralista, que a través de intervención estatal en la economía, permitió el surgimiento y/o llegada de organizaciones públicas a la ciudad, lo cual tuvo como impacto el aumento del empleo público y de la población urbana, a expensas del deterioro rural y el estancamiento de dicha población.

Los flujos migratorios de esos primeros doce años, permitieron que la población urbana se incrementara en un 197\%, situación que llevó al Estado a través del ICT a desarrollar los primeros programas de vivienda pública terminada en la década de los años sesenta, pero también los primeros fraccionamientos públicos para programas de autoconstrucción, que a la postre fueron la plataforma de los fraccionamientos privados irregulares y de las primeras invasiones de Montería. Es decir, el fenómeno de la urbanización informal en Montería se inicia en los años sesenta, ante la insuficiencia de los programas públicos de viviendas terminadas, y sigue su curso en las siguientes décadas, convirtiéndose incluso, en un modelo legítimo de ocupación ${ }^{183}$.

\footnotetext{
${ }^{183}$ Esta apreciación será ampliada y corroborada en el capítulo V, correspondiente a impacto urbanístico de la urbanización marginal.
} 


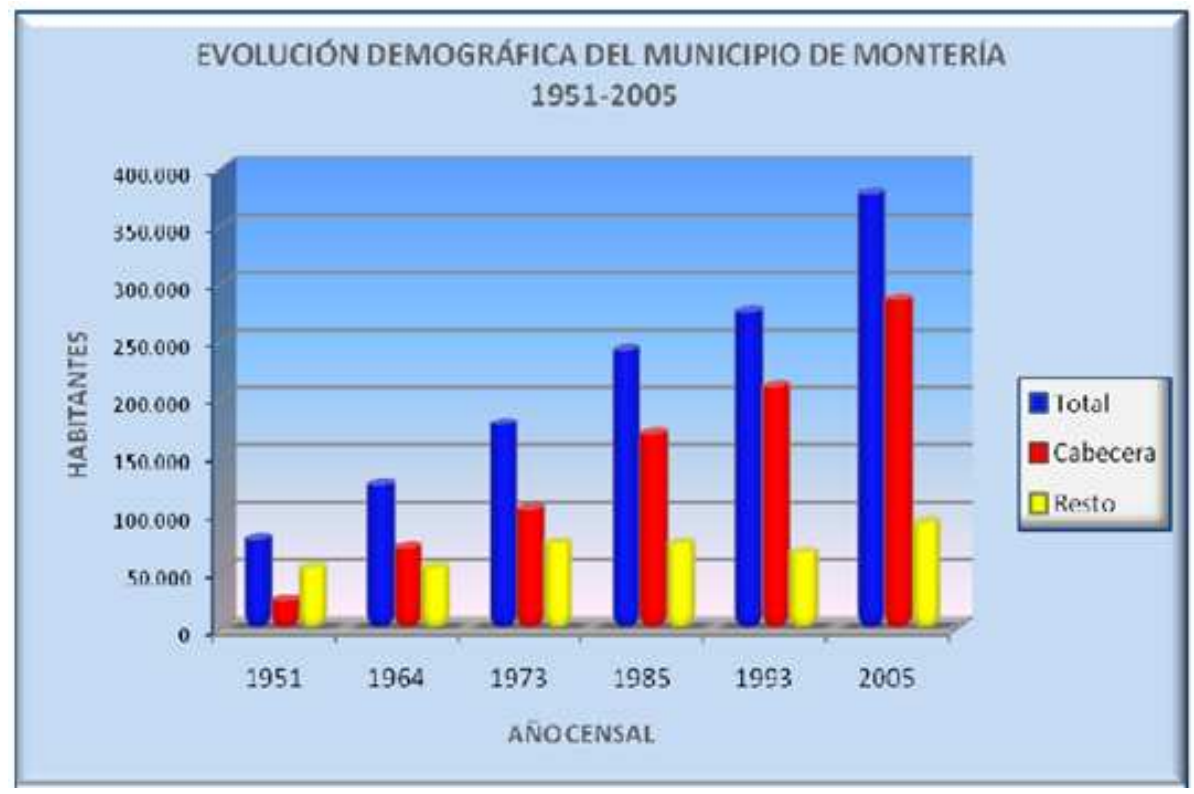

Fuente: Censos DANE en POT 2002-2015

Ilustración 46. Evolución demográfica en Montería

El mayor impacto sobre la población ocurrió precisamente en el primer periodo, porque a partir de las siguientes décadas, el incremento de la población, aunque altamente significativo, no tuvo el mismo volumen de crecimiento inicial. Esta situación, a nuestro juicio, obedeció a algunas políticas económicas de estabilización que buscaban la reactivación del campo y desestimular los flujos de campesino hacia las ciudades, esencialmente en el gobierno del presidente Alfonso López Michelsen (1974-1978), con su plan de desarrollo "La Revolución en Marcha", que pretendía dar una adecuada aplicación a la ley de tierras de 1936. No obstante, en la década de los ochenta se reanudarían los flujos migratorios, principalmente aquellos forzados ${ }^{184}$, los cuales se intensificarían en los años noventa y agudizarían la presión por la vivienda y el déficit de ellas.

\footnotetext{
${ }^{184}$ Aunque se especula mucho acerca del número de desplazados llegados a la ciudad de Montería, la cifra oficial que registra Acción Social de la Presidencia de la Republica para los periodos 1996-2008, asciende a 27.000 personas; es decir 2.250 personas en promedio anual, durante los últimos 13 años, quienes evidentemente se terminan instalando en invasiones o alojados en los asentamientos más precarios de la ciudad. Este comportamiento se ilustrará en el capítulo V, pero manifestamos que se encuentra disponible en los ajustes realizados en el año 2009 al plan de ordenamiento territorial 20022015. Capítulo III, Diagnostico, Pág. 490.
} 


\begin{tabular}{|ccccccccc|}
\hline ESTRATO & POBLACIÓN & $\mathbf{\%}$ & VIVIENDA & $\mathbf{\%}$ & HOGARES & $\%$ & $\begin{array}{c}\text { DEFICIT } \\
\text { DE VIVIENDA }\end{array}$ & \% \\
\hline $\mathbf{1}$ & 111.621 & 39,6 & 20.118 & 36,4 & 31.891 & 39,6 & 11.773 & 46,6 \\
\hline $\mathbf{2}$ & 78.078 & 27,7 & 15.033 & 27,2 & 22.308 & 27,7 & 7.275 & 28,8 \\
\hline $\mathbf{3}$ & 54.401 & 19,3 & 11.220 & 20,3 & 15.543 & 19,3 & 4.323 & 17,1 \\
\hline $\mathbf{4}$ & 16.912 & 6,0 & 3.758 & 6,8 & 4.832 & 6 & 1.074 & 4,2 \\
\hline $\mathbf{5}$ & 14.657 & 5,2 & 3.537 & 6,4 & 4.188 & 5,2 & 651 & 2,6 \\
\hline $\mathbf{6}$ & 6.202 & 2,2 & 1.603 & 2,9 & 1.772 & 2,2 & 169 & 0,7 \\
\hline TOTAL & $\mathbf{2 8 1 . 8 7 1}$ & $\mathbf{1 0 0}$ & $\mathbf{5 5 . 2 6 9}$ & $\mathbf{1 0 0}$ & $\mathbf{8 0 . 5 3 4}$ & $\mathbf{1 0 0}$ & $\mathbf{2 5 . 2 6 5}$ & $\mathbf{1 0 0}$ \\
\hline
\end{tabular}

Fuente: Cálculos del P.O.T 2002 con base en censo DANE $2005^{185}$

Tabla 14. Población y déficit cuantitativo de vivienda por estrato año 2000

Estos incrementos de población se traducirían en altos déficits de viviendas, afectando todos los sectores socio-económicos, pero principalmente a los estratos 1 y 2 , que concentran el $67 \%$ de los habitantes, e igual porcentaje de hogares de esta capital. Bajo estas perspectivas, consideramos oportuno destacar que los abiertos desequilibrios aquí expresados son el reflejo de una situación deficitaria permanente, que explica la existencia de un gran volumen de asentamientos irregulares en esta ciudad, iniciada en la década ya anteriormente anotada, pero con gran impacto en la actualidad.

Analizando las causas de los últimos flujos migratorios hacia la ciudad, consideramos que ésta, finalmente no es elegida como un escenario de oportunidades, sino más bien, como un escenario de refugio para desplazados por el conflicto armado entre actores ilegales que luchan por el control de los suelos más fértiles ${ }^{186}$ o por territorios geoestratégicos para exportación de drogas y/o importación ilegal de armas. Sin embargo reiteramos, que la ciudad no tiene la capacidad para responder oportunamente a esos inesperados cambios de población ni a las necesidades de empleo, vivienda y dotaciones públicas.

\footnotetext{
${ }^{185}$ Consideramos pertinente incluir estos cálculos del POT, sin dejar de considerar que, y por obvias razones, presentan diferencias con los datos del DANE, principalmente, en cuanto a déficit de vivienda.

${ }^{186}$ El colectivo de víctimas de la violencia en Colombia reclaman diez millones de hectáreas de tierras hurtadas; la Contraloría Nacional establece que son tres millones de hectáreas, y el Instituto Colombiano de Desarrollo Territorial (INCODER), determina que el total de los suelos despojados a los campesinos en todo el territorio nacional es de cinco millones de hectáreas. Las cifras registradas para el departamento de Córdoba, que figura entre los seis departamentos con mayor concentración de la tierra, asciende a 200.000 hectáreas. Esta información se puede ampliar en: "El manejo de tierras en Colombia naufragó en la corrupción. Las nuevas leyes le dan un impulso a la contrarreforma agraria. Fichas de un rompecabezas que encajan perfectamente para legalizar un nuevo y perverso orden de las cosas". Texto disponible en http://www.semana.com/wf ImprimirArticulo.aspx?IdArt=115489
} 
La incapacidad del Estado para dar respuesta a las necesidades de desplazados y también de los sectores sociales más vulnerables de la ciudad, genera una problemática social, que en este caso, es resuelta directamente por la comunidad, mediante invasiones de terrenos públicos o privados para viviendas, y de espacio público para desarrollar diferentes actividades económicas informales de subsistencia. El resultado de esta situación es la conformación de una ciudad informal, en la que confluyen simultáneamente asentamientos irregulares, que se caracterizan por su precariedad urbanística o por el origen legal o ilegal del terreno; es decir una ciudad conformada por barrios urbanísticamente informales, o por debajo de las normas urbanas, y barrios irregulares en lo referente a dominio del terreno.

En cuanto a informalidad urbanística, resaltamos que la ciudad está conformada por barrios que se construyeron violando una o varias normas urbanas, pero que se encuentran en diferentes etapas de intervención, y en lo referente a informalidad del dominio, en Montería se encuentran asentamientos con diferentes orígenes ${ }^{187}$, pero con características urbanísticas o arquitectónicas similares. Por tales motivos, consideramos conveniente establecer tres categorías para los barrios que violaron las normas legales del dominio, e igual número para aquellos que violaron las normas urbanas de construcción. En este orden de ideas a los primeros los subdividimos en: 1) asentamientos por invasión 2) asentamientos por fraccionamiento irregular, y 3) asentamiento por fraccionamiento público; y a los segundos en: 1) barrios precarios 2) barrios semi-consolidados, y 3) barrios consolidados.

Antes de comenzar con la referencia de cada una de las categorías de asentamientos informales de Montería, consideramos oportuno destacar que dichos asentamientos, sean de invasión, fraccionamiento irregular o promoción pública, siguieron modelos de

\footnotetext{
187 Víctor Negrete en el año 1994, establece la existencia de 12.508 viviendas precarias en 31 asentamientos irregulares, que albergaban 70.934 habitantes, dentro de los cuales, 24.484 se consideran como desplazados por la violencia. Sin embargo, para el año 2001, según el mismo autor, estas cifras se incrementaron a 18.776 viviendas, 35 asentamientos irregulares y 32.652 desplazados. Estos datos se encuentran publicados en Negrete, Víctor (2001): El Proceso de Reubicación de Población Desplazada por la Violencia en Predios Rurales del municipio de Montería. ACNUR-UNISINU.
} 
ocupación y/o autoconstrucción similares al de las "coreas" en Barcelona, las favelas en Brasil o los "pueblos jóvenes" en Perú ${ }^{188}$. Este modelo es denominado en Colombia "desarrollo progresivo", y es utilizado preferiblemente para referirse a la vivienda individual y no al asentamiento como conjunto. Sin embargo, desde esta investigación, creemos más acertado utilizar el concepto de asentamiento de transición o asentamiento de lento desarrollo, en vez de "desarrollo progresivo".

\subsubsection{Asentamientos por Invasión}

El Diccionario de la Real Academia Española define Invasión como la ocupación irregular o anormal de un lugar. García de Hernández ${ }^{189}$, en cambio considera similares los términos invasión y ocupación, y para ello sustenta que ocupar significa tomar posesión de un territorio, sin tener en cuenta la legalidad o ilegalidad de la acción. Esta autora también sostiene la hipótesis de que la invasión es el principal hilo conductor de los asentamientos informales de Latinoamérica, con la cual estamos de acuerdo, pero considerando que existen otros hilos conductores de informalidad como los loteos irregulares privados o los fraccionamientos públicos para programas de autoconstrucción.

La misma autora, considera que los propietarios de los terrenos invadidos se convierten en gestores activos en la formación o consolidación de asentamientos informales, es decir, cuando éstos se convencen de que sus terrenos no son aptos para construir, ya sea por sus características físicas, o por su localización, deciden sacar el mayor provecho por cualquier vía. Sostiene además, que cualquier situación irregular sobre las tierras, termina generalmente en diálogos, concertaciones y negociaciones entre propietarios y tomistas ${ }^{190}$.

\footnotetext{
${ }^{188}$ Sobre el proceso de las coreas de Barcelona, las barriadas de Lima y las Favelas de Río, ampliaremos en el siguiente apartado.

189 García de Hernández, Norma (2006): “La Formación de Asentamientos Informales: Un proceso gestado por diferentes actores sociales". Revista Scripta Nova. Vol. X, № 218. Agosto 1. http://www.ub.es/geocrit/sn/sn-218-50.htm. Consultado 23 de julio de 2010.

${ }^{190}$ El término tomista, proviene de la palabra Toma, que significa arrebatar, usurpar o despojar, y es utilizado para hacer referencia a los ocupantes de terrenos por vías de hecho, principalmente en los procesos de negociación.
} 
Como aspecto significativo de este fenómeno, acentuamos que los terrenos de mayor disponibilidad para los invasores en las ciudades latinoamericanas, son generalmente: los suelos degradados; los suelos fiscales; las reservas naturales; las zonas aledañas a grandes infreastructuras, y las zonas cercanas a fuertes actividades económicas. En el caso de la ciudad de Bogotá, por ejemplo, asentamientos informales como Patio Bonito, San Cristobal y San Blas se constituyeron cerca de un equipamiento importante como la Central de Abastos y en zonas de explotación económicas asociadas a canteras y ladrilleras ${ }^{191}$.

En cuanto a la ciudad de Montería, consideramos que las invasiones sí han sido ese hilo conductor de informalidad, ya que permitió la consolidación de diferentes asentamientos en los mismos terrenos de ocupación inicial. Sin embargo, es adecuado aclarar que no todas las invasiones en esta ciudad, tuvieron el objetivo de consolidarse en el terreno de ocupación inicial, y por el contrario, en ocasiones ese suelo fue solamente utilizado como instrumento de presión, para lograr negociar una premeditada reubicación en un sitio referenciado con anterioridad. Esta apreciación será ampliada y corroborada en el siguiente apartado.

En la invasión de terrenos en Montería, además de los invasores, también participan activamente líderes sociales, cuadros políticos, miembros de comunidades religiosas, organizaciones no gubernamentales y funcionaros de la administración municipal, departamental o nacional. Sobre este último grupo, es importante manifestar que la pasividad institucional o complicidad del Estado, es un factor clave para la consecución del objetivo, y al cual se le asigna una alta cuota de responsabilidad en la proliferación de este fenómeno en los países latinoamericanos.

Con respecto a la participación del Estado, directa o indirecta, Clichesvsky ${ }^{192}$ anota que éste, promueve las ocupaciones cuando las tolera y las admite; Lovera ${ }^{193}$, por su parte,

\footnotetext{
191 Carrasco Rey, René (2004): "Barrios marginales en el Ordenamiento de Bogotá". Revista Bitácora Universidad Nacional de Bogotá. Vol. 8 № 1. Enero - Diciembre 2004. pp. 56-63

${ }^{192}$ Clichevsky, Nora (2003): "Pobreza y acceso al suelo urbano. Algunas interrogantes sobre políticas de urbanización". Santiago de Chile: CEPAL- NACIONES UNIDAS, 2003. Serie Medio Ambiente y desarrollo. No. 75.
} 
considera esa tolerancia como una Intervención Encubierta del Estado, y Castells ${ }^{194}$, reconoce que si no fuera por la permisividad de éste, o por el apoyo de factores políticos, la existencia de los asentamientos informales no sería posible. En el caso concreto de Montería, la experiencia de la invasión Cantaclaro, es un fiel reflejo de la acción, omisión, intervención encubierta, permisividad o la tolerancia, que manifiestan estos autores.

En esa misma dinámica, autores como Françoise Tomas ${ }^{195}$, asigna una mayor permisividad a los gobiernos de tendencia izquierdista en Latinoamérica, y Norma García $^{196}$, afirma que la participación encubierta del Estado, es la que posibilita la existencia de tantos desarrollos informales en el contexto latinoamericano. Sin embargo, consideramos desde esta investigación, que éste no ha sido el caso de Colombia, y mucho menos el de Montería, en donde han predominado gobiernos populistas, pero no de tendencias izquierdistas.

En términos generales, la invasión de terrenos es un proceso planeado o concertado por los diferentes actores que en él participan, y su éxito precisamente depende de ello, pero existen aspectos claves como: la elección del terreno, el nivel de organización del colectivo, el liderazgo político y la calidad del suelo seleccionado para la ocupación los que finalmente permiten el cumplimiento del propósito principal. En este sentido, no resulta desacertado afirmar que, las invasiones de terrenos no son procesos tan espontáneos como aparentan ser.

Bajo estas perspectivas, expresamos que el éxito de las invasiones de Montería, obedece a que cada uno de los actores sociales que participan en cada proceso, logra satisfacer necesidades o intereses, ya sea de manera parcial o total. Este éxito,

\footnotetext{
${ }^{193}$ Lovera, Alberto (1997): Se Busca Espacio Habitable. Las Formas de acceso al espacio habitable y su legitimación. En AA. VV. (1997): Barrios y Propiedad de la Tierra. Una discusión. Caracas. U.C.V. pp. 107 129.

194 Castells, Manuel (1986): La Ciudad y las Masas: sociología de los movimientos urbanos. Alianza editorial. Madrid.

195 Tomas, François (1995): La irregularidad en el desarrollo urbano de América Latina. En García de Hernández, Norma (2006): Op. Cit Pág. 6.

${ }^{196}$ Ibíd. Pág. 7
} 
evidentemente, se apoya en la capacidad de liderazgo, organización y planeación de estos procesos, lo cual se ve reflejado en el número de asentamientos que se constituyeron mediante ocupación por vías de hecho, y que hoy son una realidad dentro de esta ciudad.

Ahora, en la ciudad de Montería se interpreta a priori, y de manera desconstextualizada, que los actores beneficiados en el proceso de invasión son únicamente los invasores, porque lograron resolver, aunque de manera precaria, el problema de la vivienda. No obstante, resaltamos que detrás de la satisfacción de esta necesidad, también salen favorecidas las administraciones municipales y los propietarios de suelos degradados de escaso valor; las primeras resuelven a bajo costo la presión social por demanda de suelo o vivienda, mientras los segundos, logran obtener mayores ingresos por suelos poco rentables, debido a sus condiciones naturales o de localización.

Con respecto a estos procesos irregulares de ocupación, Negrete ${ }^{197}$ considera que para sostenerlos y para consolidarlos en el tiempo, es de mucha importancia la memoria histórica, porque permite mantener presente quiénes fueron los invasores, cuáles fueron los intereses de los organizadores y quiénes apoyaron. En este sentido, él manifiesta que es el conocimiento de la historia el que permite la continuidad del proceso y la creación de identidad por el asentamiento en que se habita.

El mismo autor destaca tres etapas en el proceso de Invasión y para ello tiene en cuenta la calidad de los materiales de construcción utilizados por los ocupantes durante cada una de las fases: instalación, aceptación y legalización. En cada una de estas etapas los invasores toman diversas precauciones que inciden directamente en la utilización de materiales transitorios o duraderos.

En la fase de instalación el primer objetivo es el de indicar posesión con materiales sin valor económico para evitar pérdidas en los desalojos o posibles incautaciones por parte de las autoridades. El principal papel de los materiales en este periodo es el de

\footnotetext{
197 Negrete, Víctor (1999): Los Asentamientos Subnormales de Montería. Universidad del Sinú.
} Montería. Pág. 23. 
proteger del sol, la lluvia o el viento, para lo cual es suficiente con cartón, plastico, lata, y estacas no comerciales; además son requeridos otros elementos comerciales como el alambre, fibra sintetica, clavos, martillos, horcones y hamacas para el descanso.

La segunda etapa o fase de aceptación de la invasión está sujeta a la determinación positiva de la administración municipal y en ella los parapetos instalados inicialmente son reemplazados por Ranchos de mayor consistencia que se construyen con materiales más duraderos como: madera, guadua ${ }^{198}$, bahareque ${ }^{199}$, palma y zinc. Estos ranchos se convierten en permanentes para muchas familias del asentamiento, y para otras, la evolución a la tercera fase lleva varias décadas.

Con la legalización del asentamiento por parte de la administración municipal llega la tercera fase o incorporción de materiales definitivos como asbesto, cemento, hierro, cristales, baldosa, e incluso el marmol. La incorporación de dichos materiales están sujetas al poder adquisitivo de las familias, a los subsidios estatales o a la financiación que las instituciones financieras puedan realizar.

En esta investigación nos identificamos con esta clasificación, pero consideramos además, que estas fases se pueden diferenciar también por aspectos relacionados con el uso dado por los ocupantes o por la percepción del dominio que tengan los invasores. En cuanto a percepción del dominio, establecemos entonces tres fases: 1) fase de incertidumbre; 2) fase de esperanza, y 3) fase de certeza.

La fase de incertidumbre se caracteriza por la desconfianza ante un posible desalojo, razón por la cual, los ocupantes asumen el papel de centinelas, con el objetivo de vigilar los movimientos de las autoridades, e impedir la llegada de personas ajenas a la ocupación; la fase de esperanza, en cambio, se caracteriza por los niveles de confianza

\footnotetext{
198 La guadua es un material natural, o producto forestal, colombiano que permite la construcción de artesanías, casas y puentes. Uno de los arquitectos más destacados por sus trabajos con este material es el colombiano Simón Pérez, quien la denomina "acero vegetal". Algunos de sus proyectos se encuentran disponibles en http://www.larevista.ec/especiales/edificar2011/bambu.html

${ }^{199}$ El bahareque es un sistema de construcción de vivienda de los pueblos indígenas de América, a partir de palos entretejidos con cañas y barro. http://es.wikipedia.org/wiki/Bahareque
} 
que genera la aceptación de las autoridades, la identificación plena de vecinos y las posibilidades futuras de legalizar la ocupación. Finalmente, la fase de certeza, se caracteriza por los altos niveles de identidad con el territorio que genera la propiedad legal de la vivienda.

Es significativo anotar que, en la primera etapa no siempre ocupan las mismas personas que se asentarán definitivamente en el predio, ya sea por razones de confianza o por la presencia de invasores profesionales en el proceso. Un ejemplo de ello es la ocupación que hace un familiar cuando la persona que cumpe los requisitos se encuentra laborando, o también cuando los necesitados se encuentran imposibilitados por razones de edad o discapacidad. La incertidumbre que caracteriza a esta fase, dificulta cualquier tipo de relaciones mercantiles que se pretenda realizar.

En la segunda fase quedan definidas las personas o familias que se asentarán en la vivienda, y además, se realizan transaciones mercantiles mediante alquileres informales o palabra de compraventa, que posteriormente se consolida. En el caso de la invasión Cantaclaro, por ejemplo, con solo diez años de constitución y sin la legalización de la propiedad, ya se encontraban alquiladas 308 viviendas, una cifra muy alta si se tiene en cuenta que el número total de las vivendas existentes en el asentamiento apenas llegaba a 3.745 unidades $^{200}$.

La tercera fase, que también denominamos como poslegalización, aumenta la seguridad para realizar inversiones a las viviendas y para establecer transacciones de tipo mercantil, principalmente alquiler de apartamentos o habitaciones. En esta fase, por un lado, se logra acceder a ese crédito financiero al que tanto alude Hernando de Soto ${ }^{201}$; y por el otro, con esos recursos, se logran hacer efectivas las mejoras, ampliaciones de vivendas, o divisiones de ellas, con el objetivo, precisamente de alquilar y mejorar los ingresos familiares.

\footnotetext{
${ }^{200}$ Negrete, Víctor. Op. Cit. Pág. 22

${ }^{201}$ Economista peruano, autor del libro El otro Sendero y el Misterio del Capital publicado en 1986, en el que destaca los beneficios que representa la legalización de actividades informales y el papel que juega la legalidad de la propiedad de las viviendas como instrumento de acceso al crédito en el sistema financiero.
} 
Como es natural, en estos asentamientos informales de Montería inicialmente no estuvieron presentes las técnicas urbanísticas de zonificación, densificación y definiciones tipológicas, ni las variables de planeamiento e infraestructura que distinguen a la vivienda en el mercado formal, y a las cuales se refiere Gaja Díaz ${ }^{202}$. En el mismo plano, también destacamos que los suelos de dichos asentamientos, generalmente carecen de precio monetario, y su adquisición se puede lograr mediante diferentes modos especiales; como por ejemplo, las retribuciones en votos para el político que facilita o respalda dicha adquisición.

\subsubsection{Surgimiento, ubicación y situación de las invasiones de Montería.}

Si bien es cierto que las primeras ocupaciones irregulares colectivas comenzaron en la década de los años cincuenta del siglo XX, también es indudable que la mayor dinámica de las invasiones se alcanzaría en la década de los ochenta con los asentamientos de Cantaclaro, Robinson Pitalúa, la Candelaria, Ranchos del INAT, Camilo Torres y Casa Finca, entre otros. Esta gran dinámica seguiría en los años noventa con el surgimiento de las nuevas invasiones del Poblado, Paz del Río, Mi Ranchito, y los Colores, y se extendería a los primeros años del siglo XXI con las Invasiones de Villa Cielo, Villa Jiménez, Furatena, Villa Paz y Nueva Esperanza en el oriente y sur de la ciudad. En este orden de ideas, consideramos pertinente ubicar gráficamente dichas invasiones y describir algunos aspectos de ellas en este apartado, pero anotamos que su impacto sobre la morfología urbana y el ambiente serán evaluados en el siguiente capítulo.

\footnotetext{
202 Gaja Díaz, Fernando (1984): La Promoción Pública de la Vivienda en Valencia. Universidad Politécnica de Valencia. España. Pág. 30.
} 


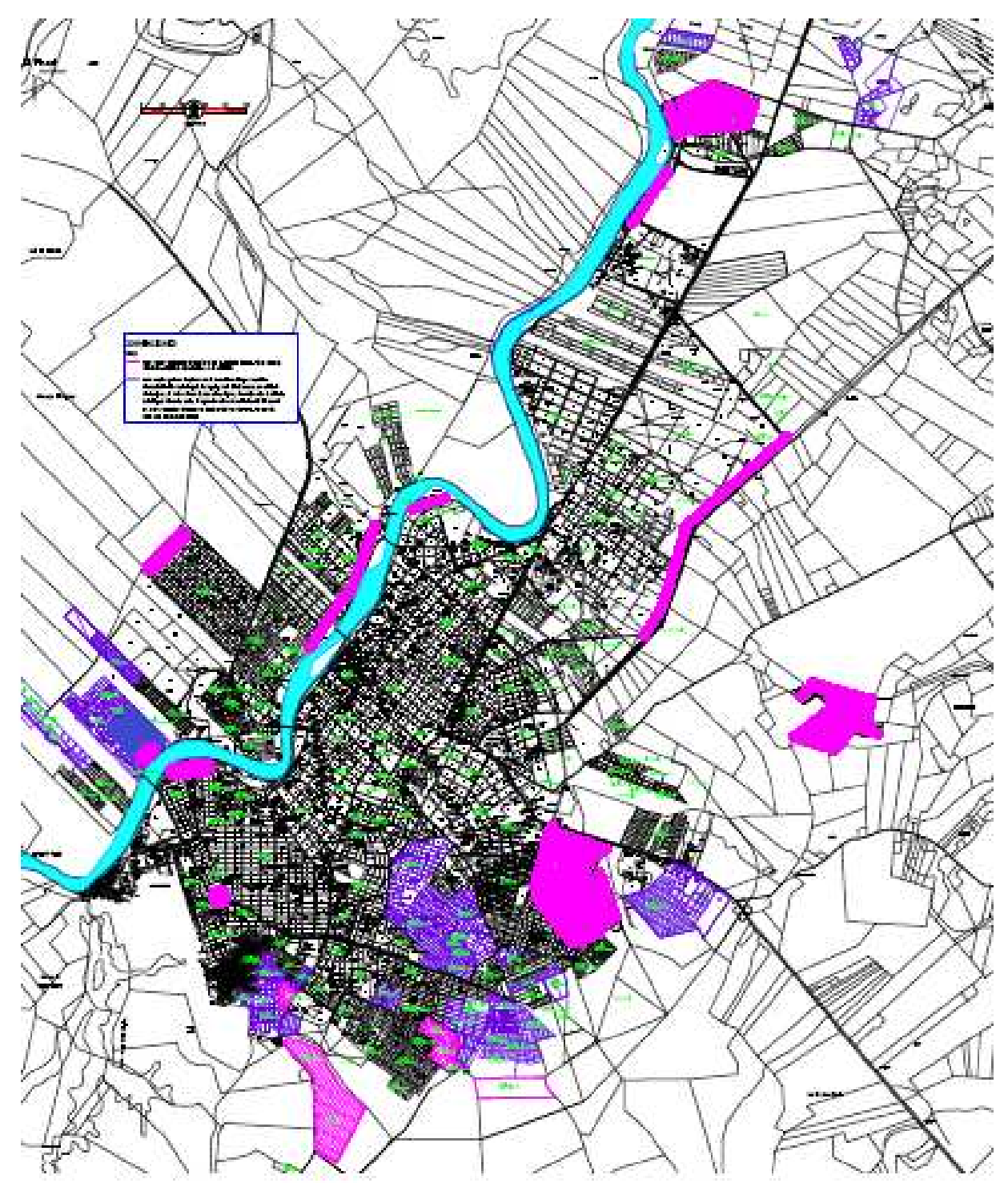

BARRIOS SURGIDOS POR INVASIÓN

Fuente: Elaborado por Elkin Herrera y Jhon Pinedo 2011

Ilustración 47. Barrios surgidos por procesos de invasión

Como se puede apreciar en el plano, los barrios de invasión se emplazaron en todos los puntos cardinales de la ciudad, pero estos emplazamientos no fueron tan dispersos, sino más bien, concentrados en grandes superficies, principalmente en el oriente y norte de la ciudad. Igualmente se aprecian invasiones lineales en ambos bordes del río Sinú y sobre el canal oriental que conduce aguas pluviales y residuales con dirección sur a norte.

Los asentamientos conformados por procesos de invasión más antiguos son 14 de julio, el Cerro, Brisas del Sinú y 7 de Mayo, surgidos entre los cincuenta y los ochenta, 
pero los de mayor superficie, son Cantaclaro, Villa Cielo, Villa Jiménez, Robinson Pitalúa, Furatena y Nueva Esperanza, todos ellos nacidos después de los años ochenta. Estos últimos sectores, se caracterizan además, por altos niveles de precariedad, inseguridad, y por concentrar grandes volúmenes de población y actividades económicas informales.

En lo referente al barrio Cantaclaro, el más extenso de todos, destacamos que fue constituido en una superficie de 91 hectáreas en el oriente de la ciudad sobre la carretera que comunica a Montería con la ciudad de Medellín, y lleva el nombre de la finca que se encontraba allí ubicada, antes de que sus propietarios León Dereix y Hugo Londoño la vendieran al Instituto de Crédito Territorial para un proyecto de urbanización ${ }^{203}$.

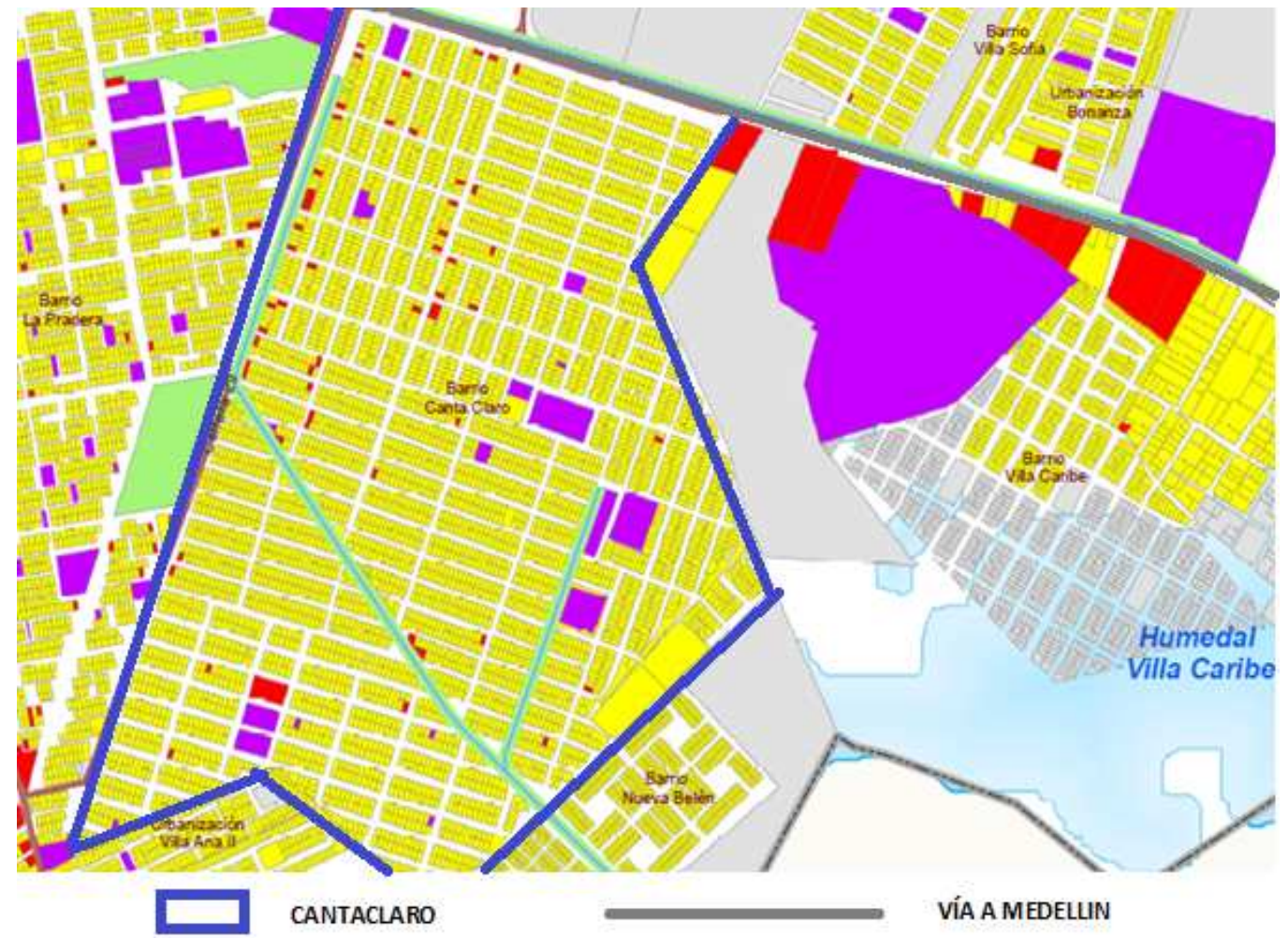

Fuente: eleaboración propia con base en el POT 2002-2015 Ilustración 48. Barrio Cantaclaro

\footnotetext{
203 Negrete Barrera, Víctor y Otros (1999): La Pobreza dentro de la Pobreza. Cantaclaro y su Canal. Universidad del Sinú. Montería. Pág. 10
} 
La venta de la finca Cantaclaro al Instituto de Crédito Territorial, fue aprovechada por algunos dirigentes políticos, quienes organizaron la invasión inicial de un lote de nueve hectáreas con la complacencia de funcionarios de esta institución. Esta primera toma fue planeada el 27 de agosto de 1988 bajo la coordinación de los líderes comunitarios Marciano Córdoba, Orlando Padrón, Fernando Mass y José Manuel Barón. Posteriormente se incorporaron los líderes populares y políticos, Luis Narváez, Mateo Paternina, Edwin Aguirre, Marcos Arteaga, Daniel Ramos, Gamaliel Brunal, Claudia Pérez y Limberto Reyes ${ }^{204}$.

En este proceso son destacables los testimonios posteriores de líderes políticos como Manuel Causil y Jairo Banda, quienes revelaron aspectos claves para el éxito de la toma, y dentro de los cuales sobresalen el momento oportuno de la ocupación y la certeza de que el Instituto de Crédito Territorial (ICT) era el propietario legal del terreno "Nosotros no sabíamos que Cantaclaro era del ICT (...) Luego se supo, no sabemos cómo lo averiguaron, que de verdad el terreno pertenecía al ICT a pesar de sus constantes negativas. Esta seguridad nos animó y bajo una fuerte lluvia el 7 de septiembre de 1988, varios grupos, como orientados por una mano y voz invisible nos metimos a la tierra"205.

Los grupos a los que se refieren en estos testimonios fueron siete, los cuales se encargaron de ocupar el mismo número de sectores, posteriormente denominados el Ñipi, el Paraíso, la Represa, la Isla, las Cañas, el Níspero y la Carretera. En la coordinación de estos grupos participaron, reiteramos, significativos líderes comunales y políticos, dentro de los que se destacaron, Plinio Negrete, José Mendoza, Javier Salgado, Roger Figueroa, Marina Barrios, Soro Padilla, Elís Páez, Rosemberg Villalva, Manuel Causil, Jairo Banda, Plinio Salgado, Marciano Galeno, Marcos Pedroza y Carmelo Pión ${ }^{206}$.

Las funciones de estos líderes dentro del proceso estuvieron circunscritas a la entrega de lotes a las familias; mantener libres los espacios para vías y zonas verdes; llevar

\footnotetext{
204 Ibíd. Pág. 11

205 Ibíd. Pág. 12

${ }^{206}$ Ibíd. Pág. 13
} 
censo y control de todo el personal; adelantar contactos para obtener servicios básicos y asistencia a las reuniones convocadas para consolidar la ocupación. La entrega de los lotes a las familias debía realizarse después de verificar de que éstas no figuraban como propietarias en el registro público.

Durante la ocupación de la primera porción de la finca, ninguna autoridad policial o administrativa se hizo presente, ni formalizaron demanda legal alguna, lo cual estimuló la toma posterior de las ochenta y dos hectáreas restantes del predio. Esta primera toma fue denominada La Unión y justificada con el alto déficit de vivienda, los altos costos en los arriendos y la ausencia de programas de vivienda pública que argumentaban los ocupantes.

En cuanto al uso anterior del suelo, conviene anotar que el terreno era utilizado para ganadería, pero también se encontraban plantados algunos árboles frutales como mangos y nísperos. No obstante, anotamos que a pesar de la gran capacidad agrológica del territorio, gran superficie de estos terrenos son compatibles con el uso residencial y su impacto ambiental es menor que el ocasionado por otros asentamientos informales de la ciudad.

La extensión de Cantaclaro registrada en el Instituto Geográfico Agustín Codazzi corresponde a 90.89 hectáreas, que se encuentran distribuidas en 236 manzanas, donde la manzana promedio está conformada por 36 lotes de 105 metros cuadrados (7 $x$ 15). El ancho de las calles se estableció en nueve metros y el de los andenes en un metro. Para el trazado de las calles fue necesaria la colaboración de una comisión topográfica del ICT seccional de Bogotá, y para los equipamientos se destinaron cinco manzanas.

Como datos complementarios destacamos que en el año 1999 ya se encontraban constituidas en este asentamiento 3.745 viviendas, las cuales estaban habitadas por 17.455 personas de 4.538 familias. Igualmente resaltamos que para esa misma época, del total de viviendas constituidas, apenas el 34\% (1301 unidades) habían logrado edificar sus paredes con bloque de cemento o ladrillos y por el contrario 2.444 
viviendas mantenían sus paredes con madera burda, guadua, zinc, bahareque y lata $(\text { chapa })^{207}$.

Además de la precariedad de las paredes después de diez años también se mantenía la precariedad en pisos y en cubiertas. En el caso del piso, la evolución es más lenta que la de las paredes, ya que para el mismo periodo apenas el $23 \%$ de las viviendas había logrado acceder a piso de cemento o baldosas, contra el $77 \%$ que mantienen su piso natural de tierra. En cambio, las condiciones de las cubiertas eran un poco más alentadoras por la presencia de materiales duraderos en el $40 \%$ de las viviendas y la permanencia de un elemento natural como la palma en otro $55 \%$ del total de ellas ${ }^{208}$.

Este referente permite estimar que diez años fueron insuficientes para la consolidación urbanística del asentamiento y que el tiempo de consolidación dentro de esta dinámica, siempre estará sujeto a la evolución individual de la vivienda. No obstante es relevante anotar que para este periodo ya se había logrado la electrificación legal del $95 \%$ del asentamiento, $80 \%$ de cobertura de acueducto y $10 \%$ de gas natural, así como la asignación de subsidios de mejoramiento de vivienda por parte del Instituto Nacional de Reforma Urbana (INURBE).

Estos datos se han visto incrementados en los últimos diez años y de acuerdo con la información suministrada por la Junta de Acción Comunal del Barrio ${ }^{209}$, en la actualidad el número de habitantes asciende a cuarenta y cinco mil personas de aproximadamente siete mil hogares. En este momento y después de veinte años se evidencia la presencia de materiales constructivos duraderos en aproximadamente el $70 \%$ de las viviendas pero las condiciones para el 30\% restante siguen siendo precarias y aún permanecen en ellas materiales transitorios como los anteriormente mencionados.

\footnotetext{
${ }^{207}$ Ibíd. Pág. 18.

${ }^{208}$ Ibíd. Pág. 19

209 Datos suministrados por el líder fundador y miembro de la Junta de Acción Comunal Hernando Elis, en entrevista concedida a Jorge López el día 11 de septiembre de 2010. Quien manifestó que los lideres Edwin Aguirre, Marcos Arteaga, Daniel Ramos, Gamaliel Brunal, Claudia Pérez y Limberto Reyes no participaron en la fundación del barrio. Sobre el dominio de la vivienda, manifestó que 1.114 familias aún no cuentan con la titularidad sobre la propiedad.
} 
Finalizamos este recorrido por la invasión más grande de la ciudad, destacando que dentro de las precariedades notables en este periodo se evidencia la falta de alcantarillado, zonas verdes, cobertura directa de agua potable para el $30 \%$ de los beneficiarios de los habitantes, el hacinamiento de más de tres personas por cuarto que manifiestan más de dos mil setecientas familias, la falta de algunos equipamientos básicos que aún no lograban construirse, la inexistencia de una red viaria adecuada para transporte público de pasajeros y la presencia de pandillas juveniles.

Sin embargo, también es notable que en los espacios destinados para dotaciones públicas, ya se encuentren ubicados una cancha de futbol, un centro de atención médica de urgencias (CAMU), así como los colegios BEMPOSTA, Victoria Manzur, Severo García y el Paraíso. El centro médico es de nivel de atención básica; la cancha los Fundadores es utilizada por jóvenes y adultos para actividades deportivas, y las escuelas ofrecen educación primaria y bachillerato en jornada diurna a cuatro mil setecientos estudiantes.

Otra invasión de gran impacto es la de Robinson Pitalúa, cuyo surgimiento obedece a la reubicación de unas 550 familias que habían resultado desalojadas de otros terrenos ubicados al oriente de la ciudad sobre el canal de aguas pluviales en ese mismo sector. El proceso de realojo fue concertado con la administración municipal y se realizó en agosto de 1988 cerca a los predios que ahora correspondían al barrio la Candelaria y Paz del Río.

En total se repartieron 458 lotes que hoy se encuentran ocupados por viviendas inacabadas en su mayoría, con presencia aún de materiales transitorios que se encuentran conectadas por un sistema precario de vías internas y carentes de dotaciones públicas significativas. No obstante, ya se encuentra electrificado, dotado de redes de abastecimiento de agua e integrado por medio del sistema de transporte público. 


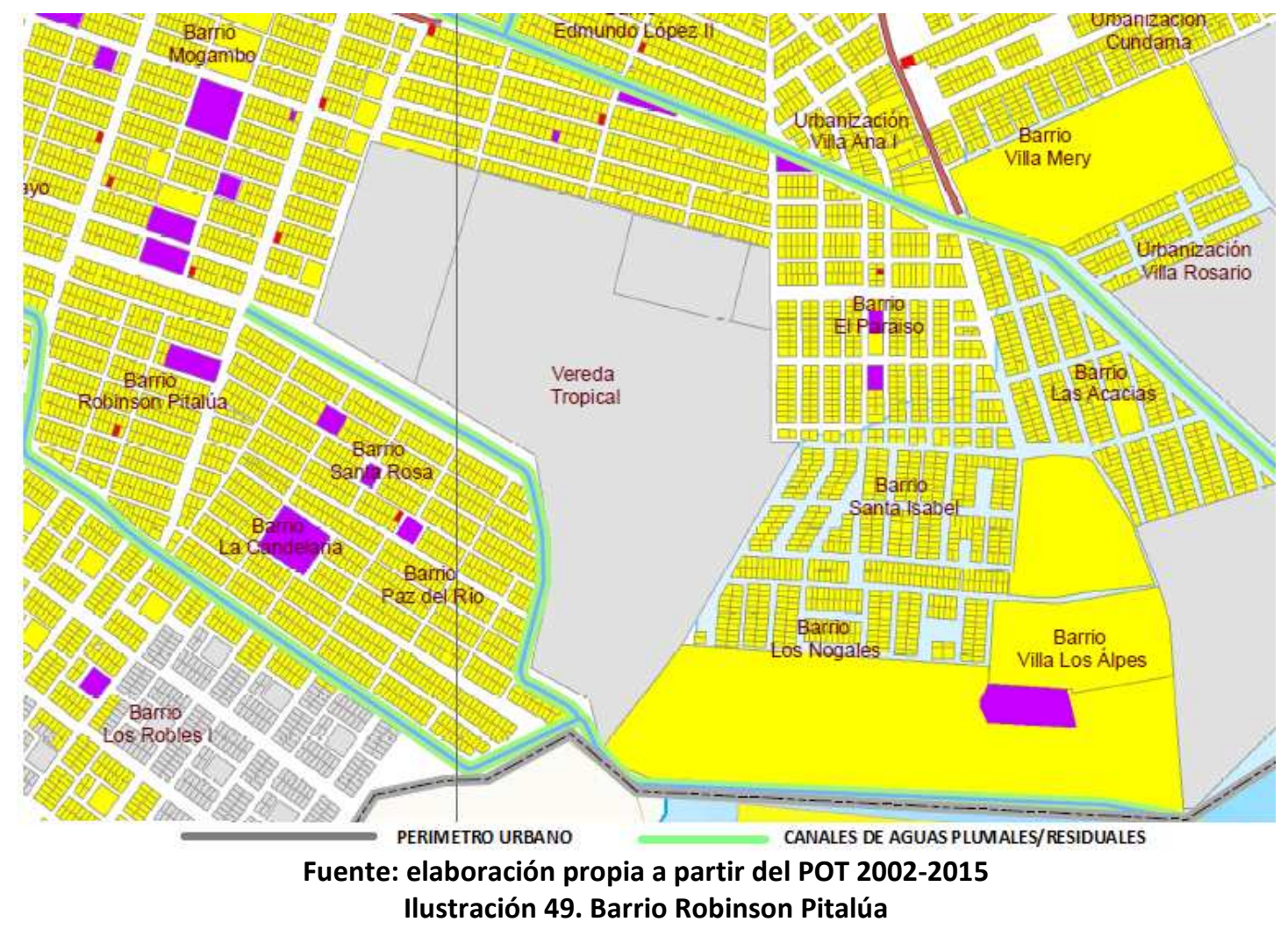

Varios de sus líderes comunitarios se encuentran vinculados a movimientos políticos tradicionales, logrando conseguir en estos veintidós años, algunas mejoras para el sector o para las viviendas mediante gestión de subsidios o de recursos. Sobresale el liderazgo de Miriam Daza, Débora Seña, Rosalba Sáenz, Isabel Palencia, Ciria Osorio, Nurys Murillo, Rosa Causil, Carmen Vellojín, Camila Agamez, Nancy Payares y Eduardo Núñez.

La propiedad de las viviendas en su mayoría ha sido legalizada, e incluso, ya algunas de ellas cambiaron de propietarios y otras se encuentran ocupadas por medio de la figura de alquiler. Sin embargo un gran número de ellas no se encuentran terminadas y mantienen las características de precariedad que identifica a los asentamientos informales recientemente constituidos.

En el entorno de Robinson Pitalúa, surgieron inmediatamente las invasiones de la Candelaria, Santa Rosa y Paz del Río, siendo este último el más reciente de los tres, ya que fue constituido en el año 1990, con la orientación de líderes políticos dentro de los cuales se destacan Gerardo Pérez Clamerán y Álvaro Ríos. Esta invasión fue realizada por 138 familias, provenientes de la zona urbana de Montería y de áreas rurales de 
Valencia, Tierralta y Urabá, quienes en total sumaron una población inicial de 1639 personas $^{210}$.

Este asentamiento se encuentra conformado actualmente por 336 viviendas, heterogéneas en cuanto a su estado arquitectónico, en donde predomina el alojamiento precario e inacabado, con altos niveles de hacinamiento, pisos de tierra, cubiertas inconsistentes, paredes con materiales transitorios y sin cobertura total de saneamiento básico ni alcantarillado. Sin embargo, cuentan con equipamientos comunitarios como la guardería infantil y la escuela de primaria.

En esta invasión sobresale la participación de personas como Arnulfo Mendoza, Rosa Inés Sáenz, Cecilia Morales, Oneida Martínez, Emilia Martínez y Brenda Morfi, quienes junto a Visión Mundial, Cruz Roja, Secretaría de salud y la Red de Solidaridad Social, han logrado desarrollar diferentes programas orientados a mejorar el entorno del sector, la vivienda, la recreación, la educación, letrinas y salud de los niños.

La Candelaria, en cambio, fue constituida dos años antes, sobre terrenos de propiedad del Instituto de Crédito Territorial, ocupados por 2.591 personas de 536 familias, de las cuales el $65 \%$ eran desplazadas de Urabá y San Jorge, el $20 \%$ eran provenientes de zonas rurales del municipio y apenas el $15 \%$ correspondía a personas nativas de la cabecera municipal ${ }^{211}$. Estas familias lograron ubicarse finalmente en este sector, ante un intento fallido de instalarse en otro lote de propiedad privada.

Este asentamiento se encuentra actualmente en proceso de consolidación, pero las condiciones higiénico-sanitarias del entorno siguen siendo precarias puesto que aún no está dotado de la totalidad de servicios básicos, vías y equipamientos colectivos. No obstante, se ha logrado la construcción de una escuela, el arreglo de la vía principal que permite el ingreso de todo tipo de vehículos, la instalación de energía y parte de la tubería para el acueducto.

\footnotetext{
210 Ibíd. Pág. 43.

${ }^{211}$ Ibíd. Pág. 37
} 
Los habitantes de la Candelaria aún vierten sus aguas residuales a cunetas y al canal de aguas pluviales, y para la disposición de excretas la mejor alternativa ante la falta de alcantarillado es el pozo séptico que las familias instalaron paulatinamente de manera individual. Es apropiado manifestar que algunas familias solamente pudieron instalar pozos sépticos después de diez años de constituido el asentamiento y su viviendas permanecen en estado precario.

Al igual que en la invasión Cantaclaro, en este asentamiento también se asentaron algunas familias a la orilla del canal de aguas pluviales y residuales, quienes comenzaron a llegar aisladamente a partir del año 1966 como desplazados de la violencia, y actualmente suman un total de treinta y cinco familias en el sector denominado por ellos mismos como el Enjambre.

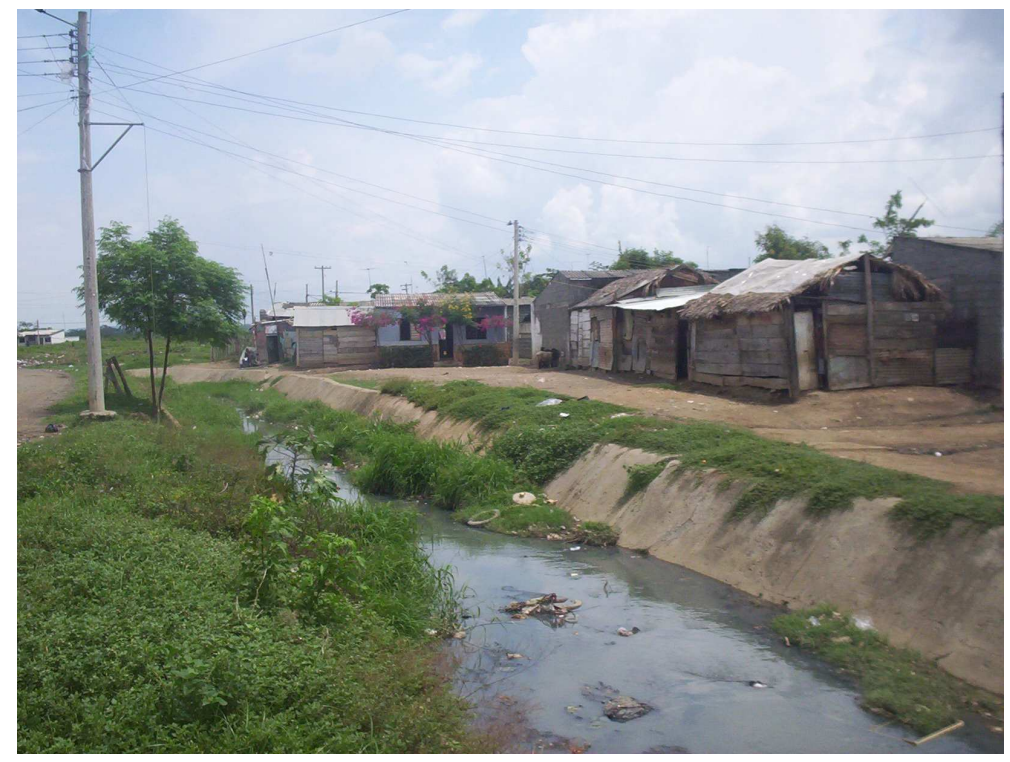

Foto: Jhon Pinedo López 2007

Ilustración 50. El Enjambre

Con el apoyo de algunas organizaciones no gubernamentales como Acción Contra el Hambre, Visión Mundial, la Fundación María Cano y la Junta de Acción Comunal, los habitantes de la Candelaria han logrado desarrollar actividades relacionadas con el mejoramiento del sector, arreglo de vía, capacitaciones, guardería infantil, mejoramiento de vivienda, letrinas, recreación, nutrición, saneamiento básico, y electrificación. Sin embargo, las condiciones en el Enjambre y en todo el sector siguen siendo insalubres para sus habitantes. 
En cuanto a condiciones arquitectónicas en el asentamiento aún permanecen viviendas con materiales transitorios, o elementos de la región, como el bahareque, la guadua, la palma, y madera. No obstante, a la fecha de diciembre de 2010 un $70 \%$ de las viviendas ya contaban con materiales más resistentes como el zinc, asbesto, bloque de cemento, hormigón y baldosas.

El paisaje del sector no es el más agradable por las condiciones desfavorables que ofrece el entorno ante la falta de pertenencia de los habitantes con su espacio privado o público, con excepción de un grupo de personas que constantemente participan en la gestión de obras o programas, y dentro de los cuales merecen reconocimiento Luís Mestra, Manuel Salcedo, Jimmy Madera, María Banquet, Hernán Kerguelén, Domingo Ramos, Francisco Montes y Pedro Fuentes, entre otros. A ellos se les reconoce una alta cuota de participación en los logros del asentamiento así como también en la solución de calamidades sociales o emergencias naturales presentadas.

Por su parte, Santa Rosa es una invasión constituida en febrero de 1989, sobre un terreno cenagoso perteneciente al Instituto de Crédito Territorial ICT, en el sur de la ciudad, que permitió la subdivisión de 215 lotes de 28 metros cuadrados (7x4), que albergan a igual número de familias, con una población aproximada de 1.045 habitantes. El asentamiento cuenta actualmente con energía eléctrica y con abastecimiento de agua potable pero las condiciones de las viviendas siguen siendo precarias al igual que las condiciones urbanísticas del sector y veinte años después de su constitución predominan las viviendas inacabadas así como la presencia de materiales transitorios en muchas de ellas.

Al igual que la Candelaria y Paz del Río, el asentamiento cuenta con líderes comunales dinámicos que luchan por mejoras del entorno y dentro de los cuales se destacan Esterlinda Ascendra, Nelfi Arango y Luz Marina Carvajal, quienes con su gestión han logrado conseguir la construcción de una escuela, centro de salud, drenaje para cunetas, mejoramiento de viviendas, arreglo de vía principal, equipamiento religioso, conformación de madres comunitarias y relleno de las zonas más vulnerables a las inundaciones. 
Dejamos el suroriente y pasamos al extremo norte de la ciudad donde se ubican las invasiones del 7 de Mayo, 20 de Julio y Camilo Torres, emplazadas cerca al tradicional caserío de Mocarí en el kilometro ocho de la vía que conduce al municipio de Cereté, pero incorporado oficialmente al perímetro urbano desde hace algunos años. Los dos primeros llevan esos nombres como homenajes a al 7 de mayo de 1976 y el 20 de julio de 1978, fechas en las que se realizaron las respectivas invasiones; por su parte, el Camilo Torres fue constituido en 1980 para reubicar a unos invasores de las orillas del Río Sinú a la altura del barrio la Coquera.



En los tres barrios se asienta una población aproximada a las 8.600 personas, quienes se alojan en 1.667 casas distribuidas de la siguiente manera: Camilo Torres, 800 viviendas; 20 de Julio, 670 y 7 de Mayo, 197 casas. En ellos se han realizado programas asilados para el mejoramiento de la calidad de vida que se traducen en mejora de vivienda, escuelas, capacitación, salud, instalación de letrinas y construcción de pozos sépticos.

En veinte años los tres asentamientos han evolucionado apenas lo necesario para acceder a servicios públicos básicos pero la calidad de la vivienda así como la urbanística siguen siendo precarias. La disposición del espacio público es demasiado 
limitada y se evidencia la falta de equipamientos recreativos, deportivos y culturales pero proliferan equipamientos religiosos precarios o consolidados de algunas denominaciones como la Cuadrangular, Adventista, Pentecostal, Evangelistas, Católica y Mormones.

Estos barrios generan un gran impacto sobre el ambiente, el paisaje urbano y el Río Sinú, principalmente el 7 de Mayo; por un lado, parte de los residuos generados por los residentes de la ribera invadida son arrojados al cauce de esta fuente hídrica, y por el otro lado, el gris estado de las viviendas contrasta con el verde de la naturaleza, lo cual descarta cualquier posibilidad de tener un agradable paisaje urbano.

Otras invasiones de gran impacto en la ciudad, por superficie, ubicación y tamaño de la población fueron las de Villa Cielo, y Villa Jiménez, emplazadas ambas fuera del perímetro urbano de Montería, y con gran impacto sobre la morfología urbana y los ecosistemas locales, principalmente Villa Jiménez, por conformarse en un humedal del suroriente con alto potencial de reserva, pero no protegido oportunamente por la autoridad ambiental ni por el plan de ordenamiento territorial 2002-2015. 


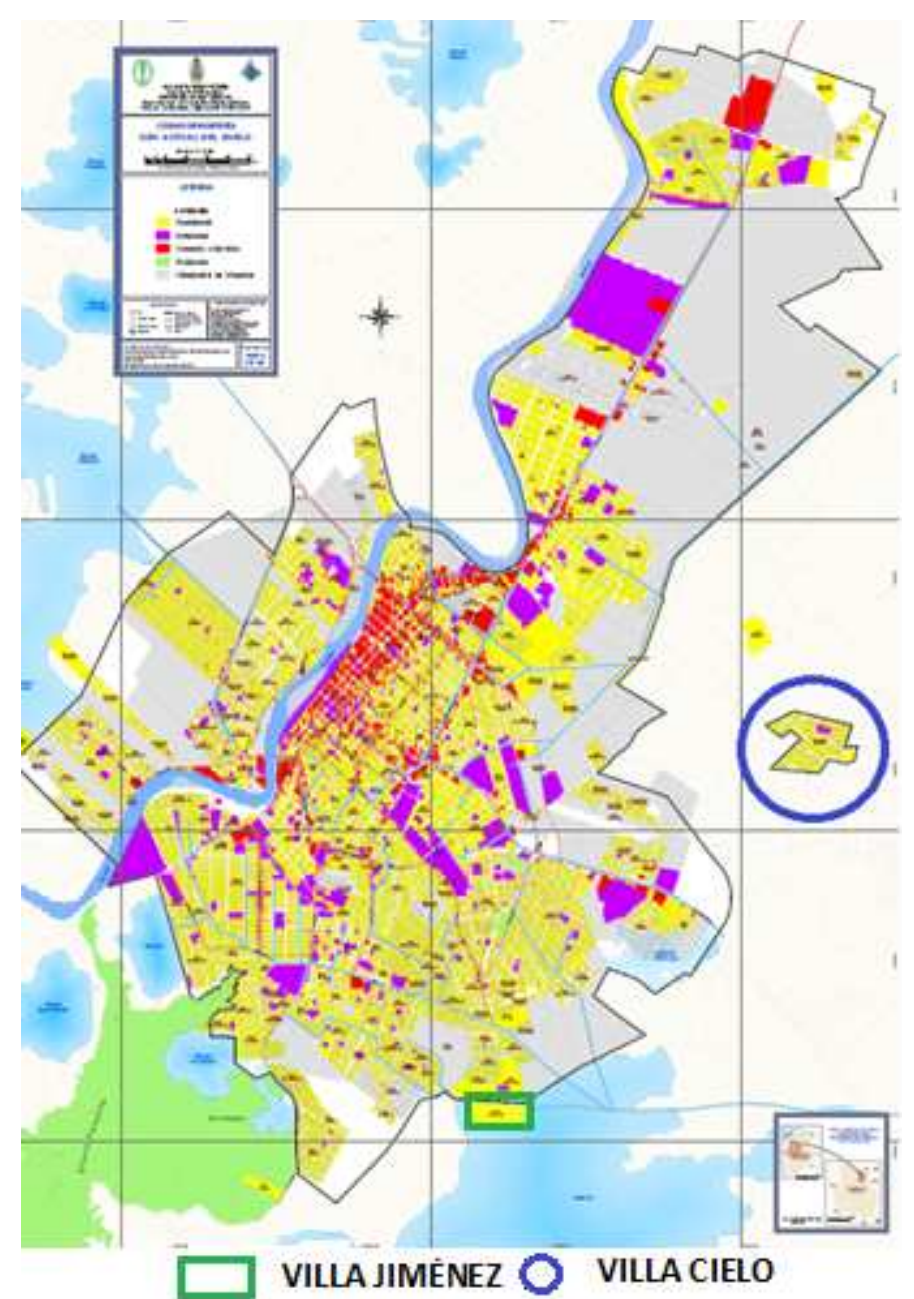

Elaboración propia a partir del POT 2002-2015 Ilustración 52. Ubicación Villa Jiménez y Villa Cielo

Villa Cielo se emplazó en la finca de propiedad de Carlos Castillo, la cual fue comprada por la alcaldía y subdividida en 600 lotes de $7 \mathrm{~m} \times 14 \mathrm{~m}$, para reubicar por sorteo a los invasores del sector la palma en el occidente de la ciudad distribuidos. Este es uno de los asentamientos más precarios de la ciudad de Montería y su impacto sobre la infraestructura y morfología urbana serán analizados en el siguiente capítulo.

Por su parte, Villa Jiménez es un asentamiento informal ubicado en el sur de la ciudad y promovido por la administración del alcalde Luis Jiménez Espitia en el año 2003, quien precisamente reubicó en ese año a la población damnificada por las inundaciones de la laguna de oxidación de occidente y a invasores de zonas aledañas. En la actualidad el barrio está conformado por 720 familias que se asientan en 701 infraviviendas y lleva su nombre en homenaje a este alcalde de Montería. 


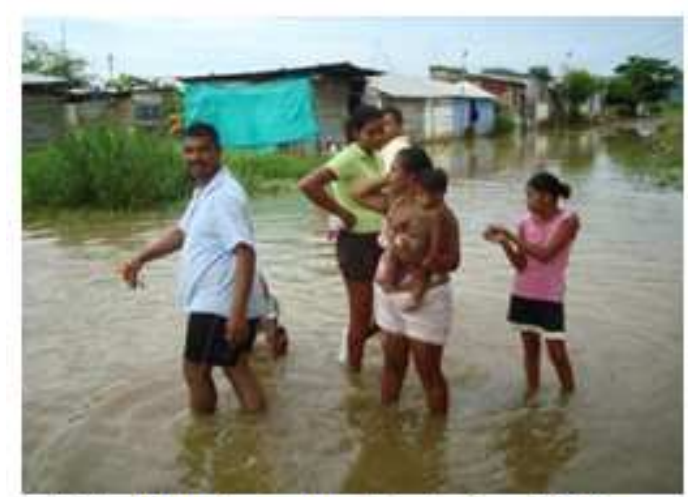

Foto: El Universal de Monteria - 2010

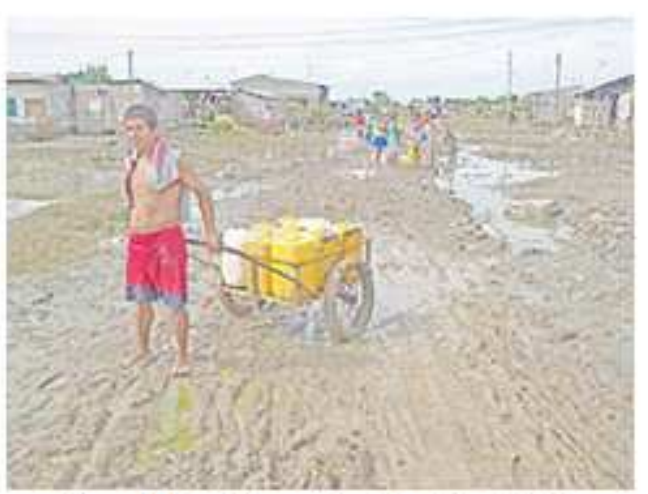

Foto: El Meridiano de Córdoba 2010

Ilustración 53. Inundaciones en Villa Jiménez

Estas viviendas se encuentran en un área rodeada por tres canales de desagües, dos humedales y una pequeña laguna situada en el centro del asentamiento, la cual se aprecia con claridad en las imágenes. Ante las condiciones del terreno, se propuso inicialmente que la reubicación fuera transitoria mientras se lograba adquirir un mejor predio, pero el tiempo pasó y en escasos siete años la población se consolidó aceleradamente en el sitio.

Las consecuencias de esta elección se viven anualmente con las frecuentes inundaciones ocasionadas por las lluvias, y para su solución se requiere un sistema integral de drenaje que asciende aproximadamente a cien millones de dólares americanos. No obstante, y a pesar de estar inundado de agua por todas partes, el asentamiento no cuenta con abastecimiento de agua potable y su estado es totalmente precario.

Sobre la consolidación de este asentamiento, el actual alcalde Marcos Daniel Pineda ha descartado plenamente cualquier posibilidad de reubicación, y respaldado en precarios argumentos de índole financiero, solicitó su reconocimiento por medio de los ajustes realizados al Plan de Ordenamiento Territorial de Montería. El mencionado alcalde, señala con el espejo retrovisor a los anteriores gobiernos y omite las recomendaciones del director del organismo ambiental para respaldar una decisión políticamente correcta, pero ambientalmente nefasta.

"Respeto la posición del director de la CVS, pero la de él es ambiental y seguro tendrá argumentos valederos. En ningún momento le estoy restando 
importancia a que estos humedales tienen que conservarse. En ningún momento estoy contradiciéndolo. Antes, por el contrario, estoy corroborando que este barrio nunca debió asentarse en el sitio donde hoy está asentado. Pero yo, como administrador del Municipio, conociendo la capacidad administrativa y financiera, y toda la problemática global, tengo que priorizar y tomar decisiones a corto, mediano y largo plazo"212.

Con estas ambiguas palabras este alcalde sostuvo de manera lacónica que por encima de cualquier consideración ambiental, estaba primero la situación financiera del municipio y que era más "sensato" para la administración municipal consolidar 15 asentamientos con treinta y cinco mil familias que pretender reubicarlos.

Pasando a otro sector de la ciudad, destacamos que en el occidente se encuentra la invasión del Poblado, conocida también con el nombre de la Turbina, por encontrarse ubicada allí, una caseta de bombeo de agua. Este asentamiento, además, se emplaza en una zona inundable y húmeda, aledaña al área marginal del barrio de promoción pública del Dorado, y su efecto sobre el ecosistema natural será analizado en el capítulo $v$ de impacto ambiental.

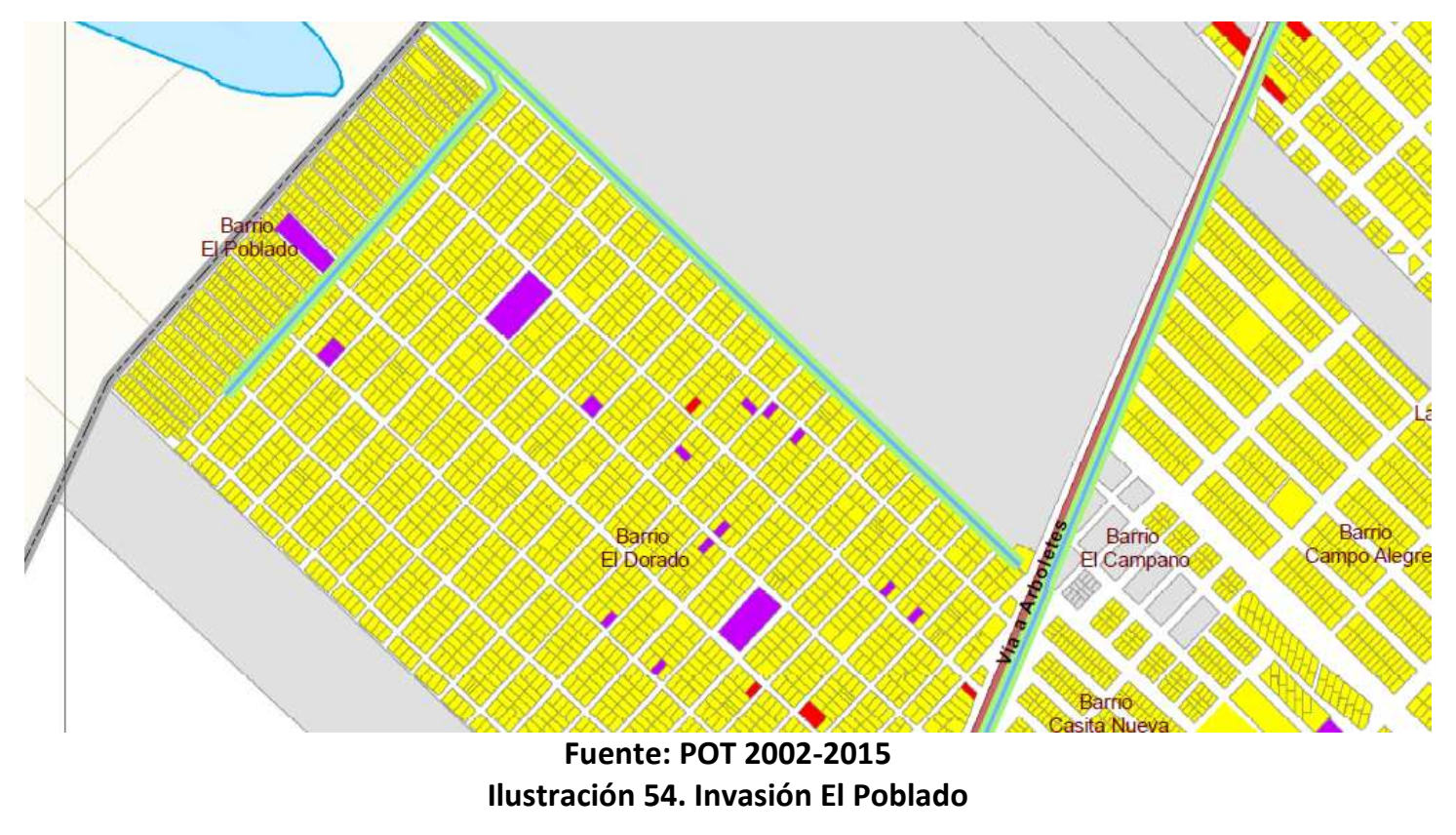

\footnotetext{
212 Texto tomado de la declaración concedida por el Alcalde Marcos Pineda García a los periodistas Barney Berrocal y Rahomir Benítez y publicado en el artículo: "Villa Jiménez, la manzana de la discordia". Diario El Meridiano de Córdoba. Agosto 6 del 2010. Pág. 5ạ
} 
El Poblado es uno de los asentamientos más precarios de la ciudad y está conformado por 550 infraviviendas construidas con diversidad de materiales como el bloque de arena, ladrillo, madera, bahareque, zinc, lata, plástico y cartón, el asbesto, el zinc, la palma y la teja plástica. El asentamiento lo conforman veinte manzanas y su disposición se realizó de manera perpendicular a la dispuesta en el barrio de promoción pública el Dorado; situación ésta, que será analizada de manera ilustrada en el apartado de impacto urbanístico.

Este asentamiento, reiteramos, se encuentra ubicado en zona inundable, pero su nombre no se incluye dentro de la lista de asentamientos del occidente que serán reubicados por parte de la alcaldía de Montería, y su consolidación es inminente, a pesar de presentar escasos avances en materia urbanística, arquitectónica, seguridad, equipamientos, espacio público, y títulos de vivienda. Este sector, actualmente, es uno de los más perjudicados por las inundaciones causadas en esta ciudad por las fuertes lluvias de los años 2010 y 2011.

Siguiendo con este recorrido, anotamos que en el sur de la ciudad se encuentra la invasión el Cerro, la más antigua de Montería $^{213}$, pero emplazada en la serranía de Sierra Chiquita, principal pulmón del entorno urbano. Las ocupaciones ilegales en esta colina comenzaron en el año 1958, con la instalación de aproximadamente una docena de infraviviendas y la apertura de varios caminos peatonales ${ }^{214}$. Esta invasión fue creciendo paulatinamente hasta consolidarse en los años 70, época en la que comienzan los primeros desplazamientos hacia esta capital.

\footnotetext{
213 Resaltamos que existen otros barrios que surgieron por procesos de invasión en la década de los cincuenta, sesenta y setenta, pero que a diferencia del Cerro, ya se encuentran consolidados en cuestiones de dominio legal y urbanístico. Estos barrios son el 14 de Julio, Brisas del Sinú, Santafé, Policarpa, San Martín, Pastrana Borrero y Policarpa Salavarrieta, y su análisis se realizará en los apartados de asentamientos informales por fraccionamientos públicos y de impacto urbanístico.

214 Pérez, Amnerys (2003): "El Cerro Quiere Volver a Respirar I". El Meridiano de Córdoba. Abril 20 de 2003. Pág. 5A. Disponible en http://www.biodiversityreporting.org/article
} 


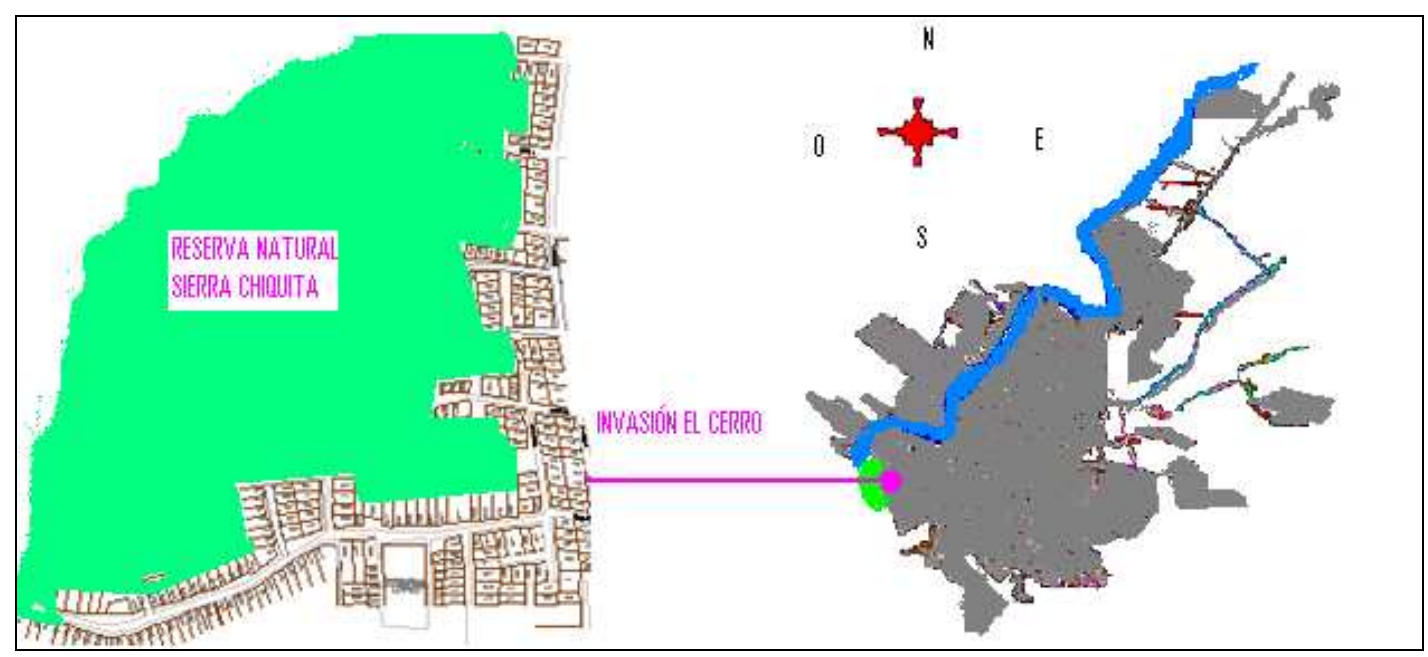

Fuente: elaboración propia

Ilustración 55. Morfología y ubicación del Cerro

La "consolidación" de esta invasión estuvo estimulada, entre otras, por la construcción de barrios de promoción pública a su alrededor y dentro de los cuales se destacan la Granja, Policarpa Salavarrieta, Santander y Pastrana Borrero. En este sentido, Negrete $^{215}$, anota que este asentamiento ha sido ocupado en varias oportunidades que corresponden a diferentes épocas; la primera transcurre desde su origen hasta el año de 1997, fecha en el que fueron reubicadas 400 familias de un total de 450 ; y la segunda época que se inicia en 1998 con la llegada de 330 nuevas familias que se sumaron a las 50 que no lograron ser realojadas, lo cual les permitió un mayor afianzamiento sobre el lugar.

Como se anotaba, en el año 1997 el Fondo de Vivienda Municipal de Montería reubicó a 400 familias en el barrio Colina Real, pero no se tomaron las medidas necesarias para evitar la invasión por parte de nuevas familias que siguieron llegando paulatinamente hasta completar nuevamente un número cercano al medio millar. De este número, doscientos diez hogares fueron realojadas posteriormente y un número similar siguen allí asentadas esperando reubicación y padeciendo con los deslizamientos que generan las continuas lluvias ${ }^{216}$.

\footnotetext{
${ }^{215}$ Negrete Barrera, Víctor (1999):Op. cit. Pág. 73

216 Martínez, Lidy \& Berrocal, Barney (2010): “El Cerro Sigue Cediendo”. El Meridiano de Córdoba. Julio 26 de 2010. Pág. 5A. Disponible en http://www.elmeridianodecordoba.com.co/
} 


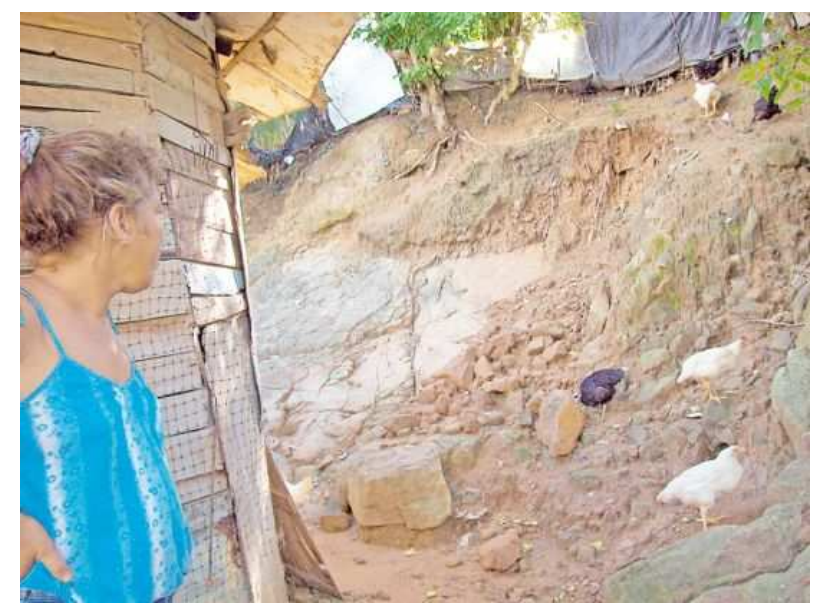

Foto: El Meridiano de Córdoba 2010

llustración 56. Riesgo de deslizamiento en el Cerro

La segunda reubicación se realizó en el año 2002 y de ella se beneficiaron 210 familias, quienes fueron reubicados en la ya mencionada invasión Villa Cielo al nororiente de la ciudad, y quedaron pendientes para ello 170 familias. No obstante, al asentamiento siguieron llegando nuevas familias y a la fecha de 2011 la actual administración tiene censadas 248 familias pendientes por reubicar y así lograr la plena recuperación de esta reserva.

Las dos reubicaciones anotadas fueron realizadas también sobre terrenos no apropiados y en el caso de Colina Real fue necesario utilizar treinta mil volquetas de balasto para rellenar un área inundable de 13.7 hectáreas adquiridas por la administración municipal y de la cual salieron 687 lotes de 98 metros cuadrados (7x14), que permitieron el realojo de 366 familias del Cerro y 321 familias de otras zonas y desplazados por la violencia ${ }^{217}$. En este par de casos se evidencia una clara institucionalización de la informalidad urbana así como gran indiferencia con los ecosistemas naturales del territorio.

En lo referente al dominio del terreno donde se ubica el Cerro, es pertinente anotar que cincuenta y una hectáreas de esta reserva forestal son reclamadas por la familia del fallecido ex-concejal de Montería, Antonio María Zumaqué Hernández, quien fue la persona que fraccionó el terreno en la década de los años setenta, y vendió los lotes

\footnotetext{
217 Negrete, Víctor y Bedoya Belia (2007): Las Peleas en Casa y el Maltrato Infantil. CEDAL-Unisinú. Montería. Pág. 9.
} 
que hoy constituyen el barrio informal Alfonso López en la falda del cerro. No se tiene evidencia de que alguien haya comprado lotes en el cerro pero algunas personas afirman haber pagado $\$ 4.000$ (\$US 50) de la época al fallecido ex-concejal ${ }^{218}$.

Sobre este mismo aspecto, Negrete ${ }^{219}$, anota que los dirigentes políticos de los partidos tradicionales de Montería promovieron, respaldaron o realizaron invasiones en diferentes partes de la ciudad y con previos acuerdos con el Instituto de Crédito Territorial (ICT) lograron construcciones, adjudicaciones y legalizaciones. Este autor destaca que uno de esos líderes fue precisamente Antonio Zumaqué, quien adquirió por compra y apropiación dichos terrenos para posteriormente venderlos subdivididos.

La superficie de los lotes del Cerro no supera los 21 metros cuadrados ( $7 \times 3$ ), y por las características del terreno no ha sido viable la instalación de redes de abastecimiento de aguas ni derivaciones clandestinas. Tampoco es viable al acceso de vehículos recolectores de basuras ni la construcción de pozos sépticos que permitan la utilización adecuada de letrinas.

Es evidente que esta invasión es una de la de mayor impacto ambiental negativo para la ciudad, razón por la cual, se propuso la reforestación como primera solución para mitigar dicho impacto y así recuperar totalmente esta reserva natural. Sobre este particular, resaltamos que en el año de 2002, el alcalde Luis Jiménez Espitia socializó una propuesta ambiental de reforestación que pretendía convertirla en un gran pulmón de oxigeno y en escenario parcial para el culto religioso ${ }^{220}$ y la recreación. Sin embargo, la propuesta no se materializaría, debido a que la inversión requerida superaba los seis millones de dólares del año en mención, y los recursos disponibles del municipio para dicho proyecto, no superaban los cuarenta mil dólares.

\footnotetext{
218 Pérez, Amnerys (2003): “El Cerro Quiere Volver a Respirar II". El Meridiano de Córdoba. Abril 27 de 2003. Pág. 5A. Disponible en http://www.biodiversityreporting.org/article.

${ }^{219}$ Negrete, Víctor (1999): Op. cit. Pág. 9.

220 Durante las décadas de los 70 y 80, la tradición católica festejaba anualmente la resurrección de Cristo. La celebración se realizaba en la cúspide del Cerro y era denominada como la Quema de Judas.
} 
Otras invasiones de gran impacto ambiental en Montería son las de tipo lineal que se presentan en las márgenes del río Sinú, orillas del canal de Cantaclaro y canal del distrito de riego del INAT. Estos asentamientos son denominados el Bongo, Nuevo Milenio, el Canal, Ranchos del INAT, Sucre y Playa Brígida, que pese a sus condiciones de insalubridad y del gran impacto que generan a los canales y a la principal fuente hídrica, aún no han podido ser desmantelados por ninguna de las administraciones municipales de los últimos treinta años.



Fuente: Elaboración propia con base en el POT 2002-2015 Ilustración 57. Invasiones Lineales en Montería 
Las invasiones del Bongo y Ranchos del INAT con treinta y cinco y veintisiete años, respectivamente son las más antiguas en el género lineal, y quizás las generadoras de mayores traumas, urbanísticos, sociales y ambientales; ya qué, en el caso de la primera, permitió la consolidación de veinte viviendas en materiales duraderos, y en la segunda, a pesar de dos reubicaciones, no se ha logrado desmantelar el asentamiento ni disminuir el número de infraviviendas.

La invasión Ranchos del INAT, se inició en el año 1985 después de una fallida ocupación a un terreno cercano a este sector, y su longitud lineal es de cuatro kilómetros sobre el borde del canal de riego del sector nororiente del distrito de riego de Montería. Los ocupantes de este asentamiento ascienden aproximadamente a mil quinientas personas que se establecen en infraviviendas de veinticuatro metros cuadrados (4x6), que se caracterizan por encontrarse en estado de instalación, con materiales transitorios como el cartón, plástico, lata y madera. La mayoría de estas infraviviendas utilizan la palma de cera como cubierta, mantienen pisos de tierra y sus baños se conectan directamente con el canal.

Los líderes más sobresalientes son Ana Díaz, José Luis Ubarnes y Elkin Padilla, los cuales gestionaron una pileta pública, dos hogares infantiles y una escuela de primaria que llegó a atender 45 niños, pero no han conseguido proyecto alguno con las instituciones municipales o con los políticos tradicionales. Las ayudas o programas les han provenido de organizaciones como Acción Contra el Hambre, Revivir y la Fundación María Cano.

En lo referente al asentamiento sobre el canal de Cantaclaro, destacamos que está conformado por 155 viviendas, donde se alojan aproximadamente unas 780 personas, quienes se encuentran expuestas a elevadas condiciones de insalubridad $y$ precariedad. Ante la imposibilidad de reubicación, estos residentes reciben atención humanitaria por parte de organizaciones no gubernamentales que los apoyan con programas de salud, capacitación y mejoramiento de la vivienda. 

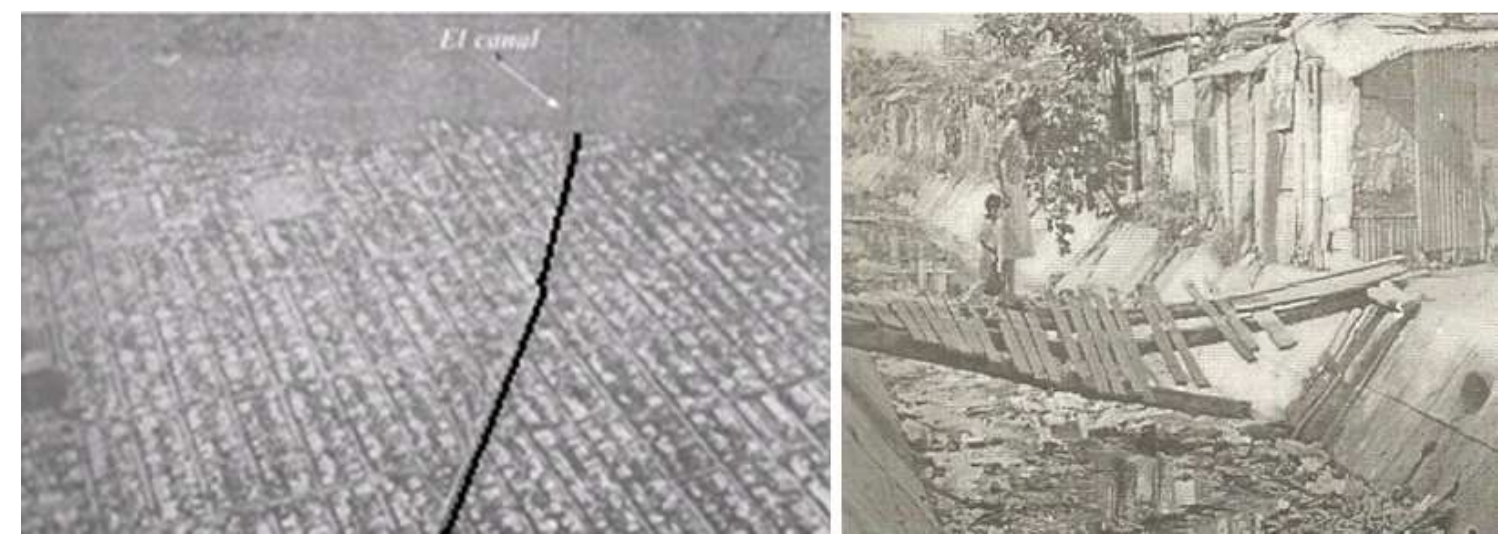

Fuente fotográfica: Víctor Negrete 1999

Ilustración 58. Invasión Canal Cantaclaro

Por su parte la invasión lineal Nuevo Milenio fue constituida paulatinamente desde 1994 a orillas del río Sinú a la altura del barrio informal Brisas del Sinú. En ella se asientan setenta familias, que llegaron de manera dispersa en igual número de infraviviendas con superficies de veinticuatro metros cuadrados (6x4), en los que predominan materiales transitorios como lata, madera burda, cartón y el zinc. La mayoría de estas infraviviendas no están subdivididas en cuartos, y sus baños se conectan directamente al Río; y al igual que las de otras invasiones, generan un gran impacto sobre la fuente hídrica, que será analizado en el apartado de impacto ambiental.

Otros asentamientos surgidos mediante procesos de invasión fueron Villa Paz, Furatena y Nueva Esperanza, que junto a las ya mencionadas Villa Cielo y Villa Jiménez, contribuyeron a calmar la gran última tensión que se presentó en esta ciudad por la vivienda, pero a expensas de la ampliación de la tugurización del sur, suroriente y oriente de la ciudad. El impacto social, económico, ecológico y urbanístico de estas invasiones será analizado con lujo de detalles en el capitulo quinto de esta investigación.

Finalizamos este análisis de los asentamientos de invasión, anotando que en el Plan de Ordenamiento Territorial 2002-2011 se programó la reubicación de las invasiones de Sucre, Playa Brígida, Ranchos del INAT, el Bongo, Nuevo Milenio, Casa Finca, Canal de Cantaclaro y el Cerro. Sin embargo, dichas reubicaciones no se han realizado a noviembre del año 2011, y los principales obstáculos que tiene el municipio, además 
de su precario presupuesto financiero, son los niveles de consolidación de algunas unidades de vivienda, el tiempo de permanencia de los invasores y la identidad de éstos con su territorio.

\subsubsection{Asentamientos informales por fraccionamientos privados}

Son denominados también como Barrios Piratas, Urbanizaciones Piratas o Fraccionamientos Clandestinos ${ }^{221}$, y corresponden a otra modalidad de la informalidad urbana que se ha establecido en el mercado de suelos. Clichevsky ${ }^{222}$, por ejemplo, manifiesta que en los mercados informales de terrenos se establecen varios mecanismos de negociación, dentro de los cuales se encuentran los Loteos Clandestinos y Loteos Irregulares.

Esta autora establece una diferenciación entre loteos irregulares y loteos clandestinos. Considera a los primeros, como los lotes que se venden sin completar todos los requisitos contemplados en la legislación vigente, y a los segundos, como aquellos que se negocian sin cumplirse requisito alguno $y$ al margen de cualquier solicitud de aprobación. "Los loteos irregulares son aquellos que fueron vendidos cuando aun les faltaba algunas de las condiciones que indica la legislación, mientas que los loteos clandestinos o "piratas" son los que nunca se han presentado ante las autoridades, para su aprobación y solo podrán ser legales a través de normas especiales" 223 . En esta investigación, y por las características del contexto y de la producción de suelos, no establecemos diferencia alguna entre estos fraccionamientos al margen de la ley, y consideramos preferible clasificarlos a todos ellos como fraccionamientos irregulares.

Este tipo de producción de suelo ha sido muy dinámico en Latinoamérica, y para su regularización ha sido necesaria la aprobación de varias legislaciones en diferentes

\footnotetext{
${ }^{221}$ Norma García destaca que estas denominaciones fueron incorporados anteriormente por autores como Duhau (1993), Echavarría (1995) y Lovera (1997). Cfr. En García, Norma (2005); Op. Cit. Disponible en http://www.ub.es/geocrit/sn/sn-218-50.htm

${ }^{222}$ Clichevsky, Nora (2003): Pobreza y Acceso al Suelo Urbano. Algunos Interrogantes sobre las Políticas de Regularización en América Latina. CEPAL. Santiago de Chile. Pág. 17.

${ }^{223}$ Clichevsky, Nora (2000): Op. Cit. Pág. 16
} 
épocas y por distintos gobiernos. Sin embargo, las leyes aprobadas en Colombia, Perú, México, Argentina, Brasil, Ecuador y Chile terminaron estimulando la creación de nuevas villas, favelas y loteos clandestinos ${ }^{224}$.

Los loteos clandestinos y los procesos de autoconstrucción, también contribuyeron a la constitución de asentamientos al margen del planeamiento urbanístico y de la normativa ambiental, sobre todo en las principales capitales de Colombia. Este proceso es denominado en el país con el nombre de "Barrio Pirata" pero en Montería no se utiliza esa acepción, sino la de "Barrio Subnormal".

Los barrios "subnormales" constituidos a partir de fraccionamientos irregulares en Montería, siguen un largo periodo de autoconstrucción, el cual es un proceso que permite satisfacer la necesidad de vivienda, pero al mismo tiempo es un generador de informalidad urbana. La autoconstrucción es un modelo importado y promovido por el Instituto de Crédito Territorial (ICT) a partir de los años cincuenta, que aún sigue vigente como política pública de vivienda en Colombia y en esta ciudad.

Sobre la experiencia de otros contextos geográficos, García Herrera ${ }^{225}$, por ejemplo, considera que la formación de la Ciudad Marginal de Santa Cruz de Tenerife, comienza con los procesos de autoconstrucción a partir de 1940, y es una respuesta a las condiciones socioeconómicas desfavorables que presentaban los demandantes de vivienda para la época. Esta autora, relaciona el fenómeno de la informalidad con tres aspectos, que denominó: 1) ausencia o insuficiencia de una política de vivienda; 2) gestión municipal permisiva, y 3) los elevados precios de la vivienda de mercado.

Los aspectos positivos que destaca esta autora, son afines a los de cualquier contexto y dentro de los que sobresalen: solución de viviendas a familias vulnerables; contribución a la demanda de mano de obra; pago del lote a plazos, y la construcción

${ }^{224}$ Ibíd. pp. 21 - 28

225 García Herrera, Luz (2005): Santa Cruz de Tenerife, la formación de la ciudad Marginal. Ediciones Idea. http://www.edicionesidea.com/aplicacion/colecciones/ver.asp?ID=28. Consultado julio 22 de 2010. 
gradual de la vivienda. Ella incorpora un nuevo concepto denominado "Viviendas de Autopromoción" para expresar que la vivienda ya no es construida directamente por el propietario, y su uso se destina para el alquiler parcial o total del inmueble.

Sobre este último concepto, o más bien fase de la autoconstrucción, conviene anotar que es una instancia dependiente de la consolidación del asentamiento, de la tipología de la vivienda, densidad de la población y de la disponibilidad de suelo. Un buen ejemplo de Vivienda de Autopromoción en Colombia es la ciudad de Bogotá, en donde la vivienda informal unifamiliar fue transformada paulatinamente por sus propietarios en multifamiliares de tres, cuatro y hasta cinco alturas.

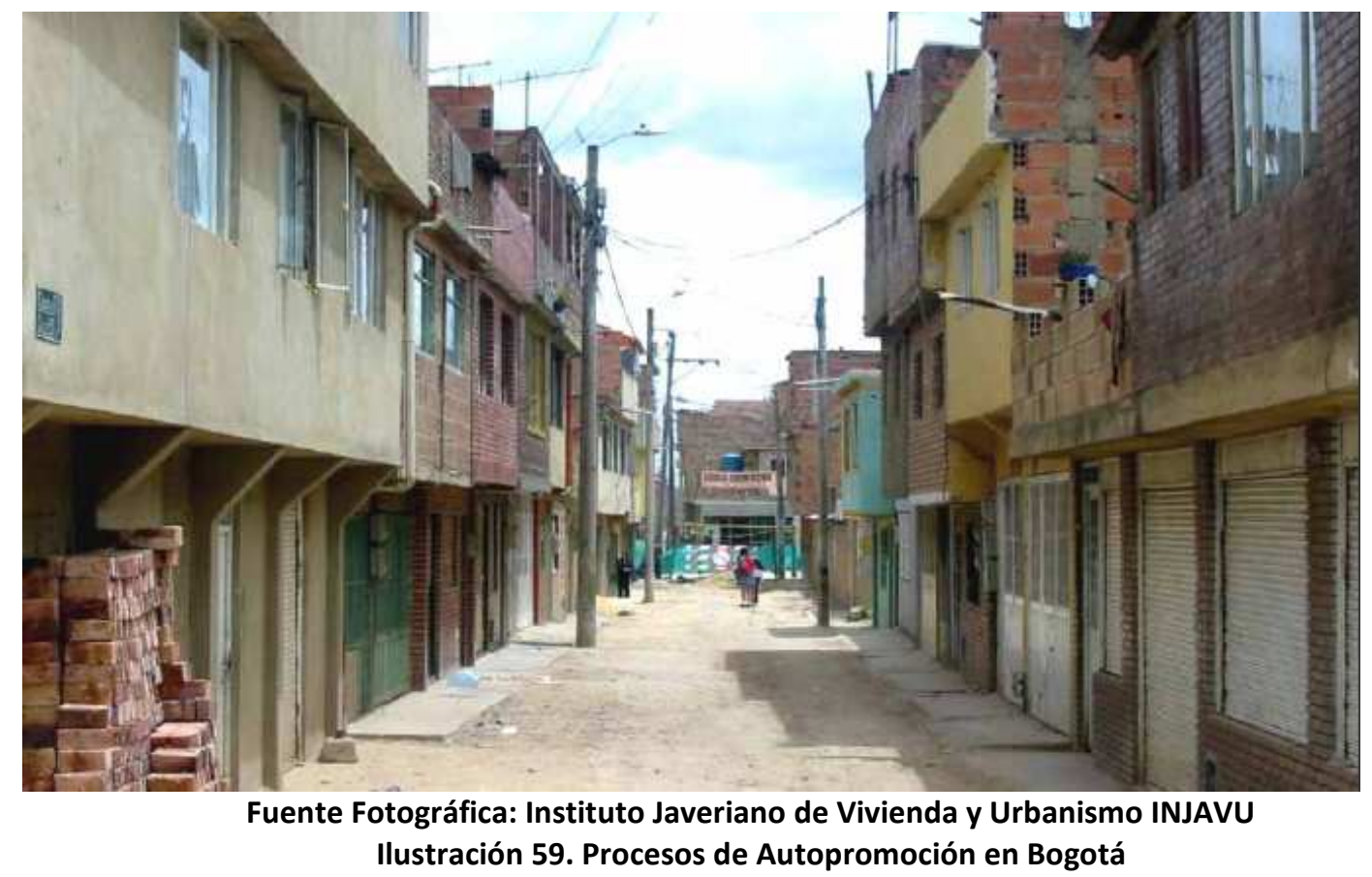

Esta vivienda de autopromoción logró su consolidación precisamente en los barrios piratas de Bogotá, pero también alcanzó a consolidarse en las comunas de Medellín, los distritos de Cali y barrios populares de Bucaramanga. Este proceso consiguió establecerse en estas ciudades a pesar de sus condiciones montañosas, pero no se incorporó a la costa Caribe ni a la ciudad de Montería, debido a su mayor disponibilidad de suelos y al menor tamaño de población.

El fenómeno de urbanización pirata en Colombia data de los años cincuenta y su evolución se asocia a factores endógenos o exógenos relacionados directamente con la 
vivienda. En este sentido, González Zapata ${ }^{226}$, destaca varios momentos y necesidades que inciden en la producción de éstas y con los cuales nos identificamos: un primer momento, en donde, la preocupación del Estado era por la sanidad y el crecimiento ordenado, "acorde con los preceptos de la carta de Atenas"; un segundo momento en el que la preocupación es por la oferta de vivienda obrera, y un tercer momento, asociado a la escasez y calidad de esa vivienda obrera.

Según esta autora, y con ello también estamos de acuerdo, es en el segundo momento, el periodo en el que el Estado, ante la incapacidad de atender toda la demanda de vivienda, permite la aparición de los urbanizadores piratas, quienes se preocupan más, por la cantidad ofrecida, que por la calidad de la vivienda. Esta situación se mantuvo en el tiempo y actualmente contribuye proporcionalmente a la precariedad habitacional y a la informalidad urbana de las ciudades colombianas.

Para contener la arremetida de este tipo de urbanizadores el Estado Colombiano recurrió a Ley 66 de 1968, por medio de la cual se regulan las actividades de urbanización, construcción y crédito para la adquisición de viviendas y se determina su inspección y vigilancia. Esta Ley fue aprobada por el Congreso de Colombia el 26 de diciembre de ese mismo año con el objetivo de frenar los asentamientos ilegales y los conflictos que éstos generaban.

Mediante esta ley, el Superintendente Bancario sería la autoridad encargada de aprobar las solicitudes orientadas a desarrollar planes de vivienda y programas de urbanización ${ }^{227}$. Esta ley determinaría igualmente que, la resolución de aprobación del superintendente debería ser registrada en el libro primero de la oficina de Registro de Instrumentos Públicos y Privados, así como la protocolización en Notaría Pública.

\footnotetext{
226 González Zapata, Gloria (2009): Gestión de los Asentamientos Informales: Un Asunto de Política Pública. Universidad Nacional de Colombia. Medellín. pág. 62

227 Entiéndase por plan o programa la adecuación de terrenos para la construcción de viviendas o la edificación de las mismas, cuando las unidades proyectadas sean cinco o más. (Ley 66:Art. 2)
} 
En el caso de los propietarios o interesados en desarrollar proyectos, la ley los obligaba a urbanizar los terrenos y a dotarlos de los servicios públicos básicos, pero el artículo 10 les dejó abierta la posibilidad de transmitirlas a terceros o a descargarlas a los adquirientes. Este artículo establece que "La obligación de ejecutar las obras de urbanismos y de dotar a los inmuebles que se enajenen o prometan enajenar de los servicios públicos exigidos por las autoridades distritales o municipales en los planes o programas a que se refiere la presente Ley, no podrá descargarse en los adquirientes o transmitirse a terceros, salvo cuando se trate de contratos celebrados con otra persona dedicada a la misma actividad y ambos se hallen inscritos ante el Superintendente Bancario, en los términos del artículo 3 de esta Ley o cuando se trate de enajenar el terreno en bruto como un todo y no como parte de un plan de urbanización". Esta ventana fue aprovechada por los negociantes de proyectos de viviendas, los cuales se adaptaron cómodamente a una norma inocua e incapaz de reducir la acometida de fraccionamientos clandestinos y asentamientos informales.

Esta Ley, ni fue efectiva para contener la proliferación de desarrollos informales, ni tampoco contribuyó a frenar la invasión del patrimonio ecológico en las ciudades. Incorporó conceptos como: salubridad de las obras, viviendas con fácil acceso, y zonas urbanizables con adecuada comunicación, pero no definió criterios ambientales que delimitaran estos conceptos, y que evitaran la apropiación por cualquier vía, de zonas de gran riqueza ambiental.

Después de hacer las anteriores anotaciones y retomando el contexto de Montería en lo relacionado con asentamientos constituidos por fraccionamientos irregulares, es conveniente anotar que dicha Ley fue ignorada dentro del proceso de construcción de barrios a partir de la década del sesenta, dentro de los cuales sobresalen los barrios: Alfonso López, Los Araujos, y la Esperanza.

Sin embargo, la década de los años ochenta es el periodo más dinámico que tiene la construcción de vivienda en esta ciudad, como consecuencia de los proyectos que se ejecutaban dentro del programa de viviendas públicas sin cuota inicial del presidente Belisario Betancur Cuartas durante el periodo 1982 - 1986. En este periodo, como ya se anotó anteriormente, se construyen en el sur los barrios Mogambo, Villa Margarita 
y Panzenú, que estimularon el surgimiento de fraccionamientos privados irregulares en ese mismo sector.

Estos fraccioamentos irregulares son el Seis de Marzo, Edmundo López, Mogambito, urbanización el Alivio, Vereda Tropical, los Nogales, Santa Isabel, Damasco, San Cristobal, Villa Arleth, los Alpes, las Américas, Vereda Tropical, el Paraiso, Primero de Mayo y Nueva Galilea. Ninguno de estos asentamientos, después treinta años, ha logrado optimas condiciones urbanisticas, e incluso, algunos como Mogambito, Edmundo López y Primero de Mayo, siguen presentando altos niveles de precariedad en la vivienda.

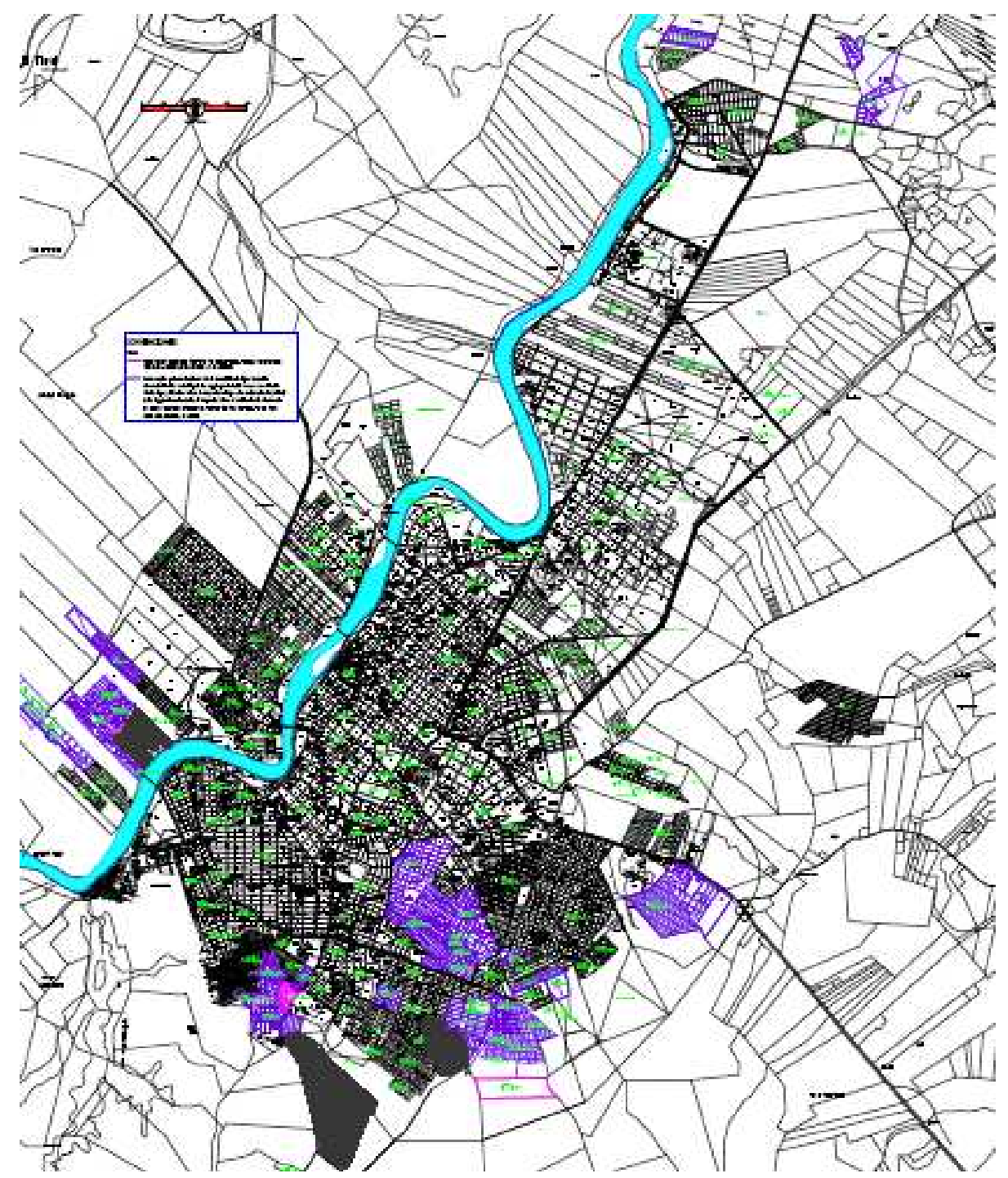

BARRIOS POR FRACCIONAMIENTOS IRREGULARES

Fuente: plano elaborado por Elkin Herrera y Jhon Pinedo 2011 Ilustración 60. Barrios por fraccionamientos privados irregulares 
Otros asentamientos surgidos por esta modalidad en otros sectores son Altos de California (Dulce Hogar), Villa Caribe, Caribe, el Níspero, la Palma, Mi Ranchito, la Vid, Villa Nazaret, los Ebanos, Villa Karime, Vista Hermosa, Villa Ana, Villa Mery, Villa Arleth, Paz del Norte, Palma Verde, el Ceibal y la Campiña. Éstos, al igual que los mencionados Alfonso López, Araujos y la Esperanza siguen en este siglo XXI con altos niveles de informalidad urbanistica y arquitectonica, y lo más preocupante de todo es que su desarrollo avanza demasiado lento y por ahora no se vislumbra su consolidación.

\subsubsection{Asentamientos Informales por fraccionamientos públicos ${ }^{228}$.}

Ya anotamos a comienzos de este apartado que los fraccionamientos públicos para viviendas de autoconstrucción en esta ciudad se inician como programas complementarios del Instituto de Crédito Territorial, ante la incapacidad financiera para construir viviendas públicas terminadas. Igualmente se anotó que estos primeros fraccionamientos se realizaron en la década de los años sesenta en el sur, aprovechando las dotaciones e infraestructura de los barrios del P-5 y de la Granja.

Reiteramos, que estos asentamientos a pesar de la formalidad jurídica en el dominio del terreno, presentan altos niveles de informalidad urbanística y arquitectónica, esencialmente en cuanto a infraestructuras colectivas y a normas de construcción de la vivienda individual o de los equipamientos comunitarios. Sin embargo, algunos de estos fraccionamientos ya se encuentran en la etapa de consolidación a pesar de seguir presentando deficiencias urbanísticas y arquitectónicas en sus viviendas.

\footnotetext{
228 Bahr y Mertins dividen los barrios informales de acuerdo con su estatus jurídico en: barrios marginales ilegales (invasión); semilegales (piratas), y legales (tugurios legales), éstos últimos con patrocinio estatal. Bahr, Jurgen y Mertins, Gunter (1984): Un modelo de la diferenciación socio-espacial de la metrópolis de América Latina. En Torres, Carlos Alberto (2009): Op. Cit. Pág. 47. Por su parte Jorge Lombardi establece dos tipos de informalidad: involuntaria y voluntaria; la primera la define como aquella que los individuos deben resignarse a aceptar por su extremada condición de pobreza, y la segunda es la producida por quienes pudiendo asumir los costos de la formalidad no lo hacen, y un claro ejemplo enunciado por él, son los barrios cerrados. Lombardi, Jorge (2001). "Autogestión y participación en la ciudad informal". En: Piñón, Juan Luis (coord.) La recomposición de la ciudad informal. Valencia: Congreso Internacional Ciudad Informal. Universidad Politécnica de Valencia. Valencia, España.
} 
No hay la menor duda de que los fraccionamientos públicos en Colombia, surgieron como alternativa ${ }^{229}$, ante la incapacidad presupuestal que presentaba el ICT para atender con proyectos de vivienda pública terminada la demanda real de la población. Esta limitación presupuestal permitiría al Estado aprovechar los terrenos aledaños a los proyectos de vivienda pública, para fraccionarlos y entregarlos en la modalidad denominada Lotes con Servicios.

Como ya anotábamos, después de culminados los proyectos de los barrios la Granja y $\mathrm{P}-5$, se inician los primeros fraccionamientos públicos de lotes en el sur de la ciudad, y los primeros asentamientos constituidos bajo esta modalidad fueron: el Prado y Boston en el año 1965, y, San Martín, Pastrana Borrero, Policarpa Salavarrieta, Santafé y Santander, a partir de 1969. Los dos primeros aprovecharon las dotaciones e infraestructura del P-5, mientras que los otros seis aprovecharon las redes instaladas en el barrio la Granja.

\footnotetext{
${ }^{229}$ Sin embargo, autores como Fernando Viviescas manifiestan que la autoconstrucción no es implementada como una alternativa para construir y recrear un hábitat sino impuesta como la única salida que le queda a la mayoría de la población colombiana para levantarse un refugio. Viviescas Monsalve, Fernando et al. (1989): La calidad espacial urbana de los barrios para sectores de bajos ingresos en Medellín: en Torres, Carlos Alberto (2009): Op. Cit. Pág. 45.
} 




Los lotes individuales del Prado y Boston fueron asignados gratuitamente a sus beneficiarios a partir del año 1965 en el sur de la ciudad, y la superficie de cada lote correspondió a 162 metros cuadrados $(9 \times 18)$. Los dos sectores fueron dotados de los servicios básicos de agua potable y energía eléctrica pero sin alcantarillado ni redes telefónicas, y sus emplazamientos estuvieron determinados por la infraestructura del proyecto de vivienda del barrio P-5, entregado un par de años antes por el ICT.

En estos dos primeros fraccionamientos públicos se entregaron 255 lotes a igual número de familias beneficiarias, quienes debieron asumir totalmente los costos de construcción de la vivienda a partir de la entrega del respectivo lote. En el barrio el Prado se asignaron 150 lotes y en El Boston 105, los cuales se convirtieron en el punto de partida de los procesos masivos de autoconstrucción o de desarrollo progresivo en Montería. 
La planeación aquí jugó un papel importante y los equipamientos colectivos del barrio P-5 permitirían posteriormente integrar y atender las necesidades colectivas de la población de los fraccionamientos públicos del Prado y Boston. Sin embargo, al fraccionamiento del Prado se le asignaron reservas de suelos importantes para espacio público, que posteriormente fueron aprovechadas para construir un parque de pequeña escala y una escuela de primaria con capacidad para cien alumnos; en cambio para el barrio Boston, se asignó una superficie de apenas 324 metros cuadrados $(9 \mathrm{x}$ 36) en donde se construyó una escuela de primaria, que posteriormente dejo de funcionar y sus instalaciones fueron invadidas por una familia que aún permanece allí.

En lo referente a los fraccionamientos públicos surgidos a partir del proyecto del barrio la Granja, destacamos que permitieron la entrega de 3.167 lotes de 162 metros cuadrados $(9 \times 18)$, ante la presión ejercida por las familias no beneficiarias de los proyectos de vivienda terminada, quienes comenzaron a invadir espacios públicos de los proyectos mencionados, e incluso, terrenos correspondientes a los nuevos fraccionamientos de San Martin, Policarpa Salavarrieta, Santafé, Pastrana Borrero y Santander.

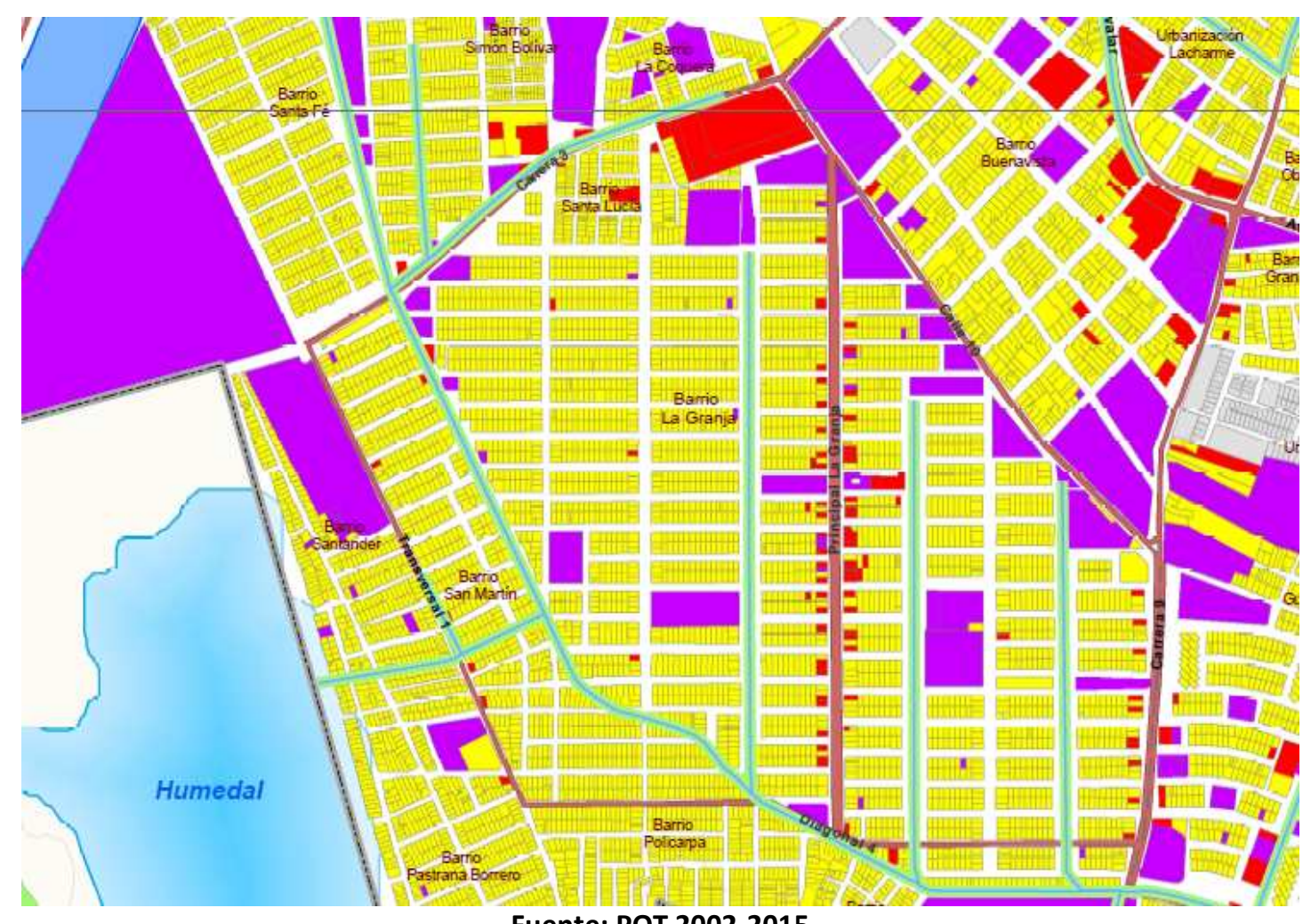

Fuente: POT 2002-2015

Ilustración 62. Fraccionamientos Públicos Policarpa, Santafé, Santander, San Martín y Pastrana B. 
Estos fraccionamientos se realizarían sobre una superficie cercana a las noventa hectáreas, superior a las 82 hectáreas donde se desarrolló el barrio de la Granja, pero insuficientes, ya que nuevamente surgió otra invasión entre el río Sinú y el barrio Santafé, con 487 lotes que fue denominada Brisas del Sinú. Esta invasión sería legalizada posteriormente por el Instituto de Crédito Territorial, e incluso, en dichos lotes se construyeron 120 viviendas públicas, que favorecieron a igual número de familias invasoras; es decir, una combinación de invasión, con fraccionamiento público y programa de vivienda terminada, razón por la cual, la clasificamos en esta categoría.

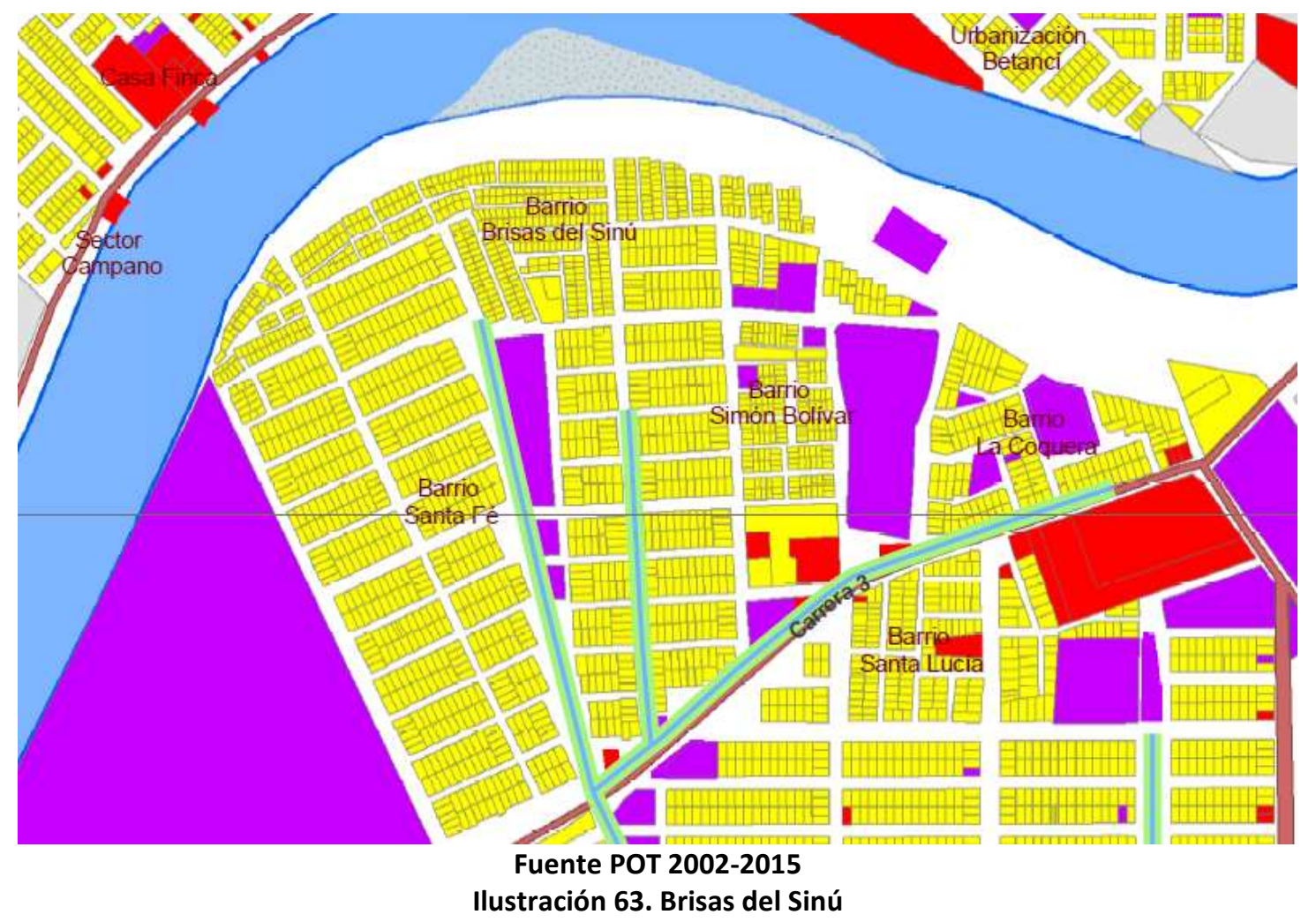

El barrio la Granja como gran proyecto de vivienda pública terminada $(2.300$ viviendas), quedó muy bien dotado de equipamientos, principalmente educativos, y a diferencia del P-5, no contó con espacios para equipamientos deportivos. Sin embargo, esta situación facilitaría posteriormente el acceso de los jóvenes de los barrios Policarpa y San Martín a los colegios Cecilia Lleras, Santander, Policarpa y Antonia Santos, todos ellos ubicados en el barrio en mención. En este aspecto debemos destacar que en estos dos fraccionamientos públicos no se reservó suelo para equipamiento alguno. 
En cambio en los fraccionamientos de Santander y Pastrana Borrero se reservaron suelos donde posteriormente se construyeron el colegio Normal de Varones y el Mercedes Abrego, respectivamente. No se destinó más suelo para equipamientos deportivos ni para recreativos, pero se destaca un equipamiento de alto impacto urbanístico, al lado del barrio Santafé, correspondiente a la decimoprimera brigada del ejército, que a su vez, se convierte en el límite del perímetro urbano por ese sector de la ciudad.

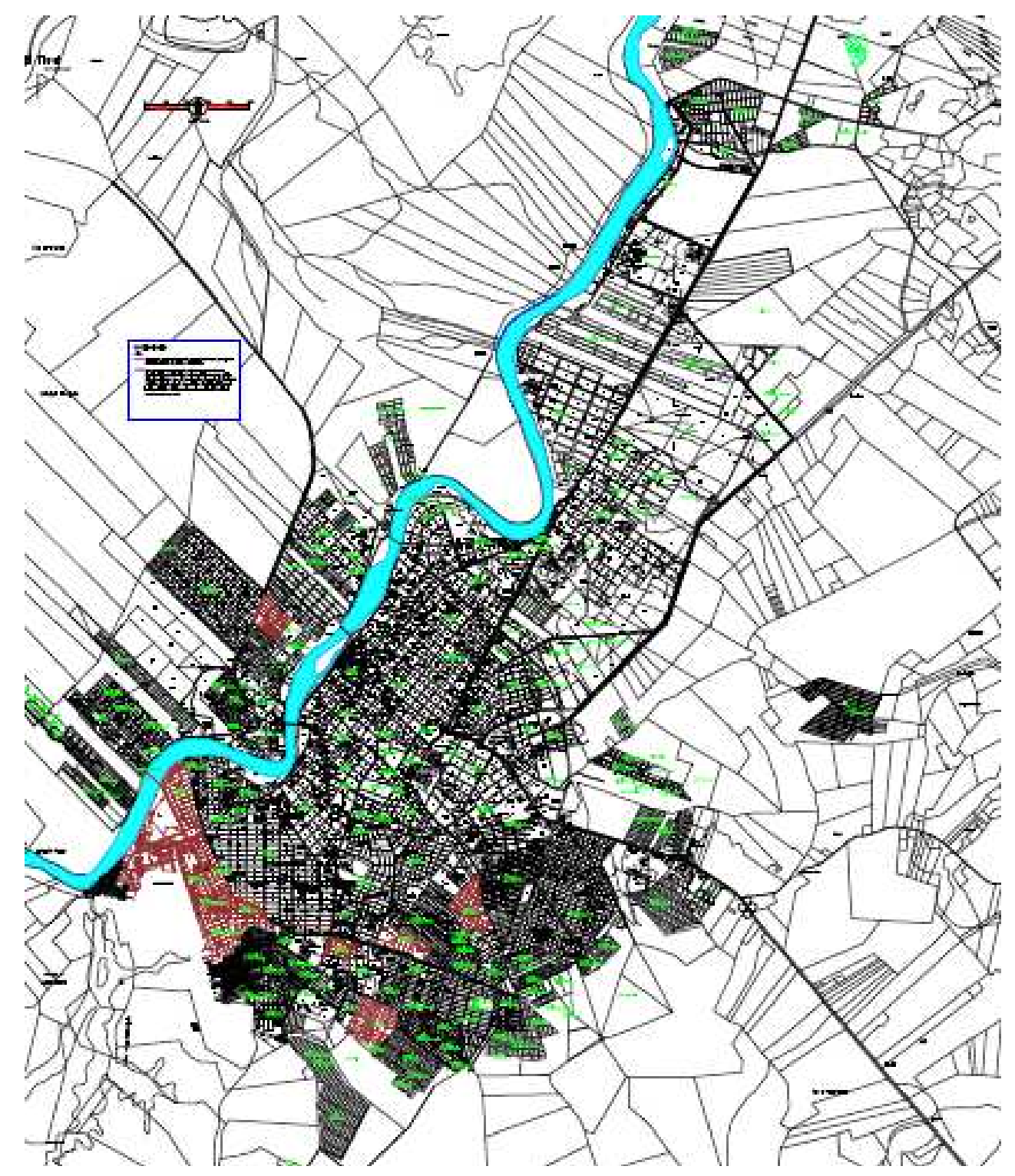

BARRIOS POR FRACCIONANIENTOS PÚBLICOS

Fuente: plano elaborado por Elkin Herrera y Jhon Pinedo 2011 Ilustración 64. Barrios por fraccionamientos públicos 
Como se anotó con anterioridad, tanto los fraccionamientos públicos de los años sesenta como los de los setenta, ya se encuentran consolidados desde el punto de vista jurídico, pero sus condiciones urbano-ambientales siguen siendo deficientes, debido a la falta de espacio público, alumbrado eficiente, calidad arquitectónica de las viviendas, del estado precario de sus vías, existencia de alcantarillas a cielo abierto, deficiencias del transporte público, exceso de ruido generado por equipos de sonido que utilizan los sitios expendedores de licores y los niveles de inseguridad que padecen los habitantes de varios sectores de esos barrios. No obstante, resaltamos que por esta misma modalidad posteriormente surgieron Casita Nueva, los Colores, Colina Real y el Alivio, que aún se encuentran en estado de semiconsolidación, e incluso, algunos sectores reflejan altos niveles de precariedad.

\subsubsection{Asentamientos Precarios}

Por asentamientos precarios, se califica desde esta investigación, a aquellos cuya totalidad de viviendas, o gran parte de ellas, aún permanecen en estado transitorio o en condiciones físico-ambientales degradantes. Se caracterizan además, por carecer de todos o algunos de los servicios básicos, así como de equipamientos colectivos o espacios para su edificación en el futuro.

Es una categoría que corresponde específicamente a los primeros años de las invasiones o de loteos irregulares o públicos. El periodo de permanencia en esta categoría se encuentra sujeto a diferentes variables como: el contexto geográfico, desarrollo socio-económico del municipio, ingresos fiscales, condiciones topográficas, nivel de organización de la comunidad, grado de escolaridad de la población y los escrúpulos inherentes a los políticos que controlan el proceso. 


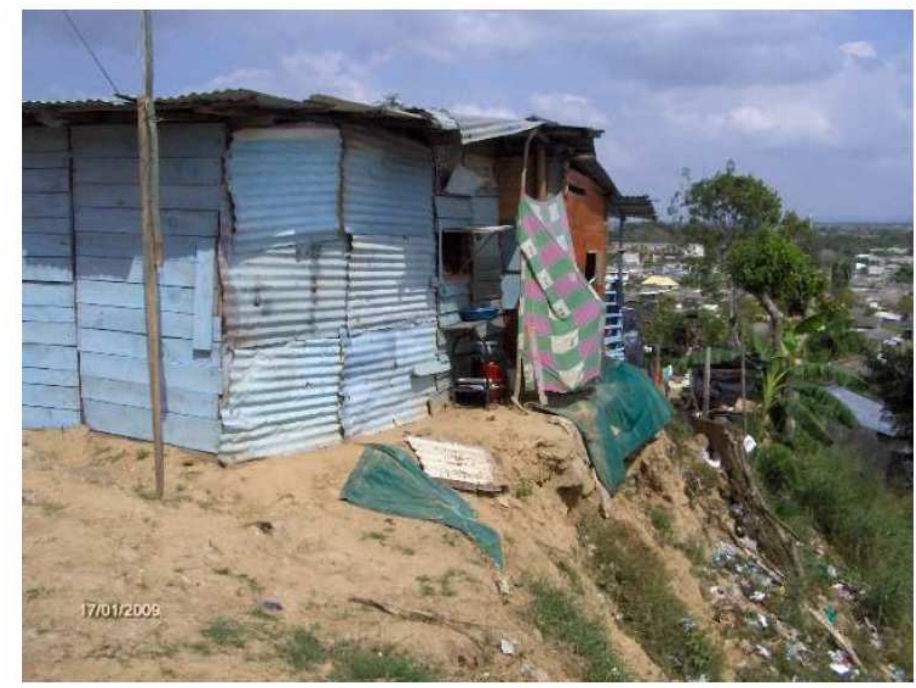

Fuente Fotográfica: POT 2002-2015

Ilustración 65. Infraviviendas en la invasión el cerro

En un asentamiento precario el alojamiento se encuentra conformado inicialmente por "edificaciones" donde predominan materiales de desecho como cartón, plástico, chapa y madera. El suministro de los servicios públicos es clandestino y se obtiene de manera colectiva a través de depósitos o albercas comunitarias, así como por medio de redes eléctricas provisionales, que son instaladas de forma desordenada y peligrosa para la población.

Las únicas dotaciones públicas de las que disponen son las vías, las cuales generalmente son caminos intransitables para el tráfico automotor. No disponen de espacios colectivos, plazas, o equipamientos, pero aparentemente si cuentan con los espacios para su construcción. Carecen de sanitarios, servicio de transporte colectivo y alumbrado público.

Las primeras construcciones con materiales duraderos comienzan tímidamente después del primer año, al igual que las primeras actividades comerciales, como tiendas, ferretería, panadería y construcción de bloques. Este ambiente empieza a contagiarse gradualmente hasta transformar físicamente las condiciones del barrio a la categoría de asentamiento semi-consolidado.

En el caso de Montería, los asentamientos precarios se mantienen en esta categoría durante periodos de hasta diez años y en algunas circunstancias esta condición la mantienen por espacios que ascienden a los veinte años. Sin embargo, desde esta 
investigación consideramos que un asentamiento mantiene dicha categoría, cuando más del $50 \%$ de sus viviendas permanecen con materiales transitorios, o se encuentran arquitectónicamente inacabadas; las redes de energía siguen representando peligro; el sistema de acueducto es ineficiente, los equipamientos son transitorios, y el alcantarillado es a cielo abierto.
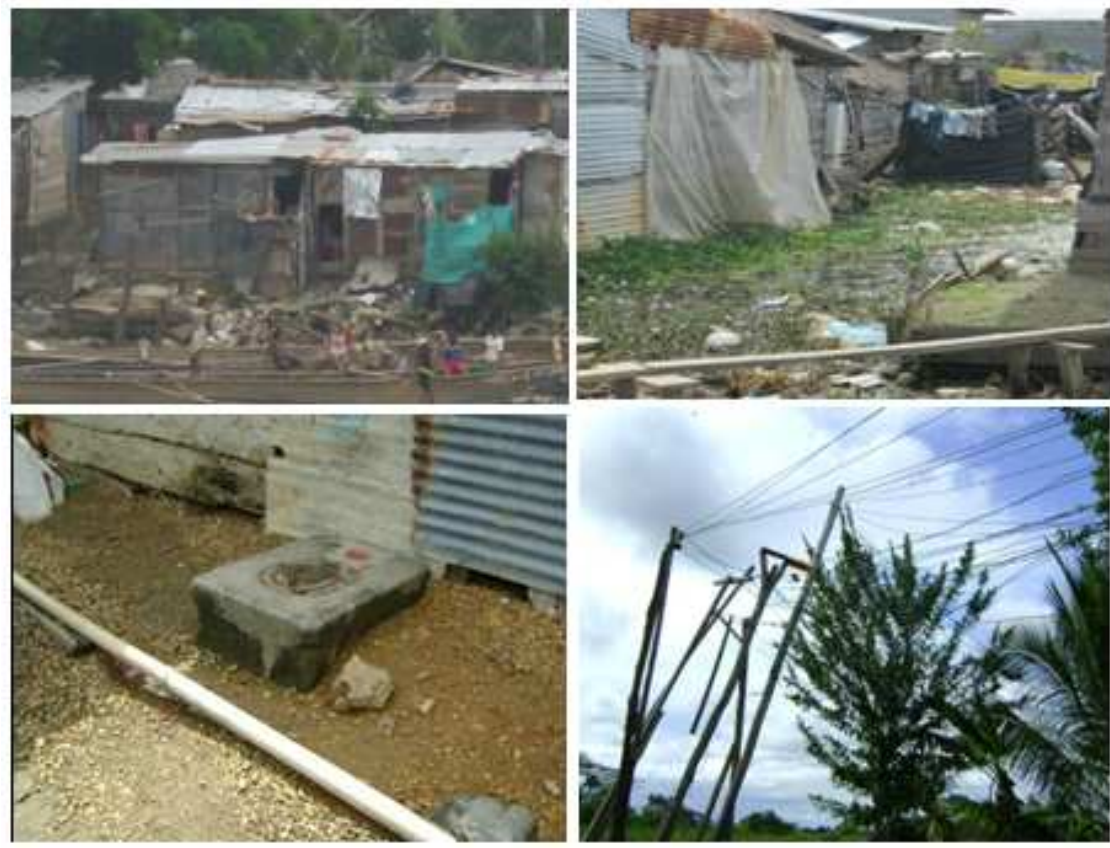

Fotografías: Hernando Pérez 2010

llustración 66. Asentamientos Nuevo Milenio - Villa Jiménez - El Poblado

Las condiciones físicas, los materiales constructivos de las viviendas, las improvisadas redes eléctricas, el estado de las vías, las alcantarillas a cielo abierto y los basureros satélites de estos asentamientos, generan un impacto negativo sobre el ambiente, el cual se traduce en malos olores, presencia de roedores, estancamiento de aguas putrefactas, deterioro de la salud pública y modificación desfavorable del paisaje natural.

Los asentamientos precarios que esta investigación identificó en la ciudad de Montería, se caracterizan por la heterogeneidad, generada por variables como la antigüedad, estado de las vías, equipamientos, calidad de los servicios básicos, transporte público, saneamiento básico, disposición de residuos, vocación inicial del suelo, arborización, alumbrado público y ruido. 


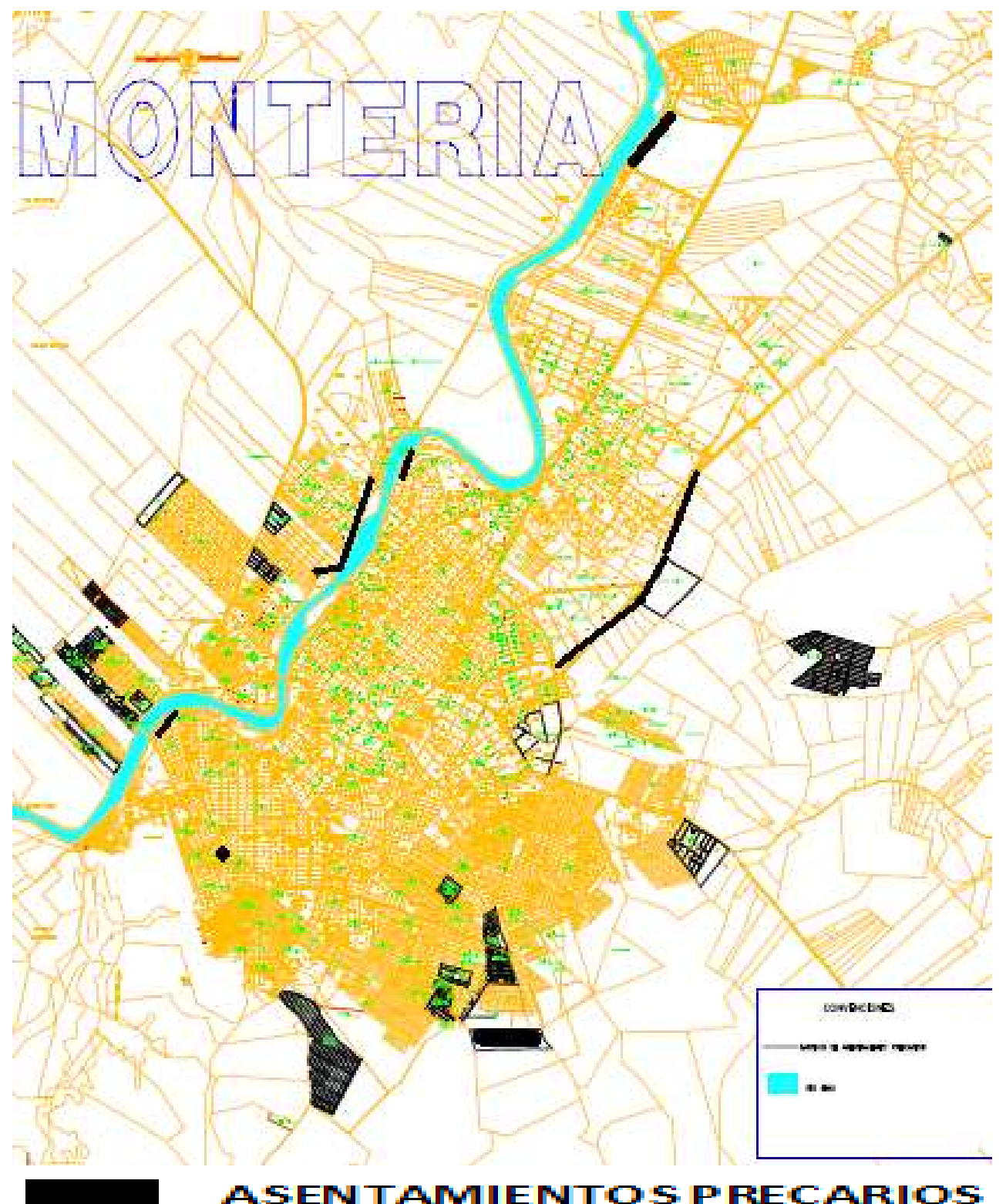

Fuente: plano elaborado por Elkin Herrera y Jhon Pinedo 2011 Ilustración 67. Asentamientos Precarios

En esta categoría clasifican asentamientos constituidos por medio de invasiones, loteos públicos o loteos irregulares, ya sea en zonas aptas para uso residencial o en zonas de alto riesgo para el medio ambiente o para las personas. Dentro de los asentamientos identificados aparecen algunos que por razones del planeamiento o por consideraciones medioambientales, se encuentran programados para reubicación desde el año 2002, pero que sin embargo clasifican dentro de la categoría de precarios.

Estos asentamientos son Villa Paz, Furatena, el Enjambre, Villa Jiménez, el Bongo, el Cerro, el Campano, Paz del Río, Nuevo Milenio, Villa Nazaret, la Bonga, Nueva 
Esperanza, el Ébano, la Vid, el Níspero, el Poblado, los Colores, Ranchos del INAT, la Palma, Santa Isabel, el Paraíso, los Alpes, Santa Rosa, la Candelaria, Casa Finca, 25 de Agosto, Caribe, Vereda Tropical, Mi Ranchito, Villa Cielo, Damasco, San Cristóbal, Villa Rocío, 7 de Mayo, Casita Nueva y Altos de California.
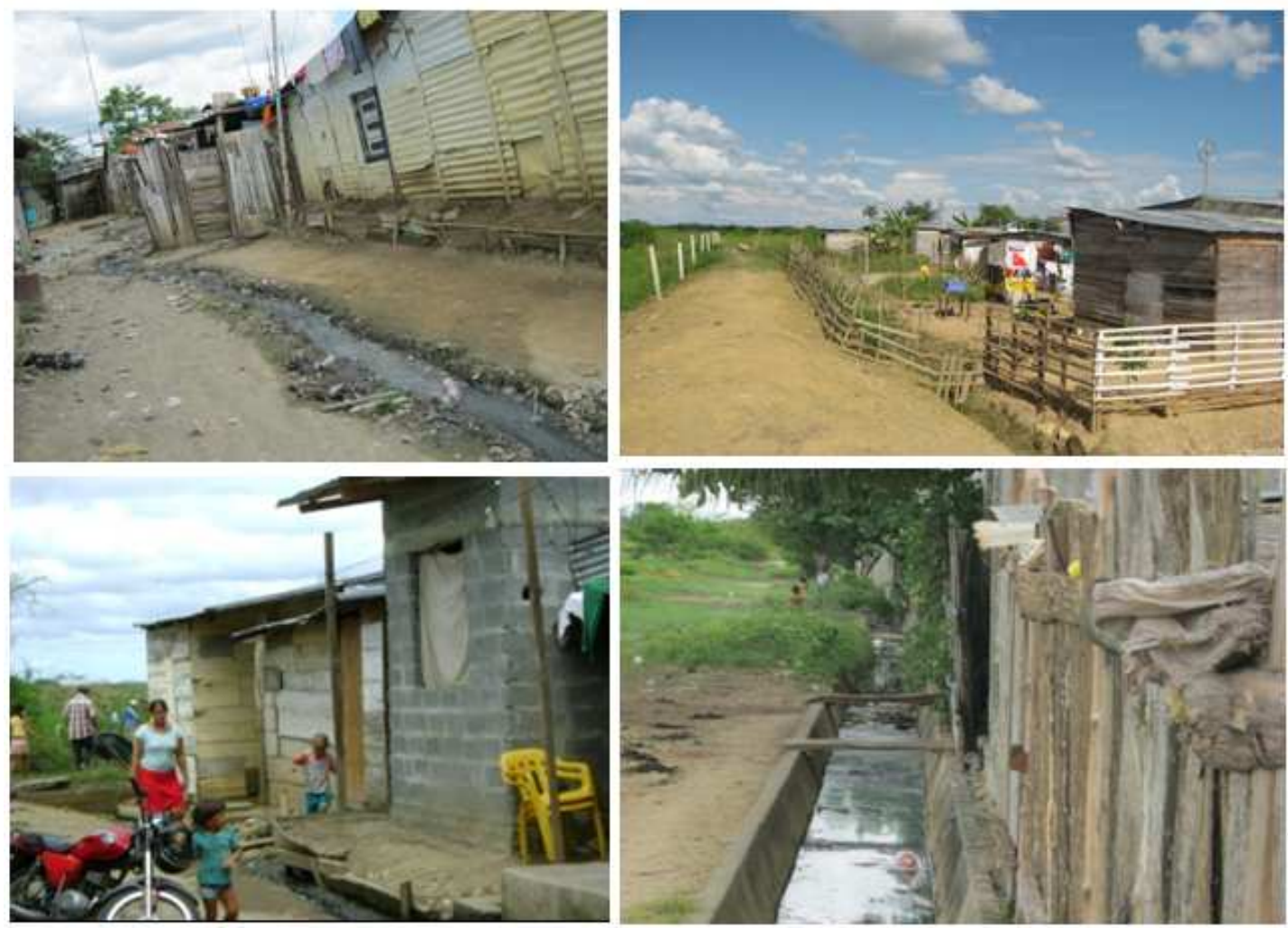

Fotgrafías Hernando Pérez 2010

Ilustración 68. Asentamientos La Vid y El Níspero

Finalmente, destacamos que la constitución de la mayoría de ellos no supera los diez años, pero sin embargo, asentamientos como el Cerro y Ranchos del INAT, fueron constituidos hace más de veinte años por medio de invasiones a zonas de alto riesgo ambiental. Esta situación no ha permitido la evolución de la vivienda ni del asentamiento como conjunto, pero si el relevo entre diferentes propietarios, que algunas veces no logran obtener el dominio de la vivienda en ese lugar sino el derecho a una reubicación. 


\subsubsection{Asentamientos Semi-consolidados}

Clasifican dentro de esta categoría los asentamientos que presentan algunas intervenciones de tipo urbanístico, dotacional, así como la finalización arquitectónica de más del $50 \%$ de las viviendas que lo conforman. El periodo de tiempo que se requiere para acceder a esta categoría también depende del contexto nacional y de las condiciones socioeconómicas de cada región, pero para el caso de Montería dicho periodo oscila entre diez y veinte años, e inclusive en situaciones específicas se ha extendido a treinta años.
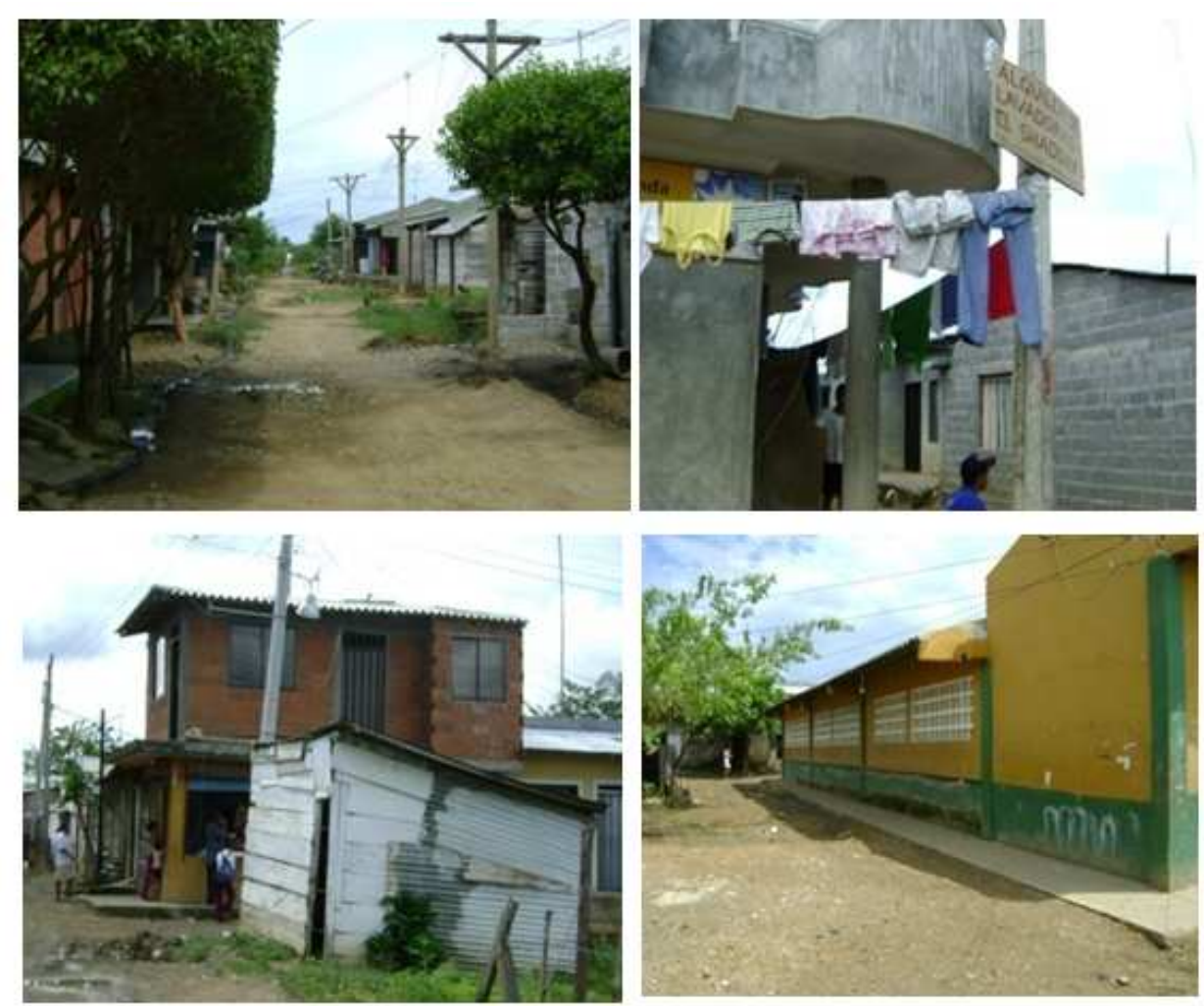

Fotografía Hernando Pérez 2010

Ilustración 69. Asentamiento Semiconsolidado

Estos asentamientos se encuentran conformados por viviendas heterogéneas que se caracterizan por haber incorporado materiales constructivos duraderos y por la edificación parcial de equipamientos básicos. La heterogeneidad mencionada se manifiesta en la coexistencia de viviendas acabadas, inacabadas y precarias, representando estos dos últimos grupos el número más significativo dentro del asentamiento. 
Los asentamientos semi-consolidados cuentan con equipamientos educativos, de bienestar social, así como con canchas deportivas multifuncionales que permiten la recreación o el deporte de los diferentes grupos de población. Estos equipamientos son construidos progresivamente, aunque por lo general comienzan su funcionamiento en condiciones físicas inconclusas o carentes de las principales dotaciones, mobiliario y/o equipos.

En esta fase comienza la instalación o ampliación de redes de infraestructura básica de agua potable y energía, e igualmente se inicia la prestación del servicio colectivo de transporte, así como la adecuación de vías primarias por medio de concreto o de asfalto. La calidad de estos servicios está determinada por la ubicación del asentamiento y por el tamaño de la población; sin embargo, la prestación de éstos se caracteriza por su baja calidad.

Esta baja calidad en la prestación de los servicios básicos es corroborada por medio de indicadores establecidos en esta investigación y dentro de los cuales se encuentran: número de vehículos, frecuencia de salida de vehículos, modelo de los vehículos, frecuencia de recogida de residuos, interrupciones en el fluido eléctrico, interrupciones en el suministro de agua, estado de las redes eléctricas aéreas, y alumbrado público.
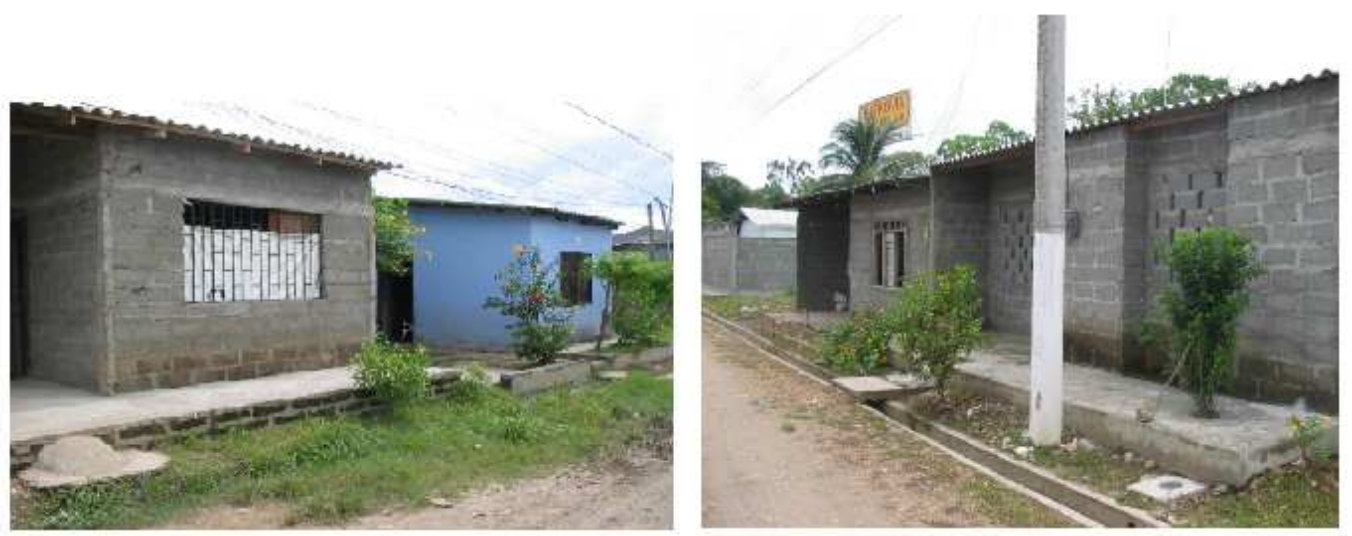

Fuente fotográfica: Alcaldía de Montería 2010 Ilustración 70. Asentamiento Semiconsolidado

En esta fase, aún se mantienen ocupantes que no cuentan con el dominio legal de la vivienda pero se encuentran en ese proceso o mantienen documentos parciales de 
compraventa. No obstante, se establecen relaciones mercantiles como la venta o alquiler de la vivienda, ya sea de forma parcial o total, mediante acuerdos o nuevos documentos de compraventa autenticados en notaría.

Es en esta etapa donde los propietarios de las viviendas comienzan a apropiarse del escaso espacio público del que se dispone, lo cual se ve reflejado en la construcción de corredores o terrazas fuera del paramento, reduciendo hasta tres metros la superficie de la vía, afectando e imposibilitando en el presente la construcción del andén para peatones. Sin embargo, la situación pasa desapercibida para las autoridades y la comunidad debido a la ausencia de transporte público colectivo en estos primeros años.
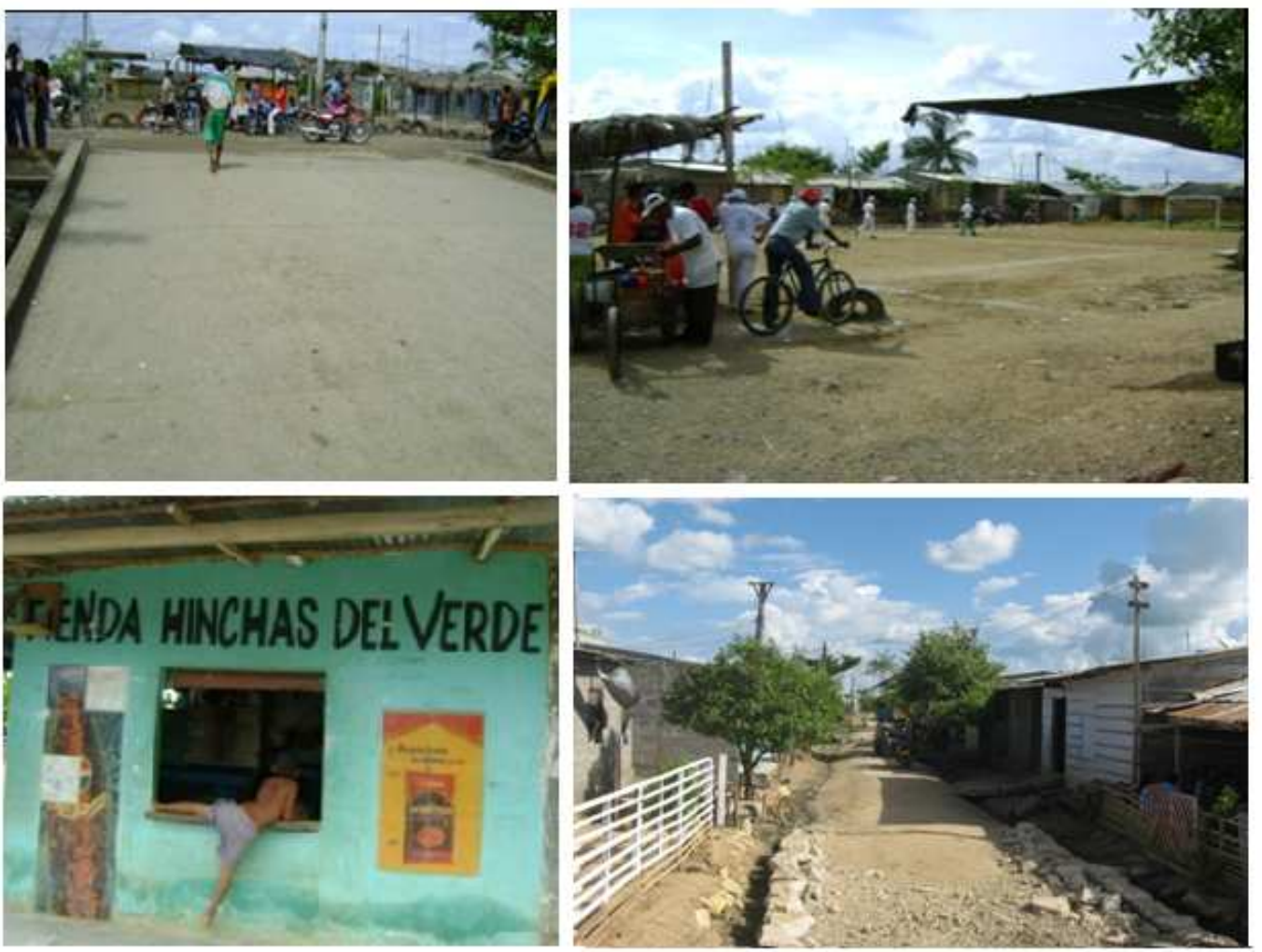

Fotografías: Hernando Pérez 2010

Ilustración 71. Inicio de dotaciones públicas - vía de acceso -cancha deportiva

Dentro de esta categoría de asentamientos se encuentran Cantaclaro, Robinson Pitalúa, Rancho Grande, el Dorado, Caracolí, los Colores, los Araujos, Alfonso López, Dos de Septiembre, Urbanización Araujo, Colina Real, los Robles, Pablo VI, Camilo Torres, 20 de Julio, Edmundo López, Mogambito, los Nogales, Villa Luz, las Américas, 
Santa Isabel, el Paraíso, Camilo Torres, COMFACOR, los Cedros, los Alpes, la Esperanza, el Tambo y Urbanización Manuel Antonio Buelvas.

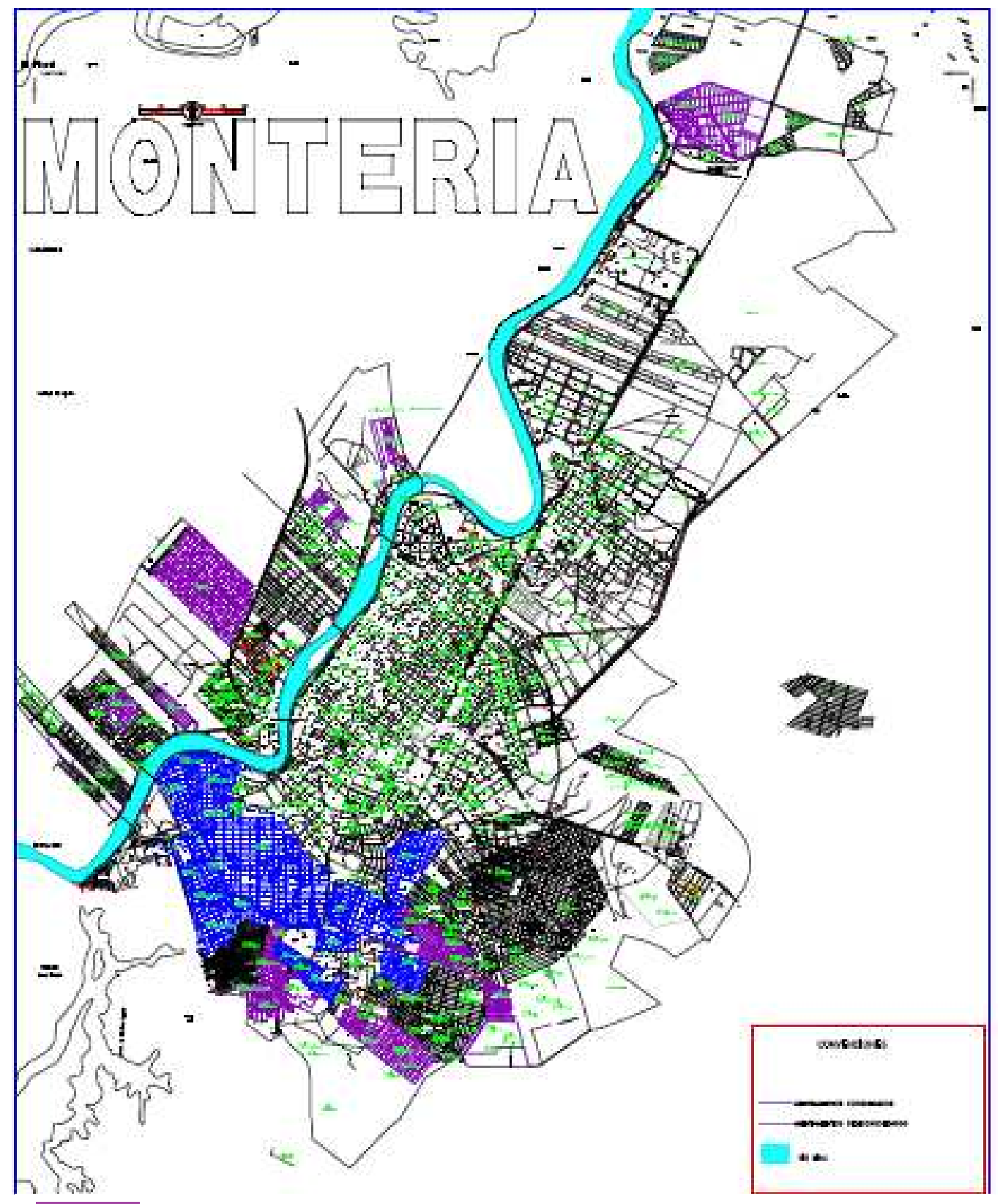

ASENTAMIENTOS SEMICON SOLIDADOS Fuente: plano elaborado por Elkin Herrera y Jhon Pinedo 2011 llustración 72. Asentamientos Semiconsolidados

Finalizamos, destacando que la mejor situación en esta categoría la presentan los barrios el Dorado y Rancho Grande en el occidente, fundamentalmente porque se encuentran conectados físicamente mediante dos vías internas adecuadas, que permiten la prestación del servicio público de transporte y la ubicación de establecimientos de servicios comerciales y educativos. Sin embargo, no se puede 
decir lo mismo del barrio Nuevo Milenio en ese sector, ni de los asentamientos ubicados en el suroriente, que a pesar de contar con algunos equipamientos educativos importantes, aún siguen padeciendo por un viario deficiente, que le impide una armoniosa integración física y lo aleja de los niveles de los barrios consolidados.

\subsubsection{Asentamientos Consolidados}

Los asentamientos correspondientes a esta categoría son aquellos que logaron acceder a todos los servicios públicos básicos, culminación de sus equipamientos, dominio legal de la vivienda, prestación del servicio de transporte público, pavimentación de vías principales, construcción de andenes para peatones y culminación de más del 90\% del total de las viviendas. No obstante, esta consolidación no ha sido suficiente para lograr óptima calidad urbanística, ni para mitigar el impacto ambiental causado.

Para esta investigación, dicha consolidación representa formalidad en cuanto al dominio de la vivienda, pero no en lo referente a la formalidad desde los preceptos del urbanismo. En este sentido, es importante anotar que estos asentamientos, a pesar de la legalización del dominio y de las mejoras urbanísticas realizadas, aún permanecen dentro de la informalidad urbana.

Esta informalidad urbana se manifiesta en déficit de equipamientos, espacios públicos, sistemas óptimos de drenaje y vías de comunicación adecuadas para el tráfico motorizado y peatonal. Otro aspecto asociado a esta informalidad es el de la calidad de los servicios públicos básicos, la apropiación del espacio público por parte de las viviendas, el incumplimiento de nomas urbanas de convivencia, así como los problemas ambientales asociados a los conflictos en el uso de ejes funcionales.

Estos ejes funcionales son básicamente canales de aguas servidas o aguas pluviales, parques, plazas y vías, las cuales son utilizadas para depositar basura y para actividades mercantiles que elevan los niveles de ruido hasta ocasionar contaminación auditiva. Igualmente son aprovechados para el depósito ocasional de basuras, algunos vacíos residuales o lotes especulativos, denominados de "engorde". 
El periodo de tiempo requerido por los asentamientos para llegar a esta instancia de consolidación ha sido superior a cuarenta años, pero para algunos loteos de promoción pública este periodo es inferior, debido a la planificación que hubo en la localización del asentamiento. Este es el caso de los barrios el Prado, Boston y Seis de Marzo en el sur de la ciudad, que aprovecharon la infraestructura y las vías del barrio P-5 a partir del año 1963.
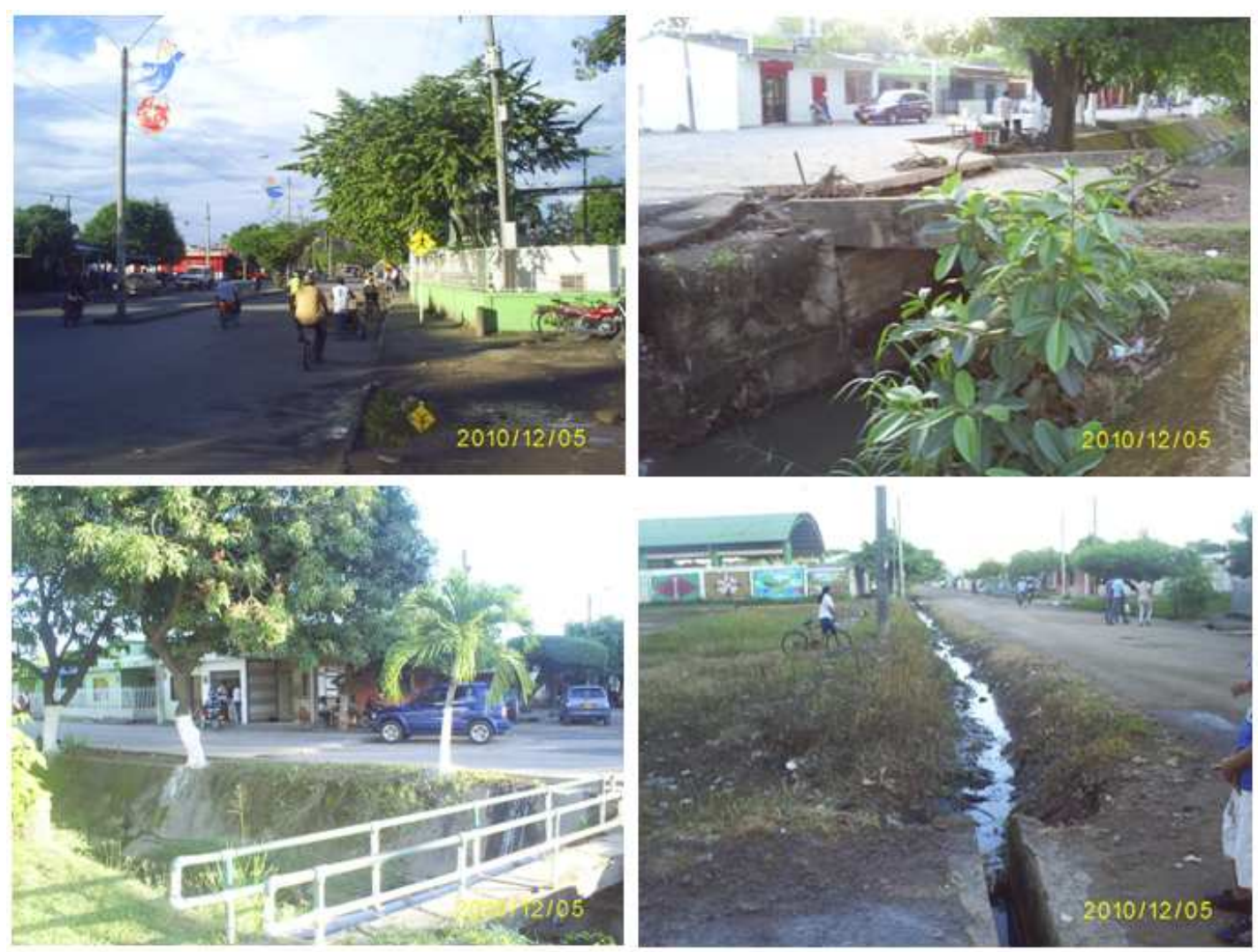

Fotografías: Jhon Pinedo López 2010

Ilustración 73. Vías - Canales - Puentes y Equipamientos en barrios Consolidados

Además de los barrios el Prado, Boston y Seis de Marzo, también llegaron hasta esta instancia, los barrios de promoción pública del P-5, la Granja, Pastrana Borrero, Santander, San Martín, Policarpa Salavarrieta, Santafé, Brisas del Sinú, los Robles, Panzenú, Villa Margarita, Mogambo, Holanda y Simón Bolívar. Estos barrios se encuentran en esta categoría desde hace varios años pero su calidad urbanoambiental sigue siendo deficiente, lo cual los mantienen sometidos a permanentes intervenciones públicas. 


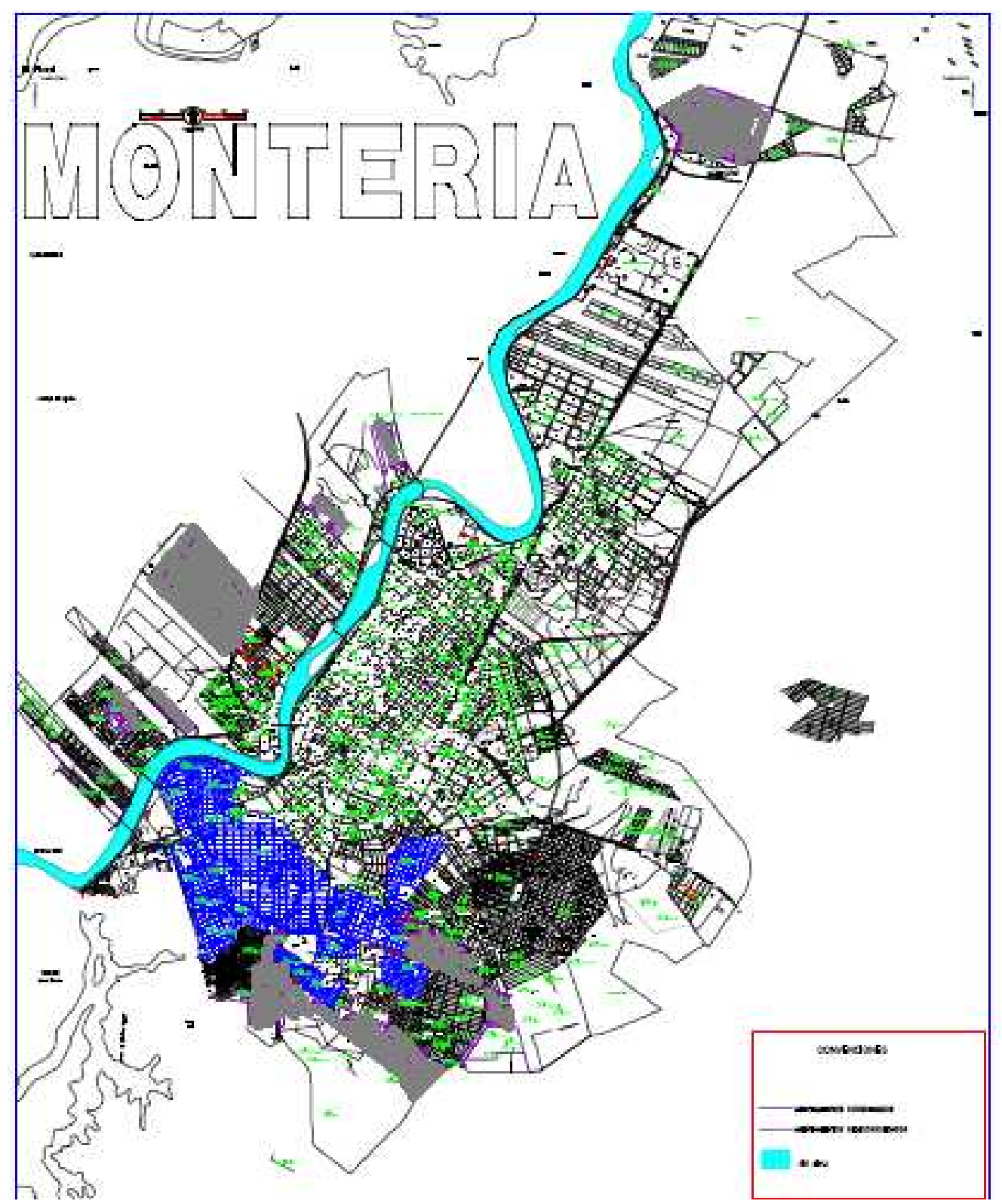

ASENTAMIENTOS CONSOLIDADOS Fuente: plano elaborado por Elkin Herrera y Jhon Pinedo 2011 Ilustración 74. Asentamientos Consolidados

El desarrollo progresivo, o más bien el lento desarrollo, de las viviendas de estos asentamientos es asumido inicialmente por los ocupantes, beneficiarios 0 compradores, pero en segunda instancia interviene el Estado a través de los subsidios y de los créditos reembolsables a mediano o corto plazo. En cambio, las obras de infraestructura y de mejoras urbanísticas siempre son trasladadas en su totalidad a las administraciones públicas. 
En su proceso de consolidación estos barrios no alcanzan la calidad urbanística suficiente para garantizar óptima calidad de vida a sus habitantes o a la población que se desplaza por ellos. Un ejemplo de estos se evidencia en la calle principal del barrio el Prado, en donde la pavimentación de la vía y la apropiación del espacio público de los propietarios de las viviendas, no permitió la construcción de andenes ni de barreras arquitectónicas para proteger a los residentes, peatones y ciclistas.



Terminamos este análisis de los asentamientos consolidados, manifestando que esta etapa de consolidación brinda una seguridad jurídica y algunas mejoras urbanísticas, pero no garantiza la solución inmediata a los desequilibrios generados por los patrones de informalidad que acompañan al asentamiento desde su origen. Un claro ejemplo de estos desequilibrios se refleja en las frecuentes interrupciones generadas por ubicación de viviendas en espacios dotacionales de sectores, que dificultan la finalización oportuna de obras, y desnudan la debilidad institucional e improvisación de los funcionarios públicos. A estos aspectos se suma igualmente, la falta de participación de la comunidad, el autoritarismo de los gobernantes, el protagonismo del tráfico motorizado, la poca sensibilidad ambiental y el desapego a las normas urbanas o ambientales. 


\section{CAPITULO 5}

\section{IMPACTO AMBIENTAL}

Esta investigación define al impacto ambiental de la urbanización marginal como la alteración que los asentamientos informales ocasionan a la sociedad, economía, ecosistemas y a la ciudad como conjunto urbano. En este orden de ideas, el ambiente es analizado desde aquí, como un sistema en el que interactúan cuatro factores: social, ecológico, económico y urbanístico.



Fuente: elaborado por Jhon Pinedo con base en Carlos Martín Cantarino (2000)

Esquema 1. Susbistemas del Ambiente

Estos cuatro factores son equematizados de manera horizontal debido a la interdependencia que existe entre ellos, y a la equilibrada posibildad que tiene cada uno de ellos de impactar, negativa o positivamente, el ambiente como sistema. Sin embargo, el estudio de estos cuatro factores que conforman el ambiente, consideramos conveniente iniciarlo por la variable social, y finalizarlo por la variable ecológica.

El estudio de la variable social, económica y urbanística en el orden propuesto, facilita el analisis de la variable ecológica, y por ende, permite una mejor comprensión del impacto ambiental que genera el fenomeno de urbanización marginal en la ciudad de Montería. En este sentido, el estudio no muestra preocupación solamente por un factor, sino que considera que los cuatro factores son igual de importantes para lograr el equilibrio ambiental en una ciudad. 


\subsection{IMPACTO SOCIAL}

Si bien, la sociología utiliza métodos de investigación empírica para medir las relaciones sociales dentro de los colectivos, en esta investigación, el impacto social se encuentra asociado a una serie de indicadores que manifiestan la calidad de vida de la población que reside en los asentamientos informales de la ciudad de Montería. Los indicadores seleccionados se encuentran incluidos dentro de los derechos sociales de la Constitución Política de Colombia y expresan niveles de escolaridad, salud, organización, desempleo, delincuencia y participación ciudadana.

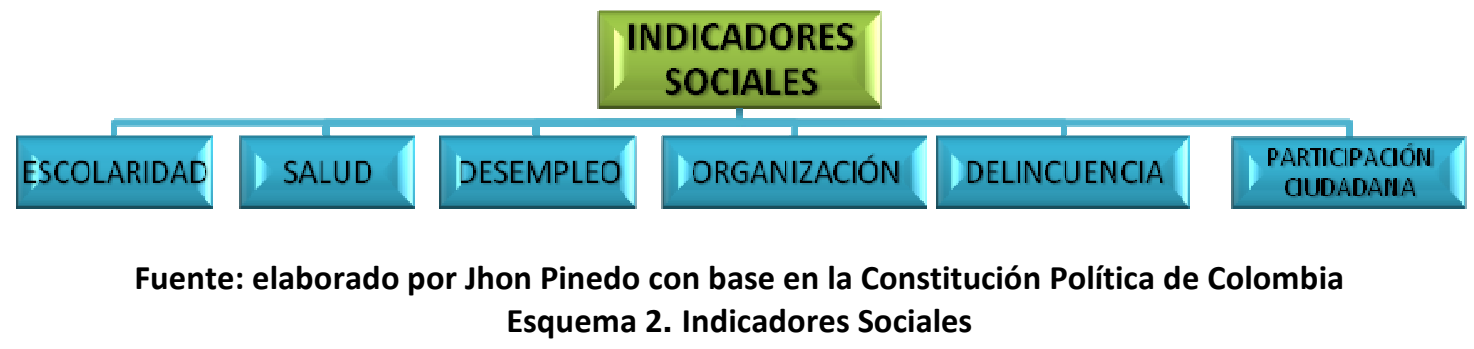

Estos indicadores son considerados como los más pertinentes para esta investigación, por la incidencia que tienen dentro de la conformación, evolución y consolidación de los asentamientos informales de Montería. No obstante, es oportuno anotar que dentro de los indicadores sociales también se encuentran aquellos relacionados con el Género, Vivienda, Migraciones, Servicios Públicos, Espacio Público, Esperanza de Vida al Nacer, Acceso a Agua Potable y todos los concernientes al desarrollo humano, y que además son tenidos en cuenta por instituciones como el Banco Mundial, El Departamento Administrativo Nacional de Estadística (DANE), el Plan de Naciones Unidas para el Desarrollo PNUD y por la Comisión Económica para América Latina (CEPAL).

\subsubsection{Escolaridad}

El nivel de escolaridad de los adultos en estos asentamientos es muy bajo con respecto a la escolaridad del resto de la población. Sin embargo, es significativo anotar que los jóvenes de estos barrios cuentan con la posibilidad de acceder a veintiséis escuelas públicas construidas durante los últimos veinticinco años, y asimismo mejorar su nivel en este indicador. En dichos asentamientos, también han logrado funcionar 
simultáneamente quince escuelas comunitarias, patrocinadas por organizaciones no gubernamentales, grupo religiosos o particulares ${ }^{230}$.

Según Negrete ${ }^{231}$, las escuelas públicas albergaban en el año 2002 una población de 15.669 estudiantes en primaria y bachillerato, principalmente matriculados en el estrato uno de barrios informales del suroriente, occidente y norte de la ciudad, como; Cantaclaro, Villa Rocío, Villa los Alpes, el Paraíso, Edmundo López, Mogambito, el Alivio el Laguito, Rancho Grande, el Dorado, el Poblado, la Esperanza, Minuto de Dios, 7 de Mayo, Mocarí y Camilo Torres.

En el año 2009, la ciudad de Montería presenta datos con cambios significativos en la oferta y en la demanda de educación en todos sus niveles: primaria, bachillerato y media vocacional. La secretaría de educación municipal reporta para esta fecha un total de 267 equipamientos educativos oficiales, de los cuales 195 se encuentran en el área urbana. Igualmente se reportan 61 equipamientos privados de educación primaria, 17 instituciones técnicas y 36 jardines infantiles.

La educación primaria tiene su mayor demanda en los asentamientos informales del suroriente y norte, en los cuales se presentan indicadores que ascienden a 48 cupos por hectárea. Sobre este particular, el POT 2002 - 2015, estableció cinco categorías, las cuales son denominadas de la siguiente manera: a) demanda muy baja; b) demanda baja; c) demanda moderada: d) demanda alta, y e) demanda muy alta.

Las escuelas de asentamientos informales con demanda baja y muy baja son los Bongos, Luis Carlos Galán, Manuel Jiménez, la Esperanza, Villa Luz, el Tambo, Manuel Ruiz Álvarez, el Rosario, el Campano, Caracolí, el Níspero, Casa Finca, el Ébano, Villa Nazaret, el Portal, la Navarra, los Robles, las Américas, Damasco, Guadalajara, Vereda Tropical, los Nogales, Villa Los Alpes, Villa Rosario, Villa Neli y Villa Ana.

\footnotetext{
${ }^{230}$ Negrete, Víctor (2004): Situación actual de las comunidades culturales urbano marginales de Montería. Universidad del Sinú Montería. Pág. 17

${ }^{231}$ Ibíd. Pág. 18
} 


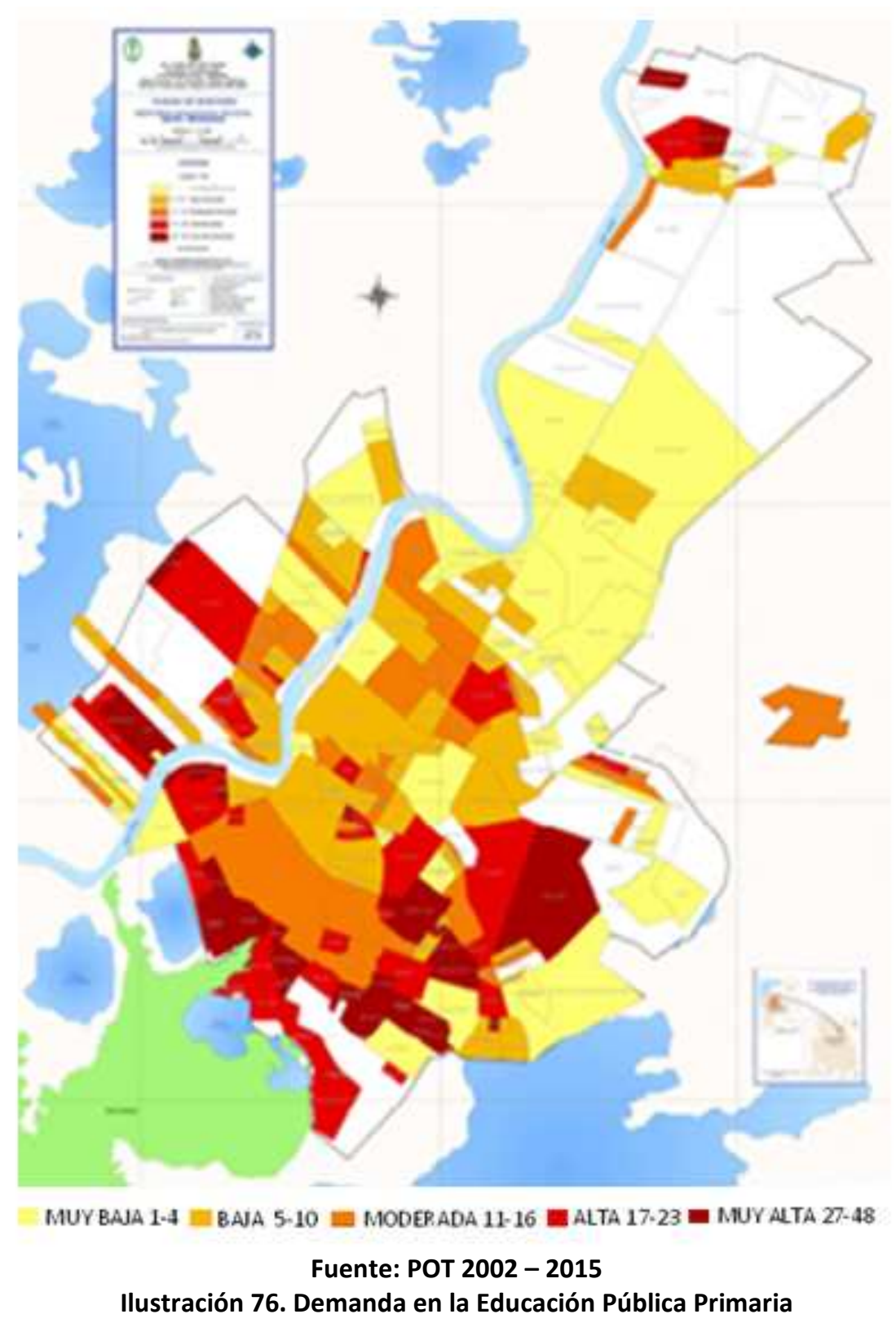

En cambio las demandas altas y muy altas se encuentran en los barrios 20 de Julio, Camilo Torres, el Poblado, el Dorado, Villa Sinú, Mi Ranchito, Rancho Grande, Nuevo Horizonte, la Palma, Brisas del Sinú, Santafé, San Martín, Policarpa, Pastrana Borrero, Alfonso López, las Colinas, los Araujos, Pablo Sexto, Dos de Septiembre, Nueva Esperanza, Villa Paz, Furatena, Paz del Río, la Candelaria, Colina Real, Primero de Mayo, Robinson Pitalúa, Santa Rosa, Edmundo López, Mogambito, Mogambo, Santa Isabel, el Paraíso, Cantaclaro, San Cristóbal y Seis de Marzo.

En lo referente a equipamientos públicos de bachillerato, éstos presentan una distribución proporcional al número de habitantes de cada comuna, a los años de 
constitución del asentamiento y a la densidad del sector. No obstante, se refleja un desequilibrio entre oferta y demanda de estudiantes de las comunas 1 y 2 , como consecuencia del continuo crecimiento de los últimos diez años en el occidente de la ciudad.

\begin{tabular}{|c|c|}
\hline COMUNA N $^{\circ}$ & $\mathrm{N}^{\circ}$ DE EQUIPAMIENTOS EDUCATIVOS \\
\hline 1 & 5 \\
\hline 2 & 4 \\
\hline 3 & 15 \\
\hline 4 & 17 \\
\hline 5 & 7 \\
\hline 6 & 10 \\
\hline 7 & 2 \\
\hline 8 & 5 \\
\hline 9 & 6 \\
\hline \multicolumn{2}{|c|}{ Fuente: POT 2002 - 2015 } \\
\hline
\end{tabular}

Tabla 15. Equipamientos Educativos por Comuna

Estos desequilibrios conllevan a que las instituciones educativas el Dorado y Rancho Grande del occidente de la ciudad, presenten áreas de influencia de 698 y 593 hectáreas, respectivamente. En el oriente y en el sur también se encuentran Instituciones con amplia superficie de influencia como Victoria Manzur en Cantaclaro y Santa María Goretti en el P-5, con 687 y 601 hectáreas de cobertura.

El sur presenta la más alta oferta educativa de bachillerato público, debido a la presencia del mayor número de colegios, que además cuentan con superficies construidas superiores a cinco mil metros cuadrados y dentro de los que se destacan: Cecilia de Lleras, Cristóbal Colon, Antonia Santos, General Santander, Policarpa Salavarrieta, Mercedes Abrego, Guillermo León Valencia, Santa María Goretti y Robinson Pitalua.

Sin embargo, algunos sectores del norte y del occidente de la ciudad presentan alto déficit de cupos escolares que afectan directamente a los jóvenes de los barrios informales 20 de Julio, Camilo Torres, 7 de Mayo, la Esperanza, el Dorado, el Poblado, Mi Ranchito, Rancho Grande, Nuevo Horizonte, la Palma, el Níspero, los Colores, 
Navarra, el Portal y el Ébano. Este déficit, es traducido por el $\mathrm{POT}^{232}$, como setenta alumnos por hectárea sin cobertura dentro del mismo asentamiento.

En lo relacionado con Educación Superior, para el año 2010, Montería se consolida como una ciudad universitaria y dentro de estas instituciones sobresalen nueve universidades: Cooperativa, Luis Amigó, CUN, UNICIENCIA, Pontificia Bolivariana, San Martín, CECAR, UNISINÚ y UNICÓRDOBA (única pública y con cobertura de 10.000 estudiantes). La tercera y cuarta se encuentran ubicadas en el centro de la ciudad, en edificios inapropiados para educación, mientras que las restantes se ubican en el norte y occidente, en instalaciones adecuadas y con población promedio de 2.000 estudiantes. Sin embargo la población de los asentamientos informales sigue sin mayores posibilidades de acceder a ellas y los cupos que ofrece una sola universidad pública, no permite el acceso a la mayoría de estos jóvenes.

Los bajos niveles de escolaridad ${ }^{233}$, la falta de apego a las normas, así como el desconocimiento de ellas, se manifiestan en comportamientos individuales o colectivos no favorables para la convivencia armónica ni para el desarrollo humano de la mayoría de la población de los asentamientos informales. Estos aspectos, asociados a fenómenos como el desplazamiento forzado, la inequidad de género, la desconfianza política y la enorme desigualdad en la redistribución de la renta, alimentan la falta de identidad o de pertenencia con esta ciudad.

Este bajo nivel de pertenencia se refleja en la falta de compromisos que tienen los habitantes para contribuir al mantenimiento y a la conservación de sus sectores dentro de la ciudad. La indiferencia ante problemas de la comunidad, la ausencia de programas de educación ciudadana, y la falta de conciencia colectiva estimulan el maltrato a la naturaleza, a lo público, al mobiliario, a los equipamientos y a la estructura urbana de Montería.

\footnotetext{
${ }^{232}$ Alcaldía de Montería (2010): Plan de Ordenamiento Territorial de Montería 2002-2015. Diagnóstico. Pág. 274.

${ }^{233}$ Víctor Negrete, identifica en los asentamientos más precarios a 935 jefes de hogar sin realizar ningún año de estudio; a 1244 adultos sin terminar estudios de primaria; 345 que cursaron algún año de bachillerato y un reducido número de 39 personas que lograron graduarse de bachiller o técnico, y no hay presencia de tecnólogos o profesionales. Sin embargo, hay registro de ellos en asentamientos semiconsolidados y consolidados. Negrete, Víctor (1999): Op. Cit. Pág. 44.
} 
La indisciplina en el consumo, el derroche de recursos, la ausencia de políticas públicas sociales o ambientales, y la mentalidad paternalista que se tiene del Estado, son aspectos que se combinan para impulsar a la población a arrojar basuras en su entorno, en los canales de aguas pluviales, en las alcantarillas a cielo abierto, a no sacar los desechos en las horas indicadas para la recolección, a no clasificarlos, a eludir compromisos ciudadanos, a no participar en reuniones de interés general para el barrio o en la conformación de organizaciones sociales.

El trabajo comunitario o la solución a los problemas sociales son considerados como obligación exclusiva de los líderes, del Estado o de organizaciones no gubernamentales, pero en ningún momento se considera como el compromiso de todo un colectivo que debe orientar su propio desarrollo. Esta indiferencia hacia la participación o hacia la organización social se manifiesta en adultos y jóvenes, pero son estos últimos los más apáticos a la hora de asumir compromisos.

Sin embargo, la evolución o consolidación de estos asentamientos, se debe en gran parte a la tenacidad de algunos líderes comunitarios a la hora de articular su trabajo con dirigentes políticos o con organizaciones sociales. Su capacidad de liderazgo ha permitido la conformación de colectivos sociales, empresas comunitarias, organizaciones populares de vivienda, juntas de acción comunal organizaciones cívicas, religiosas, así como la conformación de clubes deportivos, recreativos y culturales.

La estratificación socioeconómica que el Departamento Nacional de Planeación (DNP), establece en Colombia, con fines redistributivos, se convierte en un instrumento de interpretación maniquea ${ }^{234}$, que estimula muchas veces a la estigmatización de los residentes de estos asentamientos, e incluso, a la discriminación social por parte de diferentes actores económicos, sociales o políticos de la ciudad. Igualmente, esta

\footnotetext{
234 Sin pretender, en absoluto, asumir una posición clasista, consideramos por nuestra experiencia en esta ciudad, que la estratificación socioeconómica del lugar donde se habita, favorece para acceder a un subsidio o cupo escolar, pero increíblemente, puede convertirse en un factor desfavorable para el acceso a ciertos empleos. En este sentido, resaltamos que aún persisten estructuras mentales colonialistas, que mantienen alienadas la mente de algunas personas con relativo poder económico o político, o con algún rango intermedio dentro de la jerarquía de una organización empresarial, quienes generalmente apoyan sus decisiones de selección de personal en prejuicios sociales asociados al patrimonio, la familia y lugar de residencia.
} 
estratificación sigue siendo un factor determinante para acceder a la educación superior en esta ciudad.

Los bajos niveles de escolaridad en estos asentamientos tienden a compensarse con subsidios precarios a la población, sobre todo en los últimos gobiernos populistas de derecha, los cuales le siguen apostando al oscurantismo como doctrina de dominación. En este aspecto, consideramos que los subsidios entregados durante los dos gobiernos del presidente Álvaro Uribe Vélez, fomentaron elevados niveles de conformismo y desestimularon el interés de sus beneficiarios para vincularse a actividades productivas formales.

Estos subsidios, prolongados indefinidamente, diseñados sin objetivos redistributivos pero si claramente con fines políticos, generaron un impacto social negativo, porque no fueron orientados a fomentar la capacitación o a estimular el empleo, y si más bien, contribuyeron relativamente a la improductividad, informalidad económica y aumento de la población. Estos tres últimos aspectos se vieron dinamizados debido a que dichos subsidios son asignados de acuerdo con el número de hijos en la escuela y/o a la condición de desempleado.

La improductividad, informalidad y aumento de población son indirectamente estimuladas, ya que las personas desempleadas encuentran en el subsidio una motivación a la cual no están dispuestos a renunciar, o también, cuando las familias más vulnerables ven en el aumento de la natalidad una oportunidad de obtener mayores ayudas. Esto, por supuesto, es insostenible presupuestalmente y más en un país endeudado, con elevada evasión fiscal y bajos niveles de competitividad ${ }^{235}$; pero igualmente somos conscientes, de que sin estos subsidios la situación en estos momentos sería peor para estos grupos sociales.

235 En el Ranking de Competitividad Mundial elaborado por el Institute For Managment Development IMD de Suiza para el año 2010, Colombia figura en el puesto 45 entre 58 países. Este ranking mide cuatro factores: eficiencia de gobierno; infraestructura; eficiencia de las empresas, y desempeño económico. Disponible en: http://www.deganadores.com/index. Consultado el 15 de Octubre de 2010. 


\subsubsection{Salud}

La apertura de nuevas empresas privadas de salud en Colombia con el apoyo de la ley 100 de 1992, y la creación del sistema público de régimen subsidiado (SISBEN) en 1993, permitieron la ampliación de la cobertura de este servicio básico a nivel nacional, departamental y municipal. En el caso de Montería, esto dos aspectos se reflejan en la existencia de 72 empresas prestadoras de dicho servicio, así como en la afiliación de 232.442 beneficiarios del subsidio estatal, reportados hasta el año 2010 por la alcaldía municipal de esta ciudad.

Sin embargo, la calidad de los servicios de salud, y las condiciones higiénico-sanitarias en que viven los sectores más vulnerables de la población, no contribuyen a evitar enfermedades de tipo respiratorio, dermatológico y gastrointestinal, de infantes, adolecentes y adultos. Estas enfermedades, son ocasionadas por vectores, presentes principalmente, en asentamientos informales con alcantarillas a cielo abierto, aguas pluviales estancadas por falta de drenaje y descomposición de residuos sólidos, en los cuales proliferan zancudos, roedores y plagas.

\begin{tabular}{lc}
\hline \multicolumn{1}{c}{ ENFERMEDADES } & CASOS \\
\hline DENGUE CLASICO & 182 \\
DENGUE HEMORRAGICO & 38 \\
MALARIA & 120 \\
TUBERCULOSIS & 31 \\
DESNUTRICIÓN AGUDA & 5170 \\
INFECCIÓN RESPIRATORIA AGUDA & 1760 \\
ANEMIA & 1582 \\
PARASITOSIS INSTESTINAL & 1388 \\
ENFERMEDAD DIARREICA AGUDA & 1126 \\
\hline
\end{tabular}

Fuente: Secretaría de Salud, UNISINÚ y UNICÓRDOBA 2007 Tabla 16. Patologías atendidas en Montería

La desnutrición aguda, las enfermedades diarreicas, la parasitosis intestinal y las infecciones respiratorias agudas son las patologías más frecuentes en la población infantil. No obstante, las cifras de dengue clásico, dengue hemorrágico, malaria y 
tuberculosis son muy elevadas, si se tiene en cuenta los riesgos que ellas generan, los modelos de salud preventivos y los avances de la medicina en el siglo XXI.

Los reportes oficiales son aproximados a estudios realizados por organizaciones no gubernamentales o por instituciones multilaterales como la Organización Panamericana de la Salud. Esta última entidad, realizó una investigación ${ }^{236}$ en los asentamientos informales de Montería, en donde además de identificarse casos de enfermedades diarreicas, respiratorias, dermatológicas, anemia y desnutrición, también se identifican aspectos en materia sexual y reproductiva de la población desplazada y receptora que habita dichos asentamientos.

Las principales causas de enfermedad percibidas en la población fueron la infección respiratoria aguda, con 393 casos por cada 10.000 habitantes: la enfermedad diarreica aguda, con 246 casos y las dermatológicas, con 64 casos por cada 10.000 habitantes. En cuanto a reproducción sexual, se determinó que el 73\% de las mujeres en situación de desplazamiento que habitaban estos asentamientos tenían más de tres hijos, y el $20 \%$ de las adolescentes se encontraban embarazadas o ya habían sido madres.

Las enfermedades dermatológicas así como las diarreicas se presentan con mayor tendencia en la población infantil que habita y juega cerca de los canales de aguas residuales o en charcos de aguas estancadas que permanecen en estos sectores en la época de inundaciones. A estas patologías también se suma la bronconeumonía reportada en los últimos meses por los centros de atención médica de la Granja, Cantaclaro, el Amparo y Sucre.

Los informes de FABEGER LTDA ${ }^{237}$, para la secretaría de salud departamental en el año 2010, reportan un promedio de 2420 urgencias atendidas mensualmente por los

\footnotetext{
${ }^{236}$ Organización Panamericana de la Salud y Universidad de Antioquia (2004): Salud y Desplazamiento en Colombia. Disponible en http://www.disaster-info.net/desplazados y consultado el 2 de diciembre de 2010.

${ }^{237}$ Centro Regulador de Urgencias de la Secretaría Departamental de Salud, encargada de llevar las estadísticas de urgencias médicas atendidas mensualmente en el departamento de Córdoba. Información reportada por el funcionario, Nilson de la Ossa, y disponible en www.cordoba.gov.co/docs/crue comportamiento julio 2010.pdf
} 
centros médicos de la ciudad de Montería. El 25\% de estas urgencias corresponden a menores de 14 años, de los cuales son atendidos por problemas de bronconeumonía, 142 casos; anemia 48 casos, y pediatría 305 casos. También se incluyen en estas urgencias reportadas, 39 pacientes mensuales por accidentes de tráfico.

Los accidentes de tráfico son ocasionados principalmente por motocicletas de transporte informal que prestan servicios entre asentamientos informales, o entre éstos, y zonas céntricas de la ciudad. Tanto estos accidentes, como las enfermedades descritas, suelen asociar frecuentemente a población vulnerable de asentamientos marginales, que logran acceso al sistema por medio del régimen subsidiado de salud SISBEN.

\begin{tabular}{|lcc|}
\hline ASENTAMIENTO INFORMAL & COMUNA & $\mathrm{N}^{\circ}$ DE AFILIADOS AL SISBEN \\
\hline CANTA CLARO & 6 & 21.647 \\
VILLA CIELO & 8 & 5.619 \\
FURATENA & 4 & 5.431 \\
2O DE JULIO & 9 & 2.622 \\
EL POBLADO & 1 & 2.306 \\
EL PARAISO & 4 & 1.994 \\
EL NISPERO & 1 & 1.853 \\
VILLA PAZ & 4 & 789 \\
\hline
\end{tabular}

Fuente: Oficina del SISBEN - Alcaldía de Montería 2010

Tabla 17. Beneficiarios del subsidio de salud en Montería

El número de personas con subsidios de salud en Montería reportadas por la oficina del SISBEN para el año de 2010 asciende a 232.442, las cuales corresponden a los estratos socioeconómicos 1 y 2 , de los sectores informales o de la población desplazada, y/o en situación de vulnerabilidad. El mayor número de subsidiados por el Estado se encuentran en los asentamientos informales de Cantaclaro, Villa Cielo, Furatena, 20 de Julio, el Poblado y el Paraíso.

Los demás subsidiados se encuentran dispersos de manera homogénea en los asentamientos informales de menor población, tales como: Nuevo Milenio, Ranchos del INAT, Santa Rosa, Candelaria, los Nogales, Minuto de Dios, Mi ranchito, el Cerro, Alfonso López, los Araujos, Villa Jiménez, Villa Arlet, 7 de Mayo, Colina Real, el Bongo, Santafé y Brisas del Sinú. Sin embargo, algunos residentes de estos asentamientos, que 
están vinculados laboralmente a empresas formales, se encuentran integrados al sistema de salud mediante el régimen contributivo.

La población subsidiada en Montería asciende al 70\%, mientras el régimen contributivo apenas se acerca al 25\%, situación similar a la de la región Caribe, pero diferente a la Nacional, en la que aún se encuentran por fuera del sistema un $13.8 \%$ del total de la población ${ }^{238}$. Esta situación desequilibrada entre el régimen contributivo y subsidiado se traduce en un modelo insostenible, basado además en intervenciones curativas y no preventivas que permitan mejorar la calidad de vida de sus habitantes, principalmente de aquellos que viven en condiciones higiénicas y sanitarias desfavorables o en situación de informalidad.

Las brigadas de salud realizadas anualmente en estos asentamientos por organizaciones no gubernamentales, permiten desparasitar en promedio a 1.500 niños menores de catorce años y atender algunos casos de menores con problemas visuales, auditivos, caries dental, desnutrición, retraso en el crecimiento, problemas de conducta, enfermedades diarreicas, dermatológicas y respiratorias.

Dentro de estas organizaciones no gubernamentales sobresalen entidades reconocidas como Visión Mundial y Acción contra el Hambre, pero también se destaca el aporte a programas de salud por parte de BEMPOSTA, Plan Internacional, Club Kiwanis y la Corporación Betancí. El aporte realizado por estas instituciones ha permitido diagnosticar, cuantificar e identificar causas de las patologías que padecen los menores de los asentamientos informales más precarios.

\footnotetext{
${ }^{238}$ DANE-ECV (2008): Población Afilada al Sistema General de Seguridad Social en Salud. Total Nacional y por Regiones. Disponible en: http://www.dane.gov.co
} 


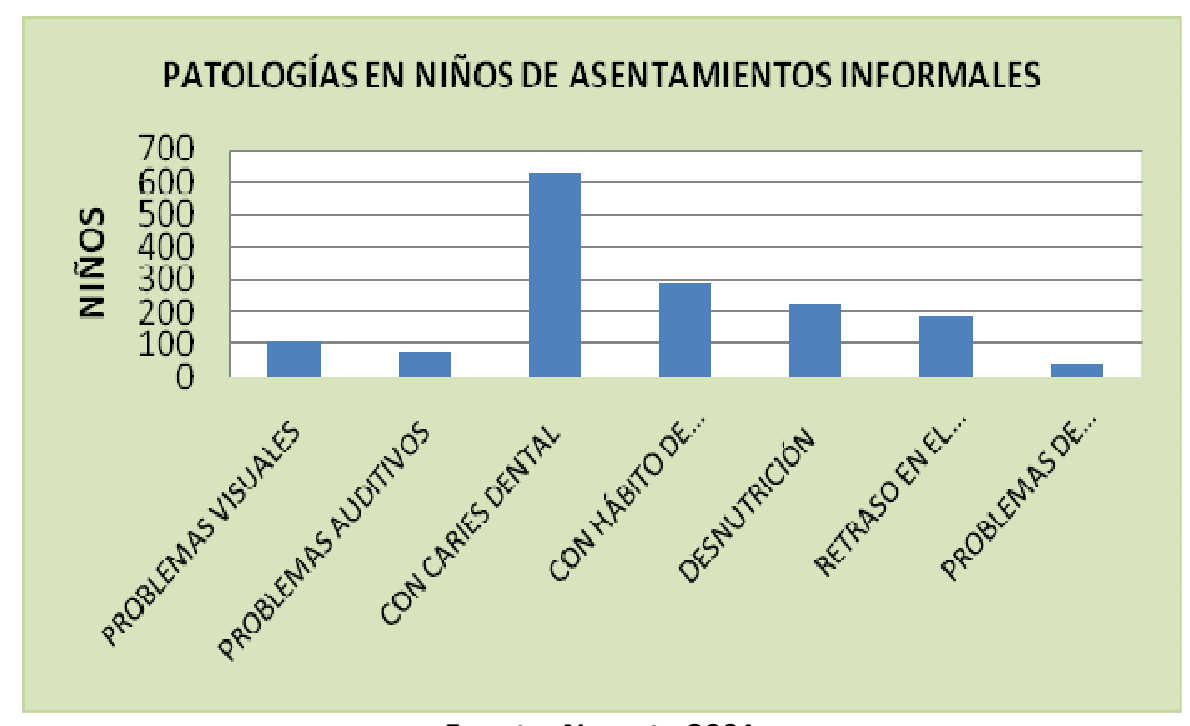

Fuente: Negrete 2001

Ilustración 77. Principales patologías en infantes de asentamientos informales

Los datos presentados corresponden al diagnóstico realizado a 1.500 niños menores de catorce años de los barrios la Candelaria, Paz del Río, Santa Rosa, Nuevo Milenio, Robinson Pitalúa y Casa Finca, así como a 100 niños menores de diez años de las orillas de canales. Los primeros, arrojaron elevados casos de caries dental, desnutrición y retraso en el crecimiento; mientras que en los segundos se identificaron 81 menores con parasitosis intestinal, la cual es ocasionada principalmente por ingestión de alimentos contaminados con parásitos o por agua contaminada con materia fecal ${ }^{239}$.

El mismo diagnóstico determinó que el $43 \%$ de los niños con parasitosis intestinal padecía de multiparasitismo o presencia simultánea de amebas, lombrices y tenias. No obstante, se demostró que la contaminación del agua consumida, no era ocasionada en la fuente, sino por los tanques inadecuados, que se utilizaban en los procesos de recolección, transporte o depósito del líquido.

En cuanto al tema de la salud, es importante anotar que las enfermedades descritas prevalecen principalmente en los asentamientos precarios que no cuentan con el servicio domiciliario de agua, ni con las instalaciones adecuadas para aseo personal o preparación de alimentos. Sin embargo, dichas enfermedades logran disminuir en la

239 Negrete Barrera, Víctor (2001): Asentamientos Subnormales de Montería Receptores de Desplazados. Unisinú. 
medida que evoluciona el asentamiento y mejora la condición higiénico-sanitaria de la vivienda de la ciudad de Montería.

Uno de los datos más alarmantes, considerado desde esta investigación, tiene que ver con los problemas de conducta encontrado en los niños de estos barrios, los cuales se encuentran expuestos a las tensiones del entorno, a las pandillas y a los grupos violentos que reclutan adolecentes para sus filas. En este aspecto, la administración municipal, los padres de familia y las instituciones educativas no han logrado diseñar un instrumento eficaz para esta problemática psicosocial.

Por último, se ha evidenciado en el terreno y en los estudios consultados, que las enfermedades de la población informal se asocian a pisos de tierra, a las condiciones o inexistencia de letrinas, a condiciones antihigiénicas de cocinas, baños o patios, a la coexistencia con alcantarillas a cielo abierto, basuras o zancudos y al transporte de agua desde piletas públicas hacia las viviendas. Esta ultima situación, mantuvo una fuerte incidencia debido a la utilización de tanques inapropiados que contaminaban el agua potable, pero que tiende a reducirse con la ampliación de este servicio al 98\% de los asentamientos de la ciudad, incluidos los informales.

\subsubsection{Desempleo}

Antes de abordar este tema, es importante anotar que la población total en edad de trabajar (PET) para el año de 2009 ascendió a 238.000 personas (77.1\%), de un total de 378.980 habitantes ${ }^{240}$. Igualmente anotamos que en este apartado se analizarán aspectos relacionados con la población desempleada y no con la estructura de la fuerza de trabajo; ésta última, por su pertinencia, será analizada ampliamente en el capítulo de impacto económico.

\footnotetext{
${ }^{240}$ Banco de la Republica (2009): Informe de Coyuntura Económica Regional (ICER) para Córdoba. Texto disponible en http://www.banrepblica.gov.co
} 


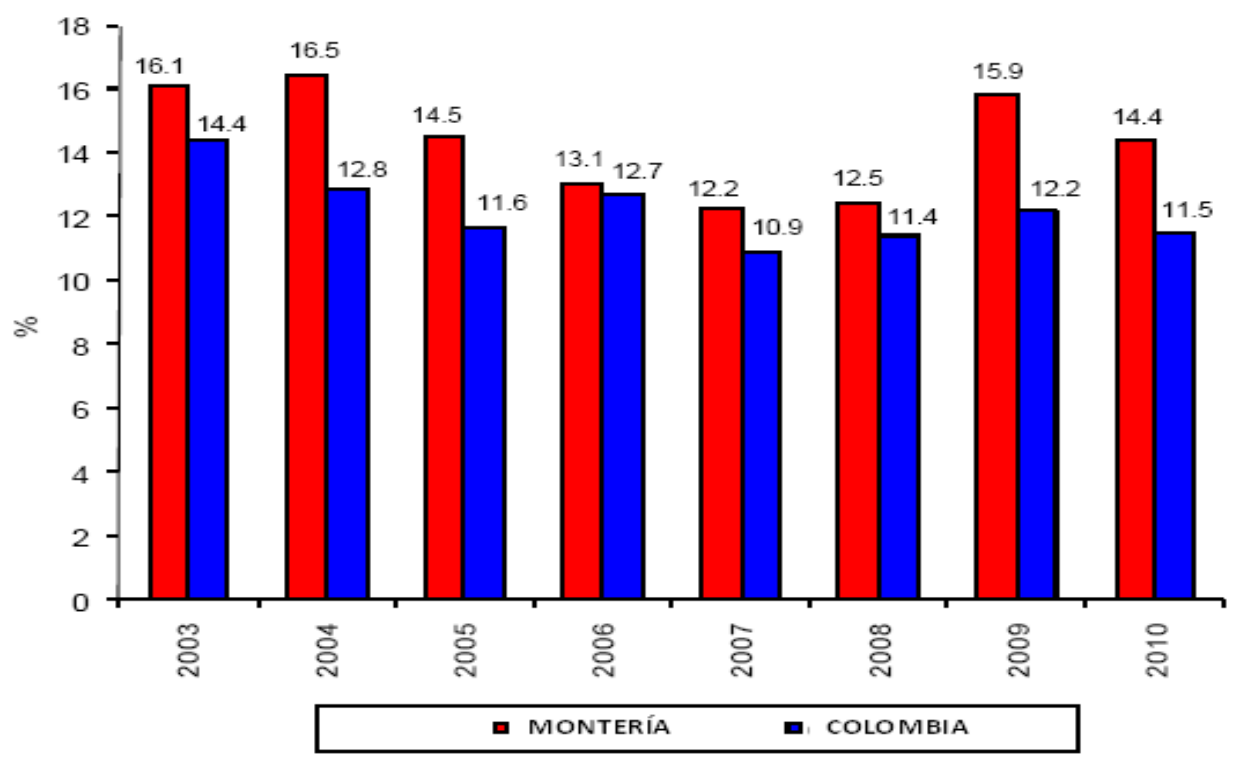

Fuente: DANE 2010

Ilustración 78. Tasa de desempleo en Montería y en Colombia 2003 - 2010

El desempleo en Montería es un fenómeno crónico que históricamente ha estado por encima del promedio nacional, y con pocas posibilidades de mejorar las elevadas tasas de los últimos años. Las tendencias muestran una disminución del fenómeno entre los años 2006 y 2008, periodo caracterizado por la reactivación de la construcción y la constitución de nuevas empresas del sector terciario en esta ciudad.

Estas actividades de construcción y de tercerización, actualmente no son suficientes para ocupar la creciente demanda de empleo de la población, especialmente la desplazada, ni para reemplazar las empresas estatales privatizadas, que durante muchos años fueron las principales empleadoras en una región con bajo desarrollo tecnológico e industrial, y con gran dependencia de la ganadería extensiva, generadora de pocos puestos de trabajo.

Las escasas posibilidades de generación de empleo afecta a todos los sectores de la población, pero los sectores más afectados en Montería son, los desplazados provenientes de zonas rurales, y la población marginada con bajos niveles de escolaridad o cualificación. Son estas personas, las que presentan mayor dificultad para integrarse a actividades fundamentalmente terciarias, que generalmente requieren algún grado de capacitación. 
En este orden de ideas, a los habitantes de los asentamientos informales les corresponde una baja participación en el mercado laboral de Montería. A las dificultades descritas, se le suman limitaciones racionales de distancia o transporte, así como, reiteramos, aspectos de tipo colonialista, asociados a prejuicios clasistas de orden socioeconómico o de dinastías, que aún se mantienen arraigadas en las mentes de un gran sector de la población.

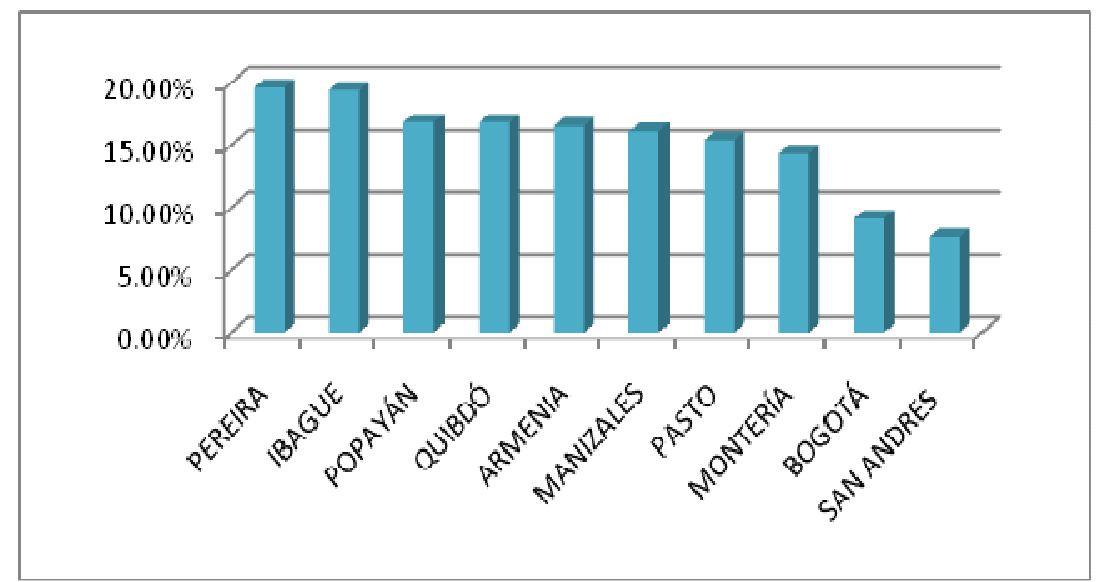

Fuente: DANE 2010

Ilustración 79. Desempleo en ciudades colombianas 2010

Resaltamos que Montería es la octava ciudad con mayor desempleo en Colombia, después de Pereira, Popayán, Armenia, Ibagué, Manizales, Pasto, Cali y Quibdó. La tasa de desempleo registrada por el DANE en el mes de octubre de 2010 para Pereira fue de 19.6\%, seguida de Ibagué, 19.4\%; Popayán y Quibdó, 16.8\%; Armenia, 16.5\%, y Manizales, $16.1 \%$. Montería con el $14.3 \%$, es la ciudad del Caribe colombiano, con mayor porcentaje de desocupados en el periodo referenciado. 


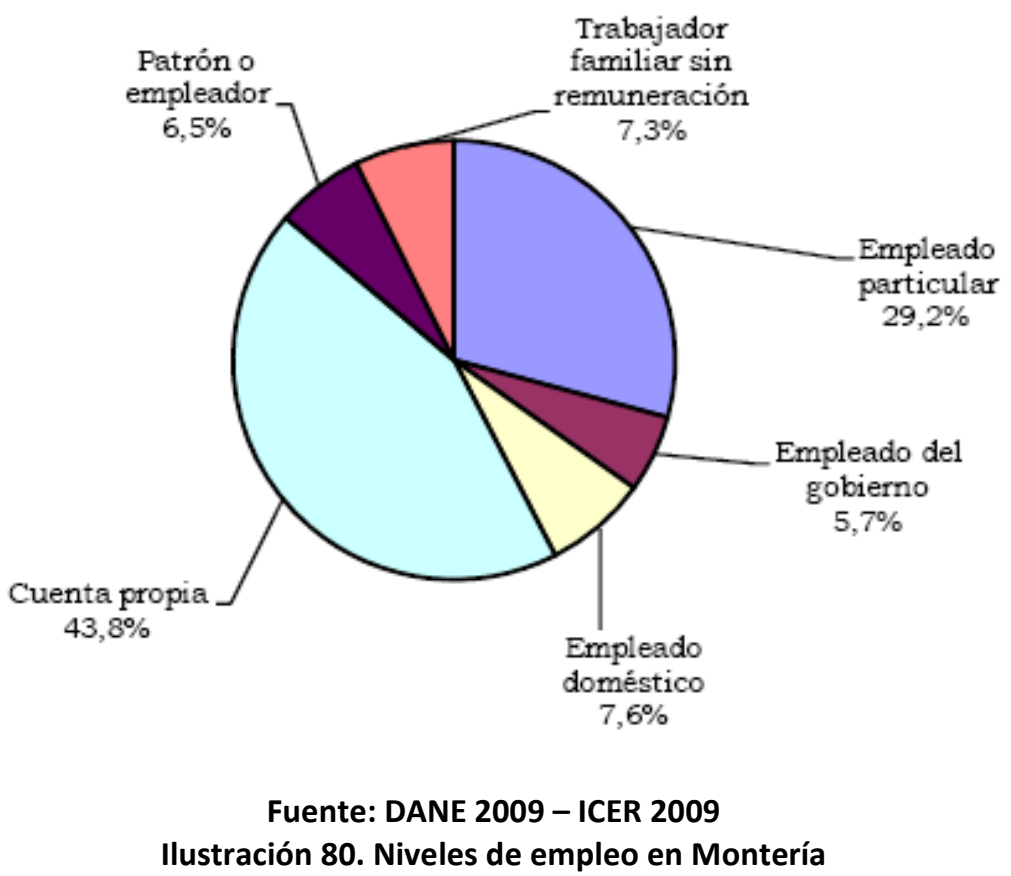

El 14.3\% de desempleados en Montería es un porcentaje demasiado reducido que se obtiene gracias a una metodología destinada a excluir a los parados que se ven obligados a desarrollar actividades informales por cuenta propia, para obtener un ingreso mínimo de subsistencia. Este gran ejército de desempleados figura en las estadísticas oficiales del DANE, como trabajadores por cuenta propia, pero la realidad es que se encuentran por fuera del mercado laboral formal, y marginados de la seguridad social.

Sobre datos relacionados con desempleados de asentamientos informales, Negrete ${ }^{241}$, establece cuatro categorías o estratos para esta población. Estas categorías, denominadas por él como, "La Pobreza dentro de la Pobreza", fueron establecidas de acuerdo a factores socio-económicos, dentro de los cuales sobresalen: ingreso, ocupación, escolaridad y calidad de la vivienda de una población relativamente homogénea. Los niveles van del 1 al 4, correspondiendo el primero al nivel más desfavorable, mientras que el segundo corresponde a las personas que presentan las mejores condiciones del barrio, principalmente en cuanto a ingreso y calidad de la vivienda.

\footnotetext{
${ }^{241}$ Negrete Barrera, Víctor y Otros (1999): Los Asentamientos Subnormales de Montería. Universidad del Sinú. Montería.
} 
En la categoría 1, este autor ubica a los desocupados sin ingresos, a amas de casa dedicadas al lavado de ropa ajena, y jóvenes sin oficio; en la 2, a lavadores de carro, moto, vendedores de pescado, bono loto, lotería, y de jugos; en la 3, a albañiles, maestros de obra, madres comunitarias, modistas, mecánicos, electricistas, ebanistas y conductores, y en la 4, se encuentran los tenderos, comerciantes, prestamistas de dinero y empleados de empresas privadas o del gobierno.

La presente investigación se identifica con la categorización social enunciada, pero considera que tres categorías son suficientes, y que además, hace falta incorporar los oficios desempeñados a partir del año 2000 en el mercado informal de la economía. Estos oficios son básicamente el mototaxismo y los servicios de atención inmediata de telecomunicación móvil e internet SAI, los cuales serán analizados con mayor amplitud en el apartado de impacto económico.

Curiosamente las actividades económicas, tanto formales como informales, en la ciudad de Montería, suelen ser valoradas o estigmatizadas, y con ello también se valora o estigmatiza a la persona que las desempeñe. En este sentido, es común subestimar a priori a vendedores ambulantes de pescado, de refrescos caseros, mototaxistas, recicladores, vendedores de buñuelos, helados, loterías, albañiles, ayudantes de construcción, carpinteros, latoneros (chapistas), mecánicos, pintores, artesanos, lavadores de carros, lavanderas, planchadoras de ropa y servicio domestico.

Sin tener en cuenta dichos prejuicios, sino las condiciones en que la persona desempeña estas actividades, así como el nivel de ingresos y la calidad de vida, esta investigación prefiere clasificar a los residentes de estos asentamientos en tres grupos de población: a) grupo de alta vulnerabilidad; b) grupo de mediana vulnerabilidad, y c) grupo de baja vulnerabilidad. El primer grupo incluye a las personas que no perciben ningún tipo de ingresos; es decir a los desocupados crónicos, adultos en estado de indigencia y amas de casa dedicadas a oficios del hogar en condiciones miserables, quienes son los que presentan absoluto grado de dependencia, ya sea familiar o estatal. 
El segundo grupo o de vulnerabilidad media, incluye a personas dedicadas a actividades informales con fines lícitos, dentro de los cuales sobresalen vendedores ambulantes de todo tipo de alimentos o bebidas, lavadoras o planchadoras de ropa, lavadores de carros, lavadores de motocicletas, albañiles, ayudantes de construcción, maestros de obra, modistas, mecánicos, chapistas, madres comunitarias. Esta población a pesar de sus esfuerzos y dedicación no obtienen el reconocimiento ni el ingreso suficiente que les permita elevar su calidad de vida, pero de una u otra forma, obtienen un ingreso para su supervivencia que disminuye su grado de dependencia.

En el grupo tres se encuentran las personas de mejor nivel de vida del barrio, y dentro de los cuales figuran principalmente los tenderos, comerciantes, panaderos, ferreteros, fabricantes de bloques, prestamistas y propietarios de locutorios. Este grupo solo se conforma después de algunos años de constituido el barrio, específicamente a partir de la fase de semi-consolidación, cuando sus emprendedores comienzan la dinámica económica y social en condiciones de informalidad o sin incorporación a la seguridad social.

\subsubsection{Organización}

Son diversas las organizaciones sociales que se conforman cada año en la ciudad de Montería, las cuales tienen como objetivo mejorar las condiciones de vida de la población que no alcanza a satisfacer sus necesidades básicas ni colectivas. Estas organizaciones son constituidas a su vez, por iniciativas de líderes que coordinan diferentes colectivos en asentamientos informales, destacándose primordialmente colectivos de jóvenes, ancianos, afrocolombianos, indígenas, campesinos, mujer cabeza de hogar, a favor de la equidad de género, cultura, deportistas y ambientalistas.

Las organizaciones sociales en esta ciudad son apoyadas desde el año 2005 por la Red Humana y Social de Córdoba, así como por la Oficina de Participación Comunitaria de la Alcaldía. Este apoyo consiste en complementar, por parte de la administración 
pública, las iniciativas emprendidas por las comunidades hacia la búsqueda del bienestar colectivo y de la defensa de lo público.

Los objetivos y las buenas intenciones de estas instituciones no han sido suficientes para consolidar el tejido social en estos asentamientos y menos en la ciudad de Montería. Hasta estos momentos, los recursos asignados para este fin, no permiten consolidar el entorno barrial como escenario de convivencia, ni fortalecer los procesos de desarrollo humano, participación comunitaria, participación democrática, cultura ciudadana, así como tampoco la defensa de la población más vulnerable o el diseño de acertadas políticas públicas.

En el mismo sentido, no se logró conseguir objetivos relacionados con nuevos esquemas de gerencia social integral propuestos en los diferentes planes de desarrollo de Montería, y que buscaban sobre el papel, la participación directa de la comunidad en la formulación, planeación, ejecución, control y evaluación de los programas o proyectos realizados por la administración municipal. El ambiente social y el surgimiento de actores violentos en el escenario político, han impedido la participación de actores sociales en la toma de decisiones trascendentales para el desarrollo de esta ciudad.

El ambiente de tensión ocasionado por actores violentos como guerrilleros, paramilitares o redes de narcotraficantes, desestimula la participación democrática, la protesta, las veedurías ciudadanas, la investigación social, la elaboración de planes de desarrollo barrial, comunal o corregimental. En este orden de ideas, la planeación, preparación y ejecución de proyectos comunitarios, muchas veces no son el producto de la concertación de la comunidad, sino de la voluntad o intereses de los administradores de turno o de los actores armados; y por cuestiones del mismo sistema político clientelar, generalmente la rentabilidad política o financiera de estos proyectos es antepuesta a la rentabilidad social.

Sin embargo, la evolución de los asentamientos ha sido posible, gracias al esfuerzo colectivo de un reducido sector de la comunidad que organizadamente constituyen las Juntas de Acción Comunal o participan como voluntarios o activistas de organizaciones 
estatales o no gubernamentales como la Red de Solidaridad Social, Instituto Colombiano de Bienestar Familiar, Secretaría de Salud, Cruz Roja, Visión Mundial, Acción Contra el Hambre, Madres Comunitarias, Hogares Comunitarios y Ollas Comunitarias.

\subsubsection{Delincuencia}

Este es un fenómeno que está en ascenso en las principales ciudades del mundo desarrollado y subdesarrollado, y a la cual no escapan las ciudades colombianas y mucho menos una ciudad tan informal como Montería. El incremento de las actividades delictivas ha ido de la mano con la globalización neoliberal, concentración urbana de la población, ingobernabilidad, impunidad, corrupción pública y con la falta de oportunidades de los sectores más vulnerables de la sociedad.

El delito presenta niveles alarmantes en los diferentes continentes del planeta, y actualmente gran parte de las principales ciudades del mundo presentan altos niveles de inseguridad, incluidas europeas y norteamericanas, que padecen fenómenos similares a los de ciudades africanas, asiáticas o latinoamericanas. Este fenómeno suele estar expresado en actividades de narcotráfico, violencia, inseguridad, pandillas, hurtos, atracos, asesinatos, secuestros, extorsiones, violaciones, y hasta xenofobia de jóvenes extremistas. No obstante, la situación más preocupante es el alto número de homicidios ejecutados anualmente en las ciudades latinoamericanas. 


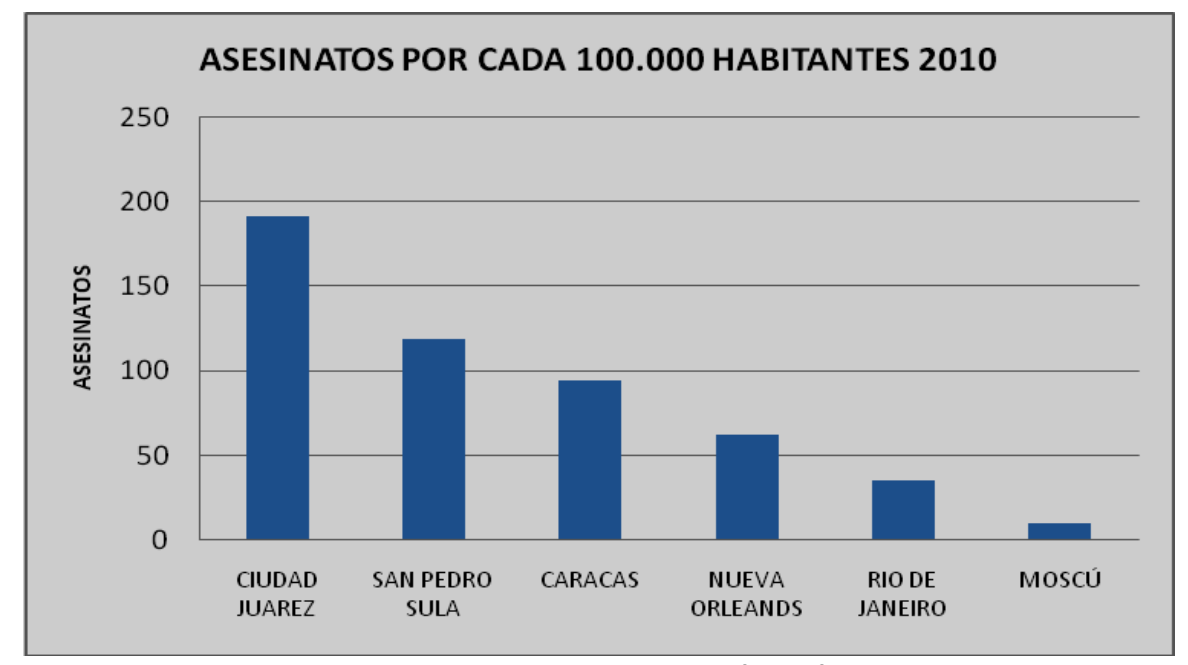

Fuente: Radio Nederland (2010)

llustración 81. Ciudades más inseguras en el mundo

Las diez ciudades más peligrosas del mundo para el 2010 fueron Ciudad Juárez en México, San Pedro Sula en Honduras, Caracas, Nueva Orleans, Moscú, Port Moresby en Nueva Guinea Papúa, Río de Janeiro, Bangkok y Bagdad ${ }^{242}$. Los datos más complicados se presentan en Ciudad Juárez y San Pedro Sula, donde además de los graves problemas urbanos, también padecen por la guerra entre carteles de narcotraficantes, y enfrentamientos entre maras, que luchan por el dominio del negocio de las drogas y el control del territorio; estas situaciones dejan indicadores de 191 asesinatos por cada 100.000 habitantes en la primera, y 119 asesinatos por cada 100.000 habitantes en la segunda.

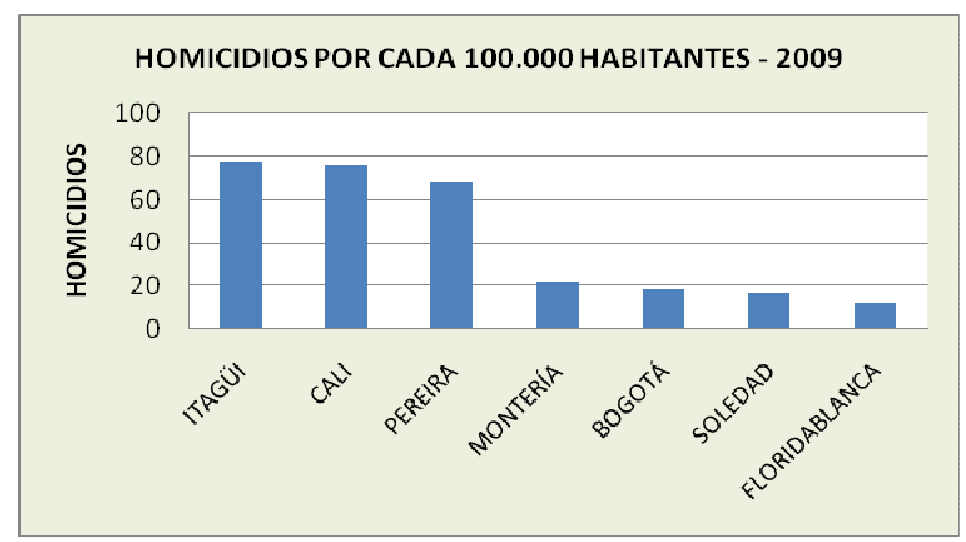

Fuente: Rangel, Alfredo 2010

Ilustración 82. Homicidios en ciudades colombianas

242 Hochgemuth, Marco (2010): “Las diez ciudades más inseguras del mundo". Radio Nederland. Diciembre 8 de 2010. Disponible en http://www.rnw.nl/espanol/article/las-diez-ciudades-masinseguras-del-mundo 
En las ciudades colombianas las cifras de homicidios son inferiores a los datos de las consideradas más peligrosas del mundo, con excepción de Moscú, que registra 9 homicidios por cada 100.000 habitantes. Las menores tasas se encuentran en Bogotá con 19, Soledad, 17 y Floridablanca 12; mientras que las mayores se registran en Itagüí con 78, Cali, 76 y Pereira con 68. Montería ocupa un lugar intermedio con 22 homicidios por cada 100.000 habitantes, pero es la ciudad con mayor incremento de asesinatos en el periodo $2003-2009^{243}$.

En el contexto nacional, la tasa es de 33 homicidios por cada 100.000 habitantes, pero a diferencia de Montería, hubo una disminución del 45\%, al pasar de 29.000 asesinatos en el 2002 a 16.140 en el $2008^{244}$. Esta disminución es el producto del aumento del pie de fuerza pública y del control territorial que ahora ejerce el Estado en zonas tradicionalmente dominada por actores armados del narcotráfico, las guerrillas o paramilitares.

En la década de los años 80, estos grupos armados comenzaron la disputa por el reclutamiento de jóvenes vulnerables y por el control territorial de asentamientos informales de todo el país. Las principales áreas de lucha fueron las comunas de Medellín, Ciudad Bolívar en Bogotá, Distritos Populares de Cali, y los barrios populares de Cartagena, Barranquilla y Montería. En el caso de Montería, los primeros reclutamientos urbanos vinieron del Ejército Popular de Liberación (EPL), y posteriormente de las Autodefensas Campesinas de Córdoba y Urabá (ACCU).

La posterior desmovilización de estos actores armados y la debilidad de la política de reinserción social, permitió que varios centenares de los excombatientes se trasladaran a las principales capitales y a las ciudades intermedias a engrosar los cinturones de miseria. Los empleos generados no fueron suficientes para vincular a cerca de cincuenta mil desmovilizados de los paramilitares y de las guerrillas, lo cual

\footnotetext{
243 Rangel, Alfredo (2010): “Las ciudades más peligrosas". Revista Semana. Julio 31 de 2010. Disponible en http://www.semana.com/noticias-opinion/ciudades-peligrosas/142429.aspx

244 Naranjo, Oscar (2009): Cuarta Rendición de Cuentas sobre Derechos Humanos. Presidencia de la República de Colombia. Disponible en http://web.presidencia.gov.co/sp/2009/enero/19/07192009.html
} 
disparó los niveles de delito y aumentó la inseguridad en las diferentes ciudades de Colombia.

Según datos de la Alta Consejería para la Reintegración, de los cincuenta mil personas que han dejado las armas en el país, 20.883 se capacitaron, 1.200 murieron y 4.500 volvieron a delinquir, de los cuales hay 2.200 detenidos por dichos delitos ${ }^{245}$. En la ciudad de Montería, la oficina de Acción Social registra 1.202 desmovilizados, que se distribuyen principalmente en los asentamientos informales de Cantaclaro, Mocarí, Rancho Grande, Edmundo López, el Poblado, la Candelaria, Villa Cielo, Colina Real, Nueva Esperanza, Alfonso López, Furatena, Ranchos del INAT, Santafé y Villa Paz ${ }^{246}$.

\begin{tabular}{lc}
\hline BARRIO & $N^{\circ}$ DE DESMOVILIZADOS RESIDENTES \\
\hline CANTA CLARO & 165 \\
\hline MOCARÍ & 86 \\
\hline RANCHO GRANDE & 83 \\
\hline LA GRANJA & 60 \\
\hline EDMUNDO LÓPEZ & 50 \\
\hline SANTAFE & 45 \\
\hline LA CANDELARIA & 38 \\
\hline ALFONSO LÓPEZ & 35 \\
\hline VILLA CIELO & 35 \\
\hline COLINA REAL & 29 \\
\hline NUEVA ESPERANZA & 28 \\
\hline EL POBLADO & 25 \\
\hline FURATENA & 19 \\
\hline RANCHOS DEL INAT & 18 \\
VILLA PAZ & 18 \\
\hline Tabla 18. Desmovilizados residentes en Montería \\
\hline
\end{tabular}

Como se anotaba anteriormente, muchas de esas personas se dedicaron a la capacitación, al trabajo, a la informalidad, pero desafortunadamente algunos volvieron

\footnotetext{
245 López, Paula (2009): "Hace falta más plata y compromiso para desmovilizados". El Colombiano. Junio 30 de 2009. Disponible en http://www.elcolombiano.com

246 Garcés y Negrete (2010): Análisis Sociopolítico de Montería y Propuestas de Liderazgo, Participación y Compromiso Ciudadano. Universidad del Sinú. Disponible en http://www.viva.org.co/cajavirtual/svc0211/articulo0848 211.pdf
} 
a reincidir en el delito, incidiendo esto en el número de homicidios, hurtos, atracos, lesiones personales, pandillas, expendios de drogas y lugares clandestinos para la prostitución. En la invasión de Sucre, Cantaclaro, Villa Cielo, Colina Real, Araujos, Robinson Pitalua, el Poblado y Dos de Septiembre, la policía ha desmantelado varias redes y sellado diferentes sitios pero hasta el momento los problemas continúan.

Estos asentamientos pretenden ser controlados, y en algunos casos lo son, por grupos de narcotraficantes que operan de manera organizada con el apoyo de las denominadas bandas criminales (BACRIM), o pandillas juveniles, que se dedican al micro-tráfico de drogas y a la defensa de los territorios, generando situaciones complicadas y tensiones para el resto de la población, las cuales terminan generalmente como víctimas de dichos delincuentes y estigmatizados por algunos sectores de la sociedad.

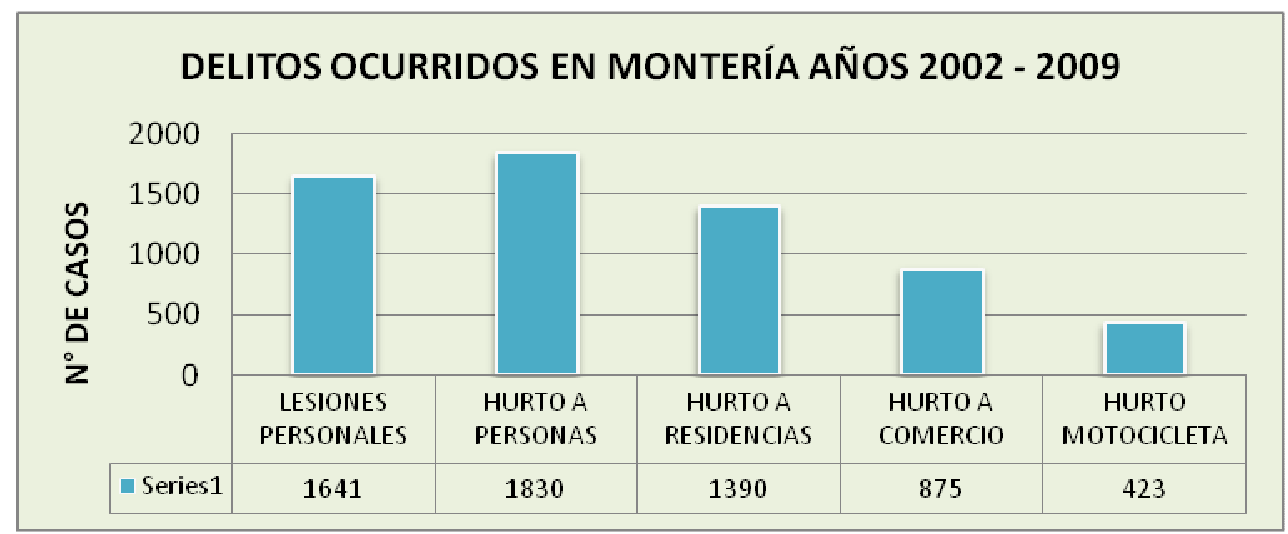

Fuente: Garcés y Negrete (2010)

Ilustración 83. Delitos ocurridos en Montería entre los años 2002 y 2009

Las bandas criminales identificadas por la policía nacional actualmente son la de "los Urabeños", "los Paisas", "las Águilas Negras y "los Rastrojos", las cuales mantienen una violenta disputa por el control del negocio del narcotráfico a nivel nacional. Estas cuatro bandas operan en Montería, y su pie de fuerza había sido estimado por las autoridades locales en 300 hombres para finales del 2009, y a ellas se les sindica de gran parte de los homicidios y de los delitos sucedidos en esta ciudad en los últimos años $^{247}$.

\footnotetext{
${ }^{247}$ Velasco, Henry y Benítez, Rahomir (2010): “Cuantos miembros tienen las Bacrim en el departamento Córdoba". El Meridiano de Córdoba. Montería, 22 de noviembre de 2010.
} 
La presencia de bandas de narcotraficantes es un fenómeno que desplazó a los grupos guerrilleros del dominio territorial que tradicionalmente ejercieron sobre los asentamientos informales en Colombia, principalmente los de las comunas de Medellín, los distritos de Cali y los cerros de Ciudad Bolívar en Bogotá. Sin embargo, es importante precisar que este fenómeno se presenta desde hace mucho tiempo en las chabolas, en las favelas y recientemente en las villas de Argentina ${ }^{248}$.

En este sentido, un significativo número de asentamientos informales latinoamericanos, incluidos los de Montería, terminaron siendo un nicho de mercado importante para esa gran multinacional del delito, denominada narcotráfico, y de cuyas actividades también se desprenden los enfrentamientos violentos, asesinatos, hurtos, venganzas, justicia privada, ejecuciones, violaciones, pandillas, prostitución infantil, extorsiones, secuestros, improductividad económica, corrupción y subdesarrollo crónico.

\footnotetext{
248 En este país, este fenómeno ha sido denominado por las autoridades como "La Favelización de los barrios de emergencia" y sus manifestaciones se traducen en presencia de organizaciones delictivas y redes de narcotraficantes, que con el tiempo van conformando fuerzas de seguridad propia. Más información sobre este aspecto la encuentra en Cuellar, Nicolás (2010): Buenos Aires se faveliza. El Espectador, 21 de diciembre. Sección Internacional.
} 


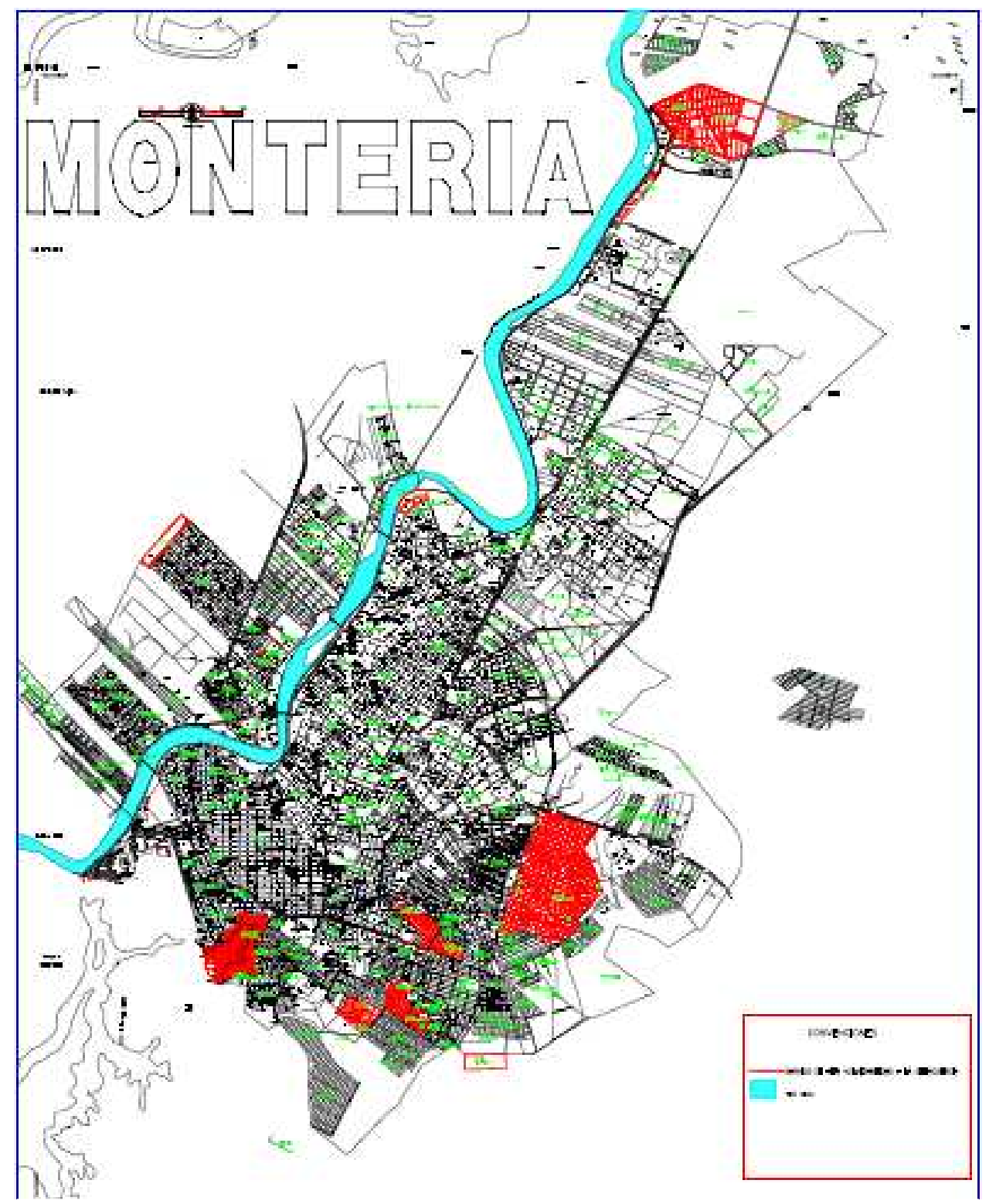

BARRIOS DE MÁS ALTA VULNERABILIDAD AL DELTTO

Fuente: plano elaborado por Elkin Herrera y Jhon Pinedo 2011

Ilustración 84. Barrios de alta vulnerabilidad a la delincuencia

Los anteriores delitos, además de ser reportados periódicamente por la Policía Departamental, también son recreados diariamente por la televisión local y por las páginas judiciales de los diarios El Meridiano de Córdoba y El Universal de Montería. Los asentamientos informales más expuestos a la delincuencia y a las pandillas en estos momentos son: Robinson Pitalua, las Colinas, la Candelaria, Edmundo López, 
Colina Real y el Cerro ${ }^{249}$. Sin embargo, es oportuno anotar que, la gran mayoría de los habitantes de los asentamientos informales son personas pacificas y trabajadoras, que generalmente terminan siendo víctimas de la fuerza, la coerción o intimidación.

Sobre este último aspecto, Cepeda y Rojas ${ }^{250}$, consideran que esta región ha padecido formas extremas de violencia como consecuencia de la lucha por la tierra. En esta disputa se han presentado extorsiones, secuestros, masacres y desapariciones forzadas por parte de grupos guerrilleros y/o paramilitares, en su afán de imponer un modelo social favorable a sus intereses o al de las elites locales.

Estos autores, cuestionan el autoritarismo armado de los grupos guerrilleros y sus barbaridades, así como la imposición de un modelo social de concentración de tierras, dirigido por grupos paramilitares, que logró la monopolización del suelo con la complicidad de las autoridades y de todos los sectores de la sociedad, a expensas de desplazamientos, intimidación por la vía del terror, masacres y usurpación de tierras a gran escala. Critican fuertemente, la consolidación de un modelo paramilitar de control de la sociedad y sus instituciones, que terminó por ser "socialmente aceptado" $^{251}$.

Para finalizar, la delincuencia en Montería ha estado asociada, en sus justas proporciones, a fenómenos como el desplazamiento forzado y la conformación de asentamientos informales. La población de dichos asentamientos, se ve involucrada, directa o indirectamente, en los conflictos generados por los diferentes actores que pretenden tomar el control de sus territorios. También han influido el desempleo y la conformación de los denominados frentes de seguridad ciudadano ${ }^{252}$, los cuales

\footnotetext{
${ }^{249}$ Avendaño, Gudifredo (2010): "Por accionar de Pandillas habrá toque de Queda para menores en Montería". El Tiempo.com Bogotá 7 de abril de 2010. Disponible en http://www.eltiempo.com/archivo/documento/CMS-7551907

${ }^{250}$ Cepeda, Iván y Rojas, Jorge (2008): A las Puertas del Ubérrimo. Nomos Impresores. Bogotá.

251 Ibíd. Pág. 149

252 Los Frentes de Seguridad Ciudadana son redes de civiles legitimadas por el Estado para brindar apoyo a la fuerza pública y seguridad a la comunidad. La operación de estos frentes, al igual que las cooperativas de seguridad privada Convivir, fueron duramente cuestionados por sus excesos y abusos, y porque además facilitaron el acceso de los delincuentes a las armas.
} 
contribuyeron a que muchos civiles se armaran para la protección, pero también para delinquir.

\subsubsection{Participación Ciudadana}

En nuestro contexto no existe la suficiente cultura política que facilite la participación activa de los ciudadanos en los asuntos públicos ni en las decisiones trascendentales para sus barrios o para su ciudad. En este aspecto, Montería se encuentra distante de ciudades de mayor tradición participativa como Bogotá, Medellín, Bucaramanga, Barranquilla, Cali, Manizales y Armenia; en las que, inclusive, siguen abiertos los espacios para la protesta social.

Los derechos consagrados en la Constitución Política de Colombia y la Ley 134 de 1994, brindan instrumentos de participación ciudadana como el Referendo, Plebiscito, Consulta Popular, Revocatoria del Mandato y el Cabildo Abierto. Estos instrumentos, con excepción del último, aún no se han hecho efectivos, pero su aplicación es requerida urgentemente en el control social que los ciudadanos están obligados a realizar sobre los administradores públicos, y sobre la adecuada asignación de recursos que éstos deben realizar para los diferentes proyectos comunitarios.

Tradicionalmente, y como se anotaba en apartado anterior, en este contexto geográfico la clase dirigente ha recurrido sistemáticamente al oscurantismo en su afán obstinado de mantener el poder. El resultado de esta política anacrónica, es una población predominantemente ignorante e indiferente ante asuntos públicos, caracterizada por altos niveles de abstención, o por acceder a participar en los términos clientelistas impuesto por sus gobernantes.

El sistema político impuesto, es un modelo clientelar en el que las dádivas y la demagogia de los aspirantes se ajusta a las ilusiones o necesidades de una población altamente vulnerable y dispuesta a enajenar su voto por empleo, contratos, subsidios, dinero o especie. En este orden de ideas, la democracia en Colombia se ha restringido únicamente a la participación en las elecciones, y los electores terminaron asumiendo que su voto debe tener una retribución personal. 
Con esta percepción, la participación ciudadana siempre ha estado sujeta a una dádiva, que generalmente no alcanza para toda la población, pero que en términos electorales y económicos favorece significativamente a los aspirantes. En estos términos, se degrada la democracia, y a cambio se fortalece la corrupción, la desigualdad, la concentración y la perpetuación de la miseria.

Este modelo opera con mucha fuerza en Montería, y aparte del empleo público, contratos y subsidios escolares, los candidatos también ofrecen lotes, cemento, asbesto, zinc, hierro, pintura, mercados, madera, baldosas, bloques, ladrillos, sanitarios, lavamanos. De esta forma se constituyen, políticamente hablando, matrimonios clientelistas indisolubles, en el que tanto elector como gobernante se aman, pero también se chantajean, se extorsionan, se incumplen, se mienten y en arriesgados casos se llega a la infidelidad.

El clientelismo extermina la participación democrática, la protesta social, el control social e induce a la eterna subordinación, al arribismo, a la ignorancia, a la improductividad. También fomenta la proliferación de asentamientos informales, de invasiones promovidas por políticos a cambio del denominado voto de agradecimiento $^{253}$.

No se puede omitir por ningún motivo, que la consolidación de los asentamientos informales en Montería obedece a una política clientelista iniciada por sus gobernantes locales con la entrega de los primeros lotes en terrenos municipales hace cincuenta años. Posterior a la entrega de lote, siguieron, además de las dadivas anteriormente enunciadas, la instalación de redes, el alumbrado público, subsidios, escrituras, transporte y equipamientos, los cuales se entregaban paralelamente con la fechas de elecciones, y con las respectivas garantías de cada una de las partes.

Sin embargo, el modelo se ha diseñado tan milimétricamente por parte de los gobernantes, que los habitantes de los asentamientos informales, consideran que las

\footnotetext{
${ }^{253}$ El novelista cordobés David Sánchez Juliao, se refiere al voto de agradecimiento como la fidelidad que profesa un elector a un gobernante o gamonal después de haber recibido una dádiva importante, y dentro de la cuales, las más comunes son la vivienda, el lote o el empleo. Más datos sobre el clientelismo político se consigue en. Sánchez Juliao, David (2009): El Hombre que era así: por qué somos tan dejaos....Seminario Andino Editores. Bucaramanga.
} 
intervenciones urbanas o dotaciones públicas realizadas en sus barrios son el producto del altruismo de los dirigentes y no de los impuestos que pagan los ciudadanos. Desde esta óptica, los electores de estos asentamientos siempre se verán obligados a votar por agradecimiento o por el interés de satisfacer necesidades individuales o colectivas.

La peor parte de este perverso modelo radica en que los proyectos no son concertados con la comunidad, ni su realización obedece a necesidades prioritarias, sino a intereses económicos o estratégicos de los dirigentes. Es así como la comunidad ni se entera, ni participa en la elaboración de los planes de desarrollo o planes de ordenamiento territorial, y desconoce todos los instrumentos que le brinda la ley.

No obstante, hay una reducida minoría de hombres y mujeres con gran capacidad de liderazgo, que con mucho esfuerzo logran aceptables avances en materia de servicios básicos y de dotaciones públicas. Sobre la identidad de estos líderes, ya se hizo referencia en el capitulo cuatro de esta investigación, así como de las grandes problemas que ellos perciben en materia de acompañamiento, de participación comunitaria y de compromiso político.

Estos líderes, a pesar de su buena voluntad y su deseo de servir a la comunidad, terminan siendo víctimas, muchas veces, de la falta de compromiso de sus vecinos, y del oportunismo político de algunos dirigentes. Los primeros, carecen de conciencia colectiva y eluden la búsqueda de soluciones y los segundos, los reducen a simples fichas políticas. Tanto los unos como los otros, no reconocen el trabajo del líder y por lo general terminan subestimándolo, estigmatizándolo, relevándolo o degradando su dignidad.

No se puede dejar de reconocer algunos avances en cuanto a participación, pero por el momento no se vislumbra una participación comunitaria libre de manipulaciones políticas y con la autonomía suficiente para mejorar el entorno de los asentamientos informales o la calidad de vida de su gente en tiempos más reducidos. El analfabetismo político, la indiferencia, el conformismo, la apatía, la ausencia de líderes capacitados, y la criminalización de la protesta social, siguen siendo instrumentos desfavorables para el desarrollo urbano, que deben ser replanteados, sobre todo, si se tiene en cuenta 
que éste debe ser un proceso democrático más concertado, o por lo menos más alejado de autoritarismos de gamonales o de actores armados.

\subsection{IMPACTO ECONÓMICO}

En el aspecto económico, muchas de las actividades que se desarrollan en estos asentamientos son de carácter informal, y las personas excluidas del mercado laboral generan sus ingresos a partir de actividades informales de producción, comercialización y consumo de bienes y servicios. No obstante, los ingresos generados en la economía informal ${ }^{254}$, son insuficientes para atender las necesidades de una familia.

La economía informal en Montería es una alternativa de ingresos, pero con fuerte impacto para la población y elevados costos fiscales para el municipio. En primer lugar, deja por fuera de los planes de pensiones y de salud a la mayoría de sus trabajadores y en segundo lugar, disminuye los recursos para la administración municipal debido a la reducción de la base impositiva, lo cual debe ser compensado generalmente mediante subsidios a la salud y mayores impuestos para los propietarios de inmuebles o empresas legales.

El sector informal, a pesar de ser una alternativa de ingresos para el $51 \%$ de la población ocupada, es un constante obstáculo para el desarrollo socio-económico de la ciudad, por la competencia desleal de quienes evaden el Impuesto al Valor Agregado, el Impuesto a la Renta y las Contribuciones Parafiscales de Destinación Especifica, que financian al Instituto Colombiano de Bienestar Familiar (ICBF) y al Servicio Nacional de Aprendizaje (SENA).

\footnotetext{
254 WIEGO (Women in Informal Employement Globalizing and Organizing) propone la siguiente definición: "Todos los trabajadores (rurales y urbanos) que no gozan de un salario constante y suficiente, así como todos los trabajadores a cuenta propia -excepto los técnicos y los profesionales-forman parte de la economía informal. Los pequeños comerciantes y productores, los microemprendedores, los empleados domésticos, los trabajadores a cuenta propia que trabajan en sus respectivas casas y los trabajadores ocasionales (los lustradores, los transportistas, la gente que trabaja a domicilio, por ejemplo en la confección o en la electrónica, y los vendedores ambulantes) integran la categoría informal de la economía". Citado por Lucia Rosales (2007): Reseña sobre la Economía Informal y su Organización en América Latina. Global Labour Institute.
} 
En estas condiciones, toda la carga tributaria recae sobre las escasas empresas formales, lo cual eleva sus costos, y las obliga a disminuir costos laborales como única alternativa de supervivencia en el mercado. Esta disminución se traduce en poca generación de puestos de trabajo y en empleos totalmente precarios, que condenan a los empleados de Montería a vivir eternamente en la absoluta miseria.

Las actividades de la economía informal se desarrollan tanto en áreas formales como informales, y debido a su fuerte dinámica, la población se ve afectada por la invasión del espacio público, los ruidos, olores y vertidos producidos. En muchas oportunidades los residuos generados en diferentes sectores son arrojados de manera irresponsable, obligatoria o inconsciente a las calles o directamente al río Sinú. Sobre este río, también se realiza la explotación informal de materiales como grava y arena, utilizados para la fabricación de bloques y concreto en esta ciudad, así como en otros municipios. Estas explotaciones se realizan sin regulaciones por parte de las autoridades ambientales en zona urbana, a la altura del asentamiento informal Brisas del Sinú, y frente al antiguo hospital San Jerónimo, generando procesos erosivos a lo largo de la rivera de esta fuente hídrica.

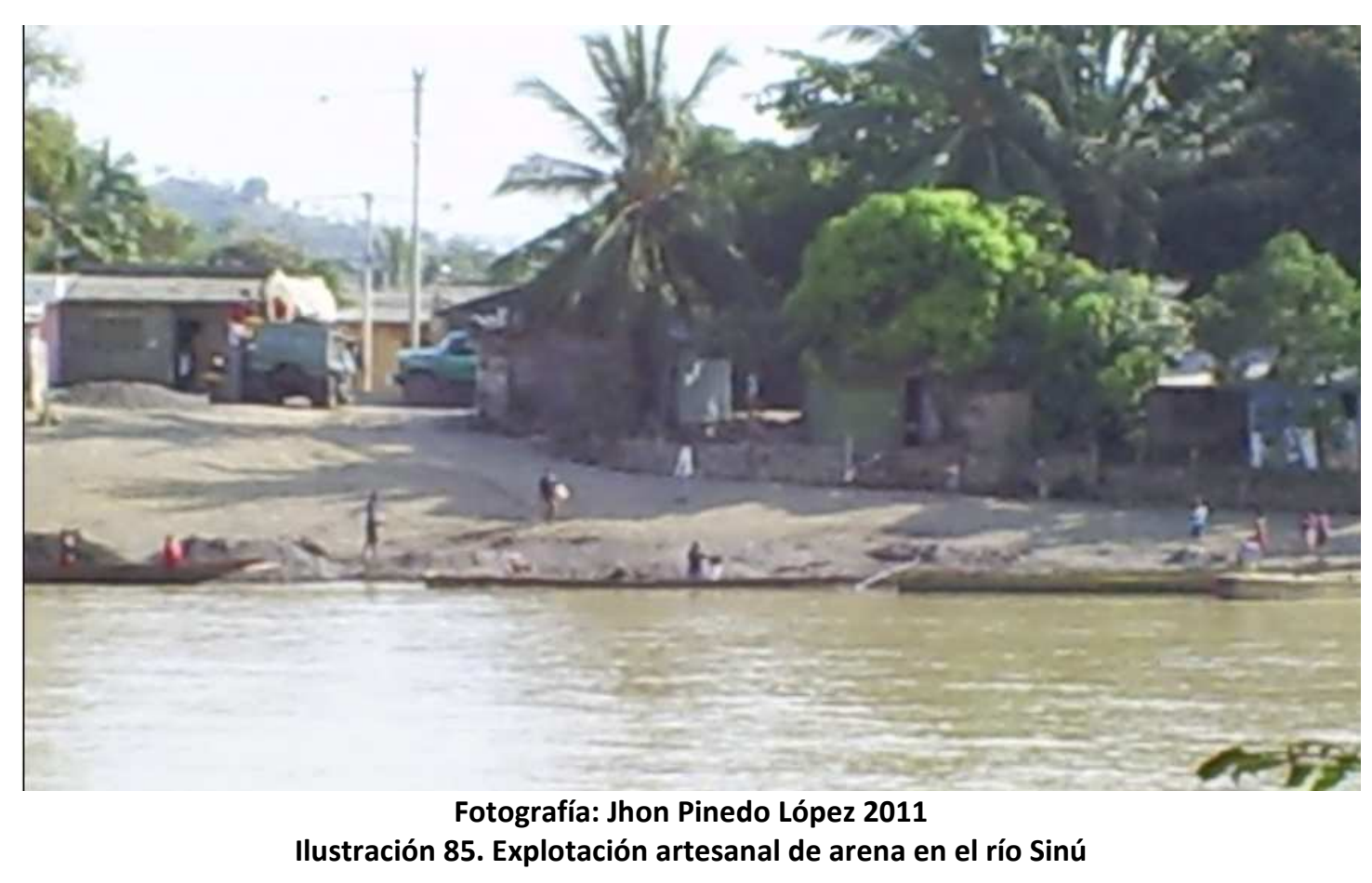


Esta actividad es una fuente de subsistencia, con alta dependencia para las personas dedicadas a ella, quienes, dicho de paso, no tienen otras posibilidades de ingresos económicos por fuera de la misma. En este proceso de extracción de materiales participan diferentes grupos, que van desde los que extraen el material con ayuda de los canoeros, los que descargan, cargadores, hasta llegar a los intermediarios o transportadores.

Por otra parte, los niveles de desempleo que presenta la ciudad se reflejan en las diversas actividades económicas informales ejercidas dentro y fuera de los asentamientos marginales o legalmente constituidos. La tasa de desempleados en Montería, supera el $12 \%$ de la población económicamente activa, establecida en 137.006 personas para una ciudad que cuenta con un total de 378.980 habitantes $^{255}$.

ESTRUCTURA DE LA FUERZA DE TRABAJO AÑO 2006

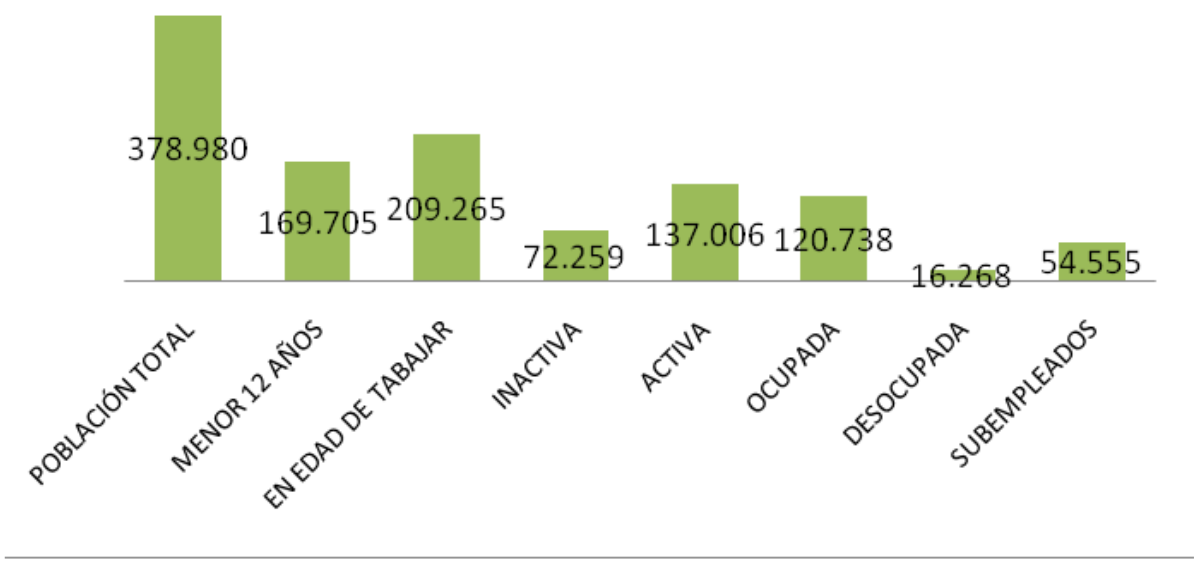

Fuente: POT 2002-2015

llustración 86. Estructura de la fuerza de trabajo en Montería

Las estadísticas construidas por el DANE 2005, registran una población ocupada de 120.738 personas pero no establecen diferencias entre ocupación formal e informal, así como tampoco especifican características del subempleo. No obstante, dichas estadísticas, indican que el nivel de informalidad en esta ciudad asciende al $51 \%$ de la población ocupada, lo cual se manifiesta en los conflictos generados por las actividades que se desarrollan sobre el espacio público, alterando la movilidad en toda la ciudad o la convivencia en los asentamientos informales.

${ }^{255}$ Censo realizado por el Departamento nacional de estadística DANE en el año 2005 y disponible en http:// www.dane.gov.co. 


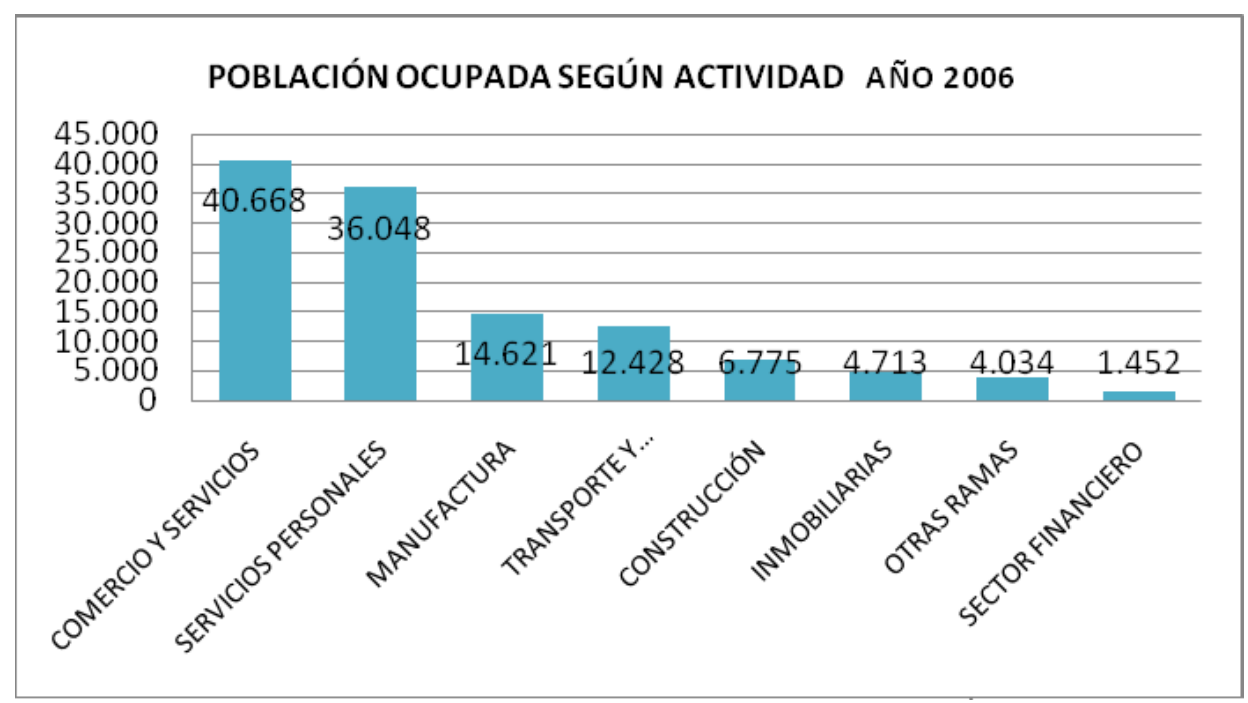

Fuente: POT 2002-2015

Ilustración 87. Población ocupada por actividad en Montería

La estructura económica de Montería depende basicamete del sector terciario, el cual ocupa formal e informalmente aproximadamente al $69 \%$ de la población ocupada. En este sector el mayor número de ocupados se encuentra en el comercio, en los restarurantes, en los hoteles, las discotecas, el transporte, las tiendas de barrio, los talleres, las entidades financieras y las inmobiliarias. Sin embargo, muchas de estas actvidades son desarrolladas de manera informal en el centro de la ciudad y en los asentamientos informales.

La manufactura emplea a casi quince mil personas, el transporte a un número cercano a los trece mil, la construcción a cerca de siete mil y otras actividades asociadas a la ganadería, silvicultura, así como a la agricultura, alcanzan a generar un poco más de cuatro mil ocupaciones. En cada una de estas actividades hay manifestaciones de informalidad, y los casos más evidentes se presentan en el transporte de pasajeros y en la construcción. 


\title{
Población Ocupada
}

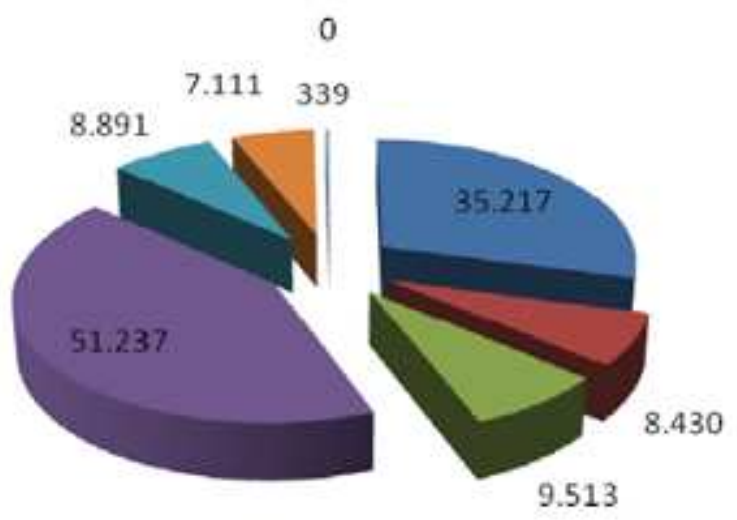

\author{
E Obrero, Empleado \\ particular \\ - Obrero, empleado del \\ gobierno \\ Empleado doméstico \\ - Trabajador por cuenta \\ propia \\ 폴 Patrón o empleador \\ - Trabajador familiar sin \\ remuneración
}

Fuente: DANE 2005 y POT 2002-2015

Ilustración 88. Población empleada en Montería

Dentro de los ocupados que figuran como trabajador por cuenta propia, o como obrero o empleado particular, se encuentran los trabajadores de la construcción, los mototaxistas, los conductores de taxis piratas, de colectivos y de los denominados carros peseros. La mayoría de esta población manifiesta que son propietarios de los automotores, por tanto, también son patrono o empleador; y los que no lo son, mantienen relaciones contractuales verbales y en pocos casos contratos laborales.

Acceden a estos contratos laborales, los conductores que prestan sus servicios a las empresas legales Movitaxi, Metrosinú, y Monteriana de Transporte. También acceden a esta instancia, los trabajadores de la construcción que logran vincularse temporalmente a constructoras reconocidas. Sin embargo, la actividad de construcción de vivienda en esta ciudad, sigue siendo ejercida mayoritariamente por maestros de obras empíricos, contratados de manera informal.

Los trabajadores informales, naturalmente por condiciones de ingreso, residen en barrios de caracteristicas similares, pero no necesarimente todos desarrollan sus actividades dentro del mismo sector y por el contrario dichas actividades se extienden al resto de la ciudad, hasta contagiarla de gran dosis de informalidad. Es importante anotar, que esta informalidad se inscribe en una economía de supervivencia que no permite los procesos de acumulación. 
En este orden de ideas, se recurre a la informalidad con fines licitos de supervivencia y no con fines criminales de acumulación o poder, como suele ser el caso de la informalidad asociada a trafico de armas, de narcoticos, de personas, explotación infantil, explotación sexual, contrabando de licores o de mercancías. No obstante, en estos asentamientos se presentan brotes de violencia, delito e inseguridad como en el resto de la ciudad, del país o del mundo; pero no en las mismas proporciones que se generan en escenarios informales asociados a la ilegalidad criminal.

Por otra parte, la proliferación de actividades económicas informales, asociadas a la saturación del centro de la ciudad, está obligando a las empresas a descentralizar sus servicios hacia nuevas centralidades urbanas como el centro comercial Alamedas del Sinú y Plaza de la Castellana, ubicadas estratégicamente en el norte de la ciudad. En este proceso se encuentran empresas financieras, supermercados de cadenas, restaurantes, almacenes comerciales, telecomunicaciones y servicios de recreación.

Los asentamientos informales no participan de esta descentralización de actividades, ni se ven favorecidos con la ubicación de las nuevas centralidades urbanas de tipo comercial, las cuales son establecidas a grandes distancias de ellos. La capacidad adquisitiva de esta población no garantiza la rentabilidad financiera de grandes proyectos, y la infraestructura física es una limitante que no estimula la inversión de los grandes empresarios.

La ausencia de grandes proyectos en estos sectores estimula las pequeñas inversiones de residentes de estos asentamientos, y permite la formalización de pequeñas manufacturas o establecimientos comerciales. Esta situación se refleja en el número de matriculas para registro mercantil solicitadas por pequeños negocios bajo la figura jurídica de persona natural. 


\begin{tabular}{|c|c|c|c|c|c|}
\hline CLASES & MATRICULAS & RENOVACIÓN & CANCELACIÓN & TOTAL & $\%$ \\
\hline Personas Naturales & 2.657 & 5.873 & 923 & 7.607 & 82,6 \\
\hline Empresas Unipersonales & 106 & 213 & 38 & 281 & 3,1 \\
\hline Sociedades. Limitadas & 216 & 837 & 65 & 988 & 10,7 \\
\hline Sociedades Anónimas & 40 & 142 & 10 & 172 & 1,9 \\
\hline Sociedades Colectivas & 0 & 1 & 0 & 1 & 0,0 \\
\hline Sociedades Comandita Simple & 18 & 46 & 3 & 61 & 0,7 \\
\hline Sociedades Comnndita por Acciones & 0 & 2 & 0 & 2 & 0.0 \\
\hline Sociedades Extranjeras & 0 & 0 & 0 & 0 & 0.0 \\
\hline Empresas Asociativas de Trabajo & 20 & 90 & 15 & 95 & 1,0 \\
\hline $\begin{array}{l}\text { Sociedades Agrarias de } \\
\text { Transformación }\end{array}$ & 0 & 0 & 0 & 0 & 0.0 \\
\hline TOTAL & 3.057 & 7.204 & 1.054 & 9.207 & 100.0 \\
\hline
\end{tabular}

Fuente: Cámara de Comercio y POT 2002-2015

Tabla 19. Registro Mercantil 2008

El total de negocios comerciales registrados para ese mismo año asciende a 10.261 establecimientos, dentro de los cuales también figuran los de barrios informales semiconsolidados o consolidados del occidente, suroriente, norte y oriente de la ciudad. Sin embargo, hay que anotar la gran dinámica económica de los barrios de promoción pública de la Granja, la Pradera, el P-5 y Mogambo, así como su aporte en el número de establecimientos.

Entre tanto, los asentamientos informales de Cantaclaro, Robinson Pitalúa, el Dorado, Villa Cielo y Mocarí se convierten en sectores comercialmente dinámicos, que paulatinamente han ido consolidando subcentralidades en su territorio con la apertura de nuevas tiendas, ferreterías, almacenes, peluquerías, panaderías, cafeterías y restaurantes.

Los equipamientos educativos construidos en Mogambo, Robinson Pitalua, Camilo Torres, Villa Cielo, Cantaclaro, el Dorado, Santander y Policarpa, contribuyen a dinamizar las actividades comerciales en cada uno de estos barrios. Estos equipamientos son lugares de alta concurrencia que posibilitan servicios complementarios de papelería, fotocopiados, alimentos, bebidas, video juegos y locutorios.

El promedio de estudiantes en estos equipamientos es de mil quinientos estudiantes en diferentes jornadas, lo cual se convierte en un estimulo para los vendedores ambulantes a la hora de la entrada o salida de los educandos. Los productos más 
apetecidos en la puerta de las escuelas refrescos, helados y alimentos de preparación casera, que generalmente no superan los $\$ 500$ (\$US 0.25).

Con estos niveles de informalidad en la economía, la ciudad presenta unas condiciones lamentables de competitividad a nivel nacional, lo cual se ve reflejado en la ubicación obtenida en el Indicador Global de Competitividad de las Ciudades Colombianas, elaborado por el Observatorio del Caribe para el año $2008^{256}$. En este estudio, Montería ocupó el puesto veintidós entre 24 ciudades estudiadas, y los factores que se tuvieron en cuenta fueron: recurso humano, ciencia y tecnología, infraestructura, finanzas, gestión empresarial, medioambiente, fortaleza económica, internacionalización y gobierno e instituciones.

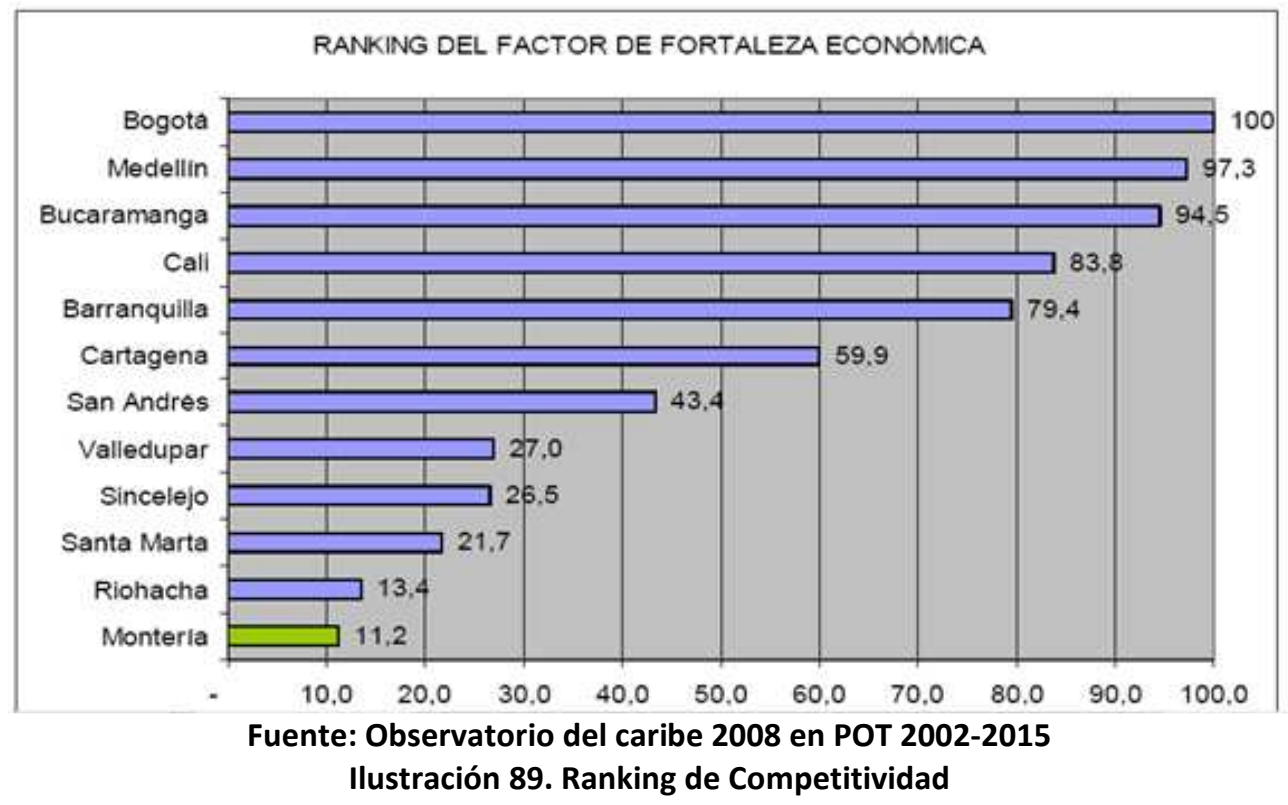

En el ranking global de competitividad, Montería apenas supera a las ciudades de Riohacha y Sincelejo, pero eso no es suficiente para disminuir la enorme distancia que la separa de Barranquilla, Cartagena, Santa Marta, Bucaramanga, Medellín, Cali y Bogotá. Sin embargo, en el factor de fortaleza económica es superada por todas las ciudades del Caribe; este factor mide índice de densidad industrial, necesidades básicas insatisfechas y PIB per cápita.

\footnotetext{
${ }^{256}$ Observatorio del Caribe (2008): Indicador Global de Competitividad de las ciudades colombianas. Documento disponible en: http://www.ocaribe.org/publicacionesinfo.php?la=es\&id publicacion=4
} 
Este bajo nivel de competitividad de nuestra ciudad está determinado por una débil estructura económica, que no cuenta con infraestructura tecnológica, infraestructura física, capital financiero ni grandes empresas. No obstante, la ausencia de estos factores se convierte en un gran estimulo para que sus habitantes desarrollen actividades económicas a pequeñas escalas de manera formal o informal. Dentro de las principales actividades informales se destacan: el comercio, el transporte, las telecomunicaciones, la construcción y la manufactura.

\subsubsection{Comercio Informal}

Esta actividad, es la primera dentro de las cinco principales manifestaciones de la economía informal en Montería, y su análisis se realizó a partir de información obtenida en todos los sectores, incluidos los asentamientos informales. Los datos aquí presentados se obtuvieron por medio de instrumentos como la observación, la entrevista y la encuesta. Esta última fue aplicada durante el año 2007 a mil personas, que fueron seleccionadas de manera intencionada, en el centro y en la periferia de la ciudad.

No fue posible realizar un censo de todos los actores informales de la economía local, pero un registro elaborado por medio de la observación directa, permitió identificar una población informal cercana a la reportada por el DANE ${ }^{257}$. El comercio, en esta modalidad, es una actividad que ocupa aproximadamente a 30.000 personas, el transporte a unas 10.000 , las telecomunicaciones a cerca de 5.000 y la construcción a una cifra similar a esta última.

De las aproximadamente 30.000 personas dedicadas al comercio informal en Montería, cerca de unas 6.000 , son simultáneamente productores y comercializadores de sus productos. Entre el $80 \%$ y $85 \%$ de ellos realizan su producción de manera totalmente artesanal, que por lo general son alimentos o bebidas refrescantes; el restante $15 \%$, la realiza por medio de manufactura a menor escala. Dentro de los

\footnotetext{
257 EI DANE reportó en el año 2005, 51.237 trabajadores por cuenta propia en Montería. Este dato ya aparece en el apartado anterior.
} 
bienes manufacturados se destacan las confecciones, calzado, pan, bloques, ladrillos, ventanas, puertas, y materiales para el aseo.

En los sectores más concurridos, como el centro y algunas subcentralidades ${ }^{258}$ del sur, oriente y occidente de la ciudad, los ingresos de los comerciantes informales son más elevados que en las áreas periféricas y marginales. Las actividades comerciales se realizan de manera ambulante o de forma geoestacionaria, y en pocos casos se pueden realizar de manera mixta; es decir, aquella que combina las dos modalidades, y que es utilizada principalmente para eludir la presión de las autoridades en sitios neurálgicos.

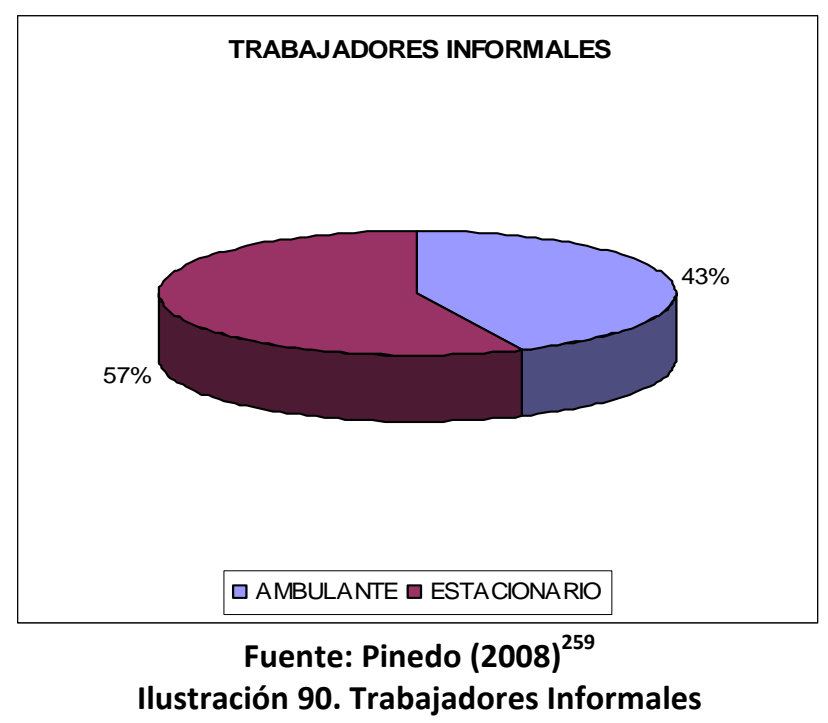

El estudio nos muestra que la población de comerciantes informales corresponde a un $57 \%$ de vendedores estacionarios y un $43 \%$ de vendedores ambulantes. Los vendedores informales estacionarios se ubican, en su gran mayoría, en el centro de la ciudad. Los sectores más críticos se encuentran en las carreras segunda, tercera y cuarta entre calles veintiuna y cuarenta y una. En este sector de la ciudad es donde se

\footnotetext{
${ }^{258}$ En esta investigación se prefiere asignar este término a lo subcentros constituidos en asentamientos informales o formales como Cantaclaro, 2 de Septiembre, Mocarí, Alfonso López, Mogambo, La Granja, La Pradera, El P-5, El Dorado y Juan XXII.

259 Pinedo López, Jhon (2008): Estudio de La Economía Informal en Montería. Ponencia presentada en la Universidad Nacional Sede Medellín. disponible en:

http://www.institutodeestudiosurbanos.com/descargas/doc details/164-estudio-de-la-economiainformal-en-monteria.html
} 
presentan las mayores tensiones sociales y urbanas por la invasión del espacio público y por los elevados niveles de ruido generados por el uso de parlantes y equipos de sonidos. Igualmente se presenta contaminación por residuos sólidos y por vertidos que son arrojados al Río Sinú.
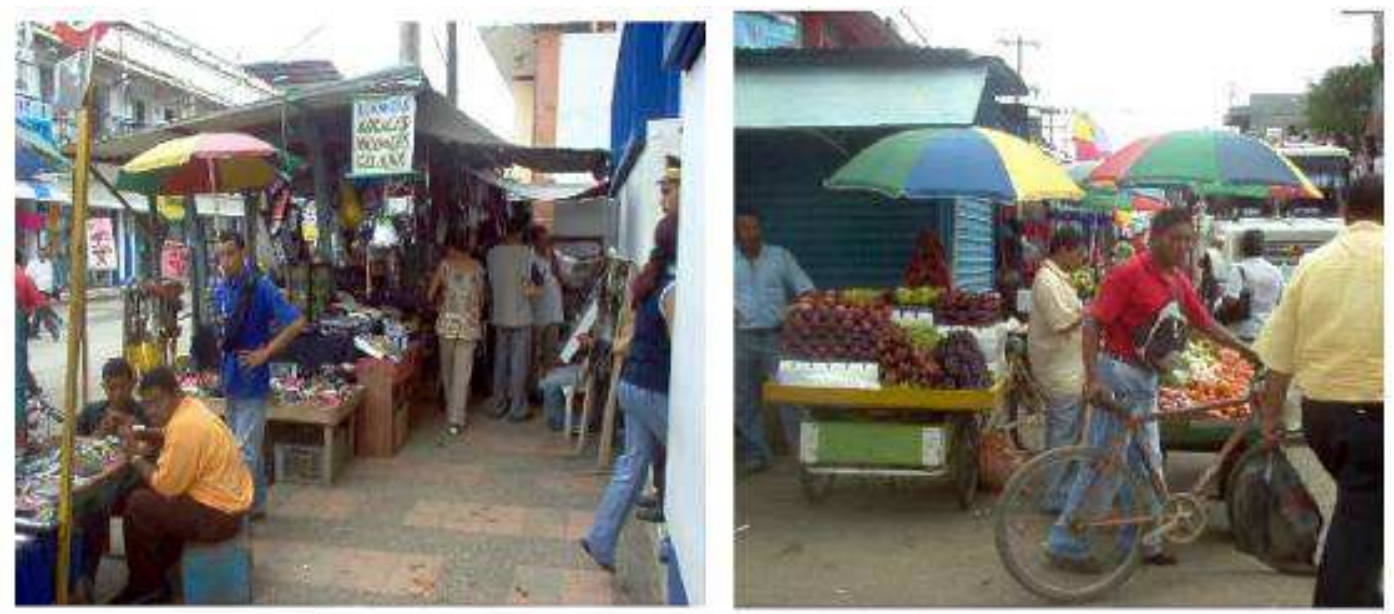

Fotografías: Jhon Pinedo 2007

Ilustración 91. Invasión espacio público por comercio informal

Los vendedores estacionarios se encuentran dispersos igualmente en otros sectores como la Granja, el Prado, Santafé, Santander, la Circunvalar y en los escenarios deportivos. En estos sectores los negocios de consumo y venta de licores sobrepasan de manera irracional los decibeles permitidos en áreas residenciales; se puede incluir dentro de los sectores con elevados niveles de ruido a la calle cuarenta y una entre carreras tercera y circunvalar.

Por otra parte, los vendedores ambulantes generan menos tensiones y conflictos que los estacionarios, sobre todo en el centro de la ciudad, ya que desarrollan sus actividades de forma dinámica y menos traumática, apoyados en vehículos personales como triciclos, bicicletas o carretas de madera.

Las ventas estacionarias en el centro de la ciudad ofrecen electrodomésticos, vestido, calzado y productos de cacharrería tales como; cepillos, cremas, adornos, labiales, baterías, estuches, bolsos, billeteras, correas, cuadernos, lápices, espejos, maletines, morrales, maletas, adornos, cubiertos, platos, vasos y artesanías. Estos comerciantes 
manejan grandes inventarios, nacionales o importados, legales o de contrabando, y además obtienen los ingresos más altos de la población informal.

Los vendedores ambulantes se dedican en su gran mayoría a la comercialización de bebidas y alimentos, tales como: jugos naturales caseros, empanadas, buñuelos, frutas, verduras, rosquillas, diabolines, helados, café, granizados, butifarra, peto, bollos de maíz, arepas, cocadas, panelas, natillas, mazamorra, pescados, carne de cerdo, chorizos, plátanos, agua empacada y toda una variedad de dulces y de pasabolas típicos de la región.

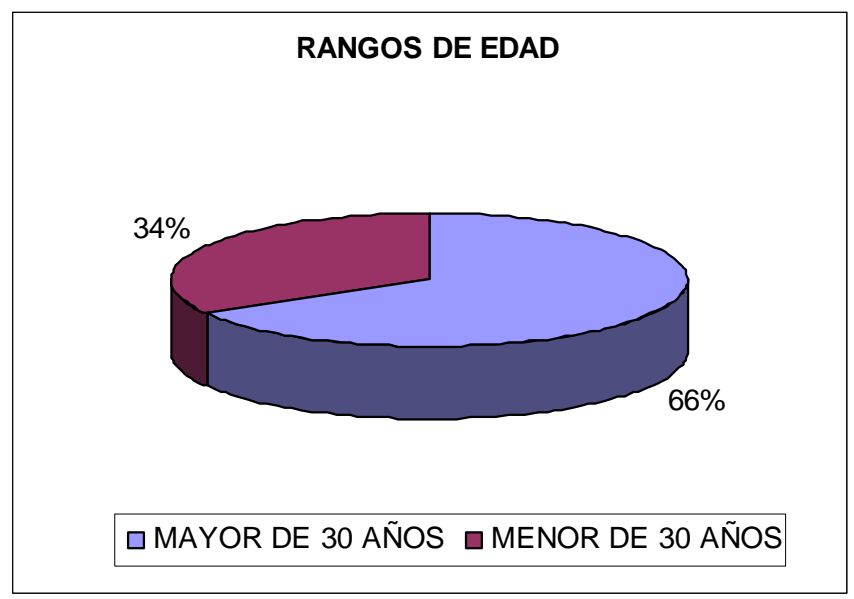

Fuente: Pinedo 2008

Ilustración 92. Rangos de edad de trabajadores informales

La edad se ha convertido en uno de los principales problemas para conseguir empleo en esta ciudad, y así lo manifestaron el $66 \%$ de las personas consultadas, quienes cuentan con más de 30 años y padecen en carne propia las desventajas de competir por trabajos no calificados con jóvenes de menor edad. En algunos casos estas personas han estado empleadas anteriormente y recurren a las actividades informales como alternativa de generación de ingresos por cuenta propia.

Es importante destacar que de este porcentaje un $10 \%$ aproximadamente tiene una edad superior a los 45 años, lo cual hace más difícil la posibilidad de acceder al empleo formal. El panorama más desalentador es para los mayores de 55 años, quienes se encuentran laborando en actividades desfavorables, con bajos niveles de escolaridad y con poca probabilidad de ingresar al mercado laboral. 


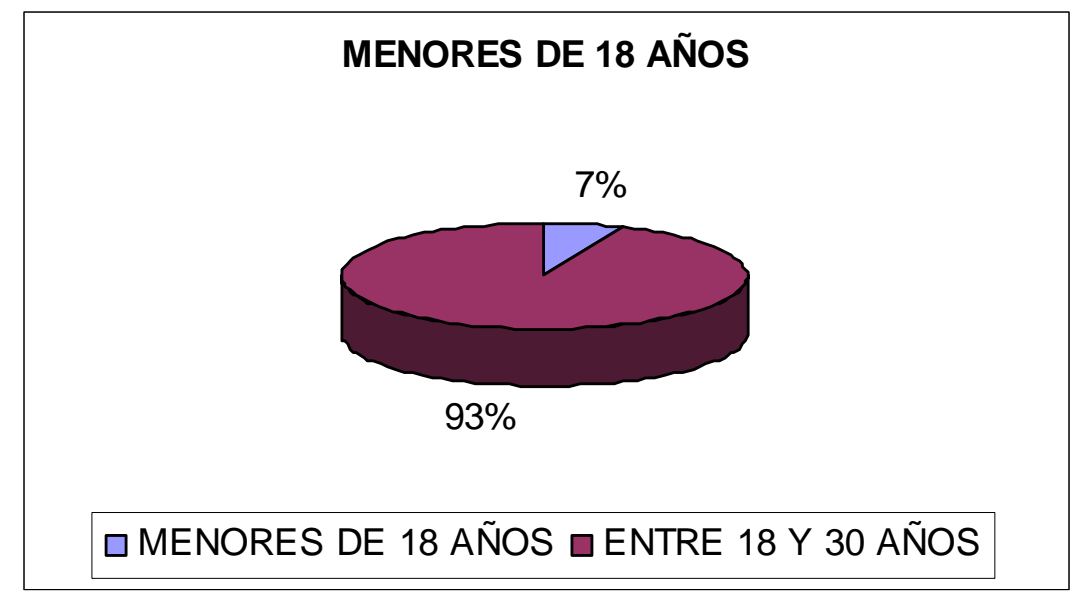

Fuente: Pinedo 2008

llustración 93. Menores de edad en trabajo informal

Los jóvenes menores de 18 años corresponden al 7\% del total menor de 30 años encuestados, y es la población más dinámica y optimista con respecto a su futuro. En este grupo se encuentran estudiantes de bachillerato que combinan sus estudios con las ventas e inclusive jóvenes de instituciones de educación superior de los ciclos técnico y tecnólogo.

En este rango se encuentran adolescentes e infantes quienes colaboran con el sustento de sus familias, y que por lo general se dedican a las ventas de bebidas y alimentos elaboradas por sus padres. Las ventas son realizadas de manera ambulante, preferiblemente en horas diurnas, pero también en horarios nocturnos y durante los fines de semana.

Los sectores más concurridos por este grupo se encuentran en la periferia de la ciudad, en la Granja, el Prado, P-5, Mogambo, Santafé, Santander, Policarpa, Brisas del Sinú, Cantaclaro, Robinson Pitalúa, el Dorado, el Poblado, Alfonso López, los Araujos, los Nogales, 20 de Julio, 7 de Mayo, la Palma y la Pradera y el 6 de Marzo. También realizan sus ventas en eventos populares y en los torneos deportivos que se realizan en los escenarios deportivos de estos mismos barrios. 




Fuente: Pinedo (2008)

Ilustración 94. Trabajadores informales por género

En cuanto al género, la mujer realiza un aporte significativo a este sector de la economía, y su participación corresponde al $29 \%$ del total de los encuestados. En este grupo se encuentran mujeres de todas las edades, que en la mayoría de casos son cabeza de hogar, y se desempeñan como auxiliares de ventas o propietarias de negocios estacionarios en el centro y en los barrios la Granja, Mogambo, la Pradera, Robinson Pitalúa, Cantaclaro y Mocarí.

En el suroriente se concentra las ventas de alimentos y bebidas atendidas por mujeres. Estas ventas se realizan generalmente en los denominados piqueteaderos o puestos de comidas rápidas, los cuales se encuentran dispersos por diferentes barrios informales, preferiblemente en el espacio público, permaneciendo abierto entre las siete de la mañana y las once de la noche, y atendidos por mujeres en compañía de niñas o de adolescentes.

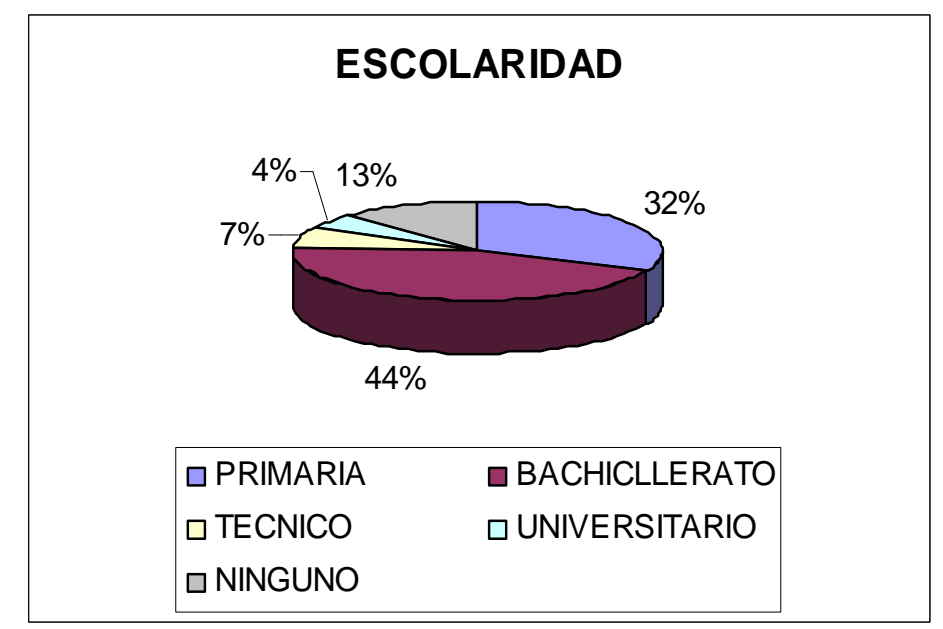

Fuente: Pinedo 2008

Ilustración 95. Niveles de escolaridad de los trabajadores infórmales 
Sobre el nivel formativo de esta población, se evidenció el bajo grado de escolaridad a nivel universitario y técnico, lo cual limita los indicadores de cualificación de más del $80 \%$ de los actores encuestados. Escasamente, el 4\% logró terminar una carrera universitaria y el 7\% obtuvo alguna formación técnica. Sin embargo, la mayor participación de este colectivo, se encuentra representada por personas que apenas realizaron estudios de bachillerato o educación primaria, en proporciones cercanas, al $44 \%$ y $32 \%$, respectivamente; la peor parte, correspondió para el $13 \%$ de los encuestados, principalmente campesinos desplazados por la violencia, quienes manifestaron no tener ningún grado de formación escolar.

Se logró corroborar que, al igual que en la economía formal, las ocupaciones dentro de la informalidad, también se encuentran asociadas a los niveles de escolaridad, así como a las expectativas de ingreso. Las personas con formación universitaria son propietarias de medianos negocios, ubicados generalmente en el centro de la ciudad; mientras que las personas con estudios primarios o sin escolaridad, son las que realizan los trabajos más exigentes y con los ingresos más precarios.

Los trabajadores informales con los ingresos más precarios manifiestan su imposibilidad de cotizar como autónomos a la seguridad social, sea ésta, salud, pensiones o cesantías. Hasta el año 2007 , el $45 \%$ de esta población aún se encontraba por fuera del sistema de salud, lo cual obligó a la administración municipal a gestionar recursos para vincularlos al régimen subsidiado de salud.

El 78\% de estas personas, como es natural, son de la ciudad de Montería, pero se aprecia una significativa participación de migrantes de otros municipios del departamento de Córdoba, como Lorica, Planeta Rica, San Pelayo, Moñitos, Valencia y Tierralta. Así mimo, se nota una presencia significativa de personas llegadas de los vecinos departamentos de Antioquia, Bolívar y Sucre.

Es importante anotar que el $14 \%$ de estas personas provienen de zonas de conflicto armado y que de una u otra forma han sido desplazadas de su lugar de origen. Sin embargo, por el crecimiento y las expectativas que genera esta ciudad, han llegado también personas de regiones más distantes, como Cundinamarca, Santander, 
Risaralda y el Valle del Cauca, quienes naturalmente presentan dificultades de tipo climático o cultural.

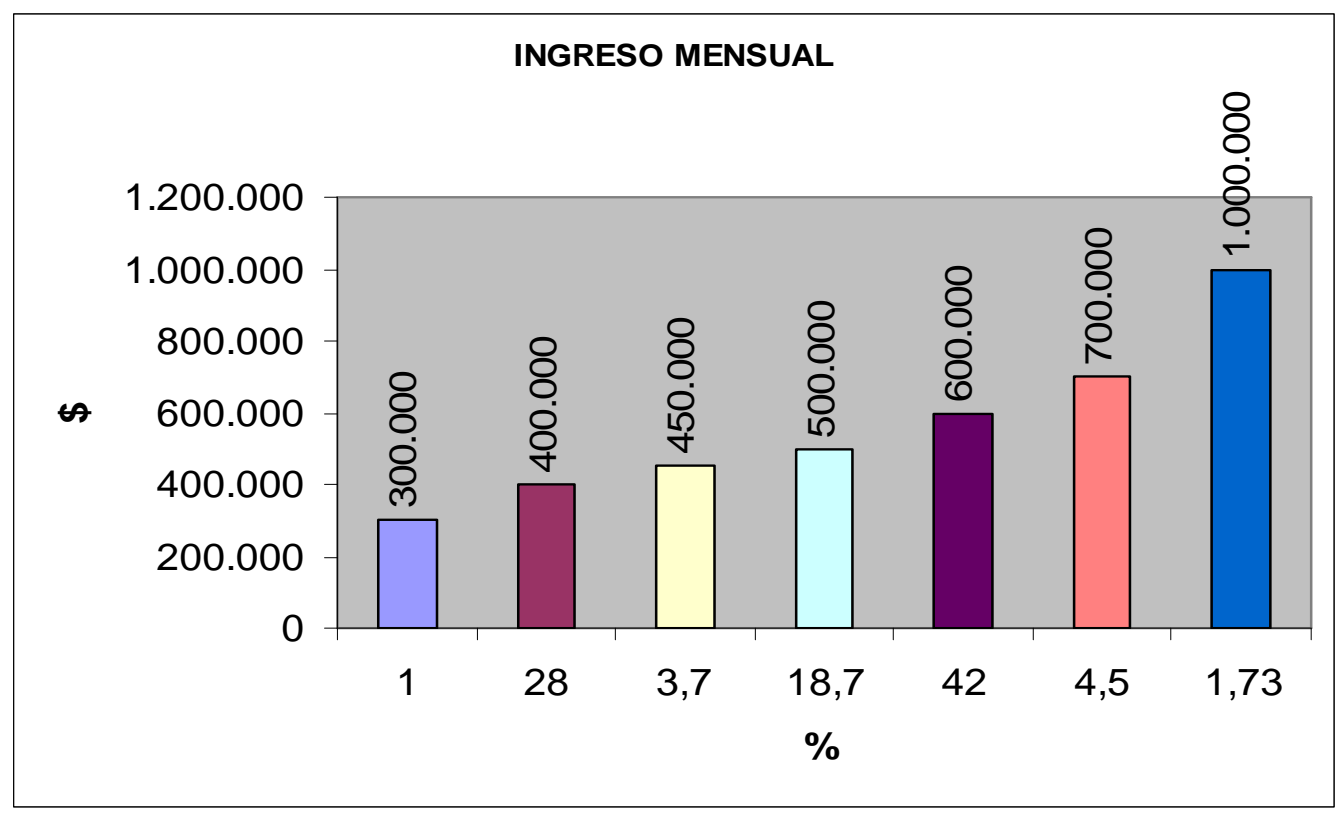

Fuente: Pinedo 2008

Ilustración 96. Ingresos de los comerciantes informales

El ingreso de los trabajadores informales está determinado por la actividad elegida y por el sector donde se realiza. En este aspecto, destacamos que un vendedor informal obtiene ingresos mensuales entre $\$ 300.000$ (\$US 150) y $\$ 1.000 .000$ (\$US 500), para el año 2007, y las actividades que mayores utilidades reportan son aquellas desempeñadas en el centro de la ciudad, con las inversiones más significativas en mercancías y en condiciones excepcionales de ubicación.

Estos ingresos están determinados, evidentemente, por la inversión realizada por cada comerciante o vendedor informal. En el centro de la ciudad, como se anotaba anteriormente, hay inversiones en electrodomésticos, calzado y ropa, que algunas veces sobrepasan $\$ 20.000 .000$ (\$US 10.000 año 2007). Igualmente, hay actividades de aceptable rentabilidad, que no requieren inversiones superiores a $\$ 1.000 .000$ (\$US 500), pero que se constituyen en la principal opción para las personas sin recursos financieros, y sin posibilidades de acceder al crédito.

El $42 \%$ de los encuestados manifiesta tener ingresos mensuales aproximados a $\$ 600.000$ (\$US 300); el $28 \%$ a $\$ 400.000$ (\$US 200); el $18.7 \%$ a $\$ 500.000$ (\$US 250 ); el 
$4.5 \%$ de $\$ 700.000$ (\$US 350); el $3.7 \%$ a $\$ 450.000$ (\$US 225); el $1.73 \%$ a $\$ 1.000 .000$ (\$US 500), y el $1.37 \%$ ni siquiera supera los $\$ 300.000$ (\$US 150) de ingreso por mes. Estas son cifras del 2007, pero destacamos que la contención de los salarios que el Fondo Monetario Internacional impone a varios países latinoamericanos, incluido Colombia, y la política macroeconómica de lucha contra la inflación, no han permitido mayor variación de los ingresos de los colombianos en los últimos cinco años; ni para trabajadores informales ni para empleados formales.

De acuerdo a esta información se infiere que el promedio de ingresos de los trabajadores informales equivale a $\$ 531.800$ (\$US 270). Esta estimación se realiza a pesar de presentarse una pequeña diferencia entre el ingreso de algunos vendedores estacionarios y el de algunos vendedores ambulantes, es decir, los comerciantes estacionarios ubicados en sitios excepcionales del centro y los comerciantes móviles de verduras, legumbres, frutas, y café.

La homogeneidad evidenciada en el ingreso de estos trabajadores permite igualmente estimar que el promedio anual de ingreso por trabajador equivale a $\$ 6.318 .000$ (\$US 3.200). Esta semejanza hace referencia a que cerca del $93 \%$ de los comerciantes perciben ingresos comprendidos entre $\$ 400.000$ (\$US 200) y $\$ 600.000$ (\$US 300) mensuales, y dentro de los cuales, se destacan vendedores ambulantes o estacionarios de productos masivos de consumo, tales como, refrescos, bollos, carnes, quesos, ceviches y pescados.

El estudio realizado permite estimar también que el comercio informal aporta aproximadamente $\$ 204.000 .000 .000$ (\$US 102.000.000 de 2007)) al Producto Interior Bruto de Montería. Esta es una cifra muy significativa, si se tiene en cuenta que los movimientos financieros realizados en esta ciudad en el año 2006 correspondieron a $\$ 350.000 .000$ (\$US 180.000.000) ) $^{260}$.EI PIB de Montería, para el año 2007 ha sido estimado por esta investigación, en \$US $800.000 .000^{261}$.

\footnotetext{
${ }^{260}$ Tasa de cambio de 2007 y datos suministrados por la Superintendencia Financiera.

261 Estimación realizada con base en el PIB 2006 del Departamento de Córdoba que registró el Banco de la Republica.
} 
El desarrollo de la economía informal genera muchos impactos, y uno de los más traumáticos, desde el punto de vista urbanístico, es la invasión del espacio público, la cual es fomentada principalmente, por los vendedores estacionarios que ubican sus negocios en andenes, vías y plazas de la ciudad. Esta situación dificulta la movilidad de las personas y genera fuertes tensiones sociales entre peatones, conductores $y$ comerciantes. El mayor damnificado de esta situación es el peatón, quien frecuentemente es desplazado del andén y obligado a compartir la calle con automóviles, autobuses y motocicletas.

También genera impactos al ambiente que afectan negativamente a los ecosistemas y a la salud, originados por la producción de residuos sólidos o líquidos, por la emisión de ruidos y olores que emanan algunas actividades realizadas a orillas del río Sinú. Estas actividades son el lavado de automóviles y la comercialización de pescado a la altura de la calle 17 y 36, respectivamente, y a las cuales nos referiremos en el apartado sobre impacto ecológico.

Igualmente, es importante anotar, aunque sea de manera breve, el impacto que genera la presencia de prostitutas y recicladores en el centro de la ciudad. Las primeras, son "condenadas" por los sectores más conservadores de esta sociedad, dentro de esquemas doctrinarios y bajo lecciones de moralina; mientras que los segundos, son estigmatizados por un sector más amplio de la población, quienes consideran al reciclaje como una actividad propia de indigentes o drogadictos.

En el centro de Montería, por medio de la observación directa, se pudo identificar ejerciendo la prostitución callejera a cuarenta y dos mujeres, quienes desempeñan sus actividades en horario diurno o nocturno, en condiciones sanitarias desfavorables. Los sitios preferidos para atraer clientes son las calles treinta y seis, treinta y siete y treinta y ocho; con carrera segunda. Por respeto a su dignidad humana no fueron encuestadas, pero en charlas prudentes con algunas, se pudo conocer su bajo nivel escolar, su condición de desplazadas y su residencia en invasiones.

En cuanto al grupo de recicladores, no fue posible realizar un registro directo de ellos, pero se pudo identificar a un número cercano a las trescientas cincuenta personas 
dedicadas a la recolección diaria de los residuos generados en zonas céntricas, residenciales, comerciales e industriales. Algunos de ellos manifiestan estar organizados en una cooperativa y utilizan triciclos o carretas, pero la gran mayoría recicla de manera desorganizada e individual, y además, transportan sus productos sin la ayuda de vehículos.

Finalmente, se puede indicar que el comercio informal aporta aproximadamente el $40 \%$ de los trabajadores informales de Montería, convirtiéndose en una alternativa que no requiere de grandes inversiones de capital. Los comerciantes informales pertenecen a los estratos socioeconómicos 1 o 2, no manejan grandes inventarios ni cupos de crédito, y sus ingresos dependen altamente del lugar, la actividad y de factores exógenos o coyunturales.

\subsubsection{Transporte Informal}

El transporte público en motocicleta o mototaxismo, es un fenómeno surgido en el departamento de Córdoba en el año 1990, pero propagado al Caribe colombiano a mediados de la misma década, y al resto del país a partir del año 2000. Sin embargo, no es fenómeno exclusivo de nuestro contexto, y por el contrario también se presenta desde hace varios años en otros países latinoamericanos y asiáticos. En Colombia, las regiones con mayor impacto son el Caribe y Antioquia, en donde operan 86.000 y 10.000 mototaxistas, respectivamente ${ }^{262}$.

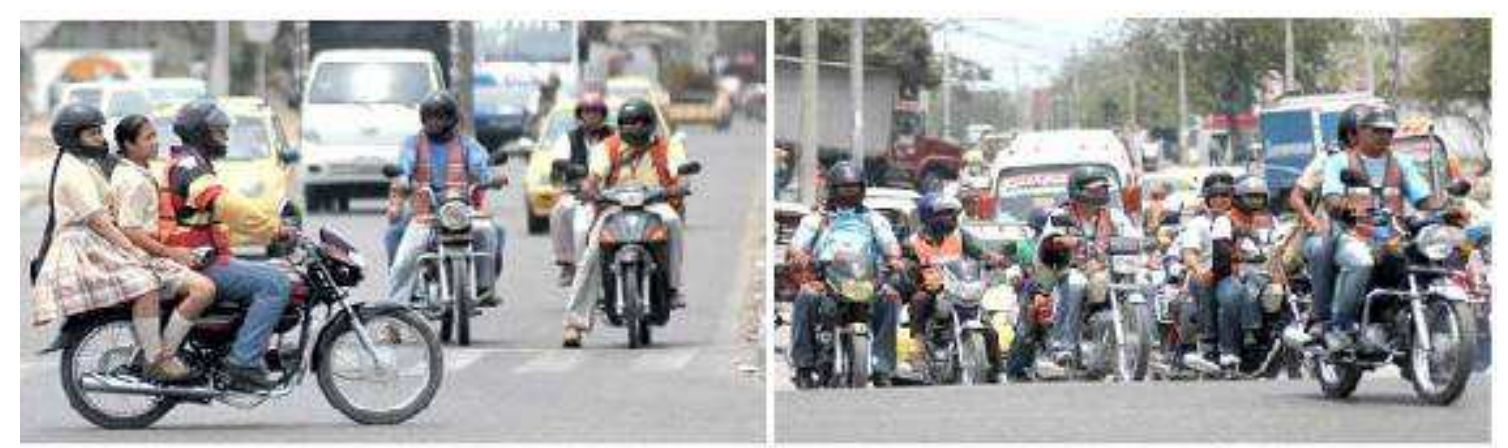

Fuente fotográfica: Diario El Tiempo 2008

llustración 97. Mototaxismo en Colombia

\footnotetext{
262 Diario el Tiempo (2008): "Ineficaces han resultado medidas del Gobierno y de las alcaldías para evitar el aumento del mototaxismo". Redacción. Abril 13. Bogotá. Disponible en el www.eltiempo.com
} 
Según datos del mismo informe del diario El Tiempo, las ciudades con mayor número de mototaxistas en este momento son Barranquilla y Cartagena, con 25.000 y 20.000 operadores de este servicio informal, respectivamente. Posteriormente se encuentran Sincelejo, Montería, Santa Marta, Riohacha y Valledupar con cifras homogéneas que oscilan entre los 5.000 y 10.000 mototaxistas.

Con el objetivo de desestimular esta actividad informal, el gobierno nacional expidió en el año 2006, el Decreto 2961, por medio del cual se dictan medidas tendientes a controlar la prestación del servicio público de transporte en motocicleta. En dicho decreto, se traslada a las administraciones municipales la responsabilidad de restringir la circulación de parrilleros (acompañantes) por zonas de su jurisdicción, o en horarios especiales. También establece sanciones para los infractores, e incorpora multas similares a las previstas en el Código Nacional de Tránsito Terrestre del año 2002.

En septiembre del 2006, el alcalde de Montería León Fidel Ojeda Moreno, expidió el Decreto 0270 que contempla los martes sin moto, los jueves sin parrillero y la prohibición del ingreso de motocicletas con parrillero al centro de la ciudad. Estas determinaciones desataron una protesta frontal de los mototaxistas, que alteró el orden público, dejando 17 detenidos y 43 autobuses semidestruidos ${ }^{263}$.

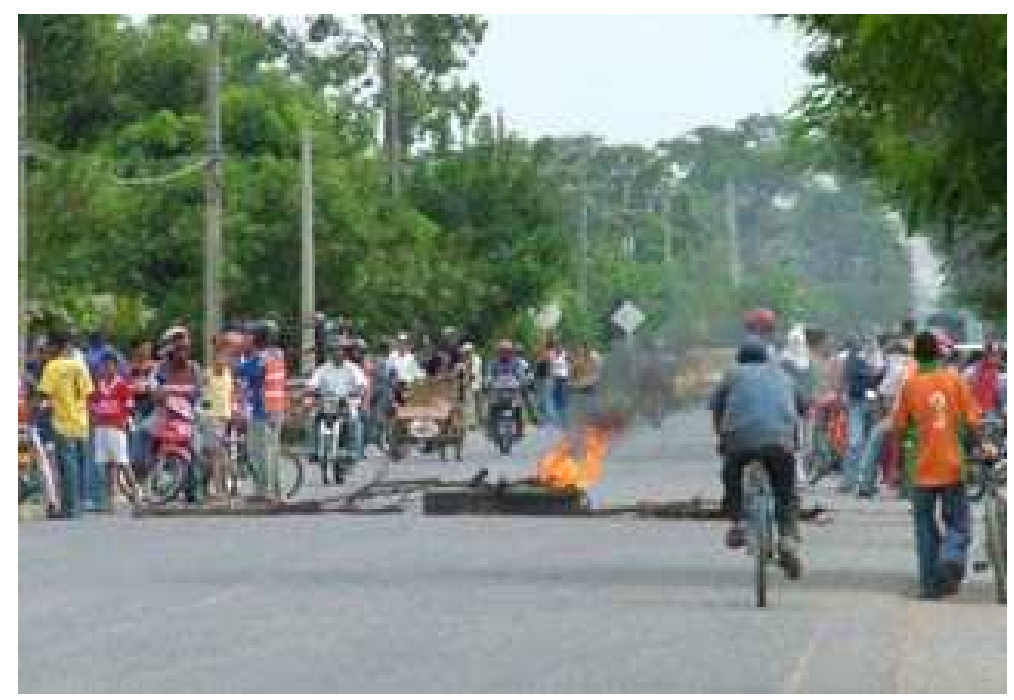

Fuente Fotográfica: El Meridiano de Córdoba 2006 Ilustración 98. Protesta de mototaxistas en Montería

263 Semana (2006): "Que hacer con el Mototaxismo". Redacción. Septiembre 26. Disponible en http://semana.com/wf InfoArticulo.aspx?idArt=96997 
El 8 de septiembre del año 2009, el Alcalde Marcos Daniel Pineda García, expidió el Decreto 0745, que prohíbe la circulación de motocicletas los sábados, domingos y festivos, entre las nueve de la noche y las cinco de la madrugada. Un año más tarde, y ante el entusiasmo generado por una anunciada disminución de la accidentalidad en esta ciudad, el mismo alcalde, prorrogó todas estas restricciones, mediante el Decreto 0716 de 2010.

Como se anotaba anteriormente, las restricciones impuestas a partir del año 2006, tenían como primer objetivo, desestimular el fenómeno ilegal del transporte público en motocicleta, pero dicho objetivo no se cumplió, y por el contario, el fenómeno aumentó desproporcionadamente en todo el país. Este aumento de la actividad informal tuvo mayor impacto en las ciudades del Caribe y en especial en la ciudad de Montería.

En Colombia, el número de transportadores informales en motocicletas pasó de unos 200.000 en el año 2006 a un número cercano a los 500.000 en el $2008^{264}$; mientras que en Montería, según datos entregados por el presidente de la Asociación de Mototaxistas de Córdoba ASOMOCOR, Miguel Ángel Celis Cabeza, se transitó de 3.750 en el 2008 a 7.000 mototaxistas en el $2009^{265}$.

La evidencia deja al descubierto la incapacidad del Estado, para solucionar el problema del mototaxismo, y ha llevado, a funcionarios de las administraciones municipales, a escudarse habilidosamente, en aspectos relacionados con el mejoramiento de la movilidad y la diminución de la tasa de accidentalidad. "Teniendo en cuenta los buenos resultados que hemos obtenido en materia de movilidad, decidimos prorrogar por un año el decreto 0270, que contempla la aplicación de los Martes sin Moto y los Jueves

\footnotetext{
264 Torres, John y Pineda, Viviana (2008): "Aumento del Mototaxismo ya se percibe en varios barrios de Bogotá": Diario El Tiempo. Redacción. Bogotá, mayo 4. Disponible en http://www.eltiempo.com/archivo/documento/CMS-4142083
}

265 El Meridiano de Córdoba (2009): “Mototaxistas se duplicaron". Redacción. Montería, 29 de mayo. Disponible en http://elmeridianodecordoba.com.co/archivo/mototaxistas-se-duplicaron 
Sin Parrillero, además de la prohibición del ingreso de motocicletas con parrillero al centro de la ciudad"266.

La misma funcionaria que difunde satisfactoriamente estos logros, sostiene además, que la disminución en la tasa de accidentalidad vehicular con víctimas mortales presentada entre el 2008 y el 2010, es el fruto de las medidas decretadas en la ciudad. Sin embargo, no hace referencia a las fuertes tensiones sociales, las reales tasas de accidentes menores y los enormes problemas de movilidad a los que se enfrentan peatones y ciclistas, ni mucho menos, al incremento de mototaxistas y de motocicletas. Sobre este último aspecto, es importante anotar que en esta ciudad se encuentran reportadas por el Registro Único Nacional de Tránsito (RUN), en el año 2009, 26.585 motocicletas, lo cual hace estimar que para el año 2010 el número de mototaxistas en Montería, asciende a diez mil.

Sobre las restricciones al uso de motocicletas, resultó demasiado evidente que no fueron el producto de un plan institucional para mejorar la movilidad, sino de la presión ejercida por los empresarios del transporte, quienes comenzaron a sentirse económicamente afectados por las bajas tarifas ofrecidas por el mototaxismo y por la positiva respuesta de los usuarios. En Montería, los empresarios afectados por la competencia informal de transporte fueron los concejales Argemiro Calderón y Héctor Frasser y la ex-aspirante a la Gobernación de Córdoba, Margarita Andrade.

Mientras los empresarios transportan treinta mil pasajeros en un día normal, el mototaxismo transporta ciento sesenta mil usuarios; el martes sin moto transportan setenta y cinco mil, y los jueves sin parrillero logran movilizar a cuarenta y cinco mil personas $^{267}$. Los transportadores manifiestan haber realizado proyecciones para movilizar diariamente 500 pasajeros por autobús, pero escasamente movilizan 320,

\footnotetext{
${ }^{266}$ Secretaria Municipal de Tránsito de Montería. Información Institucional del año 2010. Disponible en http://www.monteria-cordoba.gov.co/sitio.shtml?apc=C1n1--\&x=1731926

${ }^{267}$ El Meridiano de Córdoba (2009): "Vía libre para Pico y Placa de Motos". Redacción, Montería 23 de marzo. Disponible en http://elmeridianodecordoba.com.co/archivo/category/monteria/page/178/
} 
situación ésta, que no les permite operar con los 420 autobuses adquiridos, sino con apenas 170 de ellos ${ }^{268}$.

El mototaxismo logra movilizar ciento sesenta mil pasajeros porque ofrece una tarifa $40 \%$ inferior a la de los autobuses, y porque además prestan un servicio puerta a puerta que estimula aún más a los usuarios. Mientras en el autobús se pagaba en el 2010, \$1400 (\$US 0.8) en la mototaxi se abonaban \$1.000 (\$US 0.6); a esto se suma la baja cobertura del servicio formal, su baja frecuencia y las limitaciones de horario. También incide la inexistencia de algunas rutas que se requieren para interconectar subsectores en el suroriente, o para comunicar el sur con el occidente.

Los datos anteriores y la información obtenida a través de fuentes primarias, permiten indicar que el mototaxismo expulsó del empleo formal a 100 conductores, y cerró la posibilidad de acceso a otros 150 . Igualmente, contribuyó a la precarización de las condiciones laborales de los empleados de las empresas transportadoras, quienes deben garantizar la sostenibilidad financiera de la misma, con jornadas diarias de catorce horas por una remuneración mensual de \$715.000 (\$US 360), año 2010.

La pérdida de doscientos cincuenta empleos formales fue cuantitativamente compensada por cerca de diez mil trabajos informales que ocupan a igual número de mototaxistas, en condiciones desfavorables de seguridad y con fuertes tensiones sociales para la sociedad. Así mismo, el mototaxismo genera ingresos para los propietarios de las motocicletas, ya que no todos los mototaxistas son propietarios de ella; además logra crear empleos formales indirectos y ocupaciones informales complementarias.

Dentro de los empleos formales, se encuentran aquellos generados por: a) apertura de nuevos puntos de venta de motocicletas; b) ampliación de personal en almacenes de repuestos; c) apertura de sucursales en el centro y en la periferia; d) nuevas estaciones de gasolinas; e) entrada de empresas aseguradoras. Estos aspectos se manifiestan en una sostenida demanda por estos vehículos, repuestos, combustibles, lubricantes y

\footnotetext{
268 Figueroa, Hermes (2009): "Mototaxismo desplaza a buses urbanos en la Costa". El Universal, Cartagena 31 de diciembre. http://www.eluniversal.com.co/monter\%C3\%AD/econ\%C3\%B3mica/mototaxismodesplaza-buses-urbanos-en-la-costa
} 
seguros, la cual es atendida actualmente por unas 100 empresas que emplean aproximadamente a 1.500 personas.

Como actividades informales complementarias del mototaxismo definimos a aquellas desempeñadas en los talleres para reparación mecánica, montallantas, lavaderos y parqueaderos. La prestación de estos cuatro servicios se desarrolla en todos los sectores de la ciudad, pero primordialmente presentan una fuerte dinámica en los barrios informales y en tres puntos del río Sinú.

Se encuentran lavaderos, talleres o montallantas reconocidos y bien concurridos en los barrios informales del Dorado, el Poblado, Cantaclaro, 6 de Marzo, 2 de Septiembre, Robinson Pitalúa, Furatena, Camilo Torres, 7 de mayo, Villa Cielo, Mogambito, invasión Sucre, Brisas del Sinú, Santa fe, Alfonso López y Villa Jiménez. Estos servicios también son ofrecidos en el Centro y en barrios consolidados como la Granja, la Pradera la Ribera, P-5, Sucre y Buenavista.

Retornando al mototaxismo, y con la intención de definir características socioeconómicas de su población, es oportuno presentar los resultados de la encuesta realizada aleatoriamente a cien mototaxistas en el año 2007. Dicha encuesta tuvo como objetivo obtener información relacionada con sus ingresos, condiciones de trabajo, nivel de escolaridad, rutas de operación, lugar de residencia, estructura familiar, genero, edad y lugar de origen.

En cuanto a género y edad, se encontró que el mototaxismo es una actividad desarrollada en un $100 \%$ por personal masculino. No obstante, algunos mototaxistas manifestaron estar trabajando en motocicletas alquiladas, cuya propiedad pertenecía a mujeres. En esta actividad informal se desempeñan conductores entre 18 años y 55 años, sin predominio de ningún grupo de edad, lo cual se corrobora diariamente, al observar la gran heterogeneidad de edad en los mototaxistas que circulan por las calles de la ciudad. 


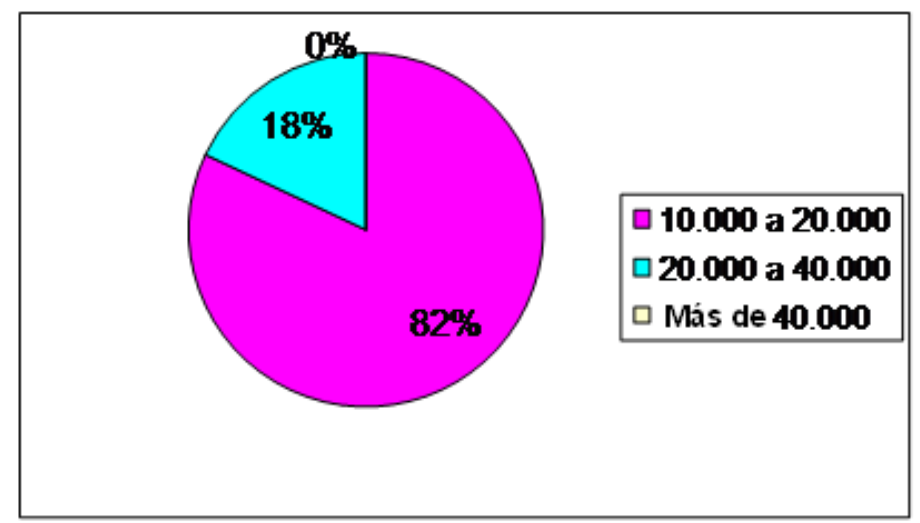

Fuente: Elaboración propia

Ilustración 99. Ingresos diarios de mototaxistas

Los ingresos percibidos diariamente en esta actividad oscilan entre los $\$ 10.000$ y $\$$ 40.000 (\$US 5 - \$US 20), que dependen principalmente del tiempo trabajado y de la propiedad de la motocicleta. Sobre este aspecto hay que destacar que apenas el $32 \%$ de los mototaxistas encuestados, resultaron ser propietarios de la motocicleta y el $68 \%$ debe pagar una cuota diaria de alquiler, establecida en \$12.000 (\$US 6).

A pesar de las extensas jornadas de trabajo, el $82 \%$ de los mototaxistas manifiestan tener ingresos inferiores a $\$ 20.000$ (\$US10), mientras el $12 \%$ expresan entradas superiores, que en ningún caso superan $\$ 40.000$ (\$US 20) diarios. El ingreso promedio de propietarios y conductores en esta ciudad asciende a \$12.000 (\$US 6) día, en una actividad que mueve alrededor de $\$ 240.000 .000$ (\$US 120.000) diarios, equivalentes a unos $\$ 86.400 .000 .000$ (\$US 43.000.000) anuales a precios del $2007^{269}$.

Sobre clima social y condiciones laborales, manifiestan sus tensas relaciones con las autoridades por la continua persecución hacia la actividad, así como su inconformidad por la elevada tarifa de alquiler. Rechazan las extorsiones permanentes de los

\footnotetext{
${ }^{269}$ En el año 2010, estos ingresos se mantenían estancados. Esta inferencia se apoya en información obtenida durante este último año, por medio del método participación acción (como usuario de este transporte), entrevistas a familiares y amigos mototaxistas, e información entregada por el presidente de la Asociación de Mototaxistas de Córdoba, ASOMOCOR, Miguel Celis Cabeza. Adicionalmente, considero importante comentar que en dicho comportamiento inciden tres factores: 1) La tarifa permanece estática en $\$ 1.000$ desde hace seis años y no se ha modificado, a pesar de que el combustible y el transporte público incrementaron sus precios. 2) La duplicación del número de mototaxistas en solo cinco años $(5.000-10.000)$ dificultan el aumento de esa tarifa, manteniendo constante los ingresos o empujándolos a la baja. 3) En los últimos cinco años la inflación en Colombia (IPC) ha estado muy controlada, afectando el aumento nominal de los salarios de los trabajadores. Sin embargo, finalizando el 2010, por algunos recorridos ya comenzaban a cobrar $\$ 1.500$ (\$US 0.75).
} 
primeros, y el oportunismo de los segundos; sobre todo, de aquellos que han llegado a ser propietarios de más de cuarenta motocicletas, gracias a la gran necesidad de los desempleados.

Esta actividad es ejercida en un $80 \%$, por habitantes de asentamientos informales y las rutas iniciales fueron precisamente dichos asentamientos, principalmente los sectores del suroriente que se encontraban incomunicados entre ellos y con el centro de la ciudad. Los barrios más beneficiados inicialmente fueron: Edmundo López, Mogambito, Cantaclaro, Robinsón Pitalúa, la Candelaria, Alfonso López, los Araujos, Villa Cielo, Paz del Río, Rancho Grande, el Dorado y el Poblado.

En la muestra no se registraron personas con formación técnica, tecnológica o universitaria, pero algunos manifiestan conocer a colegas que tienen un nivel de formación superior al bachillerato. Sin embargo, el 21\% manifestó haber terminado el bachillerato y considera que sus ingresos son inferiores a sus capacidades reales, y que además no se les ha brindado la oportunidad de seguirse capacitando o de acceder a un empleo formal. Sobre este último aspecto, el $63 \%$ manifestó no haber estado empleado en empresa alguna.

El mototaxismo es un servicio de transporte informal, pero al mismo tiempo es una alternativa de solución para 500.000 desempleados en Colombia y para un gran sector de usuarios insatisfechos del transporte público colectivo. Como se anotaba anteriormente, este fenómeno permite solucionar el problema de ingresos a unos 10.000 desempleados de Montería y resuelve las dificultades de transporte a más de 100.000 habitantes de esta ciudad.

Permite además, a pesar del riesgo que representa para sus usuarios, el acceso a personas vulnerables de sectores totalmente marginales, quienes pueden movilizarse por tarifas inferiores a las legales. La mototaxi puede representar mayor riesgo para sus pasajeros, pero igualmente significa economía y eficiencia, debido a que garantiza el servicio puerta a puerta que el transporte público colectivo no puede garantizar. 
Igualmente, facilita la comunicación entre el área urbana y zonas rurales cercanas como el Cerrito, Jaraquiel, el Sabanal, los Pericos, Aguas Negras, Guateque, el Vidrial y las Palomas. La frecuencia de las mototaxis es inferior a un minuto y el número de ellas es sesenta veces superior al número de autobuses urbanos y diez veces superior a todos los taxis. Es decir, por cada 10.000 habitantes de Montería hay: 285 mototaxis; 5 autobuses, y 28 taxis.

El mototaxismo, genera también, un fuerte impacto a cerca de mil taxis que operan en la ciudad, ocasionado específicamente, por la amplia diferencia entre sus tarifas. Una carrera en mototaxi es $75 \%$ inferior al precio que se paga por una carrera en taxi; mientras en la primera la tarifa es de $\$ 1.000$ (\$US 0.5), en el segundo, la misma asciende a $\$ 4.000$ en el año 2010. Esta diferencia desplaza la demanda del taxi, y obliga a los taxistas, en un acto de supervivencia, a ofrecer el servicio de transporte colectivo de manera clandestina.

Como acto de supervivencia, impulsa a los taxistas, aunque de manera desigual, a transportar a pasajeros colectivamente ( $\$ 1.000$ cada uno), lo cual permite competir más cómodamente con los mototaxistas, pero afectando aún más a las empresas de transporte público colectivo, Metrosinú y Monteriana Móvil. Esta competencia es más evidente en las rutas de la Pradera, Cantaclaro, Juan XXIII, la Granja, Rancho Grande, el Dorado y Mocarí.

Mención especial, en este apartado de transporte informal, merecen los carros $\operatorname{peseros}^{270}$ que desde el año 1976, vienen prestando este servicio a los habitantes del Barrio Alfonso López. Estos vehículos son camperos marcas Aro Carpati, Gas y Was, con más de 50 años de existencia, los cuales fueron habilitados desde la década mencionada para cubrir las rutas de Santafé - Santander, Calle 24 - la Julia - CamajónP-5 y Principal - Alfonso López.

\footnotetext{
270 El motivo de esta denominación obedece a que cuando estos carros iniciaron operaciones de transporte público colectivo en el año de 1976 el valor del servicio equivalía a \$1 (\$1.000 del año 2010).
} 


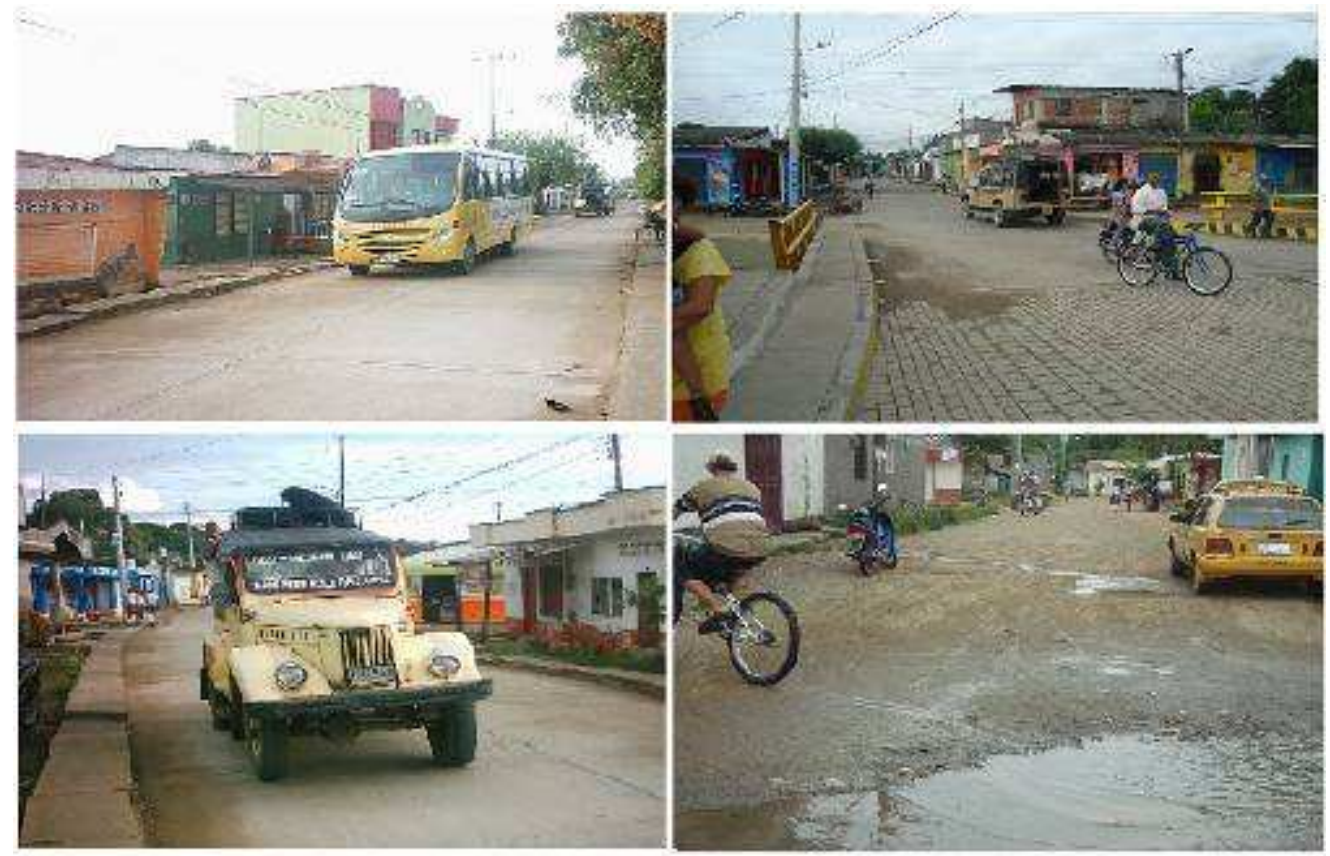

Fuente Fotográfica: Estudiantes Institución Educativa Villa Margarita 2009 Ilustración 100. Medios alternativos de transporte

Los carros peseros son vehículos no apropiados para transporte público de pasajeros, demasiado obsoletos, con capacidad para ocho personas, que frecuentemente llevan sobrecupo de tres personas, al transportar ocho pasajeros en la parte posterior y dos al lado del conductor. Sin cumplir las más mínimas normas legales para transportar pasajeros y al margen de cualquier protocolo de seguridad, actualmente se mantienen activos y con permiso de circulación, una docena de estos vehículos, en la ruta Principal-Alfonso López-Araujos, los cuales generan 24 puestos informales para 12 conductores y 12 cobradores.

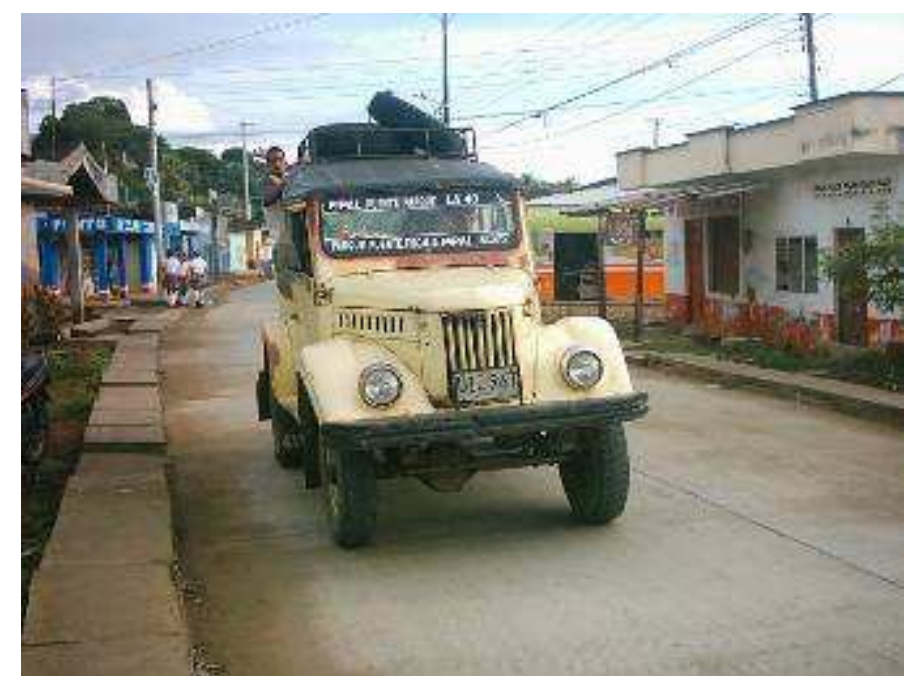

Fuente Fotográfica: Estudiantes Institución Villa Margarita 2009 Ilustración 101. Vehiculo Pesero modelo año 60 
Concluimos entonces, que el transporte informal en Montería, tiene diferentes manifestaciones, las cuales comienzan con el mototaxismo; continúan con el transporte colectivo, en taxis no autorizados para ello, y se extienden a la permanencia de los carros peseros. Todas estas manifestaciones resuelven las necesidades de la demanda y contribuyen a la generación de puestos informales de trabajo, con el aval o la complicidad de la clase dirigente, empresarios, autoridades, y por supuesto, de toda la población de los barrios marginales de esta ciudad.

\subsubsection{Servicio de telecomunicación Informal}

Esta actividad consiste en la reventa o posventa de minutos que realiza, de manera espontánea o concertada, el suscriptor de una línea de telefonía móvil a una tercera persona. Esta modalidad surge a partir de los elevados costos que representan la telefonía celular prepagada, la comunicación entre operadores distintos y la comunicación por telefonía fija en Colombia.

La reventa de minutos por parte de un suscriptor es una operación legal, que no se encuentra tipificada como delito en Colombia, ni es un acto orientado al fraude de personas naturales o jurídicas. Sin embargo, la actividad se convierte en informal cuando el suscriptor ofrece su línea telefónica, con fines mercantiles, en sitios no autorizados, en el espacio público o en negocios particulares que no han sido legalmente constituidos para dicho fin.

Al igual que en el mototaxismo, en el cual hay propietarios que viven del alquiler de sus motocicletas, en la telecomunicación informal, también se encuentran suscriptores que adquieren varia líneas telefónicas con el objetivo de explotarlas directamente en locutorios o por medio de intermediarios, a los que promete una comisión, estipulada de acuerdo con el valor de reventa de cada minuto.

El auge de este negocio es el producto de la economía que representa para los usuarios carentes de planes pospago, a quienes el minuto a operadores diferentes les cuesta en promedio $\$ 1.000$ (\$US 0.5), mientras en la calle se consigue en $\$ 200$ o $\$ 300$. 
Estas tarifas callejeras son posibles debido a los paquetes pospagos de 2.000 y 4.000 minutos, a los que solamente pueden acceder personas con solvencia económica o capacidad crediticia.

Estos paquetes, con costo promedio de $\$ 50 /$ minuto, fueron ofrecidos inicialmente a ejecutivos, pero terminaron siendo adquiridas por diversas personas que aprovecharon la posibilidad de ingresos adicionales ofrecidas por el mercado. Es importante anotar que para el acceso a esto planes, las empresas de telecomunicaciones exigen requisitos complejos que impiden el acceso del ciudadano medio.

El mencionado auge mercantil de la actividad, se sustenta en el acelerado incremento que tuvieron las líneas de telefonía móvil en apenas 15 años de operación en Colombia. El número de líneas pasó de 2.950 .000 en 1995 , año de inicio de operaciones en el país, a 37.854.564 en $2008^{271}$. Esta misma fuente, estima que la reventa de minutos, en calles o cabinas, ocupa a unos 500.000 colombianos en el territorio nacional; sin seguridad social, prestaciones o salarios, y con ingresos mensuales que apenas oscilan entre los $\$ 350.000$ y $\$ 450.000$ (\$US 170-220) del año 2009.

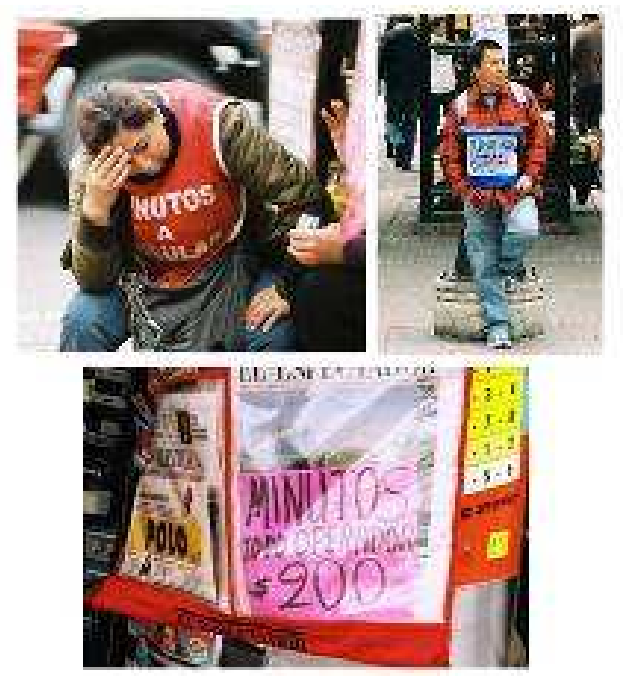

Fuente Fotográfica: El Tiempo 2009

Ilustración 102. Revendedores callejeros de minutos a celular en Colombia

\footnotetext{
${ }^{271}$ Datos suministrados por el Senador Iván Moreno Rojas en Ponencia Presentada en el Congreso de la República en septiembre del año 2009, en el Debate que buscaba defender la legalidad de la reventa de minutos en Cabina. Disponible en http://adecintel.blogia.com/2009/040508-reventa-de-minutos-decelular-no-es-ilegal.php
} 
Para controlar la proliferación de esta actividad se aprobó la Ley 1032 de 2006, la cual buscaba impedir la reventa de minutos por celular. Esta Ley resultó insuficiente y no pudo ser ejecutada por las autoridades, debido a que los revendedores siempre mantienen los documentos legales que acreditan el contrato entre un operador de telefonía celular y un usuario; por tanto, en este caso, el servicio de telecomunicaciones opera con autorización previa, no puede ser considerado clandestino ni la policía puede decomisar equipos.

Esta ley fue el producto de la presión ejercida por las tres compañías que controlan la telefonía celular en Colombia: Comcel, Telefónica- Movistar, y Tigo. Los representantes de dichas compañías sostenían que los contratos suscritos con particulares cubrían el uso personal y no el de comercio en las calles, ante lo cual los revendedores se vieron en la obligación de organizarse para lograr una salida legal que finalmente se obtuvo en debate del Congreso de La República en septiembre del 2009.

Este respaldo permitió la constitución legal de miles de locutorios en el país, pero también expandió la venta callejera en las grandes, medianas y pequeñas ciudades del territorio colombiano. No hubo excepciones y la actividad informal se convirtió en otra importante alternativa de ingresos, para los tres millones de desempleados, que en promedio, sigue reportando anualmente el Departamento Nacional de Estadística DANE.

En el caso especifico de Montería, la reventa de minutos ha seguido la misma dinámica del país, fomentando la apertura de los denominados Café-Internet ${ }^{272}$ y la proliferación de revendedores en tiendas, papelerías, almacenes, peluquerías, notarías, escenarios deportivos, restaurantes, cafeterías, plazas, parques, jardines, calles, andenes y en las puertas de sitios concurridos como iglesias, escuelas, universidades y centros comerciales.

Los vendedores de minutos operan en toda la ciudad y sus horarios son establecidos de acuerdo con el uso del suelo o con la actividad desarrollada en las diferentes zonas 272 También conocidos localmente como Servicios de Atención Inmediata (SAI). Son empresas
unipersonales legalmente constituidas y prestan los mismos servicios que los locutorios de España. 
residenciales, ya sean formales o informales. Se encuentra una gran presencia de ellos en los parques Laureano Gómez, Simón Bolívar, del Campesino, Montería Moderno, Inmediaciones de la catedral San Jerónimo, del Centro Comercial Alamedas del Sinú, de la Universidad del Sinú, del terminal de transporte y de las plazas de mercado del centro y del sur.

En la zona céntrica viven de la reventa de minutos unas 500 personas aproximadamente, quienes atienden de pie o en improvisados despachos portátiles al aire libre -una pequeña mesa y silla-, en jornadas que se inician a las 7: $00 \mathrm{AM}$ y se extienden hasta las 7:00 PM. Este horario está condicionado por las actividades formales que desarrollan las sedes administrativas, eclesiásticas, judiciales y financieras del municipio de lunes a viernes, entre las 8: $00 \mathrm{AM}$ y 6:00 PM.

Los revendedores de esta zona se encuentran dotados por dos o tres teléfonos, especialmente los que se ubican en las afueras de la alcaldía, la gobernación, los juzgados, parque Laureano Gómez, catedral San Jerónimo, notarías y Concejo municipal. En estos sitios operan unos 250 informales, que en el 50\% de los casos, no son propietarios de las líneas, sino que trabajan para "empresarios" de la informalidad; en promedio venden 200 minutos diarios a tarifas de $\$ 200$ y obtienen ingresos diarios entre \$15.000 y \$20.000 (\$US 8 - \$US 10) del año 2010.

Los otros 250 vendedores de la zona céntrica se encuentran ubicados en zonas aledañas a los Bancos Davivienda, Colmena, Colombia, Conavi, BBVA, Bogotá, Colpatria y Santander Central Hispano de la calle 29 con Carrera 3. Igualmente, se ubican en la Torre Garcés, parque Montería Moderno, Calle 41, Centro Comercial Montecentro, Academia Sandra, Mercado Central, Clínica Zaima, Urgencias de Saludcoop, Almacenes Éxito Centro, Supertiendas Olímpica de la calle 31, Edificio de la DIAN, Telecom, Centro Familiar Cristiano Calle 35 y San Andresito de la Calle 36.

Es importante anotar que en la zona céntrica funcionaban en el año 2010, unos treinta y cinco café internet legalmente constituidos, ubicados principalmente en zonas aledañas a la Universidad Cooperativa de Colombia, la Corporación Unificada de Educación Superior CUN, Corporación Educativa del Caribe CECAR, UNIREMINTON, 
UNICIENCIA, Tecnológico San Agustín, CESCOR, Colegio la Inmaculada, Cámara de Comercio, Comando de Policía y Universidad del Sinú, sede de Postgrados.

Esta gran dinámica también es observada en áreas residenciales, en las que coexisten armónicamente numerosas SAI con revendedores informales de minutos, y en donde, a diferencia de las zonas céntricas, los revendedores de minutos no atienden de pie, sino que se instalan estratégicamente en tiendas, almacenes, casas de apuestas, papelerías, heladerías, viviendas esquineras, iglesias, panaderías y portales de escuelas. La jornada laboral en estos sectores, se establece de acuerdo con las actividades escolares o comerciales que se desarrollan en ellos, y las cuales muchas veces se extienden hasta las 9 o 10 de la noche.

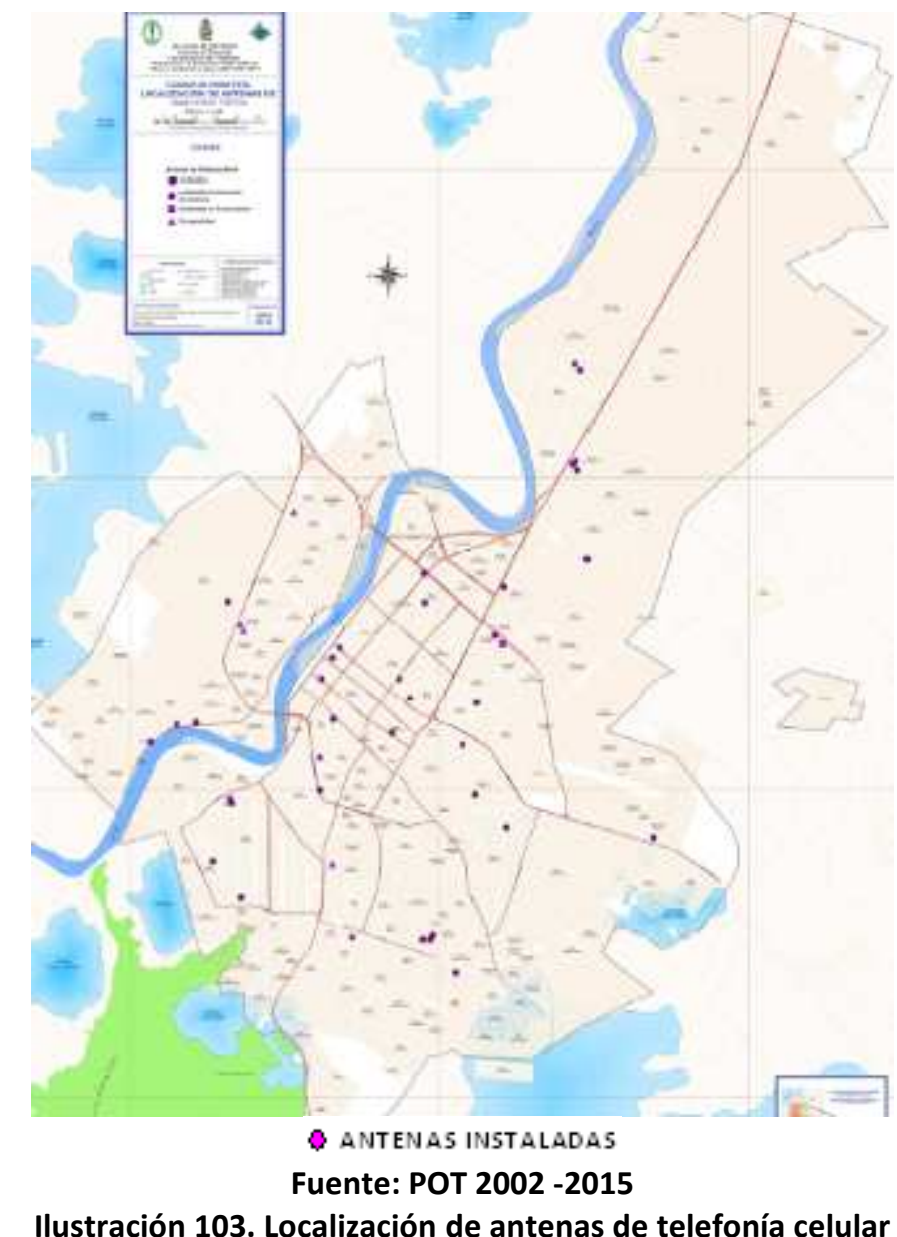

El dinamismo de las telecomunicaciones, el incremento de usuarios, la sostenida demanda por este servicio y el poder de los grandes operadores, generaron la proliferación de antenas de telefonía celular dentro del perímetro de Montería, qué tal 
y como se observa en la imagen, fueron instaladas en zona residenciales del centro, sur y occidente de la ciudad; y además, sin una normativa eficaz que regulara las distancias ni protegiera a los vecinos de los perjuicios ocasionados por estas antenas. Sin embargo, algunos afectados han presentados acciones legales para exigir su reubicación en los sitios adecuados.

Retomando el tema de la reventa informal de minutos, consideramos oportuno anotar qué, en la ciudad de Montería esta actividad se manifiesta en cuatro modalidades: 1) cuando el propietario de un local comercial o de servicios adquiere una línea telefónica con el objetivo de ofrecer el servicio de comunicación simultáneamente con su actividad comercial; 2) cuando adquiere la línea y la cede en alquiler o por comisión a familiares o personas cercanas, para que se opere desde el mismo negocio; 3 ) el dueño del negocio, brinda a un(a) vendedor(a) de minutos, la oportunidad de ubicarse fuera del negocio o dentro de él; 4) la venta es realizada desde la propia vivienda por cualquier miembro de una familia.

Como se anotaba anteriormente, los café internet son empresas legalmente constituidas, bajo la figura de Persona Natural ${ }^{273}$, cuyos márgenes de ganancias pueden permitir al propietario, su vinculación como autónomo al sistema de seguridad social. Estos márgenes son posibles, cuando el negocio se instala en vivienda propia, se atiende personalmente y la ubicación es excepcional para la clientela. Igualmente, se presentan situaciones contrarias, en las que el propietario del negocio debe pagar alquiler y transporte para llegar al sitio rentado, situación ésta, que reduce su ingreso, y dificulta o impide, su acceso a la seguridad social.

Los $S A I$, generalmente no requieren más de una persona para su funcionamiento, pero la dinámica de aquellos que se ubican excepcionalmente, en zonas céntricas o

\footnotetext{
${ }^{273}$ Unidades económicas generalmente constituidas con inversiones inferiores a \$US 2.000, dentro de las que sobresalen: peluquerías, papelerías, tiendas, $S A I$, discotecas, fotocopiadoras, talleres de motos o carros, restaurantes, heladerías y cafeterías. En el caso especifico de los $S A I$, la inversión requerida oscila entre \$US 2.000 y $\$$ U 5.000. Como dato adicional, es importante anotar qué, en el año 2008 se encontraban inscritas en la Cámara de Comercio Local 7.607 personas naturales, las cuales representaban el $82.6 \%$ del total de todas las empresas en esta ciudad. Cfr. Pág. 60. Sin embargo, y por cuestiones lógicas de mercado, estas empresas no generan empleos formales, sino que incorporan trabajadores en condiciones informales, situación ésta, que explica o ayuda a entender los altos niveles de informalidad de Montería.
} 
cercanos a instituciones educativas, brindan la posibilidad de trabajo a una segunda persona, quien es incorporada en condiciones de informalidad y con ingreso mensual concertado por debajo del salario mínimo. Sin embargo, se presentan esporádicos casos, en los que estos negocios, no son atendidos directamente por sus propietarios, sino que son administrados informalmente por dependientes o familiares.

Esta forma de informalidad, es jurídicamente cuestionable pero éticamente no censurable, debido a que los ingresos de estas empresas, escasamente generan para pagar costos de servicios públicos, alquiler y obligaciones fiscales con el municipio. Es importante anotar qué, los ingresos mensuales de estos negocios, oscilan entre $\$ 500.000$ y $\$ 2.000 .000$, y que el salario mínimo legal vigente para el año 2010 asciende a $\$ 515.000$ (\$US 260). Con estos ingresos, a un empresario le resulta poco probable, contratar legalmente a un empleado, y más, si se tiene en cuenta que los costos laborales mensuales por empleado en Colombia, con esta remuneración, equivalen a $\$ 870.000$ (es decir; costos que incluyen ingreso + prestaciones sociales de ley).

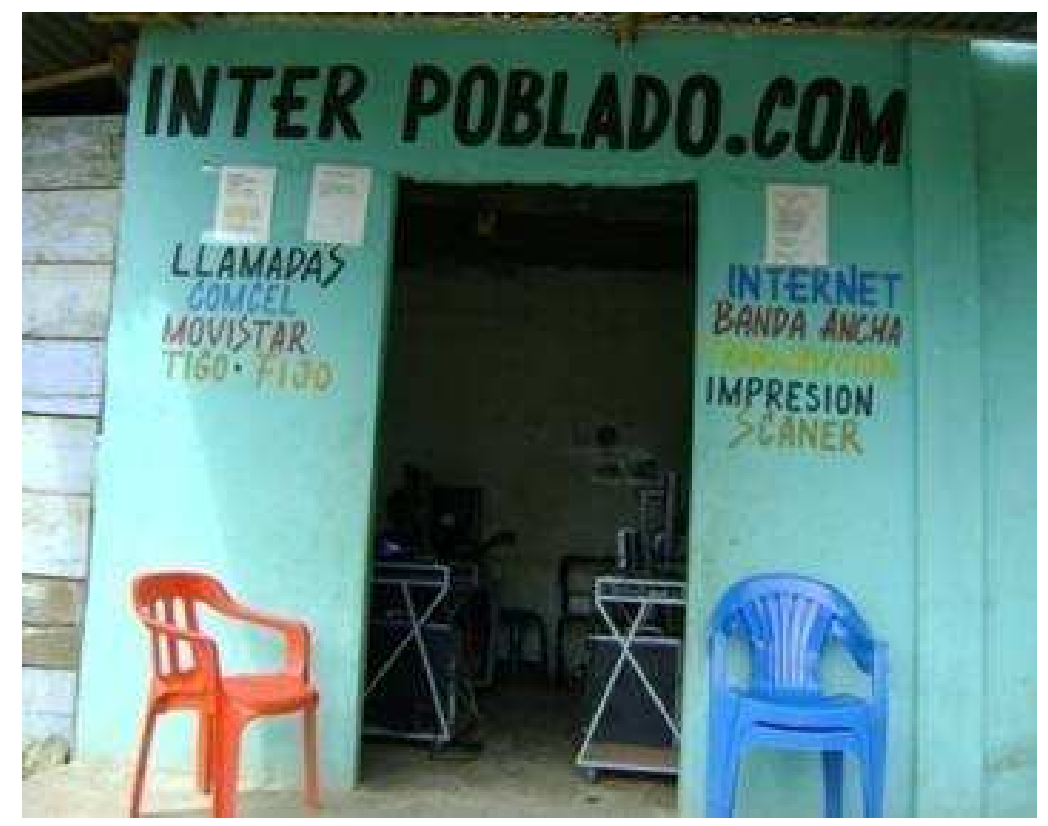

Fotografía: Hernando Pérez 2010

Ilustración 104. Café Internet (SAI) en el barrio informal El Poblado

La reventa callejera de minutos y la atención de los SAI, son actividades con gran participación femenina y de jóvenes universitarios, que contribuyen con la generación de ingresos para estos dos grupos de población, altamente afectados por las deficiencias estructurales de generación del empleo en el país. Estas dos actividades 
ocupan informalmente a unas 2.000 mujeres y a cerca de 500 estudiantes universitarios de esta ciudad.

Como actor de mercado, y teniendo en cuenta la gran demanda que existe por este servicio, esta actividad informal tiene presencia en todos los sectores de la ciudad, y de ella viven actualmente unas cinco mil personas, distribuidas entre dependientes informales de los SAI y revendedores callejeros de minutos a celular. Son cerca de 500 SAl observados en el año 2010, los cuales se encuentran concentrados principalmente en el Centro, la Granja, la Pradera, Cantaclaro, Juan XXII, Mogambo, Mocarí, el Dorado, Santa Fe, Santander y el P-5.

Así mismo, se observa gran dinámica en el P-5, el Prado, y en los barrios informales Alfonso López, los Araujos, 2 de Septiembre, 6 de Marzo, Policarpa, Rancho Grande, la Palma, el Poblado, Robinson Pitalúa, la Candelaria, los Nogales, Edmundo López, el Paraíso y Mogambito. También se observan SAI, aunque no con la misma fuerza, en los asentamientos semiconsolidados y precarios como Villa Jiménez, el Privilegio, 25 de Agosto, 7 de Mayo, Camilo Torres y Villa Cielo.

Concluimos este recorrido por las telecomunicaciones, indicando que cerca de cinco mil personas dedicadas a la reventa de minutos en Montería perciben ingresos mensuales oscilatorios entre $\$ 300.000$ y $\$ 700.000$ (\$US $150-350$ ), con promedios mensuales individuales de $\$ 500.000$ (\$US 250), obtenidos en jornadas de diez o doce horas. Las jornadas de diez horas, se llevan a cabo de lunes a viernes en el centro, y las de doce, se realizan todos los días en zonas residenciales de la ciudad. Estos datos permiten estimar qué, a pesar de sus niveles de informalidad, este subsector genera ingresos anuales aproximados a $\$ 30.000 .000 .000$ (\$US 15.000 .000 año 2010) ${ }^{274}$.

\footnotetext{
${ }^{274}$ Estas estimaciones fueron realizadas con base en información obtenida directamente de fuentes primarias a partir del año 2007. Los datos aportados son el producto de la observación directa, la entrevista y la participación acción como cliente de $S A l$ y de revendedores de minutos en el Centro y los barrios la Granja, el Prado, P-5, Galilea, Santafé, Cantaclaro, la Pradera y el Dorado. Igualmente es el producto de los testimonios de estudiantes, amas de casa, familiares y amigos cercanos que se encuentran vinculados a estas actividades.
} 


\subsubsection{Construcción Informal}

La construcción de esta ciudad, al igual que otras ciudades del país y del mundo, está ligada a sus condiciones naturales, a su historia, cultura, economía, política, al arte, la ciencia y a la tecnología. Sin embargo, el aspecto físico de Montería, refleja poco o nulo respeto por la historia, la cultura, los ecosistemas, e incluso, por el arte; lo cual la priva de estética, identidad, legalidad y de autonomía.

Su expansión física estuvo condicionada por un modelo social mediocre, cimentado principalmente en la codicia, colonización, usurpación de tierras, intimidación y nepotismo. Evidentemente, estos aspectos traerían como resultado: a) la concentración de la propiedad y del poder en pocas familias: b) rezago socioeconómico de la población; c) limitaciones de acceso, al empleo, al capital y a la propiedad; d) una alta dosis de clasismo en las relaciones sociales, que a nuestro juicio, consideramos absurda, debido a que, además de fomentar innecesarias discriminaciones, también impidió por muchos años el desarrollo del talento humano; es decir, el acceso a las artes, a la ciencia y a la educación generalmente estuvo condicionado a factores económicos y no a la capacidad de las personas, con las respectivas consecuencias negativas que ello implicó.

No obstante, y a pesar de las negativas implicaciones mencionadas, las clases dominantes lograron adoptar un modelo urbano, que les permitió mantener el control del suelo y el equilibrio entre familias y hábitat, hasta finalizada la década de los años 50, periodo éste, en el que Montería comienza su vida administrativa como capital de departamento y como ciudad receptora de migrantes del campo.

Hasta esta fecha, se mantuvo el trazado inicial, y la clase dirigente, que había gobernado cómodamente, comienza a manifestar su incapacidad para administrar, planificar y diseñar un nuevo modelo urbano de desarrollo, ajustado al incremento de la población. Esta incapacidad, asociada al centralismo de la época, se traduciría en un ensanche caótico, con graves problemas sociales, ambientales y urbanos, que conducirían finalmente a la ciudad a unos niveles insostenibles de informalidad 
económica, ambiental y urbanística, tal y como se ilustrará en el capítulo de impacto urbanístico.

El ensanche en esta ciudad, estuvo acompañado de procesos legales e ilegales de autoconstrucción, a los que fueron incorporados informalmente cientos de albañiles, maestros de obras y ayudantes de construcción. Es significativo anotar qué, la autoconstrucción se convertiría indudablemente, en el principal instrumento de crecimiento físico de esta ciudad, en el que participarían todos los sectores de la sociedad, dejando como resultado barrios muy heterogéneos, en cuanto a: calidad de vivienda, infraestructura, viario y equipamientos.

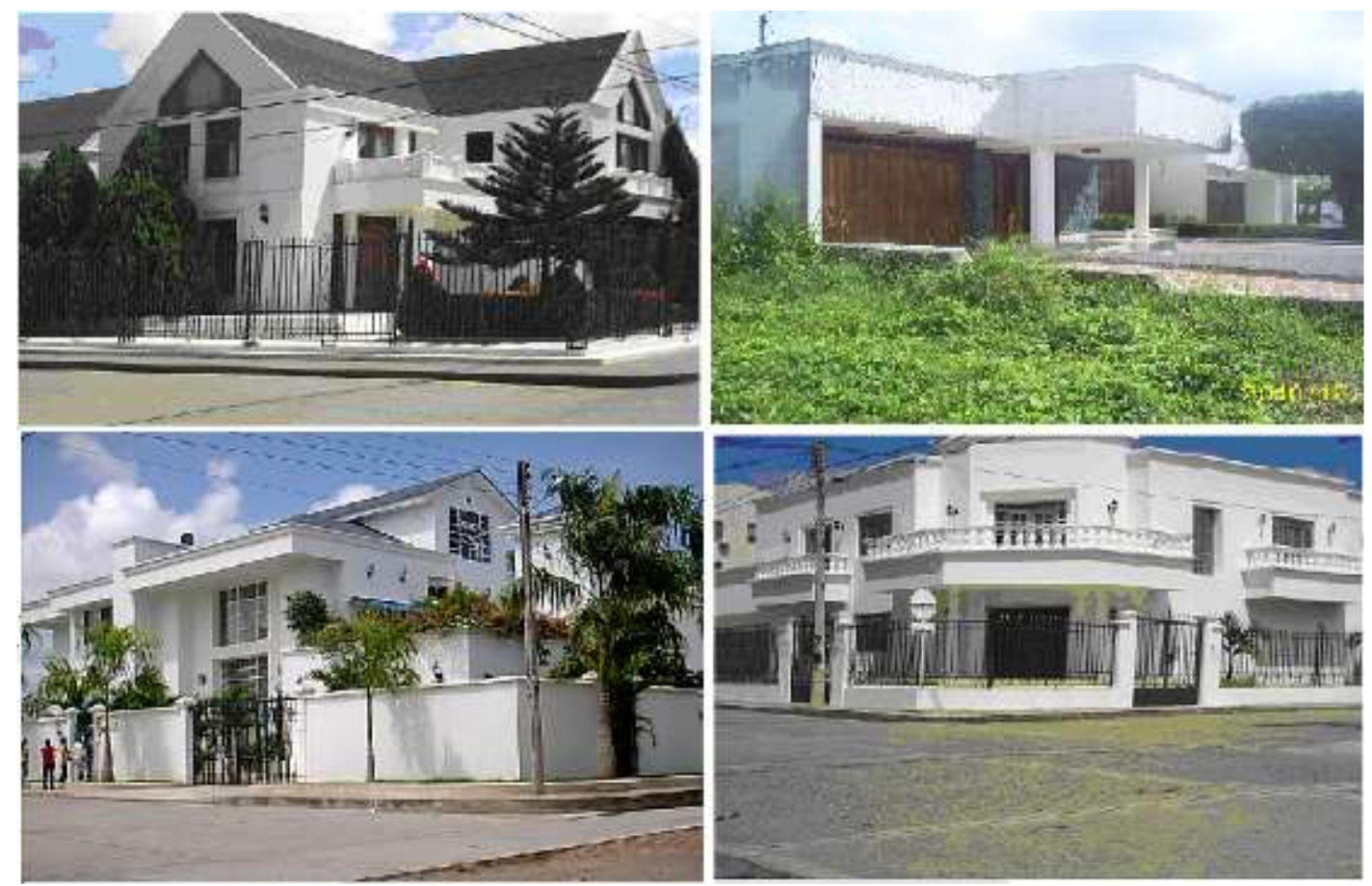

Fotografías: Jhon Pinedo 2007-2010

Ilustración 105. Viviendas barrio el Recreo

En barrios de altos ingresos como el Recreo, la Castellana, Costa de Oro, Pasatiempo, San Francisco, Robles Norte, y Castilla la Nueva, se desarrollaron procesos de autoconstrucción que permitieron la contratación de arquitectos y profesionales del diseño; mientras que en los barrios populares de estratos bajos o medios, esta actividad ha sido desarrollada por arquitectos empíricos, maestros de obras, o sencillamente, por albañiles con algún grado de experiencia. Precisamente, sobre este 
segundo grupo, recae el mayor número de viviendas edificadas en esta ciudad, situación razonable por algunos motivos que a continuación enunciamos:

1) El predominio de una arquitectura popular no compleja, que aprovechaba materiales autóctonos como la madera, la palma, el bahareque y la boñiga;

2) el rezago socioeconómico de la ciudad limitaba la inversión o demanda por grandes obras arquitectónicas;

3) al existir escasa demanda, la arquitectura era una profesión poco atractiva y monopolizada por un selecto grupo de arquitectos que tuvieron el privilegio de formarse en Bogotá o Barranquilla;

4) elevada oferta de albañiles como consecuencia de las pocas posibilidades de empleo en otras actividades o de acceso a formación profesional;

5) la primera facultad de arquitectura llegó en 1995, pero los elevados costos de matricula impiden la formación profesional de muchos jóvenes.
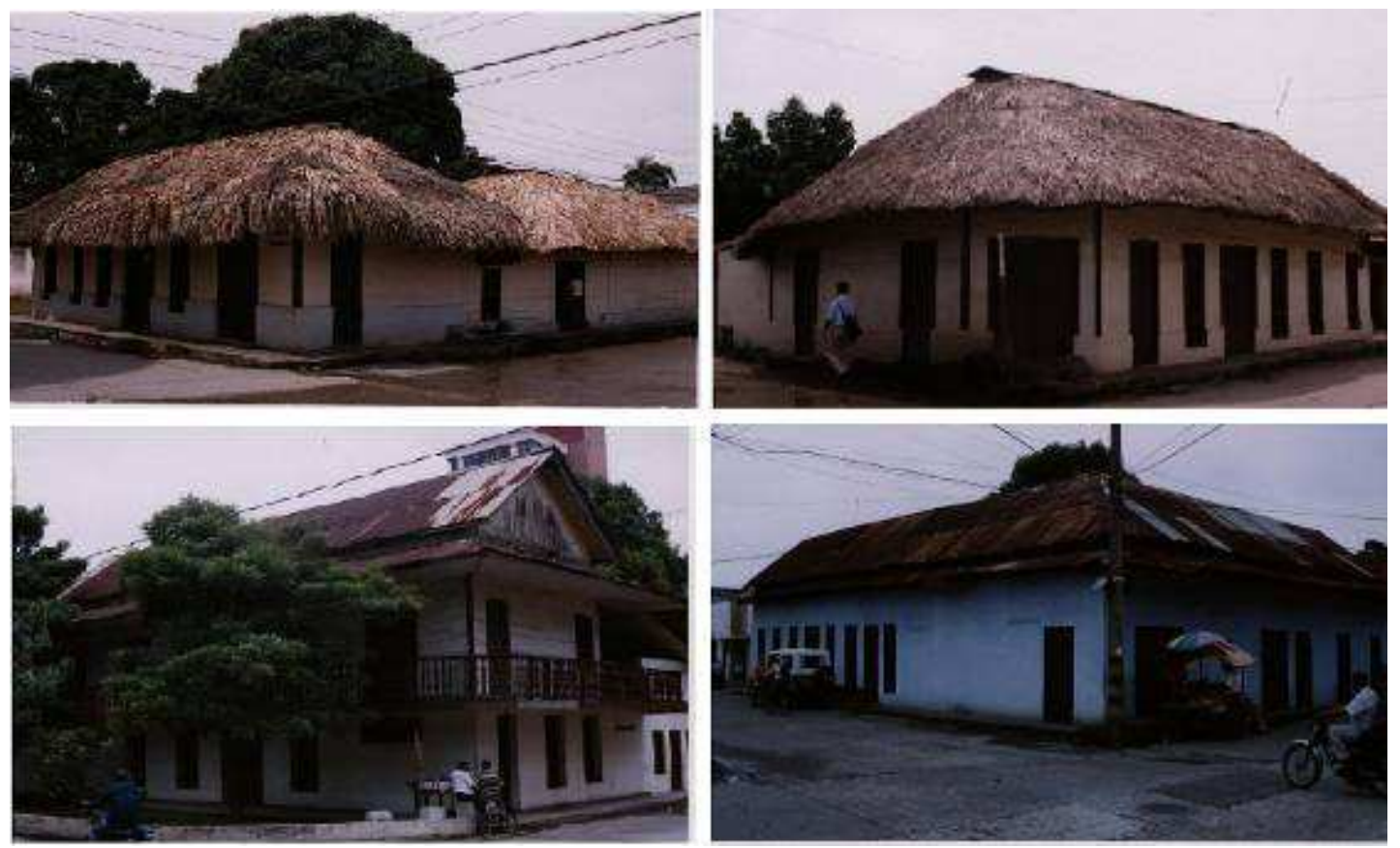

Fotografías: Jhon Pinedo 2008

Ilustración 106. Arquitectura Popular

Los anteriores motivos, por razones obvias del mercado, generaron la sobrevaloración de los servicios del arquitecto y la subestimación de los demás trabajadores de la construcción, situación ésta, que los mantuvo, y aún los mantiene trabajando, en 
condiciones contractuales precarias y relegados a ciudadanos de segunda categoría, por algunos arquitectos, el estado y la sociedad. Sin embargo, varios maestros de obra de Montería, son admirados por un gran sector de la población, quienes consideran qué, su talento y experiencia no son inferiores a la de un arquitecto profesional.

Este escenario informal del trabajador de la construcción se acompaña del escenario informal de edificación de vivienda, la cual es primordialmente construida, sin una licencia previa que regule: estructura, altura, volumen, retiro y cesiones. Es oportuno anotar que las Curadurías Urbanas, encargadas de expedir dichas licencias de construcción, fueron incompetentes hasta el año 2002, fecha de aprobación del Plan de Ordenamiento Territorial, permitiendo la aparición de miles de vivienda sin licencia previa, tanto en asentamientos legales como ilegales. No obstante, a partir del 2008, las curadurías urbanas de Montería comenzaron a ejercer mejor control.

\begin{tabular}{lrcrrr} 
Años y & \multicolumn{2}{c}{ Número de licencias } & & \multicolumn{2}{c}{ Área por construir $\left(\mathrm{m}^{2}\right)$} \\
\cline { 2 - 3 } \cline { 5 - 6 } trimestres & Total & Vivienda & & Total & Vivienda \\
\hline & & 2008 & & \\
Total & 272 & 212 & 182.507 & 139.695 \\
Primero & 62 & 53 & 43.715 & 25.116 \\
Segundo & 56 & 41 & 31.474 & 26.660 \\
Tercero & 72 & 55 & 43.840 & 35.873 \\
Cuarto & 82 & 63 & 63.478 & 52.046 \\
& & 2009 & & \\
Total & 315 & 265 & 136.708 & 98.099 \\
Primero & 61 & 49 & 29.890 & 23.958 \\
Segundo & 77 & 65 & 43.836 & 22.422 \\
Tercero & 81 & 67 & 35.918 & 30.766 \\
Cuarto & 96 & 84 & 27.064 & 20.953 \\
\hline
\end{tabular}

Fuente: DANE 2010

Tabla 20 . Número de licencias de construcción en Montería

La doble informalidad enunciada, afecta el empleo formal y la calidad urbanística, pero también se constituye en factor clave para la construcción del hábitat, generación de ingresos y dinamización de la economía. En lo referente al hábitat, estimamos desde esta investigación, que la construcción informal ha permitido, hasta el 2010, la solución parcial o total de aproximadamente veinte cinco mil viviendas construidas, principalmente en asentamientos informales de invasión o de loteos irregulares. 
También ha sido el soporte fundamental de los programas de promoción pública de lotes con servicios en los barrios del Boston, Pastrana Borrero, Policarpa Salavarrieta, Santander y el Prado.

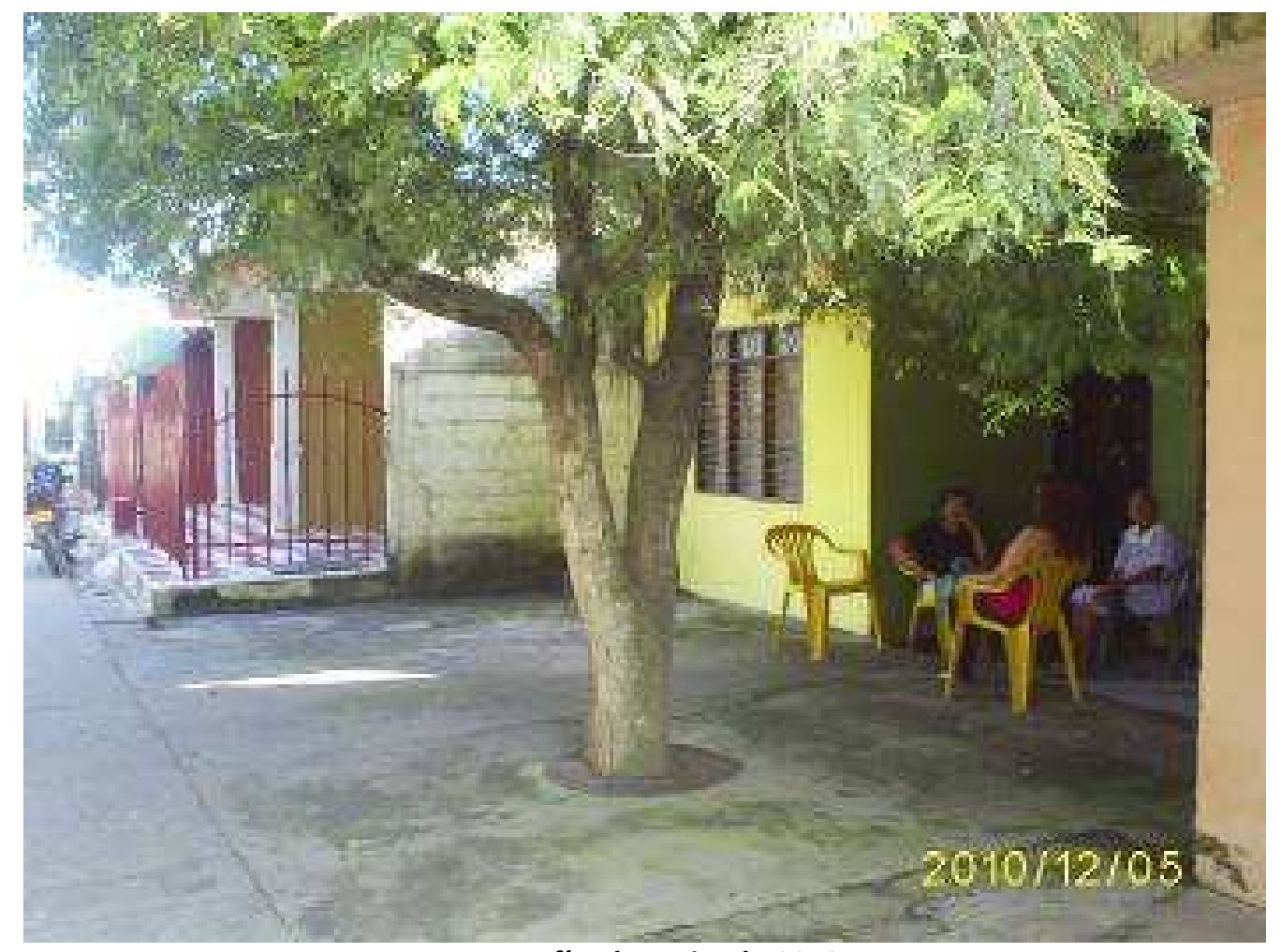

Fotografía: Jhon Pinedo 2010

Ilustración 107. Viviendas autoconstruidas barrio El Prado

La aprobación de licencias durante los últimos años reduce la construcción informal, pero no garantiza la formalización de lo empleos generados, ni de todas las viviendas construidas. Sin embargo, el $72 \%$ de las licencias aprobadas en el 2009, correspondieron a programas de vivienda unifamiliar de interés social y a multifamiliares en altura, que generaron contratos formales para las firmas constructoras y aproximadamente cinco mil empleos precarios para maestros obras, oficiales (albañiles), y ayudantes. 


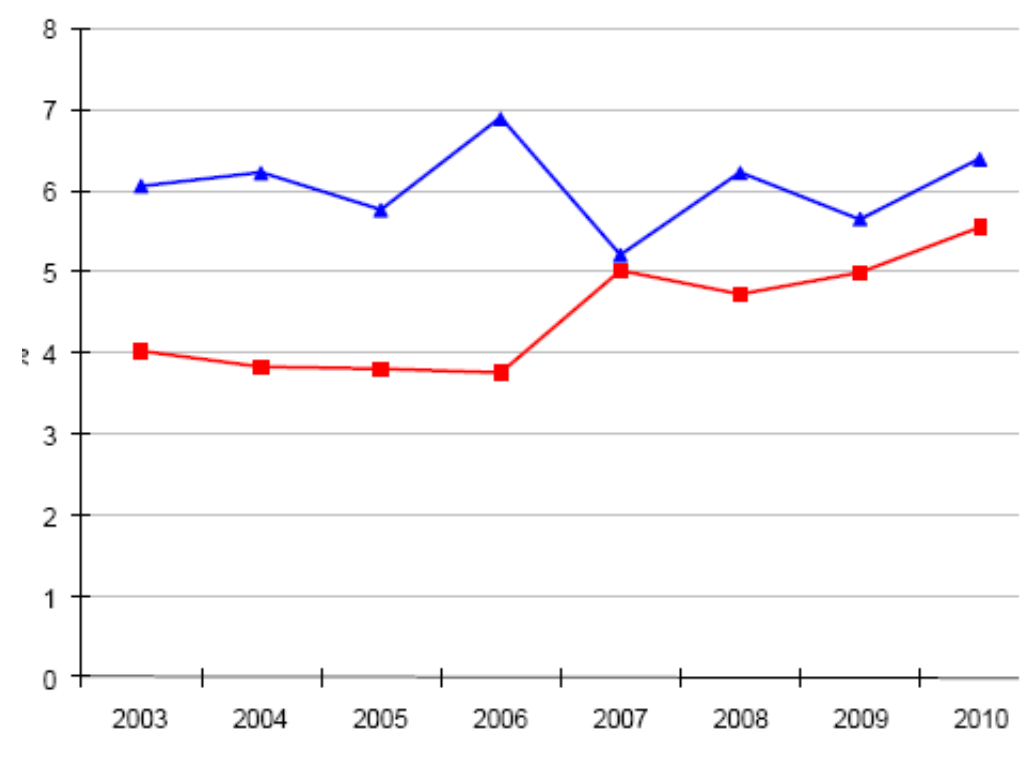

-Ocupados Construcción $\quad \rightarrow$ Ocupados Actividades Inmobiliarias

Fuente: DANE 2010 - Encuesta Continua de Hogares

Ilustración 108. Ocupados en la construcción y actividades inmobiliarias en Montería

El restante $28 \%$ de licencias correspondió a ampliación o construcción de equipamiento educativo, $14 \%$; locales comerciales, $8.5 \%$, y $5.5 \%$ a hoteles, bodegas e industria. Estas edificaciones permitieron la ocupación de otras dos mil personas, que sumadas a las cinco mil ocupados en construcción de vivienda, corresponden al $5.7 \%$ de la población ocupada en Montería para el año 2009, porcentaje éste, muy cercano a los empleados en actividades inmobiliarias.

Esta gran dinámica de los últimos cinco años en la construcción en Montería, dio paso a nuevas firmas constructoras locales y a otras que llegaron de Bogotá, Medellín y Barranquilla. Estas constructoras, a pesar de sus extraordinarios ingresos y de su gran prestigio, siguen maltratando vulgarmente a los trabajadores, a quienes vinculan a riesgos profesionales y/o planes de salud, pero les siguen desconociendo sus derechos salariales asociados a cesantías, vacaciones, primas y horas extras festivas.

A diferencia de Estados Unidos y España, por ejemplo, países en donde los ayudantes de construcción obtienen ingresos mensuales cercanos a los \$US 1.500, en Colombia, estos siguen siendo remunerados con salarios precarios que apenas ascienden al mínimo legal vigente (\$US 260), en condiciones contractuales muy desfavorables y en ambientes naturales bastante adversos como es el caso de Montería, en el que la 


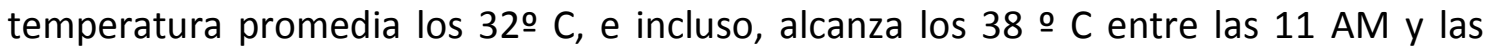
4PM.

No tenemos los datos suficientes para realizar una estimación de los ingresos generados en esta actividad en la ciudad de Montería, pero a continuación presentamos los datos exactos de las remuneraciones mensuales que las constructoras asignaron a sus trabajadores cualificados y no cualificados en el año 2010: Arquitecto residente con experiencia \$US 1.000; Arquitecto residente recién egresado \$US 750; Maestro de obra \$US 500; Oficiales, \$US 400 y Ayudantes \$US 260.

Estos ingresos, son miserables, no solamente por su baja cuantía, sino por el desconocimiento al factor salarial, las condiciones climáticas del contexto, lo exigente de la actividad, el monto de las inversiones, y por la aparente legalidad en la que transcurre esta actividad. Sobre el tema de las inversiones, es oportuno anotar que en estos últimos cinco años se construyeron o construyen obras con inversiones entre \$US 1.000 .000 y \$US 5.000.000, y dentro de las cuales sobresalen almacenes Makro, Carrefour, Cervecería Unión, Licosinú - Grupo Litoral, Clínica Montería, Clínica Oncológica, Terminal de Transporte y una docena de proyectos multifamiliares en los barrios el Recreo y la Castellana.

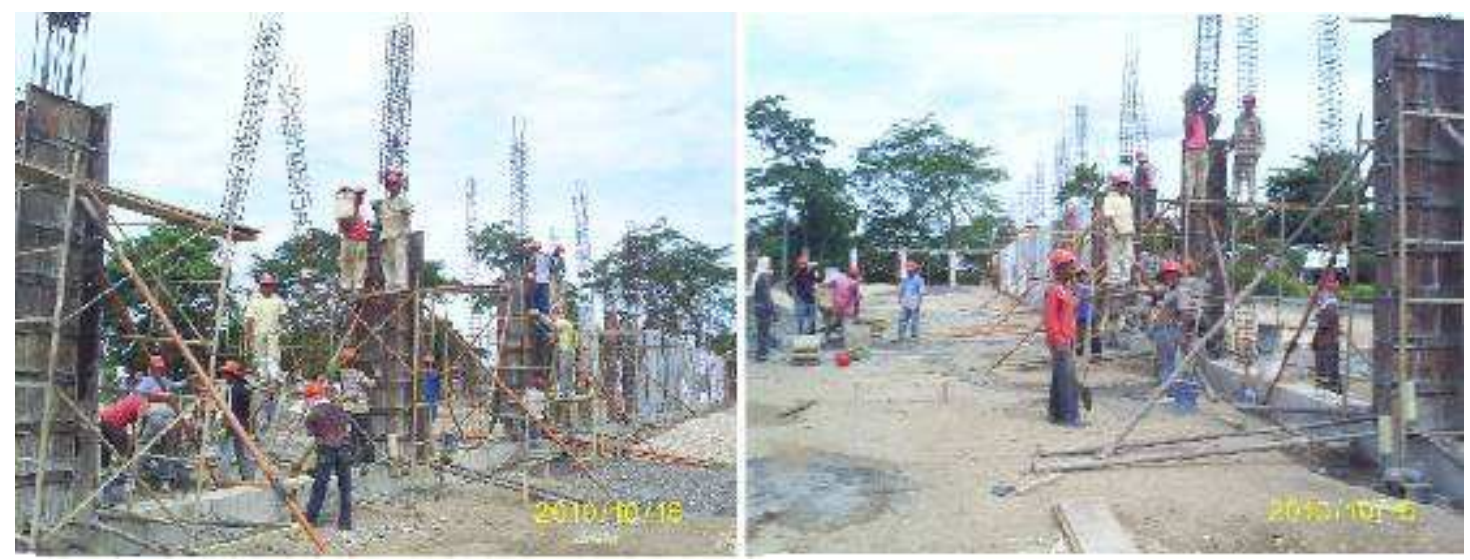

Fotografías: Jhon Pinedo 2010

Ilustración 109. Construcción de bodegas en el norte de la ciudad

Evidentemente, en este periodo la construcción generó en promedio, cerca de seis mil empleos directos por año, empleos informales que no soportaron contratos legales con los obreros, e incluso con profesionales universitarios, quienes por la situación 
socioeconómica del medio y por la enorme reserva de parados, no tienen alternativa diferente a la de trabajar en las condiciones que les imponen las firmas constructoras. Empresas estas, que cuentan con el aval de unas instituciones sumisas al capital nacional o transnacional, una sumisión incondicional al capital, pero implacable con los trabajadores de la construcción, a los que no solo se sepulta en la informalidad, sino que degrada como personas.

\subsubsection{Manufactura Informal}

Este subsector hace referencia a aquellas unidades económicas locales, que sin estar legalmente registradas, se dedican a la producción de alimentos de consumo masivo o de elementos esenciales para el hogar. Estas unidades funcionan principalmente en el interior de las viviendas; sus procesos son desarrollados individual o colectivamente; producen a menor escala, y algunas de ellas, utilizan maquinaria para la fabricación de sus productos.

Los productos elaborados por estas empresas, a pesar de no tener marcas registradas, son altamente demandados en diferentes escalas de la ciudad, ya sea barrial, zonal o urbana. La demanda de dichos productos, obedece inicialmente a factores económicos; pero no se puede dejar de lado, que en ella también inciden, aspectos culturales y condiciones climáticas, que además les garantizan, cierta ventaja sobre otros productos de origen nacional o internacional.

Dentro de los alimentos y bebidas sobresalen la producción de queso, mantequilla, turrones, bollos, refrescos hidratantes, helados, panes, rosquillas, chorizos, butifarras, tortas, pasteles, pasabocas, postres, arepas, galletas, mermeladas, pulpa de frutas, buñuelos y papas fritas. Estos bienes procesados, son comercializados directamente por sus productores, o por intermediarios, quienes los venden puerta a puerta, o en sitios de alta concurrencia como: escenarios deportivos, escuelas, universidades, iglesias y zonas comerciales; igualmente, son distribuidos en tiendas, minimercados, y cafeterías de diferente sectores de la ciudad. 
Otro subsector dinámico dentro de la manufactura informal, es el de las confecciones, el cual permite incorporar a modistas y sastres, que trabajan individualmente o de forma organizada, en el interior de sus viviendas o en escenarios compartidos. Estas empresas producen básicamente, por encargo: vestidos femeninos, pantalones masculinos, sudaderas para estudiantes y uniformes deportivos de softbol, beisbol y futbol.

Este grupo se ha visto enormemente afectado en estos últimos años con la llegada masiva de ropa de Medellín y por el contrabando que llega de la República China, situaciones éstas, que limitan su producción y reduce su mercado a los clientes tradicionales. Sin embargo, logran compensar estas desventajas competitivas, con la confección de uniformes escolares de instituciones educativas de sectores vulnerables de la ciudad y de escuelas rurales del municipio.

Además de las actividades enunciadas, también se encuentra la fabricación de bloques para construcción, negocio éste, que se ha incrementado notablemente en los últimos veinte años, permitiendo el trabajo informal de unas mil personas, que derivan su sustento exclusivamente de esta actividad. Estas unidades no requieren mayor inversión; generalmente operan por encargo; sus trabajadores obtienen ingresos variables de acuerdo con su producción, y operan sin regulación ni persecución alguna. Actualmente, se observan cerca de cien fábricas de bloques en toda la ciudad, ubicadas principalmente en barrios informales, en espacio público o a orillas del río Sinú. 


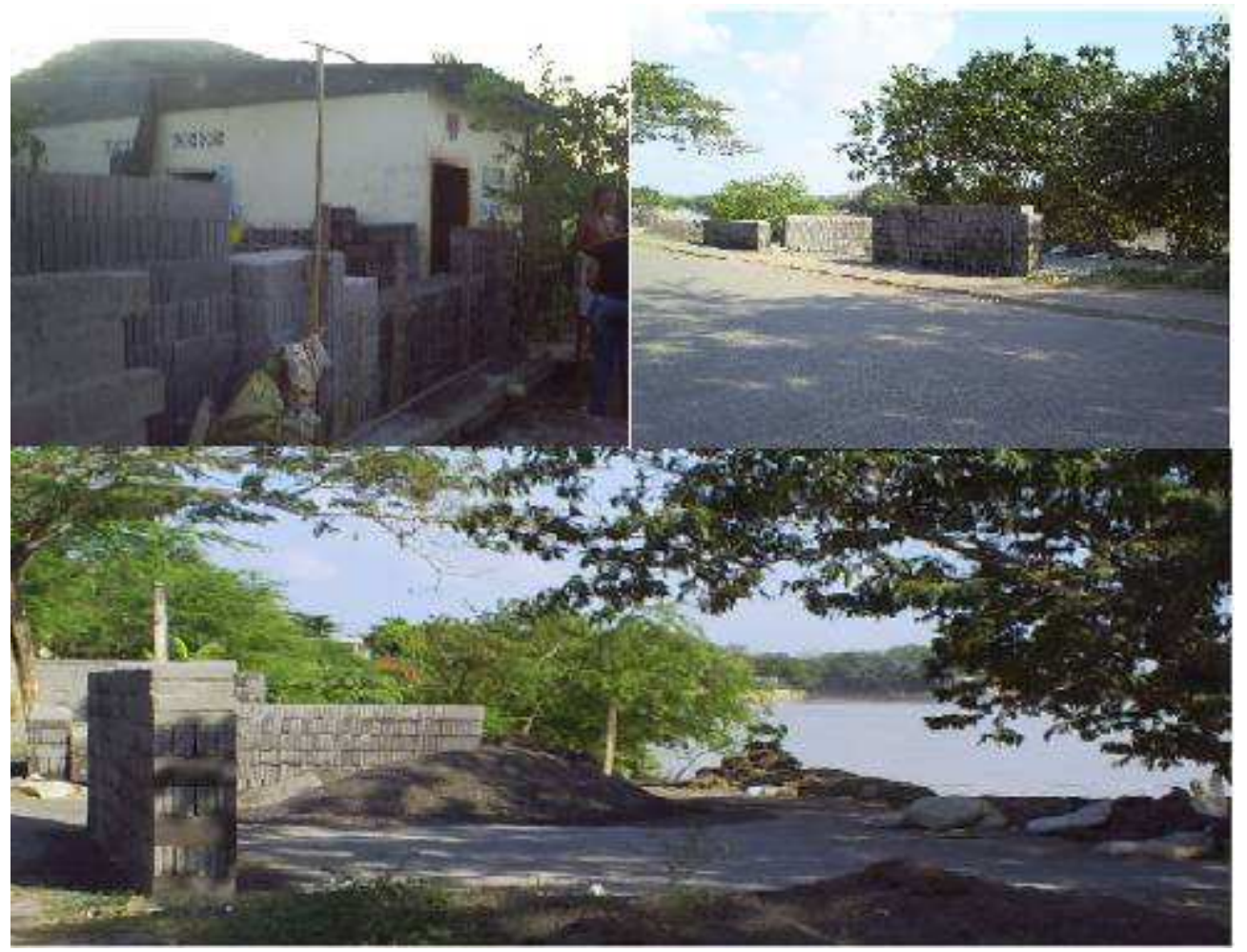

Fotografías: Jhon Pinedo 2011

Ilustración 110. Producción informal de bloque para construcción

Con la dinámica de la construcción en los últimos años, se han formalizado algunas de las fábricas de bloques que abastecen a las grandes constructoras privadas o a contratistas del Estado; pero dicha formalización no ha sido suficiente para formalizar los empleos de sus trabajadores, quienes obtienen ingresos promedios diarios de $\$ 25.000$ (\$US 12.5), en jornadas que se inician a las cuatro de la madrugada y terminan sobre las diez u once de la mañana, como consecuencia de las altas temperaturas en esta ciudad.

El precio de venta del bloque es de $\$ 500$ (\$US 0.25) la unidad, y la comisión que recibe un trabajador por cada unidad producida es de $\$ 50$ (\$US 0.025), en el año 2010. El promedio de bloques producidos por persona día, asciende a 500 unidades, y el número de trabajadores de esta fábricas oscila entre 1 y 5 , dependiendo de la demanda, y del valor de la arena. El costo de este material varía de acuerdo con el nivel del río; en verano con playa, el $\mathrm{M}^{3}$ se vende a $\$ 15.000$ (\$US 7.5), y en invierno, con alto caudal se incrementa a \$20.000 (\$US 10), situación lógica, teniendo en cuenta que la extracción es realizada por inmersión de canoeros a pulmón libre. 




Fotografía: Jhon Pinedo 2011

llustración 111. Extracción artesanal de arena en el río Sinú

Con la anterior imagen se pretende ilustrar el escenario que antecede a la fabricación del bloque, elemento éste, que al igual que la arena del río Sinú, hacen parte de nuestro acervo cultural, y que además, ha permitido a familias de diferentes generaciones, obtener ingresos de subsistencia. En este escenario, los protagonistas principales son los canoeros, personajes tradicionales de nuestra ciudad, poco valorados y a veces estigmatizados; y quienes a través de sucesivas inmersiones diarias, logran extraer la arena requerida por los fabricantes de bloque y por los constructores de la ciudad.

Continuando con otra actividad, también se observa en el mercado local, una importante presencia de productos artesanales para limpieza y aseo, dentro de los cuales sobresalen: escobas, traperos (fregonas), cepillos para barrido, recogedores, limpiadores, jabones, detergentes y ambientadores aromatizados. Estos productos son elaborados informalmente y vendidos puerta a puerta, o distribuidos por pequeñas tiendas de los barrios populares e informales; dicha venta, generalmente es realizada por los mismos fabricantes. 
Por otro lado, existe un colectivo de fabricantes difíciles de cuantificar, debido a la forma de comercialización y por las características de los productos que elaboran. Este grupo es el de productores de postres y de yogur casero, quienes generalmente no venden de manera ambulante, sino por encargo directo de familias, casas de eventos, restaurantes o cafeterías. Está conformado por madres cabeza de hogar de barrios informales y por familias tradicionales, que pese a su gran prestigio y reconocimiento, siguen sin formalizar sus negocios.

En cuanto al número de empresas manufactureras que operan informalmente en Montería, es difícil precisarlo, debido a su dispersión y clandestinidad; pero por la visibilidad y rotación de sus productos en el mercado local, estimamos que unas diez mil personas se encuentran integradas a esta actividad. Sin embargo, entre cuatro mil y cinco mil de ellas tienen doble participación en la economía informal; primero como productores, y segundo como comercializadores.

Por la dispersión y clandestinidad anotadas, resultó más sencillo identificar a estas personas cuando desarrollaban sus actividades de comercialización, lo cual permitió a su vez, su inclusión en el grupo de comerciantes. En este proceso, también se logró establecer que esta población reside mayoritariamente en asentamientos informales, y que sus productos son elaborados en la misma vivienda; en volúmenes inferiores a mil unidades, cuando dichos productos son perecederos de cortísimo plazo.

Esa doble condición, de productor y comercializador, no se traduce necesariamente en altos ingresos, y por el contrario; los productores de pasabocas, bollos, bizcochos, rosquillas, helados y galletas, tienen ingreso promedios cercanos a los $\$ 600.000$ (\$US 320 de 2010). Los escenarios de producción más dinámicos se encuentran principalmente en Cantaclaro, Robinson Pitalúa, 20 de Julio, 7 de Mayo, Villa Cielo, Alfonso López, Mocarí, el Dorado, Santafé, Brisas del Sinú, la Granja y el P-5.

Con estos datos podemos concluir que, existen en Montería, unos niveles de informalidad económica proporcionales a los niveles de informalidad urbanística, en la que participan actores sociales marginados, pero también grupos de gran poder económico, como firmas constructoras, propietarios de hipermercados, y empresarios 
del transporte. Estos grupos económicos, en vez de disminuir los niveles de informalidad laboral, terminan por propagarla a otros sectores como el de la construcción, las telecomunicaciones y el transporte.

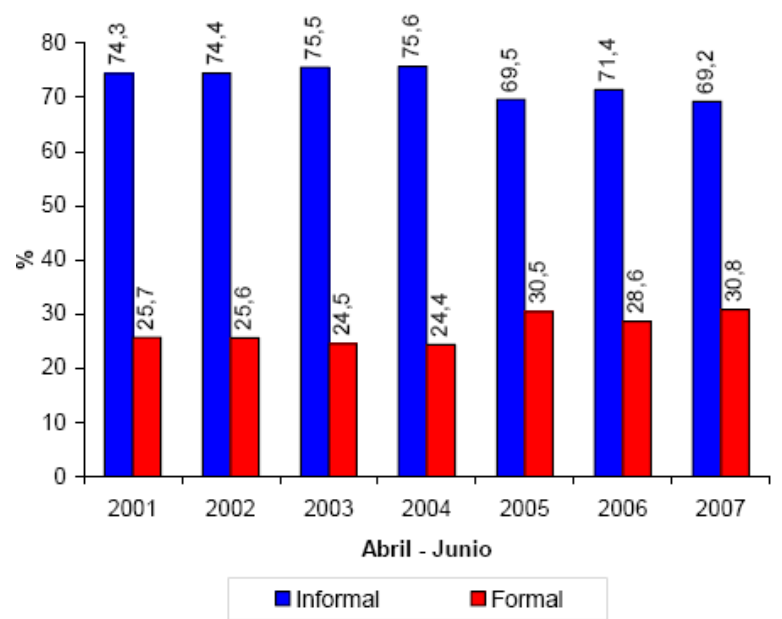

Fuente: DANE 2008 - GRAN ENCUESTA INTEGRADA DE HOGARES 2001-2007 Ilustración 112. Distribución de la ocupación en Montería

Los niveles de informalidad reportados institucionalmente promedian el $70 \%$ de la población ocupada de Montería y corrobora lo expuesto a lo largo de esta investigación. Como se aprecia en el gráfico, a partir del 2005 la ocupación informal presenta una ligera disminución, lo cual consideramos, no es el producto del aumento del empleo formal, sino de la incorporación errónea de algunos trabajadores que se encuentran vinculados laboralmente en condiciones parciales de formalidad; es decir, se encuentran afiliados a una administradora de riesgo profesional o a plan de salud, pero no tienen derecho a prestaciones sociales.

En el caso de los últimos años, se observa abiertamente en esta ciudad, un aumento y no una disminución de trabajadores informales, quienes cada vez más, recurren a los nuevos oficios que brinda el sector informal de la economía. Además de los oficios ya mencionados, existen otros que no hemos mencionado, y que evidentemente son realizados en todos los sectores de la ciudad, generando el ingreso a centenares de sus protagonistas. 


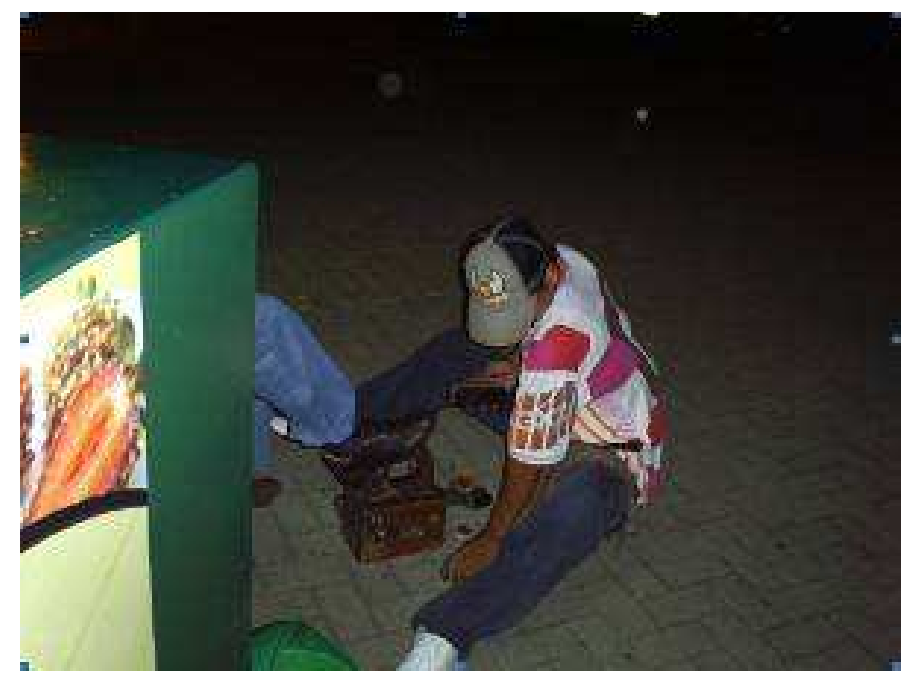

Fotografía: Bertha Katia Araujo 2011

llustración 113. Lustrador de zapatos en la avenida primera

Dentro de estas actividades se encuentran los lustradores de calzado, los denominados $\operatorname{coteros}^{275}$, los comisionistas de transporte de carga, los tramitadores de todo tipo de documentos oficiales, los voceadores de prensa, los celadores callejeros nocturnos de zonas residenciales, los cuidadores de automóviles y motocicletas. Este último oficio es un fenómeno universal, ejercido en calles, plazas, escenarios deportivos, zonas comerciales y discotecas; por sus características y por sus personajes, tiene más apariencia de mendicidad que de actividad productiva.

Este último grupo está conformado por una población heterogénea, en las que se encuentran personas analfabetas, menores de edad, estudiantes y profesionales universitarios. Destacamos en este grupo el trabajo de los lustradores y de los voceadores de prensa, a quienes consideramos desde esta investigación, como personas con gran dignidad y nobleza, a pesar de manifestar los más bajos grados de escolaridad. Los primeros cobran $\$ 2.000$ (\$US 1) por cada lustrada; y los segundos reciben $\$ 200$ (\$US 0.1) por cada periódico vendido o entregado.

En este grupo, el mayor ingreso lo obtienen los tramitadores, quienes presentan los más altos niveles de escolaridad, edad, sagacidad, efectividad y de relaciones. Se

\footnotetext{
275 Personal masculino dedicado a la carga y descarga de mercancías que llegan o salen de la ciudad. Esta actividad es desarrollada en el centro, en la ribera del Río, en los depósitos de materiales de la Granja, Cantaclaro, el Dorado, la Pradera, Mogambo, Mercado del Sur y Bodegas del Norte de la ciudad. En esta actividad se desempeñan unas 200 personas que obtienen ingresos diarios entre $\$ 20.000 \mathrm{y}$ $\$ 40.000$ (\$US10 y \$US20).
} 
dedican a gestionar o agilizar documentos públicos como: licencias de conducir, pagos de tesorería, contratos de prestación de servicios con el municipio, visas, seguros, afiliaciones al sistema subsidiado de salud, a créditos bancarios, subsidios públicos, admisión a escuelas, universidades, tesis de pregrado, títulos universitarios, citas con funcionarios e informes públicos. Dentro de estos tramitadores se encuentran abogados, economistas, funcionarios, bachilleres, técnicos, tecnólogos y personajes de la política local.

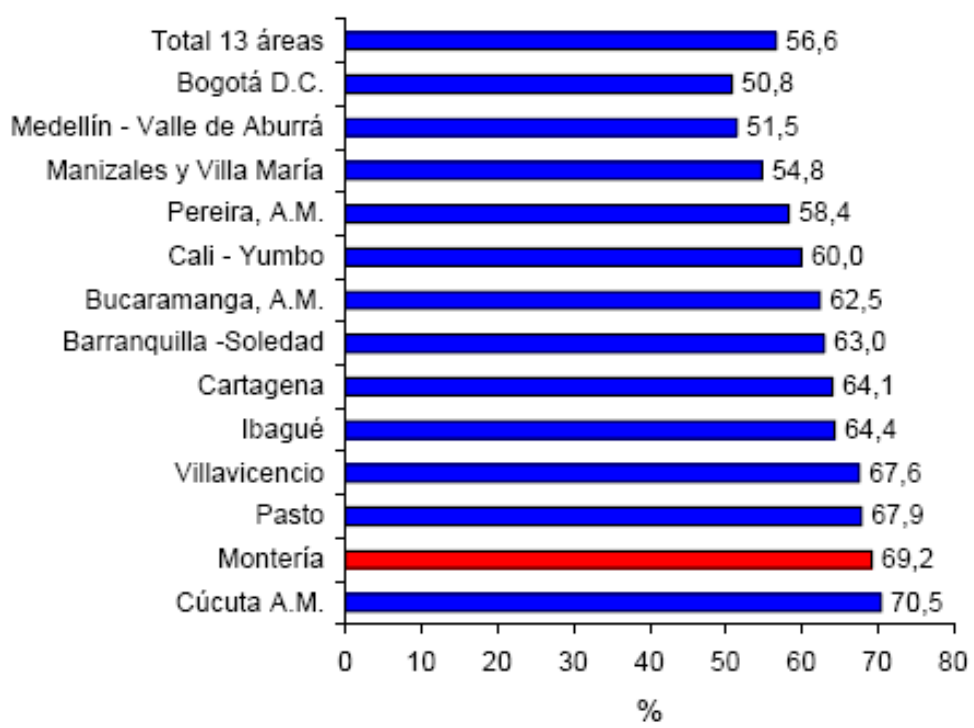

Fuente: DANE 2010 Encuesta Continua de Hogares

Ilustración 114. Porcentaje de población informal en las principales ciudades del país

Terminamos anotando que esta ciudad, es una de las capitales con mayor informalidad de Colombia, con datos precarios que superan los niveles de ciudades intermedias como Pasto, Villavicencio, Ibagué, y Pereira. Incluso, supera por más de cinco puntos a Cartagena y Barranquilla, ciudades éstas con graves problemas de informalidad en el Caribe colombiano. En el escenario de las 13 principales ciudades del país, apenas es superada por Cúcuta; esta capital limítrofe con Venezuela, tiene una tasa de 70.5 de trabajadores informales, mientras que en Montería el 69.2\% del total de ocupados se encuentran vinculados a la economía informal. 


\subsection{IMPACTO URBANISTICO}

Para analizar el impacto urbanístico es conveniente empezar analizando el plano actual de la ciudad y los usos de suelos que establece el Plan de Ordenamiento Territorial de Montería. También consideramos pertinente analizar, los instrumentos que el gobierno nacional y la administración municipal utilizan con el objetivo de corregir, o por lo menos mitigar, los desequilibrios que genera la urbanización marginal en el ámbito de la ciudad.

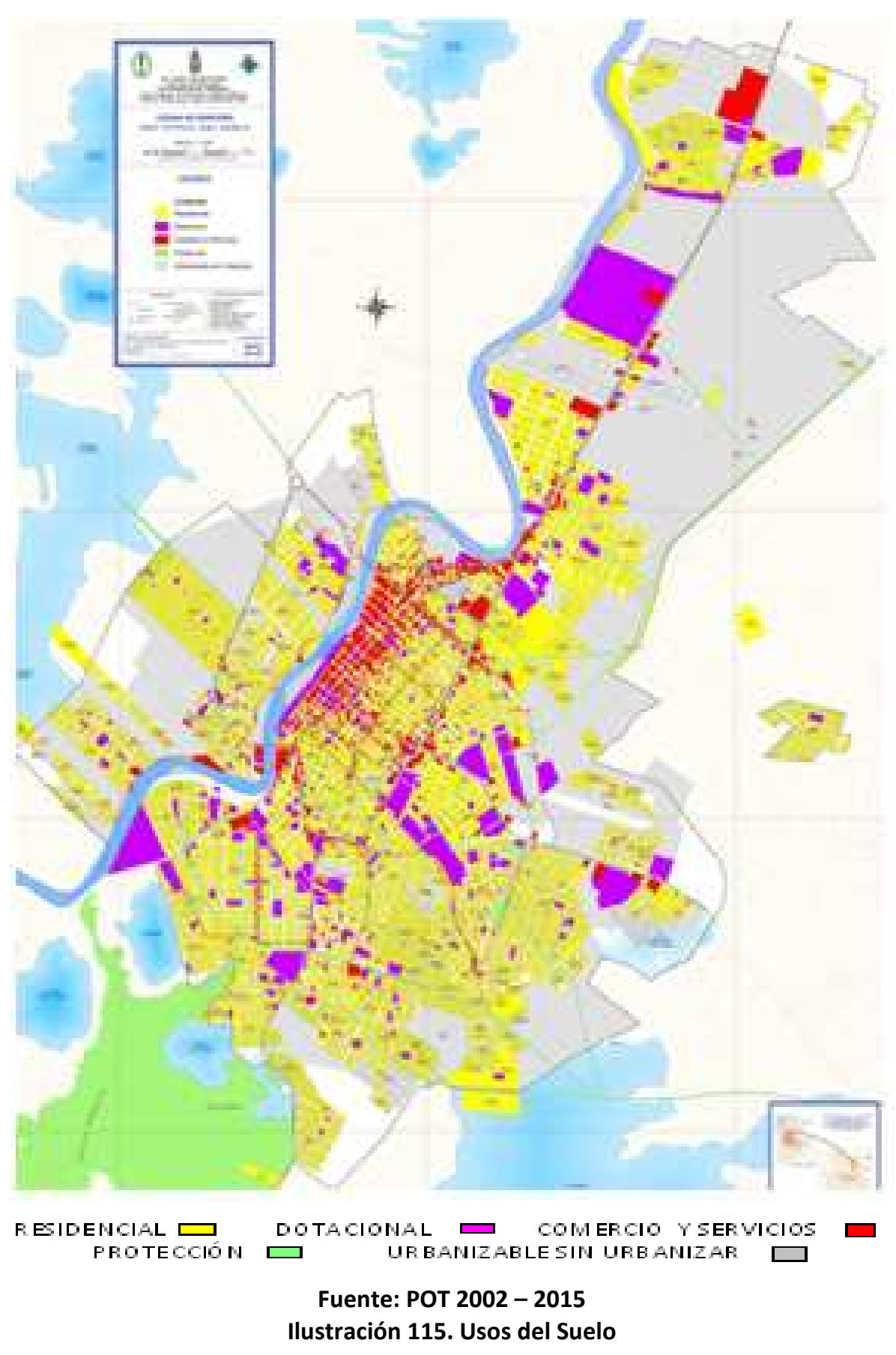


Con respecto al plano actual, comenzaremos anotando que los usos de suelo establecidos por el POT 2002 - $2015^{276}$, son: residencial, dotacional, comercial y de servicios, industrial, de protección y urbanizable sin urbanizar. El total del área urbana asciende a 2.972 hectáreas, de las cuales el $41 \%$ corresponde a residencial, $10.4 \%$ a dotacional, $4.7 \%$ a comercio y servicios, y $43.7 \%$ es superficie urbanizable aún sin urbanizar.

Por su parte el suelo de protección apenas representa una reducida superficie de cuatro hectáreas, que ni siquiera alcanza a superar el $0.1 \%$ del total urbano. Esta minúscula superficie es significativamente inferior al potencial reservable, situación bastante explicable, debido a que dicha reserva se realizó tardíamente en el año 2002 por el primer plan de ordenamiento territorial, cuando ya se habían intervenido varios ecosistemas ubicados dentro del perímetro urbano.

Como se aprecia en la ilustración 115, las áreas residenciales del occidente y suroriente mantienen predominio residencial sobre cualquier otro uso, a pesar de las primeras manifestaciones de comercio o de dotaciones que se presentan en cada uno de estos sectores. Precisamente, en dichos sectores se ubica el mayor número de barrios informales; y la inexistencia de comercio o de dotaciones en ellos, está directamente relacionada con los niveles de consolidación.

Las tendencias del crecimiento urbano en Montería manifiestan gran dinamismo en la ciudad informal, así como la existencia de dos ciudades complementarias e interdependientes: la formal y la informal. Ese dinamismo se expresa en una continua asignación de recursos, que a su vez, se traduce en construcción o ampliación de redes para abastecimiento, vías, y equipamientos educativos, deportivos, recreativos o de salud. Sin embargo, las condiciones actuales reflejan que los recursos e intervenciones han sido insuficientes para lograr un mejor equilibrio espacial, ambiental, social y económico.

La configuración urbana de Montería, permite inferir que ésta no es totalmente espontánea, situación esta, que favorece la complementariedad entre las dos

${ }^{276}$ Alcaldía de Monería (2010): Plan de ordenamiento Territorial. 2002-2015.Montería. Pág. 457 
ciudades, y mitiga proporcionalmente la marginalidad física de los barrios informales. Este estilo de planeación contribuye significativamente a la legitimación de la informalidad, pero garantiza el control político por parte de los grupos de poder y el negocio de propietarios y especuladores de suelo.

No obstante, y a pesar del sólido control político, se evidencian graves desaciertos urbanísticos que desnudan la ausencia de una política definida de desarrollo urbano, y la responsabilidad compartida de la totalidad de mandatarios que gobernaron a esta ciudad en los últimos sesenta años. Sobre este particular, conviene recordar que desaciertos urbanísticos como: deficiencia o inexistencia de infraestructura en barrios, la falta de equipamientos apropiados y el gran déficit de espacio público, son precisamente la gallina de los huevos de oro de un modelo de crecimiento, diseñado particularmente con fines de perpetuación de castas y acumulación de capital, y no con criterio de desarrollo urbano.

\subsubsection{Las Piezas urbanas como escenarios de intervención correctora}

Con el objetivo de corregir desaciertos urbanísticos y de dotar de infraestructuras a los asentamientos marginales, se estableció en el Plan de Ordenamiento Territorial del año 2002, la necesidad de dividir la ciudad en cinco piezas urbanas. "Las piezas urbanas son grandes porciones de territorio urbano y de expansión específicamente delimitadas en este Plan, que tienen características urbanísticas diferentes" (Art. 179). Las Piezas Urbanas que el Plan de Ordenamiento Territorial delimita son las siguientes: el Centro, Ciudad Norte, Ciudad Sur, Borde Occidental y Borde Oriental. 


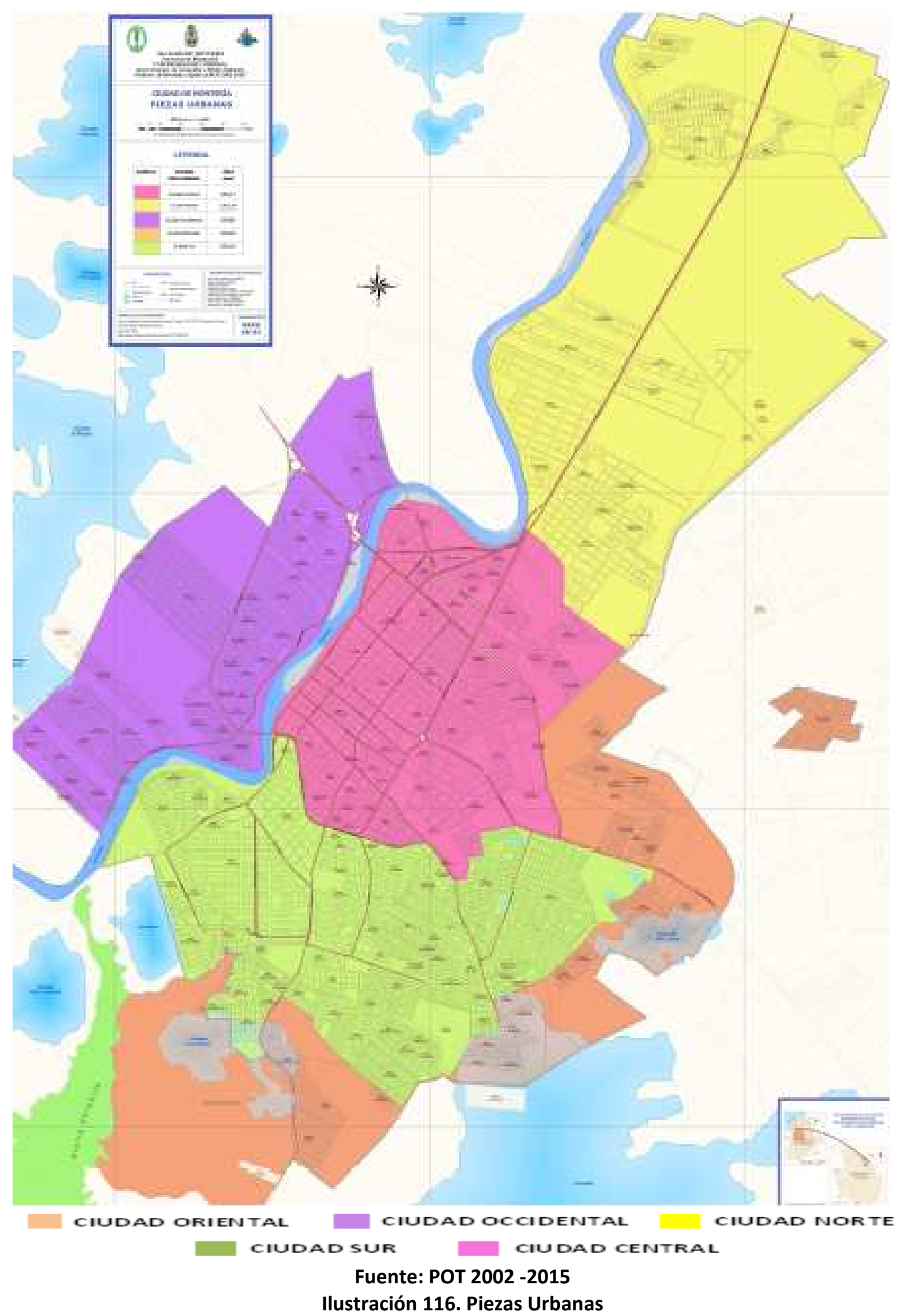

La corrección de desaciertos urbanísticos, la dotación de redes de infraestructuras en asentamiento precarios y los nuevos desarrollos serían realizados a través de las denominadas 
operaciones estructurantes $^{277}$. Estas operaciones estarían orientadas, por lo menos sobre el papel, a lograr el crecimiento programado de la ciudad, la estructuración de áreas consolidadas, la configuración del centro tradicional y a la integración de áreas marginales. Igualmente apuntarían a lograr metas definidas en el modelo de ordenamiento del plan; específicamente en lo relacionado a vivienda de interés social, renovación urbana y mejoramiento integral de barrios.



277 El Plan de ordenamiento Territorial 2002-2015, en la formulación de su modelo, define las operaciones estructurantes como aquellos instrumentos de actuación integral de largo plazo, que tienen por objetivo, la intervención pública sectorial focalizada y la incentivación de la inversión privada. Tomo I, Modelo de Ordenación. Pág. 38 
Con la integración de áreas marginales se pretende el equilibrio del territorio, comunicando los denominados "barrios subnormales", o áreas de desarrollo incompleto, a las zonas de mayor dinámica de la ciudad, mediante la configuración de la estructura física, la creación de nuevas centralidades y la dotación de equipamientos. En el plano anterior, se aprecia en rojo las operaciones estructurantes de integración de áreas marginales en asentamientos del suroriente, occidente, nororiente y norte de la ciudad.

En el occidente se busca consolidar tres centralidades en los barrios informales del Dorado, Rancho Grande y la Esperanza; en el norte se programó consolidar la centralidad Mocarí, y en el sur la de Mogambo. Los asentamientos a integrar en el occidente serían Mi Ranchito, el Níspero, Caracolí, Nuevo Horizonte, el Níspero II, el Poblado, Casita Nueva, el Campano Manuel Jiménez y Villa Luz; en el sur se beneficiarían Villa Paz, Furatena, Nueva Esperanza y los Robles II; en el norte lo harían 20 de Julio, 7 de Mayo, Villa del Sinú y Paz del Norte; mientras que en el nororiente, Villa Cielo sería incorporada al perímetro urbano.

Consideramos que las operaciones estructurantes, como intervenciones integrales, fueron programadas de acuerdo a unos efectos territoriales esperados, pero también, a una jerarquía de necesidades urbanas, sociales, económicas y ambientales de suelos estratégicos del norte y del nororiente de Montería. El desarrollo de dichas operaciones, incorporó una serie de proyectos, que se realizarían en el corto, mediano y/o largo plazo, en las diferentes piezas urbanas en las que se dividió la ciudad. Expondremos a continuación, de manera detallada, la programación, realización e impacto de las obras en cada una de estas piezas urbanas. 


\subsubsection{Pieza urbana occidental}

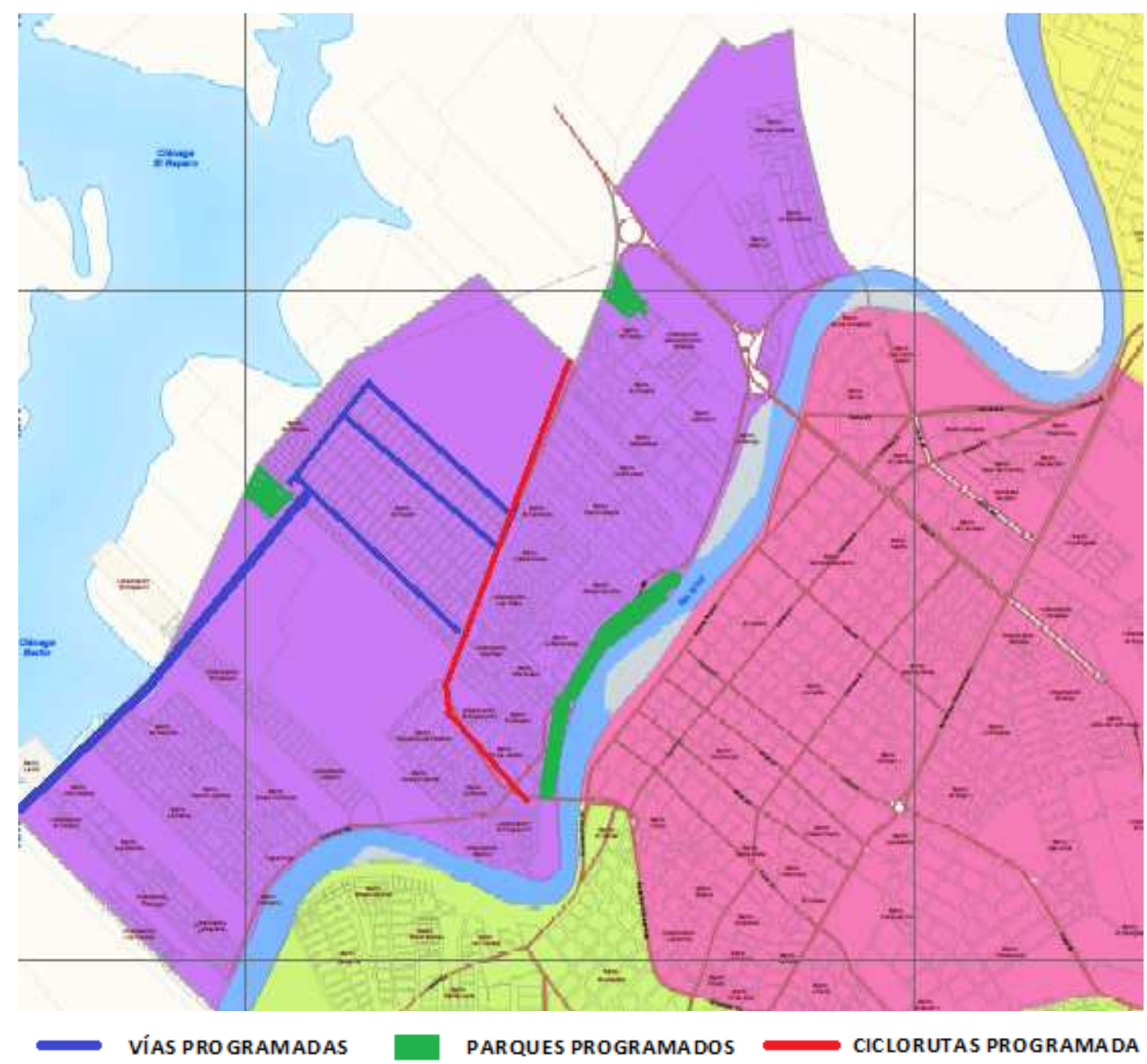

Fuente: elaboración propia a partir del POT 2002-2015 Ilustración 118. Pieza occidental

\section{Operación Rancho Grande - El Dorado}

1. Parque Recreacional Berlín (corto y mediano plazo)

2. Plaza Cívica (mediano plazo)

3. Plaza de Mercado (corto y mediano plazo)

4. Ciclorrutas (corto y mediano plazo)

5. Ampliación corredores viales (mediano plazo)

\section{Operación Río Sinú}

1. Parque lineal ecológico ronda del río Sinú (Corto y mediano plazo)

2. Ciclorrutas (corto y mediano plazo)

3. Nodo de equipamiento sobre el Eje - Centralidad Urbana - Av. $1^{a}$ W. En este nodo se encuentran programado un centro cultural, el parque recreacional la Alboraya y un centro comercial para el corto y mediano plazo. 


\section{Operación Teherán}

1. Parque recreacional Teherán (mediano plazo)

2. Estación de bomberos (mediano plazo)

3. Centro de Acopio Regional (mediano plazo)

4. Estación de cabecera (corto y mediano plazo)

5. Calle $41 \mathrm{~W}$ (corto y mediano plazo)

Esta pieza urbana tiene una superficie de 640.83 hectáreas y actualmente sus barrios requieren de la construcción de plazas, jardines, zonas recreativas, vías vehiculares, peatonales, articulación espacial entre ellos, equipamientos deportivos, culturales, educativos, de salud, comercial y ciclo-rutas para mejorar la movilidad. Está conformada por cuarenta y tres barrios de las comunas 1 y 2 , en las que sus habitantes presionan por el cumplimiento de las obras programadas. Sobre este último aspecto, conviene anotar que hasta la fecha solamente se han realizado dos de las quince intervenciones programadas, las cuales apuntaron a resolver problemas de movilidad vehicular y no a mejorar la calidad urbanística de los asentamientos precarios o semiconsolidados de este sector.

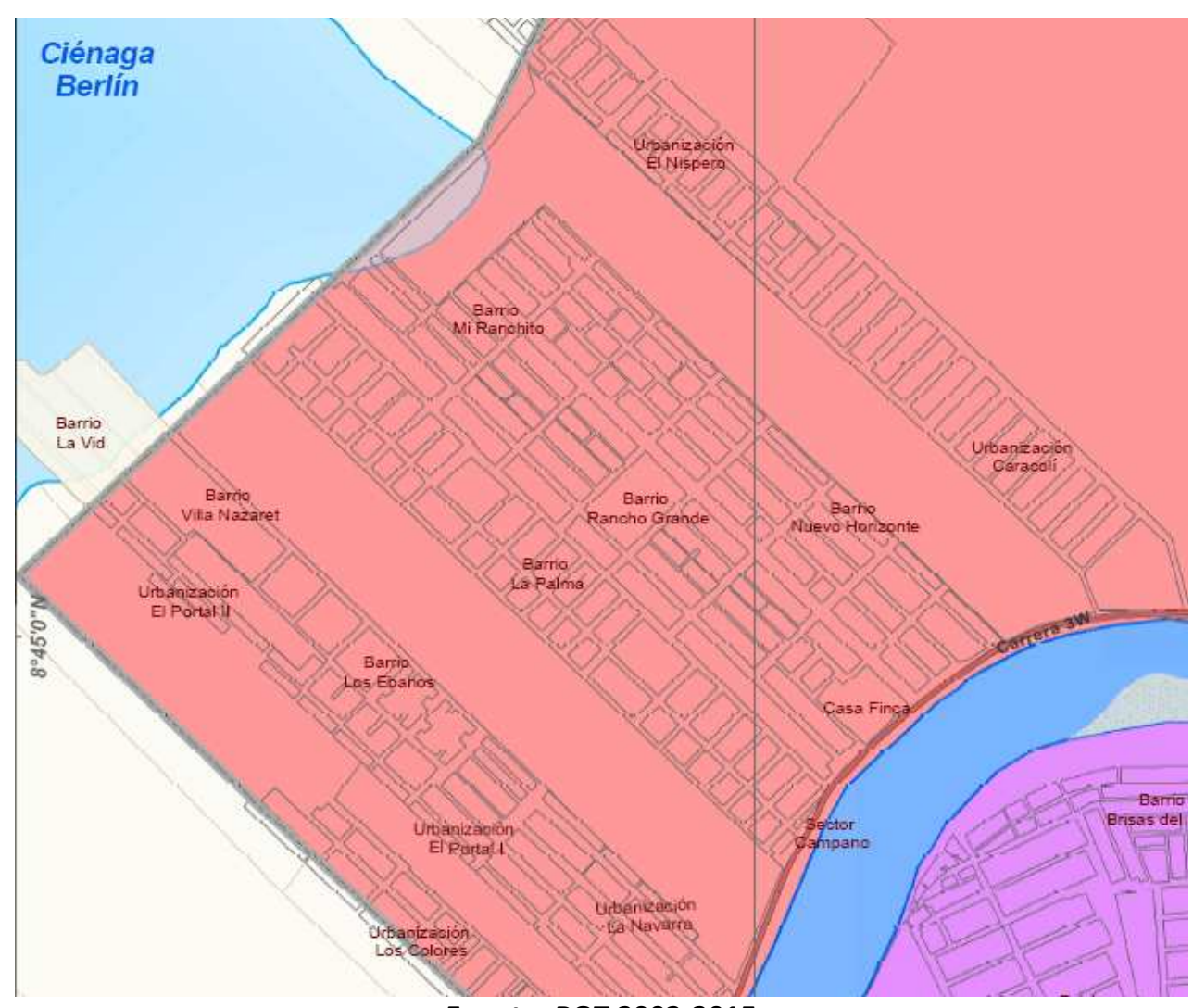

Fuente: POT 2002-2015

Ilustración 119. Asentamientos precarios y semiconsolidados pieza occidental 
Los asentamientos informales que mayor deficiencia presentan en esta pieza son: Urbanización Caracolí, los Colores, la Vid, el Ébano, la Palma, Mi Ranchito, Casa Finca, el Níspero, el Poblado, el Dorado en el sector la Turbina, Villa Nazaret, el Portal, la Fe, el Bongo, el Campano y Casita Nueva. En esta zona se programaron posteriormente obras como el denominado Gran Parque entre el barrio el Dorado y la Urbanización Caracolí; dos escenarios deportivos infantiles y de estancia; un megacolegio en el barrio los Colores: construcción de canales para conducir aguas pluviales en Panamá, Caracolí y la Palma; desarrollo de 62 hectáreas por medio de los planes parciales Teruel, COMFACOR y Palma Verde.

Estos tres planes parciales son inversiones privadas en los que se construirán viviendas unifamiliares y multifamiliares para estratos socioeconómicos altos, y en los que además, se permitirán actividades comerciales compatibles con el uso residencial. No obstante, estas intervenciones son demasiado insignificantes para generar un impacto favorable en los asentamientos más precarios de esta pieza; situación qué, sumada al incumplimiento en la ejecución de gran parte de las obras mencionadas, generó malestar colectivo y brotes separatistas ${ }^{278}$ por parte de algunos grupos políticos de la margen izquierda del Río Sinú.

\footnotetext{
278 Durante la administración de Marcos Daniel Pineda García, aumentó el malestar que desde años atrás venían manifestando líderes políticos de la margen izquierda de la ciudad, por el rezago socioespacial en el que consideran ellos, y evidentemente es así, se encuentra el occidente de Montería. Dicho malestar desencadenó un movimiento separatista, que pretendió en el año 2009 por vía legal, constituir el municipio de San Jerónimo de Buenavista, objetivo éste, que fracasó, ante la dificultad para cumplir con los requisitos mínimos exigidos por la Ley, principalmente en materia de ingresos fiscales.
} 


\subsubsection{Pieza urbana centro}



\section{Operación Centro Tradicional}

1. Proyecto Avenida 20 de Julio (corto plazo)

2. Proyecto Bulevar del Comercio (corto y mediano plazo)

3. Proyecto Mercado Central Galerías (corto plazo)

4. Proyecto Ampliación de Andenes (mediano y largo plazo)

5. Proyecto Plazas Centrales (mediano y largo plazo)

6. Proyecto Plaza Cívica Institucional - Frente a la Alcaldía - (corto y mediano plazo)

7. Proyecto Pescadería Minorista (corto plazo)

\section{Operación Puente sobre el Río Sinú}

1. Puente vehicular sobre el río Sinú calle 41 (Corto plazo)

2. Puente peatonal sobre el río Sinú calle 31 (mediano y largo plazo) 
3. Malla vial principal e intermedia (corto y mediano plazo)

\section{Operación Cantaclaro}

1. Plan vial arterial calle 41-Termiabastos-puente de la calle 1a (corto y mediano plazo).

2. Dotación de servicios comunitarios y desarrollo de la centralidad (corto y mediano plazo)

\section{Operación Nodo de Equipamiento Urbano}

1. Plaza y plataforma ceremonial -Tacasuan- (corto y mediano plazo)

2. Ciudadela cultural: Foro Municipal y Teatro. (mediano y largo plazo)

3. Adecuación y renovación de los palacios Naín y Municipal (mediano plazo)

4. Villa Olímpica y complejo deportivo. Estadio de fútbol. (Mediano plazo)

Esta pieza urbana está conformada en un $98 \%$ por asentamientos legalmente constituidos, presenta los menores desequilibrios socio-espaciales y su área asciende a 698. 17 hectáreas. Se destacan los barrios históricos de la Ceiba, Chuchurubí, Montería Moderno, Nariño, el Centro Tradicional y asentamientos de gran calidad urbanística como Pasatiempo, Costa de Oro, la Julia, Urbina, el Edén I, Ospina Pérez, Santa Clara, los Álamos, Balboa y Urbanización Lacharme. Sin embargo, en ella se encuentran la invasión de Sucre, sin intervención alguna hasta ahora, y el barrio Informal 25 de Agosto, favorecido con intervenciones de ampliación vial en el centro-oriente de la ciudad.



Fuente POT: 2002-2015

Ilustración 121. Invasiones e Intervenciones Pieza Central 
A diferencia de las otras cuatro piezas, a ésta, se le han asignado los recursos requeridos para cumplir con las intervenciones programadas, especialmente aquellas destinadas a la remodelación de los equipamientos administrativos y adecuación de vías. Estos recursos permitieron la culminación de tres grandes obras a partir del año 2004:

1) construcción del puente sobre el río Sinú a la altura de la calle 41;

2) intervención en la avenida 20 de julio, también conocida como Ronda del Sinú Fase I, y

3) El denominado Plan Vial de la calle 41.

Así mismo, se inició la restauración del pavimento de la calle 27, la remodelación de los dos parques centrales y la remodelación de los edificios donde funcionan la alcaldía y la gobernación. Estas intervenciones, según la actual administración municipal, pretenden recuperar la memoria histórica de la ciudad, y el valor patrimonial de los edificios del entorno. No obstante, desde esta investigación, consideramos que estas intervenciones no son suficientes, sino van acompañadas de un programa definido de protección y restauración de edificaciones con gran riqueza arquitectónica, artística, o cultural.

Quedan pendientes intervenciones claves para el desarrollo urbano como, la recuperación del espacio público, la renovación urbana de sectores degradados, adecuación mercado central, pescadería minorista, puente peatonal, dotación de servicios comunitarios, ciudadela cultural, complejo deportivo de la villa olímpica, legalización del barrio 25 de agosto, renovación de la denominada "olla de la droga de pueblo pescao"279 y la reubicación de los habitantes de la invasión Sucre que se encuentran asentados desde hace más de diez años en la ribera del río Sinú. Estos dos últimos sectores, Olla e Invasión, generan un fuerte impacto sobre las aguas del

\footnotetext{
${ }^{279}$ Este fue y sigue siendo un sector deprimido del centro de la ciudad, emplazado desde la calle 37 a la calle 41, sobre la ribera del Río Sinú y la Avenida Primera, con cerca de 500 habitantes, que se dedicaban principalmente a la venta de pescado. La reubicación de sus habitantes en el año 1996, no mejoró las condiciones físicas ni las de seguridad de este sector, y por el contrario, en la actualidad es un escenario de indigencia, utilizado para la venta y consumo de drogas.
} 
mencionado río, situación ésta, que será ampliada en el apartado 5.4 dedicado al impacto ecológico.

\subsubsection{Pieza urbana sur}



Fuente: elaboración propia a partir del POT 2002-2015

Ilustración 122. Pieza urbana sur

\section{Operación la Granja}

1. Plaza de Mercado (Bodegas IDEMA) (Corto plazo)

2. Centros Culturales y Artísticos (Mediano plazo)

3. Red de Ciclorrutas (corto y mediano plazo)

4. Plaza Urbana (mediano plazo)

\section{Operación Mogambo}

1. Plaza de Mercado (corto y mediano plazo)

2. Red de Ciclorrutas (corto y mediano plazo)

3. Plazas Urbanas (mediano plazo)

La pieza ciudad sur presenta los mayores conflictos urbano-ambientales, debido a que concentra el mayor número de asentamientos informales, a su elevada densidad poblacional, a la desecación de la ciénaga de los Araujos, a la invasión de la reserva ecológica de Sierra Chiquita y al alto déficit de redes de infraestructuras. Estos 
aspectos serán ampliados e ilustrados en el apartado correspondiente a impacto ecológico.

Con una superficie de 856.56 hectáreas, esta pieza urbana se encuentra conformada por las comunas tres y cuatro, en las que sobresalen los barrios de promoción pública del P-5, la Granja, Buenavista, Mogambo, Prado, Panzenú y Villa Margarita. Igualmente, se distinguen, pero por su precariedad urbanística, los asentamientos informales de las Colinas, 2 de Septiembre, Alfonso López, los Araujos, Colina Real, Brisas del Sinú, Pastrana Borrero, Policarpa, Santafé, Santander, San Martín, $1^{\circ}$ de Mayo, Candelaria, Santa Rosa, Paz del Río, Villa Ana, el Paraíso, Edmundo López I, Edmundo López II, Robinson Pitalúa, Mogambito, el Cerro, Villa Rocío, Damasco, San Cristóbal, el Alivio y Cantaclaro.

En esta pieza se encuentran programadas obras viales, ciclo-vías, dotación de redes, adecuación de espacio público, y construcción de equipamientos educativos en los barrios los Araujos y los Nogales. Las intervenciones más visibles hasta el momento son: los denominados megacolegios de los Nogales y los Araujos II; pavimentación de la calle principal de Alfonso López; acueducto de los barrios 2 de Septiembre y los Araujos; ampliación de puesto de salud de Villa Margarita; adecuación estadio de softbol Eugenio Valdez en el Prado; construcción de la Casa de la Justicia e incorporación del servicio público de transporte hasta los Araujos.

Con relación a los megacolegios, es oportuno anotar que aun no han sido culminados, pero su terminación se tiene prevista para finales del 2011, y su capacidad será de 1.600 estudiantes. Con esta cobertura, el megacolegio de los Nogales, también beneficiaría a jóvenes de los barrios Vereda Tropical, Villa Jiménez, el Paraíso, Santa Isabel, Villa de los Alpes, las Acacias, Villa Karime y Vista Hermosa, quienes actualmente asisten a la institución educativa Robinson Pitalúa. A continuación, en una de las imágenes, se muestra el estado en que se encuentra la construcción de este megacolegio, dentro de un entorno aparentemente semirural, pero perteneciente a predios del barrio informal Vereda Tropical. 

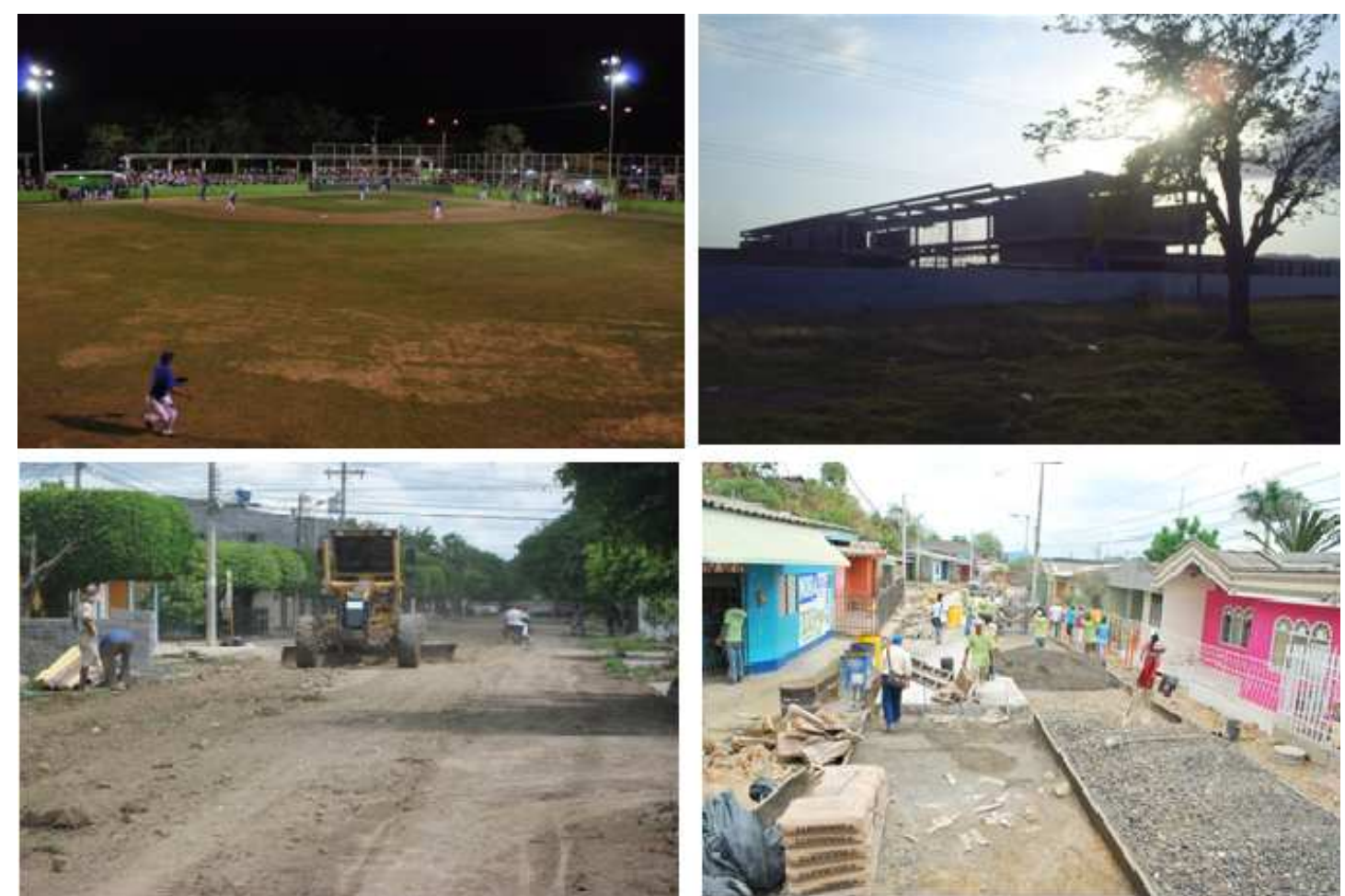

Fotografías: Jhon Pinedo - Alcaldía de Montería 2010

Ilustración 123. Intervenciones Pieza Sur

Como se aprecia en la imagen superior derecha, es una edificación de dos plantas, con caracteristica de equipamiento educativo, que evidentemente ampliará la cobertura de bachillerato en esta zona deprimida de la ciudad, pero que dificilmente contribuirá a la cohesión social o al mejoramiento urbanistico del sector. Esta obra es el producto de una coyuntura, en la que no se incluyen intervenciones complementarias de accesibilidad, espacio público o dotaciones, que integren social y espacialmente a los habitantes de estos barrios con otros sectores de la ciudad; por el contario, su ejecución ha generado una serie de suspicacias, principalmente en el gremio de educadores publicos, porque serán entregados a concesionarios privados, en vez de ser administrados directamente por la administración municipal.

Referente a otras obras programadas en esta pieza, se debe señalar que hasta el año 2011, no se cuenta con ninguna ciclo-vía, ni se ha ejecutado el primer metro longitudinal de ellas. Tampoco se ha construido los andenes peatonales de vías pavimentadas en la Granja, Santander, Policarpa, Santafé, Pastrana Borrero, Mogambo, el Prado, P-5, 6 de Marzo y Guadalajara. En estos sectores los peatones 
siguen exponiendose a la intolerancia de conductores de motocicletas, automoviles, autobuses y vehiculos de carga.

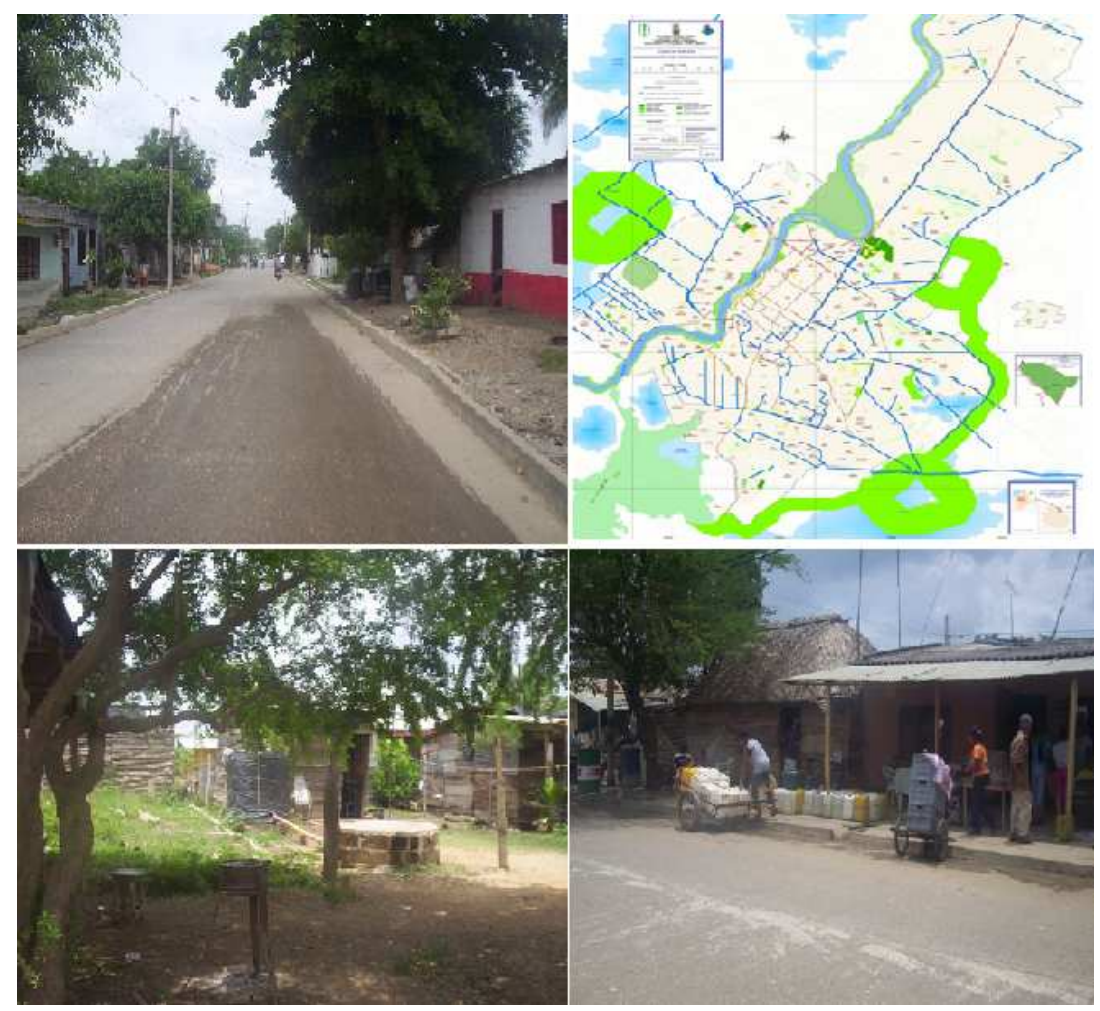

Fotografías: Jhon Pinedo López 2008

Ilustración 124. Obras inconclusas y eje ambiental proyectado en el sur

Además del retraso en la construcción de andenes y ciclorutas, también se ha incumplido con la ejecución del eje ambiental que se programó para conectar peatonalmente a la reserva natural de Sierra Chiquita con las lagunas de oxidación sur y oriental. Este proyecto tiene como objetivo, reducir el deficit de espacio público, mejorar la calidad ambiental, y ofrecer alternativas de recreación activa a los habitantes de esta zona de la ciudad, quienes carecen de equipamientos recreativos y deportivos; especialmente los residentes en los barrios informales 2 de Septiembre, los Araujos II, $1^{\circ}$ de Mayo, la Candelaria y Santa Rosa. 




Fuente: elaboración propia con base en el POT 2002-2015

Ilustración 125. Intervenciones pieza urbana sur

Como se aprecia en el plano, el mayor número de intervenciones en esta pieza, se ha orientado a la pavimentación en concreto de vías de barrios consolidados y a la construcción de algunos equipamientos educativos en asentamientos precarios o semiconsolidados. Sin embargo, hay que anotar que la prioridad en estos sectores aún no es la adecuación de vías, sino la dotación de redes de infraestructura de servicios básicos, de equipamientos comunitarios y el mejoramiento de la vivienda, principalmente en Villa Ana, la Candelaria, Mogambito, Santa Rosa, Paz del Río, Damasco, San Cristóbal, Vereda Tropical, el Paraíso, Villa Rocío y el Alivio.

En este mismo sentido, debemos destacar que los barrios consolidados mejor conectados vialmente son la Granja, Santander, Policarpa, Buenavista, la Coquera, el Prado, el P-5, Mogambo, 2 de Septiembre, Alfonso López, Panzenú, Villa Margarita, Granada y 6 de Marzo. No obstante, el estado de sus vías internas sigue siendo precario y la disponibilidad de andenes, ciclo vías y de espacios para el peatón es deficiente, o simplemente inexistente; esta situación es explicable si tenemos en cuenta el origen informal de algunos de ellos. 


\subsubsection{Pieza urbana norte}

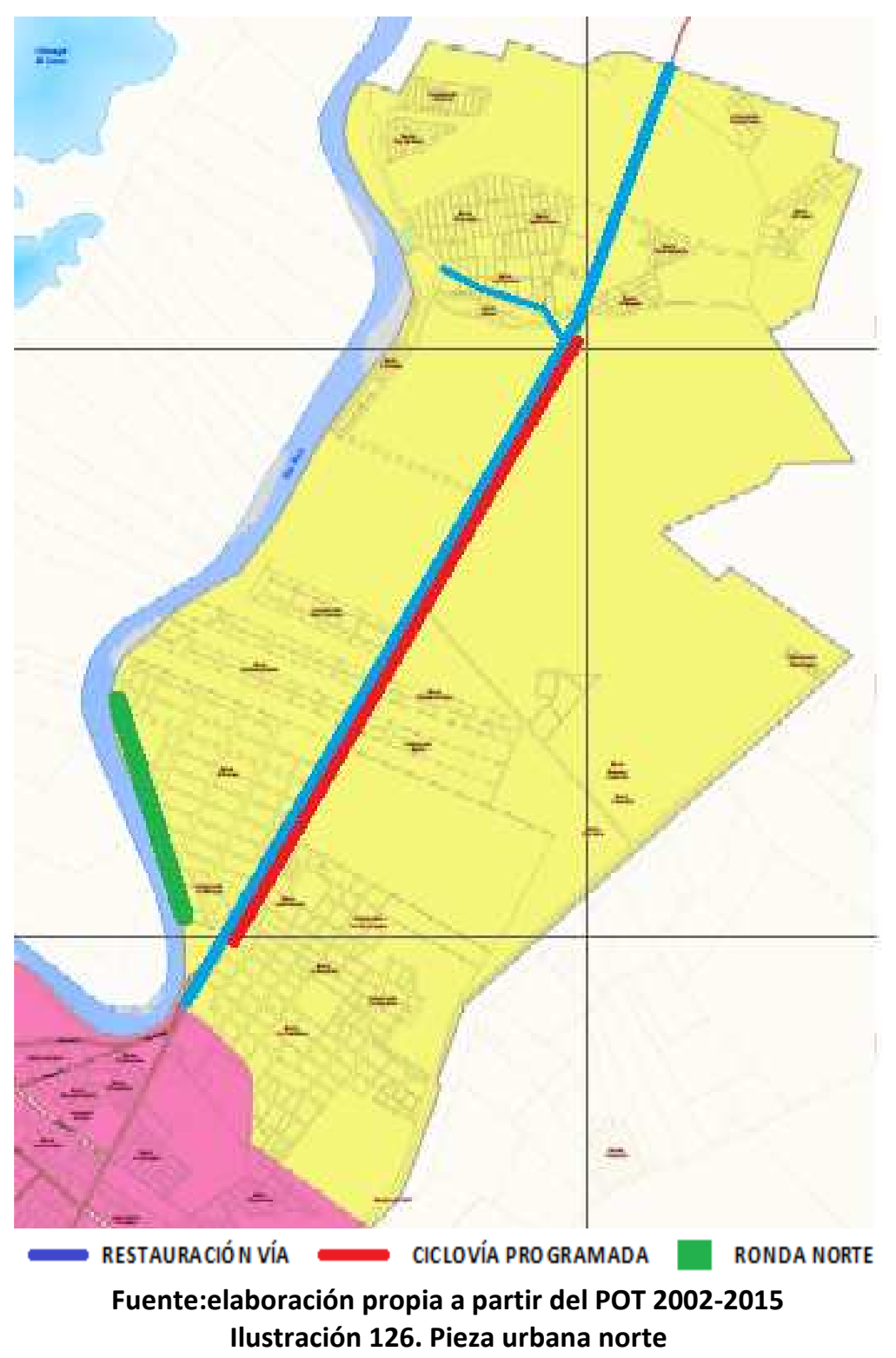

\section{Operación Zona Industrial Ecoeficiente y Avenida Primera}

1. Malla vial (corto plazo)

2. Prolongación de la Avenida 1 a (corto y mediano plazo)

3. Parque ecológico de la ronda del río Sinú (corto y mediano plazo)

4. Parque industrial ecoeficiente (corto y mediano plazo)

\section{Operación Eje Central vía a Cereté}

1. Plaza de Mercado (mediano plazo)

2. Centros Culturales (mediano y largo plazo)

3. Estación de Cabecera - Sistema de Transporte (corto y mediano plazo)

4. Sector Universitario (corto, mediano y largo plazo)

5. Clínicas (corto, mediano y largo plazo)

6. Mirador de la 56 (corto plazo) 


\section{Operación Mocarí}

1. Mejoramiento del casco fundacional de Mocarí (mediano y largo plazo)

2. Articulación vial Mocarí - Carretera (mediano plazo)

3. Dotación de servicios comunitarios (corto y mediano plazo)

4. Parque Recreacional Mocarí (corto y mediano plazo)

5. Plaza de Mercado (mediano plazo)

6. Puente Invías (mediano plazo)

Con una superficie de 1.281 hectáreas, esta pieza urbana es la más extensa y las intervenciones que en ella se programaron apuntaron principalmente a la integración espacial del territorio con el río Sinú. Una de las más importantes obras realizadas es la denominada Ronda del Sinú, que dicho sea de paso, no es más que un parque lineal paralelo a dicho Río. Este excepcional parque, además de la integración espacial, también logró convertirse en uno de los principales referentes ambientales de Montería.

Igualmente, se encuentran ubicados en esta pieza, equipamientos importantes como el Centro de Convenciones, la Universidad de Córdoba, el Colegio Lorenzo María Lleras INEM, la Universidad Pontificia Bolivariana, el Bienestar Social de la Policía, Hipermercado Éxito, Club Campestre, el Centro Comercial Plaza de la Castellana, Universidad San Martín, Colegio la Sagrada Familia, Universidad Luis Amigó, Colegio Británico, Gimnasio Vallegrande, estadio de Beisbol 18 de Junio y el club Campestre.

Esta pieza, presenta los mayores contrastes socioeconómicos y de usos, en la que confluyen barrios opulentos de estratos altos con las invasiones precarias de Ranchos del INAT, 7 de Mayo, Camilo Torres, el Ceibal y Paz del Norte. En cuanto a usos, se evidencia conflictos generados por la presencia de la fábrica de refrescos POSTOBON en el barrio residencial el Recreo, así como la incompatibilidad de estaciones de gasolina con equipamientos educativos o recreativos. 


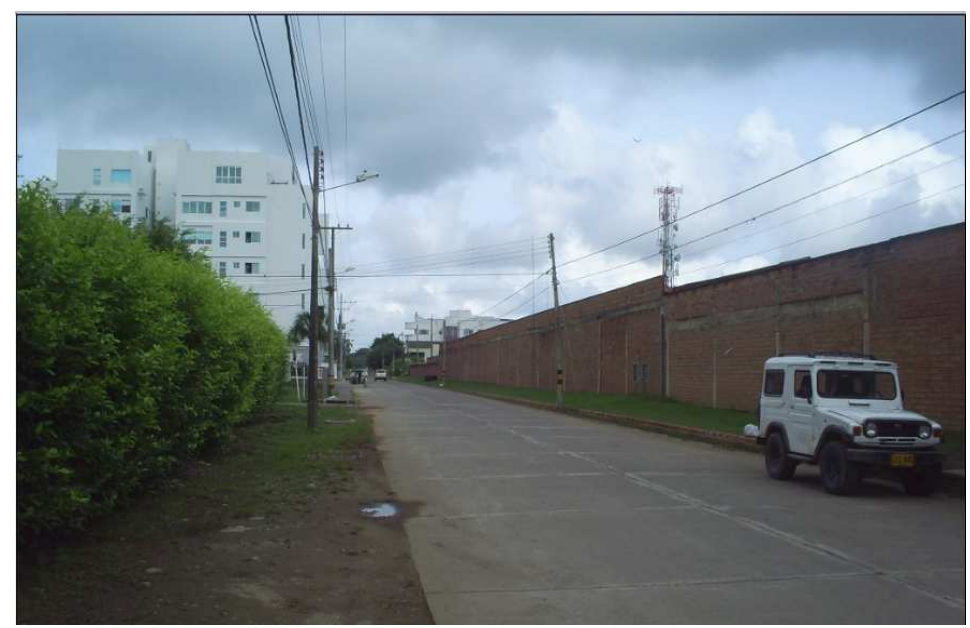

Fotografía: Bertha Katia Araujo 2011

Ilustración 127. Fábrica de bebidas POSTOBON en barrio residencial

El Recreo es el barrio más exclusivo de la ciudad, conformado por suntuosas viviendas unifamiliares y edificios multi-residenciales pertenecientes al estrato socioeconómico seis, dato éste aparentemente insignificante, pero con enorme peso debido al alto costo de los servicios públicos básicos y por el elevado precio del metro cuadrado de suelo construido. No obstante, sus redes son insuficientes, el servicio de transporte colectivo es deficiente y la Industria POSTOBON limita su crecimiento hacia el norte, e impide la intersección de la calle 70 con la avenida circunvalar.

La pieza norte presenta el mayor dinamismo formal de los últimos diez años, y en ella se han construido: clínica Montería, clínica Oncológica, restaurante Simón Parrilla, club recreativo Área Chica, Universidad San Martín, Politécnico Central, bodegas de la empresa Licosinú, Grupo Litoral, viviendas multifamiliares, edificios de oficinas e institucionales, gimnasios, discotecas, almacenes, centro de convenciones, barrios de promoción pública y expresiones de informalidad urbanística a partir de loteos irregulares en los sectores de California II, Altos de California, Portal el Norte, Bosques de Castilla, el Bosque y Palma Verde. 


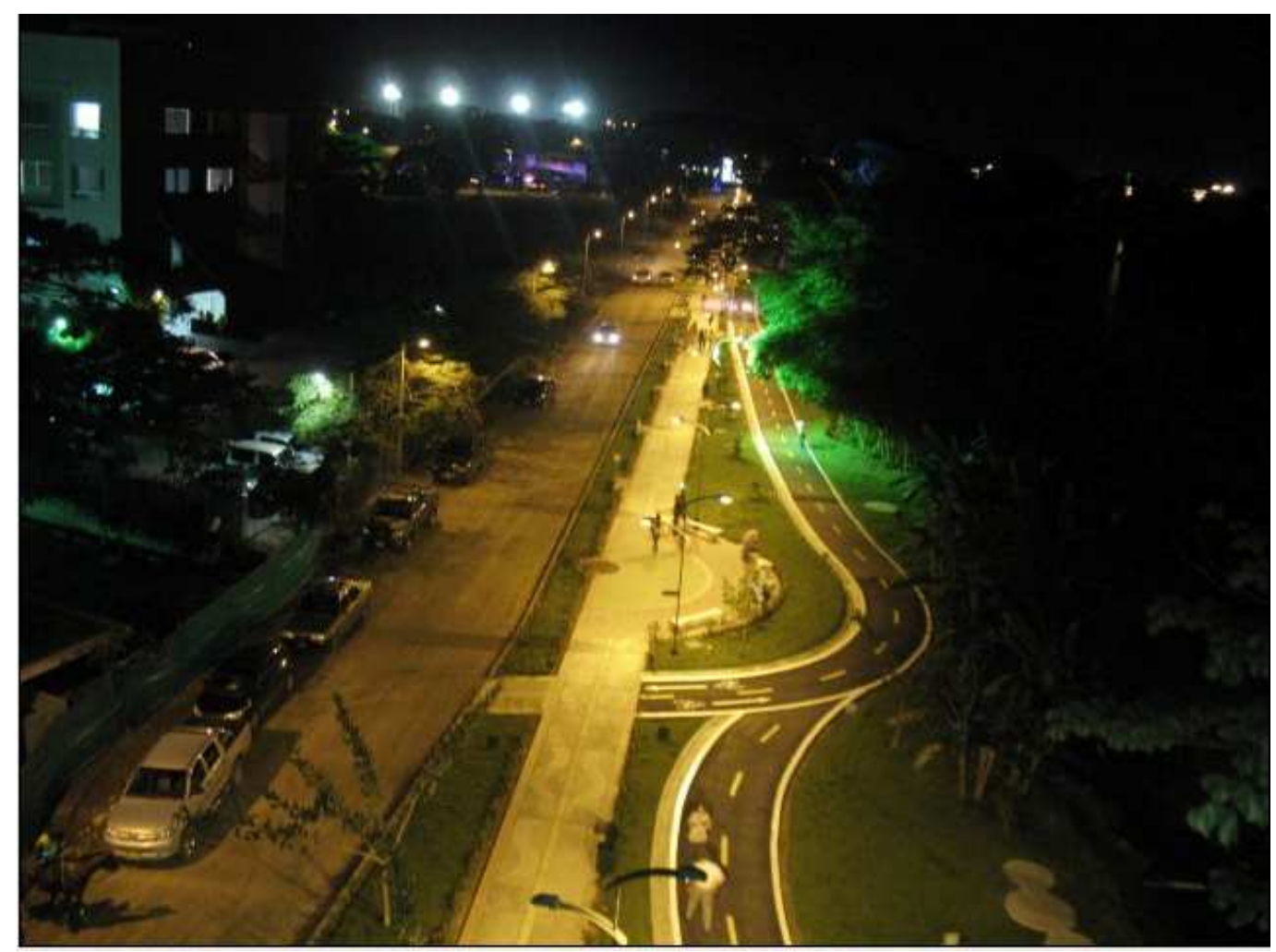

Fuente Fotográfica: Alcaldía de Montería 2010

Ilustración 128. Ronda del Sinú Norte

Por otra parte, consideramos desde esta investigación, que la construcción de la Ronda del Sinú Norte, es una obra que benefició principalmente a los habitantes del barrio el Recreo, y poco o en nada favorece a otros sectores de esta pieza urbana. En este mismo barrio, y diagonal a la POSTOBON se construye actualmente el hipermercado de la firma multinacional Home Center, situación que contribuirá a valorizar, aún más, el precio del suelo en esta zona. Con estas intervenciones realizadas en la pieza norte, el metro cuadrado de suelo en el Recreo asciende a \$US 750, mientras en los barrios populares de la misma, no supera los \$US 50, situación esta, que nos permite corroborar que los mayores contrastes de la ciudad, precisamente, se presentan es en esta pieza. 




Fuente: elaboración propia a partir del POT de Montería 2002-2015

Ilustración 129. Nuevas intervenciones y desaciertos urbanísticos

Como se anotaba y se ilustraba anteriormente, las intervenciones en esta pieza se concentraron principalmente en las inmediaciones del barrio el Recreo, y ello contribuyó al inicio de la construcción en los terrenos más costosos de la ciudad. Sin embargo, es pertinente anotar que estos suelos siempre fueron los de mayor especulación en Montería, motivo por el cual, la ciudad no logró un crecimiento más compacto, y la oferta de suelo debió trasladarse hacia zonas de alto impacto ambiental en la margen izquierda del río y en el suroriente, lo que a su vez, desencadenó en altos niveles de informalidad urbanística.

La especulación en este sector es tan excluyente, que durante más de veinte años desestimó los proyectos de inversionistas locales, y solamente la propuesta de una firma multinacional, como HOMECENTER, pudo satisfacer las expectativas de propietarios y promotores. En este momento, es la única obra que se realiza en estos terrenos, pero todo parece indicar que la especulación se extenderá por un largo periodo y en ellos no se constituirán asentamientos informales.

Para terminar con el análisis de esta pieza urbana, destacaremos que las intervenciones desarrolladas aumentaron los contrastes, y a pesar de haber integrado físicamente a varios sectores, no permitieron el mejoramiento de la calidad urbanística de barrios populares, ni la reubicación de la fábrica de refrescos Postobón. Dicha 
reubicación, se requiere urgentemente; en primer lugar por incompatibilidad de usos de suelo, y en segundo lugar, por la necesidad de reparcelar un terreno que debe conectar la calle 70 con avenida circunvalar.

\subsubsection{Pieza urbana oriental.}

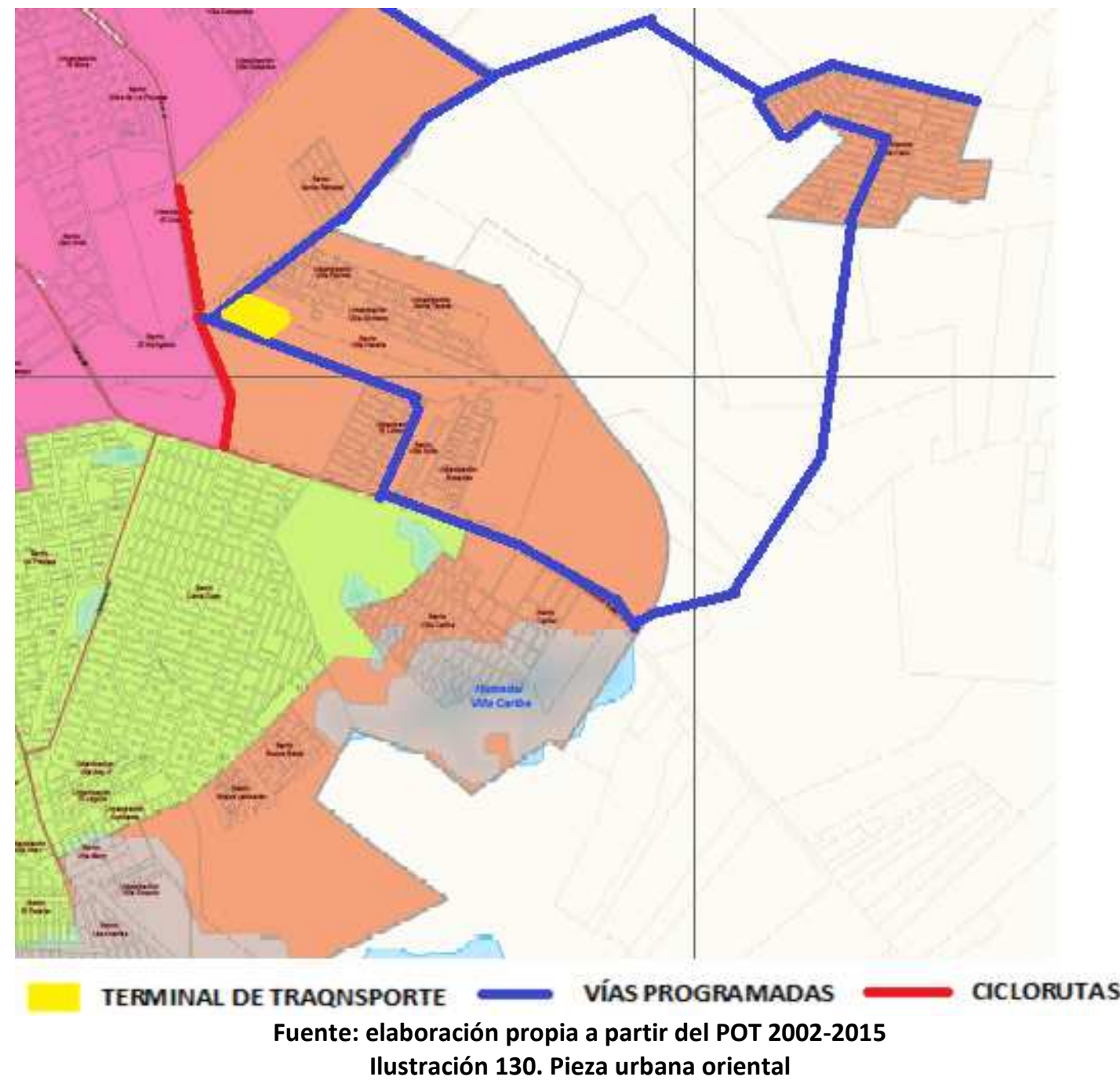

\section{Operación Anillo de Oriente}

1. Plan vial desde vía Planeta Rica -Sierra Chiquita- (corto y mediano plazo)

2. Estación de Cabecera Sur (corto y mediano plazo)

\section{Operación La Estancia}

1. Complejo deportivo. (Mediano y largo plazo)

2. Parque recreativo La Estancia (mediano y largo plazo)

3. Malla vial interna y de transporte -incluye ciclorrutas- (mediano y largo plazo) 


\section{Operación Sierra Chiquita}

1. Parque ecológico recreacional (corto, mediano y largo plazo)

2. Reforestación (corto y mediano plazo)

3. Lago Recreacional (mediano y largo plazo)

4. Senderos para ecoturismo (mediano y largo plazo)

5. Mirador (mediano y largo plazo)

6. Ciclorrutas (mediano plazo)

\section{Operación Termiabastos}

1. Terminal de Transporte (corto plazo)

2. Central de Abastos (corto y mediano plazo)

3. Puente Puerta Oriental - Anillo vial de oriente (corto y mediano plazo)

\section{Operación Anillo Intermedio}

1. Anillo Intermedio (corto y mediano plazo)

2. Estación de Cabecera Sur (corto y mediano plazo)

Esta pieza, de 838.92 hectáreas de superficie, presenta grandes conflictos urbanoambientales, ocasionados principalmente, por la invasión de los humedales Villa Jiménez, Villa Caribe y los Araujos. No obstante, se han realizado actuaciones importantes como la terminal de transporte, la prolongación en doble calzada de la calle 41 , e instalación de redes; así mismo se tienen programadas, pero aún sin ejecutar, la construcción de la central de abastos, vías vehiculares, escenarios deportivos y el parque La Estancia.

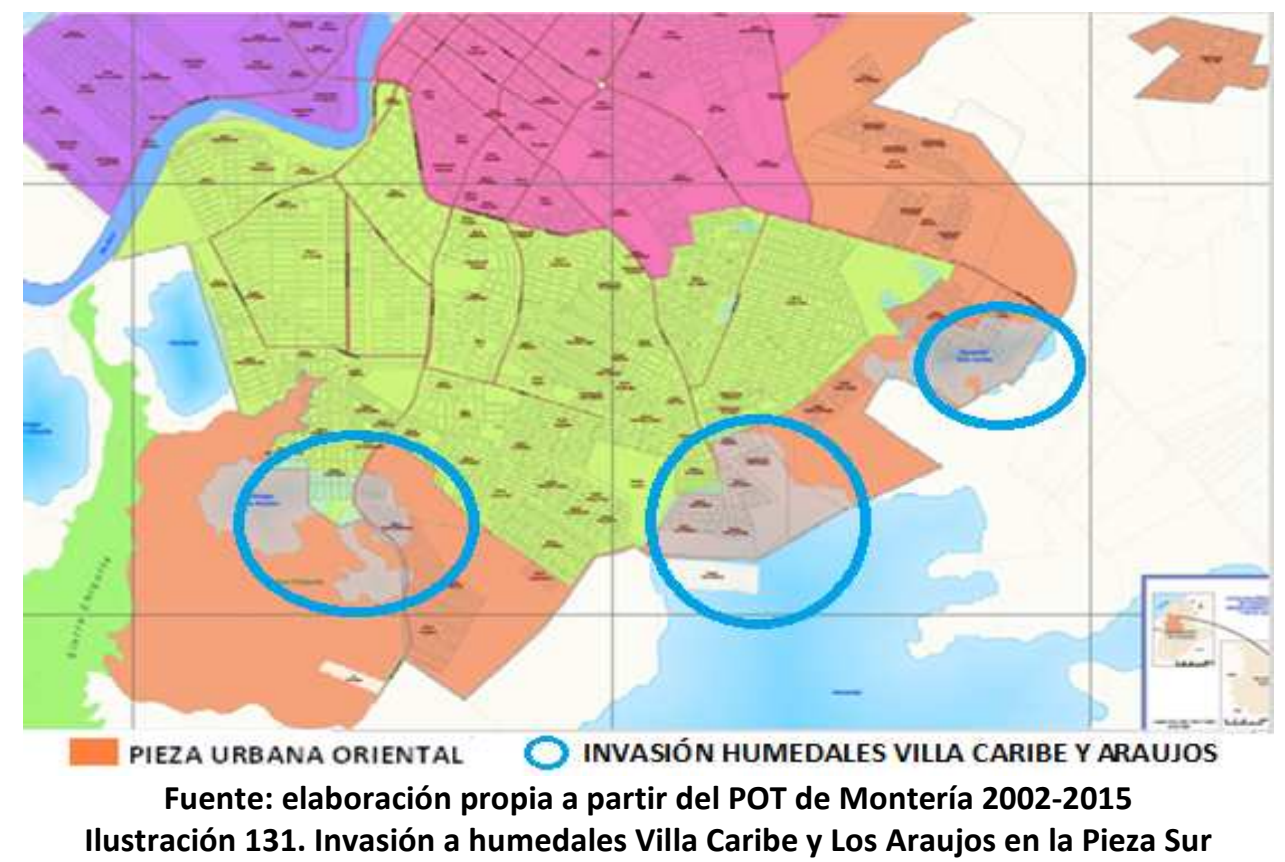


Igualmente, esta pieza se encuentra conformada por asentamientos de la comuna seis como Villa Caribe, barrio Caribe, Nueva Jerusalén, Nueva Belén, Urbanización el Limonar, Bonanza, Villa Sofía, Villa Fátima, Villa Natalia, Santa Teresa, Villa Sorrento, el Oriente, y Santa Bárbara. En ella se ubican los barrios informales Villa Cielo, Cantaclaro, 25 de Agosto, Ranchos del INAT, Villa Cielo, Villa Jiménez, Villa Paz, Furatena, Nueva Esperanza, un sector de los Araujos, los Nogales, Villa los Alpes, las Acacias, Santa Isabel, las Acacias, Villa Mery, Villa Rosario, los cuales son objetos de intervenciones urbanísticas e incluso de reubicación.

Los asentamientos Villa Cielo, Villa Paz, Furatena y Villa Jiménez son los sectores informales más grandes del oriente y suroriente de la ciudad, y a su vez, los de más reciente nacimiento. Ninguno de ellos supera los doce años, y con excepción de Villa Cielo, que se encuentra en estado de semiconsolidación, los demás permanecen en estado precario; cuentan con una frágil dotación y están expuestos a las frecuentes inundaciones causadas por las ciénagas en épocas de invierno.

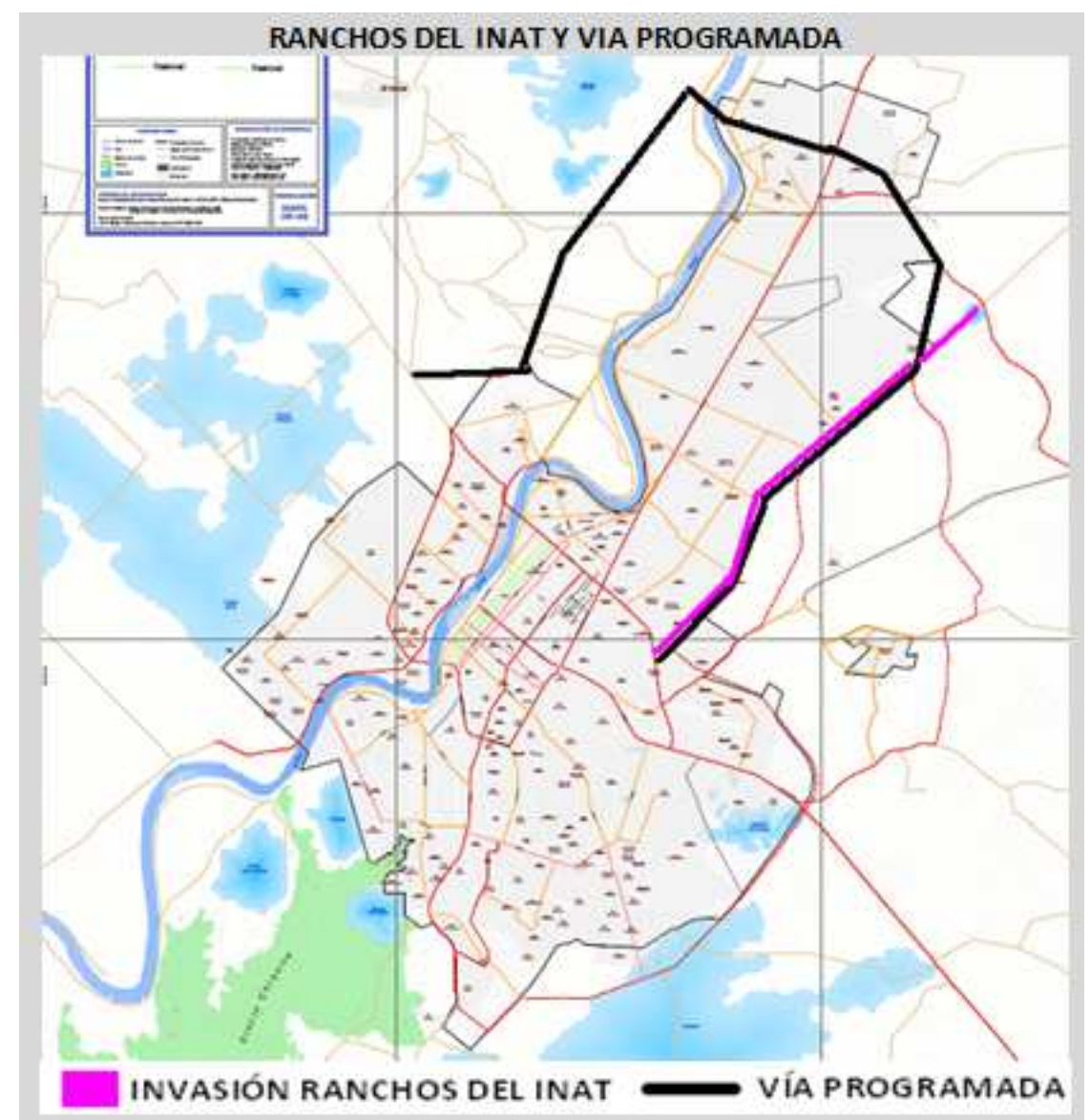

Fuente: elaboración propia a partir del POT de Montería 2002-2015 Ilustración 132. Ranchos del INAT 
En esta pieza, también se encuentra ubicada la invasión Ranchos del INAT, programada para reubicación por el plan de ordenamiento territorial, con el objetivo de darle paso a una vía paralela a la avenida circunvalar, diseñada para evitar el ingreso de los vehículos que transitan del municipio de Cereté al municipio de Planeta Rica y/o viceversa. Como se anotaba en apartado anterior, esta invasión es lineal y su recorrido transcurre entre la pieza oriental y la pieza urbana norte.

La vía en mención hace parte del uno de los denominados megaproyectos programados en el plan de ordenamiento, y además de descongestionar el tráfico de la avenida circunvalar, también permitirá conectar al oriente con el norte y el occidente de la ciudad. Para lograr esta integración, se requiere construir un tercer puente sobre el río Sinú, obra ésta, que no fue concertada, y que se constituye en una nueva amenaza para la fuente hídrica; afectada ya por proceso erosivos, derivados de la construcción del puente de la calle 41 y de las invasiones 7 de Mayo, el Bongo, Brisas del Sinú, Nuevo Milenio, Casa Finca y el Níspero.

Es significativo anotar que esta pieza define el perímetro urbano por el este y sureste de la ciudad, y se encuentra en un importante sector de desarrollo, que incluye obras de gran impacto sobre el eje de la vía a Medellín. Dentro de las obras programadas se encuentran el parque temático sobre la actividad ganadera, la gran plaza para eventos masivos, la reubicación de algunas empresas comerciales e industriales y la construcción del estadio de futbol. Esta última obra generó mucho malestar a académicos y políticos, debido a que había sido programada por el plan de ordenamiento territorial en terrenos del parque la Estancia en el suroriente de Montería.

Finalizáremos el análisis de esta pieza, comentando que la empresa agroindustrial Frigosinú, dedicada al sacrificio de ganado y procesamiento de carnes, genera un negativo impacto sobre la población del barrio Caribe, debido a los olores emanados por el proceso productivo. No obstante, debemos anotar que este barrio fue construido mediante loteo irregular en el humedal Villa Caribe, justo al lado, de otro asentamiento irregular que lleva el mismo nombre del mencionado ecosistema. Ambos barrios se encuentran en estado de semiconsolidación, y su reubicación no se 
ha planteado a pesar de sus frecuentes inundaciones; y por el contrario, el plan de ordenamiento territorial, estableció la reubicación de la empresa en la zona industrial del kilometro 10 de la vía a Medellín.

\subsubsection{Del Trazado regular al trazado irregular}

El trazado regular del centro tradicional fue abandonado en el momento que se inicia la expansión física hacia el sur, sector en el cual, el suelo disponible era bastante limitado para la urbanización, debido a las características naturales de los terrenos. Con las parcelaciones realizadas a partir del año 1930, la manzana en cuadricula desapareció para darle paso a un trazado irregular que se manifestó principalmente en los barrios Pueblo Nuevo, el Tendal, Balboa, Lacharme, Chambacú, el Coliseo, Santa Clara, la Victoria, Urbina, Obrero y 14 de Julio. Todos ellos se caracterizaron por desarrollarse en superficies inferiores a cinco hectáreas, y con excepción de Villa Clara $^{280}$, que fue un programa privado de vivienda terminada, los demás se consolidaron mediante procesos de autoconstrucción en lotes de 180 metros cuadrados $(10 \times 18)$.

\footnotetext{
${ }^{280}$ En el plano de barrios aparece como Santa Clara pero su nombre original es Villa Clara y fue uno de los pocos programas de vivienda construida que ofreció la iniciativa privada en la década de los ochenta. El costo a precios de 1980 fue de $\$ 1.800 .000$ (US\$ 6.000), cuyo valor presente correspondería a US\$ 45.000 .
} 




Fuente: elaboración propia a partir del POT 2002-2015

Ilustración 133. Cuadricula del centro y primeros trazados irregulares

El crecimiento de la época, estuvo orientado por el eje del río Sinú, y encontró su primera delimitación en el trazado de la avenida circunvalar, la cual bordeaba la ciudad por el sur, oriente y centro. Esta avenida se convirtió en el segundo eje de crecimiento a partir del año de 1960, periodo en el que se ejecutó el primer gran programa de vivienda pública en Montería, el cual fue denominado Buenavista ${ }^{281}$. Sin embargo, su ordenación se realizó siguiendo el eje del río.

Lo denominamos primer gran programa de vivienda pública por las quinientas unidades que ofreció, por su impacto sobre el plano urbano, y porque además incorporó nuevamente el esquema reticular que distinguía a la ciudad, y que se venía perdiendo con las espontáneas parcelaciones privadas de las dos décadas anteriores.

\footnotetext{
${ }^{281}$ Conviene aclarar que éste fue el segundo programa de vivienda pública en Montería, pero el primero de gran impacto que desarrollara el Instituto de Crédito Territorial. Este Instituto desarrolló su primer programa en 1952, denominado Barrio Obrero, el cual apenas brindó sesenta soluciones de viviendas en una reducida superficie, y su emplazamiento en apenas tres manzanas, no tuvo mayor impacto sobre el trazado de la ciudad. Por tal motivo, consideramos prudente no hacer mayor referencia a él.
} 
Naturalmente, su desarrollo no fue suficiente para contener las nuevas parcelaciones irregulares que iniciarían propietarios en el suroriente del barrio, y que darían paso posteriormente a barrios como Granada, Miraflores, Urbanización Samaria, Guadalajara y Casasuan.

Las parcelaciones hacia el oriente del centro tradicional siguieron su trama regular con el barrio El Edén I y la ampliación del ya constituido Antonio Nariño, el cual fue prolongado hasta la avenida circunvalar. Caso especial en este sector, merece el barrio Ospina Pérez, en el que se altera un poco la tipología de la manzana, como consecuencia de la subdivisión de sus terrenos. Es oportuno anotar que la superficie inicial de lotes en la Ceiba, Chuchurubí, Montería, Moderno, Nariño, el Edén I y Ospina Pérez correspondió en algunos casos a 800 metros cuadrados ( 20 × 40).

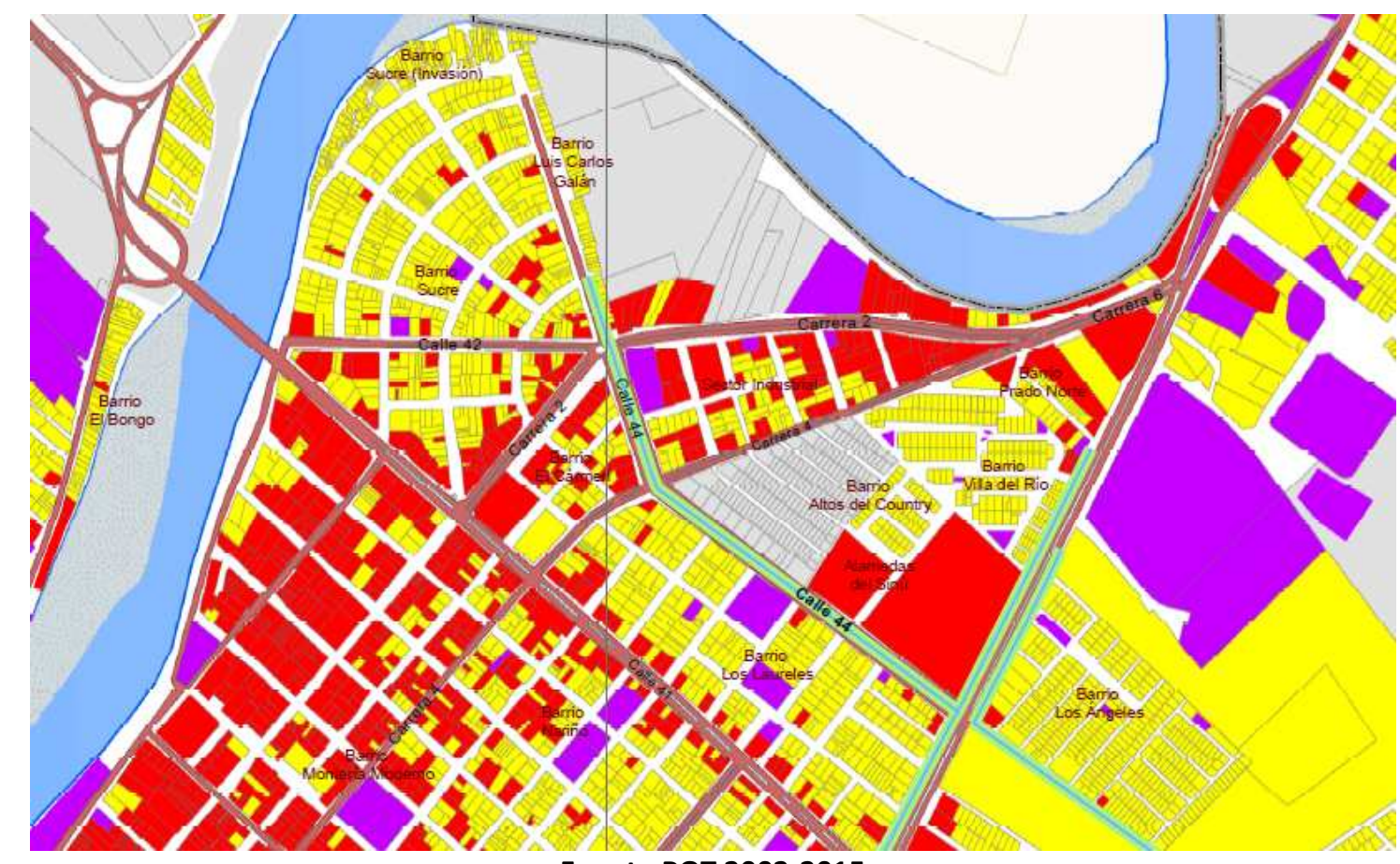

Fuente POT 2002-2015

Ilustración 134. Barrios Sucre- Invasión Sucre - El Carmen - Los Laureles

Hacia el norte se ordenaron los barrios Sucre, el Carmen, los Laureles y la Zona Industrial, que por muchos años serían el límite de la ciudad por este punto cardinal. En cuanto a Sucre, destacamos que es el quinto barrio más antiguo de la ciudad, y su ordenación radial en la década de los años 30, es obra del ingeniero Pedro Mendoza 
Somier, quien siguiendo el eje del Río, propuso lotes de 800 metros cuadrados $(20 \mathrm{x}$ 40) en 21 manzanas.

Este asentamiento, a pesar de su ordenación, presentó deficiencias urbanísticas asociadas a la falta de espacios libres y de equipamientos de recreación activa, y el área destinada para protección del río, fue posteriormente invadida por unas 100 familias, que en la actualidad vierten directamente residuos y excrementos a esta fuente hídrica. La reubicación de estos hogares está programada en el POT del año 2002, pero hasta la fecha no existe un programa de vivienda definido para ellos.



Fuente Fotográfica: Diario el Universal - 2010 llustración 135. Invasión Sucre

Veinte años después de la fundación de Sucre, surgió el barrio el Carmen, en una superficie de dos hectáreas que se extienden desde la calle 41 a la 44 y de la carrera 2 a la 4. Este barrio, al igual que la zona industrial, se ordenó siguiendo el trazado inicial en damero, lo cual facilitó la continuidad de dos grandes ejes viales como las carreras segunda y cuarta, y la conexión de éstos con la avenida circunvalar en el norte de la ciudad, a la altura de la calle 52 . 


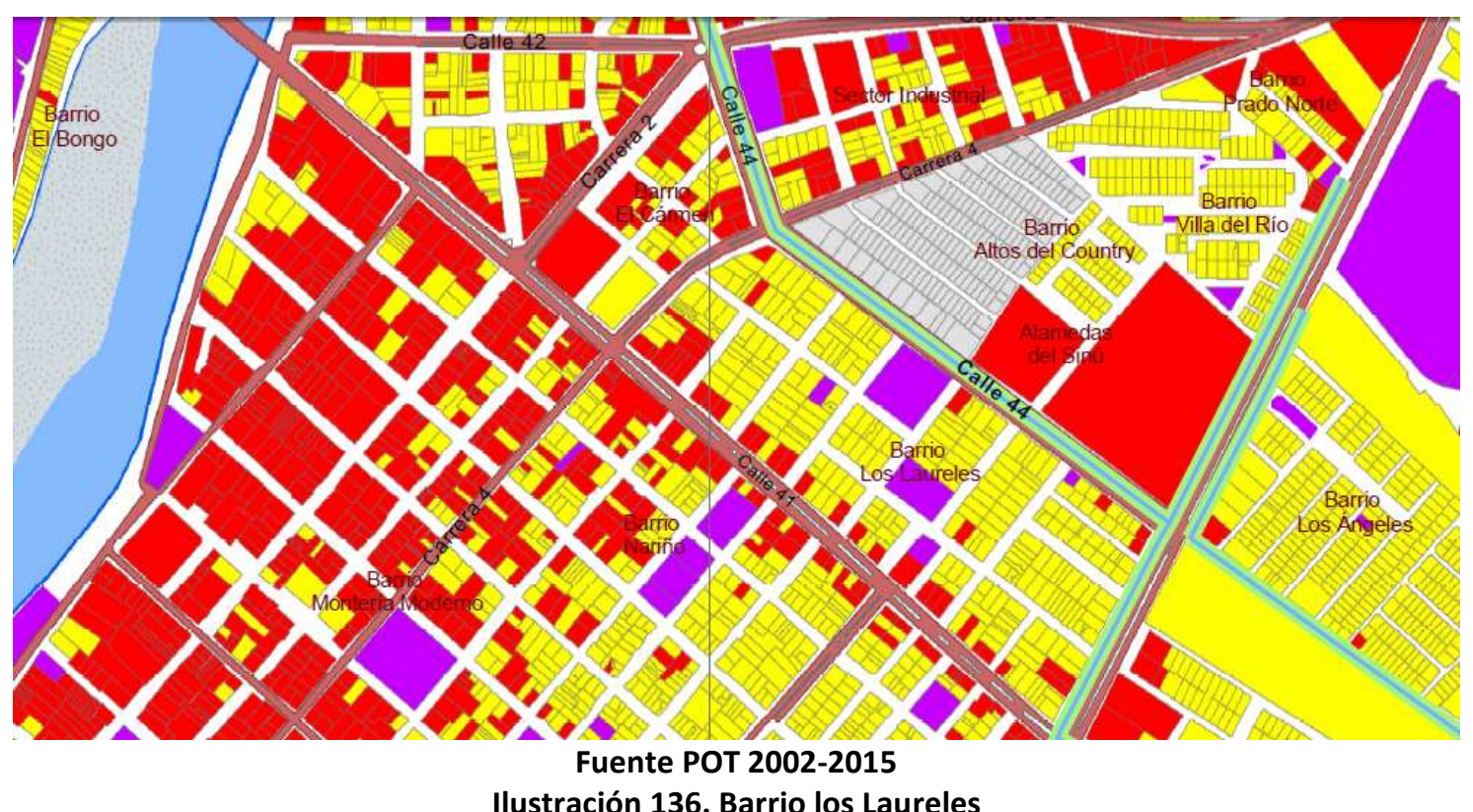

Ilustración 136. Barrio los Laureles

Posteriormente, ya en la década de los años sesenta, fue ordenado los Laureles, pero a diferencia del Carmen, este barrio no siguió el trazado de Nariño y adoptó un esquema con varias tipologías de manzana, que no favoreció la continuidad del viario, especialmente hacia el norte. La adopción de este esquema no solo afectó la integración espacial con sectores contiguos, sino que además, limitó la movilidad de los habitantes del centro y del norte de la ciudad, quienes quedarían condicionados ante la obstrucción sufrida por los ejes de las carreras 5, 6 y 9 a la altura de la calle 41.

El crecimiento hacia el norte, también se vio limitado por el poco suelo disponible entre el río y la avenida circunvalar, desde la calle 41 hasta el sitio que hoy ocupa el asilo de ancianos en la calle 52. Esta situación, generó posteriormente el surgimiento de un tercer eje de crecimiento sobre la carretera a Cartagena, que dio paso a nuevas parcelaciones en los años setenta, con lotes de 200, 300 y 400 metros cuadrados, con perfiles viales, de 8,12 y 16 metros y con aceptables reservas para equipamientos. El alto costo de estos terrenos apenas permitió el acceso de una reducida elite local, situación ésta, que contuvo el desarrollo de este sector y obligó a los actores urbanos a continuar la expansión hacia suelos del sur y del occidente de Montería; reiteramos que esta expansión permitió aumentar la oferta de suelo, pero a expensas del deterioro ambiental de los ecosistemas locales. 
En el sur siguieron los programas de vivienda pública de la Granja, la Coquera y el P-5, los cuales siguieron incorporando nuevas tipologías de manzana, así como nuevas parcelaciones. La manzana rectangular adoptada en la Granja se convirtió en el principal referente del sur, específicamente para las parcelaciones que constituyeron los barrios Santafé, Santander, San Martín, Policarpa, Santa Lucía y Pastrana Borrero. En el caso de Policarpa, la trama es alterada por la reserva natural de Sierra Chiquita, y la manzana rectangular es relegada por una tipología demasiado irregular.

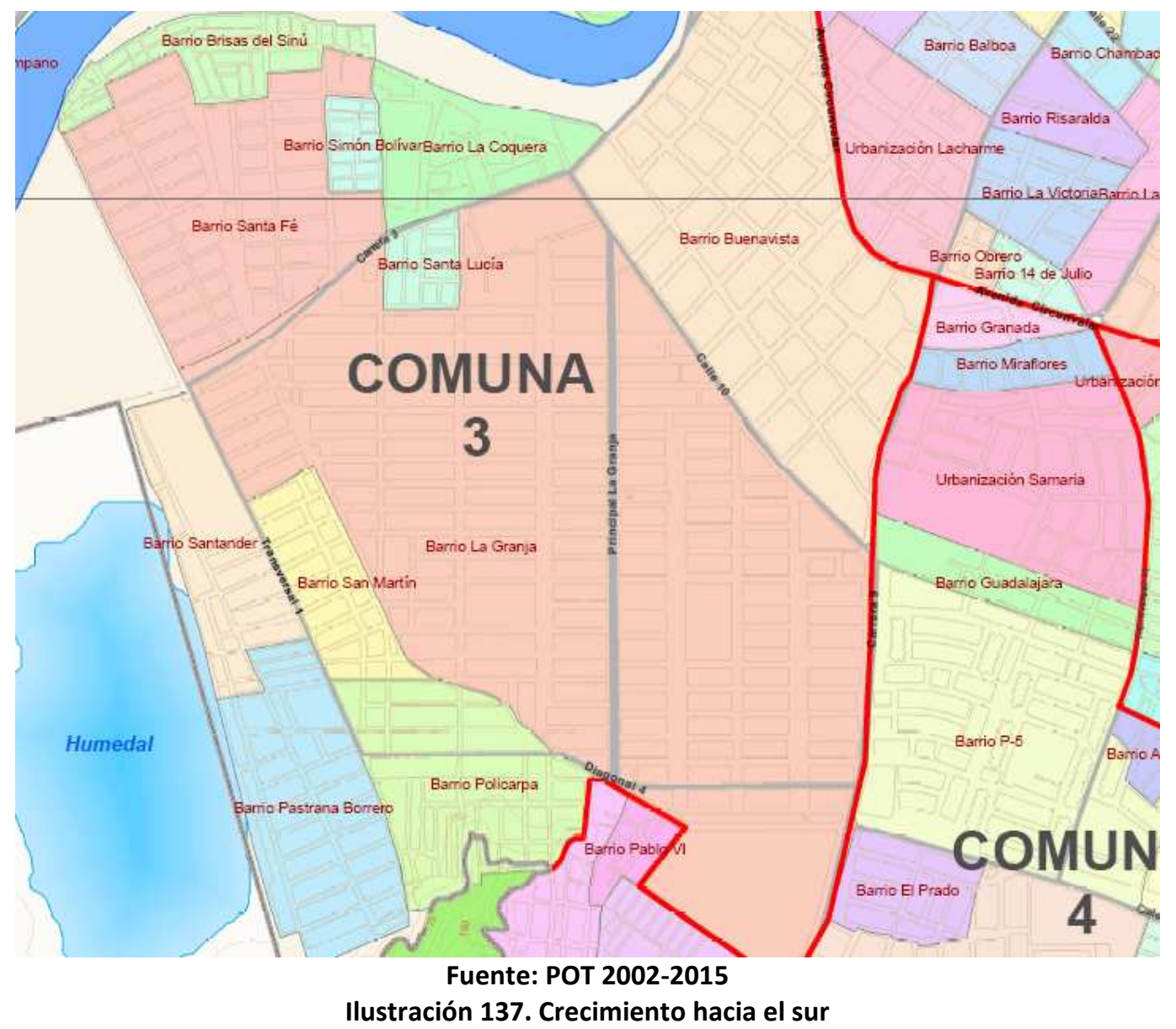

La ordenada disposición de la Granja, Santafé, Santander, San Martín, contrasta con la aparente irregularidad de la Coquera, Simón Bolívar, Santa Lucía y Brisas del Sinú. La Coquera y Simón Bolívar fueron dos programas de vivienda pública terminada de los años sesenta; Santa Lucía se desarrolló mediante loteo irregular en la misma época, y Brisas del Sinú es el producto de una invasión a orillas del río Sinú. El crecimiento de este sector encontró sus barreras en el humedal de Sierra Chiquita y en el Cerro del 
mismo nombre, a la altura de los barrios Santander, Pastrana Borrero y Policarpa; sobre los cuales se delimitó el perímetro urbano.

Entre la carrera tercera, eje del barrio Buenavista, y el río se emplazan la Coquera, Simón Bolívar, Santafé y Brisas del Sinú. La Coquera y Santafé, se constituyen a partir del eje de la carrera tercera; Simón Bolívar se construyó en un terreno adquirido por el Instituto de Crédito Territorial, y Brisas del Sinú, aprovecha un área residual entre Santafé y el eje del Río. Los cuatro barrios surgieron en precarias condiciones urbanísticas, con deficiente infraestructura de servicios básicos y con mala calidad de la vivienda, especialmente Santafé y Brisas del Sinú, en los que predominan la invasión y la autoconstrucción.

La penetración de Policarpa en la reserva de Sierra Chiquita fue seguida por la invasión las Colinas y por la parcelación irregular del barrio Alfonso López. La pendiente de estos terrenos, la poca creatividad de invasores o compradores y la falta de escrúpulos de los parceladores, contribuyeron a la desconfiguración de un trazado urbano, que ya para la década de los sesenta, intentaba consolidar una tipología de manzana rectangular, así como nuevos ejes de crecimiento en el sur de esta ciudad. Uno de estos ejes sería la carrera nueve, que conectaba a Buenavista con el P-5, el Prado, colegio Seminario Juan XXIII y el corregimiento de Guateque, y que precisamente se convertiría, a partir de los años ochenta, en un nuevo referente de crecimiento. 


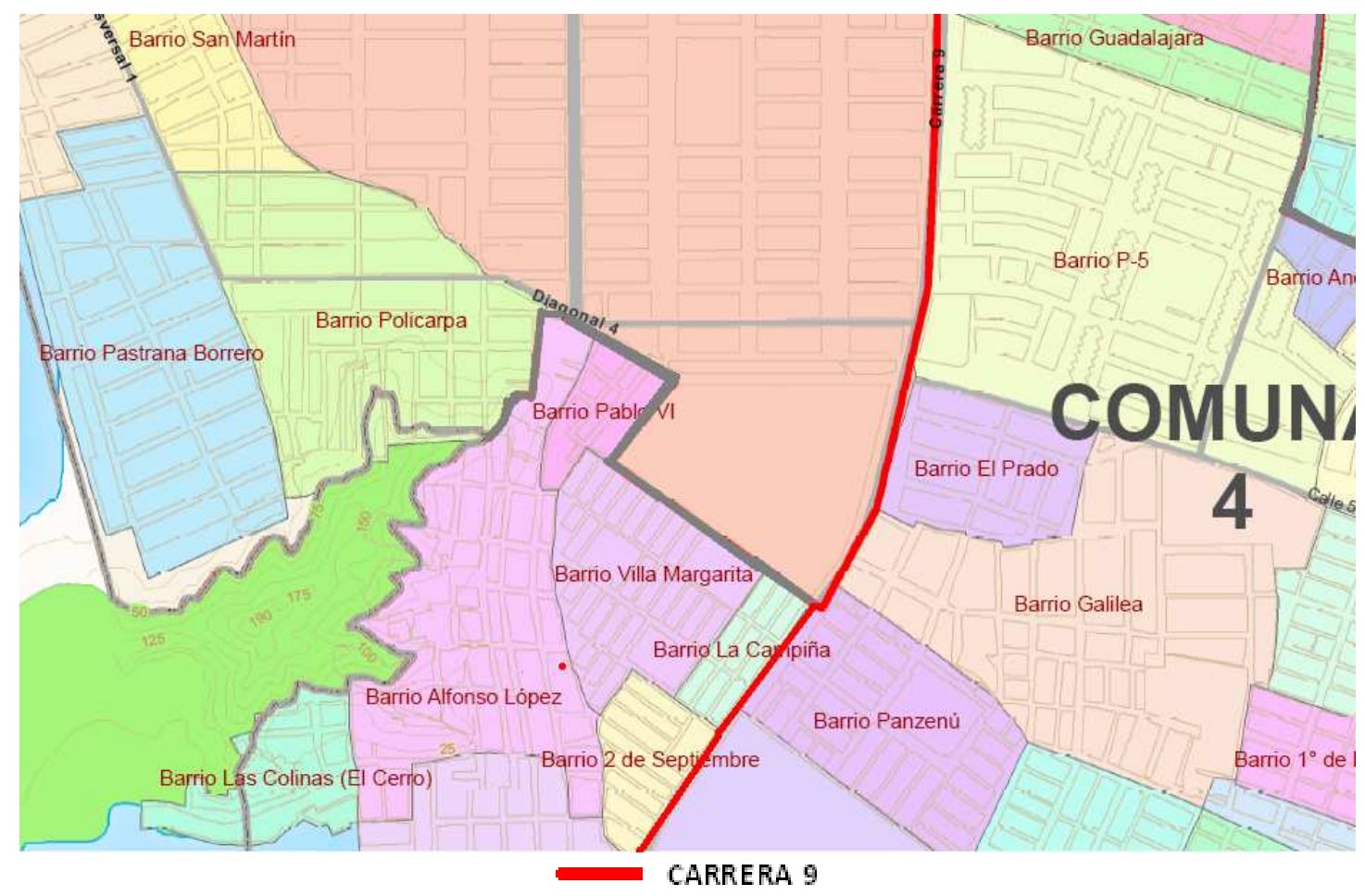

Fuente: elaboración propia con base en el POT 2002-2015 Ilustración 138. Barrios Policarpa - Alfonso López - las Colinas - P-5

La ausencia de un adecuado trazado en estos tres barrios, contrasta con el ordenado diseño del barrio P-5, que como se anotara en apartado anterior, fue un programa de vivienda pública, posterior a Buenavista y la Granja. En la ordenación de este asentamiento de 29 hectáreas se incorporaron novedosos conceptos urbanísticos que no se tuvieron en cuenta en los tres primeros programas del Instituto de Crédito Territorial. Predomina la tipología de manzana rectangular, dispuestas de manera escalonada, en las que se alternan áreas libres, zonas verdes, equipamientos y viviendas unifamiliares de planta baja.

Las viviendas de nueve de sus manzanas fueron edificadas en lotes dispuestos de manera diagonal, lo cual le aporta originalidad e identidad, ya que ningún otro barrio de esta ciudad dispone de esa ordenación. Consideramos desde esta investigación, después de corroborarlo por medio de la experiencia, que dicha ordenación favorece la ventilación y mitiga las altas temperaturas de las viviendas con orientación occidente-oriente, que son precisamente los puntos cardinales por donde sale y se oculta el sol. 
Igualmente, sobresalen en este plano, cuatro manzanas de gran superficie, que corresponden a los equipamientos educativos Cristóbal Colon y Santa María Goretti, al estadio de beisbol Eugenio Valdez y a la cancha de futbol que limita con el barrio Boston. En el mismo sentido, destacamos cuatro manzanas cuadradas de menor superficie y una rectangular vertical que corresponden a áreas libres y parques de recreación activa, y que generalmente son aprovechados por los jóvenes para la práctica de diversos deportes colectivos.

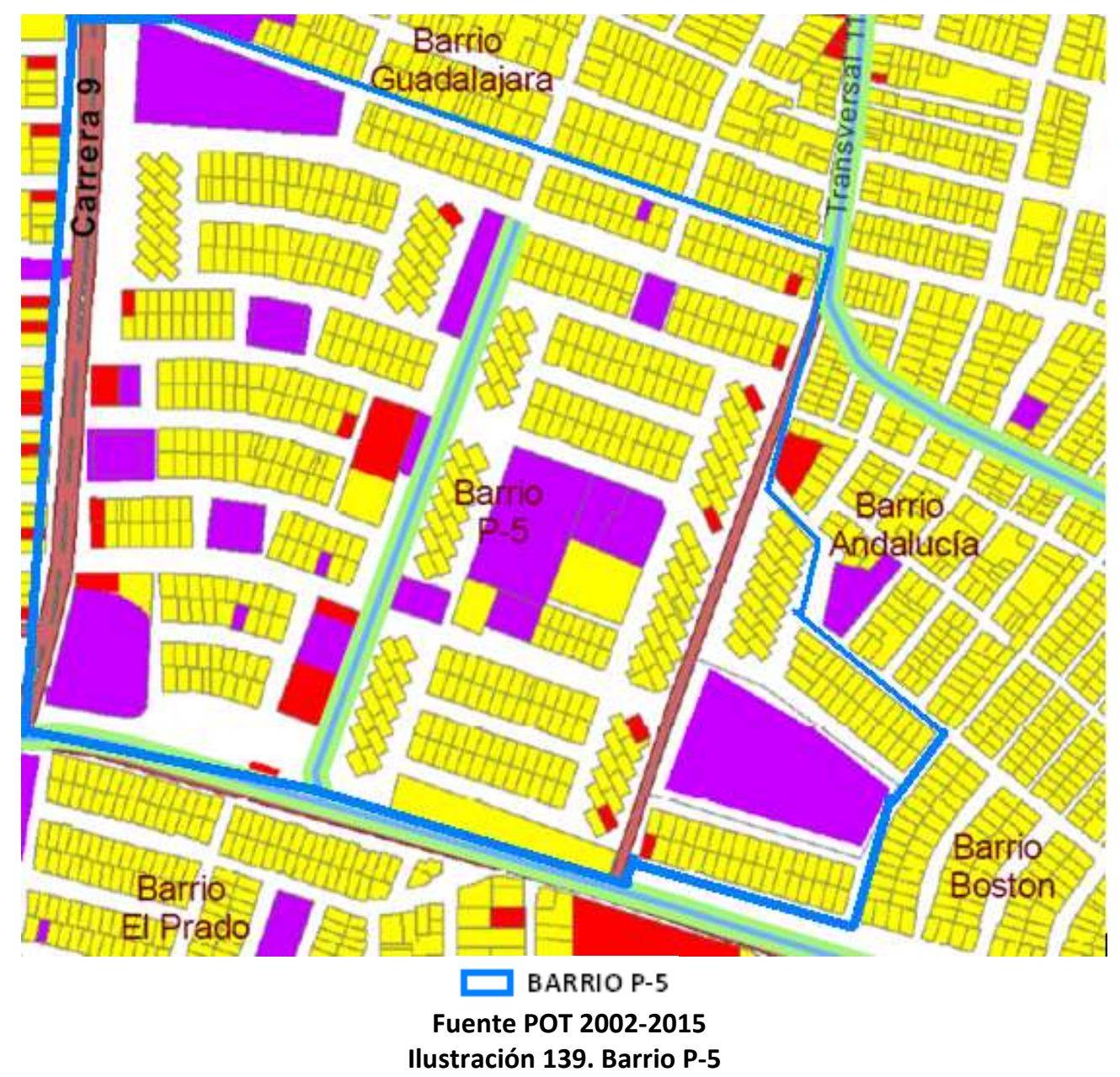

El barrio P-5, es a nuestro juicio, el asentamiento de la ciudad que más se ajusta a la normativa urbana, sobre todo en lo referente a distribución equitativa de superficies para vivienda, vías y espacio público. Sin embargo, no fue dotado oportunamente de redes de infraestructura básica como saneamiento, pavimento de vías, telefonía, alumbrado público, ni canales de aguas pluviales. La no instalación de estas redes mantuvo por muchos años, y aún mantiene a sus habitantes en unas precarias 
condiciones urbano-ambientales, debido al continuo estancamiento de aguas residuales en sus cunetas superficiales.

Después del P-5, se incorporaron al trazado de esta ciudad, mediante parcelación pública, los barrios el Prado y Boston. La ordenación, bastante simple por cierto, fue realizada por el Instituto de Crédito Territorial en dos lotes inferiores a tres hectáreas. El Prado fue ordenado sobre el canal de aguas pluviales que lo separa del P-5, quedando conformado por nueve manzanas rectangulares homogéneas y un área residual que se destinó para parque de recreación pasiva; una de dichas manzanas fue reservada para un equipamiento educativo de primaria. La manzana más representativa de estos dos sectores se encuentra ubicada en el Boston y corresponde a uno de los tres cementerios que operan en esta capital.

Hasta este momento, hemos descrito un crecimiento que combina la intervención pública con las parcelaciones privadas, pero con gran predominio de las segundas sobre las primeras. La iniciativa privada originó entre los años 1930 y $1970^{282}$, el surgimiento de los barrios Nariño, Colon, Sucre, Ospina Pérez, el Edén I, Balboa, el Coliseo, Pueblo Nuevo, la Victoria, la Julia, Chambacú, Granada, Risaralda, Urbina y Lacharme. Cada uno de estos barrios, es el resultado de 16 fraccionamientos, de igual número de propietarios de predios contiguos al centro histórico, y que en la actualidad conforman la pieza urbana central.

Por su parte, la iniciativa pública originó en el periodo de 1950 a 1970, el surgimiento de cinco programas de vivienda terminada, los cuales son: Obrero, Buenavista, la Granja, la Coquera y el P-5. Estos programas estuvieron complementados con parcelaciones públicas e invasiones que dieron paso a los barrios de autoconstrucción de Pastrana Borrero, San Martín, Policarpa, Santander, Santa Lucía, Santafé, el Prado y Boston. Cada uno de estos ocho barrios fue constituido con deficiencias urbanísticas asociadas a la instalación de redes de servicios básicos, al viario, equipamientos o

\footnotetext{
282 Información obtenida a través de entrevista a los hermanos Fermín, Miguel y Diosgracio Castro Gómez, nacidos en el barrio histórico Montería Moderno en 1926, 1928 y 1936, respectivamente, y trabajadores de la construcción durante más de cuarenta años. Entrevista realizada el día 6 de marzo de 2011, en la Vivienda de Eustorgia Castro Gómez, quien a través de su prodigiosa memoria también ha contribuido con este trabajo de investigación.
} 
áreas libres, situaciones estas, que los mantuvo por más de tres décadas en condiciones de marginalidad urbana.

Es importante precisar que en los barrios Santafé, Pastrana Borrero, San Martín, Policarpa y Santander, las familias accedieron a los lotes mediante vías de hecho, o como beneficiarios del Instituto de Crédito Territorial. El acceso por las vías de hecho contribuyó a que a estos asentamientos se les diera trato de invasiones, lo cual se vio reflejado en los largos periodos requeridos para la legalización de sus viviendas, instalación de redes de servicios básicos y dotación de espacios públicos. En este sentido, consideramos que estos cinco barrios son la expresión de lo que desde esta investigación denominamos "invasión institucional”, ya que el Estado permitió, promovió o facilitó la ocupación ilegal de sus propios terrenos, por parte de familias que demandaban viviendas.

Consideramos igualmente, que esta "invasión institucional" es un instrumento efectivo de intervención pública que no evita inversiones públicas asociadas a las dotaciones, especialmente a futuro, pero si contribuye a eludir la inversión en vivienda construida que le corresponde al Estado. Un claro ejemplo de esta situación se manifiesta en los barrios Santander, Pastrana Borrero y Policarpa, en donde la invasión de lotes estuvo acompañada de entregas formales y de reservas de tres grandes manzanas, en las que posteriormente se construyeron la escuela Normal de Barones, el colegio Mercedes Abrego y el colegio Policarpa Salavarrieta.

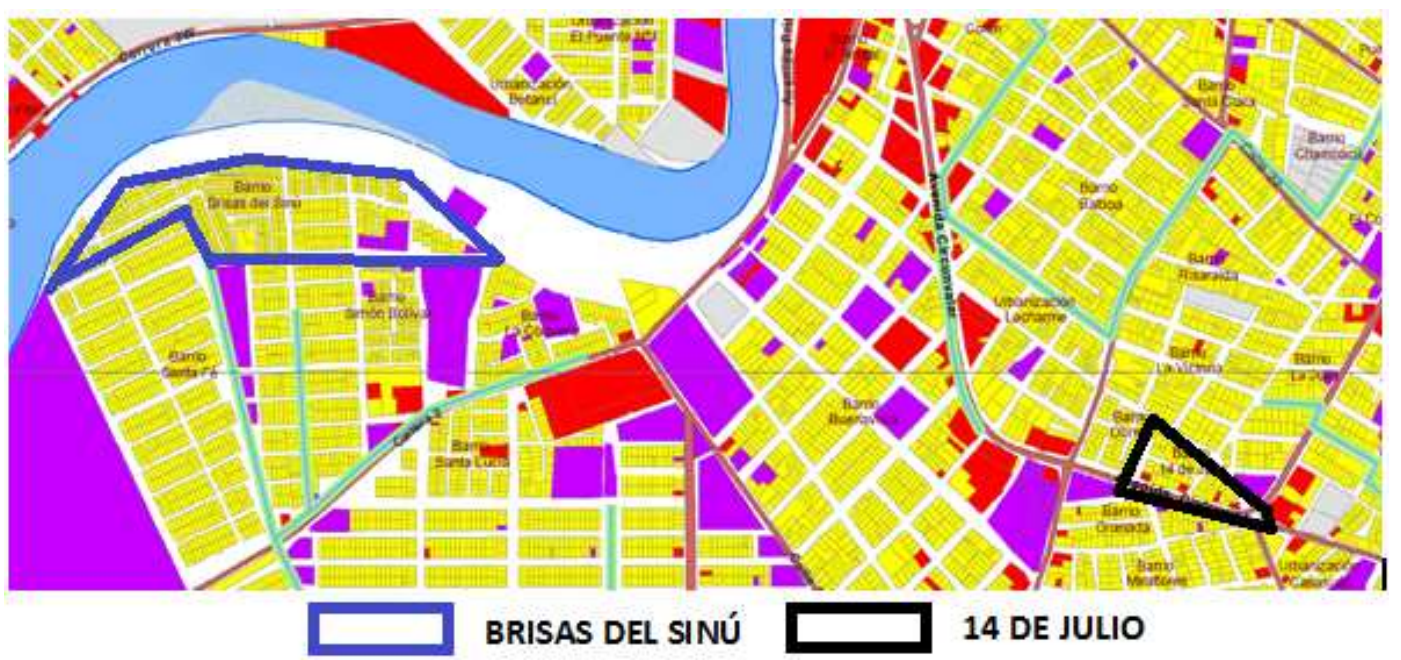

Fuente: elaboración propia con base en el POT 2002-2015 Ilustración 140. Primeras Invasiones de Montería 
En este mismo periodo, 1950 -1970, surgieron las invasiones denominadas 14 de Julio y Brisas del Sinú, que a diferencia de las invasiones institucionales, presentan un trazado bastante irregular. El 14 de Julio se constituyó en un terreno residual de dos hectáreas, sobre el eje de la avenida circunvalar, en tres manzanas bastante heterogéneas. Cada una de ellas se destinó a viviendas, pero en una cuarta manzana contigua se construyó la escuela Isabel la Católica con un poco más de 1000 metros cuadrados. Como dato relevante, destacamos su ubicación contigua al barrio Obrero, que como ya anotamos, fue el primer programa público de vivienda terminada en la ciudad de Montería en el año 1951.
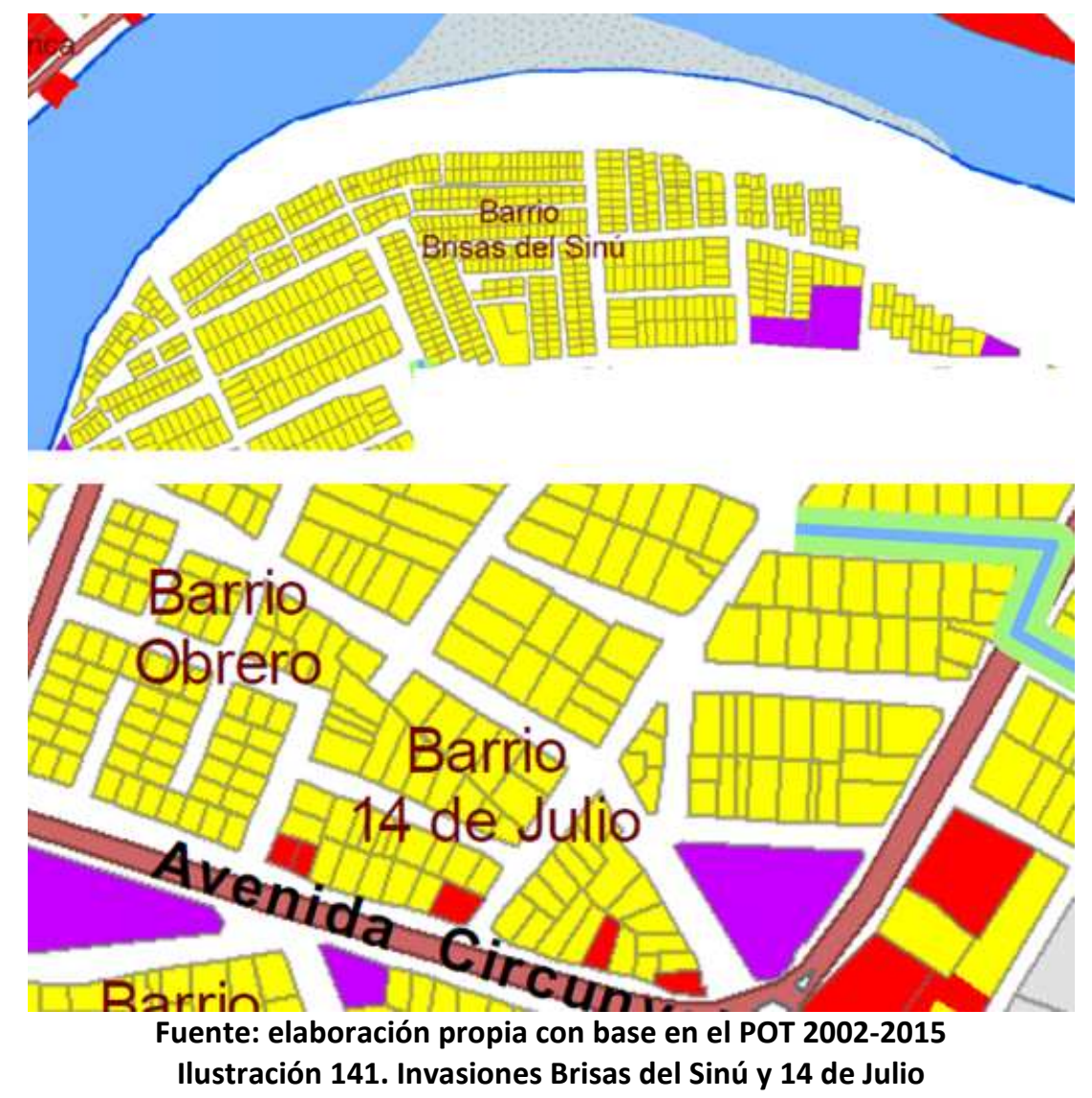

Por su parte, Brisas del Sinú se estableció en un área residual entre el Río y el barrio Santafé, en un trazado irregular que contiene treinta un manzanas dispuestas de manera horizontal y vertical. No hubo ninguna reserva de suelo para equipamientos, ni predominio de ninguna tipología de manzana, sin embargo sus ocupantes lograron establecer dos ejes viales que permiten su integración física con Santafé, Simón Bolívar y con la carrera tercera. Brisas del Sinú es, a nuestro juicio, la invasión más espontánea 
de las siete primeras que se conformaron en esta ciudad, y su trazado indica que en ella no participación los actores políticos, ni los técnicos que orientaron las ocupaciones ilegales del 14 de Julio, Santafé, Policarpa, Pastrana Borrero y San Martín.

Con el objetivo de contener la avalancha de invasiones que comenzaba a tugurizar la ciudad, el Estado colombiano ofreció en la década de los años setenta, a través del Instituto de Crédito Territorial, nuevos programas de vivienda pública terminada, los cuales incorporaron esquemas diferentes a los utilizados en Buenavista, la Granja y el P-5. Igualmente se iniciaron las parcelaciones privadas en el oriente y en el norte, específicamente, sobre la vía a Medellín y la Troncal del Caribe. La vía a Medellín se convertiría en el cuarto eje de crecimiento después de los ejes del Río, la avenida Circunvalar y la mencionada troncal del Caribe.

La vivienda pública, que hasta la fecha se había construido en el sur de la ciudad, comenzaría a construirse en el oriente y occidente. En el oriente se desarrolló el barrio de la Pradera, con un esquema que incorporó diferentes tipologías de manzana, perfiles viales heterogéneos y amplios espacios para equipamientos, en una superficie cercana a las sesenta hectáreas. Hubo gran aprovechamiento del terreno, pero no se pudo disponer de dos pequeños humedales que fueron declarados como reserva natural. 


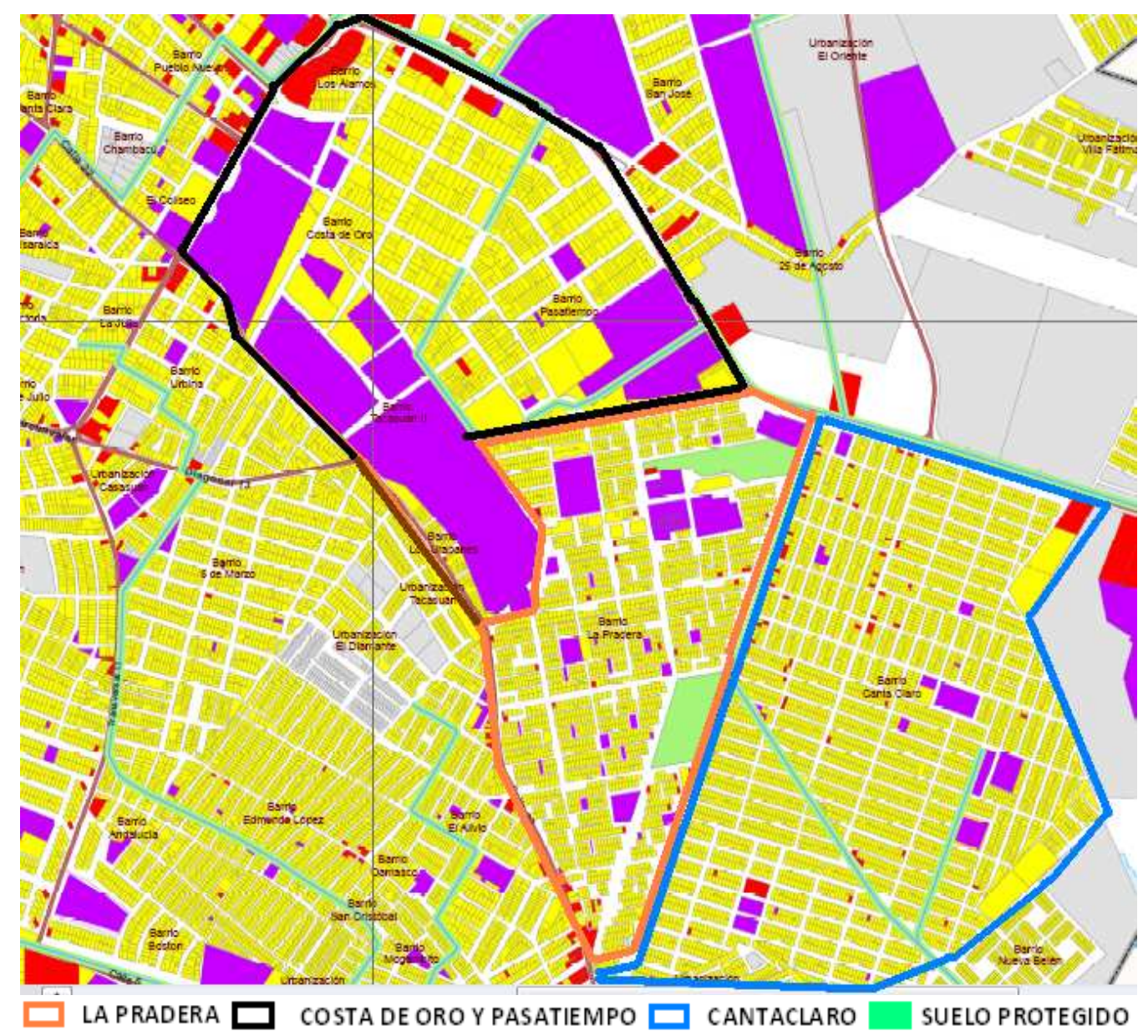

Fuente: Elaboración Propia a partir del POT 2002-2015 Ilustración 142. La Pradera y el crecimiento hacia el oriente

Este barrio estimuló el desarrollo hacia oriente que se había iniciado con dos parcelaciones privadas de gran calidad urbanística como Pasatiempo y Costa de Oro, los cuales fueron emplazados a partir de los ejes de la avenida circunvalar y la vía a Medellín en inmediaciones del antiguo aeropuerto de Montería. Es oportuno anotar que en este lote fue construido posteriormente el nuevo hospital San Jerónimo y las instalaciones del Servicio Nacional de Aprendizaje (SENA); ambas edificaciones son en planta baja, y sus obras se iniciaron a finales de la década del setenta y culminaron en los años ochenta.

La Pradera ofreció un total de 2.109 soluciones de vivienda unifamiliar de planta baja, las cuales fueron divididas en 10 etapas que incorporaron perfiles viales de $3 ; 4.4 ; 7.2$ y 14.4 metros. La primera de ellas estuvo conformada por seis manzanas rectangulares con superficies entre 1.620 y 3.564 metros cuadrados, que se ordenaron en inmediaciones del barrio Pasatiempo, entre la vía a Medellín y la calle 22. Las 107 
viviendas entregadas en esta primera fase se distinguen por su proximidad a equipamientos importantes como el hospital San Jerónimo, SENA, Instituto del Seguro Social, estación de bomberos, coliseo Happy Lora, colegio la Salle y el centro recreacional Tacasuan.

Las siguientes nueve etapas se construyeron sucesivamente a partir del año 1974, lo cual contribuyó a la consolidación de la calle 22, y a la construcción de nuevos espacios dotacionales como el estadio de béisbol menor, la cancha de futbol de la sexta etapa, el colegio Militar, liceo la Pradera, colegio Latino y el puesto de salud. La calle 22 logró una fuerte dinámica vial y comercial que la convirtió posteriormente en el eje de crecimiento de los barrios el Alivio, Villa Rocío, Villa Ana I, Villa Ana II, el Laguito, Cundama y Villa Mery, el Paraíso y las Acacias. Con excepción de Cundama y el Laguito, los demás barrios surgieron por medio de loteos irregulares que manifiestan deficiencias urbanísticas y precariedad de viviendas, vías y equipamientos.

Antes de los barrios mencionados surgieron los barrios 6 de marzo y Edmundo López, producto de parcelaciones privadas, que aprovecharon hasta el último centímetro de suelo en la venta de lotes para viviendas unifamiliares de una planta. El 6 de Marzo se emplaza entre la calle 22 y el barrio P-5 en una superficie de 36 hectáreas, que se divide en dos etapas: la primera, se caracteriza por la heterogeneidad del tamaño de sus lotes, así como por la irregularidad de sus manzanas; mientras que la segunda se destaca por la inexistencia de equipamientos y de espacio público en un trazado más regular y con manzanas más homogéneas. 




En cuanto a superficie, la primera etapa se desarrolló en un terreno de 12 hectáreas de propiedad de Rudesindo Sánchez ${ }^{283}$, quien lo fraccionó en lotes de 120, 160, 192, 250, 400 y 600 metros cuadrados, y los vendió por medio de una cooperativa que no tuvo en cuenta las cesiones correspondientes a dotaciones públicas. Su trazado estuvo determinado por la geometría del área disponible entre la calle 22 y la diagonal 13 , pero su ordenación no siguió la propuesta vial que venía en dirección norte sur, a la altura del terreno municipal que hoy ocupa el colegio público Sagrado Corazón, ni tampoco pudo seguir la trama del barrio Urbina. Esta primera etapa del 6 de Marzo se inició en 1978, con las mismas inconsistencias dejadas por anteriores parcelaciones privadas, pero con perfiles viales inferiores y sin ningún tipo de equipamientos.

La segunda etapa, en cambio, se caracteriza por el predominio de manzana rectangular con perfiles viales homogéneos de 12 metros y lotes definidos de 180 metros

\footnotetext{
${ }^{283}$ Información suministrada por Hugo Doria Bello, residente en este barrio desde su fundación en 1978, y quien en ese mismo año, compró un lote de 402 metros cuadrados (17 x 24), que posteriormente subdividió en dos lotes de 216 y 192 metros cuadrados. Estos datos fueron obtenidos mediante entrevista realizada el día 14 de marzo de 2011 en la ciudad de Montería.
} 
cuadrados $(9 \times 20)^{284}$. Sin embargo, sus parceladores no reservaron suelo alguno para dotaciones públicas, con excepción de una cuchilla ${ }^{285}$ que fue aprovechada para equipamiento religioso. Al igual que la primera etapa, la venta de lotes estuvo a cargo de una cooperativa que no cumplió con las normas urbanísticas ni los dotó de las principales infraestructuras de redes básicas. Este barrio estuvo en condiciones precarias por más de diez años y en la actualidad se encuentra en estado de consolidación.

Por su parte, el barrio Edmundo López fue el otro asentamiento informal que precedió a la Pradera, al finalizar la década de los setenta. Está conformado por cincuenta y cuatro manzanas rectangulares que se emplazan entre el Boston, P-5, la Pradera y 6 de Marzo, en un trazado regular de calles perpendiculares de seis metros de ancho. La superficie de los lotes equivale a 98 metros cuadrados $(7 \times 14)$ y apenas cuenta con 900 metros cuadrados de equipamientos que se distribuyen, entre educativo y religioso.

Estos dos barrios, se consolidaron en unas condiciones urbanísticas deficientes que posteriormente pretendieron corregirse con la ampliación de los equipamientos del barrio P-5. Tanto el 6 de Marzo como Edmundo López se encuentran muy próximos a la cancha de futbol del mencionado barrio y al cementerio del Boston, y sus paisajes son alterados por el canal de aguas residuales, los que a su vez deterioran su calidad urbana, como consecuencia de los malos olores que generan. Sin embargo, este canal, al igual que otros canales del sur, se constituye en eje dinámico de referencia; un gran ejemplo de esta situación son la transversal 11 y la calle 5, las cuales fueron aprovechadas simultáneamente como vías para el tráfico motorizado y ejes comerciales en el sur de la ciudad.

Mientras esto sucedía durante la década de los setenta en el suroriente de la ciudad, en el occidente el crecimiento comenzaba a ser orientado por el programa de vivienda

\footnotetext{
284 Zoraida Cárdenas Castro, ex-residente de este barrio, manifiesta haber comprado un lote esquinero en el año de 1980 con una superficie de 320 metros cuadrados (16 x 20), que posteriormente subdividió en dos lotes de 160 metros cuadrados. Entrevista concedida a Jhon Pinedo el día 14 de marzo de 2011.

${ }^{285}$ Terreno residual, que generalmente suele ser de geometría triangular.
} 
pública de la Ribera, caracterizado por una propuesta diferente que incorporó en su primera fase una tipología inédita para el contexto; es decir una especie de manzanas en forma de laberintos, desconocida hasta el momento. Este barrio fue emplazado sobre la vía que conduce al municipio de Arboletes en la zona costanera del departamento de Antioquia, y sobre la carretera que va al corregimiento de las Palomas en el área rural de Montería. Ambas vías se convertirían posteriormente en los dos principales ejes de crecimiento del sector occidental.

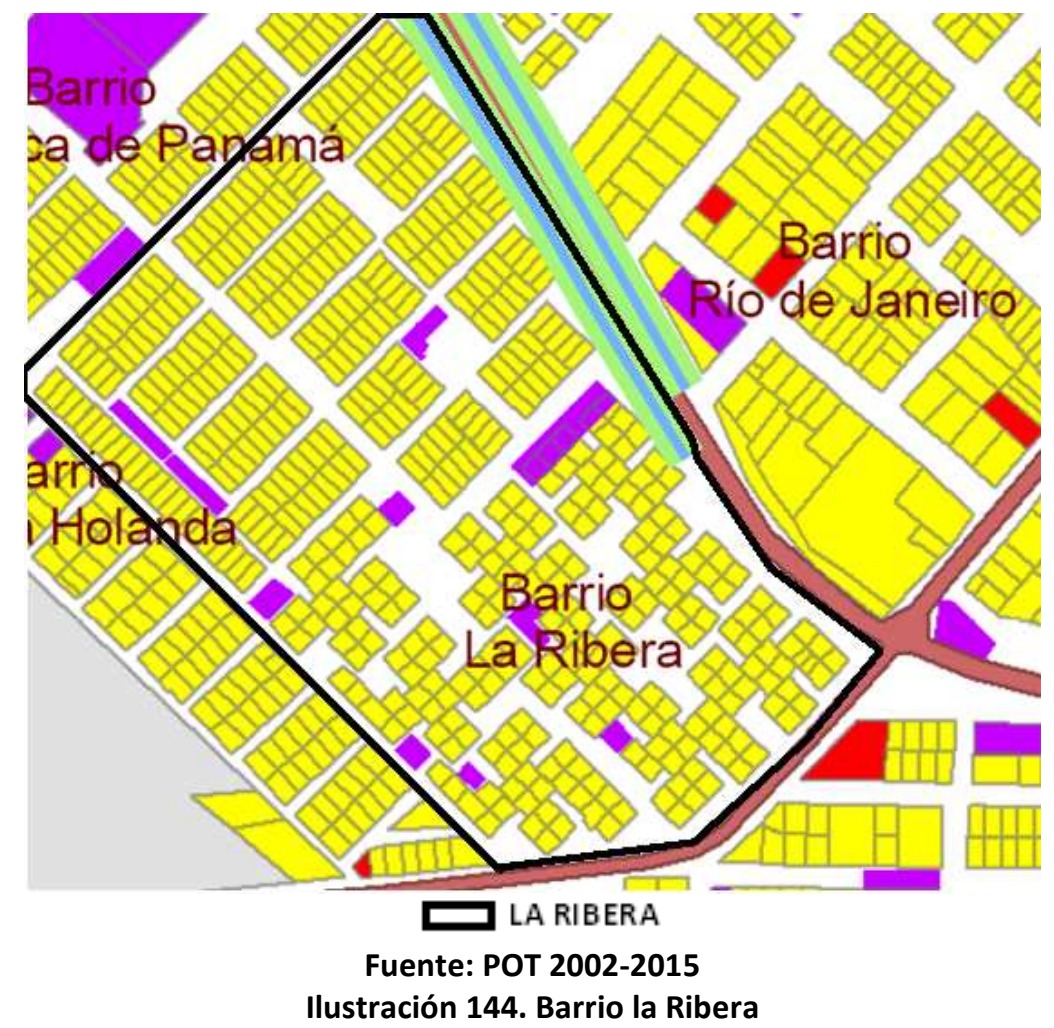

Esta propuesta reemplaza el trazado en cuadricula por una trama confusa que no definió perfiles viales como tampoco grandes equipamientos, ni adecuados espacios para recorridos internos, con desfavorable comunicación espacial con sectores contiguos, pero en cambio, facilita la circulación interna del peatón, disminuye los niveles del ruido que ocasiona el tráfico motorizado y permite la vegetación en sus espacios residuales, lo cual aumenta favorablemente la calidad ambiental del sector.

La segunda etapa de este barrio retomó la manzana rectangular, pero al igual que en la primera fase, en ésta tampoco se reservó suelo suficiente para dotar de 
equipamientos a 540 familias beneficiarias de viviendas, y la propuesta vial siguió siendo deficiente. Estas deficiencias de equipamiento fueron corregidas en el año 1979 con el programa de Panamá, en el que se construyó la iglesia católica, el colegio La Ribera y las canchas de futbol y baloncesto de Panamá. Este programa se desarrolló en 15 manzanas; 14 de ellas se destinaron a la construcción de 227 viviendas públicas y la restante es una gran manzana que albergó todos los equipamientos.

La promoción de vivienda pública en occidente dio paso al primer barrio informal de ese sector en el año 1975, el cual fue denominado la Esperanza, y establecido por vías de hecho en suelos municipales del noroccidente de la ciudad, en la vía que conduce de Montería al caserío del Vidrial. La consolidación de este asentamiento obligó a las autoridades locales a delimitar oportunamente el perímetro urbano con el objetivo de frenar nuevas invasiones sobre dicha vía o sobre terrenos aledaños.

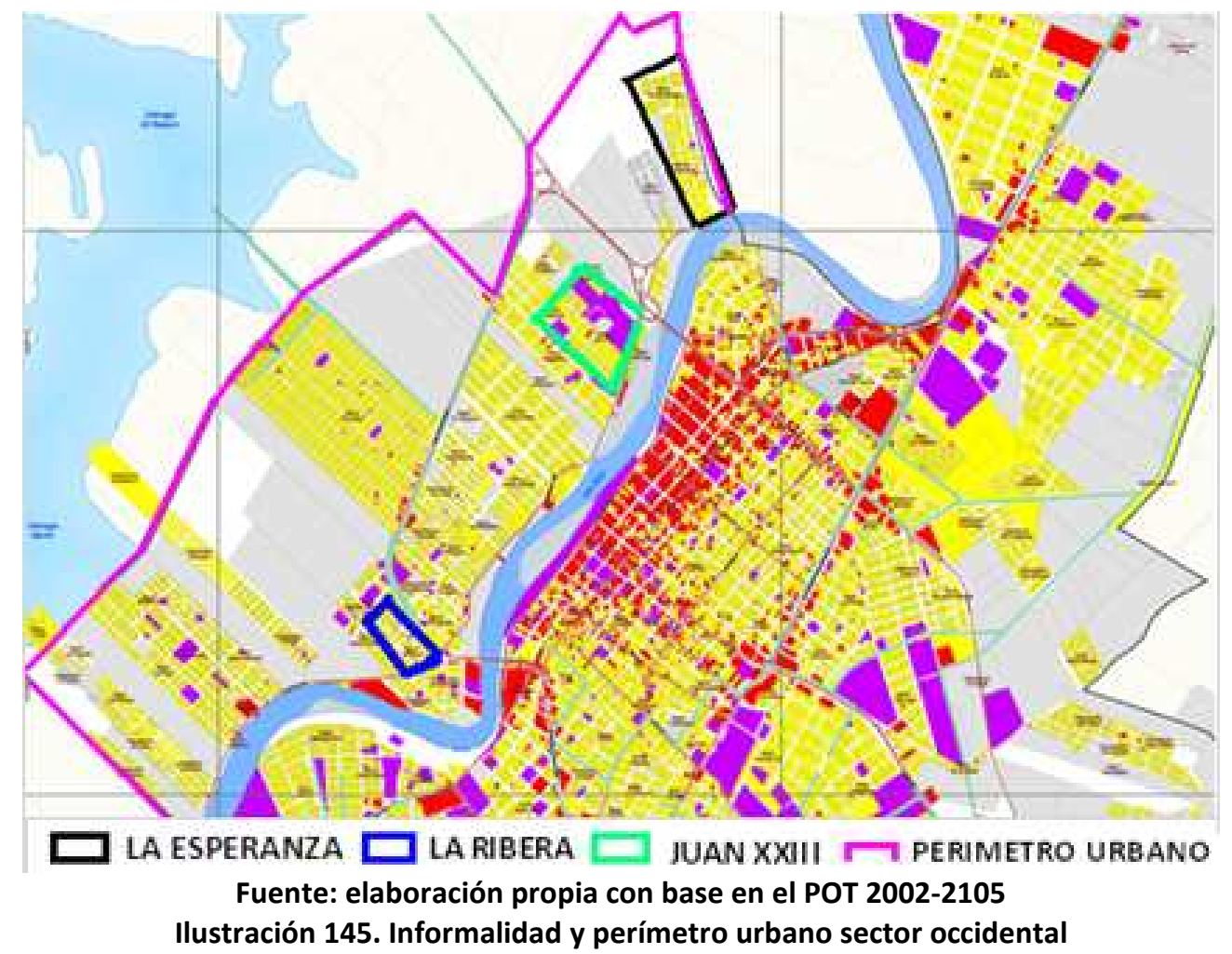

La Esperanza se encuentra distante a un kilómetro de Juan XXIII, primer barrio de la margen izquierda del Río, desarrollado por fraccionamiento privado en 1960, y a tres kilómetros de la Ribera, primer programa público de vivienda de la misma margen. Este asentamiento informal lo conforman veinticinco manzanas, heterogéneas en 
volumen y geometría, que se subdividen en aproximadamente 200 viviendas con superficies muy disimiles que promedian los 84 metros cuadrados, pero que en algunos casos asciende a 160, 180 y 200 metros cuadrados.

Este asentamiento logró reservar dos pequeñas manzanas para dotacionales y definir dos ejes viales de seis metros, los cuales fueron interrumpidos años más tarde por otro asentamiento irregular, denominado Manuel Antonio Buelvas. Ambos se encuentran en estado de semiconsolidación, y a pesar de su tiempo de existencia, aún sigue predominando la vivienda precaria, sus dos vías se encuentran sin pavimento, no cuenta con alcantarillado ni transporte público, situación ésta, que obliga a sus habitantes a depender significativamente del mototaxismo.

La década de los setenta seria el inicio de la expansión de la vivienda pública hacia el occidente de Montería, pero el gran auge de este sector comenzaría a partir de los años ochenta con los fraccionamientos privados y con el desarrollo de nuevos programas de promoción pública por parte del Instituto de Crédito Territorial. En este periodo surgieron: los barrios oficiales de Rancho Grande, el Dorado y el Tambo; los fraccionamientos privados de la Palma, el Campano y Rio de Janeiro, y las invasiones el Bongo y Casa Finca.

La invasión el Bongo ocupa linealmente la ribera del Río, desde la calle treinta y cuatro a la calle cuarenta y una, generando un fuerte impacto ambiental sobre dicha fuente hídrica. Similar situación se presenta con Casa Finca, pero a diferencia del Bongo, su deposición no es lineal, sino que se encuentra emplazado en una superficie de poco más de una hectárea y de geometría cuadrada. Los dos se encuentran en condiciones precarias, sin trazados, ni equipamientos, no tienen ninguna posibilidad de consolidación, y su reubicación es inminente, por las recomendaciones establecidas en el plan de ordenamiento territorial y por el impacto ambiental negativo que generan los vertidos, excrementos y residuos sólidos arrojados directamente a las aguas del río Sinú. Sobre este particular, ampliaremos con más detalles en el apartado correspondiente al impacto ecológico de los asentamientos informales. 


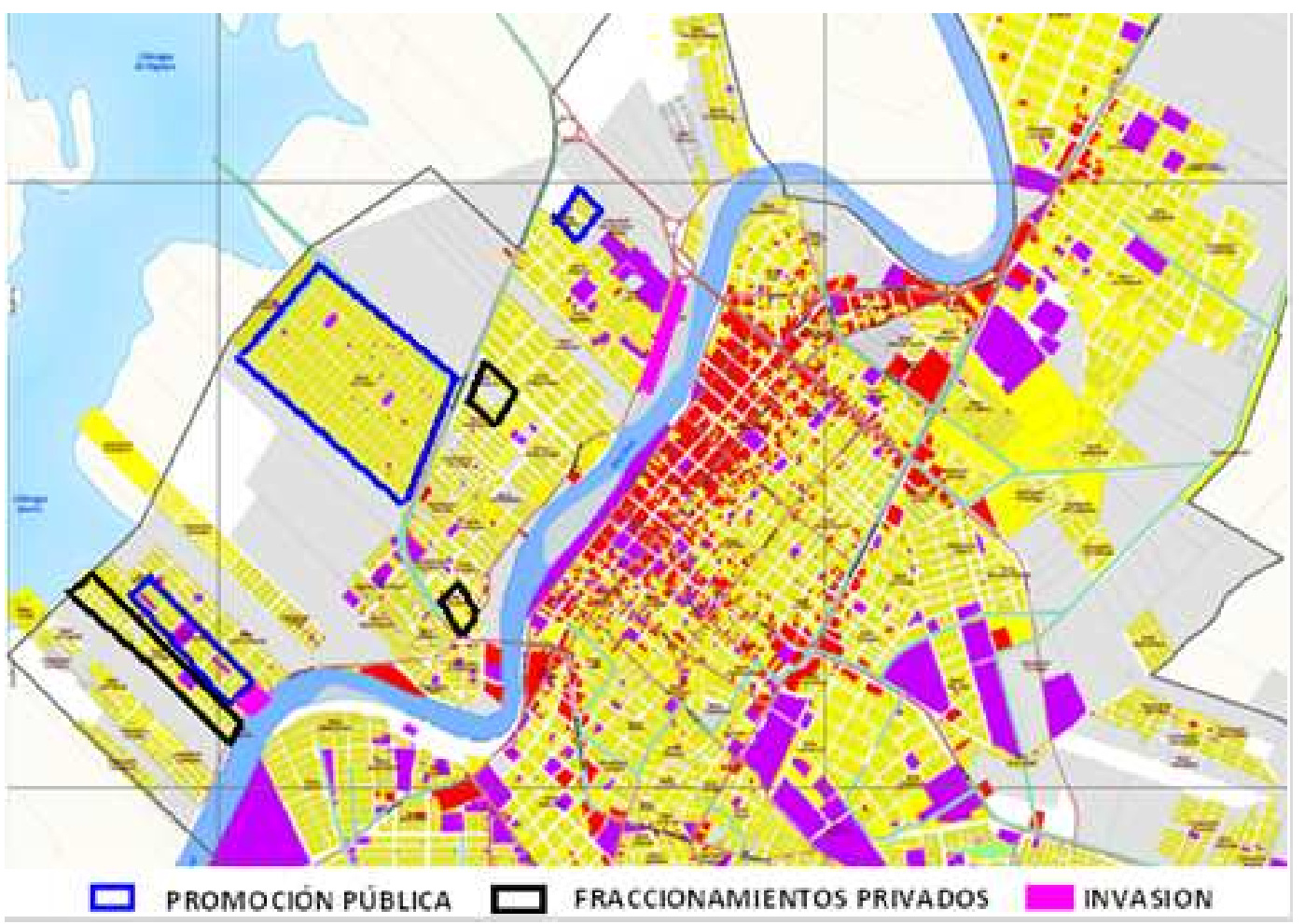

Fuente: elaboración propia con base en el POT 2002-2015 Ilustración 146. Crecimiento occidente años 80

Como se aprecia en el plano anterior, la pauta del crecimiento físico en la margen izquierda del Río, en la década de los ochenta, estuvo impuesta por la promoción pública, que por medio de los desarrollos del Dorado, Rancho Grande y El Tambo, aprovechó terrenos de dominio municipal en el centro-oriente, suroccidente y noroccidente de la ciudad. En el primer sector, sobre la vía que va al municipio de Arboletes, comenzó a desarrollarse el Dorado; en el segundo, cerca a la carretera Montería- Corregimiento de las Palomas, se desarrolló Rancho Grande, y en el tercero, al lado del barrio Juan XXIII, se construyó el Tambo.

Si recordamos un poco, tanto la Ribera como el Dorado y Rancho Grande fueron emplazados sobre dos de las tres carreteras con las que contaba el occidente hasta los años ochenta. Es importante anotar que, el mayor dinamismo, por ser una vía intermunicipal $^{286}$, lo presentaba la carretera hacia Arboletes, lo cual fue determinante para convertirla posteriormente en el principal eje comercial de ese sector de la

\footnotetext{
286 La estructura político administrativa de los departamentos en Colombia se divide en municipios, corregimientos y veredas. Las vías que conectan a los municipios se categorizan como primarias; la de los corregimientos son secundarias y las veredales hacen referencia a las terciarias.
} 
ciudad, incluso, por encima de la avenida $1 \mathrm{~W}$, que va paralela al río desde la calle veintiuna hasta la cuarentaiuna.

Cada uno de estos programas públicos produjo el denominado efecto arrastre $^{287}$ hacia la iniciativa privada, que en este caso correspondió a los fraccionamiento privados de la Palma, Río de Janeiro y el campano en la década de los ochenta. La Palma se emplazó al lado de Rancho Grande, el Campano cerca del Dorado, y Río de Janeiro, aprovechó las infraestructuras de la Ribera. Sin embargo, es importante anotar que El Tambo fue el de menor arrastre en esa década, como consecuencia de su emplazamiento, de los escasos equipamientos programados y de las deficientes redes de infraestructuras.

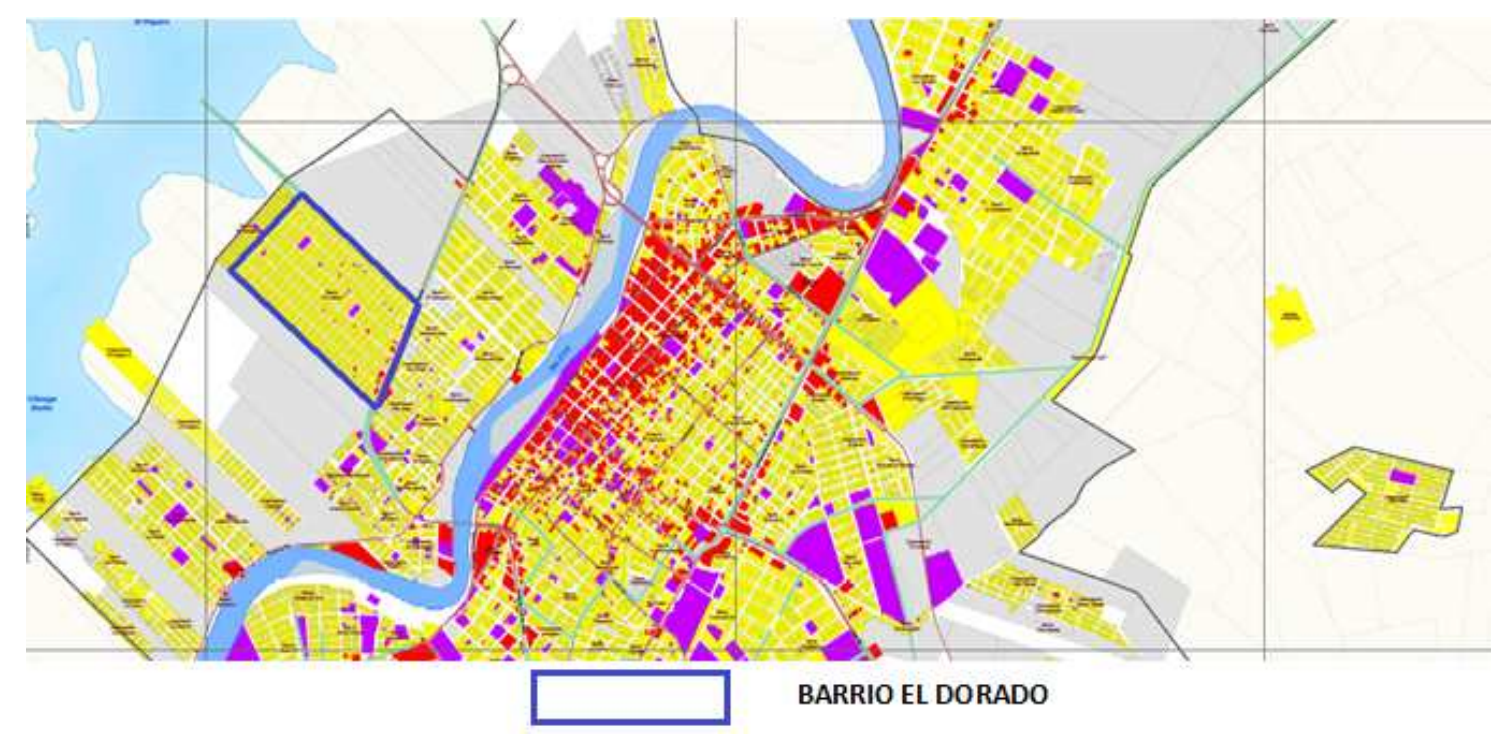

Fuente: elaboración propia con base en el POT 2002-2105 Ilustración 147. Barrio el Dorado - mayor superficie del occidente

Como se puede apreciar en el plano, el Dorado es el barrio de mayor extensión del occidente de la ciudad, y sus 61.53 hectáreas lo ubican como el tercer barrio de mayor superficie, después de Cantaclaro y la Granja. Este asentamiento, retoma el trazado en damero y su plano se caracteriza por ser el más ordenado de la margen izquierda del río, y por la buena disposición de vías. No obstante, su desarrollo se dio en condiciones

\footnotetext{
287 Las infraestructuras de los programas de vivienda pública en Montería fueron aprovechados por diferentes propietarios de terrenos para fraccionar y vender con escasa o nula inversión, lo cual corrobora lo planteado por Fernando Gaja i Díaz en su Tesis Doctoral, acerca del efecto "colonizador" o de arrastre que tienen las iniciativas públicas hacia la iniciativa privada. Gaja i Díaz, Fernando (1984): La promoción pública de la vivienda en Valencia: 1939 - 1976. Generalitat Valenciana. Valencia. Pág. 32.
} 
urbanísticas deficientes y por medio de heterogéneos procesos, que incluyeron vivienda terminada y entrega de lotes para autoconstrucción.

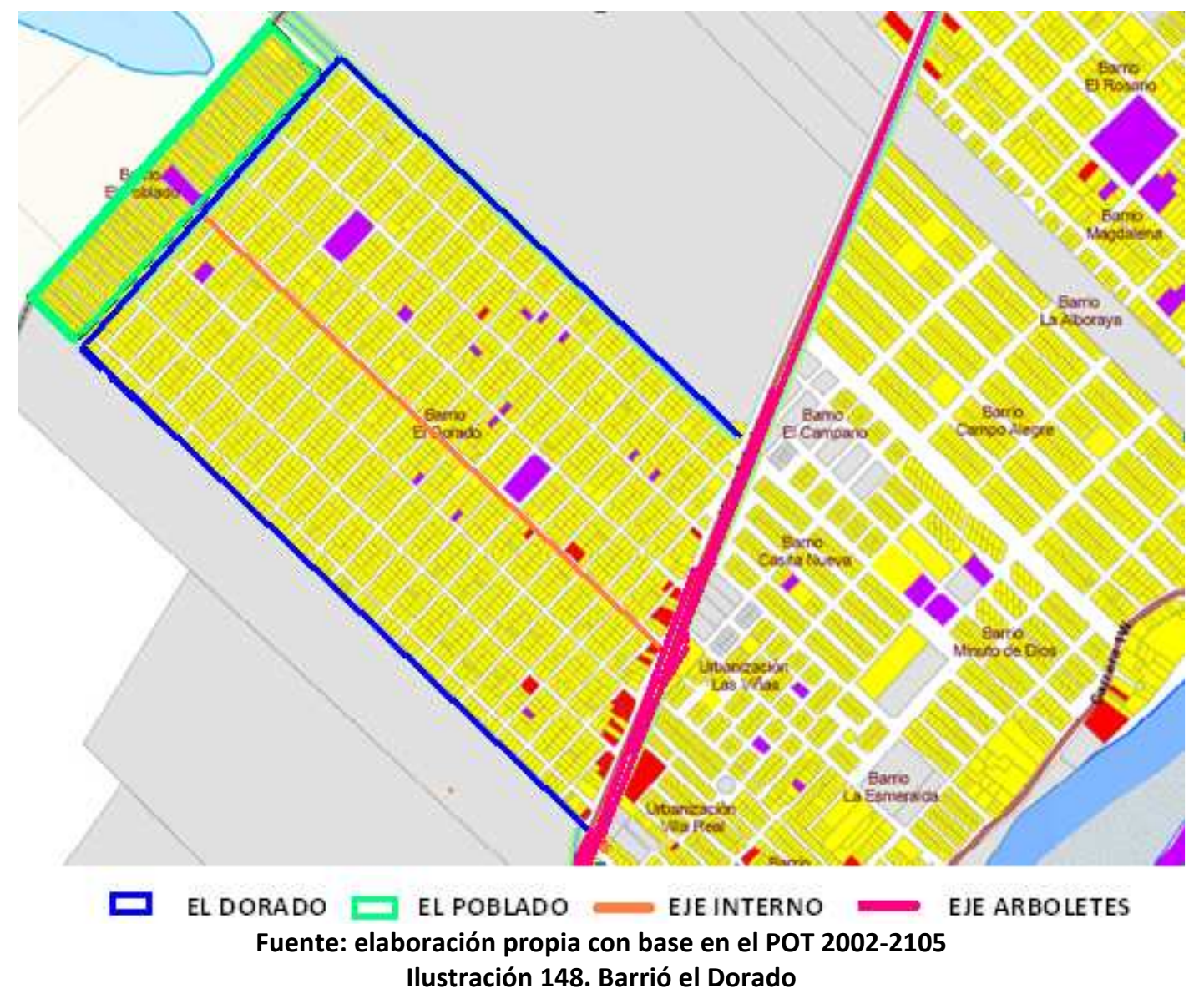

Este barrio de promoción pública, está distribuido por ciento setenta manzanas, de las cuales ciento veinte son rectangulares de $1.764 \mathrm{~m}^{2}(28 \times 63)$, dieciocho son manzanas cuadradas de $980 \mathrm{~m}^{2}$ ( $\left.28 \times 35\right)$, y el resto presentan geometrías variadas por encontrarse en zonas residuales. Sin embargo, la fuerte presión por vivienda pública obligó a reservar apenas dos de ellas para equipamientos y ninguna para áreas verdes, situación ésta, que se traduce en un elevado déficit de espacio público, que no supera los dos metros cuadrados por habitante.

Las dos manzanas reservadas para equipamientos sumaron una irrisoria superficie de $3.528 \mathrm{~m}^{2}$, ante lo cual hubo la necesidad de disponer de lotes dispersos que permitieron ampliar mínimamente la oferta de suelo para dotaciones públicas. Los dos equipamientos de mayor impacto son el colegio del Dorado, con un área construida de $800 \mathrm{~m}^{2}$ en dos alturas y la cancha de futbol. Igualmente se construyeron 
equipamientos de menor impacto urbanístico como guarderías, iglesias, cancha de microfútbol y puesto de salud.

Su emplazamiento sobre la vía que conduce al municipio de Arboletes, fue aprovechado por los beneficiarios de las viviendas cercanas a dicho carretera, quienes lo convirtieron en un gran eje comercial, pero también en un escenario de informalidad. Esta informalidad se encuentra asociada a vendedores ambulantes, estacionarios, estaderos para consumo de licores y gran presencia de mototaxistas, que posteriormente se extendería por la principal vía interna que comunica al barrio con el resto de la ciudad. En la actualidad la mayoría de las viviendas de ambos ejes, combina el uso residencial con el comercio o servicios, y en algunos casos, estas viviendas fueron transformadas totalmente a locales comerciales por medio de la construcción de una segunda planta.

La consolidación de la primera etapa del Dorado, fomentaría en los años noventa la aparición de nuevos fraccionamientos privados como las Viñas, Villa Real, Villa Nueva, la Esmeralda, Nueva Holanda, y Betancí. Igualmente permitiría el desarrollo de los programas públicos del Puente $\mathrm{N}^{\circ} 1$, Puente $\mathrm{N}^{\circ} 2$, el Amparo, Minuto de Dios y Casita Nueva. Mientras que la finalización de la segunda etapa, realizada por fraccionamiento público, sería la plataforma de una nueva invasión que se denominó el Poblado, y sobre la cual haremos referencia más adelante.

Retomando nuevamente el crecimiento del suroriente, debemos anotar que el surgimiento de la Pradera, el 6 de Marzo y Edmundo López en la década de los setenta, vino acompañado de nuevos programas públicos y parcelaciones privadas en los años ochenta, que por supuesto, facilitaron la aparición de la segunda oleada de asentamientos informales, tanto por invasiones como por fraccionamiento irregulares privados o públicos. Consideramos que la primera oleada se había presentado entre 1960 y 1969 con los barrios Santafé, Santander, Pastrana Borrero, San Martín, Policarpa Salavarrieta, Boston y Brisas del Sinú. 
Como se anotaba en apartado anterior, la década de los ochenta fue la época de mayor dinamismo en cuanto a número de programas de vivienda pública ${ }^{288}$, pero también la de mayor auge de fraccionamientos irregulares y de invasiones. En este periodo surgieron los barrios de promoción pública de Mogambo, Villa Margarita, Panzenú, Rancho Grande y Simón Bolívar, siendo Mogambo el de mayor impacto, por su superficie, por las 1.103 soluciones de vivienda que entregó y por el número de asentamientos informales que su desarrollo desencadenó. Panzenú fue entregado en el año 1983; Mogambo, Villa Margarita y Simón Bolívar en 1984, y Rancho Grande en 1985.

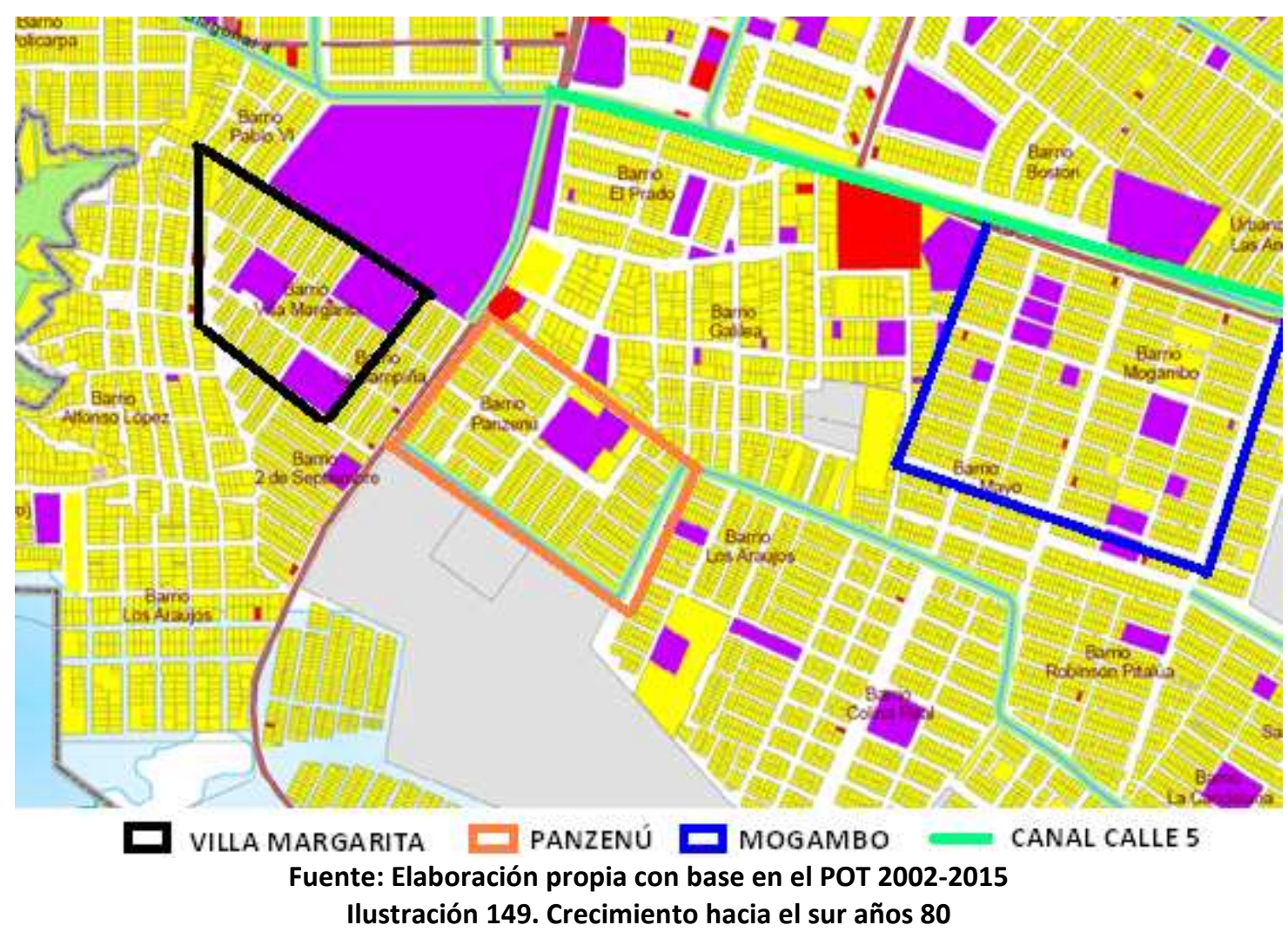

\footnotetext{
288 Destacamos que fue la época de mayor dinamismo en cuanto a número de programas públicos, más no en unidades de viviendas públicas construidas. Sobre este aspecto, conviene anotar que el Instituto de Crédito Territorial ICT, entregó 60 viviendas en su primer programa en Montería en 1952 (Obrero), 3.857 en cuatro programas durante la década de los sesenta (La Granja, Buenavista, La Coquera y P-5); 2.715 en tres programas desarrollados en los años setenta (La Pradera, La Ribera y Panamá), y 2.624 en seis programas en los ochenta (Mogambo, Villa Margarita, Panzenú, Rancho Grande, Simón Bolívar y El Tambo). No incluimos los barrios de Santafé, Policarpa, San Martín, Pastrana Borrero, Santander, Prado y Boston porque no fueron programas de vivienda terminada sino procesos de autoconstrucción a partir de fraccionamientos públicos y de invasiones realizadas en la década de los sesenta, que posteriormente fueron legalizadas por el mencionado instituto. Igualmente, resaltamos que el ICT fue liquidado por deficiente manejo financiero en el año 1991.
} 
El barrio Mogambo, al igual que el Prado, fue ordenado a partir del canal de aguas residuales y la disposición de sus manzanas se realizó en la misma dirección del mencionado eje artificial, a través de un trazado reticular, que incluye tres perfiles viales: 6.5, 10.3 y 13.3 metros. Este asentamiento está conformado por 66 manzanas rectangulares, con superficies entre 1.372 y $1.960 \mathrm{~m}^{2}$, de las cuales 60 corresponden a residencias unifamiliares de planta baja y 6 a equipamientos colectivos. Las destinadas a viviendas fueron subdivididas en áreas de $98 \mathrm{~m}^{2}$ (7x14), lográndose fraccionamientos de 14,18 y 20 lotes, en los que finalmente fueron construidas dichas viviendas.

Mogambo se emplaza en un terreno de 18.62 hectáreas, adyacente a los barrios Galilea y Boston, asentamientos éstos, en donde se encuentran la bodega (nave) de la empresa Almaviva S.A, el cementerio del Sur y la cancha de futbol. Precisamente al lado de la mencionada bodega, se construyó la escuela preescolar Mogambo y en el interior del barrio quedaron ubicados el colegio de bachillerato, la iglesia, un parque infantil, cancha de futbol, baloncesto, escuela de primaria guarderías infantiles y dos espacios libres para recreación pasiva. Conviene anotar que algunas manzanas reservadas para equipamientos, aparecen como tal en el plano, pero en realidad no son más que improvisadas cancha deportivas si infraestructura alguna, que también son utilizadas para recreación pasiva.

Villa Margarita, por su parte, fue emplazada en un terreno de 7.09 hectáreas, cerca al eje de la carrera nueve que empalma con la vía hacia el corregimiento de Guateque, entre el colegio privado Juan XXIII, el asentamiento informal Alfonso López y Panzenú. Tiene un trazado reticular, con perfil vial de 4.6 metros y 24 manzanas: 18 de ellas son rectangulares con superficies de $1.960 \mathrm{~m}^{2}$ (70x28); 3 son residuales de inferior tamaño, y 3 se destinaron para equipamientos. Sobre estas últimas manzanas, destacamos que una de ellas es de $8.400 \mathrm{~m}^{2}(120 \times 70)$ y alberga el colegio de bachillerato, mientras que las otras dos tienen superficies de $5.000 \mathrm{~m}^{2}$ cada una, albergando parque infantil y cancha de microfútbol.

En lo que respecta a Panzenú, anotaremos que su ordenación se inició a partir del eje de la carretera al corregimiento de Guateque, entre Galilea y Villa Margarita, aclarando que entre éste último y Panzenú, se interpuso un lote privado de dos hectáreas, que 
posteriormente fue fraccionado en nueve manzanas rectangulares de veinte lotes de $98 \mathrm{~m}^{2}$ cada una. Este barrio, desarrollado por autoconstrucción, fue denominado La Campiña y es otro ejemplo claro de optimo aprovechamiento de terreno, maximización del ingreso particular sin inversión ni cesión alguna, el arrastre de la iniciativa pública hacia la privada, que para el caso de Montería, consideramos se traduce en un agazapa-miento permanente de un sector parasito que se acostumbró a alimentarse del otro y además a generar informalidad urbana.

Ahora bien, tanto el desarrollo de Panzenú como el de Mogambo y Villa Margarita, se dio en una época de gran demanda de vivienda dentro de la ciudad, pero también en una época crítica de la guerra entre narcotraficantes, guerrilleros y paramilitares, que generó los desplazamientos masivos hacia las ciudades cercanas a áreas de conflictos armados. Estas dos situaciones, asociadas a factores políticos locales, estimularon el surgimiento de las invasiones y fraccionamientos irregulares, tanto público como privados que hoy se encuentran en procesos de semiconsolidación y consolidación.

Mogambo se vio inmediatamente rodeado por las invasiones de Robinson Pitalúa, $1^{\circ}$ de Mayo, Santa Rosa, la Candelaria, Paz del Río, Edmundo López II, las Américas y Mogambito. Estos ocho asentamientos surgieron todos en la década de los ochenta y fueron el producto de invasiones directas, reubicaciones de invasores de otras zonas, y asignaciones de lotes a beneficiarios seleccionados de manera clientelar por líderes políticos o líderes comunitarios familiares. Entre estos beneficiarios se encontraban frecuentemente familiares de unos y otros, quienes posteriormente negociaban con terceros $^{289}$, la entrega del lote por votos en proceso electorales o por valores que oscilaban entre $\$ 50.000$ y $\$ 200.000$ (\$US 100 - \$US 400 del año 2010).

\footnotetext{
289 Lamberto Antonio López Castro y Piedad Ríos Castro, en la década de los ochenta, obtuvieron lotes de $7 \times 14$ en las invasiones de Santa Rosa y Robinson Pitalúa, mediante el pago de dos volcos de balasto $\left(12 \mathrm{M}^{3}\right)$ y dos volcos de arena $\left(12 \mathrm{M}^{3}\right)$, cuyo valor para la época era de $\$ 40.000$ (US\$ 80 de 2010). En esa misma época Jorge López Vega y Orlando López fuentes obtuvieron lotes de 7 x 14 (previo pago de $\$ 200.000$ ) en el asentamiento $1^{\circ}$ de Mayo, el cual no fue una invasión propiamente dicha sino el fraccionamiento irregular de un terreno privado ubicado detrás de Mogambo. En el caso de los dos primeros, el arreglo se llevó a cabo con dos líderes comunitarias femeninas, y en el de los segundos, el pago se realizó a un intermediario del parcelador de esos terrenos, los cuales resultaron hipotecados. Esta información fue obtenida mediante entrevistas realizadas a Lamberto López, Piedad Ríos, Orlando López y Jorge López, los días 27 y 28 de Marzo de 2011, en la ciudad de Montería.
} 
El barrio $1^{\circ}$ de Mayo, siguió el trazado de Mogambo, y junto con Robinson Pitalúa, la Candelaria y Santa Rosa, siguieron la expansión irregular hacia el sur. La trama de estos asentamientos estuvo influenciada además por los sistemas de drenaje que buscaban mitigar inundaciones y solucionar el problema de alcantarillado de los nuevos barrios de este sector de la ciudad. Ese sistema de drenaje fue el límite hasta la década de los ochenta, y en los noventa se convirtió en el límite del perímetro urbano hacia el suroriente, con el objetivo de proteger el humedal de esa zona, que ya comenzaba a ser amenazado por algunos invasores.

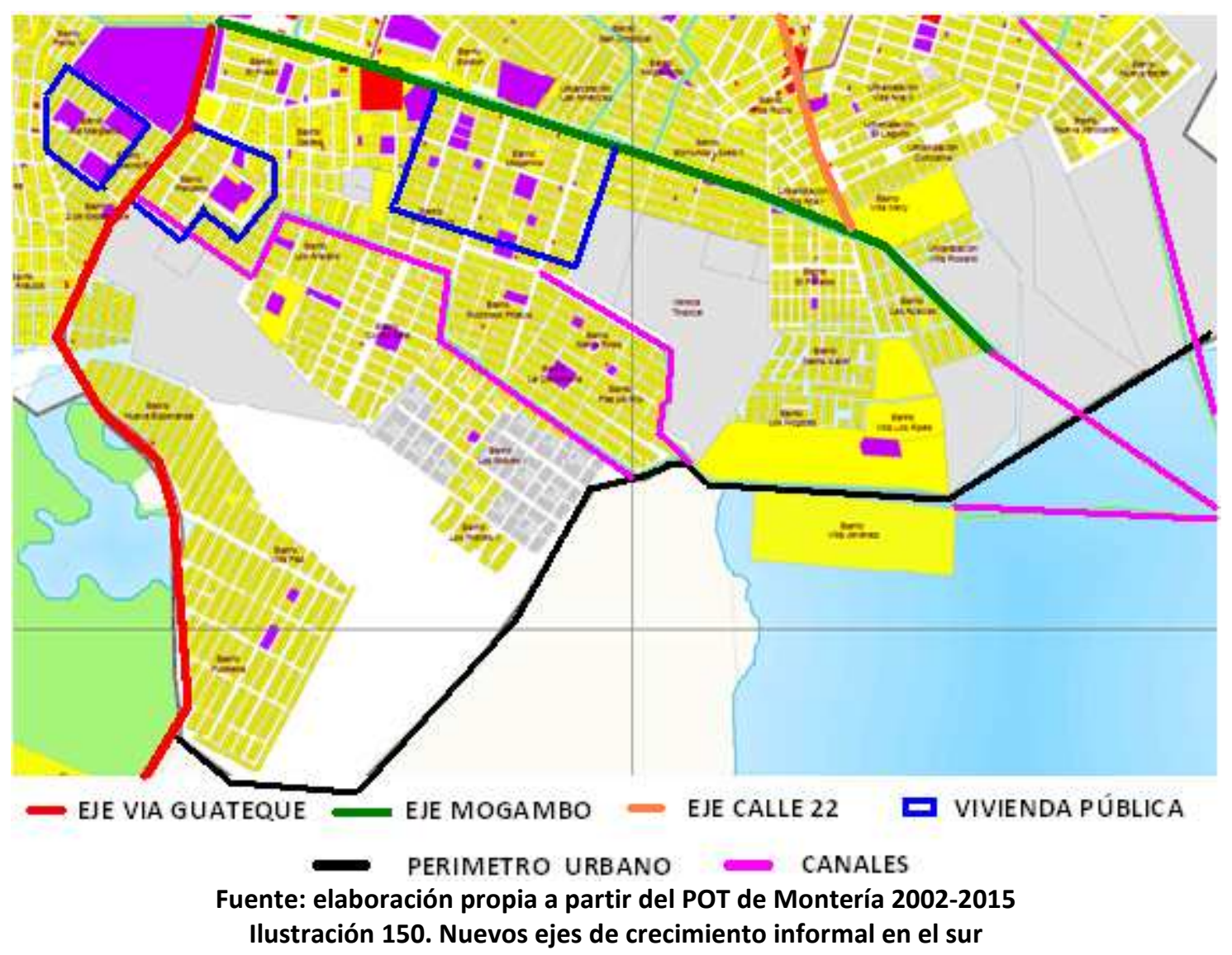

El barrio Robinson Pitalúa, es una de las invasiones promovidas y/o concertadas entre la comunidad, sectores políticos y administración municipal, como respuesta a la fuerte presión ejercida por diferentes grupos sociales, entre los que sobresalían básicamente desplazados, desempleados o víctimas del conflicto. En este orden de ideas, sus organizadores la ordenaron a partir del trazado de Mogambo, aprovechando las dos vías principales para su integración física y sus dos equipamientos más cercanos. 
Igualmente, sus ordenadores intentaron seguir el viario interno y la estructura de manzana, pero ambos se vieron obstruidas por una manzana alargada de cincuenta lotes que anteriormente habían sido ocupados por igual número de familias en sus respectivas infraviviendas. Esta situación no pudo ser solucionada debido a que esas cincuenta familias ocuparon tres años antes de que se ordenara el terreno para la ocupación de las restantes cuatrocientas noventa familias que conformaron esta gran invasión en el año 1988.

El asentamiento Robinson Pitalúa se encuentra conformado por veinticuatro manzanas, incluida una irregular de $4.800 \mathrm{~m}^{2}$ que fue ocupada antes de la “ordenación” de la invasión. Solamente $1.746 \mathrm{~m}^{2}(28 \times 63)$ de una de ellas se reservó para equipamiento, permitiendo posteriormente la construcción del colegio Robinson Pitalua, con capacidad para 1.000 estudiantes. Es oportuno anotar que en el trazado de este barrio predomina la manzana rectangular así como la existencia de dos perfiles viales: uno de 4.40 y otro de 8 metros.

Esta invasión fue inmediatamente seguida por las invasiones de la Candelaria, Santa Rosa y Paz del Río, que fueron emplazadas en terrenos contiguos de baja calidad. Los tres surgieron con características similares a Robinson Pitalúa, y permitieron, si no solucionar el problema de la vivienda, por lo menos, el acceso de 777 familias a igual número de lotes de 98 metros cuadrados $(7 \times 14)$. Sus trazados expresan una figura reticular imprecisa, en las que dos manzanas rectangulares de $4.800 \mathrm{~m}^{2}$ interrumpen la continuidad del viario, específicamente en, Paz del Río y Santa Rosa.

La ordenación de estas tres invasiones -suena paradójico, pero ha sido corroborada la previa participación de líderes comunitarios y políticos en demarcaciones, delimitaciones y cesiones-, se realizó siguiendo la dirección del canal del sur y proponiendo un nuevo canal, que a su vez sirvió de límite por el norte y oriente. Sobresale una manzana cuadriculada de $3.600 \mathrm{~m}^{2}(60 \times 60)$ en el barrio la Candelaria, en la que posteriormente se construyó el colegio de primaria con capacidad para 500 estudiantes. 
También se reservaron dos manzanas menores que se destinaron a parques, y un cuarto equipamiento, de salud, fue construido entre las viviendas de una de las dos manzanas rectangulares de $4.800 \mathrm{~m}^{2}(175 \times 28)$. La superficie de las manzanas destinada a parques es de 600 y $392 \mathrm{~m}^{2}$, respectivamente y el área reservada al cuarto equipamiento asciende a $640 \mathrm{~m}^{2}$. La ubicación de cada uno de estos cuatro equipamientos obstruye la continuidad de tres calles, cuyos perfiles corresponden a 4.4 y 6 metros, pero que de todas formas, no perturba la prestación normal de esos servicios a una población de 6.800 habitantes. Sin embargo estos asentamientos siguen adoleciendo de redes de infraestructuras, de vías adecuadas, de espacio público y de transporte colectivo.

Otros barrios surgidos en el entorno inmediato de Mogambo fueron Edmundo López II, Mogambito, San Cristóbal, las Américas, el Paraíso, Villa Ana y Villa Rocío. Con excepción del Paraíso, los demás barrios se ubican dentro de un triangulo determinado por los ejes de la calle 5 en Mogambo y la calle 22 de la Pradera. Este conjunto de barrios es el producto de fraccionamientos irregulares privados y de parcelaciones públicas promovidas por sectores políticos tradicionales o por actores políticos clandestinos.




Estos ocho barrios surgieron en condiciones urbanísticas, total o parcialmente, irregulares, pero con el suficiente respaldo político para superar problemas trascendentales asociados al dominio de los terrenos o al incumplimiento de la normativa urbana. El trazado es bastante irregular, sus viviendas se encuentran afectadas por tres canales de aguas pluviales-residuales, carecen de equipamientos de gran impacto y no definieron perfiles viales internos importantes que logren integrarlos físicamente con otros sectores de la ciudad, quedando sujetos a la calle 5 de Mogambo y a la calle 22.

La falta de vías internas importantes restringe el servicio de transporte público colectivo y obliga a sus habitantes a recurrir al mototaxismo, principalmente a los residentes de los barrios San Cristóbal, Damasco y Mogambito, quienes son los que más distantes se encuentran de los dos mencionados ejes viales. Estos tres barrios, al igual que el Alivio y las Américas, son los mayores afectados por el trazado de los canales de aguas pluviales y por el impacto que genera su polifuncionalidad; dichos canales, además de conducir aguas lluvias, también son receptores de aguas residuales de las viviendas y de todo tipo de residuos sólidos, incluidos, animales muertos.

Podemos destacar que Mogambo fue el barrio de promoción pública que mayor impacto tuvo sobre el crecimiento informal en los años ochenta. Su desarrollo permitió el surgimiento de los barrios ya mencionados y otros que surgirían a partir de los noventa, y a los cuales, nos referiremos más adelante. Sin embargo, conviene aclarar que su origen legal, su trazado y sus áreas para dotaciones públicas, contrastan con una realidad urbanística informal, que careció inicialmente y sigue careciendo, de redes de infraestructuras, pavimentos de vías, viviendas higiénicas, equipamientos de calidad, seguridad ciudadana y calidad ambiental. En pocas palabras, es un sector deprimido con características similares a la de invasiones consolidadas o de asentamientos surgidos por fraccionamientos públicos.

Por su parte, Panzenú y Villa Margarita, con menor impacto que Mogambo, estimularon el surgimiento de dos asentamientos irregulares sobre el eje de la vía a Guateque. Uno de ellos fue la Campiña, fraccionamiento privado irregular de 180 lotes, sobre el cual ya hicimos referencia; el otro es el 2 de Septiembre, invasión conformada 
por 12 manzanas y 264 lotes de $98 \mathrm{~m}^{2}$ (7x14), con 10 vías internas de 4 metros de perfil y una manzana destinada a equipamiento educativo de primaria. Estos dos barrios surgieron en 1988 y ambos aprovecharon las dotaciones públicas de Villa Margarita, que dicho sea de paso, es un barrio tan deprimido como los asentamientos irregulares de su entorno. Sin embargo el trazado de los tres asentamientos contrasta con el trazado irregular de Alfonso López y los Araujos, constituidos en la década de los setenta por medio de fraccionamientos ilegales e invasiones sobre terrenos de la reserva natural de Sierra Chiquita y la ciénaga los Araujos.

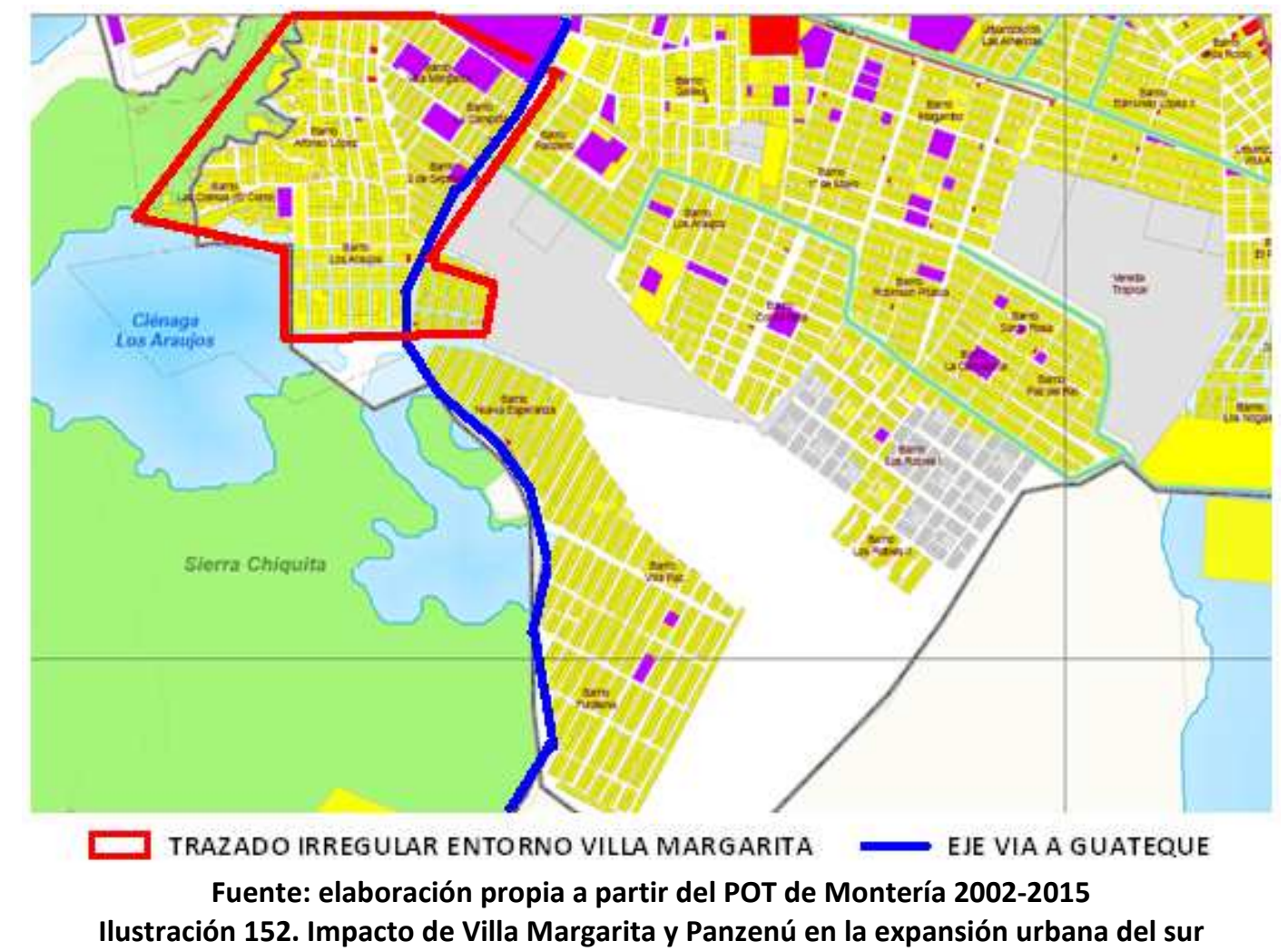

Villa Margarita y Panzenú contribuyeron a consolidar el tercer eje de crecimiento en el sur, después de la calle 5 de Mogambo y la calle 22. Este nuevo eje sería la vía que conduce al corregimiento de Guateque, y al igual que los dos primeros, se caracterizó por estimular el surgimiento de invasiones y de fraccionamientos privados clandestinos. Sin embargo, su despegue definitivo llegaría comenzando el siglo XXI, con la aparición de las Organizaciones Populares de Vivienda ${ }^{290}$ Furatena, Villa Paz y Nueva

290 "Son organizaciones populares de vivienda OPV aquellas que han sido constituidas y reconocidas como entidades sin ánimo de lucro con el objetivo de desarrollar programas de vivienda para sus 
Esperanza, que en conjunto ofrecieron cerca de 2.600 lotes de $98 \mathrm{~m}^{2}$ (7 x 14). Estos tres asentamientos surgirían en condiciones urbanísticas totalmente precarias y sus emplazamientos se realizaron en zonas inundables próximas a la ciénaga de Sierra Chiquita, que a su vez sirvió como referente para establecer el perímetro urbano por ese sector de la ciudad.

Ya hemos analizado parcialmente el crecimiento físico del sur, suroriente y occidente, pero pasemos a analizar lo que pasaba en la misma época en otros sectores como el norte y oriente de Montería. En el norte, en inmediaciones del corregimiento de Mocarí, posteriormente incorporado como barrio al perímetro urbano, surgió en el año 1976 la primera invasión de este sector, denominada 7 de Mayo; mientras que en el oriente, al lado del barrio de la Pradera, en el año 1988, fueron invadidas con el nombre de Cantaclaro, 91 hectáreas de terrenos municipales. Esta invasión, es la más grande de la ciudad, y a nuestro juicio, es la ocupación ilegal mejor planeada de este municipio.

\footnotetext{
afiliados por medio de sistemas de autogestión o participación comunitaria. Estas organizaciones pueden ser constituidas por sindicatos, cooperativas, asociaciones, fundaciones, corporaciones, juntas de acción comunal, fondos de empleados, empresas comunitarias y las demás que puedan asimilarse a las anteriores en los términos previstos por la ley. Las organizaciones deberán ejecutar sus planes de viviendas en terrenos aptos para el desarrollo urbano y de conformidad con todas las normas técnicas, urbanisticas y arquitectónicas vigentes en la localidad. Las entidades que vigilen las actividades de dichas organizaciones, en los términos del Decreto-ley 78 de 1987 y demás disposiciones sobre el régimen comunitario, adoptaran un reglamento especial que permita la recepción anticipada de dineros de sus compradores para adelantar sus planes y que a la vez resguarde suficientemente los derechos de quienes confíen sus dineros a ellas". Artículo 62 de La Ley 9 de 1989 sobre Reforma Urbana.
} 


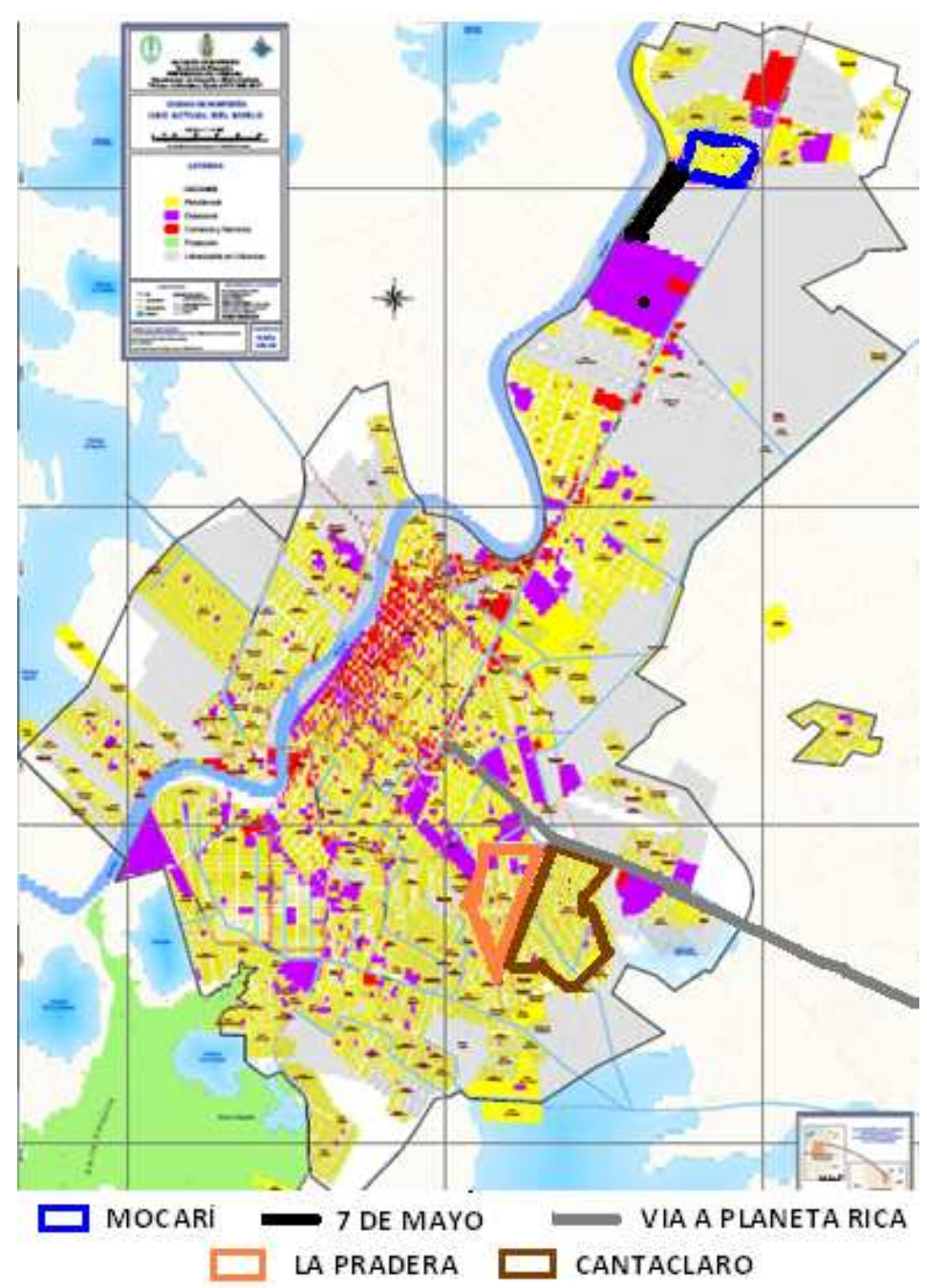

Fuente: elaboración propia a partir del POT de Montería 2002-2015 Ilustración 153. Surgimiento de 7 de Mayo y Cantaclaro

El impacto más grande de invasión en Montería lo causó Cantaclaro, ya que por medio de una no tan espontánea planeación, logró definir un trazado reticular sobre una superficie poligonal. En su trama predomina la manzana rectangular pero sobresalen seis con volúmenes diferentes que lograron reservarse para dotaciones públicas, y sobre las cuales se construyeron posteriormente los equipamientos educativos Severo J. García y Victoria Manzur, así como la cancha de futbol, un parque infantil y un centro de atención de urgencias médicas CAMU. Sin embargo estos equipamientos, al igual que una docena de manzanas, son afectados por la presencia de dos canales polifuncionales que conducen aguas pluviales y aguas residuales. 


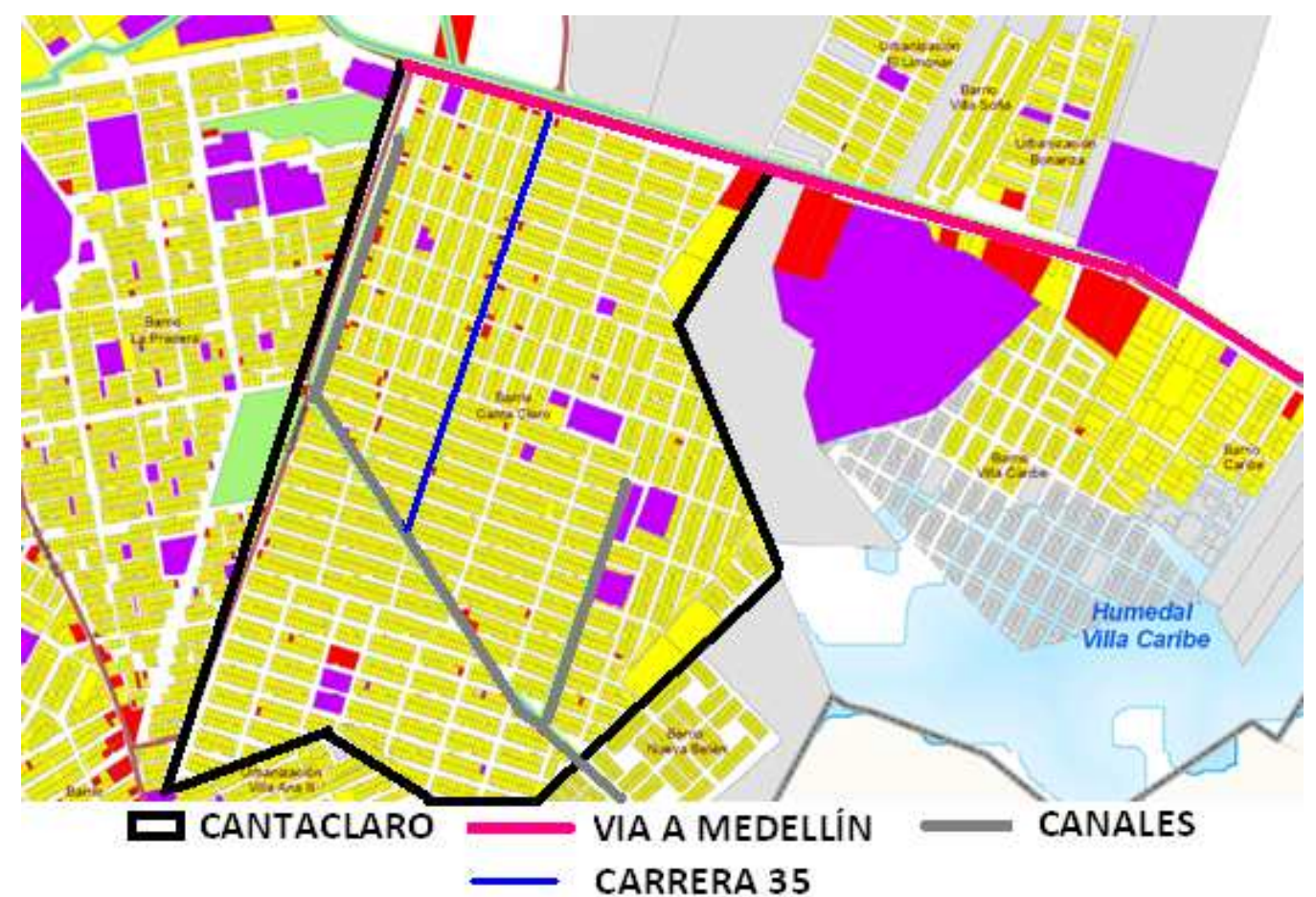

Fuente: elaboración propia a partir del POT de Montería 2002-2015 Ilustración 154. Invasión Cantaclaro

Paradójicamente, este asentamiento irregular se convirtió en dinamizador del oriente y suroriente de la ciudad, al estimular en la siguiente década, las parcelaciones privadas del Limonar, Villa Sofía, Bonanza, Caribe y Villa Caribe. Las tres primeras se realizaron dentro del marco normativo del planeamiento en lugares aptos para residencia, mientras los dos últimos se emplazaron en el humedal Villa Caribe, en un escenario de informalidad notoria, con deficiencias urbanísticas que los hacen vulnerables a las lluvias y a las inundaciones. Estos cinco asentamientos, al igual que Cantaclaro, dependen exclusivamente del eje vial que conduce a Medellín y hasta la fecha no se encuentran planeadas vías colectoras que permitan una mejor integración espacial con otros sectores de la ciudad.

Cantaclaro, aprovechó inicialmente la entrada del barrio la Pradera que viene de la vía a Medellín (Carrera 29), para conectarse con el centro de la ciudad, así como la calle 22 que comunica el centro con el oriente. Igualmente se encuentra integrado por medio de precarias vías con otros barrios informales que surgieron a partir de su constitución, y dentro de los cuales se destacan Villa Ana II, Villa Ana I, Villa Rocío, Edmundo López y Mogambo. Esta integración se realiza a través del transporte informal o de vehículos 
privados como motocicletas y bicicletas, debido a la inexistencia de rutas de transporte público por falta de vías adecuadas.

Su condición de irregular y la presencia de dos barreras no le permitieron una mejor integración física con la Pradera. En primer lugar incidió una barrera artificial representada en el canal de aguas residuales paralelo a la carrera 29 , y en segundo lugar, la presencia de una barrera natural protegida en la misma vía, que además de aislarlos espacialmente, contribuyó a la desarticulación social. Esta desarticulación social, también es el producto de imaginarios estigmatizadores, que tuvo y aun tiene, la sociedad monteriana a cerca de los habitantes de las invasiones.

Los anteriores aspectos, sumados a la falta de dinamismo del oriente de la ciudad, mantuvieron aislada a esta invasión durante más de una década, situación ésta, que se redujo en el año 2002 con la aprobación del POT y la propuesta de crecimiento de la ciudad hacia dicho sector, la cual se realizaría, esencialmente por medio de planes parciales e intervenciones, que sobre el papel pretendían la integración socio-espacial y la mitigación de desequilibrios físicos. Es conveniente anotar que la conformación original de Cantaclaro no es el producto de una ocupación colectiva del terreno, dirigida por un solo líder, sino, el resultado de ocupaciones simultáneas, orientadas por diferentes organizadores, que no lograron unificar el trazado ni una distribución más equitativa del suelo.

La ocupación simultánea por sectores fue la clave del éxito de la invasión, facilitando adecuar el trazado de acuerdo con la ubicación de cada sector y de su cercanía a las vías o los canales existentes, pero no se puede omitir igualmente, que también contribuyó a desencadenar desequilibrios socio-espaciales internos, con graves repercusiones sociales y ambientales. Los primeros, estuvieron asociados a la falta de espacios libres para los habitantes de los sectores: la Carretera, Ñipi A, Ñipi B y el Canal; mientras que los segundos, se asociaron al impacto generado por basuras y vertido de aguas residuales hacia los canales. Sobre este último aspecto, ampliaremos en el apartado 5.4, correspondiente a impacto ecológico. 


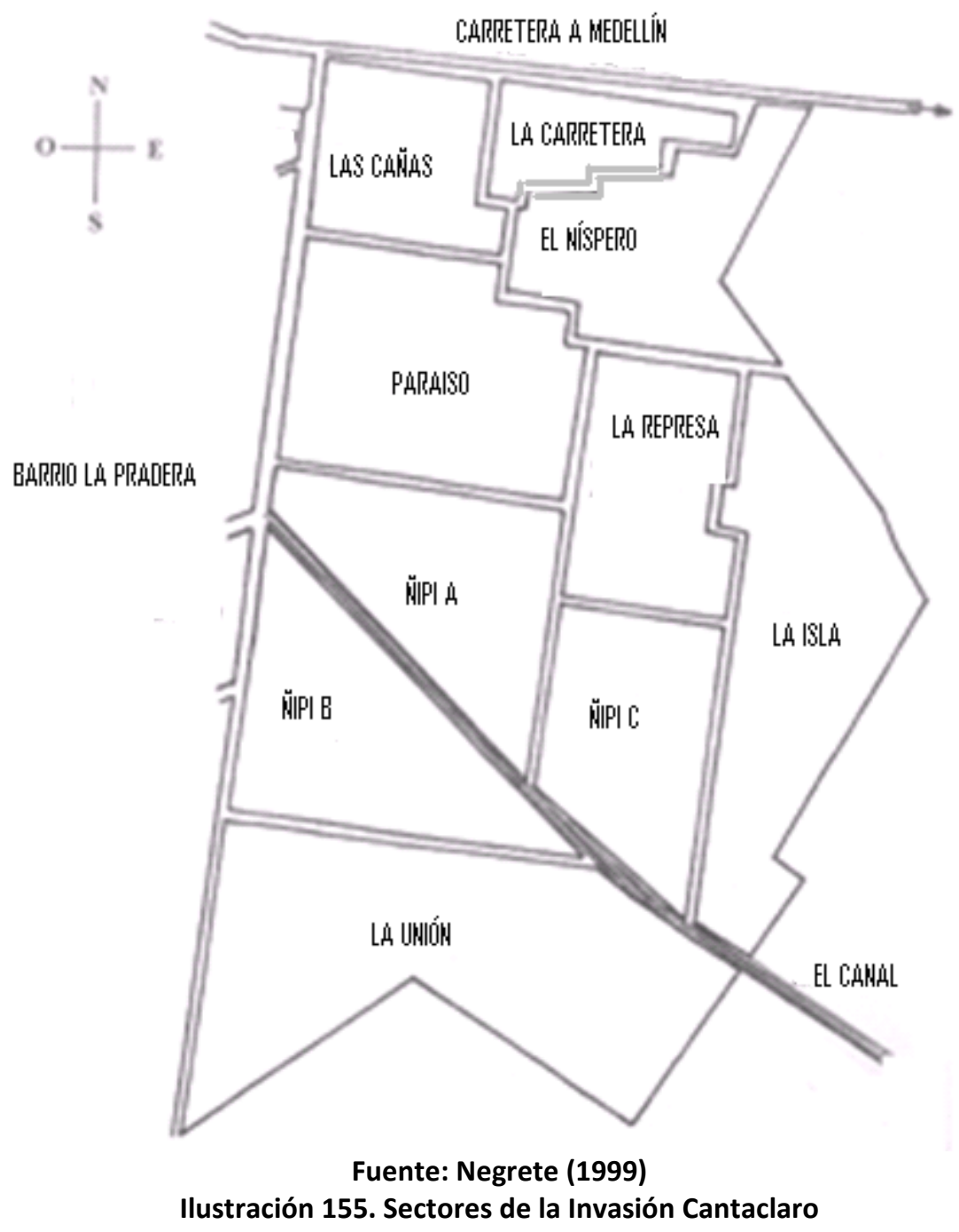

También se presentarían otros desequilibrios socio-espaciales en Cantaclaro, así como en las demás invasiones, asociados principalmente a la falta de infraestructuras, transporte público, calidad de la vivienda, dominio de la misma, estado de los canales colectores, déficit de espacio público, inseguridad ciudadana, equipamientos de baja calidad, deficiente alumbrado público, altos niveles de ruido y ausencia de vías adecuadas, con excepción de la carrera 35, principal eje vial y comercial del asentamiento.

No podemos dejar de anotar que, además de Cantaclaro, en esta década también surgieron en el oriente de la ciudad, dos invasiones lineales de bajo impacto sobre la morfología urbana. Estas ocupaciones irregulares se realizaron a partir del año 1985 y fueron denominadas 25 de Agosto y Ranchos del INAT. Sobre esta última nos hemos referido en apartado anterior, pero reiteramos que será reubicada; y sobre el 25 de 
Agosto, destacamos que con una superficie de apenas 1.4 hectáreas logró consolidarse al lado del barrio San José, aprovechando un lote contiguo al equipamiento carcelario de las Mercedes.

En cuanto a la invasión 7 de Mayo, tenemos que decir que no tuvo un gran impacto como el que ejerció Cantaclaro sobre el trazado urbano, ni permitió el surgimiento inmediato de otras invasiones, pero si se debe anotar, que fue la de mayor impacto ambiental negativo, debido a su emplazamiento a orilla del río Sinú. Esta invasión ocupó un área de 3.5 hectáreas, y se conformó por dos ejes lineales paralelos al río y tres manzanas rectangulares, que se subdividieron en 160 lotes de 84 metros cuadrados $(7 \times 14)$, y dos precarias vías con perfiles de seis metros, que conectan el asentamiento con la calle principal del barrio Mocarí. Sobre su impacto ambiental ampliaremos en el siguiente apartado, y acerca de su estado, resaltamos que surgió con agudos desequilibrios socio-espaciales como consecuencia de la falta de espacios libres y de reservas para equipamientos.

Esta invasión aprovechó los terrenos que se encontraban entre dos equipamientos educativos de gran importancia de la ciudad pero no dispuso de ninguna infraestructura básica instalada, situación que los mantuvo inicialmente marginados de servicios públicos básicos como energía y agua potable. Estos dos equipamientos son la Universidad de Córdoba y el colegio Lorenzo María Lleras, ubicados respectivamente al sur y norte del asentamiento. 


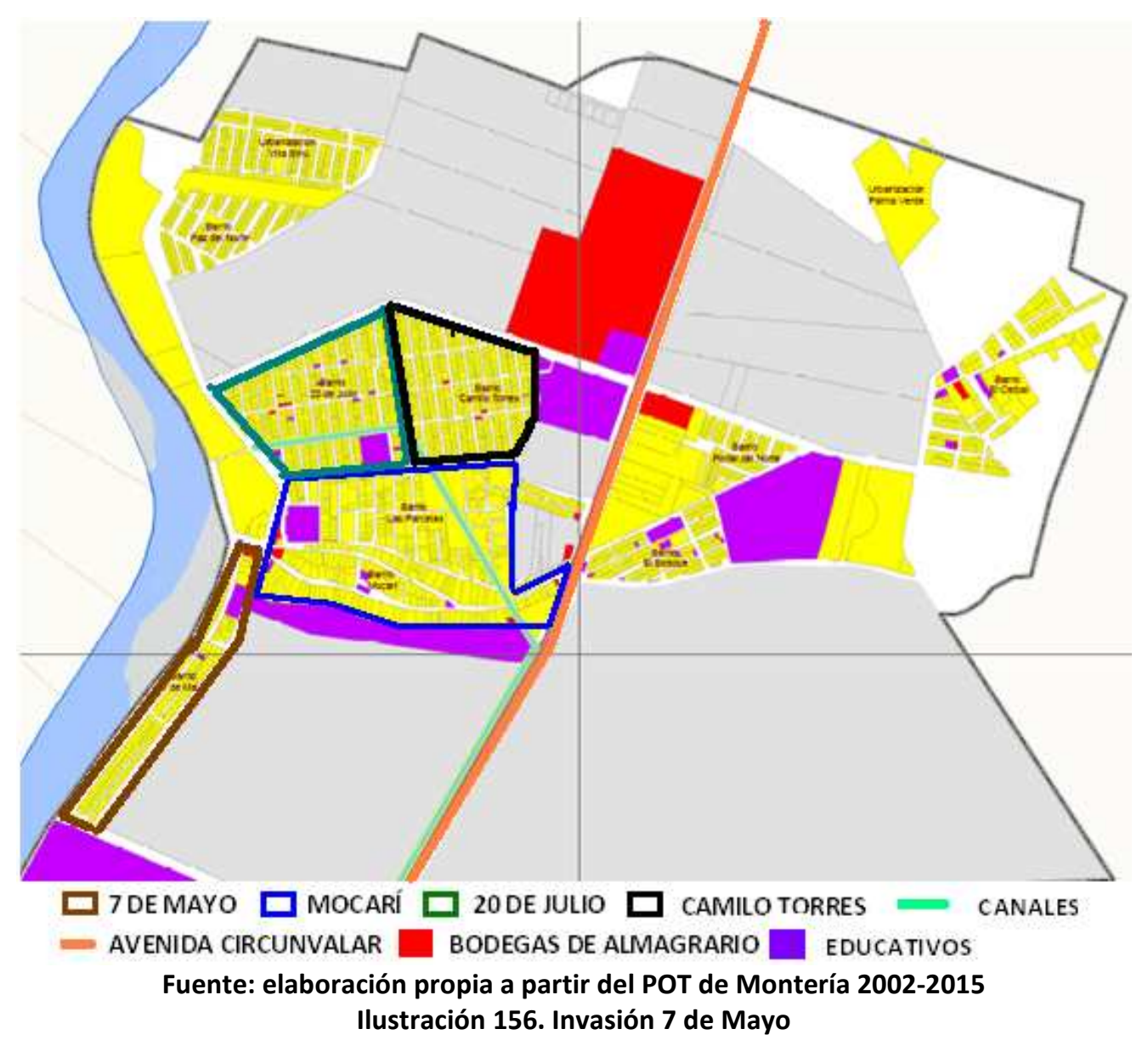

Si bien, el 7 de Mayo no fomentó otras invasiones en su entorno más inmediato, si contribuyó a que dos años después, siguieran las invasiones al norte de Mocarí, concretamente la del 20 de Julio en 1978 y Camilo Torres en 1980. Ambas definieron un trazado reticular, con perfiles viales de 8 y 10 metros, con predominio de manzanas rectangulares de 1.960 y $4.704 \mathrm{~m}^{2}$; las primeras se subdividen en 20 lotes de $98 \mathrm{~m}^{2}$ (7 x 14), mientras que las segundas están conformadas por 48 lotes de igual superficie.

El total del área ocupada por estas dos invasiones fue 18 hectáreas, de las cuales 10 correspondieron al 20 de Julio y 8 a Camilo Torres. Estas superficies fueron subdivididas en 35 y 23 manzanas, respectivamente, donde solamente una de ellas fue reservada para dotación publica, permitiendo posteriormente la construcción del colegio de bachillerato con capacidad para 1000 estudiantes. Las restantes 57 manzanas, sin excepción, se destinaron para viviendas, logrando un total de 1.035 lotes; 563 para el 20 de Julio y 472 para el Camilo Torres. 
El trazado del 20 de Julio es afectado por la presencia de dos canales de aguas pluviales-residuales y por la inadecuada disposición de cinco lotes en dos de sus manzanas. Sin embargo hay que anotar que el emplazamiento de estas dos invasiones, así como la del 7 de Mayo, se realizó entre equipamientos de gran impacto como La Universidad de Córdoba, el colegio Lorenzo María Lleras, la Universidad Pontificia Bolivariana y las bodegas de Almagrario, pero la cercanía a estos equipamientos no contribuye a mejorar su calidad urbana ni a mitigar los desequilibrios socio espaciales, o ambientales, que caracterizan a estos asentamientos informales.

Con este panorama de desequilibrios terminaba la tercera oleada de asentamientos informales en Montería, la cual tuvo mayor impacto sobre la morfología urbana que las dos anteriores, debido a la superficie de las invasiones, especialmente Cantaclaro, Robinson Pitalua, la Candelaria y el Dorado, que en conjunto superaron 200 hectáreas y 7.000 lotes para vivienda. Cada una de las oleadas fue estimulada por barrios de promoción pública, y contribuyeron a la tugurización de la ciudad, situación ésta, que se agudizaría a partir de los años noventa con la supresión del Instituto de Crédito Territorial (ICT), y la apertura del Instituto Nacional de Reforma Urbana (INURBE).

Resaltamos que el ICT en 38 años (1952 -1990), construyó 9.427 viviendas públicas y legalizó las invasiones del 14 de Julio, Santafé, San Martín, Brisas del Sinú, Santander, Pastrana Borrero y Policarpa, pero ello no fue suficiente, ya que la demanda seguía muy por encima de las posibilidades de oferta. Una oferta de vivienda, que en el caso de Montería, le correspondía asumirla al Estado, ante la vulnerabilidad de los demandantes, fundamentalmente desplazados, desempleados, trabajadores informales o empleados con salario mínimo legal. Estas características, sumadas a la incapacidad presupuestaria del Estado, terminaron por legitimar procesos irregulares de ocupación, principalmente las invasiones, que fueron continuamente adoptadas como política de vivienda pública, por lo menos para el caso de esta ciudad.

El INURBE, por su parte, comenzaría su intervención en 1992 con programas de reducida oferta de vivienda que no lograron satisfacer la creciente demanda, ni contener el surgimiento de nuevas invasiones o fraccionamientos irregulares. Estos programas se desarrollaron en el siguiente orden: Urbanización el Puente en 1992; 
barrio las Viñas, 1993; segunda etapa del Dorado, 1995; Casita Nueva, el Alivio y los Robles, entre los años 1997 y 2000; los Colores, 2002 y el Minuto de Dios en el 2003. El Minuto fue el último proyecto desarrollado por este instituto en Montería, ya que el 10 de marzo de ese mismo año, por medio del Decreto 554 se ordenó su liquidación.

El mayor número de viviendas ofrecidas por el INURBE, se construyó en los Robles, con un total de 201 unidades, seguido del Alivio con 166, Minuto de Dios con 164 y el Dorado con 116 soluciones habitacionales, mientras que los otros cuatro barrios en conjunto, apenas pudieron ofrecer 322 viviendas unifamiliares. Esta situación contribuyó posteriormente a la tugurización de estos asentamientos, especialmente Casita Nueva, el Dorado y los Colores, en donde se asignaron lotes de 98 metros cuadrados (7x14) para que sus beneficiarios iniciaran procesos de autoconstrucción de acuerdo con sus posibilidades de ingreso.

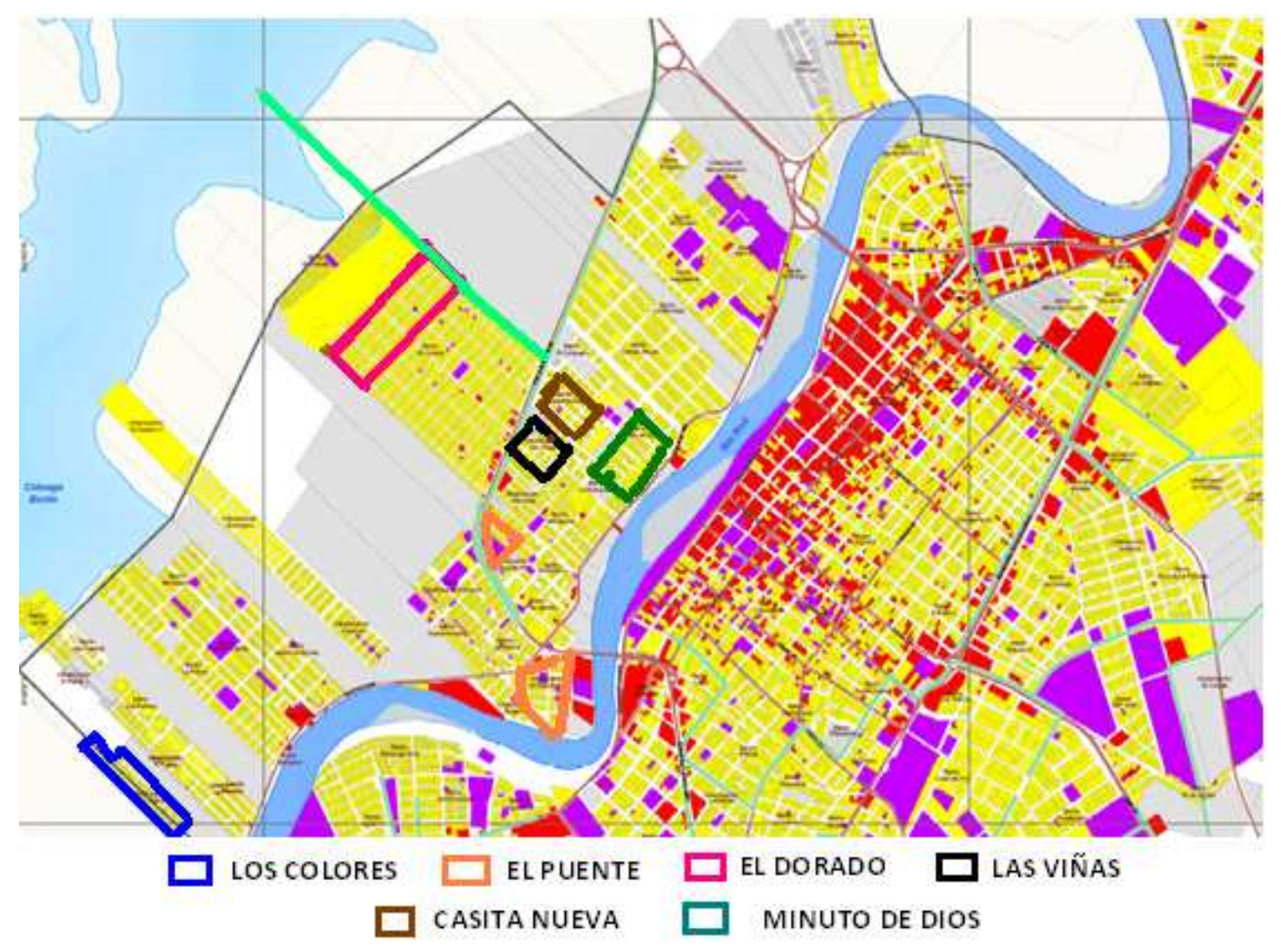

Fuente: elaboración propia a partir del РОT de Montería 2002-2015 Ilustración 157. Programas del INURBE en el occidente

Siete de estos programas se desarrollaron en la margen izquierda del río Sinú, uno en el oriente y otro más en el sur de la ciudad. En el occidente se emplazaron los 
proyectos denominados Puente $\mathrm{N}^{\circ} 1$, Puente $\mathrm{N}^{\circ} 2$, las Viñas, los Colores, Casita Nueva, el Dorado y Minuto de Dios. Con excepción de la urbanización el Puente, los demás barrios presentaron notables deficiencias urbanísticas, asociadas principalmente a la falta de espacio público, equipamientos, infraestructura de redes básicas y a mala calidad de las viviendas, especialmente aquellas surgidas por procesos de autoconstrucción.

El Puente $\mathrm{N}^{\circ} 1$ se emplazó al lado del barrio la Ribera, separado por la vía que conduce al corregimiento de las Palomas, mientras que el Puente $\mathrm{N}^{\circ} 2$ lo hizo al frente de Panamá, pero separado por la carretera que va hacia el municipio de Arboletes. Sus emplazamientos cercanos a los dos principales barrios de promoción pública del occidente y la entrega de viviendas terminadas son dos aspectos que los diferencian de las condiciones de informalidad en que fueron desarrollados los programas de los Colores, el Minuto de Dios, Casita Nueva y el Dorado. Estos cuatro asentamientos promovidos por el INURBE, reiteramos, aún presentan gran deficiencia arquitectónica en viviendas y equipamientos, así como significativas inconsistencias de tipo urbanístico.

El asentamiento de los Colores fue emplazado en el extremo suroccidente de la ciudad, y a pesar de ser un programa de vivienda pública de 85 soluciones habitacionales, terminó convertido en una invasión de más de trescientas infraviviendas, que incluso, ocuparon irregularmente cincuenta lotes por fuera del perímetro urbano, establecido precisamente en este barrio. Su trazado está conformado por once manzanas, siete de ellas son rectangulares con superficies de $1.400,2.940$ y 3.920 metros cuadrados, y seis son de volúmenes inferiores que no superan los 792 metros cuadrados. La disposición de sus manzanas y la interrupción de su viario manifiestan la irregularidad de una ocupación, que pretendió ser ocultada mediante la figura de Organización Popular de Vivienda (OPV).

Los Colores estimularon el surgimiento inmediato de tres fraccionamientos privados irregulares y de tres nuevas invasiones que tugurizaron por completo el suroccidente de Montería. Los fraccionamientos irregulares, fueron paradójicamente denominados como Urbanización el Portal I, Urbanización el Portal II y Urbanización Navarra, 
mientras que las invasiones, las denominaron: los Ébanos, Villa Nazaret y la Vid. Ni las parcelaciones privados, ni las invasiones siguieron trazado alguno, y por el contrario, se apartaron de la trama reticular que propusieron la mayoría de invasiones de los años sesenta, setenta y ochenta.

En esta misma época también surgieron en este sector, los asentamientos irregulares Mi Ranchito, Nuevo Horizonte, el Níspero I y el Níspero II. Los dos primeros aprovecharon las infraestructuras del barrio de promoción pública Rancho Grande, así como su trazado reticular, en el que predomina la manzana rectangular homogénea de 1960 metros cuadrados; mientras que los segundos, se emplazaron en la parte final de una urbanización privada de vivienda terminada, denominada Caracolí, e incluso, invadieron terrenos localizados por fuera del perímetro urbano como se apreciará en la ilustración 158.

Por su parte, las Viñas, Casita Nueva y el Minuto de Dios, se emplazaron en inmediaciones del barrio de promoción pública del Dorado, que ya a estas alturas también se consideraba como otro asentamiento subnormal. Los tres utilizaron trazados simples, no propusieron viario interno importante ni grandes equipamientos, y entregaron viviendas inacabadas arquitectónicamente de 44 metros cuadrados de construcción a sus 316 familias beneficiarias. Igualmente en estos barrios se entregaron más de 400 lotes de $84 \mathrm{~m}^{2}$ para viviendas de autoconstrucción, con perfiles viales de seis y ocho metros, sin pavimentos, redes, ni sistemas de drenaje adecuado que permitieran evacuar favorablemente las aguas pluviales y evitar las inundaciones en periodos de lluvias.

Los anteriores aspectos y la baja capacidad adquisitiva de los beneficiarios, condujeron a estos asentamientos a pésimas condiciones urbanísticas y los alejaron de los elementos que caracterizaron a los primeros programas públicos de vivienda del ICT, ya sea por falta de dotaciones públicas, precariedad de sus unidades habitacionales o por la alta vulnerabilidad de sus terrenos a la inundación. Sin embargo, esta alta vulnerabilidad no fue impedimento para que en esta misma época surgieran los fraccionamientos privados de Villa Real, Villa Nueva, el Amparo y la Esmeralda, que 
contribuyeron con la dinamización del sector, con la instalación de nuevas redes y con nuevos equipamientos.

La precariedad de los asentamientos del occidente llegó a los mismos extremos de los barrios del sur, suroriente y norte de la ciudad, y los programas de vivienda pública de la Ribera y Panamá, se vieron estéticamente empañados por los desarrollos del INURBE a partir de 1991, especialmente los de Casita Nueva, Minuto de Dios, Los Colores y el Dorado. Este último barrio, a pesar de su ordenado trazado, es un hibrido entre vivienda pública terminada y viviendas de autoconstrucción, y su emplazamiento fue aprovechado por varios actores políticos para organizar una nueva invasión sobre terrenos anegadizos muy próximos a la Ciénaga el Reparo; esta invasión fue denominada el Poblado y su ocupación colectiva se realizó en el año 1992.

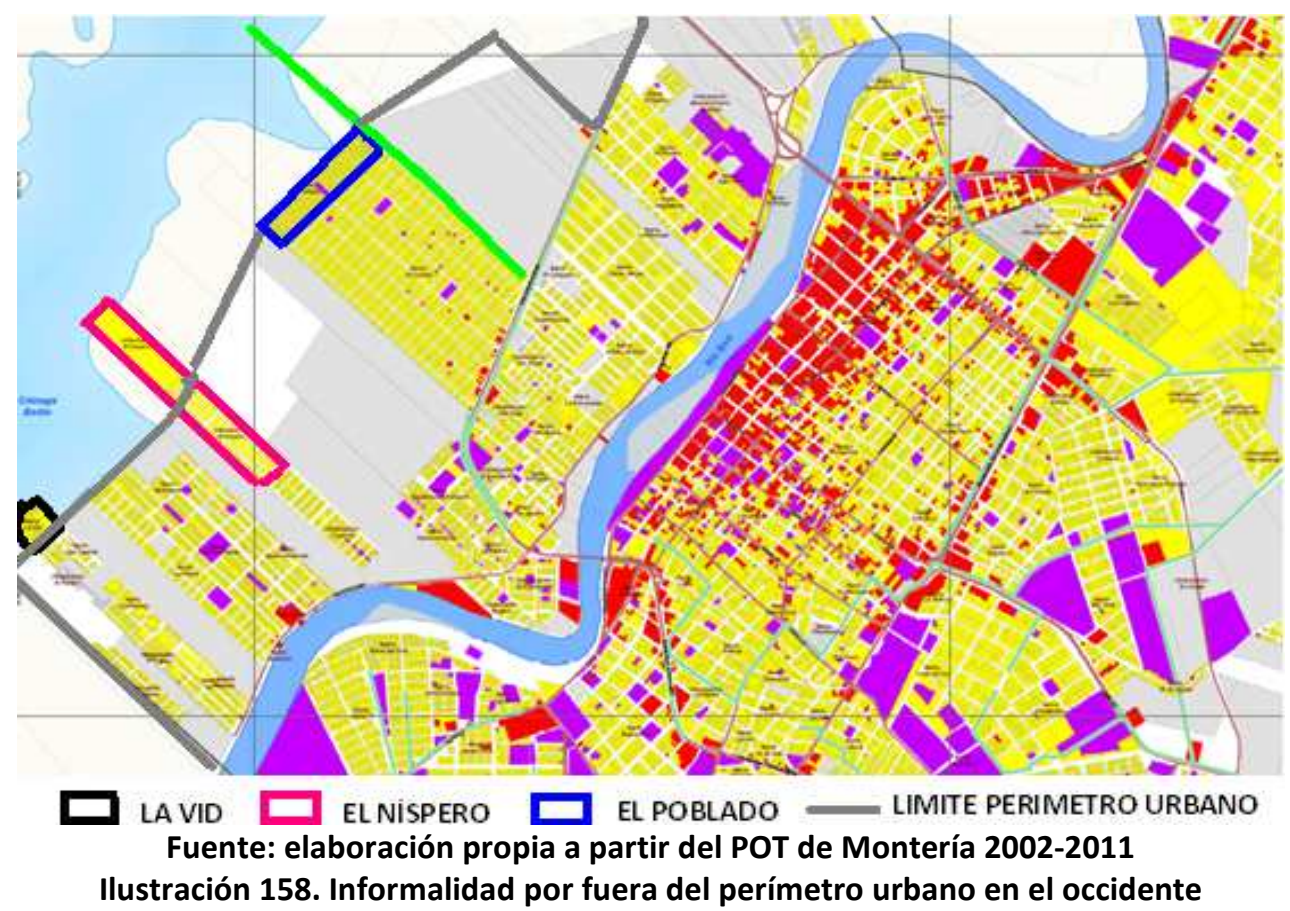

El Poblado es un asentamiento de seis hectáreas, que está conformado por veintiuna manzanas rectangulares de $2.744 \mathrm{~m}^{2}$, las cuales fueron subdivididas en 550 lotes de 98 $\mathrm{m}^{2}$. Su trazado es opuesto a la trama que debió seguir, es decir a la del barrio de promoción pública el Dorado. Tiene veinte calles internas con perfil definido de seis metros, que no conducen a lado alguno ni conectan con el viario del mencionado barrio de vivienda pública, y cuenta con un equipamiento educativo que se construyó en una superficie de $2.400 \mathrm{~m}^{2}$. Su trama es simple pero efectiva, e incluso mejor 
delineada que el de algunos fraccionamientos legales, tal y como se puede apreciar en el plano general presentado como anexo.

En cuanto a la Vid, tenemos que decir que fue de las pocas invasiones desorganizadas de Montería, en la que no hubo planeación, organización ni toma colectiva, sino por el contrario, su ocupación se realizó de manera fraccionada y dispersa totalmente irregular. El alto nivel de irregularidad de su trama obedece fundamentalmente a dos factores: en primer lugar se invadieron terrenos fuera del perímetro urbano, y en segundo lugar esa ocupación se hizo sobre la ciénaga de Berlín, alterando totalmente la actitud inicial del suelo, y contribuyendo además con ello, a aumentar el problema de las inundaciones en el occidente de la ciudad. Evidentemente, no hubo trazado, definición de viario, reserva para dotaciones o disposición efectiva de manzanas, y a la oficina de planeación le quedó grande la reubicación o la ordenación del asentamiento.

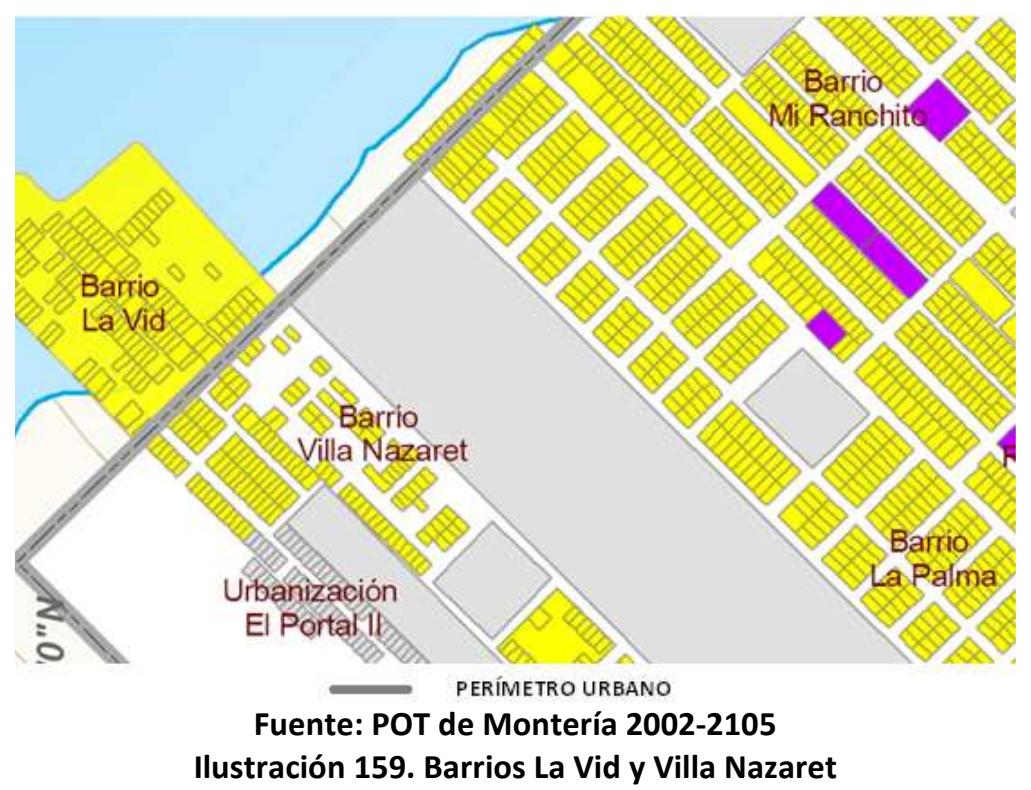

La informalidad urbanística de los barrios La Vid, Villa Nazaret y la Urbanización el Portal, no dista mucho de las condiciones de la Palma y Mi Ranchito, barrios éstos, que a pesar de presentar un trazado más regular, también son el producto de procesos informales de ocupación. Los cinco son una mezcla de fraccionamientos públicos y privados, con deficiencias similares, asociadas a la falta de infraestructura básica, de áreas libres, precariedad de la vivienda, inundaciones, ausencia de equipamientos e 
inexistencia de vías adecuadas para su integración socio-espacial. En el caso de este sector, observamos qué, los trazados regulares e irregulares del plano, presentan deficiencias urbanísticas similares, que sobre el terreno, los hacen ver igual de irregulares a todos.

Terminamos este análisis del occidente anotando que los programas del INURBE no fueron favorables para este sector, y por el contrario, su cobertura y calidad fue tan deficiente que estimularon la informalización de sus mismos programas y la proliferación de fraccionamientos irregulares o de invasiones colectivas. Se redujo la superficie del lote de $162 \mathrm{~m}^{2}$ a $98 \mathrm{~m}^{2}$ y el plano de la ciudad se vio totalmente alterado por un conjunto de trazados diferentes e inapropiados, que no aportaron nuevos ejes ni se preocuparon por dotar de áreas libres ni de equipamientos de gran jerarquía.

De igual forma, la mala calidad urbanística de los programas que se desarrollaron a partir de 1992, en la margen izquierda del río y la ausencia de una propuesta vial coherente, condenaron a los habitantes de cuarenta asentamientos a depender de sus dos únicos ejes: la vía al municipio de Arboletes y la vía al corregimiento de Las Palomas, que transcurre paralela al río, con las nomenclaturas $3 \mathrm{~W}$ y $1 \mathrm{~W}$; precisamente sobre estos dos ejes se encuentran tres grandes equipamientos educativos, de los cuales, dos pertenecen a una acaudalada familia, y el tercero corresponde a la escuela pública Normal Superior.

En el trazado actual del occidente se observan las inconsistencias de fraccionamientos regulares e irregulares que no respondieron a un proyecto colectivo de ciudad, sino a propuestas aisladas que buscaron resolver problemas fiscales o satisfacer apetitos voraces individuales. Estos aspectos se traducen en una alta informalización del sector y en una extendida precariedad de la vivienda y de las dotaciones públicas, específicamente las vías y equipamientos de los barrios los Colores, Casita Nueva, la Esperanza, el Ébano, el Níspero, Manuel Jiménez, Villa Nazaret, Mi Ranchito, el Dorado, el Portal y la Navarra. Así mismo, se traduce en impacto ambiental negativo generado por las invasiones del Bongo, Casa Finca, la Vid y el Poblado. Sobre este aspecto ampliaremos en el apartado de impacto ecológico. 
Retomando el análisis del sur y oriente, específicamente, el de los programas de vivienda pública del Alivio y los Robles, debemos manifestar que, el primero fue emplazado entre el barrio público de la Pradera y el barrio irregular Edmundo López, en un área reducida de tres hectáreas; mientras el segundo, se localizó detrás de los asentamientos irregulares Robinson Pitalúa, la Candelaria y Paz del Río, en un terreno de 11 hectáreas. El Alivio, fue ordenado a partir del canal de aguas residuales que delimita a Edmundo López y Damasco, pero su principal referencia es el eje de la calle 22 , vía esta, que lo integra espacialmente con el centro de la ciudad.

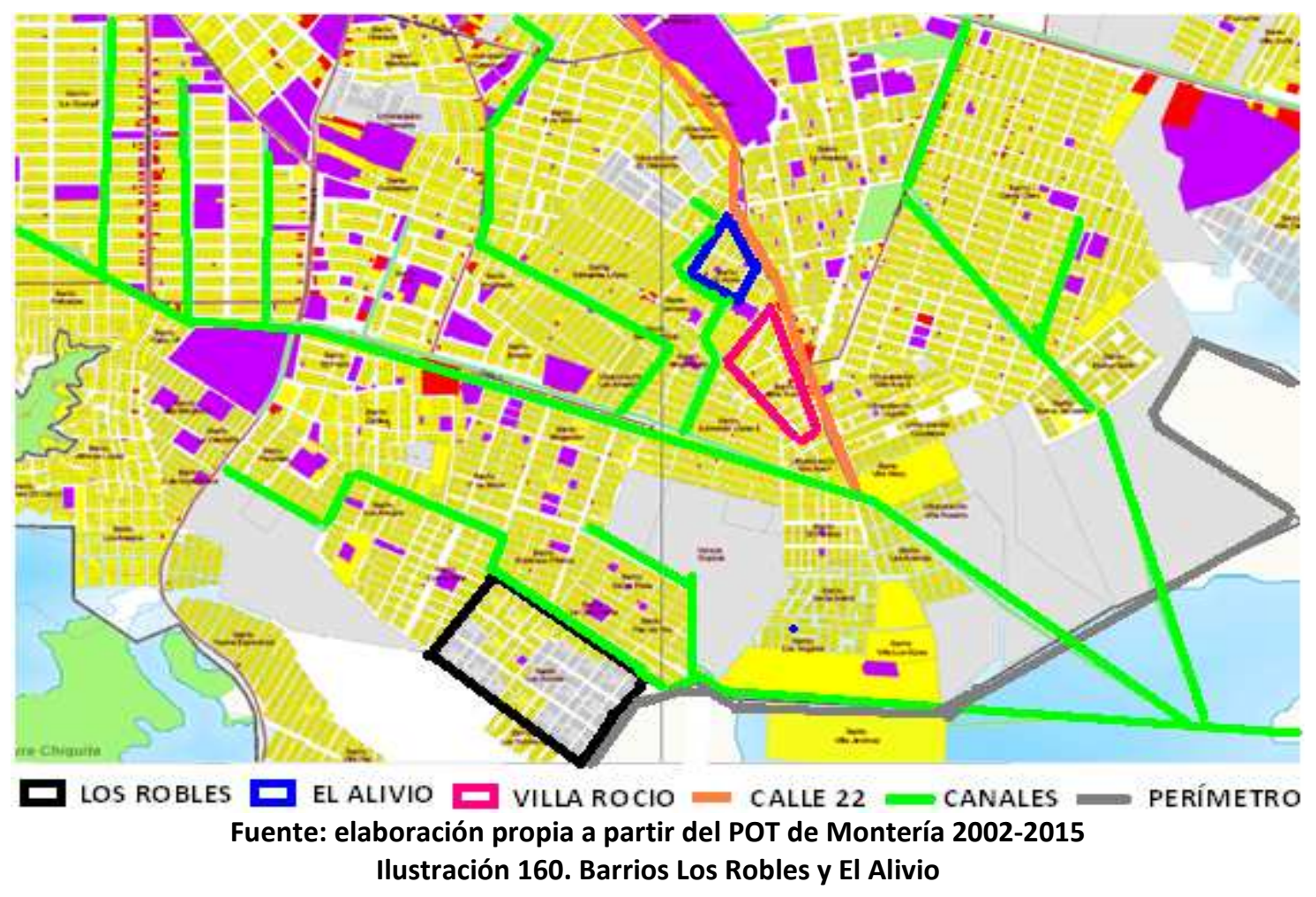

Por su parte, los Robles fue ordenado a partir del canal de aguas residuales que parte del barrio Panzenú y delimitaba a los asentamientos informales de Galilea, $1^{\circ}$ de Mayo, Robinson Pitalúa y Paz del Río. Su trazado, sobre el papel, lo conforman 90 manzanas, dispuestas de forma escalonada, con predominio de manzana rectangular de $1.372 \mathrm{~m}^{2}$, que a su vez se subdividen en 24 lotes de $98 \mathrm{~m}^{2}$. No obstante, se pudo corroborar el desarrollo de apenas 33 de ellas con 201 viviendas terminadas, y un centenar de viviendas precarias que no exceden los límites del perímetro urbano. Igualmente se corroboró la existencia de un solitario equipamiento, el cual corresponde a un Centro de Atención Inmediata de la Policía Nacional (CAI). 
Tanto los siete programas públicos del occidente como el Alivio y los Robles, se convirtieron en el punto de partida de la cuarta oleada de asentamientos informales de Montería. Esta sería la última oleada de asentamientos irregulares, que comenzaría en 1992, con el desarrollo de los primeros proyectos del INURBE, y se extendería hasta el año 2007. Conviene anotar que en este año se desarrollaron los últimos fraccionamientos irregulares en este municipio, y que durante el periodo 2008-2011, se han neutralizado media docena de intentos de invasión en el occidente y suroriente de esta ciudad.

En este último periodo, en el entorno inmediato de los barrios mencionados surgieron una variedad de asentamientos, dentro de los que se destacan: desarrollos por fraccionamientos privados, parcelaciones públicas, urbanizaciones ${ }^{291}$, y nuevos programas públicos de viviendas terminadas en condiciones urbanísticas deficientes. Los barrios que siguen al Alivio, por el eje de la calle 22 son Villa Rocío, Villa Ana I, Villa Ana II, Villa Mery, el Paraíso, las Acacias, Santa Isabel, los Nogales, Villa de los Alpes y la invasión Villa Jiménez.

Todos ellos se encuentran en condiciones de marginalidad, pero su mayor problema está asociado a las frecuentes inundaciones que padecen, principalmente las Acacias, Santa Isabel, los Nogales, Villa de los Alpes, el Paraíso y Villa Jiménez, emplazados irregularmente en terrenos de un humedal. Sin embargo, y con excepción de Villa Jiménez que se emplazó por fuera del perímetro urbano, los demás ya obtuvieron legalización.

Cuando hablamos de emplazamiento irregular nos referimos a fraccionamientos de terrenos públicos, y peor aún de fraccionamientos de suelos fiscales de gran riqueza natural o con potencial de reserva ecológica, que terminaron en manos de particulares, políticos o ex-políticos, quienes negociaron directamente o a través de

\footnotetext{
${ }^{291}$ Veinticuatro fraccionamientos irregulares en Montería han sido registrados como urbanizaciones, a pesar de no haber urbanizado los terrenos, realizado las reservas correspondientes para dotaciones públicas ni construido viviendas, contribuyendo con ello a la tugurización de la ciudad. Sin embargo, a finales de los años noventa algunas constructoras comienzan a ofrecer vivienda privada en verdaderas urbanizaciones como el Laguito y Cundama, las cuales terminaron posteriormente rodeadas por urbanizaciones irregulares.
} 
terceros lotes de $98 \mathrm{~m}^{2}(7 \times 14)$, a precios demasiado económicos y con plazos superiores a doce meses, facilitando el acceso de personas con bajo poder adquisitivo o de trabajadores informales ${ }^{292}$ de cualquier sector de la economía. Generalmente estas transacciones fueron respaldadas por medio de letras de cambio y a través de documentos de compraventa, debidamente autenticado en notaría pública pero no registrados en la oficina de instrumentos públicos.

Retomando el caso de la última oleada de asentamientos irregulares, debemos anotar que además de la invasión de Villa Jiménez en el suroriente, también se presentaron la de Villa Cielo en suelo suburbano del oriente, Villa Paz, Furatena y Nueva Esperanza en el sur, sobre el eje que conduce al corregimiento de Guateque. Igualmente se desarrollaron una serie de fraccionamientos privados en el norte que dieron paso a los barrios marginales del Bosque, Portal del Norte, Urbanización Villa Sinú, Paz del Norte, el Ceibal, Urbanización Palma Verde y la Urbanización Dulce Hogar, también conocida como Altos de California. Todos estos asentamientos se encuentran en situación de marginalidad y sus mayores problemas se encuentran asociados a la falta de vías y de transporte público, especialmente Villa Sinú, Paz del Norte, el Ceibal y Altos de California, que se encuentran en el límite del perímetro urbano y bastante distante de la avenida circunvalar, principal eje vial de ese sector y de la ciudad.

\footnotetext{
292 El testimonio de varios propietarios de viviendas precarias de distintos asentamientos informales permitió identificar nombres de líderes comunales, políticos, cooperativas, garantías y formas de pago que se establecen o establecieron para las transacciones u ocupaciones de dichos lotes. Dentro de estos propietarios se encuentran trabajadores informales como Wilson Pacheco Ríos en el barrio los Nogales, William Ramón López Fuentes de la Candelaria, Nelson López Fuentes de Robinson Pitalúa, Zoraida Cárdenas de Alfonso López, Betty Basa en Cantaclaro, Orlando López en el 1 de Mayo, Piedad Ríos Castro en Robinson Pitalúa, Eduardo Pacheco en el Cerro, Diosgracio Castro en el 2 de Septiembre y Casiano López Vega en Mogambito. Estos testimonios se obtuvieron por medio de diversas entrevistas realizadas a familiares y amigos entre el año 2004 y 2011, y sobre algunas de ellas ya nos hemos referido en apartados anteriores.
} 




La fuerte presión ejercida sobre terrenos del sur y occidente durante los años setenta y ochenta, debió trasladarse también hacia el norte y nororiente a partir de los años noventa, como consecuencia de la notable disminución en la superficie de los primeros y de la mayor disponibilidad que presentaban los segundos. Esta situación indujo a propietarios de suelos del norte a realizar fraccionamientos privados, ante los riesgos que representaban colectivos de invasores, que ya para esta década, contaban con una mayor organización, tal y como quedó posteriormente demostrado, con el éxito de las invasiones de Furatena, Villa Paz y Nueva Esperanza, así como de la invasión Villa Cielo, realizada por fuera del perímetro urbano de Montería. Sobre las cuatro, ampliaremos más adelante, algunos detalles de tipo urbanístico político y económico.

Sigamos con los fraccionamientos privados del norte, los cuales continuaron con la tendencia tradicional del contexto local, consistente en urbanizar parcialmente 
terrenos y vender lotes particulares con superficies entre 98 y 180 metros cuadrados para la autoconstrucción de viviendas. La urbanización parcial de los terrenos de este sector se tradujo en el fraccionamiento de $1.283^{293}$ lotes con deficientes instalaciones de redes de agua potable y energía, los cuales fueron vendidos a plazos, por medio de letras de cambio y con garantía de compraventa firmada ante notaría pública.

Los fraccionamientos de mayor aprovechamiento para sus propietarios fueron Paz del Norte y Villa Sinú, emplazados al norte de la invasión 20 de Julio por medio de trazados aislados que poco o nada aportan ni a la malla vial ni al espacio público de la ciudad. El primero ofreció 286 lotes de $98 \mathrm{~m}^{2}$ (7x14), en una superficie de 3.5 hectáreas, distribuidas en 18 manzanas, 15 rectangulares y 3 residuales de geometría irregular. Predomina la manzana rectangular de $1.960 \mathrm{~m}^{2}$ con 20 lotes, pero sobresalen dos alargadas de $3.038 \mathrm{~m}^{2}$, con 32 lotes para vivienda. Los perfiles de las vías son de seis y ocho metros, y hay una superficie disponible de $1.960 \mathrm{~m}^{2}$, que se asume, debe ser destinada para equipamiento o para área libre.

Villa Sinú, por su parte, fue emplazada en un área de 4.5 hectáreas, que se distribuye en 20 manzanas dispuestas de manera escalonada, es decir, vertical y horizontalmente, y dentro de las cuales sobresalen dos que no fueron subdivididas; una por ser un espacio residual inferior a $200 \mathrm{~m}^{2}$, y la otra por haber sido reservada para equipamiento público. Este fraccionamiento, sacó un relevante aprovechamiento de suelo, obteniendo 402 lotes de $98 \mathrm{~m}^{2}$ (7x14), en: siete manzanas rectangulares de $2.744 \mathrm{~m}^{2}$, una de $3.724 \mathrm{~m}^{2}$ y doce con volúmenes entre $800 \mathrm{~m}^{2}$ y $1960 \mathrm{~m}^{2}$. Al igual que Paz del Norte, presenta condiciones urbanísticas deficientes, precariedad en más del $50 \%$ de las viviendas, marginación socio espacial y dependencia de los asentamientos informales 20 de Julio y Camilo Torres.

En lo referente a los otros cuatro asentamientos de este sector, debemos destacar que el número de lotes ofertados por todos ellos fue inferior a la cantidad ofrecida por Paz del Norte y Villa Sinú. Mientras la oferta de los dos últimos ascendió a 688 lotes, la de

\footnotetext{
293 Número de predios que aparece en los planos institucionales, pero que aparentemente no corresponde al mismo número de viviendas sobre el terreno, debido a aislados procesos de especulación, subdivisión de lotes particulares y autoconstrucción de vivienda. Sin embargo, consideramos que lo dibujado y lo construido se encuentran muy aproximados.
} 
los primeros apenas pudo llegar a 595, de los cuales 207 corresponden al Ceibal, 200 al Bosque, 138 a Portal del Norte y 40 a Altos de California. La respuesta a esta asimetría la tiene la mayor superficie de los lotes del Ceibal y de Altos de california, los cuales son superiores a $180 \mathrm{~m}^{2}$. Es oportuno anotar, que esta analogía se realiza a partir de la comparación de dos áreas globales de aproximadamente nueve hectáreas; tanto para el primer grupo de barrios como para el segundo.

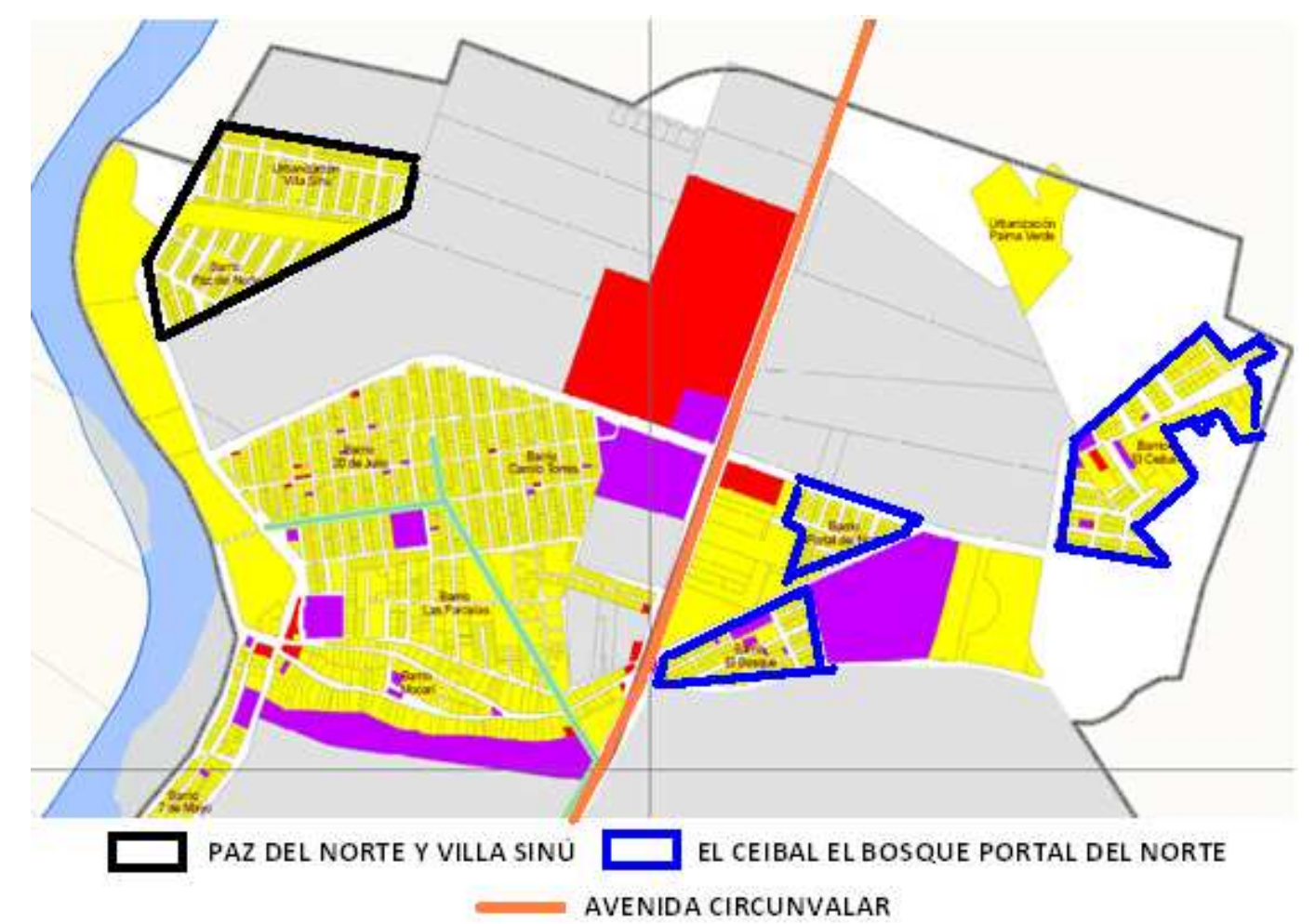

Fuente: elaboración propia a partir del POT de Montería 2002-2015 llustración 162. Asimetría en el aprovechamiento del suelo

Evidentemente, estos últimos asentamientos del norte permitieron el acceso de más de 1.200 familias a lotes para autoconstrucción de viviendas pero a expensas de nuevos procesos de marginalidad urbanística y de precariedad habitacional. Con excepción del Bosque y Portal del Norte, los demás barrios se encuentran desintegrados socio-espacialmente, con gran dependencia del transporte informal y en condiciones suburbanas desfavorables, especialmente los habitantes de Paz del Norte, Villa del Sinú y Dulce Hogar, quienes no cuentan con vías adecuadas, alumbrado público o equipamientos colectivos de salud o educación. 
Sobre el tema de los equipamientos conviene aclarar que la generosidad expresada en el plano contrasta con la realidad de este sector, ya que el emplazamiento de dos de ellos no corresponde a las demandas de estas comunidades, y por ende, no está dirigido a dichas comunidades; uno de ellos es la Universidad Pontificia Bolivariana, la más costosa de la ciudad, y el otro es una sede de la corporación autónoma regional de los valles del Sinú y del San Jorge (C.V.S.), dedicada al monitoreo ambiental por parte de funcionarios institucionales. Los elevados costos de matriculas, por un lado, y la reducida oferta de empleos, por el otro, impiden que los habitantes de estos asentamientos se beneficien directamente de los servicios de estos dos grandes equipamientos.

Mientras esto sucedía en el norte, en el sur continuaban las tensiones por la vivienda, y a los barrios surgidos en este último periodo, también se sumaban, en 1996, los programas de vivienda pública de los Araujos y de Colina Real. Estos proyectos tuvieron como objetivo la reubicación de los habitantes del Cerro y de Pueblo Pescao ${ }^{294}$, y fueron financiados por el INURBE, el Fondo de Vivienda Municipal de Interés Social, el Municipio y la Comunidad. Los Araujos entregaron 621 viviendas terminadas, mientras que Colina Real fue un programa de adjudicación de 597 lotes de $98 \mathrm{~m}^{2}$ para autoconstrucción de vivienda ${ }^{295}$.

\footnotetext{
${ }^{294}$ Este fue y sigue siendo un sector deprimido del centro de la ciudad, emplazado desde la calle 37 a la calle 41, sobre la ribera del Río Sinú y la Avenida Primera, con cerca de 500 habitantes, que se dedicaban principalmente a la venta de pescado. La reubicación de sus habitantes en el año 1996, no mejoró las condiciones físicas ni las de seguridad de este sector, y por el contrario, en la actualidad es un escenario de indigencia, utilizado para la venta y consumo de drogas.

295 Ante la incapacidad presupuestaria que siempre tuvo el Estado Colombiano para atender la demanda de la vivienda, éste optó por presentar dos modalidades de oferta: la primera orientada a la entrega de vivienda terminada y la segunda, a la entrega de lotes con servicios para autoconstrucción. Este segundo instrumento es denominado "solución de vivienda", y por su efectividad, reemplaza frecuentemente los programas de vivienda terminada, que le corresponde ofertar al Estado. En Montería se iniciaron en los años sesenta con los fraccionamientos públicos del Prado y Boston, pero ante el surgimiento de invasiones en Santafé, San Martín, Pastrana Borrero, Policarpa y Santander, terminaron por aumentarse en las siguientes décadas, hasta extenderse por toda la ciudad. Reiteramos que, desde el punto de vista financiero es totalmente favorable para el fisco, ya que el Estado abandona ese rol inicial de promotor, urbanizador, constructor, para asumir únicamente el papel de promotorurbanizador, y así trasladar el costo total o parcial de la vivienda a las familias; pero, desde el punto de vista urbanístico, estos procesos son generadores de informalidad y precariedad habitacional.
} 


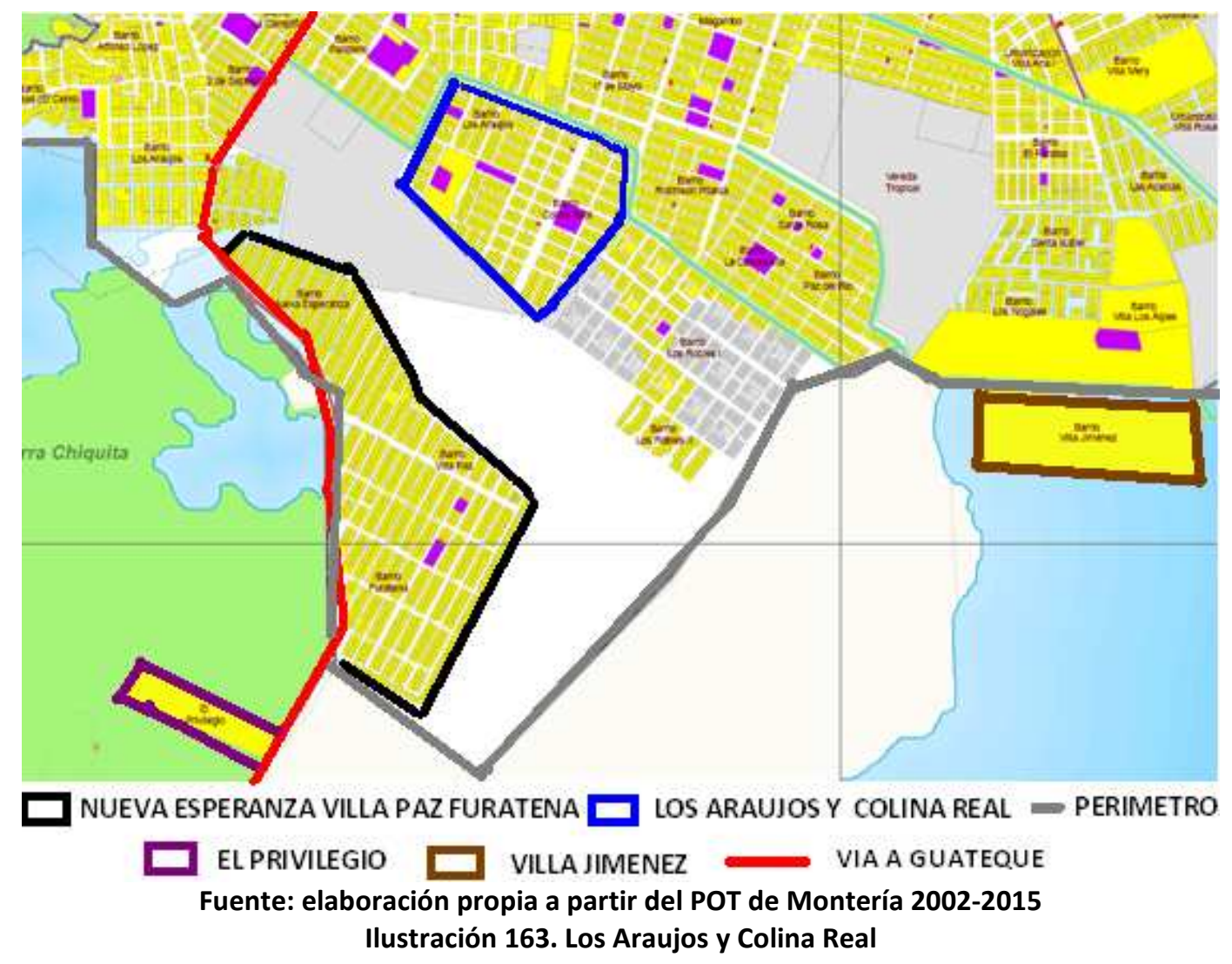

El barrio los Araujos fue emplazado en un terreno de 13 hectáreas sobre un trazado regular de 32 manzanas, pero afectado por el canal de aguas residuales del sur que lo separa de Panzenú y Galilea. En su ordenación predomina la manzana rectangular de $1.764 \mathrm{~m}^{2}$, así como tres superficies destinadas a equipamientos: una de $1.323 \mathrm{~m}^{2}$, donde se ubica una cancha de microfútbol; la segunda de $2.156 \mathrm{~m}^{2}$, donde se construyó una entidad oficial denominada Casa de la Justicia, dedicada a la solución de conflictos familiares o vecinales, y la tercera de $3.600 \mathrm{~m}^{2}$, destinada al colegio de bachillerato.

Este asentamiento tiene perfiles viales de 4,6 y 8 metros, complementados por tres puentes peatonales precarios y uno vehicular en concreto, que permiten la integración física con los barrios vecinos, pero en condiciones desfavorables para el transporte público colectivo. Al igual que los demás barrios de promoción pública, sus características físicas se asemejan a la de asentamientos informales, con urbanización incompleta, carente de alcantarillado, sin pavimentos, baja calidad de sus viviendas, ausencia de zonas verdes y con olores insoportables emanados por los sedimentos de los canales de aguas residuales. 
Colina Real, entre tanto, fue emplazada en un terreno de 13.7 hectáreas, inmediato a los Araujos, por medio de una ordenación reticular que buscó dar continuidad al viario propuesto por el mencionado asentamiento. Su trazado está conformado por un total de 43 manzanas, entre cuadradas y rectangulares, además de cuatro espacios residuales de diferentes geometrías. Estas manzanas fueron dispuestas siguiendo el eje del canal, con perfiles viales de 6,8 y 12 metros, que conectan las 687 viviendas autoconstruidas en igual número de lotes de $98 \mathrm{~m}^{2}$ (7×14). En dicho trazado, sobresale una manzana cuadrada de $3.600 \mathrm{~m}^{2}$, en la cual se construyó su único equipamiento, una escuela de primaria.

En este asentamiento, reiteramos, no se entregaron las viviendas construidas, sino los lotes para autoconstrucción y algunos subsidios en dinero o en especie para unos cincuenta beneficiarios, situación ésta que contribuyó a la tugurización del sector, sobre todo por las condiciones socioeconómicas de las familias favorecidas, las cuales procedían en su mayoría de la invasión del cerro. Cuando hablamos de tugurización nos referimos a precarias condiciones de las viviendas, vías, equipamientos, servicios básicos y condiciones sanitarias desfavorables generadas por los canales o cunetas colectoras de aguas pluviales y residuales.

Como dato adicional, comentamos que el predio de 13.7 hectáreas donde fue emplazado este barrio, corresponden a un terreno inundable, adquirido por el municipio en el año 1992, por un costo de $\$ 56.000 .000$ (aproximadamente \$126.000.000 de 2010; es decir, el equivalente a \$US 63.000 de este mismo año). Sin embargo, su adecuación resultó más costosa, debido a que el relleno necesario para levantar las viviendas requirió de aproximadamente $180.000 \mathrm{M}^{3}$ de balasto, que a valor presente representan unos \$US 100.000. Este es apenas uno de tantos ejemplos de los altos costos financieros que representa la adecuación de terrenos inundables para zonas residenciales en Montería.

Con estos dos programas se conformaba un gran bloque de asentamientos caracterizados por la informalidad y por la presencia de cuatro canales y más de un centenar de cunetas, que sobre el terreno se convirtieron en verdaderas alcantarillas a cielo abierto, con su respectivo impacto ambiental negativo, principalmente en lo 
relacionado a higiene y sanidad pública. Este bloque de barrios está conformado por Panzenú, el Prado, Galilea, los Araujos, Colina Real, Robinson Pitalúa, la Candelaria, Paz del Río, Santa Rosa, $1^{\circ}$ de Mayo, Mogambo y los Robles, el cual se integró a partir del año 2000. La calidad de sus equipamientos es deficiente y su infraestructura vial es precaria, con apenas dos ejes viales pavimentados que los integran con otros sectores de la ciudad: uno es la vía al corregimiento de Guateque y el otro es la calle 5 que inicia en el Prado para finalizar en el barrio las Acacias.

Otro gran bloque de informalidad urbanística en el sur lo conformaron los asentamientos surgidos en el entorno del programa público del Alivio, los cuales quedaron igualmente influenciados por la proliferación de canales, cunetas y vías precarias. Estos barrios son Villa Rocío, Villa Ana, Villa Mery, Damasco, las Américas, San Cristóbal, Edmundo López II, el Paraíso, las Acacias, Santa Isabel, los Nogales, Villa los Alpes y Villa Jiménez. Carecen de equipamientos básicos y la integración espacial de cada uno de ellos con el centro de la ciudad, depende exclusivamente de la calle 22.

No obstante, la última oleada de asentamientos informales no terminaría con los programas el Amparo, los Araujos y Colina Real, y por el contrario, éstos fueron insuficientes para contener la presión continua que ejercían grupos invasores sobre sus inmediatos entornos. El resultado de esta fuerte presión por la vivienda fue el surgimiento de cuatro invasiones, esta vez concertadas abiertamente, entre la administración municipal y los grupos de invasores. Esta concertación consistió en un compromiso bilateral, por medio del cual, los invasores debían constituir legalmente una Organización Popular de Vivienda (OPV), como condición indispensable para acceder colectivamente a un predio, y por otra parte, la administración se comprometía a entregar los respectivos terrenos para su fraccionamiento y ocupación.

Las Organizaciones Populares de Vivienda (OPV), exclusivas de esta última oleada de asentamientos informales, fueron Villa Cielo, Nueva Esperanza, Villa Paz, y Furatena, las cuales permitieron la entrega formal de 4.302 lotes. Villa Cielo se emplazó en un terreno de 20 hectáreas del oriente, por fuera del perímetro urbano, mientras que Nueva Esperanza, Villa Paz y Furatena se ubicaron en terrenos del sur, sobre la vía que conduce al corregimiento de Guateque, y en una superficie de 30 hectáreas. Es 
pertinente recordar que sobre el marco legal de estas organizaciones ya hicimos referencia en páginas anteriores de este mismo apartado; por tanto, consideramos ahora oportuno, analizar sus aspectos sociales, políticos y urbanísticos.

Como ya lo habíamos anotado, la conformación de estos cuatro asentamientos fue el resultado de la presión de los invasores y no de respectivos programas de vivienda pública o de entrega de lotes con servicios para una población previamente seleccionada por las instituciones. La elección del terreno, dentro de la ciénaga de los Araujos, no se hizo con criterios técnicos ni ambientales, situación ésta, que explica las pésimas condiciones urbanísticas de cada uno de ellos, y sus altos niveles de inundabilidad. Al igual que Colina Real, la adecuación de estos terrenos ha requerido de volúmenes similares de balasto y de nuevos sistemas de drenaje o de cunetas artesanales.

Con la legitimación de las invasiones a través de la figura de las organizaciones populares de vivienda, el municipio, o mejor dicho, la administración municipal iniciaba un proceso de participación activa en la tugurización de la ciudad, y entraba a solucionar la incapacidad operativa del estado central, en este caso la del INURBE, encargado de la promoción de vivienda pública en Colombia. Esta situación terminaría por agravarse con la liquidación del mencionado instituto el 10 de marzo del 2003, fecha en la cual, se le traslada la responsabilidad directa de la vivienda a las administraciones municipales, a las cajas de compensación familiar y a las propias comunidades. En esa misma fecha se expide el Decreto 555, que crea el Fondo de la Vivienda (FONVIVIENDA), encargado de administrar los recursos destinados a subsidios de Vivienda de Interés Social (VIS).

Pero antes de continuar con el proceso de ocupación de los últimos diez años, sigamos analizando el impacto que tuvieron las denominadas Organizaciones Populares de Vivienda (OPV), sobre el trazado de la ciudad, la calidad urbanística y el bienestar de sus beneficiarios. En el caso de Villa Cielo, debemos destacar que su emplazamiento por fuera del perímetro urbano generó los mayores traumas asociados a la prestación de servicios básicos, los cuales se tradujeron en fuertes tensiones sociales y 
significativos choques entre las administraciones municipales y las empresas prestadoras de servicios públicos.



Este asentamiento, con apariencia de isla en el plano urbano, se encuentra ubicado a cuatro kilómetros del perímetro urbano oriental, y dentro de sus principales características se destacan la desarticulación vial, el alto índice de aprovechamiento de suelo para vivienda y las deficientes dotaciones públicas. Este alto índice está representado en 1.702 lotes de $98 \mathrm{~m}^{2}$ (7 x 14), que se disponen en 70 manzanas heterogéneas, y se integran por medio de vías internas de 4, 6 y 8 metros.

En su trazado reticular sobresalen: una manzana rectangular de $4.000 \mathrm{~m}^{2}$, en la que se emplaza su único equipamiento educativo, la escuela de bachillerato Villa Cielo; una superficie de $2.400 \mathrm{~m}^{2}$, correspondiente a una ciénaga, y cuatro áreas de $588 \mathrm{~m}^{2}$, reservadas para equipamiento religioso, hogar infantil y salón comunal. Sin embargo, se evidencia el predominio de manzanas rectangulares de 4.900 y en menor proporción algunas con tamaños comprendidos entre 1.960 y $2.352 \mathrm{~m}^{2}$. A pesar de las respectivas reservas, aún no se han construido ninguno de los equipamientos 
programados y las diferentes actividades comunitarias se siguen desarrollando en precarias instalaciones.

Este asentamiento estuvo por más de cinco años por fuera del perímetro urbano, hasta que en el año 2006, el municipio y las empresas de servicios públicos establecieron su incorporación a él. La integración a dicho perímetro permitió la instalación paulatina de las redes de energía eléctrica y agua potable, pero no la integración física del barrio, que siguió manteniendo características suburbanas y elevadas condiciones de marginalidad, principalmente en lo relacionado a calidad de los servicios básicos y de transporte.

Llevar los servicios básicos a este barrio le representó al municipio una inversión cercana a los $\$ 1.500 .000 .000^{296}$ (\$US 750.000) del año 2009 y permitió la disminución de las tensiones sociales que se vivieron por más de cinco años como consecuencia de la falta de agua potable y de los costos que representaba para las familias el suministro de este líquido a través de carro-tanques o vendedores de agua, quienes a su vez, debían transportarlas desde el perímetro urbano. Sin embargo es significativo anotar que a pesar de sus singulares circunstancias, este asentamiento informal logró en solo ocho años, lo que otros consiguieron después de quince, veinte, e incluso, treinta años; es decir, acceder legalmente a los servicios básicos de energía y agua potable.

Con Villa Cielo no terminaría la problemática de la vivienda en Montería, y por el contrario, la invasión simultánea de cinco terrenos por parte de trece mil ocupantes en diferentes puntos de la ciudad agravaría el problema y desencadenaría una ola de confrontaciones, en la que fueron asesinadas siete personas y más de un centenar de

\footnotetext{
296 En la instalación de las redes de acueducto de Villa Cielo, Furatena, Villa Paz y Nueva Esperanza, el municipio de Montería invirtió en el año 2009 setecientos cincuenta mil dólares, los cuales provinieron del Fondo Nacional de Regalías y permitieron instalar 12 kilómetros de tubería. La instalación de redes de energía fue financiada por el municipio, la empresa de energía, pero la comunidad debió aportar el valor correspondiente al $25 \%$ de las obras, mediante pagos diferidos y concertados. Posteriormente en el año 2010, la administración municipal, con una nueva inversión de cincuenta y cinco mil dólares instaló las redes en los asentamientos informales de Villa Arleth, Villa Mery, Nueva Colombia y los Corales. En el primer proyecto se beneficiaron 4.302 Hogares, mientras que en el segundo los beneficiarios ascendieron a 300 hogares. Esta información fue publicada en el $10^{\circ}$ Informe de Gestión de la Alcaldía de Montería, páginas 3 y 4 , y se encuentra disponible en www.montería.gov.co
} 
heridos en los desalojos realizados por la fuerza pública ${ }^{297}$. El nivel de las confrontaciones, las medidas represivas de la fuerza pública y la incapacidad del Estado para controlar la situación, generaron la intervención de la Fundación para la Paz de Córdoba (FUNPAZCOR), mediante la oferta de donar un terreno de 30 hectáreas en el sur, con la condición de que se desalojaran los cinco terrenos invadidos.

“El paraestado 298 presionó la solución al ofrecer lotes suburbanos para la instalación de los invasores; casi simultáneamente apareció un volante firmado por el que se autodenominó Comando del Movimiento Muerte a Invasores, que conminaba a éstos a aceptar la generosa oferta de Funpazcor y a abandonar los lotes invadidos" ${ }^{\prime 299}$. La autora de estas revelaciones, tiene el gran mérito de documentar lo que un sector de la opinión pública ya conocía desde un par de años antes, a través de los medios de comunicación y la Fiscalía General de la Nación; es decir, la relación directa entre poderosos líderes paramilitares ${ }^{300}$ y la denominada fundación. Igualmente deja al

297 Redacción Diario El Tiempo (2000): Ofrecen Lotes para Invasores de Montería. Sección Nación. 10 de marzo, Bogotá. Disponible en: http://www.eltiempo.com/archivo/documento/MAM-1289758

298 En este caso hace referencia a los grupos paralamitares como actores políticos, pero en Colombia no son los únicos actores que operan de forma paralela a las instituciones legítimas del Estado, principalmente en aquellos municipios donde no hubo presencia estatal. No es ningún secreto que algunos municipios en Colombia estuvieron, o están controlados territorialmente por actores violentos como narcotraficantes, guerrilleros, paramilitares y delincuencia organizada, quienes finalmente ante la ausencia del Estado, son los que establecieron, o establecen las reglas de juego a la población civil, incluidos códigos de muerte. Esta ausencia estatal no solamente se refiere a la inexistencia de la fuerza pública, sino también a la no presencia de jueces, médicos y profesores, razón por la cual no compartimos plenamente la denominada "política de seguridad democrática", impuesta por el gobierno de Álvaro Uribe Vélez, 2002-2010, quien consideró obstinadamente que la ausencia del Estado se suplía exclusivamente con aumento del pie de fuerza y no con mayores programas sociales que brindaran mejores posibilidades a los habitantes de municipios rurales o de zonas alejadas de los principales centros de producción. Los resultados de dicha política fue un incremento del $40 \%$ para el pie de fuerza, que representó pasar de 308.000 efectivos en el 2002 a 431.000 en el 2008, lo que a su vez, representó menores recursos para inversión en salud, educación y programas de vivienda pública. Las cifras aquí presentadas son institucionales y se encuentran disponibles en http://www.ejercito.mil.co/?idcategoria $=214218$

${ }^{299}$ Ocampo, Gloria Isabel (2003): Urbanización por Invasión. Conflicto Urbano, Clientelismo y Resistencia en Córdoba. Revista Colombiana de Antropología. Vol.39, enero-diciembre, pp.237-272. Disponible en: http://www.icanh.gov.co/recursos user//RCA\%20Vol\%2039/v39a08.pdf

300 Miembros de las autodenominadas Autodefensas Campesinas de Córdoba y Urabá ACCU y Autodefensas Unidas de Colombia AUC, a quienes Gloria Ocampo define como una organización político-militar paralela al Estado. Op. Cit. Pág. 238. Sin embargo, es pertinente anotar que, a pesar de su enorme poder político y económico, sus máximos dirigentes fueron procesados por narcotráfico y extraditados a los Estados Unidos en el año 2008. 
descubierto la incapacidad que tuvo el estado para solucionar institucionalmente el problema de la vivienda en Montería.

Los mencionados terrenos, posteriormente fueron entregados directamente a las Organizaciones Populares de Vivienda y en sus treinta hectáreas se emplazaron los asentamientos de Nueva Esperanza, Villa Paz y Furatena. La administración municipal fue descartada por los negociadores, quienes no depositaron la suficiente confianza en ella ni le permitieron la intervención en el fraccionamiento de lotes o la asignación de los mismos. En este aspecto, el papel de la alcaldía estuvo limitado a la de simple organizador de los censos de invasores, asesorías o capacitaciones a los miembros de las OPV y a la apertura de una oficina para la atención de personas sin vivienda.

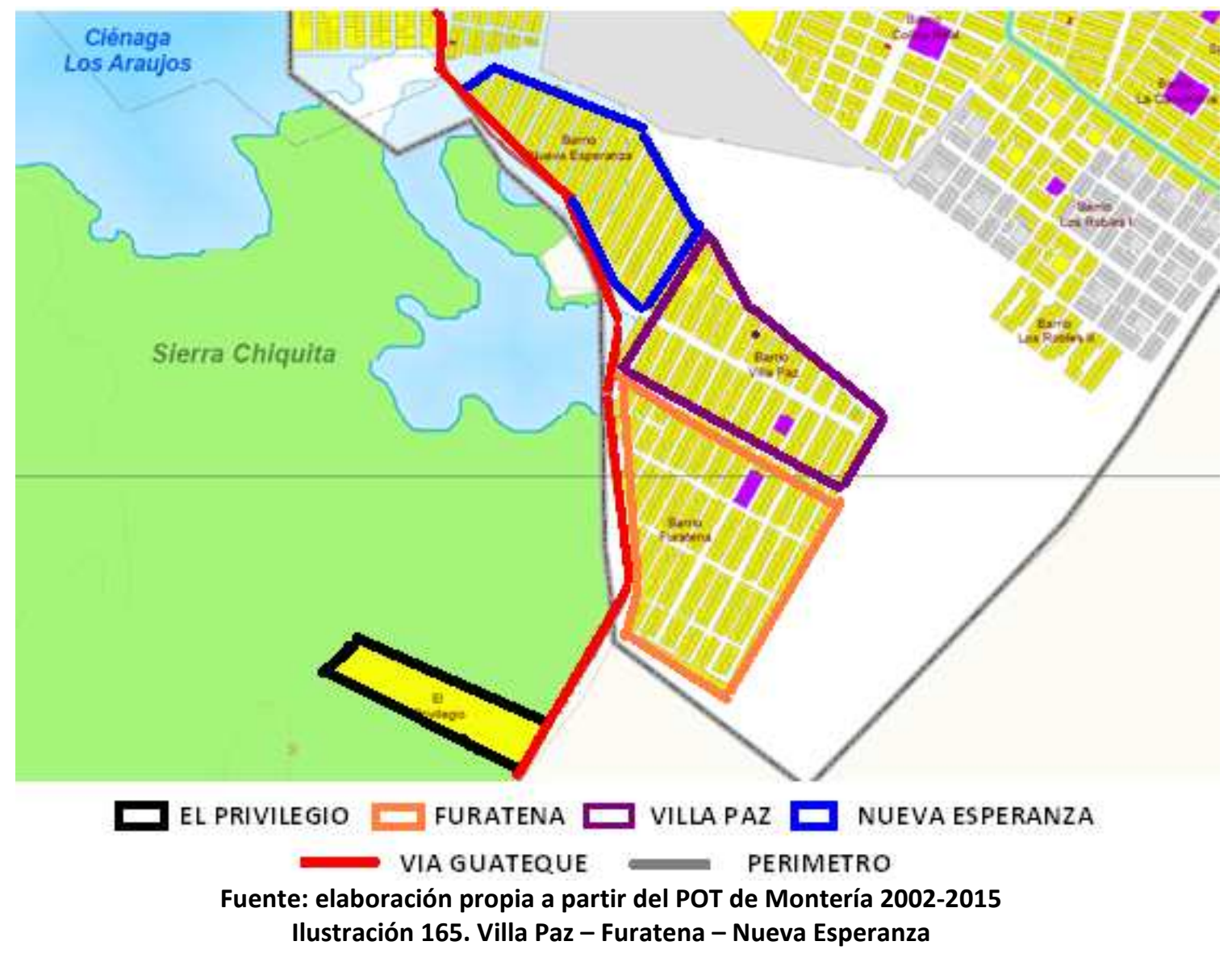

El fraccionamiento de los tres asentamientos se dio simultáneamente, mediante un trazado reticular que estuvo condicionado por el eje de la vía que conduce al corregimiento de Guateque y por los límites del terreno, especialmente en el sector de Nueva Esperanza, el cual es el que presenta mayor heterogeneidad en el tamaño de 
sus manzanas. En total son 69 manzanas, entre rectangulares, lineales y residuales, las cuales a su vez se encuentran subdivididas en 2.600 lotes de $98 \mathrm{~m}^{2}$ (7x14), y unidas por vías de cuatro y seis metros. La reserva para equipamientos fue de apenas $2.940 \mathrm{~m}^{2}$, ubicándose la escuela Manuel Ruiz en un área de $1.960 \mathrm{~m}^{2}$ (70x28), y el centro de salud en los restantes $980 \mathrm{~m}^{2}(28 \times 35)$.

En los sectores de Villa Paz y Furatena hay predominio de manzanas rectangulares de $2.940 \mathrm{~m}^{2}$ (105 x 28), mientras que en el sector de Nueva Esperanza predominan manzanas superiores a ese tamaño, e incluso, media docena de ellas superan los 5.000 $\mathrm{m}^{2}$ y están subdivididas hasta en sesenta lotes de $98 \mathrm{~m}^{2}$ (7x14). Las condiciones de sus viviendas, vías y equipamientos siguen siendo precarias, mientras que los servicios básicos de energía y agua potable, apenas se acaban de instalar en estos dos últimos años.

Como se aprecia en la ilustración 165, su emplazamiento se realizó en terrenos correspondientes a la reserva natural de Sierra Chiquita, alterando la vocación inicial de la Ciénaga de los Araujos, la cual ya había sido afectada anteriormente por los asentamientos irregulares del Cerro, Alfonso López, y los Araujos. Cada uno de ellos sirvió para delimitar el perímetro urbano por el suroccidente de la ciudad, pero no impidieron el surgimiento de una nueva invasión en el año 2007, por fuera de éste, precisamente sobre el eje de la vía a Guateque y dentro de la mencionada reserva. Esa invasión es denominada el Privilegio, y sobre ella, ampliaremos en el apartado de impacto ecológico.

Es importante anotar que, estas últimas invasiones se dieron en un nuevo escenario urbano, en donde ya habían cambiado, o mejor, desaparecido, las condiciones legales y políticas que durante más de cincuenta años permitieron la consolidación de otras invasiones en distintos sectores de la ciudad. En este sentido, estamos de acuerdo con la antropóloga Gloria Ocampo, cuando considera que jurídicamente los invasores ya no fueron los transgresores de antes porque el Estado legalizó lo que no pudo controlar. (...) "Ios invasores ya no podían ser los transgresores de antes, de modo que el Estado le suministró una identidad que les permitiera considerarlos como interlocutores legítimos: miembros de organizaciones populares de vivienda, lo cual constituyó, más 
que un ejercicio del poder de denominación, una estrategia para eximirse de la obligación de judicializar a los invasores, única vía de solución al conflicto. Como en tantas otras circunstancias, el estado se vio constreñido a legalizar lo que no podía controlar ${ }^{\prime 301}$.

En cuanto a las condiciones legales, éstas se asociaban a la responsabilidad sobre ordenación del territorio que la ley 388 de 1997 imponía a los municipios, y a la nueva política de vivienda establecida a partir del decreto presidencial 824 de 1999, firmado por el entonces presidente Andrés Pastrana Arango, que reglamentaba la Ley $3^{a}$ de 1991 sobre vivienda de interés social y formas de acceso a subsidios del Estado. Igualmente las leyes 308 de 1996 y 599 del 2000 endurecían las penas sobre invasión de tierras, incluidas aquellas zonas de especial importancia ecológica, la usurpación de tierras, y se tipificaba como delito a la urbanización ilegal.

En estas dos últimas leyes se incrementaban las penas para los invasores de terrenos, usurpadores de tierras y urbanizadores ilegales, quienes disfrutaron por más de cincuenta años de la inexistencia de leyes ejemplares y de un código penal laxo que no tipificaba como delito a la urbanización irregular y establecía penas irrisorias para usurpadores e invasores. Estas penas fueron establecidas inicialmente por el decreto ley 100 de 1980 con prisión entre uno y tres años, y con multas de $\$ 1.000$ a $\$ 20.000$; sin embargo las leyes 308 de 1996 y 599 del 2000, lograron ampliar las penas de los invasores a cinco años, y a la de los urbanizadores ilegales a siete años, con multas entre 150 y 500 salarios mínimos legales mensuales vigentes.

Por su parte, el cambio en las condiciones políticas estuvo asociado a la consolidación de un para-estado que logró la adquisición, por vías legales o ilegales, de muchos terrenos rurales, suburbanos y urbanos, al igual que la participación en corporaciones públicas y en administraciones municipales. Terrenos de dominio municipal, que por tantos años facilitaron los procesos de invasión, quedaron en manos de particulares o de paramilitares, quienes a través de sus ejércitos privados defendieron estas propiedades, complicando el trabajo de los invasores y relegaron a un segundo plano el poder de los políticos locales.

301 Op. Cit. Pág. 246. 
El trabajo de los invasores se complicó porque las invasiones siempre se habían realizado sobre terrenos municipales, y precisamente ese fue el éxito de cada una de ellas, las cuales contaron con el respaldo de políticos locales y de funcionarios ${ }^{302}$. De otro lado, el protagonismo de los políticos se vio relegado, como consecuencia de la poca disponibilidad de terrenos municipales y por el poder que obtuvieron los paramilitares en el departamento de Córdoba y en la ciudad de Montería. Un aspecto importante que esta investigación no puede omitir, son las condiciones sociales de la época, las cuales se encuentran asociadas al continuo incremento de los desplazados internos por la violencia en Colombia, que los convertía en un grupo social prioritario para el Estado, incluso, por encima de campesinos, sindicatos, colectivos sin vivienda o invasores ${ }^{303}$.

No obstante, y a pesar de las situaciones expuestas, las invasiones de Villa Cielo, Villa Paz, Nueva Esperanza y Furatena, no cerrarían la última oleada de asentamientos informales en esta ciudad, y por el contrario, los procesos de ocupación irregular se extenderían por cinco años. Sobre este aspecto, resulta oportuno anotar que ya a estas alturas (año 2003), los invasores no contaban con terrenos públicos diferentes a zonas naturales protegidas de alto impacto ambiental, como efectivamente sucedió ese mismo año con el asentamiento Villa Jiménez, el cual fue emplazado en 11.29 hectáreas de un humedal suburbano de dominio del municipio, permitiendo la reubicación de 703 nuevas familias invasoras.

\footnotetext{
302 Gloria Ocampo, desde su enfoque como antropóloga, considera que, la invasión es "un acto legitimo para los invasores y aunque es ilegal se legaliza mediante la interpretación popular de las leyes, y, sobre todo, al ser asimilado por el clientelismo, elemento definitorio del sistema político cordobés". Op. Cit. Pág.247. Coincidimos con ella, más si tenemos en cuenta, testimonios de invasores que manifiestan no haberse metido nunca en problemas con nadie porque ellos no invaden terrenos ajenos sino del "gobierno".

303 Gloria Ocampo definió a los invasores del año 2000 en Montería, "como un movimiento de raigambre societaria, que desafía al Estado, al para-estado y a la sociedad dominante, pero, para hacerlo, utiliza identidades propuestas por estas mismas entidades al tiempo que recurre a nociones, prácticas y discursos en las que se entrecruzan lo estatal, para-estatal y lo societario, lo formal y lo informal, lo legal y lo ilegal. Se trata de un movimiento social adelantado por gente que demanda vivienda, surgido de un enfrentamiento que no se define como conflicto de clase, lo cual lo diferencia de los movimientos sociales de los años 1970 y de la agitación pública de comienzos de la década de 1980". Op. Cit. Pág. 251. En este caso la identidad utilizada fue la de desplazados y su elección tuvo como objetivo lograr un reconocimiento legal que a la postre se consiguió. Sin embargo, consideramos, que no desafiaron a todos los actores y esta vez, a diferencia de invasiones anteriores, actuaron políticamente guiados por miembros del para-estado.
} 
Como habíamos anotado anteriormente, el Privilegio fue la última invasión de esta cuarta oleada, la cual ocupó en el año 2007, 1.5 hectáreas de terrenos correspondientes a la reserva natural de Sierra Chiquita, sobre la vía que conduce al corregimiento de Guateque en el sur de Montería. El Privilegio y Villa Jiménez, aún (año 2011), no han sido incorporadas al perímetro urbano, pero todo parece indicar que seguirán su estado de evolución, a pesar del alto impacto ambiental que generan y de las fuertes inundaciones que padecen sus habitantes. El emplazamiento de ambos asentamientos se aprecia en la ilustración 165 que aparece en este mismo apartado, pero se interpreta mejor en el plano urbano de usos de suelo que se anexa a este capítulo.

En definitiva, esta última oleada de asentamientos informales del siglo XXI, al igual que las tres anteriores, permitió el surgimiento de fraccionamientos privados irregulares, de invasiones públicas y de barrios de promoción pública en todos los sectores de la ciudad. Además de las invasiones ya mencionadas se desarrollaron los últimos proyectos de viviendas públicas del INURBE y los nuevos programas de vivienda subsidiados por parte de la Caja de Compensación Familiar de Córdoba (COMFACOR), el Fondo Municipal de la Vivienda, el Fondo Nacional de Vivienda y el departamento de Córdoba. Los programas de vivienda terminada después del año 2000 fueron los Robles II y las Américas en el sur; los Colores y el Minuto de Dios en el Occidente, y Villa Sorrento, Villa Fátima, Santa Teresa, Villa Natalia, Nueva Belén y Nueva Jerusalén en el oriente de la ciudad. La calidad urbanística de éstos no fue la mejor y en los casos específicos de Nueva Belén y Nueva Jerusalén, su construcción se realizó detrás de Cantaclaro, con el objetivo de reubicar a 750 familias de las invasiones de Ranchos del INAT y Jerusalén.

Los barrios de promoción pública de Villa Sorrento, Villa Fátima y Santa Teresa en el oriente fueron posteriores a la invasión Villa Cielo y este último a su vez fue primero que el terminal de transporte, caso que resulta un poco paradójico, si tenemos en cuenta que generalmente en Montería las invasiones han ido a la zaga de los programas de vivienda pública o de las infraestructuras municipales. Igualmente sucedió lo mismo en el sur con los programas los Robles I y Robles II, Nueva Belén y 
Nueva Jerusalén, constituidos después de invasiones y fraccionamientos irregulares como Cantaclaro, Colina Real, Villa Paz, Nueva esperanza y Furatena (ambas situaciones se pueden apreciar en plano urbano anexo).

En cuanto a los fraccionamientos privados irregulares, y aunque ya los hemos mencionado, destacamos en esta última oleada de asentamientos informales a los Nogales, el Paraíso, Santa Isabel, Villa de los Alpes, Villa Rosario, Villa Mery, Altos de California, Villa Natalia, los Colores, Villa Nazaret, la Vid, Urbanización la Navarra, Urbanización el Portal I, el Portal II y los Ébanos. Es significativo anotar que la presión por la vivienda y la escasa disponibilidad de suelo en el perímetro urbano fue resuelta con desarrollos en el corregimiento de Garzones, al norte de Montería en zona cercana al aeropuerto, en donde la Caja de Compensación Familiar de Córdoba desarrolló dos programas de vivienda pública subsidiada. Estos programas, naturalmente, no figuran en el plano de la ciudad, pero se denominan los Cedros y Comfacor I, y en cada uno de ellos se construyeron 300 viviendas de $70 \mathrm{~m}^{2}$, en lotes de $7 \times 14$.

Podemos anotar que el crecimiento físico de la ciudad hasta el año 1999, estuvo caracterizado por la invasión de terrenos de dominio público, pero con las nuevas políticas de vivienda se abría un nuevo capítulo de crecimiento urbano, que no frenaría el surgimiento de nuevos asentamientos irregulares pero si controlaría los reiterados procesos de invasión colectiva. Las modalidades que reemplazaron a la invasión fue la de fraccionamientos privados y la adquisición de dichos lotes por la vía de subsidio familiar, situación que no cambió en nada el panorama de una ciudad informal, y por el contrario, consideramos más bien que se pasó de un modelo de invasión a un nuevo modelo de ocupación, el cual hemos denominado “Urbavillanización"304.

\footnotetext{
304 Es un oxímoron propuesto en esta investigación, que incorpora los términos de Urbanización y de Villa. Lo utilizamos para referirnos a los asentamientos con que la institucionalidad o la ilegalidad pretenden reemplazar a las invasiones de Montería. Las"urbavillanizaciones" son efectivamente urbanizaciones incompletas o irregulares con características similares a las de las últimas "villas miserias" de Argentina, o a las de cualquier otra invasión en Latinoamérica, tanto en sus aspectos físicos como socio-económicos. Sin embargo, elegimos el nombre de villa y no otro calificativo, precisamente porque así es como se han denominado muchos barrios en esta ciudad, e incluso algunos se denominan con los dos y de ahí nuestra idea de combinar estos dos conceptos incongruentes. Una evidencia de ello son los siguientes nombres: Villa Karime, Villa Caribe, Villa Sorrento, Villa Fátima, Villa Natalia, Villa Rocío, Villa Paz, Villa Real, Urbanizaciones Villa Mery, Villa Rosario, Villa Arleth, Villa Jiménez, Villa Cielo, los Araujos, Santa Isabel, los Alpes, Vista Hermosa, los Colores, la Navarra, el Portal de Navarra y Manuel Antonio Buelvas. Todos estos asentamientos, a pesar de estar registrados como urbanizaciones, son
} 
Si la invasión fue el modelo de crecimiento urbano adoptado entre 1950 y el año 2000, la "urbavillanización" sería el nuevo modelo acogido por la institucionalidad a partir del siglo XXI. Las condiciones jurídicas establecidas, asociadas a las condiciones socioeconómicas de la población, a los problemas presupuestarios y a la consolidación del modelo neoliberal, garantizarían condiciones formales relacionadas con el dominio de los predios pero incrementaría la urbanización marginal, la precariedad de la vivienda, y condenaría a Montería a la categoría de ciudad “subnorma" ${ }^{305}$. Una ciudad "subnorma" que reduce cada vez más el espacio de la vivienda y de las dotaciones públicas a sus mínimos posibles, facilitando el acceso de sectores vulnerables a lotes marginales o viviendas mínimas ${ }^{306}$, mediante subsidios que brinda el Estado a los inscritos en el registro único de ahorradores ${ }^{307}$. En este sentido, el espacio construido de la vivienda es disminuido a $36 \mathrm{~m}^{2}$, como sucedió con las viviendas de Nueva

programas de "desarrollo progresivo" surgidos a partir de fraccionamientos privados o de invasiones encubiertas por el Estado o para-estado.

${ }^{305}$ Conceptos como ciudad espontanea, informal, marginal, subnormal e irregular se vienen utilizando desde hace varias décadas para hacer referencia a la ciudad no planificada. Sin embargo, desde esta investigación, y por las características de Montería, consideramos más apropiado denominarla CIUDAD SUBNORMA. Nos parece más acertado este concepto, ya que no tenemos parámetros concretos para diferenciar con precisión, lo normal de lo subnormal, lo regular de lo irregular y lo formal de lo informal; pero si tenemos los instrumentos normativos para definir que una ciudad si se encuentra por debajo de las normas urbanísticas, y específicamente aquellas asociadas a estándares de vivienda, equipamientos, viario, espacio público y zonas verdes.

306 La Ley 3a de 1991 establece tres tipos de soluciones de vivienda: Unidad Básica por Desarrollo Progresivo; Unidad Básica, y Vivienda Mínima. La Primera es aquella efectuada en dos etapas, comprendiendo la primera etapa, la adquisición de un lote urbanizado y la segunda etapa, la ejecución de la unidad básica; La Unidad Básica es la solución que, además del lote urbanizado incluye una edificación conformada por un espacio múltiple y baño con sanitario, lavamanos y ducha, Mientras que la Vivienda Mínima es la solución que además de la unidad básica, incluye espacios independientes para alcobas y cocina. Esta misma ley establece como lote urbanizado aquel que cuenta con disponibilidad inmediata de servicios públicos domiciliarios acueducto, alcantarillado y energía. Sin embargo el Decreto 2620 en el año 2000 incorporó tres modalidades de subsidios: 1) Para vivienda Nueva 2) Construcción en sitio propio y 3) para mejoramiento de vivienda.

307 Los artículos 22 y 35 de la Ley 3a de 1991 establecen el ahorro programado y la inscripción ante el Registro Único de Ahorradores como condición obligada para los aspirantes que pretendan acceder a los subsidios de vivienda de interés social (VIS). Como ya se anotó anteriormente, la VIS se entiende a aquella que reúne los elementos mínimos de habitabilidad, tiene un precio máximo de 135 salarios mínimos mensuales vigentes SMLMV (\$US 30.000 - 38.000 año 2011). Sin embargo el decreto ley 2190 de 2009 incorpora el concepto de vivienda de interés social prioritario VIP, cuyo precio máximo disminuye a 70 SMMLV. En ambas leyes se establece que el subsidio máximo será del $90 \%$ de estos valores, pero con el previo ahorro del $10 \%$ complementario del aspirante. 
Jerusalén ${ }^{308}$, programa de vivienda pública éste, que entregó 240 viviendas subsidiadas en el año 2010. Igualmente en esta ciudad subnorma se reduce el espacio del lote a $66 \mathrm{~m}^{2}$ y se transgrede permanentemente la norma, sobre todo, cuando se siguen entregando lotes marginales en vez de los lotes urbanizados que establece la Ley 3a de 1991.

Es oportuno anotar que en esta ciudad "subnorma" del siglo XXI, aparece el Plan de Ordenamiento Territorial, el cual permite corregir deficiencias urbanísticas y definir nuevos patrones urbanos, e incluso, sirve como instrumento mercantil de algunos terratenientes, pero en ningún momento se convierte en ese elemento ordenador aprovechable para controlar invasiones o fraccionamientos irregulares. En este sentido, no podemos manifestar que las estimula, y tampoco podemos afirmar que las elimina, tal como lo demuestra el surgimiento de los asentamientos Furatena, Villa Paz, Nueva Esperanza, los Nogales, Villa de los Alpes, Vereda Tropical, los Colores, la Vid, el Níspero, los Ébanos, Altos de California, Santa Isabel, el Paraíso, las Acacias, Villa Mery, Villa Jiménez y el Privilegio; todos ellos surgidos por invasión, sin cumplir todas las normas urbanas o por emplazarse en áreas naturales incompatibles con usos residenciales.

Todos los anteriores asentamientos surgieron después del año 2002, fecha en que se aprobó, como ya se ha destacado en anterior apartado, el primer Plan de Ordenamiento Territorial de Montería, lo cual nos permite responder a uno de los interrogantes planteados en esta investigación y formulado de la siguiente manera: ¿Surgieron nuevas invasiones después de aprobado el plan? La respuesta concreta a este interrogante se relaciona directamente con el surgimiento de Furatena, Villa Paz y Nueva Esperanza, en el año 2002, Villa Jiménez en el 2003 y el Privilegio en el 2007. Sin embargo, también se debe destacar que este plan estimuló verdaderas urbanizaciones y promovió la edificación de vivienda en altura, aunque solamente fuera para familias de ingresos altos.

\footnotetext{
308 La Urbanización Nueva Jerusalén es un programa de vivienda pública, cuyo costo ascendió a $\$ 11.249 .266 .000 .000$, (\$US6.000.000), de los cuales \$9.107.700.00.000 fueron subsidiados por el Fondo Nacional de Proyectos FONADE y el municipio de Montería. El programa entregó 240 viviendas de 36 $\mathrm{m}^{2}$, las cuales fueron construidas en lotes de $66 \mathrm{~m}^{2}(11 \times 6)$. Más información sobre este proyecto en http://www.fonade.gov.co
} 
Sobre este último aspecto, consideramos que el plan en vez de ser un instrumento equilibrador, se convierte en elemento perturbador, e incluso, inequitativo, al permitir la construcción de multifamiliares de hasta 18 alturas en barrios residenciales como el Recreo y la Castellana, que fueron planeados para viviendas unifamiliares de una o dos alturas y que no cuentan con la infraestructura adecuada para soportar incrementos tan desproporcionados, en cuanto a población y aprovechamiento de suelo. Esta situación, ya comenzó a expulsar residentes de estos barrios hacia la periferia norte y a generar fenómenos de dispersión suburbana a través de suntuosas casas campestres o de conjuntos cerrados de viviendas exclusivas.

Sin embargo, el plan también ha permitido la apertura de urbanizaciones unifamiliares con gran calidad urbanística como es el caso del Limonar, Villa Sofía, Bonanza, Monteverde, Robles del Norte, el Mora, Altos de la Floresta y el Oriente, cuyas viviendas tienen precios que oscilan entre los $\$ 100.000 .000$ y $\$ 200.000 .000$ (\$US 50.000 y \$US 100.000 del 2011), cifras muy distantes del ingreso anual del ciudadano medio en esta ciudad, que para el mismo año establecemos en $\$ 9.000 .000$ (\$US 4.500). Igualmente está permitiendo la construcción de multifamiliares que promedian las seis altura en los barrios la Española, Castilla Real y Castilla la Nueva, todos ellos al lado de la Castellana.

Con este panorama, se cierra el ciclo de la cuarta oleada de asentamientos informales en una ciudad "subnorma", que con los cambios jurídicos, sociales y políticos, termina incorporando, directa o indirectamente, un modelo alternativo que, reiteramos, aquí hemos denominado "urbavillanización", que permite la entrada de multifamiliares para estratos altos pero no para sectores populares, quienes siguen dependiendo de un subsidio que cada vez los aleja más de la vivienda terminada para acercarlo a las ahora denominadas unidades básicas de desarrollo progresivo, que siguen los mismos procesos evolutivos de las infraviviendas de invasiones, pero con la ventaja de iniciar con el dominio legal del lote.

Finalmente, manifestamos que nos encontramos frente a una ciudad "subnorma", caracterizada por desequilibrios socio-espaciales y medioambientales asociados a la 
mala calidad de la vivienda, alcantarillas a cielo abierto, vías precarias y a la precariedad de equipamientos públicos. Una ciudad con un plano en el que a veces se confunde lo público con lo privado, lo residencial con lo comercial, lo natural con lo artificial, y en el que además sobresalen desequilibrios generados por incompatibilidad de usos y por el predominio de equipamientos privados excluyentes, que no logran integrar áreas marginales.

Un plano urbano donde además se observa el gran déficit de espacios público en áreas informales del suroriente, así como docenas de canchas rústicas de futbol que no reúnen características de equipamientos, ya sea, por la ausencia de arquitectura o de condiciones mínimas de funcionalidad. Un plano plagado de asentamientos informales que no surgieron alrededor de grandes infraestructuras, si no por el contrario, sobre ejes artificiales secundarios, dentro de los cuales sobresalen los canales de aguas residuales o pluviales y las carreteras corregimentales hacia Guateque, las Palomas, el Vidrial y el Sabanal. No obstante, tampoco se puede omitir la incidencia que sobre el crecimiento de la ciudad "subnorma" ha tenido un eje natural como el río Sinú y los ejes viales primarios hacia Medellín, Cartagena y Arboletes.

\subsubsection{Densidad Poblacional Local}

Como se anotaba en apartado anterior, el área urbana ocupa el 1.3\% de un territorio municipal amplio, que asciende a 312.000 hectáreas, pero que sin embargo concentra el $75.6 \%$ de la población. Esta concentración de la población en la ciudad aumentó la densidad en algunos barrios, especialmente en los asentamientos informales, en los cuales, se asientan a su vez, un poco más de 150.000 habitantes, correspondientes a unas 30.000 familias.

A pesar de la gran disponibilidad de suelos con que cuenta el municipio, la ciudad ha crecido compactamente y el perímetro urbano aún no supera las 4.900 hectáreas, cifra esta, muy inferior a las 12.000 de Cartagena, las 15.000 de Medellín o a las 31.000 hectáreas de Bogotá. Sin embargo, ante las perspectivas de crecimiento el plan de ordenamiento territorial había programado la expansión hacia el norte y occidente, 
pero inexplicablemente en los ajustes del mismo se propuso dicha expansión para el oriente, sin dejar claramente definidos los criterios de dicho cambio, y alimentando además, el escenario para interpretaciones suspicaces.

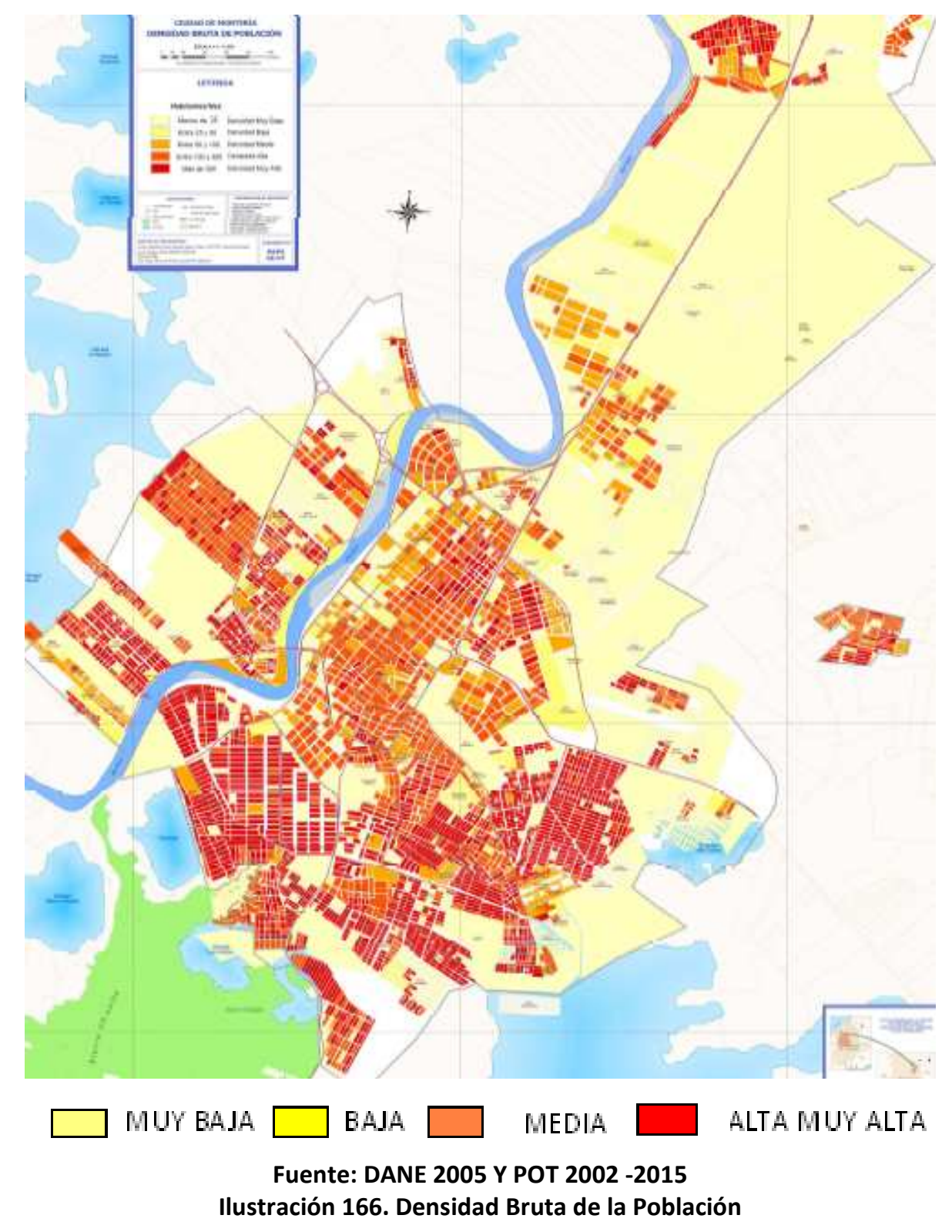

El crecimiento de esta ciudad agudizó los desequilibrios socio-espaciales que comenzaron a aparecer con las primeras invasiones o barrios incorrectamente planificados. Estos desequilibrios se manifiestan en las densidades asimétricas que presentan tanto barrios formales como informales, construidos durante los últimos veinte años en cada uno de los diferentes sectores de Montería. 
Las densidades altas y muy altas, correspondientes a rangos entre 100 y 200 habitantes/hectárea, se encuentran principalmente en las comunas tres, cuatro y uno; en los barrios Santafé, Policarpa, Pastrana Borrero, Brisas del Sinú, Cantaclaro, Robinsón Pitalúa, el Dorado y Rancho Grande. En cada una de esta comunas la densidad promedio es de 147,136 y 126 , respectivamente.

\begin{tabular}{|l|l|l|l|}
\hline \multicolumn{1}{|c|}{ COMUNA } & \multicolumn{1}{|c|}{ POBLACIÓN 2005 } & \multicolumn{1}{|c|}{ AREA (Has) } & \multicolumn{1}{|c|}{$\begin{array}{c}\text { DENSIDAD } \\
\text { (Hab/Has) }\end{array}$} \\
\hline Comuna 3 & 44588 & 302,75 & 147 \\
\hline Comuna 4 & 62700 & 461,42 & 136 \\
\hline Comuna 6 & 52720 & 419,94 & 126 \\
\hline Comuna 1 & 34073 & 397,05 & 86 \\
\hline Comuna 5 & 28843 & 374,80 & 77 \\
\hline Comuna 7 & 5060 & 100,78 & 51 \\
\hline Comuna 2 & 14082 & 279,52 & 50 \\
\hline Comuna 9 & 13676 & 361,97 & 38 \\
\hline Comuna 8 & 30833 & 1391,77 & 22 \\
\hline Promedio & & & 81 \\
\hline
\end{tabular}

Fuente: POT 2002-2015

Tabla 21. Densidad Poblacional por Comunas

En cambio las densidades más bajas, entre 10 y 50 habitantes por hectáreas, corresponden a asentamientos planificados como el Recreo, los Ángeles, la Castellana, la Floresta, El Mora y los barrios centrales de Chuchurubí, Montería Moderno, Nariño y la Ceiba, como consecuencia de procesos de gentrificación, así como del establecimiento de actividades comerciales, de servicios e incluso, industriales.

Concluimos entonces, que la densidad promedio de Montería, 81 habitantes por hectárea, se encuentra determinada por el predominio de vivienda unifamiliar de planta baja, que tuvo su origen, inicialmente en los procesos de autoconstrucción, luego en los programas de promoción pública de vivienda y posteriormente en las ocupaciones irregulares de terrenos con fines de alojamiento. Este promedio se encuentra muy distante de altas densidades como la de Sao Paulo en Brasil con 716 Habitantes/Hectárea o la de Bogotá con 427 Habitantes/Hectárea, y por debajo de la 
densidad de Valencia en España, la cual asciende a 150 Habitantes/Hectárea ${ }^{309}$. Sin embargo, destacamos que a nivel local también existen marcadas diferencias, las cuales se encuentran principalmente asociadas a factores socioeconómicos y de aprovechamiento del suelo ${ }^{310}$.

\subsubsection{Servicios Públicos Básicos. Instalación y Normalización.}

La constitución política de Colombia en su artículo 365 establece que los servicios públicos son inherentes a la finalidad del Estado y en su artículo 366 determina que será objetivo fundamental de éste, la solución de las necesidades insatisfechas de salud, educación, saneamiento ambiental y agua potable. En cambio, sobre los servicios públicos domiciliarios establece responsabilidades en cuanto a cobertura, calidad, financiación, control, inspección y vigilancia pero no define ni delimita dichos servicios. La delimitación de éstos le corresponde a la Ley 142 de 1994.

Esta Ley en su artículo 1, define que son servicios públicos domiciliarios los de acueducto, alcantarillado, aseo, energía eléctrica, distribución de gas combustible, telefonía fija pública básica conmutada y telefonía local móvil en el sector rural. Igualmente define a todos ellos como servicios públicos esenciales y traslada a los municipios la responsabilidad de garantizar la eficiente prestación, ya sea directamente por él o por particulares. Sin embargo, desde esta investigación consideramos que el transporte público colectivo también es un servicio esencial que debemos evaluar, específicamente en el escenario de informalidad urbanística de la ciudad de Montería.

\footnotetext{
309 Información obtenida en http://es.wikipedia.org/wiki/\%C3\%81rea metropolitana de Valencia. Consultada en Junio de 2011 y rectificada el 1 de marzo de 2012.
}

\footnotetext{
${ }^{310}$ Las familias de menores ingresos siguen siendo las más numerosas en esta ciudad y el mayor número de ellas se ubican en los asentamientos irregulares que mayor aprovechamiento obtienen del suelo; es decir, en aquellos que concentran gran cantidad de viviendas y que carecen de dotaciones públicas o de espacios para su construcción. Esta situación, sumada a los niveles de consolidación de los diferentes sectores, explican las grandes diferencias que registran las comunas de Montería, en cuanto a densidad de la población.
} 
Por su parte, en el plan de ordenamiento territorial de Montería 2002-2015, se definen los servicios públicos domiciliarios como aquellos bienes tangibles o intangibles suministrados a las personas, ya sea en sus viviendas o en su sitio de trabajo, para la satisfacción de sus necesidades básicas, que son prestados por el Estado o por particulares, a cambio de una tarifa pre-establecida, mediante redes físicas o humanas, con puntos terminales en donde habitan o laboran los usuarios; su regulación, control y vigilancia es competencia exclusiva del Estado.

La prestación de servicios públicos básicos en los asentamientos informales o la formalización de dichos servicios, para el caso de Montería, es un proceso que se logra después de varios años de constituido el asentamiento. La instalación de las redes básicas es una fase, generalmente posterior, a la constitución de cada asentamiento irregular, y la calidad de ellas se encuentra asociada a la superficie, densidad de la población, ubicación dentro del perímetro urbano, e incluso al peso político de sus líderes comunales y al caudal electoral del sector.

\subsubsection{Energía eléctrica}

Históricamente, la instalación de las redes eléctricas en este tipo de asentamientos ha estado ligada principalmente a programas nacionales, departamentales o municipales de electrificación. El ejemplo más reciente es el denominado Proyecto de Normalización Eléctrica (PRONE), por medio del cual se pretende la normalización del servicio de energía en barrios marginales del país. Dicho proyecto es coordinado por las administraciones departamentales, y en Montería ha permitido la legalización del servicio en los siguientes barrios: la Esperanza, Casita Nueva, los Nogales, Manuel Jiménez, Nueva Esperanza, Poblado, la Bonga, Villa Cielo, Villa Mery, Villa Arlet, Nueva Colombia, Villa Rosario y los Corales.

El servicio de energía es prestado por la empresa privada Electricaribe S.A. E.S.P., con una cobertura de 98\%, que incluye los asentamientos irregulares anteriormente mencionados y otros como la Vid, Villa Nazaret, los Ébanos, el Paraíso, las Acacias, Villa de los Alpes, Vereda Tropical, 2 de Septiembre, Furatena, Villa Paz, Villa Jiménez, el Campano, Villa Melisa, Manuel Jiménez, Playa Brígida. En estos últimos cuatro 
asentamientos aún se encuentran instalados medidores comunitarios y la tarifa a pagar colectivamente es dividida igualitariamente entre el total de las familias residentes, independientemente de su consumo individual, situación ésta, que genera tensiones cuando se presentan incrementos en el consumo de algunos hogares, a pesar de ser una medida concertada entre las dos partes y no ser impuesta por ley alguna.

Este servicio contaba hasta el año 2009 con 65.852 suscriptores, y como dato significativo destacamos que el mayor número de ellos se encuentra precisamente en el asentamiento informal de Cantaclaro, en donde la empresa Electricaribe S.A. E.S.P., reporta 4.561 suscriptores. Otros asentamientos informales con gran número de suscriptores son el Dorado, Edmundo López, 6 de Marzo y Camilo Torres, con 2.492; 1.682; 1.282, y 770 clientes, respectivamente (POT) $)^{311}$. El logro de esta gran cobertura en energía se debe a las políticas de concertación que ha realizado esta empresa con los usuarios irregulares y las facilidades de pago para la respectiva regularización, pero independientemente de dicha cobertura, debemos manifestar que la calidad del servicio no es la mejor, y las tarifas, a nuestro juicio, son demasiado altas para las sucesivas interrupciones que se presentan en el flujo de energía.

\subsubsection{Agua Potable y Saneamiento básico}

El abastecimiento de agua potable y saneamiento básico se convirtieron en un grave problema que terminó por desbordar la capacidad financiera del municipio y obligó a la actual administración a solicitar en el año 2008 recursos nacionales por el orden de cuatro millones de dólares, cifra esta, requerida para financiar la ampliación e instalación de nuevas redes en asentamientos formales e informales. Esta ampliación benefició a cerca de nueve mil familias de los barrios Brisas del Sinú, Santafé, Santander, Santa Lucía, Policarpa Salavarrieta, Pastrana Borrero, San Martín, Pablo Sexto, Alfonso López, los Araujos y Boston.

${ }^{311}$ Ajustes del Plan de Ordenamiento Territorial de Montería 2002-2015. Diagnostico. Tomo II. Pág.322. 
La cobertura, al igual que la calidad del agua potable en Montería, fue muy deficiente hasta los años noventa, época en el que el municipio entregó este servicio en concesión a la empresa privada, ante la incapacidad, o a lo mejor, involuntariedad administrativa que durante más de cincuenta años presentó la administración municipal. La cobertura hasta este periodo siempre estuvo por debajo del $70 \%$ de los hogares, y hubo asentamientos informales como Alfonso López, los Araujos, Santafé, Policarpa, San Martín, las Colinas y Brisas del Sinú, que permanecieron marginados de este servicio por más de treinta años.

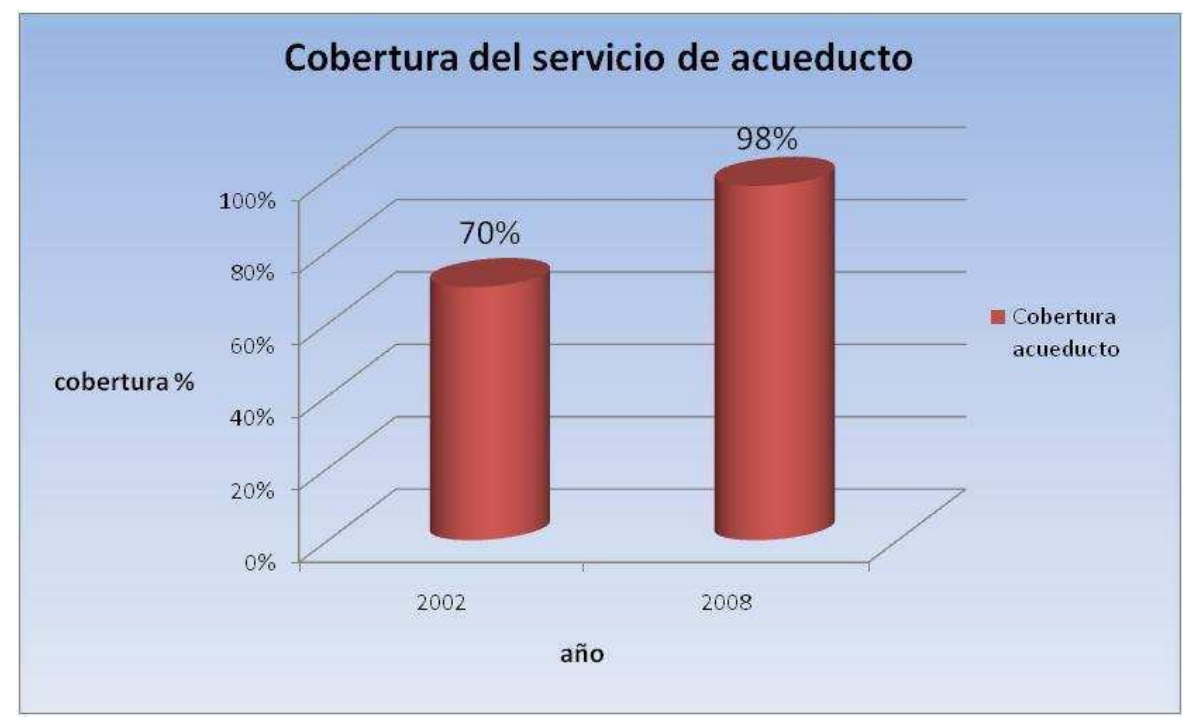

Fuente: Ajustes del POT 2002-2015

llustración 167. Evolución de la cobertura de acueducto

La expansión de las redes de agua potable hacia los barrios del sur comenzó en los años sesenta, específicamente en aquellos surgidos por procesos de autoconstrucción como el Prado, Boston, Santander, Risaralda, 14 de Julio, Urbina y Granada. Estas redes seguirían su extensión en las siguientes décadas con el surgimiento de los barrios 6 de Marzo, Edmundo López, Pablo VI, la Pradera, la Ribera, Panamá, Mogambo, Panzenú, Villa Margarita, Mogambito, $1^{\circ}$ de Mayo y Edmundo López II. Sin embargo, ninguno de ellos pudo disponer diariamente del líquido y la frecuencia de éste, sólo comenzó a mejorar con la llegada del siglo XXI. Es en este siglo cuando la cobertura logra ampliarse al $98 \%$ de los barrios de la ciudad, incluidos los últimos asentamientos irregulares de Villa Cielo, Villa Paz, Furatena y Nueva Esperanza. 
El número de usuarios de este servicio pasó de 49.325 en el año 2004 a 60.166 en el 2007 y para el 2011 el número de éstos se aproxima a 68.060. El incremento de la cobertura entre el 2004 y 2007 requirió una inversión equivalente a \$14.996.591.940 (\$US 8.000.000), mientras que para llegar a los 68.060 suscriptores se estimaron inversiones por $\$ 3.706 .500 .000$ (\$US 2.000.000) año $2008^{312}$. Entre estas inversiones se encuentran la instalación de 200 nuevos kilómetros de redes y el mejoramiento de las plantas de tratamiento de Sierra Chiquita Vieja, los Campanos, las Iguanas, Mocarí y Sierra Chiquita Nueva, que permite una capacidad de producción de 1.060 litros por segundo y la distribución a través de 500 kilómetros de redes.

Además de los asentamientos mencionados, también se logró instalar después del año 2004, las redes de agua potable en los barrios informales de Los Nogales, Paraíso, Villa de los Alpes, la Candelaria, Paz del Río, Villa Mery, Santa Rosa, Robinson Pitalúa, Santa Isabel, las Acacias, Villa Ana, Cantaclaro, Camilo Torres, 20 de Julio, la Vid, los Ébanos, los Araujos, Villa Nazaret, los Colores, el Níspero, 2 de Septiembre y Altos de California. En estos momentos solamente se encuentran marginadas de este servicio domiciliario las invasiones de Villa Jiménez, Ranchos del INAT, el Privilegio y el Cerro, las cuales cuentan con albercas comunitarias que permiten el abastecimiento de sus habitantes.

En cuanto al servicio de alcantarillado, destacamos la precaria cobertura en asentamientos informales, e incluso, sus deficientes redes en barrios considerados formales, y en algunos de promoción pública. Este es, a nuestro juicio, el mayor problema que ha presentado la ciudad durante más de cincuenta años, ya que supone problemas sanitarios y ambientales, específicamente para los barrios de la periferia que siguen marginados del servicio, a pesar de encontrarse consolidados, de haber sido regularizados, o de constituirse por medio de procesos de planificación y gestión pública.

\footnotetext{
${ }^{312}$ Datos suministrados por Proactiva Aguas de Montería S.A EPS, en el año 2008 y presentados en los ajustes del Plan de Ordenamiento Territorial 2002-2015. Diagnostico, Tomo II. Pág. 287.
} 
La operación del servicio de alcantarillado sanitario está a cargo también de la empresa Proactiva Aguas de Montería S.A. E.S.P. desde el año $2000^{313}$, y la cobertura en toda la ciudad asciende al 38\%, que corresponden a 22.908 usuarios en el año 2007. Esta cobertura es desequilibrada debido a que se concentra en el centro tradicional, en donde los colectores fueron instalados en la década de los años cincuenta. Igualmente se concentra en los barrios de altos ingresos del Recreo, la Castellana, Costa de Oro, Pasatiempo, La Julia y Urbina, cuyas redes fueron instaladas a partir de los años sesenta.

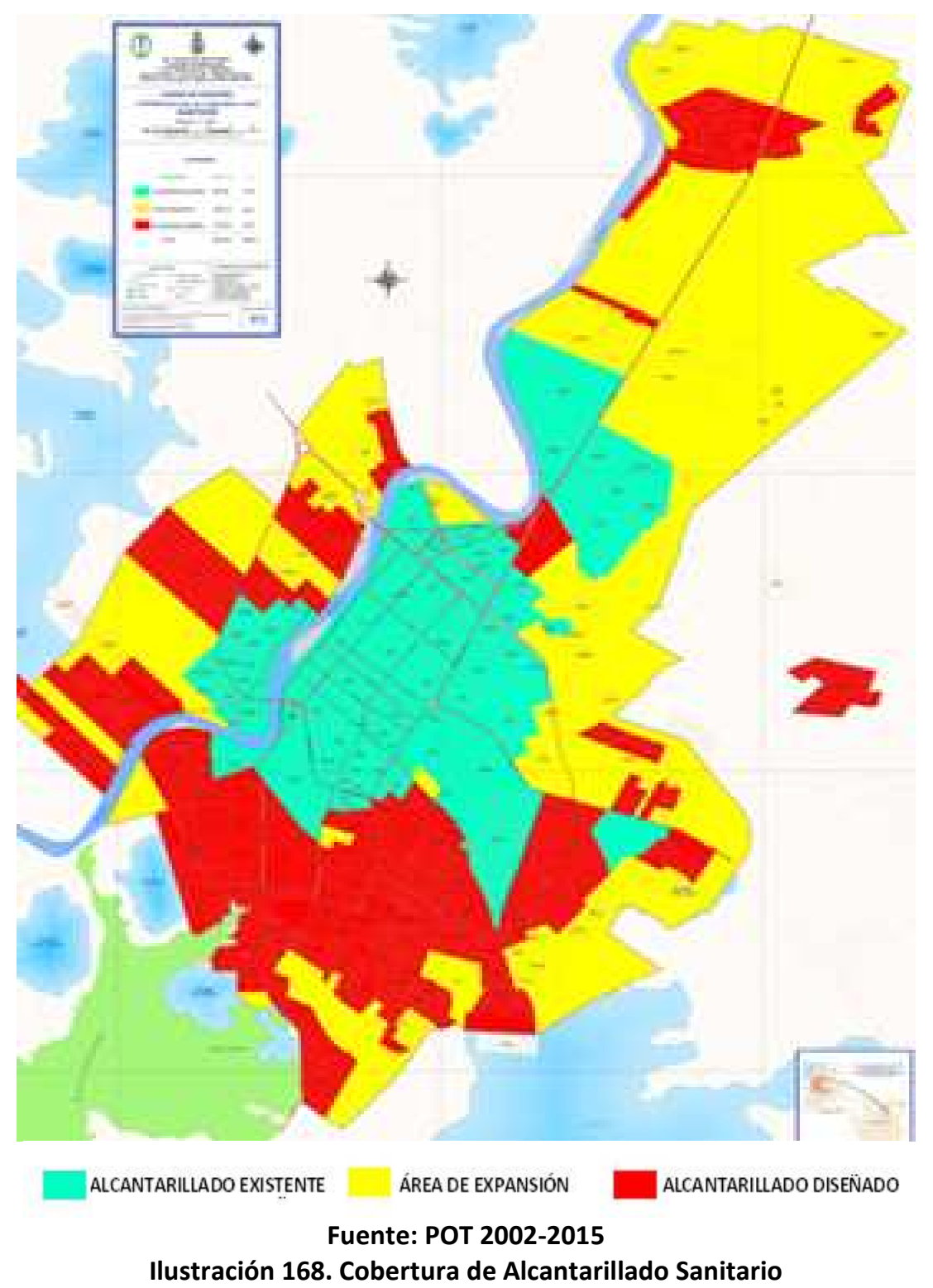

${ }^{313}$ La cobertura del alcantarillado sanitario para este año era de apenas del $25 \%$ y su operación se encontraba en manos de las empresas públicas municipales de Montería. Ajustes del POT 2002-2015. Diagnostico. Parte II, Pág. 297. 
En los ocho años transcurridos entre el 2000 y 2008, el aumento de la cobertura, permitió por fin la instalación de las redes en los barrios de promoción pública del P-5, la Granja, la Coquera, Simón Bolívar y Buenavista, desarrollados en la década de los años sesenta sin esta infraestructura. Sin embargo, en este momento aún no se cuentan con las acometidas domiciliarias, y sus habitantes siguen utilizando el pozo séptico que vienen utilizando desde hace cincuenta años, principalmente los residentes de los barrios P-5 y la Granja. Consideramos importante anotar que esta ampliación le costó al municipio \$9.707.708.000 (\$US 4.500.000), hasta el año 2008, y permitió aumentar el número de suscriptores de 16. 276 a $22.908^{314}$.

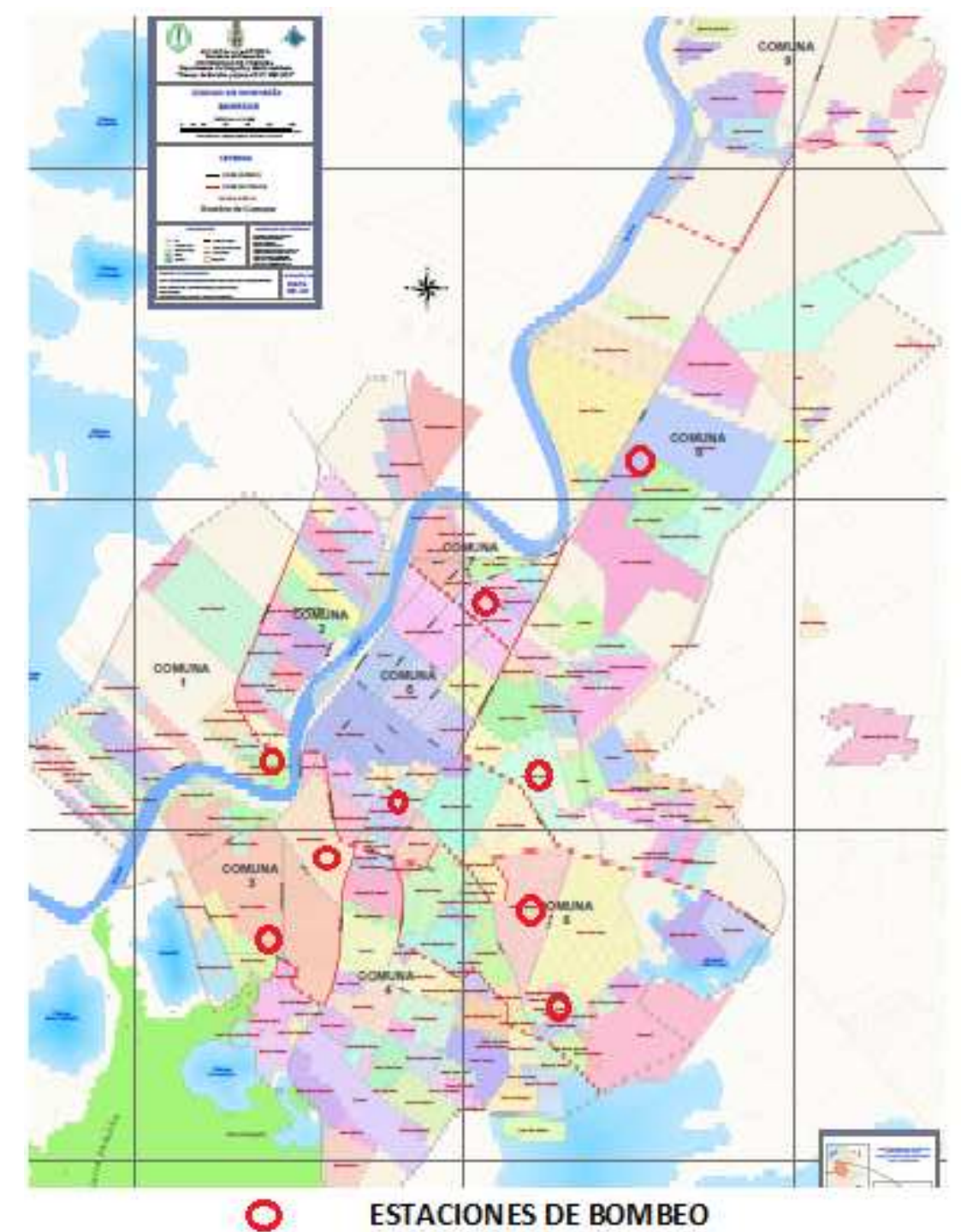

Fuente: elaboración propia con base en el POT 2002-2015 Ilustración 169. Estaciones de bombeo

314 Datos de Proactiva 2009. En Ajustes del Plan de ordenamiento Territorial de Montería 2002- 2015. Diagnostico Tomo II. Pág. 294. 
El sistema de alcantarillado sanitario cuenta con diez estaciones de bombeo de aguas residuales que se encuentran ubicadas en los barrios formales la Granja, Buenavista, la Pradera, San José, los Alcázares, la Ribera, la Julia, Laureles y el Laguito, con áreas de construcción promedio de $650 \mathrm{~m}^{2}$ y capacidad instalada que promedian los $150 \mathrm{~L} / \mathrm{S}$, pero desaprovechada en un $30 \%$. El tratamiento de las aguas residuales se lleva a cabo en tres lagunas de oxidación que se ubican en el nororiente, suroriente y occidente en zonas cercanas a los asentamientos informales de Ranchos del INAT y Villa Jiménez, sin cumplir las respectivas zonas de amortiguamiento de 500 metros que establece el Reglamento Técnico del Sector de Agua Potable y Saneamiento Básico, específicamente en el caso de Ranchos del INAT.

La baja cobertura no solamente se presenta en el alcantarillado sanitario, sino también en el alcantarillado pluvial, conformado principalmente por una red de canales superficiales que suman los 45 kilómetros de extensión. Estos canales son igualmente utilizados como colectores de aguas residuales y como vertederos de residuos sólidos, generando sedimentación, malos olores y proliferación de zancudos y ratas; principalmente en los asentamientos del sur y suroriente.

Los principales problemas por esta doble situación se evidencian en Cantaclaro, Urbanización los Araujos, Mogambito, Robinson Pitalúa, Colina Real, 6 de Marzo y Camilo Torres, 20 de Julio, Ranchos del INAT, Boston, las Américas, San Cristóbal, Villa Paz, Furatena, Alfonso López, el Poblado, el Dorado, San Martin, Santander, Policarpa, la Candelaria, Paz del Río, Santa Rosa, Vereda Tropical, el Paraíso, Edmundo López I, Edmundo López II, $1^{\circ}$ de Mayo, Villa Ana, Villa Mery, las Acacias, Villa Jiménez, el Alivio, Damasco, Santafé y Pablo VI. 


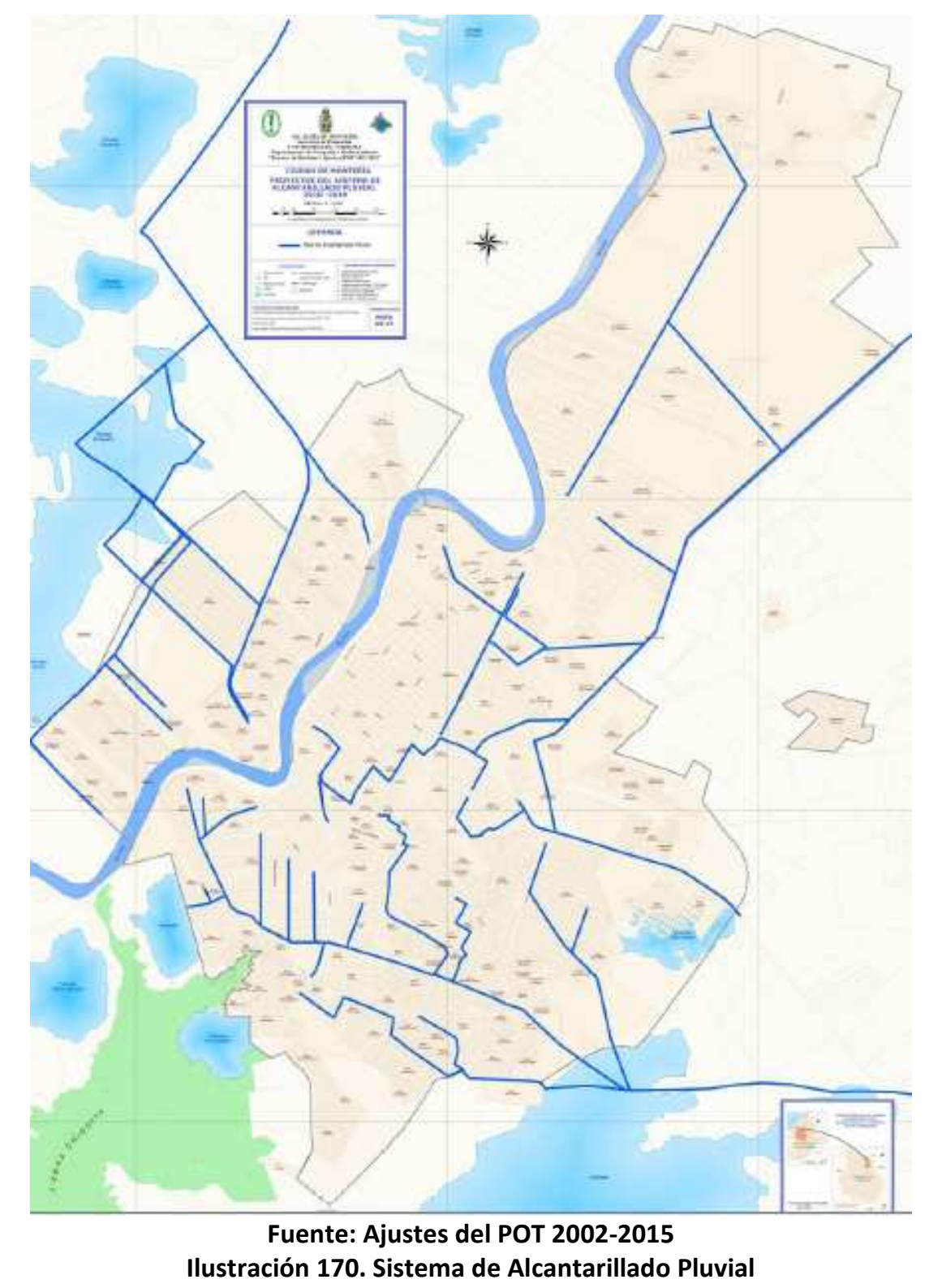

Los problemas por la triple utilización de canales pluviales también se presentan en los barrios de promoción pública de la Granja, P-5, Prado, Mogambo, Panzenú, Villa Margarita, los Robles I, Nueva Belén y Jerusalén. Igualmente, este fenómeno se manifiesta en menor proporción en barrios centrales como: Colon, Balboa, la Julia, Urbina, Chambacú, Pueblo Nuevo, los Álamos, el Edén, San José, Santa Clara, la Victoria, Ospina Pérez, el Coliseo y los Ángeles, este último, en el norte de la ciudad.

Los asentamientos informales de Alfonso López, los Araujos, la Campiña, Nueva Galilea, Pastrana Borrero, 2 de Septiembre, Villa Sinú, Paz del Norte, el Ceibal, los Nogales, Villa de los Alpes, la Vid, Vila Nazaret, los Colores, los Ébanos, Mi Ranchito, 
Rancho Grande, Nuevo Horizonte, Casita Nueva, Minuto de Dios, Manuel Jiménez, Villa Caribe y la Esperanza, no cuentan con sistemas de drenaje, y deben evacuar sus aguas residuales a través de cunetas artesanales, que generan impactos similares a los de los canales, principalmente el estancamiento de aguas lluvias o residuales, la proliferación de zancudos y permanentes emisiones de olores desagradables. Sobre canales, cunetas y lagunas de oxidación, ampliaremos en el apartado de impacto ecológico.

Finalizamos el análisis del servicio de alcantarillado, anotando que los barrios informales no tienen posibilidades de disfrutar del alcantarillado sanitario en el corto plazo debido a que recientemente la concesionaria Proactiva S.A. EPS, comenzó a proyectar la ampliación y a realizar el diseño de extensión de redes para el año 2013, el cual requiere de una inversión de $\$ 42.360 .000 .000$ (\$US 21.000.000), para aumentar de 22.908 usuarios a 41.300, correspondientes al $60 \%$ de los suscriptores proyectados $^{315}$. Sin embargo, estimamos que por la lentitud de las intervenciones requeridas para ello, este objetivo no se logrará en el tiempo indicado.

Igualmente, terminamos resaltando que el sistema de drenaje en la margen izquierda del Río es la principal alternativa para superar el problema de las inundaciones en este sector, y a nuestro juicio, debe ser la primera prioridad de esta concesionaria en la ciudad de Montería, principalmente por los grandes estragos socio-económicos causados por el fuerte invierno de los dos últimos años.

\subsubsection{Transporte Público Colectivo}

En lo concerniente al servicio de transporte públco de pasajeros, conviene destacar que, éste sigue siendo deficente en toda la ciudad, pero principalmente en el occidente y sur de la ciudad, como consecuencia de las precarias vías de comunicación y de la baja frecuencia en la salida de buses. Los barrios más afectados en el occidente son: Nueva esperanza, la Palma, Mi Ranchito, Rancho Grande, Urbanización Caracolí, Betancí, el Nispero, el Dorado, Villa Nazaret y los Colores.

${ }^{315}$ Ajustes del Plan de Ordenamiento Territorial de Montería 2002-2015. Diagnostico. Parte II, Pág. 295. 
En este mismo sector, existen barrios en donde el servicio de transporte formal sigue siendo inviable para las empresas pero no para los transportadores informales, los cuales logran satisfacer la gran demanda de la población. Dentro de los barrios con mayor demanda de transporte informal en el occidente, sobresalen: el Portal de Navarra, la Vid, el Portal, los Colores, Nazaret, Nueva Holanda y Manuel Jimenez.

Los barrios del sur tambien padecen los problemas asociados a las bajas coberturas de transporte y los más afectados son: Santafé, Brisas del Sinú, Simón Bolivar, Nueva Esperanza, Furatena, Villa Paz, los Robles, Colina Real, Edmundo López, Candelaria, Paz del Río, Santa Rosa, Mogambito, el Paraiso, Bostón y 6 de Marzo. Igualmente se presentan dificultades con el transporte público en en el sur oriente y oriente de la ciudad, en los barrios de baja accesibilidad de los Nogales, Villa Mery, Nuevo Milenio, Caribe, Ranchos del Inat y Villa Cielo.

Con el fin de mejorar este servicio en sectores informales, la actual administración municipal incorporó un proyecto de transporte masivo, relacionado con la ampliación de cobertura y apertura de nuevas rutas, que pretenden favorecer a los habitantes de los barrios Furatena, Villa Paz, Nueva Esperanza, de Septiembre, Mocarí, Villa Cielo, el Laguito, Alfonso López, los Araujos, Rancho Grande, Mi Ranchito, la Palma, el Níspero, Villa Nazaret, los Ebanos, Camilo Torres, los Cedros, Comfacor. Mogambo, Colina Real, $1^{\circ}$ de Mayo, el Paraiso, San Cristobal, las Americas, Damasco, Mogambito, Nuevo Horizonte y Vereda Tropical. 


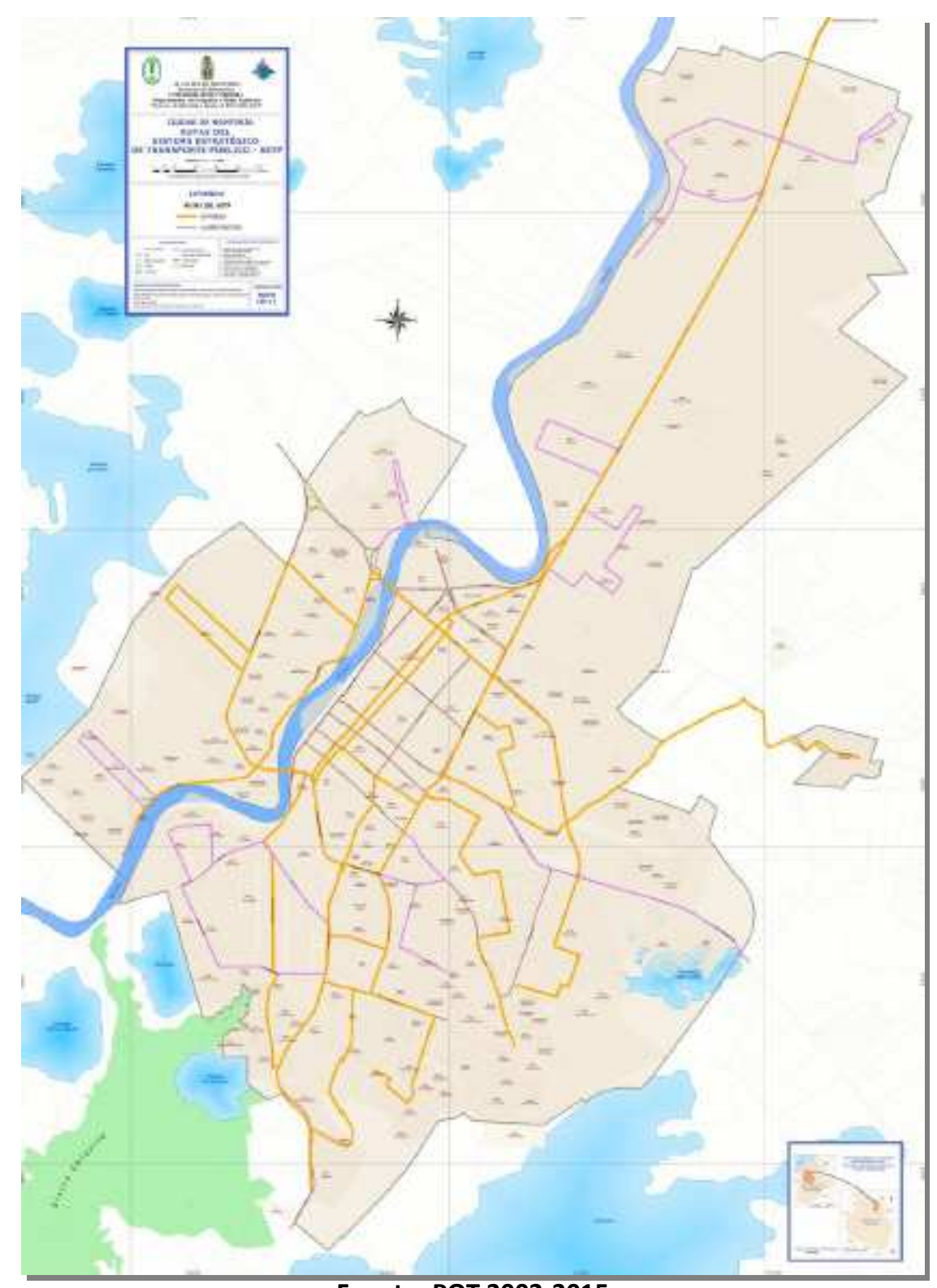

Fuente: POT 2002-2015

Ilustración 171. Rutas del Sistema Estrategico de Transporte Público Propuesto

No todas las rutas que aprecen propuestas en el plano anterior se encuetran operando en su totalidad, debido a la falta de adecuación de vías y ante los elevados costos que representan para las empresas de transporte de Metrosinú y Monteriana Móvil. Los barrios que aún no se benefician con el servicio de autobuses son: Villa Cielo, Ranchos del INAT, las Americas, el Pariso, Paz del Río, los Robles I, los Robles II, Vereda Tropical, los Nogales, Santa Isabel, las Acacias, las Americas, San Cristobal, Nueva belen, Nueva Jerusalen, Villa Jimenez, Villa Caribe, 7 de Mayo, Paz del Norte, Villa Sinú y Altos de California, los cuales siguen dependiendo principalmente del transporte informal colectivo o del mototaxismo. 
Consideramos desde aquí, que aun no existe el escenario adecuado para implementar un sistema de transporte masivo eficiente, principalmente porque no se ha cumplido con el plan vial que dicho sistema requiere, y porque además, los usuarios del transporte colectivo siguen utilizando masivamente el transporte informal de la mototaxi, con la mirada complaciente de las autoridades municipales, incapaces de garantizar un transporte público económico y eficiente para toda la población.

\subsubsection{Gas Natural Domiciliario}

La prestación de este servicio en Montería se inicia en el año 1996, dos años después de la aprobación de la ley 142 de 1994 sobre servicios públicos domiciliarios y de que el gobierno nacional lo incluyera dentro de la politica de ampliación de cobertura de servicios básicos. La distribución domiciliaria desplazó el uso de cilindros (pipetas) de gas propano que las familias venian realizando desde la década de los años sesenta, cuando decidieron reemplazar el fogon de leña por estufas que funcionaban por medio de los combustibles mencionados.

\begin{tabular}{|c|c|}
\hline Estrato & Usuarios \\
\hline $\mathbf{1}$ & 27.468 \\
\hline $\mathbf{2}$ & 16.581 \\
\hline $\mathbf{3}$ & 7.273 \\
\hline $\mathbf{4}$ & 2.635 \\
\hline $\mathbf{5}$ & 1.655 \\
\hline $\mathbf{6}$ & 922 \\
\hline Total Residencial & $\mathbf{5 6 . 5 3 4}$ \\
\hline Comercial & 621 \\
\hline Industrial & 54 \\
\hline TOTAL & $\mathbf{5 7 . 2 0 9}$ \\
\hline
\end{tabular}

Fuente: Surtigas S.A. E.S.P. 2009

Tabla 22. Usuarios del Servicio de Gas Natural 
Este servicio es prestado por la empresa privada Surtigas S.A. E.S.P., que brinda una cobertura de $79.7 \%$, con costos mensuales inferiores a \$US 5 para las familias de los estratos 1 y 2, situación esta, que facilitó la demanda en sectores irregulares con periodos inferiores a diez años de constituidos, tales como los Nogales, Villa de los Alpes, el Paraiso, los Robles I y los Robles II. Como se aprecia en el cuadro, son más de cuarenta y cuatro mil famlias de los estratos socieconómicos 1 y 2 , las que se benefician con el servicio de gas natural, principalmente residentes en asemtamientos informales semiconsolidados y consolidados.

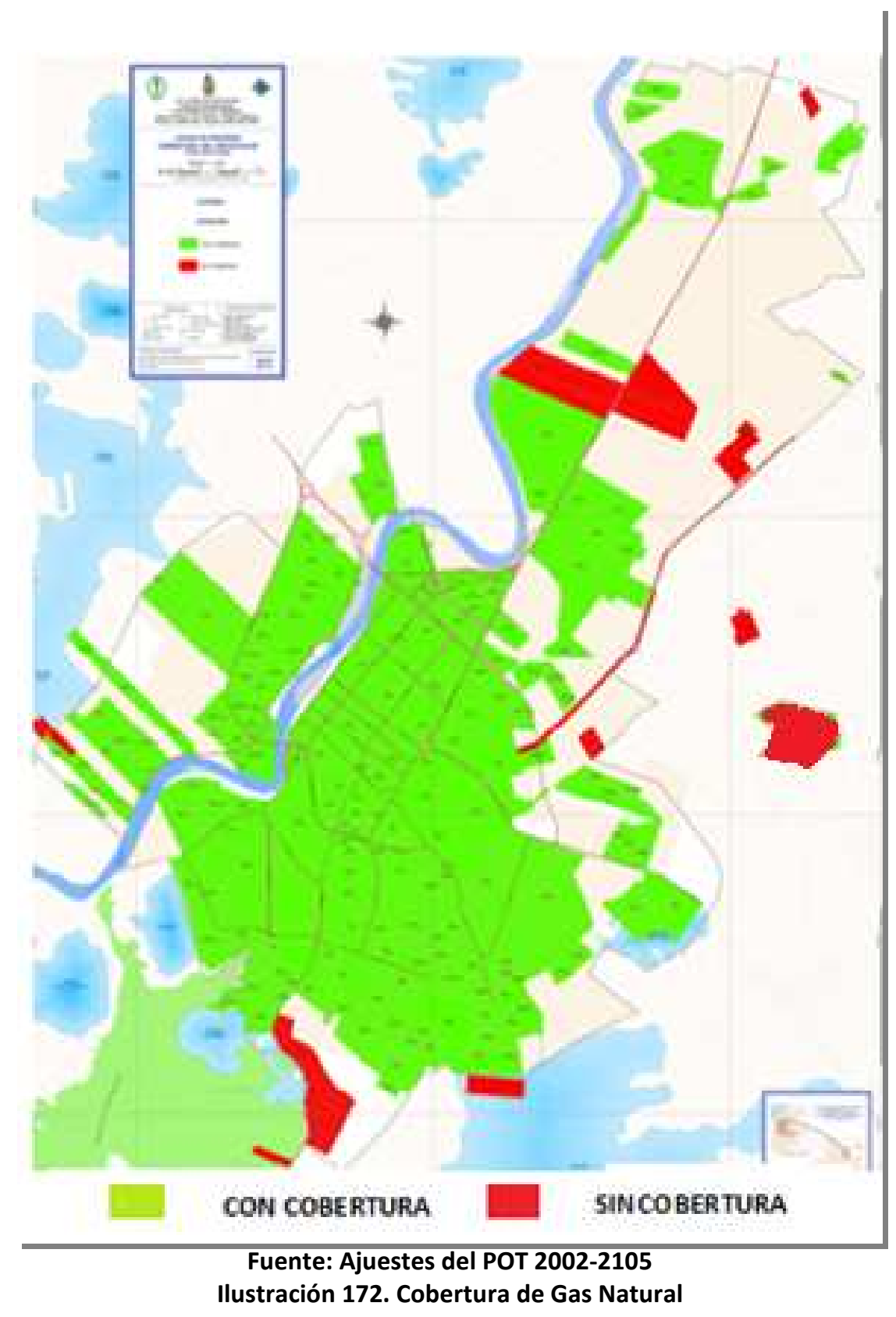


Los sectores informales que hasta el 2010 no cuentan con el servicio domiciliario de gas natural son: Villa Jimenez, el Privilegio, las Colinas, Ranchos del Inat, Palma Verde, Paz del Norte, Dulce Hogar, Urbanización Sevilla, Villa Norte, Cantabria, Urbanización Santa Barbara, Vereda Tropical, Furatena, Villa Paz y Nueva Esperanza. No obstante, en algunos de estos sectores ya comenzaron a instalarse las redes correspondientes que permitirán el acceso de sus habitantes a dicho servicio a partir del año 2011, y no se percibe inconveniente alguno para que esta empresa logre en el corto plazo la cobertura total dentro del perimetro urbano de esta ciudad.

Las zonas con mayor dificultad de integración a este servicio domiciliario en estos momentos son: el Privilegio en el sur; la Vid y Nazaret en el occidente; Palma Verde, Urbanización Cantabria, Bosques de Sevilla, Villa Norte, Dulce Hogar y Urbanización Sevilla en el norte, y Villa Cielo, Villa Jiménez y la Victoria en el oriente de la ciudad. Las menores posibilidades de integración a este servicio la tienen Villa Jiménez, el Privilegio y Ranchos del INAT, por encontrarse ubicados en zonas de reserva natural y/o viario programado, y además, por sus condiciones inciertas de legalización, esencialmente Ranchos del INAT, programada para reubicación desde hace nueve años.

\subsubsection{Servicio de Aseo}

Este servicio es prestado por la empresa privada Servigenerales S.A. ESP, encargada de realizar el limpieza de vias y áreas públicas, recolección y transporte y la disposición final de residuos. La recolección se realiza utilizando el servicio puerta a puerta y comprende todos los residuos solidos generados en zonas residenciales, comerciales, industriales, institucionales, oficiales, plazas de mercado, eventos especiales, así como los escombros clandestinos no mayores de un metro cúbico, residuos de gran tamaño y animales muertos.

La frecuencia de recolección es de tres veces por semana, incluidos algunos asentamientos informales que aun se encuetran en situaciones de precariedad urbanística como Furatena, Villa Paz, Nueva Esperanza, los Nogales, el Paraiso, Vereda Tropical, Santa Isabel, $1^{\circ}$ de Mayo, los Alpes, la Vid, el Ébano, los Colores, Casita Nueva, 
Villa Nazareth, la Turbina, el Poblado, Villa Sinú, Paz del Norte, 7 de Mayo, el Ceibal, las Colinas, los Araujos, San Cristobal, Villa Jiménez y Damasco. Incluso, en varios de ellos ya se realiza el barrido de calles una vez por semana.

En estos momentos la cobertura de este servicio se encuentra cercana al $100 \%$ en la zona urbana y es evidente que, por cuestiones de salud pública y por compromisos concertados en la concesión, los residuos generados en los asentamientos irregulares son recolectados de manera periódica en las frecuencias establecidas a costos asequibles, que para el caso de dichos sectores no superan los \$US 5 mensuales. Sin embargo, gran número de los habitantes de estos asentamientos aún no están suficientemente concienciados con la responsabilidad social de preservar el entorno, y en la actualidad siguen arrojando basuras en lotes escampados o en canales de aguas residuales, generando descomposición de residuos orgánicos y malos olores.

\begin{tabular}{|c|c|c|c|c|}
\hline \multirow{2}{*}{ Estrato o categoría } & & & & \\
\hline & $\begin{array}{l}\text { Servicio estándar } \\
\text { (normal) }\end{array}$ & $\begin{array}{l}\text { servicio sin } \\
\text { recolección puerta } \\
\text { a puerta }\end{array}$ & $\begin{array}{c}\text { servicio } \\
\text { predios } \\
\text { desocupados }\end{array}$ & total \\
\hline 1 & 21.637 & 7.013 & 87 & 28.737 \\
\hline 2 & 11.322 & 2.229 & 49 & 13.600 \\
\hline 3 & 6.157 & 45 & 101 & 6.303 \\
\hline 4 & 2.193 & 24 & 58 & 2.275 \\
\hline 5 & 1.436 & 0 & 31 & 1.467 \\
\hline 6 & 837 & 0 & 25 & 862 \\
\hline Pequeño productor oficial $0-0,5$ & 2 & 0 & 0 & 2 \\
\hline Pequeño productor oficial 0,51 - 0,75 & 2 & 0 & 0 & 2 \\
\hline Pequeño productor oficial $0,76-1$ & 84 & 2 & 1 & 87 \\
\hline Pequeño productor privado $0-0,5$ & 800 & 17 & 31 & 848 \\
\hline Pequeño productor privado $0,51-0,75$ & 2.959 & 14 & 139 & 3.112 \\
\hline pequeño productor privado $0,76-1$ & 107 & 1 & 15 & 123 \\
\hline gran productor oficial & 107 & 0 & 1 & 108 \\
\hline gran productor privado & 952 & 0 & 45 & 997 \\
\hline TOTAL & 48.595 & 9.345 & 583 & $\mathbf{5 8 . 5 2 3}$ \\
\hline
\end{tabular}

Fuente: Servigenerales y POT 2002-2015

Tabla 23. Usuarios del Servicio de Aseo 
En la ciudad no existe la cultura del reciclaje ni de los contenedores, razón por la cual los residuos sólidos no son separados ni en la fuente ni en el sitio de disposición final. Además de esto, las basuras empacadas por familias o empresas en bolsas plásticas y situadas en los frentes de las viviendas o locales comerciales, frecuentemente son destrozadas por indigentes antes de ser recolectadas por los vehículos compactadores, quedando al descubierto algunas veces la presencia de residuos domesticos peligrosos como baterías, embases de desinfectantes, insecticidas y disolventes. Igualmente quedan a la intemeperie por indeterminadas horas restos de papel higienico, toallas sanitarias y residuos organicos o alimenticios.

Corroboramos desde esta investigación que a pesar de la ampliación de la cobertura del servicio de recolección de residuos, las condiciones higiénicas de los asentamientos la Vid, Paz del Río, el Enjambre, Candelaria, el Privilegio, Villa Jiménez, Villa Rocío, el Bongo, Mi Ranchito, la Palma, Nazareth, Edmundo López II, Mogambito, Colina Real, los Araujos, Alfonso López, Villa Paz, Furatena, Nueva Esperanza, Nueva Galilea, $1^{\circ}$ de Mayo, el Paraiso, Villa de los Alpes, Colina Real, Casita Nueva, los Colores, 7 de Mayo, Nuevo Milenio y Ranchos dei INAT, siguen siendo desfavorables, especialmente en lo relacionado a desaseo de calles, canales o acumulación de basuras en áreas libres o lotes escampados. Sobre estos últimos aspectos y volúmenes de producción de residuos, ampliaremos en el apartado de impacto ecológico.

\subsubsection{Servicio de Telefonía Fija}

La demanda por el servicio de telefonía fija en Montería se vio disminuida por la dinámica presentada por la telefonía móvil en los últimos diez años y por el ingreso de empresas multinacionales a la oferta de dicho servicio. Los datos suministrados por el Sistema Único de Información (SUI) ${ }^{316}$, indican que en la ciudad de Montería se encontraban instaladas en el año 2008, 52.898 líneas telefonicas fijas, entre comerciales, industriales, institucionales y residenciales, con una cobertura urbana del 57\%. La empresa con mayor número de suscriptores es Telefónica-Telecom, con un

${ }^{316}$ Ibíd. Pág. 326. 
total de 35.278 clientes, correspondientes al $66 \%$ del mercado, segudo por Telmex y Edatel que se reaparten el restante $34 \%$ de clientes.

Sin embargo, destacamos que esta cobertura excluye asentamientos informales precarios y semiconsolidados menores de diez años, que surgieron paralelamente con el auge de la telefonía celular y en los que las comunicaciones se realizan principalmente por medio de los ya mencionados Café Internet o Servicios de Atención Inmediata (SAI). Dentro de estos asentamientos destacamos los Nogales, el Paraiso, Villa de los Alpes, las Acacias, Villa Cielo, Furatena, Villa Paz, Nueva Esperanza, Vereda Tropical, Colina Real, Santa Isabel, Villa Ana y Villa Mery, Altos de California, Villa Jimenez y el Privilegio.

Hay otros asentamientos que a pesar de tener más de diez años tampoco lograron insertarse ampliamente a la telefonía fija, principalmente aquellos surgidos por invasión como Robinson Pitalúa, la Candelaria, Paz del Rio, Santa Rosa, los Araujos, 25 de Agosto, Alfonso López, Cantaclaro, Camilo Torres, 20 de Julio, 7 de Mayo, las Colinas, 2 de Septiembre, Mogambito, Edmundo López, las Americas y San Crsitóbal. En cambio, lograron acceder a este servicio, en la década de los noventa, los habitantes de los asentamientos consolidados de Santafé, Policarpa, San Martín, Pastrana Borrero, Santander, Santa Lucía, Boston, Galilea, el Prado, Rancho Grande y el Dorado.

Por último, conviene precisar que durante más de cincuenta años este servicio sólo estuvo al alcance de familias de altos ingresos de la ciudad, y los elevados costos de comunicación marginaron de esa posibilidad a los habitantes de sectores populares. Incluso, ninguno de los primeros barrios de promoción pública de la década de los años sesenta fue dotado inicialmente con estas redes, y solamente tuvieron acceso a ellas veinte años después, cuando la empresa colombiana de telecomunicaciones TELECOM, inició el proceso de ampliación de cobertura en el país. No obstante, un número reducido de familias de la Pradera, el P-5, la Ribera, Buenavista y la Granja 
lograron acceder a lineas finalizando la decada de los setenta, básicamente con intenciones mercantiles 317 .

\subsubsection{Algunas consideraciones sobre la calidad de los servicios públicos}

Sobre la calidad de los servicios públicos básicos, consideramos que, a pesar del aumento de coberturas y ampliación de redes de infraestructuras, aún persisten asentamientos informales semiconsolidados, e incluso, consolidados con significativas deficiencias en aspectos relacionados con el transporte público colectivo, alcantarillado, acueducto y aseo y recolección de residuos sólidos. Dentro de los asentamientos que presentan mayores carencias se encuentran: el Poblado, Manuel Jimenez, Villa Jimenez, el Privilegio, el Portal los Colores, Ranchos del Inat, el Níspero, el Ébano, Villa Nazaret, Mi Ranchito, la Vid, Villa de los Alpes, los Robles I y los Robles II.

Así mismo, hace falta mejoramiento en la prestación de servicios públcos en algunos barrios informales consolidados como: Santafé, Brisas del Sinú, Policarpa Salavarrieta y Santander. Estos barrios, a pesar de contar con servicios básicos como el agua y la energía electrica, requieren de instalación del sistema de alcantarillado sanitario, de la ampliación de redes, mantenimiento de las mismas, mejor cobertura en el aseo de calles y mejoramiento de la frecuencia del transporte público colectivo.

Otros asentamientos que presentan requerimientos similares : Furatena, Villa Paz, Candelaria, Nueva Esperanza, Santa Rosa, Edmundo Lopez, los Nogales, Mogambito, San Cristobal, las Americas, el Paraiso, Villa Mery, Paz del Río, Colina Real, 2 de Septiembre, Alfonso López, los Araujos, Camilo Torres, 7 de Mayo, Villa Sorrento, Cantaclaro y la Vid, en los cuales se evidencia además, gran peligro en las redes de energía, desaseo de las calles, la falta de equipamientos comunitarios y la Invasión del

\footnotetext{
317 Las familias que accedieron a líneas telefónicas en este periodo fueron básicamente las propietarias de tiendas, almacenes o farmacias. En estos negocios, los propietarios, aprovechándose de la inexistencia de teléfonos públicos, adaptaban monederos a sus teléfonos privados o cobraban tarifas por minuto a los vecinos que requerían comunicarse con personas de empresas o instituciones.
} 
espacio públco o zonas verdes. La mayoría de estos asentamientos se encuentran ubicados en las comunas tres y cuatro del sur de la ciudad.

Igualmente, los barrios de la comuna seis presentan deficiencias asociadas a la precariedad de sus vías, falta de equipamientos, dependencia de transporte público informal, carencia de alumbrado público, ausencia de alcantarillado, mal estado de las redes de energía y deterioro del espacio público. Las principales carencias se encuentran en los barrios Villa Cielo, Nueva Colombia, los Corales, Villa Mery, Villa Rosario, Villa Arlet, Villa Jimenez y Villa de los Alpes. En esta comuna se ubica el barrio de promoción pública la Pradera, afectado por el crecimiento del sector oriental de la ciudad.

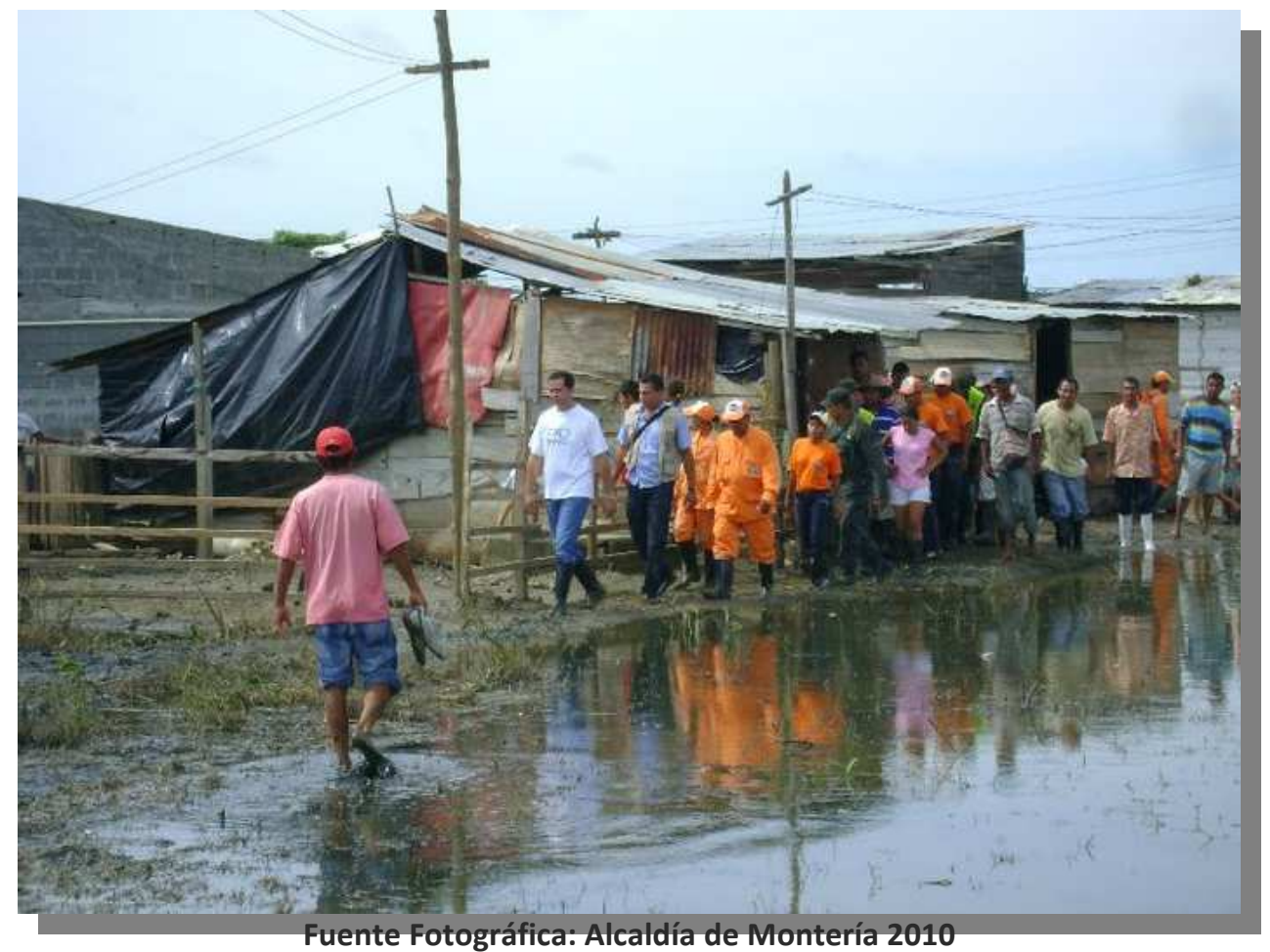

Ilustración 173. Frágil cobertura de energía electrica y drenaje precario en Villa Jiménez

Terminamos manifestando además, que se pudo corroborar mediante la observación y la experimentación que los problemas urbanísticos originados por el crecimiento informal desbordado, y asociados a la falta de instalacón de infraestructuras, inexistencia de adecuadas vías de comunicación, y baja cobertura de transporte público colectivo, son resueltos de manera transitoria, especialmente, aquellos relacionados con el fluido de energía electrica. Igualmente se corroboró la cobertura 
de servicios basicos en todas las comunas de la ciudad, pero no en el $100 \%$ de los asentamientos.

Por otro lado destacamos que la ampliación de la cobertura de servicos básicos no garantiza eficiente calidad ni la legalidad de dichos servicios, principalmente en esos asentamientos que no son viables desde el punto de vista ecologico ni urbanistico, tales como Ranchos del INAT, el Bongo, Nuevo Milenio, invasión Sucre, el privilegio y el Cerro, reflejando esta situación, altos niveles de ineficiencia administrativa e ingobernabilidad por parte de las autoridades municipales y de los organismos de control del Estado, que deben velar por la legalidad, calidad y seguridad de los ciudadanos, o por lo menos, disminuir el riesgo que generan las redes instaladas clandestinamente en estos asentamientos.

\subsubsection{Equipamientos Urbanos}

El plan de ordenamiento territorial de Montería clasifica los equipamientos en función de su área de influencia y establece las siguientes categorías: barrial, zonal, urbano y regional. En el equipamiento barrial se incluyen guarderías, escuelas, puestos de salud, tiendas de víveres, lavanderías, parques de barrio y lavanderías; en el zonal se encuentran los colegios de bachillerato, templos, lugares de culto, y parques con tres o más escenarios deportivos; en el urbano se incorporan los centros comerciales y los almacenes especializados, y la escala regional está conformada por las plazas de mercado, recintos feriales, hospitales, terminal de transporte y aeropuertos. Esta clasificación es reglamentada por el Decreto 0576 del año 2003.

De acuerdo a su funcionalidad los equipamientos en esta ciudad se dividen en: dotacionales, y, en comercio y servicios. Los primeros están constituidos por los colectivos, deportivos, parques y servicios básicos urbanos, mientras que en los segundos se incluyen todos aquellos asociados a servicios empresariales, servicios personales, servicios alimentarios, servicios profesionales, técnicos y especializados, ventas de combustible, diversión y esparcimiento, comunicación y entretenimiento masivo y servicios automotrices. Dentro de los equipamientos dotacionales colectivos sobresalen los educativos, culturales, de salud, bienestar social, deportivos, recreativos 
y de culto; mientras que en los servicios urbanos básicos, se destacan los de seguridad ciudadana, justicia, abastecimiento de alimentos, recintos feriales, servicios funerarios y servicios de administración pública.

En cuanto a equipamientos educativos, la ciudad cuenta con 267 establecimientos enseñanza, de los cuales 195 se encuentran en el área urbana, incluidas 61 instituciones privadas. Sin embargo se presentan desequilibrios causados por la concentración de 42 escuelas en las comunas 3,4 y 6, a expensas de un déficit en las comunas 1 , 2 y 9 , en donde la cantidad de equipamientos, no logra cubrir el área total de dichas comunas. Los colegios de bachillerato ubicados en asentamientos informales son: Villa Cielo, Villa Margarita, Camilo Torres, el Dorado, Mercedes Abrego, Policarpa Salavarrieta, Rancho Grande, Robinson Pitalúa, Victoria Manzur, Guillermo Valencia y Manuel Ruiz Álvarez.

También existen importantes colegios de bachillerato en asentamientos consolidados y barrios de promoción pública, los cuales presentan mejores instalaciones y dotaciones de equipos. Dentro de éstos, se destacan las instituciones educativas La Pradera, Antonio Nariño, Cristóbal Colon, Cecilia de Lleras, Antonia Santos, Antonio Nariño, Lorenzo María Lleras, la Inmaculada, Isabel la Católica, José María Córdoba, General Santander, Normal Superior y Santa María Goretti. Igualmente se encuentran equipamientos educativos privados como la Salle, Gimnasio Vallegrande, Gimnasio el Recreo, Colegio Británico, Mogambo, Juan Pablo II, Almirante Colon, la Sagrada Familia y COMFACOR.

\begin{tabular}{|cc|}
\hline $\mathbf{N}^{\circ}$ COMUNA & $\mathbf{N}^{\circ}$ de EQUIPAMIENTOS \\
\hline $\mathbf{1}$ & 5 \\
\hline 2 & 4 \\
3 & 15 \\
\hline 4 & 17 \\
\hline 5 & 7 \\
\hline 6 & 10 \\
\hline 7 & 2 \\
\hline 8 & 5 \\
9 & 6 \\
\hline Fuente: POT 2002-2015 - Secretaría de Educación 2009 \\
Tabla 24 Distribución del Equipamiento Educativo
\end{tabular}


En lo referente a escuelas de primaria ubicadas en los asentamientos informales destacamos las del 2 de Septiembre, Alfonso López, el Alivio, Paz del Norte, Nuevo Bosque, el Poblado, el Ceibal, San Martín, Minuto de Dios, las Colinas, Santander, Miraflores, Robinson Pitalua, Horizonte, Santa María, 6 de Marzo, Prado, Gabriela Mistral, Francisco Miranda, Panzenú, Valle del Sinú, Laureano José Mestra Mora, la Esperanza y Villa los Alpes. Todas estas escuelas presentan edificaciones en una sola planta, su área construida no supera los 5.000 metros cuadrados, y además, evidencian bastante deterioro y falta de mantenimiento.

Sobre los equipamientos de salud, debemos anotar que aquellos de mayor jerarquía como el hospital San Jerónimo y las clínicas se encuentran ubicados principalmente en el centro y norte de la ciudad. En el centro se localizan las clínicas Central, Saludcoop, Traumas y Fracturas, Zaima y Coomeva, mientras que en el norte se localizan las clínicas Montería y Oncológica. Por su parte, los centros de atención médica de urgencias CAMU se distribuyen por diferentes sectores de la ciudad de la siguiente manera: el Amparo, en la comuna 1; la Granja en la 3; Cantaclaro en la 6, Sucre en la 7 y Camilo Torres en la 9. Finalmente, los denominados puestos de salud se ubican en los barrios Villa Margarita, Nuevo Horizonte, la Candelaria, Mogambo, Santafé, Brisas del Sinú, Rancho Grande, Seis de Marzo, el Dorado, Edmundo López y Simón Bolívar.

En el plano de equipamientos colectivos destacamos por su gran impacto la Universidad de Córdoba en el norte de la ciudad, el hospital San Jerónimo en el centro, el colegio nacional José María Córdova y la escuela la Salle en el oriente y el colegio Seminario Juan XXIII en el sur, cercano a la reserva natural de Sierra Chiquita y sobre la carretera que conduce al corregimiento de Guateque. Ninguno de ellos supera las dos alturas pero se encuentran emplazados en superficies superiores a 20.000 metros cuadrados, y en el caso especifico de la universidad de Córdoba, el terreno de emplazamiento sobrepasa los 50.000 metros cuadrados.

Si equipamientos colectivos como los mencionados tienen un gran impacto sobre el plano urbano, no podemos manifestar lo mismo sobre parques, plazas o áreas libres, debido a que la ciudad no cuenta con superficies significativas para estos usos, y básicamente se reducen a espacios inferiores a 10.000 metros cuadrados para el 
centro tradicional o barrios planificados, y menores a 5.000 en los asentamientos informales. Sobre este particular, corroboramos la inexistencia de estos equipamientos en la mayoría de asentamientos informales, e incluso en algunos barios de promoción pública de vivienda.

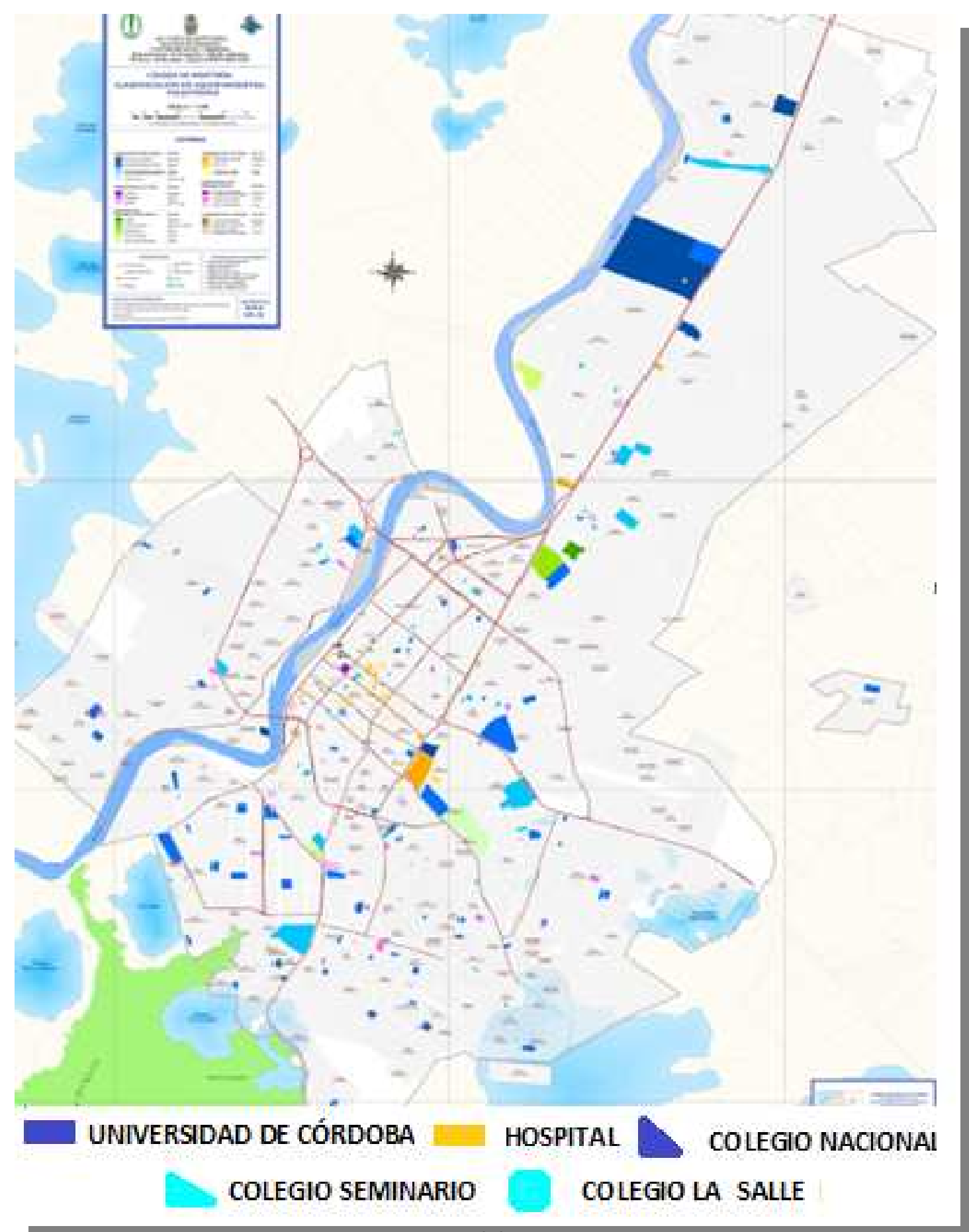


Por otra parte, algunos servicios urbanos básicos se concentran en el centro histórico, principalmente los de administración pública, generando esto, una gran dependencia del centro como principal centralidad. Entre las calles 24 y 30 con carreras 1 y 8 , se encuentran las cuatro notarías de la ciudad, la Registraduría, la Procuraduría, Contraloría, Palacio de Justicia, Alcaldía, Gobernación, Instituto Geográfico Agustín Codazzi (IGAC), Corporación de los Valles del Sinú y del San Jorge CVS, Diócesis de Montería y Curadurías Urbanas. En la calle 29 con 5 se encuentra el comando principal de la Policía Nacional y en el barrio Santafé se localiza la decimoprimera brigada del Ejército de Colombia.

De los equipamientos administrativos, un número reducido de ellos tienen sus sedes en edificaciones modernas, que fueron construidas después de la década de los años cincuenta, cuando la ciudad comenzó su vida administrativa como capital del departamento de Córdoba. Estos edificios superan las cinco alturas, destacándose por su volumen el de la Gobernación de Córdoba, Administración de Justicia Municipal, Lotería de Córdoba y el de la Corporación de los Valles del Sinú y del San Jorge CVS. Los demás equipamientos se encuentran ubicados en edificios modernos de dos o tres alturas o edificaciones antiguas de planta baja o de una altura como es el caso de la Alcaldía Municipal, el Comando de Policía el Instituto Geográfica Agustín Codazzi y la Curaduría Primera. Ninguna de esta últimas tiene un gran impacto sobre la morfología urbana ni se encuentran emplazados en terrenos superiores a los diez mil metros cuadrados.

En cambio, otros equipamientos como la decimoprimera brigada del Ejército Nacional de Colombia, el matadero municipal, el cementerio Jardines de la Esperanza, la plaza de mercado del sur, la estación de monitoreo ambiental de la C.V.S. y el terminal de transportes de Montería, tienen un impacto mayor sobre el plano urbano. Estos equipamientos se encuentran emplazados en terrenos superiores a 20.000 metros cuadrados y en el caso del batallón del ejército, su emplazamiento se encuentra cercano a la reserva natural de Sierra Chiquita, sirviendo de paso como barrera de contención al crecimiento urbano en el sector sur de esta ciudad. 


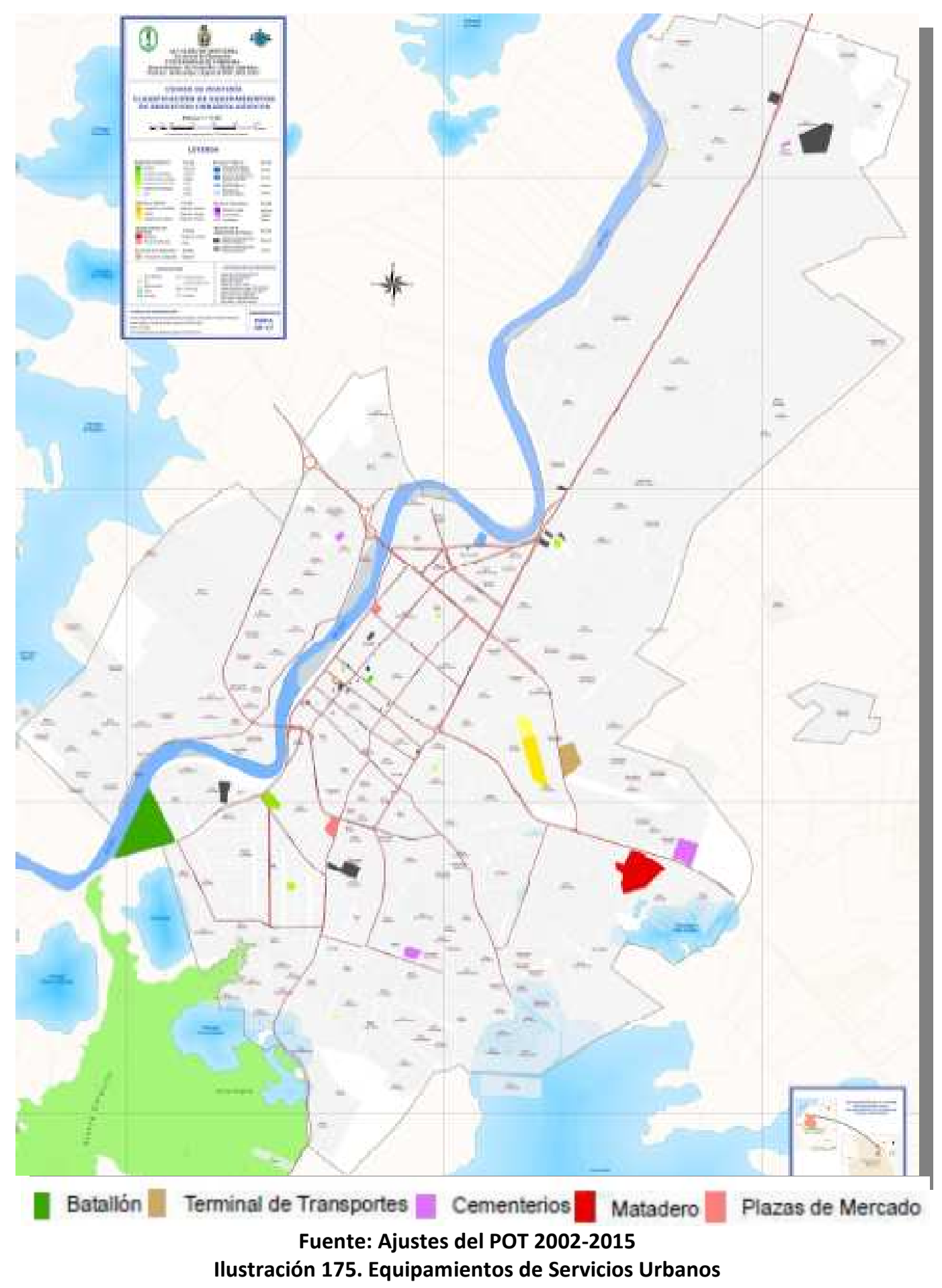

El terminal de transporte es otro de los equipamientos de mayor impacto sobre el plano urbano y se encuentra ubicado en el centro-oriente de la ciudad, en un área total de $40.000 \mathrm{~m}^{2}$ y una superficie construida de $9.782 \mathrm{~m}^{2}$ construidos, en el que sobresalen 92 locales comerciales, supermercado, estación de combustibles, y oficinas para 15 empresas de transporte intermunicipal e interdepartamental. Su construcción permitió el desarrollo de ese sector, la prolongación de la calle 41, el desarrollo de 
hoteles, las urbanizaciones de Villa Sorrento, Villa Fátima, Santa Teresa y el Oriente, así como la consolidación de la invasión 25 de Agosto.

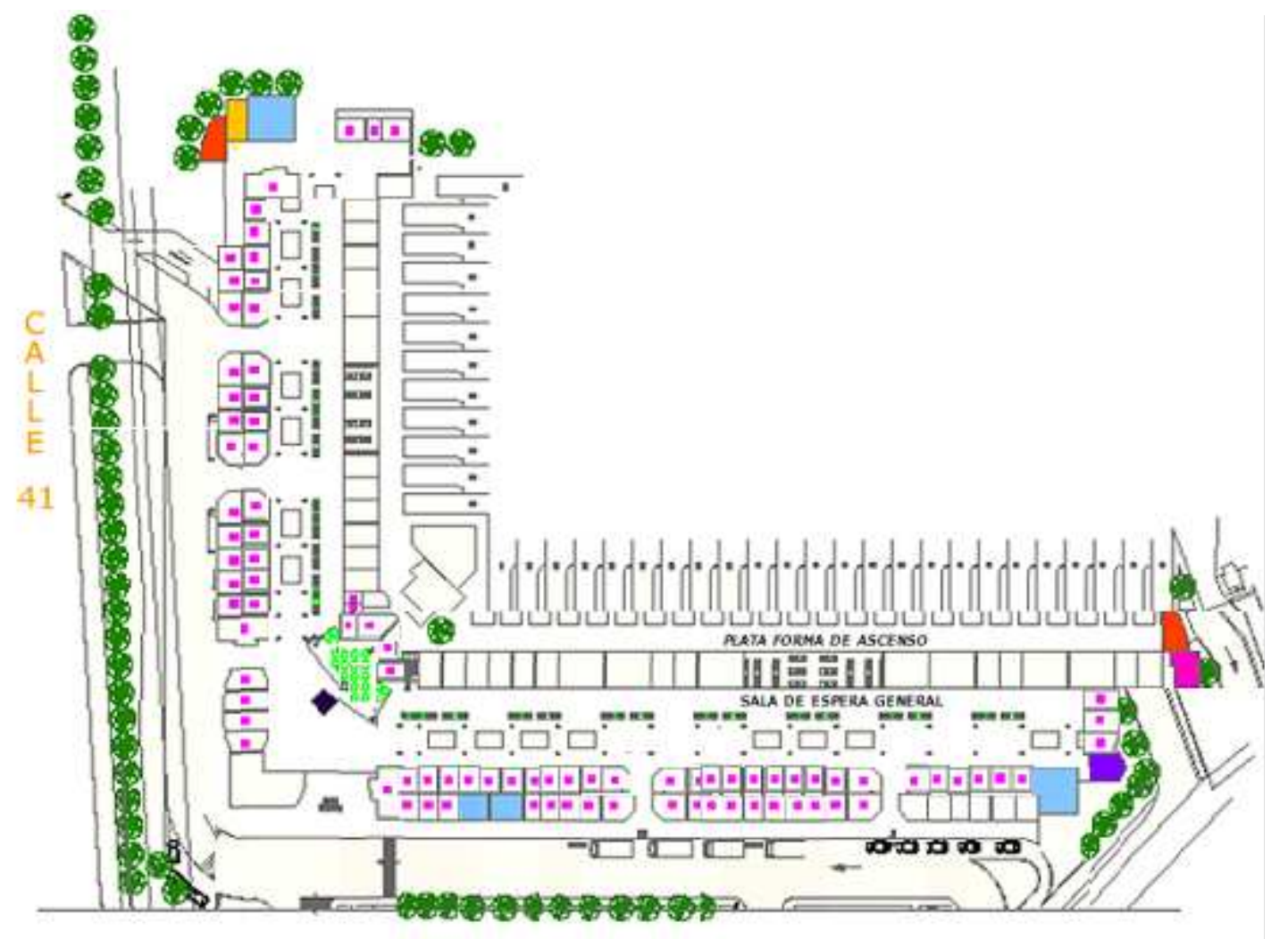

Fuente: www.termnaldetransportedemontería Ilustración 176. Terminal de Transporte

Además de este terminal de transporte inaugurado en mayo del año 2008, la ciudad cuenta además con un terminal aéreo desde el año 1972, los cuales permiten la comunicación organizada de pasajeros con otros municipios del departamento y con las principales ciudades del país. La construcción de estos dos equipamientos generó la apertura de nuevos establecimientos mercantiles, urbanizaciones privadas, barrios de promoción pública y asentamientos informales.

Desde el año 2002 se encuentra programada la construcción de la central de abastos, terminal intermunicipal, parque agroindustrial, los parques recreacionales de Sierra Chiquita, la Estancia, Berlín y Teherán, y el estadio de futbol. En estos momentos del año 2011 se inició la construcción del estadio de futbol cerca del kilometro seis de la vía a Planeta Rica, en un terreno diferente al programado en el plan de ordenamiento 
territorial 2002-2015, pero no hay nada concreto sobre el inicio de las demás equipamientos programados en el mencionado plan.

Como dato de preocupación, por lo menos desde la óptica de académico, destacamos que la ciudad no cuenta con equipamientos para el desarrollo de actividades culturales, principalmente, teatro, museo, biblioteca, ludoteca, escenario para grandes eventos, salas de cine alternativo o cinemateca. Igualmente, carece de instalaciones deportivas adecuadas para la práctica de deportes acuáticos, ni se tiene programada su construcción en el corto o mediano plazo.

Los asentamientos informales que no cuentan con ninguno de estos equipamientos ni con el suelo suficiente para su futura construcción son: Brisas del Sinú, Paz del Río, Santa Rosa, $1^{\circ}$ de Mayo, el Poblado, Mogambito, Robinson Pitalúa, Furatena, Villa Paz, 2 de Septiembre, Nueva Esperanza, los Araujos y 7 de Mayo. Estas deficiencias tienen un fuerte impacto sobre la sociedad, ya que en estos sectores, como mencionamos en apartado anterior, se presentan grandes problemas asociados a la delincuencia, embarazo de adolescentes, explotación infantil, consumo de drogas y pandillas juveniles.

Por otra parte, resaltamos que la ciudad cuenta también con equipamientos de gran impacto ambiental, dentro de los cuales es pertinente destacar el relleno sanitario, ubicado en área rural de la vereda Loma Grande a la altura del kilómetros 6 de la vía que conduce de Montería a Medellín. Este equipamiento comenzó operaciones en el año 2005 con licencia ambiental otorgada por la Corporación de los Valles del Sinú y del San Jorge, en una superficie de 10 hectáreas y con un plan de manejo ambiental que pretende mitigar el impacto que generan los lixiviados, la alteración del paisaje y los olores ocasionados por la descomposición de la materia orgánica de los residuos sólidos. 


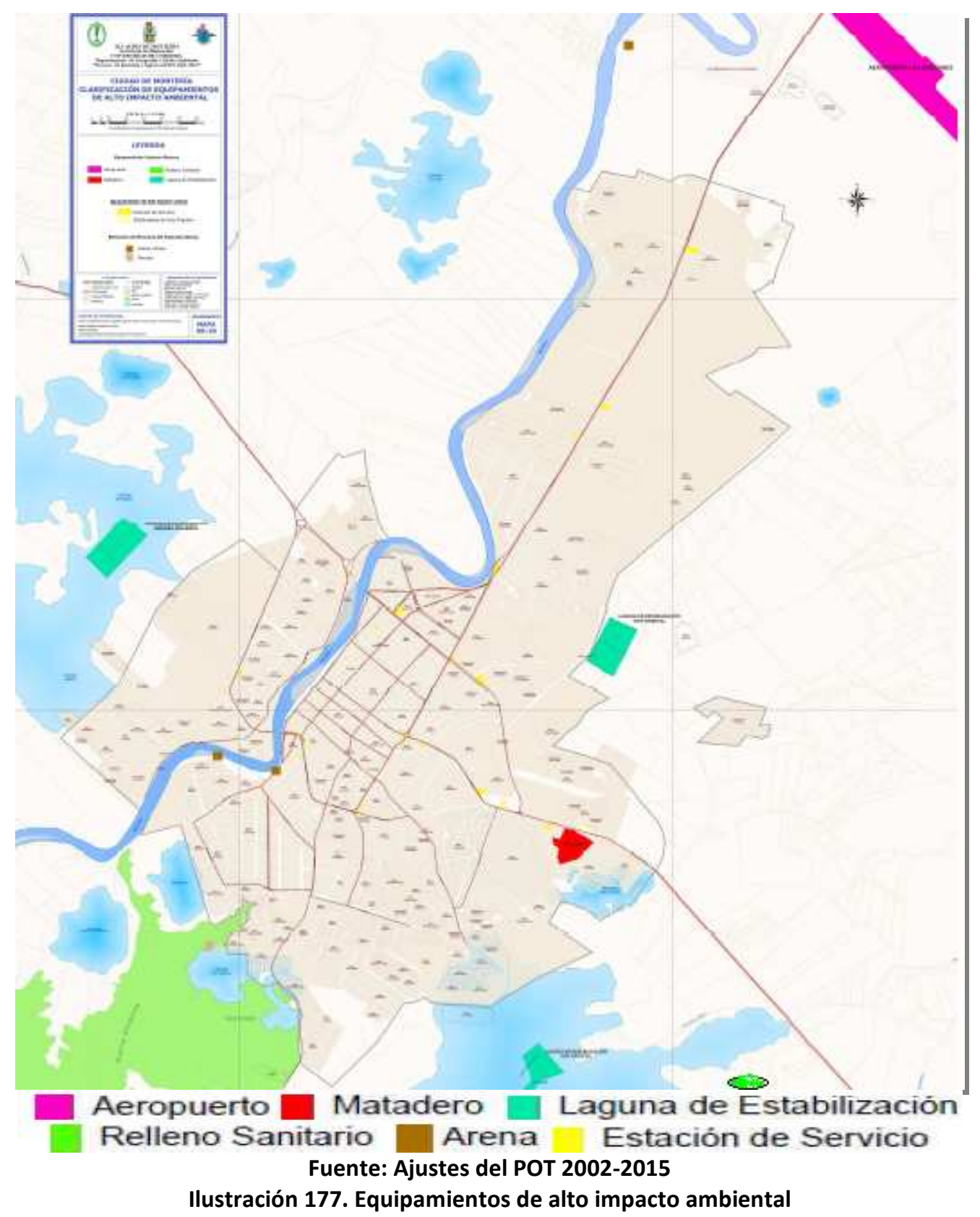

Otros equipamientos de gran impacto ambiental establecidos por el POT 2002-2015, y con los que estamos de acuerdo en esta investigación son: el aeropuerto los Garzones, con fuerte impacto auditivo para los barrios de promoción pública de los Cedros y COMFACOR, ubicados fuera del perímetro urbano en el corregimiento de Garzones; las lagunas de oxidación suroriental, nororiental y occidental, y el relleno sanitario de Loma Grande cerca a la vía a que conduce a Medellín.

Aunque en los ajustes realizados al plan de ordenamiento territorial de Montería se considera a dos explotaciones artesanales de arena como equipamientos, desde esta 
investigación consideramos que no son tales, sino simplemente actividades que generan un impacto ambiental sobre el cauce y la ribera del río Sinú. La ubicación de estas dos explotaciones se aprecia claramente en la ilustración 177; sobre ellas, ampliaremos en el apartado de impacto ecológico.

Finalizamos este análisis de los equipamientos, manifestando que a pesar de su número, son insuficientes para atender todas las demandas de la población y además su calidad arquitectónica no permite la cohesión social ni el desarrollo humano de sus habitantes, principalmente de los asentamientos informales, quienes siguen condenados a precarias dotaciones, y en muchos casos, a la inexistencia de ellas; es decir, ni la calidad ni el número de los equipamientos colectivos son suficientes para reducir la segregación social ni los problemas urbano-ambientales que caracterizan a esta ciudad subnorma.

\subsubsection{Viario}

Montería cuenta con una red viaria de 719.9 kilómetros, de los cuales 475 (66\%), se encuentran sin pavimentar, 231.9 (32.3\%) están pavimentadas, y un reducido 1.5\%, correspondientes a 10 kilómetros, han sido adoquinadas. Las vías pavimentadas se concentran principalmente en el centro histórico, en los barrios el Recreo y la Castellana, así como en las zonas comerciales más dinámicas de la periferia sur, oriental, y en menor proporción, la occidental. En el centro histórico predomina el pavimento en hormigón y en la periferia se combina el asfalto con el adoquín, pero con algunas excepciones en calles principales de barrios de promoción pública, dotadas en hormigón. 


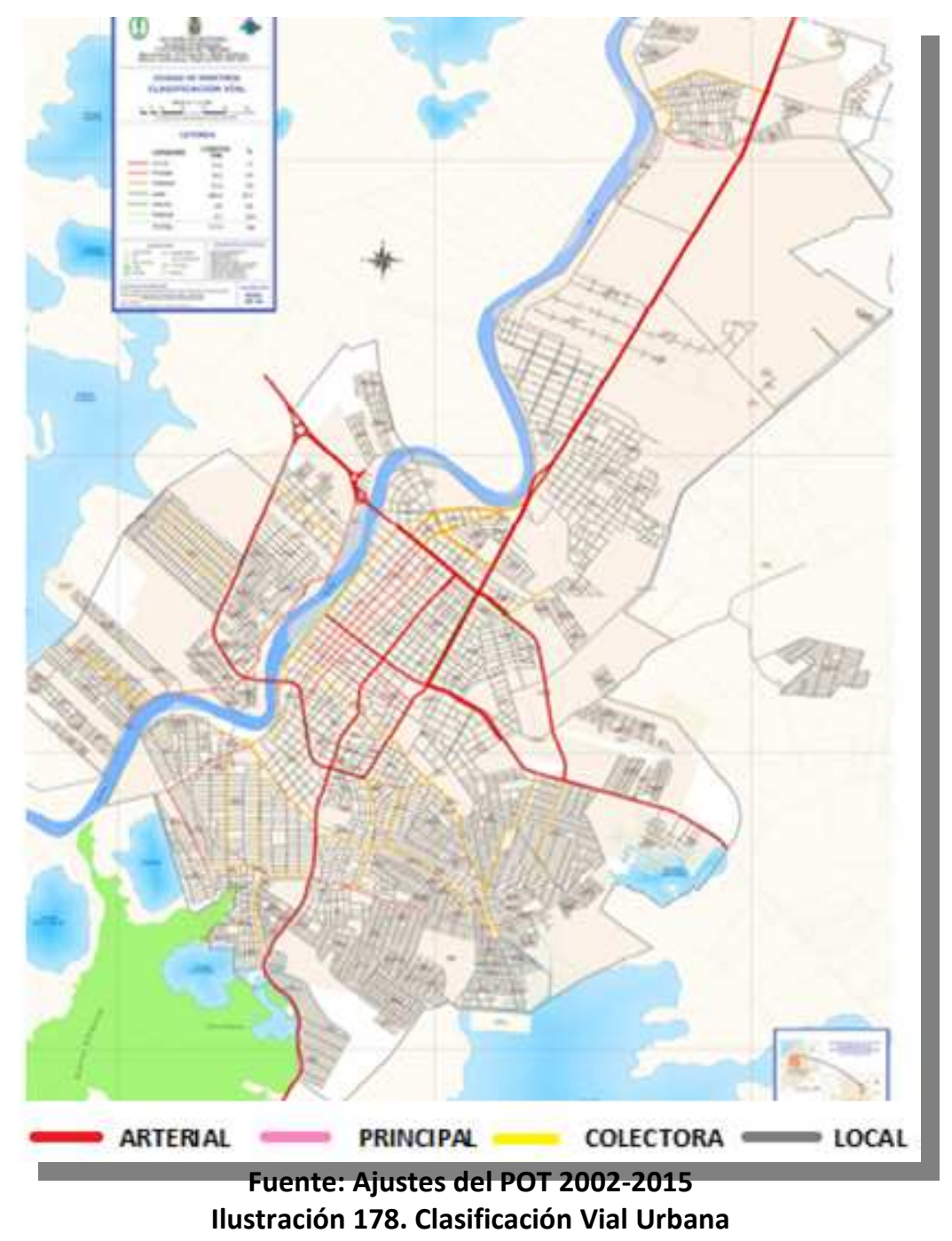

El plan de ordenamiento territorial 2002-2105, clasifica las vías de esta ciudad en seis categorías: arterial, arterial menor (principal), colectora, local, ciclovía y peatonal. Sin embargo, ante los escasos cuatro kilómetros de longitud de ciclovías y ante los risibles cien metros longitudinales de calles peatonales, consideramos oportuno destacar solamente las primeras cuatro categorías establecidas por dicho plan, las cuales corresponden al $99.4 \%$ del total y equivalentes a 715.8 kilómetros de carreteras. En este aspecto, destacamos que los perfiles de estas vías se delimitan en 12 metros para las arteriales; 10 para las arteriales menores; 8 para las colectoras, y entre 3 y 6 metros para las locales. 


\begin{tabular}{|l|r|r|}
\hline \multicolumn{1}{|c|}{ CLASE } & LONGITUD (Km) & PORCENTAJE \\
\hline ARTERIAL & 42,0 & 5,8 \\
\hline ARTERIAL MENOR & 16,3 & 2,3 \\
\hline COLECTORA & 31,5 & 4,4 \\
\hline LOCAL & 625,8 & 86,9 \\
\hline CICLOVIA & 4,1 & 0,6 \\
\hline PEATONAL & 0,1 & 0,0 \\
\hline TOTAL & 719,9 & 100,0 \\
\hline \multicolumn{2}{|r|}{ Fuente: Ajustes del POT 2002-2015 } \\
& Tabla 25. Calsificación Vial & \\
\hline
\end{tabular}

Con respecto a vías peatonales, resaltamos que en el año 2009, la administración del alcalde Marcos Daniel Pineda, determinó la peatonalización de la calle 62, entre avenida circunvalar y carrera siete del barrio la Castellana, en un sector exclusivo para diversión nocturna con predominio de restaurantes y discotecas, que paradójicamente fue denominado "Pasaje del Sol". A nuestro juicio, el nombre es paradójico puesto que las altas temperaturas del día y la inapropiada arborización no convocan a realizar recorridos diurnos, y por el contrario, el recalentamiento de sus lozas de hormigón, solamente posibilitan recorridos nocturnos, es decir paseos bajo la luz de la luna. Igualmente, consideramos demasiado jocoso que se pretenda reducir el déficit de vías peatonales con la propuesta de apenas cien metros longitudinales en cuatro años.

Por otro lado, anotamos que los 42 kilómetros de vías arteriales corresponden principalmente a la avenida Circunvalar, que transcurre desde la glorieta cercana al barrio el Tambo en el occidente hasta el aeropuerto los Garzones en el norte. Igualmente corresponden a la calle 29, que inicia su trazado en la avenida Primera y se extiende hacia la vía a Medellín; en tercer lugar a la carrera 9, desde la calle 41 hasta el barrio Furatena en el sur, y por último, a la calle 41, que conecta a la margen izquierda del río Sinú y la entrada al barrio Cantaclaro sobre la carretera a Medellín. El orden descrito, lo realizamos de acuerdo a la jerarquía y a la fecha de construcción de cada una de estas vías, resaltando que en ellas predomina el asfalto.

Las vías arteriales menores, denominadas también como principales, ascienden a 16.3 kilómetros y están conformadas por las carreras 2, 3, 4 y 5, entre la avenida 
Circunvalar y la calle 41 . También incorporamos a esta categoría la recién restaurada calle 27 y las calles 24 y 29, entre las avenidas Primera y Circunvalar. En este viario predomina el hormigón, pero su estado es deficiente, o más bien lamentable, debido a sus más de cuarenta años de antigüedad y a las constantes roturas a las que son sometidas por las diferentes empresas prestadoras de servicios públicos; ya sea, para instalación de redes, o para mantenimiento de ellas.

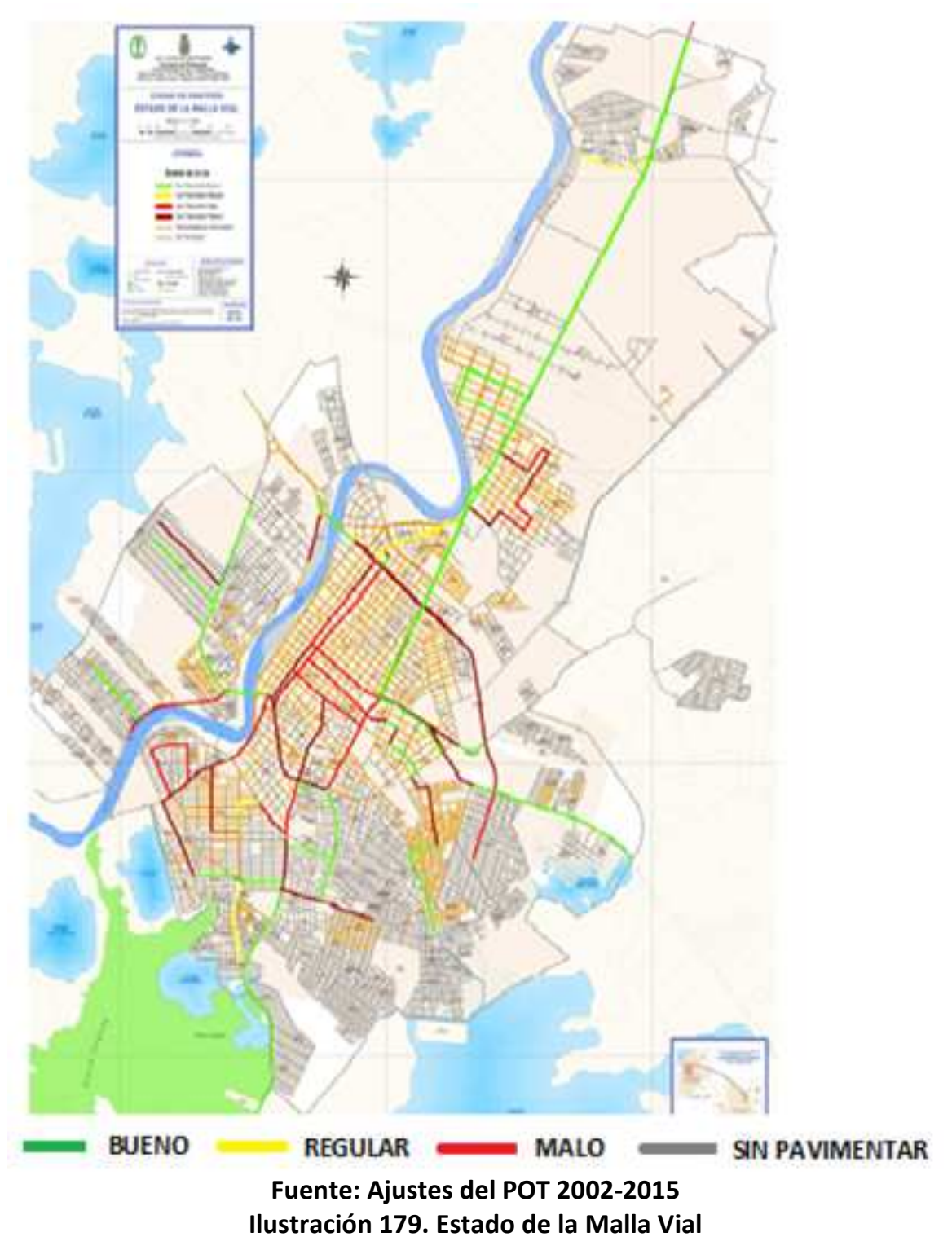

Siguiendo con la clasificación, calificamos a las vías colectoras como aquellas que conectan a los barrios de la periferia con las vías arteriales a con las calles principales que conducen al centro o hacia otros sectores de la ciudad. Los 31.5 kilómetros de ellas se concentran principalmente en los barrios de promoción pública de la Granja, La 
Pradera, Rancho Grande, P-5, Buenavista y Mogambo, y en los asentamientos informales consolidados del Dorado, Cantaclaro, Santafé, Santander, Alfonso López y 6 de Marzo. Así mismo, se encuentran vías similares en los barrios tradicionales de Sucre y los Laureles en el norte, en donde predomina el pavimento en hormigón, pero en regular estado. Resaltamos qué, algunas las vías colectoras de las invasiones 20 de Julio y Camilo Torres, aún se encuentran sin pavimentar.

Por su parte, las denominadas vías locales, corresponden a 625.8 kilómetros, de los cuales 475 se encuentran sin pavimentar y los restantes 150.8, están adoquinadas, con deficientes capas de asfaltos y con pavimento en hormigón ${ }^{318}$. Dentro de los asentamientos que no cuentan con ningún tipo de pavimento, ni se ubican sobre vías arteriales o colectoras figuran: el 7 de Mayo, 20 de Julio, Camilo Torres, Villa del Sinú, Paz del Norte, el Ceibal, Altos de California, en el norte; Villa Cielo, Villa Natalia, Villa Venecia y Santa Elena en el oriente; Colina Real, los Nogales, Brisas del Sinú, Villa Jiménez, Boston, Mogambito, las Américas, Damasco, San Cristóbal, el Paraíso, Nueva Colombia, las Acacias, Villa de los Alpes, Santa Isabel, Villa Karime, $1^{\circ}$ de Mayo, la Candelaria, Paz del Río, Santa Rosa, Robinson Pitalúa, Villa Paz, los Araujos, el Cerro y Nueva Galilea en el sur, y los Ébanos, la Vid, Villa Nazaret, los Colores, la Palma, Mi Ranchito, el Poblado, Villa Luz, la Esperanza, Manuel Jiménez y Manuel Antonio Buelvas en el occidente. El estado de la mayoría de las calles de estos barrios es bastante deficiente.

Además de los asentamientos informales mencionados, también se encuentran totalmente marginados de vías pavimentadas los barrios de promoción pública de los Robles I, los Robles II, Urbanización los Araujos, Panzenú, Villa Margarita, Nueva Jerusalén, Colina Real, Villa Sorrento, Villa Fátima, Santa Teresa y Nueva Belén. A éstos, hay que sumar igualmente el Minuto de Dios, y Casita Nueva, que a pesar de encontrarse cercanos a dos vías arteriales, no disponen de ninguna vía colectora, ni local que los pueda comunicar de mejor manera con otros sectores de la ciudad, y por el contrario en épocas de invierno sus precarias calles son intransitables.

\footnotetext{
318 Estos datos son presentados en el POT, y corresponden significativamente a lo corroborado por medio de la observación directa, principalmente en la escala urbana e intraurbana.
} 
En la misma situación de los barrios Minuto de Dios y Casita Nueva se encuentran Furatena, Nueva esperanza, 2 de Septiembre, la Campiña, Santander, Policarpa, San Martín, Caribe, Villa Caribe, Cantaclaro, Villa Rocío, Villa Ana I, Villa Ana II, Villa Mery, Villa Rosario, Edmundo López II, el Campano, las Viñas, el Amparo, el Tambo, Holanda, Caracolí, el Portal I, el Portal II y la Navarra. Estos asentamientos, con excepción de Cantaclaro, tienen el $100 \%$ de sus calles sin pavimentar, y sus habitantes se mantienen entre el polvo del verano y el abundante barro del invierno.

\begin{tabular}{|c|c|c|c|c|}
\hline COMUNA & $\begin{array}{c}\text { LONGITUD } \\
\text { PAVIMENTADA(en } \\
\mathbf{k m})\end{array}$ & $\begin{array}{c}\text { LONGITUD } \\
\text { ADOQUINADA } \\
(\mathbf{e n ~ k m )}\end{array}$ & $\begin{array}{c}\text { LONGITUD SIN } \\
\text { PAVIMENTAR } \\
(\mathbf{e n ~ k m})\end{array}$ & TOTAL(km) \\
\hline $\mathbf{1}$ & 12,4 & 0,0 & 59,7 & $\mathbf{7 2 , 1}$ \\
\hline $\mathbf{2}$ & 11,2 & 0,0 & 39,7 & $\mathbf{5 0 , 9}$ \\
\hline $\mathbf{3}$ & 14,7 & 10,2 & 45,7 & $\mathbf{7 0 , 5}$ \\
\hline $\mathbf{4}$ & 14,2 & 0,0 & 114,6 & $\mathbf{1 2 8 , 7}$ \\
\hline $\mathbf{5}$ & 69,1 & 0,08 & 15,7 & $\mathbf{8 4 , 9}$ \\
\hline $\mathbf{6}$ & 23,8 & 0,14 & 76,8 & $\mathbf{1 0 0 , 8}$ \\
\hline $\mathbf{7}$ & 15,9 & 0,0 & 5,1 & $\mathbf{2 1 , 1}$ \\
\hline $\mathbf{8}$ & $\mathbf{6 5 , 0}$ & 0,27 & 82,6 & $\mathbf{1 4 7 , 8}$ \\
\hline $\mathbf{9}$ & 5,7 & 0,29 & 35,9 & $\mathbf{4 1 , 8}$ \\
\hline & $\mathbf{2 3 1 , 9}$ & $\mathbf{1 0 , 9}$ & $\mathbf{4 7 5 , 8}$ & \\
\hline
\end{tabular}

Tabla 26. Inventario Vial por Comunas

Terminamos anotando qué, las peores condiciones viales en términos relativos y absolutos las presentan los asentamientos de la comuna nueve en el norte, los de las comunas uno y dos en el occidente, sobre la margen izquierda del río Sinú y los de la comuna cuatro en el sur de la ciudad. En cambio, las mejores condiciones se reflejan en las comunas cinco y nueve, que corresponden a los barrios tradicionales del centro de Montería y a los sectores exclusivos del Recreo y la Castellana. Estos enormes desequilibrios son los que permiten corroborar cada vez más de que Montería es, evidentemente, una Ciudad Subnorma, caracterizada por procesos informales de urbanización. 


\subsubsection{Déficit de Espacio Público}

El espacio público en Colombia es reglamentado por el Decreto 1504 de 1998, que lo define como "el conjunto de inmuebles públicos y los elementos arquitectónicos y naturales destinados por naturaleza, usos o afectación a la satisfacción de necesidades urbanas colectivas que trascienden los límites individuales de los habitantes" (Art. 2). Este mismo decreto incluye dentro de los elementos naturales a todos los relacionados con el sistema orográfico, hídrico y paisajístico. Igualmente, determina los principales elementos constitutivos artificiales que conforman el espacio público, e incluye dentro de ellos a todas las áreas integrantes de los perfiles viales, parques, plazas, plazoletas, escenarios deportivos, culturales y de espectáculos al aire libre, antejardines privados y lo referente al mobiliario urbano.

En este orden de ideas, el plan de ordenamiento territorial de Montería incorpora el concepto de espacio público artificial para referirse a equipamientos, los cuales divide en tres categorías: 1) escenarios deportivos; 2) escenarios infantiles, 3) escenarios de estancia. Los primeros son asociados primordialmente a canchas de futbol, beisbol, microfútbol, softbol, y tejo ${ }^{319}$; los segundos, los delimita a áreas libres dotadas de columpios y sube y baja; mientras que los terceros son definidos como espacios constituidos por áreas de sombra, césped y mobiliario para el descanso. En armonía con el Decreto 1504 de 1998, también determina unos elementos naturales constitutivos del espacio público, dentro de los que sobresalen la cuenca del río Sinú, ciénagas, humedales y el cerro de Sierra Chiquita.

Teniendo en cuenta las determinaciones, tanto del POT como del Decreto 1504, y de acuerdo con el inventario de espacio público existente en la ciudad de Montería, se ha podido corroborar que en aspectos relacionados con equipamientos, plazas, parques y viario, estamos muy por debajo de los estándares internacionales y de los nacionales.

\footnotetext{
${ }^{319}$ El softbol es un deporte con reconocimiento olímpico similar al beisbol, pero difiere de él, en el tamaño de la bola, las formas de los bates y las dimensiones del campo de juego. Este deporte es el más popular en la ciudad de Montería. Por su parte el Tejo, es un deporte colombiano, principalmente del interior del país, que consiste en lanzar un disco metálico en una cancha de arcilla de 18 metros de largo para explotar las mechas de pólvora que se encuentran dentro. Más información se encuentra disponible en: http://es.wikipedia.org/wiki/Tejo (deporte)
} 
El promedio de espacio público por habitante en esta ciudad no supera los 1.66 metros, incluyendo zonas verdes, cifra abiertamente distante de los 15 metros cuadrados por habitante que recomienda la legislación como espacio público mínimo para las ciudades colombianas ${ }^{320}$.

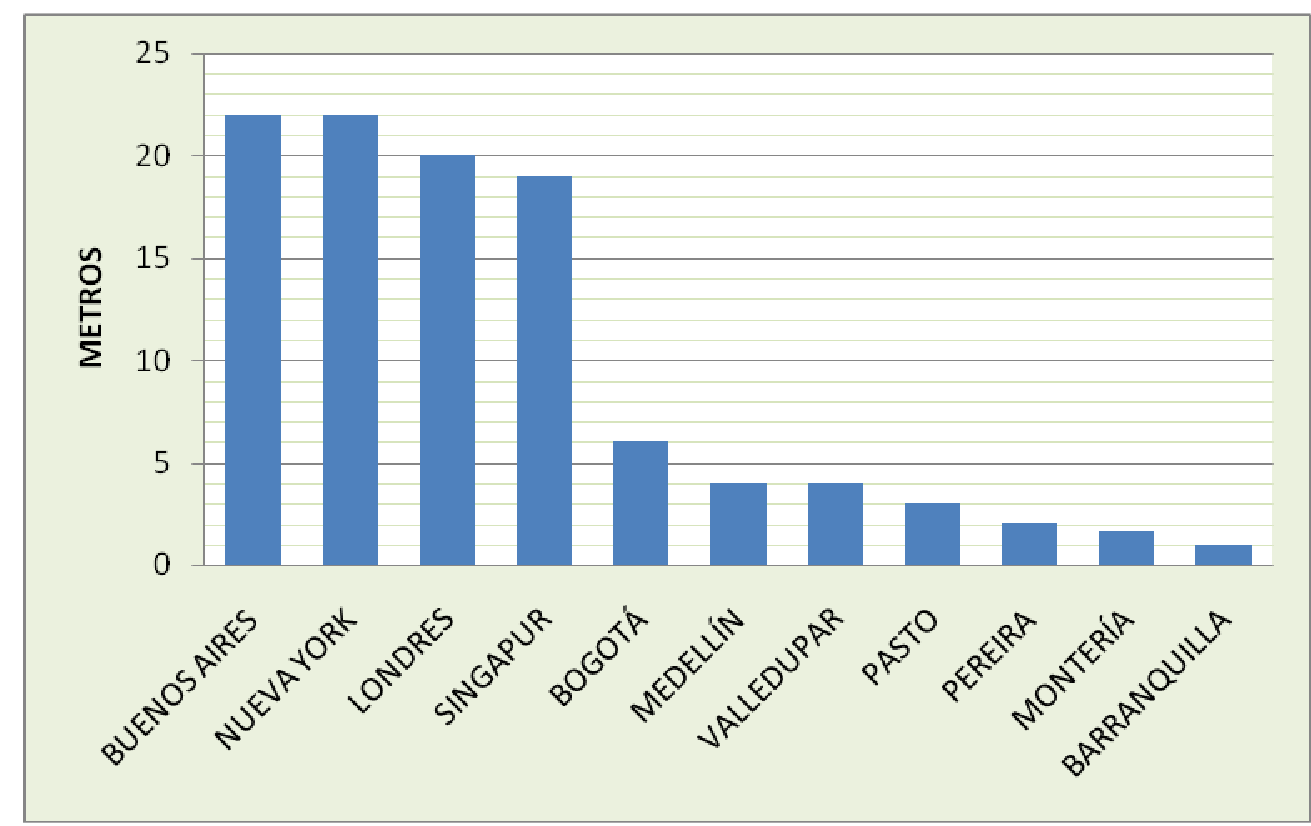

Fuente: Ajustes del POT 2002-2015

Ilustración 180. Metros de Espacio Público por Habitante

En el corto o mediano plazo es poco probable lograr el promedio de espacio público en metros cuadrados que ofrecen referentes mundiales como Buenos Aires, Nueva York, Londres o Singapur, pero si se pueden alcanzar los promedios más altos de las ciudades colombianas, especialmente, Bogotá, Medellín y Valledupar, que disfrutan de promedios cercanos a cinco metros cuadrados por habitantes, posibiltando gran calidad urbana a sus habitantes. El déficit de espacio público en Montería es de los más altos del país, y con excepción de Barranquilla, supera en este aspecto al resto de capitales de los departamentos de Colombia. Consideramos que su principal problema radica en que no cuenta actualmente con parques o zonas verdes con áreas superiores a los 10.000 metros, de los que si gozan otras capitales, incluida Barranquilla.

\footnotetext{
${ }^{320}$ Artículo 14 del Decreto 1504 de 1998, que reglamenta el manejo del espacio público en los planes de ordenamiento territorial. "Se considera como índice mínimo de espacio público efectivo, para ser obtenido por las áreas urbanas de los municipios y distritos dentro de las metas y programa de largo plazo establecidos por el Plan de Ordenamiento Territorial, un mínimo de quince $\left(15 \mathrm{~m}^{2}\right)$ metros cuadrados por habitante para ser alcanzado durante la vigencia del plan respectivo". El decreto 1504 de 1998 se encuentra disponible en http://www.alcaldiabogota.gov.co/sisjur/normas/Norma1.jsp?i=1259
} 


\begin{tabular}{|c|c|c|c|c|c|}
\hline NOMBRE & Área & $\begin{array}{c}\text { Población } \\
\text { total }\end{array}$ & $\begin{array}{l}\text { Área espacio } \\
\text { público }\end{array}$ & $\begin{array}{c}\mathrm{Mt}^{2} \text { espacio } \\
\text { Público/por hab. }\end{array}$ & $\begin{array}{c}\text { Déficit } \\
\text { cuantitativo } \\
\text { espacio público }\end{array}$ \\
\hline Comuna 1 & 3918612,4 & 34073 & 35438,9 & 1,04 & 14,0 \\
\hline Comuna 2 & 2795213,4 & 14082 & 23500,1 & 1,67 & 13,3 \\
\hline Comuna 3 & 3025559,0 & 44588 & 56859,6 & 1,28 & 13,7 \\
\hline Comuna 4 & 4627011,0 & 62700 & 69662,5 & 1,11 & 13,9 \\
\hline Comuna 5 & 3747953,8 & 28843 & 106439,0 & 3,69 & 11,3 \\
\hline Comuna 6 & 4190520,3 & 52720 & 32217,9 & 0,61 & 14,4 \\
\hline Comuna 7 & 998062,8 & 5060 & 7530,5 & 1,49 & 13,5 \\
\hline Comuna 8 & 13890000,0 & 30833 & 62481,6 & 2,03 & 13,0 \\
\hline Comuna 9 & 3601281,1 & 13676 & 23321,6 & 1,71 & 13,3 \\
\hline TOTAL & 40794213,7 & 286575 & 417451,6 & & \\
\hline PROMEDIO & & & & 1,66 & 13,37 \\
\hline
\end{tabular}

Fuente: Ajustes POT 2002-2015

Tabla 27. Espacio Público por Comunas

Sin embargo, a nivel local también se presentan notables desequilibrios en cuanto a oferta de espacio público, asociados principalmente a: condiciones socio-económicas; origen del asentamiento; ubicación del asentamiento dentro de la ciudad, y a la densidad poblacional del sector. En este sentido, los promedios más altos se encuentran en las comunas cinco y ocho, que corresponden a los barrios tradicionales del centro y a los sectores exclusivos de la Castellana y el Recreo. En el caso de la comuna cinco, el promedio de 3.69 metros cuadrados de espacio público por habitante, obedece a que en ese sector se encuentran ubicados los principales equipamientos de la ciudad: administrativos, educativos, salud, justicia, seguridad, culturales, recreativos, viarios, zonas verdes y áreas libres.

En cuanto a la comuna ocho, debemos destacar que es la de mayor extensión con 1.389 hectáreas pero la de menor densidad con apenas 22 habitantes por hectarea, resultantes de una población total de 30.883 residentes, quines disfrutan de un promedio de 2.03 metros cuadrados de espacio público. Situaciones opuestas se presentan en las comunas seis, uno y cuatro, que son las más pobladas, no disponen 
de grandes superficies y tienen los peores promedios de oferta de espacio público con $0.61,1.04$ y 1.11 , respectivamente.

Los asentamientos informales con mayores dificultades de accesibilidad al espacio público son: Villa Nazaret, Urbanización el Portal, los Colores, el Níspero, el Dorado, Manuel Jiménez, Pastrana Borrero, San Martín, Santander, las Colinas, los Araujos, Nueva Esperanza, Alfonso López, los Nogales, Villa de los Alpes, Villa Mery, Villa Cielo, Caribe, 6 de Marzo, Edmundo López, invasiones Sucre, 25 de Agosto, 7 de Mayo, Urbanización Villa Sinú, Palma Verde y Paz del Norte. Así mismo, presentan similares problemas los barrios de promoción pública de Nueva Belen, Nueva Jerusalen, Villa Sorrento, Villa Fátima y Urbanización Santa Teresa.

Otro grave problema que se presenta también en estos asentamientos es la invasión del poco espacio público del que disponen, principalmente de áreas reservadas para zonas verdes o para vías, las cuales son destinadas a más infraviviendas o a negocios. Se han presentado tensiones sociales o conflictos menores por usos de suelo en: la Esperanza, los Colores, Villa Paz, Furatena, Nueva Esperanza, el Paraíso, Colina Real, la Candelaria, P-5, Mogambo, Edmundo López, Cantaclaro, Nueva Colombia, 20 de Julio, Camilo Torres, 7 de Mayo, Santa Rosa, Mogambito, San Cristóbal, Villa Cielo, el Poblado, la Vid, el Dorado, Villa Nazaret, la Palma, las Colinas, Brisas del Sinú, Paz del Río, Villa Ana y Edmundo López II. En Mogambito, Edmundo López, Colina Real y Cantaclaro se invaden además las orillas de los canales colectores de aguas residuales, consideradas por planeación municipal y por el plan de ordenamiento territorial como espacio público.

Finalizamos este análisis sobre espacio público en Montería, anotando que su elevado déficit es ocasionado por los asentamientos informales de las últimas dos décadas, e incluso, por los barrios de promoción pública desarrollados en el mismo periodo por el INURBE. Como manifestamos en apartados anteriores, los primeros programas públicos de vivienda terminada ofrecidos por el Instituto de Crédito Territorial en la década de los sesenta y setenta, fueron generosos en espacio público y asignaron en promedio el 35\% de la superficie bruta para dichos usos. Igualmente, asentamientos informales de la época, como Santafé, Policarpa, Santander y Pastrana Borrero, 
reservaron superficies significativas en las que posteriormente se construyeron equipamientos importantes.

\subsubsection{La urbanización marginal de Montería comparada con la de otros contextos geográficos}

En este apartado intentamos establecer existencia, afinidades y diferencias entre asentamientos irregulares de distintos contextos geográficos, principalmente de Madrid y Barcelona en España; Buenos Aires en Argentina; Río de Janeiro en Brasil; Santafé de Bogotá en Colombia, y por supuesto, la ciudad de Montería, en este último país. Igualmente se pretende determinar aspectos relacionados con el origen, ubicación y evolución de dichos asentamientos, así como las respuestas que surgen de los ayuntamientos.

Comenzamos el análisis comparativo anotando que la mayoría de los asentamientos informales de Montería, se han emplazado dentro del perímetro urbano de la ciudad, con las excepciones de los barrios Villa Cielo, Villa Jiménez, la Vid y Urbanización el Privilegio. Esta dinámica de invasión dentro del perímetro urbano, permite que los costos económicos generados por instalación posterior de redes básicas no sobrepasen la capacidad financiera del municipio ni de las empresas privadas encargadas de prestar dichos servicios.

El caso del barrio Villa Cielo, como se anotaba, es un caso excepcional, que puede asemejarse más, a fenómenos externos de urbanización marginal en extrarradios, que a procesos de invasión local. Este modo de ubicación por fuera del perímetro urbano, es a nuestro juicio, una réplica a la criolla de lo que se dio a finales del siglo XIX y comienzos del XX en Madrid y Barcelona. Estas dos ciudades españolas vivieron fenómenos de urbanización marginal en sus extrarradios, que desencadenaron la parcelación de muchas fincas rurales para destinarla a la construcción de viviendas.

En el caso de la ciudad de Madrid, un ejemplo concreto del fenómeno de urbanización marginal en el extrarradio lo representa el barrio de la Prosperidad, que surge desde finales del siglo XIX, como consecuencia de los elevados precios que presentaba la 
vivienda construida dentro del ensanche y las estrictas normas de edificación que existían para la época ${ }^{321}$. Consideramos que estos dos aspectos son determinantes en cualquier contexto, incluido el de Montería, que en el siglo XXI permitió el surgimiento del barrio Villa Cielo fuera de su perímetro urbano.

La situación de Villa Cielo en Montería y la primera fase de la Prosperidad en Madrid, aunque en diferentes contextos de tiempo y espacio, se asemejan, debido a que ambos fueron constituidos por fuera del perímetro urbano o extrarradio; y además, porque la actuación de los parceladores, tanto de aquí como de allá, se limitó exclusivamente a la elaboración del plano y a la segregación de fincas. Las dos opciones resultaron inicialmente marginales, y posteriormente solucionables a través de planes de urbanización del extrarradio para Madrid y la integración de Villa Cielo al perímetro urbano de Montería.



Foto Charlotte Vorms 1999

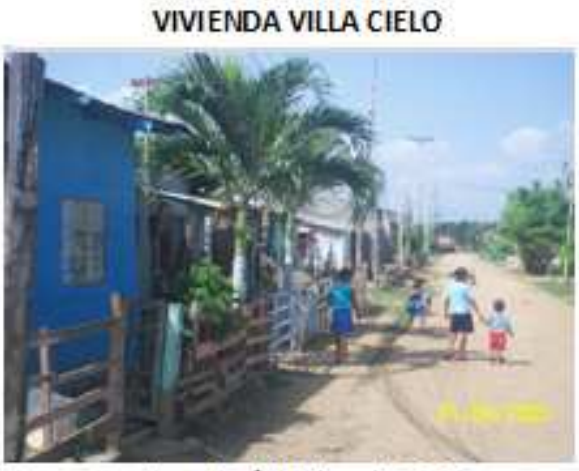

Foto Yesid Tabo ada 2005 Ilustración 181. Viviendas bajas en Madrid y Montería

La tipología de la vivienda tiene características similares a pesar de las diferencias que se presentan por las condiciones naturales y por los materiales utilizados. La vivienda que se construye en el extrarradio de Madrid, en su primera fase, al igual que la construida en Villa Cielo, es inicialmente de planta baja, patio trasero y con fachada alineada a la calle. No obstante, en la primera predomina el ladrillo y la teja de barro, mientras en la segunda los materiales presentes son el bloque de arena para estructura, y el zinc o asbesto para cubierta.

\footnotetext{
321 Vorms, Charlotte (2003): "La Urbanización Marginal del Extrarradio de Madrid: Una respuesta espontanea al problema de la vivienda. El caso de la Prosperidad (1860-1930)". Revista Electrónica Scripta Nova. http://www.ub.es/geocrit/sn/sn-146(013).htm. Consultado mayo de 2010.
} 
En lo referente al tejido social no se presentan diferencias, ya que en ambos contextos se crean vínculos sociales muy fuertes entre vecinos, los cuales se consolidan por el aislamiento espacial, por la tipología de la vivienda, por el diseño del viario y por las características del espacio público. Estos aspectos contribuyen a una apropiación colectiva de la calle o de la manzana, que suple con estrechos lazos afectivos la falta de equipamientos colectivos.

Ahora bien, en la capital española este fenómeno, denominado chabolismo, ha logrado extenderse a toda el área de la comunidad, razón por la cual, desde la década de los años ochenta del siglo XX, el Ayuntamiento de esta ciudad viene intentando erradicar el problema por la vía del desmantelamiento o de las reubicaciones. Su caso más reconocido en este siglo XXI es el de la Cañada Real Galiana, emplazada sobre los terrenos públicos de una vía pecuaria.

Este asentamiento de Madrid supera la frontera local y se extiende hacia el territorio de otros cuatro municipios: San Fernando, Getafe, Coslada y Rivas Vacíamadrid. Este sector informal es considerado el más grande de España, y en este momento alberga a más de 40.000 personas, en aproximadamente 2.000 chabolas que fueron establecidas desde hace cuarenta años a lo largo de unos 15 kilómetros. "La Cañada Real Galiana es un antiguo camino de trashumancia en el que no está permitido edificar. Pero tiene más de 2.000 casas ilegales $^{\prime \prime 322}$.

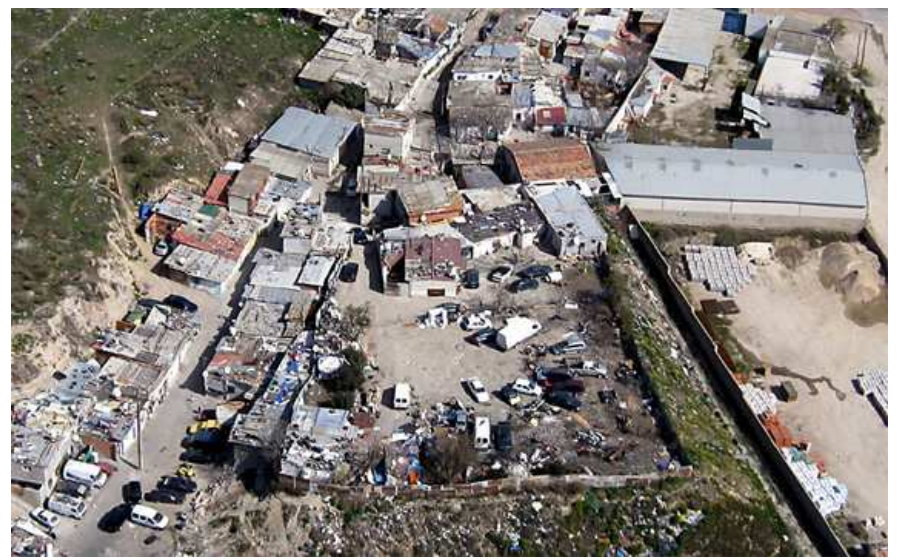

Fuente Fotográfica: $\underline{w w w . e s p o r m a d r i d . e s}-2010$

Ilustración 182. La Cañada Real Galiana

322 Scabuzzo, Claudio (2008): “Una Villa Miseria del Primer Mundo". Disponible en http://laterminalrosario.wordpress.com/2008/04/21/una-villa-miseria-delprimermundo 
La Cañada Real Galiana se ha levantado sobre dominio público, y, como estos bienes son inalienables, inembargables e imprescriptibles en el derecho español, entonces se hace poco probable, por no decir que improbable, el reconocimiento legal que pretenden sus ocupantes. Es un caso complejo, porque cualquier solución diferente al realojo, expulsión o demolición estaría al margen del derecho urbanístico, y además, estimularía nuevas ocupaciones sobre dominio público en esta capital ${ }^{323}$.

Este barrio de más de cuarenta años, es un claro ejemplo de invasión en un país desarrollado, que parcialmente presenta algunas características similares a la de invasiones latinoamericanas, que no excluyen, por supuesto, a las de Montería. Estas características se asocian a la morfología de los asentamientos, a la tipología de las infraviviendas, y a las condiciones socioeconómicas de la población. No obstante, desde esta investigación se identifica una enorme distancia, en lo relacionado a niveles de consolidación y a resultados obtenidos en cada contexto.

Así como la Cañada Real Galiana se constituyó sobre una vía pecuaria castellana, conviene anotar que en Montería, una invasión denominada Ranchos del INAT, fue constituida paralela a un eje funcional. Este asentamiento fue emplazado paralelamente a un canal de riego y se extendió linealmente sobre ese eje, sin posibilidades de crecer compactamente hacia otros terrenos que no correspondieran al borde de dicho canal. Por las condiciones de insalubridad, por la incertidumbre que genera su dominio y por las condiciones socioeconómicas de sus habitantes, las viviendas de este asentamiento no han presentado ningún tipo de evolución y se mantienen en condiciones precarias.

\footnotetext{
323 En el año 2008 la Policía y la Guardia Civil procedieron a derribar varias viviendas de este sector y a la expulsión de chabolistas. Información disponible en http://elpais.com/elpais/2008/10/14/actualidad/1223972222_850215.html
} 

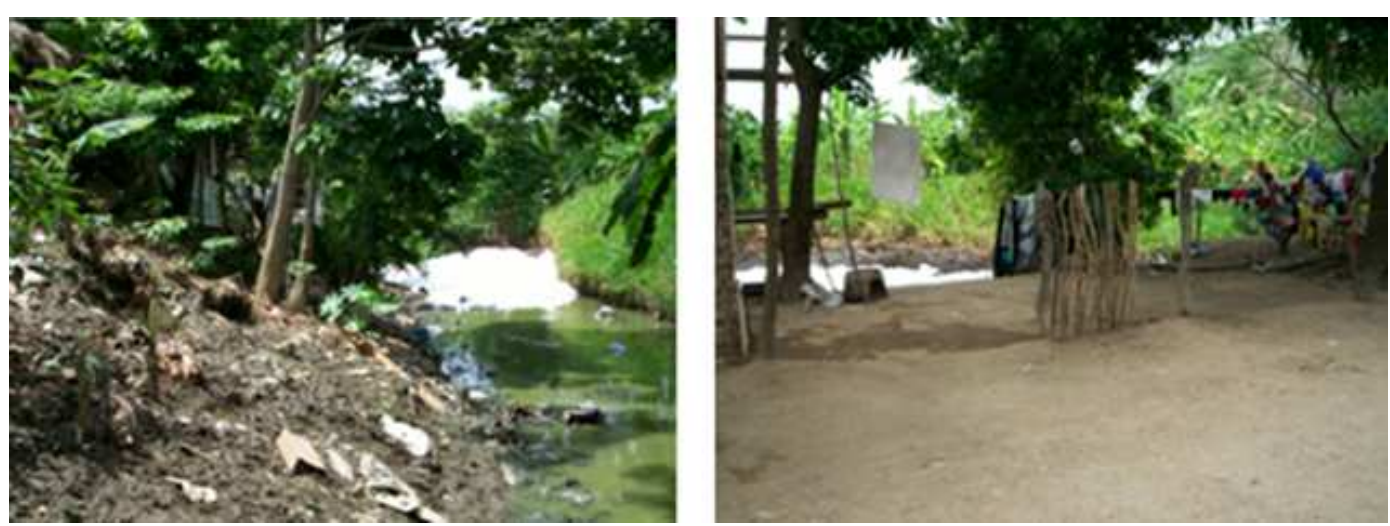

Fotografías: Yesid Taborda 2007

Ilustración 183. Canal Ranchos del INAT

Antes de analizar diferencias entre los dos asentamientos mencionados, es pertinente manifestar que las afinidades morfológicas son el resultado de asentamientos con estructuras lineales surgidos a partir de una vía pecuaria sobre territorio madrileño, o a partir de ejes como el río Sinú o canales de aguas pluviales en Montería. Esta comparación no pretende, en ningún momento, relacionar las condiciones naturales de dos territorios diferentes, sino por el contrario, hallar afinidades en contextos, que a simple vista aparentarían ser incomparables.

En lo referente a tipología de la vivienda, no existe una relación marcadamente homogénea en este aspecto, sin embargo, en ambas partes predomina la planta baja, aunque con materiales constructivos diferentes. Así mismo, se presenta fuerte incidencia de viviendas precarias, las cuales mantienen elementos transitorios a pesar de los largos años de existencia del asentamiento. Esto aparenta ser una perogrullada, pero la precariedad no se mantiene exclusivamente por incapacidad económica, sino por la incertidumbre que genera invertir en un terreno sin dominio legal.

Sobre afinidades de orden social, se puede anotar que, la población de la Cañada se encuentra conformada por colectivos excluidos, grupos de inmigrantes y por minorías étnicas, quienes presentan bajos niveles de escolaridad y poca capacidad de negociación. En este mismo sentido, las invasiones de Montería están habitadas por colectivos similares que aquí se denominan como afro-colombianos, desplazados, campesinos e indígenas. 
Las ocupantes de las dos invasiones mencionadas no han podido acceder al dominio, de la propiedad ni a ninguna dotación pública importante, a pesar de asentarse en esos terrenos desde hace cuarenta y veinticinco años respectivamente; pero la evolución del asentamiento si ha presentado diferencias de tipo constructivo y de usos. Por ejemplo, en la Cañada Real el paso del tiempo permitió la construcción de chalets y bodegas para usos diferentes, mientras que en Ranchos del INAT, el tiempo no ha permitido evolución alguna de la vivienda.

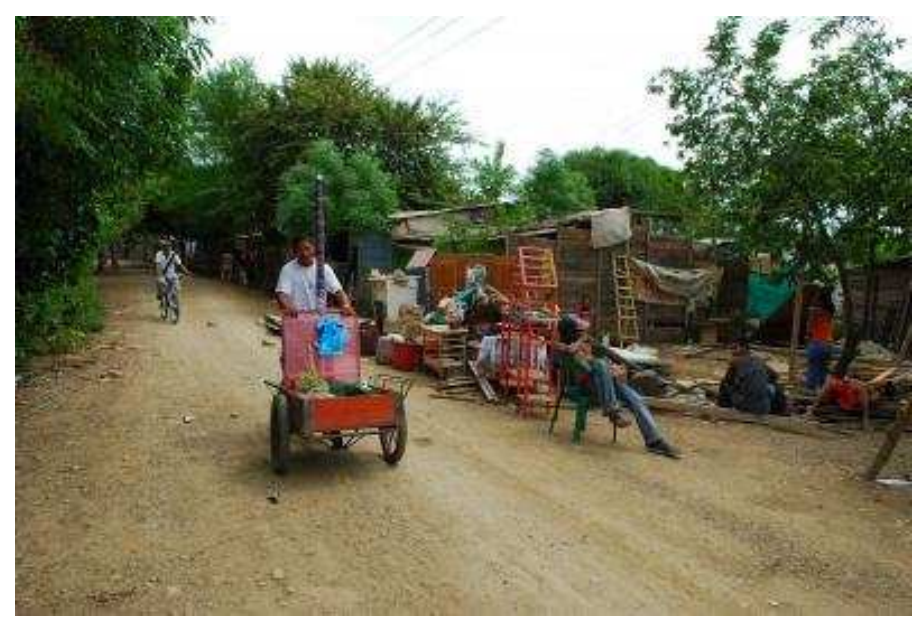

Fuente Fotográfica: Alcaldía de Montería llustración 184. Carretera Única Ranchos del INAT

La dinámica evolutiva presentada por algunas viviendas de la Cañada Real Galiana, contrasta con el estático estado de la infravivienda originaria de Ranchos del INAT. En ambos asentamientos los servicios públicos se siguen conectando de manera fraudulenta, y no ha sido posible disponer de suelo para dotaciones públicas, ni mucho menos dotarlos de ellas.

Ranchos del INAT es un caso atípico dentro de Montería, en donde las experiencias de otras invasiones culminaron de manera exitosa debido a las tendencias evolutivas de las viviendas. En este mismo sentido, la Cañada Real Galiana también es un ejemplo atípico para Madrid, y la solución para ambos contextos será la reubicación; lo cual resulta presupuestable dentro del contexto madrileño en caso de haber voluntad, pero poco presupuestable dentro del contexto monteriano, siempre acostumbrado a resolver por la vía de la consolidación del asentamiento. 
Esta invasión se considera desde esta investigación como atípica, debido a que el objetivo inicial de la ocupación no fue el de consolidar el barrio, sino ejercer un mecanismo de presión que les permitiera acceder en el futuro a una vivienda por la vía de la reubicación, como efectivamente sucedió con el 50\% de esta población y como seguramente sucederá con el resto cuando se construya la vía paralela a la avenida circunvalación que se encuentra programada dentro del plan de ordenamiento territorial de Montería.

La hipótesis de atipicidad de este asentamiento se corrobora cuando se comparan los resultados de consolidación entre ésta, y los que obtuvieron invasiones lineales constituidas sobre otros canales y sobre el borde del río Sinú en diferentes puntos de la ciudad. Dentro de estas invasiones "consolidadas" destacamos las de Brisas del Sinú, el Bongo, 7 de Mayo y Sucre sobre la ribera de la principal fuente hídrica de la ciudad.

Para el Ayuntamiento de Madrid la solución resultará más traumática debido al número de infraviviendas y a la consolidación del asentamiento. En cambio, para el municipio de Montería, la salida es más favorable como consecuencia de la nula evolución de la vivienda, y por encontrarse esta superficie calificada dentro del el POT como vía principal. Es oportuno anotar que más de 200 familias del Ranchos del INAT ya fueron reubicadas en la Urbanización Nueva Belén y quedan pendientes 350 familias por reubicar en sitio por definir.

La Cañada Real Galiana es el caso más complejo, pero no es el único de Madrid, y con respecto a este fenómeno, el Ayuntamiento de esta ciudad ha logrado desmantelar varios asentamientos que ellos denominan como Asentamientos Chabolistas. Los barrios desmantelados hasta el momento son: Plata y Castañar, El Salobral, Pitis, la Quinta y Mimbreras I, y el número de chabolas destruidas equivale a 1200 unidades de un total de 2674 infraviviendas censadas ${ }^{324}$.

\footnotetext{
324 Barroso, Javier (2007) "Cinco Mil Madrileños Viven en Chabolas". Diario El País. 11 de diciembre de 2005. Madrid. Disponible en http://www.elpais.com/articulo/madrid/5000/madrilenos/viven/chabolas/elpepuespmad/20070806elp $\underline{\operatorname{mad} 1 / T e s}$
} 
Sin embargo, el problema del chabolismo persiste en esta ciudad, y vemos que a pesar de los recursos asignados, aún no ha sido posible desmantelar otros asentamientos como el Cañaveral, Santa Catalina, el Ventorro, Mimbreras, los Trigales, Puerta de Hierro, e inclusive, el complejo caso de la Cañada Real Galiana. Posiblemente estos asentamientos serán desmantelados en el futuro, pero lo más probable es que esto no será suficiente para acabar con un fenómeno que el modelo de desarrollo neoliberal también globalizó.
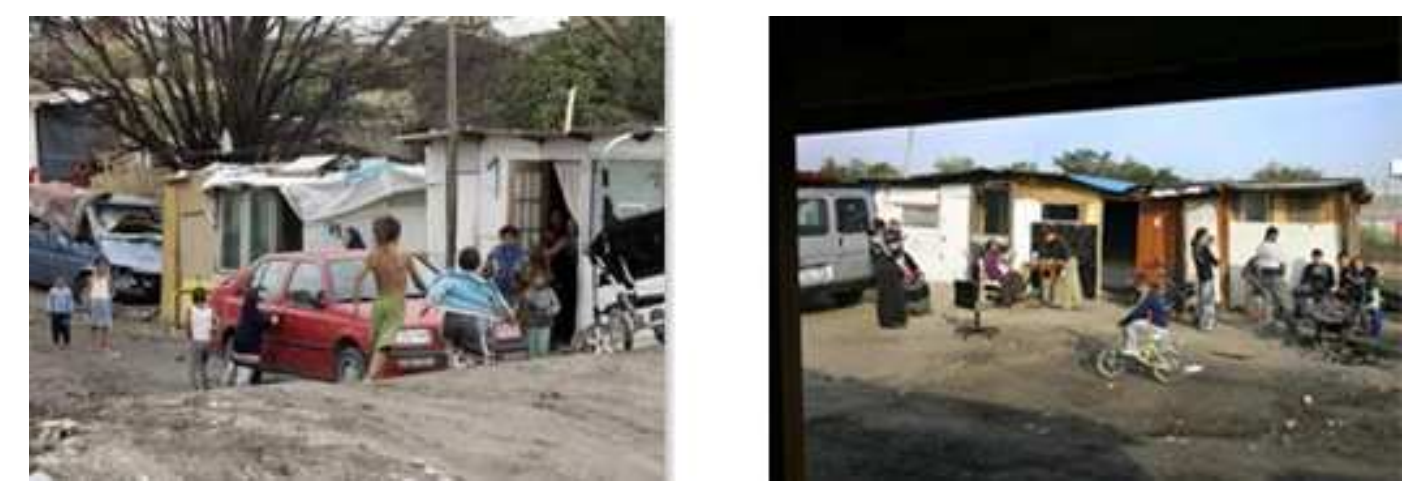

Fuente Fotográfica: http://laterminalrosario.wordpress.com Ilustración 185. Persistencia de chabolas en Madrid

Otra comparación que se puede realizar es con la urbanización marginal de la ciudad de Barcelona, contexto éste, donde se parcelaron y edificaron suelos de poca calidad, en zonas de condiciones accidentadas topográficamente, con características similares a las de áreas de ubicación de algunos asentamientos informales de Montería, pero que no se asemejan mucho en cuestiones de legalidad y de acción de la Administración Pública.

En este cuadro comparativo de contextos, destacamos que las parcelaciones y edificaciones irregulares en Barcelona se inician a comienzos de siglo XX, mientras que en Montería comienzan en la década de los años sesenta. La densidad poblacional de estos asentamientos en Barcelona es baja, en la localización de las "coreas" incide la proximidad a infraestructura y se reflejan intentos de parcelación tipo ciudad jardín, situaciones éstas que no ocurren en nuestros asentamientos, ya que presentan densidades que superan las 100 viviendas por hectáreas y con pocas excepciones se aprovechan infraestructuras de calidad. Sin embargo, en Barcelona las "coreas" se 
transforman y se consolidan con el tiempo variando a veces su densidad a diferencia de Montería donde la densidad es alta desde el inicio del asentamiento.

En Barcelona se identifican dos periodos uno que inicia en 1903 y el segundo que se da entre los años 40 y 50 por la falta de espacio residencial económico y por las migraciones campo - ciudad (demanda insatisfecha). Se presenta una ocupación y venta de zonas de terrenos no edificables por tener una topografía muy accidentada o estar reservada como parque u otro espacio público.

En esta ciudad española, que decidimos tomar como referencia por el estudio similar que realizo Joan Busquets, se dan los primeros programas de vivienda masiva en los años cincuenta a cargo de la Administración o de corporaciones públicas para satisfacer la demanda que aumentaba por las migraciones, mientras en Montería estos programas se dan en la década de los ochenta, cuando se intensifican los flujos migratorios, y cuando la presión por la vivienda aumenta las invasiones y fraccionamientos irregulares. En la primera se interviene a través de planes parciales y planes sectoriales mientras que en la segunda las intervenciones son espontaneas e individuales y se dan progresivamente en extensos periodos de tiempo.

En Barcelona el fenómeno de la "corea" inicia con la compra u ocupación para luego seguir con $20 \mathrm{~m}^{2}$ de autoconstrucción de un modulo inicial que se convierte en base de desarrollo ulterior de la vivienda. Este es el modelo que se ha adoptado y propagado en Colombia, hasta el punto de institucionalizarse y no ser considerado como algo anómalo que debe combatirse, sino por el contrario se interpreta como una política de vivienda alternativa para los sectores más vulnerables de la población.

Cambiando de contexto, pero siguiendo con el cuadro comparativo y aproximativo, es oportuno indicar que las invasiones en Latinoamérica comenzaron a establecerse a partir de los años cuarenta, y los casos más significativos se vivieron inicialmente en Buenos Aires, Río de Janeiro, Lima y Bogotá. Los sitios elegidos para conformar estos asentamientos fueron las zonas periféricas o zonas cercanas a actividades ferroviarias y portuarias como fue el caso de las villas de Argentina o de las favelas de Brasil. 
En el caso de Argentina, se destaca la conformación de las villas 31 del Retiro y Saldías, las cuales se constituyeron después de los años cuarenta, en proximidades del ferrocarril Belgrano. Estas villas son conformadas principalmente por población rural y por inmigrantes, dentro de los cuales se destacan italianos y bolivianos que comenzaron a llegar para la época ${ }^{325}$. Este autor destaca la convivencia de las Villas y los barrios obreros durante varias décadas, así como la permisividad de los diferentes gobiernos con este fenómeno.
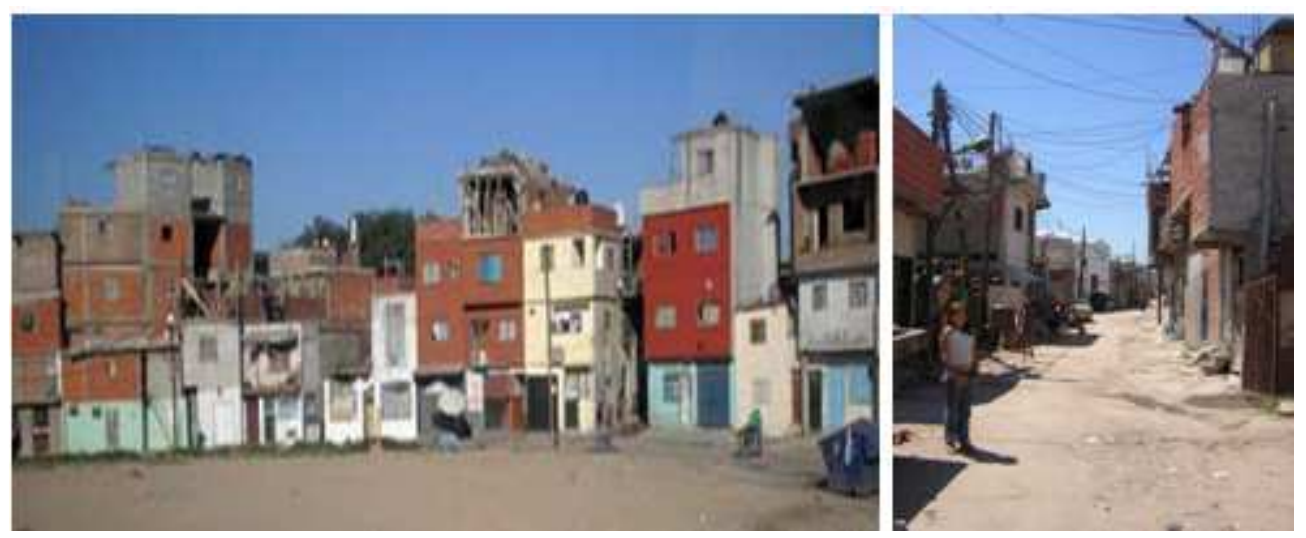

Foto Mariano García 2007

Ilustración 186. Villa 31 de Retiro Villa Soldati

En Brasil, por su parte, el origen de estos asentamientos, denominados "favelas" tuvo como principales protagonistas a la gente llegada del campo con dificultades de ahorro para acceder a vivienda formal y que procedieron a invadir terrenos desocupados en áreas insalubres o de topografía difícil, que se caracterizaban por encontrarse abandonados por sus propietarios o por escapar al control público. Estas favelas surgieron durante los dos primeros cuartos de siglo de manera espontanea y algunas veces de forma planificada por grupos organizados que incluyeron intermediarios y a veces especuladores ${ }^{326}$.

325 García, Mariano (2007): "Los años 40: crecimiento de las villas y auge de los barrios obrero". Disponible en http://www.solesdigital.com.ar/sociedad/historia villas 2.htm. Consultado Agosto 2 de 2010.

326 Andreatta, Verena (2002): “Ciudades hechas a Mano". Disponible en http://habitat.aq.upm.es/b/h23/avand.html 
En la ciudad de Bogotá, el origen de los asentamientos informales se inicia en la década de los años cincuenta, época en la que arrecia el fenómeno de la violencia política bipartidista y desencadena el éxodo del campo a la ciudad. Este éxodo genera fuertes niveles de marginación política, económica, social y cultural, que posteriormente estimularían grandes niveles de informalidad en el empleo, la vivienda y la educación.

Los barrios informales surgieron simultáneamente con grandes infraestructuras como el aeropuerto el Dorado, la autopista Norte, el Centro Administrativo, y equipamientos educativos, deportivos, recreativos y de salud. Dentro de los primeros asentamientos se destacan la Victoria, Ciudad Bolívar y San Cristóbal en el sur y suroriente de la ciudad de Bogotá.

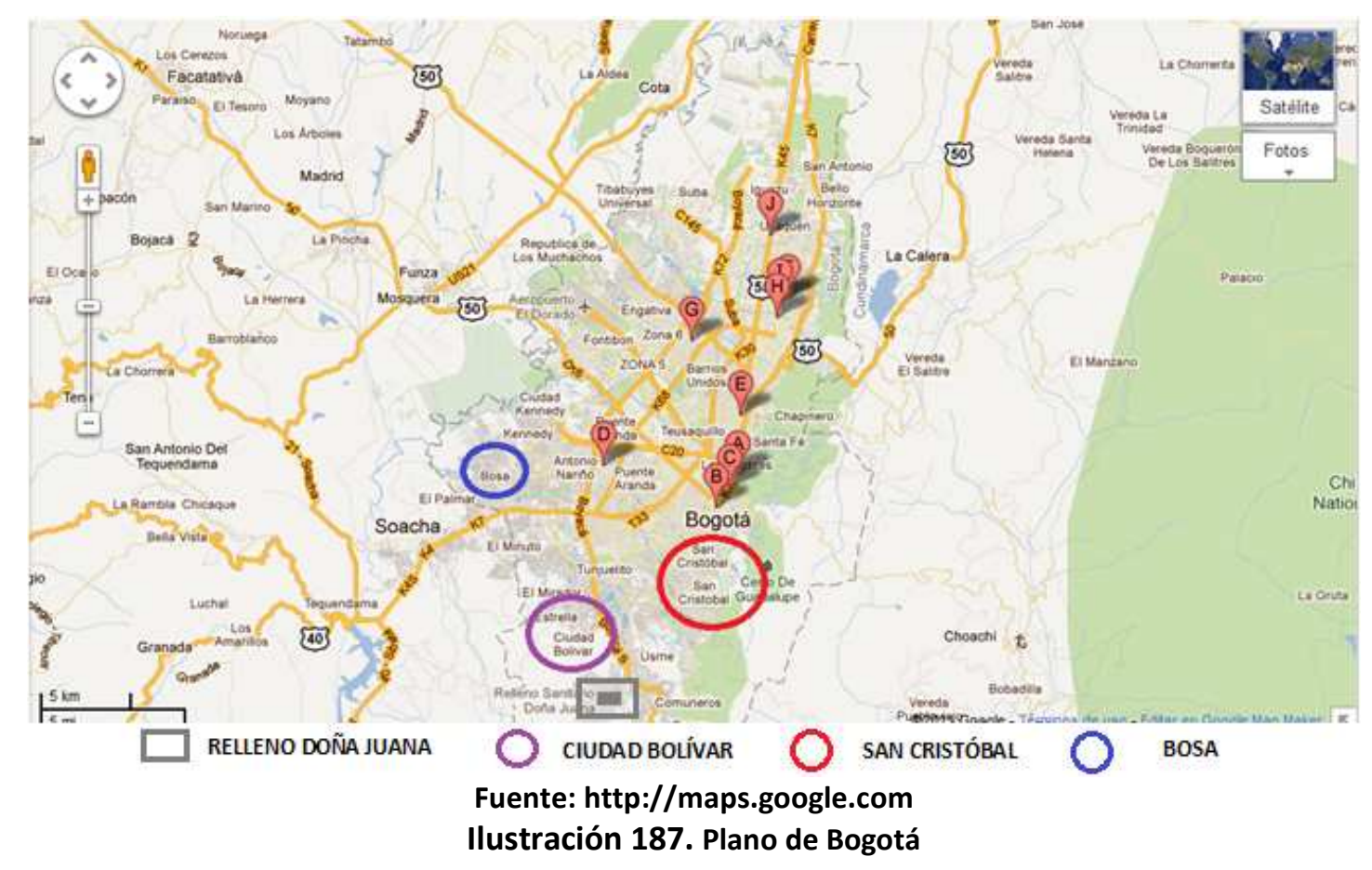

Estos barrios fueron construidos cercanos a vías nacionales, central de abastos, equipamientos y en zonas de alto riesgo o de dominio público. Igualmente se establecieron asentamientos informales en los municipios fronterizos de Usme, Suba, Engativá, Bosa, Fontibón y Usaquén ${ }^{327}$. Esta última situación contribuyó a una

\footnotetext{
327 Díaz Mosquera, Carlos (2008): Algunas Características del Proceso de Urbanización de Bogotá: Una mirada desde la marginalidad social urbana. Universidad Pedagógica Nacional. Bogotá.
} 
conurbación prematura y a la necesidad de anexar estos municipios al área urbana de Bogotá.

La anexión de estos seis municipios fue una alternativa que permitió afrontar la elevada presión por vivienda ejercida por los desplazados e inmigrantes rurales llegados a Bogotá, pero a su vez se convirtió en licencia indirecta para la depredación posterior de cerros, humedales y bosques de esta ciudad. El mayor impacto ambiental se aprecia sobre los cerros orientales, que perdieron gran parte de su vegetación ante la arremetida de los invasores.


Fuente Fotográfica: Carlos Díaz Mosquera 2008

llustración 188. Ocupación cerros de Bogotá

Las imágenes, que se remontan a la época de los años cincuenta, en Bogotá permiten apreciar que el proceso de ocupación parcial de los cerros termina convirtiéndose en ocupación total, además de transformar visiblemente el paisaje natural. Esta escena se repite de manera similar en las montañas de los andes en Colombia, Ecuador, Bolivia o Perú; en donde las barriadas, las comunas, los tugurios o los pueblos jóvenes se confunden por la topografía pero a veces se diferencian por el colorido.

Esta comparación de contextos permite corroborar que la invasión no es un fenómeno reciente ni exclusivo de las ciudades colombianas, ni mucho menos de Montería, y que por el contrario, es un modelo adoptado o permitido con anterioridad por países más desarrollados que el nuestro y con mayor apego al planeamiento urbano. Igualmente permite verificar que a pesar de las afinidades sociales o económicas encontradas, existen impactos ecológicos asimétricos, generalmente determinados por los niveles de infraestructura y/o desarrollo de las ciudades. 
En este orden de ideas, el análisis y las analogías pretenden conducir a que, en los contextos desarrollados los ocupantes tienen la posibilidad de aprovechar en primera instancia, infraestructuras como el ferrocarril, autopistas, estaciones o equipamientos; mientras que en los contextos poco desarrollados, las posibilidades se reducen solamente a ocupar zonas de alto riesgo o áreas naturales de protección, lo cual genera un impacto ambiental más negativo.

\subsubsection{Un análisis sobre el modelo de Intervención en estos asentamientos}

Ya hemos manifestado de diversas formas, y es algo natural, que la consolidación de estos asentamientos es el producto de la combinación entre intervención pública, cooperación de las organizaciones no gubernamentales (ONG), y participación comunitaria, autogestionaria, solidaria, o como se quiera denominar a la iniciativa de los habitantes de dichos asentamientos. Evidentemente, dentro de esta combinación, la mayor parte de intervención le ha correspondido al Estado, en primer lugar, con el propósito de cumplir con sus funciones constitucionales básicas, y en segundo lugar, por los elevados costos que representan estas intervenciones, para las poblaciones vulnerables o de bajo poder adquisitivo.

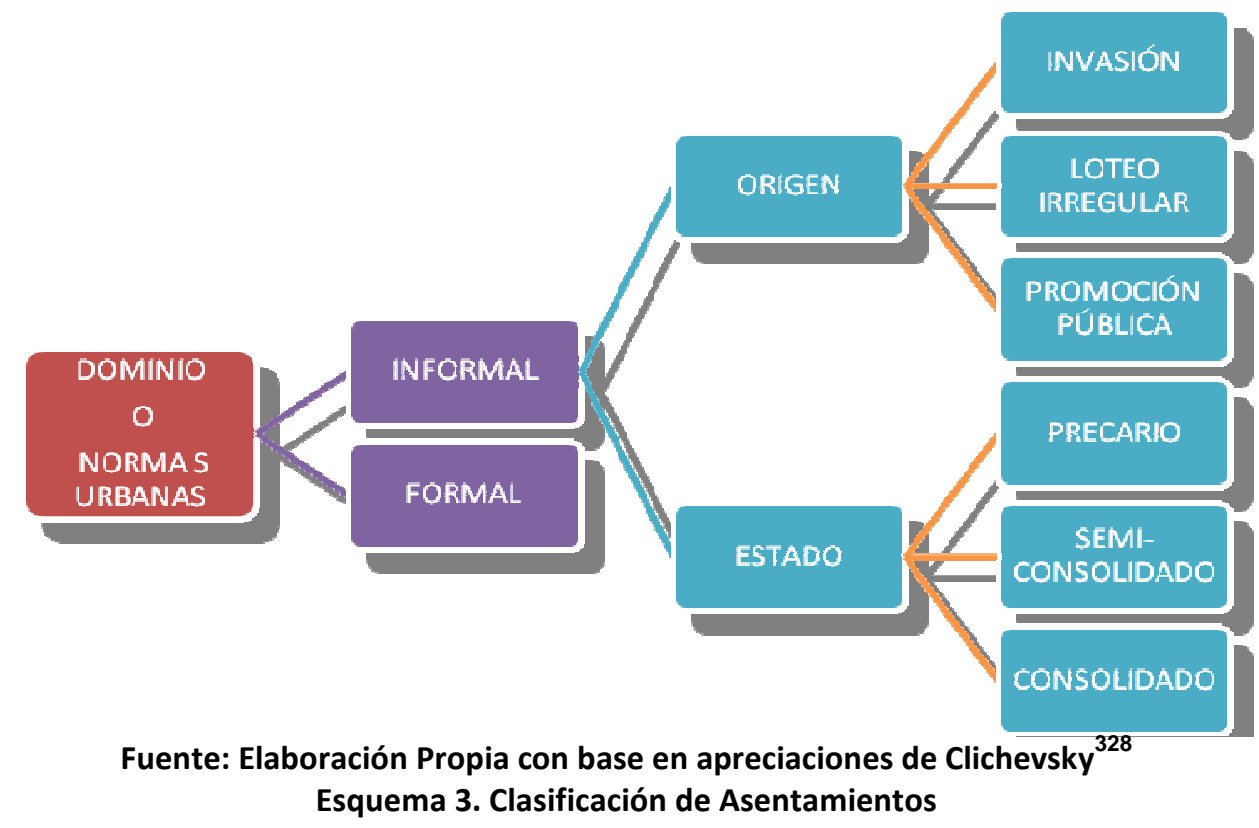

\footnotetext{
328 Clichevsky, Nora (2000): Informalidad y Segregación Urbana en América Latina. Una aproximación. CEPAL. División de Asentamientos Humanos. Santiago de Chile. Disponible en: www.eclac.org/publicaciones/xml/8/5638/lcl1430e.pdf
} 
Con el objetivo de exponer claramente nuestro análisis, consideramos pertinente partir de este esquema de clasificación de asentamientos, que proponemos desde esta investigación, el cual pretende a su vez, presentar una mejor descripción de la intervención, así como de los aciertos y desaciertos cometidos durante los procesos de semiconsolidación o consolidación de los asentamientos informales en Montería. En este esquema de clasificación se tienen en cuenta los siguientes factores: 1) dominio de la propiedad y/o normas urbanas; 2) origen del asentamiento, y 3) estado del asentamiento.

Como habíamos anotado en el capitulo cuatro, la condición de informalidad de un asentamiento puede estar asociada a la falta del dominio legal del predio o a la transgresión de las normas urbanas. Igualmente establecíamos que los asentamientos informales se originaban por medio de: 1) invasiones, 2) fraccionamientos irregulares y 3) promoción pública. Los fraccionamientos irregulares, privados o públicos, eran los que transgredían una o varias de las normas urbanísticas, y los de promoción pública los considerábamos informales cuando se desarrollaban por procesos de autoconstrucción o mediante urbanización incompleta.

También establecimos una clasificación de acuerdo con la etapa, que situamos en tres categorías o fases: a) precarios; b) semi-consolidados, y c) consolidados, las cuales se encuentran asociadas al número de años de constituido el asentamiento. Precisamente, son estas categorías las que determinan el nivel de intervención pública, el apoyo de las organizaciones no gubernamentales y la capacidad de autogestión de las comunidades. En este orden de ideas, consideramos pertinente destacar los principales desaciertos que durante más de cincuenta años han cometido los responsables de la intervención pública en la ciudad de Montería, en este tipo de asentamientos.

Con respecto a intervención pública, debemos anotar que en Colombia las normas urbanísticas, como en la mayoría de países occidentales, imponen las tres fases que se requieren para la construcción de programas de vivienda en las ciudades: parcelar; urbanizar y edificar, etapas estas, transgredidas históricamente por los urbanizadores 
populares, por los invasores o por el Estado, representado en las instituciones del ICT, INURBE, COMFACOR, FONVIVIENDA y el Fondo Municipal de la Vivienda. Estas transgresiones, desencadenaron continuamente la necesidad de establecer medidas interventoras, que generalmente no apuntaban al desarrollo urbano, sino a reparar las graves inconsistencias de dichas transgresiones, principalmente aquellas asociadas a los conflictos de usos del suelo y a la no instalación oportuna de redes de infraestructura.

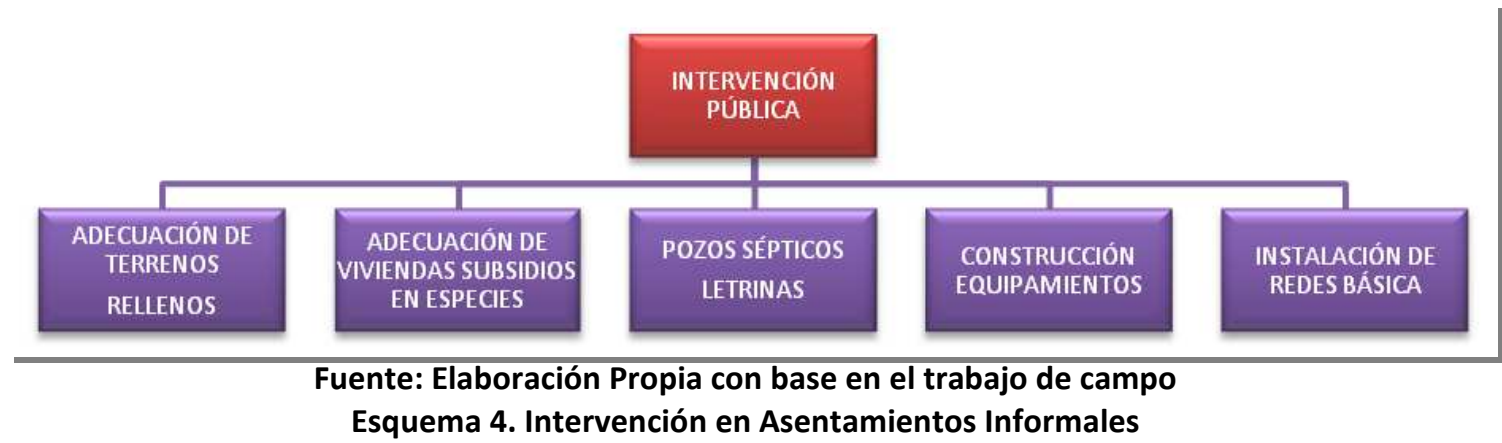

El emplazamiento de invasiones o urbanizaciones irregulares en zonas inundables o ciénagas, lleva implícita una primera intervención pública, en este caso orientada a la adecuación del terreno, mediante rellenos altamente costosos y poco efectivos. En esta primera intervención, generalmente se incluyen sistemas precarios de drenaje, que deben ser complementados posteriormente con mayores asignaciones de recursos. Luego siguen sucesivas intervenciones que van, desde la donación de materiales transitorios para adecuación de viviendas, incluidas letrinas y construcción de pozos sépticos, hasta llegar a instancias superiores de construcción de equipamientos, pavimentación de vías e instalación de redes.

Corroboramos a lo largo de estos años de investigación, que el Estado no ha sido efectivo ni ordenado en la intervención que le corresponde, al no definir programas articulados de desarrollo urbano acordes con las necesidades del asentamiento, que permita su consolidación en tiempos inferiores a treinta o cuarenta años, e incluso, que los dote inicialmente de las infraestructuras básicas. Sobre este particular destacamos que las obras no son desarrolladas por su prioridad, sino por la conveniencia de actores políticos, por la fuerza de los líderes comunitarios, por el potencial electoral del asentamiento; es decir, los recursos que se deben asignar para 
obras prioritarias en asentamientos precarios, son utilizados para obras no prioritarias en asentamientos semiconsolidados o consolidados.

\subsubsection{Una propuesta de Intervención pública en asentamientos informales}

Antes de presentar la propuesta de intervención pública para Montería es significativo destacar algunas experiencias sobre consolidación urbanística de asentamientos irregulares realizadas en otros contextos, a partir de diferenciados escenarios geográficos, sociales, culturales, políticos y económicos. Los resultados de estas experiencias, a nuestro juicio, no obedecen exclusivamente a la disponibilidad de recursos financieros, sino por el contrario, a la combinación óptima de recursos humanos, técnicos, normativos y económicos, y a la gran voluntad política de los actores implicados.

En este sentido, destacamos especialistas como John Turner ${ }^{329}$, William Magnin ${ }^{330}$ y Patricio Browne ${ }^{331}$, quienes se manifiestan a favor de soluciones de intervención en las áreas informales. Los dos primeros participaron activamente en las propuestas para las "Favelas" de Río de Janeiro y las "Barriadas" de Lima, destacando el esfuerzo colectivo de sus habitantes y las respuestas creativas e ingeniosas a situaciones complejas en entornos donde muchas veces predomina la ausencia del Estado. Por su parte, el tercero, manifiesta la necesidad de reconstruir la ciudad a partir de descubrir las interconexiones entre las formas urbanas que se presentan como desconectadas en contextos caracterizados por estratos informales que carecen, según él, de discurso y voluntad política.

John Turner, quien fue invitado a Río de Janeiro para proponer una solución al problema de la vivienda, se inclinó por la consolidación de la favela, considerando

\footnotetext{
${ }^{329}$ Las propuestas realizadas por este urbanista ingles son resaltadas en: Andreatta, Verena (2002): "Ciudades hechas a mano". Revista Hábitat. N²3. Texto consultado el 24 de Junio de 2008 y disponible en: http://habitat.aq.upm.es/boletin/n23/avand.html

${ }^{330}$ Mangin, William (1963): Op. Cit. Pág 368.

331 Browne, Patricio (2004): "Formal e Informal". Artículo publicado en www.scielo.cl/pdf/arq. Consultado diciembre de 2008.
} 
preferible su dotación mediante urbanización comunitaria e incluyendo el término de "urbanismo comunitario". Esta propuesta se hizo realidad mediante el plan director Ciudad de Río, que incorporó dos grandes proyectos: el proyecto Río - Cidade para la ciudad formal y el proyecto Favela - Barrio para la ciudad informal; en ambos se interpreta al urbanismo como "acción pública y no como pasiva formulación de códigos insuficientes" $^{\prime 332}$.

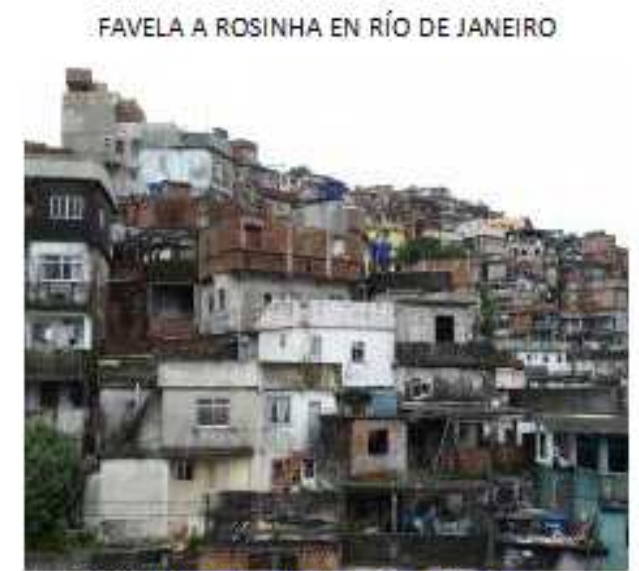

FOTO: http://vueltaalmundo.minube.com
EVOLUCIÓN DE LA FAVELA EN RIOO

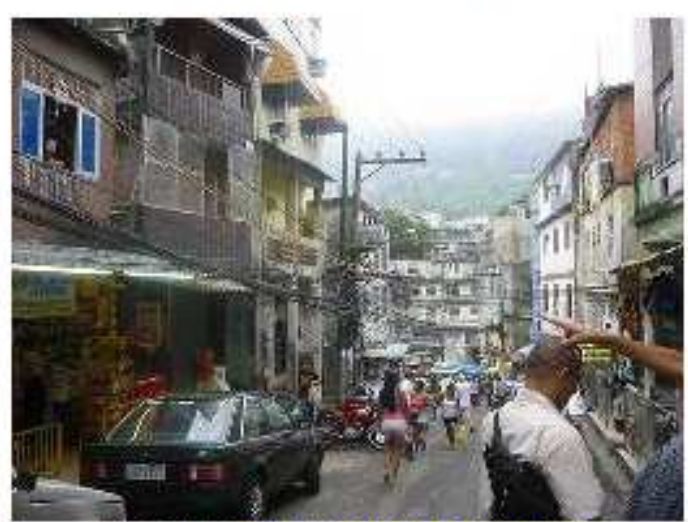

FOTO: http://www.skyscrapercity.com/

Ilustración 189. Favelas consolidadas en Río de Janeiro

El proyecto Favela - Barrio se convertiría en un referente y dentro de sus finalidades estuvieron: I) respetar y mantener las viviendas construidas con el esfuerzo de varios años, respetando valores constructivos; II) configurar o complementar la estructura urbana principal, fundamentalmente saneamiento y vías de acceso; III) introducir valores urbanísticos propios de la ciudad formal, principalmente infraestructuras y servicios públicos y sociales, y IV) resolver los problemas de riesgo ambiental, inundaciones y relocalización. Fueron 8 años de proyecto con éxito social y urbanístico donde se invirtieron 320 millones de dólares americanos con crédito del Banco Interamericano de Desarrollo en un $60 \%{ }^{333}$.

Finalizamos el análisis de esta experiencia, destacando que cuantitativamente el proyecto incluyó 124 kilómetros de canalización de torrentes y de condiciones de agua de drenaje, $800.000 \mathrm{~m}^{2}$ de calles pavimentadas, 7.800 farolas, $58.000 \mathrm{~m}^{2}$ de superficie

\footnotetext{
${ }^{332}$ Andreatta, Verena (2002): "Ciudades hechas a mano". Revista Hábitat. Pág.4. Documento consultado el 24 de Junio de 2008 y disponible en: http://habitat.aq.upm.es/boletin/n23/avand.html

${ }^{333}$ Ibíd. Pág. 6
} 
de ladera estabilizada, 292.000 metros de alcantarillado, 7.000 piezas de mobiliario urbano y $351.000 \mathrm{~m}^{2}$. Además se logró crear un centenar de cooperativas de trabajadores locales, 6 centros de información, 3 áreas deportivas, $90.000 \mathrm{~m}^{2}$ edificados de escuelas, guarderías y viviendas para realojo así como la concesión de 800.000 títulos de propiedad $^{334}$.

Otra experiencia destacable es la de Lima en el Perú, ya que allí, ante la notable dimensión de la urbanización marginal, se hizo necesaria la promulgación de la Ley 13517 de Barrios Marginales, en el año 1961, mediante la cual se asigna mayor responsabilidad al Estado en la solución del fenómeno. Estos compromisos se orientaron a la consolidación de estos sectores, mediante la inversión pública en construcción de vías, dotación de redes de servicios básicos y otorgamiento de títulos de propiedad, que fueron posibles con el apoyo de créditos del Banco Interamericano de Desarrollo (BID) y Banco Mundial.

Las inversiones públicas permitieron la legalización de 1.473 barrios en Lima, pero no la consolidación de todos, y de acuerdo con el informe de la Comisión de Formalización de la Propiedad Informal (COFOPRI), solamente el $11 \%$ de ellos fueron considerados como altamente consolidados; es decir, quedaron dotados de todos los procesos de urbanización y se superaron los problemas arquitectónicos de las viviendas y espacios públicos $^{335}$. No obstante, consideramos que 162 barrios altamente consolidados es una cifra importante, si se tiene en cuenta que otros 350 asentamientos fueron categorizados por la misma institución como consolidados, y una cifra igual como medianamente consolidados.

\footnotetext{
${ }^{334}$ Andreatta, Verena (2002): OP. Cit. Pág. 6.

${ }^{335}$ Comisión de Formalización de la Propiedad Informal (COFOPRI) [2002]: "Informe sobre la dinámica de los asentamientos humanos en Lima". Texto disponible en http://www.cofopri.gob.pe/pdpu/pdf/DinamicaAsentamHumanos.pdf
} 


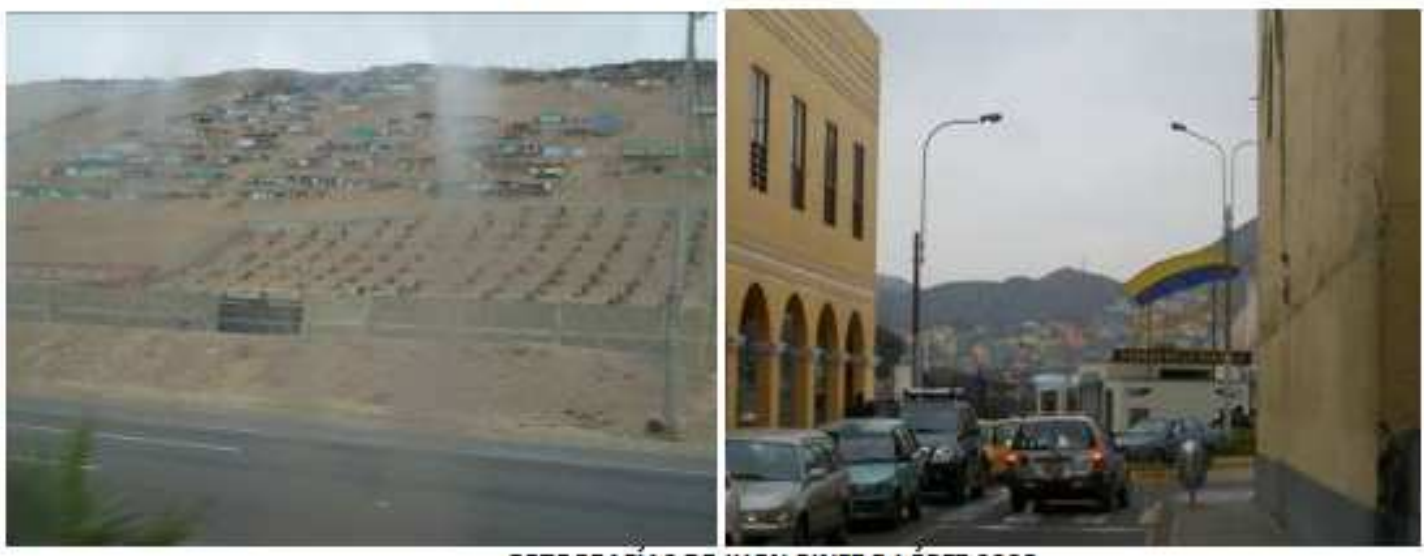

FOTOGRAFIAS DE JHON PINEDO LÓPEZ 2008

Ilustración 190. Pueblos Jovenes en Lima

Finalizamos la mirada a este contexto con las imágenes de dos pueblos jovenes en Lima en las que se alcanzan a apreciar caracteristicas diferenciadas, en cuanto a consolidación y ubicación. Mientras uno de ellos se encuentra ubicado en la zona periferica, y con cierta dificultad de integración espacial, por su distancia con el eje vial, el otro ya está integrado a la zona institucional y altamente consolidado, convirtiendose incluso, en un referente turistico.

Dejamos de lado Lima, y pasamos a analizar la experiencia de la urbanización marginal en Barcelona en España, y especificamente la representada por Busquets ${ }^{336}$ en su trabajo sobre los barrios de "coreas" desarrollado en los años 70. En este trabajo, que analiza la morfología parcelaria y tipología edificatoria de los barrios, Sant Josep, Torre Baró, la Guardia, Can Paulet, Flor de Marg y Costeres, entre otros, el autor se inclina por la legalización.

El fenómeno de la urbanización marginal en esta ciudad española fue resuelto por medio de planes parciales de desarrollo urbano y plan especial de rehabilitación, que permitieron la introducción de normas legales de promoción de la edificación, relacionadas con trámites oficiales de proyectos, superficies mínimas, licencias de obras, planos de ejecución, acabados exteriores y cierres de aceras. Igualmente se incorporaron normas que permitieron la instalación de los servicios de alcantarillado,

${ }^{336}$ Busquets, Joan (1999): Op. Cit. Pág. 176. 
pavimentación, aceras, alumbrado público y acceso de conexión sobre una superficie aproximada de 900 hectáreas de urbanización marginal ${ }^{337}$.

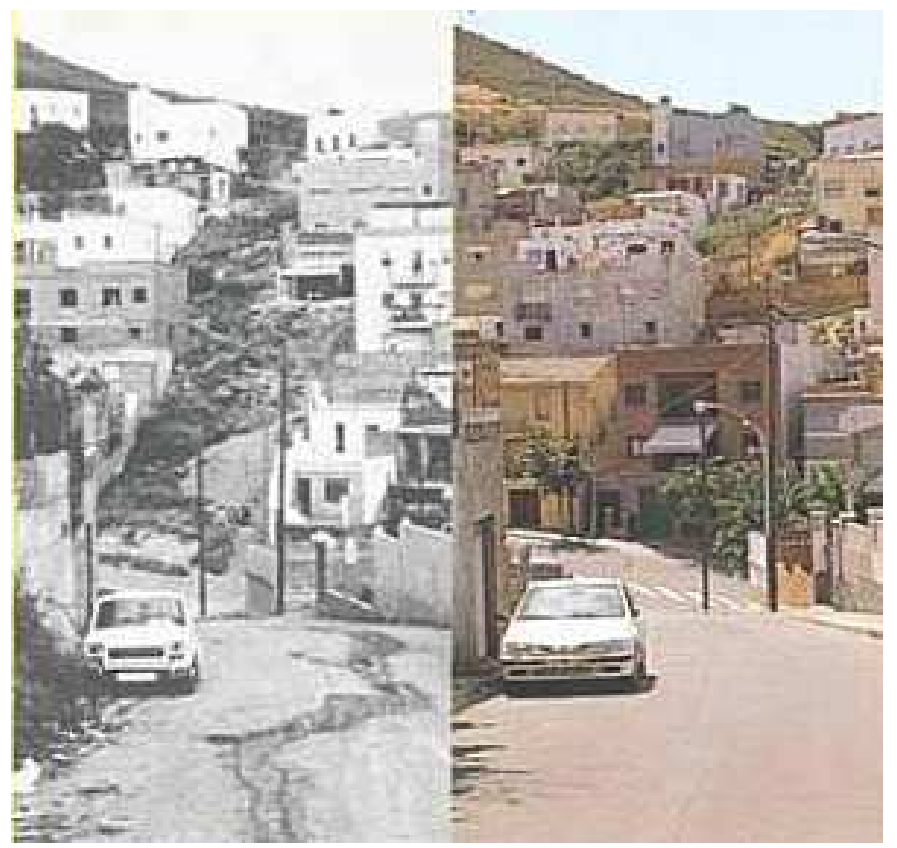

Foto Portada Libro Urbanización Marginal de Joan Busquets llustración 191. Urbanización marginal en Barcelona

Para el logro de los objetivos de legalización en este contexto geográfico, fueron necesarios variados tipos de intervención, dentro de los cuales sobresalen tratamientos encaminados a mejorar las condiciones de residencia, tales como: instalación de servicios básicos, facilidades para finalizar la construcción, ampliación o remodelación de la vivienda, que fueron financiadas complementariamente por ayuntamiento y propietarios, mediante contribuciones especiales o a través de reivindicaciones de vecinos. En lo referente a espacio público, fue necesario obtener suelo para plazas, parques y equipamientos, mediante cesión compensada, o expropiación, en el caso de obras más extensas ${ }^{338}$.

Aunque existen otras experiencias significativas, consideramos oportuno destacar las de estos contextos, principalmente por el impacto que tuvo la consolidación de las barriadas y las favelas en el surgimiento de nuevos asentamientos en esas mismas ciudades y en el resto de Latinoamérica. En segundo lugar, consideramos de gran

\footnotetext{
337 Ibíd. Pág. 171.

338 Ibíd. Pág. 171.
} 
importancia la experiencia de Barcelona, porque permitió conocer la universalidad del fenómeno y la capacidad de responder mediante soluciones alternativas diferentes a las políticas de derribo; es decir, es más significativa una intervención reparadora e integradora que una política restrictiva o derribadora.

Sin embargo, consideramos que una política reparadora e integradora debe ser concertada por todos los actores urbanos que intervienen en estos procesos, principalmente en los contextos donde el Estado ha sido permisivo con estas formas de ocupación, e incluso donde las promueve abiertamente ante su incapacidad presupuestaria para responder a las demandas de vivienda de los sectores más vulnerables de la población. En este orden de ideas, estimamos conveniente proponer el siguiente modelo de intervención pública para la reparación e integración de los asentamientos informales en Montería.

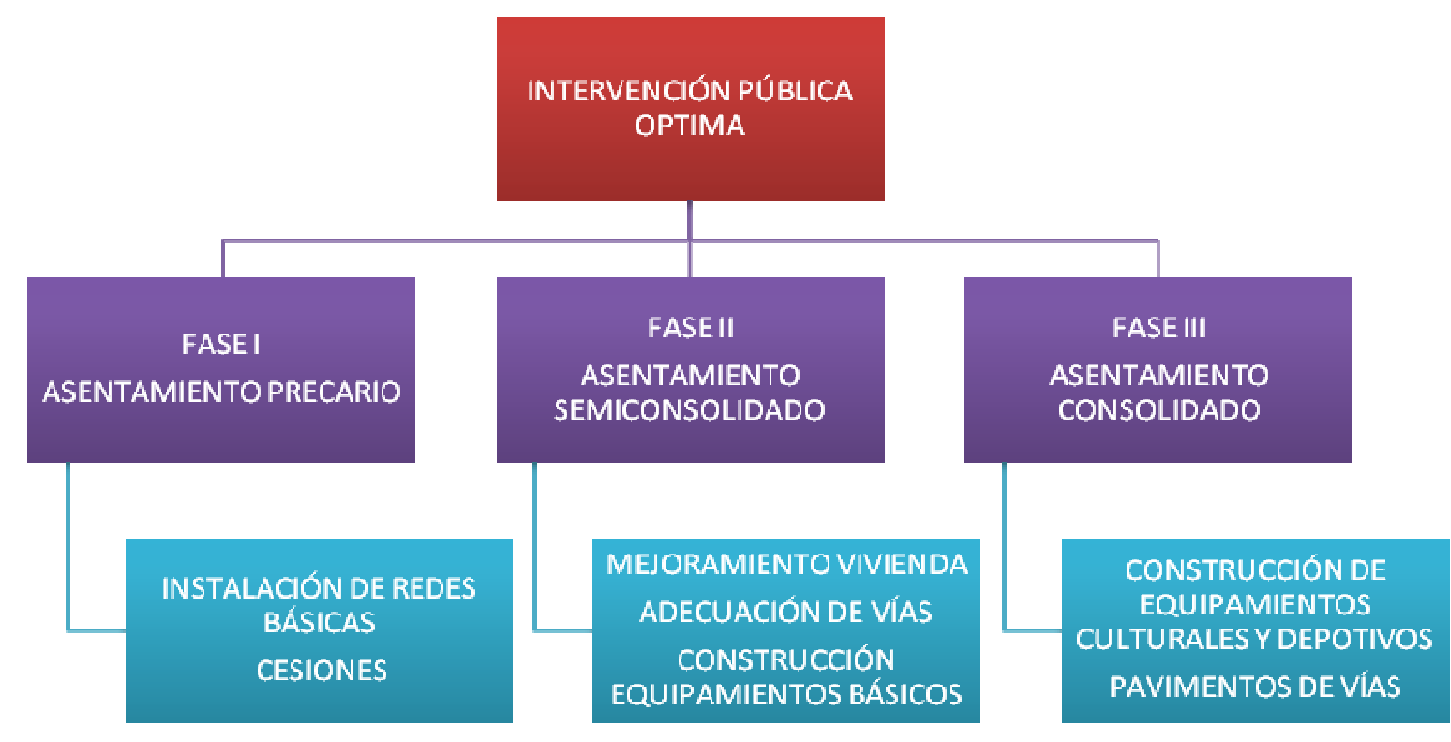

Fuente: Elaboración Propia

Esquema 5. Modelo Propuesto de Intervención Pública en Asentamientos Informales

Este esquema es, a nuestro juicio, el modelo apropiado de intervención pública en asentamientos informales, pero la experiencia en Montería refleja situaciones totalmente diferentes, que llevaron en muchas oportunidades a la realización de obras anacrónicas, o de primera fase, después de veinte, treinta y hasta cuarenta años de constituido el asentamiento. En otras oportunidades, se construyeron equipamientos en sectores precarios de fuerte caudal electoral, cuando realmente la comunidad tenía 
otras prioridades asociadas a necesidades básicas de alojamiento o de suministro de agua potable o energía.

Igualmente podemos señalar la pavimentación en hormigón de calles en sectores en donde no se habían instalado colectores de saneamiento u otro tipo de redes, generando esto en etapas posteriores, además de la vergüenza pública, traumas en la movilidad e incremento de costos. Este tipo de inconsistencias en la intervención pública la denominamos, desde nuestro enfoque, como excentricidades urbanas y el anacronismo en las obras preferimos denominarlo distorsiones urbanísticas. Ambos son el producto de un modelo de intervención diseñado desacertadamente, o de manera esquizofrénica, con ignorancia o con pleno conocimiento de su impacto sobre el espacio construido en esta ciudad, que reiteramos, desde esta investigación hemos denominado "SUBNORMA".

Por las razones expuestas, estimamos pertinente proponer este esquema de intervención pública en los asentamientos informales de Montería, que dicho sea de paso, no es un modelo producto de la imaginación ni de la creatividad, sino del sentido común que genera el planeamiento urbanístico o la aplicación de las normas urbanas establecidas por la legislación colombiana. Esta propuesta de intervención no está diseñada para resolver inmediatamente los problemas de la ciudad subnorma, pero si para optimizar los escasos recursos fiscales y para disminuir los periodos de consolidación urbanística de antiguas invasiones 0 de las denominadas urbavillanizaciones del presente o del futuro, que a nuestro parecer son inevitables, por lo menos en el mediano plazo.

Por último, después de los evidentes desaciertos urbanísticos y de los ineficientes resultados en materia de optimización de recursos fiscales, consideramos que le corresponde a la Administración Pública diseñar nuevos esquemas de intervención, sobre todo en un contexto socio-económico tan frágil como el de la ciudad de Montería, en donde la intervención de la comunidad de los asentamientos informales se reduce a participar en procesos autogestionarios, generalmente financiados con recursos públicos, y en donde además, la participación de las organizaciones no 
gubernamentales escasamente permite contribuir con prestación de servicios básicos, pero no con el desarrollo ni financiación de grandes obras urbanísticas o emblemáticos proyectos arquitectónicos.

\subsection{IMPACTO ECOLÓGICO}

En esta investigación delimitamos el impacto ecológico al efecto causado por los asentamientos informales sobre los principales ecosistemas locales, tales como el río Sinú, la reserva natural Sierra Chiquita y las ciénagas de Berlín, el Reparo, la Trampa, los Araujos y Villa Jiménez. El efecto aquí analizado se encuentra asociado directamente a fenómenos de erosión y remoción en masa en ladera, erosión sobre la ribera del río, contaminación de la fuente hídrica, desecación de ciénagas, deforestación y tubificación. Los efectos causados por el emplazamiento de asentamientos en zonas de alto potencial natural lo representamos a través del siguiente esquema.

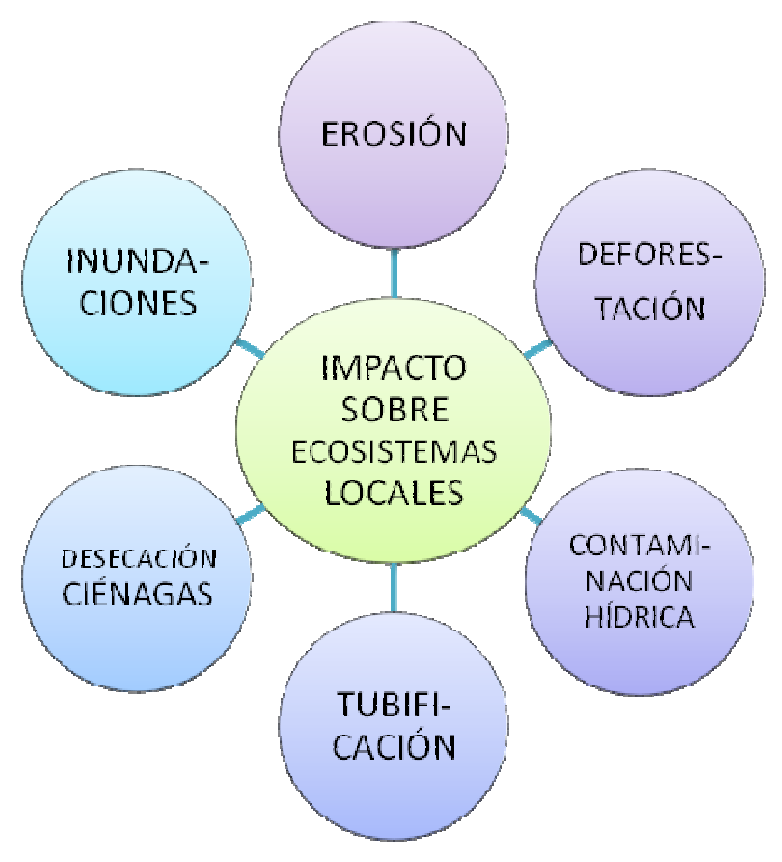

Fuente: Elaboración Propia

Esquema 6. Impacto de los asentamientos informales sobre los ecosistemas locales

La mayor amenaza por erosión se presenta en el norte de la ciudad, desde la calle 44 en el barrio Sucre hasta la calle 58 con carrera segunda. Este mismo fenómeno se evidencia en el occidente a la altura del asentamiento informal el Bongo, así como 
también en el sur sobre la margen derecha de los sectores de Brisas del Sinú y Nuevo Milenio. En los sectores descritos, además del asentamiento mencionado, se encuentran ubicados dos puntos de extracción artesanal de arena, dos lavaderos de automóviles, uno de motocicletas, la invasión Sucre, restaurantes, y el puente sobre la calle 42, con respectivas incidencias en el proceso erosivo y de contaminación hídrica.


Fuente Fotgráfica: POT 2002-2015 Ilustración 192. Erosión sobre el río Sinú

Destacamos que el cauce del río Sinú es de 310 kilometros longitudinales, que van desde su nacimiento en el municipio de Tierralta y su desembocadura en el mar Caribe, y de los cuales, 54.7 de ellos, presentan problemas de erosión por situaciones antrópicas o naturales, y que para el caso especifico de la ciudad de Montería, corresponden a 12.35 kilometros lineales de cauce, de los que se encuentran afectados por erosión 3.98 kilometros (2.5 en la margen izquierda y 1.48 en la margen derecha) $)^{339}$.

La margen izquierda corresponde al occidente de la ciudad, y consideramos que es el sector más afectado, principalmente por la inadecuada construcción de la vía que conduce al corregimiento de las Palomas y de la carretera $1 \mathrm{~W}$ que transcurre paralela al Río, desde el asentamiento informal los Colores hasta el barrio la Esperanza. Igualmente, se ubican ilegalmente en ese sector, a la altura del barrio Rancho Grande, lavaderos de automoviles, camiones y motocicletas.

Es pertinente manifestar que en este fenómeno erosivo no solamente tienen incidencia los asentamientos informales, las intervenciones realizadas y las actividades

\footnotetext{
339 Alcaldía de Montería (2010): Ajustes del Plan de Ordenamiento Territorial 2002-2015. Diagnostico Parte I Pág. 80.
} 
descritas, sino también la desecación de ciénagas, la obstrucción de canales que las alimentaban y la utilización de terraplenes en zonas rurales, con el objetivo de aumentar las fronterras agricolas o de extender las superficies para explotación ganadera. Sin excepción y sin plena conciencia de las consecuencias ambientales posteriores, campesinos, propietarios, terratenientes, ganaderos, urbanizadores e invasores urbanos, recurrieron sistemáticamente a las mencionadas barreras artificiales y contribuyeron con la erosión que actualmente sufre la ribera del río Sinú.

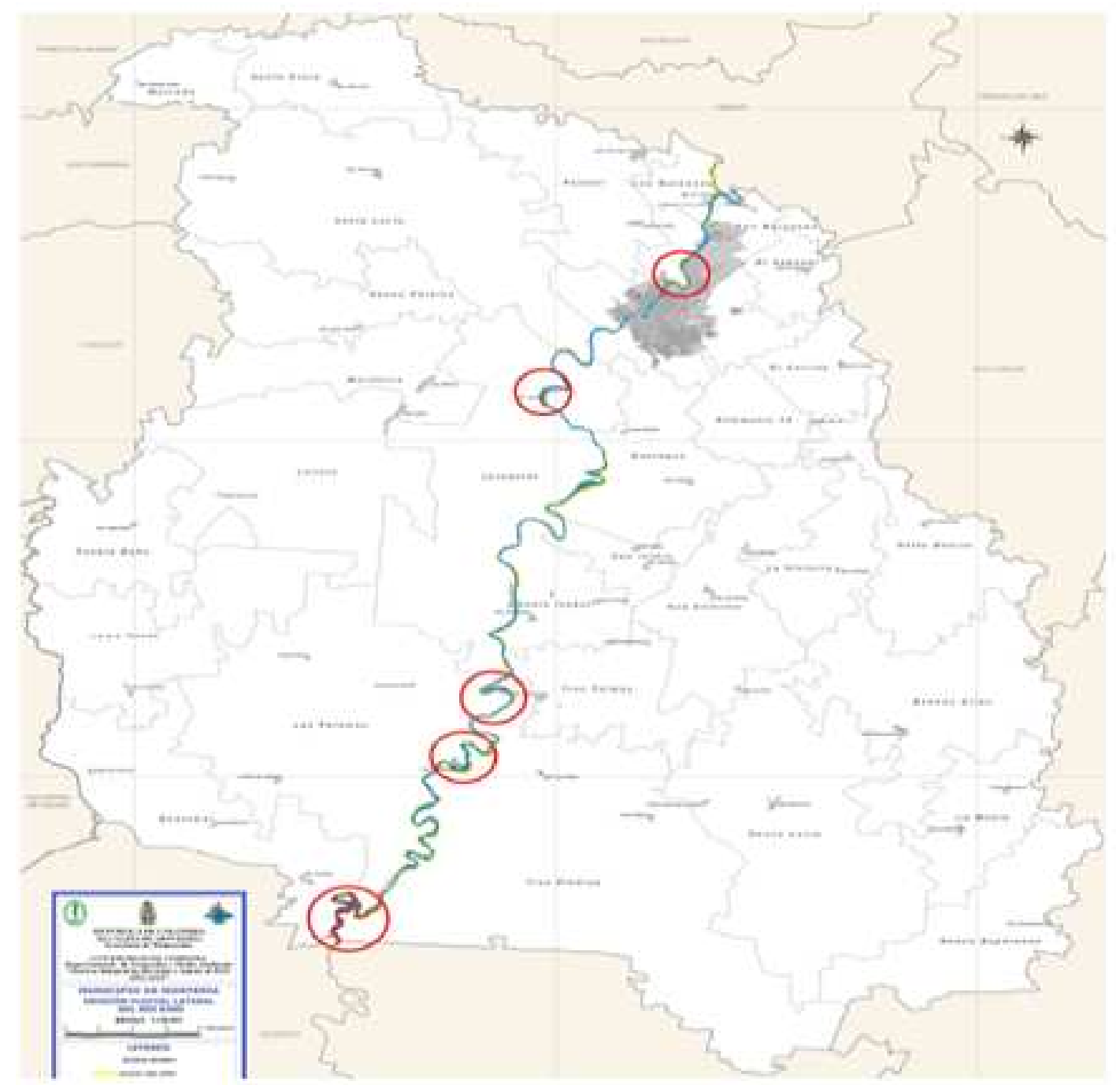

O problemas erosinos

Fuente: POT 2002-2105

llustración 193. Erosión sobre el río Sinú

La erosión afecta igualmente a las laderas de la Reserva Natural Sierra Chiquita, la cual se traduce en constantes deslizamientos de tierra que degradan la vocación natural del suelo y limitan su función ecológica. Los asentamientos informales que alteraron el 
estado de la reserva natural fueron: las Colinas, Alfonso López, los Araujos, Pastrana Borrero y Policarpa Salavarrieta, que a su vez, son definidos por el plan de ordenamiento territorial como áreas de amenaza alta por remosión en masa.

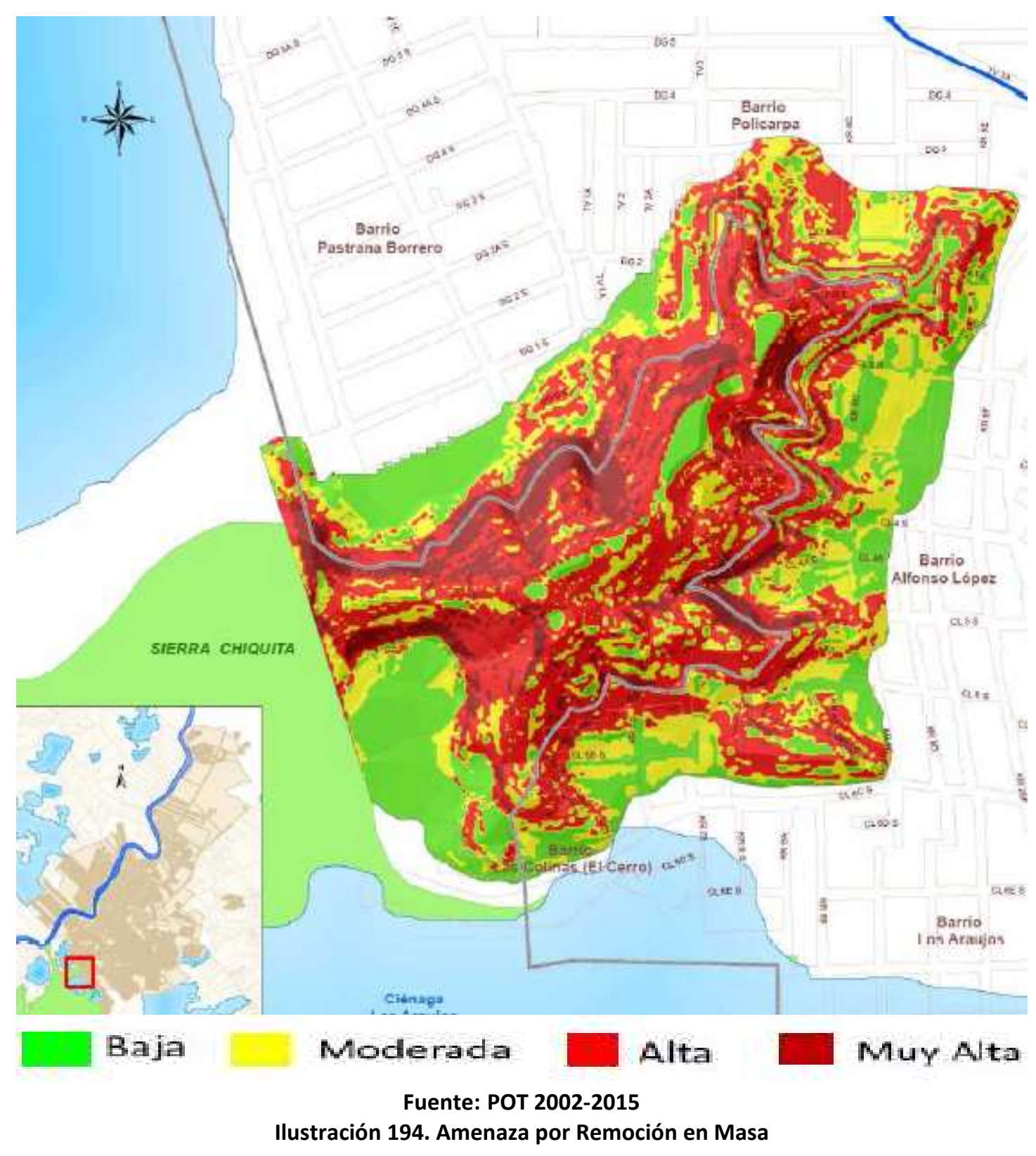

La remoción en masa que afecta a Sierra Chiquita, es el producto de la intervención antrópica y de las frecuentes e intensas lluvias de los periodos invernales. Esta intervención antrópica está directamente relacionada con la presencia de infraviviendas carentes de los servicios básicos necesarios para impedir la llegada constante de todo tipo de vertidos a las masas rocosas de la reserva; son aproximadamente cuatrocientas infraviviendas que han estado vertiendo diferentes 
residuos sólidos y liquidos por más de cuarenta años, y a pesar de los desalojos y de las tres reubicaciones realizadas, el número de éstas no se reduce y en ellas aún permanecen alojadas igual número de familias.
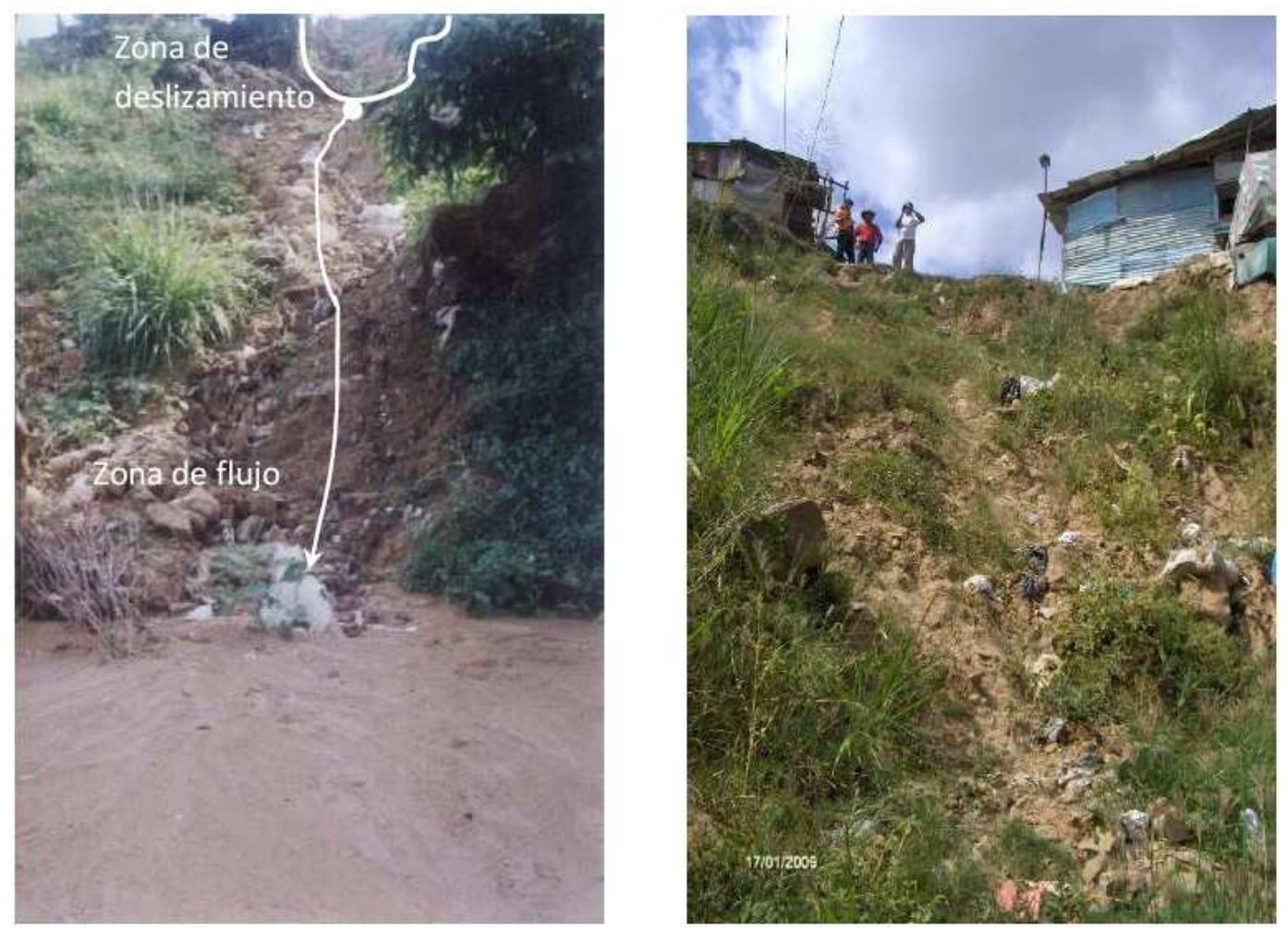

Fuente: Barrera y Barrios (2005) En POT 2002 - 2015

Ilustración 195. Erosión y Remoción en Masa en la Reserva Natural Sierra Chiquita

Las imágenes muestran zonas de deslizamientos y la presencia de infraviviendas que inciden en el aumento del flujo, sobre todo en épocas invernales. El epicentro del fenómeno es el asentamiento de las Colinas, pero no se puede omitir el alto riesgo que representan esos deslizamientos para los habitantes del barrio Alfonso López y en menor proporción para los residentes más próximos de Policarpa Salavarrieta y Pastrana Borrero. En definitiva, el emplazamiento de estos cuatro asentamientos alteró la cobertura vegetal de esta reserva natural, transformando el paisaje del bosque natural en un paisaje artificial poco agradable para la vista de observadores y/o amantes de la naturaleza. 


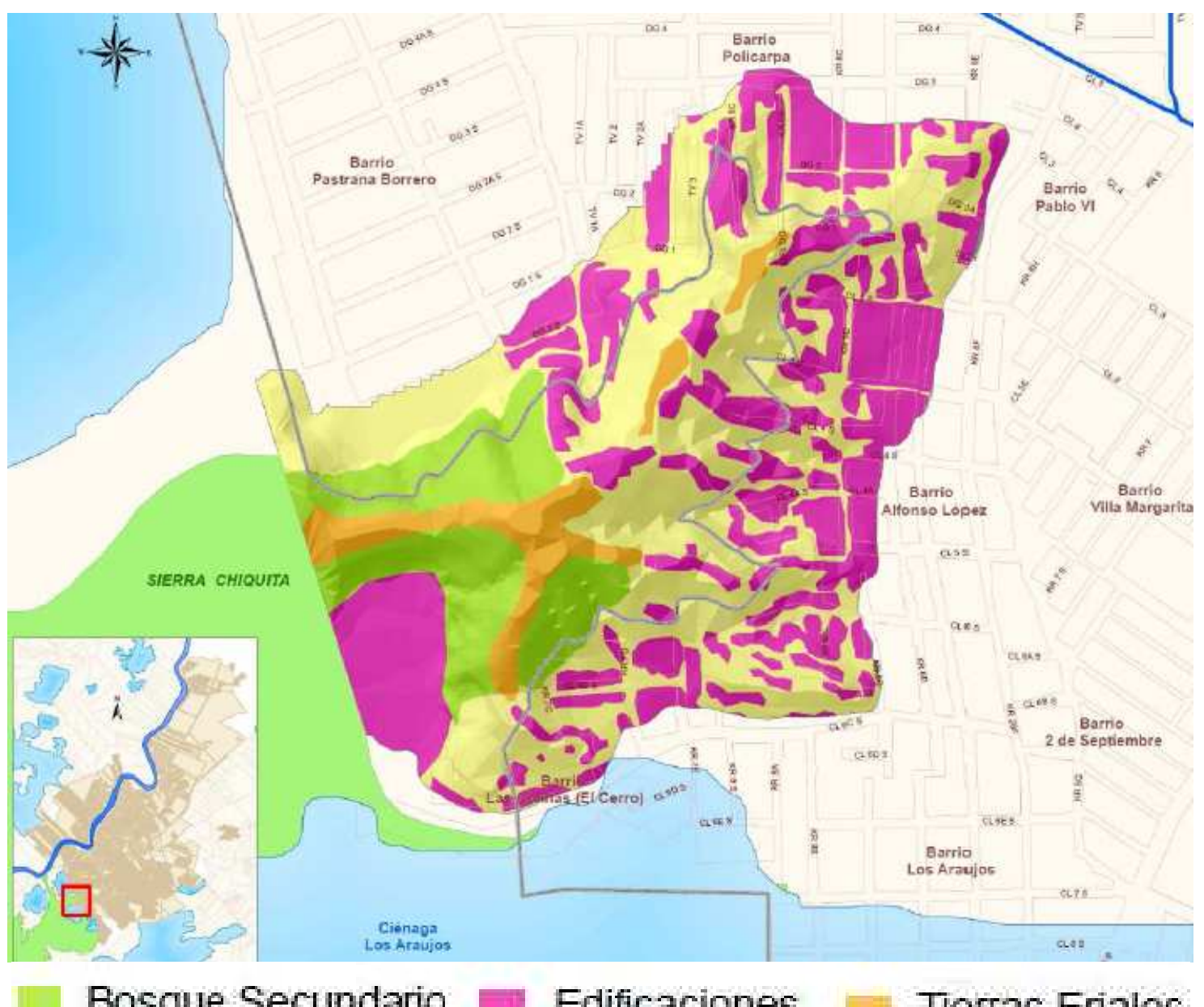

Bosque Secundario Edificaciones Tierras Eriales

Fuente POT 2002-2015

Ilustración 196. Cobertura Vegetal

La superficie total de la reserva intervenida es de aproximadamente diez hectáreas y sus edificaciones corresponden mayoritariamente a viviendas unifamiliares de planta baja, y en aislados casos a viviendas de dos alturas, que son utilizadas simultáneamente para alojamientos y negocios. Es pertinente destacar que la invasión el Cerro ocupa 3.9 hectáreas de las diez intervenidas y cerca de trescientas viviendas, que con aisladas excepciones, se encuentran construidas con materiales transitorios; mientras que las viviendas con mayor impacto de Alfonso López, Policarpa y Pastrana Borrero suman un total cercano a las doscientas, pero a diferencia de las del Cerro, la mayoría de éstas cuentan con materiales duraderos, aunque con enormes deficiencias arquitectónicas y urbanísticas. 
Consideramos que las edificaciones de los tres barrios consolidados han generado un impacto severo, pero no totalmente irreversible, y que la reubicación de las viviendas del Cerro, solamente permitirán en el largo plazo, la recuperación de 3.9 hectáreas de esta gran reserva natural de Montería. No obstante, es indudable que con un gran esfuerzo de tipo presupuestal, con voluntad política y con criterios de sostenibilidad ambiental, la administración municipal podría recuperar las restantes seis hectáreas que fueron deforestadas, y que además, presentan problemas erosivos.

\subsubsection{Condiciones medioambientales y perspectivas}

Montería, comparada dentro del contexto nacional, cuenta con favorables condiciones medioambientales, lo cual se refleja en la ubicación obtenida en el Indicador Global de Competitividad de Ciudades $2008^{340}$, en el que únicamente es superado por Riohacha y San Andrés. Para la construcción del factor ${ }^{341}$ medioambiental se tuvo en cuenta indicadores relacionados con el consumo de agua en metros cúbicos y producción de residuos sólidos en toneladas, pero no a su tratamiento, disposición final o recuperación.

\footnotetext{
340 OBSERVATORIO DEL CARIBE COLOMBIANO (2008): Indicador Global de Competitividad. Documento disponible en: http://www.ocaribe.org/sid/indicador global competitividad.php.

${ }^{341}$ Para la construcción del Indicador Global de Competitividad el Observatorio del Caribe Colombiano tuvo en cuenta, además del factor medioambiente, los siguientes factores: Recurso humano, Ciencia y tecnología, Infraestructura, Finanzas, Gestión empresarial, Fortaleza económica, Internacionalización y Gobierno e Instituciones. Es decir, es un indicador que se orienta más a medir el crecimiento económico de las ciudades que el desarrollo humano de sus habitantes
} 


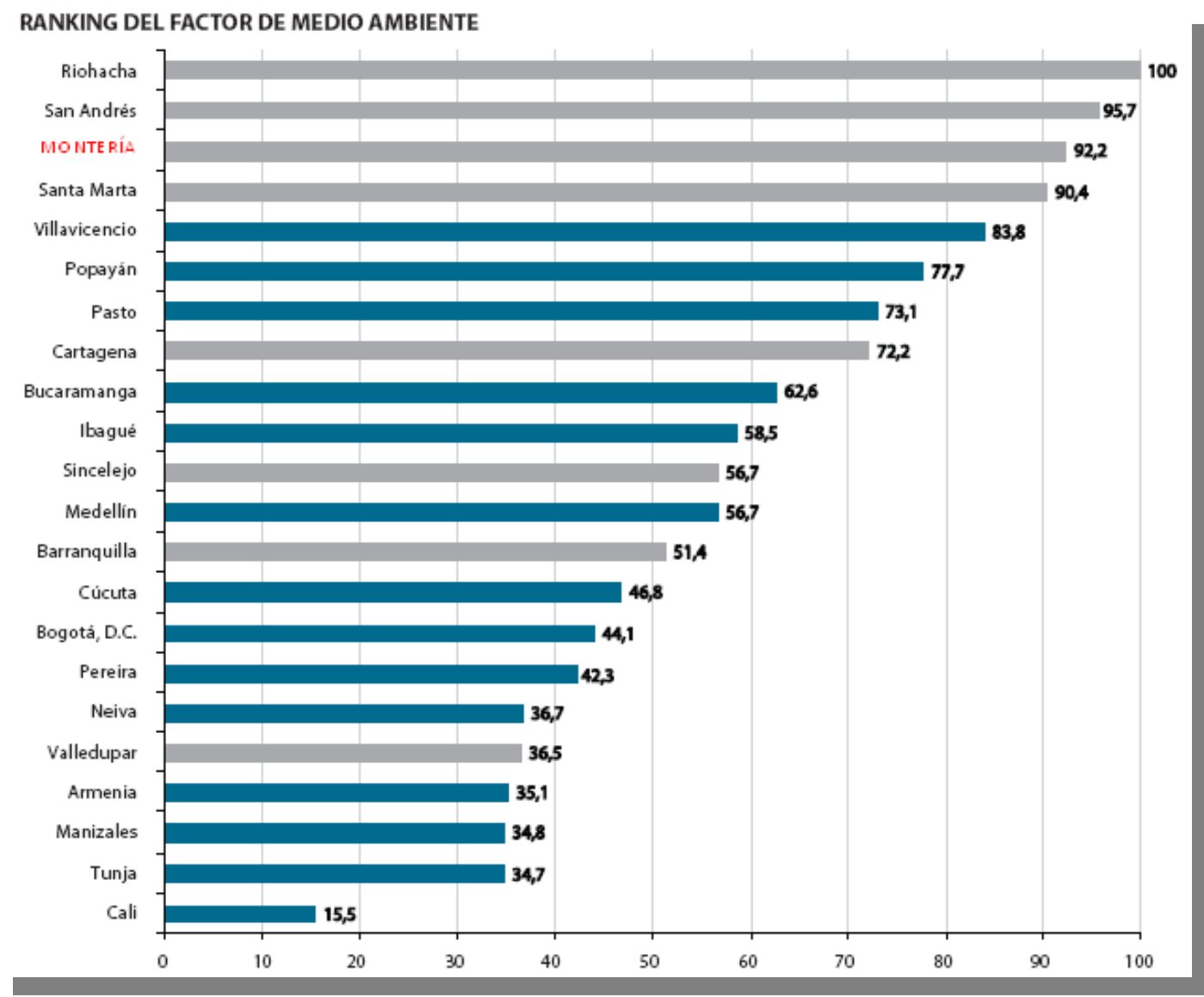

Fuente: Observatorio del Caribe 2008

Ilustración 197. Ubicación de Montería en el factor ambiental del ranking nacional de competitividad

De acuerdo con los datos sobre medio ambiente presentados por el Observatorio del Caribe en el estudio sobre Competitividad, Montería presenta buenos resultados en cuanto a bajos niveles de consumo de agua y de producción de residuos sólidos. En lo referente al recurso hídrico, la ciudad registró un consumo de $310.063 \mathrm{~m}^{3}$ por cada 10.000 habitantes en el año 2005, que correspondió al séptimo más bajo del país; y en cuanto a generación de residuos sólidos, el promedio mensual ascendió a 160 toneladas por cada 10.000 habitantes, correspondiente a la cuarta más baja producción entre las veintidós ciudades estudiadas. Estos datos permiten corroborar que los habitantes de los asentamientos informales, a pesar de su gran número, no son grandes generadores de residuos, situación bastante comprensible, debido a su bajo poder adquisitivo y a las tendencias de consumo locales.

Sobre el tema de los residuos sólidos, es pertinente anotar que la recolección en esta ciudad oscila entre 165 y 287 toneladas por día, equivalentes 6.184 toneladas mensuales, que no incluyen actividades de separación anterior. No obstante, el 
potencial reciclable de basura se ha estimado en $17.7 \%$ para cartón y papel; $10.5 \%$ para plásticos, y $4.5 \%$ para vidrio ${ }^{342}$. Sobre este último aspecto, destacamos que a pesar de no existir una política pública ambiental definida para la ciudad, existen iniciativas comunitarias o solidarias dedicadas a la clasificación y recuperación de residuos, y un ejemplo de ello, es la Cooperativa de Recicladores de Montería, que recupera mensualmente un promedio de 34 toneladas de envases y bolsas de plástico, y unas 20 toneladas entre papel y cartón.

En el tema de disposición final de residuos se evidencia un mejoramiento ambiental desde hace seis años, cuando la concesionaria de aseo Parques Nueva Montería obtuvo en el año 2005 licencia ambiental otorgada por la Corporación Autónoma de los Valles del Sinú y del San Jorge C.V.S. para construir y operar el relleno sanitario. Este relleno que comenzó a operar en marzo de 2006 cuenta con un área de 6.5 hectáreas y una vida útil de 20 años, la cual se ve amenazada por la utilización de otros municipios como Cereté, San Carlos, Ciénaga de Oro, Cotorra, San Pelayo, Planeta Rica y Pueblo Nuevo.



Estas son las imágenes del relleno sanitario que nos suministró la empresa UNIASEO, interventora del servicio de aseo en la ciudad de Montería, por intermedio de su funcionario Álvaro Ceballos, para destacar los cambios que se han venido presentando en el Relleno Sanitario desde el año 2008, cuando se decidió retirar a las personas que

\footnotetext{
342 Caracterización realizada por el Plan de Gestión Integral de Residuos Sólidos de Montería en el año 2005. Esta información fue suministrada por el Ingeniero de Relleno de la Empresa SERVIGENERAL S.A., Carlos Mario Martínez el día 13 de octubre de 2009.
} 
desde hace más de treinta años venían separando y clasificando residuos reutilizables, tanto en el botadero a cielo abierto, como en el mismo relleno. Las personas que aparecen en la fotografía izquierda, posteriormente conformarían la Cooperativa de Recicladores de Montería, que hasta la fecha sigue laborando de manera organizada en diferentes sectores de la ciudad.

\subsubsection{Dificultades para la Sostenibilidad Ecológica y otros impactos}

Sobre este concepto, Agudelo Patiño ${ }^{343}$ considera que en algunas ciudades, además de la sostenibilidad ecológica, también se encuentran comprometidas la gobernabilidad, la habitabilidad y la productividad. Según este autor, la sostenibilidad ecológica hace referencia a dos ámbitos específicos: el de los ecosistemas o medio ambiente urbano y el de las relaciones sociales. Sobre su primera afirmación, nosotros coincidimos con él, pero con respecto a la sostenibilidad ecológica, preferimos delimitarla a un solo ámbito: el de los ecosistemas o medio ambiente urbano, y trasladar el análisis de las relaciones sociales a un ámbito diferente, es decir, al social. Sin embargo, corroboramos desde esta investigación que la insostenibilidad de algunos de los ecosistemas locales de Montería, es el producto de la ingobernabilidad, del deterioro de las relaciones sociales y productivas, y de la primacía de los intereses privados sobre los públicos en estos cincuenta y nueve años de vida administrativa como capital de departamento.

En el deterioro de los ecosistemas locales juega un papel importante lo que Girardet ${ }^{344}$ denomina "Metabolismo Lineal de las Ciudades", es decir, la entrada de mercancías, agua, combustible, madera y alimentos, que a su vez, generan salidas o emisiones de gases residuales, desechos sólidos o vertidos líquidos. También consideramos oportuno incorporar a este metabolismo lineal de las ciudades la entrada y salida de

\footnotetext{
${ }^{343}$ Agudelo Patiño, Luis Carlos (2004): Evaluación de la sostenibilidad ecológica del área metropolitana de Medellín. Tesis Doctoral U.P.V. Valencia. España. Pág. 180

${ }^{344}$ Girardet, Herbert (1992): Ciudades Alternativas para una Vida Urbana Sostenible. Celeste. Ediciones, Madrid. En Agudelo Patiño, Luis Carlos (2004): Op. Cit. Pág. 186.
} 
personas, que resultan de los dinámicos flujos migratorios o de los forzados desplazamientos del campo a la ciudad o entre ciudades.

Estos dinámicos flujos migratorios no son ajenos a las ciudades colombianas y mucho menos a Montería, que recibe continuamente personas desplazadas por la violencia, que alteran su metabolismo lineal de entrada y salida. En esta alteración del metabolismo, tienen gran incidencia los asentamientos informales, debido a su elevada población, alto consumo de mercancías, agua, combustible, madera, alimentos y suelos, principalmente el de los ecosistemas locales de mayor potencial natural.

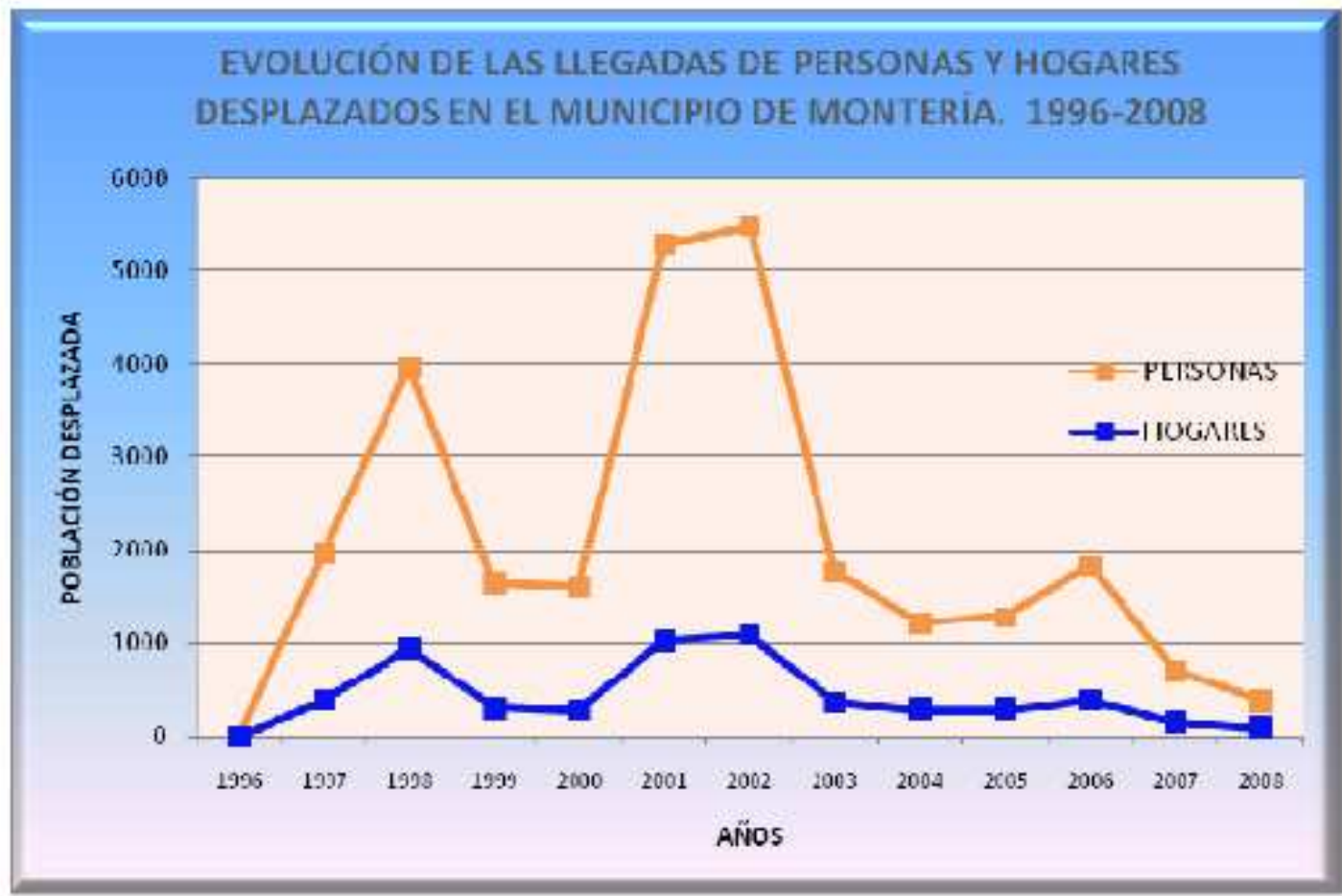

Fuente: Acción Social 2009 en РОT 2002-2105

Ilustración 199. Desplazados Ilegados a Montería entre 1996 y 2008

Las cerca de veintisiete mil personas que llegaron desplazadas en los últimos quince años, no tuvieron opciones diferentes a las invasiones, fundamentalmente aquellas que se emplazaron en zonas de alta vulnerabilidad ambiental y que deben ser reubicadas por su fuerte impacto ecológico. Dentro de los asentamientos que el plan de ordenamiento territorial 2002-2011, incluyó para reubicación, por su negativo impacto ambiental se encuentran: Casa Finca, Ranchos del INAT, Nuevo Milenio, el Canal de Cantaclaro, Sucre, el Poblado, el Enjambre, el Cerro y 7 de Mayo. Sin 
embargo, hasta la fecha dicha reubicación no se ha realizado, y algunos de ellos siguen vertiendo directamente al río.

Siguiendo con el tema de los impactos, consideramos que el mayor efecto de la urbanización marginal en Montería se encuentra asociado a la destrucción de cuerpos de aguas de la cuenca del río Sinú, y dentro de los cuales sobresalen particularmente, las ciénagas de Berlín, el Reparo y la Trampa, ubicadas en el occidente de la ciudad. Los barrios constituidos en esta zona se encuentran en alto riesgo de inundación, especialmente los asentamientos informales de la Vid, los Colores, el Dorado, el Poblado, Villa Nazaret, el Níspero, la Palma, Mi Ranchito, el Ébano, Rancho Grande, Casa Finca, el Portal, la Navarra, el Amparo y el Minuto de Dios.



Fuente: POT de Montería 2002-2015

Ilustración 200. Emplazamiento de la Vid y Los Nísperos en la Ciénaga Berlín

Dentro de estos barrios, la Vid y el Níspero en el occidente, se encuentran por fuera del perímetro urbano, así como Villa Jiménez y el Privilegio en el suroriente y sur de la ciudad. La Vid y el Níspero ocupan una porción de terreno de la ciénaga de Berlín, con los elevados costos ambientales que ello representa, además del riesgo de inundación de otros asentamientos del entorno como los Colores, Villa Nazaret y la Palma. Igualmente existe alta amenaza de inundación en los barrios Villa Real, Villa Nueva, Juan XXIII, el Tambo, la Esperanza, Mi Ranchito, Casita Nueva y Manuel Antonio Buelvas. 


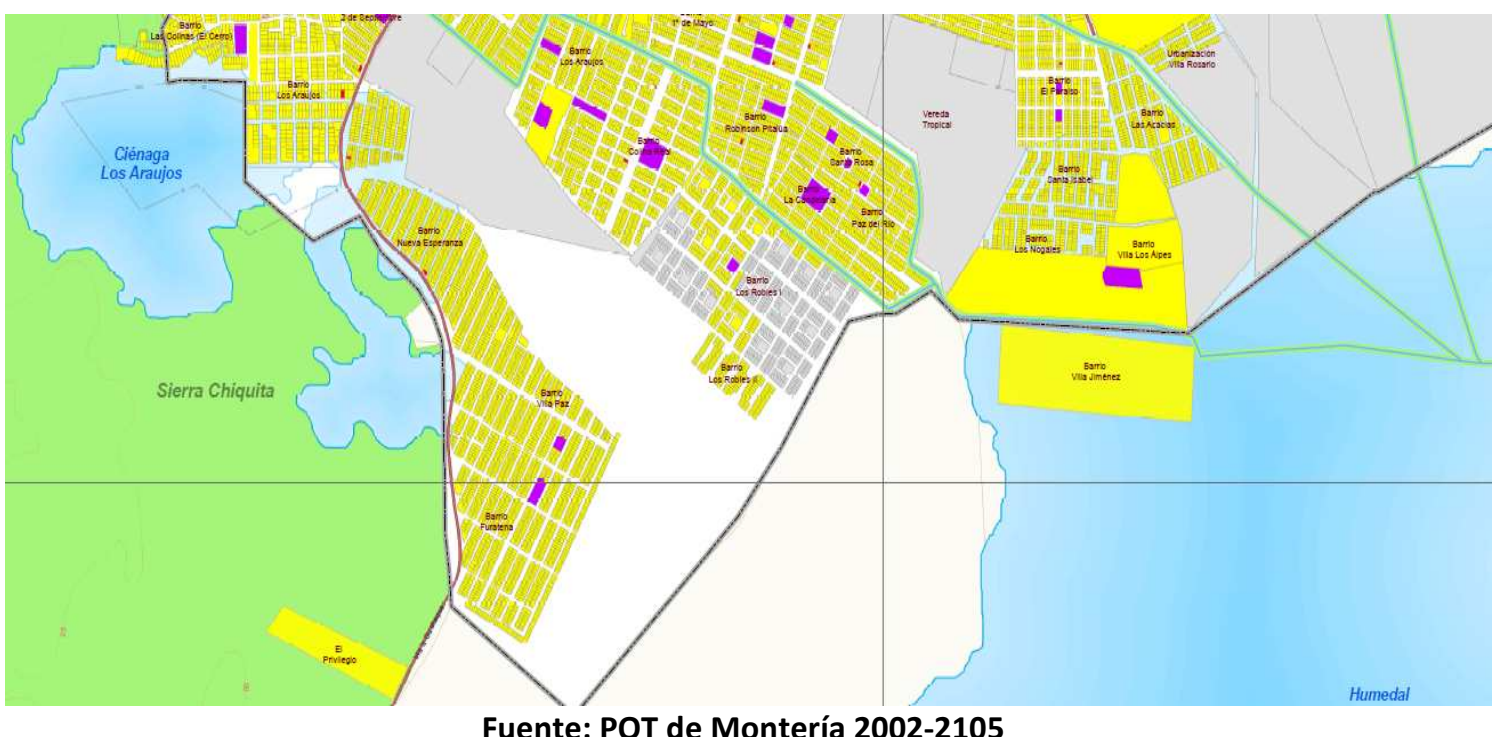

Fuente: POT de Montería 2002-2105

Ilustración 201. Emplazamientos sobre la reserva Sierra Chiquita y Ciénagas Araujos y Villa Caribe

En el entorno de Sierra Chiquita se ubican los asentamientos de Furatena, Villa Paz, Nueva Esperanza, Alfonso López y el Cerro; pero dentro la reserva propiamente, además del Cerro, también se encuentra el Privilegio, con gran impacto negativo sobre el paisaje. Así mismo, presentan impacto negativo el emplazamiento del barrio los Araujos, en la ciénaga que lleva el mismo nombre y la invasión Villa Jiménez en el humedal ubicado en el suroriente de la ciudad de Montería. Los barrios con mayor vulnerabilidad a las inundaciones, a pesar de los enormes esfuerzos de relleno en este sector son: Villa Jiménez, Furatena, Villa Paz, Nueva Esperanza, los Nogales y Villa de los Alpes. 


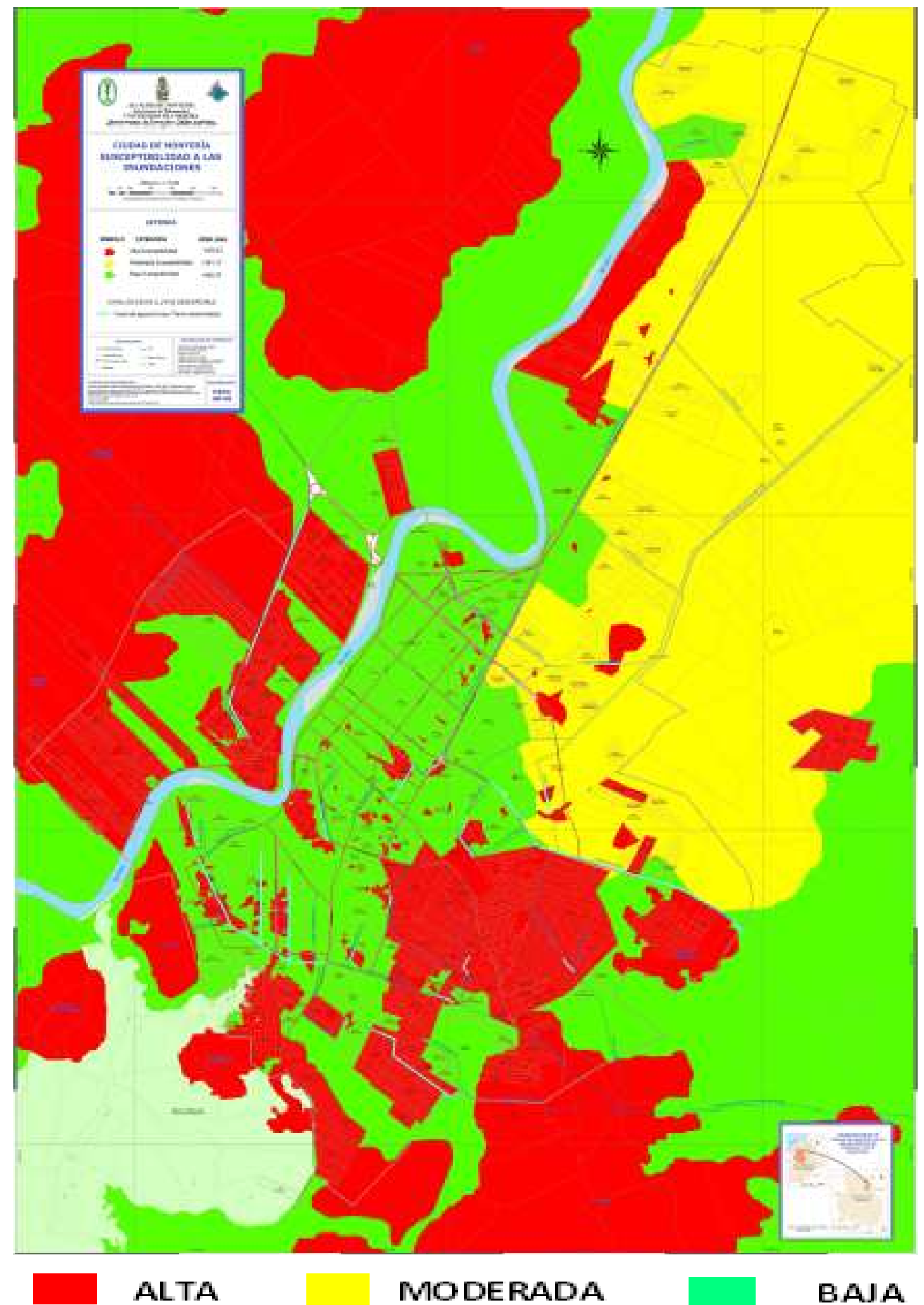

Fuente: POT de Montería 2002-2015

llustración 202. Vulnerabilidad a Inundaciones

La mayor vulnerabilidad a la inundación la presentan los asentamientos informales del occidente y suroriente de Montería, así como el 7 de Mayo en el norte y Villa Cielo en el oriente. Los sectores calificados como de alta amenaza de inundación por el POT 
2002-2015 son: el 25 de Agosto, el limonar, Cantaclaro, la Pradera, 6 de Marzo, el Diamante, Edmundo López, Damasco, el Alivio, San Cristóbal, Mogambito, Villa Rocío, Villa Ana II, Boston, Mogambo, la Candelaria, Robinson Pitalúa, Paz del Río, los Robles, Colina Real, Urbanización los Araujos, Panzenú, Villa Margarita, Alfonso López, los Colores, el Portal, la Navarra, Nazaret, los Ébanos, la Vid, el Campano, la Palma, Rancho Grande, Betancí, Caracolí, Nueva Holanda, la Ribera, Villa Real, Villa Nueva, Río de janeiro, Casita Nueva, Minuto de Dios, la Magdalena, Juan XXIII, Manuel Antonio Buelvas, el Tambo, Villa Jiménez y Villa Cielo.

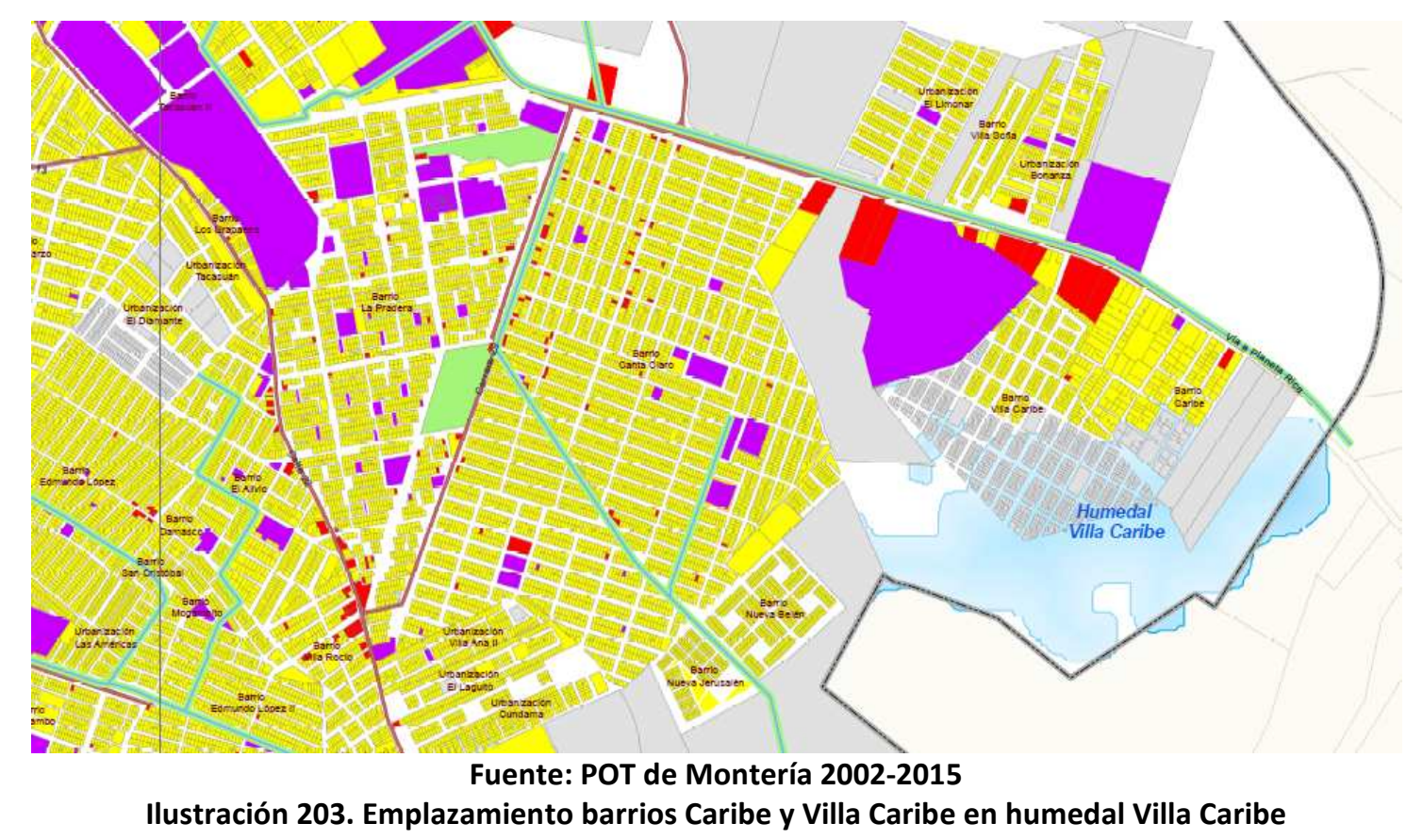

En el oriente, además de Villa Cielo y Cantaclaro, también se encuentran en situación de alta vulnerabilidad a las inundaciones, los barrios Caribe y Villa Caribe, emplazados en gran parte, en el humedal del mismo nombre. Estos dos barrios no fueron constituidos por medio de invasiones, sino a través de fraccionamientos irregulares de desarrollo progresivo, que iniciaron su trazado a partir de la vía a Medellín, pero afectando más de cinco hectáreas de dicho humedal y estableciendo el límite del perímetro urbano por este sector de la ciudad de Montería.

Las repetidas inundaciones en amplios sectores de la zona urbana y los infructuosos esfuerzos por erradicarlas, generan un permanente debate acerca de sus causas. En 
este sentido, Sánchez y Giraldo ${ }^{345}$, consideran que las inundaciones periódicas que se presentan en la ciudad de Montería obedecen al deterioro ambiental ocasionado por políticas gubernamentales que buscaban resolver problemas de emergencia en tierras de hacendados, ubicadas aguas arriba del río Sinú a la altura del corregimiento de las Palomas en la margen izquierda. Dentro de estas políticas se incluyeron el taponamiento de varias bocas del río que nutrían y daban vida a una serie de caños, así como el relleno de ciénagas y humedales para dedicarlos a explotación ganadera o agrícola.

\begin{tabular}{|l|c|c|c|}
\multicolumn{1}{|c|}{ Ciénaga } & $\begin{array}{c}\text { Transformación } \\
\text { total }\end{array}$ & $\begin{array}{c}\text { Perturbación } \\
\text { severa }\end{array}$ & $\begin{array}{c}\text { Perturbación } \\
\text { puntual }\end{array}$ \\
\hline Broquelito (Margen izquierda) & $\mathrm{X}$ & & \\
\hline Lamemanga (margen izquierda) & $\mathrm{X}$ & & \\
\hline El Deseo (margen izquierda) & $\mathrm{X}$ & & \\
\hline Lamina (margen izquierda) & $\mathrm{X}$ & & \\
\hline Las Brisas (margen izquierda) & & $\mathrm{X}$ & \\
\hline El Congo (margen izquierda) & $\mathrm{X}$ & & \\
\hline Morrocoy (margen izquierda) & $\mathrm{X}$ & & \\
\hline La Sirena (margen izquierda) & $\mathrm{X}$ & & \\
\hline Monteblanco (margen izquierda) & $\mathrm{X}$ & & \\
\hline Enea (margen izquierda) & $\mathrm{X}$ & & \\
\hline Todos Veran (Palotal) & & $\mathrm{X}$ & \\
\hline Ciénaga larga (Palotal) & & $\mathrm{X}$ & \\
\hline Pisalindo (Palotal) & & $\mathrm{X}$ & \\
\hline La Trampa (Montería) & & $\mathrm{X}$ & \\
\hline El Reparo (Montería) & & $\mathrm{X}$ & \\
\hline Redonda o Martinica (Montería) & & $\mathrm{X}$ & \\
\hline Berlín (Montería) & & $\mathrm{X}$ & \\
\hline El Coco (Montería) & & & \\
\hline
\end{tabular}

Fuente: POT de Montería 2002-2105

Tabla 28. Situación actual de los Humedales de Montería

La desecación de las ciénagas se dio por medio de camellones o rellenos en épocas de verano, que permitieron la apropiación ilegal de propietarios legales de predios cercanos, para dedicarlas a las actividades mencionadas o a la urbanización irregular, en el caso de las zonas urbanas o suburbanas. En este proceso de arrasamiento de humedales sufrieron transformaciones totales nueve ciénagas, mientras que ocho de ellas, sufren perturbación severa, es decir, un deterioro ambiental agudo, que puede ser reversible o irreversible. En este aspecto, la ciénaga de Berlín, a diferencia de las

\footnotetext{
345 Observatorio del Caribe Colombiano (2009): Montería de Espaldas al Sinú. (Relatores):Sofán Sánchez, Antonio y Giraldo García, Mario Pág. 282-309
} 
del resto del cuadro anterior, es la única afectada por procesos de urbanización irregular, sin dejar de anotar el riesgo al que se exponen las del Reparo y la Trampa, muy cercanas al perímetro urbano de occidente.
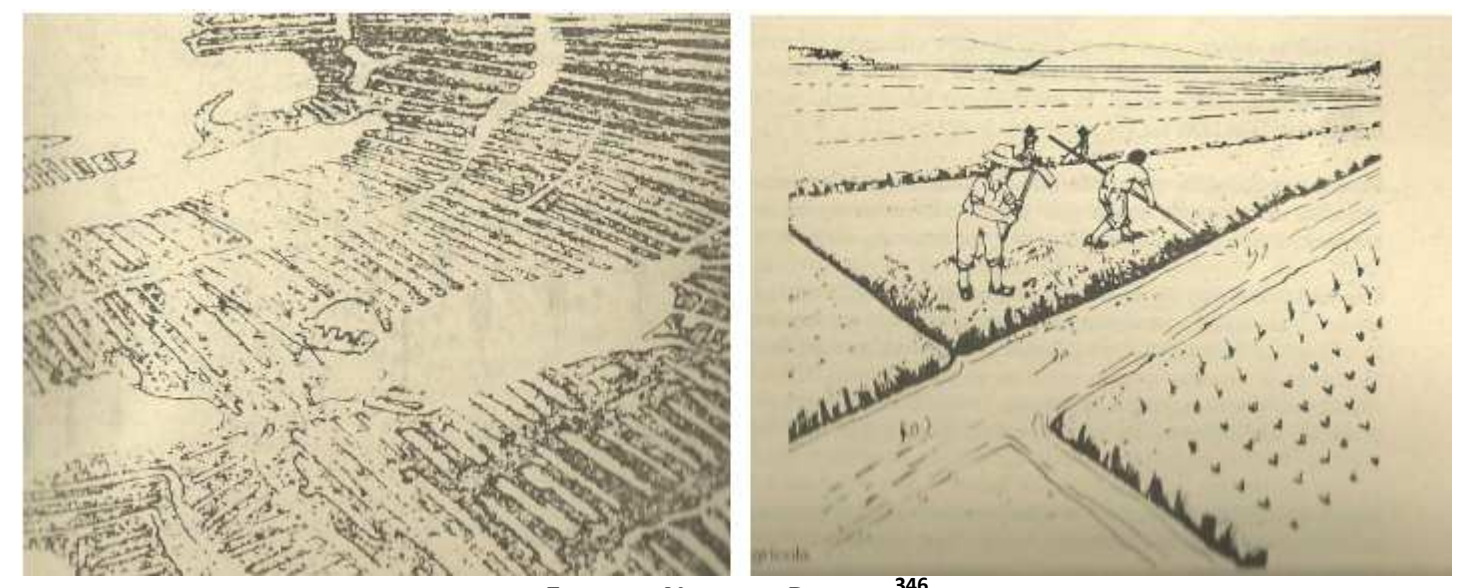

Fuente: Negrete Barrera ${ }^{346}$

Ilustración 204. Esquema de camellones construidos en zonas cenagosas

El secamiento intencionado de las ciénagas los Araujos, Berlín, el Reparo y Villa Caribe, conllevó a un impacto sobre la fauna local, que se tradujo en la disminución o extinción de especies animales como el armadillo (dasipus novencintus), hicotea (trachemys callirostris), morrocoy (chelonoidis carbonaria), sábalo (tarpon atlanticus), babilla (caimán fuscus), pato (anade real), manatí (trichechus manatus), doncellas (coris julis), bagre (sorubim cuspicaudatus), mojarra amarilla (caquetaia kraussi), cocobolo (aequidens pulcher), barbul (pimelodus clarias), moncholo (hoplias malabaricus), cacucho negro (hemancistius wilsoni), y chavarrí (chauna chavarria) ${ }^{347}$. La pesca de alguno de estos animales, principalmente la del moncholo y la mojarra amarilla, sirvieron de sustento o alimentos a diferentes familias monterianas por más de cinco décadas, pero su extinción definitiva, terminó con este par de posibilidades, tanto para pescadores como para consumidores.

\footnotetext{
${ }^{346}$ Negrete Barrera, Víctor (Editor): Memorias del Taller Nuestras Ciénagas. Montería, Abril, 10 y 11 de 1992. Pág. 93.

${ }^{347}$ Ibíd. Pág. 30.
} 


\subsubsection{Impacto generado por la red de canales de aguas pluviales}

El problema de las inundaciones en la zona urbana de Montería se ha intentado resolver por medio de un precario sistema de drenaje, el cual está conformado por cerca de cuarenta y cinco kilómetros de canales, que atraviesan la ciudad de sur a norte y de occidente a oriente. Estos canales fueron diseñados para conducir las aguas hasta el municipio de Ciénaga de Oro, en el norte del departamento y distante a unos treinta kilómetros de esta ciudad, pero desafortunadamente, algunos de ellos vierten directamente las aguas sobre zonas de las ciénagas cercanas, principalmente las de Berlín y la Redonda en el occidente.

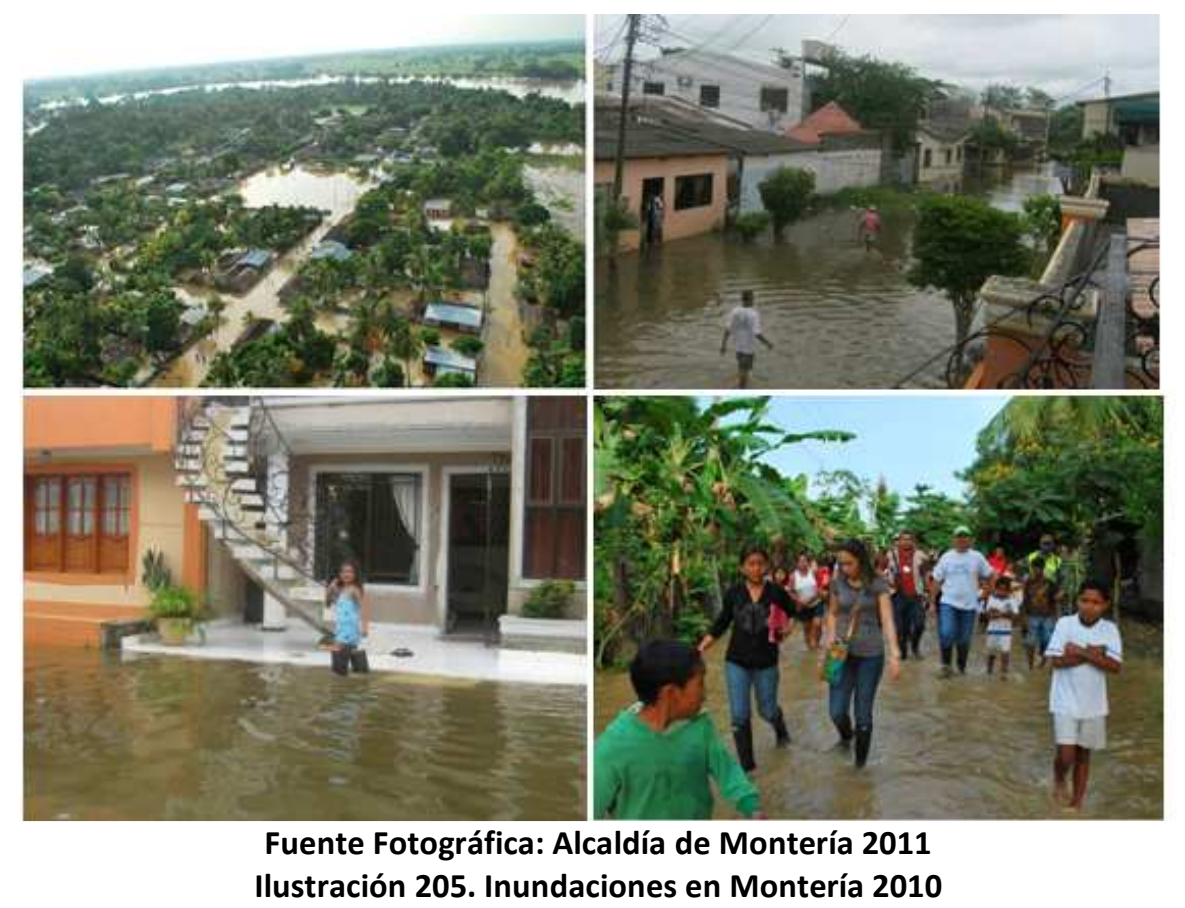

Como se había comentado en apartado anterior, los canales que fueron inicialmente diseñados para conducir aguas pluviales, terminaron siendo utilizados igualmente como alcantarillas y como vertederos de basuras, situaciones estas que disminuyen la velocidad de flujo por debajo de 0.75 metros/segundo, facilitando la acumulación de sedimentos $^{348}$, taponamientos, desbordamientos, proliferación de malos olores y

\footnotetext{
${ }^{348}$ Buena parte de estos sedimentos tienen origen en las aguas residuales y en la falta de pavimentación de las vías, lo cual favorece la acumulación de arenas y polvos. Sobre este particular, ya se han realizado consultorías que corroboran la presencia de aguas residuales en los canales pluviales, con excepción del canal de la Avenida Circunvalar y el Colector Sur, que atienden el centro de la ciudad donde existe alcantarillado sanitario. POT de Montería 2002-2015. Diagnostico, Parte II, Pág. 303.
} 
vectores. Esta situación se presenta con mayor intensidad en los canales que aún no han sido intervenidos o dotados de lozas de hormigón.

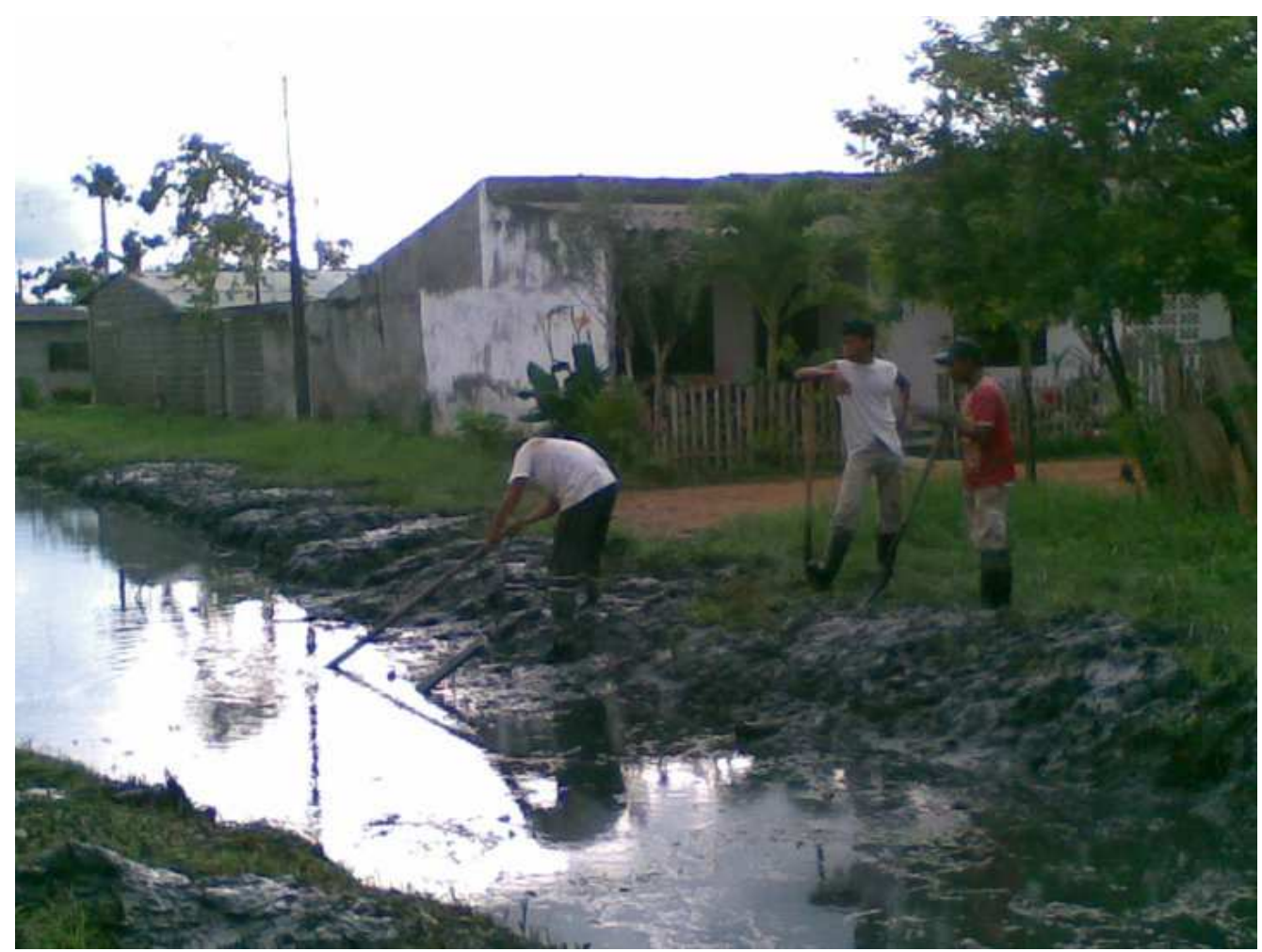

Fuente Fotográfica: Alcaldía de Montería 2010

llustración 206. Sedimentación en canales de asentamientos semiconsolidados

Situaciones similares se presentan en los canales en tierra firme de los barrios precarios que se en el entorno de Sierra Chiquita, específicamente en: Furatena, Villa Paz, los Araujos, Nueva Esperanza, Alfonso López, la Campiña y 2 de Septiembre. En este sector del sur arranca el canal principal los Araujos, que se extiende hacia el oriente pasando por Nueva Galilea, $1^{\circ}$ de Mayo, Colina Real, el Paraíso, los Robles, la Candelaria, Robinson Pitalúa, Paz del Río, Santa Rosa, los Robles, los Nogales, Villa de los Alpes, Santa Isabel y Villa Jiménez. Es oportuno, anotar que en el plano no aparecen los canales de Villa Paz, Furatena y Nueva Esperanza, los cuales se encuentran apenas en etapa de diseño. 


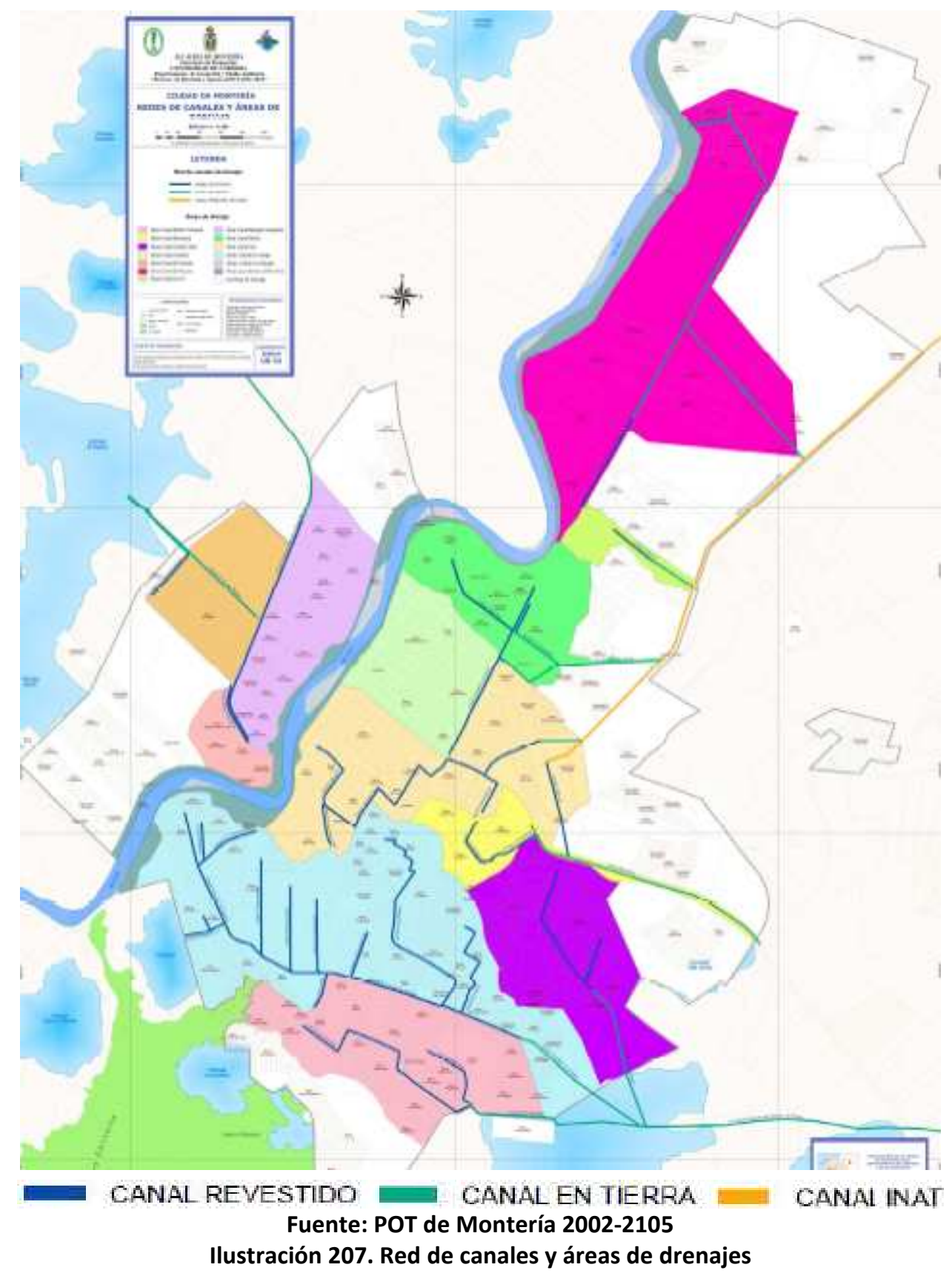

También presentan sedimentación, aunque en menor proporción, los canales de los primeros barrios de promoción pública y de los asentamientos informales consolidados, construidos hace más de cuarenta años, a través de la primera red de drenaje del sur y el canal principal la Granja. Este canal arranca en el barrio Santafé y discurre por Santander, San Martín, Policarpa, la Granja, Pablo VI, el Prado, P-5, Boston, Mogambo, Edmundo López II, Villa Ana y el Paraíso, hasta conectar posteriormente con el canal principal de los Araujos y el canal secundario de 
Mogambo, a la altura del humedal Villa Jiménez, y terminar en el canal del Purgatorio en el kilometro siete de la vía que conduce a Medellín.

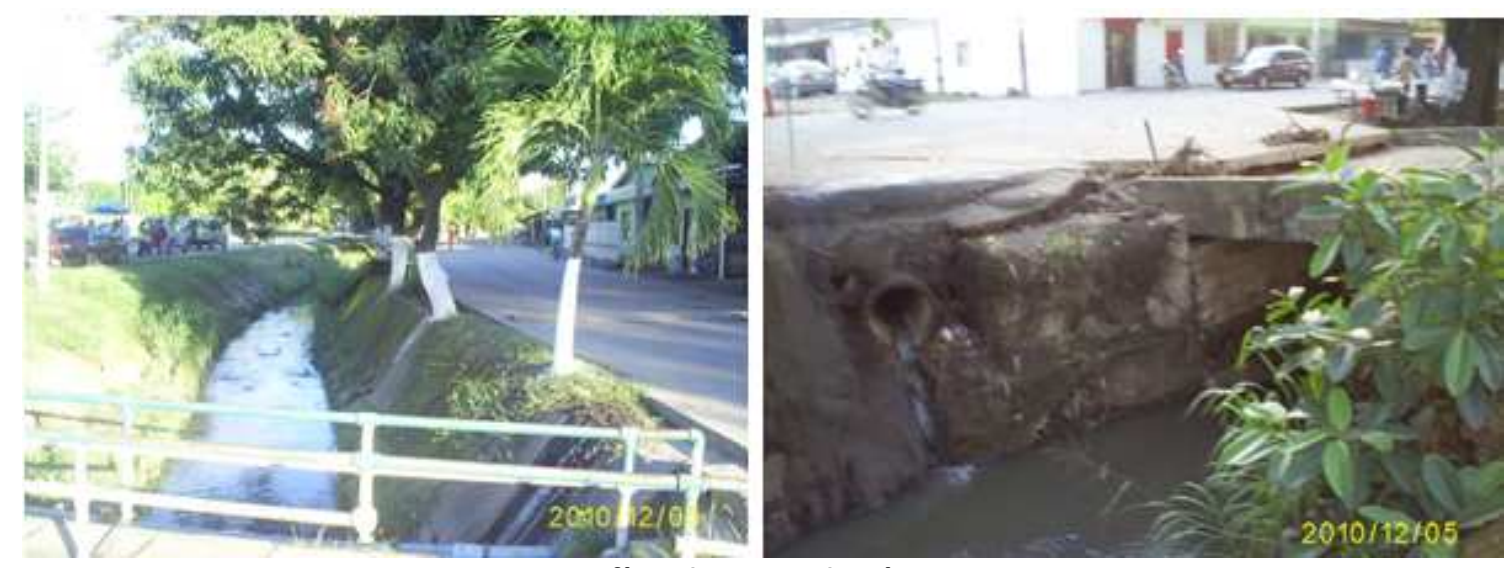

Fotografías: Jhon Pinedo López 2010

Ilustración 208. Canales pluviales revertidos pero receptores de aguas residuales

La ilustración 15 corresponde al canal principal la Granja, a la altura de los barrios de promoción pública del Prado y del P-5, revertido en hormigón desde el año de 1978, pero sobre el cual se sigue vertiendo aguas residuales, generando olores insoportables a los habitantes de las diagonales 3 y 4 de los respectivos barrios. Los niveles de sedimentación y los crónicos olores que ellos ocasionan, requieren ser neutralizados con periódicas limpiezas por parte de la administración municipal o directamente por los afectados.

Para finalizar con este análisis, destacamos que en la actualidad existen trece áreas de drenaje en la zona urbana, estas son: Panamá, Bonanza, Cantaclaro, Central, el Dorado, el Recreo, Calle 61, Margen Izquierda, Norte, Sur, la Granja, los Araujos, y una que vierte directamente al río Sinú. En esta última área de drenaje se encuentran los asentamientos irregulares del borde del Río, Brisas del Sinú, el Bongo, Nuevo Milenio, invasión Sucre y 7 de Mayo, que como ya hemos anotado, vierten directamente aguas residuales y excrementos a la fuente hídrica bajo la mirada complaciente y la indiferencia de autoridades administrativas y ambientales. 


\subsubsection{El fenómeno de la tubificación en la invasión el Cerro}

Son varios los impactos que a la luz de la realidad sufre esta reserva forestal por albergar a más de setecientas ochenta familias durante más de cuatro décadas: deforestación, remoción en masa y erosión. Sin embargo, el fenómeno más visible y considerado por tanto como el de mayor impacto sobre el ecosistema es la deforestación. Este fenómeno, sumado a las sobrecargas de basuras y excrementos producidos, genera la pérdida de la capa vegetal de la reserva, dando en algunas ocasiones como resultado los deslizamientos de tierra, principalmente en épocas de lluvias.

Ahora bien, además de la deforestación, de la erosión y de los deslizamientos de tierra, el cerro también padece de un fenómeno poco visible denominado tubificación, o erosión tubular, el cual ocasiona los deslizamientos de tierras que se presentan aisladamente en esta colina. La tubificación identificada en el cerro de Montería se puede expresar como perforaciones en el suelo, producidas por aguas lluvias que no puede circular de manera natural, como consecuencia de la obstaculización de las viviendas ubicadas en esta pendiente.

El ingeniero Agrónomo Iván Bustamante Barrera ${ }^{349}$, considera que el problema más grande del Cerro se encuentra debajo; este problema es la tubificación, un fenómeno que casi nadie ve. Este ingeniero manifiesta igualmente que este fenómeno se presenta cuando el agua que debe circular de manera vertical termina haciéndolo de manera horizontal porque no tiene para donde correr, formando un túnel en el suelo, que posteriormente con el peso de las casas, las vías, y el caminar de la misma gente, termina generando el hundimiento de superficies de ladera.

\footnotetext{
349 En Pérez, Amnerys (2003): “El Cerro Quiere Volver a Respirar III". El Meridiano de Córdoba. Mayo 4 de 2003. Pág. 5A. Disponible en http://www.biodiversityreporting.org/article.
} 
Por su parte, la ingeniera Geóloga María Isabel Toro Quijano ${ }^{350}$, considera que la degradación de "el Cerro" es la consecuencia de la erosión laminar y de la tubificación. Ella define a la primera, como un proceso superficial de remoción del suelo, y a la segunda como un proceso subsuperficial, en el cual las partículas arrancadas empiezan a generar unos conductos en el suelo. El impacto generado por estos fenómenos explica la perdida de fertilidad y los deslizamientos que se evidencian en esta colina; de igual modo, alertan sobre la urgente necesidad de intervención forestal y edafológica requerida para evitar su degradación total.

Sin embargo, conviene anotar que este no es un fenómeno nuevo ni exclusivo de Montería, y por el contrario, ya ha sido identificado y estudiado anteriormente por diferentes autores ${ }^{351}$, quienes corroboraron la presencia del problema en diferentes regiones, en valles del Mississippi, la Florida, Holanda y Perú, entre otros. Estos autores definen en sus respectivos estudios que la tubificación "es un fenómeno mediante el cual el agua disuelve partículas de suelo generando espacios huecos en una masa o capa del suelo". Igualmente coinciden en establecer que ésta se puede presentar en cualquier tipo de suelos, incluidas: sabanas, laderas o valles de los grandes ríos.

\footnotetext{
${ }^{350}$ En Pérez, Amnerys (2003): "El Cerro Quiere Volver a Respirar IV". El Meridiano de Córdoba. Mayo 11 de 2003. Pág. 5A. Disponible en http://www.biodiversityreporting.org/article.

351 Rayano, Manuel (2000): Fenómenos de Tubificación en Presas Pequeñas de Tierra. Documento disponible en http://www1.unne.edu.ar/cyt/2001/7-Tecnologicas/T-035.pdf

Xiangye, Li y Arroyo, Víctor (2002): Impactos de Fuerzas de Filtración y Tubificación retrograda a la inestabilidad de talud y erosión hídrica. Texto disponible en http://www.revista.unam.mx/vol.12/num2/art14/ Garay, Hilda y Alva, Jorge (2005): Identificación y Ensayos en Suelos Dispersivos. Documento disponible en: http://www.cismid.uni.edu.pe/descargas/a labgeo/labgeo18 p.pdf
} 


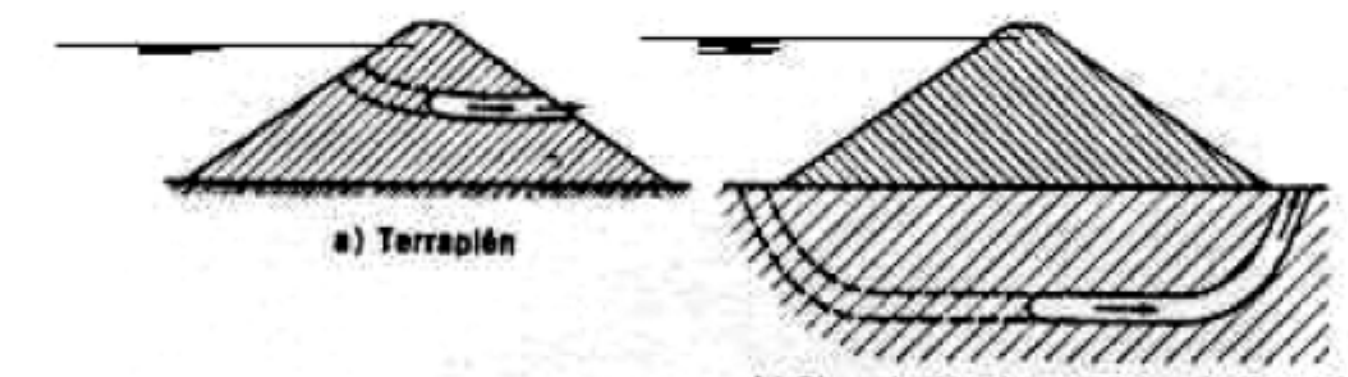

b) Clmentecion de una prasa de tierra

Fuente: Marsal-Reséndiz, 1979 en Rayano 2000.

Ilustración 209. Tubificación

En este esquema, su autor pretende explicar que el conducto se forma por las zonas geológicamente más débiles, por planos de identificación permeable o en cualquier otra zona de concentración de flujo. Aunque aquí se toma como referencia las presas, consideramos que es una situación similar a la presentada en la colina de Sierra Chiquita en Montería, en donde, según el concepto del ingeniero Bustamante Barrera, la porosidad de rocas y suelos ya ha sido saturada por el flujo del agua, propiciando hundimientos que a la postre terminaron reflejándose en problemas superficiales de esta reserva natural de la ciudad.

Manteniendo la prudencia que corresponde y aprovechando su autoridad como experto en suelos, así como de su conocimiento sobre el área de estudio, consideramos razonable apoyarnos en el mencionado ingeniero, quien concluye que el tipo de construcción desarrollada en el Cerro de Montería, ha favorecido la tubificación, porque permite el estancamiento de aguas en determinados puntos o casas sin un tratamiento racional. De acuerdo con sus estimaciones, el problema radica en que las aguas estancadas se filtran hasta llegar a un punto en donde no encuentran permeabilidad. 


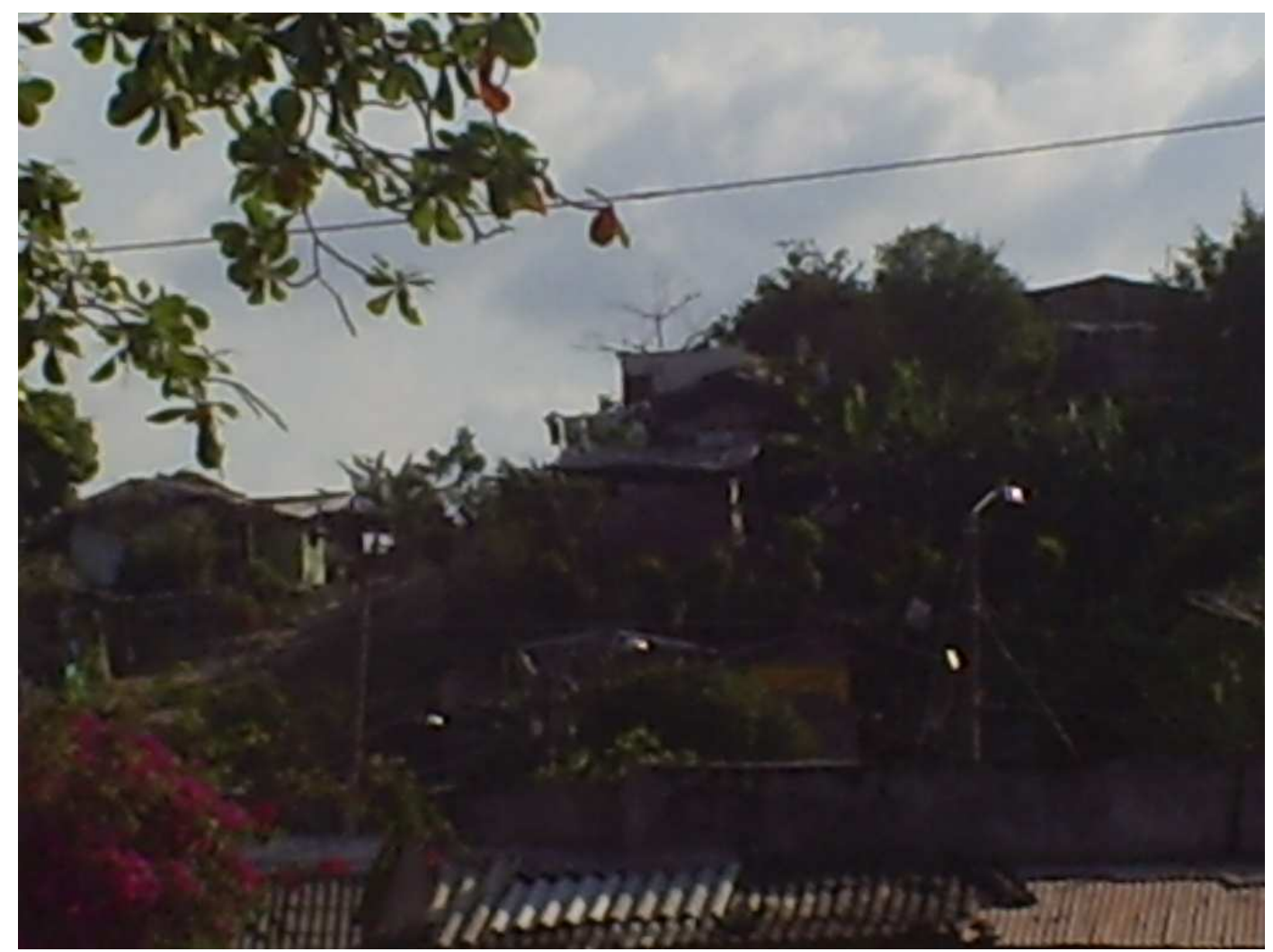

Fotografía: Jhon Pinedo López 2011

Ilustración 210. Ocupación en el cerro Sierra Chiquita

Efectivamente, como él lo expone, el método de construcción utilizado en este cerro, al igual que en los demás suelos montañosos del país, es el "banqueo escalonado", es decir, los ocupantes cavan la montaña y ubican la vivienda, desprotegiendo el suelo, principalmente de las aguas lluvias. Con este método de construcción no solamente el suelo queda expuesto a las aguas proveninetes de las lluvias, sino también a vertidos residuales, excrementos y todo tipo de residuos solidos, que a la postre, y de acuerdo con lo analizado, terminan influyendo sobre el fenomeno de la tubificación. Sobre las consecuencias, debemos anotar que además de los procesos erosivos mostrados en este apartado, también se han presentado deslizamientos de tierra significativos en los años 1998, 1999, 2002, 2007, 2009; y como ya se manifestó anteriormente, en estos momentos la zona se encuentra en alto riesgo de deslizamientos. 


\subsubsection{Contaminación Auditiva}

Los niveles de ruido que se presentan en diferentes sectores de Montería superan los 70 decibeles establecidos por la Organización Mundial de la Salud como el límite superior deseable. En este sentido, los mayores traumas no son ocasionados inicialmente por tráfico motorizado o por industria pesada, sino por los locales de ocio que se ubican de manera dispersa en asentamientos formales e informales de la ciudad. Estos locales de ocio son pequeños negocios dedicados a la venta y consumo de licores, amenizados con equipos de sonidos musicales y denominados en nuestro contexto como: estancos, estaderos, bares, fuentes de sodas o discotecas. Independientemente del nombre asignado, prestan servicios similares y no existen marcadas diferencias entre ellos.

La mayoría de estos locales obtienen permisos de la administración municipal, pero sus actividades trascienden los límites de la formalidad, debido a que frecuentemente el volumen de sus equipos musicales excede los niveles de ruidos permitidos para las zonas residenciales donde muchos de ellos se ubican. El límite de ruido establecido por la secretaría de salud de Montería para zonas residenciales es de $65 \mathrm{~dB}$, pero desde acá corroboramos que en algunos asentamientos informales el ruido asciende a 70, 75, e incluso, a $80 \mathrm{~dB}$ en horas de la noche, situación que conlleva a continuas tensiones entre residentes y propietarios.

Con el respaldo de la secretaría de salud, que nos facilitó un sonómetro, pudimos corroborar en el barrio Juan XXIII del occidente de la ciudad, que en la tienda Súper 2005, el expendio de licores Guacherna y el bar la Palmera, el ruido oscila entre 70 y 95 decibeles a partir de las quince horas, prolongándose hasta las veinticuatro horas. Esta es una zona de la avenida $1 \mathrm{~W}$, cercana a la Universidad del Sinú, especializada en servicios de papelería, fotocopiado y transcripción, pero también aprovechada en la noche como escenario para la rumba y el consumo de licores; incluso también es utilizada en horas de la tarde por los estudiantes más bohemios de dicha universidad. 
Igualmente corroboramos que en las calles 35, 36 y 37 con carreras segunda y tercera, el ruido supera los 90 decibeles como consecuencia de bocinas y parlantes utilizados por vendedores ambulantes y almacenes dedicados al comercio. Por su parte, la calle 41 es afectada auditivamente por el restaurante el Rodadero, la heladería Sierra Nevada, el bar Timbalero salsa y por las bocinas de autobuses. Esta calle, se ha convertido en una de las más conflictivas del centro de la ciudad, perturbada por riñas callejeras, alta presencia de indigentes, prostitutas, mendigos, drogodependientes y por ruidos que alcanzan los 93 decibeles en horas de la noche.

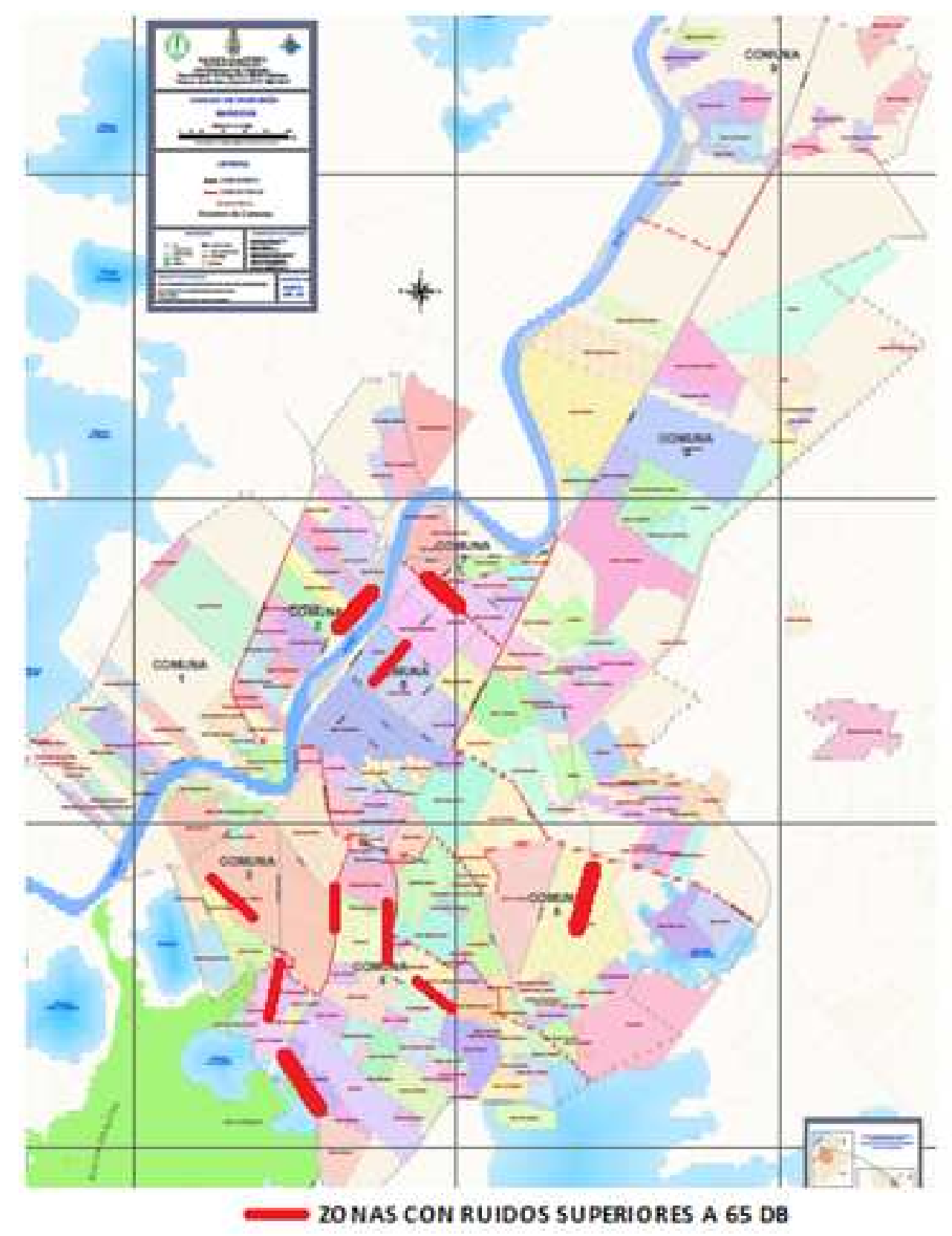

Fuente: Elaboración Propia a partir del POT 2002-2015 Ilustración 211. Sectores con mayor contaminación auditiva 
Sin embargo, a nuestro modo de percibir, la zona más crítica en cuanto a contaminación auditiva es el sur de la ciudad, debido a la gran presencia de billares, licoreras, kioscos, estaderos y todo tipo de negocios dedicados a la venta y consumo de licor. Esta es una de las principales actividades económicas del sector, de las que muchas familias obtienen su único sustento económico, razón por la cual, generalmente las autoridades se ven obligadas a hacerse las de la vista gorda. El ruido promedio de las vías comerciales de los barrios más dinámicos, oscila entre 81 y 97 decibeles, siendo los más afectados, el P-5, la Granja, Santafé, Alfonso López, los Araujos, 2 de Septiembre, 6 de Marzo y Cantaclaro, que aparecen resaltados en rojo en el plano anterior.

Por último, anotamos que a pesar de no figurar en el plano como sectores auditivamente contaminados, también se identificaron problemas de ruido por altos volúmenes de equipos musicales en negocios de los asentamientos informales Robinsón Pitalúa, Camilo Torres, Policarpa Salavarrieta, San Martín, Edmundo López, Santander, Pastrana Borrero, el Paraíso, Furatena y Villa Cielo. En estos asentamientos, al igual que en los mencionados anteriormente, por cuestiones de acervo cultural, sus habitantes exceden con cierta frecuencia los niveles de ruido permitidos a través de las denominadas parrandas ${ }^{352}$.

En este orden de ideas podemos concluir que los niveles de ruido no solamente generan contaminación auditiva en las zonas comerciales de los sectores informales más dinámicos, sino que frecuentemente generan tensiones entre vecinos, por el excesivo volumen que algunos de ellos les da a sus equipos musicales, lo cual termina afectando la calidad ambiental del sector y la calidad de vida de sus habitantes. Sobre este particular, conviene anotar, que hasta en los asentamientos más precarios se

\footnotetext{
352 Las personas oriundas del Caribe colombiano históricamente se han caracterizado por su identidad con el folklore, la danza, la música y las festividades, lo cual se ve reflejado en sucesivas fiestas patronales, tradicionales, populares y familiares. Cada una de estas fiestas, denominadas por algunas personas como parrandas, son generalmente amenizadas por potentes equipos musicales o "PICK-UPS". Estas características culturales, sumadas a la escasa oferta de ocio en Montería, conlleva a sus habitantes a recurrir permanentemente a parrandas familiares, barriales, municipales, o a parrandas ofrecidas por los negocios, casi que como única alternativa de diversión.
} 
corroboró la existencia tanto de equipos musicales en hogares como de negocios para consumo de licores amenizados con el infaltable pickup.

\subsubsection{Un esquema de valoración de impacto ecológico de la urbanización marginal}

En la actualidad existen modelos de evaluación de impacto ambiental propuestos por varios autores de diferentes disciplinas con el objetivo de prevenir, o por lo menos mitigar, los efectos negativos que la realización de algunas intervenciones humanas causan sobre el medio natural. Dentro de estos autores destacamos a Gómez Orea ${ }^{353}$, Conesa Fernández-Vitora ${ }^{354}$, Martin Cantarino ${ }^{355}$ y Agudelo Patiño ${ }^{356}$, cuyos modelos consideramos bastante acertados, sencillos y con favorable aceptación en el escenario académico de nuestro contexto geográfico y en el de España.

Los modelos de evaluación de impacto ambiental han sido adoptados por Estados e instituciones mediante decretos o leyes a partir del año 1969, cuando surge la National Environmental Policy Act (NEPA), primera legislación sobre este tipo de evaluaciones, a la que se sumaron posteriormente la Directiva 85337 del 27 de junio de 1985 de la Comunidad Europea y el Real Decreto Legislativo 1302 de 1986 en España. Igualmente se emitió y aprobó la Directiva 9711 de la mencionada comunidad y el Real Decreto 1241 de 1988, en el Estado español, en los cuales se especifica la necesidad de someter determinados proyectos a valoración ambiental, e inclusive, la de exigir la incorporación de evaluación de impacto ambiental dentro de los instrumentos de planificación.

La evaluación de impacto ambiental, sobre el papel, apunta principalmente a prevenir o a utilizar medidas protectoras antes que recurrir a medidas correctoras, y para eso

\footnotetext{
353 Gómez Orea, Domingo (1999): Evaluación del Impacto Ambiental. Ed. Mundi--Prensa y Editorial Agrícola Española, S.A. Madrid.

354 Conesa Fernández-Vítora, Vicente (1997): Guía Metodológica para la Evaluación del Impacto Ambiental. Editorial Mundi-Prensa. Madrid.

355 Martin Cantarino, Carlos (1999): El Estudio de Impacto Ambiental. Publicaciones Universidad de Alicante. Alicante.

${ }^{356}$ Agudelo Patiño, Luis Carlos (2004): Op. Cit.
} 
establece criterios para identificación de variables ambientales, que generalmente son analizadas desde dos medios: el físico y el socioeconómico. El primero incluye elementos como el clima, suelo, fauna, vegetación, paisaje, agua, aire, e incluso, ecología; mientras que del segundo, hacen partes aspectos sociológicos, económicos y urbanísticos.

La valoración de los diferentes elementos es posible mediante indicadores que permiten identificar cualquier modificación de los usos del suelo, en los recursos naturales, emisiones de contaminantes, riesgos naturales e impactos secundarios. Esta valoración puede realizarse antes de una intervención, durante ella, al finalizarla, o unos años después de finalizada dicha intervención. Sin embargo, lo ideal es que la evaluación se realice antes de la intervención y no después de realizada o de haber ocasionado impactos negativos al medio físico o socio-económico.

En lo referente al contexto colombiano, el Decreto Ley 2811 de 1974 o Código Natural de Recursos Naturales y Protección al Medio Ambiente, comienza determinando que el ambiente es un patrimonio común y para su preservación y manejo deben trabajar tanto el Estado como los particulares. Este Decreto tuvo tres objetivos que a la postre no fueron logrados: utilización racional de recursos naturales renovables; prevenir y controlar la sobre-explotación de recursos no renovables, y regular la conducta humana, así como la actividad de la administración pública respecto del medioambiente.

En este Código de Recursos Naturales no se establece un marco conceptual claro para definir el ambiente pero si se definen claramente los elementos a regular, al igual que los aspectos relacionados con el dominio y explotación de esos elementos naturales. Sin embargo, es notoria su nula efectividad debido a que durante su vigencia se desecaron grandes superficies de humedales para fines latifundistas o para asentamientos urbanos o rurales. En Montería, por ejemplo fueron desecadas las ciénagas del Cerrito y de Martinica en zona rural, y en el área urbana fueron invadidas áreas de humedales en el occidente y sur para asentamientos humanos. 
Posteriormente, en el año de 1993 el Congreso de la República aprueba la ley 99 sobre Medio Ambiente, que en su artículo 49 incorpora la obligatoriedad de la licencia ambiental para la ejecución de obras, el establecimiento de industrias o el desarrollo de cualquier actividad que pueda producir deterioro a los recursos naturales o modificar notablemente el paisaje. Así mismo se establecen en los artículos 56 y 57 de la misma Ley, el Diagnostico Ambiental de Alternativas y el Estudio de Impacto Ambiental para las intervenciones que requieran de dicha licencia. Esta ley fue complementada con el Decreto 1728 de 2002, que reglamenta el título VIII sobre licencias ambientales.

Este decreto adopta definiciones para los conceptos de efecto ambiental, evaluación de riesgo, impacto ambiental, medidas de compensación, corrección, mitigación, prevención y plan de manejo ambiental. El plan de manejo ambiental, es el documento que después de realizada la evaluación ambiental, establece las acciones que se deben implementar para prevenir, mitigar, corregir o compensar los impactos ambientales ocasionados por la ejecución o realización de un proyecto, obra o actividad. En este sentido, y con el fin de dar cumplimiento a los compromisos adquiridos en las cumbres mundiales sobre calentamiento global, el Ministerio de Ambiente, Vivienda y Desarrollo Territorial de Colombia (MAVDT), establece un sistema de indicadores ambientales urbanos a partir de temas y subtemas que incluyen indicadores de presión, estado y respuesta ${ }^{357}$. Los elementos a tener en cuenta son: agua subterránea, agua superficial, aire, biodiversidad, energía, población, suelo, transporte, producción limpia y residuos sólidos.

Es evidente que los modelos de evaluación de impacto ambiental se encuentran diseñados fundamentalmente para realizarlos o aplicarlos antes ${ }^{358}$ de cualquier intervención y consideramos que eso debe ser lo ideal, pero a la vez somos

\footnotetext{
357 Luis Carlos Agudelo Patiño tomando a Quiroga (2001), establece dos indicadores de Desarrollo Sostenible IDS: 1) Presión-Estado-Respuesta PER, y Causa-Efecto y Acción Reacción, Ibíd. Pág. 151.

${ }^{358}$ De acuerdo con el tiempo en el que se realicen los tipos de evaluación son: ex -ante; de proceso; ex post, y de impacto. (Pérez Serrano, 1999). Tomado de http://es.wikipedia.org/wiki/Evaluaci\%C3\%B3n de proyectos
} 
conscientes, y la experiencia así lo demuestra, que hasta el momento las decisiones son determinadas prioritariamente con criterios económicos y con escaso razonamiento sobre el impacto ecológico, social o urbanístico. Igualmente se pudo corroborar que en nuestro contexto de estudio, diferentes intervenciones omitieron dichas evaluaciones, y las decisiones fueron el producto de situaciones coyunturales. Un ejemplo claro de ello son los emplazamientos de asentamientos en zonas de alto valor ambiental como Sierra Chiquita, los humedales, la ciénaga de Berlín y la ribera del río Sinú.

El impacto ecológico ocasionado por el emplazamiento de esos asentamientos irregulares en zonas de alto riesgo ambiental, por razones más que obvias, no se ha valorado, ni mucho menos se ha dimensionado con la responsabilidad que corresponde. No obstante, consideramos que los datos obtenidos en esta investigación y expresados a lo largo de ella, más la corroboración empírica, permitieron identificar, aunque más de manera cualitativa que cuantitativa, el nivel de vulnerabilidad de los ecosistemas locales, así como la disminución o extinción de algunos de ellos. El impacto ecológico ocasionado por más de cuarenta años de urbanización marginal en la ciudad de Montería lo representamos a través del siguiente esquema.



Fuente: Elaboración Propia a partir de datos institucionales y corroboración empírica Esquema 7. Impacto Ecológico de la Urbanización Marginal en Montería 
Consideramos que estos modelos no son aplicables rígidamente y por el contrario su aplicación debe realizarse de acuerdo con las características naturales, sociales y económicas de cada contexto. Inclusive, sobre este particular, Martín Cantarino 359 considera, y con ello estamos de acuerdo, que la práctica de la Evaluación de Impacto Ambiental presenta limitaciones del método científico, asociadas principalmente a las restricciones de información, de tiempo y de medios, que obligan a presentar metodologías más flexibles, eso sí, sin dejar de lado dos responsabilidades: la búsqueda de objetividad científica y las obligaciones éticas hacia la sociedad para la que trabajan.

Como se ha manifestado a lo largo de esta investigación, el emplazamiento de algunos asentamientos se ha realizado sobre terrenos de una ladera en la reserva natural Sierra Chiquita, lo cual genera un primer impacto directo cuantificable en hectáreas deforestadas. Esta superficie deforestada inicial se encuentra cercana a las diez hectáreas, siendo reemplazadas por las viviendas de los barrios Alfonso López, los Araujos, el Cerro, el Privilegio, y un sector de Pastrana Borrero y del Policarpa Salavarrieta.

Aunque autores como Agudelo Patiño ${ }^{360}$, resaltan la inexistencia de instrumentos técnicos o indicadores en nuestro medio para medir los efectos ocasionados por los problemas ecológicos sobre la salud humana, desde esta investigación consideramos que dichos efectos son sencillamente identificables a partir de patologías asociadas a condiciones sanitarias desfavorables de asentamientos informales ubicados en zonas naturales no aptas para usos residenciales, y que terminan generando enfermedades, principalmente en la población infantil por su alta vulnerabilidad a vectores como: aguas estancadas o zancudos.

Nuestro esquema de medición de impacto ambiental, que aclaramos es diferente al de impacto ecológico, se aproxima al utilizado por este autor en la evaluación de la sostenibilidad ecológica del área metropolitana de Medellín, específicamente a los

\footnotetext{
359 Martin Cantarino, Carlos (1999): Op cit. Pág.11

${ }^{360}$ Agudelo Patiño (2004): Op. Cit. Pág. 11.
} 
indicadores asociados a sostenibilidad urbana. Dentro de estos indicadores él destaca: biofísicos como agua - suelo - aire; sociales como empleo - salud - seguridad ciudadana; urbanísticos como vivienda - espacio público - equipamiento - movilidad transporte, y por último, producción y consumo de agua, energía, contaminación del aire, vertimientos líquidos, residuos sólidos y alimentación. Sin embargo, y por obvias razones, en nuestro estudio consideramos pertinente desestimar el tema relacionado con la contaminación del aire.

Un aspecto destacable dentro del trabajo de este autor es la distinción que establece entre indicadores de flujo e indicadores de calidad. Los primeros miden el consumo final de energía, la intensidad energética local, producción de energía renovables, recuperación de residuos metropolitanos, intensidad de producción de residuos de la economía local, abastecimiento de agua metropolitana, intensidad de consumo de agua, gestión de aguas residuales, emisión de contaminantes atmosféricos, emisión de gases que contribuyen al efecto invernadero, emisión de contaminantes atmosféricos. Igualmente establece unos indicadores de calidad que considera: las personas expuestas a niveles sonoros significativos; estado ecológico de los ríos y la superficie forestal quemada.

Ahora, si bien admitimos una gran diferencia entre impacto ecológico y evaluación de la sostenibilidad ecológica, sobre todo si se pretende obtener mediciones mediante indicadores de flujo en ambas evaluaciones, también debemos admitir una aproximación entre ellas, utilizando únicamente los denominados indicadores de calidad a que se refiere el mencionado autor. En el caso de nuestra investigación, consideramos que para medir el impacto ecológico de la urbanización marginal no es relevante la utilización de indicadores de flujo, pero si la de indicadores de calidad, como por ejemplo: el estado ecológico de la ribera del río Sinú, la superficie forestal destruida en Sierra Chiquita y los elevados niveles sonoros que afectan a la población en diferentes sectores de la ciudad.

No debemos dejar de lado que dentro del objetivo central de esta investigación se encuentra el de establecer el impacto ambiental de la urbanización marginal en esta ciudad, siendo entonces el factor ecológico, junto al social, el económico y el 
urbanístico, los cuatro factores que de manera interrelacionada conforman el componente ambiental definido en el marco conceptual. En este orden de ideas, queremos puntualizar que el esquema de impacto ecológico hace parte de un gran esquema de impacto ambiental presentado al comienzo de este quinto capítulo y sobre el cual profundizaremos después de finalizado el análisis del factor ecológico que por ahora estamos realizando.

El esquema de impacto ecológico elaborado en este estudio, entonces, expresa los efectos negativos que sobre los ecosistemas locales ocasionaron las diferentes urbanizaciones marginales emplazadas sobre ellos y las actividades realizadas por los habitantes de dichas urbanizaciones. Este efecto, como se ha demostrado a lo largo de este capítulo, se traduce básicamente en seis fenómenos que afectan directamente terrenos de la reserva natural de Sierra Chiquita, de humedales del occidente, oriente y suroriente y aguas y ribera del río Sinú, tanto en el perímetro urbano como fuera de él.

Estos seis fenómenos, reiteramos son: la deforestación, la erosión, la contaminación de las aguas del río, desecación de ciénagas, las inundaciones y la tubificación. Con excepción de este último, los demás son demasiado evidentes a la mirada de los observadores, y el mayor impacto visual se presenta en la colina de Sierra Chiquita, como consecuencia de la deforestación de herbáceos, plantas arbustivas y arboles; erosión laminar y de aislados deslizamientos de tierras sucedidos en los últimos veinte años. Igualmente, estos tres fenómenos afectan las riberas del río, principalmente en los ya mencionados sectores de Nuevo Milenio, el Bongo, Casa Finca, 7 de Mayo e invasión Sucre.

Estos cinco asentamientos, además, vierten directamente aguas residuales y aguas fecales al río, aumentando los niveles de contaminación de la fuente hídrica, de por sí ya contaminada por los residuos de aceites emanados de los lavaderos de automóviles y motocicletas ubicados en el barrio Rancho Grande y a la altura de las calles 48,49 y 50. Sobre este fenómeno, estudios realizados a partir de 1992 por el laboratorio de aguas y saneamiento de la Fundación Internacional de Acción contra el Hambre 
confirman que los habitantes de los barrios el Enjambre, la Candelaria, Paz del Río y Santa Rosa consumen el líquido contaminados con coliformes fecales ${ }^{361}$.
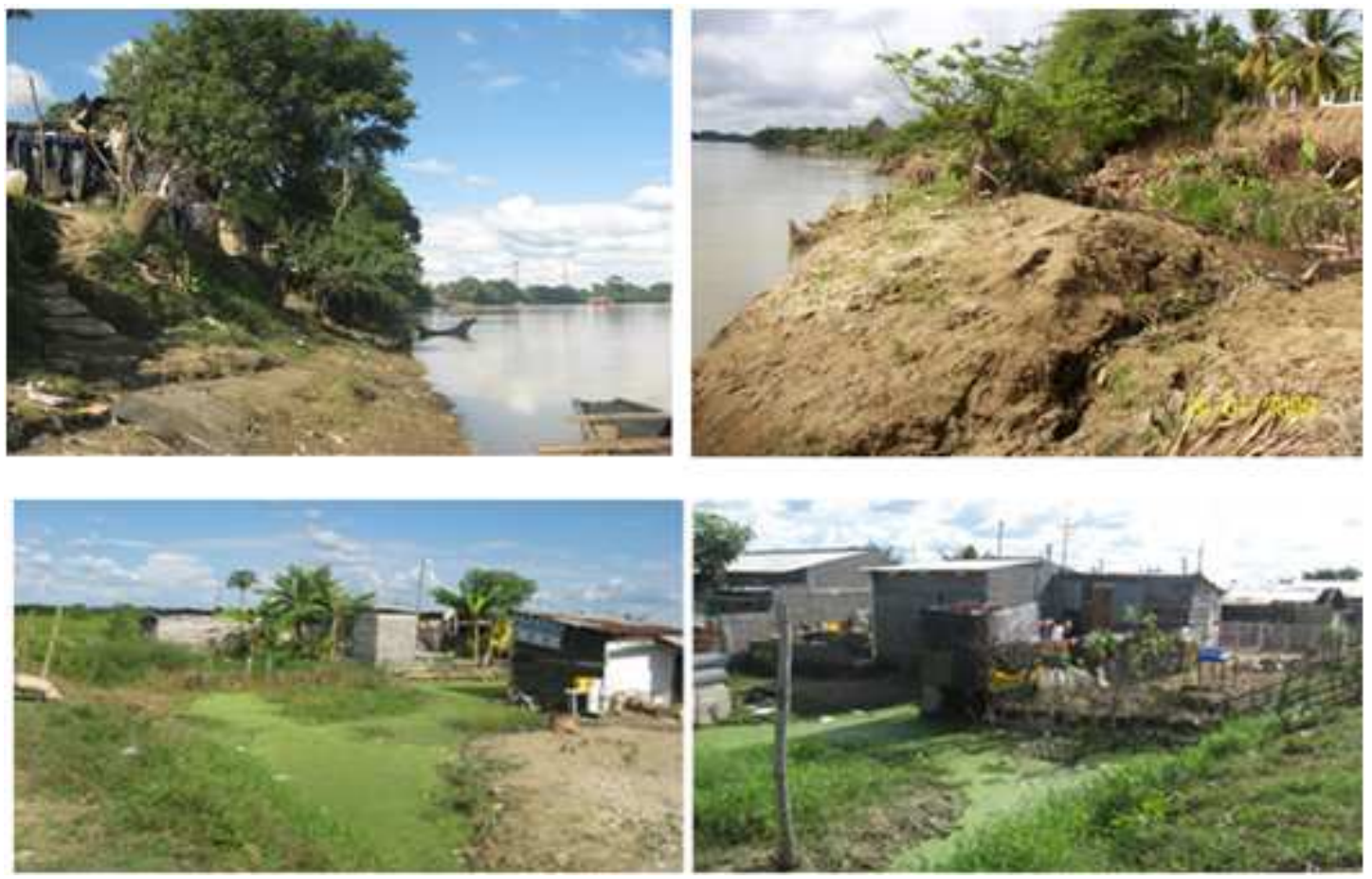

Fuente Fotográfica: Hernando Pérez 2010 y POT 2002-2015 Ilustración 212. Impacto ecológico de la Urbanización Marginal

Otro efecto negativo generado por la urbanización marginal en Montería es el desecamiento de ciénagas y humedales, medible en hectáreas que corresponden a las superficies de los asentamientos de la Vid, Villa Jiménez, Caribe, Villa Nazaret, los Araujos y Villa Caribe. Las ciénagas alteradas por el emplazamiento de estos asentamientos y por la construcción de canales de drenaje, y que ya hemos ilustrado con imágenes, son: Sierra Chiquita, Tiogil, Araujos, Reparo, Berlín, Vila Caribe y Villa Jiménez, recibiendo además, aguas residuales de los habitantes del Dorado, el Poblado, la Palma y Rancho Grande, entre otros. De cuarenta y ocho ciénagas que existían en el territorio municipal, dieciocho de ellos ya no existen ${ }^{362}$.

\footnotetext{
${ }^{361}$ En la crónica "Sedientos" de la periodista Erly Rojas Salguero, se desnudan los principales problemas asociados a provisión y consumo de agua en esta ciudad. Ver crónica completa en http://lacomunidad.elpais.com/gilma-gamez/2010/2/12/ganadora-los-premios-periodismo-colrensa-lacategoria

362 Op. Cit. Parte II. Pág. 138.
} 
La desecación de ciénagas genera otro fenómeno de gran impacto que termina afectando no solamente a estos ecosistemas, sino también a superficies aledañas a ellas. Este fenómeno es la inundación, que afecta periódicamente a más de cincuenta barrios de la margen izquierda y del suroriente de la ciudad, sin encontrarse hasta la fecha una solución definitiva, que por lo menos, permita mitigar los enormes traumas sociales, sanitarios y económicos de la población más vulnerable a ella. En los barrios la Vid, Villa Nazaret, el Níspero, el Poblado, Villa Paz, Villa Cielo y Villa Jiménez se presentan los mayores problemas asociados a las inundaciones.
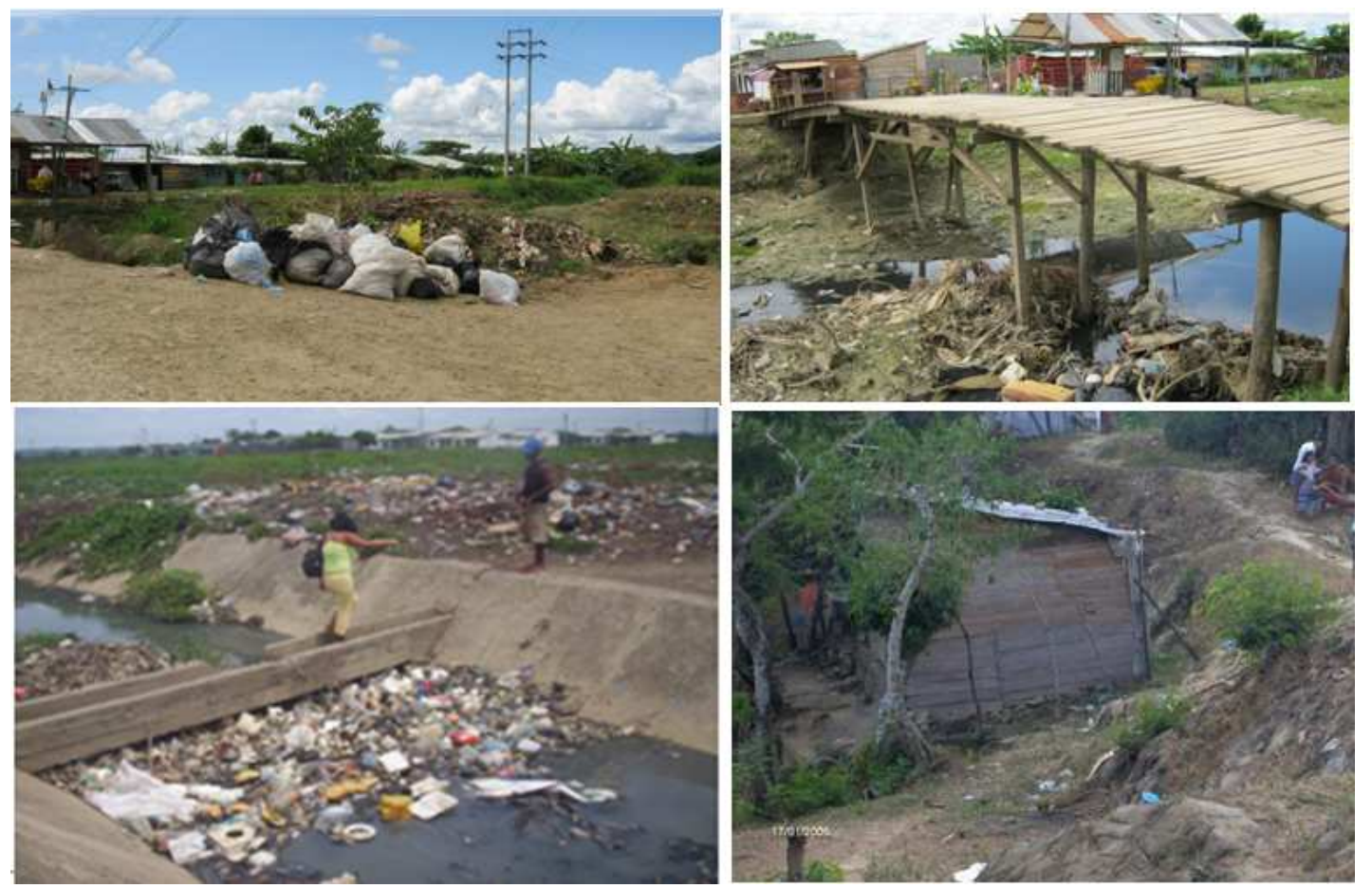

Fotografías: Jhon Pinedo 2007 y POT 2002-2105

Ilustración 213. Efectos ecológicos generados por actividades humanas

En cuanto a la inundación, consideramos oportuno destacar que en esta ciudad, este fenómeno se presenta por dos situaciones: por desbordamiento del río Sinú y por anegamiento causado por las Iluvias. En este orden de ideas, las inundaciones de mayor frecuencia, más alta magnitud y más elevado número de damnificados son aquellas causadas por las lluvias ${ }^{363}$.

\footnotetext{
${ }^{363}$ El número de damnificados económicos por el fuerte invierno del año 2010 en el departamento de Córdoba ascendió a 169.446 y en la ciudad de Montería a 50.000. Más información sobre estos datos se encuentra disponible en: http://www.elpais.com.co/elpais/colombia/noticias/invierno-deja-dosmillones-damnificados-en-28-departamentos-2
} 
En cuanto a los efectos negativos generados por actividades desarrolladas por habitantes de estos asentamientos, corroboramos que los más evidentes, perceptibles y perjudiciales para la salud de los ecosistemas y de las personas son la inadecuada disposición de residuos sólidos, el vertimiento de aguas residuales a cielo abierto, los desagradables olores que ambas generan y la contaminación auditiva que ocasionan actividades de ocio mediante los ruidos producidos por el excesivo volumen de los ya mencionados equipos musicales. Cada uno de estos fenómenos, incide, no solo en la calidad de vida de los residentes de estos sectores, sino en el resto de la población, o por lo menos en la población flotante que debe acudir a dichos sectores.

Los residuos acumulados y los sedimentos producidos por las aguas residuales de los canales generan olores desagradables crónicos, que como ya hemos manifestado anteriormente, son insoportables para las personas no residentes en sus áreas de influencia. Con respecto a este fenómeno, no conocemos hasta el momento un instrumento técnico de medición, ni contamos con reportes clínicos de enfermedades relacionados con él, pero si se cuenta con la percepción olfativa directa de las personas, quienes manifiestan que Montería huele mal en algunos sectores de ella. Esta percepción de mal olor se describe en olor de alcantarillas, aguas residuales, basuras y combustibles; y los sitios específicos descritos son: las calles de los barrios del sur, las invasiones y las calles de Cantaclaro ${ }^{364}$.

Sin embargo, se pudo corroborar que, a pesar de la inadecuada disposición de basuras dada por parte de un significativo sector de esta población, los volúmenes de residuos en estos asentamientos no son elevados, y por el contrario, por su bajo poder adquisitivo no son grandes consumidores, ni generadores de chatarras o residuos altamente contaminantes como plástico, vidrio, pilas, electrodomésticos y computadores $^{365}$. Esta población aún no accede a los hipermercados o grandes

\footnotetext{
${ }^{364}$ Restrepo Valencia, Marleny (2007): Montería Imaginada. Editorial Guadalupe. Bogotá. Pág. 41.

365 Álvaro Ceballos Barón, supervisor de la empresa UNIASEO, interventora de aseo en esta ciudad, nos manifestó que el principal problema de estos barrios es la indisciplina de sus habitantes para cumplir con las horas de sacada de basura, amarrado de bolsas y disposición inadecuadas en sitios por donde los carros recolectores no pueden entrar como consecuencia del estado de las vías o inexistencia de ellas. Manifiesta igualmente que los volúmenes de residuos en estos asentamientos es inferior a los de los
} 
superficies debido a sus precarios ingresos y sus niveles de consumo se reducen a obtener escasamente los productos necesarios para la subsistencia en tiendas informales que venden al detalle y mantienen el sistema de crédito o de pago posterior, el cual generalmente se hace semanal o quincenal.

A estas limitaciones de tipo presupuestal hay que adicionar hábitos de consumo bastante tradicionales, que no permiten alta demanda de productos enlatados ni de bebidas en envases desechables, es decir, permanece una cultura de preparación de comidas, de poco consumo de alimentos congelados, con un mercado agrícola fuerte de amplia oferta de frutas, legumbres, granos y carnes. En estas tendencias inciden dos factores bien importantes: en primer lugar, la gran disponibilidad de tiempo que manejan las personas desempleadas o en actividades informales por cuenta propia; y en segundo lugar, las cómodas distancias que aún mantiene la ciudad para comunicar por medio de recorridos relativamente cortos entre lugar de residencia y de trabajo.

Otro aspecto bien importante para anotar es que en las familias aun predomina el consumo de agua hervida o en algunos casos mediante filtros purificadores, razón por la cual, no existe mayor demanda de agua en garrafas desechables, caso ampliamente diferente al de Europa, en donde se evidencia un elevado consumo del liquido envasado. No obstante, es pertinente manifestar que desde hace escasos diez años se comenzó a empacar agua en bolsas plásticas de $250 \mathrm{ml}$, con precios promedio de diez centavos de dólar, generando una gran demanda y producción de basura, que termina generalmente en las calles.

Bajo las circunstancias enunciadas, consideramos entonces que el principal problema de las basuras en estos asentamientos, más allá de su volumen y peligrosidad, es el inadecuado, o más bien irresponsable tratamiento, dado por un gran sector de sus habitantes cuando deciden arrojarlas a los canales o a la intemperie, sin medir las consecuencias posteriores que para ellos mismos trae la descomposición. Este inadecuado tratamiento de basuras genera los olores desagradables y contribuye a

barrios del norte y del centro de la ciudad. Entrevista concedida a Jhon Pinedo López el día sábado 26 de marzo de 2011 en la Corporación Unificada Nacional de Educación Superior CUN de Montería. 
obstruir el flujo de las aguas residuales de los canales, desencadenando en algunos casos problemas de inundación para esos sectores.

Como se ha planteado en nuestro esquema de impacto ecológico, los residuos sólidos, las aguas residuales, los olores desagradables y los ruidos inapropiados, se constituyen en los cuatro principales fenómenos generados por las actividades de los habitantes de la urbanización marginal, con los cuales muchos de ellos se acostumbraron a vivir, sin dar manifestaciones de malestar, asumiendo así un estilo de vida, que al parecer y por la actitud frente a su entorno, no les preocupa ni les interesa modificar. Sobre este aspecto, corroboramos que las pésimas condiciones sanitarias del entorno de varios sectores son el producto de una inadecuada actitud de sus habitantes frente al mismo entorno y no de la empresa encargada del servicio público de aseo.

Finalizamos este análisis de impacto ecológico de la urbanización marginal, reiterando nuestra posición de flexibilidad a partir del contexto geográfico social, político, económico, el cual permitió adaptar un esquema basado en impactos sucedidos por intervenciones realizadas con gran anterioridad en el tiempo, en algunos casos reversibles y en otros irreversibles. Irreversibles en el caso de la erosión y desecación de ciénagas, y reversibles en lo relacionado con la deforestación y contaminación de la fuente hídrica, pero a expensas de grandes inversiones, que en estos momentos las autoridades administrativas se muestran incapaces de financiar.

En el mismo sentido, consideramos oportuno anotar que el objetivo de este esquema se orienta a identificar y describir los diferentes efectos negativos ocasionados por la urbanización marginal sobre los ecosistemas locales pero no a cuantificar la superficie afectada de cada uno de ellos. Si bien se logró establecer la disminución o extinción de algunas especies animales asociadas a las ciénagas, así como la desaparición de humedales y zonas forestadas, no estaban dentro de los propósitos de la investigación medir con exactitud la superficie afectada. Sin embargo a lo largo del estudio se incluyen estimaciones relacionadas con los aspectos cuantitativos, y que por supuesto, pueden ser considerados como otro tema de estudio para el futuro por otras disciplinas diferentes al urbanismo. 


\subsubsection{Del esquema de impacto ambiental inicial a un esquema final}

El esquema sobre el impacto ambiental de la urbanización marginal con que iniciábamos este análisis se elaboró a partir de cuatro sistemas: social, económico, urbanístico y ecológico, los cuales fueron analizados por separado en el mismo orden descrito. El estudio detallado de cada aspecto permitió establecer su grado de interrelación y la incidencia que tiene cada sistema sobre los demás, o sobre el ambiente en su aspecto integral. Esta interrelación la representamos inicialmente de la siguiente manera.

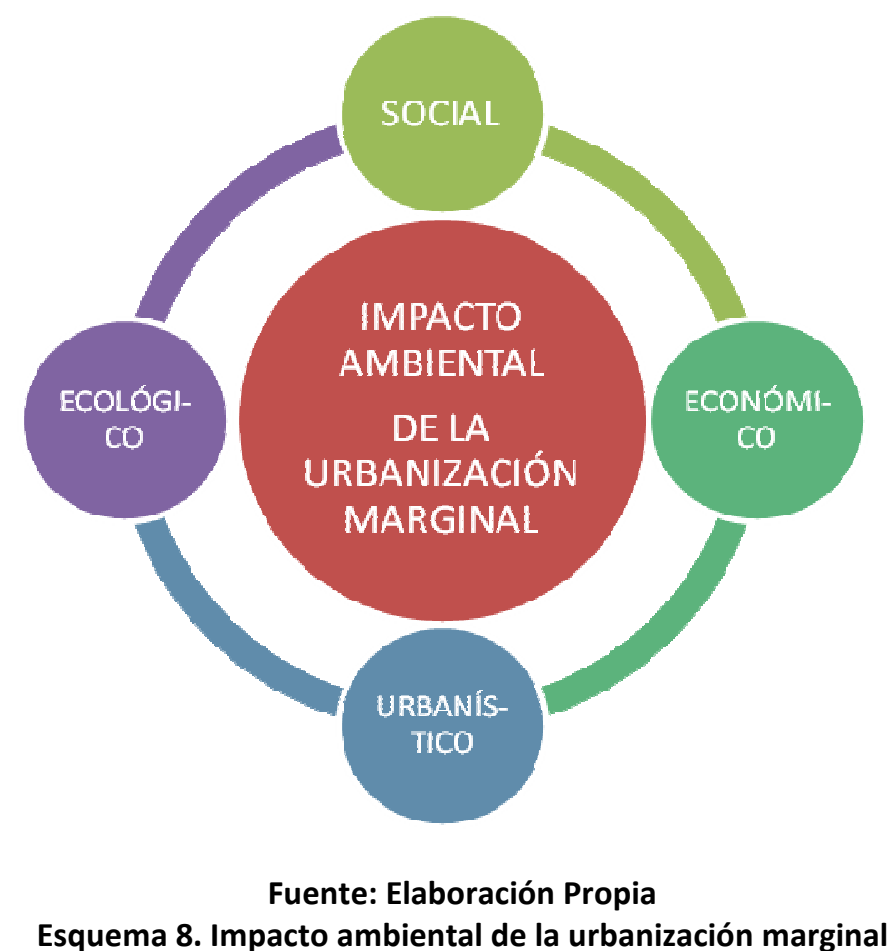

La forma como se han interrelacionado estos sistemas en Montería, generó una secuencia de efectos negativos, aumentados y agudizados con el transcurrir de los años, hasta conformar una especie de círculo vicioso que encierra enfermedades infectocontagiosas, desempleo, depredación de recursos naturales, informalidad económica y los grandes problemas urbanísticos mencionados a lo largo de la investigación. Esta manera, digamos que inapropiada, de interrelación, es la respuesta no solo al atraso socioeconómico de la población, sino a la existencia de una ciudad, urbanísticamente, "subnorma". 
En este sentido, corroboramos que el impacto ambiental negativo de la urbanización marginal en Montería no se origina en la ocupación de suelos de gran riqueza natural susceptibles de reserva, sino que tiene su origen en decisiones socio-políticas que sistemáticamente llevaron a la privatización de ecosistemas de dominio público mediante mecanismos fraudulentos de apropiación. Es un modelo de ocupación del territorio impuesto por la clase dirigente a partir de vías de hecho y adoptado inicialmente sin mayor resistencia por parte de todos los sectores de la sociedad, pero posteriormente con graves consecuencias de tipo social, económico, ecológico y urbanístico.

Estimamos complejo comenzar cualquier análisis de impacto ambiental sin tener en cuenta la organización social en un territorio, motivo por el cual consideramos conveniente establecer un modelo de análisis sustentado a partir de los cuatro sistemas descritos, que nos permite a la vez, establecer diferencias entre impacto ambiental e impacto ecológico y tomar distancia de quienes lo puedan interpretar, o lo interpreten, como conceptos sinónimos. Inclusive, no concebimos conveniente realizar un análisis de impacto ecológico, sin considerar la interrelación que existe entre los actores sociales, económicos y políticos de una ciudad o una región. El siguiente esquema expresa, a partir de la ocupación posterior del suelo, la interacción entre estos cuatro sistemas y los efectos que dicha interacción ocasiona para el ambiente, desde el enfoque holístico, en la ciudad de Montería. 


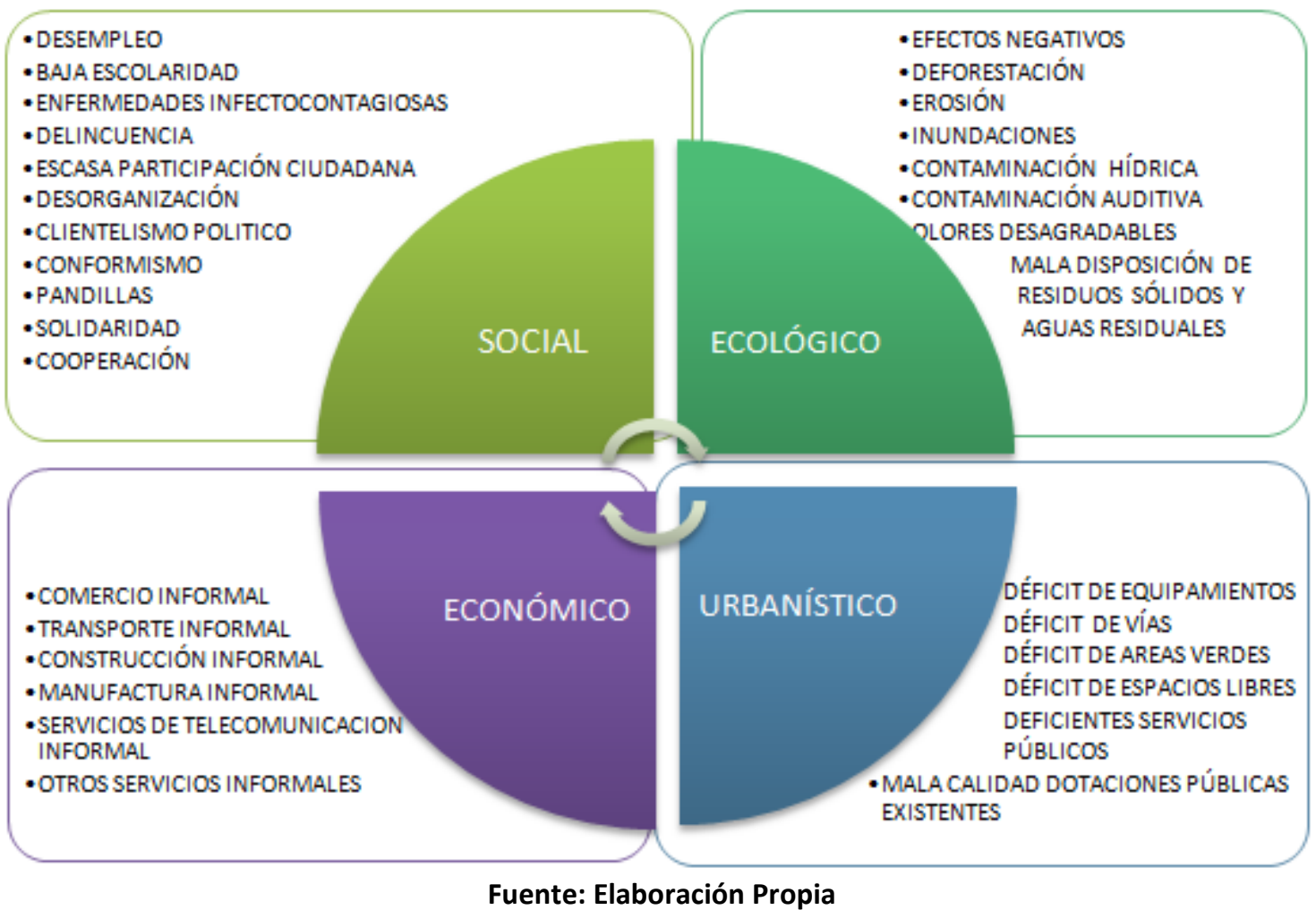

Esquema 9. Resultado Final del Impacto Ambiental de la Urbanización Marginal en Montería

Hemos descrito a lo largo de éste y de los anteriores capítulos, una serie de problemas originados, como ya anotamos, en una organización social que diseñó un modelo de ocupación poco favorable para el desarrollo humano y sostenible de la ciudad. Un modelo que no solamente ha concentrado la tierra sino que además ha expoliado tierras de gran riqueza faunística, hídrica y forestal de conservación, para convertirlas en simples mercancías para especulación y acumulación. Tanto la concentración de la tierra como la expoliación de ciénagas, bosques o colinas, restringieron las posibilidades de supervivencia de grupos sociales, cuya alimentación y economía dependía en gran medida de la pesca o de la agricultura.

Igualmente, frenó las posibilidades de desarrollo de la región, al establecer usos inapropiados sobre suelos de gran capacidad agrológica para dedicarlos a ganadería o a la especulación, generando esto desempleo estructural en el campo y en la misma ciudad, con las respectivas implicaciones que conlleva. Con el crecimiento de la población el desempleo estructural se volvió insostenible, generando conflictos, desplazamientos y elevados niveles de informalidad en la economía, en la ocupación de la tierra y en el espacio construido. 
Con este panorama de desempleo crónico, de concentración de la tierra y ocupación por vías de hecho, que con gran frecuencia utilizaba métodos violentos, el empobrecimiento de gran sector de la población fue inminente, que no tuvo más remedio, sino el de asumir las mismas formas de ocupación instauradas por la clase dirigente. En este aspecto, cada vez más, el acceso al suelo se hacía más complicado, y los ecosistemas más frágiles se constituyeron en la mejor opción para esta gran masa de desempleados urbanos o marginados del campo.

Sin empleo y sin tierra las condiciones sociales se deterioraron significativamente hasta superar tasas de desempleo y de analfabetismo superiores al $20 \%$, lo cual se convirtió en un instrumento ideal para la explotación económica y la manipulación política que consolidó el clientelismo político, que con el transcurrir de los años garantizaría la posibilidad de acceso de los "ciudadanos" a un lote, vivienda y dotaciones públicas. También brindaría la posibilidad de que sus hijos ingresaran a las escuelas públicas, al empleo público, a los subsidios y a créditos públicos; aunque pocos eran los elegidos y muchos los marginados, independientemente de la participación en los procesos electorales.

En estas circunstancias los marginados sociales, económicos y políticos fueron emplazándose cada vez más en terrenos no aptos para usos residenciales, en situaciones sanitarias totalmente desfavorables y en las peores condiciones urbanísticas, sufriendo diferentes tipos de exclusión y padeciendo las enfermedades que ocasionan los entornos insalubres, pero con la firme convicción de que la promesa de los políticos se convertiría en realidad. ¿Cuáles eran estas promesas? Calzar los terrenos que se inundaban, construir canales, mejorar la vivienda, legalizar el dominio de ella, regularizar el asentamiento, conseguir las vacunas para erradicar las enfermedades infantiles, las dermatológicas, las diarreicas, arreglar las vías, llevar la energía, el agua potable, construir una escuela, un puesto de salud, un auxilio, un empleo público, un subsidio para vivienda.

¿Cuánto tardó ese proceso? Ese proceso demoró para algunos cinco años, para otros diez, quince veinte, treinta, cuarenta, cincuenta, una generación, dos generaciones, 
incumplimientos, decepciones. En este clientelismo político se involucró un gran sector de la población, pero a pesar de eso, no todos recibieron lo que consideraban merecían por su voto, e incluso, algunas familias manifiestan que aparte del lote jamás recibieron un subsidio, crédito público, cupo educativo, empleo público ni alguna de las dadivas que electores y elegidos establecieron dentro del sistema clientelar. Hoy por hoy, aún hay personas que siguen esperando esas dadivas prometidas por políticos, con la certeza de que en las próximas elecciones, si llegarán.

¿Qué pasó después del cumplimiento de algunas promesas? Después de estabilizar terrenos, construir canales, centros de salud, escuelas, instalar redes de servicios básicos e iglesias, se han mejorado varios sectores, pero muchos de ellos siguen con los problemas expuestos en el esquema de impacto ambiental: inundaciones, canales de aguas pluviales contaminados por aguas residuales, inadecuado tratamiento de basuras, olores desagradables, ruidos excesivos o inapropiados, enfermedades infectocontagiosas, desempleo, inseguridad, baja escolaridad, comercio informal, transporte informal, construcción informal, déficit de equipamientos, de espacio público, equipamientos existentes de baja calidad, calles precarias, alcantarillas a cielo abierto, más de siete mil predios ocupados informalmente sin regularizar, inseguridad, pandillas, erosión, deforestación, programas de cooperación por parte de ONG, proliferación de iglesias evangélicas que operan como microempresas de la fe, angustias, temores, esperanzas, solidaridad, espontaneidad, deseos de muchas personas por salir honestamente adelante, y por supuesto, la buena intención de contados académicos, dispuestos a corregir los desequilibrios generados por una clase dirigente codiciosa y de muy bajo perfil político, principalmente aquellos que insisten con ese modelo inapropiado de ocupación, el cual hemos denominado urbavillanización.

Todo el anterior escenario queda distribuido en asentamientos precarios, semiconsolidados y consolidados con necesidades colectivas por resolver y graves inconsistencias urbanísticas que requieren la aplicación de un modelo más eficiente de intervención pública y mejor asignación de recursos orientados a prevenir impactos negativos futuros sobre los elementos que conforman el ambiente de esta ciudad, y no 
a seguir despilfarrando todo tipo de recursos en reparaciones altamente costosas y poco efectivas para el mejoramiento de la calidad de vida y de ese mismo ambiente.

Finalizamos esta investigación, manifestando que este deterioro ambiental, principalmente en lo ecológico, es totalmente innecesario, injustificado, improcedente, o como se quiera denominar desde cualquiera de las lógicas, más si se tiene en cuenta que esa misma política de vivienda, generadora de tanto asentamiento informal, se pudo haber desarrollado sobre otros terrenos disponibles de la ciudad, ya fuera de propiedad pública o privada. Es decir, la utilización de los principales ecosistemas, no obedeció a un déficit de terrenos, sino a un proceso inconveniente de especulación por concentración de suelo por parte de unos propietarios que abiertamente ejercieron de juez y parte. En este orden de ideas, no solamente fue desacertada la política de vivienda, sino los elevados niveles de concentración, especulación y cinismo de las autoridades municipales de la época, quienes fomentaron la expoliación y depredación de ecosistemas.

Consideramos entonces que el principal problema dentro de este análisis para la ciudad de Montería, no son los asentamientos informales, ni su número, ni la población como tal, sino las condiciones sociales, económicas, urbanísticas y ecológicas resultantes de sus emplazamientos en sitios no aptos para vivienda o susceptibles de reserva natural. Eso no significa que estemos de acuerdo con ese perverso modelo de vivienda adoptado, ni con la ya mencionada urbavillanización que ahora pretende sustituir a la invasión y barrios de promoción pública, con el sofisma de formalidad del dominio de una vivienda que no existe, o mejor dicho, con la formalidad de un predio, cada vez más reducido, en el que se emplazará otra infravivienda, y otra y otra......... 


\section{CONCLUSIONES}

La investigación sobre el impacto ambiental de la urbanización marginal en la ciudad de Montería a partir del análisis de cuatro aspectos nos permitió obtener resultados definitivos que complementan, y además amplían los múltiples aportes, que desde diferentes disciplinas, han realizado destacados investigadores, principalmente desde la arquitectura, el derecho, el urbanismo y la sociología. En este orden de ideas, manifestamos que el análisis social, económico, urbanístico y ecológico del fenómeno de la Urbanización Marginal efectuado en esta tesis nos condujo a las siguientes conclusiones:

\subsection{CONCLUSIONES ASOCIADAS A ASPECTOS SOCIALES Y JURÍDICOS}

1. Actores que participan en el surgimiento. En la invasión de suelos así como en los fraccionamientos irregulares de terrenos para asentamientos en Montería participaron inicialmente diferentes actores. En estos procesos, además de invasores o fraccionadores, también participaron: líderes sociales, políticos, religiosos e institucionales, y su éxito se encuentra asociado precisamente a la satisfacción de necesidades o intereses de cada uno de estos actores sociales, ya sea de manera parcial o total, así como al nivel de liderazgo, organización y planeación en dicho proceso. En este aspecto, los invasores logran resolver, aunque de manera precaria, el problema de la vivienda; los propietarios o fraccionadores de suelos degradados y de escaso valor comercial, consiguen mejores precios por ellos, generalmente con rescursos fiscales; los politicos obtienen beneficios electorales y mayor capacidad de dominación, y las autoridades municipales disminuyen con menores costos economicos, la presión por la vivienda.

2. Actores participantes en la consolidación de los asentamientos informales. La consolidación de estos asentamientos es el producto de la combinación entre intervención pública, cooperación de las Organizaciones No Gubernamentales (ONG), y participación comunitaria. Evidentemente, dentro de esta combinación, la 
mayor parte de intervención le ha correspondido al Estado, en primer lugar, con el propósito de cumplir con sus funciones constitucionales básicas, y en segundo lugar, por los elevados costos que representan estas intervenciones, para las poblaciones vulnerables o de bajo poder adquisitivo.

3. Percepción del dominio. Con respecto a la percepción del dominio los invasores presentan tres estados psicosociales:

a) Incertidumbre, es una etapa caracterizada por la desconfianza y el temor, en la que los ocupantes asumen el papel de centinelas, con el objetivo de evitar desalojos o la llegada de nuevos invasores. En esta primera etapa no siempre ocupan las mismas personas que se asentarán definitivamente en el predio, ya sea por relevo entre familiares o por la presencia de invasores profesionales. La incertidumbre de los invasores en esta fase, dificulta cualquier tipo de relaciones mercantiles relacionadas con los lotes;

b) Esperanza, la cual es una época en donde los ocupantes ya asumen su rol de residentes, pero sin contar aún con las escrituras de dominio legal del predio, sin embargo, aquí se presentan aisladas relaciones mercantiles, que se traducen en alquileres informales o promesas de compraventa, posteriormente ejecutables, $y$

c) Certeza, caracterizada por la seguridad que brinda el dominio del suelo, el nuevo rol de propietario y por la posibilidad de acceder, por fin, a créditos con el sistema financiero, o de vender a buen precio para comprar en mejor sector de la ciudad.

4. Tipología de los asentamientos informales. Teniendo en cuenta, tanto el dominio de la propiedad como el cumplimiento de las normas urbanisticas, los asentamientos informales de Montería presentan la siguiente tipología:
a) Invasión
b) Fraccionamientos irregulares privados 
c) Promoción pública

Dentro de esta tipología, la invasión no es la primera modalidad de ocupación, ni en antigüedad ni en número, pero si es un instrumento bastante efectivo, que contribuye desde la década de los años cincuenta, a la conformación de treinta y cinco asentamientos, inclusive en terrenos de los principales ecosistemas de la ciudad. Por su parte, los fraccionamientos irregulares privados son aquellos que vienen transgrediendo las normas urbanísticas desde los años cuarenta, cuando comenzó la expansión hacia el sur. Hasta la fecha esta modalidad ha contribuido con el surgimiento de más de cien barrios, desarrollados por medio de procesos de autoconstrucción. Así mismo, los asentamientos informales de promoción pública son aquellos que se desarrollaron mediante procesos de autoconstrucción, pero transgrediendo normas urbanísticas, o por medio de programas incompletos de vivienda terminada, que generalmente incumplieron con uno o varios de los procesos formales de la urbanización. Los fraccionamientos públicos surgieron como alternativa del Estado, ante su incapacidad financiera para atender la elevada demanda de vivienda, y preferiblemente fueron emplazados en terrenos aledaños a programas de vivienda pública terminada. Para diferenciarlos de los fraccionamientos irregulares privados se les denomina "Iotes con servicios", lo cual equivale a conexión con redes de energía y agua potable.

5. Patrón de conducta de los habitantes. Un gran sector de los habitantes de estos asentamientos demuestra bajo nivel de pertenencia, lo cual se refleja en su falta de compromisos o nula participación en el mantenimiento y adecuada conservación de sus sectores dentro de la ciudad. En este sentido, la indiferencia ante problemas de la comunidad, la ausencia de programas de educación ciudadana y la falta de conciencia colectiva son aspectos que contribuyen con el maltrato a la naturaleza, a lo público, al mobiliario, a los equipamientos y a la estructura urbana de Montería. Igualmente, la ausencia de políticas públicas ambientales y la mentalidad paternalista que se tiene del Estado, inducen indirectamente a la población a arrojar basuras en su entorno, en canales de aguas pluviales, a no sacar los desechos en las horas indicadas por la empresa recolectora, a no clasificar los 
residuos, a eludir compromisos ciudadanos y a no participar en reuniones de interés general para el barrio ni en la conformación de organizaciones cívicas.

6. Vulnerabilidad social de la población. Las condiciones en que los habitantes de estos asentamientos desempeñan sus actividades económicas, el nivel de ingresos y la calidad de vida, permitieron establecer tres grupos en función de los niveles de vulnerabilidad para esta población:

a) alta vulnerabilidad

b) mediana vulnerabilidad

c) baja vulnerabilidad.

El primer grupo incluye a las personas que no perciben ningún tipo de ingresos; es decir a los desocupados crónicos, adultos en estado de indigencia y amas de casa dedicadas exclusivamente a oficios del hogar en condiciones desfavorables, quienes son los que presentan absoluto grado de dependencia, ya sea familiar o estatal. El grupo de vulnerabilidad media, incluye a personas dedicadas a actividades informales con fines lícitos, dentro de los cuales sobresalen vendedores ambulantes de todo tipo de alimentos o bebidas, lavadoras o planchadoras de ropa, lavadores de carros, lavadores de motocicletas, albañiles, ayudantes de construcción, maestros de obra, modistas, mecánicos, chapistas, madres comunitarias. Esta población a pesar de sus esfuerzos y dedicación no obtienen el reconocimiento ni el ingreso suficiente que les permita elevar su calidad de vida, pero de una u otra forma, obtienen un ingreso para su supervivencia que disminuye su grado de dependencia. En el grupo tres se encuentran las personas de mejor nivel de vida del barrio, y dentro de los cuales figuran principalmente los tenderos, comerciantes, panaderos, ferreteros, fabricantes de bloques, prestamistas y propietarios de locutorios. Este menor nivel de vulnerabilidad solo es posible lograrlo después de algunos años de constituido el barrio, específicamente a partir de la fase de semi-consolidación cuando los emprendedores comienzan la dinámica económica y social en condiciones de informalidad o sin incorporación a la seguridad social. 
7. Emplazamiento de asentamientos marginales en terrenos públicos. Se establecen como emplazamientos irregulares de alto impacto a los fraccionamientos de terrenos públicos, y peor aún, a los fraccionamientos de suelos fiscales de gran riqueza natural o con potencial de reserva ecológica, que terminaron en manos de particulares, políticos o ex-políticos, quienes negociaron directamente o a través de terceros lotes de 98 o $162 \mathrm{~m}^{2}$. Estas transacciones, generalmente fueron financiadas, pero respaldadas por letras de cambio o a través de documentos de compraventa debidamente autenticados en notaría pública.

8. Cambio de escenario: tipificación penal de la urbanización ilegal. Las últimas invasiones de Montería, sucedidas después del año 2000, se realizaron en un escenario legal y político diferente al establecido durante más de cincuenta años y que permitieron el éxito de las anteriores invasiones. En cuanto a lo legal, para este periodo ya se encontraba vigente la ley 599 del 2000, que endurecía las penas sobre invasión de tierras, incluidas aquellas zonas de especial importancia ecológica, la usurpación de tierras, y se tipificaba como delito a la urbanización ilegal, razón por la cual, el Estado se vio obligado a darle un reconocimiento legal a los invasores mediante el reconocimiento como miembros de Organizaciones Populares de Vivienda (OPV), para evitar su judicialización y brindar una solución; es decir, el Estado terminó legalizando estas nuevas invasiones ante su incapacidad para controlarlas. En lo referente a lo político, el cambio estuvo asociado al surgimiento de un para-Estado que logró la adquisición, por vías legales o ilegales, de terrenos rurales, suburbanos y urbanos, al igual que la participación en corporaciones públicas y en administraciones municipales. En este aspecto, los terrenos de dominio municipal, que por tantos años facilitaron los procesos de invasión, quedaron en manos de paramilitares, quienes asumieron el protagonismo principal y relegaron a un segundo plano el poder de gamonales y políticos tradicionales.

9. Normatividad urbanística y transgresión. Las normas urbanísticas relacionadas con la parcelación, la urbanización y la edificación han sido transgredidas 
históricamente por los urbanizadores populares, por los invasores o por el Estado, representado en las instituciones del ICT, INURBE, COMFACOR, FONVIVIENDA y el Fondo Municipal de la Vivienda. Estas transgresiones, desencadenaron continuamente la necesidad de establecer medidas interventoras, que generalmente no apuntaban al desarrollo urbano, sino a reparar las graves inconsistencias de dichas transgresiones, principalmente aquellas asociadas a los conflictos de usos del suelo y a la no instalación oportuna de redes de infraestructura.

\subsection{CONCLUSIONES ASOCIADAS A ASPECTOS URBANÍSTICOS Y ARQUITECTÓNICOS}

1. Proceso. En el proceso de invasión de terrenos, teniendo en cuenta el tipo o utilización de materiales constructivos se identificaron tres fases:

a) Instalación, cuyo primer objetivo es el de establecer posesión, pero con materiales transitorios (cartón, lata, plastico, etc.), de bajo valor económico, para evitar pérdidas en los desalojos o posibles incautaciones por parte de las autoridades;

b) Aceptación de la invasión, la cual está sujeta a una decisión favorable de la Administración municipal. En esta segunda fase los materiales transitorios instalados inicialmente son reemplazados por elementos de mayor consistencia (madera, guadua, palma, zinc), convirtiendo la infravivienda en una edificación de mayor solidez, y

c) Legalización del asentamiento por parte de la administración municipal, que da paso a la incorporción de materiales definitivos como asbesto, cemento, hierro, cristales, baldosa, e incluso marmol. La incorporación de estos materiales están sujetas al poder adquisitivo de las familias, a los subsidios estatales o a la financiación que las instituciones financieras puedan realizar. 
2. Calidad urbanística del asentamiento. En cuanto a la calidad urbanística y arquitectónica del asentamiento se identificaron tres categorías:
a) asentamientos precarios
b) asentamientos semiconsolidados
c) asentamientos consolidados

En los primeros gran parte de las viviendas permanecen en estado transitorio, es decir presencia mayoritaria de infraviviendas en condiciones físico-ambientales desfavorables, estos asentamientos carecen de todos o algunos de los servicios básicos, de equipamientos colectivos o de espacios para su edificación, sus únicas dotaciones públicas son vías o caminos intransitables para el tráfico automotor, la mayoría de ellos no supera el promedio de diez años, pero por razones de incertidumbre algunos dobla dicho periodo, específicamente cuando esperan indefinidamente una reubicación.

En los segundos, por su parte, hay mayor heterogeneidad de vivienda, es decir en ellos se combinan infraviviendas con edificaciones terminadas o inacabadas, se caracterizan por la edificación parcial de equipamientos básicos, que generalmente comienzan su funcionamiento en condiciones arquitectónicas inconclusas o carentes de las principales dotaciones, mobiliario y/o equipos. En esta fase comienza la instalación o ampliación de redes de infraestructura básica de agua potable y energía, e igualmente se inicia la prestación del servicio colectivo de transporte, así como la adecuación de vías primarias por medio de concreto o de asfalto. No todos sus ocupantes cuentan con el dominio legal de la vivienda y pese a ello, comienzan a apropiarse del escaso espacio público del que se dispone, mediante la construcción de corredores o terrazas fuera del paramento, reduciendo hasta en dos metros la superficie de la vía, concretamente la del andén; esta etapa transcurre a partir de los diez años y se puede extender hasta los veinte o treinta años. 
Finalmente, los asentamientos consolidados son aquellos que logaron acceder a todos los servicios públicos básicos, culminación de sus equipamientos, dominio legal de la vivienda, prestación del servicio de transporte público, pavimentación de vías principales, construcción de andenes para peatones y culminación arquitectónica de más del $90 \%$ de las viviendas. Sin embargo, esta consolidación no ha sido suficiente para lograr optima calidad urbanística, ni para mitigar el impacto negativo sobre los ecosistemas, lo cual significa que la legalización del dominio y las intervenciones urbanísticas mejoran la calidad urbana del sector, pero no son suficientes para corregir todas las transgresiones realizadas a las normas urbanísticas o ambientales en el pasado. El periodo de tiempo requerido para llegar a esta instancia de consolidación es superior a cuarenta años, pero para el caso específico de algunos fraccionamientos de promoción pública, este periodo fue inferior debido a que en la elección del terreno se tuvo en cuenta la proximidad a infraestructuras de programas de vivienda terminada.

3. La invasión del espacio público. Uno de los impactos más traumáticos de la economía informal, desde el punto de vista urbanístico, es la invasión del espacio público, la cual es fomentada principalmente, por los vendedores estacionarios que ubican sus negocios en andenes, vías y plazas de la ciudad. Esta situación dificulta la movilidad de las personas y genera fuertes tensiones sociales entre peatones, conductores y comerciantes. El mayor damnificado de esta situación es el peatón, quien frecuentemente es desplazado del andén y obligado a compartir la calle con automóviles, autobuses y motocicletas. Igualmente, generan un impacto negativo otras actividades económicas informales como el lavado de automóviles y la comercialización de pescado a orillas del río Sinú, debido a los olores y vertidos producidos por ambas, y que además, van a parar directamente a la fuente hídrica hasta contaminarla con residuos de combustibles y lubricantes.

4. La construcción de la vivienda. La informalidad urbana en esta ciudad se constituye en factor clave para la construcción de la vivienda, generación de ingresos y dinamización de la economía. En lo referente a la vivienda, corroboramos que la arquitectura popular, es decir, aquella no diseñada ni 
ejecutada por arquitectos profesionales, ha permitido hasta el 2010, la construcción parcial o total de aproximadamente (25.000) veinticinco mil viviendas, principalmente en asentamientos surgidos por invasión y/o fraccionamientos irregulares. También ha sido el soporte fundamental de los programas de promoción pública de lotes con servicios, desarrollados mediantes procesos de autoconstrucción en los barrios Boston, Pastrana Borrero, Policarpa Salavarrieta, Santander y el Prado.

5. Periodificación en el desarrollo de la urbanización marginal en Montería. La urbanización marginal no es un fenómeno aleatorio en Montería, sino un modelo social de ocupación que permitió el surgimiento de invasiones simultáneas, asociadas a situaciones estructurales o coyunturales. En este orden de ideas, dentro de la configuración del espacio urbano de esta ciudad, destacamos cuatro oleadas de asentamientos informales:

a) la transcurrida en los años sesenta

b) durante los años setenta

c) los años ochenta y noventa, y

d) a partir del año 2000

La tercera oleada tuvo el mayor impacto sobre la morfología urbana, debido a la superficie de las invasiones, especialmente Cantaclaro, Robinson Pitalúa, la Candelaria y un sector del Dorado, que en conjunto superaron 200 hectáreas con 7.000 lotes para infravivienda. Sin embargo, es significativo destacar el efecto arrastre que representaron los programas de vivienda pública terminada para cada una de estas oleadas; es decir, la Granja y el P-5 en los sesenta, la Pradera y la Ribera en los setenta, Mogambo en los ochenta, y los Robles después del año 2000.

6. Las áreas de centralidad y los asentamientos informales. Los asentamientos informales no participan de la descentralización o desconcentración de ciertas actividades, principalmente financieras y ocio, ni se ven favorecidos con la ubicación de nuevas centralidades urbanas de tipo comercial, es decir centros 
comerciales de gran superficie o hipermercados de cadena, los cuales son establecidas a grandes distancias de ellos. Esta población es la más numerosa, pero su capacidad adquisitiva no garantiza la rentabilidad financiera de grandes proyectos, y la infraestructura física es una limitante que no estimula la inversión de grandes empresarios.

7. Vivienda pública y fraccionamientos públicos para procesos de autoconstrucción. El Instituto Colombiano de Crédito Territorial (ICT), en 38 años (1952 -1990), construyó 9.427 viviendas públicas y legalizó las invasiones del 14 de Julio, Santafé, San Martín, Brisas del Sinú, Santander, Pastrana Borrero y Policarpa, mientras que el INURBE en 11 años (1992-2003) escasamente construyó 939 viviendas. Los programas del INURBE no fueron favorables para la estructura urbana de esta ciudad, porque no contribuyeron a la cohesión física ni social, y por el contrario, su cobertura y calidad fue tan deficiente que estimularon la informalización de los mismos programas, así como la proliferación de fraccionamientos irregulares e invasiones colectivas. Con estos programas se redujo la superficie del lote de $162 \mathrm{~m}^{2}$ a $98 \mathrm{~m}^{2}$ y el plano de la ciudad se vio significativamente alterado por una diversidad de trazados inapropiados, que no aportaron nuevos ejes, ni se preocuparon por dotar de áreas libres ni de equipamientos de gran jerarquía. De igual forma, la mala calidad urbanística de los programas de la margen izquierda del río y la ausencia de una propuesta vial coherente, condenaron a los habitantes de cuarenta asentamientos a depender de sus dos únicos ejes: la vía al municipio de Arboletes y la vía al corregimiento de las Palomas, que transcurre paralela al río, con las nomenclaturas $3 \mathrm{~W}$ y $1 \mathrm{~W}$. 


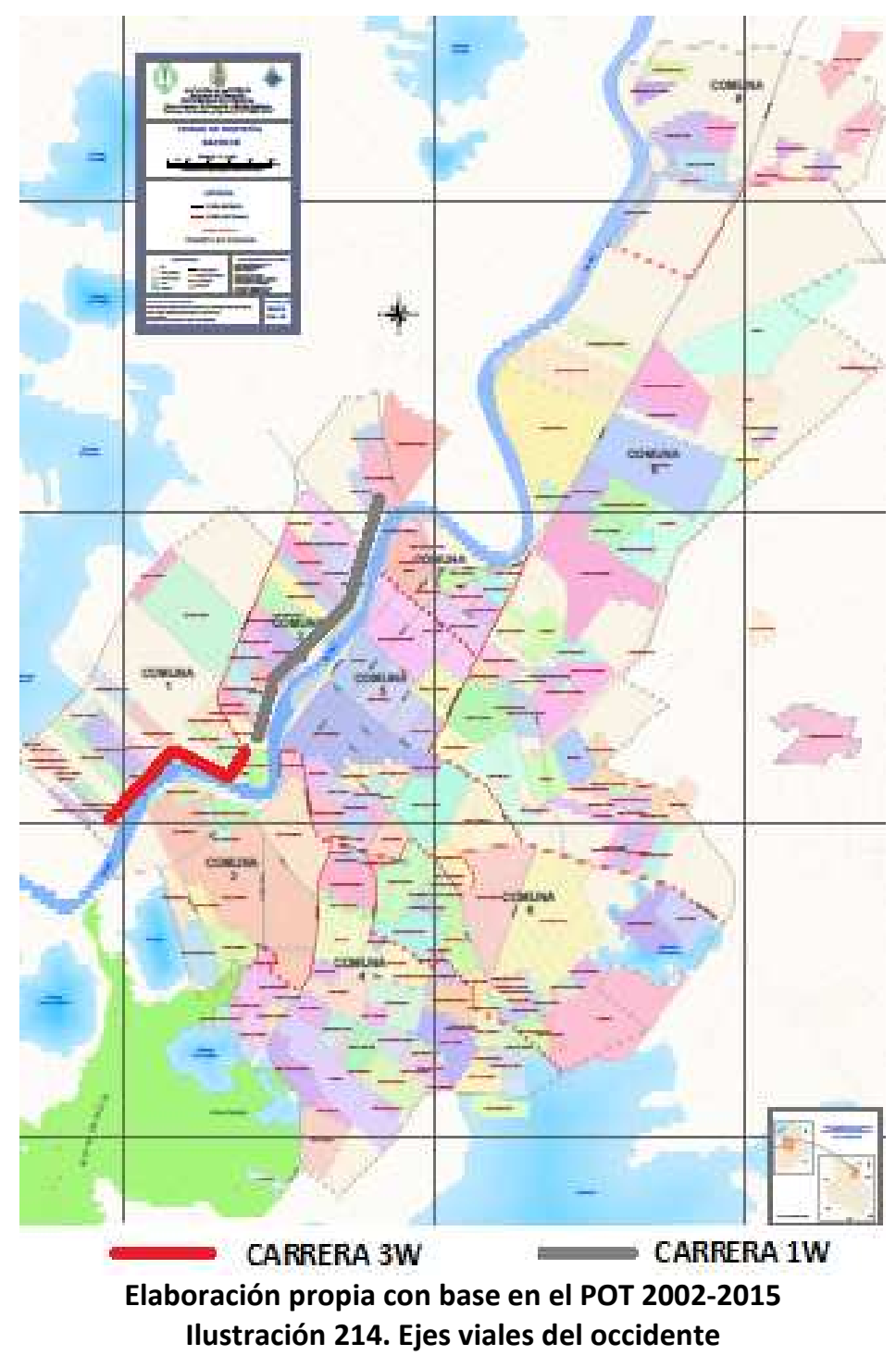

8. Fomento de la precariedad habitacional, arquitectónica y urbanística. Debido a su debilidad presupuestaria, el Estado colombiano, a través de sus diferentes instituciones de vivienda, optó por presentar dos modalidades de oferta: la primera orientada a la entrega de vivienda terminada y la segunda, a la entrega de lotes con servicios para autoconstrucción. Este segundo instrumento es denominado "Iotes con servicios", y por su efectividad, reemplaza frecuentemente los programas de vivienda terminada, que le corresponde ofertar al Estado Social de Bienestar, y que para el caso de Montería se iniciaron en los años sesenta con los fraccionamientos públicos del Prado y Boston, pero ante el surgimiento de invasiones en Santafé, San Martín, Pastrana Borrero, Policarpa y Santander, terminaron por aumentarse en las siguientes décadas, hasta extenderse por toda la ciudad. Esta modalidad, desde el punto de vista financiero 
es favorable para el erario, ya que el Estado abandona ese rol inicial de promotorurbanizador-constructor, para asumir únicamente el papel de promotorurbanizador, y así trasladar el costo total o parcial de la vivienda a las familias; pero, desde el punto de vista urbanístico, esta modalidad es gran generadora de informalidad y precariedad habitacional.

9. Evolución en los procesos de producción de la urbanización marginal: la "urbavillanización". Con el cambio en las condiciones socio-políticas se abre un nuevo capítulo en la construcción del espacio urbano, que permitiría controlar los reiterados procesos de invasión colectiva, pero no el fenómeno de la urbanización marginal. La ocupación por invasión es reemplazada por fraccionamientos privados que permiten la adquisición legal del lote por medio de compra directa o por vía subsidiada (subsidio familiar). Esta modalidad no cambia en nada el panorama de informalidad urbanística; es decir del modelo de invasión se pasa a un modelo que hemos denominado como "urbavillanización". Éste, es un modelo de ocupación propuesto por la institucionalidad y desarrollado mediante programas públicos de autoconstrucción, cuyo resultado final son las "urbavillanizaciones". Las urbavillanizaciones, a su vez, son urbanizaciones incompletas, con características similares a las de las últimas "villas miserias" de Argentina, o a las de cualquier otra invasión en Latinoamérica, tanto en sus aspectos físicos como socio-económicos, pero a diferencia de estas últimas, sus ocupantes no acceden a sus lotes por las vías de hecho sino por vías legales.

10. El modelo de "Urbavillanización. El modelo de "Urbavillanización" garantiza condiciones jurídicas relacionadas con el dominio de los predios pero no extingue la urbanización marginal ni la precariedad de la vivienda. Este modelo consolida a Montería, como lo que desde aquí denominamos, "ciudad subnorma", y posibilita el acceso legal de la población vulnerable al suelo mediante subsidios estatales, pero reduciendo cada vez más el espacio de la vivienda y de las dotaciones públicas a sus mínimos posibles. En este sentido, el espacio construido de la vivienda pública fue gradualmente disminuido de 75 a $36 \mathrm{~m}^{2}$ y el del lote de 162 a $66 \mathrm{~m}^{2}$, con transgresión permanentemente de las norma urbanísticas, sobre todo, 
cuando se siguen entregando lotes marginales en vez de los lotes urbanizados, tal y como lo establecen la Ley 3a de 1991, el artículo 51 de la constitución política de Colombia, el Plan de Desarrollo Nacional y el Plan de Ordenamiento Territorial de Montería 2002-2105.

11. Características de la "ciudad subnorma" Urbanísticamente nos encontramos frente a una "ciudad subnorma", caracterizada por desequilibrios socio-espaciales y medioambientales, asociados a la mala calidad de la vivienda, a alcantarillas a cielo abierto, a vías precarias y a la precariedad de equipamientos públicos. Una ciudad con un plano en el que a veces se confunde lo público con lo privado, lo residencial con lo comercial, lo natural con lo artificial, y en el que además sobresalen desequilibrios generados por incompatibilidad de usos y por el predominio de equipamientos privados excluyentes que no logran integrar áreas marginales. Igualmente se observa el gran déficit de espacios público en áreas informales del suroriente, así como docenas de canchas deportivas rusticas que no reúnen características de equipamientos, ya sea, por la ausencia de arquitectura o de condiciones mínimas de funcionalidad. Una ciudad plagada de urbanizaciones marginales que no surgieron alrededor de grandes infraestructuras, sino por el contrario, sobre ejes artificiales secundarios como canales de aguas residuales, canales de aguas pluviales y carreteras corregimentales, eso sí, sin dejar de desconocer la incidencia del río Sinú y de los ejes viales primarios que conducen a Medellín, Cartagena y Arboletes.

12. Los Programas de Vivienda Pública y la extensión del modelo de "Urbavillanización" Los últimos programas de vivienda pública, después de la liquidación del INURBE en el año 2000, fueron desarrollados por parte de la Caja de Compensación Familiar de Córdoba (COMFACOR), el Fondo Municipal de la Vivienda, el Fondo Nacional de Vivienda y el Departamento de Córdoba. Estos programas son Villa Sorrento, Villa Fátima, Santa Teresa, Villa Natalia, Nueva Belén y Nueva Jerusalén en el oriente de la ciudad, los cuales presentaron deficiente calidad urbanística, y en el caso especifico de Nueva Belén y Nueva 
Jerusalén, fueron emplazados detrás de la invasión Cantaclaro, con el objetivo de reubicar a familias de las invasiones Ranchos del INAT y Jerusalén. Cada uno de estos programas tiene características de "urbavillanizaciones", ya sea, por el tamaño infrahumano de sus viviendas, $36 \mathrm{~m}^{2}$ o por las deficiencias urbanísticas, principalmente en lo referente a equipamientos, espacios libres y viarios.

13. El Planeamiento Urbanístico y la "desmarginalización" de Montería. La aprobación del primer Plan de Ordenamiento Territorial, en esta "ciudad subnorma" en el año 2002, aunque tardíamente, permite corregir deficiencias urbanísticas y definir nuevos patrones urbanos, pero no se convierte en un elemento ordenador aprovechable para controlar invasiones o fraccionamientos irregulares, tal y como lo demuestra el surgimiento de los asentamientos Furatena, Villa Paz, Nueva Esperanza, los Nogales, Villa de los Alpes, Vereda Tropical, los Colores, la Vid, el Níspero, los Ébanos, Altos de California, Santa Isabel, el Paraíso, las Acacias, Villa Mery, Villa Jiménez y el Privilegio, surgidos por invasión o por fraccionamientos privados, sin cumplir todas las normas urbanas o por emplazarse en áreas naturales incompatibles con usos residenciales. Tampoco ha sido suficiente con los instrumentos utilizados por este plan para "desmarginalizar" la ciudad; es decir, las denominadas "Operaciones Estructurantes" diseñadas para la "desmarginalización" de la ciudad, escasamente han contribuido a la instalación de redes de servicios básicos, pero no a acertadas intervenciones urbanísticas o dotaciones públicas de calidad que permitan una mejor integración socio-espacial y económica para estos sectores. No obstante, consideramos que diez años no son suficientes, ni el presupuesto de la ciudad lo permite, y por el contrario, un programa coherente de desmarginalización para esta ciudad solo sería posible a través de un gran Plan Estratégico y de sólidas fuentes de financiación.

14. El modelo urbano de la urbanización marginal: densidad, compacidad, dotaciones. Las urbanizaciones marginales tienen variadas densidades que en algunos alcanzan los 130 habitantes por hectáreas, muy bajas, si se comparan con 
las de las principales ciudades latinoamericanas o europeas, pero eso sí, más alto que las densidades de los barrios formales de esta ciudad, que en promedio no superan los 81 habitantes por hectáreas. Estas marcadas diferencias obedecen a factores socio-económicos asociados a ingresos y tamaño familiar, fácilmente explicables debido a que en esta ciudad las familias más numerosas son las de menores ingresos, y el mayor número de ellas, por razones obvias residen en estos asentamientos. Con estas perspectivas, la urbanización marginal maximiza el aprovechamiento del suelo, es decir, asigna la mayor superficie posible para alojamiento y la menor superficie posible para dotaciones públicas, facilitando esta distribución, el establecimiento de mayor número de familias, quienes generalmente terminan hacinadas en infraviviendas, sobre todo los grupos familiares conformados por más de diez personas.

\subsection{CONCLUSIONES ASOCIADAS A ASPECTOS ECONÓMICOS}

1. Origen y consolidación. En el origen y consolidación de las Urbanizaciones Marginales en Montería inciden tres factores:

a) el desequilibrio entre demanda y oferta de vivienda a partir del año 1950, cuando se inicia el traslado de la población rural hacia la ciudad. En esta época el mercado no puede brindar soluciones efectivas en valor de cambio debido a las condiciones socioeconómicas de la población, es decir, la baja capacidad adquisitiva de las familias no estimula la construcción de vivienda terminada, sino los fraccionamientos para autoconstrucción. Por otro lado, el Estado no tiene la capacidad de responder acertadamente, y limitadamente ofrece en esta década, a través del Instituto de Crédito Territorial (ICT), un sólo programa de vivienda pública, con apenas 60 viviendas terminadas, denominado "Barrio Obrero"

b) la ciudad no es un gran centro de producción ni gran generadora de empleo con capacidad de contribuir a mejorar el poder adquisitivo de las personas llegadas del campo en busca de oportunidades, sino más bien una 
alternativa de refugio para los desplazados por la violencia política o conflictos por la lucha de la tierra, y

c) la alianza entre urbanizadores irregulares, funcionarios de la administración y políticos de la región, permite la ocupación irregular de suelos, la legalización de invasiones, la titularización de predios y la venta de lotes en terrenos sin urbanizar, en donde los mayores beneficiados son los políticos, quienes obtienen grandes beneficios electorales a costa de la necesidad y bajos niveles de escolaridad de la población.

2. Simetría entre la informalidad económica y urbanística. Montería presenta unos niveles de informalidad económica proporcionales a los niveles de informalidad urbanística, en la que participan actores sociales marginados, pero también grupos de gran poder económico, como firmas constructoras, propietarios de hipermercados, y empresarios del transporte, quienes en vez de disminuir los niveles de informalidad laboral, terminan por propagarla a sectores como el de la construcción, el comercio, las telecomunicaciones y el transporte, hasta convertirla en un círculo vicioso que se perpetua en forma de miseria económica y miseria físico-espacial.

3. Movilidad y transporte informal. El mototaxismo es una alternativa informal que transporta en esta ciudad a ciento sesenta mil usuarios diariamente, mientras los empresarios del transporte colectivo formal únicamente trasladan a treinta mil pasajeros, lo cual debe ser compensado con restricciones a las motocicletas durante dos días a la semana. La mayor demanda por este tipo de transporte obedece a que ofrece una tarifa $40 \%$ inferior a la de los autobuses, y porque además presta un servicio puerta a puerta, que estimula aún más a los usuarios. Así mismo inciden en esta demanda, la baja cobertura del servicio formal, su baja frecuencia, las limitaciones de horario y la inexistencia de algunas rutas fundamentales para interconectar subsectores en el suroriente, o para comunicar el sur con el occidente. 
4. Informalidad sobre informalidad. La reventa de minutos de telefonía móvil es una actividad económica informal que se desarrolla con gran fuerza en las viviendas o negocios de los asentamientos informales mediante cuatro modalidades:

a) cuando el propietario de un local comercial o de servicios adquiere una línea telefónica con el objetivo de ofrecer el servicio de comunicación simultáneamente con su actividad comercial;

b) cuando adquiere la línea y la cede en alquiler o por comisión a familiares o personas cercanas, para que se opere desde el mismo negocio;

c) el dueño del negocio, brinda a un(a) vendedor(a) de minutos, la oportunidad de ubicarse fuera del negocio o dentro de él;

d) la venta es realizada desde la propia vivienda por cualquier miembro de una familia.

5. Balance sobre el papel del Estado. La Administración Pública, en ninguno de sus tres niveles, ha sido efectiva ni ordenada en lo correspondiente a su responsabilidad, al no definir programas articulados de desarrollo urbano acordes con las necesidades de la urbanización marginal, que permita su consolidación en tiempos inferiores a treinta o cuarenta años, e incluso, que los dote inicialmente de las infraestructuras básicas. Sobre este particular destacamos que las obras no son desarrolladas por su prioridad, sino por la conveniencia de actores políticos, por la fuerza de los líderes comunitarios, por el potencial electoral del asentamiento. En este sentido consideramos pertinente la aplicación del modelo de intervención pública que proponemos en esta investigación, y cuyo objetivo está direccionado a la optimización de recursos, a partir de intervenciones ordenadas que se inician con la instalación de todas las redes de servicios públicos, siguiendo posteriormente con el mejoramiento de la vivienda, adecuación de vías y construcción de equipamientos, para finalizar con la construcción de los equipamientos culturales y pavimento de vías. 


\subsection{CONCLUSIONES ASOCIADAS A ESPECTOS ECOLÓGICOS}

1. Insalubridad ambiental y riesgos sanitarios. Los habitantes de los asentamientos precarios tienen mayores riesgos de contraer enfermedades debido a las desfavorables condiciones higiénicas de las infraviviendas y a la insalubridad del entorno donde residen. Las enfermedades a las que están mayormente expuestos son a las de tipo respiratorio, dermatológico y gastrointestinal, principalmente infantes y adolescentes, quienes ante la falta de espacios libres, continuamente juegan con aguas pluviales estancadas, en zonas aledañas a alcantarillas a cielo abierto. Así mismo se exponen frecuentemente a residuos sólidos no recolectados, en los cuales proliferan zancudos, roedores y plagas. Los mayores problemas gastrointestinales se presentan en los asentamientos que no cuentan con el servicio domiciliario de agua, ni con las instalaciones adecuadas para aseo personal o preparación de alimentos. Sin embargo, el número de afectados por dichas enfermedades logra disminuir en la medida que evoluciona el asentamiento y mejoran las condiciones de salubridad.

2. El impacto ecológico de la urbanización marginal. El impacto ecológico de la urbanización marginal se manifiesta en la alteración de los siguientes ecosistemas: río Sinú, reserva natural Sierra Chiquita y las ciénagas de Berlín, el Reparo, la Trampa, los Araujos y Villa Jiménez.

Los fenómenos resultantes de la intervención son:

a) erosión y remoción en ladera

b) inundaciones

c) contaminación de la fuente hídrica

d) desecación de ciénagas

e) deforestación

f) tubificación. 
Con excepción de este último, los demás son demasiado evidentes a la mirada de los observadores, y el mayor impacto visual se presenta en la colina de Sierra Chiquita, como consecuencia de la deforestación de herbáceos, plantas arbustivas y arboles; erosión laminar y de aislados deslizamientos de tierras sucedidos en los últimos veinte años. Igualmente, estos tres fenómenos afectan las riberas del río, especialmente en los asentamientos Nuevo Milenio, el Bongo, Casa Finca, 7 de Mayo e invasión Sucre, cuyos habitantes vierten directamente aguas residuales y excrementos a las aguas del mencionado río.

3. Impactos ambientales causado por los habitantes de los asentamientos marginales. En cuanto a los efectos negativos generados por actividades desarrolladas por habitantes de estos asentamientos, corroboramos que los más evidentes, perceptibles y perjudiciales para la salud de los ecosistemas y de las personas son:

a) inadecuada disposición de residuos sólidos

b) vertimiento de aguas residuales a cielo abierto

c) desagradables olores que ambas generan

d) contaminación auditiva ocasionada por actividades de ocio mediante los ruidos producidos por el excesivo volumen de los ya mencionados equipos musicales.

Cada uno de estos fenómenos, incide, no solo en la calidad de vida de los residentes de estos sectores, sino en el resto de la población, o por lo menos en la población flotante que debe acudir a dichos sectores.

4. El origen del fenómeno. Corroboramos en esta investigación que el impacto ambiental negativo de la urbanización marginal en Montería no se origina en la ocupación de suelos de gran riqueza natural susceptibles de reserva, sino que tiene su origen en decisiones socio-políticas que sistemáticamente llevaron a la privatización de ecosistemas de dominio público mediante mecanismos 
fraudulentos de apropiación. En este sentido, resaltamos que el modelo de ocupación del territorio es impuesto por la propia clase dirigente a partir de vías de hecho, y adoptado inicialmente sin mayor resistencia por parte de todos los sectores de la sociedad, pero posteriormente con graves consecuencias de tipo social, económico, ecológico y urbanístico.

5. Concentración de la tierra y expoliación de ecosistemas. El modelo de ocupación impuesto por la clase dirigente de esta ciudad, no solamente ha concentrado la tierra sino que además ha expoliado tierras de gran riqueza faunística, hídrica y forestal de conservación, para convertirlas en simples mercancías para especulación y acumulación. Tanto la concentración de la tierra como la expoliación de ciénagas, bosques o colinas, restringieron las posibilidades de supervivencia de grupos sociales, cuya alimentación y economía dependía en gran medida de la pesca o de la agricultura.

6. Una depredación injustificada. El deterioro ambiental ocasionado por este modelo de ocupación, principalmente el ecológico, es totalmente innecesario, injustificado, improcedente, o como se quiera denominar desde cualquiera de las lógicas; más si se tiene en cuenta, que esa misma política de vivienda, generadora de tanto asentamiento informal, se pudo haber desarrollado sobre otros terrenos disponibles de la ciudad, ya fuera de propiedad pública o privada. Es decir, la utilización de los principales ecosistemas, no obedeció a un déficit de terrenos, sino a un proceso inconveniente de especulación por concentración de suelo llevado a cabo por unos propietarios que abiertamente ejercieron de juez y parte. En este orden de ideas no solamente fue improcedente la política de vivienda, sino los elevados niveles de concentración, especulación y depredación de ecosistemas, por parte de unos gamonales que pocas veces jugaron limpio, por lo menos, con el medio ambiente. 


\subsection{DOS CONSIDERACIONES FINALES}

1. Establecemos que con el panorama de desempleo crónico, la elevada concentración de la tierra y la ocupación por vías de hecho de las elites locales, que con gran frecuencia utilizaba métodos violentos, a los sectores más vulnerables de la población no les quedó más remedio sino el de recurrir a las mismas formas de ocupación instauradas por la clase dirigente. En este aspecto cada vez más el acceso al suelo era más complicado y los ecosistemas más frágiles se constituyeron en la mejor opción para el acceso de esta gran masa de desempleados urbanos o marginados del campo.

2. Consideramos finalmente, que el principal problema para la ciudad de Montería, no son los asentamientos informales, ni su número, ni la población como tal, sino las condiciones sociales, económicas, urbanísticas y ecológicas resultantes de sus emplazamientos en sitios no aptos para vivienda o susceptibles de reserva natural. Sin embargo, eso no significa que estemos de acuerdo con ese inapropiado modelo de vivienda, ni con la ya mencionada urbavillanización, que ahora pretende sustituir a la invasión y barrios de promoción pública, por el sofisma de una formalidad en dominio de una vivienda que no existe, o mejor dicho, con la formalidad jurídica de un predio cada vez más reducido y en el que se emplazarán nuevas infraviviendas. 


\section{REFERENCIAS Y BIBLIOGRAFÍA COMPLEMENTARIA}

\subsection{REFERENCIAS}

Agudelo Patiño, Luis Carlos (2004): Evaluación de la sostenibilidad ecológica del área metropolitana de Medellín. U.P.V. Valencia.

Alcaldía de Bogotá (2010): Bogotá: Ciudad de Estadísticas. Boletín N²2. Densidades Urbanas. http://www.sdp.gov.co/resources/Cartilla 22 Densidad Urbana Bogota.pdf

Alcaldía de Montería (2001): Plan de Desarrollo de Montería 2001-2003. Capítulo II. Prioridad № 2. Desmarginación. Estrategia № 3. www.alcaldiademonteria.tripod.com/plan desarrollo02.html

- (2002): Plan de Ordenamiento Territorial 2002-2011.

- (2004): Plan de Desarrollo 2004 -2007. "Por el camino correcto". www.alcladiademonteria.gov.co

- (2008): Plan de Desarrollo 2008 - 2011. "Juntos Podemos Más" www.alcladiademonteria.gov.co

- (2010): 10 Informe de Gestión. www.montería.gov.co

- (2010): Ajustes al Plan de Ordenamiento Territorial 2002-2015. Cap. I. Expediente Municipal del Plan de Ordenamiento Territorial.

- (2010): Presupuesto de ingresos, rentas y recursos de capital 2010: http://www.monteriacordoba.gov.co/presupuesto.shtml?apc=fpxx1\&x=1731482

- (2011): Ajustes al Plan de Ordenamiento Territorial de Montería 2002-2015. Diagnostico Parte I.

Andreatta, Verena (2002): "Ciudades hechas a Mano". Disponible en http://habitat.aq.upm.es/b/n23/avand.html

Arango Escobar, Gilberto (1990): La Ciudad Informal siglo XXI. Universidad Nacional de Colombia. Medellín.

- (1982): "El Frente Nacional y las Políticas de Vivienda en Colombia: algunas hipótesis". http://www.bdigital.unal.edu.co/3018/1/GAE09-TF4237.pdf

Arango Quintero, Juan Carlos. Aproximación a los procesos de transmisión de la desigualdad social y económica en Colombia: 1990-2000. En publicación: Desigualdad y exclusión en Colombia (1990-2000) Los problemas nutricionales desde una aproximación del enfoque de las capacidades humanas. Tesis (Maestría en Ciencia 
Política). Colombia: IEP UDEA, Instituto de Estudios Políticos, Universidad Antioquia, $2005 . \quad$ [Citado: 13/9/2011]. http://bibliotecavirtual.clacso.org.ar/ar/libros/colombia/iep/tesis/hambredemocracia.pdf

Astengo, Giovanni (1966): Enciclopedia Universale dell'Arte. Instituto per la Collaborazione Culturales. Roma En: Luque Valdivia, José y Marrodán, Esperanza (coord.) [2004]: Constructores de la Ciudad Contemporánea. Universidad de Navarra. España, pp. 99 -109.

Avendaño, Gudifredo (2010): "Por accionar de Pandillas habrá toque de Queda para menores en Montería". El Tiempo.com Bogotá 7 de abril de 2010. http://www.eltiempo.com/archivo/documento/CMS-7551907

Bahr, Jurgen y Mertins, Gunter (1984): Un modelo de la diferenciación socio-espacial de la metrópolis de América Latina. En Torres, Carlos Alberto (2009): Ciudad Informal Colombiana. Universidad Nacional de Colombia.

Banco de la Republica (2009): Informe de Coyuntura Económica Regional (ICER) para Córdoba. http://www.banrepblica.gov.co

Banco de la República y Departamento Administrativo Nacional de Estadística, DANE (2007): Informe de Coyuntura Económica Regional para el Departamento de Córdoba. Montería.

Barroso, Javier (2007) "Cinco Mil Madrileños Viven en Chabolas". El País, 11 diciembre 2005.http://www.elpais.com/articulo/madrid/5000/madrilenos/viven/chabolas/elpep uespmad/20070806elpmad 1/Tes

Berrocal, Barney y Benítez, Rahomir (2010): "Villa Jiménez, la manzana de la discordia". El Meridiano de Córdoba, agosto 6. Montería.

Borda, Jordi y Castells, Manuel (1997): Local y Global. Ediciones Tauros. Madrid.

Brand, Peter; Coupé, Françoise y Ortiz, Catalina (2006): Suelo Urbano y Vivienda para la Población de Ingresos Bajos: Estudios de caso: Bogotá - Soacha - Mosquera; Medellín y Área Metropolitana Peter. Development Planning Unit - DPU. University College London. Medellin.

Browne, Patricio (2004): "Formal e Informal". www.scielo.cl/pdf/arq

Busquets Cano, Joan (1999): La Urbanización Marginal. Ediciones UPC. Barcelona.

Cámara Colombiana de la Construcción (CAMACOL) [2010]: "Construcción en Colombia" http://www.congresocamacol.com/adminsite/memorias/temp/archiArchivo20100423 021011.pdf 
Camargo Sierra, Angélica (2004): Perfil de la Informalidad Urbana. Universidad Piloto de Colombia. Santafé de Bogotá.

Carrasco Rey, René (2004): "Barrios marginales en el Ordenamiento de Bogotá". Revista Bitácora Universidad Nacional de Bogotá. Vol. 8 № 1. Enero - Diciembre 2004, pp. 56-63.

Casariego Ramírez, Joaquín (1987): Las Palmas. Dependencia, Marginalidad y Autoconstrucción. Instituto de Estudios de Administración Local, Madrid.

Castells, Manuel (1986): La ciudad y las masas: sociología de los movimientos urbanos. Alianza editorial. Madrid.

- (2007): “Globalización y antiglobalización". El País. 24 de julio. Madrid. España. www.elpais.com/articulo/opinión

- (1974): La Cuestión Urbana. Ediciones Siglo XXI México D.F.

- (1993): “La urbanización popular en América Latina. Institucionalización o pactos sociales". En Azuela Antonio (coordinador). La urbanización popular y el orden jurídico en América Latina. UNAM. México, pp.19-30.

Castillo Osorio, Benjamín (2007): Dinámica del Sector Empresarial en Montería. Universidad del Sinú. Montería. Colombia.

Centro de Estudios de la Construcción y el desarrollo Urbano CENAC (2004): "Empleo generado en los planes de construcción del Instituto de Crédito Territorial". http://www.cenac.org.co/noticias eventos.shtml

Comisión Económica para América Latina (CEPAL) [1990]: La Marginalidad Urbana en América Latina: la dimensión espacial. Santiago de Chile.

— [2010]: Población y Salud en América Latina. Santiago de Chile.

Cepeda, Iván y Rojas, Jorge (2008): A las Puertas del Ubérrimo. Nomos Impresores. Bogotá.

Cerdá, Idelfonso (1968): Teoría General de La Urbanización, Institutos de Estudios Fiscales. Barcelona.

Clichevsky, Nora (2000): Informalidad y Segregación Urbana en América Latina. Una aproximación. CEPAL. División de Asentamientos Humanos. Santiago de Chile. Disponible en: www.eclac.org/publicaciones/xml/8/5638/lcl1430e.pdf

- (2003): "Pobreza y acceso al suelo urbano. Algunas interrogantes sobre políticas de urbanización". Santiago de Chile: CEPAL- NACIONES UNIDAS. Serie Medio Ambiente y desarrollo. No. 75. 
Comisión de Formalización de la Propiedad Informal (COFOPRI) [2002]: "Informe sobre la dinámica de los asentamientos humanos en Lima". http://www.cofopri.gob.pe/pdpu/pdf/DinamicaAsentamHumanos.pdf

Conesa Fernández-Vítora, Vicente (1997): Guía Metodológica para la Evaluación del Impacto Ambiental. Editorial Mundi-Prensa. Madrid.

Consultoría para los Derechos Humanos y el Desplazamiento CODHES (2008): "Población desplazada en Colombia". http://www.codhes.org.

Crismatt Mouthon, Carlos (2009): "La Fundación de Montería". http://www.cordoba.gov.co/cordobadigital/Cordoba Monteria.html

Cuellar, Nicolás (2010): "Buenos Aires se faveliza". El Espectador, 21 de diciembre. Sección Internacional. Bogotá.

Cuervo González, Luis Mauricio (1997): Evolución Reciente de las Disparidades Económicas Territoriales en América Latina. http://www.eumed.net/libros/2010d/766/Primacia\%20urbana\%20caracteristicas\%20d el\%20concepto\%20y\%20evolucion\%20historica\%20del\%20fenomeno\%20en\%20Ameri ca\%20Latina.htm

Dahau, Emilio (2003): La Ciudad Informal. Universidad Autónoma Metropolitana. BeloHorizonte.

Departamento Nacional de Estadística (DANE) [2010]: División Político - Administrativa de Colombia. www.dane.gov.co

- [2008]: Población Afilada al Sistema General de Seguridad Social en Salud. Total Nacional y por Regiones. http://www.dane.gov.co

— [2001]: Estudio sobre el Sector Informal. www.dane.gov.co

- [2005]: Censo Nacional 2005. www.dane.gov.co

Departamento Nacional de Planeación (DNP) [2006]: Plan de Desarrollo 2002-2006 http://www.dnp.gov.co/Portals/0/archivos/documentos/GCRP/PND/PND.pdf

- [2008]: Orientaciones para elaborar los Programas de Gobierno. DNP. Bogotá. http://www.confenacol.org/cartillas/Cartillaelaborar.pdf

- [2004]. Documento 3305 de 2004. Lineamientos para optimizar la política de desarrollo urbano. Santafé de Bogotá.

Diario el Tiempo (2008): "Ineficaces han resultado medidas del Gobierno y de las alcaldías para evitar el aumento del mototaxismo". Redacción. Abril 13. Bogotá.www.eltiempo.com 
Díaz Mosquera, Carlos (2008): Algunas Características del Proceso de Urbanización de Bogotá: Una mirada desde la marginalidad social urbana. Universidad Pedagógica Nacional. Bogotá.

Dorney, R. S. (1977): Environmental Assessment: the ecological dimension. Citado en: Martín Cantarino, Carlos (1992): El Estudio de Impacto Ambiental. Publicaciones Universidad de Alicante. Alicante.

Duhau, Emilio (1998): Hábitat Popular y Política Urbana. Miguel Ángel Porrua. México.

- (2003): "La ciudad Informal. El orden urbano y el derecho a la ciudad". http://www.fcp.uncu.edu.ar/upload/duhau-2003.pdf

Eberstadt, Rudolf (2009): Manual sobre la cuestión y el origen de la Vivienda. En García, Marta y Alonso José (Coordinadores) [2004]: Constructores de la Ciudad Contemporánea. Universidad de Navarra. España, pp. 349-357.

El Meridiano de Córdoba (2009): "Mototaxistas se duplicaron". Redacción. Montería, 29 de mayo. http://elmeridianodecordoba.com.co/archivo/mototaxistas-se-duplicaron

- (2009): "Vía libre para Pico y Placa de Motos". Redacción, Montería 23 de marzo. http://elmeridianodecordoba.com.co/archivo/category/monteria/page/178/

El País (2010): "Invierno deja dos millones de damnificados" http://www.elpais.com.co/elpais/colombia/noticias/invierno-deja-dos-millonesdamnificados-en-28-departamentos-2

Espinosa Restrepo, León (2000): El Estado en la construcción de las áreas residenciales de Bogotá. Maestría en Urbanismo. Universidad Nacional. Bogotá. http://www.facartes.unal.edu.co/portal/publicaciones/urbanismos/urbanismos2/Esta do construccion areas residenciales.pdf

Exbrayat, Jaime (1996). Historia de Montería. Tercera Edición. Editorial Domus Libri. Montería.

Fernandes, Edesio y Varley, Ann (1998): Ciudades Ilegales. Promesha. Cochabamba, Bolivia

Figueroa, Hermes (2009): "Mototaxismo desplaza a buses urbanos en la Costa". El Universal, Cartagena 31 de diciembre. http://www.eluniversal.com.co/monter\%C3\%AD/econ\%C3\%B3mica/mototaxismodesplaza-buses-urbanos-en-la-costa

Folguera Grassi, Francisco (1959). Urbanismo para Todos. Colegio Oficial de Arquitectos de Cataluña. Barcelona. En: Luque, José; Puy, Juan Pablo y Oto, Alberto (coord.) [2004]: Constructores de la Ciudad Contemporánea. Universidad de Navarra. España, pp. 367-373. 
Fondo Nacional de Salud y Bienestar Social (FNSBS) [1960]: Barriadas de Lima Metropolitana. Departamento de Servicio Social y Vivienda. Sección de Investigaciones Sociales. Lima

Friedman, Milton (1996): Capitalismo y Libertad. Ediciones Rialp. México.

Gaja Díaz, Fernando (1984): La promoción Pública de la Vivienda en Valencia. 1939 1976. Generalitat Valenciana. Valencia.

- (2002): Revolución Informacional, Crisis Ecológica y Urbanismo. Ediciones U.P.V. Valencia.

Garay, Hilda y Alva, Jorge (2005): "Identificación y Ensayos en Suelos Dispersivos". http://www.cismid.uni.edu.pe/descargas/a labgeo/labgeo18 p.pdf

Garcés y Negrete (2010): Análisis Sociopolítico de Montería y Propuestas de Liderazgo, Participación y Compromiso Ciudadano. Universidad del Sinú. http://www.viva.org.co/cajavirtual/svc0211/articulo0848 211.pdf

García de Hernández, Norma (2006): "La Formación de Asentamientos Informales: Un proceso gestado por diferentes actores sociales". Revista Scripta Nova. Vol. X, № 218. http://www.ub.es/geocrit/sn/sn-218-50.htm

García Herrera, Luz (2005): Santa Cruz de Tenerife, la formación de la ciudad Marginal. http://www.edicionesidea.com/aplicacion/colecciones/ver.asp?ID=28.

García Mariano (2007): "Los años 40: crecimiento de las villas y auge de los barrios obrero".http://www.solesdigital.com.ar/sociedad/historia villas 2.htm.

García-Abad, Alonso (2007): "El Medio Ambiente: Concepto, Significado y Carácter". http://www.geogra.uah.es/igabad/pdf 06-07/DOC02.pdf

Girardet, Herbert (1992): Ciudades Alternativas para una Vida Urbana Sostenible. En Agudelo Patiño, Luis Carlos (2004): Evaluación de la sostenibilidad ecológica del área metropolitana de Medellín. Tesis Doctoral U.P.V. Valencia. España.

Gómez Orea, Domingo (1992): Evaluación de Impacto Ambiental. Editorial Agrícola España S.A. Madrid

González Zapata, Gloria (2009): Gestión de los Asentamientos Informales: Un Asunto de Política Pública. Universidad Nacional de Colombia. Medellín.

Hochgemuth, Marco (2010): "Las diez ciudades más inseguras del mundo". Radio Nederland. Diciembre 8 de 2010. http://www.rnw.nl/espanol/article/las-diezciudades-mas-inseguras-del-mundo 
Jaramillo, Samuel y otros (2006): Informalidad de la vivienda en Bucaramanga y Cartagena. Documento CEDE Universidad de los Andes. Bogotá.

Kay, Cristóbal (1998): Revista Nueva Sociedad № 158, pp. 110 - 119. http://biblioteca.hegoa.ehu.es/system/ebooks/7009/original/Estructuralismoyteoriad eladependen.pdf.

Le Corbusier (1989): Principios de Urbanismo. La Carta de Atenas. Editorial Ariel, S.A. Barcelona.

Lynch, Kevin (1994): La Imagen de la Ciudad. Gustavo Gili, S.A. Barcelona.

Lombardi, Jorge (2001). “Autogestión y participación en la ciudad informal”. En: Piñón, Juan Luis (coord.) La recomposición de la ciudad informal. Valencia: Congreso Internacional Ciudad Informal. Universidad Politécnica de Valencia. Valencia, España.

López Morales, Gloria (2006): "Globalización y Desarrollo Local" en AA.VV. Manejo y Gestión de Centros Históricos. Conferencias de los encuentros internacionales II y III de 2003 y 2004. Ediciones Boloña. La Habana, pp. 71-75.

López, Paula (2009): "Hace falta más plata y compromiso para desmovilizados". El Colombiano. Junio 30 de 2009. http://www.elcolombiano.com

Lovera, Alberto (1983): "Indagaciones sobre la producción de viviendas en los barrios de ranchos". Revista Interamericana de Planeación" Vol. XVII Nº6

- (1997): "Se Busca Espacio Habitable. Las Formas de acceso al espacio habitable y su legitimación". En AA. VV. Barrios y Propiedad de la Tierra. Una discusión. Caracas. U.C.V, pp. $107-129$.

Maestre Corena Jaime (2005): "Hábitat Popular en Cartagena. El Asentamiento Informal; única alternativa para los pobladores urbanos y los inmigrantes de escasos recursos". Revista de Ciencias Humanas y de la Salud, pp. 41-51.

Mangin, William (1963): "Urbanisation case history in Perú". En Architectural Digest, 33 (8): 366-370.

Martin Cantarino, Carlos (1999): El Estudio de Impacto Ambiental. Publicaciones Universidad de Alicante. Alicante.

Martínez, Lidy \& Berrocal, Barney (2010): “El Cerro Sigue Cediendo". El Meridiano de Córdoba. Julio 26 de 2010. Pág. 5A. http://www.elmeridianodecordoba.com.co

Matos Mar, José (1968): “Urbanización y Barriadas en América del Sur". IEP. Lima. Perú.

— (1977): “Las barriadas de Lima 1957”. IEP, Lima. Perú. 
- (1984): Desborde Popular y Crisis del Estado. Institutos de Estudios Peruanos IEP. Lima. http://lanic.utexas.edu/project/laoap/iep/ddtlibro.25pdf

Maya Sierra, Tania (2000): "Áreas residenciales y desarrollo urbano en Bogotá". Maestría en Urbanismo. Universidad Nacional de Bogotá. http://facartes.unal.edu.co/portal/publicaciones/urbanismos/urbanismos2/Areas resi denciales desarrollo urbano.pdf

Naranjo, Oscar (2009): Cuarta Rendición de Cuentas sobre Derechos Humanos. Presidencia de la República de Colombia. http://web.presidencia.gov.co/sp/2009/enero/19/07192009.html

Negrete Barrera, Víctor (1999): Los Asentamientos Subnormales de Montería. Acción Contra el Hambre y UNISINU. Montería.

- (2001): Asentamientos Subnormales de Montería Receptores de Desplazados. UNISINÚ.

- (Editor) [1992]: Memorias del Taller Nuestras Ciénagas. Montería, Abril, 10 y 11 de 1992.

- (1999): La Pobreza dentro de la Pobreza. Cantaclaro y su Canal. Universidad del Sinú. Montería.

- (2001): El proceso de reubicación de población desplazada por la violencia en predios rurales del municipio de Montería. ACNUR-UNISINU.

- (2004): Situación actual de las comunidades culturales urbano marginales de Montería. Universidad del Sinú Montería.

Negrete, Víctor y Bedoya Belia (2007): Las Peleas en Casa y el Maltrato Infantil. CEDALUNISINÚ. Montería.

Negrete, Víctor y Garcés, Miguel (2010): Análisis Sociopolítico de Montería y propuestas sobre liderazgo, participación y compromiso ciudadano. Ediciones UNISINU. Montería. http://www.viva.org.co/cajavirtual/svc0211/articulo0848 211.pdf

Observatorio del Caribe Colombiano (2008): Indicador Global de Competitividad. http://www.ocaribe.org/sid/indicador global competitividad.php.

Ocampo, Gloria Isabel (2003): “Urbanización por Invasión. Conflicto Urbano, Clientelismo y Resistencia en Córdoba". Revista Colombiana de Antropología. Vol.39, enero-diciembre,

http://www.icanh.gov.co/recursos user//RCA\%20Vol\%2039/v39a08.pdf

pp.237-272.

Organización Panamericana de la Salud y Universidad de Antioquia (2004): Salud y Desplazamiento en Colombia. http://www.disaster-info.net/desplazados 
Ortega, Jorge; Valencia, Nidia; y Restrepo, Marleny (2007): "La Economía Política de la Pobreza y la Desigualdad Social: El caso de Montería". http://www.javeriana.edu.co.

Pelli, Víctor (1997): "El Sector Popular en la Construcción democrática del Hábitat". http://habitat.aq.upm.es

Pérez, Amnerys (2003): "El Cerro Quiere Volver a Respirar II". El Meridiano de Córdoba. Abril 27 de 2003. Pág. 5A. http://www.biodiversityreporting.org/article

- (2003): "El Cerro Quiere Volver a Respirar III". El Meridiano de Córdoba, mayo 4 de 2003. Pág. 5A. http://www.biodiversityreporting.org/article.

- (2003): "El Cerro Quiere Volver a Respirar IV". El Meridiano de Córdoba. Mayo 11 de 2003. Pág. 5A. http://www.biodiversityreporting.org/article.

Pinedo López, Jhon (2008): "Estudio de La Economía Informal en Montería". Ponencia presentada en la Universidad Nacional Sede Medellín. http://www.institutodeestudiosurbanos.com/descargas/doc details/164-estudio-dela-economia-informal-en-monteria.html

Plan de Naciones Unidas para el Desarrollo (PNUD) [2011]: Informe de Desarrollo Humano 2011. http://www.pnudcolombia.org/indh2011/index.php/elinforme/informe-completo

Presidencia de la República (2006): Construir ciudades amables. Visión II Centenario. http://www.presidencia.gov.co.

Puche, Edgardo (1988): Crónicas y Estampas Monterianas. Gráficas Urra. Montería.

Ramírez, Juan Carlos (2010): Gasto Social y Presión Fiscal. CEPAL. http://www.slideshare.net/alianzaporlaninez/gasto-social-y-presin-fiscal

Rangel, Alfredo (2010): "Las ciudades más peligrosas". Revista Semana. Julio 31 de 2010. http://www.semana.com/noticias-opinion/ciudades-peligrosas/142429.aspx

Rayano, Manuel (2000): Fenómenos de Tubificación en Presas Pequeñas de Tierra. http://www1.unne.edu.ar/cyt/2001/7-Tecnologicas/T-035.pdf

Redacción Diario El Tiempo (2000): "Ofrecen Lotes para Invasores de Montería". Sección Nación. 10 de marzo, Bogotá. http://www.eltiempo.com/archivo/documento/MAM-1289758

Restrepo Valencia, Marleny (2007): Montería Imaginada. Editorial Guadalupe. Montería.

Revista Semana (2012): Informe "Desigualdad Extrema". 12 de Marzo de 2012. http://www.semana.com/nacion/desigualdad-extrema/153207-3.aspx 
- (2010): "El manejo de tierras en Colombia naufragó en la corrupción. Las nuevas leyes le dan un impulso a la contrarreforma agraria. Fichas de un rompecabezas que encajan perfectamente para legalizar un nuevo y perverso orden de las cosas". http://www.semana.com/wf ImprimirArticulo.aspx?ldArt=115489

- (2006): "Que hacer con el Mototaxismo". Redacción. Septiembre 26. http://semana.com/wf InfoArticulo.aspx?idArt=96997

Rojas Salguero, Erly (2010): "Sedientos". http://lacomunidad.elpais.com/gilmagamez/2010/2/12/ganadora-los-premios-periodismo-colrensa-la-categoria

Rossi, Aldo (1971): La arquitectura de la Ciudad. Gustavo Gili, S.A. Barcelona.

Rueda, Néstor (2002): Evolución de las Políticas Normativas y Planes de Ordenamiento Urbano en la ciudad de Bucaramanga durante el siglo XX. Revista M Vol. 1 № 2.

Saldarriaga Roa, Alberto (2001): La Ciudad Informal en Colombia: ¿problema o solución? En Piñón, Juan Luis (coord.) [2001]: La Recomposición de la Ciudad Informal. $\mathrm{ClCl}$ - UPV. Valencia, pp. $41-52$.

Sánchez Juliao, David (2009): El hombre que era así. Seminario Andino Editores. Bucaramanga.

Scabuzzo, Claudio (2008): "Una Villa Miseria del Primer Mundo". http://laterminalrosario.wordpress.com/2008/04/21/una-villa-miseria-

delprimermundo

Secretaria Municipal de Tránsito de Montería (2010): Información Institucional del año 2010. http://www.monteria-cordoba.gov.co/sitio.shtml?apc=C1n1--\&x=1731926

Sen, Amartya (2000): Desarrollo y Libertad. Planeta. Madrid.

Smolka, Martín (2003): "Informalidad Urbana y precios de la tierra". Lincoln Institute of Land Policy. http://www.lincolninst.edu/pubs/825 Informalidad--pobreza-urbana-yprecios-de-la-tierra

Sola-Morales i Rubio, Manuel (1997): Las Formas de Crecimiento Urbano. Ediciones UPC. Barcelona

Tomas, François (1995): La irregularidad en el desarrollo urbano de América Latina. En García de Hernández, Norma (2006): "La Formación de Asentamientos Informales: Un proceso gestado por diferentes actores sociales". Revista Scripta Nova. Vol. X, № 218.

Torres, Carlos Alberto (2009): Ciudad Informal Colombiana. Universidad Nacional de Colombia. http://es.scribd.com/doc/53976196/Ciudad-Informal-Colombiana. 
Torres, John y Pineda, Viviana (2008): “Aumento del Mototaxismo ya se percibe en varios barrios de Bogotá": Diario El Tiempo. Redacción. Bogotá, mayo 4. http://www.eltiempo.com/archivo/documento/CMS-4142083

Turner, John (1963): “Lima barriadas today". Architectural Digest, 33 (8): 375-380.

- (1965): "Limas Barriadas and Corralones: suburbs vs. slums". Ekisties. Marzo Vol. 19.

- (1976): Vivienda todo el poder para los usuarios. Hacía la economía en la construcción del entorno. Blume, edición española. Madrid.

Universidad del Rosario (2007): Política de Vivienda - Alcances y Perspectivas. Revista Universidad, Ciencia y Desarrollo. Fascículo 11. Santafé de Bogotá. http://www.urosario.edu.co/urosario files/3f/3fd62460-2c03-46e6-a455-

5315894deee1.pdf

Velasco, Henry y Benítez, Rahomir (2010): “Cuantos miembros tienen las Bacrim en el departamento Córdoba". El Meridiano de Córdoba. Montería, 22 de noviembre de 2010.

Viviescas Monsalve, Fernando et al. (1989): La calidad espacial urbana de los barrios para sectores de bajos ingresos en Medellín. En Torres, Carlos Alberto (2009): Ciudad Informal Colombiana. Universidad Nacional de Colombia.

Vorms, Charlotte (2003): "La Urbanización Marginal del Extrarradio de Madrid: Una respuesta espontanea al problema de la vivienda. El caso de la Prosperidad (18601930)". Revista Electrónica Scripta Nova. http://www.ub.es/geocrit/sn/sn146(013).htm.

Xiangye, Li y Arroyo, Víctor (2002): "Impactos de Fuerzas de Filtración y Tubificación retrograda a la inestabilidad de talud y erosión hídrica". http://www.revista.unam.mx/vol.12/num2/art14/ 


\subsection{BIBLIOGRAFÍA COMPLEMENTARIA}

Alcaldía Mayor de Bogotá (2002): Ciudadela el recreo. Memorias del Modelo de gestión de Metro-vivienda. Editorial Panamericana. Bogotá.

Álvarez, Richard y Llorente, Fernando (2002): Intervención urbana en los asentamientos subnormales no consolidados de la margen Izquierda del río Sinú. Tesis de Arquitectura. Universidad del Sinú. Montería.

Anaya, Alfredo (2000): Caracterización del Empleo, Subempleo y Desempleo en Montería. Universidad del Sinú. Montería.

Bazant, Joan (1998): Manual de Diseño Urbano. Editorial Trillas. México D.F.

Bellet, Carme y LLop, Josep (2000): Ciudades Intermedias, urbanización y sostenibilidad. Editorial Milenio. Madrid.

Benévolo, Leonardo (1982): Diseño de la Ciudad. El arte y la Ciudad Contemporánea. Barcelona.

— (1992): Orígenes del Urbanismo Moderno. Celeste. Madrid.

Bonet Correa, Antonio (1989): Las Claves del Urbanismo. Ediciones Ariel, S.A. Barcelona.

Borda, Jordi y Castells, Manuel (1997): Local y Global. Ediciones Tauros. Madrid.

Borja, Jordi y Muxa, Zaida (2003): El Espacio Público, Ciudad y Ciudadanía. Electa. Barcelona.

— (2004): Urbanismo en el siglo XXI. Ediciones UPC. Barcelona.

Borja, Jordi y otros (2001): Ciudad para la sociedad del siglo XXI. Ediciones ICARO. Valencia.

Brambilla, Roberto y Longo Giani (1989): Centros Urbanos Peatonales. Editorial OikosTau, S.A. Barcelona.

Campos Venuti, Giuseppe (1967): La administración del Urbanismo. Gustavo Gili, S.A. Barcelona.

— (1981): Urbanismo y Austeridad. Siglo XXI. Madrid. 196 Págs.

Capel, Horacio (2002): La Morfología de las Ciudades. Editorial del Serbal. Barcelona.

Castro, Heber y Llorente, Samuel (2000): Sierra Chiquita. Estribación de la Serranía San Jerónimo. Universidad del Sinú. Montería. 
Centro de Cultura Contemporánea de Barcelona (1997): La Ciudad Sostenible. The Sustainable City. Diputación de Barcelona.

Cerdá, Idelfonso (1968): Teoría General de la Urbanización. Instituto de Estudios Fiscales. Barcelona.

- (1991): Teoría de la Construcción de las Ciudades. Cerdá y Barcelona. Ministerio para la Administración Pública y Ayuntamiento de Barcelona. Madrid. Original de 1859.

- (1991): Teoría de la Viabilidad Urbana. Cerdá y Madrid. Ministerio para la Administración Pública y Ayuntamiento de Madrid. Original de 1861.

Corporación de los Valles del Sinú y del San Jorge C.V.S. (2000): Plan de Gestión Ambiental del departamento de Córdoba 1999 - 2003. Montería.

Craviño, María Cristina (2007): Las Villas de la Ciudad. Mercado e Informalidad Urbana. Universidad de General Sarmiento. Buenos Aires.

Cristopher, Alexander (1976): Urbanismo y Participación. Gustavo Gili, S.A. Barcelona.

Cuervo, Luis y González, Josefina (1997): Industria y Ciudades en la Era de la Mundialización. Un enfoque socio-espacial. Tercer Mundo, Colciencias y CIDER. Santafé de Bogotá.

Departamento Nacional de Planeación (DNP) [2002]: Plan de Desarrollo Hacia un Estado Comunitario 2002 - 2006. Santafé de Bogotá.

— (1983): Plan de Desarrollo: Cambio con Equidad 1982 - 1986. www.dnp.gov.co

Elizagarate, Victoria de (2003): Marketing de Ciudades. Ediciones Pirámide. Madrid.

Elizalde, Antonio (2003): Desarrollo Humano y Ética para la Sustentabilidad. PNUD. Universidad Bolivariana. Santiago de Chile.

Engels, Friedrich (1977): El Problema de la Vivienda y las Grandes Ciudades. Gustavo Gili, S.A. Barcelona.

Fariña, José (2000): La Protección del Patrimonio Urbano. Ediciones Akal. Madrid.

Fernández Güel, José (1997): Planificación estratégica de Ciudades. Gustavo Gili, S.A.

Fernández, Edesio (2002): Do Codigo Civil ao Estaturo da Cidades. Revista Urbana № 30. Caracas.

Font, Jaime y Pujadas Roma (1998): Ordenación y Planificación Territorial, Editorial Síntesis, Madrid. 
Gaja i Díaz, Fernando (2006) Urbanismo y Sostenibilidad ¿Una Contradicción en los términos? Revista Ingeniería y Territorio, № Monográfico 75. La Ciudad Habitable

Galbraith, John Kenneth (2004): La Economía del Fraude Inocente. La verdad de nuestro tiempo. Editorial Crítica. Barcelona.

García Canclini, Néstor (1995): Conflictos Culturales de la Globalización. Grijalbo. México D.F.

- (1995): Consumidores y Ciudadanos. Conflictos Multiculturales de la Globalización. Grijalbo. México D.F.

García Vásquez, Carlos (2004): Ciudad Hojaldre. Visiones urbanas del siglo XXI. Gustavo Gili, S.A.

Gómez López, Claudia (2000): Influencia de la promoción pública de la vivienda en el desarrollo de la mancha urbana de la ciudad de San Miguel de Tucumán. Elementos para la comprensión urbana. Tesis Doctoral. UPV. Valencia.

González, Mélida y otros (2005): Antecedentes Históricos de la Vivienda Subsidiada en Montería. Trabajo de Grado. Universidad del Sinú. Montería.

Granados Delgado, Oscar (2001): Estimación del Balance Energético de la ciudad de Montería, Universidad de los Andes, Santafé de Bogotá.

Gravagnvolo, Benedetto (1998): Historia del Urbanismo en Europa 1750 - 1960. Ediciones Akal, S.A. 486 Págs.

Guarín Cobos, Andrés (2003): Cartagena de Indias. Asentamientos Informales en la década de los 90. Revista Bitácora Urbano Territorial № 7. Vol. 1.

Harvey, David (1979): Urbanismo y Desigualdad Social. Editorial Siglo XXI. Madrid.

Hernández, Mario y Márquez, Oscar (2003): Desarrollo Urbano. Manejo Integral de Residuos Sólidos. Universidad del Sinú. Montería.

Instituto de Crédito Territorial (ICT) [1978]: Inventario de zonas subnormales de vivienda y proyectos de desarrollo progresivo 1972 - 1976. Editado por el I.C.T. Santafé de Bogotá.

Instituto Geográfico Agustín Codazzi (IGAC) [1997]: Guía Metodológica para la Formulación del Plan de Ordenamiento Territorial Municipal, Santafé de Bogotá.

Lewis, David (1970): La Ciudad. Problema de Diseño y estructura. Gustavo Gili, S.A. Barcelona. 
López Candeira, José (1997): Diseño Urbano. Teoría y Práctica. Editorial Munilla - Leira.

López, Ramón (1993): Ciudad y urbanismo a finales del siglo XXI. Universidad de Valencia - Ediciones Guada.

Lorenzo Galligo, Pedro (2005): Un Techo para Vivir. CYTED y Ediciones UPC. Barcelona.

Max-Neef, Manfred y Elizalde, Antonio (1996): Desarrollo a Escala Humana. Ediciones Momo. Santafé de Bogotá.

Mejía, Luz Adriana (2004) La ordenación del territorio frente a la relocalización de asentamientos humanos en Colombia. U.P.V. Valencia.

Melon Muñoz, Alfonso y otros (1999): Urbanismo. Memento Práctico. Ediciones Francis Lefebvre. Madrid.

Millán Orozco, David (2001): De la Generación Espontánea a la Formalidad Planificada. En Piñón, Juan Luis y otros. La Recomposición de la Ciudad Informal ClCl. Valencia. 2001. Págs. $56-72$.

Moreno, Carmen y Sibaja, Enrique (2005): Reforma Integral en el Barrio Villa Cielo. Implementando Materiales Bioclimáticos. Universidad del Sinú. Montería.

Moya González, Luis (1983): Barrios de promoción Oficial. Madrid 1939 - 1976. Graficinco, S.A. Madrid.

Muxi, Zaida (2004): La Arquitectura de la Ciudad Global. Gustavo Gili, S.A. Barcelona.

Naranjo Giraldo, Gloria y otros (2003): Tras las Huellas Ciudadanas. Instituto de Estudios Políticos. http:// bibliotecavirtual.claso.org.ar/libros/Colombia.

Negrete Barrera, Víctor (1994): Los Desplazados por la Violencia en Colombia. El caso de Córdoba. Universidad del Sinú. Montería.

Pedro, Aurora (2000): Espacio urbano y política de Vivienda, Generalitat Valenciana. Valencia.

Pergolis, Juan (2005): Bogotá Fragmentada. Tercer Mundo Editores. Santafé de Bogotá.

Perloff, Harvey (1973): La calidad del medio ambiente urbano, Ediciones Oikos-Tau, S.A., Barcelona.

Piñón, Juan Luis (2005): Diez Observaciones sobre la ciudad Americana. Revista Ciudades. Universidad de Valladolid. № 9. 
- (2005): La Ciudad Iberoamericana más allá de la cuadricula. Revista Ciudades. № 9. Universidad de Valladolid.

- (coord.) [2001)]: La recomposición de la ciudad informal. CICI-UPC. Valencia.

Plan de Naciones Unidas para el Desarrollo (PNUD) [2008]: Informe de Desarrollo Humano 2007-2008. Mundi-Prensa Libros, S.A. Madrid.

Puche, Edgardo (2001): Crónicas y Estampas Monterianas. Editorial Omega. Montería.

Republica de Colombia (1991): Constitución Política de Colombia. Ediciones Momo. Santafé de Bogotá.

- (1994): Ley 134 sobre Mecanismos de Participación Ciudadana. Momo. Santafé de Bogotá.

— (1994): Ley 136 sobre Modernización de Municipios. Momo. Santafé de Bogotá.

- (1994): Ley 152 sobre Planes de Desarrollo. Momo. Santafé de Bogotá.

— (1999): Ley 99 sobre Medioambiente. Ediciones Momo. Santafé de Bogotá.

- (1994): Ley 142 de sobre Modernización de los Servicios Públicos Domiciliarios. Momo. Santafé de Bogotá.

- (1994): Ley 361 sobre Limitados Físicos y Personas con Orientación Disminuida. Momo. Santafé de Bogotá.

- (1997): Ley 387 de 1997. Atención, Protección y Estabilización Socioeconómica de los Desplazados. Momo. Santafé de Bogotá.

- (1998): Decreto 1504 sobre manejo del Espacio Público. Momo. Santafé de Bogotá.

- (2004): Documento CONPES 3305. Lineamientos para optimizar la Política de desarrollo Urbano. Santafé de Bogotá.

Ruano, Miguel (1999): Ecourbanismo. Entornos Humanos Sostenibles: 60 proyectos. Gustavo Gili, S.A. Barcelona.

Sachs, Jeffrey (2005): El Fin de la Pobreza. Como conseguirla en nuestro tiempo. Editorial Debate. Barcelona.

Salas, Julián y Calavides, Felipe (2006): Los Programas de la Ciudad Informal, herramientas de lucha contra la pobreza. http://www.recolecta.net. 
Saldarriaga, Alberto y Arango, Carlos (1986): La Lucha por la Vivienda en Colombia. Ediciones Ecoe. Santafé de Bogotá.

Santana, Vega, Juan (1999): Diccionario cultural de Córdoba, Domus Libri, Montería.

Sen, Amartya (2001): Desarrollo y Libertad. Editorial Planeta. Madrid.

Sharp, Thomas (1959): Planeamiento Urbano. Ediciones Infinito. Buenos Aires. Traducido al castellano por Jorge Hardoy.

Solá-Morales, Manuel de (1997): Las Formas de Crecimiento Urbano. UPC. Barcelona.

Smolka, Martim y Furtado, Fernanda (2001): Recuperación de Plusvalía en América Latina. Pontificia Universidad Católica de Chile. Santiago de Chile.

Smolka, Martim y Mullany, Laura (2007): Perspectivas Urbanas. www.lincolninst.edu.publ.

Stiglitz, Joseph (2002): El Malestar en la Globalización. Tauros. Madrid.

- (2003): Los Felices 90. La semilla de la destrucción. Tauros. Santafé de Bogotá.

Terán, Fernando de (1978): Planeamiento Urbano. Gustavo Gili, S.A. Barcelona.

— (1982): El Problema Urbano. Salvat Editores. Barcelona.

Torres, Carlos Alberto (2001): Nuevas periferias Urbanas y Tendencias de la Ciudad Informal en Colombia en los años 90. Piñón, Juan Luis y otros (2000). La recomposición de la ciudad informal. Valencia. Págs. 151-157

Unidad Municipal de Asistencia Técnica Agropecuaria (UMATA) [1999]. Informes sobre Agricultura. Montería.

Varela, Marta Rocío (2007): La recomposición de la ciudad informal. El modelo de Redes Vecinales MDRV a escala intraurbana. UPV. Valencia.

Zarate Martín, Antonio (1991): El Espacio Interior de la Ciudad. Editorial Síntesis. Madrid. 


\section{ANEXO}

FORMATOS DE ENCUESTAS REALIZADAS A POBLACIÓN DE TRABAJADORES

INFORMALES EN LA CIUDAD DE MONTERÍA 


\section{ESTUDIO SOBRE COMERCIO INFORMAL EN MONTERIA \\ INVESTIGADOR JHON PINEDO LÓPEZ \\ ENCUESTA COMERCIANTES INFORMALES}

Fecha- Sector-

Ambulante ( ) Estacionario ( )

Nombre-

Edad-

Sexo: masculino ( ) femenino ( )

Estado civil: soltero ( ) casado ( ) Separado ( ) unión libre ( )

Número de hijos-

Personas a cargo-

Lugar de origen-

Dirección residencia-

Estudios: primaria completa ( ) incompleta ( ) Bachillerato completo ( ) incompleto ( )

Técnico ( ) Tecnólogo ( ) superior ( )

Actividad -

Ingresos (10.000-20.000) ( ) (20.000-40.000) ( ) (>40.000) ( )

¿Está afiliado a algún régimen de seguridad social? SI ( ) NO ( )

¿Estuvo empleado alguna vez?

Si ( ) No ( ) Actividad-

¿Cómo es su relación con las autoridades?

Buena ( ) Regular ( ) Mala ( ) 
¿Cómo es su relación con los demás vendedores?

Buena ( ) Regular ( ) Mala ( )

¿Practica algún juego de azar?

Si ( ) No ( )

¿Ha recibido capacitación en ventas o en manipulación de alimentos?

Si ( ) No ( ) 


\section{PROYECTO \\ IMPACTO SOCIOECONOMICO DEL MOTOTAXISMO Y SU APORTE A LA GENERACION \\ DE EMPLEO, EN LA CIUDAD DE MONTERIA}

Investigador Jhon Pinedo López

ENCUESTA A MOTOTAXISTAS DE MONTERÍA

1. ¿La Moto es propia? SI - NO -

2. ¿Cuánto paga de Tarifa? -

3. ¿Cuál es el promedio diario de carreras? -

4. ¿En qué horas produce más?:

4:00 AM -10.00 AM -

10.00 AM - 3.00PM-

3:00 PM - 8:00 PM-

8:00 PM 11:00 PM-

5.- ¿Qué día de la semana le va mejor:

Lunes - Miércoles - Viernes - Sábado- Domingo-

6. ¿A qué bahía pertenece? --

7. ¿Cuánto consume diario de gasolina? \$-

8. ¿Cuánto le queda liquido a usted diariamente?

Entre $\$ 10.000$ Y $\$ 20000-$

Entre $\$ 20.000$ Y $\$ 40.000-$

Más DE $\$ 40.000$

9. ¿Se registró en el último censo? SI- NO-

10. ¿Cuando no está trabajando a qué otra actividad se dedica?

Familia - Otro trabajo- ¿Cuál? -

Deporte- Descansa-

11. ¿Tiene otra profesión? SI ( ) NO ( ) ¿Cuál? — 
12. Edad

Menor de 20 años

Entre 20 y 30

Entre 30 y 40

Entre 40 y 50

Mayor de 50

13. Estado civil:

Soltero ( ) Casado ( ) Separado ( ) Unión libre ( )

14. Número de Hijos -

15. Personas a cargo -

16. Lugar de Origen.

Montería - otro lugar - ¿Cuál? -

17. Estudios.

Primaria Completa () Primaria Incompleta () Bachillerato Completo ()

Bachillerato Incompleto ( ) Técnico ( ) Tecnólogo ( ) Universitarios ( )

18. Está afiliado a un régimen de seguridad social.

Si ( ) No ( )

19. ¿Estuvo empleado alguna vez?

$\mathrm{Si}$ ( ) No ( )

20. ¿Cómo es su Relación con las autoridades?

Buena ( ) Regular ( ) Mala ( )

21. Ha recibido capacitación en conducción

$\mathrm{Si}$ ( ) No ( ) 